\title{
GEOGRAFIA, EDUCAÇÃO E CIDADANIA
}

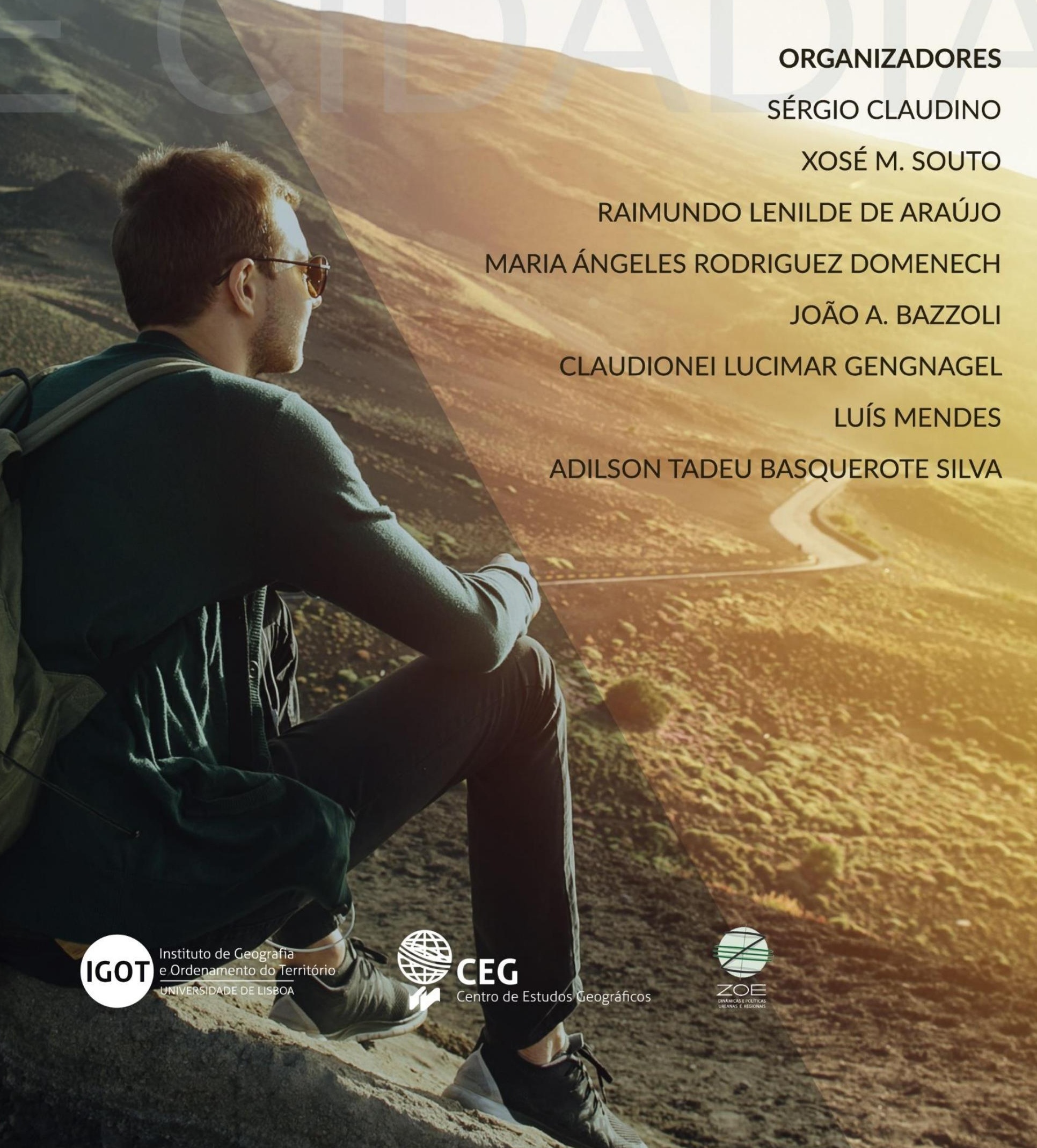




\section{FICHA CATALOGRÁFICA}

Título: Geografia, Educação e Cidadania

Organizadores: Sérgio Claudino, Xosé M. Souto, Mํㅡㄹ Angeles Rodriguez Domenech, João Bazzoli, Raimundo Lenilde, Claudionei Lucimar Gengnagel, Luís Mendes, Adilson Tadeu Basquerote Silva

Editor: Centro de Estudos Geográficos da Universidade de Lisboa

Local de Edição: Lisboa

Data: 2019

ISBN: 978-972-636-276-0

doi: 10.33787/CEG20190004

Este livro é financiado por fundos nacionais através da FCT- Fundação para a Ciência e Tecnologia, I.P. (UID/GEO/00295/2013) 


\title{
COMISSÃO CIENTÍFICA DO LIVRO
}

\author{
GEOFORO-Foro Iberoamericano de Geografia, Educação e Sociedade, \\ Universidade de Valência \\ Xosé Manuel Souto González \\ COORDENADOR
}

Universidade Federal da Fronteira Sul

Adriana Maria Andreis

Universidade Federal Fluminense

Ana Claudia Carvalho Giordani

Universidade de São Paulo

Andrea Coelho Lastória

Universidade Federal do Tocantis Antônia Márcia Duarte Queiroz João A. Bazzoli

Mariela Cristina Ayres de Oliveira

Universidad de Valencia

Benito Campo

Universidade Federal do Pará

Daniel Mallmann Vallerius

Instituto Federal do Rio Grande do Norte

Edseisy Silva Barbalho Tavares

Universidade Estadual do Oeste do Paraná

Geliane Toffolo

Universidade Estadual de Alagoas José Lidemberg de Sousa Lopes
Universidade de Passo Fundo

Luciane Rodrigues de Bitencourt

Universidade Federal do Piauí

Marcos Antonio de Castro Marques

Teixeira

Mugiany Oliveira Brito Portela

Raimundo Lenilde de Araújo

Universidade Federal do Sul e

Sudeste do Pará

Marcus Vinicius Mariano de Souza

Universidade de Castilla-La Mancha María Ángeles Rodriguez Domenech

Universidade Federal de Santa

Catarina

Rosemy Nascimento

Sandra Mendonça

Instituto de Geografia e Ordenamento do Território/Universidade de Lisboa Sérgio Claudino

Universidade Estadual Paulista,

Faculdade de Filosofia e Ciências,

Campus Marília

Silvia Aparecida Sousa Fernandes 


\section{COMISSÃO EDITORIAL}

Universidade de Lisboa

Sérgio Claudino
Universidade de Passo Fundo

Claudionei Lucimar Gengnagel

\section{COORDENADORES}

Instituto de Geografia e Ordenamento do Território/Universidade de Lisboa Luís Filipe Gonçalves Mendes

Universidade de Castilla-La-Mancha

María Ángeles Rodriguez Domenech

Universidade Federal do Tocantis

João A. Bazzoli

Universidade Federal do Piauí

Raimundo Lenilde de Araújo

GEOFORO-Foro Iberoamericano de Geografia, Educação e Sociedade, Universidade de Valência

Xosé Manuel Souto González

Universidade Federal de Santa Catarina

Adilson Tadeu Basquerote Silva 


\section{PREFÁCIO}

Pensar a Educação no tempo que vivemos é, cada vez mais, pensar um futuro que já é presente, pensar problemas globais que requerem ação local, pensar que a formação de todos não pode deixar de olhar para cada um. O desafio da massificação da escolarização passa por não confundir acesso a uma educação de qualidade com uma padronização cega que transforma a escola num redutor instrumento de transmissão de informação que não se converte em conhecimento e sabedoria.

É neste contexto que hoje, conforme previsto no Perfil dos Alunos à saída da escolaridade obrigatória, na Estratégia de Educação para a Cidadania e no regime legal para a Educação Inclusiva, inscrevemos no currículo nacional português um leque muito mais abrangente e exigente de competências a desenvolver: a resolução de problemas, a capacidade de pensar analítica, crítica e criativamente, a preocupação com a sustentabilidade, o ambiente e o bem-estar individual e comunitário. As falsas dicotomias que, por vezes, afastam a racionalidade dos debates sobre educação advogam que, quando se usa a palavra "competência", nos afastamos de conteúdos e de conhecimentos. A falácia está na ideia de que é possível ser-se competente sem a mobilização de conhecimentos ou que os conhecimentos que não são mobilizados para uma ação consciente perduram.

A iniciativa "Nós propomos!", retratada neste volume a partir da reflexão que as inúmeras experiências locais proporcionam, é um dos melhores exemplos do quanto a Escola pode fazer no cumprimento deste ambicioso desígnio de promover melhores aprendizagens, mais cidadania e mais inclusão. Os conteúdos da Geografia são mobilizados para uma intervenção cívica consciente; os alunos são chamados a perceber que têm o direito e o dever de agir, a tomar consciência de que a sua voz conta. Aprendem melhor porque agem, porque precisam do conhecimento, e participam porque descobrem que a cidadania se constrói a partir da competência que o conhecimento gera.

O exercício da cidadania ativa passa, em primeira instância, pela promoção de um sentimento de pertença. Também quando falamos de inclusão, estamos sempre a falar daqueles que têm de sentir que pertencem a uma comunidade. Nós somos cidadãos do mundo, mas somos os nossos territórios, somos os nossos lugares, somos as relações que se estabelecem localmente, somos as ações que, em pequenos gestos, contribuem para a sustentabilidade do Planeta. E é por isso que a contextualização das aprendizagens é fundamental para que estas ocorram. E é por 
isso que a Geografia, em articulação com as outras áreas do currículo, é um instrumento para uma educação inclusiva. Porque permite sair das paredes da escola e ir aos bairros e perceber melhor.

Parabéns a todas as escolas e comunidades que já dizem "nós propomos" aprendizagens melhores para todos os alunos.

João Costa

Secretário de Estado da Educação 


\section{APRESENTAÇÃO}

\section{A cidadania territorial como projeto}

De 7 a 12 de setembro de 2018, realizou-se no Instituto de Geografia e Ordenamento do Território da Universidade de Lisboa/IGOT-ULisboa o I Congresso Nós Propomos: Geografia, Educação e Cidadania. Como o título do Congresso rapidamente evidencia, - Congresso decorreu e refletiu a investigação desenvolvida no Projeto Nós Propomos! Cidadania e Inovação na Educação Geográfica, surgido no IGOT-ULisboa, em 2011, e entretanto difundido por outros países. Na realidade, o Projeto Nós Propomos!, para além da sua difusão em Portugal, está hoje presente no Brasil (desde 2014, adquirindo hoje uma assinalável expansão), Espanha (2016), Moçambique (2017), Colômbia (2018), Perú (2018) e México (2018). O Congresso impôs-se, de alguma forma, pela necessidade de partilhar experiências, muito ricas e diversas, desenvolvidas nestes países, e de consolidar a rede daqueles que constroem 0 Projeto nas suas universidades, escolas e cidades. Nesse sentido, o Congresso surgiu para acolher e potenciar a produção científica em torno do Projeto e uma rede de trabalho construída ao ritmo de sucessivas e localizadas adesões ao Projeto. $O$ Projeto Nós Propomos! é o projeto educativo com origem em Portugal e que mais rapidamente se internacionalizou. No Rio de Janeiro, no Colégio Pedro II, em 2020, teremos o II Congresso.

Contudo, o Congresso, ele abriu-se à produção em Geografia e em Educação, ultrapassando o âmbito do Projeto Nós Propomos! Mas há um denominador comum que o leitor encontra neste livro, inspirada no Projeto: a preocupação pela cidadania e, em particular, pela cidadania territorial, entendida como o compromisso de cada um de nós na construção de territórios mais justos e sustentáveis, desse logo à escala local. A produção em Geografia, seja de Geografia Física ou de Geografia Humana, para assumirmos os dois grandes ramos tradicionais, ou a produção em Educação, têm sempre como preocupação comum a promoção de atitudes de cidadania, entre os alunos ou a população, mais em geral.

O Projeto Nós Propomos!, ponto de partida do Congresso, desafia os alunos a identificarem problemas da comunidade que sejam relevantes para alunos ou formandos, a realizarem pesquisa documental e trabalho de campo sobre o problema identificado (seja a construção de abrigo para uma paragem de autocarro, a reabilitação de um prédio em ruinas no centro da cidade e que pode ter utilizações 
sociais variadas, a construção de um museu virtual das produções locais ou uma aplicação para o telemóvel, que informe dos eventos locais), a apresentarem propostas de solução e, finalmente, a partilharem as suas propostas com a comunidade, na perspetiva da sua implementação e discussão. Como refere, no Prefácio, o Sr. Secretário de Estado da Educação, os conteúdos da Geografia são mobilizados para uma intervenção cívica consciente. No Projeto, adota-se uma metodologia simples, passível de ser implementada na generalidade das escolas, e flexível, no respeito pelas circunstâncias concretas de cada escola, de cada comunidade, de cada país. Numa disciplina herdeira tanto de um paradigma universalista, através dos racionalistas do final do século XVIII, como de um paradigma nacionalista, no século XIX, a escala local surge desvalorizada na educação geográfica. A grande rutura do Projeto Nós Propomos! reside, precisamente, em colocar a escala local no centro da disciplina de Geografia e de se assumir, de forma inequívoca, o compromisso da escola na construção de uma comunidade mais harmónica e sustentável. Não é mais aceitável que se aborde (e ainda bem) o mundo, o país e se desvalorize a comunidade que habitamos e que constitui o nosso primeiro espaço de cidadania, ainda que em necessário diálogo com as restantes escalas. Como refere o Sr. Secretário de Estado da Educação no seu Prefácio a este livro, "Nós somos cidadãos do mundo, mas somos os nossos territórios, somos os nossos lugares, somos as relações que se estabelecem localmente".

O carater construtivista do Projeto (através da valorização dos interesses dos alunos), o caráter local do território de estudo e de intervenção, a realização do trabalho de campo, com apelo à auscultação das populações sobre as soluções para os problemas identificados, e a partilha das propostas são as traves-mestras da identidade do Projeto, a que se acrescenta a incorporação da própria designação do Projeto (Nós Propomos!), frequentemente adaptada às línguas dos vários países participantes.

O Projeto Nós Propomos! coloca os alunos no centro do processo educativo e este I Congresso Iberoamericano refletiu esta mesma realidade: contou com a participação de cerca de 70 alunos, de Portugal, Espanha (em maior número) e Brasil, num esforço frequentemente hercúleo dos seus docentes, que em muitas comunicações deram testemunho direto das suas experiências. Esta presença e participação de alunos, enquadrados pelos seus pais, constituiu, sem dúvida, uma marca distintiva deste Congresso. Em várias comunicações eles são co-autores, destes que são os seus primeiros textos publicados - e a eles dirigimos uma saudação especial. 
O livro integra três domínios. O primeiro sobre, o Projeto Nós Propomos!, compreende dois eixos, o primeiro sobre "Experiências Escolares", com 17 textos; o segundo Eixo, sobre "Perspetivas e Reflexões Teóricas e Metodológicas", possui 33 capítulos. O domínio seguinte, sobre "Experiências educativas alternativas", compreende textos não diretamente relacionados com o Projeto Nós Propomos!, mas que vão igualmente ao encontro da procura de propostas inovadoras do ponto de vista pedagógicodidático, compreendendo 17 textos. O Domínio C, sore "Educação e Multidisciplinaridade", igualmente com 17 capítulos, compreende experiências relacionadas ou não com o Projeto Nós Propomos!, em que a contribuição de várias áreas disciplinares é marcante.

A publicação em ebook responde a dois objetivos: a escassez de recursos financeiros para uma publicação em papel de 1000 páginas páginas e, naturalmente, ao esforço de ter a maior divulgação possível na comunidade científica.

Para a produção deste livro, muito contribuíram a Comissão Científica do Congresso, presidida pelo Professor Souto González, presidente do Conselho Diretivo do GEOFORUM e professor da Universidade de Valência, e a Comissão Editorial, presidida pelo professor da Universidade de Passo Fundo, Claudionei Lucimar Gengnagel, que desenvolveu um trabalho aturado. Um agradecimento também ao ZOE/Centro de Estudos Geográficos e ao IGOT-ULisboa, editores desta publicação.

O penúltimo agradecimento vai para todos os autores que contribuíram para esta obra. $\mathrm{O}$ derradeiro agradecimento vai para o leitor, que dá significado à mesma. Estão aqui identificadas e analisadas muitas e diversas práticas de cidadania - ao leitor fica agora a disponibilidade de uma leitura atenta, sempre crítica e, seguramente, proveitosa.

\section{Sérgio Claudino}

Presidente da Comissão Organizadora do I Congresso Iberoamericano Nós Propomos: Geografia, Educação e Cidadania 


\section{ÍNDICE}

\section{DOMÍNIO A: Projeto Nós Propomos! \\ Eixo 1: Experiências escolares}

"Nós propomos!" Cidade de Goiás - GO / Brasil: construção do pensamento geográfico dos alunos para a atuação cidadã.

ALEXSANDER BATISTA E SILVA. UELINTON BARBOSA RODRIGUES.

$(\mathrm{Re})$ significando o espaço urbano: os estudantes do Ensino Médio como produtores de conhecimento

CLAUDIONEI LUCIMAR GENGNAGEL. CHILAVERT TOPOLSKI.

Ensinar e aprender Geografia por meio do Projeto Nós Propomos: a experiência do Distrito Federal

CRISTINA MARIA COSTA LEITE

Nós propomos novos usos do território potiguar: experiência no Ensino Médio Técnico Integrado

EDSEISY SILVA BARBALHO TAVARES. CAMILA TAUMATURGO. AMANDA DIAS

As Tecnologias da Informação e Comunicação e a educação geográfica para a formação da cidadania espacial nas escolas públicas de Fortaleza / Brasil

EMANUELLA VIEIRA

A importância do Projeto Nós Propomos para uma cidadania participativa. .86

FILOMENA CLEMENTE

Nós Propomos! Estudo de caso na educação geográfica

GRACIELI DAIANE GNOATTO HRCHOROVITCH. GELIANE TOFFOLO

Educação Ambiental, mídias digitais e uso racional da água: Esquadrão Aquaeri nas escolas da rede pública municipal de São Paulo do Potengi/RN

JENIFFER CAMPOS DE AZEVEDO VARELA. EDSEISY SILVA BARBALHO TAVARES

O Início da Educação Cidadã nas Cidades de Palmas e Araguaína/TO, através do projeto Nós Propomos!

JORDANA COELHO GONSALVES. MARIELA CRISTINA AYRES DE OLIVEIRA

Nós propomos em Taguatinga-DF: dando novos significados às geografias locais .. 140

LEONARDO FERREIRA FARIAS DA CUNHA

Geografia escolar e cidadania: contribuições de discentes do Colégio Técnico de Teresina/PI

MARCOS ANTONIO DE CASTRO MARQUES TEIXEIRA. RAIMUNDO LENILDE DE ARAÚJO

Manifestações Culturais da comunidade do Porto do Capim, João Pessoa, Paraíba, Brasil .....

MARIA EDUARDA DOS SANTOS. ANNA THERESA ROSENHAIM. JOAZADAQUE DE SOUZA

Processo de revitalização e histórico de lutas da comunidade do Porto do Capim, João

Pessoa, Paraíba, Brasil 183

RAQUEL SOARES PEREIRA. JOAZADAQUE DE SOUZA. REGINA CELLY DA SILVA 
Nós Propomos! Taguatinga-DF: pesquisa e experiência com alunos do $2^{\circ}$ ano do

Ensino Médio

RODRIGO CAPELLE SUESS

Extensão e participação social: Nós Propomos

JOÃO APARECIDO BAZZOLI. MARIA DA VITORIA COSTA E SILVA. TATIANA SOUSA

Projeto Nós Propomos! Ações para a redução da violência contra a mulher no Ced 310 de Santa Maria/DF

VÂNIA LÚCIA COSTA ALVES SOUZA. CRISTINA MARIA COSTA LEITE

La mirada interesada a mi barrio VICENT PERIS DE SALES

\section{DOMÍNIO A: Projeto Nós Propomos! \\ Eixo 2: Perspetivas e reflexões teóricas e metodológicas}

O Nós Propomos no Paranoá-DF: um olhar geográfico sobre a cidade. 263 DENISE MOTA PEREIRA DA SILVA

Construindo pensadores espaciais críticos: a importância do Projeto Nós Propomos! e do Concurso de Fotografia em Portugal.

DIOGO GASPAR SILVA. RICARDO A. C. GARCIA

Nós Propomos! Metodologia do Estudo de Caso no ensino da Geografia na UNIOESTE/Pato Branco/PR/Brasil

ELIANE MARIA ROZIN. ANA CLAUDIA BIZ

Geografia Escolar e o Projeto Nós Propomos: Construção/consolidação da cidadania e da justiça espacial

HUGO DE CARVALHO SOBRINHO

Nós Propomos - O verdadeiro papel da extensão universitária 326

HUGO FABIANO DOMINIQUINI. JOAO A. BAZZOLI. MARIELA AYRES DE OLIVEIRA

O Projeto Nós Propomos! A construção de uma cidadania territorial. A experiência da Sertã

ILDA BICACRO. SÉRGIO CLAUDINO

Nós propomos!: uma análise sob a ótica da gestão social.

JOÃO APARECIDO BAZZOLI. AIRTON CARDOSO CANÇADO

Trilhas Palmarinas: contribuição para educação geográfica de União dos Palmares, Alagoas, Brasil.

JOSÉ LIDEMBERG DE SOUSA LOPES. MARIA EDINEY FERREIRA DA SILVA

Nós Propomos Paraíba! e o patrimônio histórico, artístico e cultural do centro do município de João Pessoa, Paraíba, Brasil.

JOAZADAQUE LUCENA DE SOUZA. REGINA CELLY DA SILVA. RAQUEL PEREIRA

Nosotros Proponemos: un proyecto globalizador para la enseñanza 395 JUAN MARTIN MARTÍN. MARIA LUISA VÁZQUEZ SÁNCHEZ

Potencialidades del dron (drone) en el Proyecto Nosotros Proponemos. 414 JUAN MARTÍN MARTÍN. MARÍA LUISA VÁZQUEZ SÁNCHEZ 
Nós Propomos! Ensino e pesquisa de Geografia desde o estudo de caso 431

MAFALDA NESI FRANCISCHETT. SÉRGIO CLAUDINO. ROSANA BIRAL LEME

Evolución y Análisis de la Participación en el Proyecto Educativo ¡Nosotros

Proponemos! en Ciudad Real.

MIGUEL GONZÁLEZ-MOHINO. MARÍA RODRÍGUEZ-DOMENECH. ANA CALLEJAS-ALBIÑANA

A problematização da qualidade do abastecimento de água da área rural de Francisco

Beltrão - Paraná, Brasil - por meio do ensino de Geografia 461

ROSANA CRISTINA BIRAL LEME

Aprendizagem na Educação Geográfica à luz da neurociência - as experiências "A escola faz o vídeo", "Com-vida" e "Nós Propomos!". 473

ROSEMY DA SILVA NASCIMENTO. RODRIGO SARTORIO. SÉRGIO CLAUDINO

Práticas educativas e a formação cidadã no Brasil 490

THAIS ANGELA DE AZEVEDO. ANDREA LASTÓRIA. SILVIA DE SOUSA FERNANDES

\section{DOMÍNIO B: Experiências educativas alternativas}

O mapa no ensino de geografia: um olhar para as transformações no espaço .506 ANA CLAUDIA BIZ

Ações educativas e fortalecimento da cidadania na escola Sesquicentenário, João

Pessoa, Paraíba, Brasil 515

ANNA THERESA ROSENHAIM. MARIA EDUARDA DOS SANTOS. REGINA DA SILVA

Aprender Geografia simulando uma intervenção espacial na cidade .530 ARMSTRONG MIRANDA EVANGELISTA

A Geografia no Ensino Médio na América Latina: o caso do Brasil e da Argentina...540 CLÉZIO DOS SANTOS

Geoprocessamento como instrumento na educação geográfica usando a metodologia ativa do Projeto Nós Propomos! ....

EDUARDO S. HEUSSER. ROSEMY S. NASCIMENTO

A charge como recurso didático: relato de experiência do CETI Governador Freitas Neto, município de Teresina, Piauí, Brasil .... 566

EMANUEL ALBUQUERQUE. MAICON BATISTA. MARCONDES SOUSA. SIMONE DA SILVA

El paseo geoliterario: una experiencia propedéutica para una ciudadanía competencial .579

JOSÉ RAMÓN PEDRAZA SERRANO. RICARDO MANUEL LUQUE REVUELTO

Conhecendo os problemas de saúde urbana nas aulas de Geografia: proposta de sequência didática no Município de Olinda, Brasil .598

JOSÉ ROBERTO HENRIQUE SOUZA SOARES. ANSELMO VASCONCELOS BEZERRA

Uso educativo de la bicicleta y formación ciudadana 616 LILIANA ANGÉLICA RODRÍGUEZ PIZZINATO

Mouse nas mãos, ideias para construir uma geografia cidadã. 630 LUIZ MARTINS JUNIOR. ROSA E. M. W. MARTINS

O estudo dos espaços públicos: propostas para o ensino de Geografia e cidadania 642 MUGIANY OLIVEIRA BRITO PORTELA. JOSIVANE JOSÉ DE ALENCAR 
Educação Geográfica e População - analogias entre a Geografia que se pratica e a que se almeja

NAJLA MEHANNA MORMUL

Diálogos com a experiência de estágio supervisionado I e II no ensino de Geografia 668

NAJLA MEHANNA MORMUL. GILVANA FATIMA CARVALHO

La enseñanza del río Guadalquivir: experiencias didácticas en Educación Infantil y Primaria 683

RICARDO MANUEL LUQUE REVUELTO. JOSÉ RAMÓN PEDRAZA SERRANO

A Educação Geográfica e o desenvolvimento de competências de pesquisa no Ensino Secundário: uma experiência didática 704 RICARDO COSCURÃO

Aprendizagem Geográfica baseado em problemas. O pensamento (geo)computacional no ensino secundário 720

ROBERTO DE OLIVEIRA MACHADO

Os conteúdos escolares de Geografia no estágio supervisionado em Pedagogia ....736 VANICE SCHOSSLER SBARDELOTTO

\section{DOMÍNIO C: Educação e Multidisciplinaridade}

O uso de dispositivos móveis na Educação Básica brasileira: um Mapeamento na Pesquisa Educacional. NASCIMENTO

ADILSON BASQUEROTE. EDUARDO HEUSSER. MORGANA SCHELLER. ROSEMY

O processo de gestão escolar nos Centros Municipais de Educação Infantil em Francisco Beltrão - Paraná - Brasil.

ANDREIA ZUCHELLI CUCCHI. MAFALDA NESI FRANCISCHETT

A Geografia na espacialização dos Centros Municipais de Educação Infantil em Francisco Beltrão - Paraná - Brasil.

ANDREIA ZUCHELLI CUCCHI. MAFALDA NESI FRANCISCHETT

Elaboração e publicação de um jornal escolar: uma proposta colaborativa na Educação Básica

EDUARDO S. HEUSSER. ADILSON BASQUEROTE SILVA. ROSEMY S. NASCIMENTO

¿Es posible educar para la participación ciudadana dentro de la estructura escolar?

FRANCISCO F. GARCÍA PÉREZ

A pesquisa participante na formação continuada de professores

GELIANE TOFFOLO. ROBERTO GRECO

Programa Institucional de Bolsa de Iniciação à Docência (PIBID): instrumentos de construção da relação universidade e escola

LIANA RAQUEL LIMA VIEIRA. RAIMUNDO LENILDE DE ARAÚJO

¿Qué contenidos se enseñan y aprenden en la Universidad? Influencia de la formación del profesorado en el fomento de la ciudadanía.

NOELIA PÉREZ-RODRÍGUEZ. NICOLÁS DE-ALBA-FERNÁNDEZ. ELISA NAVARRO-MEDINA 
Posse da terra e organização na Região do Baixo Amazonas

PAULO FERREIRA

El patrimonio minero como propuesta de innovación educativa para la educación ciudadana y sus valores

TERESA PULIDO NEVADO. FRANCISCO JAVIER JARAÍZ CABANILLAS

A Educação Ambiental nos Projetos Políticos Pedagógicos de Escolas Municipais . 890 VANICE SCHOSSLER SBARDELOTTO

As tecnologias digitais de informação na formação continuada dos professores do ensino superior

VERA LUCIA FORTES ZENI. ELTON ZENI

Mapeamento Geoparticipativo 3P: informação, formação e empoderamento 918 DANIELA CAMPOLINA. LUSSANDRA GIANASI.

Cidadania territorial em pesquisa: Nós Propomos em Chapecó/SC 938 ADRIANA MARIA ANDREIS

"Nós Propomos..." Um Projeto à frente do seu tempo" 952 ANABELLA VAZ

A representação do lugar: um repensar sobre a realidade vivida 968 GABRIELA GERON. ROSEMY DA SILVA NASCIMENTO

O Processo de Revitalização do Centro Histórico de João Pessoa, Paraiba, Brasil.. 981 REGINA DA SILVA. ANNA ROSENHAIM. MARIA EDUARDA VIANA DOS SANTOS

Xàbia, ¿es posible vivir en un pueblo más sostenible? Proyecto "Nós Propomos!"..996 ISABEL HENAREJOS CRESPO. ESTHER CARDONA SANZ 


\title{
DOMÍNIO A \\ Projeto Nós Propomos!
}

\author{
Eixo 1
}

Experiências escolares 


\title{
“Nós propomos!" Cidade de Goiás - GO / Brasil: construção do pensamento geográfico dos alunos para a atuação cidadã
}

\author{
Alexsander Batista e SILVA ${ }^{1}$ \\ UELINTON BARBOSA RODRIGUES ${ }^{2}$
}

\section{Resumo}

Trata-se de uma pesquisa coletiva que envolvem as Universidades Estadual e Federal Goiás em parceria com a Universidade de Lisboa, que já desenvolve no Instituto de Geografia e Ordenamento do Território o "Projeto Nós Propomos! Cidadania e Inovação na Educação Geográfica". O projeto destina-se a alunos do ensino básico para contribuir com sua formação desafiando-os a fazer interseções entre cotidiano e conteúdos geográficos, a partir da identificação de problemas locais, discussão e propostas de alternativas de soluções com práticas espaciais cidadãs. No caso específico desta parte da pesquisa maior que ora apresentamos, será desenvolvido no Colégio Estadual de Aplicação Manuel Caiado localizado na cidade de Goiás-GO / Brasil, tendo como temática "A água e o meio-ambiente no município de Goiás". A partir do acompanhamento de todo o percurso do "Nós Propomos!" na escola, o objetivo é analisar o processo de formação do conhecimento geográfico dos alunos em práticas espaciais cidadãs.

Palavras-chave: Projeto; escola básica; meio ambiente; práticas espaciais; cidadania.

\section{Resumen}

Se trata de una investigación colectiva que implica las Universidades Estadual y Federal de Goiás en colaboración con la Universidad de Lisboa, que ya se desarrolla en el Instituto de Geografía y Ordenación del Territorio, el "Proyecto ¡Nosotros proponemos! Ciudadanía e Innovación en la Educación Geográfica". El proyecto se

\footnotetext{
${ }_{1}^{1}$ Professor da Universidade Estadual de Goiás/Brasil, lexgeo10@gmail.com

${ }^{2}$ Professor da Universidade Estadual de Goiás/Brasil, uelintonbarbosa@hotmail.com
} 
destina a alumnos de enseñanza básica para contribuir con su formación desafiándolos a hacer intersecciones entre cotidiano y contenidos geográficos, a partir de la identificación de problemas locales, discusión y propuestas de alternativas de soluciones con prácticas espaciales ciudadanas. En el caso específico de esta parte de investigación mayor que ahora presentamos, será desarrollado en el Colegio Estadual de Aplicación Manuel Caiado ubicado en la ciudad de Goiás-GO / Brasil, teniendo como temática "El agua y el medio ambiente en el municipio de Goiás". A partir del seguimiento de todo el recorrido del "¡Nosotros proponemos!" en la escuela, el objetivo es analizar el proceso de formación del conocimiento geográfico de los alumnos en prácticas espaciales ciudadanas.

Palabras clave: Proyecto; escuela básica; medio ambiente; prácticas espaciales; ciudadanía.

\section{Introdução}

Este artigo tem o intento de apresentar as principais ideias presentes no projeto "Nós Propomos! Cidade de Goiás", o qual está vinculado ao projeto maior intitulado "Nós Propomos! Goiás", este desenvolvido na escala do estado de Goiás/Brasil. O projeto na cidade de Goiás está em fase embrionária o que não nos permite aqui ir muito além dos elementos que constam em nosso plano de ação/pesquisa.

Nesse primeiro momento é importante ressaltar que o projeto acima citado possui duas dimensões, uma alinhada à extensão e outra à pesquisa. A primeira, toma por base a metodologia empregada no projeto concebido e inicialmente desenvolvido junto às escolas portuguesas, o "Nós Propomos! Cidadania e Inovação na Educação Geográfica", coordenado desde o Instituto de Geografia e Ordenamento do Território da Universidade de Lisboa pelo Professor Sérgio Claudino. A segunda dimensão relaciona-se investigação, cujo objetivo é de analisar como se dá a construção do pensamento geográfico dos estudantes que participam do "Nós Propomos!", projeto que visa fomentar o protagonismo juvenil rumo a uma atuação cidadã.

\section{Elementos basilares do projeto}

Esta proposta tem por base trabalhos da Rede de Ensino e Pesquisa sobre Educação e Cidade, vinculada ao Laboratório de Estudos e Pesquisas em Educação Geográfica (LEPEG) da Universidade Federal de Goiás e cadastrada junto à FAPEG, que 
apresenta como ações principais a pesquisa sobre ensino e elaboração de materiais didáticos da Região Metropolitana de Goiânia em parceria com os professores da Educação Básica. Ainda, constituem-se como referências, a pesquisa "A formação do professor de Geografia para atuar na educação cidadã" que resultou em uma intervenção didática "Movimentos populacionais e prática cidadã em Caturaí"; e o projeto produtividade (CNPq, 2016-2019) "A mediação didática para o estudo de cidade e a formação de professores em Geografia" visando compreender a formação de professores para atuação cidadã.

Trata-se de uma pesquisa coletiva desenvolvida no âmbito ao Laboratório de Estudos e Pesquisas em Educação Geográfica (LEPEG) do Instituto de Estudos SócioAmbientais -IESA por meio de seus professores/pesquisadores oriundos dos câmpus de Goiânia e Aparecida de Goiânia da Universidade Federal de Goiás (UFG) e dos câmpus Cora Coralina e Porangatu da Universidade Estadual de Goiás (UEG).

Em um primeiro momento os membros pesquisadores e colaboradores envolvidos na pesquisa elaboraram coletivamente a problemática, os objetivos, bem como as orientações teórico-metodológicas da pesquisa. Num segundo momento cada professor/pesquisador do LEPEG individualmente ou em grupo é responsável por coordenar a partir de sua instituição e câmpus universitário irá acompanhar e subsidiar a instituição escolar e o professor de Geografia do ensino básico a desenvolver o projeto "Nós Propomos!" em seu município. A partir do acompanhamento de todo o percurso do "Nós Propomos!" teremos elementos para a análise aceca do processo de formação do conhecimento geográfico dos alunos em práticas espaciais cidadãs.

Nesse contexto, para desenvolver este projeto realizou-se parceria com a Universidade de Lisboa, que já desenvolve no Instituto de Geografia e Ordenamento do Território - IGOT, daquela Universidade, o "Projeto Nós Propomos! Cidadania e Inovação na Educação Geográfica", que em outros países e no Brasil já tem atuação em diferentes níveis e modalidades de ensino. No estado de Goiás, esta proposta, sob a responsabilidade de pesquisadores docentes da UFG e UEG, destina-se a alunos da educação básica para contribuir com sua formação desafiando-os a fazer interseções entre cotidiano e conteúdos geográficos, a partir da identificação de problemas locais, discussão e propostas de alternativas de soluções com práticas espaciais cidadãs.

Assim, em território goiano o projeto destina-se a alunos do ensino básico para contribuir com sua formação desafiando-os a fazer interseções entre cotidiano e conteúdos geográficos, a partir da identificação de problemas locais, discussão e 
propostas de alternativas de soluções com práticas espaciais cidadãs. No caso específico desta parte de pesquisa maior, que será coordenada e realizada a partir do Laboratório de Formação e Pesquisa em Ensino de Geografia - GeoEscolar do Curso de Geografia do Câmpus Cora Coralina/UEG, as atividades serão desenvolvidas em uma escola pública na cidade de Goiás, a saber o Colégio Estadual de Aplicação Professor Manuel Caiado.

Dito em outras palavras, o projeto ora apresentado compõe um projeto maior. Projeto esse que será desenvolvido no âmbito do estado de Goiás, tendo como recorte espacial para obtenção de dados diretos quatro diferentes municípios do estado de Goiás. A parcela dessa pesquisa maior que possui como recorte espacial a cidade de Goiás ficara sob nossa coordenação. A qual terá os mesmos encaminhamentos teórico e metodológicos da pesquisa maior, assim como será realizada pari passu com esta.

\section{Pressupostos}

Essas pesquisas geográficas apontam para um ensino de Geografia que resulte em aprendizagens significativas para a vida dos alunos, estabelecendo relações entre vida cotidiana e práticas cidadãs, o que está delineado em Cavalcanti (2008; 2013; 2014).

Nesse sentido, surgem as questões norteadoras desse projeto: é possível mobilizar a construção do pensamento geográfico dos alunos para atuarem na prática cidadã? Como os jovens que estão na educação básica constroem um pensamento teóricoconceitual sobre a cidade e a vida urbana capazes de fundamentar sua atuação cidadã? É possível, por meio dos conteúdos geográficos, promover o exercício da cidadania dos alunos no lugar em que vivem? Em que medida os alunos expressam que exercem práticas espaciais cidadãs na sua cidade?

É importante compreender a concepção de cidade e cidadania pelo ponto de vista geográfico. É na cidade que se produz o modo de vida dominante na sociedade contemporânea. Dessa forma, o tema cidade, no ensino de Geografia, contribui para a compreensão do espaço urbano, para a prática cidadã e para possibilitar o trabalho com os conceitos geográficos de paisagem, lugar e território, muito presentes nos orientadores curriculares para o ensino de Geografia. Ademais, conforme Lefebvre (1991); Santos (1996) e Harvey (2004) há na cidade o predomínio da expressão social, por essa razão estudar a cidade é também estudar a sociedade. 
Em relação à cidadania, além da dimensão política, há outras perspectivas, tendo em vista as intensas reivindicações de inclusão social, de respeito à diversidade e de direitos mais amplos para melhores condições de vida e de sobrevivência. Trata-se de uma concepção que "exercita o direito a ter direitos, aquela que cria direitos, no cotidiano, na prática da vida coletiva e pública" (Cavalcanti, 2001, p. 20). Define-se, desse modo, como noção ampla e multidimensional (Benevides, 2004); destacandose, para os fins desse projeto, sua dimensão territorial, formulada nos termos de direito ao usufruto, à condição de habitar e viver na cidade (Lefebvre, 1991).

Assim, se pensa em uma cidadania que promova a consciência crítica dos alunos sobre a sua realidade social, sobre seu direito a condições mais dignas de sobrevivência, direito às suas manifestações culturais, sobre o direito de acesso ao conhecimento da geografia escolar e aos espaços da cidade.

Pensa-se em cidadania que promova consciência crítica sobre o direito a condições dignas de sobrevivência, a manifestações culturais, e ao acesso ao conhecimento.

\section{Objetivos da pesquisa}

Nosso objetivo geral é analisar o processo de formação do conhecimento geográfico dos alunos em práticas espaciais cidadãs a partir de projetos de intervenção ("Nós Propomos!" Cidade de Goiás) desenvolvidos na escola.

A partir do escopo maior acima citado, delimitamos como objetivos específicos: Constituir grupos de trabalho com pesquisadores e o professores de Geografia e outros profissionais da educação básica para desenvolver as ações da pesquisa; Caracterizar as interseções entre cotidiano, conteúdos geográficos e práticas cidadãs como dimensões do processo de formação do pensamento geográfico; Realizar as atividades previstas para o projeto "Nós Propomos!" cidade de Goiás, em uma escola pública do município, em parceria colaborativa entre universidade e escola; Identificar conceitos geográficos mobilizados e internalizados pelos alunos na realização de práticas cidadãs; Analisar as potencialidades da difusão da ciência geográfica para as práticas cidadãs, por meio da escola básica. 


\section{Metodologia a ser empregada}

Adota-se a metodologia qualitativa, com enfoque na pesquisa colaborativa, pelo fato de nessa perspectiva o objeto de análise ser problematizado e investigado em colaboração (Thiollent, 2005). Para sua realização, estão previstas quatro etapas:

- Formação do grupo de trabalho de pesquisadores - o objetivo é planejar e realizar a pesquisa, por meio de reuniões periódicas nas instituições dos pesquisadores participantes.

- Elaboração de diretrizes do projeto - produção de documento com orientações metodológicas para o desenvolvimento do projeto na escola. Parte-se da adoção das teorias críticas da Geografia e da Educação, especialmente, a teoria Histórico-cultural; adota-se como temática central "a cidade e as práticas espaciais cidadãs", problematizada a partir de eixos temáticos: espaço público, moradia, mobilidade, sítio urbano e as questões ambientais. A proposta metodológica é trabalhar com projetos baseados na resolução de problemas. Far-se-á a revisão bibliográfica para a produção do documento a ser disponibilizado para a escola participante.

- Realização das atividades do projeto com a colaboração da escola - estabelecer ações de cooperação com uma escola pública estadual localizada na cidade de Goiás, com a qual os pesquisadores já têm parceria em função de outras atividades de ensino e/ou de pesquisa. As atividades serão desenvolvidas por meio de grupo de trabalho com o professor e outros profissionais da escola envolvidos, trabalho dos alunos e acompanhamento periódico na escola. O grupo de trabalho com professor da escola, envolvendo os pesquisadores e professores, terá como finalidade estabelecer o diálogo e fazer a abertura e o encerramento do "Nós Propomos!" em suas duas edições, em Goiânia. Esses trabalhos serão realizados com o auxílio de um roteiro a ser elaborado com o objetivo de apresentar as informações do projeto e também de conhecer e utilizar as concepções dos professores sobre o projeto antes e após sua realização. O trabalho dos alunos, com a orientação docente consistirá em: identificar problemas locais articulados aos eixos citados anteriormente; realizar trabalho de campo; sistematizar explicações e apresentar propostas de solução para o problema no formato de memorial descritivo e apresentação em seminário; e encaminhar resultados para autoridades pertinentes. O acompanhamento periódico nas escolas será feito pelos pesquisadores locais, que darão o suporte necessário durante a realização do projeto, para tanto será utilizado uma ficha de registro. 
- Avaliação e Sistematização das contribuições do Projeto "Nós Propomos!" - A avaliação será de modo contínuo por meio dos grupos de trabalhos e acompanhamento periódico e terá como culminância o seminário de encerramento em Goiânia. Esse seminário será o momento em que os alunos apresentarão os projetos com os respectivos resultados e proposições, contará com a participação de todos os envolvidos na pesquisa, incluindo pesquisadores consultores. Na sistematização objetiva-se compreender a formação de conhecimento geográfico e a atuação cidadã. Serão considerados os posicionamentos teóricos; as contribuições dos professores e dos alunos das escolas participantes; e comparações possíveis com resultados de Portugal. Assim, todos os instrumentos da pesquisa serão considerados na análise. Os resultados serão publicados em eventos e revistas, e registrados no relatório final.

\section{Colaboradores e parceiros}

Como já salientado anteriormente a pesquisa "Nós Propomos!" Cidade de Goiás, por se inserir numa pesquisa mais ampla "Nós Propomos!" Goiás, tem em sua gênese uma rede de colaborações e parecerias.

A proposta de pesquisa será desenvolvida no âmbito do Laboratório de Estudos e Pesquisas em Educação Geográfica (LEPEG) e programa de pesquisa e pósgraduação em Geografia do Instituto de Estudos Socio-Ambientais da Universidade Federal de Goiás (IESA/UFG), com articulação com alguns pesquisadores oriundos de investigação correlata, interinstitucional já concluída, realizada em diferentes estados no Brasil (São Paulo, Rio Grande do Sul) e em outros países (Chile, Portugal e Espanha), que convergiram no propósito de experimentar estratégias de formação para a cidadania.

Assim, dar-se-á a continuidade à parceria já estabelecida com o Instituto de Geografia e Ordenamento do Território (IGOT) da Universidade de Lisboa, via o Prof. Dr. Sérgio Claudino e com o curso de Geografia da Universidade Regional do Noroeste do Estado do Rio Grande do Sul, via Profa. Dra. Helena Copetti Callai.

No estado de Goiás, será iniciada uma parceria com o novo campus da Universidade Federal de Goiás, por meio dos cursos de Geologia e de Engenharia de transportes, via os professores Dr. José de Araújo Nogueira Neto e Dr. Alex Mota dos Santos, parceria importante tendo em vista o conhecimento acumulado desses investigadores a respeito da temática de transporte e sítio urbano, o que contribuirá para ampliar as leituras sobre a cidade em uma perspectiva cidadã. 
Ainda no estado de Goiás, será firmada a parceria com a Universidade Estadual de Goiás, via cursos de Geografia dos câmpus Cora Coralina e câmpus Porangatu, por meio dos professores Dr. Alexsander Batista e Silva e Dra. Claudia do Carmo Rosa. Trata-se de professores, que cursaram o mestrado e o doutorado no IESA/UFG e que estão criando seus próprios grupos de estudo e pesquisa em suas instituições de trabalho. Assim, a realização deste projeto de pesquisa cumpre dentre outras demandas a tarefa de apoiar o fortalecimento da pesquisa em ensino de Geografia no interior do estado de Goiás.

A parceria com os professores de Geografia da educação básica via redes municipal e estadual de ensino também já existe por meio da realização de outros trabalhos sendo possível agora dar continuidade e consolidar os vínculos universidade/escola e fazer um trabalho mais consistente e articulado em rede. No caso específico do projeto na cidade de Goiás a escola parceira com já mencionado é o Colégio Estadual de Aplicação Professor Manuel Caiado e o professor de Geografia responsável pelo desenvolvimento do "Nós Propomos!" é o professor Jean Molinari.

Ressalta-se ainda que para a realização desta proposta de pesquisa o apoio dessas instituições, especialmente do estado de Goiás, é essencial na disponibilização de meios de transporte para a realização dos Seminários de culminância do projeto em Goiânia e na disponibilização de infraestrutura predial, técnica e pessoal.

\section{O estágio atual de desenvolvimento do projeto}

Nossa ação inicial, no fim do primeiro semestre do corrente ano, foi apresentar as diretrizes gerais do projeto "Nós Propomos!" ao professor de Geografia e à equipe gestora do Colégio Estadual de Aplicação Professor Manuel Caiado. Na oportunidade o professor Jean Molinari responsável pela disciplina de Geografia nas turmas do turno matutino, demonstrou interesse em desenvolver as atividades do projeto, com a anuência da gestão da escola.

Numa segunda reunião de trabalho com o professor regente (Figura 1), ficou definido que a turma do $3^{\circ}$ ano A do ensino médio (Figura 2) iria desenvolver as atividades do projeto.

Figura 1 -Reunião no Colégio Aplicação com o professor de Geografia Jean Molinari (centro) e a equipe da UEG, professor Alexsander (à esquerda) e professor Uelinton (à direita). 


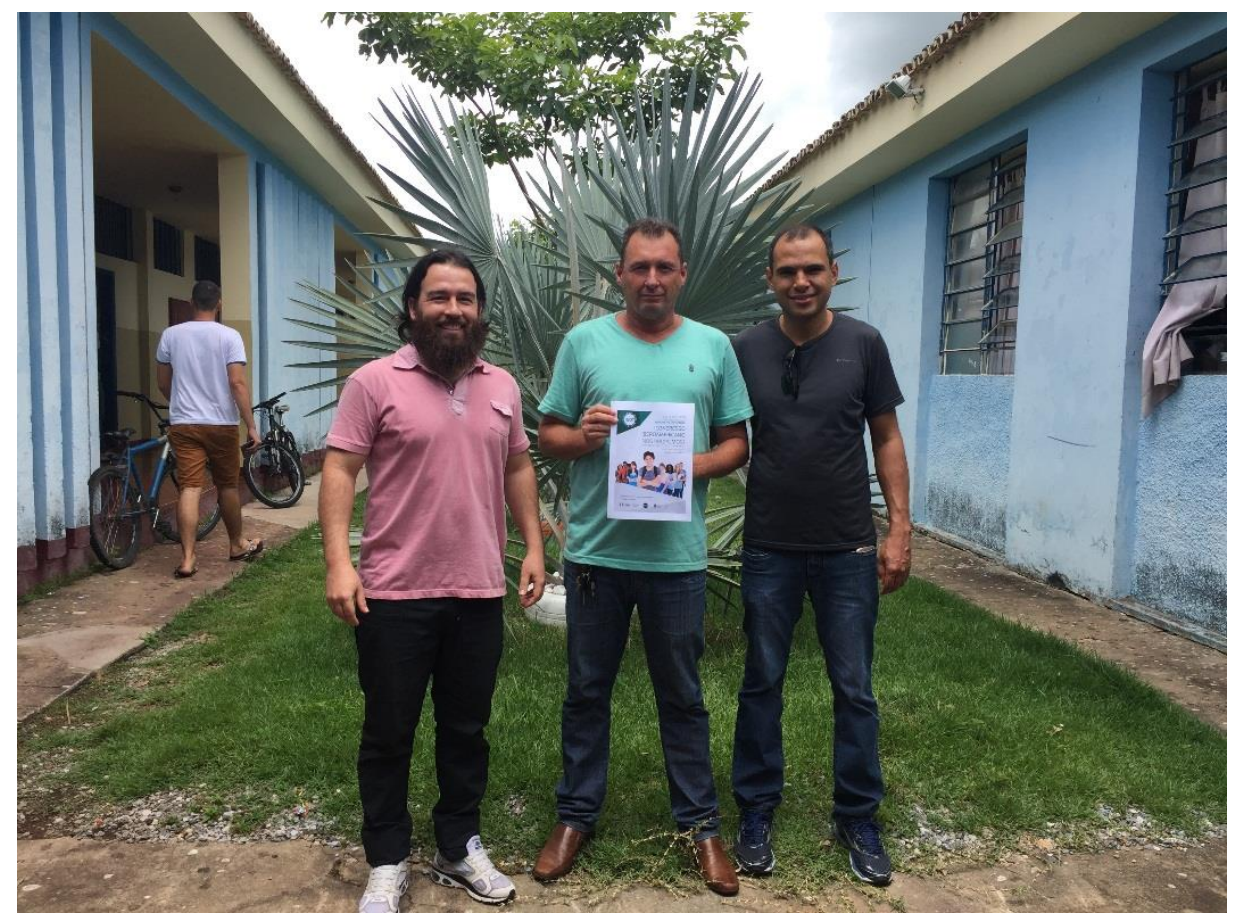

Fonte: Projeto "Nós Propomos!" Cidadade de Goiás 2018.

Figura 2- Turma do 3a ano A em aula acerca da questão ambiental no município de Goiás-GO/Brasil.

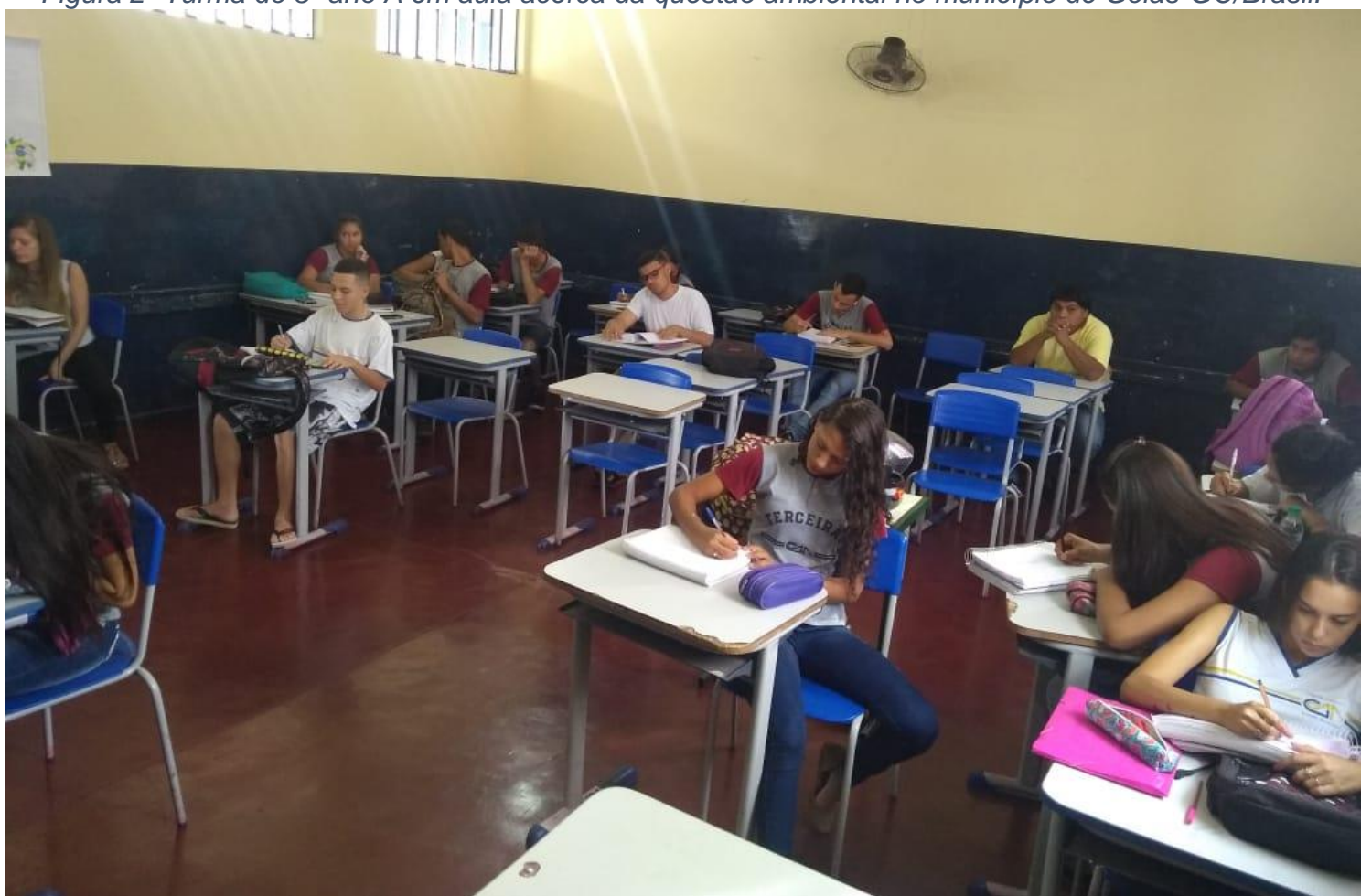

Fonte: Projeto “Nós Propomos!" Cidadade de Goiás 2018.

O professor regente da escola estabeleceu como tema geral para o projeto a questão ambiental. A turma do $3^{\circ}$ ano A possui estagiárias do curso de Geografia (estudantes do $4^{\circ}$ ano de licenciatura da UEG), as quais foram incluídas pelo professor regente 
nas atividade do "Nós Propomos!". Juntamente com a dupla de estagiárias, o professor elaborou e ministrou cinco aulas com a proposta do projeto, sendo uma explicando as diretrizes do "Nós Propomos!", outras três destacando e problematizando as questões ambientais em diferentes escalas e mais uma de preparação para o trabalho de campo. O qual ainda não ocorreu em decorrência do calendário escolar.

O trabalho de campo terá como for pensado a partir do que propõe Claudino (2018), como um conjunto de atividades de aprendizagem que possibilita os alunos apropriarem-se de novas informações, desenvolvem a capacidade de observação direta, tratamento e análise de dados, o que contribui para o pensar geográfico. $O$ roteiro privilegiará no centro histórico e imediação. Terão como pontos de parada 0 Córrego do Prata, a Praça do Chafariz, a Praça do Coreto e o Rio Vermelho. Ao longo do trajeto a ideia é incitar a observação por parte dos estudantes, com foco principal nas questões ambientais da cidade. No trabalho de campo será possível abordar diversas facetas dos dilemas ambientais presentes no espaço vivido pelos estudantes.

Posteriormente a turma do $3^{\circ}$ ano A será dividida em grupos para operacionalizar as pesquisas sobre os temas específicos, dentro que quadro das questões ambientais. Cada grupo irá pesquisar sobre uma temática, momento em que realização entrevistas com a comunidade, sistematizarão os dados, e elaborarão as propostas para solucionar ou mitigar os problemas locais. Finalizarão com as apresentações ao grupo maior (turma do $3^{\circ}$ ano) na escola e posteriormente no I Seminário "Nós Propomos!" Goiás.

O projeto terá um momento de culminância que será um evento. O primeiro seminário do "Nós Propomos!" Goiás será realizado nas dependências do Instituto de Estudos Sócio Ambientais IESA/UFG em Goiânia, no dia 04 de dezembro. Aos moldes do que ocorre com o projeto em Portugal, iremos viabilizar a ida dos estudantes e professores das escolas participantes à universidade para apresentarem suas propostas. Além disso, a comissão organizadora do seminário está preparando uma recepção aos escolares e atividades como, uma visita dirigida aos laboratórios do IESA e ao câmpus universitário.

O grupo do "Nós Propomos!" Cidade de Goiás comparecerá ao evento com os alunos do 3ํano A e o professor de Geografia do Colégio Aplicação, além de professores e alunos do Curso de Geografia da UEG - Câmpus Cora Coralina envolvidos com as atividades do projeto. $O$ intuito é de que o grupo possa participar qualitativamente do 
evento de culminância do projeto, trocando experiências as mais diversas no campo da educação geográfica e cidadania.

\section{Conclusão}

Imaginamos que com a realização do projeto de pesquisa, ora apresentado, podemos contribuir com os sujeitos envolvidos e as instituições participantes, assim como para Geografia enquanto ciência e disciplina escolar.

Uma primeira contribuição que vislumbramos será para a instituição escolar, pois as atividades do projeto já estão trazendo uma dinâmica diferente à escola. Também no âmbito da escola, o professor de Geografia a partir das de reuniões e atividades relacionadas ao projeto que terá condições de acumular elementos para reflexão no que concerne sua formação docente no trabalho. Na ponta do projeto estão os estudantes da escola, em especial aqueles diretamente envolvidos nas atividades do "Nós Propomos!", nesta edição o $3^{\circ}$ ano A, que a partir da realização do projeto "Nó Propomos!" Cidade de Goiás, serão incitados a debater e compreender criticamente seu espaço de vivência, tendo como mote a identificação de problemas locais e a proposição de soluções. O que representa um exercício concreto de cidadania.

Para o câmpus Cora Coralina, assim como para a Universidade Estadual de Goiás como um todo o projeto possibilitará uma aproximação com a educação básica, além da produção de conhecimento no campo da Geografia, mais especificamente da educação geográfica. Os professores/pesquisadores e estudantes universitários envolvidos com a pesquisa terão condições de refletir sobre diversos temas, como formação docente, ensino de Geografia, cidadania entre outros ao longo do desenvolvimento da pesquisa. Esses sujeitos terão sua formação ampliada com pesquisa.

\section{Referências bibliográficas}

Benevides, M. V. M. (2004). Cidadania e Direitos Humanos. In: J. S. Carvalho (Org.) Educação, Cidadania e Direitos Humanos. Petrópolis - RJ: Vozes.

Cavalcanti, Lana de S. A metrópole em foco no ensino de Geografia: o que/para que/para quem ensinar? PAULA, Flávia M. de A. e outros (orgs.). Ensino de Geografia e Metrópole. Goiânia-GO. Gráfica e Editora América, 2014. 
Cavalcanti, L. S. (2013). Ensino de Geografia na escola. Campinas - SP: Papirus.

Cavalcanti, L. S. (2008). A Geografia escolar e a cidade. Campinas - SP: Papirus.

Cavalcanti, L. S. (2001). Geografia da Cidade. Goiânia: Alternativa.

Claudino, S. (2018). Educação Geográfica, trabalho de campo e cidadania: o Projeto Nós Propomos. In F. H. Veiga, (Org.) O ensino na escola de hoje: teoria, investigação e aplicação. Lisboa: Climepsi Editores.

Harvey, D. (2004). Espaços de Esperança. São Paulo: Edições Loyola.

Lefebvre, H. (1991). O direito à cidade. São Paulo: Morais.

Santos, M. (1997). Metamorfose do Espaço Habitado. São Paulo: HUCITEC.

Thiollent, M. (2005). Metodologia da pesquisa-ação. São Paulo: Cortez. 


\section{(Re)significando o espaço urbano: os estudantes do Ensino Médio como produtores de conhecimento}

Claudione LuCimar GenGNAGEL ${ }^{1}$

CHILAVERT TOPOLSKI ${ }^{2}$

\section{Resumo}

A formação de um cidadão crítico e atuante, pressupõe, dentre outros conhecimentos, a compreensão do espaço urbano. Com o desenvolvimento do Projeto Nós Propomos em uma escola da rede privada do município de Passo Fundo/RS/Brasil, os educandos da $2^{a}$ série do Ensino Médio tiveram em 2017 momentos de construção, reflexão, análise e crítica do espaço urbano onde habitam. Assim, efetivou-se pesquisas em diferentes segmentos urbanos do município, sendo que os próprios educandos foram responsáveis por todo o trabalho. Com o protagonismo do discente, foi oportunizada a construção de novos saberes e a reconstrução da ideia de urbano. Tendo em vista a realização de tal atividade, cuja importância está relacionada ao saber geográfico e a formação cidadã, o presente trabalho tem o objetivo de observar, a partir das percepções dos alunos, a (re)significação do espaço urbano a partir das interlocuções existentes entre o projeto desenvolvido, a ciência e o ensino de geografia.

Palavras-chave: espaço urbano; cidadania; geografia; ensino; percepção.

\section{Abstract}

The formation of a critical and active citizen presupposes, among other knowledge, the understanding of the urban space. With the development of the project Nós Propomos

\footnotetext{
${ }^{1}$ Professor do curso de Geografia da Universidade de Passo Fundo (UPF), Passo Fundo, RS/Brasil, claudionei@upf.br

2 Acadêmico do curso de Geografia da Universidade de Passo Fundo (UPF), Passo Fundo /RS/Brasil, 159253@upf.br
} 
in a private school in the city of Passo Fundo, RS, Brazil, students in the second year of high school in 2017 had moments of reflection, analysis and constructive criticism of the urban space where they live. Thus, research was carried out in different urban segments of the municipality, and the students themselves were responsible for all the work. With students' protagonism, the construction of new knowledge and the reconstruction of the idea of urban were made possible. Regarding the making of this activity, which importance is related to geographic knowledge and citizen education, the present work has the objective of observing, from the students' perceptions, the (re)signification of the urban space from the existing interlocutions between the developed project, the science and the teaching of geography.

Keywords: urban space; citizenship; geography; teaching; perception.

\section{Introdução}

O espaço, conforme Santos, (2014a, p. 78) "[...] é o resultado da ação dos homens sobre o próprio espaço [...]". 'Partindo-se deste pressuposto, infere-se que o espaço urbano constitui-se a partir de uma complexidade de funções as quais a atividade humana desempenha sobre o mesmo. Este espaço antropizado apresenta contrastes, características e uma organização que reflete a própria ordem social vigente. Portanto, pensar o espaço urbano é pensar a sociedade em sua dimensão espacial.

A formação de um cidadão capaz de compreender criticamente seu local de vivência e o modo como se organiza este lugar, demanda um conjunto de saberes a serem construídos, dentre estes, o conhecimento do espaço urbano é fundamental. Mesmo que este não seja o local onde vivem todos os indivíduos, na conjuntura social atual, o urbano se articula direta ou indiretamente com a vida da maior parte da população. Assim, este trabalho se constrói na perspectiva da imprescindibilidade de conhecer 0 espaço urbano de modo analítico e problematizador, de analisar o mesmo como elemento fundamental para a formação de pessoas, em especial, como função do ensino de geografia.

Neste sentido, existem práticas educacionais que vêm contribuindo para 0 entendimento da cidade e do urbano. Apresenta-se, aqui, o projeto Nós Propomos desenvolvido no Centro de Ensino Médio Integrado UPF, escola da rede privada do Município de Passo Fundo/RS/Brasil. Tal experiência, desenvolvida em 2017 com estudantes da $2^{\mathrm{a}}$ série do Ensino Médio, propôs que os educandos fossem os criadores e executores de pesquisas relativas à vida urbana no município 
supramencionado. Assim sendo, os mesmos foram protagonistas de momentos de conhecimento e reflexão sobre o urbano de Passo Fundo.

O objetivo da presente produção é observar, a partir das percepções dos estudantes que fizeram parte do projeto, a (re)construção da visão de espaço urbano, a partir de pesquisas realizadas ao longo de 2017 com o desenvolvimento do projeto Nós Propomos. De maneira específica busca-se verificar o potencial do trabalho produzido no que se refere a efetiva formação do cidadão e a construção da aprendizagem através da reflexão sobre o urbano; identificar possíveis mudanças nas percepções dos estudantes acerca de determinados componentes do espaço urbano e; compreender as interlocuções existentes entre o projeto desenvolvido, a Ciência Geográfica e o ensino de Geografia, analisando suas potencialidades e limitações.

Para tanto, metodologicamente, foi construído uma pesquisa bibliográfica para a compreensão da ideia de espaço urbano e realizou-se uma pesquisa de campo junto aos estudantes que participaram do projeto, a partir de questionários. Em vista disso, foi possível conhecer como teoricamente é concebida a ideia de urbano e como o projeto desenvolvido contribuiu para a atribuição de novos significados ao espaço urbano de estudo. $O$ trabalho organiza-se em quatro partes, a primeira diz respeito à fundamentação teórico-conceitual acerca do espaço urbano, a segunda compreende uma discussão sobre a interface entre o ensino de geografia e o estudo do urbano, a terceira concerne a análise das percepções obtidas através dos questionários e a quarta e última parte são as considerações finais.

\section{Espaço urbano: conceitos, ideias e reflexões}

O espaço urbano é dotado de uma grande complexidade. A ação do ser humano sobre uma determinada base territorial, cuja finalidade é atender as demandas da sociedade, envolve questões geográficas nem um pouco simples. Por isso, tendo em vista os objetivos do presente texto, torna-se importante discutir e refletir sobre a ideia de urbano. Neste primeiro momento propõe-se algumas considerações para a compreensão deste espaço. Desse modo, constrói-se uma matriz teórica a qual alicerça o seguimento do texto e as análises propostas.

Diante do exposto, considera-se que o espaço urbano da cidade capitalista é constituído por variados usufrutos do solo, os quais são contíguos entre si. Esses usos, definem locais fragmentados segundo suas diversas funcionalidades, porém os mesmos estão conectados. Isso acontece em virtude das relações espaciais dentre as 
múltiplas áreas. Este espaço é ainda, uma imagem que representa a sociedade no qual está inserido, refletindo suas estruturas. Contudo, também influencia o social, pois as ações humanas no urbano vão ter reflexos para com a sociedade. Ainda, o espaço urbano caracteriza-se pelas simbologias daqueles que o habitam (Corrêa, 2003).

A partir desta apreensão nota-se a dimensão da ação humana a qual modela o seu meio, seja fisicamente ou socialmente. Dessa maneira é importante, principalmente pela ótica da Geografia, entender que o urbano está associado de alguma forma com a terra que é base para suas atividades. Beaujeu-Garnier (1997) ao se referir ao ambiente urbano, expressa uma relação dialética entre a base física e a atividade antrópica. Segundo a autora "[...] o espaço produzido resultante do meio físico e da acção humana que participou no nascimento e desenvolvimento urbano e oferece agora, à cidade contemporânea, um quadro susceptível de ser modificado [...]" (1997, p. 33).

O espaço urbano é fundamentalmente vinculado a sociedade da qual ele faz parte. Portanto, a urbanização do século XXI está intimamente relacionada ao sistema político-econômico vigente e também de forma mais ou menos intensa com a globalização. Dessa forma o urbano é marcado pelo processo de mundialização capitalista. Basta andar pelos centros urbanos, os quais estão repletos de publicidade, ou observar as diferentes marcas de automóveis, alimentos e roupas que a população consome, concebendo, desta forma, o lugar próprio para o consumo. Como afirma Rolnik (2004, p. 29) "Sem dúvida, é possível dizer que hoje o mercado domina a cidade".

O consumo aparece como elemento intrínseco da urbanização ligada às relações de mercado. Tal consumo, a nível de Brasil, vem sendo expandido, tanto no que se refere à bens duráveis, à serviços, quanto à ideias e à informação, isto vem proporcionando a amplificação da urbanização (Santos, 2014b). Portanto, o espaço urbanizado tem o consumo como uma de suas frentes, a qual possibilita sua expansão e ao mesmo tempo molda as relações sociais estabelecidas. Por isso, pensar o urbano vinculado ao consumo, criticamente, torna-se fundamental.

Este urbano, no qual sublevam-se as relações de mercado, configura um espaço de disparidade. Assim "[...] a desigualdade constitui-se em característica do espaço urbano capitalista" (Corrêa, 2003, p. 8). Por conseguinte, os espaços são ocupados pelos indivíduos de maneiras diferentes. Isso se expressa em virtude da diferença de 
classes. O espaço urbano capitalista é também elemento passível de mercar. Neste sentido:

\begin{abstract}
Mundializado, o espaço fragmenta-se através de formas de apropriação para o trabalho, para o lazer, para o morar, para o consumo, etc. Deste modo, o espaço fragmenta-se em espaços separados, parcelas fixas, como conseqüência de uma atividade parcelada fundada no trabalho abstrato. $O$ espaço aparece como mercadoria, apesar de suas especificidades, produzido e vendido enquanto solo urbano, cujo conteúdo escapa aos indivíduos, posto que submissos à troca e à especulação - uma troca que se autonomiza em relação ao uso num processo de produção assentado na propriedade privada da terra que gera a apropriação diferenciada do espaço por estratos diferenciados da sociedade. (Carlos, 2007, p. 36).
\end{abstract}

Acerca das desigualdades do espaço urbano brasileiro cabe destacar as disparidades intraurbanas e a segregação espacial. Ribeiro (2015, p. 171) fala sobre o processo de reprodução de "[...] uma sociedade que naturaliza as explorações, expropriações, as hierarquizações, a pobreza, a espoliação, e que claramente está expressa na paisagem atual das cidades". Esta paisagem urbana atual compõe um cenário junto às demais contradições do sistema capitalista. Ressalta-se, por conseguinte estas duas questões que estão relacionados a tal paisagem urbana. A primeira, as dessemelhanças intraurbanas, referem-se à inequidade dentro de áreas que compõem um mesmo espaço urbano. A segunda, segregação espacial, remete à espacialização no urbano de uma estrutura de classes (Corrêa, 2003).

Estes apontamentos sobre o espaço urbano são apenas alguns, dentre toda a complexidade epistemológica e metodológica de abordar a espacialidade. Assim, propostas as reflexões iniciais, aproximamos na próxima parte do escrito sobre o tema problematizado, relacionando-o com o ensino de Geografia. Buscando, teoricamente estabelecer nexos a partir dos quais se materializará a análises das percepções dos alunos em relação à suas ações no projeto já mencionado.

\title{
3 O ensino de geografia e o espaço urbano: algumas aproximações
}

Os temas relativos ao espaço urbano são cada vez mais relevantes ao ensino de geografia. Afirma-se isso, com base no relatório publicado pelas Nações Unidas, intitulado World Urbanization Prospects, o qual revela que a percentagem da população urbana mundial deverá chegar a 66\% em 2050 (World urbanization prospects, 2014). Portanto, significa que haverão mais pessoas vivendo em áreas urbanizadas e o ensino de geografia não pode relegar tal temática à um segundo plano. Torna-se cada vez mais iminente que o espaço urbano seja conhecido de forma 
crítica e que seus problemas e diferentes realidades sejam pensadas, discutidas e refletidas pelos alunos. Nesta segunda parte do texto desenvolve-se uma discussão cujo propósito é explicitar a interface ensino de geografia e o urbano.

Um primeiro ponto, o qual destacamos, é a necessidade de que o aluno possa pensar o urbano de modo crítico. Não é suficiente compreender a cidade do século XXI a partir de uma concepção positivista de ensino para se concretizar uma formação cidadã. Este tema dinâmico, cheio de antagonismos e contradições requer um olhar crítico e necessita ser problematizado em sala de aula. Conforme Damiani (2000, p. 54) "É preciso ir além do positivismo, enxergar o que aparece como incoerência, o que não se adequa aos modelos, enquanto contradição do espaço [...]". O educando precisa ser capaz de conhecer o urbano e questionar suas estruturas, sua organização e o papel dele enquanto membro de uma sociedade. A geografia tem um papel basilar, para que o aluno possa transgredir as barreiras que a conjuntura social deu a ele. Para isso se efetivar, "Só um pensamento dialético permite esse salto e essa mudança de qualidade do pensar" (Damiani, 2000, p. 54).

No que se refere ao urbano como elemento cognoscível é necessário que o aluno consiga relacionar o espaço urbano vivido e o espaço urbano versado. Segundo Cavalcanti (2013, p. 91) “A cidade estudada nas aulas de geografia não é a mesma vivida empiricamente pelos alunos. Ela é uma abstração, uma construção teórica, uma leitura sobre a realidade". Nesse sentido, o propósito do ensino de geografia deve estar em construir esforços para realizar tal abstração, mas também em estabelecer ligações entre a realidade empírica do educando com o espaço que é estudado pela ciência geográfica.

Para a formação da cidadania, o ensino da ciência geográfica traz aportes no que se refere ao seu potencial de conhecimento e entendimento do mundo em que o discente vive (Cavalcanti, 2002). A ponderação acerca dos elementos do cotidiano da cidade e também do próprio conhecimento empírico do educando, quando problematizado, construindo um saber com bases científicas, constituem-se como subsídios importantes ao empoderamento do educando, que poderá compreender a realidade (Callai \& Moraes, 2017). Nesse sentido, cabe ressaltar a significância real do papel do docente em colaborar efetivamente para o saber crítico sobre o urbano.

Reiterar o direito à cidade é uma prática que defronta-se à organização da sociedade atual (Cavalcanti, 2002). Ensinar sobre o urbano, deve considerar a reafirmação desse direito bem como a compreensão do mesmo. De acordo com Cavalcanti (2002, p. 66) "[...] o exercício pleno da cidadania significa, entre outras coisas, o direito ao 
ambiente. Trata-se do direito de construir e usufruir de ambientes sadios, saudáveis, ecologicamente corretos, em todos os lugares, incluindo as cidades e o ambiente urbano". Como é sabido nem todas as pessoas podem usufruir dos benefícios da vida urbana. O espaço, como já colocamos, é muitas vezes desigual e segregado. Contudo, o ensino com enfoque no espaço, deve valorizar este direito ambiental, de modo que o educando seja capaz de conhecê-lo e de advogar em defesa do mesmo de maneira democrática e consciente.

\section{Contextualização do projeto Nós Propomos e análise das percepções}

O projeto Nós Propomos ${ }^{3}$ foi implantado no Centro de Ensino Médio Integrado UPF em 2017. O objetivo principal do projeto é inserir os estudantes do ensino médio na comunidade escolar onde os mesmos estão inseridos, a fim de transformar uma dada realidade e formar um conhecimento calcado na solução de problemas, dificuldades e anseios regionais.

No ano exposto, os estudantes da então $2^{\underline{a}}$ série foram desafiados a escolher uma área do município de Passo Fundo e, a partir da mesma, pensar em possíveis problemas que a sociedade local enfrenta. A turma foi dividida em quatro grupos e os temas escolhidos para pesquisa foram: no Bairro José Alexandre Zachia - problema do lixo, animais abandonados, alimentação saudável; no Parque da Gare - problema com a iluminação pública.

Após a divisão, os estudantes criaram os objetivos da pesquisa, formularam hipóteses e foram dialogar com coordenadores de cursos de graduação da Universidade de Passo Fundo. A aproximação da educação básica com o ensino superior objetivou estreitar os laços entre estes dois níveis de ensino e fazer com que os estudantes tirassem possíveis dúvidas referente aos seus projetos.

$\mathrm{Na}$ sequência, cada grupo criou o seu questionário e todos realizaram a coleta de informações em campo. No retorno, os estudantes organizaram um seminário para apresentação dos dados coletados e as possíveis soluções para os impasses visualizados.

\footnotetext{
${ }^{3}$ O projeto foi criado no Instituto de Geografia e Ordenamento do Território da Universidade de Lisboa no ano letivo de 2011/12. Posteriormente, alargou-se a escolas de praticamente todo o território português, também às Regiões Autónomas dos Açores e da Madeira. O fato de se dirigir diretamente à resolução de problemas comunitários, com enfoque a cidadania territorial local, ajuda a explicar a sua expansão internacional (Brasil, Colômbia, Espanha, México, Moçambique e Peru). No território brasileiro, várias universidades adotaram e ressignificaram o projeto de acordo com seus contextos.
} 
Somente após concluir todas as etapas do projeto Nós Propomos é que o presente trabalho se efetivou. Para verificar uma possível (re)significação da ideia de urbano pelos estudantes do ensino médio que fizeram parte do projeto, foi elaborado um questionário. Este requeria informações sobre o município em que o estudante reside, a idade do mesmo, e continha mais seis questões, sendo três fechadas e três abertas. No dia 10 de agosto de 2018, foi realizada a pesquisa com os discentes. Neste momento do texto, serão analisadas as respostas obtidas pelos questionários, procurando observar, especialmente, como a percepção dos alunos sobre o espaço urbano, o qual conceituamos e discutimos na primeira seção, pode ter sido reconstruída após as atividades do projeto supracitado.

Os 32 estudantes que responderam o questionário estudam na $3^{\text {a }}$ série do ensino médio e fizeram parte do Nós Propomos em 2017. A faixa etária dos mesmos varia entre 16 e 18 anos (5 alunos com 16 anos; 23 com 17 anos; 4 com 18 anos de idade). O estudantes residem em quatro municípios diferentes, sendo: Passo Fundo/RS (residência de 28 alunos), Marau/RS (residência de 2 alunos), Erechim/RS (residência de 1 aluno) e Tapejara/RS (residência de 1 aluno). Dessa forma, observa-se que a maior parte dos estudantes vive no mesmo município onde foi desenvolvido o projeto.

No que concerne a realização das tarefas desempenhadas questionou-se qual foi considerada mais importante, sendo elas: 1) criação do projeto em sala de aula durante as aulas de geografia; 2) criação das perguntas que compuseram a pesquisa; 3) aplicação dos questionários; 4) apresentação dos resultados obtidos. A partir destas possibilidades, os alunos enumeraram em ordem de importância as atividades, sendo que 1 representava a mais relevante e a 4 como menos relevante.

Os resultados mostraram que a aplicação dos questionários foi julgada por 20 alunos como a tarefa mais significativa, enquanto a que menos agradou foi a criação das perguntas (13 alunos). Observa-se, assim, que mesmo todas as atividades sendo relevantes e necessárias para o andamento das atividades, os estudantes gostam da prática fora da sala de aula. Nesse sentido, o trabalho de campo torna-se imprescindível e relevante para o projeto.

Quando questionados se foi possível conhecer, pelo menos, uma área do urbano do município de Passo Fundo, a maior parte dos discentes afirmou que sim. Em números, 22 alunos assinalaram que foi possível conhecer uma parte do espaço urbano passofundense a partir do desenvolvimento do projeto, 10 alunos declararam que parcialmente foi possível conhecer o espaço urbano e nenhum aluno respondeu que 
não foi possível. Sobre tais dados cabe ressaltar, preliminarmente, a pertinência do projeto para que os educandos possam, minimamente, conhecer o urbano e, portanto, se apropriar das suas informações expressas nas paisagens antropizadas, construindo aprendizagens sobre o espaço em questão.

$\mathrm{Na}$ pergunta seguinte os estudantes foram indagados se após as suas intervenções com a realização da coleta de informações, houve mudança na ideia que eles haviam construído sobre o espaço urbano. Dos 32 estudantes, 18 disseram ter mudado sua ideia de forma parcial, 12 alegaram que houve uma mudança de ideia sobre o espaço em questão em termos totais e, 2 alunos expuseram que não houve mudança alguma. Para compreender melhor esta indagação, o quarto questionamento buscou verificar como o aluno enxergava o local onde realizou a coleta de informações antes e como enxerga depois de ter feito parte das ações. Para expor tais visões elaborou-se 0 Figura 1, o qual demonstra paralelamente como os alunos viam e como vêem hoje o local de realização de suas tarefas no Nós Propomos. Nesta Figura foram sintetizadas as respostas dos educandos e expostas em forma de itens.

Observando a Figura 1 nota-se uma mudança na percepção sobre o local onde se realizou o projeto. Tanto no Bairro José Alexandre Zachia, quanto no Parque da Gare, a maior parte dos alunos reconstruiu sua visão sobre um espaço intraurbano. Tal mudança se deu para alguns de forma parcial e para outros de forma absoluta, como verifica-se em respostas como: "local humilde, porém não da forma como se pensava", "conheci a realidade como ela é" e "realidade melhor do que imaginava".

Como indicado anteriormente, o espaço urbano da cidade capitalista manifesta disparidades e como aponta Sobarzo (2010) Passo Fundo possui acentuadas desigualdades socioespaciais. Os espaços intraurbanos, os quais foram campo para o desenvolvimento das atividades do Nós Propomos, são localizados em situações diferentes, cada um com suas especificidades. O Parque da Gare é localizado no setor urbano que compreende a área central da cidade. Já o Bairro José Alexandre Zachia é um bairro periférico, bastante afastado do centro da cidade (Silva, Spinelli \& Fioreze, 2009).

Esses espaços refletem as diferenças sociais do urbano do município e precisam ser conhecidos para além do que o senso comum difunde. Ao observar o Figura 1, é possível observar, que a primeira visão dos estudantes sobre o Bairro José Alexandre Zachia era de um lugar essencialmente pobre, com condições precárias, além de um local marcado por preconceito sobre seus habitantes. Porém, as visões após a 
realização do projeto mostram uma evolução. Este espaço visto antes de maneira estática e com certa hostilidade passou a ser percebido de outra forma. Essas visões secundárias apontam que, no entanto, o bairro possui problemas e dificuldades, porém a busca por mudança existe, os moradores são pessoas diferentes do que os discentes imaginavam e que muitos olhares ditos anteriormente não correspondem à realidade.

Figura 1 - Comparativo entre as visões que os educandos anteriores a realização do projeto e as visões posteriores a tal sobre os dois locais onde foram efetivadas as pesquisas

\begin{tabular}{|c|c|c|}
\hline $\begin{array}{l}\text { Local da } \\
\text { atividade }\end{array}$ & $\begin{array}{l}\text { Visão do antes da realização do } \\
\text { projeto }\end{array}$ & $\begin{array}{l}\text { Visão do local depois da realização do } \\
\text { projeto }\end{array}$ \\
\hline $\begin{array}{l}\text { Bairro } \\
\text { José } \\
\text { Alexandre } \\
\text { Zachia }\end{array}$ & $\begin{array}{l}\text {-Conhecia o local, apenas por boatos; } \\
\text {-Não conhecia o local; } \\
\text {-Local isolado e de difícil acesso; } \\
\text {-Violento; }\end{array}$ & $\begin{array}{l}\text {-Vizinhança agradável e pessoas simpática } \\
\text { - Pessoas que têm consciência do } \\
\text { problemas de sua comunidade; } \\
\text { - Pessoas que buscam melhorar }\end{array}$ \\
\hline
\end{tabular}

-Extremamente pobre;

-Habitado por uma população que não se preocupava com problemas sociais;

-Habitado por pessoas que não estariam abertas ao diálogo;

-Habitado por uma população com carência de alimentos;

-Muitos animais abandonados;

-Habitado por pessoas com pouca instrução;

-Pensou que seria alvo de preconceito ou estranhamento no bairro;

-Bairro sem pavimentação:

-Local bagunçado;

-Lixo espalhado nas ruas;

-Presença de pessoas envolvidas com a criminalidade;

-Ambientes precários e desorganizados;

-Preconceito acerca do local e das pessoas que o habitam;

-Sem estabelecimentos comerciais;

-Habitado por pessoas que não se alimentam de maneira saudável; condições de vida;

-Bairro com dificuldades;

-Pessoas abertas ao diálogo;

- Lugar de fácil acesso;

-Alimentação não é um problema tão expressivo;

-Muitos animais abandonados;

-Passou a ter um melhor conhecimento dos bairros da cidade e das condições de vida dos habitantes;

-Local humilde, porém não da forma como se pensava;

-Moradores receptivos;

-Bairro pavimentado;

-Local, parcialmente organizado;

-Não é sujo da forma que imaginou que seria;

-Riqueza cultural;

-Confirmou em partes a ideia que tinha do bairro;

-Ambiente com seus problemas e com seus - Sem potencial de melhorar suas condições de vida;

-Ambiente com problemas sociais;

-Bairro muito grande;

-Local com poucas casas, pouco comércio e interatividade;

aspectos positivos

-Realidade melhor do que imaginava;

-Relativamente organizado;

-Mudança de conceito;

-Conheci a realidade como ela é;

-Local menos violento do que pensava;

-Bairro em desenvolvimento;

-Existência de comércios e serviços;

-Falta de investimento público no local (para coleta de lixo):

-Não é um local com condições tão precárias como se pensava;

-Este espaço demanda projetos;

-Aumentou a vontade de contribuir para a vida desses moradores;

-Potencial para melhorar suas condições;

-Não mudou pois, o local era familiar;

-Bairro menor do que imaginava;

-Simplicidade, porém com espírito de comunidade e de organização;

-Boas casas;

Parque da -Inexistência de problemas de iluminação - Local com pouca segurança;

$\begin{array}{ll}\text { Gare - } & \text { pública; } \\ \text { Área } & \text {-Local bem preservado }\end{array}$

-Problemas com iluminação pública

-Grande presença de pessoas no local a 


\begin{tabular}{|c|c|c|}
\hline $\begin{array}{l}\text { central da } \\
\text { cidade }\end{array}$ & $\begin{array}{l}\text {-Local seguro; } \\
\text { - Desconhecia o intenso fluxo de } \\
\text { pessoas no local; } \\
\text {-Ambiente bem iluminado e organizado; }\end{array}$ & $\begin{array}{l}\text { noite; } \\
\text {-Ambiente desorganizado; } \\
\text { Ambiente com seus problemas e com seus } \\
\text { aspectos positivos; } \\
\text {-Falta de investimento público no local; }\end{array}$ \\
\hline
\end{tabular}

Fonte: Organização dos autores a partir dos questionários analisados

Sobre o Parque da Gare, foi observado uma alteração de percepção oposta à que houve acerca do Bairro José Alexandre Zachia. Percebido, inicialmente, como um local preservado, seguro e com boas condições, típico da área central do urbano, depois do projeto passou a ser visto como um local que não desfruta de tal perfeição. Os alunos, conhecendo o local e entrevistando pessoas, narraram ter conhecido problemas que afetam este espaço, como a falta de segurança e de iluminação pública, passando, assim, a perceber o local considerando seus contrastes.

Essa mudança constatada, a qual foi possível a partir da prática realizada pelo projeto, pelo contato com a comunidade e pelo conhecimento da realidade espacial, revela a importância da criticidade. Só é possível mudar de percepção e refletir sobre o espaço se houver crítica. Os discentes ao desenvolverem as atividades, em especial a visita aos dois locais já mencionados, puderam ver as contradições do espaço. Notaram que um bairro periférico, segregado e com problemas sociais não se resume somente a isso. Nele existe busca por mudança, organização, coletividade e os preconceitos sobre este espaço foram questionados. Da mesma forma, em um espaço central que tem detém boas condições socioespaciais, também sofre com determinados problemas.

A seguinte questão, procurava saber, especificamente, a opinião de cada estudante sobre a contribuição do projeto para alteração da percepção sobre o urbano de Passo Fundo. Dos educandos, 27 afirmaram que o Nós Propomos contribuiu para alterar a visão sobre o urbano e Passo Fundo, 3 disseram que não contribuiu, 1 declarou que contribuiu em partes e 1 não respondeu. As justificativas, daqueles que consideraram que o projeto auxiliou na mudança de percepção do urbano foram variadas. Dentre elas, foi destacado o conhecimento das diferentes realidades da cidade, 0 conhecimento dos problemas urbanos e como resolvê-los, a construção de novas interpretações da cidade e a experiência junto dos lugares e das pessoas.

Por fim, foi pedido que os estudantes opinassem sobre a continuidade do Projeto Nós Propomos. Quase a totalidade dos estudantes pensa que o projeto deve ter continuidade, 31 alunos disseram que sim e 1 não respondeu. Dentre os argumentos para tal, foi exposto: os potenciais do projeto de conhecimento das realidades locais, 
as propostas do projeto, as perspectivas de mudanças e de melhorias na cidade, a mudança de ideias e desconstrução de preconceitos que surge como consequência das ações do projeto, o conhecimento, a formação humana e o fato de o saída da comodidade que o projeto proporciona aos participantes. Por conseguinte, nota-se que os alunos percebem a relevância do projeto e suas ações. Um aluno escreveu como motivação para a continuidade do projeto: "[...] acredito ser fundamental conhecer as necessidade do local onde reside, bem como propor ideias que possam auxiliar na resolução de problemas existentes", que é justamente o objetivo do projeto.

\section{Conclusão}

A busca por identificar a (re)significação da ideia de espaço urbano, a qual teve como base as percepções de alunos que participaram do Projeto Nós Propomos constituíram o propósito deste trabalho. Antes de propor as análises, foi necessário construir-se, no que tange a teoria, a ideia de urbano e algumas associações entre este e o ensino de Geografia. A partir das discussões, pode-se compreender que o espaço urbano e seus antagonismos devem ser ser tratados pelo ensino de geografia de forma que dê conta de sua complexidade.

Diante disso, pode-se notar que o projeto está contribuindo para o entendimento desta realidade espacial complexa. Apesar das potencialidades, a proposta que é desenvolvida junto a comunidade possui algumas limitações, como o transporte para deslocamento até a mesma e o tempo desprendido para planejamento, criação dos instrumentos, aplicação, tabulação e análise. Porém, como foi comprovado pelas análises e números expostos, a maior parte dos discentes participantes do projeto reconheceu a importância do projeto para a mudança do olhar sobre o urbano e também reiteraram a necessidade de que o mesmo tenha continuidade.

A mudança de percepção do urbano foi verificada a partir das respostas e argumentações dos estudantes. Os alunos, em sua maior parte construíram novos significados ao espaços intraurbanos que foram âmbito de ação do projeto. Os mesmos afirmaram que de uma forma ou outra foi alterada a percepção. Assim, estes espaços dotados de diferentes características, que antes eram vistos de uma forma mais simplista ou mesmo preconceituosa, foram conhecidos de maneira problematizada com o contato direto com o ambiente e seus moradores. Foi com o processo de produção de conhecimentos e de propor soluções à problemática de cada 
lugar que os educandos puderam romper com determinadas visões e, portanto, construir novas.

Como já colocado, a reflexão crítica do espaço construída na prática deu a base para tal (re)construção. Desta forma, o conhecimento puro da realidade aparece como um pilar estruturador do ensino crítico. Como assinalado, com a discussão sobre ensinoespaço urbano, a formação da cidadania é uma finalidade do ensino de geografia. Por isso, a formação cidadã é uma tarefa que pressupõe o entendimento daquilo que compõe o real. O espaço onde existem indivíduos, instituições e diversas funcionalidades deve ser apropriado cognitivamente pelo estudante e refletido. Dessa maneira transcendendo os limites do senso comum, alcançando a compreensão real do espaço geográfico que se poderá aspirar formar, de fato, um cidadão crítico. Ressalta-se, finalmente, que o Nós Propomos, fundamentando-se nas análises construídas, vem auxiliando nesta perspectiva.

Reconstruir, desconstruir, refletir e repensar a visão sobre a realidade urbana é fundamental. O ensino de Geografia necessita propiciar aos alunos a possibilidade real de compreender o espaço. Almeja-se, por fim, que mais ações, projetos e iniciativas possam se multiplicar e que os estudantes tenham a oportunidade de conhecer o espaço urbano de forma complexa e crítica.

\section{Referências bibliográficas}

Beaujeu-Garnier, J. (1997). Geografia Urbana. Lisboa: Fundação Calouste Gulbenkian.

Callai, H. C., Moraes, M. M. (2017). Educação geográfica, cidadania e cidade - ACTA Geográfica, Edição especial, 82-100. doi: http://dx.doi.org/10.5654/acta.v0i0.4771

Carlos, A. F. A. (2007). O lugar no/do mundo. São Paulo: FFLCH.

Cavalcanti, L. S. (2002). Geografia e práticas de ensino. Goiânia: Alternativa.

Cavalcanti, L. S. (2013). A cidade ensinada e a cidade vivida: encontros e reflexões no ensino de geografia. In L. S. Cavalcanti (Org.). Temas da Geografia na escola básica (pp. 65-93). Campinas, SP: Papirus.

Corrêa, R. L. (2003). O espaço urbano. São Paulo: Ática.

Damiani, A. L. (2000). A geografia e a construção da cidadania. In A. F. A. Carlos (Org.). A geografia em sala de aula (pp. 50-61). São Paulo: Editora Contexto. 
Ribeiro, F. V. (2015). Produção contraditória do espaço urbano e resistências. In A. F. A. Carlos (Org.). Crise urbana (pp. 171-186). São Paulo: Editora Contexto.

Rolnik, R. (2004). O que é cidade. São Paulo: Brasiliense.

Santos, M. (2014a). Metamorfoses do espaço habitado. São Paulo: Editora da Universidade de São Paulo.

Santos, M. (2014b). Da totalidade ao lugar. São Paulo: Editora da Universidade de São Paulo.

Silva, A. M. R., Spinelli, J., Fioreze, Z. G. (Orgs.) (2009). Atlas geográfico de Passo Fundo. Passo Fundo: Méritos; IMED.

Sobarzo, O. (2010). Passo Fundo: cidade média com funções comerciais de serviços e de apoio ao agronegócio. In M. E. B. SPOSITO, D., ELIAS, B. R. SOARES (Orgs.). Passo Fundo e Mossoró (pp. 31-101). São Paulo: Expressão Popular.

World urbanization prospects. (2014). New York: United Nations, Dept. of International Economic and Social Affairs. 


\section{Ensinar e aprender Geografia por meio do Projeto Nós Propomos: a experiência do Distrito Federal}

CRISTINA MARIA COSTA LEITE ${ }^{1}$

\section{Resumo}

A Educação na contemporaneidade assume uma responsabilidade ímpar no processo de formação de capacidades críticas, para lidar de maneira propositiva, com a rapidez com que são estabelecidos novos padrões de conduta, normas e regras de convivência social, que se colocam ao dia a dia do indivíduo. Nesse contexto, o presente artigo analisa o Projeto NÓS PROPOMOS com base em alguns fundamentos postos pela Geografia Escolar Brasileira contemporânea, em especial a que se desenrola no território do Distrito Federal. Esse, ao se diferenciar das demais unidades federativas, imputa ao desenvolvimento do Projeto uma lógica particular, de (re)conhecimento de seu próprio território, e (re)significação de sua identidade, as quais apresentam estreitas relações com o sentido de construção e consolidação dos processos de cidadania, viabilizados por meio de novas formas de ensinar e aprender Geografia, decorrentes das atividades implementadas no NÓS PROPOMOS.

Palavras chave: Geografia Escolar; Projeto Nós Propomos; Distrito Federal/Brasil

\section{Abstract}

Education in the contemporary world assumes a unique responsibility in the process of building critical capacities, to deal in a proper manner, with the speed with which new standards of conduct, norms and rules of social coexistence are established, which are placed, in an agile dynamism, to day-to-day of the individual. In this context, the current article analyzes the Proposed NÓS PROPOMOS based on some theories put up by contemporary Brazilian School Geography, in particular that unfolds in the territory of the Federal District. This territory of Federal District is different from the other Brazilian

\footnotetext{
${ }^{1}$ Professora Adjunta da Universidade de Brasília, criscostaleite@gmail.com
} 
states. This difference imputes a particular logic in the development of the project, which is the re-knowledge of its territory and re-signification of its identity, which has direct relations consistent on building and consolidation the process of citizenship, treated through new forms of teaching and learning Geography, resulting from the project NÓS PROPOMOS.

Keywords: School Geography; Project We Proposed; Distrito Federal / Brazil

\section{A Educação na contemporaneidade}

Vivemos um tempo complexo. Numa perspectiva mais global, percebemos um contexto de mundo desigual, com polos hegemônicos espalhados pelo mundo, economia globalizada a uns e segregadora às regiões/países excluídos desse processo. Observamos comportamentos padronizados ao lado de culturas diversas, que rompem ou, pelo menos, clamam por isso, com os processos decorrentes da homogeneização imposta às sociedades urbanizadas; empresas transnacionais que mobilizam e monopolizam territórios e o capital, sempre, cada vez mais, territorializado e de posse de uma parcela mínima da população mundial; concentração de renda e capital nas mãos de poucos, em detrimento da esmagadora maioria da população mundial. Nos tornamos reféns dessas armadilhas construídas por nós mesmos, no avanço inclemente da (des)educação; da perda de referenciais identitários, de memória, de valores, moral e ética, de pequenos princípios cotidianos, familiares e vividos, que nos imputam o título de humanos. Essa imensa contradição, posta à escala global, se manifesta de modo contundente por aqui, no Brasil.

Neste país de imensos contrastes, de proporções continentais e diverso, se estabelece uma trajetória histórica contraditória, num processo de produção espacial marcado pelas disputas entre os interesses do estado e das elites que o sustentaram, após a proclamação da república. Na busca pelo desenvolvimento e crescimento econômico, pautado por modelos econométricos e exógenos, o povo foi esquecido (desconsiderado?) - aquele diverso, perdido nos rincões deste território, distantes dos centros ou, simplesmente alijados às periferias. Assim, num processo paulatino e progressivo, com muitas idas e vindas, redescobrimos a democracia e iniciamos nova trajetória rumo ao enfrentamento e equacionamento das mazelas sociais, decorrentes das ações que produziram a má distribuição da renda, sua concentração a uma ínfima parcela da população e, por consequência, a geração de uma imensa e absurda desigualdade social. 
Adentramos o século XXI com problemas estruturais graves, mas confiantes pela retomada da democracia que, em essência, poderia resultar na construção de um outro padrão de desenvolvimento, mais igualitário, participativo, consultivo e (re)integrador daquelas "minorias majoritárias" às ações com impacto direto e/ou indireto as suas vidas e ao seu território. Tal intenção, então, notadamente a partir de meados dos anos 2000, resignificou algumas funções do Estado brasileiro e, entre essas, merece destaque a Educação.

A Educação na contemporaneidade assume, entre outros, um novo e específico papel: o de resistência ao processo homogeneizador de condutas, estabelecidas e por muitas vezes impostas, por determinantes de ordem global, muito além do território local. Tal função expressa uma nova dimensão, que incorpora a responsabilidade de promover a reflexão sobre o que é ou não adequado a um determinado local. Desse modo, um dos desafios que se impõe à Educação contemporânea, diz respeito à formação de capacidades críticas, para lidar de maneira propositiva, com a rapidez com que são estabelecidos novos padrões de conduta, normas e regras de convivência social que se colocam, numa dinâmica ágil, ao dia a dia do indivíduo. Nesse sentido, a importância da Educação reside do fato de frear e filtrar aquela intenção homogeneizadora, que tende a neutralizar a diversidade, mediante supressão, desvalorização, mesclagem, substituição de identidades ou outras particularidades territorializadas, que não se enquadrem na lógica do mercado globalizado, característica estrutural da sociedade atual (Hall, 2003). Em consequência, a Educação se vê diante da necessidade de contribuir para a formação de um cidadão, que não se distancie da ética, que saiba não somente compreender a realidade, em todas suas complexas relações de causa e efeito mas, principalmente, ter ciência de que dispõe de possibilidades efetivas para assumir um papel ativo na formação de uma sociedade mais justa e igualitária, mediante a preservação da diversidade cultural e sem abrir mão de referências identitárias e territorializadas.

Com as mudanças nos padrões de socialização, então, surgem novas formas de mediação nas diferentes práticas, inclusive aquelas associadas às práticas de ensinar e aprender e, consequentemente, aos modos de se construir conhecimentos. É nesse contexto, portanto, que a Educação assume uma importante expressão: habilitar o indivíduo a efetuar uma leitura original do global, no sentido de promover uma negociação entre conhecimento e as práticas locais, a fim gerar uma reflexão que se traduza em ações concretas e benéficas à sociedade onde se encontra. Educação auxilia o ser humano a aprender a utilizar as ferramentas de produção de significados 
e de construção da realidade, para adaptar-se melhor ao mundo em que se encontra. Nesse sentido, fornece habilidades, formas de pensar, sentir e falar, utilizar, modificar e produzir ferramentas, assim como formas preferenciais de usar uma sequência de estratégias e lógicas que posteriormente podem ser negociadas (Leite, 2012); ela não é neutra, nem está destituída de consequências econômicas e sociais. Por isso, a Educação é sempre política, não está sozinha e não pode ser planejada como se estivesse: existe em uma cultura (Bruner, 2001) que é diversa e desigual e, por conseguinte, plena de contradições e conflitos.

Diante dessas considerações relativas ao papel da Educação nas primeiras décadas do século XXI, torna-se pertinente evidenciar que a Ciência Geográfica e, nesse contexto, a Geografia Escolar, também tem um papel importante a cumprir, como veremos a seguir.

\section{A Geografia na Educação Contemporânea}

A Geografia constitui-se um campo do conhecimento que tem o espaço como seu objeto primordial de análise. Mesmo com fundamentações filosóficas distintas, a exemplo da organização espacial na perspectiva do materialismo histórico dialético ou do espaço vivido na vertente fenomenológica, o espaço e a própria dimensão da espacialidade expressam a contribuição dos geógrafos à análise da sociedade. Como conhecimento, surge na Grécia $^{2}$ antiga, onde é denominada história natural ou filosofia natural, e vai se consolidando ao longo dos séculos, por estar associado às necessidades de sobrevivência de grupos, povos e até mesmo do Estado, conquista de territórios, identificação de rotas comerciais, mercados, produtos, etc. Desse modo, esse saber vinculado ao conhecimento do meio físico e dos fenômenos naturais constituía-se útil e necessário, não somente ao homem, mas também à organização de suas sociedades, por estar relacionada às questões de ordem prática como, por exemplo, as observações astronômicas que referenciavam os processos de orientação (Leite, 2012).

Como ciência surge depois, no século XIX, na Alemanha, influenciada pelo processo de unificação desse Estado, as condições históricas da sistematização do

\footnotetext{
${ }^{2}$ Para Rana (2008, p.49) existem evidências de um saber denominado natureza geográfica na Grécia Antiga, onde duas tradições básicas foram identificadas nos estudos geográficos: a matemática começando com Thales e Hipparchus e sumarizadas por Ptolomeu; tradição literária começando com Homero, incluindo Hecateus e sumarizada por Estrabão. Nesse contexto merecem destaque as obras Geographia de Aristóteles (384 a 322 AC) e Geographike Hyphegesis de Ptomolmeu (Século 2 DC).
} 
conhecimento geográfico fundamentada no positivismo (Andrade, 2008). Desse momento até o atual, passou por reformulações que cunharam vertentes de análise, alteraram seu objeto e até mesmo sua própria fundamentação filosófica, que permaneceu centrada no positivismo até a década de 1970 e, depois disso, ampliou seu espectro de investigação, ao enquadrar-se em outras fundamentações, como as citadas anteriormente e, ainda, o existencialismo e o estruturalismo. Interessante observar, porém, que no curso de sua evolução e mesmo antes de sua sistematização como ciência, esse campo de conhecimento já existia no âmbito das escolas. Tal situação nos permite afirmar que esse saber vem sendo trabalhado desde os primórdios da escola e do próprio processo de escolarização.

Não se pretende, aqui, efetuar uma análise histórica da dimensão escolar do conhecimento geográfico e seu papel frente aos distintos momentos de seu próprio desenvolvimento mas, tão somente, ressaltar sua existência como um componente curricular, que apresenta estreita relação com a ciência geográfica, com o processo de consolidação do Estado, do estabelecimento de referenciais indenitários e, numa perspectiva mais contemporânea, com a valorização do lugar, leitura de mundo e formação da cidadania. Isso posto, pode-se afirmar que, apesar da Geografia acadêmica e da Geografia Escolar analisarem a realidade pela mesma perspectiva - 0 espaço - o modo pelo qual cada uma compõe e organiza seus temas de estudo é diferente. Enquanto uma se realiza na Universidade a outra se dá na escola, não são iguais, mas se complementam e compartilham a mesma estrutura epistêmica.

A Geografia Escolar é o conhecimento geográfico efetivamente ensinado, veiculado e trabalhado em sala de aula, constituída pelas Geografias acadêmica, didatizada e de tradição prática; por serem feitas por professores, expressam as crenças de sua própria vida, o conjunto de concepções decorrentes de sua formação profissional, bem como suas práticas sociais, de poder e a instituída pela própria escola:

a Geografia escolar não se ensina, ela se constrói, se realiza. Ela tem um movimento próprio, relativamente independente, realizado pelos professores e demais sujeitos da prática escolar, que tomam decisões sobre o que é ensinado efetivamente (Cavalcanti, 2008, p. 28)

A Geografia Escolar é, portanto, praticada cotidianamente por todos os entes envolvidos no contexto educativo e educacional e apresenta duas dimensões complementares: a primeira refere-se ao papel que esta área do conhecimento tem em relação ao processo de construção da cidadania. Ao considerar a dimensão do urbano, expressa no concreto da cidade, em geral, e da cidade do aluno, em 
particular, se estabelecem fundamentos à compreensão da dinâmica urbana, cotidianamente vivida por cada aluno, imprescindíveis à significação de conteúdos e, por conseguinte, ao próprio desenvolvimento da noção de cidadania. Isso se viabiliza, então, pela consideração da perspectiva intraurbana na análise espacial, a partir do lugar do aluno. Em consequência, os conceitos de cidade/urbano, lugar, paisagem e território articulam os saberes construídos coletivamente pelos envolvidos no contexto de ensino/aprendizagem.

A segunda dimensão refere-se a uma linguagem imagética, apropriada pela Geografia para expressar não somente sínteses espaciais, como também aspectos essenciais e particulares da espacialidade: a Cartografia. Essa se constitui uma linguagem da geografia, um sistema código de comunicação. Por meio dessa são representados os fenômenos na superfície terrestre, definidas suas localizações, visualizadas suas distribuições, entre outras possibilidades de análise, passíveis de compreensão por meio das sínteses espaciais concretizadas no mapa. Assim, articula fatos, conceitos e sistemas conceituais, que permitem ler e escrever as características do território (Catellar, 2005). Entretanto, constitui-se, também, alternativa metodológica para o ensino/aprendizagem em Geografia, na medida em que permeia todos os conteúdos desse campo disciplinar, possibilitando a identificação /localização de fenômenos e objetos, bem como suas relações intrínsecas e, ainda, a compreensão dos conflitos inerentes ao próprio processo de ocupação do espaço. Porém, a Cartografia também é conteúdo, pois o processo de apreensão do espaço por meio da imagem demanda um conjunto de conhecimentos específicos, os quais possuem convenções particulares, que precisam ser conhecidas para permitir a leitura e interpretação do espaço.

Ambas as dimensões - urbano pela cidade do aluno como ponto de partida para a formação da noção de cidadania e o código de comunicação para leitura do mundo, expresso pela cartografia - articulam-se na construção dos saberes geográficos construídos em sala de aula e expressam um novo modo de considerar a escolarização dessa área do conhecimento. Tal reconhecimento, porém, é recente e, quando revisitado à luz das relações de ensino/aprendizagem, denota a necessidade de reflexão e aprofundamento sobre o processo de sua implementação, no cotidiano das escolas, notadamente nas cidades que compõem o território do DF. 


\section{A Geografia Escolar no Distrito Federal}

Ao considerar-se a dimensão do urbano no Distrito Federal, constata-se que sua expressão cotidiana - suas cidades - apresenta uma situação ímpar e complexa à compreensão, principalmente por ser diferente das demais unidades federativas brasileiras. Nesse sentido, torna-se necessário efetuar algumas considerações, para evidenciar importância dessa temática à escolarização.

Inicialmente, cabe lembrar que a história do DF no Planalto Central brasileiro associase à construção de Brasília, como nova capital da República, que foi construída para abrigar os funcionários públicos e os demais profissionais vinculados direta ou indiretamente ao poder público, que tinham assegurados um espaço de moradia nessa cidade. Àqueles que vieram para construir a cidade, a mão de obra operária e de prestação de serviços não enquadrada no funcionalismo público, ficou à deriva do território Brasília e se constituiu num emblemático problema social, em paralelo com o nascimento e consolidação da nova capital do país. O resultado desse processo concretizou-se na criação das cidades satélites, concebidas como o lugar para o assentamento dessas populações, mão de obra para Brasília, cidades dormitórios. Nessa perspectiva consagrou-se um modelo centro periferia, onde o centro corresponde à Brasília e a periferia, em média cerca de $30 \mathrm{Km}$ distantes desse centro, as demais localidades que surgiram em virtude da construção: Núcleo Bandeirante, Gama, Taguatinga, Sobradinho, Paranoá e Ceilândia. Agregaram-se a esse processo de periferização à Brasília as cidades de Brazlândia, cuja data de criação remonta a 1933, e Planaltina de 1859, cuja existência anterior à criação de Brasília não foi suficiente para superar sua condição periférica (Paviani,1999).

A marca dessa segregação - funcionários públicos em Brasília e o restante da população nas demais cidades-satélites - concretizou-se no território por meio da rede de saneamento básico, cuja espacialização evidenciou um anel sanitário de proteção a Brasília. Em outras palavras, em um território delimitado pelo acesso a infraestrutura de saneamento, como um anel em torno de Brasília, encontrava-se o centro. A partir dele, localizava-se a periferia, desprovida dessa mesma condição (Carpintero, 1998). A espacialização dessa conjuntura, desigual, serve para ilustrar dimensões muito diferenciadas da vida em um território polinucleado e multifacetado, subordinado à lógica de um centro artificialmente construído. Além disso, do ponto de vista das populações que constituem a história desse território, justifica a apreensão da realidade em perspectivas radicalmente opostas, pautadas pelo resgate de velhas 
histórias e pela estruturação das novas, numa dialética contínua, inerente ao próprio processo de produção do espaço.

Assim, a partir da inauguração da capital do país, inicia-se uma periodização linear de histórias, que emergem subordinadas a Brasília e como decorrência desta. $\mathrm{Na}$ realidade, ao longo do processo de consolidação dessa cidade, inclusive como o centro político nacional, evidencia-se uma hegemonia de Brasília nas referências identitárias de uma população que, majoritariamente, não habita esta cidade. De acordo com os dados da Pesquisa Distrital por Amostra de Domicílios/PDAD (SEPLAN/CODEPLAN, 2015), o Distrito Federal tem uma população de 2.906.574 habitantes, dos quais apenas 210.067 correspondem a Brasília (cerca de 10\%). A esse respeito é interessante observar uma confusão acerca do entendimento desse território, resultado das lógicas diversas que o construíram e do discurso hegemônico proveniente do centro Brasília. Nesse sentido, em pesquisa referente à percepção do que é Brasília, na perspectiva de moradores do DF e seu Entorno, Cidade (2004) identifica que o entendimento sobre o que vem a ser Brasília é ambíguo e muda de acordo com a origem do depoente.

Os moradores das localidades limítrofes ao DF (Entorno) consideram Brasília como todo o território do DF. Aqueles que vivem nas demais cidades percebem de modo muito claro uma distinção entre Brasília e as satélites, referindo-se à primeira como Plano Piloto. A exceção a tal clareza ocorre quando se considera Brasília na perspectiva de sua importância nacional (é a capital) ou como identificação de procedência a pessoas de outros Estados. Do mesmo modo, aos habitantes de Brasília cabe uma percepção muito precisa de que as Cidades Satélites não correspondem a Brasília. Importante ressaltar que o termo Cidade Satélite foi extinto na gestão do governo Cristovam Buarque (1995-1998), por meio do Decreto $\mathrm{n}$. 10.040/98, passando a ser designado apenas por cidade.

Diante do exposto, uma Geografia Escolar adequada às particularidades do território do DF demanda um processo de busca, resgate e valorização das histórias de vida das populações das localidades "não Brasília", a fim de reedificar a memória de um território que se constituiu no processo de segregação espacial, imposto pela construção da capital e que vem superando sua condição de periferia, estabelecendo novos arranjos territoriais e desconstruindo a identidade brasiliense, a partir do estabelecimento de outras, ainda desconhecidas, recentes, híbridas e em franco processo de reafirmação e legitimidade. Tal reflexão é decorrente da necessidade de se considerar o lugar do aluno, como elemento de fundamental importância às 
mediações relacionadas ao processo de construção de conceitos, num contexto de aprendizagem pautado pela perspectiva histórico cultural. A opção pelo estudo da cidade do estudante apresenta correspondência com as proposições de Cavalcanti (2008), para quem a cidade é:

um espaço geográfico, um conjunto de objetos e ações, que expressa o lugar de existência das pessoas (...) um lugar onde se produz um modo de vida, é o lugar onde se exerce no cotidiano a cidadania; (...) é um lugar que abriga, produz e reproduz culturas (p. 66, 67,71).

Desse modo, assume-se que a cidade se constitui um lugar de formação, que educa na medida em que a relação do sujeito nesse lugar se expressa por sua interação ativa, por suas ações, seu comportamento e seus valores, os quais se formam e se realizam nessa interação. Enquanto lugar de formação, a cidade apresenta possibilidades, evidenciadas por três perspectivas, que justificam sua consideração. A primeira diz respeito a aprender na cidade e significa considerar a cidade como conteúdo; a segunda refere-se a aprender da cidade e evidencia o papel da cidade enquanto transmissora de informação e cultura; a terceira é relativa ao aprender a cidade. Nessa a escola constitui-se um agente de fundamental importância, no tocante à aprendizagem da leitura de suas cidades pelos seus alunos (Cavalcanti, 2008). Tais argumentos atestam a importância do estudo das cidades do DF, não somente no contexto da escolarização em Geografia, como também da formação de professores que atuarão no âmbito de toda a Educação Básica.

As considerações apresentadas até o momento objetivaram explicitar o contexto no qual está inserido o Projeto Nós Propomos no DF. Nesse sentido, tiveram a intenção de reconhecer que existe, de fato, uma ambiguidade sobre o que vem a ser Brasília, notadamente quando se consideram perspectivas diferenciadas referentes à identificação do território e ao sentido de territorialidade, compreendido como um sentimento de pertencimento a um dado local e/ou compartilhamento de uma identidade comum. Em qualquer que seja o caso, tal situação pode justificar a ausência das histórias dos territórios satélites, a partir da percepção das pessoas que ali viveram; por alguma razão essas histórias ficaram esparsas, dispersas e ainda não se traduziram nem se configuraram como memória coletiva de uma população satélite. Em outras palavras, se não há memória sobre os lugares além de Brasília, como se desenvolve uma identidade sobre um território que não seja esse? Como se consolida a noção de cidadania? Essa situação significa negação das identidades locais? Atesta uma supervalorização de Brasília em detrimento dos demais lugares? Denota um conteúdo ideológico, um viés de dominação, ao subjugar tudo o que não é Brasília? 
Escamoteia um conflito de classes? Camufla a segregação? Essa problematização assume um caráter de extrema importância quando se consideram as relações intrínsecas entre memória, identidade e cidadania. Aplicadas ao caso do DF, cujo território é composto, majoritariamente, por cidades de médio porte, consolidadas como núcleos urbanos, essa situação se impõe à reflexão.

\section{A Geografia Escolar e o Projeto Nós Propomos}

A reflexão referente às identidades das cidades que compõem o universo do Distrito Federal é decorrente da necessidade de se considerar o lugar do estudante, como elemento de fundamental importância às mediações relacionadas ao processo de construção de conceitos, num contexto de aprendizagem pautado pela perspectiva sociocultural. $\mathrm{O}$ atendimento dessa necessidade, porém, evidenciou um problema: a esmagadora maioria das informações existentes sobre os lugares/cidades do DF correspondem aos dados oficiais. Nesse sentido, referem-se, basicamente, aos dados socioeconômicos e raras vezes aos aspectos culturais, reduzidos aos eventos realizados periodicamente nas várias localidades.

Assim, à Geografia Escolar algumas questões constituem-se relevantes à construção de conhecimentos geográficos, de um lado, e à construção/consolidação do sentido de cidadania, de outro: o lugar dos estudantes. Esse é o seu local de moradia; é o território onde vivem e usufruem dos serviços disponibilizados pela infraestrutura urbana. São as ruas percorridas para acesso à escola, casa de parentes, amigos, os lugares de compras e de lazer. Este é o lugar conhecido cotidianamente; é onde a vida se constitui. No caso do Distrito Federal, porém, cujo território é fracionado em regiões administrativas, com cidades em configurações espaciais diversas, e muitas das vezes desconhecidas, construir um entendimento sobre a cidade do aluno assume uma importância vital à construção e consolidação de seu sentido de cidadania. E é justamente nessa perspectiva que o Projeto Nós Propomos adquire uma função particular à construção de uma Geografia Escolar aos estudantes do DF.

O projeto Nós propomos surgiu em 2011, no Instituto de Geografia e Ordenamento do Território/IGOT da Universidade de Lisboa, liderado pelo professor Sérgio Claudino. O Nós propomos tem por objetivo principal dinamizar o estudo de caso e promover a autonomia dos estudantes, mediante identificação de problemas locais, execução de trabalho de campo e apresentação de sugestões de intervenção (Claudino, 2018). Nessa intenção, o projeto define eixos estruturantes, que orientam as ações a serem 
adotadas. São eles: promover uma ativa cidadania territorial junto da comunidade escolar; aproximar o poder local das comunidades por meio da participação dos jovens e das suas escolas; contribuir para o desenvolvimento sustentável das localidades e dos municípios onde se desenvolve; valorizar o Estudo de Caso como trabalho experimental sobre problemas locais; promover abordagens metodológicas inovadoras no âmbito do ensino de Geografia; incentivar a atividade de investigação em Geografia; mobilizar alunos e professores para a utilização de tecnologias de informação, em estudos de âmbito prático e fomentar redes de cooperação entre atores locais, como universidades, escolas, autarquias, associações locais e empresas (Claudino, 2018).

Tais intenções correspondem aos princípios norteadores de uma perspectiva socioconstrutivista no ensino de Geografia nas escolas de Educação Básica, pois possibilitam: a reafirmação do Lugar como importante dimensão espacial; a articulação Local-Global como superposição escalar potencializadora do raciocínio espacial complexo; a formação de conceitos geográficos instrumentalizadores do pensamento espacial; a inclusão da discussão de temas emergentes para a compreensão da espacialidade contemporânea; o desenvolvimento da linguagem cartográfica; a educação Ambiental e a decorrente preocupação com o conceito de ambiente e ambiência; a incorporação de outras formas de linguagem (Cavalcanti, 1998).

Além disso, evidenciam novas formas de ensinar, na medida em que propiciam aos alunos uma possibilidade de ensinar conteúdos que os façam compreender a espacialidade atual e, assim, gerar modos e ações por meio de atividades propostas em sala, bem como trabalhos que desenvolvam certas capacidades e habilidades. Nesse sentido, espera-se a formação de uma atitude indagadora diante da realidade que se observa e se vive cotidianamente, de um lado, bem como a capacidade de análise da realidade de fatos e fenômenos, em um contexto sócio espacial, de outro. Tais expectativas evidenciam a consideração de que os objetos de estudo têm diferentes escalas, e por isso devem ser analisadas suas inserções locais e globais. Denotam, ainda: que existe uma multiplicidade de perspectivas e tipos de conhecimentos; que conhecer é construir subjetivamente a realidade; que existem temas polêmicos e, por isso, há sempre mais de uma perspectiva na construção de explicações sobre uma dada realidade; que a compreensão dos fenômenos, dos processos e da própria geografia são históricos; e, a convicção de que aprender sobre o espaço é relevante, pois constitui-se uma dimensão da realidade (Cavalcanti, 1998; 2002; 2012). 


\section{Projeto Nós Propomos na Geografia Escolar do Distrito Federal}

A implementação no projeto no Brasil impôs algumas alterações de ordem operacional, sem afetar as concepções fundamentais do Nós propomos. Assim, no caso brasileiro, observa-se que a disciplina de Geografia, no âmbito da Educação Básica, engloba milhares de alunos, distribuídos em um território imenso e com expressiva diversidade, o que impõe, a priori, uma contextualização das particularidades de cada um, como guia à orientação das ações. Nesse sentido, a viabilização do projeto passa por possibilitar o trabalho de pesquisa na área de residência dos alunos, ou pelo menos em sua cidade, sensibilizar para problemas territoriais locais, motivar à elaboração e apresentação de propostas de intervenção local e, igualmente, permitir uma aproximação e intensificar o processo de construção de conhecimentos em Geografia.

$\mathrm{Na}$ esfera do Distrito Federal a proposta foi acolhida pelos pesquisadores do Grupo de Pesquisa em Ensino Aprendizagem e Formação de Professores em Geografia/GEAF, sob coordenação da professora Cristina Maria Costa Leite da Universidade de Brasília - UnB, para sua execução nas escolas públicas do Distrito Federal, a partir de 2017, em parceria direta com professores da rede pública de ensino desta unidade federativa, de diferentes escolas públicas e Regiões Administrativas/RA's.

Os professores da Educação Básica que participam do Nós Propomos - DF, são todos pós-graduandos em Geografia na UnB, em nível de mestrado e doutorado, e membros do GEAF. Isso significa que ao passo do processo de implementação prática da proposta, as questões relativas à Geografia Escolar, aos processos de ensinar e aprender nessa área, o cenário educativo e educacional brasileiro, entre outros assuntos vinculados, foram estudados pelo grupo de pesquisa e se constituíram fundamentos teóricos às ações práticas que estavam em curso no âmbito das escolas. Importante ressaltar, nessa situação, a relevância da pesquisa à prática do professor, ao processo de ação-reflexão-acão, fundamentais aos propósitos da formação dos professores, em pleno processo de qualificação para melhoria de sua própria prática docente. 
Nessa perspectiva, os professores tiveram total autonomia para pensar e decidir um caminho à execução do projeto. Assim, todos eles, até mesmo para validar as proposições teóricas do grupo, iniciaram seus projetos a partir da explicação da proposta geral aos seus alunos. Em consequência, todos os projetos foram adaptados à realidade brasileira, aos tempos do calendário escolar, da rotina da escola, do currículo, elaborados coletivamente pelos professores e seus alunos, validados pela direção e coordenação da escola, e atenderam, unicamente, aos interesses dos jovens, em suas cidades.

A escolha das cidades do DF para implementação do Nós Propomos se deu em virtude da localidade de trabalho dos professores envolvidos, pesquisadores do GEAF - Taguatinga, Paranoá, Santa Maria e Ceilândia - e envolveram alunos dos anos finais do Ensino Fundamental e também Ensino Médio. As temáticas foram variadas, mas direta ou indiretamente, o estudo da cidade foi contemplado. O processo de execução mobilizou sobremaneira as escolas envolvidas, contou com participação de autoridades, motivou alunos, professores e comunidade, melhorou o processo de aprendizagem em Geografia, a auto-estima dos alunos, a melhoria do espaço escolar e estabeleceu, efetivamente, um elo entre a construção de conhecimentos geográficos e a consolidação da noção de cidadania.

Em Taguatinga dois professores de uma mesma escola de Ensino Médio implementaram o projeto. Mais de 400 alunos do primeiro e segundo ano se envolveram. Como sugere a proposta pedagógica do projeto, os alunos, a partir de suas realidades, escolheram temáticas/problemas que poderiam estudar e depois propor medidas de solução ou amenização desses problemas detectados. As atividades envolveram além de atividades internas, como colóquios e seminários com representantes do poder público, especialistas e lideranças de movimentos sociais, participações em eventos externos de natureza acadêmica, visitas à Câmara Legislativa do Distrito Federal e ao Tribunal de Justiça. A dinâmica foi toda feita em Grupos de 7 integrantes em média, ao final do projeto as propostas pensadas, analisadas e discutidas eram apresentadas à comunidade escolar de maneira oral e também por escrito na forma de pôster. Os temas trabalhados foram: segurança; transporte e trânsito; serviços públicos; problemas sociais; saúde; educação; meio ambiente; cultura; crise hídrica.

No Paranoá, o projeto se deu com alunos do Ensino Fundamental que cursavam o nono ano. Com um trabalho inicial de pesquisa histórica sobre a cidade, marcado por surpresas e descobertas, uma vez que muitas regiões administrativas do Distrito 
Federal têm suas próprias histórias ofuscadas ou até negligenciadas pela história da região administrativa número um, o Plano Piloto onde está localizada Brasília, a capital. Feito o reconhecimento, os alunos definiram temas e iniciaram a pesquisa. Se dividiram em grupos e contaram não só com a professora de Geografia que conduziu o projeto, mas professores de outras disciplinas que aceitaram a missão de serem orientadores das atividades. Os temas tratados foram: lixo; vias de circulação para pedestres; comércio ilegal; acidentes de trânsito; consumo de drogas; alimentação escolar; cultura alimentar; Lago Paranoá. Ao final um seminário foi realizado para que os alunos apresentassem as propostas pensadas na presença de autoridades vinculadas às temáticas escolhidas.

Na cidade de Santa Maria o projeto aconteceu em uma escola de Ensino Médio e tratou da temática da Violência contra a mulher. Na fase inicial, o problema mais recorrente nas falas dos alunos foi a violência urbana, contudo, após discussões e estudos sobre os tipos de violência, afunilou-se para a violência contra a mulher. Nas pesquisas com a comunidade escolar buscou-se identificar também as causas e contextos nos quais essa violência ocorria. No intuito de ouvir especialistas, os alunos fizeram contato com do Centro Judiciário da mulher do Tribunal de Justiça do Distrito Federal. A iniciativa foi exitosa e gerou inclusive um prêmio para escola como boa prática.

Em Ceilândia o Nós Propomos ocorreu numa escola de Ensino fundamental em área rural e abordou temas relacionados às questões ambientais, especialmente os recursos hídricos. Os contextos rural e urbano foram trabalhados de modo a provocar situações em que os alunos a pensassem a respeito das particularidades, conflitos de uso e complementaridades entre o campo e a cidade. A partir disso elaboraram as propostas.

\section{Considerações finais}

Ao final, percebeu-se um processo trabalhoso, porém passível de realização, que demonstrou um universo de possibilidades, não somente à construção de conhecimentos geográficos, mas também à conformação da identidade e construção/consolidação do sentido de cidadania, aos alunos em suas próprias cidades. As experiências vividas nas diversas escolas demonstraram que identidade e a cidadania se configuram, então, numa relação com vários aportes culturais, que 
podem existir concomitantemente e conviver, desde que seja considerada e re-situada em uma comunidade multicontextual.

Assim, a identidade dinamizada por esse processo será uma narração ritualizada, um relato construído e reconstruído, incessantemente, junto com os outros. Por isso, pode-se afirmar que a identidade é, também, uma co-produção. Essa co-produção se realiza em condições desiguais, entre os variados atores e poderes que nela intervém; se recompõe nos desiguais circuitos de produção, comunicação e apropriação da cultura. Esses modos diversos de co-produção devem ser considerados ao se relacionar identidade e cidadania.

E aqui se sobressai a importância deste projeto no DF, que possibilitou a co-produção de um processo de desvelamento das cidades, na perspectiva de seus jovens moradores. O olhar para a cidade, de forma atenta, foi revelador para muitos alunos. Perceber a própria realidade, seus problemas e desafios não se constituía até então um exercício rotineiro. O despertar para uma postura cidadã nesse sentido, teve relação com o aumento da percepção e o reforço dos laços de identidade com os espaços de vivência.

\section{Referências}

De Andrade, M. C. Geografia ciência da sociedade. Editora Universitária UFPE, 2006.

Bruner, J. (2001). A Cultura da Educação. Tradução Marcos Domingues. Porto Alegre: Artmed.

Callai, H. C. (2000). Estudar o lugar para compreender o mundo. In A. C. Castrogiovanni, (org.). Ensino de Geografia: Práticas e Textualizações no Cotidiano (pp.83-134). Porto Alegre/RS: Ed. Mediação.

Canclini, N. G. (2008) Culturas Híbridas. São Paulo: EDUSP.

Carpintero, A. C. (1998). Brasília: Prática e Teoria Urbanística no Brasil - 1956-1988. Tese de doutorado. São Paulo: FAU-USP.

Castellar, S. M. V. (2005). Educação Geográfica: a psicogenética e o conhecimento escolar (pp. 209-225). In Caderno Cedes, Campinas 25(66). Disponível em http://www.cedes.unicamp.br

Cavalcanti, L. de S. (1998). Geografia, Escola e Construção de Conhecimentos. Campinas/SP: Ed. Papirus.

(2002). Geografia e Práticas de Ensino. Goiania: Alternativa. 
(2008) . A Geografia Escolar e a Cidade: ensaio sobre o ensino de geografia para a vida urbana cotidiana. Campinas: Papirus.

(2012). O ensino de Geografia na escola. Campinas: Papirus.

Cidade, L. C. \& Moraes, L. B. de. (jan/abr, 2004). Metropolização, imagem ambiental e identidade de cidade no Distrito Federal (pp. 21-37). Rio Claro: AGETEO, Geografia, 29(1).

Claudino, S. (2018). Projeto Nós Propomos - Inovação e Cidadania na Educação Geográfica. Disponível em: http://www.igot.ulisboa.pt/projeto-nos-propomos/Acesso em 05.05.2018

Hall, S. (2003) A identidade Cultural na pós-modernidade. Rio de Janeiro: DPA.

Leite, C. M. C. (2012) O lugar e a construção da identidade: os significados construídos por professores de geografia do ensino fundamental. (Tese de Doutorado) - Universidade de Brasília, Faculdade de Educação, Brasília.

(2002). Geografia no Ensino Fundamental. In Universidade de Brasília/ Departamento de Geografia, Coleção Espaço e Geografia, 5(2), Gestão Urbana e Regional, Brasília.

Leite, C. M. C. \& Barbato, S. B. (2011). Reflexões sobre a construção do conceito de lugar na escola contemporânea (p.1-31). Coleção Espaço \& Geografia, Brasília, 14(2).

Governo Do Distrito Federal (2015). Pesquisa Distrital por Amostra de Domicílios. Brasília: CODEPLAN/SEPLAN.

Rana, L. Geographical Thought Systematic Record of Evolution. New Delhi/India: Concept Publishing Company, 2008.

Paviani, A.(1999). Gestão do território com exclusão socioespacial. In A. Paviani. (org.) Brasília - Gestão Urbana: Conflitos e Cidadania. Brasília: Ed. UnB. 


\title{
Nós propomos novos usos do território potiguar: experiência no Ensino Médio Técnico Integrado
}

\author{
EdSEISY SILVA BARBALHO TAVARES ${ }^{1}$ \\ Camila Nascimento de Oliveira Taumaturgo²
}

AMANDA CAROLYNe MELO Dias ${ }^{3}$

\section{Resumo}

A educação geográfica se constitui numa formação fundamental para o exercício da cidadania. Assim, integramos ao ensino de Geografia desenvolvido no IFRN campus São Paulo do Potengi, a pesquisa e a extensão, e os conhecimentos de Artes e Informática, além das áreas técnicas de Meio Ambiente e Edificações. O projeto Nós Propomos novos usos do território potiguar, realizado com as turmas do 1\%/20 ano do Ensino Médio Técnico Integrado dos cursos de Meio Ambiente e Edificações, consiste num projeto interdisciplinar em que utilizamos o Estudo do meio como metodologia de ensino, sendo identificados problemas territoriais locais, realizadas pesquisas teóricas e de campo e propostas intervenções, as quais são socializadas com a comunidade interna e externa da instituição e a gestão pública dos municípios. Assim, o projeto torna o ensino de geografia significativo na vida dos alunos e os mesmos passam a analisar criticamente as realidades espaciais e a apresentar uma postura cidadã.

Palavras-chave: Geografia; cidadania; ensino; pesquisa; extensão.

\footnotetext{
${ }^{1}$ Professora de Geografia do Instituto Federal do Rio Grande do Norte (IFRN), campus de São Paulo do Potengi, edseisy.tavares@ifrn.edu.br.

2 Professora de Informática do Instituto Federal do Rio Grande do Norte (IFRN), campus de São Paulo do Potengi, camila.taumaturgo@ifrn.edu.br.

${ }^{3}$ Bolsista do projeto financiado pelo IFRN, campus de São Paulo do Potengi, amandacarolyne7@hotmail.com.

Dainara Cristina de Moura Melo. Aluna do curso de Edificações IFRN, campus de São Paulo do Potengi, dainarammelo@gmail.com.

lasmin Ayla Medeiros Costa. Aluna do curso de Meio Ambiente IFRN, campus de São Paulo do Potengi, iasmin.ayla@yahoo.com.
} 


\section{Abstract}

The geographical education has been done in an important formation to the citizenship exercise. Thus, we integrate the geography teaching developed at the IFRN campus São Paulo do Potengi, the research and the extension, and the computing and art's knowledge, as well as the technical areas of environment and buildings. In the project we propose new uses of the Potiguar territory, carried out with the classes of the 1st / 2nd year of Integrated Technical High School of Environment and Building courses, is an interdisciplinary project in which we use the study of the geographic environment as teaching methodology, being identified local territorial problems, carried out theoretical and field research and proposed interventions, which are socialized with the internal and external community of the institution and the public management of the municipalities. Thus, the project makes the teaching of geography meaningful in students' lives, and they begin to critically analyze the spatial realities and present a citizen's posture.

Keywords: Geography; Citizenship; Teaching: Research: Extension.

\section{Introdução}

O Instituto Federal do Rio Grande do Norte (IFRN) desde o ano de 2003 vem expandindo seus campus no estado do Rio Grande do Norte, tal como ocorreu com outras instituições da rede federal de educação profissional a nível nacional. A implantação dessas novas instituições de ensino fruto da adoção uma política de expansão, ampliação e de interiorização da Educação Profissional, Tecnológica e Superior no território brasileiro, totalizam em 2018, 21 campus no estado. Na terceira fase da expansão ocorrida em 2013, tivemos a instalação de três novos campus dentre os quais, o campus São Paulo do Potengi.

O IFRN São Paulo do Potengi inicia as suas atividades letivas no ano de 2014 com os cursos Técnicos Integrados de Nível Médio em Meio Ambiente e Edificações e o curso Subsequente em Edificações, possibilitando a população da região do Potengi mais uma oferta de serviços educacionais e consequentemente também uma atividade que pode mudar a dinâmica territorial do município de São Paulo do Potengi e de sua área de influência. Os municípios de residência declarados pelos alunos do IFRN campus 
São Paulo do Potengi no ano de 2018 no ato da matrícula são Barcelona, Lagoa de Velhos, Santa Maria, Riachuelo, Ruy Barbosa, São Pedro, São Tomé, Senador Elói de Souza, Caiçara do Rio do Vento, lelmo Marinho, Sítio Novo, Serra Caiada, Bom Jesus, Macaíba, Boa Saúde, Monte Alegre, Lagoa Salgada e até de Natal, Parnamirim, Currais Novos e São Fernando (que são casos isolados) (Figura 1). Portanto, são dados que revelam a importância dessa instituição de ensino na área de abrangência territorial que contempla.

Figura 1 - Residência dos alunos do IFRN - São Paulo do Potengi

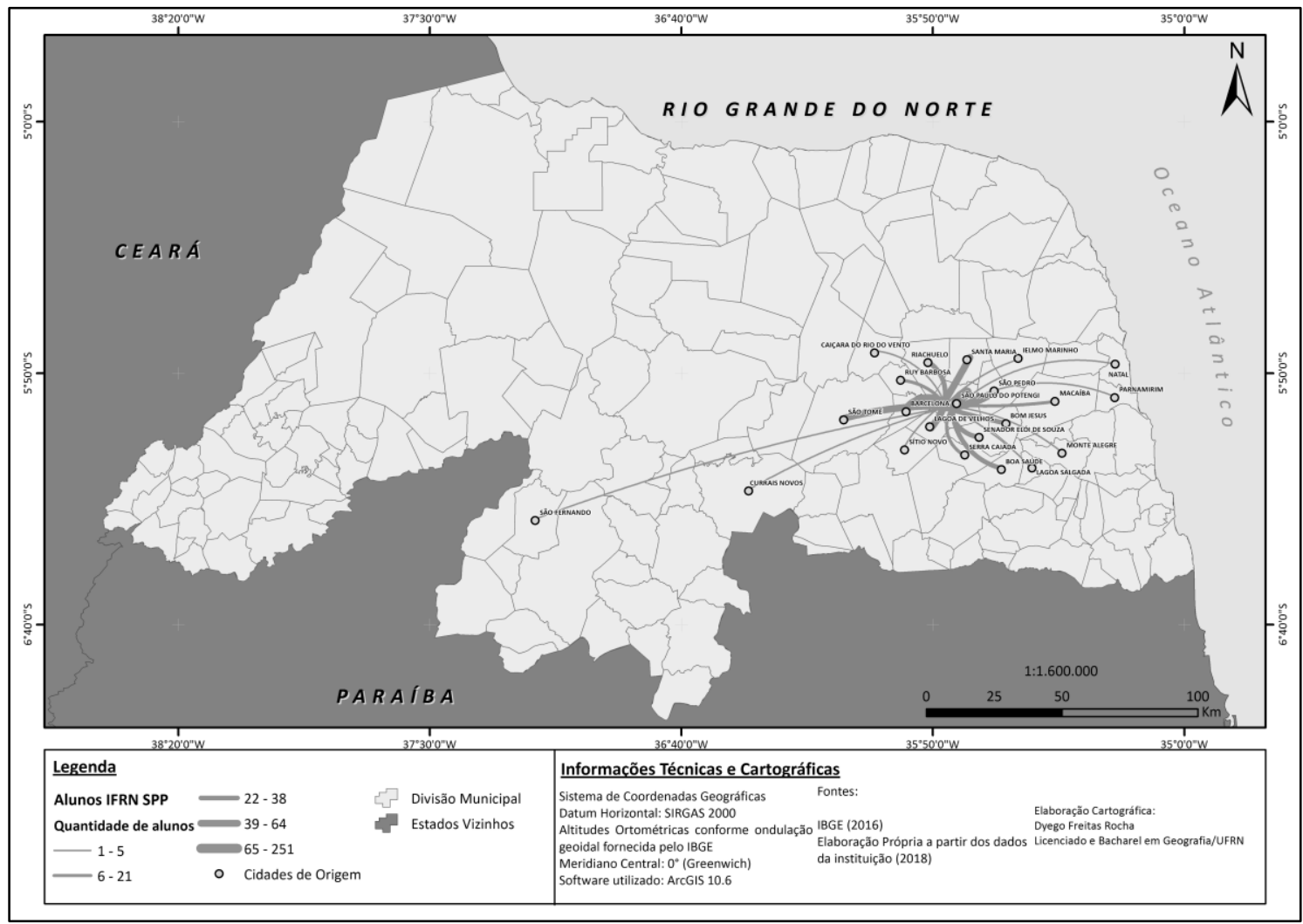

Fonte: IFRN - 2018

A instituição defende enquanto sua função social o comprometimento "com a formação humana integral, com o exercício da cidadania e com a produção e a socialização do conhecimento, visando, sobretudo, a transformação da realidade na perspectiva da igualdade e da justiça sociais" (Brasil, IFRN, p. 21). Nesse sentido, entendemos que a parceria com o projeto Nós Propomos nos ajuda a convergir para o cumprimento dos nossos objetivos educacionais e institucionais, principalmente no que se refere à contribuição as questões locais e regionais. 
Cavalcanti (2012, p. 188) entende que o desenvolvimento de projetos na escola, anuncia os seguintes objetivos: A construção de conhecimentos pelo aluno (formação de atitude indagadora, capacidade de identificar problemas, de construir conceitos e de processar informações); a prática da busca de conhecimento; a prática do trabalho coletivo (importante do ponto de vista afetivo e disciplinar, pois favorece a cooperação nos trabalhos, a divisão de tarefas e o respeito ao trabalho do outro; e, do ponto de vista intelectual, favorece a construção potencializadora do desenvolvimento); a tomada de decisões sobre aspectos da realidade pesquisada e a habilidade para apresentação de resultados de investigação.

Nessa perspectiva, a cooperação entre o IFRN São Paulo do Potengi e o projeto Nós Propomos surgido no Instituto de Geografia e Ordenamento do Território da Universidade de Lisboa (IGOT/UL), em Portugal entre os anos de 2011 e 2012, ocorreu a partir do segundo semestre de 2017 . O projeto que já realiza a sua $7^{a}$ edição nas escolas de Portugal, conta com diversas parcerias nacionais e internacionais com Universidades e escolas de diversos países como Brasil, Espanha, Colômbia e Peru. No IFRN campus São Paulo do Potengi, o projeto inicia suas atividades com o título "Nós propomos novos usos do território potiguar" e busca promover uma educação geográfica baseada na cidadania territorial, relacionando ensino de Geografia, pesquisa e extensão, além dos conhecimentos técnicos das áreas de Meio Ambiente e Edificações, a partir da identificação e proposição de intervenções aos problemas locais. Em 2017 integraram o projeto as turmas dos $1^{\circ}$ anos do Ensino Médio Integrado dos Cursos de Meio Ambiente e Edificações (totalizando 4 turmas), sendo a continuidade do projeto realizada em 2018, por um grupo desses alunos que em 2018, cursam o $2^{\circ}$ ano.

\section{Sensibilização e pesquisa: os primeiros passos do Nós Propomos no IFRN}

Iniciamos as atividades reunindo um grupo de docentes do campus IFRN São Paulo do Potengi que se integraram a equipe. O projeto foi cadastrado no Edital de fluxo contínuo da extensão em 2017 e a equipe reuniu professores de Geografia, Artes, Informática e das áreas técnicas de Edificações e Meio Ambiente que construíram conjuntamente metas e atividades a serem desenvolvidas para a primeira fase do Nós Propomos novos usos do território potiguar. Entendemos que um projeto dessa natureza precisa ser realizado de forma interdisciplinar, considerando que "a necessidade de diálogo, de aprendizado mútuo e de superação das fronteiras 
artificiais fica ainda mais evidente quando se trata de pensar além da problemática, buscando refletir também sobre as soluções - ou, como já brincou alguém, sobre a "solucionática" (Souza, 2006, p. 100).

A primeira atividade foi a sensibilização dos alunos para participarem do projeto que foi integrado enquanto metodologia da disciplina de Geografia, embora contando com a contribuição dos conhecimentos das demais áreas. $O$ ensino de geografia deve consistir num processo de ensino-aprendizagem que permita a formação cidadã dessa sociedade que usa os territórios, para que o mesmo possa ser usado de forma mais justa e igualitária. De acordo com Cavalcanti (2012, p. 110) “o ensino de geografia tem razão de ser na escolarização formal de jovens como contribuição para suas práticas socioespaciais, cotidianas e não cotidianas". De tal modo, entendemos que no ensino de geografia, os conhecimentos geográficos precisam ser significativos para a vida dos discentes, contribuindo com a análise crítica da realidade espacial e dos usos do território da escala global a local. Para Cavalcanti (2012, p. 116), "os conteúdos geográficos trabalhados em sala de aula devem ter significado para os alunos, devem servir para sua compreensão do mundo e de seu lugar no mundo".

Após os alunos se integrarem ao projeto, foi lançado o concurso do logotipo e a partir de uma votação da comunidade interna e externa ao IFRN foi escolhido um logotipo que representa os sujeitos sociais enquanto agentes dos usos e das questões territoriais envolvidas num recorte espacial que parte do estado à região do Potengi (Figura 2).

Figura 2 - Logotipo do projeto Nós Propomos do IFRN - São Paulo do Potengi

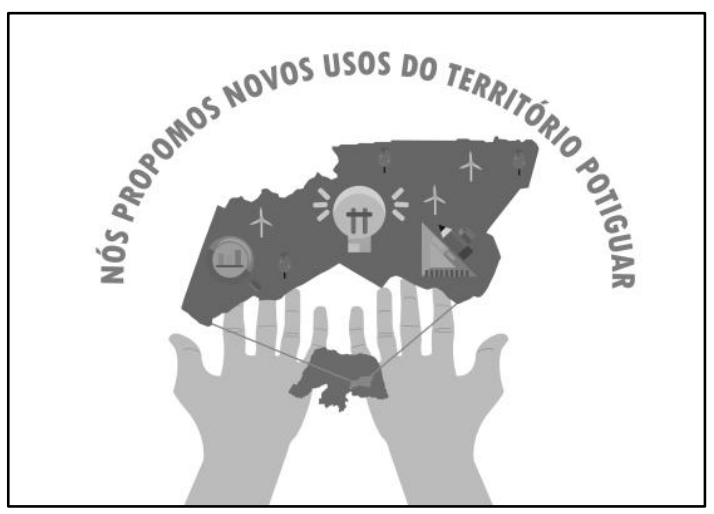

Autoria: landerson Gomes, 2017.

Ainda tivemos como produtos dos trabalhos de campo e da elaboração das propostas, outros concursos internos, como de fotografia, vídeo e texto, cujo material foi exposto 
no Seminário para apresentação dos projetos e também no dia do Meio Ambiente, 5 de junho de 2018, em que realizamos uma ação no bairro Juremal em São Paulo do Potengi e na oportunidade foram exibidas as fotografias e vídeos produzidos pelos alunos. Uma parte do material produzido também foi enviada para os concursos do I Congresso Iberoamericano Nós Propomos! Geografia, Educação e Cidadania, alguns estando entre os primeiros lugares (Figura 3).

\section{Figura 3 - Fotografias das pesquisas de campo realizadas projeto}

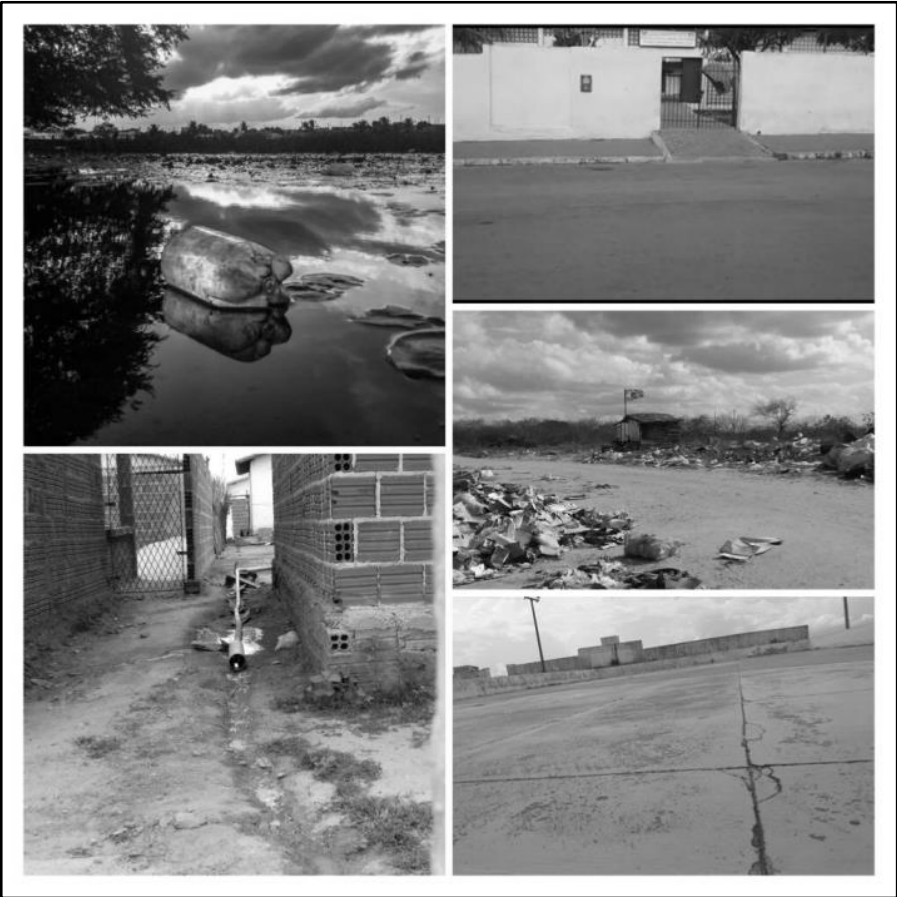

Fonte: Nós Propomos, 2017-2018.

O projeto Nós Propomos desenvolvido no IFRN São Paulo do Potengi, conta com uma plataforma digital, no seguinte endereço: http://www2.ifrn.edu.br/nospropomosifrnssp/, que é um espaço destinado a apresentar o projeto e suas ações, como também representa um canal de comunicação com os alunos e interessados para envio, armazenamento de arquivos e disponibilização dos materiais textuais, imagens e vídeos que vão sendo produzidos no percurso do seu desenvolvimento.

Reunidos em grupos, os alunos levantaram problemas territoriais locais das comunidades nas quais residem. Foram realizadas pesquisa de campo e aplicado um inquérito que tinha o objetivo de conhecer melhor o território local em que vivem os participantes do projeto, as suas opiniões sobre os seus problemas e o papel de cada um, na respectiva resolução. Identificados os problemas territoriais, os alunos realizaram pesquisa teórica e em campo (Figura 3) sobre a problemática em questão, 
participaram de minicurso sobre a "Elaboração de projetos de pesquisa geográfica e Estudo do Meio", e passaram a elaborar com a orientação dos professores, suas propostas de intervenção. As propostas de intervenção no território local, contemplaram a princípio 11 municípios (São Paulo do Potengi, São Pedro, Barcelona, Riachuelo, São Tomé, Lagoa de Velhos, Boa Saúde, Macaíba, Ruy Barbosa, Senador Elói de Souza e Bom Jesus), no entanto após essa primeira fase em que todo os grupos realizaram a atividade da disciplina, apenas 4 municípios permaneceram entre as propostas a serem elaboradas e discutidas com a comunidade na perspectiva de implementação (Figura 4).

Figura 4 - Mapa dos municípios contemplados nas fases 1 e 2 do projeto Nós Propomos no IFRN São Paulo do Potengi

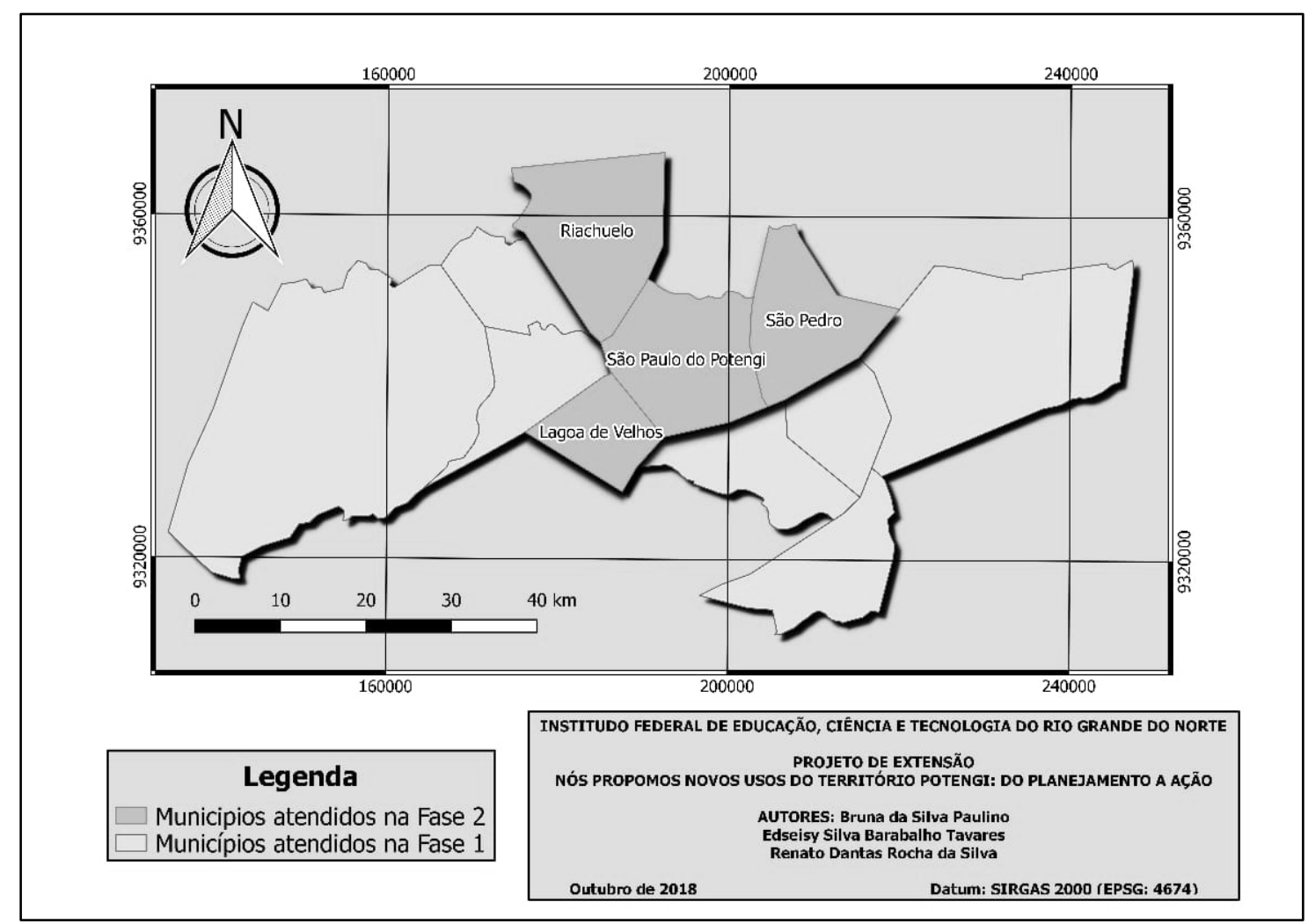

Fonte: Paulino; Tavares; Silva, 2018.

Recorremos ao estudo meio, porque como destaca Cavalcanti (2012, p. 190), pode estar relacionado a um tipo de atividade escolar de pesquisa mais ampla ou a "um procedimento específico para tratamento de conteúdos de geografia", que visa inicialmente sensibilizar as percepções dos alunos no processo de conhecimento para que se proceda à elaboração conceitual. A adoção de métodos de ensino interdisciplinar como o estudo do meio proporciona aos alunos e professores "contato direto com uma determinada realidade, um meio qualquer, rural ou urbano, que se 
dedica estudar" (Lopes \& Pontuschka, 2009, p. 174), de modo "a melhorar a formação do aluno, construindo um currículo mais próximo dos seus interesses e da realidade vivida" (Lopes \& Pontuschka, 2009, p. 179), sendo a escolha dos temas e lugares de pesquisa definidos pelos sujeitos do processo de ensino-aprendizagem considerando o contexto territorial no qual a instituição está inserida.

Para os projetos que se julgou necessário, foi realizada uma cartografia, de modo a representar a situação pesquisada e/ou proposta. A cartografia contou com a colaboração do professor e dos alunos que no semestre 2017.2 cursavam a disciplina Cartografia Ambiental. Os projetos foram elaborados seguindo as normas para trabalhos científicos da Associação Brasileira de Normas Técnicas (ABNT), de modo que além de ser um projeto que prima pela formação cidadã e por uma educação geográfica significativa, ainda contribui com a formação acadêmica dos alunos. Os temas envolveram diversas temáticas territoriais, muitas delas abordando e mantendo relação direta com a formação técnica das áreas que estão cursando. Foram elaborados projetos cujos problemas estão arrolados por questões ambientais como usos e poluição de recursos hídricos, saneamento básico, principalmente quanto a despejos de resíduos sólidos e esgotamento sanitário; e também quanto a edificações que precisam de recuperação/construção - foram identificados muitos espaços públicos apresentando problemas de infraestrutura que associados a questões sociais, tem seu uso comprometido, como recuperação de bibliotecas, quadras de esportes, academia de idosos, praças, acessibilidade, segurança e sinalização de vias e escolas e até iluminação pública.

Tanto durante a pesquisa quanto após a elaboração dos projetos, os alunos conversaram com a comunidade e gestão pública municipal para levantar os problemas, buscar informações e dados. E no Seminário realizado no IFRN São Paulo do Potengi em abril de 2018, convidamos os gestores públicos dos 11 municípios para apresentar as propostas de intervenções e sensibilizá-los para implementá-las (Figura 5). Assim, o projeto vem sendo discutido e apresentado em eventos e atividades internas e externas ao IFRN, como congressos e também eventos regionais tais como, I Encontro Estadual de Formação de Lideranças da Agricultura Familiar Potiguar (LIDERAF) e Capriferia, realizado em 2017 em São Paulo do Potengi e Jornada Pedagógica do município de São Pedro em 2018. 


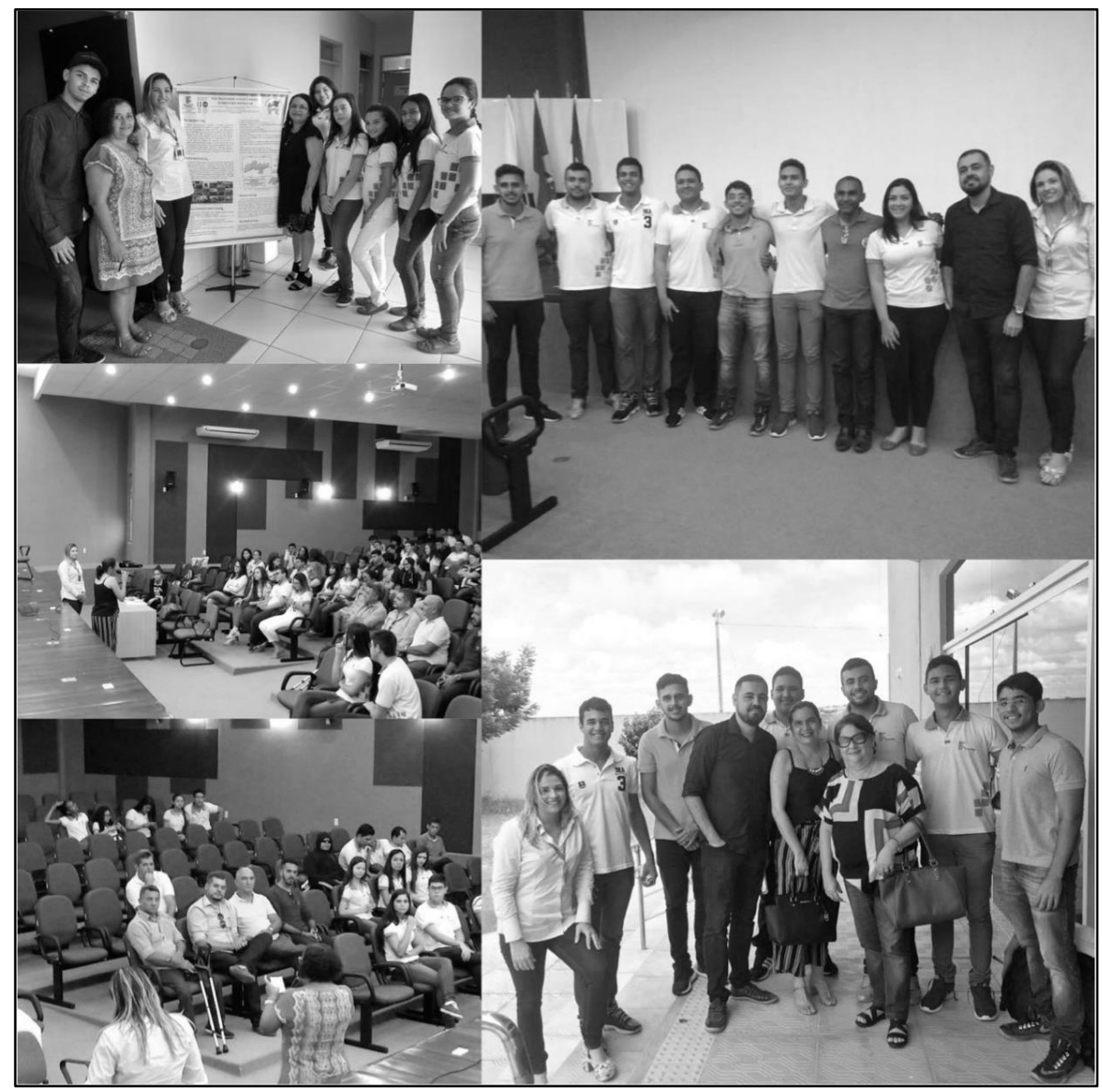

Fonte: Nós Propomos, 2018.

\section{Nós Propomos no território do Potengi: do planejamento à ação}

Após a culminância da primeira fase do projeto que ocorreu com o Seminário, tivemos a renovação do projeto para que as propostas de intervenção sejam não apenas apresentadas, mas discutidas com a comunidade e gestores públicos, de modo a poderem ser implementadas nos municípios.

A metodologia da segunda fase consistiu na continuidade de pesquisa sobre as intervenções, mas também na realização de reuniões e oficinas com a comunidade e com os gestores responsáveis pelos referentes setores dos problemas para expormos as propostas e como foram realizados os estudos e a pesquisa sobre o problema. As equipes que permaneceram enquanto alunos vinculados ao projeto de extensão e também de projetos de pesquisa vinculados ao Nós Propomos, ainda estão realizando reuniões, para discutir as ações que precisam ser implementadas para concretização das propostas apresentadas e outros já estão realizando e acompanhando as 
propostas, entendendo que a mudança social deve "contemplar não apenas as relações sociais mas, igualmente, a espacialidade" (Souza, 2006, p 61).

O projeto que tratou da questão da iluminação pública entre o IFRN e o centro do município de São Paulo do Potengi, realizou entrevistas e reuniões com os secretários municipais e já foi efetuada a iluminação da rua no final do ano de 2017 (Figura 6). Os alunos do turno da tarde e os que iriam ingressar no turno noturno em 2018 demonstraram na aplicação dos questionários uma grande preocupação com a segurança devido a ausência de iluminação nessa área da cidade.

Figura 6 - Reunião com os secretários do município de São Paulo do Potengi/RN e rua que teve a implantação do sistema de iluminação pública.

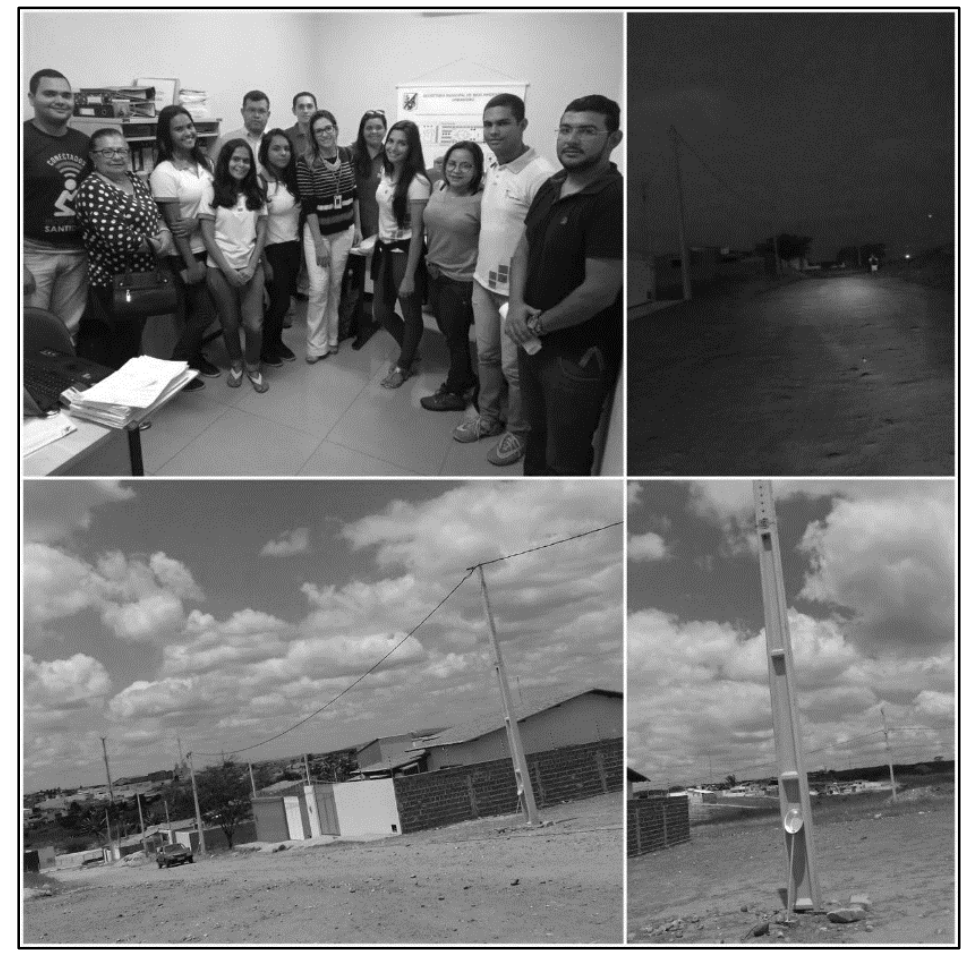

Fonte: Nós Propomos IFRN SPP, 2017.

Como destacado anteriormente, a maioria das propostas de intervenção estão sendo desenvolvidas a partir das contribuições da formação profissional das duas áreas técnicas dos discentes. De tal modo, em São Paulo do Potengi, ainda são desenvolvidos dois projetos: o Aquaeri, que consiste num projeto de pesquisa que vem desenvolvendo um aplicativo móvel para ser utilizado enquanto ferramenta didáticopedagógica de educação ambiental. O público será alunos das escolas que cursam o Ensino Fundamental II, com o objetivo de estimulá-los a fazerem um consumo consciente e sustentável de recursos hídricos, tão escassos nas diversas escalas geográficas, inclusive no município de São Paulo do Potengi/RN. A plataforma digital 
desse projeto já se encontra disponível em: https://esquadraoaquaeri.wixsite.com/aquaeri e tem procurado aprofundar essas questões, elaborando e disponibilizando um material audiovisual (vídeos, quiz) centrado na temática do uso racional dos recursos hídricos da região e nas residências. E também um projeto de reuso de águas cinzas, que conta com a instalação de uma estação experimental implantada numa residência da comunidade Monsenhor Expedito. De acordo com Dantas (2018, s.p.), orientador da proposta, essa ação "traz benefícios para os moradores à medida que evita o despejo, como estava ocorrendo em seus quintais, de material inadequado diretamente no solo, possibilitando que a água utilizada passe por um tratamento antes de ser descartada".

O projeto "Implantação das lixeiras e projeto de educação ambiental para descarte do lixo no município de São Pedro/RN" foi discutido durante o encontro da Jornada Pedagógica que reuniu os professores e gestores da educação do município e estamos tentando articular a realização de um projeto de educação ambiental trabalhando com artes nas escolas municipais e a realização de oficinas para produção de lixeiras a serem instaladas no centro da cidade. Ainda em São Pedro temos outra proposta de intervenção que busca aproveitar um espaço público do território municipal para a construção de uma praça com equipamentos de academia e parque visando atender idosos e crianças. O estudo previu a acessibilidade, vagas de estacionamento, a inclusão de bancos, jardineiras e o emprego de areia em parte da praça para reduzir os custos de manutenção.

No município de Riachuelo estão sendo desenvolvidos dois projetos: o projeto do transporte escolar entre o município de Riachuelo e o campus do IFRN São Paulo do Potengi, o qual tem contado com o apoio de alguns vereados do município, da gestão do IFRN e de sua assistência social para juntos tentarmos com a gestão do município de Riachuelo buscar uma alternativa que viabilize esse transporte para os alunos de baixa renda, que vem encontrado dificuldades de permanência na instituição. Mas apesar de já ter ocorrido uma reunião sobre a proposta diretamente com a prefeitura, ainda não foi possível solucionar a questão; A outra proposta para o município de Riachuelo se refere ao problema identificado quanto as condições de acessibilidade presentes na calçada da Escola Estadual Manoel Severiano, situado à Rua Luiz Gonzaga Cavalcanti, município de Riachuelo-RN, sendo proposto o nivelamento da calçada, a readequação da rampa existente no portão de acesso para pedestres, a inclusão de uma rampa entre a sarjeta e calçada, a utilização de piso tátil de alerta e 
direcional e também o uso de lixeiras que estão sendo confeccionadas a partir de pneus usados.

Em Lagoa de Velhos, o projeto "Despoluição e revitalização da lagoa de Lagoa de Velhos", já discutiu a proposta com a gestão municipal, sendo exposto o projeto e apontado os problemas identificados na lagoa e as ações previstas já iniciaram. $O$ material para as oficinas de produção das lixeiras vem sendo recolhido e palestras integrando a proposta de educação ambiental foram realizadas para crianças com o objetivo de sensibilizar a comunidade em relação à resíduos sólidos e permanência de animais na lagoa (Figura 7).

Figura 7 - Palestras e oficinas realizadas em São Pedro

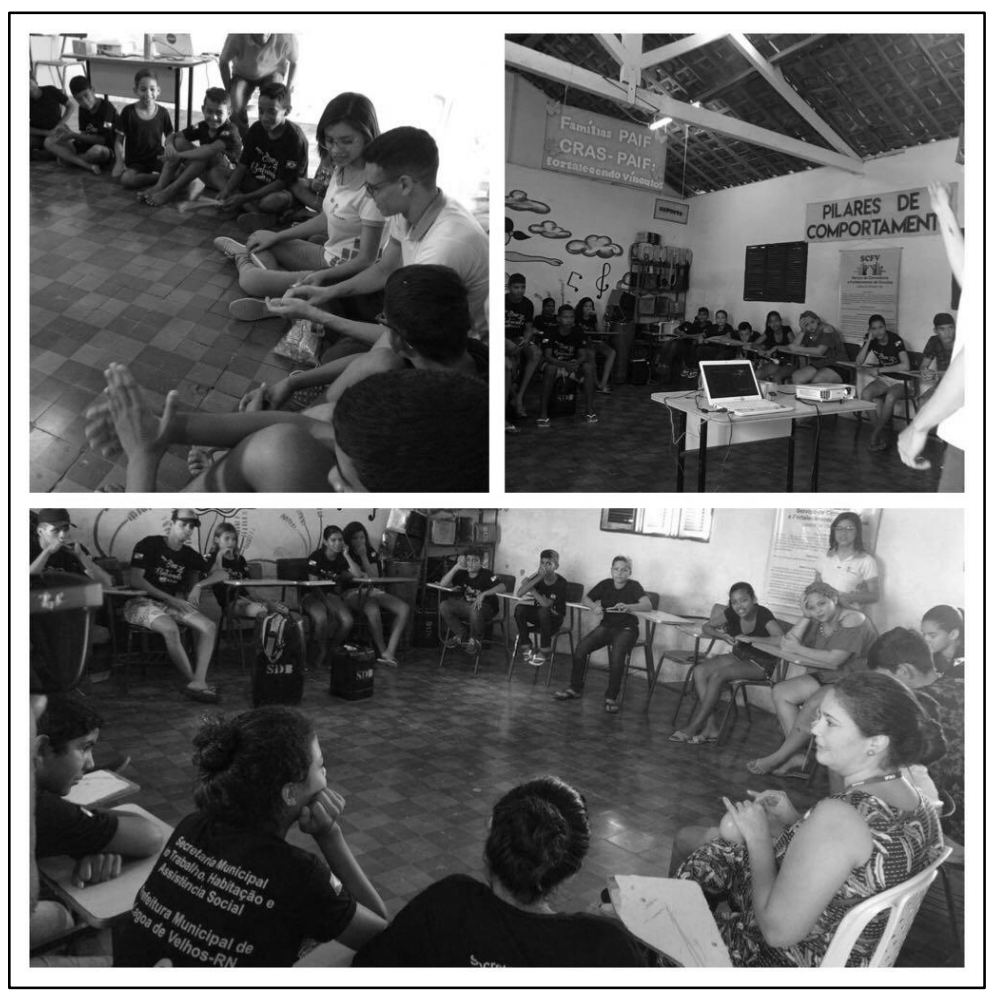

Fonte: Nós Propomos IFRN SPP, 2018

\section{Conclusão}

Para Santos (1998, p. 116) "é impossível imaginar uma cidadania concreta que prescinda do componente territorial", portanto, a Geografia pode contribuir nesse processo formativo dos nossos jovens. Entretanto, o projeto educativo assumido precisa permitir aos alunos o desenvolvimento de capacidades e habilidades que os possibilitem participar ativamente no planejamento e gestão do lugar onde vivem. 
Reportando-se especificamente às cidades, Cavalcanti (2012) assevera o papel da escola nessa formação cidadã e como a Geografia enquanto a ciência do espaço geográfico tem possibilidades de ter seu ensino orientado para um trabalho de educação geográfica para a cidadania. Mas, para tanto, esclarece que se faz necessário que se organize projetos que identifiquem e discutam expectativas e representações que os alunos tenham em relação à cidade, exercitando práticas cidadãs de organização coletiva com pautas definidas e propiciando canais de participação efetiva desse grupo de cidadãos na gestão de sua cidade (Cavalcanti, 2012, p. 126).

Assim, destacamos que os projetos/propostas de intervenção elaborados e apresentados pelos alunos do IFRN, identificam problemas locais e propõem ações para resolver ou minimizar os mesmos. De tal modo, beneficia não apenas os discentes que terão uma formação acadêmica e profissional orientada para uma cidadania territorial, mas a comunidade local que pode apontar os problemas e ainda ser contemplada com propostas de intervenção que chegarem a ser acolhidas pela população e poder público local.

O projeto "Nós propomos novos usos do território potiguar" adota as caraterísticas gerais das experiências desenvolvidas em outras Universidades, mas considera a realidade da nossa comunidade escolar e do nosso território, de tal modo realizamos um projeto de extensão vinculado a um de ensino interdisciplinar que se dedicou a pesquisar os problemas territoriais locais, a partir dos conhecimentos geográficos e técnicos das áreas de Meio Ambiente e Edificações para propor soluções. Nessa perspectiva, buscamos tornar os conteúdos significativos e estimular a produção de novos conhecimentos, como também adotamos um cunho extensionista ao beneficiar e interagirmos com a comunidade local. Ainda entendemos que o envolvimento dos alunos no projeto e suas atividades nos ajuda a reduzir a evasão escolar, possibilitando que os discentes estejam mais atentos aos problemas do lugar em que vivem, disseminando uma preocupação dos mesmos para com a sociedade.

\section{Referências bibliográficas}

Brasil, IFRN. (2012). Projeto Político-Pedagógico do IFRN: uma construção coletiva. Fonte: Instituto Federal de Educação, Ciência e Tecnologia do Rio Grande do Norte: http://portal.ifrn.edu.br/institucional/projeto-politico-pedagogico-1

Cavalcanti, L. de S. (2012). O ensino de geografia na escola. Campinas, SP: Papirus. 
Lopes, C. S. \& Pontuschka, N. N. (2009). Estudo do meio: teoria e prática. Geografia (Londrina) v. 18, n.2. Disponível em: http//www.uel.br/revistas/uel/index.php/geografia/.

Santos, M. (1998). O espaço do cidadão. São Paulo: Nobel.

Silva, R. D. R. da. (2018, Setembro). Público. NEPP e "Nós Propomos" instalam unidade experimental de tratamento de águas. Disponível em: http://portal.ifrn.edu.br/campus/sao-paulo-do-potengi/noticias/nepp-e-201cnospropomos201d-instalam-unidade-experimental-de-tratamento-de-aguas.

Souza, M. L. de. (2006). Mudar a cidade. Rio de Janeiro: Bertrand Brasil. 


\section{As Tecnologias da Informação e Comunicação e a educação geográfica para a formação da cidadania espacial nas escolas públicas de Fortaleza / Brasil}

EMANUELLA VIEIRA ${ }^{1}$

\section{Resumo}

A presente investigação visa analisar a utilização das Tecnologias de Informação e Comunicação (TIC) nas escolas de Ensino Médio da cidade de Fortaleza/Brasil como ferramentas importantes no desenvolvimento de uma consciência espacial cidadã, permitindo construir experiências de ensino/aprendizagem mais motivadoras, aproximando a escola dos interesses dos alunos. Na pesquisa que se apresenta, investigou-se a maneira como os alunos observam a utilização das TIC em sala de aula, as vantagens e desvantagens que os mesmos encontram em sua mobilização durante aquelas. Procura-se compreender como a utilização das TIC possibilita o desenvolvimento de uma consciência cidadã e de uma cidadania espacial numa perspectiva de apropriação e intervenção sobre o espaço local. Para isso foram analisados os projetos Nós Propomos: Cidadania e Inovação na Educação Geográfica da Universidade de Lisboa e o NTPPS, Núcleo de Trabalho, Pesquisas e Práticas Sociais, desenvolvido pela Secretaria de Educação do Estado do Ceará. Ambos são trabalhados em consonância em escolas públicas do estado do Ceará.

Palavras-chave: cidadania espacial; educação geográfica; TIC; Nós Propomos; NTPPS.

\footnotetext{
1 Professora da Rede Estadual de Ensino Médio do governo do estado do Ceará, estudante de doutoramento, IGOT/Universidade de Lisboa, emanuellacruzvieira@gmail.com
} 


\section{Abstract}

The present research aims at analyzing the use of Information and Communication Technologies (ICT) in the secondary schools of the city of Fortaleza / Brazil as important tools in the development of a citizen space awareness, allowing the construction of teaching / learning experiences more motivating, school of student interests. In the research presented, we investigated how ${ }^{2}$ students observe the use of ICT in the classroom, the advantages and disadvantages that they find in their mobilization during those. It seeks to understand how the use of ICT makes possible the development of a citizen's conscience and a space citizenship in a perspective of appropriation and intervention on the local space. For that, we analyzed the projects We propose: Citizenship and Innovation in Geographic Education of the University of Lisbon and the NTPPS, Nucleus of Work, Research and Social Practices, developed by the Education Department of the State of Ceará. Both are worked in consonance in public schools of the state of Ceará.

Keywords: space citizenship; geographical education; ICT; We propose; NTPPS.

\section{Introdução}

A pesquisa que apresentamos analisa a utilização das Tecnologias de Informação e Comunicação (TIC) na Educação Geográfica, de forma a contribuir para o desenvolvimento de uma cidadania espacial. A nossa investigação origina-se de duas ideias centrais; a primeira é a relação que as TIC estão assumindo com os temas transversais, tendo em vista a prática da cidadania. A segunda ideia, refere-se às potencialidades das TIC na transformação da prática docente, potenciando rupturas com as práticas estabelecidas e aproximando a escola do quotidiano dos alunos pelo que também importa incentivar sua implementação no processo de ensino e aprendizagem.

Faremos uma reflexão acerca dos trabalhos que estão sendo desenvolvidos pelos alunos de cinco escolas públicas de Ensino Médio da cidade de Fortaleza/Brasil durante o ano de 2018, no âmbito do projeto Nós Propomos! Cidadania e Inovação na Educação Geográfica, o qual é trabalhado em consonância com o projeto Núcleo de Trabalho, Pesquisas e Práticas Sociais (NTPPS), da Secretaria de Educação do Estado do Ceará. Ambos projetos possuem os objetivos de promover o protagonismo estudantil, desenvolver competências sócioemocionais e propiciar o desenvolvimento 
de uma cidadania ativa, mobilizando os alunos para a identificação dos principais problemas locais e propondo alternativas fundamentadas para resolução dos mesmos.

Com o objetivo de analisar 0 uso das TIC nas escolas de Fortaleza e o desenvolvimento de uma cidadania espacial foi aplicado um questionário a 70 alunos de três escolas públicas de Ensino Médio na cidade de Fortaleza, as quais participam dos projetos Nós Propomos e NTPPS, realizamos a criação de mapas para identificar os problemas relacionados às dificuldades que os estudantes possuem para exercer sua cidadania e a proposição para solução dos problemas. Apresentamos, em seguida, uma breve reflexão sobre a importância das TIC no ensino aprendizagem; posteriormente, abordaremos sobre a inserção das TIC na educação brasileira e sua utilização, faremos uma breve exposição sobre cidadania espacial, faremos o contexto da investigação e análise das atividades realizadas. Por fim, serão apresentadas algumas reflexões sobre os breves resultados e identificação de alguns desafios que se colocam à escola em geral e para o ensino e aprendizagem da Geografia em particular.

\section{A importância das TIC no ensino e na aprendizagem}

As Tecnologias da Informação e Comunicação (TIC) são utilizadas para agrupar, difundir e compartilhar informações. Elas são mediadoras das comunicações e informações, as quais auxiliam em um objetivo (SILVA, 2001; IMBERNÓN, 2010; MORAN et al, 2012). As TIC são compreendidas como um conjunto de recursos tecnológicos, os quais estão integrados, que propiciam, por meio das telecomunicações ou através das funções de software e hardware, a automação e comunicação no mundo dos negócios, na pesquisa científica e no processo de ensino e aprendizagem (MIRANDA, 2009).

Segundo Ricoy (2005) as TIC são ferramentas educativas com grande potencialidade na promoção de um ensino mais centrado no aluno, dessa forma são muito importantes na alteração das concepções tradicionais de ensino. A utilização das TIC em educação possibilita uma participação mais ativa dos alunos, suscita a curiosidade, proporcionando uma maior eficácia no processo de ensino/aprendizagem, pois propicia uma maior apreensão dos conteúdos e de forma crítica, desenvolvendo novas metodologias de trabalho para uma melhor aprendizagem.

A utilização das TIC em sala de aula implica, assim, uma alteração importante no papel tradicionalmente desempenhado por professores e alunos. Sem esta mudança, 
a utilização das TIC em sala de aula poderá correr o risco de ser uma extensão de um ensino tradicionalmente centrado no professor, tal como Area (2010) procurou demonstrar. No entanto, esta renovação das práticas docentes terá que passar por um processo de formação inicial e contínua que possibilite a implementação de novos modelos de ensino e aprendizagem apoiados no uso das TIC.

\section{As TIC na Educação Brasileira}

No Brasil, as primeiras ações de inserção das TIC na educação remontam ao final da década de 1970, por iniciativa do governo federal, que verificou a necessidade de delinear uma política pública para a inclusão da informática na educação do Brasil, sendo utilizada como estratégia para o desenvolvimento tecnológico, fomentando a criação de produtos da microeletrônica, o atendimento das demandas dos setores produtivos para a contratação de profissionais com competência científica-tecnológica e incentivo a formação na área (Almeida, 2008; Bonilla, 2010). Segundo Almeida (2008), esta iniciativa originou um espaço em que pesquisadores e educadores que se dedicavam a estudos sobre computadores e educação pudessem dialogar, viabilizando a articulação entre pesquisa e ensino que classificou, posteriormente, como elemento chave das atividades da área.

O uso das TIC na educação surgiu para auxiliar na busca por qualidade do processo educacional. A apropriada utilização dessas tecnologias no ensino faz com que haja a necessidade de uma constante atualização por parte dos professores.

Os avanços na tecnologia têm influenciado de maneira determinante as relações sociais, atingindo diretamente a escola e seus principais atores, professores e alunos. Alguns educadores se veem diante de uma problemática, por um lado, do pouco conhecimento em TIC, do constrangimento em reconhecer sua falta de habilidade no que concerne às tecnologias e do fraco acesso às mídias de produção e disseminação do conhecimento científico; por outro lado, são confrontados com a facilidade e o desprendimento dos alunos em utilizar as tecnologias.

Com a inserção das ferramentas tecnológicas nas escolas, ocorreu o desenvolvimento de uma cultura tecnológica nas mesmas, possibilitando a promoção da inclusão digital da comunidade escolar no sentido de uma autonomia social, uma perspectiva fundamental para a redução das desigualdades sociais e para o desenvolvimento. Portanto, revela-se a importância das políticas públicas para a implementação das tecnologias digitais na escola, para que, dessa forma, haja uma promoção das 
correções no sistema educacional, pois suas assimetrias são evidenciadas pelo desempenho dos estudantes através do uso da linguagem da geração digital, em uma sociedade tecnologizada.

\section{As potencialidades das TIC a formação da cidadania espacial}

As mudanças tecnológicas perpassam a pedagogia e a metodologia da Educação Geográfica (Freeman, 1997). Considerando as metodologias e tecnologias de valorização do espaço em contexto educativo, considera-se que estas se apresentam como recursos potencialmente motivadores, unificadores e estruturantes pela aplicação transversal dos conteúdos programáticos (Carlos,2015).

A utilização das tecnologias no contexto escolar e sua integração em atividades que promovam o uso dos conceitos espaciais na busca do entendimento e no desenvolvimento de entendimento e na busca de resoluções para problemas locais, partindo para o global. Nesse sentido, o trabalho dos projetos Nós Propomos e NTPPS executam a busca por soluções da problemática em que a comunidade está inserida, fazendo uso das ferramentas tecnológicas e de conceitos espaciais, fazendo com que os alunos se apropriem criticamente do espaço em que estão inseridos.

Gryl \& Jekel (2012) definem cidadania espacial como a capacidade de se apropriar criticamente do espaço através de meios democráticos, e com a finalidade de participar na sociedade. Tal como salientado pelos autores, esta afirmação equivale a uma forma intencional e crítica de aceitar significados atribuídos a certos espaços (gerados coletivamente ou por intermédio de setores de poder da sociedade) ou de participar activamente na mudança dos significados desses espaços, pressupondo ambas as abordagens uma compreensão emancipatória da aprendizagem e do ensino, onde não se toma o mundo atual como um dado adquirido (Carlos,2015).

\section{Contexto da investigação e atividades realizadas}

A investigação decorreu em três escolas de ensino médio da cidade de Fortaleza, sendo estas: Escola de Ensino Médio Dona Hilza Diogo de Oliveira, Escola de Ensino Médio e Tempo Integral Liceu Vila Velha e Escola de Ensino Médio e Tempo Integral Matias Beck, as quais estão localizadas nos bairros da Barra do Ceará, Vicente Pinzón e Vila Velha, de acordo com a SEDUC-CE são classificadas pelos níveis A, B e C, respectivamente, sendo esta classificação decorrente da quantidade de matrículas e de resultados em avaliações internas e externas. As escolas funcionam nos turnos 
manhã, tarde e noite. Todas estão equipadas com bibliotecas, laboratório de ciências, quadra de esportes, excetuando a EEM Dona Hilza Diogo de Oliveira, que está em reforma e o uso da quadra está impossibilitado, sala de professores, sala de diretoria, sala para coordenação pedagógica e uma secretaria, além de laboratórios de informática ligados à rede mundial, contudo, este estava em reforma ficando apenas 6 computadores para uso dos alunos.

Trata-se de uma pesquisa quantitativa e de caráter exploratório, pois Gil (2008) considera que a pesquisa exploratória tem como objetivo principal desenvolver, esclarecer e modificar conceitos e ideias, tendo em vista a formulação de problemas mais precisos ou hipóteses pesquisáveis para estudos posteriores. Para Zikmund (2000), os estudos exploratórios, geralmente, são úteis para diagnosticar situações, explorar alternativas ou descobrir novas ideias.

Para realização desta pesquisa utilizamos inquéritos fechados compostos por três perguntas para que os estudantes da disciplina de Geografia respondessem sobre a frequência quanto à utilização dos recursos de aprendizagem em suas atividades, o impacto quanto à utilização das TIC na escola e as aulas de preferência dos alunos. Posteriormente eles criaram mapas que representavam as principais limitações enfrentados por sua comunidade para o exercício da cidadania.

\subsection{Resultados das atividades realizadas}

Os gráficos abaixo referem-se aos resultados dos inquéritos aplicados nas escolas de Fortaleza. 
Figura 2 - Frequência de utilização dos recursos didáticos em atividades escolares

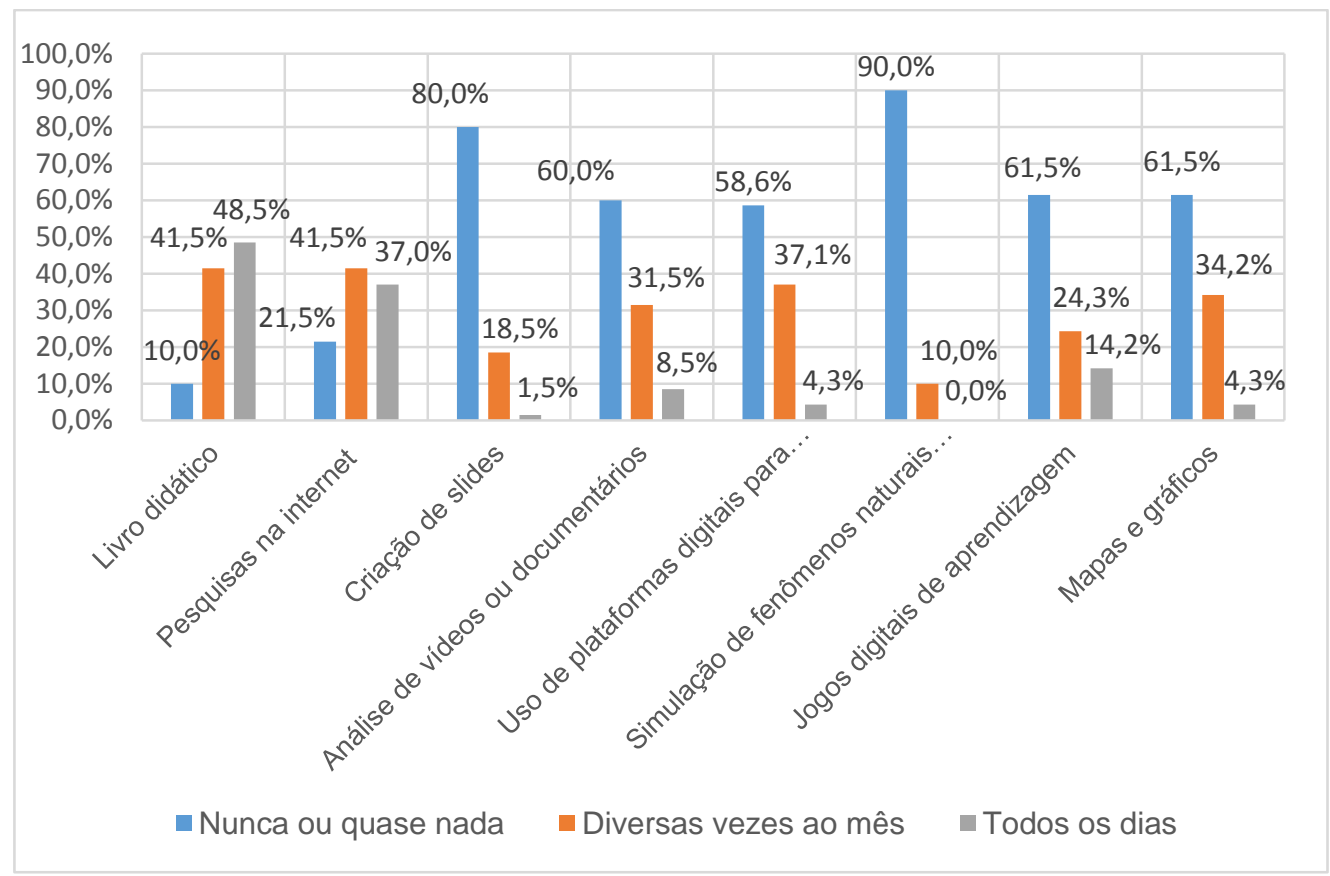

Fonte: elaboração própria

A partir do exposto podemos verificar que o livro didático é o recurso utilizado de maneira mais frequente pela maioria dos alunos, entretanto $10 \%$ deles nunca usam o livro didático em suas atividades escolares, mesmo os possuindo, pois, todos os livros são entregues a todos os alunos no início do ano letivo. assim como uso da internet para pesquisas acontece de forma mais rotineira, porém há um percentual de $21,5 \%$ dos alunos que nunca ou quase nunca usaram a internet como recurso didático o quadro se agrava quando nos referimos à criação de slides, pois $80 \%$ dos estudantes nunca ou quase nunca utilizaram criaram slides em suas atividades didáticopedagógicas, refletindo no pouco uso dos recursos tecnológicos, tal fato também se repete quanto à análise de vídeos ou de documentários, pois identificamos que $60 \%$ dos estudantes nunca ou quase nunca fizeram análise de vídeos, no que concerne às plataformas digitais o percentual é praticamente o mesmo quanto à análise de vídeos, refletindo na baixíssima utilização das plataformas digitais para resolução de atividades, o pior se verifica quando observamos a simulação de fenômenos naturais ou humanos, em que apenas $10 \%$ dos alunos já fizeram uso deste recurso, o mesmo ocorre com a análise de vídeos ou documentários e no uso das plataformas digitais, porém o quadro se agrava com a simulação de fenômenos naturais pois $90 \%$ nunca ou quase nunca fez ou participou de simulações de fenômenos naturais, já 61,5\% dos alunos nunca ou quase nunca participaram de jogos digitais de aprendizagem e no 
que diz respeito à análise de mapas e gráficos mais de $61,5 \%$ dos alunos das escolas pesquisadas de Fortaleza nunca ou quase nunca realizaram esta atividade.

Dessa forma, verificamos que há problemas de infraestrutura de apoio ao uso dos recursos tecnológicos, além da subutilização dos recursos didáticos pedagógicos e pouca inovação das metodologias de trabalho, havendo a necessidade de renovação das práticas docentes, para implementação de novos modelos de ensino e aprendizagem apoiados no uso das TIC (ÁREA et al ,2010).

\section{Figura 3 - Você considera a utilização das TIC durante as aulas e para a realização de atividades um} impacto positivo? Por quê?

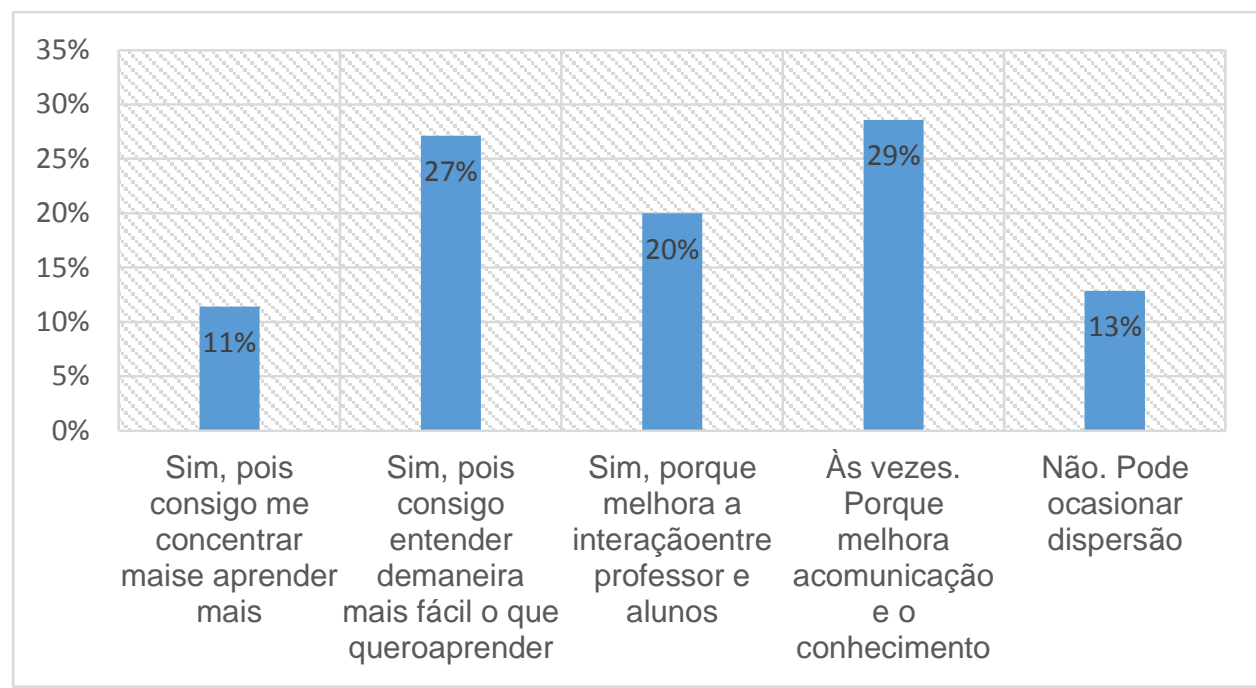

Fonte: elaboração própria

No que se refere aos impactos provocados pelas TIC, identificamos que $11 \%$ dos alunos pesquisados consideram que a utilização das TIC para realização de atividades escolares gera impacto positivo, pois conseguem ter maior concentração e maior aprendizagem, já $27 \%$ dos estudantes pesquisados declararam que as TIC possuem impacto positivo porque auxiliam na compreensão dos conteúdos. Há um percentual de $20 \%$ dos estudantes inquiridos que julga as TIC com potencial para melhorar a interação entre professor e alunos, já $29 \%$ dos alunos consideram que às vezes as TIC melhoram a comunicação e o conhecimento, sendo um impacto positivo, contudo $10 \%$ dos estudantes acreditam que as TIC não possuem impacto positivo por ocasionar a dispersão, provocando a indisciplina, consequentemente atrapalhando no aprendizado. 
Figura 4 - Quais as aulas de sua preferência?

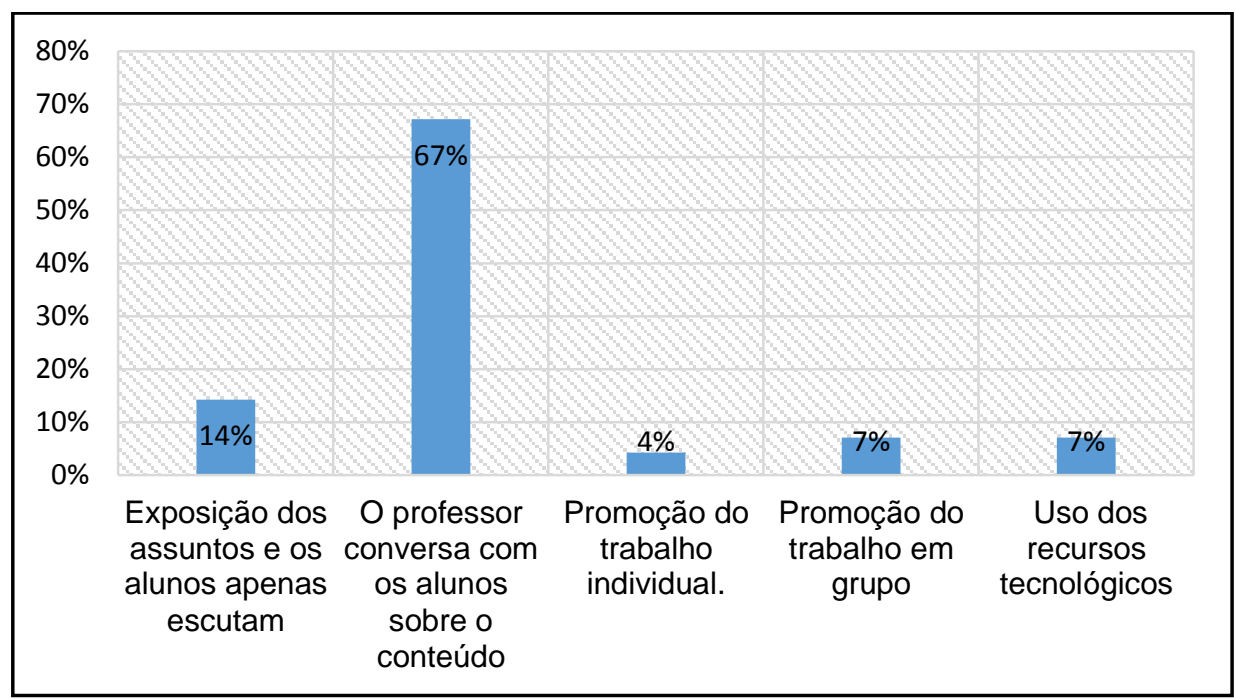

Fonte: elaboração própria

A última questão diz respeito às aulas apontadas preferencialmente pelos alunos e $14 \%$ deles preferem aulas tradicionais, em contrapartida $67 \%$ dos alunos pesquisados têm preferência por aulas em que o docente expõe o conteúdo e conversa sobre o tema, nesse sentido há uma maior interação entre os sujeitos da aprendizagem. Apenas $4 \%$ dos estudantes têm predileção por aulas em que ocorre a promoção do trabalho individual e 7\% escolheram as aulas em que ocorre a promoção do trabalho em grupo e o mesmo percentual se repete nas aulas em que usa-se os recursos tecnológicos. Nesse caso, as escolas apresentaram problemas com a infraestrutura dos recursos apresentados.

\subsection{Pesquisa: Fase 2}

A segunda etapa da pesquisa consistiu em relacionar o uso das TIC na Educação Geográfica e seus reflexos na cidadania espacial e consistiu fundamentou-se na utilização do Google Maps para localizar a morada dos estudantes e o uso de softwares para retratar, através de símbolos, a falta de políticas públicas para o exercício da cidadania a falta de políticas públicas para o exercício da cidadania e a leitura de textos sobre o tema em análise. 
Figura 5 - A falta de políticas públicas para o exercício da cidadania
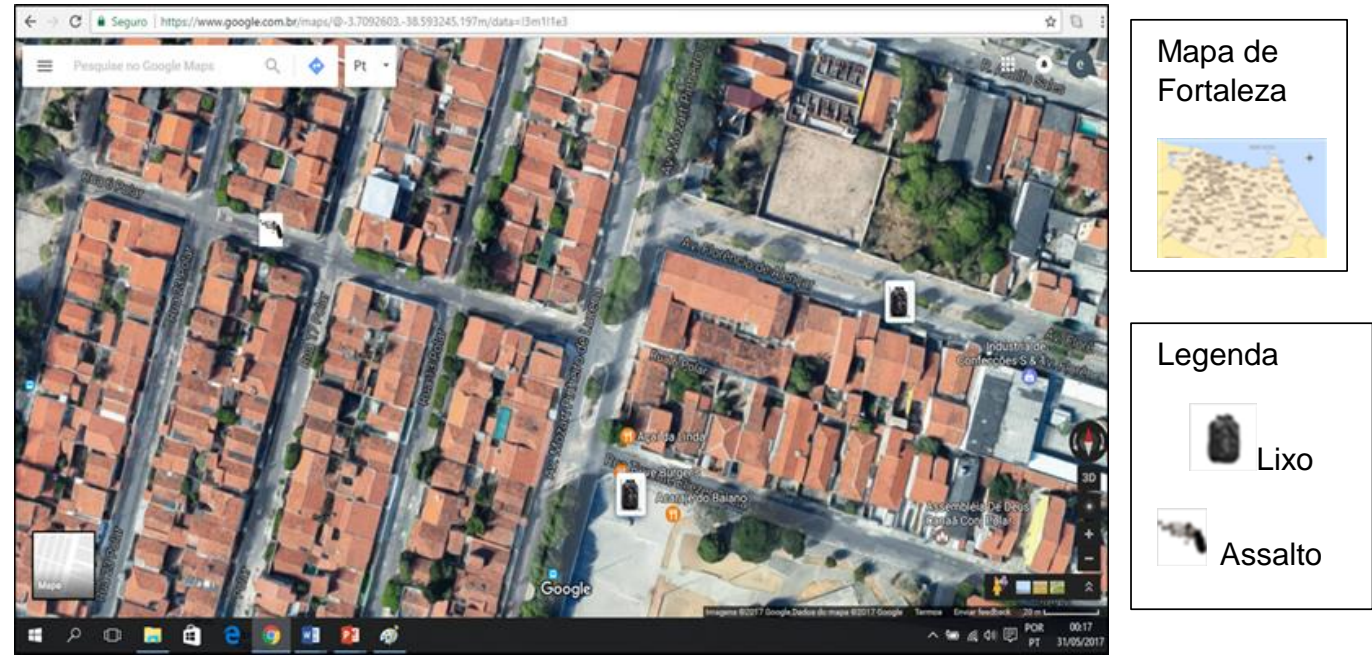

Fonte: www.google.com.br/maps/@-3.7092603-38.593245.197m/data=J3m1/1e3,2017

Figura 6 -

para 0

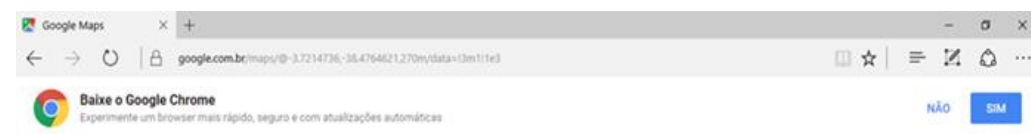

As limitações

cidadania

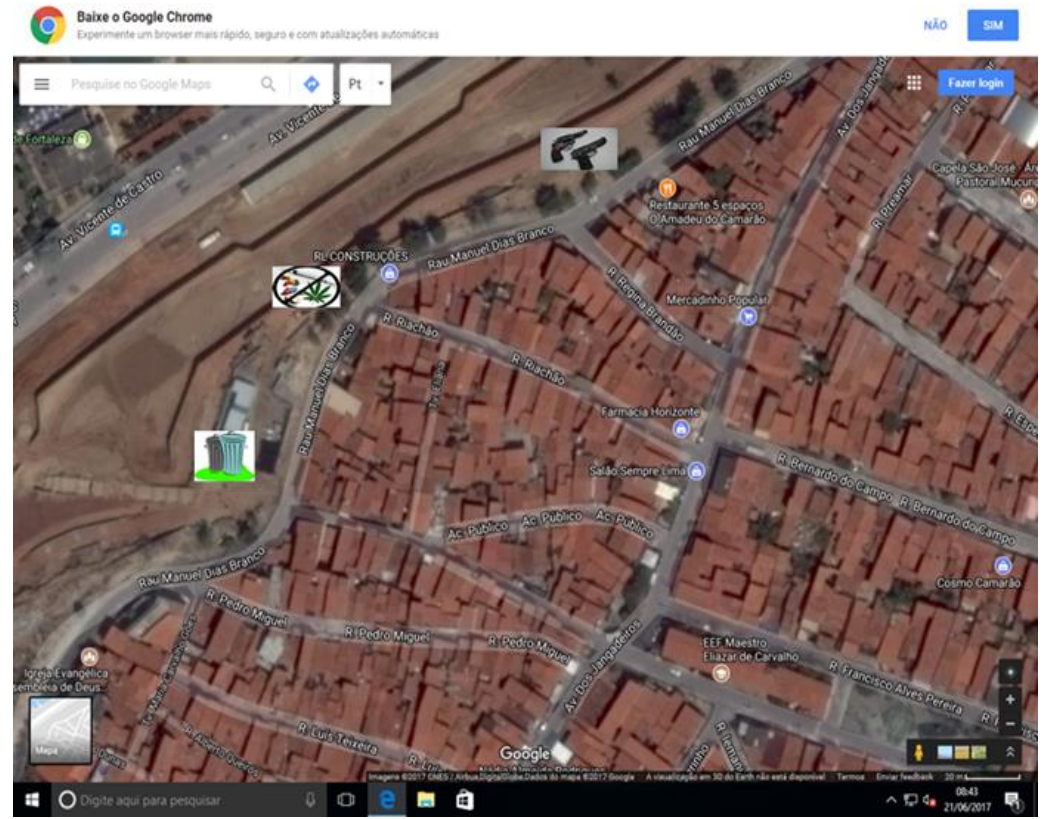

\section{Mapa de}

Fortaleza

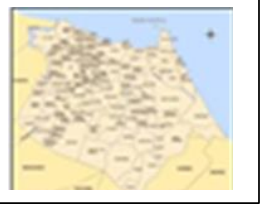

Legenda:

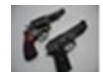

Assalto

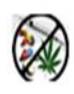

Drogas

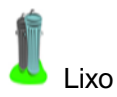

Fonte: www.google.com/maps/@-3.7265484-38,4772968,470m data=J3m1/

A partir do exposto, verifica-se a vivência dos alunos com a cidadania espacial, em que os mesmos consideraram que a cidadania está relacionada com seu direito de ir e vir, tendo este direito muitas vezes impedido devido à problemática local, detectando a ineficiência das atuais políticas públicas para o exercício da cidadania.

Com o objetivo de associar as TIC, educação geográfica e cidadania, os estudantes i) identificaram os problemas que mais afetam suas comunidades, ii) os localizaram 
pontualmente através do Google Maps, iii) desenvolveram mapas utilizando as ferramentas tecnológicas para criação de símbolos que representassem objetivos nos mapas, iv) fizeram suas exposições em redes sociais e propuseram criação de um aplicativo que visasse contribuir e ao mesmo tempo se beneficiar de um "bem em comum", alertando à população sobre violência no local, mostrando caminhos alternativos, para minimizar os efeitos da violência, além indicar os serviços locais, e mostrar os lugares de real destino do lixo. Dessa forma, tentariam mudar a realidade posta ou mitigando os efeitos da ineficiência das políticas públicas locais.

Askins \& Fuller (2008) afirmam que ensinar e aprender sobre cidadania exige a adoção de relação entre as pessoas em seu contexto espacial, local e ambiental - e a geografia está posicionada para empreender esta função na educação. Num texto da Thematic network for Geography in higher education meeting (2009), destaca-se a Geografia como ciência que prepara cidadãos ativos espacialmente conscientes. Ela permite que os alunos desenvolvam uma consciência da relevância das questões em diferentes escalas, desde a escala local até o mundo globalizado.

\section{Considerações finais}

O trabalho desenvolvido permitiu chegar a algumas reflexões importantes. A primeira, é que as TIC ainda são pouco utilizadas em sala de aula, mesmo sendo importantes no sentido de desenvolver um ensino mais motivante, com maior comunicação e facilitando a aprendizagem. A utilização eficaz das TIC implica no desenvolvimento de novas metodologias de trabalho, propiciando uma alteração na forma de ensinar (Almeida e Valente, 2011) - e este é talvez um dos desafios mais importantes a vencer na maioria das disciplinas escolares e também pelos professores de Geografia, pois devem estar abertos para pensar processos diferentes que também possibilitem a construção do conhecimento (Kenski, 2002).

O que a investigação exploratória demonstrou é que a utilização das TIC em sala de aula ainda não ocorre de maneira frequente, por vezes por falta de infraestrutura adequada, outras pelo fato de os professores não terem o domínio das ferramentas tecnológicas. Tendo sido uma experiência no âmbito das temáticas da Geografia escolar, também ficou evidenciado que a Geografia tem muito a beneficiar com a utilização das TIC.

O que parece claro é o fato de ao desenvolver a utilização das TIC na escola (e na disciplina de Geografia) e a cidadania espacial está-se a contribuir para o 
desenvolvimento de competências de localização e atuação no espaço muito importantes para a formação de cidadãos mais informados, tal como é preconizado nos documentos orientadores da introdução das TIC no ensino

\section{Referências bibliográficas}

Almeida, M. E. (2008). Educação e tecnologias no Brasil e em Portugal em três momentos de sua história. Educação, Formação \& Tecnologias, 1(1), 23-36.

Almeida, M. E., \& Valente, J. A. (2011). Tecnologias e currículo: trajetórias convergentes ou divergentes? São Paulo: Paulus.

Almeida, M.E, Silva, B.E., \& D’água, S. (2017). Ensino Secundário e TIC: uma reflexão sobre a Educação em Portugal, Revista Educação em Questão. V. 55, n. 44, p. 191215.

Area, M., González, D., Cepeda, O., \& Sanabria, A. (2010). Un análisis de las actividades didácticas con TIC en aulas de educación secundaria. Pixel-Bit Revista de Medios y Educación, 38, 187-199.

Askins, K. \& Fuller, D (2008). Citizenship and geography _the 'geographies of citizenship‘_Geography and Environmental Management; Northumbria University.

Belloni, M.L. (2005). O que é mídia-educação (2 ed.). Campinas: Autores Associados.

Bonilla, M.H (2010). Políticas Públicas para a Inclusão Digital nas Escolas. Motrivivência. 34, 40-60.

Bonilla, M. H. S., \& Pretto, N. L.(2000) Políticas Brasileiras de Educação e Informática. Disponível em: < http://www2.ufba.br/ bonilla/politicas.htm> Acessado em 01/02/2017.

Brasil. (1997) Ministério da Educação - Secretaria de Educação a Distância. Programa Nacional de Informática na Educação - Proinfo. Brasília.

Callai, H., \& Santos, M.F. (2009). Tecnologias de informação no ensino da geografia. In $10^{\circ}$ Encontro Nacional da Prática do Ensino em Geografia, Porto Alegre/Br.

Carlos, V. (2015). Tecnologias de informação geográfica e a promoção do pensamento crítico espacial. Tese de doutoramento, Universidade de Aveiro, Aveiro. 
Freeman, D. (1997). Using information technology and new technologies in geography. Teaching and and learning geography, 202-217

Gesser, V. (2012). Novas tecnologias e educação superior: avanços, desdobramentos, implicações e limites para a qualidade da aprendizagem. Revista Iberoamericana de Informática Educativa, 16, 23 -31.

Gil, A. C. (2008). Métodos e técnicas de pesquisa social (4 ed.). São Paulo: Atlas.

Imbernóm, F. (2010). Formação docente e profissional: formar-se para a mudança e a incerteza. São Paulo: Cortez.

Kenski, V. M.(2002) Educação e tecnologias: o novo ritmo da informação. Campinas: Papirus.

Miranda, G. L. (2007). Limites e possibilidades das TIC na educação. Disponível em <http://sisifo.fpce.ul.pt>. Acessado em 31/05/2016.

Moraes, M. C. Subsídios para fundamentação do Programa Nacional de Informática na Educação (Proinfo). Disponível em:<http://www. dominiopublico.gov.br/pesquisa/ DetalheObraForm.do?select_action=\&co_obra=22150 >. Acessado em 05/09/2017.

Moran, J. (2012). A educação que desejamos: novos desafios e como chegar lá. 5á ed. Campinas: Papirus.

Nascimento, J. (2007) Histórico da Informática Educativa no Brasil. Unidade 1. Brasília: Universidade de Brasília.

Ricoy, M. C (2005) Utilización de los recursos y medios de comunicación social en la educación. Revista Perspectiva, v. 23 (1).

Ricoy, M. e Couto, M. (2012). Os recursos educativos e a utilização das TIC no Ensino Secundário na Matemática. Revista Portuguesa de Educação, 25(2), pp.241-262.

Salgueiro, M.G. (2013). Um olhar sobre as TIC no ensino do Português: conceções e práticas docentes no Concelho de Almada. Dissertação de Mestrado. Universidade de Lisboa.

Silva, M. (2001). Sala de aula interativa: a educação presencial e a distância em sintonia com a era digital e com a cidadania. In Congresso Brasileiro da Comunicação, Campo Grande/Brasil. 
Thematic network for Geography in higher education meeting (2009). Citizenship in higher education geography: a draft benchmark statement. Herodot, Dublin, Ireland. March 2009.

UNESCO (2016) Educação e tecnologias no Brasil: um estudo de caso longitudinal sobre o uso das tecnologias de informação e comunicação em 12 escolas públicas.

<<http://cetic.br/media/docs/publicacoes/7/EstudoSetorialNICbr_TIC-

Educacao.pdf $>>$ Acessado em 24/02/2017

Zikmund, W. G. (2000). Business research methods. 5.ed. Fort Worth, TX: Dryden. 


\section{A importância do Projeto Nós Propomos para uma cidadania participativa}

FILOMENA CLEMENTE ${ }^{1}$

\section{Resumo}

Este artigo pretende refletir sobre o contributo do Projeto Nós Propomos para 0 desenvolvimento de competências enunciadas no perfil dos alunos do século XXI, documento de referência recente publicado pelo Ministério da Educação de Portugal (26 de julho de 2017). No $11^{\circ}$ ano do Ensino Secundário, na disciplina de Geografia $A$, em Portugal, realiza-se um "Estudo de Caso". Assim, o Projeto "Nós Propomos! Cidadania, Sustentabilidade e Inovação na Educação Geográfica" concretiza a implementação do Estudo de Caso, aproxima os alunos à autarquia e ao respetivo Plano Diretor Municipal/PDM, sensibiliza para os problemas territoriais locais, motiva para a elaboração e apresentação de propostas de intervenção local e, por último, estimula a cooperação entre, a escola e entidades públicas e privadas. Por último, far-se-á uma retrospetiva da participação no Projeto Nós Propomos desde o primeiro ano em 2011/2012, o primeiro lugar no ano letivo de 2015/2016 e a participação no último ano de 2017/2018, no Agrupamento de Escolas Ibn Mucana, município de Cascais, distrito de Lisboa. E ainda, uma reflexão da importância da implementação do Projeto para os alunos, mas também, para a motivação dos professores e ainda, para a visibilidade e notoriedade da Escola, quer a nível local, nacional e também a nível internacional.

Palavras-chave: Inovação Educacional; Educação Geográfica; Cidadania Participativa; Projeto Nós Propomos.

\footnotetext{
${ }^{1}$ Research Assistant Climate Change and Environmental Systems - ZEPHYRUS, Centro de Estudos Geográficos/IGOT-Universidade de Lisboa. Professora de Geografia no Agrupamento de Escolas Ibn Mucana, filomenaclemente@gmail.com
} 


\section{Abstract}

The present research aims to reflect on the contribution the "We Proposed Project" for the development of competences enunciated in 21st century students profile, a recent document published by the Portuguese Ministry of Education (july 26, 2017). In the 11th year of Secondary Education, in Geography A discipline, in Portugal, a "Case Study". Thus, the We Proposed! Citizenship, Sustainability and Innovation in Geographic Education Project concretizes the implementation of the Case Study, brings the students closer to the municipality and the respective Municipal Master Plan (PDM), sensitizes local territorial problems, motivates the preparation and presentation of proposals for local intervention and, finally, it encourages cooperation between the school and public and private entities. Finally, a retrospective of the participation in the We Proposed Project from the first year in 2011/2012, the first place in 2015/2016 and the participation in the last year of 2017/2018, in Agrupamento de Escolas Ibn Mucana, Cascais Municipality, Lisbon district. Also, a reflection on the importance of implementing the Project for students, but also for the teacher's motivation and also for the visibility and notoriety of the School, both locally, nationally and also internationally.

Keywords: Educational Innovation; Geographic Education; Citizenship Participation; Project We Proposed.

\section{Introdução}

O presente artigo pretende refletir sobre o contributo do Projeto Nós Propomos para o desenvolvimento de competências enunciadas no perfil dos alunos do século XXI.

A metodologia utilizada para atingir o propósito deste trabalho baseou-se na pesquisa bibliográfica, na experiência acumulada com a implementação do projeto Nós Propomos ao longo de quatro anos, na Escola Básica e Secundária Ibn Mucana em turmas do décimo primeiro ano e ainda, nas reflexões e debates de temas que envolvem os problemas dos alunos.

Far-se-á uma retrospetiva da participação no Projeto Nós Propomos desde o primeiro ano em 2011/2012, o primeiro lugar no ano letivo de 2015/2016 e a participação no último ano de 2017/2018.

Por último, uma reflexão da importância da implementação do Projeto para os alunos, mas também, para a motivação dos professores e ainda, para a visibilidade e notoriedade da Escola, quer a nível local, nacional e também a nível internacional. 


\section{Diversidade e diferenciação curricular}

Com a massificação do ensino as questões da diversidade tornam-se pertinentes para uma redefinição das práticas de inclusão social e de integração escolar. Segundo F. Sousa (2007) a construção de novas pedagogias e métodos de trabalho põe definitivamente em causa a ideia de um modelo escolar único e unificado.

Por outro lado, os desafios colocados pelas novas tecnologias têm vindo a revolucionar o dia-a-dia das sociedades e das escolas. Mas, segundo Manuel Castells, o essencial reside na aquisição de uma capacidade intelectual de aprendizagem e de desenvolvimento, o que coloca os professores no centro da "nova pedagogia" (2001, p. 278). Para isso, considera-se fundamental que os professores entendam ser prioritário uma aposta na sua formação ao longo da vida.

A diferenciação é igualmente vista como um meio de atenuar as dificuldades dos alunos "com necessidades especiais". A escola, bem como os docentes preocupam-se com estes alunos, integrando as problemáticas específicas numa visão mais ampla. $\mathrm{E}$ assim, a pedagogia diferenciada torna-se um meio de prevenção do abandono escolar precoce (Feyfant, 2012).

Ao identificarmos a necessidade de diferenciação surge a necessidade de desenvolver trabalho de projeto. Já em 1968 John Dewey referia o poder de conceber projetos com a liberdade, idêntica ao autocontrolo, porque a conceção dos fins e a organização dos meios são um trabalho de inteligência. Assim, consideramos que o trabalho de projeto é fundamental, quer para os alunos, quer para os docentes no processo de ensinoaprendizagem.

Um projeto autêntico deve encontrar o seu ponto de partida no impulso do educando e pressupõe a visão de um fim e uma previsão das consequências que resultariam da ação. Segundo Dewey (1968) a formulação de um projeto é uma operação intelectual bastante complexa e implica: a observação do território; o conhecimento produzido no passado e a avaliação das observações.

Assim, como já tinha sido referido por Dewey (1968), não deveremos esquecer que devemos, em primeiro lugar estar atentos às aptidões, às necessidades e às experiências vivenciadas pelos alunos e, depois, desenvolver propostas que se traduzam num projeto que seja elaborado pelo grupo de trabalho. Este deverá ser um trabalho cooperativo, com sugestões do professor e contribuições de todos os que integram o grupo e que se empenham numa experiência educativa. Pretende-se que 
haja uma troca reciproca entre professor e alunos desenvolvendo o projeto num processo de inteligência socializada.

\section{O perfil do aluno do século XXI}

O Perfil dos Alunos à Saída da Escolaridade Obrigatória, homologado pelo Despacho $n^{\circ}$ 6478/2017, 26 de julho, afirma-se como referencial para as decisões a adotar por decisores e atores educativos ao nível dos estabelecimentos de educação e ensino e dos organismos responsáveis pelas políticas educativas, constituindo-se como matriz comum para todas as escolas e ofertas educativas no âmbito da escolaridade obrigatória, designadamente ao nível curricular, no planeamento, na realização e na avaliação interna e externa do ensino e da aprendizagem.

Despacho no 6478/2017

Segundo Guilherme de Oliveira Martins (2017), a educação para todos, consagrada como primeiro objetivo mundial da UNESCO, obriga à consideração da diversidade e da complexidade como fatores a ter em conta ao definir o que se pretende para a aprendizagem dos alunos à saída dos doze anos da escolaridade obrigatória. Perante os outros e a diversidade do mundo, a mudança e a incerteza, temos de formar pessoas autónomas e responsáveis e cidadãos participativos.

Figura 7 - O perfil do aluno do século XXI à saída da escolaridade obrigatória.

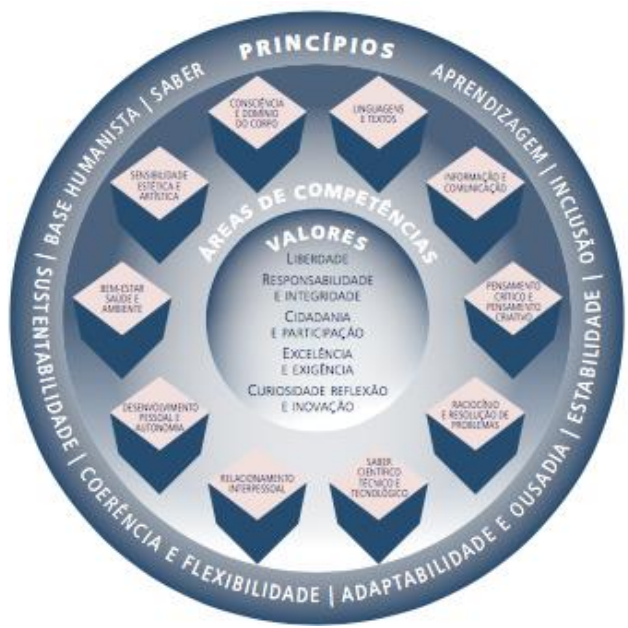

Fonte: https://dge.mec.pt/sites/default/files/Noticias_Imagens/perfil_do_aluno.pdf

A 26 de julho de 2017 o despacho $n^{\circ} 6478$ define o novo perfil dos alunos à saída da escolaridade obrigatória (figura 1) e pressupõe alterações de práticas pedagógicas e 
didáticas de forma a se adaptar às finalidades do perfil de competências dos alunos (figura 2).

Figura 8 - Esquema conceptual de definição de competência

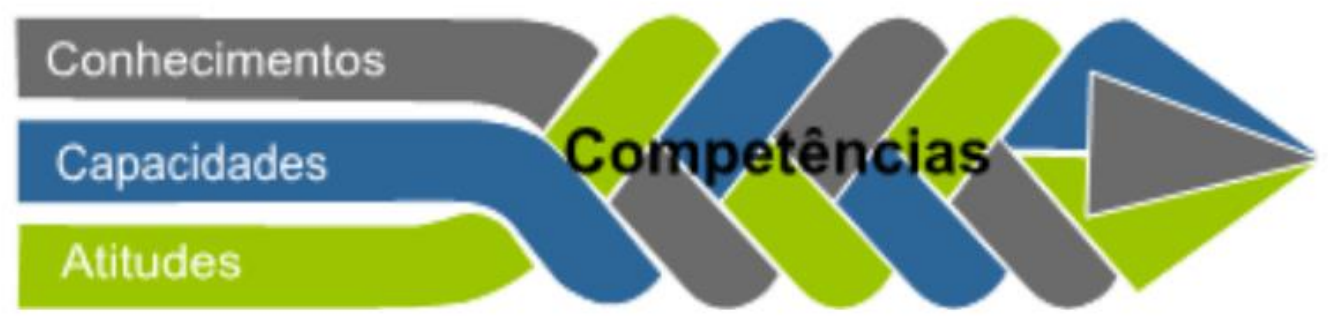

Fonte: https://dge.mec.pt/sites/default/files/Noticias Imagens/perfil do aluno.pdf

O referido documento apresenta um conjunto de ações que são determinantes para alcançar o perfil dos alunos do século XXI e muitas delas integram e são desenvolvidas com a implementação do Projeto "Nós Propomos". Destaca-se entre as várias ações as seguintes:

- Abordar os conteúdos de cada área do saber associando-os a situações e problemas presentes no quotidiano da vida do aluno ou presentes no meio sociocultural e geográfico em que se insere;

- Organizar o ensino prevendo a experimentação de técnicas, instrumentos e formas de trabalho diversificados, promovendo intencionalmente, atividades de observação, questionamento da realidade e integração de saberes;

- Organizar e desenvolver atividades cooperativas, orientadas para a integração e troca de saberes, a tomada de consciência de si, dos outros e do meio e a realização de projetos intra e extracurriculares;

- organizar o ensino prevendo a utilização crítica de fontes de informação diversas e das tecnologias da informação e comunicação;

- promover de modo sistemático e intencional, na sala de aula e fora dela, atividades que permitam ao aluno fazer escolhas, confrontar pontos de vista, resolver problemas e tomar decisões com base em valores;

- criar na escola espaços e tempos para que os alunos intervenham livre e responsavelmente;

- valorizar, na avaliação das aprendizagens do aluno, o trabalho de livre iniciativa, incentivando a intervenção positiva no meio escolar e na comunidade. 


\section{Projeto "Nós Propomos! Cidadania e Inovação na Educação Geográfica"}

O Projeto "Nós Propomos! Cidadania e Inovação na Educação Geográfica", é promovido pelo Instituto de Geografia e Ordenamento do Território da Universidade de Lisboa/IGOT, contando também com a colaboração da ESRI Portugal (Empresa privada de Sistemas de Informação Geográfica).

Há um apelo crescente à participação pública nas tomadas de decisão relativas ao ordenamento do território, numa perspetiva de governança e de cidadania territorial. Este apelo cruza-se com a preocupação em promover uma educação geográfica comprometida com o desenvolvimento sustentável e que ganha particular relevância à escala local.

Assim, o Projeto Nós Propomos, contribui para o desenvolvimento das competências enunciadas no perfil do aluno, com os seguintes objetivos:

i) promover uma ativa cidadania territorial junto da comunidade escolar;

ii) aproximar o poder local (Câmaras, Juntas de Freguesia) das comunidades, através da participação dos jovens e das suas escolas;

iii) contribuir para um desenvolvimento sustentável das localidades e dos municípios onde se desenvolve;

iv) valorizar o Estudo de Caso, quando contemplado no Programa, como trabalho experimental sobre problemas locais;

v) promover abordagens metodológicas inovadoras no âmbito do ensino da Geografia; vi) incentivar a atividade de investigação em Geografia;

vii) mobilizar alunos e professores para a utilização de tecnologias de informação, em estudos de âmbito prático;

viii) fomentar redes de cooperação entre atores locais, como universidades, escolas, autarquias, associações locais e empresas.

No $11^{\circ}$ ano do Ensino Secundário, na disciplina de Geografia A, em Portugal, realizase um "Estudo de Caso", que deverá privilegiar o trabalho de pesquisa na área de residência dos alunos. Assim, o Projeto Nós Propomos! Cidadania, Sustentabilidade e Inovação na Educação Geográfica concretiza a implementação do Estudo de Caso, aproxima os alunos à autarquia e ao respetivo Plano Diretor Municipal/PDM, sensibiliza para os problemas territoriais locais, motiva para a elaboração e apresentação de propostas de intervenção local e, por último, estimula a cooperação entre, a escola e entidades públicas e privadas. 
A Escola Ibn Mucana participa no Projeto Nós Propomos desde o primeiro ano de implementação do projeto, no ano letivo de 2011/2012, no ano letivo de 2015/2016, obteve o primeiro lugar e no ano de $2017 / 2018$, obteve o primeiro lugar em fotografia (figura 3).

Figura 9 - Participação da Escola Ibn Mucana no Projeto Nós Propomos

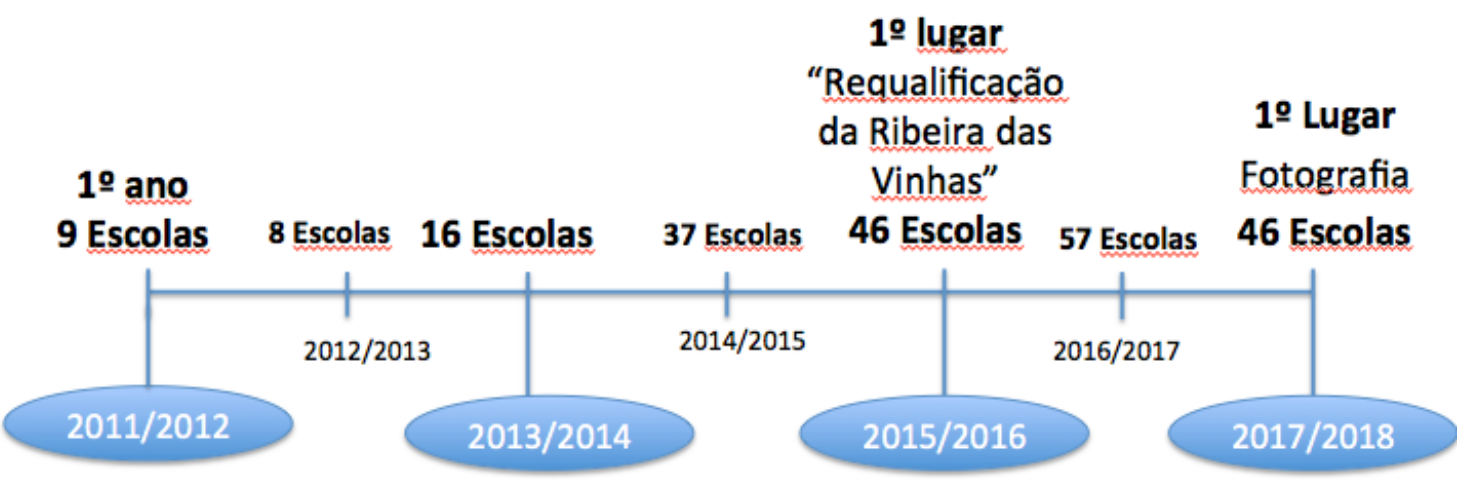

Fonte: Elaboração própria, 2018

Os alunos identificam um problema no território e fazem pesquisa bibliográfica sobre o tema. No segunda fase estabelece-se um protocolo de colaboração com a Câmara Municipal de Cascais que atribui técnicos em função da temática em estudo e que apoiam nas saídas de campo. Por último, os alunos indicam propostas de resolução, dos problemas identificados. O projeto vencedor no ano letivo de 2015/2016, "Requalificação da Ribeira das Vinhas", foi posteriormente implementado pela Câmara Municipal de Cascais. Os cinco alunos e a professora foram premiados com uma visita de estudo ao Parlamento Europeu em Bruxelas, a Paris e a Guernica.

Salientamos a importância da implementação do Projeto para os alunos, mas também, para a motivação dos professores e ainda, para a visibilidade e notoriedade da Escola, quer a nível local, nacional e também a nível internacional.

\section{Conclusão}

Assim, com a massificação do ensino/diversidade, com a necessidade de práticas de inclusão social e de integração escolar (decreto-lei no 55/2018 de 6 de julho), com as novas tecnologias de informação e comunicação, e o apelo crescente à participação pública nas tomadas de decisão relativas ao ordenamento do território, numa perspetiva de governança e de cidadania territorial, surge a necessidade de desenvolver trabalho de projeto, nomeadamente o Projeto Nós Propomos. 
A Implementação do Projeto Nós Propomos incentiva a consolidação de uma cidadania territorial em que os alunos desenvolvem um olhar crítico para o espaço que os rodeia construindo um saber geográfico a partir da reflexão, pesquisa e proposta de intervenção.

O projeto é determinante para alcançar muitas das ações previstas no perfil dos alunos do século XXl". Destacando-se entre as várias ações as seguintes: os conteúdos de cada área do saber devem estar associados a situações e problemas presentes no quotidiano da vida do aluno ou presentes no meio sociocultural e geográfico em que se insere; o ensino deve-se organizar prevendo a experimentação de técnicas, instrumentos e formas de trabalho diversificados, promovendo intencionalmente, atividades de observação, questionamento da realidade $\mathrm{e}$ integração de saberes; organizar e desenvolver atividades cooperativas, orientadas para a integração e troca de saberes, a tomada de consciência de si, dos outros e do meio e a realização de projetos intra e extracurriculares; e ainda, valorizar, na avaliação das aprendizagens do aluno, o trabalho de livre iniciativa, incentivando a intervenção positiva no meio escolar e na comunidade.

O Projeto é, ainda, fundamental para a motivação dos alunos e dos professores. E, por último, para a visibilidade e notoriedade da Escola, quer a nível local, nacional e também a nível internacional.

\section{Referências bibliográficas}

Castells, Manuel (2001). The internet galaxy. Oxford: Oxford University Press.

Dewey, J. (1968). Expérience et éducation, Paris: A. Colin, pp. 117-123. In E. Leite, Trabalho de projeto. (1990). Porto: Edições Afrontamento.

Feyfant Annie (2012). Enseignement primaire: les élèves à risque (de décrochage). Dossier de Veille de l'IFÉ, n 80 , décembre. Lyon: ENS de Lyon.

Sousa, F. (2007). Uma diferenciação curricular inclusiva é possível? Procurando oportunidades numa escola açoriana. In Fórum de Estudos de Educação Inclusiva, David Rodrigues (org.), "Investigação em Educação Inclusiva", vol. 2. Cruz Quebrada: Universidade Técnica de Lisboa - Faculdade de Motricidade Humana, p. 93-119.

Despacho no 6478 de 26 de julho de 2017. Retrieved from https://dge.mec.pt/sites/default/files/Noticias_Imagens/perfil_do_aluno.pdf 


\section{Nós Propomos! Estudo de caso na educação geográfica ${ }^{1}$}

GRACIELI DAIANE GNOATTO HRCHOROVITCH ${ }^{2}$

GELIANE TOFFOLO 3

\section{Resumo}

O Projeto "Nós Propomos! Geografia, educação e cidadania" se caracteriza como um estudo de caso realizado na educação básica por meio da Geografia. Está acontecendo desde 2017, na Escola Estadual Irmão Isidoro Dumont - Ensino Fundamental, no município de Itapejara D’Oeste, no estado do Paraná/Brasil, em uma classe do $7^{\circ}$ ano B, com 40 estudantes. Tem como objetivo investigar e identificar os problemas do espaço geográfico urbano e propor ações que viabilizem soluções para os mesmos. O projeto tem o propósito de contribuir significativamente para a formação cidadã, no desenvolvimento cognitivo dos estudantes, por meio do estudo dos problemas da cidade que, muitas vezes, são ignorados pelo poder público e pela comunidade em geral. A temática principal do projeto é de pensar a Geografia por meio da participação investigativa com os estudantes. No ano de 2017 foram desenvolvidas ações indicativas do projeto, sendo elas: 1) Identificação da escola, da turma, dos sujeitos da pesquisa; 2) Apresentação da proposta, o pedido de anuência, de consentimento da direção e da Secretaria de Estado da Educação do Paraná; 3) Apresentação da proposta para os dirigentes e estudantes; 4) Organização das equipes de trabalho, na escola; 5) Escolha do logotipo; 6) Definição dos temas da pesquisa; 7) Planejamento do trabalho de campo. Os resultados demonstram que os estudantes, as famílias e a comunidade estão envolvidos diretamente com a escola, no desenvolvimento do projeto. Isto despertou interesse nos participantes e os pais demonstraram satisfação e responsabilidade em contribuir na efetivação do Projeto.

Palavras-chave: educação geográfica, cidadania, lugar.

\footnotetext{
${ }^{1}$ Projeto orientado pela docente Mafalda Nesi Francischett da Universidade Estadual do Oeste do Paraná - UNIOESTE

2 Professora da Secretaria de Estado da Educação do Paraná - SEED, mestranda da Universidade Estadual do Oeste do Paraná - UNIOESTE, grazy_gh@hotmail.com

3 Docente da Universidade Estadual do Oeste do Paraná - UNIOESTE, geliane_unioeste@hotmail.com
} 


\section{Abstract}

The We Proposed Project! Geography, education and citizenship is characterized as a case study carried out in basic education through Geography. It has been happening since 2017, at the State School Isidoro Dumont - Elementary School, in the city of Itapejara D'Oeste, in the state of Paraná / Brazil, in a class of the 7th year B, with 40 students. Its objectives to investigate and identify the problems of urban geographic space and propose actions that allow solutions to them. The project aims to contribute significantly to citizen formation, in the cognitive development of students by studying of the problems of the city that, are often, ignored by public power and the community broad. The main theme of the project is to think about Geography by the investigative participation with the students. In the year 2017, were developed indicative actions of the project, being: 1) Identification of the school, the class, the research people; 2) Presentation of the proposal, the request for consent, consent of the direction and the Education Secretary of the Parana State ; 3) Presentation of the proposal for the leaders and students; 4) Organization of work teams in the school; 5) Logo choice; 6) Definition of research themes; 7) Field work planning. The results demonstrate that students, families and the community are directly involved with the school in the development of the project. This aroused interest in the participants and the parents showed satisfaction and responsibility in contributing to the project's effectiveness.

Keywords: geographical education, citizenship, place.

\section{Introdução}

O projeto "Nós Propomos! Geografia, educação e cidadania" surge como proposta de pesquisa e ensino desenvolvido em Itapejara D’Oeste/PR/Brasil, por meio de parceria entre a Prof. Doutora Mafalda Nesi Francischett (Universidade Estadual do Oeste do Paraná - UNIOESTE), no início do ano de 2017 e o Prof. Doutor Sérgio Claudino (Universidade de Lisboa - IGOT) e visa a troca de experiências na formação da cidadania.

O propósito é identificar os problemas da cidade, com base nos conteúdos geográficos com o $7^{\circ}$ ano (2017) e o $8^{\circ}$ ano (2018), da Escola Estadual Irmão Isidoro Dumont, no município de Itapejara D’Oeste/Paraná/Brasil. Assim, apresenta propostas elaboradas pelos estudantes e apresentadas ao poder público do município, por meio de colóquio na Câmara de Vereadores. Avalia como o estudo de Geografia e do lugar contribuem para a formação dos estudantes, principalmente os inseridos no projeto "Nós Propomos!". Isto significa estudar e reconhecer as possibilidades e limites de trabalhar 
conjuntamente escola-pais-comunidade-poder público, de modo a avaliar como o estudo do lugar e esta metodologia contribui para a formação dos estudantes para a cidadania.

A pesquisa aborda fatos, abordagens, dados, entrevistas e análises, que ajudaram a esclarecer os problemas do lugar, pois "[...] numa pesquisa qualitativa o foco é a profundidade, aprendendo fenômenos, trabalhando na perspectiva subjetiva, com dados obtidos por intermédio da observação livre, entrevistas semi-estruturadas, dentre os instrumentos" (Vasconcelos, 2010, p. 232).

A pesquisa se desenvolveu por meio de levantamento bibliográfico; entrevistas; relato de experiências práticas e análise de situações reais que ocorreram na escola. Busca, também, contribuir para a formação e integração dos estudantes, professores, escola, comunidade, envolvidos no processo. Nesse contexto, vinculamos o ensino de Geografia à realidade do estudante, sua participação efetiva nesse processo de formação da cidadania.

\section{Caracterizando o local da pesquisa}

O município de Itapejara D Oeste - PR, onde ocorre o projeto "Nós Propomos! Geografia, educação e cidadania", tem um território com desenvolvimento significativo na produção de grãos, principalmente de soja, milho e trigo, mas também de outros produtos agrícolas. Localiza-se entre os municípios de Bom Sucesso do Sul, Coronel Vivida, Francisco Beltrão, Pato Branco, São João e Verê, situado no Sudoeste do Paraná/Brasil, conforme sua localização no mapa a seguir. 
Figura 1 - Mapa da região Sudoeste do Paraná.

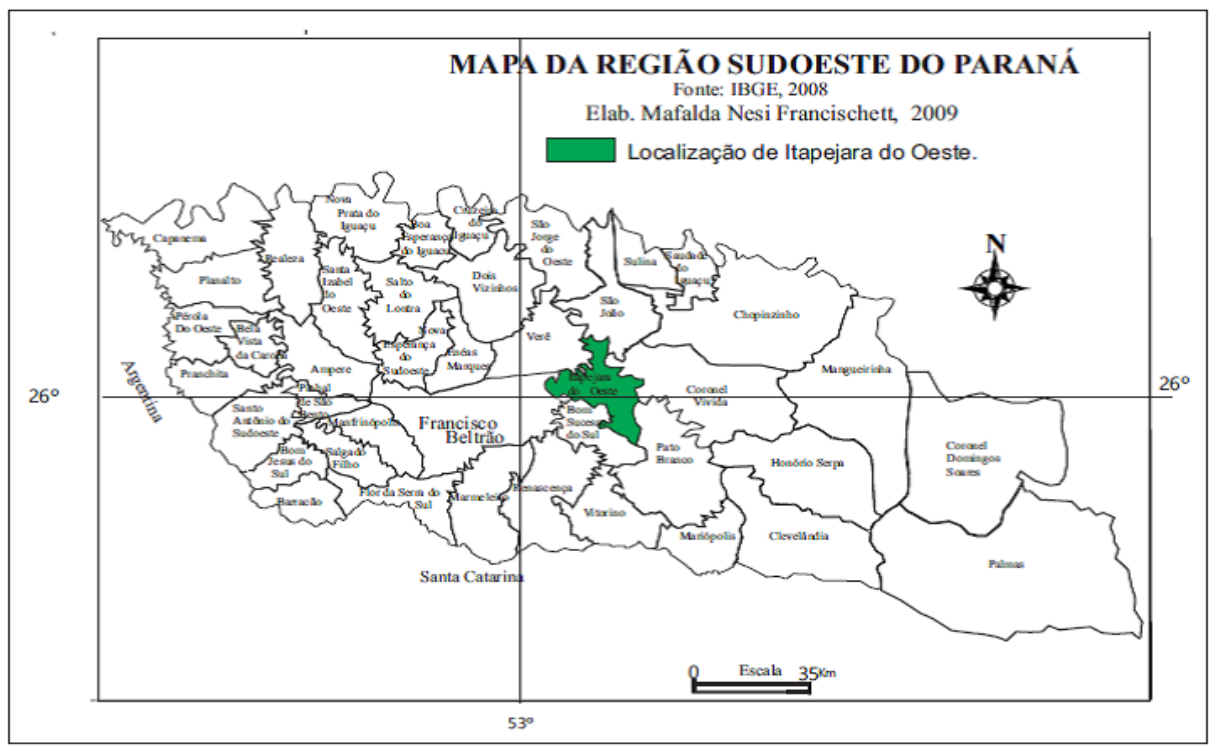

Sobre Itapejara do Oeste, Maycot (2001) comenta que em 1937 surgiu, no Sudoeste do Paraná, este lugarejo denominado de Lageado dos Guedes. Teve como primeiro morador o Sr. Simplício de Paula Guedes, embora seu desenvolvimento começou a ser percebido lá pelas décadas de 1950 e 1960, por ocasião da emancipação do município.

Com o passar do tempo o vilarejo expandiu, apareceram caminhos e isto possibilitou melhoria na vida de seus habitantes. Mas o maior problema era em relação à aquisição das terras, das propriedades.

Com o intuito de desenvolver o vilarejo e acabar com o problema referente a aquisição de terras, adotou-se como alternativa a toca dessas, entre o pioneiro José Moreira Soares e um dos primeiros moradores que apresentava resistência em ceder seus terrenos para a colonização. Uma vez solucionado o impasse, a área outrora permutada foi dividida em lotes e comercializada a preços moderados, além de algumas doações incentivando assim a vinda especialmente de migrantes gaúchos e catarinenses (Maycot, 2001, p. 15).

O primeiro nome oficial da vila foi Chá da Gralha, pertencente ao Distrito de Coxilha Rica. "Muitos pioneiros afirmam que essa estranha denominação inicial originou-se de uma disputa política entre os moradores dessas duas localidades, que brigavam pela instalação da cidade" (Maycot, 2001, p. 16). Havia disputa de onde seria a sede, a cidade: "Inicialmente Coxilha Rica era mais desenvolvida, por isso seus habitantes reclamavam junto as autoridades o direito desse distrito receber o título de município" (Maycot, 2001, p. 16).

Segundo Maycot (2001), a intenção dos moradores de Coxilha Rica, foi de que a sede, respectivamente a prefeitura, fosse construída nessa localidade. Porém, o proprietário 
das terras queria um valor muito alto pela venda das mesmas, obrigando os interessados a mudarem os planos e adquirirem os lotes na comunidade do Chá da Gralha, sendo que essa decisão contribuiu para o estabelecimento e pela fixação da área central urbana de Itapejara D’Oeste.

Por volta de 1950, o município passou por transformações que possibilitaram aos colonizadores fixarem residência. Assim, construíram uma escola, para atender a demanda e suprir as necessidades educacionais existentes na época. "Em 1949, sentindo a necessidade de atender a pequena demanda da população carente por uma verdadeira formação escolar, que até então era inexistente, um grupo de pessoas se uniram e decidiram pela criação de uma sociedade escolar. (Maycot, 2001, p. 16).

Os imigrantes chegaram de várias regiões do país, na busca de vida melhor para suas famílias e instalaram comércios no vilarejo. A economia se baseava na caça, pesca e na agricultura tradicional, para a subsistência das famílias e faziam trocas de suprimentos entre elas.

O progresso era nitidamente perceptível, dessa maneira em 1950 os moradores resolveram substituir o seu estranho nome inicial para Tapejara, sendo mudado posteriormente para Itapejara, devido existência de outra cidade paranaense que possuía a mesma denominação, além do que procuraram batizá-la de conformidade com uma característica própria do lugar. Percebeu-se então a grande presença de pedras no povoado e decidiram chamá-la de Itapejara, pois na língua tupi a palavra significa pedregulho ou caminho das pedras, sendo acrescentado em 51 o termo D’Oeste (Maycot, 2001, p. 17).

Segundo Maycot (2001), garantida pela Assembleia Legislativa do Estado, por meio da aprovação da Lei o 4.859, de 28 de abril de 1964, o território foi desmembrado de Pato Branco e de Francisco Beltrão. Instalado oficialmente em 14 de dezembro do mesmo ano. Na sequência, foram escolhidos (através de eleições) os mandatários, que exerceram essas funções de 1965 a 1968.

No ano de 1968, o destaque foi para a chegada dos Irmãos Maristas, que foram importantes para Itapejara D’Oeste, no impulso para a área educacional.

A intensa batalha travada em favor da área educacional, cultural, social, religiosa não parou, pois em 1968 aqui apontaram os Irmãos Maristas, destacando-se como percursores Beno Tomasoni (Diretor do ginásio em 1968 e novamente em 1985), Miguel Toukacz e Josefat Kmita, que contribuíram imensamente para o crescimento espiritual especialmente das crianças e jovens (Maycot, 2001, p. 24).

A chegada Marista foi festejada pela população, pela importância que essa instituição traria para a educação no lugar. Consta no Projeto Político Pedagógico (PPP) da Escola Estadual Irmão Isidoro Dumont (2016), que a tradição pedagógica Marista 
surge da experiência e da reflexão educativa desenvolvida por Marcelino Champagnat e os primeiros Irmãos Maristas, quando fundaram essa Congregação, em 02 de Janeiro de 1817, em La Valla, Sudeste da França.

A Escola nasceu de contribuições comunitárias dos pais, dos alunos, promoções, fundos provenientes como: eventos culturais, cinema, taxas, que a Associação Educacional, Cultural e Assistencial de Itapejara D’Oeste promovia. Em 1967, pelo Decreto no 4089 de 15 de Dezembro do mesmo ano, recebeu a devida autorização para o funcionamento pelo período de 2(dois) anos, com a denominação de Ginásio Agrícola. Em 06 de fevereiro de 1968, o Ginásio Agrícola existente na comunidade foi entregue à ABEC, que passaria a administrá-lo com o uso e usufruto ad perpetuam do terreno e prédio, uma vez que o imóvel, propriedade da Mitra Diocesana de Palmas, foi cedido aos Irmãos Maristas para a finalidade da educação (Paraná, 2016, p. 04).

A instituição passou por profundas transformações ao longo de sua história. Sua direção e orientação pedagógica ficaram em regime conveniado entre o estado do Paraná e a Associação Brasileira de Educação e Cultura - ABEC (Irmão Maristas). No ano de 1992, um diretor leigo assumiu a direção, o Professor Alcides Frandoloso. O nome da escola foi uma homenagem ao Irmão Isidoro Dumont.

[...] o qual, além de excelente professor, foi fundador da coleção didática da FTD o Brasil, autor de livros escolares, diretor de vários colégios e superior provincial dos Irmãos Maristas. Pelo decreto de no 20843, de 17 de Agosto de 1970, o estabelecimento passou a chamar-se Ginásio Estadual Irmão Isidoro Dumont, e foi reconhecido pela resolução ํㅡ 2.807 de 27 de Outubro de 1982 (Paraná, 2016, p.8).

Vale ressaltar que a Frère Théophane Durand (FTD) é uma empresa editorial, da qual os Irmãos Maristas fazem parte, e muitos livros trabalhados em suas instituições se vinculam a esta editora.

Em 1970, o nome da instituição mudou para Escola Estadual Irmão Isidoro Dumont. Nessa época houve, também, a introdução paulatina da reforma de ensino, onde as turmas de $1^{\underline{a}}$ a $4^{\underline{a}}$ séries foram renomeadas para $5^{\underline{a}}$ a $8^{\underline{a}}$ série do $1^{\circ}$ Grau. A escola mantém bom nível de ensino e se destaca regionalmente, como província Marista. Todos os seus professores possuem curso de Pós-Graduação e recebem constantemente formação dos Irmãos Maristas. A maioria dos professores foram exalunos da escola (Paraná, 2016).

A Escola Estadual Irmão Isidoro Dumont - E. F oferta, atualmente, o Ensino Fundamental e atende 558 estudantes (2017) em dois períodos - matutino e vespertino. Localiza-se na Rua Fernando Ferrari, $n^{\circ} 218$, no município de Itapejara D’Oeste - Paraná. A instituição se distância, aproximadamente $30 \mathrm{~km}$ do Núcleo Regional de Educação de Pato Branco e $30 \mathrm{Km}$ da Unioeste de Francisco Beltrão. A 
entidade mantenedora é o Governo do Estado do Paraná. O público que a instituição atende são estudantes dos anos finais do Ensino Fundamental, $6^{\circ}$ ano ao $9^{\circ}$ ano. A Instituição foi escolhida para desenvolvimento da pesquisa, pois é a maior do município a ofertar o Ensino Fundamental e, no ano de 2017, esta pesquisadora, exaluna e docente, o que facilitou, assim a implementação e condução do projeto.

\section{Parcerias com o projeto Nós Propomos!}

O Projeto Nós Propomos! Foi apresentado no início do ano de 2017, pela professora Doutora Mafalda Nesi Francischett (orientadora) como sendo uma proposta para ser desenvolvida ao longo do Programa de Pós-Graduação - mestrado em Geografia e teve como objetivo, analisar as possibilidades e os limites do ensino e aprendizagem do lugar, com base nos conteúdos geográficos e no Estudo de Caso.

O projeto foi acolhido como um grande desafio para trabalhar na escola. Foi organizado um grupo de trabalho e de estudos, que apoiou em todas as ações desenvolvidas no projeto. Antes de cada ação, o grupo se reunia e decidia conjuntamente como seria executada a ação desejada. Faz parte desse grupo a professora Doutora Mafalda Nesi Francischett (orientadora), Prof ${ }^{a}$. Doutora Geliane Toffolo (coorientadora), Ana Claudia Biz (Doutoranda) e Eliane Rozin (Mestranda).

O Projeto "Nós Propomos! Cidadania e Inovação na Educação Geográfica" surgiu em Portugal, no Instituto de Geografia e Ordenamento do Território da Universidade de Lisboa/IGOT-UL, em 2011/12, na disciplina de Geografia, e foi criado com o objetivo de dinamizar a realização do Estudo de Caso. Depois, o Projeto alargou-se a outros níveis e modalidades de ensino e a outros países, incluindo o Brasil. O projeto busca desafiar os estudantes a identificarem problemas locais, a realizarem trabalho de campo sobre os mesmos e a apresentarem propostas de solução para os mesmos, numa perspectiva de cidadania territorial (Francischett, 2017).

Segundo Claudino (2014) o projeto contribui para a inovação numa educação geográfica e na construção da cidadania territorial.

O Projeto "Nós Propomos! (original)" Aborda 14 tópicos princípios sendo eles: 1) Cidadania territorial; 2) Simplicidade metodológica; 3) Inclusão; 4) Construtivismo; 5) Diálogo/horizontalidade; 6) Afetividade; 7) Parcerias; 8) Valorização de diferentes competências; 9) Auto-emulação; 10) Multidisciplinaridade; 11) O trabalho em rede; 11) O trabalho em rede; 12) Mobilidade; 13) Investigação; 14) Divulgação (Francischett, 2017). 
O projeto tem eixos de ação com a participação dos estudantes como sujeitos do processo. Isto significa algumas etapas como: a) a identificação de problemas locais; b) o trabalho de campo; c) a apresentação de propostas de intervenção. Assim sendo, o propósito é de apontar e discutir as soluções dos problemas. Destaque para as principais fases: a) reunião com os docentes envolvidos; b) Assinatura de protocolos com as autarquias; c) Inscrição dos alunos no sítio do Projeto e do Facebook no sítio do Projeto (www.nospropomos.igot.ul.pt); d) Identificação dos problemas locais pelos estudantes (Francischett, 2017).

O artigo, aqui apresentado, faz parte do subprojeto "Nós Propomos! Ensino de Geografia", com significado na pesquisa na Unioeste/FB/PR, e segue as características do projeto original, mas considerando as especificidades da região Sudoeste do Paraná (Francischett, 2017).

Em outubro de 2017, o Prof. Doutor Sérgio Claudino visitou a Escola Estadual Irmão Isidoro Dumont, onde ocorreu a assinatura do Acordo de Cooperação entre o Instituto de Geografia e Ordenamento do Território da Universidade de Lisboa/IGOT-UL, a Universidade Estadual do Oeste do Paraná/Campus de Francisco Beltrão/UNIOESTE e a Escola Estadual Irmão Isidoro Dumont.

\section{Metodologias utilizada no projeto}

O estudo de caso se apresenta como um caminho para o desenvolvimento da pesquisa, em que fatos científicos raramente se baseiam em experimentos únicos; mas, num conjunto múltiplo de experiências sobre o fenômeno, sob condições diferentes. É uma estratégia utilizada em diferentes questões de interesse de estudo, quando se refere ao como e ao porquê. Quando o pesquisador tem pouco controle sobre os acontecimentos e fatos e o contexto pesquisado ele se dirige a um fenômeno contemporâneo, atual em um contexto natural, como exemplo: a escola (Yin, 2001).

Foi nesse contexto escolar que o artigo apresentado se desenvolveu e buscou, nessa metodologia, alicerces para aprimorar seu conhecimento.

Segundo Claudino (2014), ao observar a prática escolar nas escolas, o Estudo de Caso era esquecido, preferindo os professores centrar-se na aprendizagem dos conteúdos avaliados nos exames nacionais de Geografia, de onde estão ausentes o Estudo de Caso.

Cada estratégia utilizada pelo pesquisador proporciona vantagens e desvantagens em sua utilização. Segundo Yin (2001), existem, basicamente, três vantagens e 
desvantagens, sendo elas: o tipo de questão da pesquisa, o controle que o pesquisador possui sobre os eventos comportamentais efetivos, o foco em fenômenos históricos em oposição a fenômenos contemporâneos.

Em geral, os estudos de caso representam a estratégia preferida quando se colocam questões do tipo "como" e por que", quando o pesquisador tem pouco controle sobre os eventos e quando o foco se encontra em fenômenos contemporâneos inseridos em algum contexto da vida real (Yin, 2001, p. 19).

O estudo de caso contribui de forma ampla para a compreensão de fenômenos individuais, organizacionais, sociais e políticos, visando compreender fenômenos sociais complexos (Yin, 2001).

Em resumo, o estudo de caso permite uma investigação para se preservar as características holísticas e significativas dos eventos da vida real - tais como ciclos individuais, processos organizacionais e administrativos, mudanças ocorridas em regiões urbanas, relações internacionais e a maturação em alguns setores (Yin, 2001, p. 21).

Neste artigo, que tem o estudo de caso como metodologia, desenvolvido na Escola Estadual Irmão Isidoro Dumont, as ações foram construídas com os estudantes e com a equipe escolar, durante os dois anos de desenvolvimento da pesquisa. Isto é justificado por Yin (2001), ao afirmar que os estudos de caso utilizados no ensino não precisam se preocupar com a apresentação justa e rigorosa dos dados empíricos. Por isto, há flexibilidade na apresentação do contexto da pesquisa, neste trabalho. Buscando utilizar essa metodologia, o projeto "Nós Propomos! Geografia, educação e cidadania" iniciou em meados de Julho de 2017. Foi para a Escola, com o consentimento da direção e anuência da Secretaria de Estado da Educação SEED/PR, por meio da assinatura do termo de cooperação com o projeto "Nós Propomos! Geografia, educação e cidadania". A pesquisa iniciou em 2017 e continua em 2018, com as seguintes fases:

\section{Quadro 1 - Fases do projeto Nós Propomos! Itapejara D’Oeste /PR}

\begin{tabular}{|c|c|}
\hline Fases & Descrição \\
\hline $1^{\text {a }}$ Fase & $\begin{array}{l}\text { Identificação: da escola, da(s) turma(s), dos sujeitos onde foi acoplada a pesquisa. } \\
\text { Apresentamos a proposta e o pedido de anuência, de consentimento da direção. }\end{array}$ \\
\hline 2a Fase & $\begin{array}{l}\text { Apresentação da proposta para a Secretaria de Estado da Educação - SEED/ PR: } \\
\text { encaminhamos o projeto para a Secretaria de Estado da Educação - SEED pedindo } \\
\text { autorização para realizar pesquisa científica nas unidades vinculadas a SEED, conforme } \\
\text { instrução publicada no Diário Oficial no } 9.661 \text { de } 22 \text { de março de } 2016 \text {. }\end{array}$ \\
\hline 3a Fase & $\begin{array}{l}\text { Apresentação da proposta para os estudantes e "sondagem": discutiu-se os objetivos, a } \\
\text { metodologia e foram traçadas as diretrizes. }\end{array}$ \\
\hline 4a Fase & $\begin{array}{l}\text { Definição do tema do projeto: formação dos grupos (escola, universidade e alunos) para } \\
\text { definir o tema. }\end{array}$ \\
\hline 5a Fase & Organização das equipes para o trabalho: estabelecimento de metas e um cronograma; \\
\hline 6⿳亠口冋丁口 Fase & Escolha do logotipo: os grupos criaram um logotipo identificando-os. \\
\hline $7^{\mathrm{a}}$ Fase & $\begin{array}{l}\text { Planejamento do trabalho de campo: traçar um roteiro para a identificação dos } \\
\text { problemas. }\end{array}$ \\
\hline
\end{tabular}




\begin{tabular}{|c|c|}
\hline $8^{\text {a }}$ Fase & $\begin{array}{l}\text { Realização do trabalho de campo: os estudantes foram a campo, fotografaram, } \\
\text { filmaram... os espaços da área urbana previamente estabelecidos e identificados os } \\
\text { problemas. Escutaram a população e os comerciantes por meio de pequenos inquéritos } \\
\text { ou entrevistas. }\end{array}$ \\
\hline 9a Fase & $\begin{array}{l}\text { Apresentação do diagnóstico: Ocorreu a socialização do diagnóstico entre todos os } \\
\text { participantes. }\end{array}$ \\
\hline $10^{\mathrm{a}}$ Fase & $\begin{array}{l}\text { Elaboração de propostas pelos estudantes: os estudantes elaboraram as propostas que } \\
\text { visaram minimizar, resolver ou enfrentar os problemas do espaço urbano do município. }\end{array}$ \\
\hline 11' Fase & $\begin{array}{l}\text { Fórum de socialização: apresentação das propostas de intervenção para solução dos } \\
\text { problemas diagnosticados e estudados pelos estudantes para os demais estudantes, } \\
\text { direção, coordenação, pais e poder público. }\end{array}$ \\
\hline 12 Fase & $\begin{array}{l}\text { Auto avaliação do projeto: foi realizada uma auto avaliação com os estudantes e demais } \\
\text { membros da escola que participam do projeto, a universidade e os pais, a fim de que o } \\
\text { grupo pudesse fazer uma análise do projeto. }\end{array}$ \\
\hline $13^{a} F$ & s realizadas. \\
\hline 14ㄹ Fase & 9 \\
\hline
\end{tabular}

Elaborado pela autora, 2017.

A turma onde o projeto foi/está sendo aplicado é o $7^{\circ}$ ano B (2017), 8ํㅡ B (2018), período matutino, da Escola Estadual Irmão Isidoro Dumont/Itapejara D’Oeste/Paraná, com 35 estudantes, com idade entre 13 e 15 anos. No ano de 2017, em sala de aula, o projeto foi apresentado aos estudantes e as famílias tomaram consciência da participação e se comprometeram em ajudar seus filhos. Os estudantes se organizaram em seis grupos, que reuniram-se e escolheram o nome para os representar, também foi efetivada a escolha do logotipo para cada grupo. 0 grupo 01 escolheu como nome "Todos juntos por uma cidade melhor"; grupo 02 "Defensores dos animais"; grupo 03 "Olhar para o futuro"; grupo 04 "Winx a favor dos pets"; grupo 05 "Loucos da quebrada" e grupo 06 "Melhorando o mundo".

Os grupos representaram sua perspectiva em relação ao projeto Nós Propomos! Através dos logotipos, sendo eles: 
Figura 2: Representação do logotipo

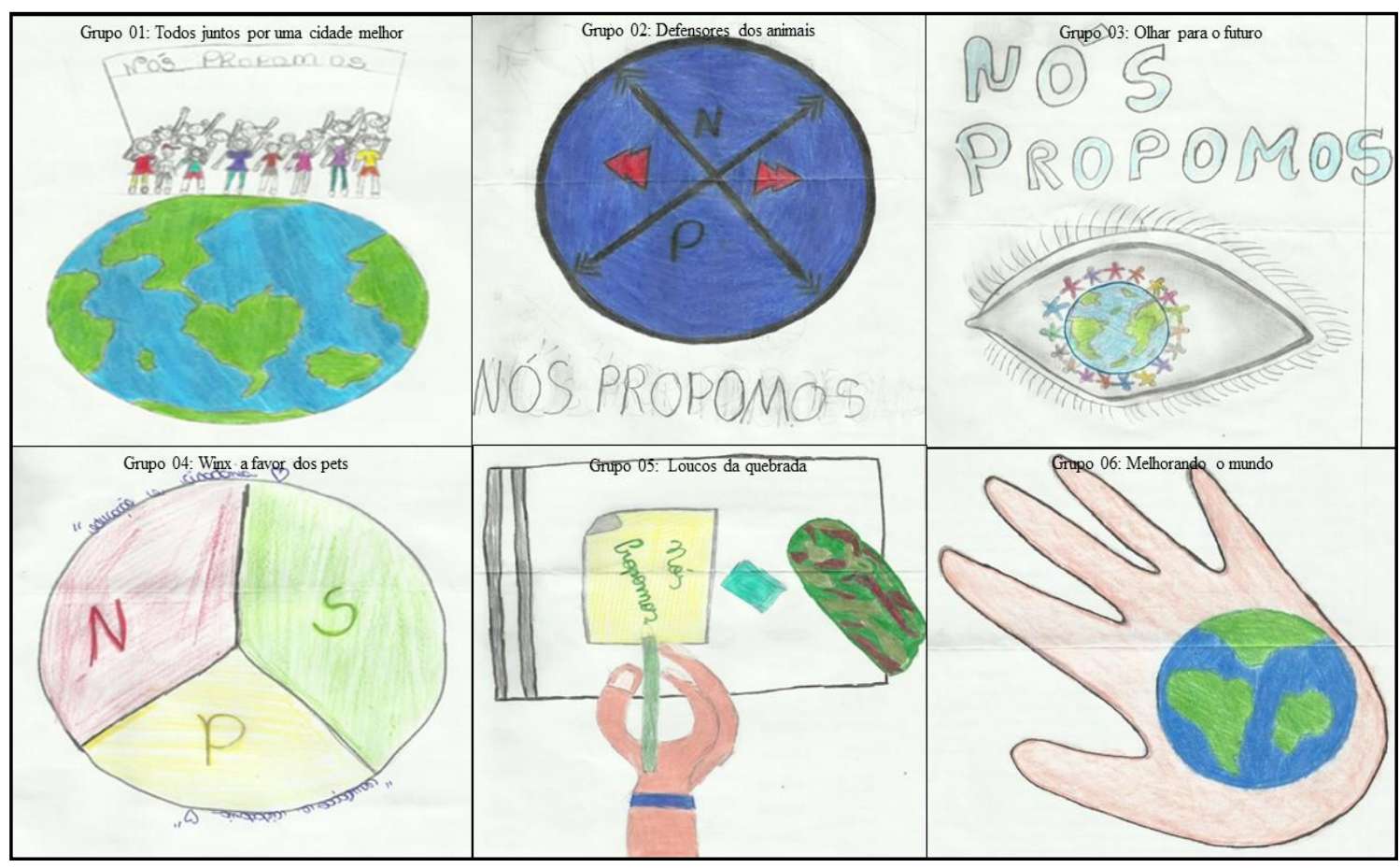

Fonte: Elaborado pelos estudantes, 2017.

Em relação ao logotipo, o grupo 01 colocou em evidência a necessidade de mudança na vida da sociedade e no planeta Terra. Ressaltou a importância de todos os lugares estarem envolvidos, ou seja, uma causa universal, mudar o mundo pela vida das pessoas.

O grupo 02 trouxe a seguinte perspectiva: "Nosso grupo representa partes do planeta Terra, que seriam a água e a Terra, que são representados pelas letras e símbolos". O planeta é representado pelo círculo azul, e as letras N e P representam "Nós Propomos".

Para os integrantes do grupo 03, o logotipo representa o olhar para o futuro da sociedade. O olho seria o planeta Terra e as pessoas juntas, de diversas cores, a diferença entre os seres humanos. O olhar das pessoas em relação às outras, sua perspectiva.

O grupo 04 buscou representar a paz, destacou a importância da mesma para a construção de um mundo melhor. O círculo representa o planeta Terra, e as letras $\mathrm{N}$, $\mathrm{S}$ e $\mathrm{P}$ seriam a sigla do "Nós Propomos". Destaque também a frase elencada no desenho; "educação e cidadania" com destaque para a paz. O grupo não definiu o motivo da utilização das cores: vermelho, verde e amarelo. 
Para o grupo 05, seus integrantes colocaram no logotipo a representação uma pessoa, escreveram para um mundo melhor, onde todos são importantes nessa construção. Não houve motivo para definição das cores, foram escolhidas aleatoriamente. Outra observação importante do grupo foi de que eles estavam em dúvida do que representar e em alguns momentos houve impasse para escolher o desenho que melhor os representaria, mas chegaram a um consenso e representaram em forma de mão e lápis sua perspectiva em relação ao projeto "Nós Propomos! Geografia, educação e cidadania".

Já o grupo 06 buscou representar o mundo: "Gostaríamos que as pessoas parassem para pensar no nosso planeta e no lugar onde vivemos". O planeta Terra é representado pelo círculo central e a mão representa a força que cada ser humano tem na construção de um mundo melhor.

Os grupos buscaram representar as suas perspectivas em relação ao projeto "Nós Propomos! Geografia, educação e cidadania", definiram imagens que pudessem melhor representá-los. Foi uma atividade importante para os estudantes, estimulando a trabalhar em grupo, tomar decisões coletivas, integrá-los com a finalidade do projeto.

Outro desafio encontrado foi definir o lugar da cidade onde os grupos desenvolveriam a pesquisa, o tema/problemática, e, o planejamento do trabalho de campo. Para isso trabalhamos o mapa urbano de Itapejara D'Oeste e o plano diretor do município. Cada grupo escolheu e definiu o lugar de atuação para o projeto, sua problemática e seus motivos para essa escolha.

As problemáticas abordadas pelos grupos foram as mais variadas possíveis. Dos seis grupos, cinco definiram temas diferentes. Foram muitos encontros, muitas reuniões, discussões e debates, para que os grupos pudessem definir suas problemáticas. Houve divergências e conflito de ideias, mas foram superados pelo diálogo.

A seguir, quadro 2, que apresenta o tema, motivo da escolha, problema, onde ocorre (lugar) e o que os estudantes pretendiam fazer:

Quadro 2 - Problemática abordadas pelos grupos

\begin{tabular}{|c|c|c|c|c|c|}
\hline Grupo & Tema & $\begin{array}{c}\text { Motivo da } \\
\text { escolha do tema }\end{array}$ & Problema & $\begin{array}{l}\text { Onde } \\
\text { ocorre }\end{array}$ & $\begin{array}{l}\text { O que pretende } \\
\text { fazer }\end{array}$ \\
\hline 1 & Calçadas & $\begin{array}{l}\text { Porque as } \\
\text { calçadas estão } \\
\text { destruídas e não } \\
\text { há acessibilidade }\end{array}$ & $\begin{array}{l}\text { Calçadas destruídas e } \\
\text { falta de acessibilidade }\end{array}$ & $\begin{array}{l}\text { Centro da } \\
\text { cidade }\end{array}$ & $\begin{array}{l}\text { Arrumar as } \\
\text { calçadas e } \\
\text { melhorar sua } \\
\text { acessibilidade } \\
\text { com rampas } \\
\text { para cadeirantes. }\end{array}$ \\
\hline
\end{tabular}




\begin{tabular}{|c|c|c|c|c|c|}
\hline 2 & $\begin{array}{l}\text { Animais } \\
\text { abandonados }\end{array}$ & $\begin{array}{l}\text { Porque há muitos } \\
\text { animais } \\
\text { abandonados. }\end{array}$ & $\begin{array}{l}\text { Os animais estão } \\
\text { atacando as pessoas, } \\
\text { transmitindo doenças, } \\
\text { além de serem } \\
\text { maltratados nas ruas. }\end{array}$ & $\begin{array}{l}\text { Bairro } \\
\text { Guarani }\end{array}$ & $\begin{array}{l}\text { Encaminhar para } \\
\text { adoção. }\end{array}$ \\
\hline 3 & Lixo & $\begin{array}{l}\text { É um problema } \\
\text { encontrado em } \\
\text { diferentes bairros. }\end{array}$ & Mau cheiro do lixo & $\begin{array}{l}\text { Bairro } \\
\text { Guarani }\end{array}$ & $\begin{array}{l}\text { Lixeiras } \\
\text { individuais para } \\
\text { cada morador } \\
\text { evitar o mau } \\
\text { cheiro provocado } \\
\text { pelo lixo. }\end{array}$ \\
\hline 4 & $\begin{array}{l}\text { Animais } \\
\text { abandonados }\end{array}$ & $\begin{array}{l}\text { Para salvar os } \\
\text { animais. }\end{array}$ & $\begin{array}{lr}\text { Muitos animais são } \\
\text { mortos } & \text { e } \\
\text { abandonados. } & \end{array}$ & $\begin{array}{l}\text { Bairro } \\
\text { Guarani }\end{array}$ & $\begin{array}{lr}\text { Construir } & \text { uma } \\
\text { associação para } \\
\text { cuidar desses } \\
\text { animais. }\end{array}$ \\
\hline 5 & $\begin{array}{ll}\text { Ponto } & \mathrm{de} \\
\text { Ônibus } & \end{array}$ & $\begin{array}{l}\dot{E} \text { um problema } \\
\text { que dá muitas } \\
\text { brigas. }\end{array}$ & $\begin{array}{l}\text { Quando chove, as } \\
\text { crianças se molham } \\
\text { para entrar no ônibus. }\end{array}$ & $\begin{array}{l}\text { Vila } \\
\text { verde }\end{array}$ & $\begin{array}{l}\text { Fazer um ponto } \\
\text { de ônibus mais } \\
\text { perto de onde o } \\
\text { ônibus para. }\end{array}$ \\
\hline 6 & Semáforo & $\begin{array}{l}\text { Porque seria mais } \\
\text { útil para a cidade. }\end{array}$ & $\begin{array}{lr}\text { Os motoristas não } \\
\text { respeitam } & \text { os } \\
\text { pedestres. } & \\
\end{array}$ & $\begin{array}{l}\text { Centro da } \\
\text { cidade }\end{array}$ & $\begin{array}{l}\text { Instalar } \\
\text { semáforos em } \\
\text { toda a avenida. }\end{array}$ \\
\hline
\end{tabular}

Elaboração: Estudantes, 2018. Organizado pela autora, 2018.

Na sequência, os grupos foram a campo para buscar as informações e constatar se realmente o problema existia na prática. Para isso, os grupos organizaram pequenos inquéritos para entrevistar os moradores, filmaram e fotografaram. Essa prática foi importante para que os estudantes pudessem vivenciar o lugar e constatar se realmente o problema existia e qual a visão dos moradores daquele lugar em relação à problemática abordada pelos grupos. A seguir, imagem de alguns grupos na coleta de dados realizada no mês de maio de 2018 . 
Figura 3 - Grupo 02: problema-animais abandonados

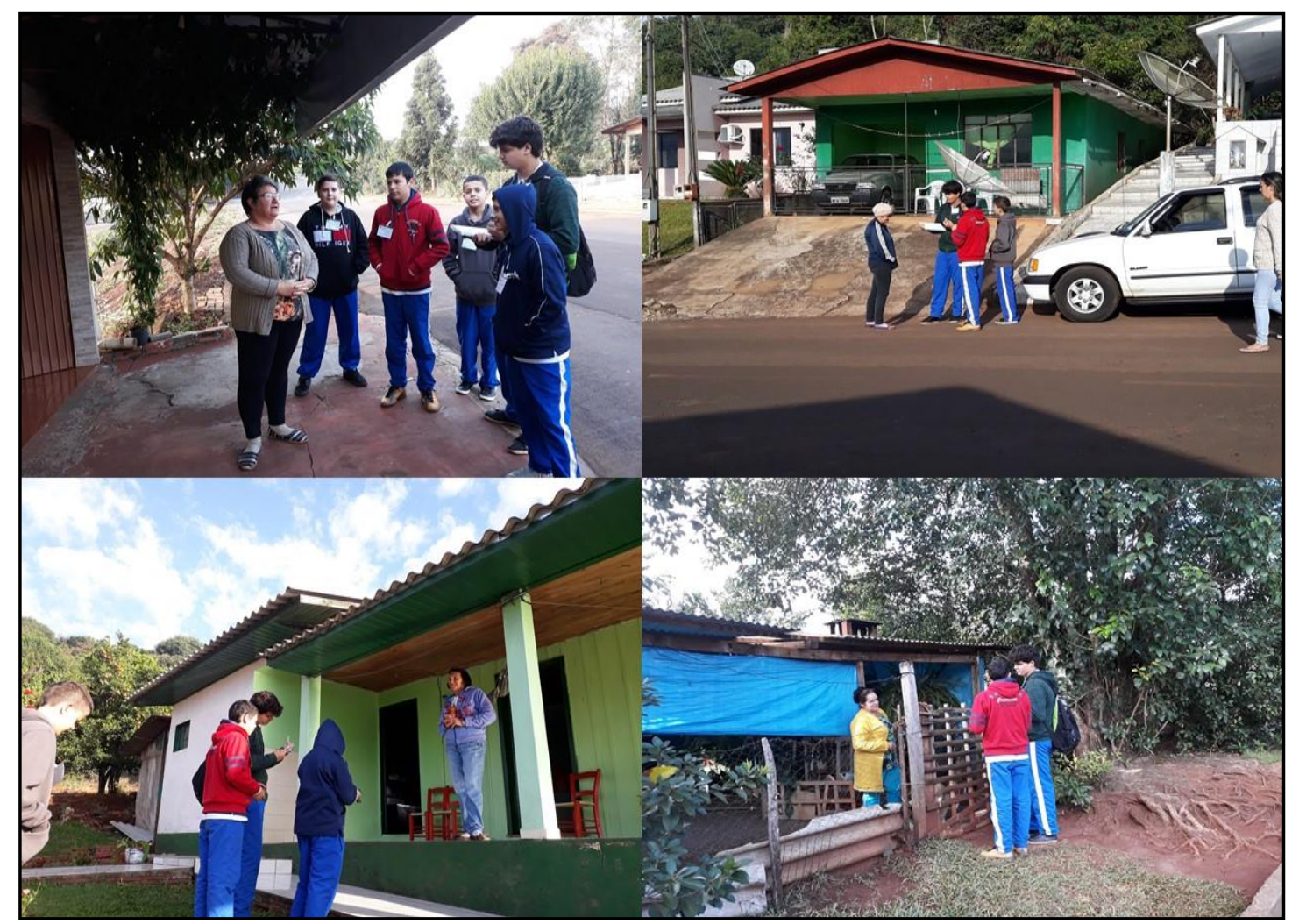

Elaborado pela autora, 2018.

Figura 4 - Grupo 01: problema-calçadas

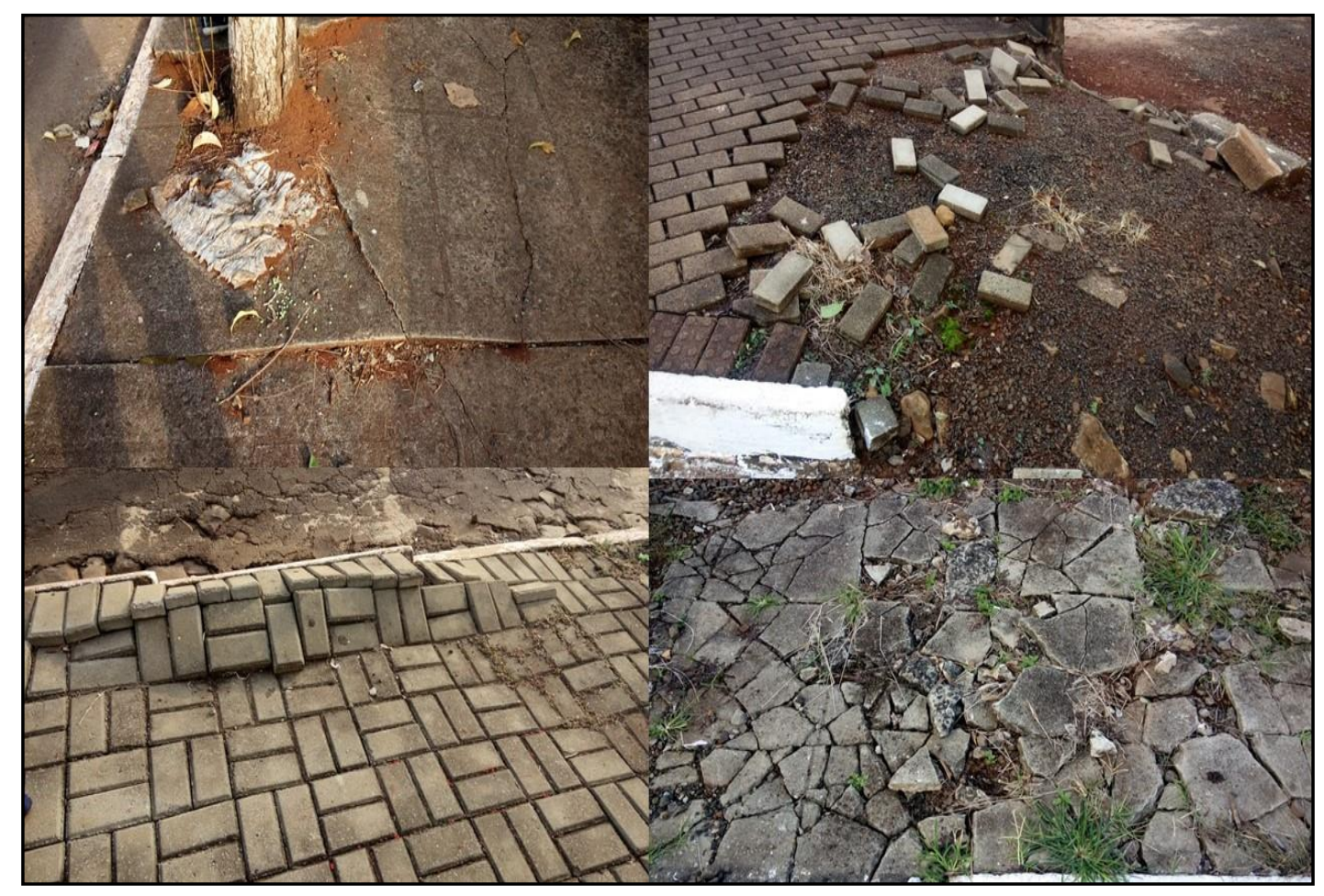

Fonte: GRUPO 01, 2018.

Figura 5-Grupo 03: problema - lixo 


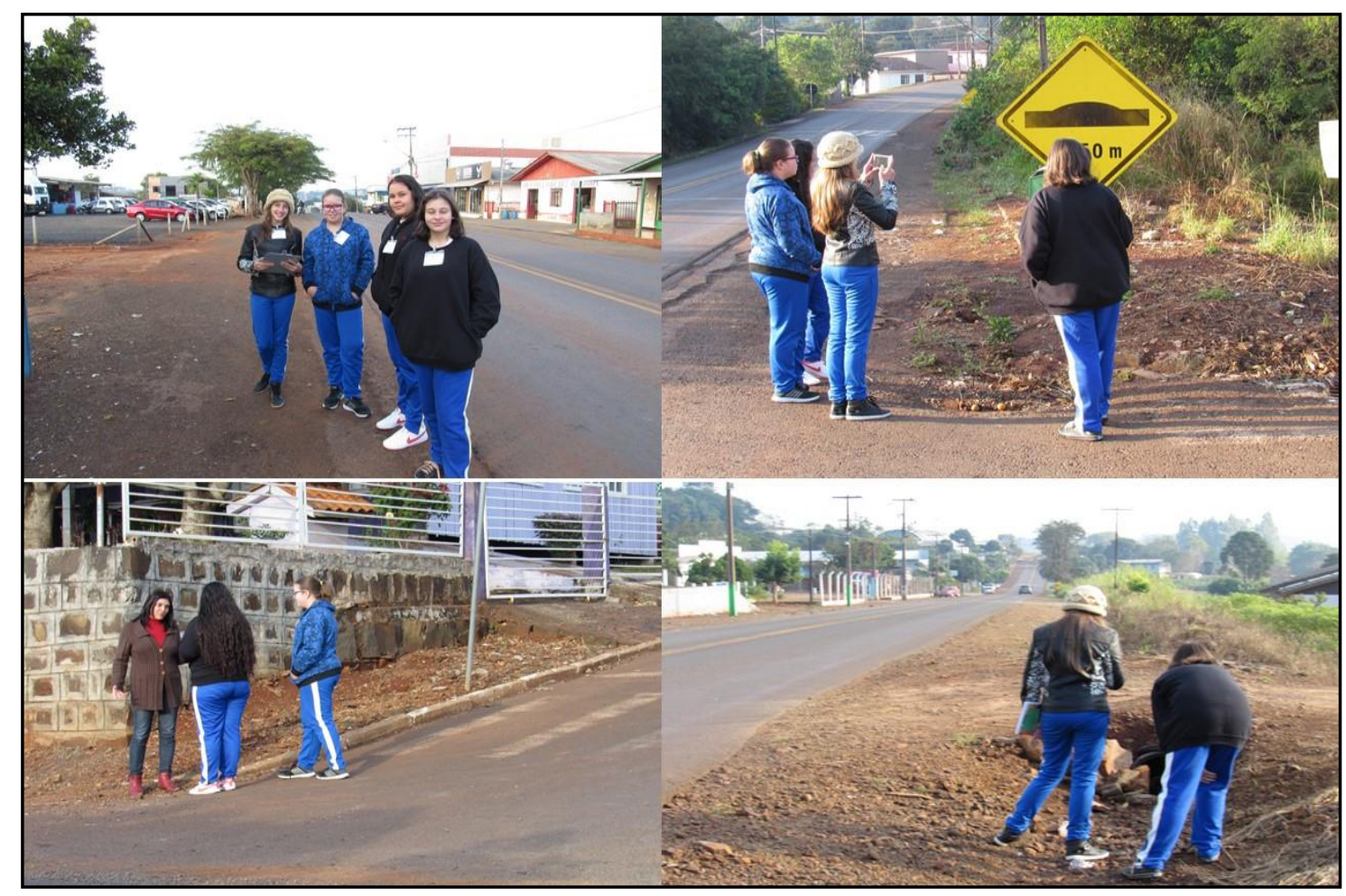

Fonte: Grupo 03, 2018.

Esta fase do projeto foi de grande importância, pois os estudantes puderam vivenciar os problemas, ouvir da população que reside naquele lugar pesquisado se realmente o problema existia e suas sugestões em relação a eles. Na sequência, os estudantes foram desafiados a buscar soluções para os problemas encontrados, já que todos os grupos chegaram à conclusão que os problemas levantados realmente existiam.

O grupo 01, que aborda o tema calçadas, no Centro da cidade, após constatar o problema sugeriu: fazer calçadas novas, rampas de acessibilidade, aumentar o tamanho dos passeios para os cadeirantes se deslocarem.

Em relação ao grupo 02, que trata dos animais abandonados, no Bairro Guarani, o grupo coloca como possíveis soluções a sensibilização da população em relação ao tema, pedir para os governantes apoiarem a Organização Não Governamental (ONG) do município, construção de um canil, castrar os animais e doar a quem cuida.

O grupo 03, com tema lixo, no Bairro Guarani, ressaltou que a população precisa ter mais respeito em relação ao lixo, que poderiam ser instaladas lixeiras individuais para facilitar a coleta e sensibilizar a população para esse problema.

O grupo 04, que trata dos animais abandonados, no Bairro Guarani, destaca como solução a colaboração da sociedade para ajudar a ONG, a construção de uma instituição para abrigar os animais, uma forma de ajudar as pessoas que adotam os animais a cuidar e não abandonar novamente esses animais. 
Para o grupo 05, com tema ponto de ônibus, no Bairro Vila Verde, as possíveis soluções seriam construir um novo ponto de ônibus no final do bairro, para que as crianças no entorno se beneficiassem, construir calçadas e limpar a sujeira (mato) próximo ao ponto de ônibus que já existe. Outra sugestão foi de se organizar, de forma diferente, o embarque e o desembarque dos estudantes, para facilitar e se tornar mais acessível o local. O grupo 05 observou novos problemas, que foi o mau estado do campo de futebol, reforma das calçadas no bairro, poluição do cemitério em uma propriedade vizinha ao bairro. As sugestões para esses novos problemas abordados pelo grupo seriam a reforma do campo de futebol e a construção de um parque para as crianças, nesse mesmo local, construção de calçadas no bairro e adequação do cemitério.

Já o grupo 06, que aborda a temática referente ao semáforo, no centro da cidade, sugeriu como forma de solução para o problema do trânsito de Itapejara D'Oeste PR, instalar semáforo no cruzamento próximo ao supermercado, No Ponto, a Matriz, e no cruzamento próximo ao Posto do Lira.

Os grupos levantaram os problemas e propuseram as soluções, na sequência do projeto essas sugestões foram apresentadas na Universidade Estadual do Oeste do Paraná - Unioeste em forma de colóquios e foram levadas ao poder público, na Câmara de Vereadores, em uma sessão realizada no dia 29/10/2018.

Ao propor as soluções os estudantes puderam compreender sua importância e seu papel enquanto cidadãos. Olhar o lugar onde vivemos e tentar propor ações a fim de minimizar esses problemas não é tarefa fácil, é um caminho difícil, mas através da educação pode ser superado e auxiliar a formar indivíduos atuantes na sociedade onde vivem.

\section{Considerações}

O projeto "Nós Propomos! Geografia, educação e cidadania" está sendo desenvolvido para identificar os problemas da cidade e sugerir possíveis soluções para os mesmos. Vale lembrar que o projeto ainda está em desenvolvimento e que a avaliação geral do projeto se dará somente em dezembro de 2018. A comunidade de Itapejara D'Oeste PR se mostrou disposta e acolhedora ao receber os estudantes, sentindo-se útil ao projeto e seu desenvolvimento. Em relação à Instituição, o projeto recebeu apoio desde o início e contribuiu para que ele se desenvolvesse da melhor forma possível. 
Alguns professores contribuem para que o projeto pudesse ser aplicado, cedendo suas aulas e acompanhando a turma no desenvolvimento de algumas atividades. A interdisciplinaridade aparece de forma espontânea durante as atividades desenvolvidas.

Em relação à turma, podemos dizer que é/foi ativa, buscam desenvolver suas temáticas com seriedade e entusiasmo. No início da formação dos grupos houve divergências, mas que foram superadas ao longo do tempo.

Em relação às famílias dos estudantes, percebe-se que os mesmos acompanham o desenvolvimento do projeto e auxiliam, dentro do possível, seus filhos. No desenvolvimento do projeto percebemos que existem dificuldades, e muitas, desde a falta de recursos financeiros, dificuldades de locomoção, material impresso, apoio em relação a determinados segmentos da sociedade, como o poder público do município, dentre outros. Mas cada um está sendo superado, passo a passo.

O projeto visou/visa contribuir para a formação de estudantes mais críticos e atuantes na sociedade e a escola pode contribuir para esse aprendizado.

\section{Referências bibliográficas}

Claudino, S. (2014). Escola, educação geográfica e cidadania territorial. Scripta Nova. Revista Electrónica de Geografía y Ciencias sociales, 494(09).

Francischett, M. N. (2017). Nós Propomos! Ensino de Geografia com significado na pesquisa na Unioeste/FB/Paraná. Francisco Beltrão: Unioeste.

Maycot, É. (2001). Caminhos da história Itapejarense. LogoArt: Pato Branco.

Paraná. (2016). Projeto Político Pedagógico (PPP) da Escola Estadual Irmão Isidoro Dumont. Itapejara D'Oeste/ PR.

Vasconcelos, I. C. O. (2010). Estratégias metodológicas da pesquisa: decisões no estudo da prática didática-pedagógica. Univ. Rel. Int., Brasília, 8(1), pp. 231-243, jan./jun.

Yin, R. K. (2001). Estudo de caso: planejamento e métodos. Porto Alegre: Bookman.

Disponível em: https://saudeglobaldotorg1.files.wordpress.com/2014/02/yi

nmetodologia_da_pesquisa_estudo_de_caso_yin.pdf 


\section{Educação Ambiental, mídias digitais e uso racional da água: Esquadrão Aquaeri nas escolas da rede pública municipal de São Paulo do Potengi/RN}

JENIFFER CAMPOS DE AZEVEDO VARELA ${ }^{1}$

EdSEISY SILVA BARBALHO TAVARES ${ }^{2}$

\section{Resumo}

Diante da necessidade do consumo consciente e sustentável de recursos hídricos tão escassos nas diversas escalas geográficas, inclusive no município de São Paulo do Potengi/RN, identificamos que o uso desses recursos a nível local e regional precisa ser investigado e propostas ações para economizar e preservá-lo. Nesse sentido, no âmbito do projeto "Nós Propomos novos usos do território potiguar", desenvolvido no IFRN São Paulo do Potengi, realizamos uma pesquisa sobre como os jovens que estudam na rede pública municipal de ensino compreendem e usam esses recursos. $A$ partir dessa pesquisa, reconhecemos a necessidade de aprofundamento dessas questões, sendo, portanto, propostas a elaboração de ferramentas didáticopedagógicas, usando-se aparatos de mídia digital (vídeos digitais, quiz virtual, site e

\footnotetext{
${ }^{1}$ Professora de Sociologia do Instituto Federal do Rio Grande do Norte (IFRN), Natal, coordenadora do projeto Aquaeri, jeniffer.varela@ifrn.edu.br.

${ }^{2}$ Professora de Geografia do Instituto Federal do Rio Grande do Norte (IFRN), campus de São Paulo do Potengi, coordenadora do "Projeto Nós propomos novos usos do território potiguar", edseisy.tavares@ifrn.edu.br.

Ana Biatrys Moura. Aluna do curso de Meio Ambiente IFRN campus de São Paulo do Potengi, biatrysm@gmail.com.

Ana Lígia de Araújo Nicácio. Aluna do curso de Meio Ambiente IFRN campus de São Paulo do Potengi, analigianicacio@gmail.com.

Anne Louise de Carvalho Soares. Aluna do curso de Meio Ambiente IFRN campus de São Paulo do Potengi, alouisecs@gmail.com.

Karylen Radmylla Silva Lopes. Aluna do curso de Meio Ambiente IFRN campus de São Paulo do Potengi, radmylla.lopes@gmail.com.

Renata Lima dos Santos. Aluna do curso de Meio Ambiente IFRN campus de São Paulo do Potengi, renatalimasantos087@gmail.com.
} 
aplicativo móvel educativo), para o desenvolvimento de um projeto de educação ambiental nas escolas centrado na temática do uso racional da água.

Palavras-chave: Educação Ambiental; uso racional da água; ferramentas didáticopedagógicas; mídias digitais.

\section{Abstract}

In view of the need to consciously and sustainably consume water resources that are so scarce at the various geographic scales, including in the city of São Paulo do Potengi / RN, we identify that the use of these resources at local and regional level needs to be investigated and actions proposed to save and preserve it. In this sense, within the framework of the project "We propose new uses of the Potiguar territory", developed in the IFRN São Paulo do Potengi, we conducted a research about how the young people who study in the municipal public school understand and use these resources. Based on this research, we recognize the need to deepen these issues, and therefore, the proposals are the development of pedagogical-didatic tools, using digital media devices (digital videos, virtual quiz, website and educational mobile app), for development of an environmental education project in schools focused on the rational use of water.

Keywords: Environmental education; Rational water use; Pedagogical-didactic tools; Digital Medias.

\section{Introdução}

O projeto "Nós Propomos novos usos do território potiguar" teve início no Instituto Federal de Educação, Ciência e Tecnologia do Rio Grande do Norte (IFRN), campus São Paulo do Potengi, no segundo semestre de 2017, quando foi realizada a proposta de implementação do projeto e os alunos iniciaram a identificação dos problemas territoriais locais. O projeto passou a ser desenvolvido com os alunos que cursavam o $1^{\circ}$ ano do Ensino Médio dos cursos de Meio Ambiente e Edificações. Os projetos desenvolvidos pelos alunos contemplaram 11 municípios do estado (figura 1), a maioria pertencente à região do Potengi no estado do Rio Grande do Norte. Nessa fase, foi realizada a identificação dos problemas e construídos os projetos por intermédio de pesquisa teórica e de campo, contemplando as diversas temáticas que reuniram de forma interdisciplinar a Geografia e as áreas técnicas de Meio Ambiente e Edificações, além de Artes e Informática. Entendemos que é essencial que esse 
projeto ocorra de forma interdisciplinar, assim sendo, adotada "uma cooperação intensa e coordenada, sobre a base de uma finalidade (e de uma problemática) comum" (Souza, 2006, p. 100). As propostas foram sendo desenvolvidas nos semestres 2017.2 e 2018.1 e apresentadas a comunidade interna e externa, inclusive com a participação de representantes dos gestores públicos dos municípios envolvidos, em abril de 2018.

A educação geográfica e a interdisciplinaridade no desenvolvimento das propostas de intervenção do projeto Nós Propomos no IFRN São Paulo do Potengi, vem buscando promover a cidadania territorial, portanto projetos voltados para a educação ambiental são essenciais para a comunidade. Nesse sentido concordamos com Barbosa (2017, p. 73) que "independente do lugar e escala a ser desenvolvida no processo de ensino e aprendizagem de Geografia a temática ambiental se constitui como conhecimento estratégico para construção de uma sociedade mais crítica e atuante aos desafios presentes".

O grupo Aquaeri (junção dos termos em latim aqua e sustineri; Água Sustentável) já vinha trabalhando em torno da problemática da Educação Ambiental em relação à gestão dos recursos hídricos e aproveitou o objetivo do projeto Nós Propomos para dar continuidade às atividades orientadas ao uso racional da água, identificando o acesso de informações e conhecimento dos alunos do Ensino Fundamental II das Escolas Municipal Deputado Djalma Marinho e Estadual Senador Dinarte Mariz acerca desse recurso essencial para a vida. Assim, diante dos resultados apontados em pesquisa de campo, o grupo Aquaeri propôs um projeto de Educação Ambiental apoiado no uso das mídias digitais e direcionado as escolas do município.

Após essa primeira fase de identificação e pesquisa sobre os temas, escolhidos pelos alunos, e apresentadas as propostas de intervenção, alguns grupos decidiram permanecer na segunda fase do projeto, na qual continuamos com as pesquisas e estamos discutindo com a comunidade e gestores públicos municipais a implementação das mesmas. Nessa fase, estamos com propostas de intervenção em quatro municípios (figura 1), por intermédio de ações voltadas diretamente a resolução de problemas locais e alguns a partir da realização de parcerias em Trabalhos de Conclusão de Cursos e no desenvolvimento de projetos de pesquisas. A partir dessa forma de atuação, podemos constatar tanto a ampliação dos objetos de pesquisa, como também o amadurecimento das propostas de intervenção, tal como vem ocorrendo com o Aquaeri que, neste momento, desenvolve a seguinte pesquisa: 
"Aquaeri - aplicativo móvel educativo para o uso racional da água”, no município de São Paulo do Potengi.

Figura 1 - Mapa dos municípios contemplados nas fases 1 e 2 do projeto Nós Propomos no IFRN São Paulo do Potengi

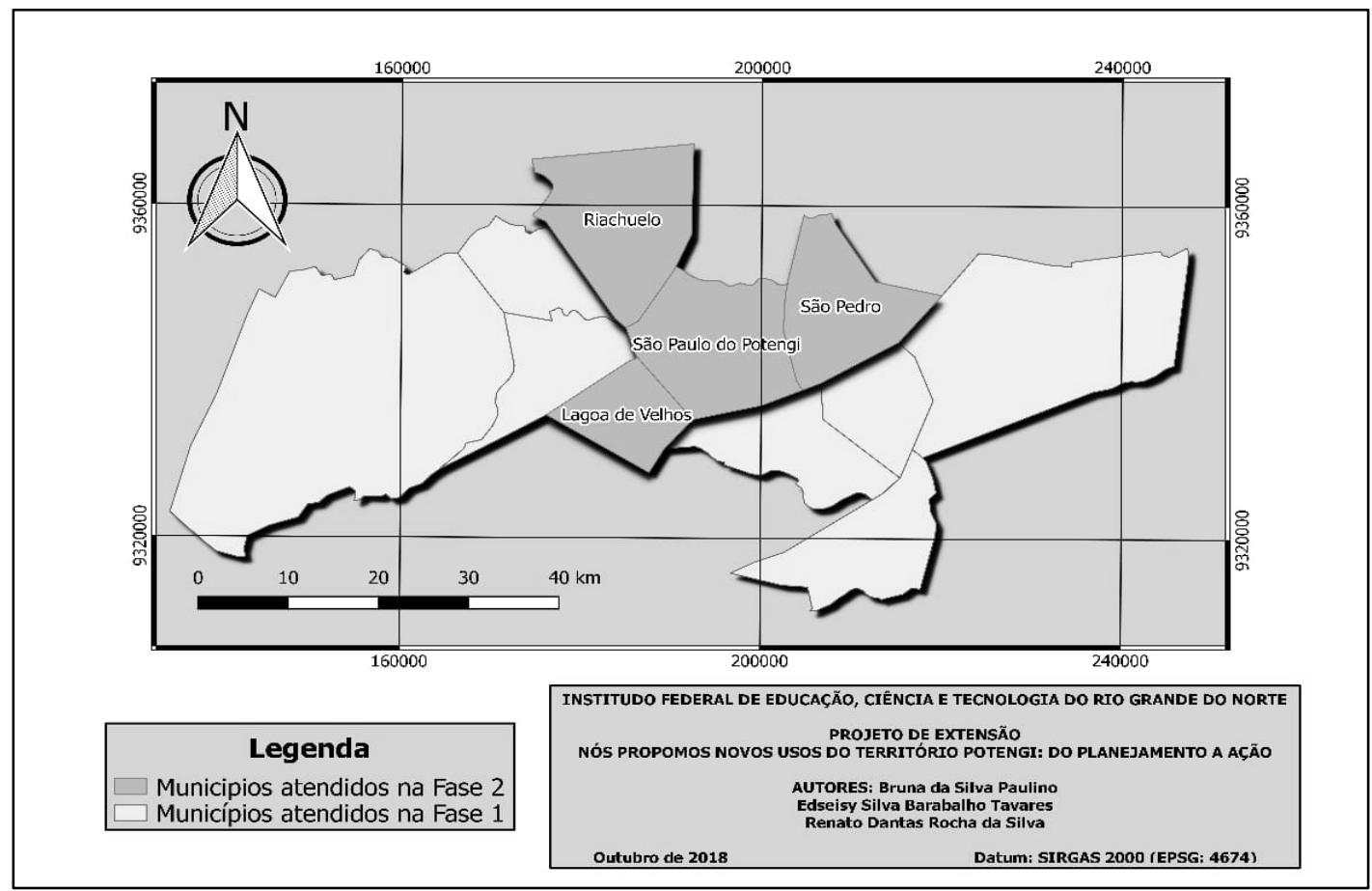

Fonte: Paulino; Tavares; Silva, 2018.

\section{Bacia do Potengi e a sua atual situação.}

O projeto Aquaeri tem como recorte espacial o município de São Paulo do Potengi, que de acordo com o Plano Territorial de Desenvolvimento Rural Sustentável do Potengi, é o município de maior centralidade da região, que recebe a denominação de Potengi e compreende 11 municípios: Barcelona, Bom Jesus, lelmo Marinho, Lagoa de Velhos, Riachuelo, Ruy Barbosa, Santa Maria, São Tomé, São Paulo do Potengi, São Pedro, Senador Elói de Souza. A regionalização apresentada pelo Plano considerou questões ambientais, econômicas, culturais, políticas e institucionais similares (Brasil, 2011). No que se refere à questão hídrica, a região é banhada por 5 (cinco) bacias hidrográficas, sendo uma das mais importantes, a Bacia do Potengi que banha todos os municípios da região (figura 2). 
Figura 2 - Mapa das bacias hidrográficas do território do Potengi

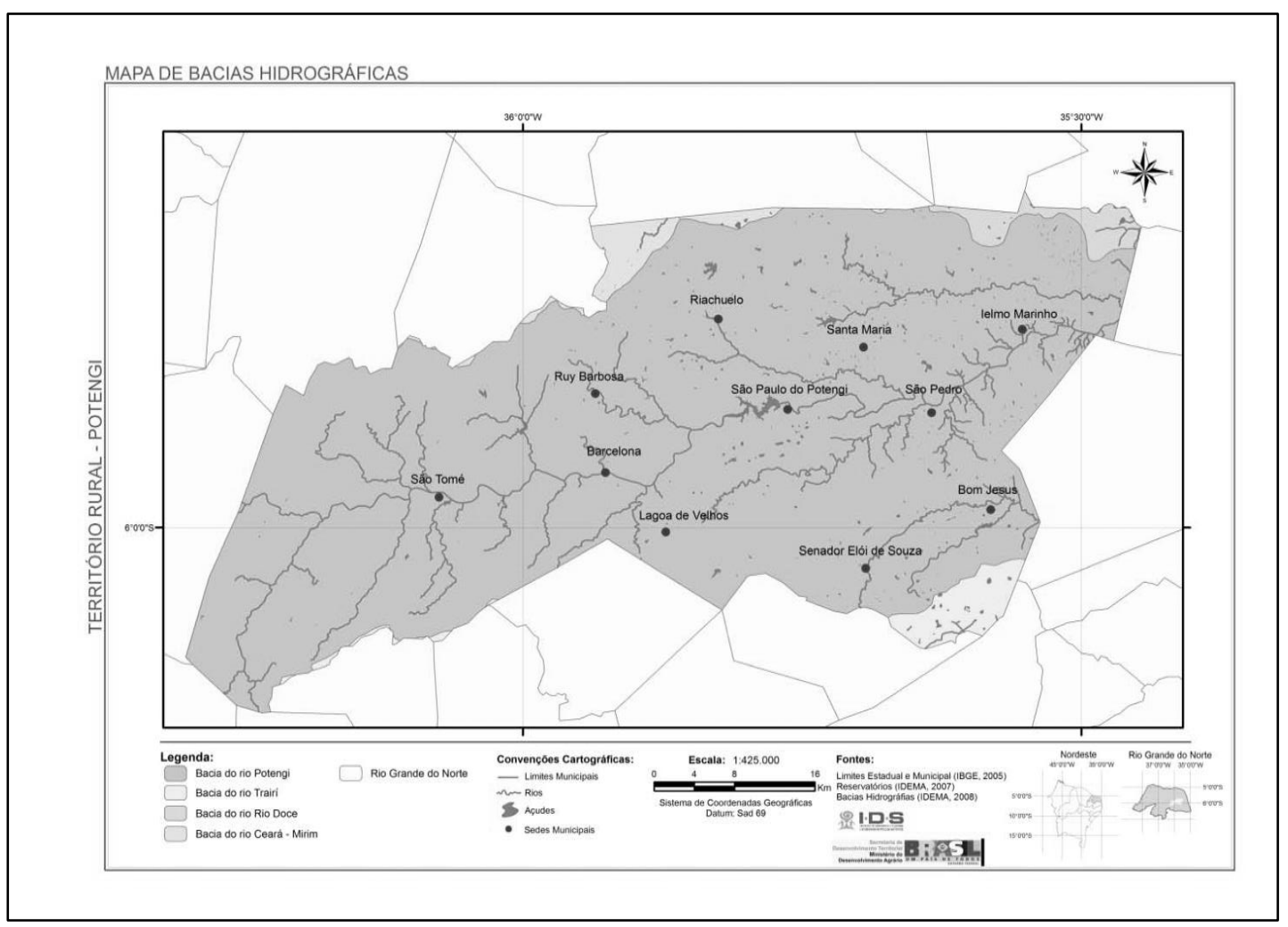

Fonte: Brasil, 2011.

Assim, foi principalmente sob essa bacia hidrográfica, sua situação e seu uso que o grupo Aquarei se deteve nas pesquisas e quanto aos encaminhamentos para a proposta de intervenção, buscando promover por intermédio de vídeos, um quiz e das informações fornecidas no site esquadraoaquaeri.wixsite.com/aquaeri, uma sensibilização para um trabalho de Educação Ambiental nas escolas do município.

A bacia do Potengi segundo o Instituto de Gestão das Águas do Rio Grande do Norte (IGARN) ocupa uma superfície de $4.093 \mathrm{~km} 2$, o que corresponde a cerca de 7,7 \% do território estadual, se estendendo desde o município de Cerro Corá até Natal, capital do estado, passando além da região do Potengi, por outros municípios. Em São Paulo do Potengi é possível observar a poluição do rio causada pelo lançamento de resíduos sólidos e lançamento de esgotos sanitários sobre o manancial em vários pontos do território municipal, como revelam as figuras 3 e 4 . Essa ação inadequada prejudica ainda mais a situação hídrica da região, dado promover um processo de eutrofização que aliado a "vazão baixa com um escoamento superficial que não é suficiente para as futuras demandas" (Brasil, 2011, p. 70), ocasiona dificuldades de abastecimento de água para o consumo humano e também para as atividades agrícolas, principalmente porque as águas superficiais são as principais fontes de disponibilidade hídrica na 
região. Quanto à situação dos poços do Território do Potengi, o Plano apresentou que em " $83 \%$ deles a água é considerada salina e 14\% considerada salobra. Ou seja, impróprias para o humano. Apenas $4 \%$ das águas (...) são consideradas doces, sendo $62 \%$ desta água via poços, localizada no município de lelmo Marinho" (Brasil, 2011, p. 75).

Figura 3 e 4 - Resíduos sólido e esgotos lançados sobre o Rio Potengi

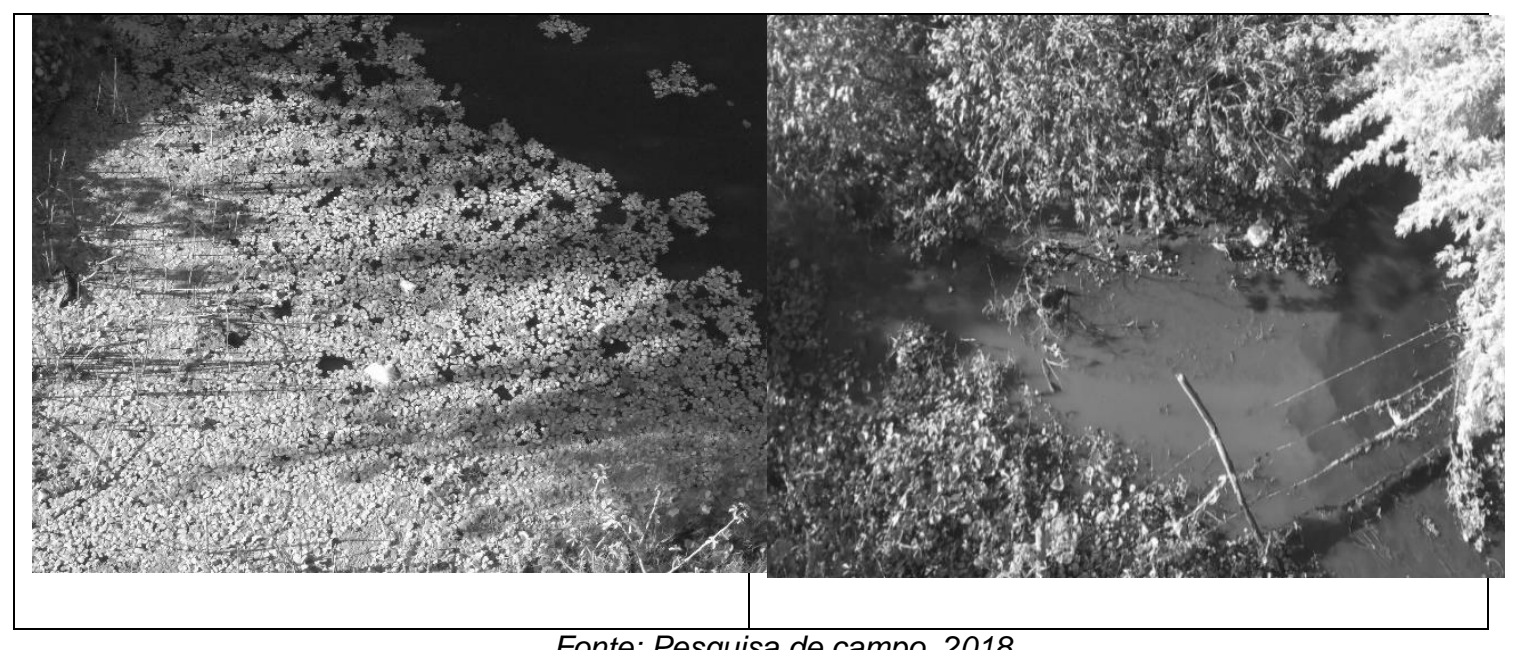

Fonte: Pesquisa de campo, 2018

Os rios são fontes de alimentação e abastecimento de água para as populações humanas e animais, todavia, como apontam Marchesan e Funez (2017), atualmente tornaram-se verdadeiras "lixeiras" de resíduos gerados pela civilização humana. Como podemos constatar nas imagens ao longo do curso do rio Potengi, ao banhar o município de São Paulo do Potengi, há notoriamente uma falta de conscientização da população quanto aos riscos promovidos por tal poluição para a continuidade do uso desse recurso que, conforme já apontado, ainda tem na escassez devido aos longos períodos de estiagem, mais um elemento que interfere na disponibilidade hídrica da região. A barragem Campo Grande, por exemplo, um dos maiores reservatórios de água do município e que pereniza o rio de São Paulo do Potengi até Natal, se encontra com níveis muito baixos nos últimos anos (figura 5). A imagem revela a preocupante crise hídrica na região, que vem perdurando por longos cinco anos. Nas fotos podemos ver a barragem em tempos de cheias (à esquerda) e, mais recentemente, com apenas $2 \%$ de sua capacidade hídrica (à direita), situação registrada em 28 de setembro de 2017. 
Figura 5 - Fotos da Barragem Campo Grande, no municipio de São Paulo do Potengi.

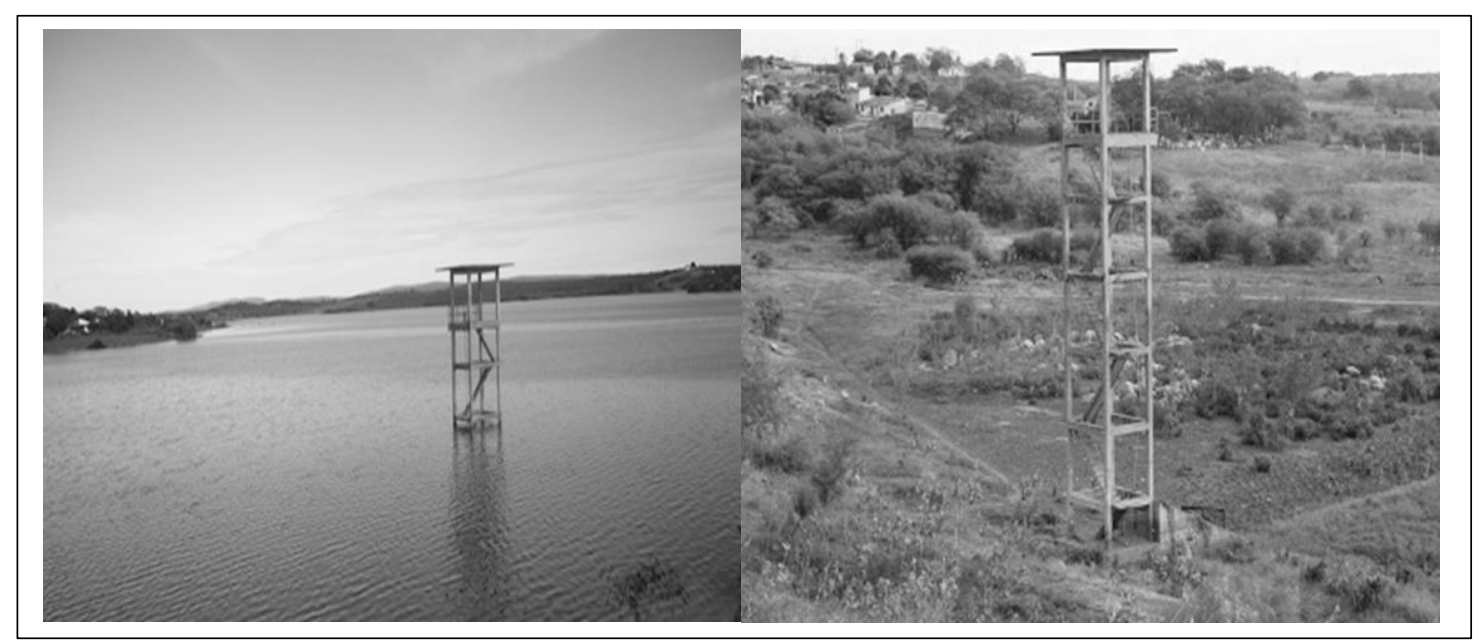

Fonte: Silvério Alves (2017)

Diante do cenário exposto, os próprios estudantes do curso de Meio Ambiente, vinculados ao projeto Aquaeri, perceberam a urgência de um trabalho voltado para a Educação Ambiental da comunidade de São Paulo do Potengi, "que conceba a ciência, o meio ambiente e a educação enquanto vetores essenciais para construção de uma sociedade que sustente e respeite os bens naturais" (Santos, 2002). Nesta perspectiva, é essencial o acesso à Educação Ambiental nas escolas, para que tenhamos a formação de cidadãos que possuam um pensamento crítico e consciente em relação aos recursos hídricos.

\section{Uso consciente da água e educação ambiental em São Paulo do Potengi}

Educação Ambiental pode ser definida pela Conferência Intergovernamental de Tbilisi, em outubro de 1977, como:

A Educação Ambiental é um processo de reconhecimento de valores e classificação de conceitos, objetivando o desenvolvimento das habilidades e modificando as atitudes em relação ao meio, para entender e apreciar as inter-relações entre os seres humanos, suas culturas e seus meios biofísicos. A Educação Ambiental também está relacionada com a prática das tomadas de decisões e a ética que conduzem para a melhoria da qualidade de vida. (Brasil, 2014, p.11)

Os debates em torno do que seria o foco da Educação Ambiental, tanto na seleção das problemáticas quanto na delimitação de prioridades, vêm cada vez mais apontando para a composição de uma educação voltada para a cidadania. Essa reivindicação da dimensão política da Educação Ambiental propõe que a mesma deva ser construída dentro de uma perspectiva socioambiental que considere a relação 
homem-natureza conectada às questões econômicas, sociais e culturais. Surge a percepção de que a construção de uma mentalidade crítica precisa estar agregada ao princípio de compromisso dos sujeitos com o meio ambiente. Assim, a Educação Ambiental, como educação política, deve estar comprometida com a ampliação da cidadania e da intervenção direta dos cidadãos na busca de soluções e alternativas voltadas para o bem comum. Contudo, a edificação desse comprometimento dos sujeitos, com seu papel cidadão, também deve perpassar a construção de novos comportamentos e hábitos. Então, sem descartar a centralidade do elemento reflexivo (do "porque" fazer), destaca-se a importância dos elementos participativos e comportamentais (do "como" fazer).

O Aquaeri é um projeto que busca somar os conteúdos apontados acima: exercício da cidadania, sustentabilidade e educação ambiental com foco na preservação dos recursos hídricos. A partir dos debates realizados pelos alunos do curso Técnico Integrado em Meio Ambiente, campus São Paulo do Potengi, o projeto nasceu com o objetivo de compor uma proposta de Educação Ambiental na comunidade escolar do município, a partir do tema do Uso Racional de Recursos Hídricos. As principais propostas seriam: conscientizar as pessoas quanto ao uso excessivo da água e educar os cidadãos (nomeadamente os jovens) sobre o uso adequado desse recurso natural. Essa estratégia surgiu da própria percepção dos estudantes quanto à necessidade de convidar a sociedade para um questionamento urgente: a água é um recurso inesgotável?

A partir dessas inquietações, as alunas do projeto partiram para realizar um levantamento de campo, aplicando um questionário simples a oitenta estudantes das Escolas Deputado Djalma Marinho e Senador Dinarte Mariz de São Paulo do Potengi. O objetivo, neste momento, era conseguir perceber a abrangência da Educação Ambiental dentro das referidas escolas, como também, apurar o quantitativo de alunos que tiveram acesso a informações sobre o uso racional dos recursos hídricos. Nesse sentido, foram realizados os seguintes questionamentos: 
1. Ao longo da sua vida, você já foi informado sobre o uso consciente da água?

2. Se sim, onde você teve acesso a informações sobre o uso consciente da agua?

3. Sua escola faz atividades que visam à educação ambiental?

Figura 6 - Gráfico referente ao conhecimento sobre o uso consciente da água

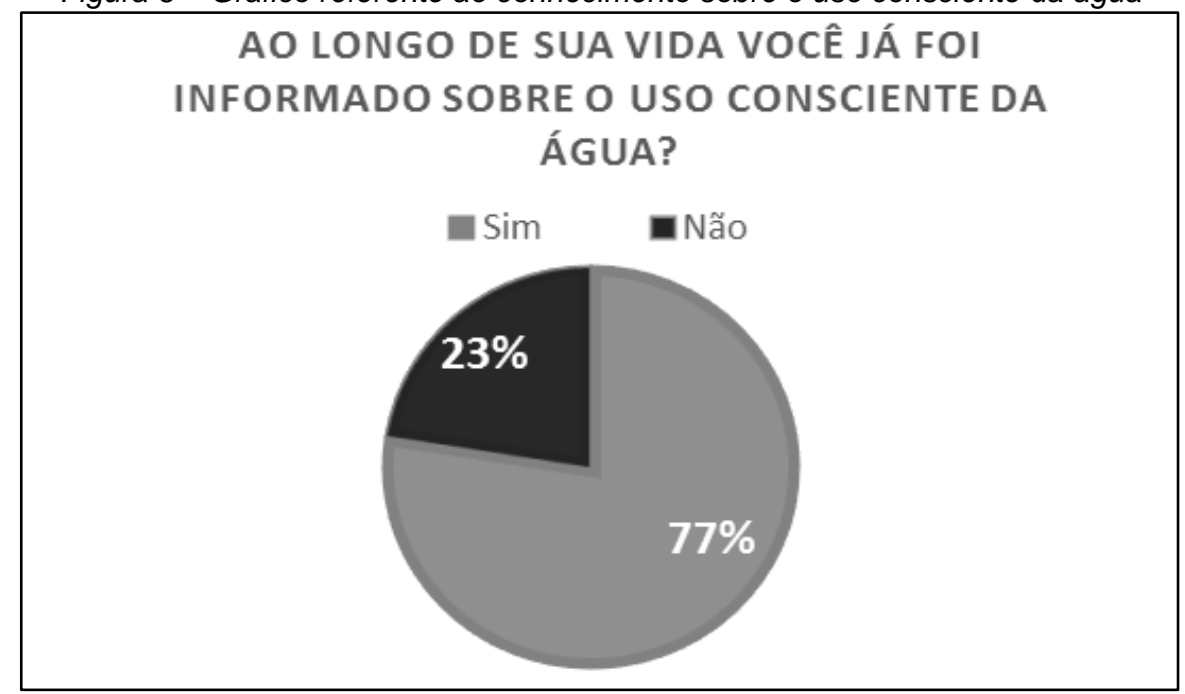

Fonte: Pesquisa de Campo, 2017.

O gráfico acima (figura 6) representa o resultado obtido a partir do primeiro questionamento. Assim, foi possivel constatar que, entre os estudantes das escolas pesquisadas (de acordo com o grupo amostral), setenta e sete por cento $(77 \%)$ já foram informados sobre o uso consciente da água em algum momento de suas vidas, restando vinte e três por cento (23\%), do grupo pesquisado, que declararam desconhecer a temática do uso consciente da água.

Buscando apurar a fonte das informações recebidas por esses alunos, os que declararam "já ter sido informados sobre o uso consciente da água", a pesquisa de campo revelou que apenas trinta um por cento $(31 \%)$ obtiveram esse conhecimento dentro da escola, o que fica evidenciado no gráfico destacado na figura 7 .

Diante desta afirmativa, a questão seguinte se referiu à presença de atividades destinadas a Educação Ambiental dentro do espaço escolar e, assim, obtivemos os seguintes resultados, apontados no gráfico subsequente (figura 8). 
Figura 7- Gráfico referente à fonte de informações sobre o uso consciente da agua

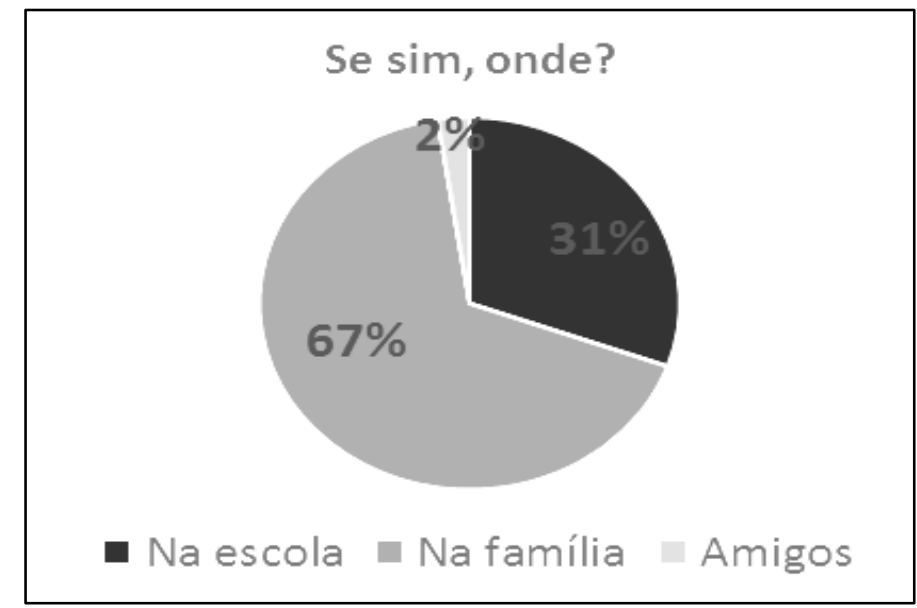

Fonte: Pesquisa de Campo, 2017.

Figura 8 - Gráfico referente à realização de atividades de educação ambiental por parte das instituições de ensino

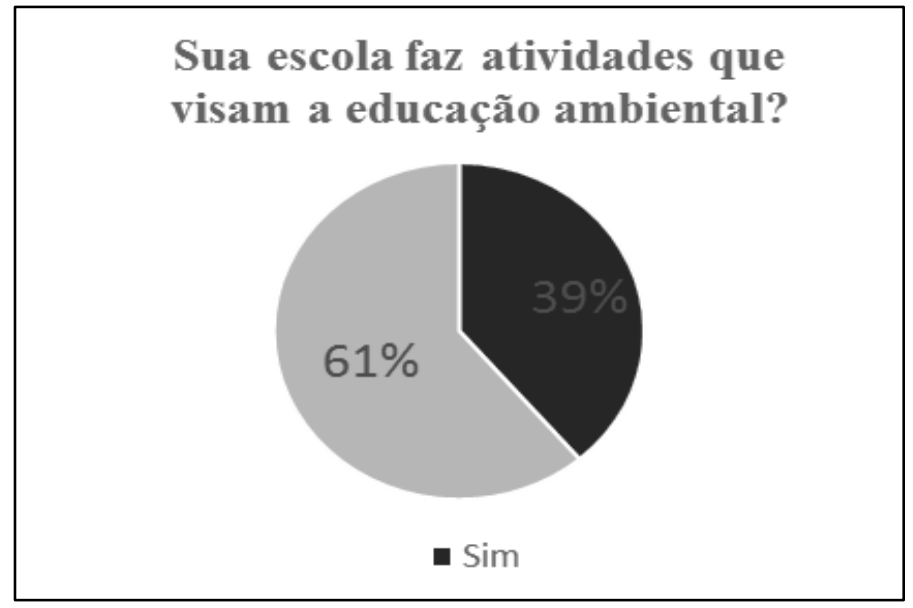

Fonte: Pesquisa de Campo, 2017.

Cruzando os dados observados nos gráficos, é possível perceber a falta de uma participação efetiva das escolas na construção de uma consciência ambiental por meio dos princípios da Educação Ambiental, já que a escola representou apenas trinta e nove por cento (39\%) das respostas positivas ao terceiro questionamento feito aos estudantes. No tocante a temática do uso racional da agua, a família aparece como o espaço mais ativo na transmissão dessa consciência. Portanto, a pesquisa de campo, nos levou a crer que a escola aparentemente não tem assumido protagonismo na educação ambiental dos jovens estudantes da região.

\section{Propostas de intervenção}


Como constatamos há uma conscientização em relação ao uso sustentável dos recursos hídricos, contudo, a educação ambiental não vem sendo efetivamente realizada nas escolas do município de São Paulo do Potengi pesquisadas. Nesse sentido, depois de identificada essa problemática - não apenas quanto a ter conhecimento, mas em realmente a manter práticas sustentáveis, especificamente quanto à utilização dos recursos hídricos - o grupo Aquaeri propôs uma intervenção a se realizar nas escolas. Entendendo que a escola e em particular os professores de Geografia, juntamente com as demais áreas, devem direcionar o seu trabalho para a "construção de um pensamento geográfico sobre a cidade em que seus alunos vivem, sendo esse um instrumento potencializador de transformação da realidade e da construção da cidadania" (Santos, 2017, p. 103).

Considerando o interesse dos jovens da faixa etária que cursam o Ensino Fundamental, o poder despertado pelas mídias digitais e a reconhecida relevância do uso desses recursos para o processo de ensino aprendizagem, buscou-se criar ferramentas digitais adaptadas a esse público para fomentar a discussão sobre o tema e tentar provocar a construção de conhecimentos que, por fim, permitam sensibilizar os jovens para que novas ações sejam tomadas diariamente e os recursos hídricos possam ser melhor aproveitados.

Para tal proposta, foi criado o site, cujo objetivo é a interação virtual com os estudantes e demais visitantes, onde existem links de artigos, dicas e recursos áudio visuais que incentivem o uso consciente da água. Dentre os meios audiovisuais, foram disponibilizados dois vídeos: um reflexivo que expõe a situação da Bacia do Potengi, no município de São Paulo do Potengi, em períodos anteriores, no contexto atual e uma perspectiva para o futuro, caso não sejam adotadas atitudes diferentes voltadas para o cuidado adequado com a água e também o ambiente no qual estamos inseridos; e outro que apresenta alguns hábitos cotidianos que podem ser adotados para diminuir o desperdício da água consumida nas residências. O site também apresenta um quiz com questões interativas que, ao serem respondidas, identificam, avaliam e mostram ao jogador se o mesmo tem ações voltadas para a economia ou desperdício de água.

A proposta de educação ambiental nas referidas escolas em São Paulo do Potengi também se voltou para o desenvolvimento de um projeto de pesquisa para a produção de um aplicativo móvel a ser disponibilizado enquanto ferramenta de educação ambiental, especificamente orientada para o uso racional da água nas residências. Portanto, o aplicativo consistirá em uma opção de instrumento didático-pedagógico 
que, mostrando como em uma residência vários hábitos podem ser adotados para economizar água, teremos a aplicação de mais um recurso tecnológico que, dentre as outras mídias digitais, também poderão nos auxiliar de forma dinâmica e intuitiva a melhor usar os recursos hídricos. Considerando que para Porto (2015), a utilização desses recursos no processo de ensino e aprendizagem permite a transmissão das informações e construção de conhecimentos de forma atrativa.

Além dos materiais tecnológicos, o projeto também contempla a realização de intervenções presenciais no ambiente escolar. Nas referidas escolas e no próprio IFRN foram realizadas dinâmicas e atividades com perguntas e respostas sobre o uso consciente da água. Os ganhadores desse quiz que aconteceu na II SEMADEC (Semana de Arte, Cultura e Desporto) do IFRN São Paulo do Potengi com a comunidade externa e alunos do IFRN, foram premiados com copos para que possam evitar a utilização de descartáveis. Outra intervenção do grupo aconteceu na data em que se comemora o Dia mundial da água, 22 de março de 2018, momento em que no IFRN - Campus São Paulo do Potengi, foram realizadas atividades culturais como exposição musical, poética e teatral (figura 9), além dos vídeos produzidos pelo grupo, portanto, produções voltadas para a conscientização sobre o consumo sustentável e preservação dos recursos hídricos.

Figura 9 - Fotos das apresentações e aplicação do quiz no IFRN São Paulo do Potengi no Dia Mundial da Água

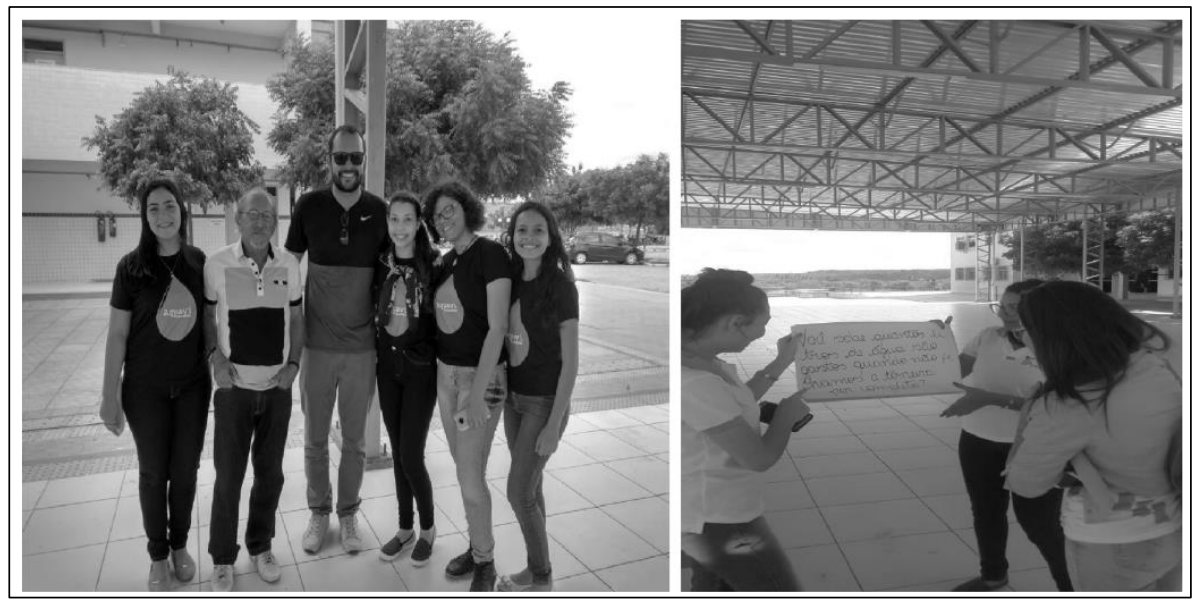

Fonte: Tavares, 2018.

No dia do Meio Ambiente, 5 de junho de 2018, o projeto Nós Propomos também teve uma ação no bairro Juremal em São Paulo do Potengi e na oportunidade também foi feita a exposição do vídeo produzido pelo grupo, inclusive o vídeo ficou em 3 o lugar no 
concurso do I Congresso Ibero-Americano Nós Propomos! Geografia, Educação e Cidadania (figura 10).

Figura 10 - Fotos da Premiação pelo 3 Iugar do vídeo Aquaeri no I Congresso Ibero-Americano Nós Propomos! Geografia, Educação e Cidadania

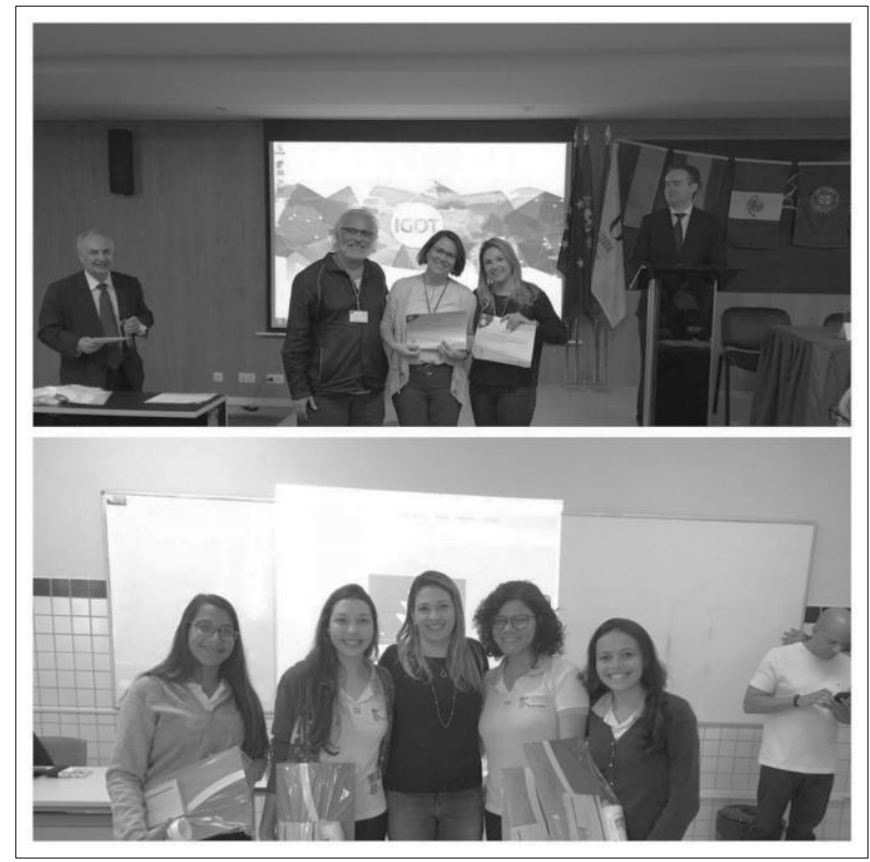

Fonte: Tavares, 2018.

\section{Conclusão}

O projeto Aquaeri, alinhado aos principios do Nós Propomos, tem buscado os caminhos para um efetivo engajamento ambiental dos estudantes e da comunidade local. A pesquisa de campo levou as alunas do projeto a concluirem que se for aplicada uma Educação Ambiental nas escolas, será notável a mudança de comportamento dos jovens, o que pode contribuir na consolidação de uma cultura mais conscientizada quanto ao uso adequado dos recursos hídricos.

Segundo Carvalho (2004), a formação de uma atitude ética e política é a grande contribuição que a educação ambiental pode dar em um mundo em crise como o que vivemos, modificando as atitudes e, consequentemente, o modo de agir na sociedade. Portanto, não se restringindo apenas à transmissão de informações ou à inclusão de regras de comportamento, a educação ambiental deve estar engajada na construção de uma nova cultura e, assim, não atuar apenas para a preservação do meio ambiente, mas também para a melhoria da qualidade de vida dos indivíduos. Segundo Berna (2001), não adianta se tornar mais consciente dos problemas ambientais sem 
se tornar mais ativo, crítico, participativo. Logo, os estudantes precisam pôr em prática os valores adquiridos através desta educação para que exerçam sua cidadania.

Por meio das ferramentas de ensino-aprendizagem propostas pelo Aquaeri, pretendese aplicar a Educação Ambiental de forma dinâmica e intuitiva, para que, a partir do aprendido o aluno crie uma postura crítica a respeito dos problemas ambientais e a externalize. Assim, pensou-se na inclusão das mídias digitais como ferramenta mediadora da Educação Ambiental uma vez que, segundo Porto (2015), a utilização destas mídias na aprendizagem possibilita a inovação nas práticas educativas, como a transmissão de informações de forma atrativa. A inserção de aparatos tecnológicos é de grande importância para a assimilação do discente, quanto aos objetivos propostos pela ferramenta didático-pedagógica, uma vez que estes recursos estão fortemente presente no nosso cotidiano.

Em vista dos argumentos apresentados concluímos que, se a Educação Ambiental for aplicada de maneira eficiente na vida escolar dos jovens cidadãos, trará resultados positivos para o meio ambiente e para a formação do indivíduo na sociedade. As ferramentas educativas propostas pelo Aquaeri trazem, assim, essa educação de uma forma dinâmica para que os jovens possam ser atraidos, de forma criativa, e se integrarem na construção de uma consciência ambiental que os desperte para colocála em prática no seu dia a dia. Além de pensar nas futuras gerações que poderão desfrutar e crescer em um ambiente de desenvolvimento sustentável, onde as pessoas tenham consciência sobre a importância da preservação dos recursos hídricos.

\section{Referências bibliográficas}

Barbosa, M. E. (2017). O conceito de ambiente: diálogos e práticas educativas. In.: Oliveira, K. A. T. de. \& Pires, L. M. Ensinar sobre a cidade (pp. 73-89). Goiânia: Espaço Acadêmico.

Berna, V. S. D. (2001). Como Fazer Educação Ambiental. São Paulo: Paulus.

Brasil. (2011). Plano Territorial de Desenvolvimento Rural Sustentável do Potengi. Fonte: Ministério do Desenvolvimento Agrário (MDA): http://sit.mda.gov.br/download/ptdrs/ptdrs_qua_territorio123.pdf.

Brasil. (2014). ProNea: Programa Nacional de Educação Ambiental. Fonte: Ministério da Educação. Brasília: MEC. 
Carvalho, I. C. M. (2004). Educação Ambiental: a formação do sujeito ecológico. São Paulo: Cortez.

Marchesan, J., Funez, M. L. (2017). Gestão da água em Bacias Hidrográficas. Curitiba: Appris.

Porto, R. G. C. (2015). O Uso Das Mídias na Educação Ambiental. Trabalho de Conclusão de Curso. Porto Alegre: UFRGS.

Santos, V. L. M. (2002). Barranco Alto: Uma Nova Experiência na Educação Ambiental. Cuiabá: Universitária.

Santos, L. A. dos. (2017). Elementos didáticos da pesquisa para o ensino do conteúdo da cidade. In.: Oliveira, K. A. T. de. \& Pires, L. M. Ensinar sobre a cidade (pp. 73-89). Goiânia: Espaço Acadêmico.

Souza, M. L. de. (2006). Mudar a cidade. Rio de Janeiro: Bertrand Brasil. 


\title{
O Início da Educação Cidadã nas Cidades de Palmas e Araguaína/TO, através do projeto Nós Propomos!
}

\author{
JORDANA COELHO GONSALVES ${ }^{1}$ \\ Mariela Cristina Ayres De Oliveira ${ }^{2}$
}

\section{Resumo}

O direito à cidade tem na participação popular democrática um importante fator de fortalecimento. O presente artigo tem como objetivo destacar a importância da extensão universitária através do projeto "Nós Propomos!", um projeto da UFT em convênio com a Universidade de Lisboa - IGOT (Instituto de Geografia e Ordenamento do Território) e parceria com a Secretaria estadual de educação, juventude e esporte. A ação é voltada aos jovens do Ensino Médio da Rede Pública Estadual de Palmas e Araguaína no processo de participação da sociedade civil no aprimoramento das discussões sobre questões locais. As atividades se dividem em 10 etapas sendo desenvolvidas por alunos do ensino médio da rede pública, que são estimulados a exercerem a cidadania plena pela participação nas decisões que versam sobre a cidade, identificando problemas urbanos e formulando propostas para a resolução dos mesmos. Logo, o projeto se apresenta como um instrumento de democratização do saber, que envolve ações direcionadas ao exercício da cidadania. Com a qualidade de abranger pontos estratégicos da cidade, abarcando todo o território palmense e assim, contemplando os diferentes contextos socioespaciais ampliando o diálogo não só entre professores e estudantes dos vários níveis escolares, como também das diferentes realidades territoriais.

Palavras-chave: Urbanismo e Sociedade, Extensão universitária.

\footnotetext{
1 Discente do curso de Arquitetura e Urbanismo Universidade Federal do Tocantins, jojo.coelho77@mail.uft.edu.br

2 Professora Associada DE, Universidade Federal do Tocantins, mariela@uft.edu.br
} 


\section{Abstract}

The right to the city has in democratic popular participation an important factor of strengthening. This article aims to highlight the importance of university extension through the "Nós Propomos!" Project, a UFT project in partnership with the University of Lisbon - IGOT (Institute of Geography and Spatial Planning) and partnership with the State Secretariat of education, youth and sport. The action includes at the high school youth of the State Public Network of Palmas and Araguaina in the process of civil society participation in the improvement of the discussions on local issues. The activities have 10 stages developed by public high school students. Students are encouraged to exercise full citizenship by participating in decisions about the city; they identify urban problems and formulate proposals for their resolution. Therefore, the project presents itself as an instrument for the democratization of knowledge, which involves actions directed at the exercise of citizenship. With the quality of covering strategic points of the city, encompassing the entire territory of the city and thus contemplating the different socio-spatial contexts, broadening the dialogue not only between teachers and between students of different levels of school, but also of different territorial realities.

Keywords: Urbanism and Society, University Extension.

\section{Introdução}

A participação popular democrática é um importante fator para que o direito à cidade seja garantido. $O$ desenvolvimento de uma governança territorial participativa sugere o despertar de uma consciência cidadã pautada pela sua efetiva atuação dentro da urbe. No Brasil, a democracia participativa tem como referência a Constituição Federal (BRASIL, 1988) que, ao constituir o Estado Democrático de Direito, fundamentou-o na cidadania e no pluralismo político com a finalidade de garantir a democracia participativa e direta. Para possibilitar essa experiência, o legislador criou um conjunto de arranjos institucionais, entre eles o Orçamento Participativo, a Conferência da Cidade e os Planos Setoriais com participação popular. Portanto, constata-se a incipiência do processo participativo no Brasil e, embora haja intensidade de ações e grande interesse por resultados positivos, existem ainda poucos e pontuais indicativos de sucesso nas atividades participativas.

O presente artigo tem como objetivo destacar a importância da extensão universitária através do projeto "Nós Propomos !" no processo de participação da sociedade civil no 
aprimoramento das discussões sobre questões locais, desde a sua primeira edição em 2016. As atividades se dividem em 10 etapas sendo desenvolvidas por alunos do ensino médio da rede públicas que são estimulados a exercerem a cidadania plena, pela participação nas decisões que versam sobre a cidade, identificando problemas urbanos e formulando propostas para a resolução dos mesmos. O projeto se apresenta primeiramente pelo contato com as escolas, sensibilização e apresentação do Projeto; Formação de grupos colaborativos de trabalho para desenvolvimento do Projeto; Manifestação de interesse da escola em participar das atividades e ações do Projeto; atividades técnicas, nivelamento e qualificação; Desenvolvendo o Projeto; Pesquisa documental e revisão de literatura; Trabalho de campo e outras técnicas de pesquisa; Como resolver o problema estudado; Como desenvolver e finalizar o trabalho e finalizando com a socialização no Seminário anual.

Relata-se assim, como aconteceu o processo de construção do projeto diante de cada etapa desenvolvida, demonstrando como ocorreu a sensibilização nas escolas, a formação de grupos dispostos e engajados e as potencialidades e dificuldades envolvidas durante o processo construtivo das propostas até a sua exposição no seminário anual. Frisa-se aqui a importância de se desenvolver meios para que, tais projetos sejam concretizados dentro da cidade, por meio de análise do blog do projeto. Para apresentar o processo evolutivo do projeto, serão relatadas as etapas desenvolvidas no decorrer das edições por meio do acompanhamento do blog do projeto. Exemplificando por meio de relatos e entrevistas os 10 passos descritos no Manual Nós propomos.

\section{Resultados}

Em fevereiro de 2016, A UFT (Universidade Federal do Tocantins) em parceria com a SEDUC (Secretaria da Educação, Juventude e Esportes), realiza o lançamento do projeto Nós propomos! Com o tema Cidadania, Sustentabilidade e Inovação na Educação que tem como foco o desenvolvimento do conhecimento do processo de urbanização e dos Planos Diretores da capital de Palmas e dos municípios de Araguaína e Gurupi.

O evento de oficialização do projeto foi um marco muito importante com a participação de alunos de escolas estaduais de Palmas, para sensibilização dos alunos perante proposta. Segundo Mota (2016), durante o lançamento, o secretário da Educação, Juventude e Esportes, Dr Adão Francisco de Oliveira, (figura 1) enfatizou o desenvolvimento dos educandos ao participar do processo formativo proposto. No qual 
seria uma importante oportunidade para o aluno conhecer o plano diretor, a organização territorial onde reside, reconhecendo diversos aspectos que vão permitir que eles fossem sujeitos da própria história e defendam também o interesse coletivo cooperando com a dinâmica urbana.

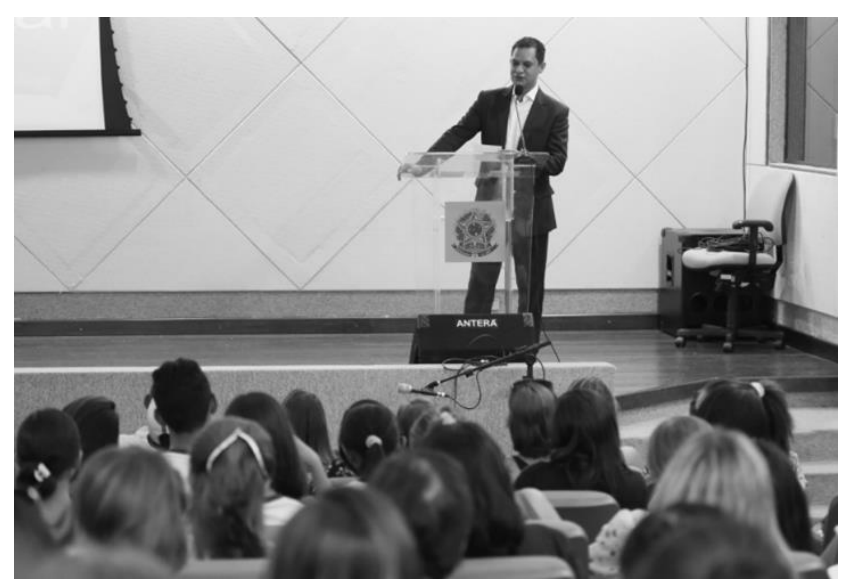

Figura 1 - Secretário da Educação, Juventude e Esportes.

Fonte: Nós propomos, 2017.

O coordenador do "Nós Propomos" no Tocantins, professor da UFT, Doutor João Bazzoli, (figura 2) apresentou o projeto frisando a inserção dos alunos e professores das escolas participantes nas discussões que podem contribuir para o melhor aproveitamento dos espaços da cidade.

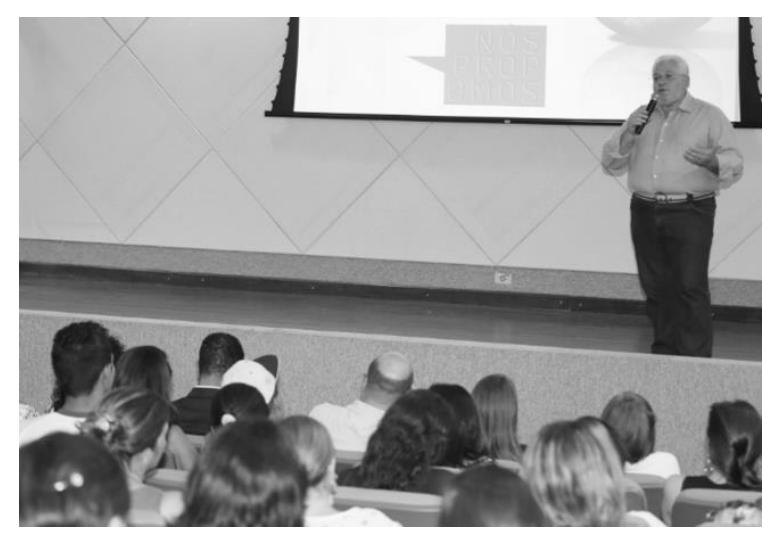

Figura 2 - Coordenador do Projeto.

Fonte: Nós propomos, 2017.

Em Palmas as primeiras escolas que aderiram ao projeto foram o Centro de Ensino Médio (CEM) de Taquaralto, CEM Santa Rita de Cássia, Colégio Estadual Raquel de Queiroz, CEM Castro Alves, Colégio Estadual Liberdade e Colégio Estadual São José. Sendo este o segundo passo, vale ressaltar a importância das mesmas estarem localizadas em pontos estratégicos da cidade, abarcando todo o território palmense e assim contemplando os diferentes contextos socioespaciais. (figura 3). 


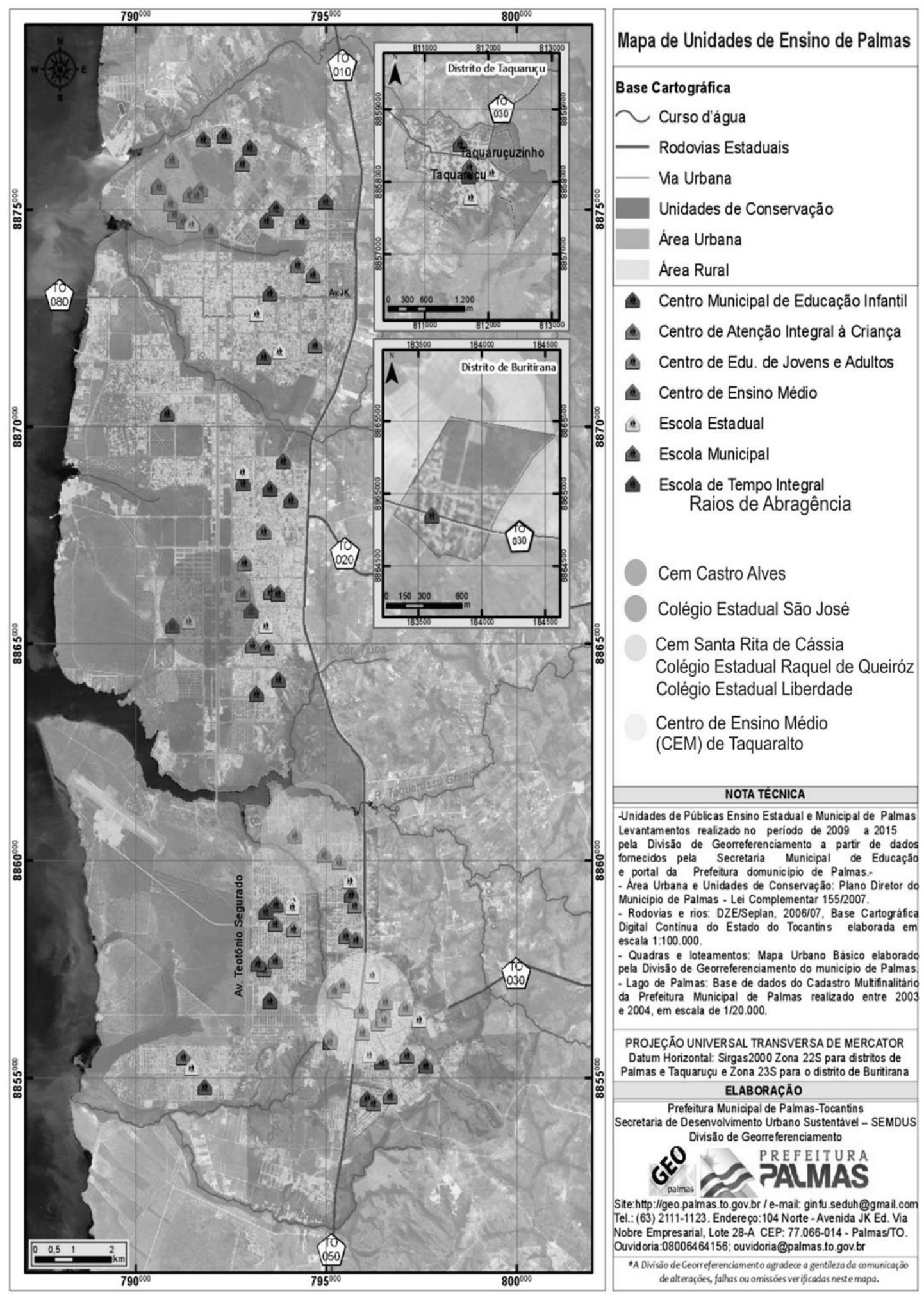

Figura 3 - Mapa espacialização das escolas envolvidas.

Fonte: GEOPALMAS, 2018 - Adaptado pelos autores.

Para o pleno desenvolvimento do projeto, a universidade Federal do Tocantins selecionou seis bolsistas dos cursos de Arquitetura e Urbanismo, Direito e 
Comunicação Social. A equipe é composta também por dois alunos de direito que coordenaram as ações entre bolsistas e entre as atividades desenvolvidas na disciplina de direito urbanístico. Durante esta etapa foram elaboradas diretrizes e propostas iniciais para a construção da primeira edição.

Durante os contatos iniciais com as escolas a equipe identificou os primeiros impasses, tais como a dificuldade dos participantes em entender a dinâmica do projeto e de amplias suas ações para além do perpectiva pedagógica interna de cada escola. Propoe-se então, a elaboração da cartilha ${ }^{3}$ para participantes e o auxílio para elucidar aos professores das escolas participantes para que o projeto seja realizado de maneira que atinja o contexto citadino do local. Logo adiante, a cartilha é apresentada às escolas Escola Estadual Liberdade e Centro de Ensino Médio (CEM) Castro Alves e disponibilizadas nas demais.

Em paralelo, em março de 2016 o projeto é lançado na cidade de Araguaína e na cidade de Gurupi. Araguaina ao norte do estado e outra ao sul do estado respectivamente no qual é apresentada a sistematização e operacionalização para as escolas participantes. Ambos apresentando presença do Poder executivo municipal, Secretarias Municipais, de educação e de infraestrutura urbana. No mesmo período, em Araguaína, são realizadas palestras de nivelamento ministradas pelo Arquiteto Urbanista Lúcio Cavalcante, membro do Instituto Brasileiro de Arquitetura do Tocantins. O trabalho tem a finalidade de discutir os mecanismos para a participação efetiva da população no cumprimento da gestão participativa, prevista pelo Estatuto da Cidade (Brasil, 2008).

A oportunidade de conciliar o projeto com a revisão do Plano Diretor que acontecia na cidade permitiu ampliar o estímulo aos jovens educandos de conhecer e participar do processo da construção da cidade de maneira efetiva. De acordo com o blog Nós Propomos (Nós Propomos, 10/03/2016), as resoluções dos problemas urbanos propostas pelos alunos poderão integrar este instrumento de planejamento importante para a cidade. O Projeto pretende aflorar este sentimento de pertencimento à cidade pelos jovens e fortalecer o seu interesse de aprender, de compreender e de praticar a cidadania.

Em Março de 2016 o projeto se entende para a cidade de Gurupi (figura 4) com a partida de um evento que expôs a operacionalização das atividades do projeto. Dentre os participantes teve a presenças da Secretaria da Educação (SEDUC) e Diretoria

\footnotetext{
${ }^{3}$ A cartilha aqui colocada foi publicada em2017, pela EDUFT. Ver referencia Bazzoli et al, 2017.
} 
Regional de Ensino (DRE) e também representantes da Prefeitura Municipal. O evento pode contar com todos os agentes ativos da cidade demonstrando grande interesse em contribuir com o projeto. Além disso, os agentes públicos se disponibilizaram a contribuir no repasse de dados e informações disponíveis na prefeitura para a análise dos alunos e futuras propostas.

No decorrer do projeto atividades são realizadas no aprimoramento do projeto, é desenvolvido o seminário nacional na Universidade de Lisboa, no qual o Professor João Bazzoli, coordenador da equipe no Estado do Tocantins, relatou a importância das atividades realizadas para a garantia da cidadania. Ainda foi construído juntamente com o grupo o modelo dos trabalhos escritos e slides para as a apresentações no final de cada seminário Estadual que ocorrerá ao final do ano.

Figura 4 - Secretário da Educação, Juventude e Esportes

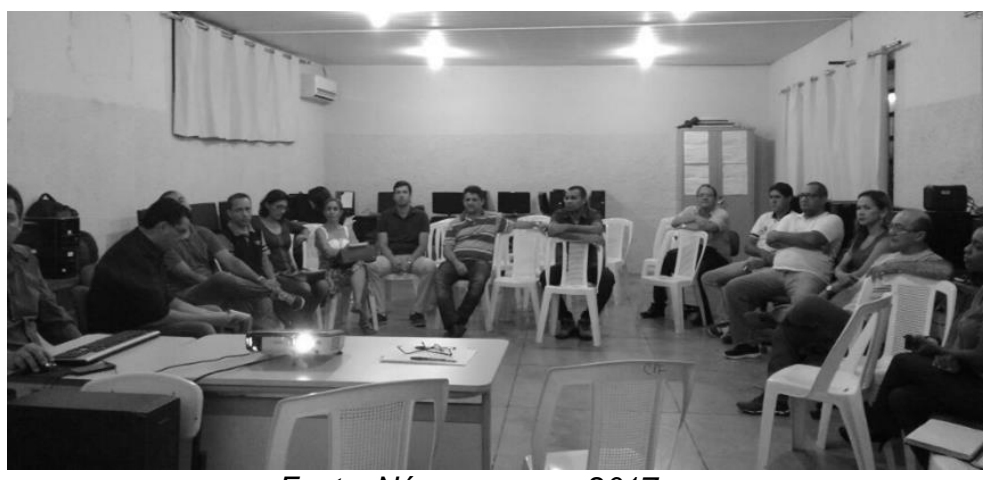

Fonte: Nós propomos 2017.

Em abril, 2016, a Universidade Federal em parceira com a SEDUC realizam um Workshop com o título: "Cidadania e a participação social: um tema transversal na educação - Brasil/Portugal". Com o intuito de instruir os alunos e professores das escolas participantes na discussão dos problemas urbanos locais visando à contribuição no fortalecimento da gestão democrática. O evento contou com o apoio da Defensoria Pública, do Núcleo de Estudos Urbanos e das Cidades (UFT), e também o programa de Mestrado em Desenvolvimento Regional (UFT), Curso de Direito (UFT) e Curso de Arquitetura e Urbanismo (UFT). (Nós Propomos, 28/04/2016). Neste mesmo período é apresentado ao Colégio Estadual São José uma atividade de nivelamento e a lançamento da Cartilha: Nós Propomos!, (figura 5)

Demonstrando o processo para a identificação dos problemas/temas que serão trabalhados. É destacada também a importância das visitas de campo para o conhecimento da realidade do local, identificando e caracterizando as necessidades do problema a ser trabalhado. No mês de Maio a Escola Cem Taquaralto recebe visita da equipe, que com o suporte de vídeos da série "Como hackear a cidade" discute 
sobre os problemas urbanos e como trabalhar na melhoria das intercorrencias apresentadas. (figuras 5 e 6 ).

Figuras 5 e 6 - Oficina de nivelamento Colégio

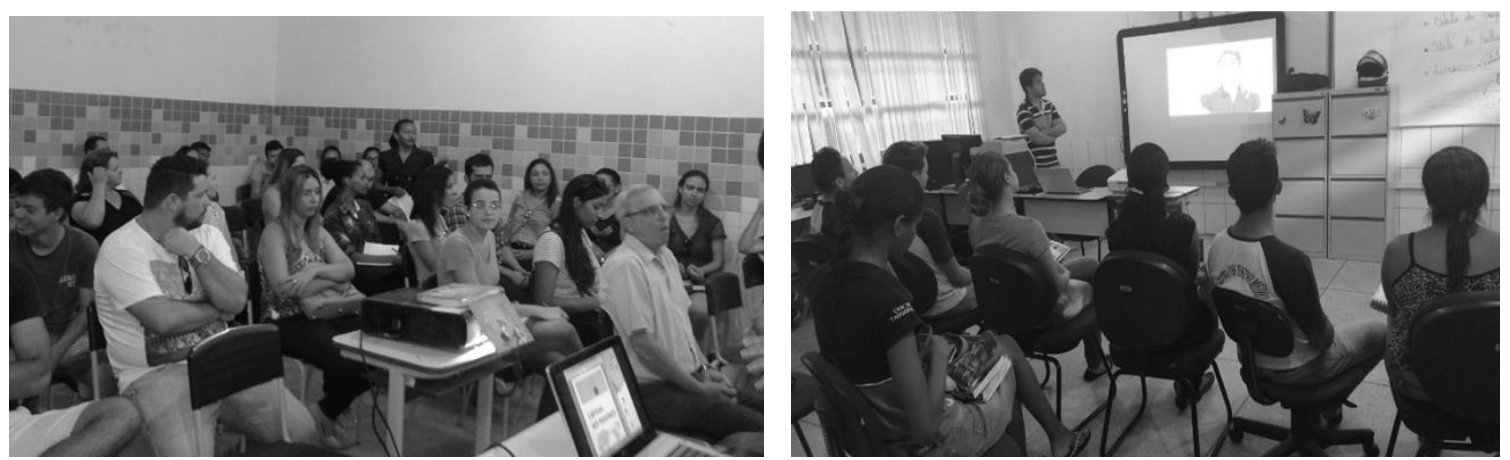

Estadual São José e Cem Taquaralto, respectivamente.

Fonte: Nós propomos, 2017.

Neste período, maio de 2016, iniciou-se a revisão do Plano Diretor de Palmas, ocorrendo à primeira audiência, um evento importante para a formação dos alunos participantes do projeto. Estes debates foram enriquecedores para a capacitação da equipe de gestores do projeto do sentido de ampliar o conhecimento e visualização das temáticas, uma vez que possuem maior proximidade da realidade local e da prática. (Nós Propomos 26/05/2016).

As tecnologias, com destaque à internet, atualmente se fazem presentes em todos os contextos, estas, oferecem incontáveis possibilidades de comunicação, interação e busca de informações. Dentre tantas possibilidades que estão à disposição na internet, os blogs destacam-se por oportunizar uma inter-relação entre quem transmite a informação e quem as lê. Pontes e Filho (2011) referem que o fato do blog permitir que o internauta comente as postagens, possibilita o diálogo deste com o autor e do autor com o leitor. Os comentários refletem a concordância ou discordância do leitor em relação ao que foi postado, dando margem às discussões, acréscimos de conteúdos, entre outras possibilidades, este recurso permite que os usuários interajam, fato que diferencia o ato de navegar do ato de blogar, já que o primeiro limita a leitura do internauta aos resultados que se lhe apresentam.

Com este intuito, a divulgação dos acontecimentos desenvolvidos pelo projeto, ocorre conforme os cronogramas gerais. Nas reuniões periódicas entre colaboradores do projeto são decidido quais ações serão desenvolvidas no decorrer das semanas e dentro disso são criadas atas para controle das medidas que serão tomadas, nas quais a partir de levantamentos fotográficos e criação de textos informativos são formuladas as edições para publicação no blog. (Ver figuras 7 e 8). 

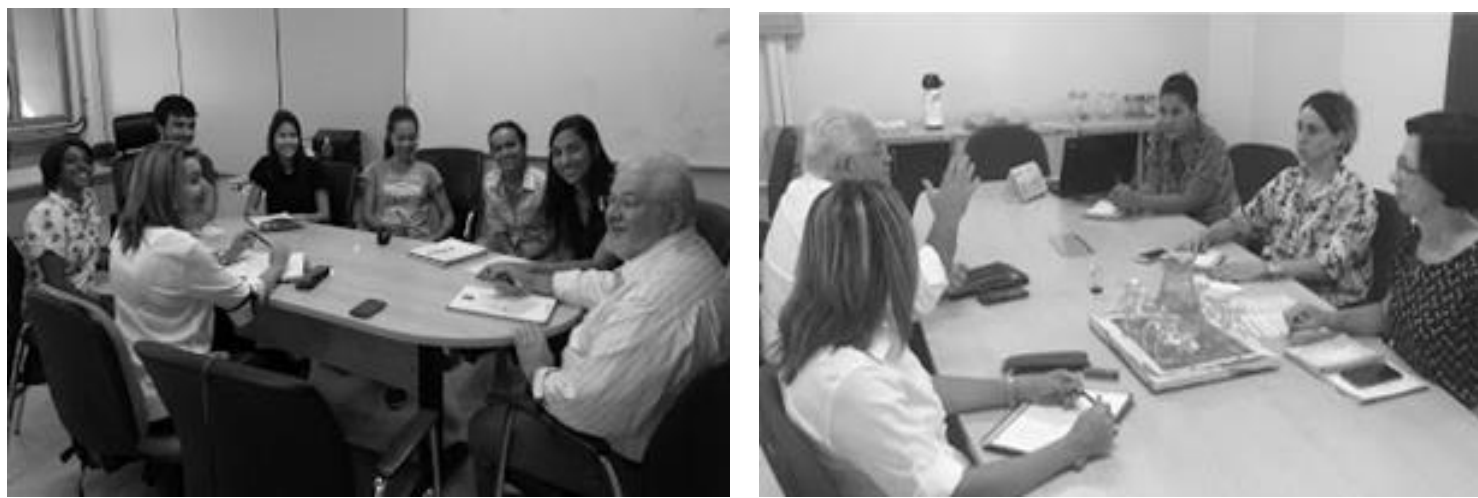

Figuras 7 e 8 - Reunião com equipe do Projeto.

Fonte: Nós propomos, 2017.

Estas reuniões são noticiadas no blog, e aconteceram em diferentes períodos no decorrer do projeto. A equipe sempre composta por alunos de graduação e/ou do programa de Mestrado em Desenvolvimento Regional sistematizam as idéias juntamente com o professor e coordenador do Projeto João Bazzoli e participante integrante da Seduc. Estas informações são repassadas para o blog, para que os interessados possam acompanhar todas as fases e processos que o projeto esteja passando.

Eventualmente, são realizadas oficinas de nivelamento para definir a metodologia que será aplicada para os alunos das escolas participantes. A partir disso são produzidos materiais para subsidiar a transmissão das informações referentes aos objetivos do projeto. (Ver figuras 9 e 10).

Figuras 9 e10 - Oficinas de nivelamento.
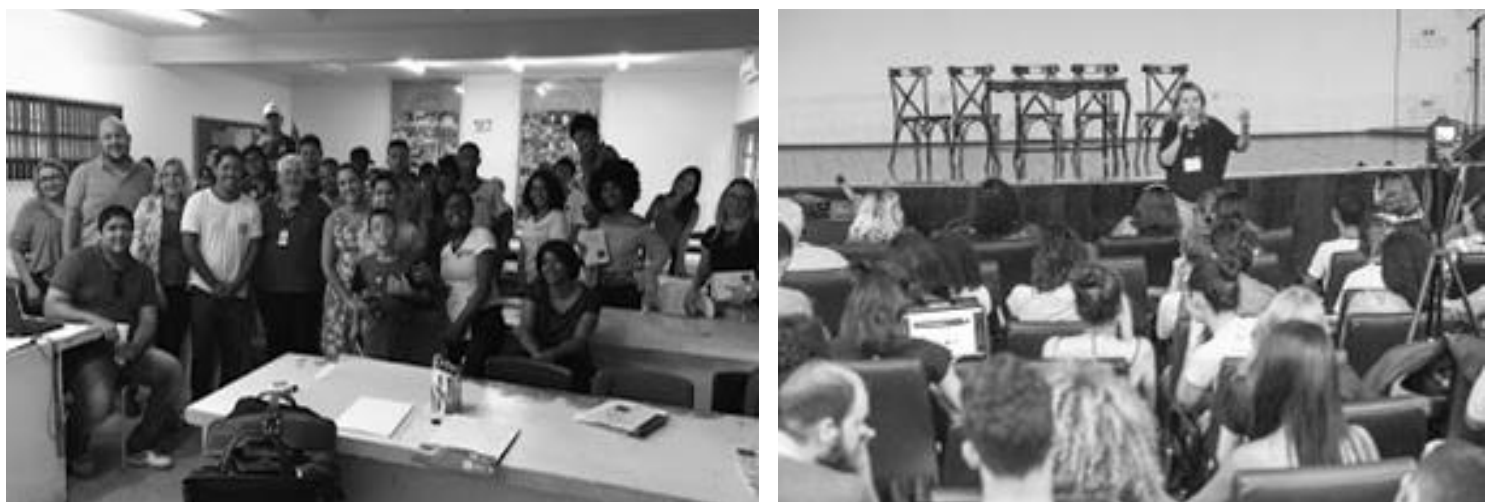

Fonte: Nós Propomos, 2017

Com o objetivo de facilitar a execução das atividades no desenvolvimento do Projeto "Nós Propomos!" pelos alunos das escolas da rede estadual a equipe da Universidade Federal do Tocantins (UFT) resolveu elaborar um Manual (Bazzoli et. El, 2017), que foi estruturado nas dimensões teóricas e práticas. A dimensão teórica desta publicação 
buscou, por meio de revisão de literatura pertinente e atual, discutir no campo educacional e interdisciplinar às tendências ao debate sobre o Direito à Cidade $e$ participação social, propondo e integrando a multiescalaridade entre os níveis de ensino envolvidos com o Projeto.

A dimensão prática buscou mostrar - como fazer - e trazem os 10 passos recomendados para a execução das atividades propostas pelo Projeto. Cada passo foi detalhadamente transcrito para facilitar na estruturação das atividades desenvolvidas pelos participantes durante as edições anuais. (Ver figura 11).

Figura 11 - Manual do Projeto

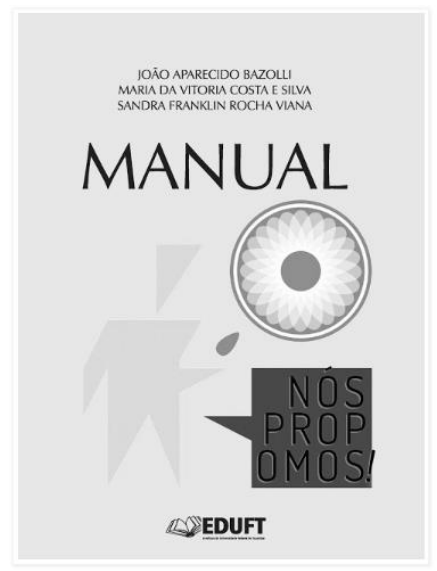

Fonte: Nós Propomos, 2017.

No decorrer do ano são realizadas reuniões nas escolas, além de reuniões com a equipe para arremates das atividades que vêm sendo produzidas. Todos esses processos foram devidamente publicados no blog com intuito de registrar as atividades e servir de meio comunicativo entre o projeto e a comunidade interessada. Até aqui foram expostos os principais acontecimentos da primeira Edição. Mais detalhes podem ser acompanhados através do link: <http://nospropomos.blogspot.com/>.

$\mathrm{Na}$ Edição/2018 o projeto retoma as ações a partir de oficina de nivelamento realizadas em Palmas e Araguaína, neste evento foram mostrados os avanços promovidos por esta tecnologia educacional, procedida avaliação de resultados da edição passada e coletadas sugestões de melhorias para o desenvolvimento desta edição. A UFT de Palmas pretende como suporte às escolas participantes, oferecer com frequência quinzenal oficinas temáticas. Em Araguaína o Projeto inicia com evento na Delegacia Regional de Ensino onde são apresentados os resultados da edição de 2017 e proposto o planejamento para 2018. Nesta cidade o Projeto está vinculado ao curso de Geografia e dentro do critério de autonomia para a sua 
execução os coordenadores e os envolvidos nas atividades tiveram de experimentar as adequações que mais estejam próximas da realidade local no desenvolvimento dos trabalhos do Projeto. (Ver figuras 12 e 13).

Figuras 12 e 13 - Oficinas de nivelamento da $2^{\circ}$ Edição.
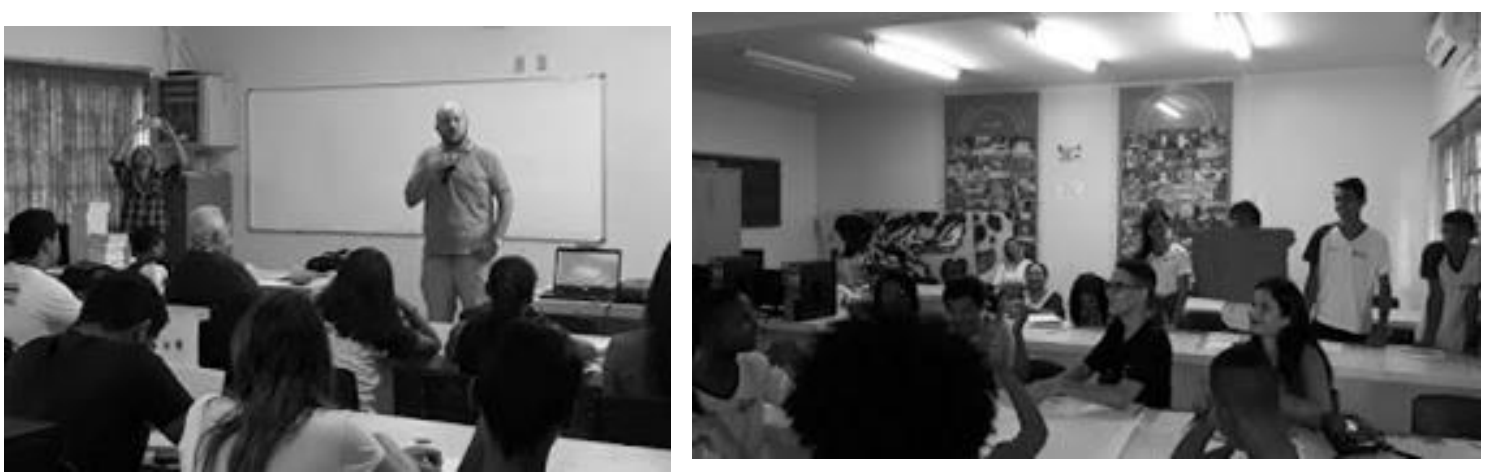

Fonte: Nós propomos, 2018.

No decorrer das atividades, é desenvolvido um livro para compilar as produções e conquistas, no qual o projeto Nós Propomos, lança o livro: A EXTENSÃO UNIVERSITÁRIA COMO INDUTORA A CIDADANIA: A EXPERIÊNCIA DO "NÓS PROPOMOS". O livro trata da importância do projeto como intermediador entre o diálogo acadêmico e o social. Mostra o processo histórico de construção desse projeto de extensão no Estado do Tocantins, pela Universidade Federal do Tocantins (UFT).

São apresentadas as atividades e ações que evidenciam o desenvolvimento e o aprimoramento da educação cidadã nas decisões locais, além de destacar pontos importantes resultantes da integração e do diálogo entre níveis escolares e, finalmente, promover a análise crítica sobre as fragilidades do processo participativo nas decisões locais, respaldada em artigos que objetivam fortalecer o debate temático epistemológico, isso com o propósito de sedimentar o pensamento sobre a extensão universitária a partir de atividades estruturadas na formação cidadã e na democracia participativa. (Ver figuras 14 e 15).

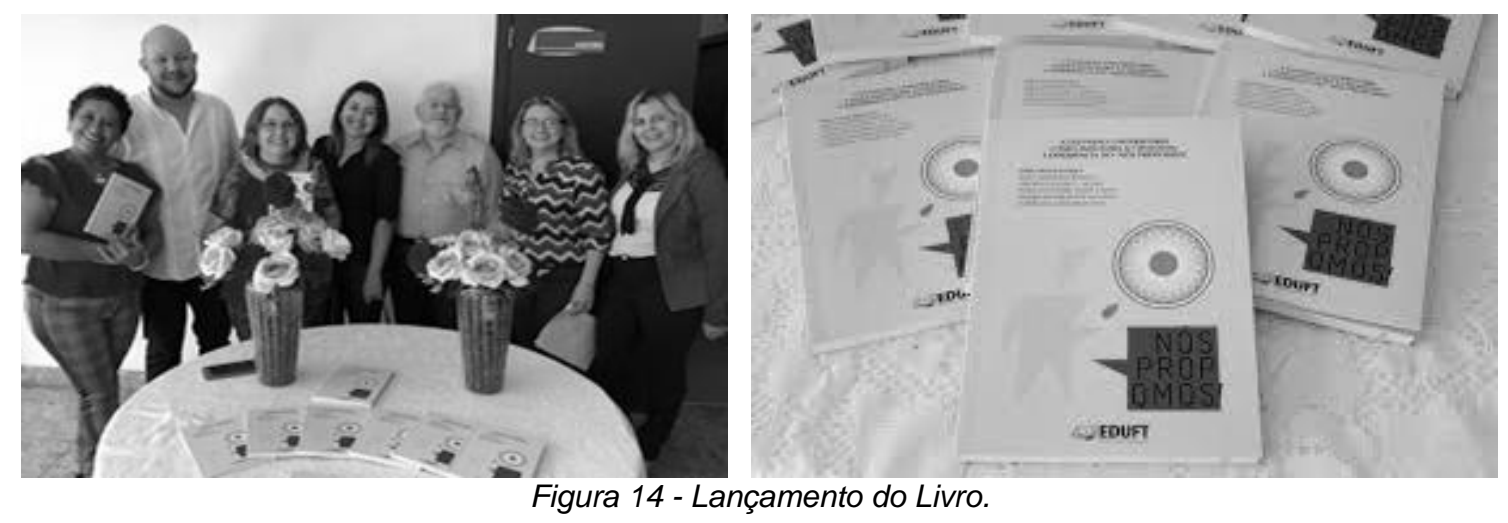


Logo após, ocorreu no auditório do Centro Universitário Integrado de Ciência, Cultura e Arte (Cuica), no Câmpus de Palmas da UFT, data (13/11/2017), o II Seminário Estadual do projeto de extensão Nós Propomos. A programação se estendeu ao longo do dia e foi ocasião reservado para as apresentações dos trabalhos dos alunos secundaristas. Sendo assim, este constituiu momento ímpar para que os alunos tivessem a oportunidade de expor tudo que haviam aprendido e produzido no decorrer desta edição do projeto. Os presentes foram agraciados com propostas inventivas e viáveis, demonstrando a assimilação destes do viés de participação social proposto pelo projeto. (Ver figuras 16 e 17).

Figuras 16 e 17 - I/ Seminário Estadual.

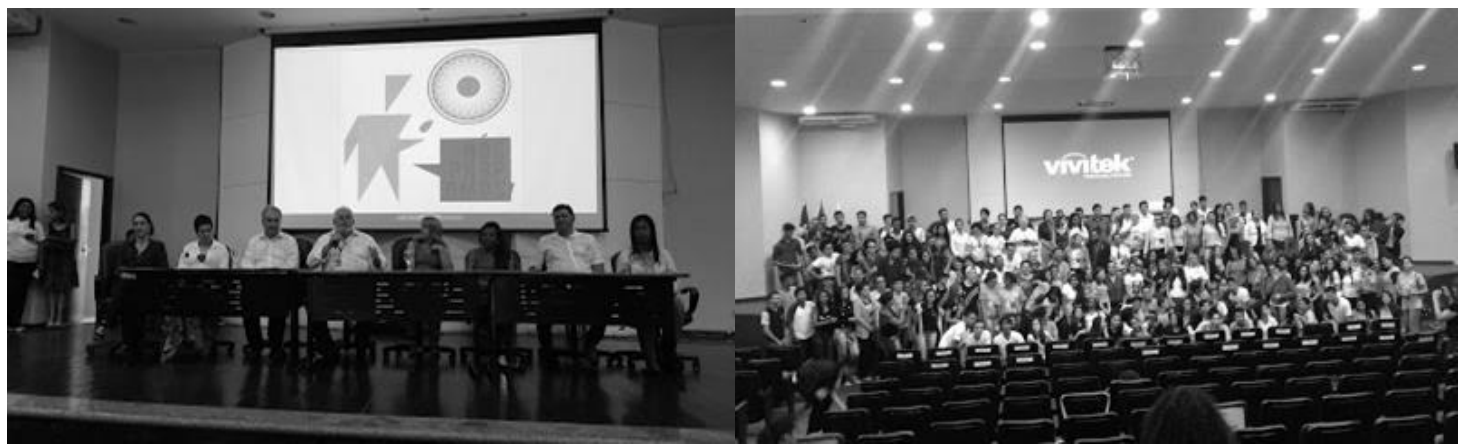

Fonte: Nós propomos, 2018.

A partir dessas informações disponíveis no blog, uma equipe de apoio financeiro às ações de cunho social tiveram acesso às propostas desenvolvidas pelos alunos e se interessaram em colaborar. Sendo assim, a proposta vencedora do II Seminário Estadual do projeto de extensão Nós Propomos, teve a oportunidade de tornar-se ação concreta e, por meio do apoio financeiro da Fundação Alphaville, juntamente com a comunidade envolvida, o espaço foi reformado e qualificado. (figuras 18 e 19).
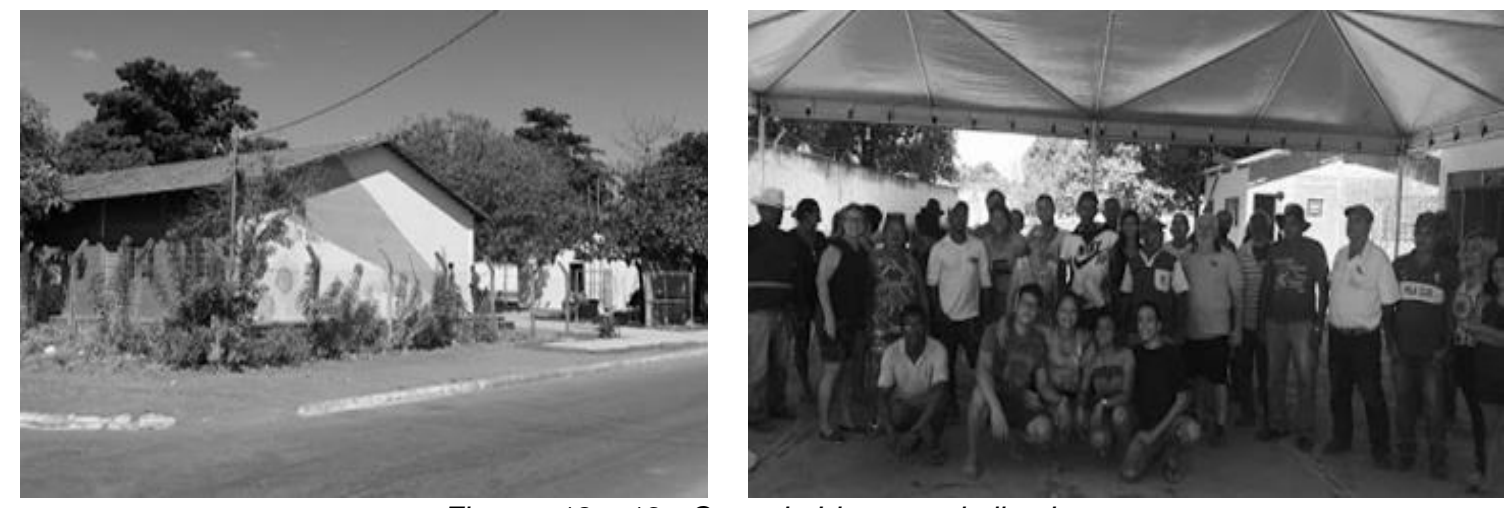

Figuras 18 e 19 - Casa de Idosos revitalizada.

Fonte: Nós propomos, 2018. 


\section{Conclusão}

As atividades consistem substancialmente na identificação de problemas urbanos locais, na promoção de pesquisa de campo e consulta à comunidade, e na elaboração e apresentação das propostas de resolução dos problemas encontrados. Com as atividades desenvolvidas durante a execução do Projeto se pretende conscientizar os participantes acerca da necessidade da criação de espaços estimulantes para programar alternativas diversificadas de democracia participativa, pela consolidação de canais abertos e alternativos (a exemplo deste Projeto), com a finalidade de garantir uma participação plural e qualificada na gestão democrática das cidades.

O trabalho desenvolvido possibilita ao longo do tempo ampliar o envolvimento público em atividades participativas através de iniciativas que possibilitem uma elevação do nível de consciência dos participantes, sempre numa perspectiva pluralista. Pretendese enfatizar aos alunos participantes, que os estímulos às mudanças de comportamento apontam para a existência de um potencial para ampliar sua dinâmica interativa, como cidadãos ativos com o Poder Público, também, estimular e consolidar um eficiente e consistente processo de participação popular para mostrar que é necessário assegurar, por meio da cidadania efetiva, a promoção do desenvolvimento das cidades, onde as pessoas e o meio ambiente estejam inseridos.

\section{Referências bibliográficas}

Bazzoli, J.A.; Costa e Silva, M. de V.; Viana, S. F. R. Manual Nós Propomos. EDUFT, $1^{\circ}$ ed. 50 p.ISBN 978-85-60487-28-8, 2017

Nós Propomos. CEM Taquaralto recebe visita dos alunos do projeto. Quinta-feira, 26 de maio de 2016. Dísponível em: <http://nospropomos.blogspot.com/2016/04/equipeuft-e-seduc-presentes-no.html> Acesso em: 10 de Maio de 2018.

Nós Propomos. Equipe UFT e SEDUC presentes no Seminário Nacional do Projeto Nós Propomos. Quinta, 28 de abril de 2016. Dísponível em: < http://nospropomos.blogspot.com/2016/04/equipe-uft-e-seduc-presentes-no.html> Acesso em: 10 de Maio de 2018.

Nós Propomos. Lançamento do Projeto em Araguaína. Domingo, 10 de abril de 2016 Dísponível em: < http://nospropomos.blogspot.com/2016/04/equipe-uft-e-seducpresentes-no.html> Acesso em: 10 de Maio de 2018. 
Brasil. Casa Civil. (2001, Julho). Subchefia para Assuntos Jurídicos. Lei n. 10.257, de 10 de julho de 2001. Regulamenta os arts. 182 e 183 da Constituição Federal estabelece diretrizes gerais da política urbana e dá outras providências. Diário Oficial da União.

<http://www.planalto.gov.br/ccivil_03/leis/LEIS_2001/L10257.htm>. Acesso em: 19 de Maio de 2018.

Brasil. Senado Federal, Subsecretaria de Edições Técnicas Estatuto da Cidade. Lei $\mathrm{n}^{\circ}$ 10.257, de 10 de julho de 2001 - Vetos Presidenciais - Lei $n^{\circ}$ 6.766, de 19 de dezembro de 1979 - Lei $n^{\circ}$ 8.245, de 18 de outubro de 1991 - Decreto no 5.790/2006. $3^{\circ}$.ed. Brasília, 2008. 102 p.

Mota, Núbia Daiana. (2016, Fevereiro). Governo do Estado do Tocantins. Portal do aluno SEDUC, 2016. Web. 23 de Fevereiro de 2016. Dísponível em: $<$ https://seduc.to.gov.br/noticia/2016/2/23/cerca-de-20-mil-estudantes-de-escolas estaduais-de-palmas-gurupi-e-araguaina-participarao-do-projeto-de-intervencaourbana-nos-propomos/.> Acesso em: 10 de Maio de 2018.

Nogueira, M. das D. P.). Políticas da Extensão Universitária Brasileira. Belo Horizonte: Ed. UFMG. 200

Pontes. R.L.J; Filho, J.A.C. O uso do blog como ferramenta de ensino-aprendizagem por professores participantes do Projeto Um Computador por Aluno (UCA). Anais do XXII SBIE - XVII WIE. Aracaju. Novembro, 2011, 


\section{Nós propomos em Taguatinga- DF: dando novos significados às geografias locais ${ }^{1}$}

LEONARDO FERREIRA FARIAS DA CUNHA ${ }^{2}$

\section{Resumo}

O Projeto Nós Propomos tem-se apresentado como uma possibilidade efetiva de promover a aprendizagem de geografias locais numa perspectiva cidadã. A problematização de contextos nos quais os alunos da Educação Básica estão inseridos, mobiliza conceitos e ressignifica a Geografia na escola como um conhecimento útil para que os alunos pensem a própria espacialidade. Neste sentido, o presente artigo tem por objetivo compartilhar e discutir a experiência de implementação do Nós Propomos em duas escolas públicas de Taguatinga, cidade do Distrito Federal - Brasil. Desse modo, por meio de uma abordagem qualitativa pretendeu-se refletir sobre os efeitos que essa iniciativa teve no processo de ensino e aprendizagem dos alunos, visto que o lugar é pensado em suas particularidades, para servir ao exercício da leitura geográfica de questões que ocorrem em diferentes escalas. Como resultado, foi possível perceber um aumento do interesse dos alunos pelos temas locais e pela Geografia Escolar como um conhecimento a ser aplicado muito além da escola.

Palavras-chave: Ensino e aprendizagem; Geografia Escolar; Lugar; cidadania.

\section{Abstract}

The We Propose Project has been presented as an effective possibility to promote the learning of local geographies from a citizen perspective. The problematization of

\footnotetext{
${ }^{1}$ Agradeço à Fundação de Amparo à Pesquisa do Distrito Federal (FAP-DF) e a Universidade de Brasília (UnB) pelo auxílio financeiro concedido para a participação no I Congresso Iberoamericano Nós Propomos e consequente apresentação deste trabalho.

${ }^{2}$ Professor da Carreira do Magistério público da Secretaria de Estado de Educação do Distrito Federal-Brasil, leoffarias@yahoo.com.br.
} 
contexts in which the students of Basic Education are inserted, mobilizes concepts and reaffirms the Geography in the school as a useful knowledge for the students to think their own spatiality. In this sense, the objective of this article is to share and discuss the experience of implementation of the We Propose in two public schools in Taguatinga, a city of the Federal District - Brazil. This way, through a qualitative approach, it was intended to think over the effects that this initiative had on the teaching and learning process of students, since the place is thought of its peculiarities, to serve to the exercise of the geographic reading of questions that occur on different scales, as a result, it was possible to perceive an increase in students' interest in local subjects and in School Geography as a knowledge to be applied well beyond school.

Keywords: Teaching and Learning; School Geography; Place; Citizenship.

\section{Introdução ${ }^{3}$}

As vivências rotineiras podem servir como motivação para ensinar e também aprender. Desde que problematizadas, as referências que os alunos apresentam servem ao trabalho didático-pedagógico do professor. A Geografia traz a possibilidade de se trabalhar com o lugar, que é em certa medida uma síntese do espaço geográfico. O lugar se conecta a outros pelos próprios vínculos do espaço geográfico, que é uma totalidade socioespacial e físico-natural, Moreira (2012).

Compreender os lugares e suas interações é um exercício de análise em diferentes escalas. O interesse dos alunos pode ser despertado a partir de temas dos espaços com os quais possuem algum vínculo. Há um consenso sobre o uso dos espaços de vivência nos processos de ensino e aprendizagem, dada a sua capacidade de mobilizar os conhecimentos prévios e a experiência dos alunos sobre o assunto a ser estudado (Castellar, 2010; Callai, 2000; Cavalcanti, 2013; Leite, 2012).

Sendo assim, usar as práticas sociais dos alunos como recurso para uma estratégia de ensino colabora para que a motivação seja maior com relação aos conteúdos trabalhados. Para Gasparin (2012), os conteúdos escolares não interessam a priori e automaticamente aos estudantes, eles precisam ser contextualizados de modo que possam se tornar interessantes e colaborarem para uma aprendizagem socialmente significativa.

\footnotetext{
${ }^{3}$ Parte desse texto compõe um capítulo do livro: Ensinar e Aprender Geografia por meio do Projeto Nós Propomos. Publicado em 2018 e lançado no I Congresso Iberoamericano Nós Propomos. A referência bibliográfica do mesmo se encontra ao final deste artigo.
} 
Nesta perspectiva, é preciso compreender essa leitura dos espaços de vivencias que os alunos trazem consigo. Ainda que ela se mostre confusa, que traga uma carga acentuada de senso comum, ela é a representação de uma totalidade, é a concepção muitas vezes naturalizada de uma realidade (Gasparin, 2012). Usá-la em favor da possibilidade de construir conhecimento territorialmente localizado é oportuno, afinal, os alunos conhecem seus espaços e atribuem significados que podem ser recursos preciosos para o professor.

Neste sentido, de acordo com Cavalcanti (2005), ao discorrer sobre as fases que compreendem a formação de conceitos científicos de acordo Vigotsky, diz que eles se dão entre dois pontos: a formulação de conceitos cotidianos, que são vagos, sincréticos e dotados de espontaneidade, vistos inclusive como pseudoconceitos; e os conceitos científicos que são conscientemente definidos. A espontaneidade típica dos conceitos cotidianos, na perspectiva da psicologia vigotskiana, é o que permitirá depois de certo nível, a construção de um conceito científico numa relação que vai do interpessoal para o intrapessoal, do exterior para o interior, embora não de forma passiva.

Isto só reforça a ideia de que os conceitos e as representações da vivência e do cotidiano, quando trazidos para o diálogo na relação professor-aluno, permitem uma aprendizagem mais efetiva, assim como um ensino mais eficaz. Nesse processo dialógico a experiência anterior do aluno e a perspicácia do professor se unem para traçar o caminho necessário para ensino e a aprendizagem dos conteúdos convencionais. Nessa concepção, tais conteúdos já podem ser conhecidos em certa medida pelos alunos, embora não numa perspectiva científica. Quando isso acontece, muda a relação cognitiva do indivíduo com o mundo.

O projeto denominado "Nós Propomos" tem em sua essência a característica de trabalhar com o cotidiano dos envolvidos, no sentido de propor uma reflexão sobre os espaços de vivências dos mesmos, uma leitura analítica e propositiva das espacialidades vivenciadas. Isso reforça a importância da educação geográfica como propiciadora de habilidades que permitem "verler" (KAERCHER, 2013) a realidade, pensando-a geograficamente. Sendo assim, esta iniciativa torna-se muito oportuna para a Geografia Escolar, e explica as experiências exitosas que obteve em Portugal, onde surge, e em outros países a exemplo do Brasil.

Dito isto, o presente texto tem por objetivo compartilhar e discutir a experiência de implementação do "Nós Propomos" em duas escolas públicas de Taguatinga, cidade 
do Distrito Federal - Brasil nos anos de 2017 e 2018. O Projeto se realizou em duas escolas públicas de Ensino Médio em turmas de $2^{\circ}$ ano, nas aulas de Geografia, envolvendo aproximadamente 200 alunos. As temáticas das atividades se dividiram em duas frentes. Em uma das escolas foi trabalhado a crise hídrica que acometeu o Distrito Federal do Brasil desde o fim de 2016 até o presente momento, na outra os alunos como de praste, escolheram temas que lhes chamavam a atenção em seus espaços de vivências. Objetivamos também fazer uma reflexão a respeito da importância da análise geográfica dos fenômenos, com foco na espacialidade a partir dos apontamentos de Roque Ascenção e Valadão (2017).

\section{Taguatinga}

Taguatinga é uma das 31 regiões administrativas -RAs do Distrito Federal. Com uma população de 222.598 habitantes é a segunda RA em termos populacionais (Codeplan, 2016). Fundada em 5 de junho de 1958, a partir de uma fazenda de mesmo nome, Taguatinga surge em função do superpovoamento da Cidade Livre, atualmente R.A do Núcleo Bandeirante, que não tinha mais como receber o contigente de trabalhadores atraídos pelas oportunidades que a construção da nova capital brasileira abrira. De sua área original outras RAs surgiriam, por pressão demográfica e demanda habitacional, nascem portanto, Ceilândia e Samambaia. Por conta de outros desmembramentos surgem também Águas Claras e Vicente Pires.

A cidade possui uma dinâmica própria, o que lhe dá o posto de segunda centralidade no Distrito Federal. Sua população apresenta um grau de independência maior, em relação RA 01 onde se localiza a capital administrativamente denominada Plano Piloto, que é Brasília. Essa dinâmica se dá em função das atividades comerciais, do mercado de trabalho, dos variados serviços públicos, da oferta de atividades de cultura e opções de lazer, que é maior do que as outras RAs próximas. Apresenta renda domiciliar média elevada superando $\mathrm{R} \$ 6.000,00$ divididos advinda de trabalhadores vinculados à empresas privadas, autônomos e funcionários públicos (Codeplan, 2016).

A maioria dos residentes trabalham na própria $R A$, o segundo local de trabalho é a RA do Plano Piloto, e uma pequena parte em outras localidades. Concentra uma população com características educacionais significativas quanto a formação, pois $27 \%$ possui ensino médio completo e $22,11 \%$ da população tem nível superior e/ou pós-graduação, conforme tabela 1 (Codeplan, 2016). 
Tabela 1- Evolução de Indicadores Socioeconômicos Taguatinga 2011/2013/2016

\begin{tabular}{|c|c|c|c|c|c|}
\hline \multirow[b]{2}{*}{ Indicadores Socioeconômicos } & \multicolumn{2}{|c|}{2011} & \multicolumn{2}{|c|}{2013} & \multirow{2}{*}{$\begin{array}{c}2016^{\star *} \\
\text { Taguatinga }\end{array}$} \\
\hline & Taguatinga & DF & Taguatinga & DF & \\
\hline População estimada & 197.783 & 2.556 .149 & 212.863 & 2.786 .684 & 222.598 \\
\hline Domicílios urbanos estimados & 65.182 & 784.092 & 66.702 & 821.130 & 69.678 \\
\hline Renda Domiciliar real (a preços de março 2016) & $6.139,59$ & $6.435,95$ & $6.359,06$ & $6.221,08$ & $6.072,92$ \\
\hline Renda Per capita real (a preços de março 2016) & $1.817,90$ & $1.828,98$ & $2.028,34$ & $1.847,79$ & $1.998,14$ \\
\hline $\mathrm{N}^{0}$ médio de moradores por domicilio & 3,03 & 3,26 & 3,19 & 3,39 & 3,19 \\
\hline$\%$ de moradores analfabetos & 1,38 & 3,71 & 1,47 & 1,90 & 1,48 \\
\hline$\%$ de moradores com nível superior completo* & 17,11 & 15,87 & 18,24 & 17,27 & 22,11 \\
\hline$\%$ de domicilios com automóvel & 66,41 & 62,86 & 71,41 & 66,13 & 72,27 \\
\hline$\%$ de domicilios com TV por assinatura & 21,24 & 24,32 & 50,51 & 43,72 & 60,33 \\
\hline Índice de Gini & 0,453 & 0,510 & 0,453 & 0,474 & 0,442 \\
\hline
\end{tabular}

*Inclusive especialização, mestrado e doutorado ** Pesquisa realizada nos meses de janeiro a maio de $2016 \mathrm{com}$ amostra de 1.500 domicílios.

Fonte: Codeplan - Pesquisa Distrital por Amostra de Domicilios - PDAD - 2011/2013/2016

Embora se configure como um aglomerado urbano consolidado, Taguatinga tem apresentado um razoável crescimento vertical, uma vez que não há mais, áreas para expansão da mancha urbana horizontalmente, situação que impõe desafios para a gestão deste espaço. De todo modo, a cidade também apresenta problemas urbanos, típicos de uma área metropolitana em expansão. Neste sentido, existe um déficit habitacional, carência de uma infraestrutura urbana básica para toda população, acentuados índices de violência e desigualdade social, deteriorização do centro como local de moradia, além do acentuado adensamento populacional com agravamento de problemas ambientais, dificuldades com o transporte e a mobilidade.

\section{As escolas participantes do Projeto.}

O Centro de Ensino Médio Ave Branca, também conhecido pela sigla CEMAB, recebeu o projeto em 2017. Essa escola está no centro da cidade, inserida numa malha urbana consolidada e adensada, composta por áreas residenciais de classe média, comércio diversificado, e intenso fluxo de pessoas. Recebe uma diversidade de alunos oriundos não apenas de suas imediaçõe, mas também de áreas periféricas da própria Taguatinga e de outras regiões administrativas como Ceilândia, Samambaia, Riacho Fundo, Recanto das Emas, Águas Claras e até mesmo do entorno do DF, como Santo Antônio do Descoberto e Águas Lindas pertencentes ao estado de Goiás. 
Sendo assim, embora receba alunos de classe média, também acolhe alunos que possuem diversas vulnerabilidades sociais (Distrito Federal, 2016a). É uma escola de grande porte, com mais de 2500 alunos, e possui tradição na cidade, pois existe desde 1961 e foi responsável pela formação de várias gerações.

Funciona em três turnos ofertando o Ensino Médio. Em termos de estrutura conta com Auditório, refeitório, laboratórios de ciências e informática, três quadras poliesportivas, sendo uma delas coberta. Possui 28 salas de aula (equipadas com recursos audiovisuais), sala de professores, sala de coordenação e biblioteca. Parte dos alunos do turno matutino são atendidos também à tarde com atividades da escola integral, que inclui reforço escolar, música e língua estrangeira. Há também uma estrutura para abrigar o serviço de orientação educacional.

Figura 1. Centro de Ensino Médio Ave Branca (CEMAB) em Taguatinga-DF.

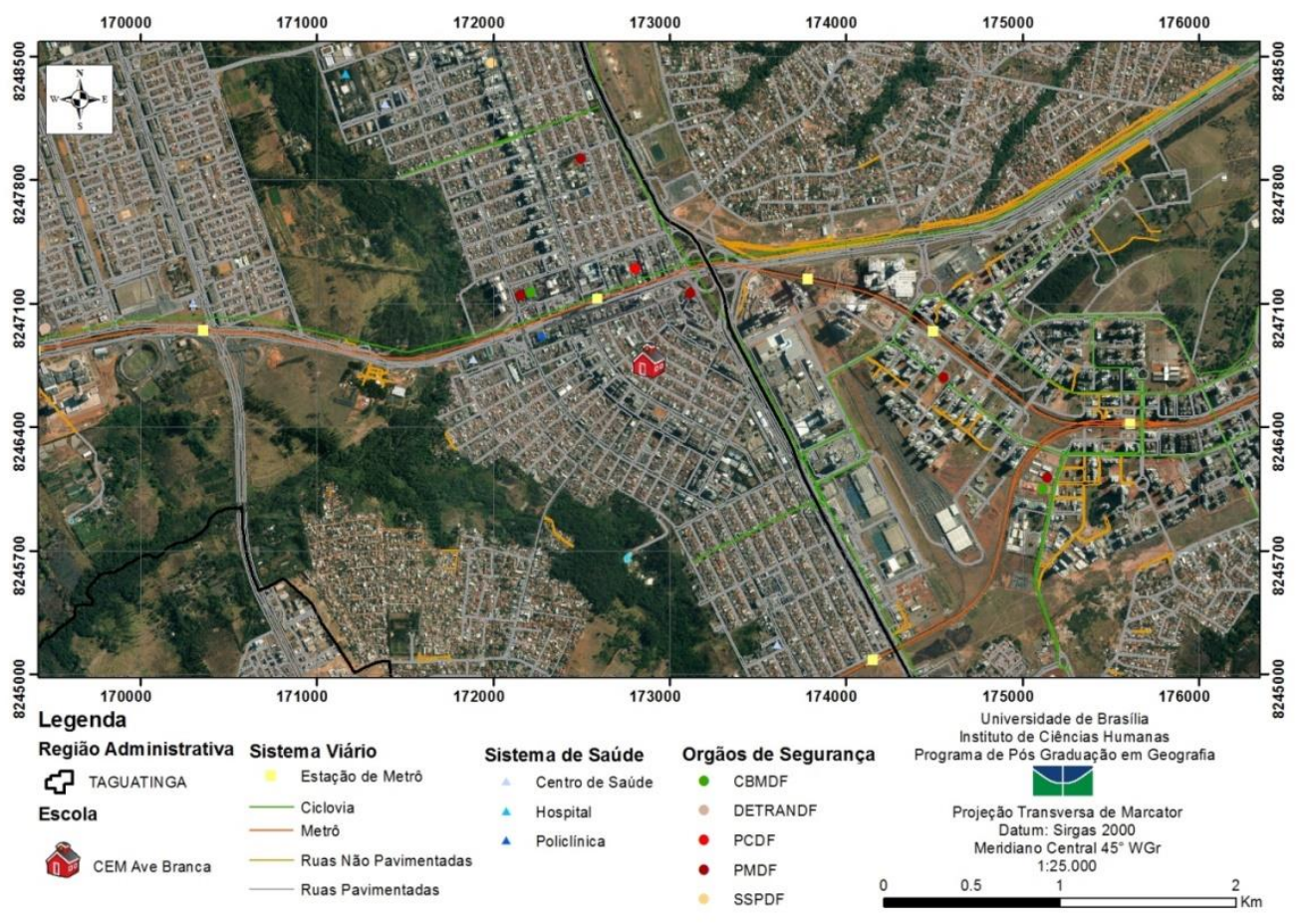

Fonte: elaborado por Gabriela Branquinho em parceria com o autor (2018). 
Figura 2. Centro de Ensino Médio 03 (CEM 03) em Taguatinga-DF

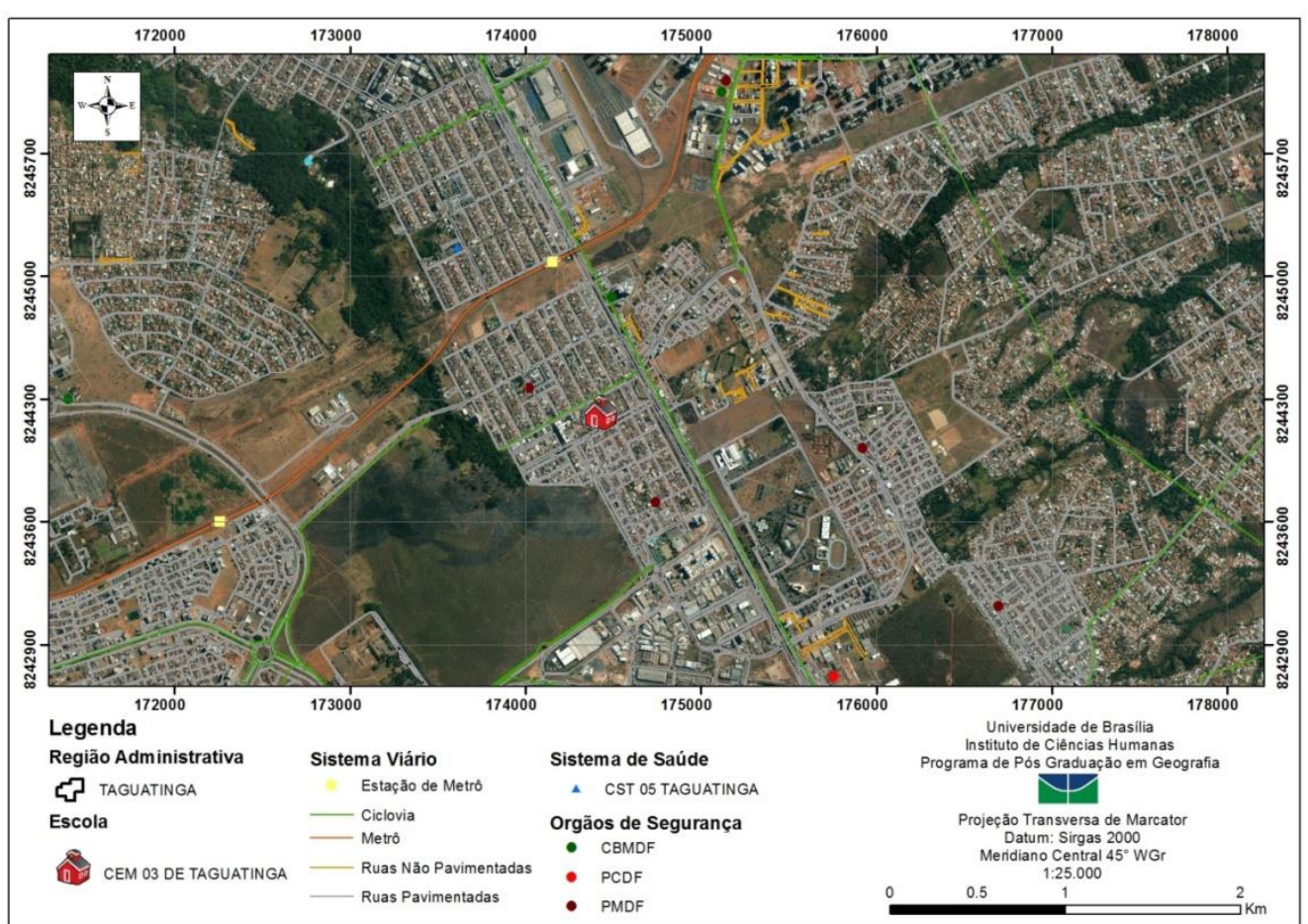

Fonte: elaborado por Gabriela Branquinho em parceria com o autor (2018).

O Centro de Ensino Médio 03, também chamado pela sigla CEM 03, localiza-se na porção sul de Taguatinga foi criado em 1971 e ofertou cursos em diferentes níveis ao longo de sua existência, até que em meados dos anos 1990 concentrou suas atividades na oferta do ensino médio apenas, e é o que vigora até hoje. Está numa área residencial, que se avizinha a um setor de oficinas e que passa por mudanças espaciais, tendo em vista a adaptação das formas às novas funções, como por exemplo, um hospital de grande porte bem próximo à escola. Este empreendimento acaba por atrair outros estabelecimentos como clínicas, farmácias e laboratórios.

Recebe alunos de Taguatinga, Águas Claras (Areal) e Samambaia, principalmente. Além daqueles, que em menor número, são oriundos de Águas Claras (porção vertical), Recanto das Emas, Riacho Fundo I e Riacho Fundo II e até do entorno (Distrito Federal, 2016b). A escola possui aproximadamente 1200 alunos distribuídos nos três anos do Ensino Médio em dois turnos, o matutino e o vespertino. Conta com uma estrutura que compreende: 1 quadra poliesportiva coberta e duas a céu aberto; auditório; biblioteca; laboratório de informática; 19 salas de aulas; refeitório; 2 salas de multimeios com projetores e sistemas de som e sala de orientação educacional. 


\section{Os caminhos metodológicos da pesquisa e as suas temáticas.}

Por meio de uma abordagem qualitativa pretendeu-se refletir sobre os efeitos que essa iniciativa teve no processo de ensino e aprendizagem dos alunos, visto que o lugar é pensado em suas particularidades, para servir ao exercício da leitura geográfica de questões que ocorrem em diferentes escalas, daí as escolha de temáticas que sejam socialmente significativas.

Figura 3 - Problemas indicados pelos alunos do CEM 03 na fase inicial do projeto.

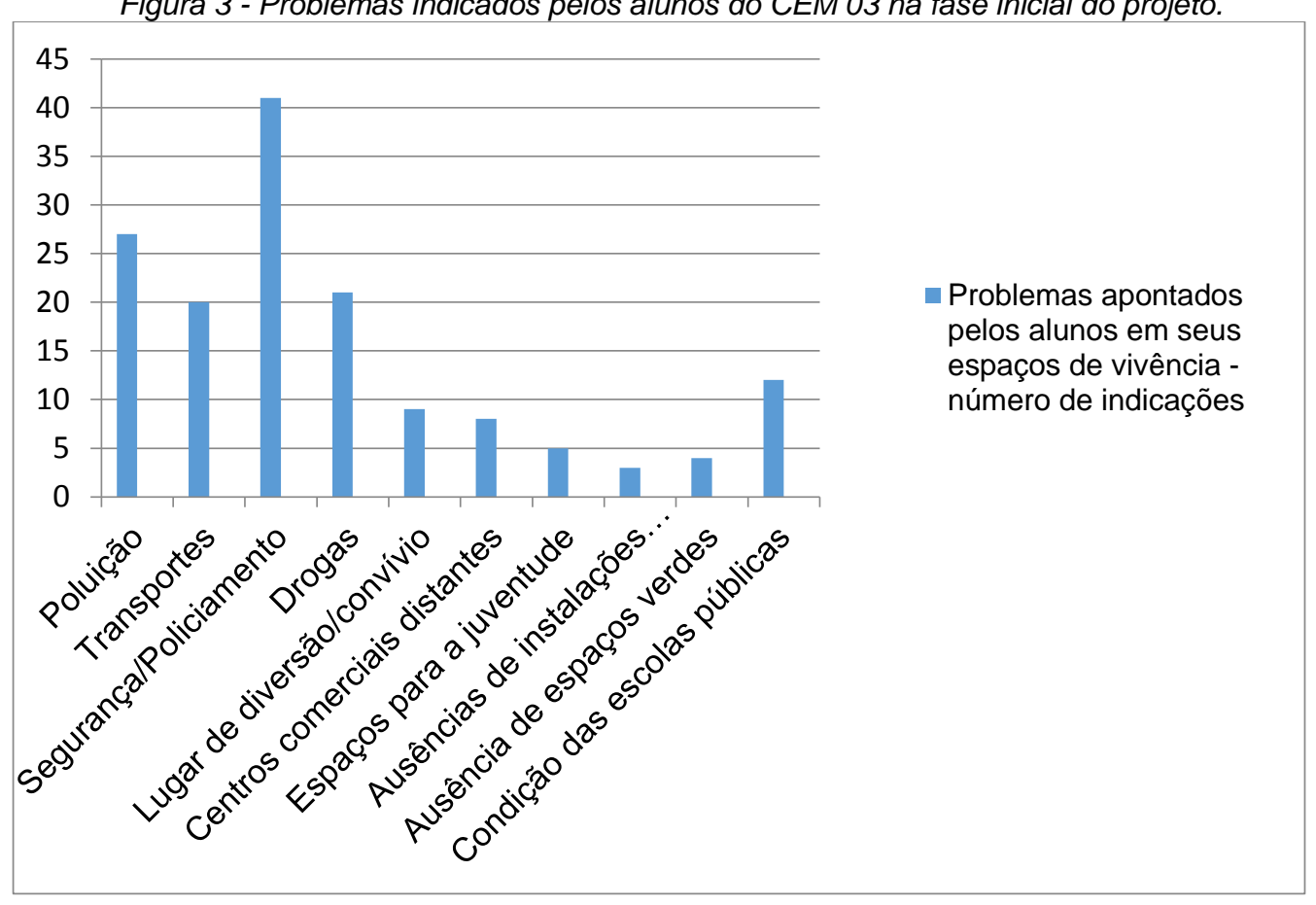

Fonte: elaborado pelo autor (2018)

De modo geral, as temáticas do "Nós Propomos" são escolhidas mediante um levantamento feito junto aos estudantes a partir do que eles observam em seus espaços de vivências, de tal forma que o que torna-se alvo das pesquisas e posteriores proposições são as que mais se destacam. Este foi o caso do CEM 03, onde projeto se realizou no primeiro semestre de 2018, os problemas identificados mediante um levantamento inicial revelaram os dados expostos na figura 3. Foram realizados vários projetos contemplando boa parte das temáticas previamente identificadas.

No caso do CEMAB, a temática da crise hídrica foi induzida, uma vez que ela tomou tamanha proporção que acabou por afetar a rotina de todos, inclusive com racionamento que interrompia o fornecimento uma vez por semana por pelo menos 24 horas. Assim, era quase inescapável a quem vivesse ou passasse pelo Distrito 
Federal, durante sua vigência, não fosse por ela afetado. Era um assunto inafastável, haja vista a importância da água como "recurso vital e econômico múltiplo, utilizada como fator fundamental de saúde pública e de desenvolvimento econômico" (Custódio, 2006, p.176).

Como as causas da crise hídrica eram múltiplas e era possível relacioná-la a fatores naturais, socioespaciais e, sobretudo, de gestão governamental, era preciso criar um consenso. Para tanto, foi realizado inicialmente a técnica do grupo focal para apreender o que os alunos sabiam a respeito da crise hídrica, e desse modo construir uma estratégia de trabalho. Em cada uma das turmas envolvidas foi aplicada esta técnica.

O grupo focal como técnica de pesquisa qualitativa, consiste numa entrevista grupal que se adequa a propostas de pesquisas que visam dentre outras possibilidades, reunir informações convergentes sobre um tema para posterior tomada de decisão (Gondim, 2002; (Jardim, 2002). Segundo Morgan (1997) esta técnica permite uma interação grupal que produz dados e insights que seriam menos acessíveis sem essa atividade. Isto permite uma grande quantidade de trocas sobre um determinado tema num período de tempo limitado. O pesquisador nesse sentido torna-se um moderador e os envolvidos podem expor, defender e ratificar suas posições sobre a temática posta em discussão.

Segundo Gui (2003) o grupo focal permite que as representações sociais venham à tona, e as conversações se aproximem das exposições espontâneas, como em conversas diárias. Por isto, esta escolha epistemológica é a que melhor atende à tentativa de capturar estas representações, ainda que numa reunião provocada, mas que pode, não obstante suas limitações, revelar uma originalidade.

Após a realização do grupo focal com as turmas participantes, as falas que foram gravadas e transcritas revelaram as noções que os alunos tinham a respeito da crise hídrica. Os dados produzidos revelaram que, de um modo geral, eles tinham alguma compreensão da crise hídrica no Distrito Federal, no entanto, o entendimento era quase que uma reprodução literal de notícias jornalísticas sem muita reflexão. Além disso, constatou-se que os alunos faziam, por desconhecimento, uso inadequado ou equivocado de termos e conceitos.

O fato de reproduzirem os discursos que ouviam em casa ou na mídia é significativo para pensar o ensino, porque os alunos os tomavam como suficientes para explicar a situação, sem fazerem uso de outros elementos inclusive os conteúdos trabalhados 
pela Geografia Escolar. Dessa maneira, o grupo focal teve o papel de indicar um norte para as atividades que seriam realizadas, inclusive sanar dúvidas e auxiliar os alunos na compreensão do fenômeno para analisá-lo geograficamente, levando conta sua espacialidade.

Desse modo as temáticas desenvolvidas no CEM 03 e CEMAB embora escolhidas numa e induzida em outra, contemplavam uma características importante do "Nós Propomos", pensar as geografias locais, entendê-las, identificar problemas e propor soluções. A escola precisa discutir os assuntos correlatos à comunidade que se encontra, não deixando apenas para os órgãos governamentais, técnicos e especialistas. Para os alunos, tanto a crise hídrica quanto os problemas de transporte, segurança, poluição e etc deixaram de ser informações distantes e ocuparam as discussões diárias. Indagações sobre as causas, sobre a legitimidade e a veracidade dos anúncios do governo foram levantadas.

Desse modo, tornou-se crucial, sobretudo na escola, espaço da educação formal, mobilizadora de habilidades, conhecimentos e valores (FREIRE, 1994), entender o problema para além do senso comum. Além disso, colaborar para que os alunos tivessem uma participação ativa, transformadora e cidadã nesses processos, que se desenrolava em sua cidade. Neste sentido, o "Nós Propomos" contemplava essa expectativa da educação, da escola e em particular, da Geografia Escolar.

\section{Resultados e discussões: as etapas do projeto e seus desdobramentos.}

Partindo da premissa que a Geografia tem um papel relevante enquanto disciplina escolar, pois agrega à educação básica um conjunto de conhecimentos que permitem aos alunos desenvolverem habilidades para analisar a realidade. Considerando também, que é no ambiente escolar que os sujeitos do processo de ensino e aprendizagem, em especial, professores e alunos constroem a Geografia que acontece de fato na escola, pensou-se a estratégia de trabalho do Projeto.

A partir das informações provenientes dos grupos focais e do interesse pelos problemas locais ficou evidente a necessidade de trabalhar termos e conceitos relevantes para a compreensão dos fenômenos em questão, uma vez que, por não serem de domínio dos alunos, inviabilizaria algo mais importante ainda, a análise geográfica destes fenômenos. 
Além disso, como parâmetro de ação didática e pedagógica entendemos que cabe à Geografia Escolar "a construção de práticas pedagógicas comprometidas com a espacialidade de fenômenos" (Roque Ascenção e Valadão, 2017, p. 187) e, para que isso ocorra, há conceitos fundamentais a se levar em conta neste exercício, pois as espacialidades de modo geral apresentam:

\begin{abstract}
marcado dinamismo ao longo do tempo, dinamismo engendrado por uma vasta gama de processos, cuja ação pode se dar em recortes dimensionais contrastantes, do micro ao macro. Esses são, portanto, os conceitos que estruturam a análise geográfica de fatos e fenômenos - o espaço / as espacialidades; as escalas temporais; os processos naturais e antropogênicos/sociais; as escalas dimensionais (Roque Ascenção e Valadão, 2017, p. 186).
\end{abstract}

A proposta dos referidos autores quanto a práticas pedagógicas que consideram a espacialidade, se faz contrariamente ao que está posto e é recorrente nas aulas de Geografia na Educação Básica, "um ensino descritivo, fragmentado, assentado no estudo isolado dos componentes espaciais" (Roque ascenção e Valadão, 2014, p.7). Apresentar e analisar a espacialidade dos fenômenos estudados é, neste sentido, o objetivo maior do ensino de Geografia.

Os componentes espaciais sejam os físico-naturais ou os sociais são importantes como suportes de uma análise geográfica, mas não devem compor o cerne do ensino de Geografia. Em verdade os componentes devem concorrer para que as situações de aprendizagem na Geografia Escolar promovam o raciocínio geográfico que, posto em prática, promove a interação e o diálogo entre os conceitos que estruturam a análise geográfica, a saber: espaço, escala, tempo e processos.

Desta maneira, as etapas foram pensadas de modo a viabilizar que os alunos, ao final do projeto, tivessem condições de analisar a crise hídrica e os outros temas para além dos seus efeitos imediatos. Que pudessem percebê-los também no sentido geográfico, considerando os processos sociais e físico-naturais, a multiescalaridade e as dimensões temporais envolvidas. Exercitando o raciocínio geográfico com base no tripé metodológico: localizar, descrever e interpretar (Roque Ascenção e Valadão, 2017)

\title{
Etapa 1
}

Consistiu num conjunto aulas expositivas e dialogadas, debates e seminários (quadros 1,2 e 3), em que ,divididos em grupos, os alunos estudaram as temáticas em diferentes aspectos a fim de produzirem um consenso. Nesta etapa, exercitamos a análise geográfica do fenômeno, sugerida anteriormente, atentando aos processos 
naturais e antropogênicos/sociais que permeavam as temáticas. Considerou-se, por

\section{ATIVIDADE NÓS PROPOMOS - ORIENTAÇÕES PARA O SEMINÁRIO - CAUSAS DA CRISE HÍDRICA}

Roteiro: Os alunos divididos em três grupos farão uma pesquisa sobre as possíveis causas/fatores a se considerar quando analisamos a crise hídrica do Distrito Federal.

\begin{tabular}{|l||l|l||}
\hline \hline \multicolumn{2}{|c||}{ TEMAS } \\
\hline \hline $\begin{array}{l}\text { Grupo A: explicitar os } \\
\text { fatores naturais } \\
\text { relacionados. }\end{array}$ & $\begin{array}{l}\text { Grupo B: explicitar os } \\
\text { fatores } \\
\text { socioeconômicos } \\
\text { relacionados. }\end{array}$ & $\begin{array}{l}\text { explicitar os fatores } \\
\text { vinculados à gestão } \\
\text { governamental. }\end{array}$ \\
& & \\
\hline
\end{tabular}

exemplo, a irregularidade do regime pluviométrico nos dois anos anteriores - que não justificava a crise como um todo, mas contribuía para o delineamento de questões somadas à ocupação desordenada do espaço urbano, inclusive sobre áreas de mananciais e de recarga dos mesmos.

\section{Quadro 1 - Descrição da proposta do Seminário 1 CEMAB - Causas e fatores que que explicam a crise hídrica no Distrito Federal.}

Fonte: elaborado pelo o autor

Atentamo-nos também às escalas temporais que deveriam ser consideradas, tendo em vista que a manifestação dos problemas em questão não se relacionavam somente a eventos imediatamente anteriores, pelo contrário, apresentavam vínculos com situações e negligências passadas. Quanto a crise hídrica por exemplo, havia um conjunto de obras de engenharia que se encontravam atrasadas e que teriam o papel de compatibilizar a oferta do sistema de abastecimento com a expansão urbana e demográfica do Distrito Federal.

Quadro 2 - Descrição da proposta do Seminário 2 CEMAB - Crise hídrica com perspectivas a partir de Taguatinga.

\section{ATIVIDADE NÓS PROPOMOS - ORIENTAÇÕES PARA O SEMINÁRIO SOBRE A CRISE HÍDRICA COM PERSPECTIVAS A PARTIR DE TAGUATINGA}

Roteiro: Os alunos divididos em cinco grupos devem caracterizar a situação de Taguatinga conforme tema; relacionar o "problema" com os conteúdos trabalhados nas últimas aulas de geografia; fotografar ou coletar na internet imagens que possam ilustrar a situação; indicar causas, relações, extensão e propor soluções para os problemas estudados; apresentar à turma os resultados.

\section{TEMAS}




\begin{tabular}{|c|c|c|c|c|}
\hline $\begin{array}{l}\text { Situação dos } \\
\text { corpos } \\
\text { hídricos que } \\
\text { cortam } \\
\text { Taguatinga. }\end{array}$ & $\begin{array}{c}\text { Processo de } \\
\text { ocupação e } \\
\text { urbanização } \\
\text { de } \\
\text { Taguatinga. }\end{array}$ & $\begin{array}{c}\text { Caracterização } \\
\text { das microbacias } \\
\text { de Taguatinga do } \\
\text { ponto de vista do } \\
\text { usos realizados. }\end{array}$ & $\begin{array}{c}\text { Usos } \\
\text { inadequados da } \\
\text { água por } \\
\text { pessoas/empre } \\
\text { sas. }\end{array}$ & $\begin{array}{c}\text { Situação } \\
\text { das } \\
\text { nascentes } \\
\text { que existem } \\
\text { em } \\
\text { Taquatinga }\end{array}$ \\
\hline
\end{tabular}

Fonte: elaborado pelo o autor

As dimensões da crise hídrica também foram alvo de discussões, pois, embora houvesse fatores locais importantes, ela se inseria num contexto maior de variações no regime pluviométrico - a exemplo da crise hídrica no sudeste brasileiro entre 20142016 - somada à negligência dos gestores públicos (Jardim, 2016), expondo os moradores a racionamentos de água. Desse modo, destacamos a possibilidade de analisá-la desde sua manifestação local, nas residências dos estudantes e na escola, por exemplo, até sua ocorrência em um plano maior, fazendo conexões com outros contextos para além do Distrito Federal.

Quadro 3 - Descrição da proposta do Seminário 1 CEM 03 - Crise hídrica com perspectivas a partir de Taguatinga.

\begin{tabular}{|c|}
\hline $\begin{array}{c}\text { ATIVIDADE NÓS PROPOMOS - ORIENTAÇÕES PARA O SEMINÁRIO SOBRE } \\
\text { PROBLEMAS LOCAIS }\end{array}$ \\
\hline $\begin{array}{l}\text { Roteiro: Os alunos divididos em grupos devem caracterizar a problemática escolhida; } \\
\text { relacionar o "problema" com os conteúdos trabalhados nas últimas aulas de } \\
\text { geografia; fotografar ou coletar na internet imagens que possam ilustrar a situação; } \\
\text { indicar causas, relações, extensão e propor soluções para os problemas estudados; } \\
\text { apresentar à turma os resultados. }\end{array}$ \\
\hline \hline TEMAS APRESENTADOS \\
\hline \hline Poluição nas ruas/Reciclagem \\
\hline \hline Transporte público \\
\hline \hline Percepção de segurança da população/ Policiamento nas proximidades da escola \\
\hline Situação das calçadas e mobilidade \\
\hline \hline Atendimento de saúde com foco em prevenção \\
\hline \hline Poluição do ar e uso de automotores \\
\hline \hline Policiamento nas proximidades da escola \\
\hline \hline Mobilidade urbana e transporte público \\
\hline \hline Espaços de lazer e recreação \\
\hline \hline
\end{tabular}

Fonte: elaborado pelo o autor 
Essas considerações colaboraram para não só relacionar os fenômenos aos processos que os geravam, mas também para que os alunos compreendessem da espacialidade dos fenômenos estudados. Permitiram a superação de uma abordagem superficial, reprodutora de um senso comum que não pode permanecer ante 0 trabalho do professor na relação de ensino e aprendizagem e da educação geográfica como "uma maneira específica de raciocinar e interpretar a realidade e as relações espaciais" (Cavalcanti, p.35 2008).

\section{Etapa 2}

A segunda etapa compreendeu atividades que permitiram o contato com técnicos e/ou especialistas na escola (figura 4), com a organização de pequenos colóquios que muito colaboraram com o projeto, além da participação em eventos externos. Para os alunos do CEMAB foi importante a participação no $1^{\circ}$ Seminário Temático do Instituto de Ciências Humanas da Universidade de Brasília-Unb, intitulado Crise Hídrica: apurando responsabilidades socioambientais do passado, presente e futuro (Figura 5).

Figura 4 - Colóquio temático sobre a crise hídrica do DF no CEMAB com convidados da SEMA-DF, UnB e Sindágua-DF.

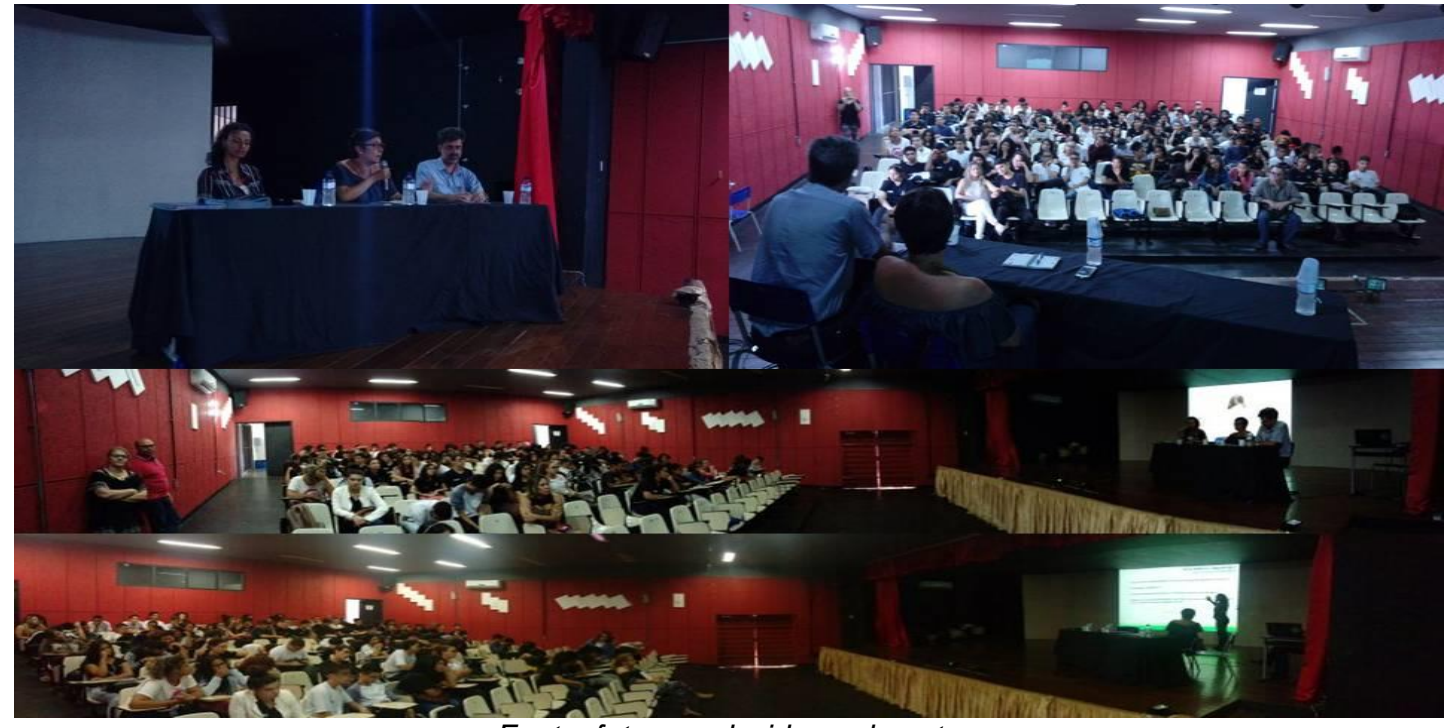

Fonte: fotos produzidas pelo autor.

Figura 5 - Participação de alunos representantes do CEMAB no seminário sobre crise hídrica na Universidade de Brasília. 


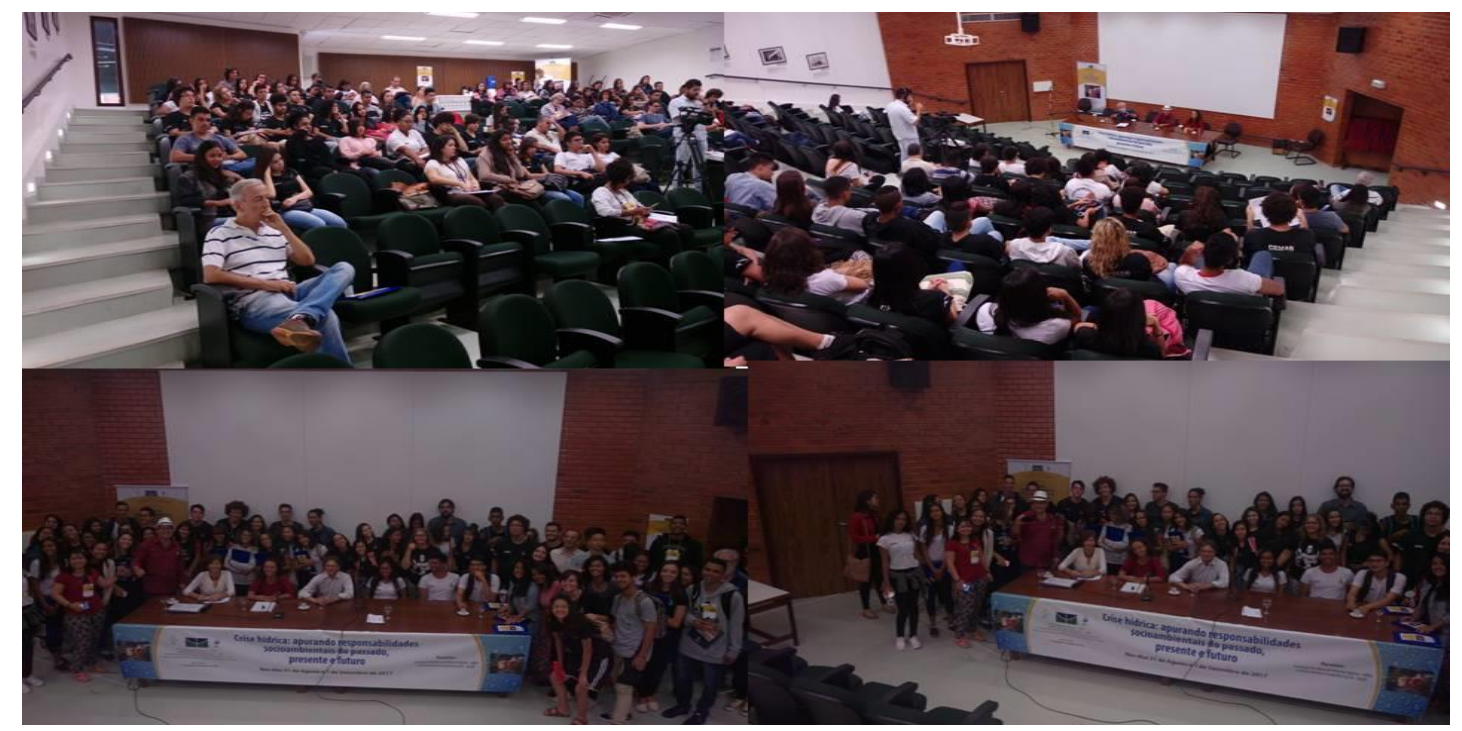

Fonte: fotos produzidas pelo autor.

No caso dos alunos do CEM 03 um encontro, no auditório da escola, com a administradora de Taguatinga foi bastante produtivo, pois, permitiu que os alunos conhecessem a dinâmica de resolução de problemas da cidade do ponto de vista da gestão. Nesta altura do projeto, as informações adquiridas junto aos profissionais e especialistas se somaram às compreensões iniciais de modo a oferecer subsídio para a tarefa final: a proposição de medidas que pudessem solucionar ou amenizar os problemas identificados e analisados.

\section{Etapa 3}

Na terceira etapa, ocorreu a culminância do projeto, quando os resultados obtidos via pesquisa, debatidos em sala e esclarecidos nos eventos interno e externo, embasaram as proposições feitas pelos alunos. Esta fase compreendeu a apresentação das propostas por meio de um trabalho escrito que deveria ser defendido oralmente. Como todo o projeto foi desenvolvido em grupos, cada turma se organizou em cinco grupos, que elaboraram pelo menos 3 propostas, totalizando 20 trabalhos.

Colaborando com a abordagem escolhida definiu-se um critério quanto a natureza das proposições, que elas fossem pensadas a partir de três eixos: dos gestores, da comunidade e do cidadão. Para ilustrar, destacamos a seguir as propostas idealizadas pelos alunos do CEMAB que trabalharam com a crise hídrica. Com base nas informações obtidas ao longo processo, novidade para a maioria dos alunos, as 
propostas apresentadas orbitaram em torno de alguns subtemas conforme quadros 4, 5 e 6.

Quadro 4. Proposta com foco nos gestores

\begin{tabular}{|l|l|}
\hline \multicolumn{2}{|c|}{ SÍNTESE DAS PROPOSTAS DIRIGIDAS AOS GESTORES } \\
\hline Subtema gerador & Propostas \\
\hline $\begin{array}{l}\text { Bacia hidrográfica e Zoneamento } \\
\text { Ecológico e Econômico }\end{array}$ & $\begin{array}{l}\text { Planejar, e reorganizar ,na medida do } \\
\text { possível, a cidade a partir da lógica das } \\
\text { bacias hidrográficas envolvidas. Proteger } \\
\text { nascentes e áreas de recarga. Aplicar as } \\
\text { leis vigentes }\end{array}$ \\
\hline Uso da água na agricultura & $\begin{array}{l}\text { Disciplinar o uso da água na agricultura, } \\
\text { sobretudo no longo período de estiagem } \\
\text { que o cerrado enfrenta sazonalmente. } \\
\text { Aplicar as leis vigentes. }\end{array}$ \\
\hline $\begin{array}{l}\text { Defeitos e danos à rede de distribuição } \\
\text { de água. }\end{array}$ & $\begin{array}{l}\text { Monitorar os danos e defeitos para evitar } \\
\text { o desperdício na rede de distribuição de } \\
\text { água. }\end{array}$ \\
\hline
\end{tabular}

Fonte: elaborado pelo autor.

Quadro 5. Proposta com foco na comunidade

\begin{tabular}{|l|l|}
\hline \multicolumn{2}{|c|}{ SÍNTESE DAS PROPOSTAS DIRIGIDAS À COMUNIDADE } \\
\hline Subtema gerador & Propostas \\
\hline Economia e uso consciente da água. & $\begin{array}{l}\text { Uso de aplicativos para monitorar e } \\
\text { denunciar usos inadequados e } \\
\text { desperdícios; Realizar ao máximo a } \\
\text { reutilização da água proveniente da rede. } \\
\text { Captar água da chuva nas escolas } \\
\text { usando-a para limpeza e conservação; } \\
\text { Usar água potável apenas para beber, } \\
\text { higienização e preparo de alimentos. }\end{array}$ \\
\hline Áreas verdes urbanas & $\begin{array}{l}\text { Proteger as áreas verdes remanescentes } \\
\text { na cidade dada a importância delas na } \\
\text { recarga dos depósitos subterrâneos de } \\
\text { água. }\end{array}$ \\
\hline
\end{tabular}

Fonte: elaborado pelo autor.

Quadro 6. Propostas com foco no cidadão.

\begin{tabular}{|l|l|}
\hline \multicolumn{2}{|c|}{ SÍNTESE DAS PROPOSTAS DIRIGIDAS AO CIDADÃO } \\
\hline Subtema gerador & Propostas \\
\hline $\begin{array}{l}\text { Informação precisa e de qualidade sobre } \\
\text { os recursos hídricos }\end{array}$ & $\begin{array}{l}\text { Buscar ao máximo informações precisas } \\
\text { para agir da maneira mais responsável e }\end{array}$ \\
\hline
\end{tabular}


\begin{tabular}{|l|l}
\hline & cidadã possível no uso da água.
\end{tabular}

Fonte: elaborado pelo autor.

\section{Conclusão}

As temáticas trabalhadas por meio do "Nós Propomos" nas duas escolas participantes se mostraram como oportunidades didáticas e pedagógicas muito valiosas para 0 ensino e a aprendizagem, conferindo uma abordagem reflexiva e propositiva a partir de geografias locais. O envolvimento do público discente com o projeto revelou um aumento do interesse dos pelos temas da realidade vivenciada por eles, interese por um novo conhecimento de espaços do cotidiano. A Geografia Escolar ganhou para esses alunos aplicabilidade para além da escola. A abordagem baseada na espacialidade dos fatos e fenômenos pode ressignificar a Geografia Escolar, uma vez que essa disciplina é marcada muitas vezes por um ensino informativo, fragmentado e que distancia os alunos de suas realidades imediatas.

Pensar o lugar construindo conhecimentos que possibilitem ampliar a compreensão da realidade numa perspectiva territorial e cidadã pode fazer com que a Geografia, por meio da escola, reencontre sua função social. Acreditamos que essa função conta inevitavelmente com dois aspectos pelo menos: a contribuição que a Geografia como ciência pode dar, que é permitir que os alunos leiam a realidade numa perspectiva geográfica, atentos às espacialidades que os fenômenos têm; a capacidade de aplicar os conhecimentos da Geografia Escolar às realidades mais imediatas, o dia a dia, resignificando as vivências a partir de um conjunto de conceitos fundantes da Geografia.

Diante disso a participação dos alunos em processos de pesquisa, análise e ainda que didaticamente, tomada de decisões como se fossem gestores de suas cidades foi crucial para houvesse uma participação cidadã. $O$ fato de se sentirem integrados e convidados a pensar os próprios espaços mudou a percepção de nossos alunos como habitantes e como cidadãos.

\section{Referências bibliográficas}

Cavalcanti, L. S. (2008). A Geografia escolar e a cidade: Ensaios de Geografia para a vida urbana cotidiana. Campinas, SP: Papirus. 
Cavalcanti, L. S. (2005). Cotidiana mediação pedagógica e formação de conceitos: uma contribuição de Vygotsky ao ensino de geografia. Cad. Cedes, 25, 6, 185-207.

Cavalcanti, L. S. (2013). Geografia, escola e construção de conhecimentos. Campinas (SP), 18ª edição. Papirus.

Castellar, S. M. V. (2010). Educação Geográfica: Formação e didática. In: MORAIS, E. M. B.; MORAES, L. B. (Orgs.). Formação de professores: conteúdos e metodologias no ensino de Geografia. Goiânia: Nepeg.

Codeplan - Companhia de Planejamento do Distrito Federal. Pesquisa Distrital por Amostra de domicílios - PDAD - 2016 - Taguatinga - (2016). Brasília: CODEPLAN/SEPLAN/GDF.

Custódio, V. A relação cidade-água nos artigosdos anais da Associação de Geógrafos Brasileiros(AGB). (2006). In: Geousp -espaço e tempo. São Paulo. n.20. p. 175-182. DOI: http://dx.doi.org/10.11606/issn.2179-0892.geousp.2006.74014

Distrito Federal. Secretaria de Estado de Educação do Distrito Federal. Centro de Ensino Médio Ave Branca. Projeto político-pedagógico. Taguatinga: SEEDF, 2016a․

Distrito Federal. Secretaria de Estado de Educação do Distrito Federal. Centro de Ensino Médio 03. Projeto político-pedagógico. (2016b). Taguatinga: SEEDF,

Gasparin, J. L. (2012). Uma didática para a pedagogia histórico-crítica. 5a edição revisada. Campinas, SP. Autores Associados.

Gondim, S.M. (2002). Grupos focais como técnica de investigação qualitativa: Desafios metodológicos. Paidéia. Cadernos de Psicologia e Educação, 12(24), 149-161.

Gui, R. T. (2003). Grupo focal em pesquisa qualitativa aplicada: intersubjetividade e construção de sentido. Revista Psicologia Organizações e Trabalho, v. 3, n. 1, p. 135159.

Jardim, C. H. (2016). A " crise hídrica" no sudeste do Brasil: aspectos climáticos e repercussões ambientais. Revista Tamoios, v. 11, n. 2.

Kaercher, N. A. (2013). Docenciando me existencio, existenciando, penso a docência, porque ela me constitui como ser do e no mundo. In: Eunice Isaias da Silva; Lucineide Mendes Pires. (Org.). Desafios da didática de Geografia. 1ed. Goiânia, Go: PUC/Go, v. 1, p. 177-193. 
Leite, C. M. C. O lugar e a construção da identidade: os significados construídos por professores de Geografia do ensino fundamental. 2012. xvii, 222 f. Tese (Doutorado em Educação)—Universidade de Brasília, Brasília, 2012.

Moreira, R. (2012). Geografia e práxis: a presença do espaço na teoria e na prática geográficas. São Paulo: Contexto.

MORGAN, D. L. (1997) Focus group as qualitative research. SAGE Publications. London.

ROQUE ASCENÇÃO, V. de O; VALADÃO, R. C. (2014). Professor de Geografia: entre o Estudo do Fenômeno e a Interpretação da Espacialidade do Fenômeno. Scripta Nova. Revista Electrónica de Geografía y Ciencias Sociales, v. 18. http://dx.doi.org/10.1344/sn2014.18.14965

ROQUE ASCENÇÃO, V. de O; VALADÃO, R. C. (2017). Por uma geomorfologia socialmente significativa na geografia escolar: uma contribuição a partir de conceitos fundantes. Acta Geográfica, p. 179-195. http://dx.doi.org/10.5654/acta.v0i0.4780. 


\section{Geografia escolar e cidadania: contribuições de discentes do Colégio Técnico de Teresina/PI}

Marcos antonio de Castro Marques TEIXEIRA ${ }^{4}$ RAIMUNDO LENILDE DE ARAÚJO ${ }^{5}$

\section{Resumo}

A estrutura fundiária do Piauí tem no quadro social do campo a prevalência da pobreza e exclusão social. Para atenuar, programas e políticas públicas foram criadas, pois, o Estado possui história de exploração de terras, criação de bovinos, instalação de núcleos de povoamento e das primeiras áreas de latifúndio. Considerando o cenário do Nordeste do Brasil, foi desenvolvido com estudantes do terceiro ano do Curso de Técnico em Agropecuária, do Colégio Técnico de Teresina, um projeto de estudos com o objetivo de identificar a importância da atividade econômica para a composição da renda da família de pequenos produtores rurais. Para a sistematização, os discentes identificaram as necessidades da família, realizaram estudos para fundamentar o projeto e apresentaram propostas como a utilização racional da água; para o controle de doenças de aves; para a geração de renda familiar associada à criação de caprinos e ao cultivo da palma forrageira (Opuntiacochenillifera). Os resultados mostraram as diversas possibilidades que os estudos realizados pela disciplina de Geografia na escola tendem a contribuir para o fortalecimento do projeto de cidadania a partir da racionalização quanto à utilização dos recursos naturais e do retorno econômico na forma de renda para a família. Concluiu-se que fazer estudos de Geografia escolar, a partir do conhecimento da realidade de discentes, proporciona a construção de projeto de cidadania e a melhoria de condições de vida no contexto familiar.

Palavras-chave: Piauí. Geografia. Família. Renda. Cidadania.

\footnotetext{
${ }_{5}^{4}$ Professor do Colégio Técnico de Teresina. Teresina/Piauí, marcosteixeira@ifpi.edu.br

5 Professor do Curso de Geografia da Universidade Federal do Piaui, Teresina/Piauí, raimundolenilde@ufpi.edu.br
} 


\section{Abstract}

Piauí land structure has, in the social context of the countryside, the prevalence of poverty and social exclusion. In order to attenuate, public programs and policies have been created, since the State has a history of land exploration, cattle breeding, settlements and first areas of estate. Considering the scenario of the Northeast of Brazil, a study project was developed with agriculture students from the Third Year of Teresina Technical College with the purpose of identifying the importance of the economic activity for the composition of the family income of small farmers. For the systematization, the students identified the needs of the family, carried out studies to support the project and presented proposals such as the rational use of water; the control of bird diseases; the generation of family income associated with the creation of goats and to the cultivation of forage palm (Opuntiacochenillifera). The results showed the different possibilities that the studies carried out by Geography in the school tend to contribute to the strengthening of a citzenchip project, based on the rationalization of the use of natural resources and the economic return in the form of income for the family. It was concluded that studies in Geography, based on knowledge of students reality, provides the construction of a citizenship project and the improvement of living conditions in the family context.

Keywords: Piauí. Geography. Family. Income. Citizenship.

\section{Introdução}

A estrutura fundiária do Piauí tem no quadro social do campo a prevalência da pobreza e exclusão social. Para atenuar, programas e políticas públicas foram criadas, pois, o Estado possui história de exploração de terras, criação de bovinos, instalação de núcleos de povoamento e das primeiras áreas de latifúndio. Considerando o cenário do Nordeste do Brasil, foi desenvolvido com estudantes do $3^{\circ}$ ano do Curso de Técnico em Agropecuária, do Colégio Técnico de Teresina, um projeto de estudos com o objetivo de identificar a importância da atividade econômica para a composição da renda da família de pequenos produtores rurais. Para a sistematização, os discentes identificaram as necessidades da família, realizaram estudos para fundamentar o projeto e apresentaram propostas como a utilização racional da água; para o controle de doenças de aves; para a geração de renda familiar associada à criação de caprinos e ao cultivo da palma forrageira (Opuntiacochenillifera). Os resultados mostraram as diversas possibilidades que os estudos realizados pela 
disciplina de Geografia na escola tendem a contribuir para o fortalecimento do projeto de cidadania a partir da racionalização quanto à utilização dos recursos naturais e do retorno econômico na forma de renda para a família. Concluiu-se que fazer estudos de Geografia escolar, a partir do conhecimento da realidade de discentes, proporciona a construção de projeto de cidadania e a melhoria de condições de vida no contexto familiar.

Este estudo inicia com uma proposta aos moldes do Projeto Nos Propomos!, idealizado em 2011, no IGOT, Instituto de Geografia e Ordenamento do Território, da Universidade de Lisboa, Portugal, coordenado pelo Prof. Dr. Sérgio Claudino. Na cidade de Teresina-PI, o projeto foi apresentado em 2017, pelo prof. Dr. Raimundo Lenilde de Araújo, do Curso de Licenciatura em Geografia da Universidade Federal do Piauí. A iniciativa durante a disciplina de Geografia, no Colégio Técnico de Teresina, CTT, ligado à Universidade Federal do Piauí, UFPI, teve como ênfase uma provocação aos alunos do $3^{\circ}$ ano do curso Técnico em Agropecuária, no sentido de identificar como os mesmos observam o setor primário do Estado do Piauí e ao mesmo tempo, proporem uma maneira de melhorar a atividade produtiva. Esse estudo iniciado em 2017, teve uma orientação no sentido de identificar os principais problemas da agropecuária piauiense, de como executar, bem como a apresentação de sugestões na intervenção do processo.

No processo de identificação dos problemas da agropecuária local, baseou-se nas questões históricas da colonização piauiense. Foram destacadas uma projeção da estrutura fundiária do Estado do Piauí, objetivando uma radiografia desses aspectos, pois o quadro social do campo evidenciou pobreza e exclusão social, que resultaram nas dificuldades enfrentadas pelos pequenos produtores na sua sobrevivência no mercado.

Para atenuar esses conflitos, vários programas e políticas públicas foram sendo introduzidos. Contudo, não surtiram o efeito desejável, pois o Estado possui uma herança histórica de exploração de terras a serviço inicialmente do Reino de Portugal, para a criação do gado bovino, onde foram instalados os primeiros núcleos de povoamento e com eles as primeiras áreas de latifúndio.

Assim, o Piauí possui um legado diferente das demais regiões do nordeste brasileiro. Pois, enquanto no litoral, principalmente, Bahia e Pernambuco caracterizavam-se na produção da cana-de-açúcar, aqui proliferaram extensos latifúndios ligados à atividade pecuária. 
Nesse sentido, as terras do Piauí, localizadas numa área de transição entre o Sertão (semiárido) com um clima quente e seco e a Amazônia (Equatorial) com um clima quente e úmido, e uma associação de fatores como a vegetação e a existência de extensos pastos naturais, facilitaram a criação do gado bovino.

Com base nas primeiras seções de fundamentações teóricas junto aos alunos, estes, percebem que o atraso da agricultura piauiense está vinculado ao exame do subsetor básico da economia estadual e à criação extensiva de bovinos, já que foi essa atividade que determinou consideravelmente a distribuição demográfica, a disponibilidade de mão-de-obra e a própria estrutura fundiária.

Da criação extensiva derivaram três fatores impeditivos do desenvolvimento das atividades agrícolas: a concentração da propriedade da terra, a destinação da terra para os pastos e a ausência de um mercado interno estimulador (Teixeira, 2011).

Desse modo, Evangelista e Teixeira (2018), afirmam que Geografia econômica e política são importantes e estão há muito tempo no temário geográfico, sendo essenciais para compreender a organização territorial. A distribuição e relações dos objetos geográficos dependem de fatores econômicos e geopolíticos; o funcionamento do espaço está relacionado a esses fatores. As relações espaciais entre áreas diferentes são bastante presentes, e, também, estão ligadas aos mesmos, assim como a compreensão das desigualdades entre as diferentes sociedades e territórios. Todavia, problematizar a relação economia-espaço precisa superar o tom descritivo que suscita o aprendizado mecânico pela factualidade e abrir o enfoque para a contextualidade, atento à noção de totalidade espacial em um cenário de produção flexível e diversas relações. Por vezes, o viés economicista enuvia a força da explicação geográfica dos processos socioespaciais, deixando de nomear termos geográficos próprios cunhados por novas teorizações.

Essa abordagem inicial faz-se necessária, pois os aspectos ligados aos aspectos naturais, são marcados por um tratamento descritivo, sem haver exploração dos aspectos explicativos, criando dificuldades para a compreensão sistemática por parte do aluno. Segundo Evangelista e Teixeira (2018) numa referência a Salvador (2000); Moreira (1998), as abordagens fragmentárias pouco contribuem para uma aprendizagem significativa.

De acordo com Morin (2002), o grande volume de informações disponíveis ao aluno, em seus diferentes meios, sejam eles impressos ou digitalizados, sobrecarregam as mentes frequentemente com conteúdo de pouca relevância. 
Assim, com o apoio da fundamentação teórica do formato do modelo de exploração econômica piauiense, os discentes partiram para a parte prática: a geração de diversos temas de intervenção junto ao pequeno agricultor, aquele que está fora do eixo econômico, para que estes possam melhorar, não somente a renda, mas a qualidade de sua produção.

Como fazer? Para isso foi questionado ao aluno como apontar respostas a determinados problemas comuns dentro do cenário do pequeno produtor rural. Foi elaborado um pequeno questionário de perguntas simples, mas significativas desses problemas. Como boa parte dos estudantes são residentes do Colégio Técnico de Teresina, mas oriundos de outros municípios do Estado, os alunos reconheceram que o fator produtivo e como manter o rebanho nas contradições climáticas do Estado, com a falta de d'agua e seca foram considerados os mais acentuados. Com base nessas informações em sala de aula, propôs-se, então, para os alunos do $3^{\circ}$ ano do Curso Técnico em Agropecuária, soluções para os pequenos produtores rurais em uma determinada localidade geográfica do Estado do Piauí, de acordo com a divisão territorial, conforme figura em anexo:

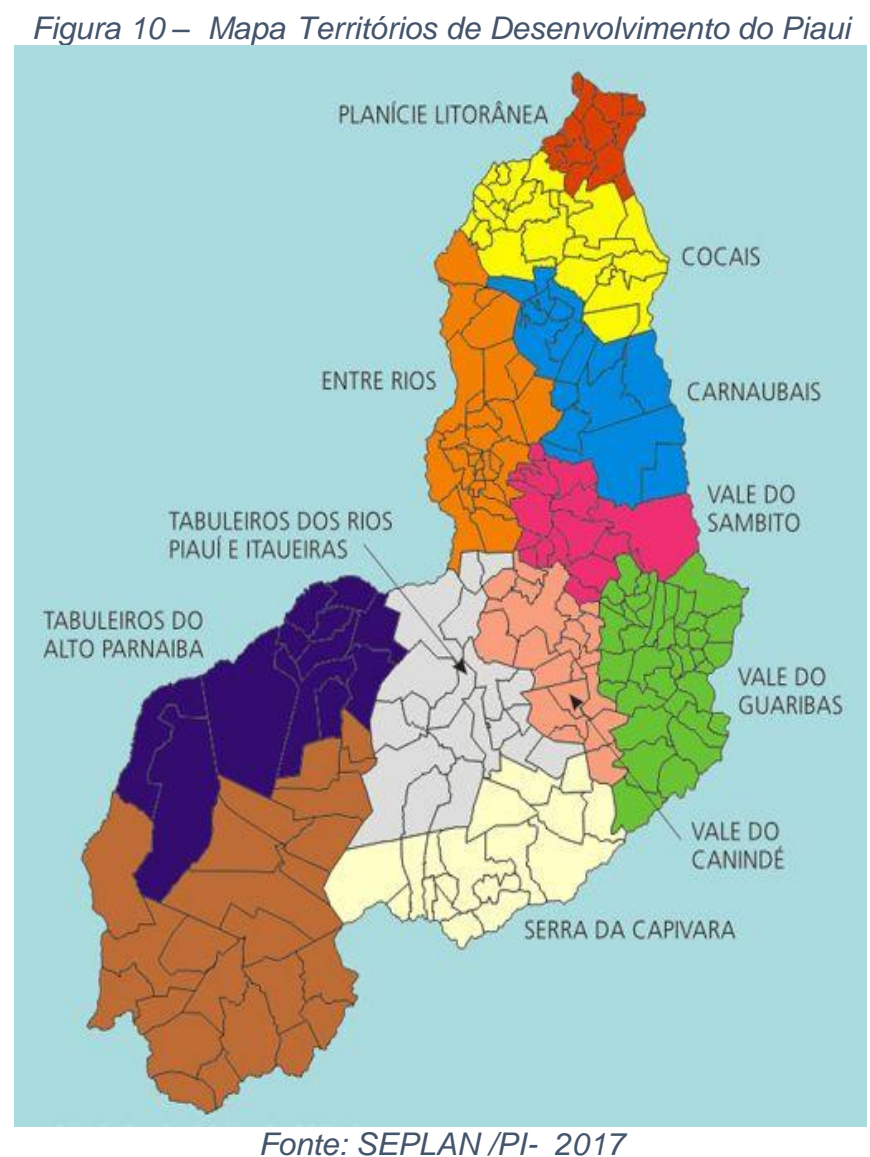


Para a sistematização, os discentes identificaram as necessidades da família, realizaram estudos para fundamentar o projeto e apresentaram propostas como a utilização racional da água, para o controle de doenças de aves, para a geração de renda familiar associada à criação de caprinos e ao cultivo da palma forrageira (Opuntiacochenillifera).

Esta última proposta foi considerada a mais relevante pois a equipe se baseou em estudos realizados dentro da própria instituição de ensino, cujo projeto foi supervisionado pelos professores da área técnica. A importância do projeto se dá por atender às necessidades mínimas do pequeno produtor carente de recursos seja econômico ou natural, mas que possam subsidiar uma renda menor e manter o que é mais importante: o homem dentro do seu território de origem. Foram pressupostos do projeto apresentado: 1- não possuir renda para investir em arraçoamento (providenciar o alimento dos animais ou alimentá-los com ração): a palma tem valor nutritivo igual ou superior à outras rações. O pequeno agricultor não irá precisar de investimento, senão em tempo para plantar. O uso da forrageira permite uma ganha média de peso de $190 \mathrm{a}$ 260g; 2- não possuir meios hídricos para investir no sustento do rebanho: a palma possui cerca de $80 \%$ de água em sua composição. Isso resulta na diminuição do consumo externo de água pelo os animais - os resultados médios da diminuição de água giram em torno de 1,8 I para $700 \mathrm{ml} ; 3$ - precisar de um complemento na renda: 0 uso da cactácea poderá sustentar o rebanho que poderá ser comercializado, mas, além disso, a própria planta pode ser vendida a outros pequenos produtores em períodos de seca extrema; 4 - não sabe como aproveitar seu terreno: a planta é uma boa alternativa até mesmo para agricultores de pequenas áreas. Sua produtividade pode chegar até 40.000 plantas por hectare dependendo do manejo.

Figura 2 - Fotografias das pesquisas de campo realizadas pelo projeto
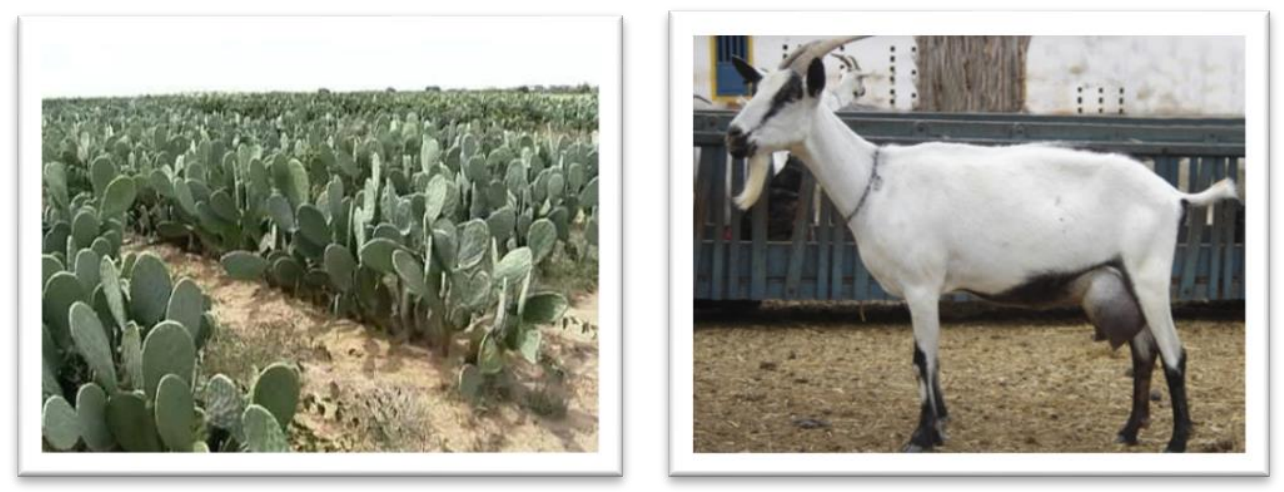

Fonte: Jorge Fernando CTT/UFPI 2017 
A formatação da ideia do projeto apresentado em 2017 em sala de aula, mostrou-se como uma oportunidade didática e pedagógica bastante benéfica, pois foi compartilhado junto aos discentes um novo olhar sobre o ensino de Geografia, menos descritivo e fracionado, apresentando-se com uma linguagem mais clara e compreensível. Os resultados, ainda no ano de 2017, foram destacados pelos alunos participantes do projeto, quando estes foram para o mercado de trabalho. Alguns relataram que pequenos agricultores, ligados à cooperativas ou Sindicatos de trabalhadores rurais, avançaram no modelo de produção bem como na renda, baseando-se na construção de novos parâmetros de modelo produtivo.

\section{Conclusão}

O projeto Nós Propomos!, apresentou uma alternativa de viabilidade no pensamento crítico para os estudantes, em que os mesmos, conheçam e reflitam sobre os métodos descritivos do estudo da geografia econômica gerados nos livros didáticos. Permitiu, ainda, perceber a articulação e suas contradições de diferentes áreas, atividades e sistemas de relações. O esforço em tentar diminuir desigualdades esbarra nas estruturas arcaicas de gestores que ainda preserva, como receita administrativa, políticas assistencialistas e compensatórias que não atendem aos interesses da população. Isso é um reflexo histórico da construção da territorialidade do Estado do Piauí, que nos deixou, como herança da nossa colonização, uma estrutura de posse de terras ainda baseada no latifúndio e nas injustas relações de trabalho no campo.

\section{Referências}

Evangelista, A. M. e Teixeira, M. A. de C. M. (2018) A experiencia do PNLD: tópicos reflexivos sobre o livro didático de Geografia no Ensino Médio. IN TONINI, I. M., et al. São Leopoldo: Oikos.

Moreira, M. A. (1998) Aprendizagem significativa. Brasília: UnB

Morin, E. (2002) A cabeça bem-feita. Repensar a reforma, repensar o pensamento. Rio de Janeiro: Bertrand Brasil

Piauí. Secretaria de Planejamento (2018, Setembro) Disponível em: http://www.seplan.pi.gov.br/mapa-grande.pdf.

Salvador, C. C.et al. (2000) Psicologia do ensino. Porto Alegre: Artes Médicas Sul 
Teixeira, M. A. de C.M. (2011). Agricultura Urbana na cidade de Teresina: hortas comunitárias: políticas públicas ou segurança alimentar? Tese (doutorado), Universidade Estadual Paulista-UNESP-Campus Rio Claro. 


\title{
Manifestações Culturais da comunidade do Porto do Capim, João Pessoa, Paraíba, Brasil
}

\author{
MARIA EDUARDA VIANA PONTES DOS SANTOS ${ }^{1}$ \\ ANNA THERESA ROSENHAIM ${ }^{2}$ \\ JOAZADAQUE LUCENA DE SOUZA ${ }^{3}$
}

\section{Resumo}

O projeto Nós Propomos! Paraíba: revitalizando a cidadania através da educação é uma iniciativa da Universidade Estadual da Paraíba e Centro Estadual Experimental de Ensino-Aprendizagem Sesquicentenário que tem por objetivo compreender a dinâmica urbana do Centro Histórico de João Pessoa, estado da Paraíba. A comunidade Porto do Capim localiza-se no bairro do Varadouro, na região central da cidade, apresenta grande vulnerabilidade social, uma infraestrutura defasada e oferta insatisfatória de serviços públicos de água tratada, saneamento básico, coleta de lixo, educação, saúde, além de ser marginalizada e rotulada como um local violento pela mídia tradicional, mas por outro lado possui uma riqueza cultural bastante pujante, demonstrando apreço às tradições locais ligadas à dança, folclore, culinária, preservação do meio ambiente, respeito ao rio e a convivência comunitária há pelo menos 70 anos. Durante uma visita realizada em 11//05/2018 foi possível vivenciar as manifestações artísticas que emergem do coletivo de mulheres Garças do Sanhauá, que além de participarem ativamente do enfrentamento ao processo de revitalização proposto pela prefeitura municipal de João Pessoa, também coordenam o Ponto de Cultura Comunitário, onde desenvolvem o projeto Vivenciando o Porto e oferecem palestras sobre o histórico da comunidade, passeio guiado pelas ruas e contemplação do rio que banha a área, apresentações de dança e teatro e organização de festas

\footnotetext{
1 Estudante do 2o Ano do Ensino Médio do Centro Estadual Experimental de EnsinoAprendizagem Sesquicentenário, Rede Estadual da Paraíba, mariaeduardapontes69@gmail.com

2 Estudante do $3^{\text {o }}$ Ano do Ensino Médio do Centro Estadual Experimental de EnsinoAprendizagem Sesquicentenário, Rede Estadual da Paraíba, annatheresarosenhaim@gmail.com

${ }^{3}$ Professor do Centro Estadual Experimental de Ensino-Aprendizagem Sesquicentenário, Rede Estadual da Paraíba, joazadaque@hotmail.com
} 
juninas com a presença de participantes de diversas gerações. Contudo, essa riqueza cultural não é valorizada pelo poder público e os artistas locais não recebem o incentivo adequado e permanecem invisíveis à maioria esmagadora da população da capital paraibana.

Palavras-chave: Manifestações Culturais; Rio Sanhauá; Garças do Sanhauá; Requalificação; Porto do Capim

\section{Abstract}

The project Nós Propomos! Paraiba: revitalizing citizenship through education" was implemented in the year 2018, through an institutional agreement between experimental state teaching-learning center Sesquicentenário, public school of the state education network, and the state university of Paraiba with the objective of understanding the revitalization process of the historical center of João Pessoa, Paraiba, Brazil. This research aims to analyze the ways how the revitalization process of the Historical Center of João Pessoa/PB is linked to the sociospatial dynamics of this area, as well as the existing interaction among the elements of its present situation. On the same way, is part of our interest the identification of the kind of policies carried on by the State, together with the economic power constitutive representation. We defined the period between the 1980 years until nowadays as the scope of our work, looking forward the production and reproduction of the mentioned space. We also analyze the contradiction between the government official speech and its effective practice through the actions toward the revitalization process. Our research covers the community of Porto do Capim mobilization on face of governmental actions. We identify that, these urban interaction process directly affects the life of the local dwellers, considering that these people are the historical dwellers haring their way of life, activities and feeling of affection for the Historical Center.

Keywords: Cultural manifestations; Local artists; Herons of the Sanhauá; Requalification; Port of Capim

\section{Introdução}

Um dos focos do projeto Nós Propomos! Paraíba durante o ano de 2018, foi o de analisar as características econômicas, sociais, culturais e os modos de vida da população residente na comunidade do Porto do Capim, situada as margens do rio Sanhauá, no centro do município de João Pessoa e, sobretudo, compreender as tensões desencadeadas a partir da implementação do projeto de revitalização da área 
por parte da Prefeitura de João Pessoa, que tem a intenção de realizar a retirada dos moradores da região e reassentá-la em conjuntos residenciais localizados em áreas periféricas da cidade, gerando cenários de segregação socioespacial. As principais justificativas levantadas pelo poder público para seguir com o projeto de revitalização reside na necessidade de preservar o patrimônio do Centro Histórico de João Pessoa, que abrange um conjunto arquitetônico com mais de 700 edificações que remonta 433 anos de história, através de uma readequação da área para a construção de um pátio de eventos no atual terreno da comunidade, onde ocorreriam apresentações culturais que por sua vez, impulsionariam o turismo da capital paraibana. Essas ações do Estado estão intimamente alinhadas aos interesses do capital privado, ao favorecimento da indústria de grandes eventos e a ampliação da especulação imobiliária nesse território. A ideia de higienizar o espaço urbano com a expulsão dos moradores da área histórica da cidade está intimamente associada a um processo de desvalorização, não reconhecimento e invisibilização das atividades culturais desenvolvidas por artistas populares residentes na comunidade do Porto do Capim, ou seja, uma negação da cultura local sob a justificativa de estar trazendo cultura para a região, mas que na prática é apenas uma tentativa de esconder a materialização do processo de Gentrificação.

Um dos eixos temáticos do projeto se propôs à conhecer e, de alguma forma, auxiliar na divulgação das as manifestações culturais da comunidade do Porto do Capim. Os resultados dessa iniciativa foram obtidos a partir de uma ampla leitura de material bibliográfico sobre as características culturais; coleta de dados sobre o modo de vida e questões socioeconômicas vigentes na comunidade, ouvir os relatos das lideranças comunitárias e a realização de uma visita de estudos ao Porto do Capim com o intuito de participar do Projeto Vivenciando o Porto, promovido pelo coletivo de mulheres Garças do Sanhauá, ligado ao Ponto de Cultura Comunitário, apreender a efervescência das apresentações culturais do xote das meninas e entender um pouco sobre as diversas expressões artísticas da atualidade, que representam cerca de 70 anos de história, memória, sentimento de pertencimento e uma identidade cultural bastante singular.

No dia 11 de maio de 2018, estudantes e professores do Nós Propomos Paraíba realizaram uma visita de estudos à comunidade Porto do Capim com o objetivo de conhecer sua história, a lutas frente ao processo de retirada dos moradores da região com objetivo de "revitalizar" a área e prepará-la para a indústria de grandes eventos; entender a relação dos moradores com o rio e a identidade cultural relacionada as lendas e histórias contadas de geração a geração; compreender o papel das 
manifestações culturais ligadas a literatura, dança, música, teatro, artesanato e culinária na contrução de uma identidade cultural única; divulgar as atividades culturais realizadas no Porto do Capim como mais uma ferramenta da permanência da comunidade no seu lugar de origem; e, por fim, ser mais um agente de denúncia e cobrança de providências junto a o poder púlico quanto a melhoria da oferta dos serviços públicos e a implementação de um projeto de "requalificação" da infraestrutura da comunidade, trazendo os serviços básicos necessários a uma mínima qualidade de vida, mas que consiga resguardar as caracterísitcas originais da comunidade. A parceria também possibilitou a ocorrência de uma apresentação culturais na III Feira Literária do Sesquicentenário (Felis) no mês de novembro de 2018 produzida por alunos e professores do Projeto Nós Propomos paraíba sob a coordenação das professoras Albanízia Alves Diniz e Lara Torrezan Gonçalves Ramalho Nitão.

\section{Aspectos teóricos}

De acordo com Bogéa et al. (2007) o patrimônio cultural é o conjunto de bens que possui valor histórico, artístico, científico ou associativo e que define, em diferentes escalas, a identidade de uma comunidade, um Estado ou uma Nação, devendo ser preservado como legado às gerações futuras. Funari (2001) complementa o conceito com a ideia de que patrimônio, como "referência aos monumentos herdados das gerações anteriores", remete a um caráter subjetivo, a uma relação de afetividade de símbolos do passado com olhar do presente, pois os nexos entre o bem cultural e a sociedade vão além dessa relação; o caráter político e econômico torna-se intrínseco. Já Rodrigues (2001) assevera que a atual importância dada ao patrimônio pelo poder público reconhece-se não apenas o seu valor cultural, mas também o seu potencial como mercadoria de consumo cultural. Estudos de Scocuglia (2004) aponta que, na atualidade, os espaços históricos e culturais são discutidos também em relação aos seus universos de vida e de trabalho ou às suas maneiras de reivindicar direitos e expressar-se artistica e culturalmente, que enfatizam não só as condições de transformação das noções de patrimônio e de monumentos e sitíos históricos, mas também as tensões existentes no processo de preservação e revitalização de sítios históricos urbanos.

Os sítios históricos, para serem compatíveis com o decreto lei № 25, de 1937, deveriam possuir conformidade em suas características coloniais, permitindo sua conceituação como obra de arte. Deveriam, ainda, estar livres das ameaçadas de 
crescimento ou de transformações do desenvolvimento. Os sítios urbanos deveriam, assim, estar economicamente vazios e mantendo a unidade de estilo. Motta (1987) considera que, essa fase do patrimônio no Brasil, se assemelha às intervenções nos centros históricos com vistas ao consumo visual global, caracterísiticas das intervenções de finais da década de 1990. Afirma também haver um retrocesso em relação à prática da década de 1980, na qual o patrimônio teria sido valorizado por suas caracterísitcas documentais, sua trajetória e seus diversosos componentes como expressão cultural e parte de um todo socialmente construído. Segundo Gonçalves (2014), o patrimônio cultural não se trata apenas da preservação ou promoção das referências culturais de forma isolada e, sim, algo maior relacionado a importância da apropriação das mesmas pela população imersa no processo. Dessa forma, os agentes institucionais devem compreender qual é a relação que se estabelece entre um determinado bem cultural e os sujeitos sociais, sendo necessário entender como uma comunidade tradicional apropria-se desse espaço, vive o lugar, desenvolve suas atividades econômicas, produzem suas referências culturais e suas práticas cidadãs.

Estudos de Scocuglia (2004) asseveram que as instituições e grupos já existentes nessas áreas, que procuram desenvolver projetos mais pautados em reflexões e concepções de valorização dos bens culturais, bem como as comunidades usuárias deste território vêm sendo alijadas do processo de implantação desse modelo, sob o argumento de que há urgência em viabilizar a auto sustentabilidade dos sítios históricos e necessidade de cumprimento de prazos num caráter exclusivamente financeiro Menezes (2000) discorre que o mercado constitui em prática histórica e matriz geradora do processo cultural, sendo muito importante discutir as formas de intervenção do poder público ao oferecer o patrimônio cultural como mercadoria, preocupado, sobretudo, em reduzir o ônus que the cabe sobre a preservação e revitalização de áreas urbanas e em criar uma imagem da cidade de valor cultural ao valor econômico, uma fetichização da cultura.

Scoguglia (2010) relata que a definição de centro histórico que abrangeria, em princípio, apenas as características urbanísiticas, arquitetônicas e históricas passa, posteriormente, a compreender o compromisso social vinculado a política de residência e à produção de culturas e identidades. Nesse caso, o processo de patrimonialização de bens culturais urbanos, em especial das edificações e espaços públicos das áreas centrais, faz parte das políticas de imagem das cidades contemporâneas com o intuito de atrair investimentos, sobretudo voltados para expansão das atividades turísiticas. Paes-Luchiari (2005) discorre que a patrimonialização, enquanto processo, pode levar a uma redução narrativa, ao 
destacar certas áreas em detrimento de outras e assim gerar problemas urbanos relacionadosà funcionalidades e à hegemonia de usos sociais nas territorialidades dos centros históricos.

Segundo Scocuglia (2004), as intervenções urbanas têm promovido a temática de patrimônio cultura e, em alguns casos, contribuindo para a revalorização dos sítios urbanos por seu valor coletivo e por seus significados enquanto lugares públicos, mas também por seu valor econômico. Guattari (1985) considera que para ser considerado lugar, é preciso que existam práticas sociais constitutivas que sejam relacionadas ao espaço, transformando-o em território de subjetivação, que retêm significados em toda sua extensão material e simbólica, em especial edificada, incidindo sobre as ações que lhe atribuem sentidos. Para Leite (2001), as fronteiras de uma cidade nem sempre têm como consequência a formação de lugares. Entretanto, raramente os espaços segmentados pelas práticas de revitalização não resultam em lugares, reapropriando o patrimônio cultural, seja para reescrever e reinventar tradições. De acordo com Arantes (2000), as políticas de gentrificação operam com categorias residuais da tradição, como forma de relocalizá-la em contextos, cujos fluxos tendem para as operações de desencaixe dessa tradição. Esse processo tem dupla função: articular os aspectos tradicionais da cultura com as demandas de mercado - que possibilitam transformar o patrimônio em mercadoria cultural - e, a partir disso, legitimar a reinvenção de uma centralidade, restabelecendo os nexos entre identidade e lugar no contexto da socedade contemporânea.

Harvey (1992) foi um dos pioneiros a identificar uma crise de produção capitalista e com fenômeno da comunicação de massa, avaliando suas consequências em termos de uma crise discursiva e de identidade. Os referenciais de identidade sendo associados à possibilidade de consumo, passando os bens culturais a representar $\mathrm{e}$ um status diretamente ligado ao mercado. Estariam, desde então sendo abertas as portas para a reinserção dos bens culturais no circuito das comunicações, do consumo de massa e da indústria cultural. Scocuglia (2004) comenta que trata-se de uma nova ideia de cidade, de âmbito internacional, representada em parte pelos sítios históricos que passam a fazer parte do circuito internacional do mercado global, tanto como produto quanto como elemento de identificação ou diferenciação dos locais para atrair público consumidor. Zukin (1996) afirma que, além de mapear a posição entre mercado - as forças econômicas que desvinculam as pessoas de instituições sociais estabelecidas - e lugar - as forças espaciais que os ancoram ao mundo social, dando base para uma identidade estável. Enquanto a economia divide a cultura une. 
De acordo com Scocuglia (2010), os principais casos de reabilitação de centros históricos brasileiros começam após a inscrição destes lugares como patrimônio nacional ou patrimônio da humanidade. Os centros urbanos brasileiros, em geral, não são abandonados, apresentando, pelo contrário, um dinamismo no que diz respeito às atividades comerciais e residenciais, estas últimas sobretudo para as populações de baixa renda. Frequentemente considerados decadentes por suas fachadas deterioradas, falta de segurança e problemas de infraestrutura. Assim, o processo de requalificação tem sua origem num monumento ou construção do patrimônio da cidade ou por meio da criação de novos centros culturais e/ou comerciais. Por conseguinte, os fenômenos de requalificação e gentrificação no Brasil são facilmente confundidos porque embora os centros urbanos brasileiros requalificados não tenham sua população loal substituída por outra mais abastada, estes espaços tornam-se lugares de turismo e, às vezes lugares de consumo para classe média que continua a habitar em outos setores.

Nesse sentido Andrade (2007) afirma que no caso de João Pessoa, as camadas de média e alta renda passaram ocupar áreas elevadas, planas e nas próximidades do litoral, que durante o crescimento da cidade passaram a ser munidas de infraestrutura e serviços como é o caso dos bairros de Manaíra, Tambaú, Cabo Branco, Bessa, Miramar e Tambauzinho. Já as camadas de baixa renda ficaram relegadas às regiões desprovidas de infraestrutura, geralmente com topografias baixas e/ou acidentadas, quase sempre associadas aos baixos curso fluviais, como nos casos do rio Sanhauá nos bairros do Varadouro e Baixo Roger, e áreas de manguezais no bairro do Mandacarú, próximos do centro histórico de João Pessoa;

Silva (2016) relata que o projeto de Revitalização da comunidade do Porto do Capim prevê a retirada de cerca de 250 famílias, para dar lugar a uma praça de eventos que tem como objetivo a promoção de um novo polo cultural em João Pessoa, responsável por atrair capital, aumentar o fluxo de pessoas no espaço e incentivar o turismo. Sendo inscrito em um conjunto de estratégias políticas, imobiliárias e urbanísiticas, que tem desenvolvido na atual etapa do capitalismo, com orientação para a reprodução espacial, convergindo para a segregação e a hierarquização no que irá transformar a vida urbana, o cotidiano, reorientando usos, estruturas e funções do lugar. Motta (2000) aponta que o patrimônio cultural do Porto do Capim estaria comprometido a um "modelo globalizado", que desconsidera a cidade como fonte de conhecimento, em benefício de uma apropriação cenográfica, para consumom visual. E a partir dessa concepção, questiona-se a validade dos critérios de intervenção no 
espaço urbano que despreza aquilo que é referência cultural, que é mais genuíno para a comunidade local e seu significado como Lugar.

\section{Caracterização da Comunidade do Porto do Capim}

O Porto do Varadouro, localizado no centro de João Pessoa, as margens do rio Sanhauá, popularmente conhecido como Porto do Capim, foi durante muitos séculos o principal entreposto comercial do estado da Paraíba, até ser substituído com a construção do Terminal Marítimo no município de Cabedelo, situado ao norte da João Pessoa no ano de 1935. Com o fim das atividades portuárias, ocorreu uma relocação do comércio, equipamentos públicos e serviços bancários para outras regiões do centro e um declínio da economia região, acompanhado pela progressiva desvalorização imobiliária da área, de modo que as instalações desativadas passaram a ser ocupadas por famílias de trabalhadores que anteriormente estavam ligadas às atividades portuárias e pescadores que realizavam seu trabalho nas imediações dos rios região, formando a Comunidade ribeirinha do Porto do Capim.

$\mathrm{Na}$ atualidade, o Porto do Capim é uma comunidade predominantemente residencial, sendo possível encontrar um pequeno comércio local, escola pública estadual que atende apenas turmas do $4^{\circ}$ e $5^{\circ}$ anos do Ensino Fundamental I (anos iniciais), uma igreja, associação de moradores, pequenas bodegas, bares e fiteiros, que atendem à demanda da população residente. Muitos dos antigos moradores continuam a exercer atividades econômicas ligadas a pesca, coleta de mariscos e crustáceos como complemento do sustento familiar, serviços de construção de barcos, comércio ambulante e diversos trabalhos temporários. A comunidade localiza-se a poucos metros da Estação Ferroviária da Companhia Brasileira de Trens Urbanos (CBTU), do Terminal Rodoviário de João Pessoa e do Terminal de Integração de ônibus do bairro do Varadouro, estruturas fundamentais para a movimentação desses moradores para outras partes da cidade. Dessa maneira, o local pode ser entendido através de suas diversidades, como um espaço heterogêneo, misturado ao comércio informal que se situa nas suas imediações e manutenção de um processo histórico de ocupação, uso e vivências com um território tradicional, com largas evidências sobre sua importância para a preservação do próprio patrimônio histórico da cidade.

\subsection{Importância do Coletivo de Mulheres Garças do Sanhauá}


Diante das ameaças de remoção trazidas pelo Projeto de Revitalziação do Antigo Porto do Capim promovido pela Prefeitura de João Pessoa, surge a Comissão de Mulheres Porto do Capim em Ação. Este grupo tem lutado pela defesa de uma identidade territorial e pelo reconhecimento daquela porção do espaço urbano enquanto indisociável do conjunto de referências materiais e imateriais locais, reinvidincando o direito a esse lugar da cidade. A comissão não luta apenas pelo direito ao espaço físico, mas, sobretudo, pela cultura tradicional da comunidade, tendo em vista que a maioria das famílias tem manifestado o interesse de permanecer em seu território tradicional.

Gonçalves (2014) aponta que o grupo Garças do Sanhauá é formado por mulheres trabalhadoras, donas de casa, aposentadas e estudantes, que procuram organizar eventos locais, com o objetivo de mobilizar os demais moradores e fazer parcerias com políticos locais e instituições comprometidas com os movimentos sociais urbanos, na tentativa de conseguir melhorias estruturais que ainda carecem no bairro, tais como: creche, posto de saúde, ampliação da oferta de vagas na escola, segurança pública entre outras demandas. Desde sua criação, a comissão de mulheres conta com o apoio de diversos professores universitários, que participam das reuniões e colaboram na articulação dos movimentos de reinvidicação e que, por sua vez, desenvolvem pesquisas acadêmicas e projetos socioculturais na área.

\section{Efervecência Cultural do Porto do Capim}

Silva (2016) discorre que, ao longo das últimas sete décadas, mesmo a despeito das carências e da ausência de políiticas públicas que conferissem melhores condições de vida à comunidade que reside na área, o Porto do Capim se consolidou e se enraizou, mantendo um forte vínculo cultural com o rio e com o mangue, seja por meio das atividades de pesca e de lazer, seja perpetuando os rituais religiosos e festivos que acontecem no local. O manguezal, inclusive, voltou a existir na área depois que a comunidade ali se instalou, pois antes havia sido literalmente devastado para atender Às necessidades das atividades portuárias no início do século $X X$ (figuras 1 e 2). Ao longo dos anos, a comunidade conseguiu reconstituir esse ecossistema que fora devastado com a construção do Porto do Varadouro e passou a construiu fortes laços de companheirismo e vizinhança. 
Figura 1 - Porto do Varadouro - 1920

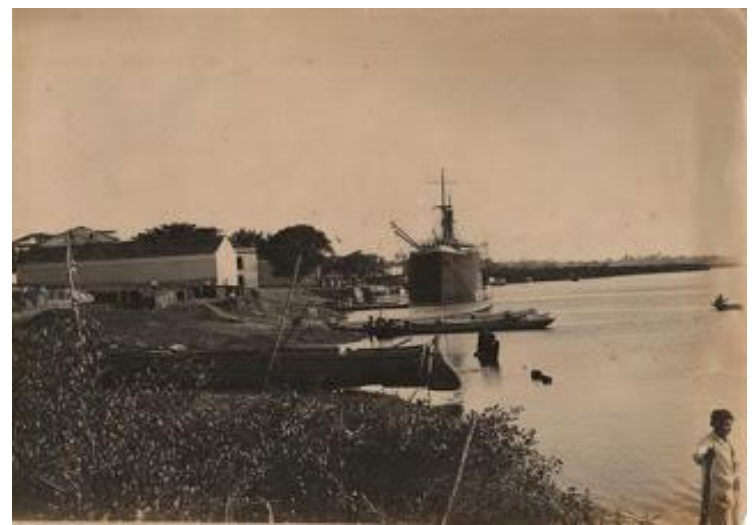

Fonte: https://1.bp.blogspot.com/
Figura 2 - Porto do Varadouro - 2018

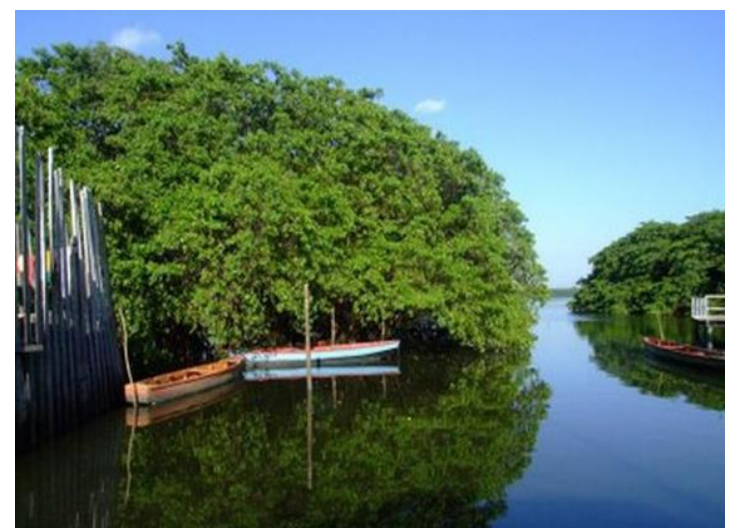

Fonte: https://www.clickpb.com.br/

Os costumes locais resistem às forças que tendem a transformá-las, fortalecem as relações de vizinhança, os espaços de convivência estimulam a troca de informação e laços de amizade. Estudos de Gonçalves (2014) ressaltam as especificidades que permeiam as relações sociais que aí se estabelecem em termos de dinâmicas sociais, as primeiras famílias chegaram na região na década de 1940 e construíram suas moradias e atualmente a maioria dos moradores fazem parte das mesmas famílias que ocuparam a região num primeiro momento. Quando se caminha entre as ruas e vielas da comunidade (figura 3), observa-se a circulação das pessoas e inicia-se um diálogo com alguns moradores é possível perceber que a organização socioespacial está baseada nas relações familiares e que a noção de teritório tem, como uma das referências, as relaçoes sociais locais. A disposição das casas está baseada em relações de vizinhança, onde o projeto de casa está intimemente ligado ao projeto familair de cada grupo residencial. Não há no Porto do Capim um morador que não tenha vínculo de parentesco estabelecido com outro morador.

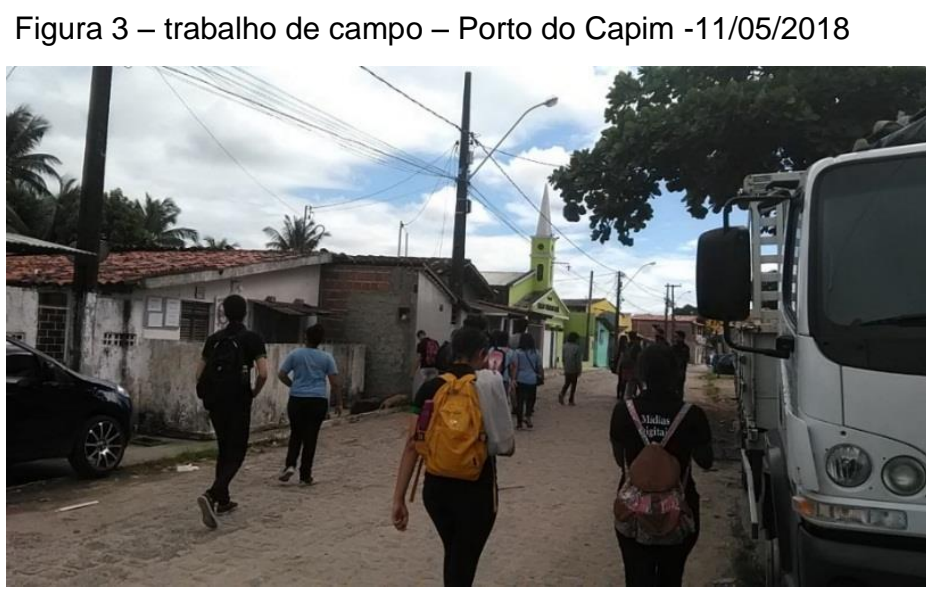

Fonte: Joazadaque Lucena de Souza 
Assim, é inegável a existência de uma identidade comum com o local que a comunidade habita e que, inclusive, confere caracterísiticas de comunidade tradicional ribeirinha, uma vez que muitos dos que habitam no local viveram e ainda vivem de atividades diretamente relacionadas com o rio Sanhauá e rio Paraíba e com as ilhas que nele existem, a exemplo da pesca, da coleta de mariscos e carangueijos, de práticas de navegação e a construção de barcos e de outros instrumentos de pesca. Nesse sentido, podemos afirmar que, ao longo dos anos, a comunidade Porto do Capim organizou suas condutas coletivas de sistemas simbólicos, passando a criar modelos, transmitidos em forma de regras que orientam as relaçoes sociais e a produção do espaço mantém através dessas ações.

No Ponto de Cultura concentram-se uma série de atividades culturais com seções de cinema, apresentações de teatro, música e dança, sendo a atividade cultural de maior relevância o Projeto Vivenciando o Porto, uma iniciativa voltada ao turismo de base comunitária, que se propõe a receber grupos de pessoas para acolhimento, pausa e prosa sobre as características e processos de luta para comunidade, um tour guiado pela comunidade, contemplação do rio Sanhauá no trapiche, construído e mantido pelos moradores da própria comunidade, degustação da culinária local (mariscada e feijoada), apresentação do Grupo Cultural "Xote das Meninas" e a venda de produtos produzidos pela comunidade.

Além de possuírem seus meios físicos de manifestar sua cultura, os moradores da comunidade também se utilizam de mitos como o Pai do Mangue e Comadre Florzinha, dentre outros meios orais como a música, sendo esses citados todos possuírem uma relação forte, desde muito jovens, com o rio Sanhauá que banha as margens da comunidade. Ainda crianças, tem como costume brincar as suas margens, e ouvir sobre as lendas relacionadas ao ambiente fluvial, sendo ensinados pelos mais velhos a respeitar suas águas estando ou não dentro delas. Ao chegar à idade adulta, esses jovens já têm consciência da importância do rio não só para a comunidade em si, mas para a própria cidade. A partir daí, já se pode ver o afeto que sentem pelo rio, pois passam os ensinamentos que receberam para as próximas gerações. A pesca é utilizada por muitos moradores da comunidade como meio de subsistência, os peixes, crustáceos e frutos do mar são utilizados para produzir pratos que refletem a culinária local dentro de um contexto regional, como o pirão, a peixada e a mariscada. No dia 08 (oito) de dezembro, ocorre a procissão em homenagem a Nossa Senhora da Conceição, realizada a mais de 50 anos, cujo trajeto leva até o Porto do Capim, onde os romeiros seguem em embarcações levando a imagem até a ilha da Santa. A santa é tida também como Senhor dos Navegantes, o que atribui um grande peso para os 
moradores da comunidade, visto que grande parte deles navegam pelas águas do rio. O ponto de Cultura também promovem a Festa de Santana no mês de julho e o Natal Cultural do Porto do Capim em dezembro de cada ano.

\subsection{Atividades desenvolvidas junto à Comunidade do Porto do Capim}

Durante a visita de estudos a comunidade do Porto do Capim realizada em 11 de maio de 2018, fomos recebidos por Rossana Holanda, moradora e a principal líder comunitária da comunidade, que realizou, juntamente com outras integrantes das Garças do Sanhauá, uma exposição sobre as condições socioambientais dessa comunidade ribeirinha e o histórico de lutas dos moradores junto ao poder público e colaboradores (figura 4) e, principalmente, a relação conflituosa com as grandes empresas instaladas no local. Posteriormente, foi realizado um tour guiado pelas ruas da comunidade, sendo possível perceber a infraestrutura precária, a falta de saneamento básico, coleta seletiva de lixo e não oferta de creches e posto de saúde na localidade, além da poluição oriunda do pó de madeira descartados de forma inadequada, podendo gerar doenças respiratórias tanto para os seus trabalhadores quanto para os moradores da região. As madeireiras também contribuem para a degradação da vegetação presentes nos manguezais. A falta de saneamento básico e a ineficiência na coleta de lixo na região contribui para acentuar a poluição do rio Sanhauá.

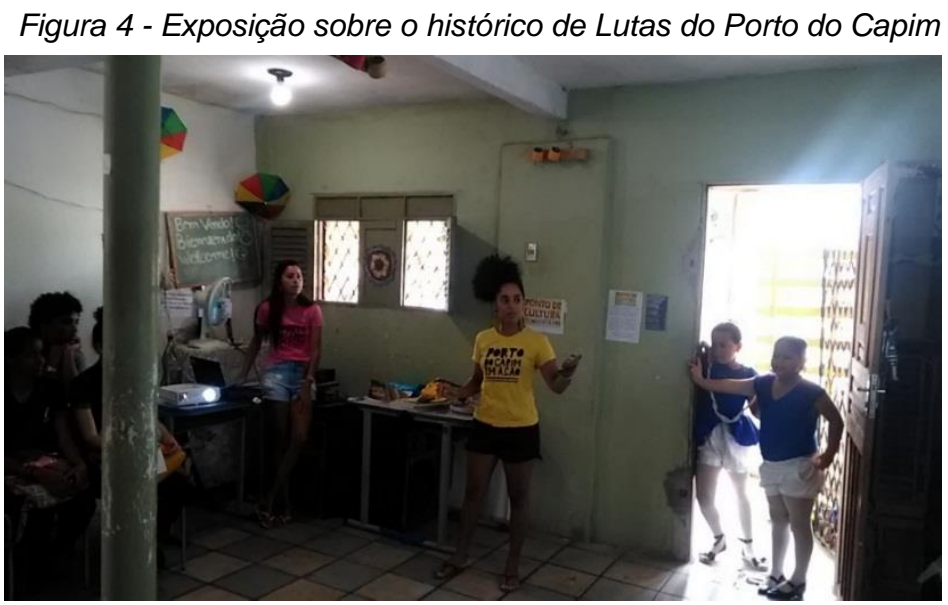

Fonte: Joazadaque Lucena de Souza

Dentre as várias atividades desenvolvidas no Ponto de Cultura Comunitário têm-se um destaque para o "Xote das Meninas" (figura 5), um grupo composto por mulheres adultas, adolescentes e crianças que cantam e dançam músicas típicas da região nordeste e outras composições musicais que se referem ao histórico da comunidade. O grupo também participou de uma apresentação (figura 6) na $3^{0}$ FELIS (Feira 
Literária do Sesquicentenário), escola pública da rede estadual de ensino da Paraíba, organizada por estudantes e professores do Projeto Nós Propomos! Paraíba: revitalizando a cidadania através da educação.

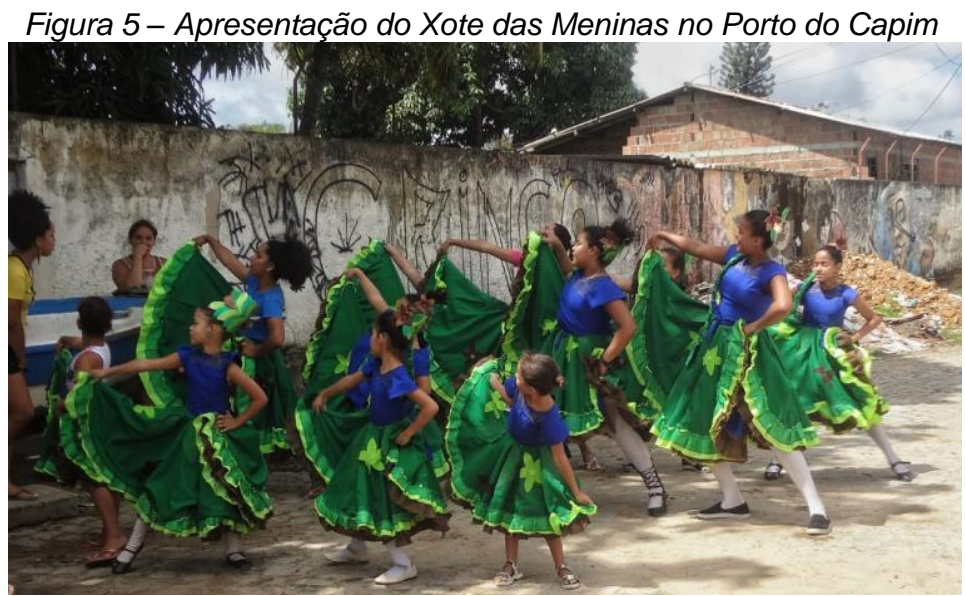

Fonte: Vitória Cristina de Oliveira Trajano

Figura 6 - Apresentação do Xote das Meninas - Felis 2018

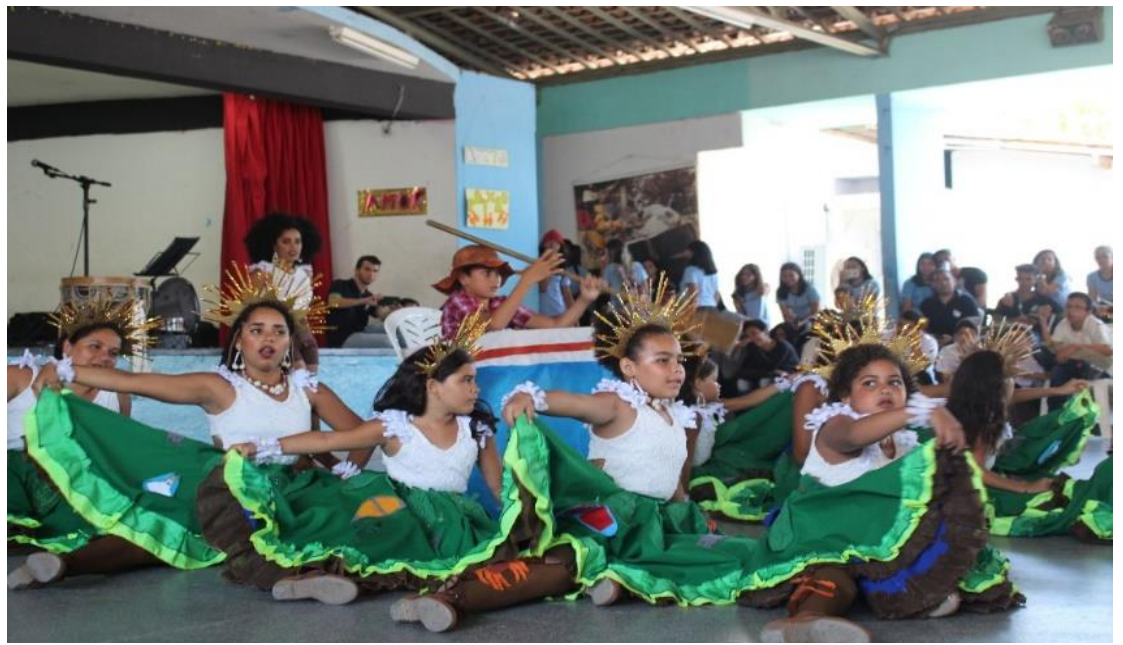

Fonte: Raquel Soares Pereira

Abaixo, temos o poema intitulado de "Um lugarzinho bem ali", criado pela moradora e líder comunitária Rossana Marlene de Holanda, que retrata que o amor do moradores para com a comunidade do Porto do Capim é mais do que uma simples relação de habitante e espaço geográfico, é uma relação afetiva e de pertencimento. Todos os moradores sonham em um dia poder ter as condições necessárias para pode disfrutar, usufruir, do local onde mora, pois é um local histórico e ele deve ser tratado com respeito. O Capim Vive! 
Quadro 1 - Poema Um Lugarzinho bem ali - Rossana Holanda

\begin{tabular}{|c|c|}
\hline $\begin{array}{c}\text { Um Lugarzinho bem ali } \\
\text { Quando ouvem seu nome } \\
\text { Nem se dá tanta importância assim. } \\
\text { Mas se forem mais além } \\
\text { Saberás, que tudo começou aqui } \\
\text { Quem lá habita, } \\
\text { É suspeito falar, } \\
\text { pois tem tantas riquezas, } \\
\text { Que nos dedos não se pode contar. } \\
\text { E se caso duvidas } \\
\text { Vem conhecer esse cantinho. } \\
\text { Se vier com bondade } \\
\text { Em troca, muito amor e carinho. }\end{array}$ & $\begin{array}{c}\text { De todas ela é única } \\
\text { Banhada pelo rio Sanhauá. } \\
\text { E os moradores la afrimam } \\
\text { "Que é nela que querem ficar" } \\
\text { Ao aproximar o fim do dia } \\
\text { O por do Sol tem Papel de seduzir, } \\
\text { Nossa gente, nosso bairro. } \\
\text { Comunidade do Porto do Capim. } \\
\text { Rossana de Holanda. }\end{array}$ \\
\hline
\end{tabular}

Fonte: Silva (2016)

\section{Conclusão}

As manifestações culturais existentes na Comunidade do Porto do Capim evidenciam o quanto não é sabido sobre o potencial de produção cultural das comunidades consideradas periféricas nas metrópoles brasileiras. A tentativa de expulsão de comunidades tradiconais da área central das grandes cidades brasileiras remtem diretamenrte ao processo de Gentrificação, que devido aos anseios da especulação imobiliária e com vistas a atender a grande industria do turismo, lazer, consumo e promoção de grandes eventos, solicita a retirada de populações que tem vínculos simbólicos com o espaço ocupado há várias décadas com a justificativa de revitalizar a cultura local mas, por outro lado, finge não considerar a imensa produção dos artistas locais residentes nessa comunidades e, comumente, promovem a sua invisibilização, colocando essas populações à margem através de um discurso de modernização das atividades urbanas. A troca de experiências entre estudantes e professores do Projeto Nós Propomos Paraíba e as lideranças comunitárias do Porto do Capim durante o ano de 2018 foi muito produtivo, servindo tanto para aproximar os jovens estudantes do ensino médio a um caso concreto de gentrificação, direcionado a comunidade do Porto do Capim, quanto por poderem se engajar na divulgação das manifestações culturais existentes na comunidade do Porto do Capim pelas redes sociais e, sobretudo, fazer o convite para apresentação do Xote das Meninas na III Feira Literária do Sesquicentenário, organizada por alunos e professores do Projeto, evidenciando que atos de cidadania que contribuem para o estudo, divugação e massifcação da produção cultural de comunidades que estão inseridas num contexto de segregação 
espacial são muito importantes no âmbito do Projeto Nós Propomos. Outras facetas da comunidade porto do capim pode ser encontrada no capítulo intitulado "Processo de revitalização e histórico de lutas da comunidade Porto do Capim" de autoria de Raquel Soares Pereira, parte integrante deste mesmo livro.

\section{Agradecimentos}

Gostaríamos de agradecer o empenho de Victor Silva Marques dos Santos, Thaís Soares de Araújo, Jefferson Nogueira Silva e Vinicius dos Santos Neves pela elaboração dos relatórios sobre a visita de estudos ao Porto do Capim, fundamentais para a construção desse capítulo de livro e as fografias de Vitória Vitória Cristina de Oliveira Trajano.

\section{Referências bibliográficas}

Andrade, P. A. F. (2007). Metamorfose dos Centros Urbanos: Uma análise das transformações na centralidade de João Pessoa-PB, 1970 - 2006. (Mestrado em Engenharias Urbana). Universidade Federal da Paraíba. João Pessoa.

Arantes, A. (2000) O Espaço da Diferença. Campinas: Editora Papirus.

Bogéa, K. S., Brito, S. R. S.; Pestana, R. G. (2007) Centro Histórico de São Luis Patrimônio Mundial. São Luís.

Decreto-Lei $n^{\circ}$ 25, de 30 de Novembro de 1937. Organiza a proteção do patrimônio histórico e artístico nacional.

Funari, P. P. (2001) Os desafios da destruição e conservação do patrimônio cultural no BrasilTrabalhos de Antropologia e Etnologia. Porto: 411/2.

Guattari, F. (1985) Espaço e Poder: a criação de territórios na cidade. Espaço e Debates, no 16. São Paulo.

Gonçalves, H. T. (2014) O Porto e a Casa: dinâmicas de transformação no uso dos espaços no centro histórico de João Pessoa. (Mestrado) - Programa de PósGraduação do Instituto do Patrimônio Histórico e Artístico Nacional. Rio de Janeiro.

Harvey, D. (1992) Condição Pós-Moderna. São Paulo: Editora Loyola.

Leite, R.P.S. (2001) Espaço público e Política do Lugares: usos do patrimônio cultural na reinvenção contemporânea do Recife Antigo. (Doutorado em Antropologia) - IFCH. Unicamp. Campinas. 
Menezes, J. L. M. (1984) A fortaleza de Santa Catarina do Cabedelo. Recife: Poll editorial.

Motta, L. (1987) A SPHAN em Ouro Preto: "uma história de conceitos e critérios". Revista do Patrimônio Histórico e Artistico Nacional n²2. Iphan.

Motta, L. (2000) A apropriação do patrimônio Urbano: do estético estilístico nacional ao consumo visual global. In: Arantes, N. A. (org). O espaço da diferença. Campinas: Papirus.

Paes-Luchiari (2005) Centros históricos - mercantilização e territorialidades do patrimônio cultural urbano" In: GEOgraphia, Revista de pós-graduação em Geografia, N. 15, UFF/R.J.

Rodrigues, M. (2001) Preservar e Consumir Turismo e Patrimônio cultural. São Paulo: Contexto.

Silva, R. C. N. (2016) revitalização do Centro Histórico de João Pessoa: uma estratégia para a reprodução do capital. (Doutorado em Geografia) - Faculdade de Filosofia, Letras e Ciências Humanas. Universidade de São Paulo. São Paulo.

Scoguglia, J. B. C. (2004) Revitalização Urbana e (Re) Invenção do Centro Histórico na Cidade de João Pessoa. João Pessoa: Editora Universitária.

Scoguglia. J.B.C. (2010) Imagens da Cidade: Patrimonialização, Cenários e práticas sociais. João Pessoa: Editora Universitária

Zukin, S. (1996) Paisagens urbanas pós-modernas: mapeando cultura e poder. Revista do IPHAN, № 24, p 205-219. 


\title{
Processo de revitalização e histórico de lutas da comunidade do Porto do Capim, João Pessoa, Paraíba, Brasil
}

\author{
RAQUEL SOARES PEREIRA ${ }^{1}$ \\ JOAZADAQUE LUCENA DE SOUZA ${ }^{2}$ \\ REGINA CELLY NOGUEIRA DA SILVA ${ }^{3}$
}

\section{Resumo}

A comunidade do Porto do Capim localiza-se as margens do rio Sanhauá, numa área de manguezais, próximo aos trilhos da Companhia de Trens Urbanos (CBTU) no centro da cidade. Vem sendo alvo do processo de revitalização proposto pela Prefeitura municipal desde a década de 1990, que consiste na retirada da população local com o objetivo de readequar o espaço urbano aos interesses imobiliários, comerciais e turísticos ligados a indústria de eventos, atendendo aos anseios do capital especulativo de grupos empresariais. Em 11/05/2018 professores e alunos do projeto visitaram o Porto do Capim, participando de um tour guiado e uma exposição realizada pelo coletivo de mulheres, pertencentes ao Ponto de Cultura da Comunidade, sobre o histórico de resistência e enfrentamento dos moradores contra o processo de gentrificação e a busca por amparo legal junto ao ministério público e justiça para garantir o direito a propriedade e posse de seus domicílios, além do respaldo de grupos da Universidade Federal de Paraíba e movimentos sociais que os auxiliaram na luta pela continuidade da ocupação, requalificação dos espaços e melhoria na oferta dos serviços públicos que visem melhorar a qualidade de vida da população de um território permeado por identidade e memória que remonta à década de 1940.

Palavras-Chave: Porto do Capim; Comunidade; Revitalização; Especulação Imobiliária; Requalificação.

\footnotetext{
1 Estudante do 3o ano do Ensino Médio do Centro Estadual Experimental de EnsinoAprendizagem Sesquicentenário, rachelsoaresperreira@gmail.com

2 Professor do Centro Estadual Experimental de Ensino-Aprendizagem Sesquicentenário, joazadaque@hotmail.com

${ }^{3}$ Professora da Universidade Estadual da Paraíba, recelly51@hotmail.com
} 


\section{Abstract}

The community of Porto do Capim is located on the banks of the Sanhauá river, in a mangrove area, next to the tracks of the company of urban trains (CBTU) in the center of the city. It has been targeting of the revitalization process proposed by the city hall since the 1990s, that consists of the withdrawing the local poputation, with the objective of reworking the urban space to real estate, commercial and tourist interests linked to the industry of events meeting the expectations of speculative capital of business groups. In 11/05/2018 teachers and students of the Project visited the "Porto do Capim" participating in guided tour and an exhibition held by the women belonging to the point of community culture about the history of resistance and confrontation of the residents against the gentrification process and the seeking protection from public prosecution and justice to ensure the right property and possession of their homes, beyond the support of groups from the Federal University of Paraiba and social movements that help in the struggle for continuity of ocupation, requalification of spaces and improvement in the provision of public services that aim improve the life quality of the population of a territory permeated for identity and memory dating back to 1940.

Keywords: "Porto do Capim", community, revitalization, speculation, real estate, requalification

\section{Introdução}

A comunidade do Porto do Capim encontra-se localizada no bairro do Varadouro, região central de João Pessoa, às margens do rio Sanhauá, lugar onde em 1585, atracou a caravela portuguesa comandada por João Tavares, que deu início ao processo de colonização da atual cidade de João Pessoa, capital do estado da Paraíba. Com o estabelecimento dos portugueses, começou-se a florescer as primeiras estradas e edificações da cidade, que agora moldava-se ao modelo mercantilista europeu a partir do Porto do Capim. Em meados de 1920 durante a gestão do presidente Epitácio Pessoa ocorreu a construção do Porto do Varadouro, que visava atender ao comércio marítimo da região. A obra foi considerada inviável e sua construção foi aprovada sem levar em consideração as consequências e as limitações da região. 
O Porto consiste em uma característica que singulariza esse núcleo da cidade, pois através do Rio [Sanhauá] dava-se entrada a tudo que era necessário para prover a urbe. Local, portanto, de chegada e saída de mercadorias e pessoas. O desenvolvimento e declínio do seu porto refletem nas distintas etapas de valorização do seu território e seria o principal responsável pelo delineamento do organismo urbano. (SILVA, Alzilene Ferreira da. 2014)

Como previsto, o porto não suportou a demanda de cargas devido aos processos de assoreamento do rio que comprometiam as embarcações (Gonçalves, 2007) e, também, por questões orçamentárias, a rota comercial foi transferida para o terminal marítimo de Cabedelo ao norte de João Pessoa, o que resultou no abandono da região portuária que atendera ao comércio português durante décadas. De acordo com Smith (2007) Todo o processo de crescimento e desenvolvimento urbano consiste em um constante arranjo, estruturação e reestruturação do espaço urbano. Nesse Sentido a região entrou em declínio, provocando a desvalorização do espaço urbano e o desamparo da classe operária que se assentaram na região que hoje constitui a comunidade do Porto do Capim.

Com o advento da Revolução de 1930, houve uma aceleração do processo de expansão e urbanização da cidade com melhorias do espaço público, pavimentação das ruas, construção de praças, iluminação, saneamento e abastecimento de água, alterando a dinâmica socioespacial que deixou de lado o caráter colonialista em substituição ao processo de 'modernização' dos espaços urbanos. A cidade passou a expandir-se não agora em direção ao mar. Essa ampliação da cidade começa a delinear uma nova maneira de relacionar-se com a cidade, onde a população de maior poder aquisitivo começa a conquistá-la. A reestruturação geográfica da economia espacial é sempre desigual (Smith, 2007). Entretanto, a modernização do espaço urbano e do estilo de vida da cidade também se fez sob o signo do medo do outro e da busca de controle social (Koury, 2005). O acesso a tais espaços como ruas e praças, através de uma severa legislação de controle de entrada pelo Poder Público, seguiuse de uma política higienista de 'maquiamento' do espaço urbano, visando 'limpar' os espaços públicos das camadas inferiores da sociedade por representarem uma ideia de hostilidade e perigo, erradicando a classe trabalhadora para os subúrbios, distantes, escondidos, com o intuito de legitimar o processo de urbanização.

Estudos de Furtado (2014) apontam que desde a década de 1990 que são pautados pelo Poder Público políticas de Revitalização do Centro Histórico de João Pessoa, que, em suma, consistem em agregar valorização imobiliária e econômica, apontando o processo de gentrificação como processo de inovação urbana, reestruturando sua 
dinâmica espacial idealizada por visões neoliberais de acordo com os interesses do capital especulativo empresarial e nesse contexto o Estado aparece não só como principal condutor dos processos de reestruturação urbana mas também, como o agente do processo de gentrificação. A Comunidade do Porto do Capim reside na região há cerca de 70 anos e, assim como os monumentos históricos, também guardam em si a história da Paraíba, tendo em vista que foi a população residente na localidade que deu origem da capital paraibana, representando de diversas maneiras, através da produção artística e cultural um passado de marginalização e descaso do poder público que desde muito tempo tem o objetivo de tomar posse deste lugar.

\section{A luta e resistência da Associação de Mulheres do Porto do Capim}

A luta pela permanência da comunidade foi encabeçada, desde 2013, pela Associação das Mulheres do Porto do Capim que, diante da consciência do seu papel vital para a dinâmica social e o sentimento de pertencimento ao local que marcou gerações de suas famílias, é, hoje, um grande marco contra o Estado que se recusa, historicamente, a promover uma rede de políticas públicas como educação, saúde e até saneamento básico e que, diante de tantos problemas, insiste em excluir a vontade da comunidade em agir em prol de sua região (figura 1). Uma luta que remonta mais do que a permanência de sua família, mas a história da cidade em si que apenas atrai o interesse estatal quando demonstra valor mercantil. A decisão do que se caracteriza como espaço público remete apenas a opinião pública. Barrar o processo de 'gentrificação', que não passa de uma dinâmica da composição local que prioriza o desenvolvimento econômico do mercado sem levar em conta as populações de baixa renda, e sim, de definir a região como propriedade dessas comunidades (figura 2).

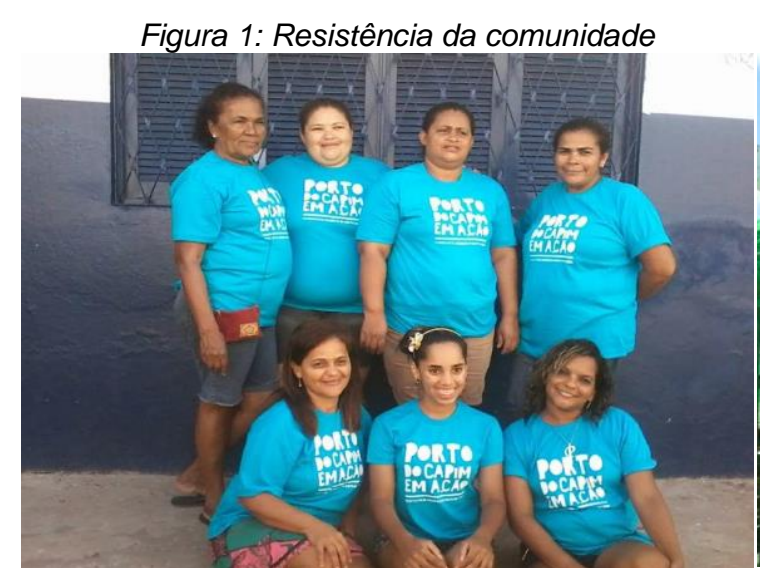

Fonte:www.museudopatrimonio.com/

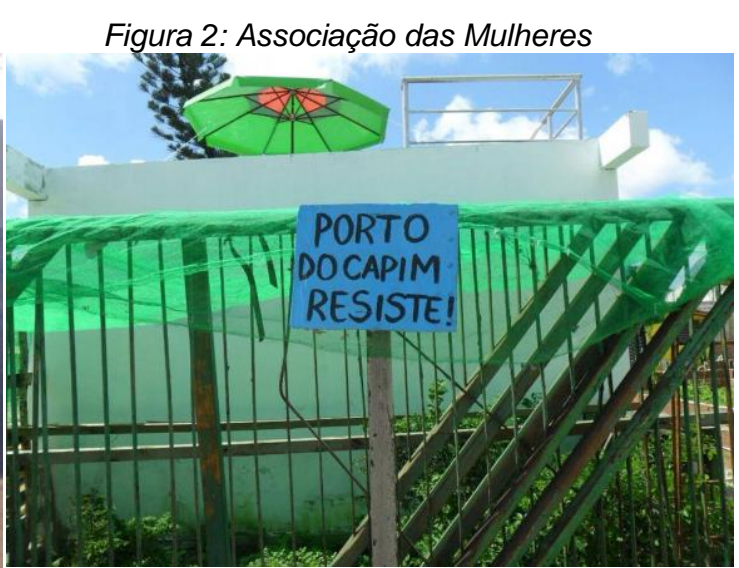

Fonte:http://asmulheresportodocapim.blogspot.com/ 
Segundo Silva (2016) O Porto do Capim, após 70 anos, ainda luta por visibilidade social, histórica, cultural e ambiental (figura 3). O reconhecimento da região como parte fundamental da cidade e o investimento público de garantia dos direitos básicos assegurados pela Constituição Federal de 1988 é a principal reivindicação atual da comunidade. O Centro Histórico possui, além do Patrimônio Histórico Material já tombado pelo IPHAN, uma vasta e valiosa produção artística e cultural imaterial que também requerem valorização e proteção como Patrimônio Cultural da Paraíba.

Figura 3: Movimento Porto do Capim em Ação, projeto em cooperação com o Subindo a Ladeira

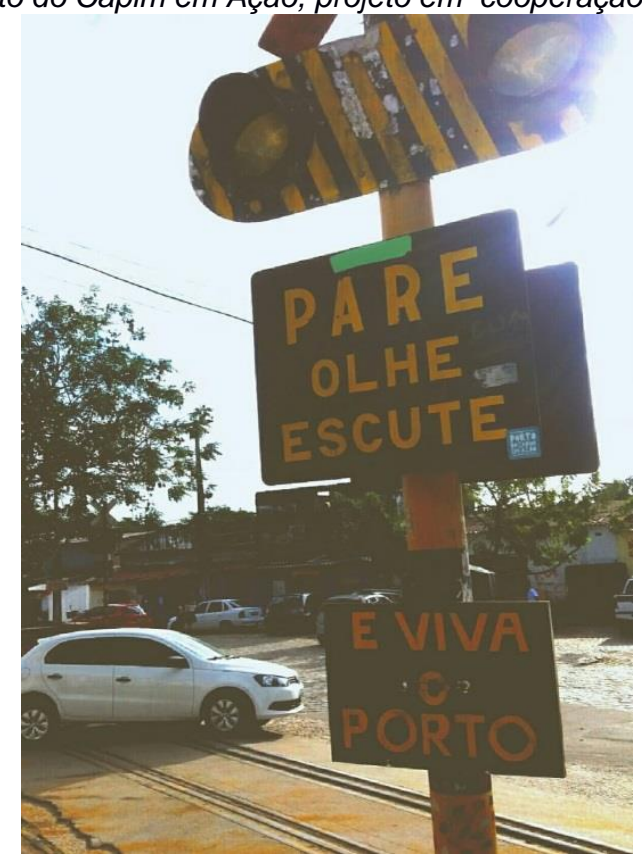

Fonte: Leonardo José Batista de Alcântara.

Tendo em vista o passado de valor incomensurável da região, realizou-se uma tentativa de resgatar o conhecimento sobre todo esse processo histórico, em volta da luta das mulheres da Comunidade Porto do Capim, com a narrativa exclusivamente protagonizada por elas que, corajosamente, ergueram-se de mãos dadas contra o despejo imposto pelo poder público embasado em alegações de projetos inviáveis que, rudemente, desqualificaram a comunidade como parte da cidade, alegando que necessitava de integração social como se a mesma já não fosse parte. A proposta tem o objetivo de explanar, por vias legais, históricas e econômicas, a importância da do Porto do Capim como Patrimônio Histórico e Cultural de João Pessoa e sua permanência na região a qual resistiu arduamente e desenvolveu-se durante gerações. Nos conformes da lei, regida pela Constituição Federal de 1988, que garante tal reconhecimento e estabelece as várias obrigações do Poder Público, a ascensão de projetos coletivos que visem o futuro e o progresso da região, 
reconhecendo o valor histórico e a produção artística e cultural, tornam-se prioridade a se concretizar.

\section{Aspectos econômicos na formação do Porto do Capim}

A Comunidade Porto do Capim, se consolidou as margens do rio Sanhauá, um dos principais afluentes da margem direita do rio Paraíba (Figura 4). A região foi responsável pelas relações econômicas entre a coroa portuguesa e a capitania da Parahyba por mais de dois séculos fazendo ligação da localidade com rotas comercias marítimas muito importantes para o desenvolvimento socioeconômico local, bem como para o seu entorno geográfico e a consolidação de ações alfandegárias que aos poucos foram se materializando em lucro para os colonizadores. Navios a vapor com capacidade de mais de 8.000 toneladas provenientes de diversas partes do globo atracavam no Porto do Capim, para serem abastecidos com a produção interna, carregados de produtos que eram depositados nos armazéns logo após serem desembarcados.

Figure 4: mapas antigos do Porto do Capim em 1630
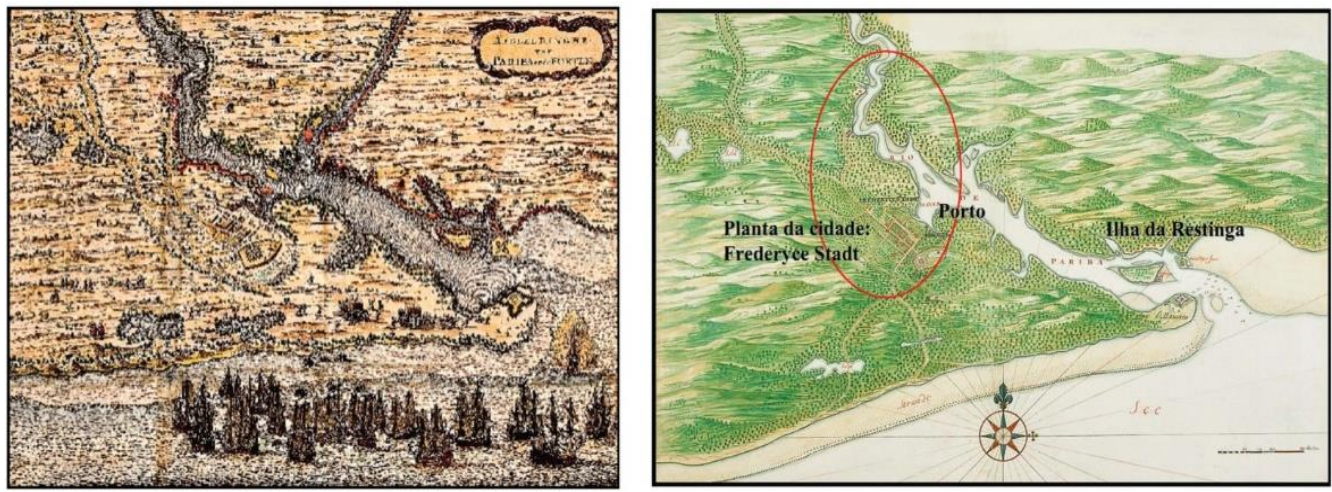

Fonte: http://portodocapimjp.blogspot.com/

Com advento da República e um novo modelo de desenvolvimento urbano, a economia local passou a sofrer interferências externas, positivas e negativas. As atividades econômicas iniciais da comunidade se desencadearam de forma simples, com o propósito quase que total, de subsistência por parte do grupo de moradores que habitavam a região, até então um grupo pequeno, cujo mesmo necessitava se desenvolver. $\mathrm{O}$ grupo de moradores passou a desenvolver atividades de pesca nos arredores da comunidade e utilizam os peixes na sua alimentação e na comercialização interna, mais intensa entre as pessoas da região, e externa, realizada entre os pescadores e comerciantes donos de frigoríficos. 
A população ribeirinha se caracterizava por um baixo poder aquisitivo e o modo de vida das pessoas variava diariamente, de acordo com as suas necessidades, tendo em vista que as construções eram realizadas sem a permissão dos órgãos responsáveis, resultado da falta de um planejamento urbano eficaz por parte do poder público. Com o passar do tempo à comunidade foi aumentando durante os anos, aglomerando mais pessoas, e consequentemente mudando as atividades socioeconômicas vigentes na região. A localidade, em torno da comunidade, tornou-se alvo de grandes empresas ao longo do tempo, com destaque para a instalação atuação das madeireiras, oficinas automotivas, lojas de varejo e atacado, fazendo com que a renda dos moradores fosse prejudicada, devido à grande variedade que as lojas possuíam de produtos, diferentemente dos moradores que vendiam, de forma informal, o que conseguiam pescar no rio e produzir, artesanato ou utensílios para pesca.

As madeireiras passaram a se destacar dentre os pontos comerciais existentes ao comprar diversos imóveis na comunidade por um preço muito baixo devido ao fato dos moradores não terem a ideia do valor imobiliário da localidade em que residiam, por conta de fatores históricos. A extração de madeira foi uma ação ostensiva realizada pelos comerciantes que a utilizavam para fazer móveis e objetos de alto valor agregado, que vinham a ser comercializados posteriormente. A degradação ambiental resultante do processo de desmatamento das espécies arbóreas dos manguezais é bastante expressivo, mas dificilmente é retratado pela mídia, mesmo se tratando de um crime ambiental contra uma Área de Preservação Permanente (APPs) e ferindo a legislação que regula as práticas de preservação do Sistema Nacional de Unidades de Conservação (SNUC). Assim podemos analisar os impactos ocasionados pelo capitalismo, exacerbado, na nossa sociedade contemporânea, principalmente em regiões que são contempladas com características naturais, atribuindo ao espaço geográfico aspectos deslumbrantes.

Algumas atividades comerciais passaram a ser desenvolvidas no Porto do Capim, através do Ponto de Cultura Comunitário coordenado pelo coletivo de mulheres Garças do Sanhauá que, por sua vez promovem palestras, tour guiado pela comunidade, atividades culturais e turísticas. Outro ponto importante é a relação de cuidado para com a natureza, aliando o uso sustentável a conservação dos recursos naturais para as próximas gerações e o mais importante: o fortalecimento dos laços afetivos e sentimento de pertencimento entre os moradores e o rio. Os moradores mais antigos da comunidade serviam como inspiração para os mais novos, transmitindo o conceito de que lugar é a região que nos traz uma relação de 
pertencimento, Milton Santos, assim eles passariam a ter a comunidade não só como lugar de morada, mas também como "lugar das recordações".

As oportunidades no mercado de trabalho para os habitantes do Porto do Capim sempre foram escassas desde o fim das atividades portuárias, somadas a baixa escolaridade, falta de oportunidades de qualificação profissional e preconceito dos empregadores relativo a origem e local de residência dos moradores, que alega e julga previamente alegando a população como criminosa, sendo uma das molas propulsoras da segregação socioespacial. Essa dificuldade de ingressar no mercado de trabalho fez com que os moradores buscassem a prática de atividades econômicas alternativas, como a comercialização de produtos na região, como a construção de barcos, pesca, coleta de mariscos, construção civil e outras atividades braçais mal remuneradas.

Os moradores passaram a comercializar picolé, "din-din”, pipoca, água, refrigerante, suco e vários outros alimentos no espaço interno da comunidade com o objetivo de obter recursos financeiros e assim conseguir suprir as suas necessidades. O grande empecilho nessas atividades é o complexo capitalista que se adentra cada vez mais na geografia espacial da comunidade, diminuindo a comercialização e tornando-a menos eficaz. O complexo hegemônico das madeireiras é o polo do capitalismo mais visível nas dependências da região ribeirinha localiza-se nas regiões mais de 15 diferentes madeireiras, cada uma possui um método de extração de matéria bruta, degradando cada vez mais o meio ambiente. Os donos alegam, quase sempre, não ter a condição financeira necessária para fornecer patrocínio às atividades culturais e eventos desenvolvidos na comunidade que são realizados para adquirir verba e tornar a história da comunidade mais conhecida, aliás, é por ela que se originou a cidade, então o descaso público e social são cada vez mais incompreensíveis.

Por fim, as ações econômicas na comunidade ribeirinha Porto do Capim se desenvolvem de forma separada, contendo o desenvolvimento interno dos moradores locais e do desenvolvimento externo do complexo econômico instalado por grandes empresas, que utilizaram do ponto estratégico para enriquecer cada vez mais seu ego econômico. As ações na comunidade são continuas, visando a melhora social, socioeconômica e cultural da localidade, proporcionando uma visão mais desmembrada dos conceitos impostos pela sociedade e pela a alta classe na sociedade nacional. 


\section{O processo "gentrificador" de reformas urbanas}

Sabe-se que o processo de reestruturação do espaço urbano atende às demandas da indústria imobiliária, que acompanha a nova ordem do capitalismo. Sendo assim, o sistema constrói um envolvente físico e social alinhado à sua imagem, no qual, primordialmente, segundo Turner (1893) estabelece a ideia de fronteira, uma linha de transição entre a civilização (progresso) e a barbárie (selvageria). Ley (1981) aponta que é possível polarizar o espaço geográfico em uma região desenvolvida e subdesenvolvida tomando como base critérios como saneamento, iluminação, circulação de mercadorias e estética. Para Smith (2007) a divisão assume a função de ratificar um processo de conquista e de acordo com Arantes (2000) a política de gentrificação introduz-se por meio de investimentos nas áreas centrais, destacadas como desvalorizadas e pela revitalização de sítios históricos nos dias atuais. Verificase então que este padrão urbanístico/corporativo se utiliza do acervo cultural, através de uma exposição fundamentada na importância da preservação da memória e recognição do lugar. Acompanhando uma direção global, os centros das cidades brasileiras similarmente se tornarão foco de tal processo. Segundo Bidou-zachariasen (2006) a partir de 1980, examina-se um novo arquétipo de administração urbana, que tem por objetivo adequar a estrutura econômica aos requerimentos do sistema. Desse modo, uma série de investimentos voltados ao tema manifesta-se, procedendo tanto do poder público quanto da iniciativa privada. Entretanto, os empreendimentos nos centros citadinos, que objetivam alterar a configuração espacial, são antecedidos pela demolição de prédios e a retirada de uma comunidade pertencente a uma camada social inferior.

O projeto de revitalização na cidade de João Pessoa, Paraíba, é integrante do programa PAC Sanhauá e o PAC Cidades Históricas, não obstante, não considera a narrativa da população em sua perspectiva identitária, utilizando-se de artifícios midiáticos para promover uma imagem desfavorável, tal qual a responsabilização da comunidade quanto a degradação do patrimônio natural e a marginalização dos moradores.

\subsection{A construção da informação}

Estudos de Abramo (1988) relaciona a fluência comercial e política na atuação da notícia divulgada pelos diferentes meios de comunicação. De forma a discorrer acerca da influência da mídia na sociedade. No âmbito da psicologia social, Moscovici (1961) afirma que as informações, em algum estágio, modificam-se. $O$ autor atesta que 
"nenhuma mente está livre dos efeitos dos condicionamentos anteriores que lhe são impostos por suas representações, linguagem ou cultura". Portanto a comunicabilidade é substancial para a construção das representações sociais. De acordo com o teórico, quanto menor a consciência do indivíduo sobre tais imagens, maior seu domínio. Dessa forma, pode-se sugerir que as informações se adaptam aos interesses de um grupo prestigioso. É indubitável que setores significativos da mídia elegem, sintetizam e reformulam acontecimentos em conformidade as diretrizes do mercado. O jornalista Perseu Abramo (1988) afirma que a maior parte do material que a imprensa oferece ao público tem algum tipo de relação com a realidade. Mas essa realidade é indireta. É uma referência indireta à realidade, mas que distorce a realidade", indicando um modelo de manipulação midiática, que é composto por fatores como: ocultação e fragmentação de notícias.

A comunidade do Porto do Capim vem sendo alvo de tal padrão midiático desde 1997. A princípio, devido a um processo de segregação espacial e invisibilização (após a desativação do porto na região) por parte do poder público. Ulteriormente, pela publicação de uma série de matérias jornalísticas tendenciosas produzidas pelos veículos de mídia hegemônicos que sempre recriminaram unicamente os moradores pela poluição do rio Sanhauá, por meio do despejo de dejetos de esgoto doméstico e suas consequências a saúde. Além disto, as impressões incluíam relatos de alguns moradores que reconheciam sua vontade do deslocamento da comunidade ribeirinha para outra área da cidade. Entretanto, esses textos não abrangiam a oferta inadequada de serviços de infraestrutura e saneamento por parte do poder público, nem opiniões múltiplas quanto à estadia da população típica que reside há anos no ambiente e desenvolveu uma relação íntima com o curso de água natural e ainda é assegurada pelo Usucapião (Figura 5), pelo conjunto cultural produzido por seus habitantes e engorda o imenso o patrimônio imaterial (ritos, crenças, músicas, danças, afazeres, comidas típicas e festas comemorativas) e a herança material, como a antiga sede da Alfândega, casa do Tesouro Provincial a sede dos Sindicatos dos Arrumadores. 
Figura 5: água do rio onde João Pessoa despontou é imprópria pra consumo.

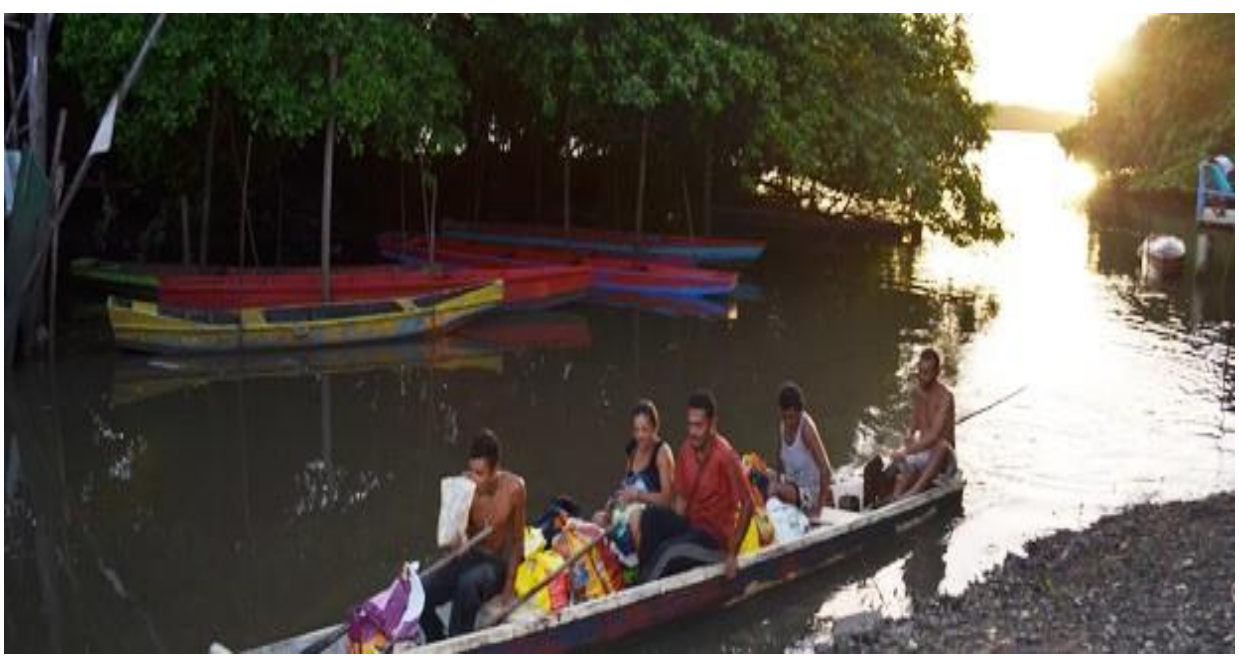

Fonte: http://g1.globo.com/pb/paraiba/noticia/2014/08/agua-do-rio-onde-joao-pessoa-nasceu-e-impropriapara-consumo-diz-ufpb.html

\subsection{Narrativa dos residentes: história dos que resistem às margens do Sanhauá}

Cosme de França, 67 anos, que vive há cerca de 15 metros do trapiche, utilizado pelos pescadores da comunidade, apesar da idade avançada prossegue com sua rotina semanal: apanhar sua canoa e ir até o rio Paraíba. Todos os filhos moram na comunidade, em casas próximas. "Meus netos pescavam comigo quando eram mais novos, agora que cresceram, ganharam o mundo. Ninguém pesca mais comigo, mas eu continuo, pego peixe de todo o tipo". Ele afirma não querer deixar o porto até sua morte (Silva, 2016).

Maria da Penha do Nascimento, 62 anos, foi morar no Porto aos 10 anos de idade. Relembra que quando chegou moravam apenas 20 famílias. Atualmente ela vê a região como um centro comercial e observa os vizinhos como uma grande família. "É um lugar muito bom de se morar, perto da feira, perto de tudo" comentou. "Eu pesco marisco desde pequena, aprendi com minha mãe. E tenho um filho que de tudo ele pega na maré. É um trabalho de família". Além de pescar, ela prepara a mariscada para vender. "O marisco e o coco são daqui. Até o coentro a gente cultiva". Embora exalte os pontos positivos, ela conhece os obstáculos do lugar: "é preciso restaurar as casas que estão em áreas de risco. Tem casa que quando a maré vem, quando chove muito, alaga. Eu acho também que precisava de uma creche" (Silva, 2016).

Pedro Paulino de Holanda, 80 anos, conheceu a comunidade do Porto do Capim quando ainda estava em fase crescimento. Ele morava em Santa Rita, na Grande João Pessoa, e, com 7 anos, começou a visitar o equipamento acompanhado de 
canoeiros vizinhos. "Eu achava bonito e importante aquilo porque era tudo claro, tudo limpo. Só encostava canoa e navio. A noite era luminosa, a gente estava daqui a um quilômetro e avistava o povo andando na beira do cais", revelou. Aos 20 anos, se mudou para a comunidade que se formou onde antes estava instalado o porto. Desde então, foi pescador, vendedor de peixe e integrou o Sindicato dos Arrumadores Portuários. Hoje, cinco gerações da família de Pedro vivem na comunidade. "Minha intenção é permanecer aqui até os últimos dias da vida", divulgou (Silva, 2016).

Rossana de Holanda, presidente da Associação de Mulheres do Porto do Capim, declara: "temos que lidar com a ameaça de remoção dos moradores há quase 20 anos. Mas o que nós precisamos mesmo é de serviços públicos básicos. A Prefeitura diz que quer trazer um complexo turístico porque a comunidade polui o rio, mas isso acontece porque não temos saneamento e o esgoto de toda a cidade baixa é jogado no rio. Além disso, não temos posto de saúde, temos que nos deslocar pra longe para sermos atendidos", informou. Para a moradora, o projeto de revitalização pode ser comutado por ações mais simples e econômicas: "tecnicamente, é possível e a identidade da comunidade, seus saberes e suas vivências seriam preservadas valorizadas", defendeu. A presidente, junto com outros habitantes, desempenha um papel de mobilização e consciencialização em intervenção pela comunidade (Silva, 2016).

\subsection{0 alicerce jurídico de defesa da comunidade Porto do Capim}

Com o advento das propostas de Revitalização do Centro Histórico, a comunidade do Porto do Capim procurou negociações com o Poder Público afim de legitimar sua permanência na zona ribeirinha como direito legal, além de explanar a atitude relapsa quanto ao meio ambiente e a preservação e o reconhecimento do Patrimônio Histórico-Cultural Imaterial que o Porto do Capim representa

Segundo o Título VIII, Capítulo III, Seção II da Constituição da República Federativa do Brasil:

Art. 216. Constituem patrimônio cultural brasileiro os bens de natureza material e imaterial, tomados individualmente ou em conjunto, portadores de referência à identidade, à ação, à memória dos diferentes grupos formadores da sociedade brasileira, nos quais se incluem: (Emenda Constitucional no 42/2003)

I - as formas de expressão;

II - os modos de criar, fazer e viver;

III - as criações científicas, artísticas e tecnológicas;

IV - as obras, objetos, documentos, edificações e demais espaços destinados às

manifestações artístico-culturais; 
V - os conjuntos urbanos e sítios de valor histórico, paisagístico, artístico, arqueológico, paleontológico, ecológico e científico

Além do mais, a ameaça de remoção rapidamente mobilizou a comunidade a recorrer ao seu direito à permanência definitiva através do Código Civil Brasileiro, que assegura, através da Lei de Usucapião o direito à posse da terra pela comunidade ribeirinha que habita a região há cerca de 70 (setenta) anos. Como discorre o artigo 191 Constituição Federal:

Art. 191. Aquele que, não sendo proprietário de imóvel rural ou urbano, possua como seu, por cinco anos ininterruptos, sem oposição, área de terra, em zona rural, não superior a cinquenta hectares, tornando-a produtiva por seu trabalho ou de sua família, tendo nela sua moradia, adquirir-lhe-á a propriedade.

Parágrafo único. Os imóveis públicos não serão adquiridos por usucapião.

Segundo o Código Civil Brasileiro em vigor, Livro III, Título III, Capítulo II, Seção I:

Art. 1.238. Aquele que, por quinze anos, sem interrupção, nem oposição, possuir como seu um imóvel, adquire-lhe a propriedade, independentemente de título e boa fé; podendo requerer ao juiz que assim o declare por sentença, a qual servirá de título para o registro no Cartório de Registro de Imóveis.

Parágrafo único. O prazo estabelecido neste artigo reduzir-se-á a dez anos se o possuidor houver estabelecido no imóvel a sua moradia habitual, ou nele realizado obras ou serviços de caráter produtivo.

Art. 1.239. Aquele que, não sendo proprietário de imóvel rural ou urbano, possua como sua, por cinco anos ininterruptos, sem oposição, área de terra em zona rural não superior a cinquenta hectares, tornando-a produtiva por seu trabalho ou de sua família, tendo nela sua moradia, adquirir-Ihe-á a propriedade.

Uma decisão judicial plena e irrevogável está longe de ser alcançada, os projetos de revitalização para a área, continuam parados, mas não extintos. A luta da Comunidade do Porto do Capim pela posse dos terrenos junto às instâncias do poder público executivo, setores do legislativo e judiciário. Ao lado dos moradores existem uma série de movimentos sociais, departamentos universitários, setores do ministério público e pareceres técnicos favoráveis de diversos órgãos da administração pública.

\section{Conclusão}

A luta pela permanência da comunidade do Porto do Capim evidencia o sentimento de pertencimento dos moradores para com a região que remonta cerca de 70 anos de residência de uma população ribeirinha que, devido ao histórico de abandono do poder público desde a construção inicial do espaço urbano são vítimas do descaso com a classe trabalhadora que residiam na área e, auxiliaram no crescimento do núcleo 
econômico da cidade, permitindo sua expansão. Quando o Porto do Capim foi desativado, a comunidade que ficou desempregada assentou-se próximo ao rio Sanhauá, desenvolvendo suas relações culturais, afetivas e de subsistência. Desde a década 1990 o Centro Histórico de João Pessoa vem sendo alvo de processos de gentrificação atrelados aos interesses econômicos imobiliários, idealizados pela nova ordem do capitalismo. Processos de Revitalização do Patrimônio Histórico proposto pelo Poder Público que pautam a remoção da comunidade para outra localidade, uma política tida como 'higienista'. A repercussão midiática foi outro fator a pesar contra a comunidade. Jornais locais que, estrategicamente, publicam matérias com o objetivo de culpar os moradores pela poluição do rio e alertando para os riscos de saúde aos moradores, excluindo a falta de infraestrutura, saneamento básico, serviços de atendimento médico e educação que afligem a comunidade, e também, a narrativa da própria comunidade de permanecer. Além disso, é atribuído à área a fantasia de perigo, violência e hostilidade, e que a área deve ser evitada por precaução pela população de João Pessoa. A comunidade do Porto do Capim vem travando um longo embate com o Governo do Estado da Paraíba e a Prefeitura Municipal para recorrer ao seu direito legal de permanecer às margens do rio, visto a sua importância histórica e econômica e a sua vasta produção cultural que podem ser vistos por toda a região tombada e que caracterizam-se, segundo a Constituição Federal de 1988 e pelo IPHAN, como Patrimônio Histórico-Cultural Imaterial, além do direito constitucional à posse da região garantidos pela Lei de Usucapião, assegurada pela Constituição Federal e o Código Civil Brasileiro. No ano de 2018, o Ministério Público Federal afastou a proposta remoção dos moradores da região que, entretanto, ainda têm que viver com esse 'fantasma' do despejo iminente, pois apesar do reconhecimento de uma série de órgãos ligados ao patrimônio e pareceres técnicos, o total e irrestrito reconhecimento jurídico da posse dos terrenos ainda não foi efetivado. Por sua vez os poderes executivos estadual e municipal ainda não demonstraram interesse quanto à promoção dos direitos básicos que a comunidade carece quanto a infraestrutura, saneamento, saúde e educação. O Porto do Capim, por meio do apoio da Universidade Federal da Paraíba que fornece, através dos jornais que circulam no Campus, a divulgação dos projetos da comunidade, a exemplo, o Projeto Subindo a Ladeira, que tenta reconectar os moradores à cidade novamente, e dos alunos dos cursos de Direito e Arquitetura da UFPB, que fornecem apoio jurídico à Associação dos Moradores do Porto buscando seu reconhecimento como parte essencial da cidade e seu direito legal à permanência e bem-estar social. 


\section{Agradecimentos}

Gostaríamos de agradecer aos estudantes Victor Silva Marques dos Santos, Leonardo José Batista de Alcântara e Arthur Augusto Nunes Alves pelo grande empenho na construção deste capítulo de livro, apesar de não poderem estar presentes no I Congresso Ibero-Americano Nós Propomos a coaautoria e os créditos também são de vocês.

\section{Referências bibliográficas}

Abramo, P. (2016) Padrões de grande imprensa manipulação na grande imprensa. São Paulo: Editora Fundação Perseu.

Arantes, A. (2000) O Espaço da Diferença. Campinas: Editora Papirus.

Bidou-Zachariasen, C. (2006) De volta à cidade: dos processos de gentrificação às políticas de "revitalização" dos centros urbanos. São Paulo. Annablume Editora.

Brasil. (1988) Constituição da República Federativa do Brasil. DF: Senado Federal: Brasília: Centro Gráfico.

Furtado C. R. (2014) Intervenção do Estado e (re)estruturação urbana: Um estudo sobre gentrificação. Cad. Metrop. São Paulo, V(16) no 322 - pp.341-363. Doi: http://dx.doi.org/10.1590/2236-9996.2014-3203

Gonçalves R. C. (2007) Guerra e Açúcares: política e economia da Parayba, 15851630. Bauru: EDUSC.

Koury, M. G. P. (2005) Viver a cidade: um estudo sobre pertença e medos. RBSE, V(4) no. 4, 11. Pag. 148.

Lei $\mathrm{n}^{\circ} 10.257 / 01$ de 10 de julho de 2001. Regulamenta os arts. 182 e 183 da Constituição Federal e estabelece diretrizes gerais da política urbana e dá outras providências.

Lei no 10.406/2002 de 10 de janeiro de 2002. Institui o Código Civil.

Lei 12.343, de 02 de dezembro de 2010. Institui o Plano Nacional de Cultura - PNC, cria o Sistema Nacional de Informações e Indicadores Culturais - SNIIC e dá outras providências.

Lei. no 12.527 de 18 de novembro de 2011. Regula o acesso a informações previsto no inciso XXXIII do art. $5^{\circ}$, no inciso II do $\S 3^{\circ}$ do art. 37 e no $\S 2^{\circ}$ do art. 216 da 
Constituição Federal; altera a Lei no 8.112, de 11 de dezembro de 1990; revoga a Lei

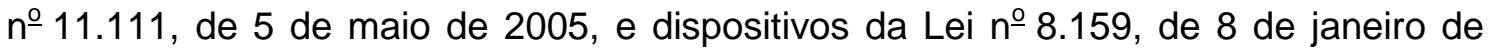
1991; e dá outras providências.

Ley, D. (1996) The New Middle Class and the Remaking of the Central City. Oxford: Oxford University.

Moscovici, S. (1961) La Psychanalyse, son image et son public. In: Revue française de sociologie, 1961, 2-4. pp. 328-330. Doi: www.persee.fr/doc/rfsoc_00352969_1961_num_2_4_5992

Smith, N. (2007) Gentrificação, a fronteira e a reestruturação do espaço urbano. São Paulo: GEOUSP - Espaço e Tempo, no 21, 15-31.

Silva, R. C. N. (2016) revitalização do Centro Histórico de João Pessoa: uma estratégia para a reprodução do capital. (Doutorado em Geografia) - Faculdade de Filosofia, Letras e Ciências Humanas. Universidade de São Paulo. São Paulo.

Silva, A. S. C. (2014) Análise Visual das Transformações na Paisagem do Porto do Capim ao Longo do Século XX e início do Século XXI: uma proposta metodológica para o uso de imagem. Monografia CCEN, UFPB.

Turner, F. J (1893) The Significance of the Frontier in American History. Madison :State Historical Society of Wisconsin. 


\section{Nós Propomos! Taguatinga-DF: pesquisa e experiência com alunos do $2^{\circ}$ ano do Ensino Médio}

RodRIgo CAPELLE Suess ${ }^{1}$

\section{Resumo}

O objetivo deste artigo é divulgar todas as ações realizadas no projeto nós propomos executado no Centro de Ensino Médio Ave Branca- Taguatinga-DF e analisar os seus principais resultados. Uma das principais metas do projeto foi promover uma ativa cidadania territorial e a inovação na educação geográfica, por meio da realização de estudos de caso sobre problemas locais e a apresentação de propostas de resolução. Os alunos tiveram o protagonismo de escolherem os temas, sendo que os mais problematizados estavam relacionados ao transporte e trânsito; educação; infraestrutura e problemas sociais. Após a apresentação dos resultados finais por meio de Pôster científico, foi respondido por 100 alunos um formulário eletrônico do Google. As principais dificuldades encontradas pelos discentes se relacionam a elaboração do banner nas normas científicas, realização de entrevistas e redação científica do texto. Em suas trajetórias escolares, 92\% não fizeram nenhum trabalho igual ou similar. Chama a atenção que $61,2 \%$ não possuem domínio básico de informática. Tivemos uma grande quantidade de respostas positivas quando foram indagados se o trabalho poderia ajudá-los em alguma situação de suas trajetórias escolares e no Ensino Superior. Observa-se que 70,1\% gostariam de participar de projetos similares no Ensino Médio. Acreditamos que por meio desse trabalho os alunos puderam descobrir e conhecer melhor seu espaço vivido e suas proximidades, se posicionando como sujeito da transformação dessas realidades. O projeto reforçou

\footnotetext{
${ }^{1}$ Professor da Carreira do Magistério Público da Secretaria de Estado de Educação do Distrito Federal-SEEDF, Pesquisador do grupo - Ensino, Aprendizagem e Formação de Professores em Geografia da Universidade de Brasília-GEAF/UnB, rodrigo.capellesuess@gmail.com
} 
alguns valores como responsabilidade, solidariedade e cidadania e, no âmbito formal, os incluíram na perspectiva da pesquisa como perspectiva educativa.

Palavras-chave: lugar; mundo vivido; educação pública; professor pesquisador; pesquisa na escola.

\section{Abstract}

The purpose of this article is to disclose all actions carried out in the project "Nós Propomos" executed at the Center of High school Ave Branca - Cemab - TaguatingaDF and analyze the main results. One of the main goals of the project was to promote a active territorial citizenship and innovation in geographic education, by conducting case studies on local problems and the submission of motions for resolutions. The students had the protagonism to choose the themes, the most problematized were related to transportation and transit; education; infrastructure and social problems. After presenting the final results by means of Scientific Poster, were answered by 100 students an electronic form from Google. Among the results we can highlight some. The main difficulties encountered by the students are related to the development of the banner in scientific norms, interviews and scientific writing of the text. In his school trajectories, 92\% did not have any same or similar work. We had a lot of positive responses when we were asked whether the work. could help them in some situation of their school trajectories and in Higher Education. It is observed that $70.1 \%$ would like to participate in similar projects in High School. We believe that through this work the students were able to discover and better know their lived space and its surroundings, positioning itself as the subject of the transformation of those realities. The project reinforced some values such as responsibility, solidarity and citizenship and, in the formal context, included them in the perspective of research as an educational perspective.

Keywords: place; world lived; public education; research teacher; research on school.

\section{Introdução}

Trata-se de uma proposta inspirada no projeto Nós propomos que surgiu em 2011 no Instituto de Geografia e Ordenamento do Território da Universidade de Lisboa, liderado pelo Professor Sérgio Claudino. O mesmo foi idealizado durante a disciplina 
de Geografia para os alunos com idades entre 16 e 17 anos com ênfase em atividades práticas sobre a realidade local. O Projeto, para além de Portugal, difundiu-se por Espanha e pelo Brasil, constituindo, presentemente, o grande projeto ibero-americano de educação geográfica. O Nós propomos tem o objetivo principal de dinamizar o estudo de caso e promover a autonomia dos estudantes orientados pelos eixos de ação como identificação dos problemas locais, execução de trabalho de campo e apresentação de sugestões de intervenção (Projeto Nós Propomos, 2017).

A proposta na esfera do Distrito Federal foi acolhida pelos pesquisadores do Grupo de Pesquisa em Ensino Aprendizagem e Formação de Professores em Geografia GEAF, de coordenação da professora Cristina Leite da Universidade de Brasília UnB, para a sua execução nas escolas públicas do Distrito Federal no ano de 2017. Entre as instituições de ensino regular que compraram a iniciativa, está o Centro de Ensino Médio Ave Branca - Cemab, tendo como propositor o professor Rodrigo Suess que é o responsável por apresentar e estabelecer laços de colaboração entre os demais professores dessa instituição.

Suess (2013) que propõem uma abordagem no ensino voltada a Geografia Humanista, considera que é urgente construir tal perspectiva no âmbito escolar, levando em conta a vida do aluno, o que ele fala, pensa, vive e deseja. No âmbito democrático nota-se um ascendente apelo para a participação pública de diversos sujeitos, pertencentes ao espaço geográfico a ser afetado pelas decisões de Governo e Estado na tomada de decisões referentes ao ordenamento do território, numa perspectiva de governança e de cidadania territorial.

Nesse aspecto, esse projeto justificou-se pela necessidade de refletir e intervir no contexto vivenciado e procurar formas inovadoras de levar o aluno a obter novos conhecimentos, habilidades e valores. Para cumprimento desse propósito, que é de permitir a reflexão, problematização e intervenção em assuntos que tocam o íntimo e o mundo vivido de cada aluno ou grupo de alunos, colocamos em uso o método científico e as interações interdisciplinares entre os campos do saber e os temas transversais (ética, pluralidade cultural, sexualidade, meio ambiente, saúde, trabalho e consumo) (Brasil, 2001).

As propostas foram livre iniciativa dos discentes que tiveram que realizar leituras do mundo em que vivem, pesquisas teóricas e práticas a respeito da temática, proposições que resultem em mudanças possíveis e uma releitura do espaço pesquisado. 
Desse modo, o projeto teve como objetivo promover ativa cidadania territorial e inovação na educação geográfica escolar, por meio da realização de estudos de caso sobre problemas locais e apresentação de propostas de resolução, no âmbito das dinâmicas sociais, culturais e ambientais do território brasileiro e do Distrito Federal, por parte dos alunos do $2^{\circ}$ ano do vespertino do Centro de Ensino Médio Ave Branca Taguatinga. Esses alunos tinham, em média, 16 anos.

Como metas específicas tivemos as seguintes: promover uma ativa cidadania e contribuir para um desenvolvimento sustentável das localidades e das regiões administrativas onde os alunos residem; Aproximar as esferas do poder e lideranças comunitárias locais através da participação da comunidade escolar do Cemab em eventos conjuntos, em especial, os alunos do $2^{\circ}$ ano do Ensino Médio e seus professores; Promover abordagens metodológicas inovadoras no âmbito do ensino da Geografia e áreas afins, com intuito de despertar a investigação como uma ferramenta de estudo; Disseminar a pesquisa como forma de produção de conhecimentos na escola, em especial o estudo de caso; Possibilitar o desenvolvimento da autonomia intelectual e o despertar do sentido crítico-reflexivo nos alunos por meio de atividades interventivas e desejo de mudança no local em que vivem; Mobilizar alunos e professores para a utilização de tecnologias de informação em estudos de âmbito prático, em especial, o Google Earth; Sensibilizar para os problemas territoriais locais e motivar para a elaboração de propostas de intervenção local; Estimular a construção de parcerias interdisciplinares entre os atores escolares e além muros da escola. Sendo assim, o objetivo desse artigo é divulgar todas as ações realizadas no projeto nós propomos executado no Centro de Ensino Médio Ave Branca - Taguatinga-DF no ano de 2017 e analisar os principais resultados.

Nesse sentido, após expor os caminhos do desenvolvimento da pesquisa, buscou-se apresentar o contexto geográfico e pedagógico que envolveu esse projeto, exibindo informações a respeito da Região Administrativa de Taguatinga, do Centro de Ensino Médio Ave Branca e tecendo relações com o currículo oficial. Por fim, são analisados os principais resultados do projeto e feito os devidos encaminhamentos.

\section{Metodologia}

A aplicação desse projeto aconteceu no Centro de Ensino Médio Ave Branca para os alunos do $2^{\circ}$ ano do turno vespertino, trata-se de sete (7) turmas, com média de 40 alunos cada. Identifica-se que esse público alvo pode ser caracterizado por alunos de diversas condições sociais, em especial, de renda baixa e média. A estrutura física 
principal utilizada foi o espaço da escola, e suplementarmente, outros espaços como órgãos públicos - Supremo Tribunal de Justiça e Congresso Nacional. No espaço escolar se fez uso das salas de aulas, do auditório e do espaço entre salas.

A participação dos discentes visou qualificar parte da nota em Geografia e Língua Portuguesa no $3^{\circ}$ e $4^{\circ}$ bimestre de 2017. Caminhou-se em dois eixos de trabalho e avaliação, um que objetivou levantar informações básicas e se constituir em fase formativa - avaliação diagnóstica, aplicação de questionários, apresentação do projeto, realização de mesas de ideias e debates - e outro eixo de trabalho e avaliação que intentou a produção de trabalhos, relatórios, pôsters científicos, materiais didáticos, apresentações orais e debates sobre essa produção.

Entre as principais ações executadas se encontram:

- Apresentação do projeto para os alunos participantes, organizar os grupos por sala e aplicar ficha de avaliação diagnóstica e de reflexão sobre participação cidadã e problemas locais (31/07/2017 a 04/08/2017);

- Definição de datas para cada grupo delimitar o tema de pesquisa, para levantarem o contexto e problema a ser pesquisado - material escrito e fotografias;

- Organização e participação de colóquio com representantes do poder público: Deputado Distrital Professor Israel; Deputado Distrital Reginaldo Veras; Administrador Regional de Taguatinga Marlon Costa e Professor Dr. Cristina Costa Leite (UnB) $(25 / 08 / 2017)$.

- Participação da Escola na Câmara (35 alunos) e do programa de TV Câmara Ligada a respeito da de partidos políticos participação da juventude na política (42 alunos) (14 e 15/09/2017).

- Organização e participação de colóquio com lideranças vinculadas a movimentos sociais: Hugo de Carvalho Sobrinho (Coord.) - Doutorando em Geografia - UnB; Erika Kokay - Deputada Federal (PT-DF); Alcinéia de Souza Silva - Mestranda em Geografia - UnB; Raquel Gomes Silva - Vice-presid. da UESDF - União dos Estudantes Secundaristas do DF; Alcineia de Souza Silva (Coord.) Alcinéia de Souza Silva Mestranda em Geografia - UnB; Márcia de Alencar - Sec. Ad. de Políticas para as Mulheres, Igualdade Racial e Direitos Humanos; Wanda Marques Araújo - União Libertária de Travestis e Mulheres Transexuais - ULTRA; Lívia Reis Cairus Bezerra (DCE-UNB); Jacira da Silva - coord. do Movimento Negro Unificado e entre outras lideranças. 
- Visita técnica ao Supremo Tribunal de Justiça com 45 alunos.

- Uso da plataforma moodle e grupos de Whatsapp para comunicação entre os grupos e o professor.

- Orientações acadêmicas aos grupos pelo professor;

- Entrega de relatórios, trabalhos escritos, pôster científicos;

- Divulgação dos resultados finais, por meio de apresentação oral e exposição dos pôsteres científicos, para a comunidade escolar por meio de culminância do projeto.

Essas etapas foram avaliadas em uma proposta formativa que levou em conta:

1. Relevância da temática/problema para a inovação e cidadania na educação geográfica;

2. Organização e coerência do projeto/proposta;

3. Inovação, criatividade, adequabilidade e exequibilidade do projeto;

4. Rigor científico e empenho no projeto;

5. Interesse e relevância das propostas de intervenção;

6. Correção linguística e clareza da redação dos trabalhos escritos e do pôster;

7. Dificuldade, capacidade em lidar com desafios e superação

8. interação entre os membros do grupos, companheirismo, amizade e coletividade.

Considera-se que essas informações sobre os desdobramentos do projeto são relevantes na análise do conteúdo apresentado no produto final - trabalho escrito e pôsteres científicos. Dessa forma, esse artigo se caracteriza pela pesquisa qualitativa, com uso da investigação bibliográfica, documental, análise de conteúdo e aplicação de formulários eletrônicos. Os pôsteres e o trabalho escrito se constituíram em nossa principal fonte de investigação por meio da análise de seus conteúdos. Complementar a essa análise temos a reflexão do formulário eletrônico do Google que foi respondido, voluntariamente, por cem (100) alunos participantes após a apresentação final, isto é, na última quinzena do mês de dezembro de 2017. Nesse formulário foram indagadas questões relacionadas ao perfil; hábitos de estudos; habilidades com informática e ABNT; dificuldades e desafios para elaboração do projeto; conhecimentos e habilidades requeridas para elaboração das propostas; domínio da linguagem acadêmica; contribuição da iniciativa para a trajetória escolar e para a comunidade 
local e entre outros apontamentos que foram apresentados e analisados na seção 3. Resultados e discussões.

\section{Contexto geográfico e pedagógico}

\section{Taguatinga}

Taguatinga soma-se a outras 30 regiões administrativas do Distrito Federal. Trata-se de um dos aglomerados urbanos mais importantes do Centro-Oeste. Sua população é de 221.909 habitantes, atrás apenas de Ceilândia no Distrito Federal - 489.735 habitantes (Pesquisa Distrital por Amostra de domicílios 2010/2011). Destaca-se por ser uma cidade que concentra população e serviços, sua densidade demográfica é de 1.828,82 hab. $/ \mathrm{km}^{2}$, seu crescimento populacional é superior a $4 \%$ ao ano e várias pessoas a procuram diariamente pela sua oferta de empregos, comércios e serviços diversificados e especializados (Codeplan, 2013).

A cidade parece ter uma dinâmica própria e bem independente, o que lhe da o posto de uma segunda centralidade no Distrito Federal, isto é, um novo centro ou segundo centro. Sua população apresenta um grau de independência maior do Plano Piloto em relação à oferta de atividades comerciais, mercado de trabalho, serviços públicos, cultura e lazer do que outras áreas na região. Isto representa que, exceto cultura e lazer (79\%), as demais categorias são realizadas em expressiva maioria (97\%) na própria região. Outro aspecto que chama atenção é a renda domiciliar média que é de $R \$ 5.138,58$, sendo que, $41,54 \%$ dos responsáveis pelos domicílios são empregados com carteira de trabalho assinada, 33,41\%, trabalhadores autônomos e 19,52\% são funcionários público/militar (Codeplan, 2013).

Expressiva parte das pessoas dessa R.A está ocupada no Comércio (28,38\%), logo atrás as mesmas estão dedicadas a Administração pública federal e distrital (22,21\%) e nos Serviços Gerais (20,78\%). Entre os residentes $43,95 \%$ trabalham na própria RA, $30,7 \%$ no Plano Piloso e 6,37\% em outros locais. Chama atenção o ganho significativo em relação aos estudos em Taguatinga, isto quer dizer que, em 2013 o percentual da população com nível superior, no âmbito da graduação e da pós-graduação (especialziação, mestrado e doutorado) vêm aumentando, atingindo 18,24\% em 2013, e por outro lado, o número de analfabetos vem caindo, com 1,47\% também em 2013 (Codeplan, 2013). 
Embora apresente malha urbana bem consolidada, Taguatinga ainda apresenta perspectivas de crescimento, em especial, o vertical. O que implica grandes responsabilidades ao poder público e aos gestores do espaço urbano em pensarem em obras e ações que permitam desafogar e dar maior mobilidade para esse importante entroncamento de fixos e fluxos no Distrito Federal. De todo modo a cidade também apresenta problemas urbanos brasileiros típicos de uma área metropolitana em expansão. Isto significa que ainda existe um déficit habitacional, carência de uma infraestrutura urbana básica para toda população, acentuados índices de violência e desigualdade social, o centro vem se deteriorizando como local de moradia, além do acentuado adensamento populacional igualmente acarretar problemas ambientais, dificuldades com o transporte e mobilidade.

\section{Centro de Ensino Médio Ave Branca - CEMAB}

O Centro de Ensino Médio Ave Branca - CEMAB, é uma instituição de ensino pública ligada a Coordenação Regional de Ensino de Taguatinga - CRET e mantida pela Secretaria de Estado de Educação do Distrito Federal - SEEDF, reconhecida por ser uma das escolas mais tradicionais dessa unidade federativa e pelas lutas travadas em nome da educação no decorrer da história do DF.

Fundada em 1961 esse espaço educativo foi responsável por formar diversas gerações, atravessou importantes momentos históricos, foi palco de lutas e resistências, viu suas instalações crescerem e se desgastarem pela ação do tempo. Já foi Ginásio de Taguatinga, Colégio de Taguatinga, Centro Educacional Ave Branca (Ceab) e, finalmente, Centro de Ensino Médio Ave Branca. A mesma já recebeu Curso de Formação de Professores e Escola de Aplicação. O seu nome carrega a mais forte marca de Taguatinga, a Ave Branca, símbolo maior desse povo (Distrito Federal, 2016).

Embora esteja localizada no centro da cidade de Taguatinga, alardeada por uma malha urbana consolidada e densificada, composta por áreas residenciais de classe média, diversos comércios e intenso fluxo de pessoas, a mesma engloba uma diversidade de alunos oriundos não apenas dessa centralidade, mas também de áreas periféricas de Taguatinga e outras regiões administrativas como Ceilândia, Samambaia, Riacho Fundo, Recanto das Emas e até mesmo do entorno do DF, como Santo Antônio do Descoberto e Águas Lindas de Goiás. Sendo assim, embora receba alunos de classe média também acolhe alunos que possui diversas vulnerabilidades sociais (Distrito Federal, 2016). 
A escola destaca-se igualmente por outras razões. Tendo como base os dados da clientela atendida pelo Programa Nacional de Alimentação Escolar (PNAE) - Censo Escolar o CEMAB possui ao todo 2.602 alunos matriculados nos turnos matutino, vespertino e noturno, deste montante 2.301 estão vinculados ao Ensino Médio. São 859 alunos matriculados no $1^{\circ}$ ano do EM, 819 no $2^{\circ}$ ano e 758 no $3^{\circ}$ ano (Fnde, 2017). Para atendimento desse público essa instituição conta com uma estrutura física que abarca 28 salas de aulas equipadas com recursos audiovisuais, laboratório de informática, sala de audiovisual, auditório, biblioteca e entre outras repartições, estando disponíveis 225 servidores para o seu bom funcionamento. Nesse cenário, o Cemab se sobressai por ser a 3ำ maior escola da rede pública do Distrito Federal em relação ao número de alunos, ficando atrás apenas do CEM 03 de Ceilândia e o CED 01 de Planaltina. No contexto de Taguatinga, a mesma é a maior escolar em número de alunos, estando a frente de escolas como CED 02 de Taguatinga e Cemeit (Quadro 1) (Distrito Federal, 2016; Fnde, 2017).

Quadro 1- As maiores escolas da rede pública em relação ao número de alunos do Distrito Federal e de Taguatinga.

\begin{tabular}{|c|c|}
\hline \multicolumn{2}{|c|}{$\begin{array}{l}\text { As } 3 \text { maiores escolas da rede pública do Distrito Federal (número } \\
\text { de alunos) }\end{array}$} \\
\hline CEM 03 DE CEILÂNDIA & 2.833 \\
\hline CED 01 DE PLANALTINA & 2647 \\
\hline CEMAB & 2.602 \\
\hline \multicolumn{2}{|c|}{$\begin{array}{l}\text { As } 3 \text { Maiores Escolas da rede pública de Taguatinga } \\
\text { (número de alunos) }\end{array}$} \\
\hline CEMAB & 2.602 \\
\hline CED 02 DE TAGUATINGA & 2.522 \\
\hline CEMEIT & 2.248 \\
\hline $\begin{array}{l}\text { Total de alunos vinculados a Secretaria de Estado de } \\
\text { Educação do Distrito Federal (SEEDF): }\end{array}$ & 482.313 \\
\hline
\end{tabular}

Fonte: FNDE, 2017. Elaboração: Rodrigo Suess, 2017.

Dados de 2015 apontam que os indicadores de aprovação são de 81,1\%, 18,7\% de reprovação e $0,2 \%$ de abandono. O publico alvo desse projeto, o $2^{\circ}$ ano do Ensino Médio, apresenta as respectivas estatísticas $84,2 \% ; 15,5 \%$ e 0,3\% e distorção idade série de $23 \%$, isto é, alunos que estão em atraso escolar de 2 anos ou mais (Qedu, 2017). Mesmo assim, o colégio é um dos que mais inscreve alunos no Programa de Avaliação Seriada - PAS da Universidade de Brasília - UnB e apresenta significativas aprovações nas principais instituições de ensino superior públicas e privadas do Distrito Federal. Trata-se de uma escola disputada da região, devido a sua boa reputação e localização, o que leva, inclusive, em época de matrícula alguns pais acamparem na escola na expectativa de conseguir uma vaga, embora, essa questão 
tenha passado para responsabilidade de um telecentro administrado pela SEEDF (Distrito Federal, 2016).

Deve-se destacar as relações afetivas e simbólicas que o Centro de Ensino Médio Ave Branca acaba favorecendo e desenvolvendo entre os seus entes, essa certamente não poderia ser quantificada, nem mensurada. Contudo, o clima da escola parece favorecer uma relação harmônica, conforme mencionado em seu Projeto PolíticoPedagógico - PPP e vivenciado pelos profissionais que ali trabalham:

A relação harmônica existente entre os integrantes da comunidade escolar faz do CEMAB uma escola acolhedora e querida por todos. Não é rara a visita de estudantes egressos, que fazem questão de demonstrar apreço por esta instituição. Muitos se tornaram advogados, políticos, médicos, juristas, entre outros; inclusive aqueles, que foram incorporados ao quadro de profissionais da escola, após a formação superior (Distrito Federal, 2016, p. 6).

A mesma ainda é reconhecida por possuir bons professores, estrutura física considerável e por ser uma escola relativamente segura, embora não esteja a salvo de um dos principais problemas das escolas brasileiras, que é o consumo de drogas ilícitas por parte de seu alunado.

\section{Currículo e conteúdo}

Na perspectiva dos Parâmetros Curriculares Nacionais do Ensino Médio a respeito das competências e habilidade a serem desenvolvidas em Geografia esse projeto visou:

\footnotetext{
- Reconhecer os fenômenos espaciais a partir da seleção, comparação e interpretação, identificando as singularidades ou generalidades de cada lugar, paisagem ou território.

- Reconhecer na aparência das formas visíveis e concretas do espaço geográfico atual a sua essência, ou seja, os processos históricos, construídos em diferentes tempos, e os processos contemporâneos, conjunto de práticas dos diferentes agentes, que resultam em profundas mudanças na organização e no conteúdo do espaço.

- Compreender e aplicar no cotidiano os conceitos básicos da Geografia (Brasil, 2000, p. 35).

... e, principalmente: "Identificar, analisar e avaliar o impacto das transformações naturais, sociais, econômicas, culturais e políticas no seu 'lugar-mundo', comparando, analisando e sintetizando a densidade das relações e transformações que tornam concreta e vivida a realidade" (Brasil, 2000, p. 35) .
}

No que se refere aos objetivos exposto no Currículo em Movimento da Secretaria de Educação do Distrito Federal para a área de ciências humanas esse projeto se aproxima de: 
a) Possibilitar que o estudante entenda a sociedade em que vive como fruto da ação humana, que se faz e refaz num processo dotado de historicidade.

b) Permitir ao estudante compreender o espaço ocupado pela sociedade como espaço construído e modificado a partir de suas interferências, entendendo-se também como produto dessas relações.

e) Propiciar ao estudante o desenvolvimento da consciência crítica sobre conhecimento, razão e realidade sócio-histórica, cultural e política (Distrito Federal, 2013, p. 59)

Em relação ao conteúdo exposto nesse mesmo documento pode-se dizer que esse projeto se aproxima também dos conteúdos: Método científico; Formação e evolução do espaço brasileiro; Caracterização ambiental do Brasil; Questão ambiental brasileira; Indicadores sociais da realidade brasileira; Espaço rural brasileiro; Espaço urbano brasileiro; Diversidades econômicas, étnicas, religiosas e culturais do Brasil; Estratificação e desigualdade social; Espaço socioeconômico brasileiro e, principalmente, Geografia do Distrito Federal e entorno (Distrito Federal, 2013). Sendo assim, se cabe agora analisar os principais resultados desse projeto.

\section{Resultados e discussões}

Os temas mais problematizados pelos alunos estavam relacionados ao transporte e trânsito; educação; infraestrutura e problemas sociais (Figura 1) de Taguatinga, embora algumas Regiões Administrativas de influência de Taguatinga tenha sido lembradas - Águas Claras, Samambaia, Ceilândia e Recanto das Emas. Contudo, deve-se destacar a multiplicidade de temas, especialmente aqueles relacionados ao espaço urbano: lixo e limpeza da cidade, segurança, reforma de escolas e hospitais, construção de ciclovias, espaços culturais, infraestrutura, orfanato, problemas urbanos causados por empresas, obras de infraestrutura e escoamento pluvial, linhas de metrô, ação social em favor dos moradores de rua, buraco nas ruas, inclusão social, saneamento básico, violência contra a mulher, parques ecológicos e revitalização de praças. A grave crise hídrica que o Distrito Federal vêm passando também foi objeto de debate (Figura 2).

Foram respondidas algumas questões por 100 alunos, após a realização dos trabalhos por meio de formulário eletrônico do Google. Entre os resultados podemos destacar alguns. As principais dificuldades encontradas pelos discentes se relacionam a realização do banner, entrevistas, escrita do trabalho, tempo para conclusão do trabalho, delimitação do tema, proposição de soluções, as normas técnicas, dificuldade de mobilização ao local de estudo, recepção de alguns entrevistados e 
órgãos públicos, dificuldades em trabalhar em grupo. Alguns alunos mencionaram que não tiveram nenhum tipo de dificuldade.

Em suas trajetórias escolares, 92\% dos alunos não fizeram nenhum trabalho igual ou similar ao Nós Propomos. Entre as habilidades prévias exigidas para elaboração dos trabalhos, foram destacados, conhecimento a respeito do tema, da cidade e das leis, empenho, concentração, zelo, atitude, raciocínio lógico, apropriação das normas da ABNT e formatação do trabalho, capacidade de escrita e redação, conhecimentos de informática, linguagem formal, elaboração de gráficos, liderança para trabalhar em grupo e conhecimento sobre leis.

Figura 1. Proporção de temas escolhidos pelos grupos

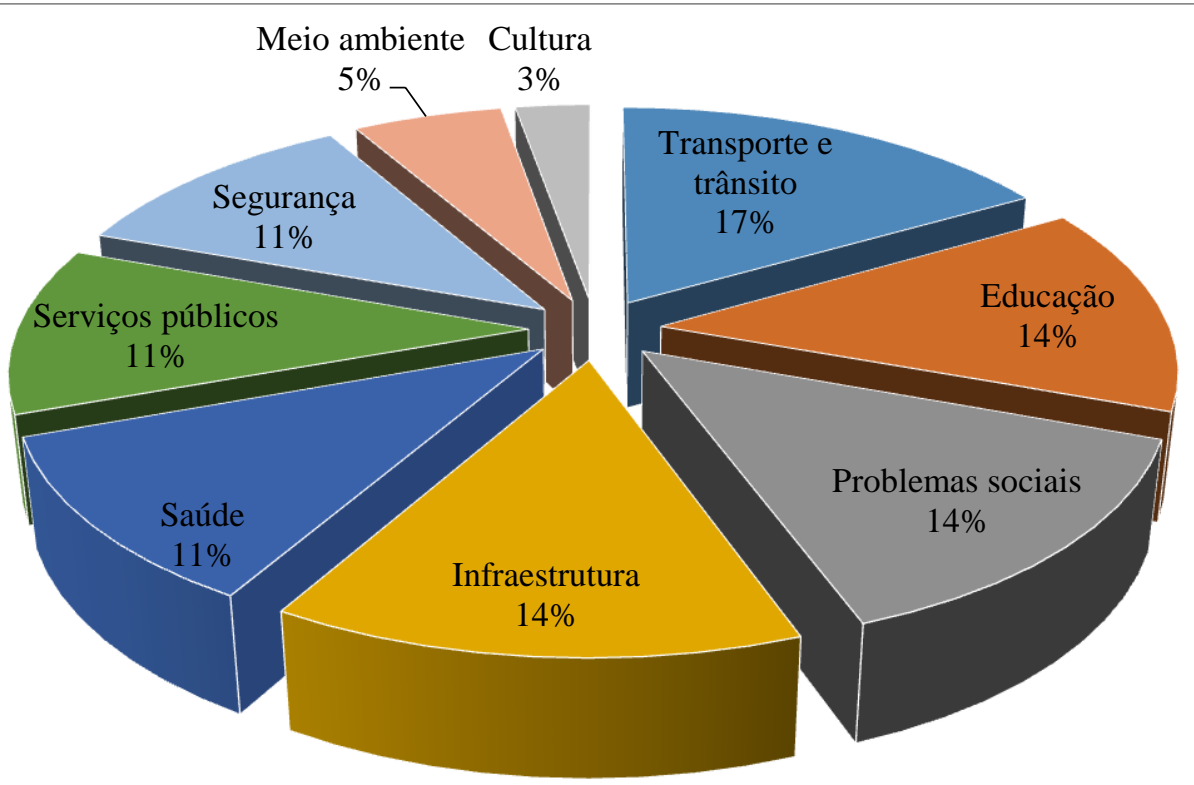

Elaboração: Autor, 2018; Fonte: Projeto Nós Propomos! Taguatinga, 2018. 
Figura 2 - Apresentação de trabalho no Centro de Ensino Médio Ave Branca

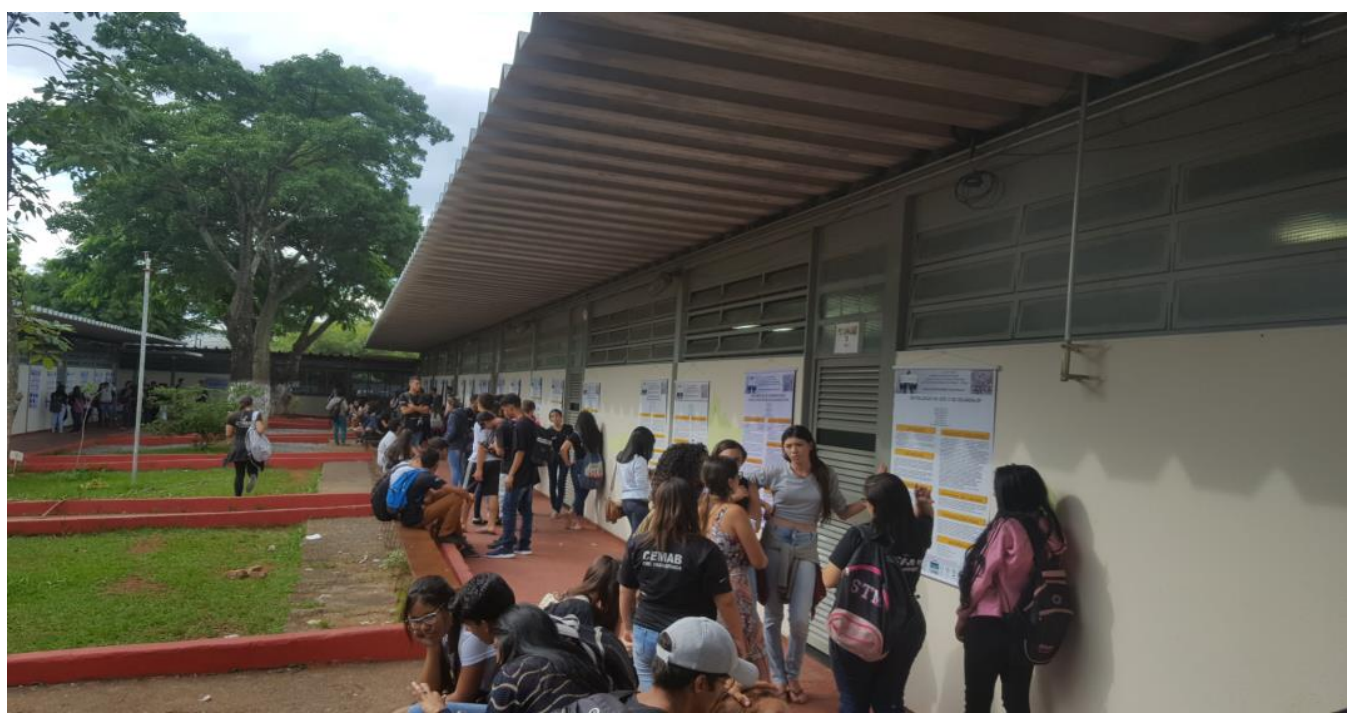

Fonte: Autor, 2017.

Questionados sobre as dificuldades em adaptar o trabalho em uma linguagem científica uma parte destacou que não tiveram muitos problemas, contudo, é significativo a quantidade de alunos que ressaltaram os desafios para escolherem as palavras certas, ordenar as ideias, fechar o pensamento, seguir as normas técnicas, apresentar e introduzir o tema, metodologia, delimitação do tamanho do texto, analisar as entrevistas e gráficos e manejo do Google Earth. Deve-se ressaltar, como mencionou alguns alunos, que trata-se de uma abordagem nova para os alunos, uma vez que os mesmos têm pouco contato com ela na educação básica. Nota-se que $61,2 \%$ não possuem domínio de informática, especialmente, em formatar o banner e o trabalho escrito, criar gráficos e tabelas. Associado a isso, 68,4\% afirmaram não possuir noções técnicas de formatação e de ABNT. Tivemos uma grande quantidade de respostas positivas quando foram indagados se o trabalho poderia ajudá-los em alguma situação de suas trajetórias escolares e no Ensino Superior.

Entre os destaques, estão a contribuição para a formação acadêmica, elaboração de pesquisas científicas e trabalhos acadêmicos, aprendizagem sobre informática, construção de novos conhecimentos sobre a cidade, na percepção das coisas e no desenvolvimento de um senso crítico e solidariedade com os outros. Pode-se indicar algumas respostas na íntegra a respeito da questão: "Vai contribuir na nossa humanidade, a vermos o mundo com outros olhos" (Aluno A); "Sim, pois depois desse trabalho comecei a pensar diferente. Me ajudou em partes na formação do caráter" (Aluno B); "Nos ajudou a enxergar e encontrar soluções para os problemas urbanos" (Aluno C); "Contribuição de conhecimento, conhecer sobre os problemas locais é importante" (Aluno D). 
Os alunos mencionaram que o trabalho pode contribuir para a comunidade escolar ao debaterem os problemas vividos e ao estudar como transformar essa realidade. "Aprender a se preocupar com a situação do Brasil" (Aluno C); "Que podemos ter a oportunidade de ter voz" (Aluno F); "Aprender lutar por um lugar melhor" (Aluno G); "Sair da comodidade e buscar soluções. Debater ideias, conhecer melhor o lugar que moramos, as formas de intervenção existentes no nosso governo" (Aluno H); "Para nós que somos estudantes, a maior contribuição foi termos ajudado pessoas com necessidades e podemos servir de exemplo" (Aluno L); "Esperamos que nossas sugestões sejam atendidas, assim a comunidade será beneficiada" (Aluno A). "Para mim, foi me induzir a ser um ser pensante, fazer avaliações, pesquisar ou seja, buscar maiores informações e refletir sobre. Para a comunidade escolar, pode se dizer que maior conhecimento da área em que habitam, e ver que alguns dos problemas puderam ser solucionados" (Aluno $\mathrm{Y}$ ).

Nota-se que após a realização dos trabalhos muitos alunos, pais e entrevistados elogiaram a proposta. Observa-se que $70,1 \%$ gostariam de participar de projetos similares no Ensino Médio. Como professor pude ver a euforia de muitos grupos a respeito dos trabalhos realizados, mesmo daqueles que de inicio não se mostraram muito interessados e também reforçar em minhas convicções a importâncias de trabalhos como esse em Geografia. Acreditamos que por meio desse trabalho os alunos puderam descobrir e conhecerem melhor seu espaço vivido e suas proximidades, além se posicionarem como sujeito da transformação dessas realidades. O projeto reforçou alguns valores como responsabilidade, solidariedade e cidadania e no âmbito formal os incluíram na perspetiva da pesquisa e do estudo de caso com instrumento de intervenção.

\section{Considerações finais}

Os principais resultados do projeto demonstram as dificuldades e desafios que esse tipo de trabalho encontra na educação básica. Trata-se de uma perspectiva nova, pouco difundida e ainda pouco assimilada na escola em consequência a uma um modelo de escola que ainda não assumiu a educação científica como fundamento basilar. Dessa forma, os alunos apresentaram dificuldades associados ao ineditismo da ação ao manejo acadêmico da elaboração do pôster científico, realização de entrevistas e a redação científica do texto. Nota-se que embora esteja inseridos na era digital, no qual o smartfone é o principal instrumento dessa inserção, a maioria possui dificuldade em informática. 
Eles reconhecem que esse tipo de ação é importante para escola cumprir o seu papel social, para aproximar a escola da comunidade local e, principalmente, para desenvolver habilidades e competências que serão aproveitadas mais adiante em sua vida escolar, especialmente, no ensino superior e no desempenho de alguma atividade profissional. Assim, mesmo tendo que enfrentar diversos percalços, parte expressiva dos alunos demonstrou o interesse em participar de projetos similares no Ensino Médio.

O objetivo do projeto foi cumprido com êxito. Diversas situações vividas pelos alunos foram identificadas e problematizadas, o estudo de caso e a investigação científica foi a base principal utilizada para o reconhecimento do problema e proposição de soluções. Essa atividade final associada a um conjunto de atividades formativas desenvolvidas desde o início do segundo semestre de 2017 permitiu uma sensibilização, apropriação e ressignificação dos conhecimentos acumulados aplicados a resolução de um problema local. Nesse sentido, acreditamos que o trabalho contribuiu para promover uma ativa cidadania territorial, possibilitou um olhar sustentável, humanista, crítico e reflexivo a respeito de suas localidades, permitindo a construção de uma autonomia intelectual, um dos primeiros passos para a constituição de um projeto de educação que tenha como base a educação científica, como defende Demo (2014). A iniciativa reforçou alguns valores como responsabilidade, solidariedade e cidadania. Sendo assim, o projeto se constituiu em uma importante inovação na educação, especialmente, na educação geográfica escolar que deve refletir na vida escolar de todos os envolvidos.

Por isso, deve-se ressaltar que o projeto possui um grande potencial para ser aplicado em outras localidades, em especial no Distrito Federal, pois a sua essência é identificar problemas locais e propor soluções, não se restringindo a um espaço ou contexto específico. Sendo assim, o foco desse projeto foi a valorização do lugar, pois acreditamos que ele contribui para um processo de ensino-aprendizagem que conduz o aluno a compreender melhor a si mesmo e o mundo em que vive, levando em conta os aspectos cognitivos, afetivos, físicos, éticos e estéticos, que possam interferir no exercício da cidadania.

Acreditamos que a ação pedagógica contribuiu para que os discentes se reconheçam como sujeitos, com possibilidade concreta de atuação no espaço por meio do lugar, capazes de compreender as aparências, ausências e múltiplas manifestações dos fenômenos geográficos. Trata-se de uma inovação da educação geográfica com possibilidades interdisciplinares que grande potencial de disseminação. 


\section{Referências}

Brasil (2000). Ministério da Educação. Parâmetros Curriculares nacionais: Ensino médio - Parte IV Ciências Humanas e suas tecnologias. Brasília: MEC.

Brasil (2001). Secretaria de Educação Fundamental. Parâmetros Curriculares Nacionais: terceiro e quarto ciclos: apresentação dos temas transversais. Brasília: MEC/SEF, $436 \mathrm{pp}$.

Codeplan - Companhia de Planejamento do Distrito Federal (2013). Pesquisa Distrital por Amostra de domicílios - PDAD - 2013 - Taguatinga - 2013. Brasília: CODEPLAN/SEPLAN/GDF.

Distrito Federal, Governo do (2013). Secretaria de Estado de Educação do Distrito Federal. Currículo em Movimento da Educação Básica: Ensino Médio. Brasília: SEEDF.

Distrito Federal, Governo do (2016). Secretaria de Estado de Educação do Distrito Federal. Centro de Ensino Ave Branca. Projeto político-pedagógico. Taguatinga: SEEDF.

Demo, P. (2014). Educação científica. Revista Brasileira de iniciação Científica, V(1), $\mathrm{N}(1), 1-19$.

Fnde - Fundo Nacional de Desenvolvimento da Educação (2017). Programa Nacional de Alimentação Escolar - Censo Escolar. Disponível em: http://www.fnde.gov.br/pnaeweb/publico/relatorioDelegacaoEstadual.do

Projeto Nós Propomos (2017). O Projeto. Disponível em: nospropomos2016.weebly.com/o-projeto.html

Qedu (2017). Centro de Ensino Médio Ave Branca. Disponível em: www.qedu.org.br/escola/245003-cem-ave-branca/sobre

SUESS, R. C. (2016). Geografia Humanista e ensino-aprendizagem: perspectivas em Formosa-GO. 2016, 171 f. (Dissertação de Mestrado). Departamento de Geografia, Universidade de Brasília. 


\title{
Extensão e participação social: Nós Propomos!
}

\author{
JoÃo APARECIDO BAZZOLI ${ }^{1}$ \\ MARIA DA VITORIA COSTA E SILVA²
}

Tatiana de Oliveira Sousa ${ }^{3}$

\section{Resumo}

Este estudo objetivou compreender a extensão universitária como meio de instigar estudantes do ensino médio a participação social. Buscou-se despertar nos estudantes das escolas públicas de ensino médio a cidadania a partir da identificação de problemas urbanos e proposições de resoluções para estes problemas. A metodologia qualitativa aplicada nesta pesquisa partiu da análise das ações e dos resultados das atividades do projeto (definida a partir do nivelamento dos universitários (graduandos e pós-graduandos da Universidade Federal do Tocantins) e dos alunos das escolas de ensino médio, para a ambientação dos pontos estruturais da proposta de extensão, que se desenvolvem com o auxílio de um planejamento anual de atividades, conforme orientações registradas em manual próprio). Nós propomos realizadas pelos estudantes de seis escolas estaduais em Palmas durante os meses de fevereiro a novembro de 2017. Este estudo constatou que o mecanismo não formal de extensão se apresenta como um modo alternativo adequado e efetivo de inserção dos estudantes secundários nos debates sobre a cidade. Concluiu-se que a extensão universitária possibilita experimentar novas ferramentas participativas não formais adequadas para a inserção de estudantes secundaristas na participação social.

Palavras-Chave: Cidadania; Gestão Participativa; Participação Social; Nós Propomos!; Extensão universitária.

\footnotetext{
${ }_{1}^{1}$ Professor Doutor, Universidade Federal do Tocantins - UFT, jbazzoli@uft.edu.br.

${ }^{2}$ Aluna Especial do Doutorado do Programa de Pós-Graduação em Desenvolvimento Regional da Universidade Federal do Tocantins - UFT, mavitcs@gmail.com.

2 Mestranda do Programa de Pós-Graduação em Desenvolvimento Regional da Universidade Federal do Tocantins - UFT, tatyanaoliveirasousa@gmail.com.
} 


\section{Abstract}

This study aimed to understand university extension as a means to instigate high school students to social participation. It was sought to awaken in the students of public high schools the citizenship from the identification of urban problems and propositions of resolutions for these problems. The qualitative methodology applied in this research was based on the analysis of the actions and results of the project activities (defined from the leveling of the university students (undergraduates and postgraduates of the Federal University of Tocantins) and the students of the secondary schools for the setting of the structural points of the extension proposal, which are developed with the aid of an annual planning of activities, according to guidelines registered in own manual. Students from six state schools in Palmas during the months of February to November 2017. This study found that the non-formal extension mechanism is presented as an appropriate and effective alternative way for secondary students to the city. It was concluded that university extension allows to try new non-formal participatory tools suitable for the insertion of secondary students in social participation.

Keyword: Citizenship; Participative management; Social Participation; We propose; University Extension.

\section{Introdução}

A sociedade do século XXI enfrenta desafios complexos e inéditos. Segundo estudos desenvolvidos por Bauman e Bordoni (2016) esta crise vivenciada em nossos tempos tem as suas raízes no passado. Por este motivo, a população está sendo chamada a acompanhar, com atenção, as crises política e econômica que abalam nossas estruturas democráticas com o propósito de intervir para a melhoria da educação fundamental e média do País, pilar central de sustentação na busca da emancipação popular.

Considerando o cenário e o acirramento do embate entre a força "hegemônica" centralizadora do poder econômico neoliberal em âmbito global e a "contra hegemônica" representada pela construção democrática centrada no reconhecimento recíproco entre identidades e culturas distintas locais (Santos, 2002, p. 74), espera-se encontrar o ponto de equilíbrio, que venha, a partir do consenso criativo e da preservação dos direitos fundamentais constitucionais, para garantir a dignidade humana e a sustentabilidade como gênero, nos termos lecionados por Habermas (2012).

Neste viés, as Universidades assumem o protagonismo na articulação de plataformas de conhecimentos que intensifiquem práticas democráticas para o fomento e a inserção da 
população nas discussões, planejamento e na execução de políticas sociais na gestão das cidades brasileiras.

Assim, este artigo objetiva compreender a importância da extensão universitária como alternativa para instigar a participação social na cidade de Palmas - TO, por meio do enfrentamento e da provocação ao amplo debate a respeito deste tema árido, sedimentado no desenvolvimento do Projeto de extensão Nós Propomos pela Universidade Federal do Tocantins.

O caminho metodológico para o desenvolvimento deste trabalho perpassou pela pesquisa empírica, com a análise da experiência do citado Projeto de extensão, que tem por finalidade despertar nos jovens estudantes das escolas de ensino médio a participação democrática. Este tipo de ação oportuniza que esses agentes democráticos sejam motivados à elaboração de propostas de resoluções de problemas urbanos e, ao final de cada ano seletivo, compartilhem estas propostas em seminário e nas instâncias comunitárias impactadas (Bazzoli, 2017).

Nesta pesquisa-ação desenvolvida aplicou-se a metodologia qualitativa, que partiu da análise dos estudos de campo e dos resultados das atividades realizadas pelos jovens estudantes do ensino médio em seis escolas da rede pública estadual do município de Palmas - TO, durante o ano letivo de 2017.

Desta maneira o relato de experiência descrito neste texto consiste numa amostra da extensão universitária no Tocantins que foi implementado a partir de novas ferramentas participativas não formais com o fim de motivar a inserção dos jovens estudantes secundaristas nos debates sobre governança, gestão pública e planejamento urbano sustentável.

\section{0 papel da extensão universitária no século XXI}

Segundo Morin (2001) precisamos entender que neste século XXI a educação tem de se reinventar pensando no homem do futuro (universal, globalizado e hiperativo) e a Universidade assume um papel importante na construção do conhecimento, fortalecida pelo respaldo constitucional do art. 207, caput, (Brasil, 1988), que relaciona o desenvolvimento de um ambiente de aprendizado teórico-prático, para além disso, condiciona esta ação à novos desafios, que emergem da sociedade, por meio da efetividade do princípio da indissociabilidade entre ensino, pesquisa e a extensão. 
Esta nova dinâmica necessita de reengenharia contínua na disseminação de saberes científicos, técnicos e populares, que oportunizem aos professores e aos estudantes construírem espaços interdisciplinares de diálogos, a fim de encontrarem respostas racionais aos complexos problemas comunitários.

O caminho para a autoformação do jovem perpassa pelo aprendizado criativo, ou seja, compreender a arte de ensinar e assumir a condição humana nas suas três dimensões: "labor, trabalho e ação". (Arendt, 2007, p. 15). Nesse contexto, o "cidadão é definido, em uma democracia, por sua solidariedade e responsabilidade em relação à sua pátria. $O$ que supõe nele o enraizamento de sua identidade nacional". (Morin, 2003, p. 63). Portanto, ensinar a viver com solidariedade é fortalecer a cidadania ativa, que se torna possível a partir do trabalho em equipe.

Assim sendo, a construção epistemológica a cargo da extensão universitária torna-se campo fecundo e "espaço do compartilhamento da ecologia de saberes", que corresponde a um canal facilitador para a constituição de sujeitos individuais e coletivos que combinam a maior sobriedade na análise dos fatos com a intensificação da luta contra a opressão. (Santos, 2006, p. 164).

O caminho racional pretendido, segundo os estudos de Santos (2006), perpassa pelo conhecimento que incentive processos autônomos dos atores sociais, principalmente dos grupos minoritários excluídos da atenção do Estado. Isto ocorre a partir do estimulo à coletividade e à participação democrática no destino da gestão pública das cidades.

No Brasil, a Lei Federal de n. 10.257 (Brasil, 2001), conhecida como Estatuto da Cidade, propõe a gestão democrática das cidades atribuindo à população e as associações representativas dos vários segmentos o direito a participar da formulação, execução e acompanhamento de planos, programas e projetos de desenvolvimento urbano.

Para Habermas (2012, p.75) essa "postura ativa se concretiza por meio da ação comunicativa", na qual os atores sociais são também responsáveis pela reconstrução do estado democrático de direito.

A postura dialógica dos atores sociais na esfera pública se propõe à eficiência dos serviços nos espaços urbanos comunitários (Habermas, 2014).

Com a aliança entre saberes científico, técnico e popular será possível estabelecer a renovação do homem como sujeito da história, capaz de produzir reformulações de políticas sociais na defesa do meio ambiente sustentável, às gerações presentes e futuras. 
Com base nesses fundamentos, a partir dos próximos tópicos do texto, abordaremos o percurso metodológico da construção do projeto Nós propomos na Universidade Federal do Tocantins (UFT) e seu desenvolvido no município de Palmas - TO, durante o ano de 2017.

\section{Percurso metodológico do Nós propomos}

O Nós propomos, de origem portuguesa, foi criado em 2011 pelo Instituto de Geografia e Ordenamento do Território da Universidade de Lisboa (IGOT-UL), com expansão para a Espanha, Colômbia, Peru, Moçambique, México e Brasil. Isto ocorreu por representar um instrumento educacional viável ao despertar a cidadania ativa, com enfoque na gestão democrática das cidades. (Bazzoli, 2017).

O Projeto chega ao Estado do Tocantins em 2015 e foi implantado pela Universidade Federal em 2016, por meio de parceria firmada com a Secretaria de Educação do Estado. Expandiu suas atividades pelas escolas de ensino médio das cidades de Palmas, Araguaína e Gurupi.

Na Universidade Federal do Tocantins participam do desenvolvimento do Projeto os cursos de Direito, Arquitetura e Urbanismo, Geografia/Araguaína e o Programa de Pós-Graduação em Desenvolvimento Regional. Importante salientar que a integração promovida no desenvolvimento do Nós Propomos tem estimulado a participação dos alunos de Graduação e de Pós-Graduação na proposta extensionista acadêmica. Os universitários, por meio do apoio técnico-científico, auxiliam professores e alunos das escolas de ensino médio na organização de eventos, como: palestras, seminários, worksohps ou mesmo na orientação de como elaborar projetos e planos de ação, que dizem respeito aos problemas locais que requerem atenção dos gestores públicos.

A metodologia dessa plataforma foi definida a partir do nivelamento dos graduandos e pósgraduandos da UFT com os alunos das escolas de ensino médio, para a ambientação dos pontos estruturais da proposta de extensão, que se desenvolve com o auxílio de um planejamento anual de atividades, conforme orientações registradas pelo manual próprio editado (Bazzoli, 2017), que consta os procedimentos a serem observados pelas escolas parceiras dessa múltipla plataforma de trabalho.

Para desenvolver o Projeto as escolas formam grupos de trabalho, com o assessoramento técnico-científico dos professores, graduandos e pós-graduandos da UFT. Esses grupos são orientados à realização de pesquisas em fontes bibliográficas interdisciplinares. 
Após as instruções iniciais, as equipes de pesquisa partem para o estudo de campo. Nesta oportunidade se aproximam da história de vida local, do espaço em que vivem.

Esse estágio do trabalho tem sido relevante para estreitar laços com as comunidades, conhecimento dos problemas sociais, culturais e da realidade econômica da região. Assim, os educandos se inserem e reconstroem a consciência de "pertencimento", por meio da educação e do trabalho coletivo com vista à busca de qualidade dos serviços comunitários, de proposição de políticas públicas, entre outras necessidades.

Após o contato com a comunidade, fazem diagnósticos e mapeiam os pontos nevrálgicos e primordiais a serem trabalhados e estudados nas rodas de palestras, workshops, seminários que são realizados nas próprias escolas ou na universidade e/ou pela coordenação e equipe técnica do projeto, com o fim de tirar dúvidas e otimizar as pesquisas das escolas secundárias.

Registra-se que a partir do envolvimento com a dinâmica do Projeto as equipes de trabalho conhece e seleciona o acervo de livros, revistas, documentos normativos que possam auxiliar na elaboração dos pré-projetos e potencializam o encaminhamento de possíveis resoluções para os problemas locais diagnosticados no espaço urbano de suas comunidades.

Fizemos um recorte para este trabalho da terceira edição do Projeto, realizada em 2017, a partir do II Seminário estadual, momento em que as escolas parceiras levaram ao conhecimento da sociedade os trabalhos desenvolvidos durante o ano letivo, resgatando eventos acadêmicos e a feira de negócios realizados no município de Palmas, ações que envolveram a apresentação dos pré-projetos com possíveis resoluções dos problemas urbanos identificados na comunidade. Esses espaços ampliados de debates oportunizaram o engajamento das equipes e proporcionaram a reformulação das propostas de melhoria dos serviços urbanos do município de Palmas - TO.

Nestas exposições foram realizadas palestras com a participação dos alunos do Programa de Pós-Graduação em Desenvolvimento Regional da Universidade Federal do Tocantins, concernentes às temáticas: Política Pública, Estatuto da Cidade, Plano-Diretor, Urbanismo, Cidadania e Participação Democrática. Também aconteceram vários momentos de integração com os alunos da graduação dos diversos cursos que integram o projeto. Por fim, as atividades do Nós propomos se concluíram com a realização do II Seminário Estadual, ocorrido em novembro de 2017. Este evento de fechamento anual das atividades foi preparado para que os alunos fizessem as exposições das propostas de resoluções de problemas urbanos identificados na comunidade. 
As recomendações mostradas no evento final revelaram como característica central a participação de atores sociais comunitários nas informações e sugestões de resoluções de problemas encontrados, mostrando que os alunos ao desenvolver os trabalhos buscaram articulação e integração com a população palmense.

Assim, como ponto forte dessa atividade se identificou o ativismo criativo dos alunos que, para além de apontar resoluções viáveis e inovadoras para os problemas locais de Palmas TO, fizeram reivindicações aos gestores públicos para a melhoria do planejamento de espaços urbanos e sugeriram políticas sociais locais, com baixo investimento e respeito ao meio ambiente. Ademais, os espaços urbanos planejados de forma coletiva, consciente e racional supõem "uma resposta pronta e adequada às demandas dos agentes, de modo a permitir que o encontro entre a ação pretendida e o objeto disponível se dê com o máximo de eficácia”. (Santos, 2006, p. 204).

Importante frisar que, por iniciativa dos alunos secundaristas, algumas dessas propostas, apresentadas no Seminário Estadual, já foram protocolizadas na Câmara de Vereadores e no executivo Municipal. Agregaram-se ao ofício dirigido ao legislativo e ao executivo, gráficos e maquetes, na tentativa de mostrar como deveriam ser estruturados os espaços urbanos, referindo-se à construção de praças, centro de convivência para idosos, parques, bebedouros públicos, iluminação pública, mobilidade, recuperação das margens de rios e/ou córregos, dentre demais proposições de melhoria para a cidade.

Ao reunir e estudar este conjunto de ações realizadas pelo Nós propomos, percebeu-se que a extensão universitária poderá se constituir numa excelente alternativa, não formal, para se instigar a gestão participativa em Palmas - TO e de possibilitar a integração de jovens ao processo de governança do município.

Constatou-se ter havido, nesse ambiente de compartilhamento de saberes popular, técnico e científico, a otimização da discussão e da aprendizagem sobre o tema Direito à Cidade.

Assim, verificou-se que, por meio do desenvolvimento prático do Nós propomos, os alunos das escolas de ensino médio, ao trabalhar com a realidade comunitária, foram se entusiasmando e resgatando o espírito proativo de pertencimento e responsabilidade pelos problemas da sua cidade. O que demonstra a "importância da extensão universitária como veículo indutor da cidadania". (Bazzoli, 2017, pp. 13-27). Tudo isso viabiliza a compreensão de que "ensinar não é transferir conhecimento, mas criar as possibilidades para a sua própria produção ou a sua construção”. (Freire, 2018, p. 47). 


\section{O caminho para a democracia participativa: discussões e resultados do Nós propomos}

Entender que a democracia seja o modelo mais aceitável para perseguir o objetivo mais nobre, o da sustentabilidade (Aragão, 2015), pretende-se com este estudo impulsionar à reflexão sobre os meios alternativos adequados e não formais de participação social, tendo em vista que o modelo tradicional formal passa por desgastes na atualidade.

Vislumbra-se que a democracia participativa na gestão de cidades abre horizontes para a proteção das minorias; a defesa e respeito dos direitos humanos; a criação de mecanismos que garantam o acesso aos direitos essenciais à dignidade humana; entre outros.

Nesse sentido, a arquitetura dialógica da esfera pública, tratada em estudos científicos, a exemplo de Habermas (2014) e Santos (2007), busca restabelecer as forças motrizes da sociedade que se remodela por meio da cooperação entre as instituições do Estado e a participação dos atores sociais, com o fim de fazer emergir a governança, aperfeiçoar a gestão pública e racionalizar os recursos orçamentários e naturais, bem como construir espaços urbanos saudáveis e sustentáveis.

Logo, se há um cenário problemático e de desesperança que deixa a sociedade em desalento, justifica, por meio da extensão universitária, que sejam desenvolvidas experiências como a relatada neste artigo, justamente porque o conhecimento emancipatório desperta os atores comunitários a "pensar sobre seu papel num país de cidadãos sem direitos, em que de um lado é vítima e tem de lidar com as consequências dessa situação, e de outro pode e deve ser agente de mudanças". (Dimenstein, 2012, p.7).

Com a reestruturação de um pensar coletivo local, a comunidade terá a possibilidade de relacionar a participação formal e a gestão democrática da cidade à Constituição Federal (Brasil, 1988), diploma que trata da política urbana, executada pelo Poder Público Municipal, que objetiva ordenar o pleno desenvolvimento das funções sociais da cidade e garantir o bem-estar de seus habitantes, conforme diretrizes fixadas pelo Estatuto da Cidade (Brasil, 2001), para além de reforçar a necessidade da gestão orçamentária participativa, com a realização de debates, audiências e consultas públicas sobre as propostas orçamentárias.

Diante desse contexto, será perceptível a importância da construção da extensão universitária como alternativa adequada que fomentará o exercício emancipatório, pois a população que conhece seus direitos e deveres assume o espírito de cidadania, coloca-se como protagonista de sua história e empodera-se para o debate público, crítico e criativo, principalmente quando chamada pelos gestores municipais e estaduais a participar de 
audiências públicas sobre a melhoria dos serviços sociais e de desenvolvimento regional sustentável. Sem embargo, a "revolução democrática do direito e da justiça só faz verdadeiramente sentido no âmbito de uma revolução democrática mais ampla que inclua a democratização do Estado e da sociedade". (Santos, 2007, p. 10).

Assim, a extensão universitária tem o papel fundamental nesse processo dialógico entre as instituições do Estado e os atores sociais, por meio da conexão entre conhecimento científico, técnico e popular, de impor respeito e atenção às contribuições de culturas diferentes, como forma de exaltar o "exercício da ecologia de saberes" (Santos, 2006, p. $164)$, bem como recriar espaços que façam reverberar a "pedagogia da autonomia." (Freire, 2018, p. 39).

Ressalta-se, segundo Santos (2002, p. 31) diante da "globalização econômica neoliberal", em que o homem tem sido levado a se tornar instrumento do consumo e do mercado, e valores como dignidade e direitos humanos são desrespeitados, será preciso, no campo das práticas capitalistas internas ou globais, a autoformação do cidadão. Assim sendo, afirma Santos (2002, p. 75), que a desconstrução deste paradigma consiste na organização de [...] lutas que tornem possível a distribuição democrática da riqueza, ou seja, uma distribuição assente em direitos de cidadania, individuais e coletivas [...]. Portanto, a consciência de que temos o direito de ser iguais quando a diferença nos inferioriza e a ser diferentes quando a igualdade nos descaracteriza.

Nesse diapasão, a sociedade brasileira, em especial a palmense, a partir da realidade local e dos complexos problemas sociais, deve participar da reconstrução do estado democrático de direito, com fim da preservação e defesa dos direitos fundamentais albergados pela Constituição Federal (Brasil, 1988).

À luz desse contexto, a Constituição Federal precisa ter força concreta e a "força normativa da Constituição depende não apenas do seu conteúdo, mas também de suas práxis". (Hesse, 1991, p. 21).

Com aporte nos resultados identificados na pesquisa acerca do Nós propomos, demonstrados na sequência do texto, é possível afirmar que a extensão universitária pode ser um canal para se estimular a participação social e democrática em Palmas - TO.

\section{Resultados das atividades desenvolvidas pelas escolas de ensino médio no município de Palmas - TO, em 2017}


De acordo com o recorte desta pesquisa em 2017 participaram da segunda edição do Nós propomos, na cidade de Palmas, seis escolas de ensino médio, identificadas na Figura 1: Colégio Estadual Dom Alano, Cem Tiradentes, Colégio Estadual São José, Cem Santa Rita, Escola Estadual Liberdade e Cem Castro Alves. 
Figura 1 - Mapa das escolas integrantes do projeto Nós propomos em Palmas.

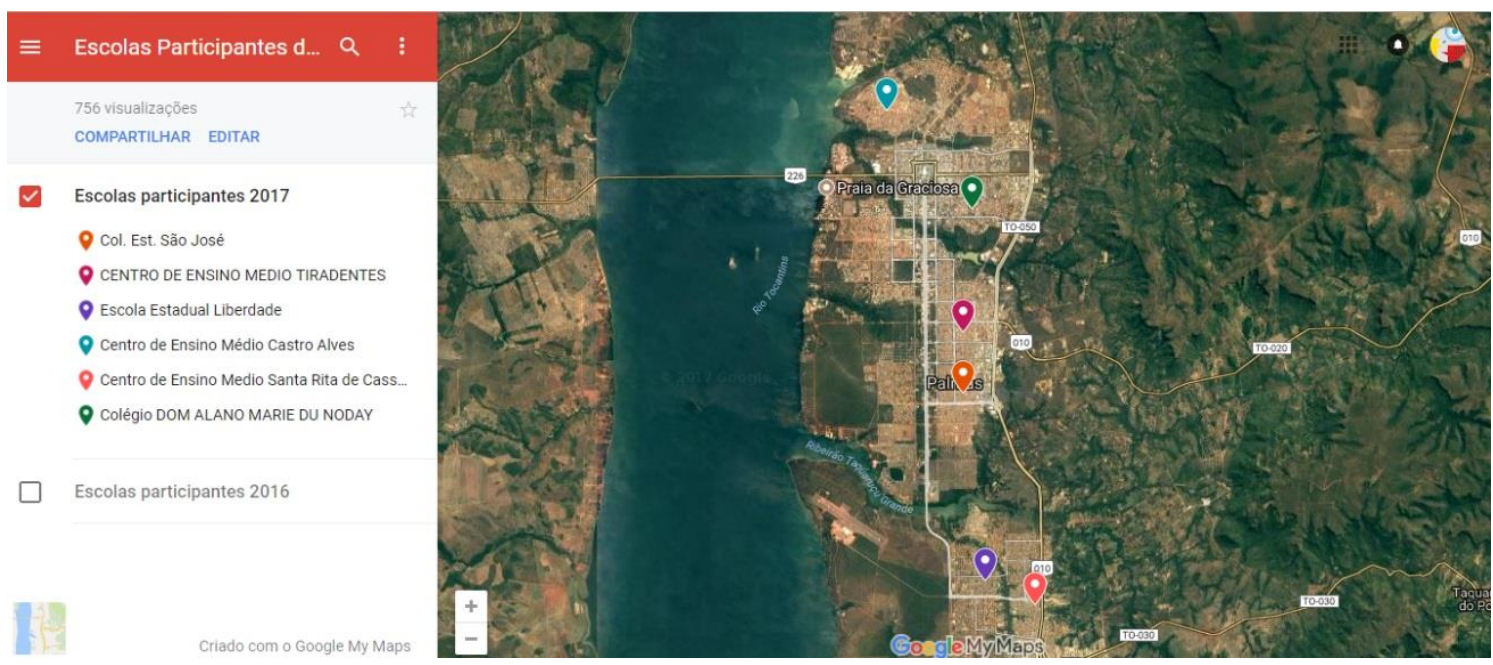

Fonte: http://nospropomos.blogspot.com/

As escolas participantes mostradas na Figura 1 apresentaram nove propostas com sugestões para resoluções de problemas envolvendo serviços de: infraestrutura; mobilidade; segurança pública; inclusão digital; revitalização de espaço público e preservação de meio ambiente, para a cidade de Palmas, proposições listadas abaixo na Tabela 1.

Tabela 1 - Temas de trabalhos apresentados no Il Seminário Nós propomos (2017).

\begin{tabular}{ll}
\multicolumn{1}{c}{ Tema } & Identificação da escola \\
\hline Hidrata Palmas & Colégio Estadual Dom Alano \\
\hline $\begin{array}{l}\text { Ausência de sinalização horizontal e vertical da } \\
\text { quadra 806 sul }\end{array}$ & CEM Tiradentes \\
\hline $\begin{array}{l}\text { Pavimentação e iluminação pública da viela da } \\
\text { quadra 806 sul }\end{array}$ & CEM Tiradentes \\
\hline $\begin{array}{l}\text { Limitações aos direitos de mobilidade urbana da } \\
\text { pessoa com deficiência }\end{array}$ & CEM Tiradentes \\
\hline Acessibilidade nos arredores do Colégio São José & Colégio Estadual São José \\
\hline Casa de passagem viver com alegria & CEM Santa Rita \\
\hline Segurança pública comunitária & Escola Estadual Liberdade \\
\hline Inclusão digital e profissional & Escola Estadual Liberdade \\
\hline Praça da juventude, mais lazer e cultura, mais vida & CEM Castro Alves \\
\hline
\end{tabular}

Fonte: http://nospropomos.blogspot.com/

Como se pode denotar, os temas referenciados pelos estudantes no Seminário estadual não são comumente objetos de atenção das gestões nas cidades brasileiras. Portanto, repetemse as reivindicações da população questionando a qualidade e/ou a melhoria das políticas públicas no Brasil, especialmente as que aproximem a população do Poder público municipal. 
Nesse viés de debate, o Nós propomos passa a ser identificado como um possível mecanismo alternativo adequado, não formal, para que se promova "a gestão democrática por meio da participação da população na execução e acompanhamento de planos, programas e projetos de desenvolvimento urbano", conforme descrito pelo Estatuto da Cidade (Brasil, 2001, p 37), com a inserção de jovens do ensino médio das escolas da rede pública, por meio da educação à cidadania ativa.

Como se observa, os jovens estudantes escolheram os temas e formaram equipes (cada uma com cinco alunos) para estudo e pesquisa sob a orientação do professor orientador de sua escola.

Nesse ano de 2017 analisado pelo estudo participaram diretamente do Projeto 45 (quarenta e cinco) alunos, com repercussão interna nas escolas participantes que atingiram indiretamente, considerando o envolvimento destes nas atividades gerais promovidas pelo projeto, de mais de 500 (quinhentos) alunos.

Neste estudo foram acompanhadas as atividades dos alunos, nas visitas comunitárias realizadas, nos encontros e reuniões de trabalho e em outros eventos do projeto. Os alunos secundaristas apresentaram os seus trabalhos constituídos de propostas de resoluções de problemas urbanos em duas oportunidades: a primeira em setembro para qualificar e coletar novas sugestões sobre o trabalho e a segunda em novembro, no Seminário estadual, para avaliação final, evento demonstrado na Figura 2 abaixo.

Figura 2 - Seminário Estadual realizado no dia 13 de novembro de 2017

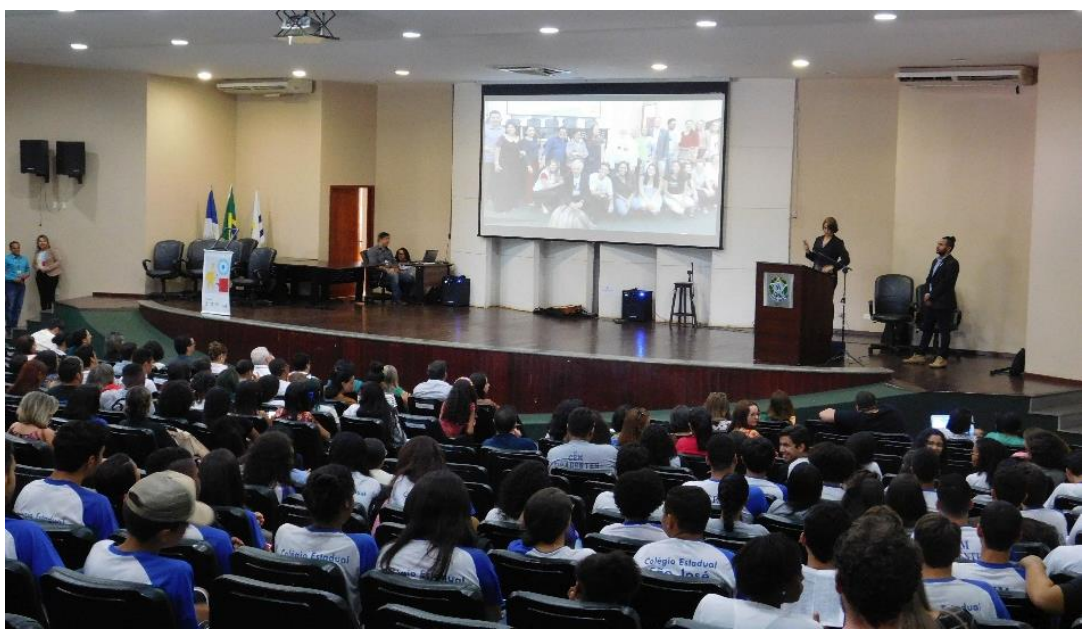

Fonte: http://nospropomos.blogspot.com/

Em ambas as apresentações os trabalhos foram avaliados por experts e estabelecidos 10 (dez) critérios para análise dos trabalhos e atribuídas notas na escala de 0 (zero) a 10 (dez) pontos, conforme descrição da Tabela 2. 
N.

\section{Critérios}

1 O trabalho está plenamente adequado ao tema proposto (referindo-se ao conteúdo apresentado - deverá estar vinculado às questões urbanas).

2 A proposta é criativa (mostra a capacidade de produzir efeitos e transformar o ambiente segundo as necessidades comunitárias).

3 A proposta é inovadora (demonstra mudança de processo no tratamento das questões urbanas e reflete pequenas melhorias e avanços nos benefícios proporcionados para a comunidade).

4 A proposta é viável (análise subjetiva - Política, Social, Operacional - se a proposta pode ser exequível, alcançar os resultados esperados e ter êxito na sua aplicação).

5 Grau de impacto da proposta na comunidade (análise subjetiva - melhoria substantiva - se a proposta poderá representar mudança substancial na melhoria da qualidade de vida na comunidade).

6 Participação social (a proposta demonstra que a comunidade estará envolvida na formulação, implantação e acompanhamento).

7 A proposta é consistente (análise subjetiva se a proposta delimita claramente o objeto de estudo, possui lógica, é razoável, apresenta critica razoável).

$8 \quad$ O grupo apresentou o trabalho com clareza na linguagem oral.

9 O conteúdo do trabalho (Slides) foi apresentado com redação estruturada e organizada de maneira lógica das partes.

10 Segurança na defesa da ideia (o grupo foi seguro na apresentação, defendeu a proposta de maneira veemente, acredita na concretização e operacionalização, o problema identificado pelo grupo está sendo atendido pela proposta de resolução).

Fonte: http://nospropomos.blogspot.com/

$\mathrm{Na}$ análise de percepção pelos avaliadores sobre os trabalhos apresentados, observou-se que entre os itens dos critérios utilizados as incidências significativas, classificadas por maiores notas, foram os itens de n. 5, 6 e 10, que estão descritos na Tabela 3 abaixo, com as respectivas notas.

N. Critérios

Tabela 3 - Critérios de avaliação

Grau de impacto da proposta na comunidade (análise subjetiva - melhoria substantiva -

5 se a proposta poderá representar mudança substancial na melhoria da qualidade de vida na comunidade

6 Participação social (a proposta demonstra que a comunidade estará envolvida na formulação, implantação e acompanhamento)

Segurança na defesa da ideia (o grupo foi seguro na apresentação, defendeu a proposta

10 de maneira veemente, acredita na concretização e operacionalização, o problema identificado pelo grupo está sendo atendido pela proposta de resolução)

Fonte: Elaboração própria.

Portanto, concluiu-se com a análise das propostas, a partir das observações dos resultados das notas aplicadas na escala de 0 (zero) a 10 (dez) pontos aos critérios mostrados na Tabela 3 acima - notas estas atribuídas pelos avaliadores das apresentações dos trabalhos nos eventos - agregou-se também, os resumos escritos entregues pelos alunos (duas laudas) explicando tecnicamente a proposta, e por fim os slides preparados para as apresentações, além da realização de entrevistas aos avaliadores para entender a visão e enfoque aplicado a cada avaliação dos grupos, que houve impacto, participação social e empoderamento local sobre as comunidades atingidas pelo Nós Propomos. 
Assim sendo, levando-se em conta os dez critérios mostrados pela Tabela 2 acima, foi possível deduzir o impacto significativo do projeto Nós propomos sobre as comunidades locais, a partir da constatação mostrada na Tabela 3 acima, de que a nota atribuída pelos jurados vislumbrando que a proposta poderá representar mudança substancial na melhoria da qualidade de vida na comunidade foi de 9,29 pontos de 10 pontos. Percebeu-se também, haver o despertar da participação social durante as atividades propostas pelo projeto em razão da nota atribuída a este critério ser de 8,71 pontos. Por fim, ficou demonstrado que os alunos acreditam na viabilização e na concretização de suas propostas apresentadas nos eventos de socialização, em razão da nota atribuída a este critério ser de 9,00 pontos. Os critérios e notas demonstrados na Tabela 3 acima ratificam os argumentos de impacto comunitário, participação social e empoderamento local.

Importante destacar a considerável avaliação em escala de pontuação pela criatividade, inovação e viabilidade das recomendações formuladas pelos grupos participantes do projeto. Este fator permitiu entender como o projeto se constitui efetivamente em modelo alternativo adequado de inserção dos jovens nos debates sobre a gestão democrática da cidade, para, além disso, poderá favorecer a melhoria do planejamento urbano sustentável nas cidades e se tornar uma importante ferramenta de política de inclusão social.

\section{Conclusão}

Neste trabalho tentamos provocar a reflexão sobre a escassez de políticas públicas aplicadas para resolução de problemas nos municípios brasileiros, com recorte na cidade de Palmas - TO. Porém a questão requer a descolonização do Poder público e a inclusão da sociedade nas discussões, planejamento e fiscalização da gestão dos municípios.

Como destaque, a luta por espaços dignos à vida em comunidade não pode ser concretizada sem a escuta e colaboração da população, conforme demonstrado nas discussões e nos resultados relatados por este estudo.

Neste sentido, este estudo permitiu, ao examinar o percurso metodológico das atividades desenvolvidas pelo projeto de extensão Nós propomos desenvolvido pela Universidade Federal do Tocantins, constatar que este mecanismo não formal de participação social se apresenta como um modelo alternativo adequado de inserção dos jovens nos debates sobre a gestão democrática da cidade e que poderá favorecer a melhoria do planejamento urbano sustentável, possibilitar a criação de políticas de inclusão social, propiciar a otimização dos recursos orçamentários e contribuir efetivamente para o desenvolvimento da região norte do Brasil. 


\section{Referências bibliográficas}

Aragão, A. (2015). Introdução. In. Aragão, A., Bester, G. M. \& Hilário, G. (Coords.). Direito e ambiente para uma democracia sustentável: diálogos multidisciplinares entre Portugal e Brasil (pp.xxi-xxv). Curitiba: Instituto Memória.

Arendt, H. (2007). A condição humana. Tradução de Roberto Raposo. Rio de Janeiro: Forense Universitária.

Bauman, Z. (2007). Tempos líquidos. Tradução Carlos Alberto Medeiros. Rio de Janeiro: Zahar.

BAUMAN, Z., \& Bordoni, C. (2016). Estado de crise. Tradução Renato Aguiar. Rio de Janeiro: Zahar.

Bazzoli, J. A., Silva, M. V. C. \& Viana, S. F. R. (2017). Manual Nós Propomos. Palmas: Universidade Federal do Tocantins.

Bazzoli, J. A., Nunes, S. C. L., Silva, M. V. C., Viana, S. F. R., \& Silva, W. C. (2017). A extensão universitária como indutora à cidadania: a experiência do Nós propomos. Palmas: Universidade Federal do Tocantins, 2017.

Brasil. Lei $n^{\circ}$ 10.257, de 10 de julho de 2001. Estatuto da cidade. Regulamenta os arts. 182 e 183 da Constituição Federal, diretrizes da política urbana. Disponível em: https://www.planalto.gov.br/ccivil 03/Leis/LEIS 2001/L10257.htm.

Constituição (1988). Constituição da República Federativa do Brasil. Brasília, DF:

Senado Federal, 1988.

Dimenstein, G. (2012). O cidadão de papel: a adolescência e os direitos humanos no Brasil. São Paulo: Ática.

Freire, P. (2018). Pedagogia da autonomia: saberes necessários à prática educativa. São Paulo: Paz e Terra.

Habermas, J. (2012). Teoria do agir comunicativo: racionalidade da ação e racionalização social. Tradução Paulo Astor Soethe. São Paulo: Editora WMF Martins Fontes.

Habermas, J. (2014). Mudança estrutural da esfera pública: investigações sobre uma categoria da sociedade burguesa. Tradução Denilson Luís Werle. São Paulo: Editora Unesp.

Hesse, K. (1991). A força normativa da constituição.Tradução de Gilmar Ferreira Mendes. Porto Alegre: Sergio Antonio Fabris Editor. 
Morin, E. (2001). Os sete saberes necessários à educação do futuro. Tradução Catarina Eleonora F. da Silva \& Jeanne Sawaya. São Paulo: Cortez, Brasília.

E. (2003). A cabeça bem-feita: repensar a reforma, reforma o pensamento. Tradução Eloá Jacobina. Rio de Janeiro: Bertrand Brasil.

Santos, B. S. (2002). A globalização e as ciências sociais. São Paulo: Cortez.

Santos, B. S. (2006). A gramática do tempo: para uma nova cultura política. São Paulo: Cortez.

Santos, B. S. (2007). Para uma revolução democrática da justiça. São Paulo: Cortez.

Santos, M. (2006). A natureza do espaço: técnica e tempo, razão e emoção. São Paulo: Editora da Universidade de São Paulo. 


\title{
Projeto Nós Propomos! Ações para a redução da violência contra a mulher no Ced 310 de Santa Maria/DF
}

\author{
VÂNIA LÚcIa Costa Alves SOUZA ${ }^{1}$ \\ Cristina Maria Costa Leite ${ }^{2}$
}

\section{Resumo}

O espaço escolar é componente de existência de pessoas, é produto e produtor de significados em ação educativa. Ao valorizar o espaço dos alunos, valoriza-se também a Geografia ao permitir que o cotidiano das pessoas seja repensado em outra lógica não dominante. A articulação ao combate à violência da mulher permeou os trabalhos desenvolvidos pelos alunos do Centro Educacional 310 de Santa Maria, DF. O projeto foi desenvolvido em três etapas. A primeira identificou, classificou os tipos de violência contra a mulher local e organizou ações para a redução desta violência. A segunda etapa envolveu a pesquisa qualitativa com colegas da escola e também a preparação de dois vídeos retratando tipos de violências e como evitá-las. A terceira etapa envolveu a construção de parcerias com representantes sociais para a promoção de debates com os alunos. Ao final a escola incluiu no Projeto Pedagógico estes debates sobre a violência de gênero com parcerias externas de rede de proteção à mulher.

Palavras-chave: violência; gênero; Direitos Humanos; preconceitos; Geografia Escolar.

\section{Abstract}

The school space is a component of existence of people, it is a product and producer of meanings in educational action. By valuing students' space, Geography is also valued by allowing the daily life of people to be rethought in another non-dominant

\footnotetext{
1 Professora de Geografia da Secretaria de Estado de Educação do Distrito Federal, Pesquisadora do GEAF/UnB-Grupo de Pesquisa, Ensino, Aprendizagem e Formação dos Professores de Geografia, costa.vania0@gmail.com

2 Professora da Faculdade de Educação e do Curso de Pós Graduação de Geografia da Universidade de Brasília, coordenadora do GEAF/UnB-Grupo de Pesquisa, Ensino, Aprendizagem e Formação dos Professores de Geografia, criscostaleite@gmail.com
} 
logic. The articulation of actions against women violence organized works evolved by the students of the Educational Center 310 of Santa Maria, DF. The project was developed in three stages: The first identified, classified types of violence against local women and organized actions to reduce this violence. The second step involved qualitative research with colleagues at the school and also the preparation of two videos depicting types of violence and how to avoid them. The third step involved building partnerships with social representatives to promote discussions with students. By the end, the school included in the Pedagogical Project these debates on gender violence with external partnerships of women's protection network.

Keywords: violence; gender; Human Rights; prejudices; School Geography.

\section{Introdução}

O PROJETO NÓS PROPOMOS ! fortalece o ensino de geografia ao convidar o discente ao exercício que envolve análise e pesquisa de seu espaço mais próximo 0 PROJETO NÓS PROPOMOS ! surgiu em 2012, na Universidade de Lisboa/IGOT - UL (Claudino, 2017), durante a disciplina de geografia para os alunos com idades entre 16 e 17 anos, com ênfase em atividades práticas sobre a realidade local. O PROJETO NÓS PROPOMOS ! tem o objetivo principal de dinamizar o estudo de caso e promover a autonomia dos estudantes orientados por eixos de ações como identificação dos problemas locais, execução de trabalho de campo e apresentação de sugestões de intervenção.

No Distrito Federal, O PROJETO NÓS PROPOMOS ! foi acolhido pelos pesquisadores do Grupo de Pesquisa em Ensino, Aprendizagem e Formação de Professores em Geografia (GEAF), sob a coordenação da professora Cristina Maria Costa Leite, da Universidade de Brasília, para a execução em algumas escolas públicas do Distrito Federal no ano de 2017. Em particular, a aplicação do projeto na escola de ensino médio ocorreu na Região Administrativa XIII, Santa Maria, DF, no Centro Educacional 310. 


\section{Contexto escolar - CED 310}

O Centro Educacional 310 é uma escola de ensino médio, criada em 2009, com intuito de atender alunos dessa etapa de ensino, especialmente aqueles que residem na área central da cidade de Santa Maria. Desde a inauguração, a escola é considerada polo/modelo no acolhimento de alunos com deficiência auditiva (DA), ou seja, é a única na região que conta com professores intérpretes de libras nas aulas. Ela recebe também vários alunos com necessidades especiais que são acompanhados por uma equipe de 12 professores na sala de recursos. Os 1.000 alunos da escola são atuantes e participam de várias competições durante todo o ano letivo. A escola recebeu várias homenagens nos últimos anos, das quais se destacam as premiações no Festival de Curtas das Escolas Públicas do DF, que contemplou seis trabalhos de alunos desta escola em 2016 e 2017. Neste ano, 2017, a escola conquistou o segundo lugar no Prêmio Escola de Atitude, competição organizada pela Controladoria Geral do Distrito Federal.

A escola está localizada na Região Administrativa XIII - Santa Maria, que fica a $26 \mathrm{~km}$ da região central do Plano Piloto. A região administrativa de Santa Maria surgiu em 1993 como fruto do programa de assentamento de famílias de baixa renda. Ela está localizada em uma área de $211 \mathrm{Km}^{2}$, rodeada por dois ribeirões: Alagados e Santa Maria. A população da cidade é de aproximadamente 125.123 habitantes, na maioria com renda média de $R \$ 3.385,00$ ou $€ 807,00$ por mês. A escolaridade da população é baixa, uma vez que a maioria dos moradores cursou apenas o ensino fundamental incompleto. Os assalariados ocupam funções predominantemente nos serviços gerais (28\%), no comércio (26\%) e na administração pública (10\%) segundo Pesquisa Distrital por Amostra de Domicílios (Codeplan, 2015).

Alguns jovens que frequentam a escola apresentam um quadro de vulnerabilidade social alta com relatos de abuso físico e sexual, casamentos precoces e gravidez na adolescência. Associado a isso, está o envolvimento dos jovens com as drogas e a criminalidade.

O PROJETO NÓS PROPOMOS ! no CED 310 contou com a participação de 20 alunos do segundo ano do turno vespertino do ensino médio. Nas aulas de geografia, eles desenvolveram o projeto em duas aulas semanais durante os meses de março a junho de 2017. Um encontro extraordinário ocorreu no segundo semestre para a articulação da roda de conversas com a participação de outros estudantes. O desenvolvimento do projeto ocorreu com as ações articuladas em três etapas: 


\section{Desenvolvimento}

\section{Escolha do tema}

\section{Etapa 1 - Sensibilização para os problemas locais, caracterização do problema}

O primeiro momento com os alunos envolveu a apresentação e a estruturação do projeto na escola. Os alunos trabalhariam um tema único; iriam identificar o problema, investigá-lo e sugerir intervenções. Dessa forma, as etapas foram construídas e direcionadas gradualmente. A pergunta inicial foi: Qual é o problema da sua quadra, local de moradia?

As respostas majoritariamente indicaram o tema de violência urbana em suas diversas formas, como assalto, estupro, roubo, brigas de gangues e violência doméstica. Mapas mentais foram realizados pelos alunos no sentido de descrever os tipos de violência e locais de ocorrência.

Em seguida, muitos debates ocorreram esclarecendo definições de violência, tais como: o que é violência? Quais são as causas da violência? Quais são os tipos de violência urbana? Como evitar a violência?

Após os estudos, muitos debates foram realizados e os alunos identificaram a violência contra a mulher como a de maior ocorrência em locais próximos de sua casa.

Delimitado o tema, os objetivos da pesquisa foram estabelecidos:

- Identificar e classificar os tipos de violência contra a mulher presentes em sua vizinhança.

- Organizar ações para a redução da violência.

Realizamos debates sobre a violência contra a mulher, a qual foi trabalhada na perspectiva sociológica, ou seja, como aquela resultante de conflitos e ausência de diálogo e civilidade. Complementamos com o enfoque nos direitos humanos, que consideram a violência como violação aos direitos civis (vida, propriedade, liberdade de ir e vir, consciência, culto), políticos (direito de votar e ser votado, participação política e social), econômicos e culturais. Nesse momento, utilizamos dinâmicas com o texto de Frei Betto (2017) sobre a Declaração dos Direitos Humanos . A Lei Maria da Penha, Lei no 11.340/2006 (Planalto, 2017a), nos artigos 20 a 30, também reforça os direitos das mulheres. A Lei do Feminicídio também foi trabalhada, a Lei $\mathrm{n}^{\circ}$ 13.104/2015 (Planalto, 2017b) torna o homicídio da mulher em um crime hediondo quando envolve violência doméstica e familiar e menospreza ou discrimina a condição 
da mulher. Tal lei é relevante para a articulação de ações que diminuam as elevadas estatísticas de mortes de mulheres pelos maridos/companheiros. Essas estatísticas revelaram que, em 2015, 4.621 mulheres foram assassinadas no Brasil, dados alarmantes do IPEA (2017), considerando uma taxa de 4,5 mortes para cada 100 mil habitantes.

Compreende-se a violência de gênero como aquela praticada contra a mulher, pelo fato de ser mulher, sem distinção de raça, classe social, religião, idade ou qualquer outra condição. É um tipo de violência que resulta de um sistema social que subordina o sexo feminino, em uma visão patriarcal de sociedade. É uma violência que acontece, principalmente, no ambiente doméstico e muitas vezes não tem registro por ser considerada "natural". A Lei Maria da Penha classifica os tipos de violência de gênero como psicológica, patrimonial, física, sexual. Esses tipos de violência foram amplamente debatidos em sala, conforme mostra a Figura 1.

A questão do preconceito se esconde nos estereótipos comuns dos papéis masculino e feminino de nossa sociedade. Para desvendar esses preconceitos, utilizamos dinâmicas de grupos com frases que revelam as nossas dificuldades em perceber essas regras sociais brasileiras e a ausência de estudo desse tópico nas escolas. Algumas categorias foram trabalhadas, como:

a. Papel tradicional feminino e masculino: refere-se às regras sociais que atribuem determinada função ao homem e à mulher e segue o modelo patriarcal de família. Exemplo de frase: A principal função da mulher é cuidar do lar, enquanto a do homem é ser o provedor.

b. Privacidade da relação: estabelece as regras sociais baseadas na concepção de que tudo que ocorre na relação do casal não pode ser levado a público e ninguém de fora tem o direito de opinar. Exemplo: Roupa suja se lava em casa.

c. Modelo de família intacta e ideal: abrange as regras sociais que primam pela união da família acima de qualquer interesse particular dos membros. Exemplo: Um casamento infeliz é melhor que um lar desfeito.

d. Responsabilidade da vítima: responsabiliza a mulher parcial ou totalmente pelo ato violento, por algo que ela (supostamente) fez ou que deriva de ser mulher. Exemplo: A mulher provoca ao querer sair sozinha. Não é à toa que o homem é violento.

e. Ciúme relacionado ao amor: refere-se às regras sociais que posicionam o ciúme como componente do amor e vice-versa. Exemplo: Ciúme é tempero do amor. 
f. Ciúme relacionado à violência: justifica a violência contra a mulher em função do ciúme. Exemplo: Quando o homem sente ciúme, é justificado que ele perca a cabeça.

g. Justificativas para a violência mesmo que o homem seja ciumento: responsabiliza outras causas para a violência. Exemplo: $E$ a crise, 0 desemprego e a constante falta de dinheiro que fazem com que o homem seja violento em casa.

Duas reportagens subsidiaram os debates. A primeira revela o cuidado que as mulheres devem ter no diagnóstico de uma relação perigosa com o parceiro. Segundo a pesquisadora Marcella Figueira em entrevista do jornal O Globo (2018) relata que a mulher brasileira ainda sofre de violência e morte decorrente dos relacionamentos abusivos; dessa forma, ela deve saber como agir nessas situações.

Observou-se que a mulher tem se sentido segura para denunciar, conforme mostra a segunda reportagem do Jornal Correio (2018), que indica o Distrito Federal com o maior número de denúncias registradas. Se, por um lado, a Lei Maria da Penha e a Lei do Feminicídio aumentam a punição e dão medidas protetivas; por outro lado, essas só têm efeito após a agressão. É necessário antecipar, ou seja, as mulheres deveriam perceber as relações abusivas e procurar os centros especializados para denunciar no Disque 180.

Nesse momento, percebemos a importância de espaços de debates sobre o tema na escola. A escola pode ser um local de informações, fazer parte da rede de proteção da mulher, divulgar procedimentos e locais que atendem as situações de risco. A ampliação e o aprimoramento da rede de atendimento à mulher são fundamentais não apenas para o melhor acompanhamento das vítimas, mas também como papel de prevenção à violência contra a mulher. Participam dessa rede os sistemas de saúde, da justiça criminal e a escola. $O$ fortalecimento dessa rede contribuiria para a construção de políticas públicas capazes de enfrentar a violência contra a mulher e promover a igualdade de gênero. 
Figura 1. Alunos debatem a violência na perspectiva dos Direitos Humanos, 2017.

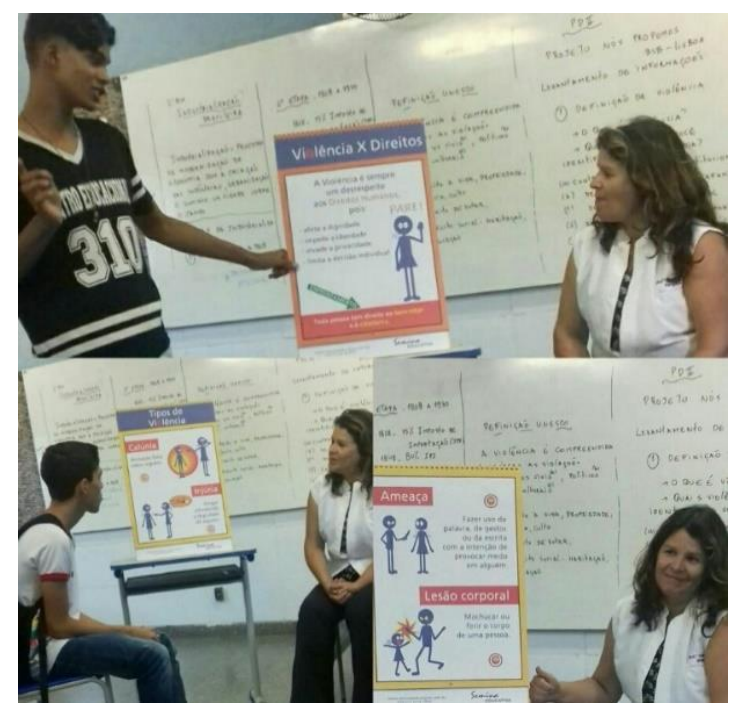

Fonte: Souza, V.L.C.A., 2017

Ao final dos debates sobre os preconceitos e as práticas discriminatórias contra a mulher, algumas questões surgiram, por exemplo, como aceitar estar presente diante de uma situação em que um homem bate em uma mulher e não se fazer nada? Será que a maioria dos colegas da escola percebe a existência dessa violência contra a mulher na sua quadra? A etapa 2 do projeto direcionou as respostas dessas questões.

\section{Intervenção}

\section{Etapa 2 - Elaboração de proposta de intervenção}

Após a delimitação do problema, os alunos optaram por estimular o debate do tema "Violência contra a mulher" no espaço escolar com incentivo à denúncia das vítimas. Para atingir esse objetivo, eles decidiram pesquisar as percepções dos colegas sobre a violência contra a mulher e, para isso, aplicaram um questionário.

As perguntas principais do questionário foram:

1. Onde você mora (quadra residencial), você presenciou algum tipo de violência contra a mulher?
A. Sim.
B. Não.

2. Quais dos itens abaixo você identifica como causa da violência?
a. Diferença de cultura/religião.
b. Desigualdade social. 

c. Racismo.
d. Machismo.
e. Drogas.
f. Distúrbios psicológicos.

3. Você acredita que a violência atinge mais as mulheres? Por quê?

4. Como evitar a violência contra a mulher?

\section{Resultados}

\subsection{Resultados dos questionários}

Os questionários foram respondidos por 120 alunos de diferentes séries do ensino médio do turno vespertino do CED 310.

1. $92 \%$ responderam que presenciaram algum tipo de violência contra a mulher em seu bairro.

2. Eles acreditam que as causas da violência decorrem de razões como percebemos na tabela 1 :

Tabela 1: Porcentagem das respostas dos questionários relativos ás causas da violência contra a mulher

\section{Causas da Violência contra a mulher}
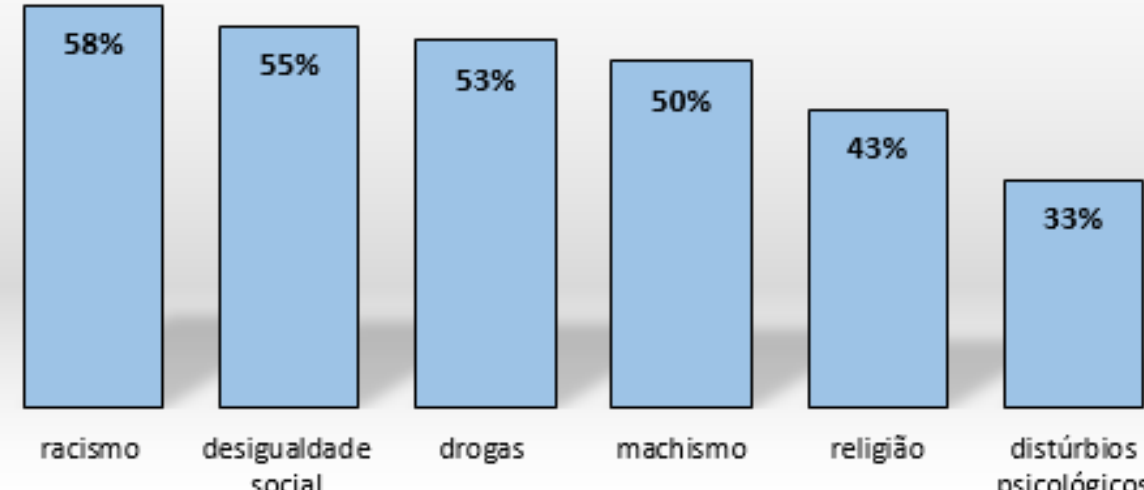

distúrbios psicológicos

Fonte: Souza, V.L.C.A., 2017

Os temas racismo, desigualdade social, machismo, religião aparecem em porcentagens próximas, o que indica que vários fatores podem levar às situações de violência contra a mulher. Tal constatação reforça a necessidade de promover na 
escola debates interdisciplinares envolvendo outros professores para melhor compreender a temática de prevenção.

3. $86 \%$ acreditam que a violência atinge mais as mulheres.

A principal razão apontada é porque a mulher é considerada frágil. Essa resposta reforça a visão patriarcal de dependência e invisibilidade da mulher, sua função social em uma visão patriarcal que, em muitos casos, não corresponde à atual situação econômica e social das mulheres, que sustentam muitas famílias no Brasil, mas não têm o reconhecimento da sociedade.

Lança também a dúvida: a mulher apanha porque é frágil? Então todos os seres frágeis devem apanhar?

4. A maioria acredita que a melhor forma de evitar a violência é a denúncia.

A pesquisa mostrou que muitos denunciariam o fato à polícia, confiando nas autoridades e leis a responsabilidade da diminuição da violência e punição dos responsáveis, como mostra a nuvem de palavras abaixo que foi construída a partir da frequencia de respostas dadas à questão: como evitar a violência contra a mulher?

Posteriormente, a turma escolheu que a melhor forma para combater a violência contra a mulher, na escola, seria incentivar as pessoas a denunciar os maus-tratos e o agressor, assim como buscar apoio psicológico para compreender os problemas de seus relacionamentos abusivos. Dessa forma, eles organizaram dois vídeos retratando dois tipos de violência e como evitá-las. A intenção é divulgar a necessidade da denúncia em casos de violência contra a mulher. Os vídeos se encontram nos links:

Violência contra a mulher

https://www.youtube.com/watch?v=ZOuXaFqoaXY

Um silêncio por amor

https://www.youtube.com/watch?v=\|IG t-8KLh0

\section{Discussão}

Articulação com os agentes externos

Etapa 3 - Construção de pareceres entre os atores escolares e não escolares 
Os alunos perceberam a ausência do debate desse tema na escola e procuraram os representantes do Centro Judiciário da Mulher do Tribunal de Justiça do Distrito Federal e Territórios (TJDFT), e da Comissão Maria da Penha, que foi à escola para participar de debates no Ced 310. Essa visita ocorreu no dia 17 de outubro de 2017, com a presença dos alunos de duas turmas do vespertino, em rodas de conversa com as equipes.

A equipe organizadora da roda de conversa pesquisou os tópicos relevantes aos alunos e professores da escola. Dessa forma, dois debates sobre a violência contra a mulher ocorreram no mesmo dia: pela manhã, durante a coordenação pedagógica com os professores, foram abordados os seguintes tópicos (Figura 2):

- significados da violência doméstica;

- Lei Maria da Penha;

- atitudes do professor diante das situações de violência doméstica;

- preparo da escola diante dessas problemáticas.

$\mathrm{Na}$ roda de conversa da tarde (Figura 3), os alunos do projeto selecionaram os tópicos:

- significados da violência doméstica;

- atitudes e encaminhamento das pessoas diante das situações de violência: o que fazer e o que não fazer;

- relato de casos recorrentes e penalidades penais;

- descrição das medidas protetivas da mulher;

- descrição dos casos de violência comuns em nossa cidade e encaminhamentos legais. 
Figura 2. Debate com os professores do turno vespertino sobre a violência contra a mulher

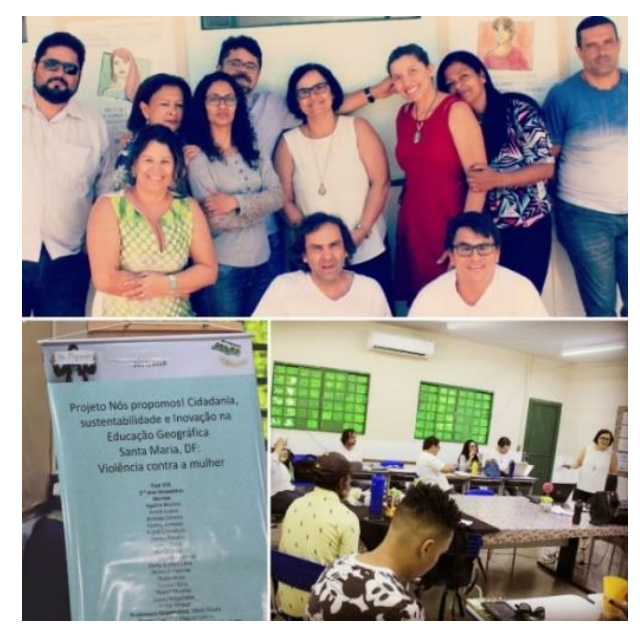

Fonte: Souza, V.L.C.A.

Figura 3. Roda de conversa com alunos do $2 E$ e $1 G$ do turno vespertino do CED 310

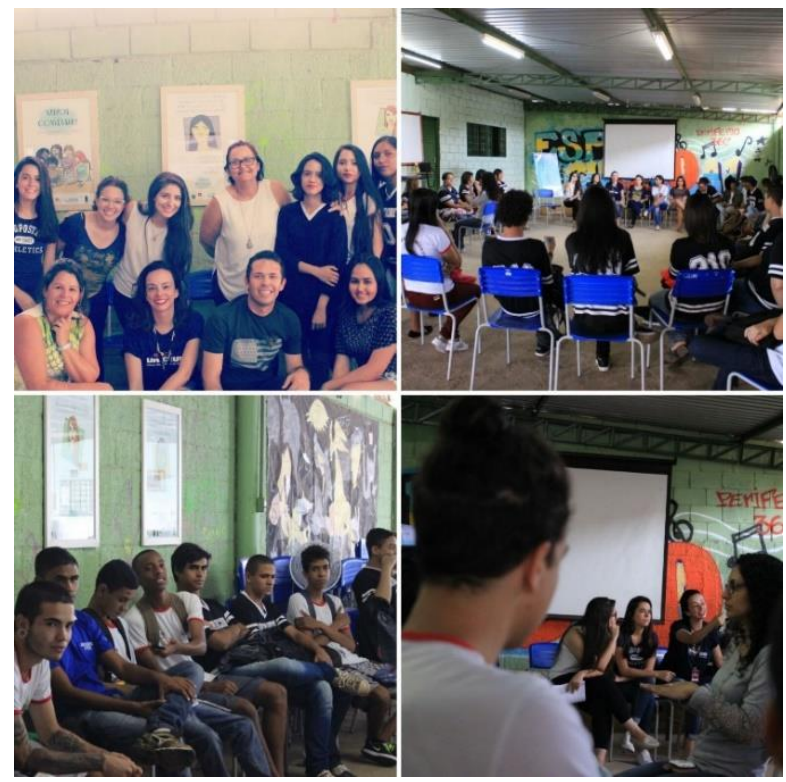

Fonte: Souza, V.L.C.A.

O sucesso dessa roda de conversa foi reconhecido na I Conferência Maria da Penha vai a escola registrado nos anais da Conferência do TJDFT( 2018) como uma das formas organizadas de articulação dos alunos da escola pública que a coloca como parte importante da rede de proteção da mulher. Portanto, "O PROJETO NÓS PROPOMOS ! Ações para a redução da Violência contra a mulher" foi escolhido como boa prática, ou seja, como aquele que promove o acesso às informações com o propósito de estimular reflexões e ações de valorização da mulher em nossa sociedade. 


\section{Considerações finais}

O projeto contou com um grande envolvimento dos alunos nas diferentes etapas. A articulação das ações, baseadas em relatos de casos de violência da realidade do aluno, foi importante no encaminhamento do trabalho nas diversas fases. A primeira etapa foi realizada com inúmeros desafios, como, por exemplo, a falta de preparação dos alunos em encaminhar os debates sobre preconceitos. Estudos de Madureira e Branco (2017) sobre as questões de gênero na sociedade indicam que o professor pode superar essa dificuldade a partir de exemplos concretos em estudos interdisciplinares no nosso caso, com a abordagem em direitos humanos.

$\mathrm{Na}$ segunda etapa, a intervenção foi adaptada às necessidades dos professores e alunos. O depoimento de uma aluna no questionário menciona que é muito difícil mudar a ocorrência da violência em nossa sociedade, pois ela está presente em todo lugar. Então a melhor maneira seria mudar os seres humanos. A educação e o acesso às informações podem oferecer oportunidades às pessoas de quebrar o ciclo da violência. A violência contra a mulher é um tema muito complexo e importante e não deve ficar ausente das discussões na escola. A prevenção à violência contra a mulher pode ter uma possível resolução coletiva a longo prazo: educar para denunciar e proteger a mulher.

Dada a complexidade do tema, é imperativa a ação conjugada da escola com os agentes externos de apoio à mulher em um trabalho a ser realizado a longo prazo. Os alunos participantes concordaram com a continuidade do trabalho em uma segunda etapa, a ser realizada em 2018. Para esse ano está planejado um trabalho coletivo que envolve os professores, o orientador educacional, a equipe do Núcleo Judiciário da Mulher do Tribunal de Justiça do Distrito Federal e dos Territórios - NJM/TJDFT - e o UniCeub, em uma segunda roda de conversa para discutir o machismo (com os meninos) e a identificação de relacionamentos abusivos (com as meninas).

O PROJETO NÓS PROPOMOS ! movimentou o ambiente escolar do CED 310, que foi revalorizado com a participação da comunidade escolar nos debates. O espaço escolar é mais que um local de conhecimento e trabalho. Ele é componente de existência de pessoas, é produto e produtor de significados em ação educativa (Silva, 2016). Ao valorizar o espaço dos alunos, valoriza-se também a Geografia ao permitir que o cotidiano das pessoas seja repensado em outra lógica não dominante.

Ao final, o trabalho desenvolvido pelos alunos foi relevante, pois permitiu a criação de espaços de debates com a temática transversal: discussão de gêneros, papéis sociais 
na escola. Além disso, a escola passa a participar da rede de proteção à mulher; no nosso caso, mulheres de periferia que lutam por melhores condições de vida.

\section{Alunos participantes:}

Alunos $2^{\circ} \mathrm{E}$ vespertino: Ágatha Moraes, André Lopes, Brenda Oliveira, Cíntia Andrade, Ingrid Conceição, James Rabelo, Karina Silva, Kelvin Silva, Maria Eduarda Barreto, Maria Eunete Lima, Mylenna Parente, Ruian Alves, Samuel Silva, Thayna Moreira, Tiago Favila, Lucas Martins, Décio Douglas.

\section{Referências Bibliográficas}

Betto, Frei (2017) Declaração Universal de Direitos Humanos. Disponível em $<$ http://www.dhnet.org.br/direitos/deconu/textos/betto.htm>

CODEPLAN/SEPLAN (2015) Pesquisa Distrital por Amostra de Domicílios. GDF, Governo do Distrito Federa, disponível em <http://www.codeplan.df.gov.br/pdad2015>

Correio (2017) Reportagem Lei Maria da Penha DF lidera número de denúncias disponível em <https://www.correio24horas.com.br/noticia/nid/lei-maria-da-penha-dflidera-numero-de-denuncias/98>

Claudino, Sérgio(2107)Projeto Nós Propomos - Inovação e Cidadania na Educação Geográfica. Disponível em< http://www.igot.ulisboa.pt/projeto-nos-propomos/>

IPEA (2017), Atlas da violência , disponível em <http://www.ipea.gov.br/atlasviolencia/download/2/2017>

Madureira, Ana F. A., Branco, Ângela U.(2015) Gênero, sexualidade e diversidade na Escola a partir da perspectiva de professores/as. Trends in Psychology, vol 23,n3 , 577-591.

O Globo(2018) Reportagem Lei Maria da Penha, 84 agressões foram registradas no DF em 2018. Disponível em < https://g1.globo.com/df/distrito-federal/noticia/lei-mariada-penha-84-agressoes-foram-registradas-no-df-em-2018.ghtml>.

Planaltoa(2006), Lei 11340, Lei Maria da Penha , disponível em <http://www.planalto.gov.br/ccivil_03/_ato2004-2006/2006/lei//11340.htm>.

Planaltob(2015), Lei 13104 disponível em <http://www.planalto.gov.br/ccivil_03/_ato2015-2018/2015/lei/L13104.htm>. 
RA

Santa

Maria(2017),

disponível

em

$<$ http://www.santamaria.df.gov.br/category/sobre-a-ra/conheca-a-ra/>.

Silva, Joseli(2016) Gênero e espaço. Esse é um tema de Geografia? In Azevedo, Daniel A., Morais, Marcelo A. Ensino de Geografia. Novos tema para a Geografia, Editora Consequencia.

TJDFT(2017), Relatório do I Congresso Maria da Penha vai à escola , disponível em $<$ https://www.tjdft.jus.br/institucional/2a-vice-presidencia/centro-judiciariomulher/relatorio-do-i-congresso-maria-da-penha-vai-a-escola> . 


\section{La mirada interesada a mi barrio}

Vicent Peris de Sales ${ }^{1}$

\section{Resumo}

La comunicación pretende explicar las decisiones y la forma en que el IES Font de Sant Lluís de València ha integrado el proyecto Nós Propomos en la programación del ámbito sociolingüístico de primero y segundo de la Educación Secundaria Obligatoria, en concreto en el primer trimestre.La metodología que propone el proyecto se adapta tanto a la manera de trabajar el curriculum por la que apostamos como al modelo de escuela y función que ella debe realizar: formar ciudadanos responsables conocedores de sus derechos e integrados en su contexto social. La dimensión internacional del proyecto y la colaboración con la Universitat de València nos ayudará a mejorar la calidad educativa y a mejorar el prestigio del centro en València.

Palabras clave: educación geográfica; educación inclusiva; proyecto curricular; interdisciplinariedad; calidad eduactiva.

\section{Abstract}

The communication aims to explain the decisions and the way in which IES Font of Sant Lluís of València has integrated the Nós Propomos project into the programming of the sociolinguistic area of first and second Secondary Education, specifically in the first term. The methodology proposed by the project is adapted to both the way of working the curriculum which we have chosen and the model of school and function that it must perform: to form responsible citizens aware of their rights and integrated into their social context. The international dimension of the project and the collaboration with the Universitat of València will help us both to improve the educational quality and to improve the prestige of the center in Valencia.

Keywords: geographic education; inclusive education; curricular project; interdisciplinary nature; quality education.

\footnotetext{
${ }^{1}$ Profesor de Educación Secundaria, jefe del departamento Geografía e Historia, IES Font de Sant Lluís València, vjperis@iesfuentesanluis.org
} 


\section{Introducción}

El derecho a la educación es básico para que se desarrolle una ciudadanía digna. La obligatoriedad de la educación básica ofrece a todos los ciudadanos este derecho atendiendo la diversidad de motivaciones e intereses de los alumnos de manera inclusiva.

A pesar de que la LOMCE en su preámbulo declara que "la escuela moderna es la valedora de la educación como utopía de justicia social y bienestar", el actual sistema educativo español está marcado por "procesos de fragmentación, segmentación y desigualdad" y no garantiza el éxito escolar de sus ciudadanos, perjudicando la cohesión y justicia social. Tarabini, Jacovkis, Montes (2017 p.4).

El riesgo de exclusión educativa se alimenta de múltiples factores Uno de los momentos relevantes en la vida académica de los alumnos es el tránsito entre las etapas educativas. Como señalan Tarabini, Jacovkis, Montes (2017 p.26) "las transiciones educativas juegan un papel clave en la explicación de los procesos de exclusión educativa, siendo especialmente relevante la transición entre la educación primaria y la secundaria."

La comunidad educativa del IES Font de Sant Lluís inició durante el curso escolar 2013-2014 un proceso de mejora en la atención a las necesidades que el contexto social demandaba. El alumnado mostraba elevados niveles de absentismo escolar y conflictividad con resultados académicos nefastos. Una de las acciones más relevantes fue la elaboración, aprovación y evaluación del Plan de Transición que la Orden 46/2011 de 8 de junio contemplava. A través de este Plan se realiza un esfuerzo por parte de la comunidad educativa de atención a la diversidad de forma integrada. La originalidad del centro es que la atención al alumnado con necesidades específicas de soporte educativo se realiza de manera integrada sin separarlos del grupo clase de referencia. Todos los alumnos de primer y segundo curso de la ESO, independientemente de sus capacidades, autoestima y conflictividad en su socialización, son atendidos en la misma aula, evitando la segregación, ofreciéndoles los mismos contenidos y evaluándoles con los mismos criterios. Los aprendizajes se organizan por proyectos trimestrales que los alumnos realizan en grupo. El Decreto 104/2018 de 27 de julio desarrolla los principios de equidad e inclusión en el sistema educativo insistiendo en la necesidad del acceso al derecho a la educación sin obstáculos. 
El equipo docente del ámbito sociolingüístico, que incluye la geografía e historia, el castellano y el valenciano, decidió el pasado curso escolar incorporarse al proyecto internacional Nós Propomos incorporándolo a la programación del centro. El proyecto, además de lo expuesto, permitía la internacionalización de los aprendizajes. Las etapas de incorporación, la motivación, los resultados obtenidos y la valoración de los mismos son las partes en las que se estructura esta comunicación.

Figura 1. Distritos de la Ciudad de València.

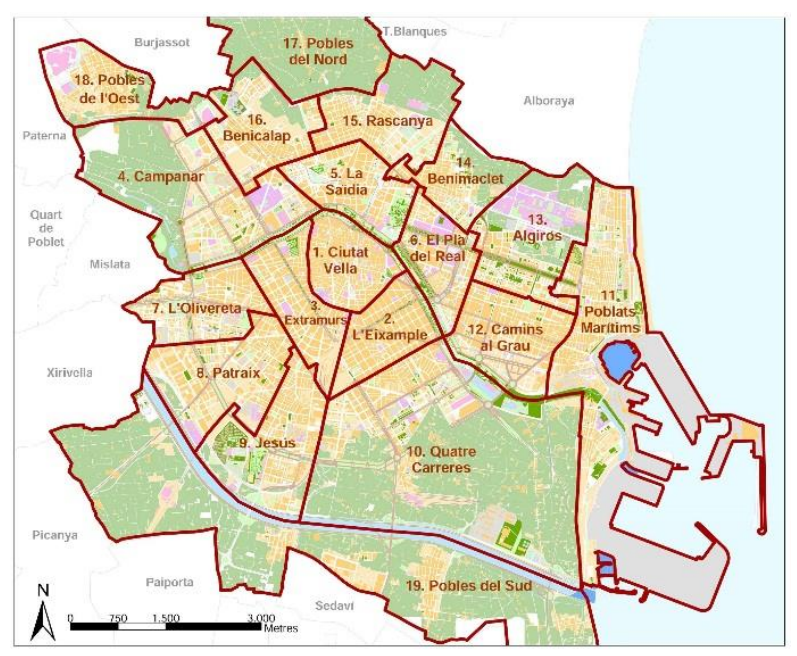

Fuente: https://goo.gl/images/JDRxMq

El instituto Font de Sant Lluís está en el barrio Na Rovella dentro del distrito Quatre Carreres. Creado en 1978, el instituto venía a satisfacer la demanda educativa en el área periférica sur de la ciudad que se urbanizaba en estos momentos. http://www.iesfsl.org/

\section{Proceso de incorporación al Proyecto Nós Propomos}
a) Características del programa Nós Propomos:

1- Programa Internacional en su séptima edición. Los países que participan son Portugal, Colombia, Brasil, Mozambique y España. En España colaboran la Universidad de Ciudad Real con centros de educación básica de esa ciudad y la Universidad de València con centros de secundaria en València y Ontinyent y de primária en Xàbia el próximo curso.

2- Demanda la colaboración imprescindible entre los centros de secundaria y la universidad por ser un proyecto de innovación para mejorar la práctica educativa.

3- Utilización del método de estudio del caso para analizar y proponer soluciones a un 
problema urbano detectado por los alumnos.

4- Proyecto muy flexible, adaptable a realidad escolar y con posibilidad de incluir otras disciplinas.

b) Temporalización del proceso:

La metodología que propone el proyecto se adapta tanto a la manera de trabajar el curriculum por la que apostamos, como al modelo de escuela y función que ella debe realizar: "contribuir para a inovação numa educação geográfica decididamente apostada na construção da cidadania territorial. (...) relacionado com a apropiação, transformação e identificação das comunidades com o territorio em que habitam. ${ }^{2 "}$ (Claudino Sérgio. 2014 p5)

El equipo docente del ámbito sociolingüístico acordó participar en el proyecto de la siguiente manera: el curriculum permite trabajar el primer trimestre sobre geografía urbana tanto en el primer como el segundo curso de la ESO. El trabajo en primero de la ESO se centraría en explicar los fundamentos del trabajo científico, la manera de abordar los estudios de caso en base a problemas detectados en salidas por el barrio. Lo planteamos como un entrenamiento de los alumnos para recoger, procesar y presentar resultados sobre un espacio conocido. En segundo de la ESO se realizaría el estudio del caso y se presentarían los resultados tanto al público en general como a las autoridades siguiendo las normas propuestas por el programa internacional. Si bien el primer año estos alumnos no han tenido un entrenamiento previo los resultados han sido satisfactorios como veremos.

El trabajo se plantea como obligatorio a todos los alumnos y deben realizar un proyecto en equipo como se viene haciendo en el ámbito sociolingüístico en los últimos cursos. La implicación del profesorado en función de su autonomía y libertad de cátedra es la que ha hecho posible que en el curso 2017-2018 hayan participado los grupos C y D de primero ESO (43 alumnos, 45\% del total) y los grupos A, C y D de segundo ESO (76 alumnos, $72 \%$ del total).

Figura 2- Temporalización de las decisiones que conducen a formar parte del proyecto.

\begin{tabular}{|l|l|}
\hline $5 / 5 / 17$ & Reunión con Profesor Souto que me explica el proyecto Nós Propomos. \\
\hline $19 / 6 / 17$ & $\begin{array}{l}\text { Reunión del equipo docente del ámbito sociolingüístico, se acuerda experimentar la } \\
\text { manera de trabajar del proyecto Nós Propomos. }\end{array}$ \\
\hline $5 / 9 / 17$ & Reunión del departamento de Sociales que acepta introducir el proyecto en la \\
\hline
\end{tabular}

\footnotetext{
${ }^{2}$ Contribuir a la innovación en una educación geográfica decididamente apostada en la construcción de la ciudadanía territorial. (...) relacionado con la apropiación, transformación e identificación de las comunidades con el territorio en que habitan.
} 


\begin{tabular}{|c|c|}
\hline & de manera experim \\
\hline 2/10/17 & $\begin{array}{l}\text { El profesor Sergio Claudino nos da la bienvenida al proyecto y nos ofrece su apoyo y } \\
\text { colaboración. }\end{array}$ \\
\hline $30 / 10 / 17$ & $\begin{array}{l}\text { Reunión del equipo docente del ámbito sociolingüístico, se acuerda participar en el } \\
\text { proyecto con los alumnos de } 2 \text { ESO e introducción al proyecto de los alumnos de } 1 \\
\text { ESO. }\end{array}$ \\
\hline 28/11/17 & $\begin{array}{l}\text { Realización seminario formación organizado por el CEFIRE: El trabajo por ámbitos } \\
\text { como nueva metodologia inclusiva de trabajo. }\end{array}$ \\
\hline $30 / 11 / 17$ & Inscripción del centro en el proyecto internacional Nós Propomos. \\
\hline $8 / 2 / 18$ & $\begin{array}{l}\text { Preparación de la presentación pública de los resultados del proyecto en València } \\
\text { junto con institutos de Ciudad Real y Ontinyent. }\end{array}$ \\
\hline $3 / 3 / 18$ & $\begin{array}{l}\text { Presentación de resultados del proyecto en España. Paraninfo de la Universidad de } \\
\text { València. }\end{array}$ \\
\hline 12/4/18 & $\begin{array}{l}\text { Presentación de los resultados del programa al Claustro y al Consejo Escolar. } \\
\text { Informe de evaluación del proyecto y petición de inclusión del proyecto Nós } \\
\text { Propomos en el Proyecto Educativo del Centro. Se aprueba. }\end{array}$ \\
\hline
\end{tabular}

Fuente: Elaboración propia.

c) Propuesta didáctica:

El principal motivo que justifica la incorporación al proyecto Nós Propomos fue que existía una confluencia entre las propuestas y las ideas que el proyecto proponía y el trabajo que estabamos intentando articular en los primeros cursos ESO des del ambito sociolingüístico.

La fundamentación teórica es necesaria para guiar una metodología clara. La confluencia de las propuestas de los profesores Xosé Manuel Souto (1994) y Francisco García Pérez $(1993,2001)$ que nos habían servido de guía para el estudio de geografía urbana con las propuestas del profesor Sérgio Claudino (2014) nos reafirmó en nuestra opción tanto teórica como metodológica. Las teorías de la comprensión ciudadana del espacio, la percepción subjetiva de las ciudades explica Souto (1994 p98)

"además de ayudarnos, a los ciudadanos, a estructurar nuestras imágenes mentales de la morfologia urbana, la escuela Humanística y de la Percepción nos permite tambièn comprender las diferentes valoraciones que hacemos de las partes o el conjunto de la ciudad (...) La escena urbana, la percepción del significado de los lugares tanto para el observador como para el vecino, se convierten así en temas de estudio para esta perspectiva de análisis del medio urbano. Un estudio de enorme trascendencia en el campo de la didáctica, pues el alumno puede reconstruir la realidad a partir de "su realidad". De esta forma el profesro aparace como el "investigador" que aporta nueva información a la clase para ser contrastada con las ideas de los alumnos. Se proboca así una situación problemática entre las ideas subjetivas y espontáneas y las informaciones conceptuales y más objectivas que ofrece el profesorado desde sus lecturas i conocimiento".

Debemos considerar además cómo el alumno recibirá e interpretará la información 
que le facilitamos para articular un camino que le permita articular una explicación coherente (Souto 2017 p.86). Dependiendo de esta comprensión el grupo-clase podrá socializar este nuevo conocimiento. Será necesario un método que guíe la selección de conceptos y procesos de razonamiento por ello elegimos el modelo didáctico propuesto por García Pérez y otros (1993) en su unidad didáctiva Vivir en la ciudad. También recurriremos al mismo autor, García Pérez (2001 p.166), para considerar las ideas previas de los alumnos y los obstáculos en la progresión de la concepción de la ciudad.

No resulta superfluo insistir en que el profesor Souto González en València con el grupo Gea-Clio y el profesor Garcia Pérez en Sevilla con el grupo IRES trabajan muchos años en grupos de investigación y renovación pedagógica centrada en el ámbito de las Ciencias Sociales conectando la reflexión teórica con la práctica en las aulas. En el mismo sentido de trabajo colaborativo y de larga trayectoria, el proyecto Nós Propomos nos pone en contacto con el profesor Sérgio Claudino y su propuesta de ciudadania territorial.

Los contenidos se plantean a través de la resolución de problemas escolares. El conocimiento de procesos sociales se adquiere a través de habilidades lingüísticocomunicativas dentro del ámbito evitando la juxtaposición de contenidos. "Adota-se, assim, claramente uma perspetiva construtivista da aprendizagem, com os temas a decorrem diretamente dos interesses dos alunos". ${ }^{3}$ (Claudino, Sérgio. 2014 p.6).

La diversidad del alumnado y las ideas previas y capacidades de los alumnos se tendrán en cuenta a la hora de la composición de grupos intentado que sean lo más heterogéneos posible.

El ámbito sociolingüístico tanto en primero como en segundo de la ESO dispone de 9 horas semanales organizadas en sesiones de dos horas. De esas nueve horas, cuatro se dedican a la elaboración y presentación del proyecto y una hora cada dos semanas para recapitular y reflexionar sobre el procedimiento. En total, ocupamos sesenta horas de trabajo en clase y ocho para reflexionar. Los útimos días cada grupo presentará su proyecto a la clase para ser evaluado.

Dotarnos de una base teórica y metodológica determinada nos ayudará a que el proceso de enseñanza-aprendizaje se convierta en una investigación para el profesor, en una experimentación que busque un modelo alternativo a la presentación de la

\footnotetext{
${ }^{3}$ Se adopta, así, claramente una perpectiva constructivista del aprendizaje, con los temas que se derivan directamente de los intereses de los alumnos
} 
ciudad como objeto de estudio que sea coherente y útil a los alumnos y profesores. Esta propuesta educativa que ahora articulamos de manera conjunta ya la intenté organizar de manera individual hace algunos años en la ciudad de Alzira (Peris de Sales, V. 2004).

El espacio urbano es entendido como un ecosistema del que podemos extraer contenidos curriculares para el ámbito sociolingüístico. La ciudad es un recurso didáctico privilegiado ya que la población escolar y sus experiencias de vida se insertan en este ambiente que ofrece una calidad de vida diferenciada a sus ocupantes.

"La geografía cuenta con un bagaje disciplinar que permite el planteamiento de enfoques globalizadores, interactivos, donde la relación personas-medio puede ser el eje didático conductor". (Garcia, F. 1993 p.40)

La propuesta de unidad didáctica del profesor Francisco García Pérez es muy apropiada para articular de forma coherente y metódica el enfoque constructuvista en el que coinciden García, Souto y Claudino. Transitar de un conocimiento vulgar problematizando su incapacidad para explicar la realidad a un conocimiento escolar que permita mejorar la explicación de la realidad de manera compartida.

También resulta pertinente conocer del proyecto Gea Clio el manual ¿Cómo abordar los problemas ambientales y sociales desde el aula? de Pilar Pérez, Santos Ramírez y Xosé M. Souto y el manual Nós Propomos de Aparecido Bazzoli, Costa e Silva y Rocha Viana 2017 Palmas Universidade Federal do Tocantins http://nospropomos.blogspot.com.br todos ellos trabajos colaborativos.

\section{Programación de aula ${ }^{4}$}

Comenzaremos presentándonos como profesor de ámbito y presentado la materia que vamos a trabajar y para qué vamos a trabajar, qué capacidades vamos a poner en práctica. De ellas destacaremos que los alumnos más que contenedores de información deben esforzarse tanto en saber conseguirla como en saber transmitirla.

Para la introducción de conceptos, primero se explicarán los más generales que permitirán agrupar los posteriores e interrelacionarlos.

\footnotetext{
${ }^{4}$ Esta programación es personal y los errores que en ella existan son de mi única responsabilidad, los profesores Maria Martínez, Estrella Sáez y Francesc Ruíz han realizado amables sugerencias lo que les agradezco.
} 
Siempre trataremos de explicar el origen y el significado de las palabras.

Los alumnos trabajarán tanto de forma individual como en grupo.

Tarea 1- Descubrir las ideas previas de los alumnos.

Realizaremos tres ejercicios:

1. Ordenar las palabras según el espacio que abarquen de mayor a menor. Subrayar las que desconozca pero ordenarlas también aunque sea de manera intuitiva.

Ej.: Ciudad, barrio, distrito, conurbación, área metropolitana, manzana, finca, piso.

2. ¿En qué parte de la ciudad vives? ¿Podrías situar tu piso en la ciudad con ayuda de la web municipal del Ajuntament de València?

3. ¿Qué diferencia un pueblo de una ciudad? Lluvia de ideas anotando las que más se repitan y las que mejor se argumenten.

Tarea 2- Introducción de conceptos.

1. La localización espacial.

Coordenadas geográficas, coordenadas históricas y los vientos.

1.1. Lectura de algunos párrafos del poema Veles e vents de Ausiàs March y contextualización histórica (campaña Nápoles). Análisis del origen del topónimo Nápoles (nea-poli) y uso literario de la comparación con "arrós al forn".

2. Introducción de conceptos.

2.1. Diferencias entre pueblo y ciudad a través de los conceptos: infraestructura, equipamiento y servicio y las relaciones entre ellos.

2.2. Relación entre concetración de recursos y consumidores y sus consecuencias: generación residuos, actividad económica, movilidad. Ciudad como ecosistema. Una desigual conectividad marca el precio del suelo.

3. La representación de la realidad. Gráficos, planos y mapas.

3.1. Definición. Presentación con interés de los datos. Permitirá entender rápidamente mucha información.

3.2. Elementos que necesitamos saber en cualquier representación y en este orden:

1) Variable/s- Elemento que posibilita la representación. 
2) Valor- Forma en que se presenta la variable. Puede ser cifra relativa, relacionada con otra variable o cifra absoluta sin relación.

3) Título- Incluye: variable, espacio y tiempo (valor opcional)

4) Leyenda- Cuatro bloques. Servirse de la media si se puede.

5) Fuente- Tres tipos posibles: Elaboración propia, desconocida o citación de la fuente.

6) Escala (puede no estar). Relación de proporcionalidad que guarda representación con la realidad. Tipos de escala: gráfica o numérica.

7) En mapas signos puntuales, lineales o espaciales.

3.3. Formas de representación:

1) Diferencia entre mapa y plano, la escala. Las dos son representaciones simplificadas, convencionales y a escala de la realidad. Gran escala-poco espacio, típico de los planos. Pequeña escala-gran espacio, típico del mapamundi.

2) Los gráficos, representaciones sin referente espacial: los presentamos por su utilidad. Si queremos representar la evolución de una variable en el tiempo usaremos el gráfico lineal (les diremos que hacemos un vídeo). Si representamos la distribución de elementos en un momento dado usaremos el gráfico de sectores (en este caso diremos estamos haciendo una foto). Otros gráficos que también explicaremos seran el gráfico de barras y la línea del tiempo.

Tarea 3 - Elabora un plano de la classe que contenga los siete elementos citados anteriormente.

Actividad que estará muy pautada por ser inicial. Las actividades a realizar serán:

1) Medir el aula en metros.

2) Orientar las paredes del aula, coordenadas geográficas.

3) Crear una escala fácil permita la representación en un folio.

4) Decidir cómo voy a simplificar. Qué elementos incluyo.

5) Crear signos de los elementos a representar. Código pictográfico o geométrico. 
6) Elaborar la representación

Tarea 4- Elaborar un plano del patio del centro. Actividad grupal. Pasos.

1) Elaborar grupos heterogéneos. Cuatro alumnos con diferentes capacidades.

2) Intentar despertar espíritu competitivo entre ellos. Voluntad de superación.

3) Pautar mucho la actividad. Como hemos dicho anteriormente, no podemos presuponer que entienden las indicaciones. La experiencia muestra que el profesor falla bastante en transmisión de información.

4) Motivar valorando los buenos resultados pero sin solucionarles los problemas que surjan.

Tarea 5- Intentar localizar el plano del patio en la web municipal. Localizar el centro escolar.

Tarea 6- Recapitulación. Repaso de los conceptos vistos hasta el momento. Forma transmisión información por parte de los alumnos. Composición de un texto resumen, tarea individual.

Tarea 7- Presentación a los alumnos proyecto Nós Propomos.

Las tareas propuestas anteriormente han sido el preàmbulo para poder iniciar el proyecto de estudio de la realidad urbana de los alumnos siguiendo el método de trabajo propuesto por Nós Propomos.

Como ya se ha dicho el proyecto está incluido en la Programación General Anual y en esta especificamos que los alumnos harán visitas al barrio, a su zona de estudio para lo que se ha pedido el pertinente permiso a los padres.

El proyecto propone un trabajo en grupos de cuatro alumnos el producto del cual será una propuesta de actuación sobre un problema detectado en el barrio.

El problema deberá ser descrito y categorizado. Derivado de la aglomeración de consumidores, recursos y actividades en las ciudades será por tanto generalizable al conjunto urbano.

El primer paso será explicar el método científico para analizar y dar solución al problema. El manual de la universidad de Tocantis dispone de unos anexos muy ilustrativos de cómo organizar el trabajo. Tendremos que definir un problema de tratamiento fácil. En primer curso ESO se ha hecho un planteamiento que, como 
veremos en las valoraciones, adolece de excesiva simplificación. Por el contrario en el segundo curso ESO el planteamiento propuesto ha sido mejor definido y, por ello, mejor resuelto por los alumnos.

Los alumnos han realizado tres salidas de aproximadamente dos horas por el barrio para seleccionar y documentar los problemas.

Los problemas se agrupan en:

1) Antropización ecosistema urbano. Producción de residuos, contaminación y su tratamiento.

2) Aglomeración de recursos y consumidores.

3) Movilidad, connexión entre oferta y demanda de bienes y servicios.

4) Viviendas, equipamientos y servicios. Diferencias en precio del suelo.

Técnica de trabajo de los grupos. Esquema propuesto por Nós Propomos.

1. Recogida información. Centrado en fotos y entrevistas a vecinos.

Problemas en la localización y en las formulación preguntas a los vecinos.

2. Descripción del problema. ¿Cuáles son las posibles causas? ¿Cuáles son las soluciones?

3. Presentación del proyecto a la clase. Valoración conjunta.

4. Exposición del proyecto en el centro. En este punto termina primer curso ESO.

5. Exposición del proyecto al público y compañeros. Paraninfo Universidad 3 marzo.

Instrumentos utilizados para la evaluación del proyecto, de las capacidades desplegadas.

1. Observación directa.

2. Cuaderno del alumno. Apuntes, composición textos, anotaciones profesor.

3. Iniciativa, autonomia y adecuación al tiempo propuesto.

4. Capacidad de trabajar en equipo.

5. Valoración de producto final. 
6. Valoración del proyecto.

\section{Los resultados. El producto final}

PRIMERO ESO Grupos C y D 66\% participación.

Lo primero que destacaremos es que la participación, a pesar de que el trabajo era obligatorio, apenas ha alcanzado los dos tercios. Varios grupos de alumnos han optado por no presentar el trabajo y por ello no han tenido una evaluación satisfactoria en el primer trimestre.

Creo que es oportuno replantearse por parte de los profesores la manera de presentar el proyecto en este grupo. Se ha simplificado en exceso la información facilitada a los alumnos y los procedimientos para realizar las tareas no han sido entendidos suficientemente por los alumnos.

Los profesores hemos presupuesto conocimientos y prácticas en los alumnos que desconocían y por ello su interpetación y puesta en práctica es manifiestamente mejorable. Respecto de los trabajos realizados los comentaré brevemente.

Las clases dedicadas a dinamizar y corregir los posibles errores del proyecto no han sido fructíferas. Puede esto deberse a que los alumnos sabían que su trabajo no iba a presentarse en público y eso ha influido en su dedicación, pero creemos que se deberá más a que los profesores en primero ESO, yo era uno de ellos, no han sabido explicar claramente el producto final que se esperaba de los alumnos. Se han centrado en recogida de fotos y entrevistas a vecinos pero se apreciaban deficiencias en el tratamiento: preguntas poco elaboradas que dirigían las respuestas, problemas puntuales, evidentes no interrelacionados y, por ello, escasamente significativos.

Podemos agrupar los proyectos por su temática de la siguiente manera:

1. Obres sense acabar.

4. Desperfectes de la ciutat.

El problema identificado era que existían demasiadas obras iniciadas que generaban molestias a los ciudadanos. No diferenciaban entre responsables públicos y privados de las obras y se centraban en casos muy concretos, no conseguieron categorizar el problema. 


\section{Quatre Carreres.}

\section{Barris de la Ciutat.}

Estos dos proyectos se han quedado en la identificación de las partes del distrito Quatre Carreres que ha sido el espacio de trabajo sobre el que se han realizado las tareas para identificar los problemas. En clase no hemos podido superar esta idea de que el trabajo era simplemente la identificación de las partes. Intentaremos en los próximos proyectos que los alumnos mediante fotos nos muestren su espacio vivido y hagan una valoración.

5. Un arbre singular desconegut al nostre barri.

Este trabajo es interesante porque una participante ha buscado ayuda familiar y ha conseguido tratar un tema de manera bastante completa. La valoración patrimonial de un árbol más que centenario en un aparcamiento del barrio.

\section{La basura.}

Aunque han tratado un tema concreto lo han hecho de forma muy general. Las fotos utilizadas no se corresponden con el barrio y las soluciones apuntadas tampoco.

Resultados en 2 ESO 100\% participación.

La participación de los alumnos de este curso ha sido fenomenal, igual que la evaluación de los resultados. Realizaron salidas al barrio para detectar problemas pero en estos grupos se aprecia una capacidad de categorización clara, una madurez no sólo explicable por la diferencia de edad, posiblemente el profesorado había explicado mejor la tarea. En los proyectos podemos diferenciar los específicamente urbanos y otros que la realidad urbana agudiza. Creo que sería interesante agrupar y diferenciar los temas específicamente sociales de los que tienen además un componente espacial.

Los alumnos se han sentido más implicados. Han hecho uso de las TIC para elaborar unos vídeos como resultado final. También destaca que algunos grupos, ante la sugerencia de los profesores de entrevistar a especialistas en el tema, no sólo han entrevistado a vecinos sino también a responsables políticos y a profesores. El título de los trabajos es más elaborado también que los anteriores. Creo que tener que presentar sus trabajos en público les ha motivado. Incluso han decidido presentar su trabajo en valenciano, lengua que la mayoría no usa habitualmente por vivir en un paisaje lingüístico castellano. Creo que los profesores han hecho un planteamiento 
más acertado y los alumnos han interpretado mejor las indicaciones de los profesores. En la presentación del dia 3 de marzo en el Paraninfo de la Universitat de València mostraron sus trabajos con cierto orgullo y los días posteriores en el centro se hicieron pases de los vídeos para muchos familiares y amigos que no habían acudido a la presentación que montamos el viernes previo a la visita a la universidad.

Tipos de problemas.

1- Generales

- Treball infantil i absentisme escolar.

- Explotació sexual i violència de génere.

- Segregació social Racisme homofòbia, xenofòbia.

- Maltractament animal.

- Premsa fiable.

- La corrupció.

2- Uso recursos

- Fum negre (contaminació).

- Contaminació acústica i lumínica.

- Contaminació de l'aigua.

- Plagas.

- Residus i neteja.

- Efectes del canvi climàtic.

3- Aglomeración

- Comercio y consumo.

- Seguridad Ciudadana.

- Jóvenes y ocio.

4- Políticas y planificación

- Urbanismo.

- Desigualtats socials. 
- Problemes d'habitatge.

- Problemes de circulació.

- El transport públic.

\section{VALORACIÓN DE LOS RESULTADOS}

Existen algunas diferencias entre los resultados esperados y los resultados obtenidos en la realización del proyecto. El producto final realizado por los alumnos no ha sido totalmente congruente con el producto programado por el equipo de profesores. Esta afirmación concuerda con la apuntada en su momento en la propuesta educativa realizada sobre la ciudad de Alzira en 2002 (Peris de Sales, V. 2004 p.72). Podemos por tanto constatar problemas que podrían ser debidos a las deficiencias del sistema educativo, no de los alumnos.

\section{Conclusiones}

Las conclusiones más relevantes que podemos destacar son las siguientes:

1- La decisión de la comunidad educativa de mejorar la calidad educativa del centro, en base a la aplicación de la orden de transición de primaria a secundaria, ha creado un entorno apropiado para poder experimentar e innovar en la praxis educativa. El ámbito sociolingüístico es el contenedor apropiado para llevar a cabo proyectos como el Nós Propomos que renovaremos anualmente al ser ya parte de nuestro proyecto educativo.

2- La respuesta de los alumnos ha sido magnífica. La motivación por descubrir, analizar y proponer soluciones a problemas que son evidentes en su entorno más cercano les ha ayudado a conocer conceptos de geografía urbana y han aumentado su autoestima, han visto valorado su trabajo y han creado competencia entre grupos por realizar un trabajo aceptable por la comunidad.

Los alumnos de segundo ESO han realizado un trabajo completo mientras que los alumnos de primero ESO han ofrecido una respuesta más mediocre, incluso algunos grupos no han terminado su proyecto.

3- El papel del profesor es clave en la creación de equipos de trabajo.

La finalidad que los profesores asignan a la educación y la función de ellos mismos como mediadores para permitir unos aprendizajes significativos por parte de los 
alumnos no es única y la participación y la colaboración en equipos de trabajo o la realización de tareas aisladas en el aula han marcado la primera diferencia entre los alumnos que han participado en el proyecto y aquellos que no han podido hacerlo.

Presentar problemas más que temas, problematizar el conocimiento es una opción educativa que hemos escogido los profesores que participamos en la elaboración de este proyecto.

4- La experiencia del profesor en programar y explicar a los alumnos qué producto final es el que se espera que elaboren también es relevante. No sólo es querer, es practicar y experimentar para mejorar la mediación con los alumnos. También es tener las habilidades necesarias para convencer a los compañeros e implicarlos en esta tarea de mejorar el trabajo que como profesionales estamos obligados.

5- Los poderes municipales de la ciudad han participado de manera diferenciada. Mientras algunos responsables municipales han participado en entrevistas de manera entusiasta, en la presentación de los resultados su presencia ha sido nula frente a la participación de representantes de Ciudad Real y Ontinyent. Una presencia institucional más visible hubiera ayudado a dar satisfacción a los alumnos. Es otro de los aspectos que debemos mejorar.

\section{Referencias bibliográficas}

Aparecido Bazzoli; Costa e Silva y Rocha Viana (2017) Manual Nós Propomos. $\begin{array}{lllll}\text { Palmas Universidade } & \text { Federal } & \text { do } & \text { Tocantins }\end{array}$ http://nospropomos.blogspot.com.br

Claudino Sérgio (2014) Escola, Educaçao geográfica e cidadania territorial. Scripta Nova. Revista Electrónica de Geografia y Ciencias Sociales ㄲo 494 (09), 2014 http://www.ub.edu/geocrit/sn/sn-496/496-09.pdf

García Pérez, Francisco y otros (1993) Vivir en la ciudad: una unidad didáctica para el estudio del medio urbano. Investigación en la Escuela, ํo 20 pp 39-64.

García Pérez, Francisco (2001). Las ideas de los alumnos. Su importancia para la organización de los contenidos curriculares. En Souto, X.M. (comp) Proyecto Gea-Clio. La didáctica de la Geografia $i$ la Història en un món globalitzat $i$ divers. Eines d'Innovació Educativa 6. L'Ullal Edicions i Federació Ensenyament CCOO. pp 156170. 
Pérez, P.; Ramírez, S.; Souto, X.M. (2006) ¿Cómo abordar los problemas ambientales y sociales des de el aula? Gea-Clio. Nau Llibres València pp 90.

Peris de Sales, Vicent (2004) La recerca d'instruments educatius a la ciutat d'Alzira. Actes de la X Assemblea d'Història de la Ribera. Volum miscel-lani. Ajuntament d'Antella, Edició a cura de Marina Estarlich Martorell. pp 69-78.

Souto González, Xosé Manuel (1994) Implicaciones didácticas del estudio geográfico de las ciudades. Investigaciones Geográficas no 12 pp 93,118.

Souto González, Xosé Manuel (2017) Los métodos didácticos en la enseñanza del espacio geográfico. En Sebastià Alcaraz y Tonda Monllor (eds) Enseñanza y aprendizaje de la geografia para el S.XXI Publicacions de la Universitat d'Alacant UNE. pp 73-76

Tarabini, A. (Dir.); Jacovkis, J.; Montes, A. Los factores de la exclusión educativa en España: Mecanismos, perfiles y espacios de intervención. Edita UNICEF Comité Español Madrid www.unicef.es. Informe encargado por UNICEF Comité Español a la Universidad Autónoma de Barcelona con el Asesoramiento científico de Juan Manuel Escudero (Universidad de Murcia). Depósito Legal M-11216-2017, ISBN 978-84942273-6-3.

\section{Legislación}

Ordre 46/2011 transició $1^{\circ-2} 2^{\text {a }}$ Conselleria Educació per la que es regula la transició des de l'etapa d'Educació Primària a l'Educació Secundària Obligatòria en la Comunitat Valenciana (DOCV 23/06/2011). Recuperat el 23-10-2017. http://www.docv.gva.es/datos/2011/06/23/pdf/2011_7216.pdf

Decret 104/2018 de 27 de juliol del Consell, pel qual es desenvolupen els principis d'equitat i d'inclusió en el sistema educatiu valencià. Recuperat 16-9-2018 https://www.dogv.gva.es/datos/2018/08/07/pdf/2018_7822.pdf Ley Orgánica 8/2013, de 9 de diciembre, para la mejora de la calidad educativa. BOE no 295 de 10/12/2013. Jefatura del EstadoReferencia: BOE-A-2013-12886 Recuperado el 28-02-2018. 


\section{DOMÍNIO A \\ Projeto Nós Propomos!}

Eixo 2

Perspetivas e reflexões teóricas e metodológicas 


\section{O Nós Propomos! no Paranoá- DF: um olhar geográfico sobre a cidade}

DENISE MOTA PEREIRA DA SILVA ${ }^{1}$

\section{Resumo}

Este trabalho é constituído por um estudo de caso da implementação do projeto Nós Propomos em uma escola de ensino fundamental, na rede pública do Paranoá, Região Administrativa do Distrito Federal, no ano de 2017. O projeto foi desenvolvido com 70 alunos de $9^{\circ}$ ano, a partir dos seguintes pressupostos pedagógicos: promoção de conhecimento a partir de pesquisa; contribuição para o desenvolvimento do raciocínio geográfico; favorecimento de uma postura cidadã frente aos problemas cotidianos da vida na cidade. Durante o $1^{\circ}$ semestre letivo, estudou-se a cidade do Paranoá tanto por meio da cartografia quanto de saídas a campo, o que permitiu pensar a sua conexão com Brasília, problematizando a configuração político-administrativa do Distrito Federal, bem como representar graficamente o lugar por meio do desenho e explorar outras linguagens como cinema e fotografia, com a finalidade de construir conceitos chaves da geografia. No $2^{\circ}$ semestre, os estudantes formaram grupos, cada um dos quais definiu um problema da cidade - tal como comércio ilegal, drogas na escola, coleta de lixo, vias de circulação para pedestres, acidentes de trânsito, uso do Lago Paranoá, cultura alimentar de jovens e alimentação escolar -, para o qual deveria propor soluções, desenvolvendo as etapas de pesquisa bibliográfica e empírica por meio de produção e análise de dados. Os estudantes receberam orientação docente ao longo de todas as atividades, cuja culminância foi a realização de um seminário, com a participação de autoridades e comunidade, no qual cada grupo expôs suas pesquisas e resultados. Houve avanços na aprendizagem com a apropriação de conhecimentos geográficos e mudança positiva de postura dos

\footnotetext{
${ }_{1}^{1}$ Professora da Secretaria de Educação do Distrito Federal- SEEDF, doutoranda em Geografia pelo Programa de Pós-Graduação em Geografia-PPGEA da Universidade de Brasília- UnB, mota.denise@uol.com.br
} 
estudantes, ao perceberem-se como agentes de transformação e produção do lugar em que vivem.

Palavras-chave: Projeto Nós Propomos; Paranoá; aprendizagem em Geografia.

\section{Abstract}

This work is a case study of the We Propose project, which was implemented in a public elementary school with students from the age group of fourteen to sixteen years old, in Paranoá, Federal District - Brazil, in 2017. The project was developed with 70 students, based on the following pedagogical presuppositions: to promote knowledge based on research, to contribute to the development of geographic reasoning, and to favor a citizen's posture in face of the daily problems of city life. In the first semester of the school year, the study of Paranoá through cartography and field trips around the city allowed the students to think about its connection with Brasília, as well as to problematize the political-administrative configuration of the Federal District, to graphically represent the place through drawing and to explore other languages such as cinema and photography with the purpose of constructing key concepts of geography. In the second semester, the students were assembled in groups and each defined a city problem for which they should propose solutions. They developed the stages of bibliographical and empirical research through the production and analysis of data on different themes: illegal trade, drugs at school, garbage, pedestrian circulation routes, traffic accidents, Paranoá Lake use, youth food culture and school feeding. Students received instructional guidance throughout all activities. The culmination of the project was the holding of a seminar, with the participation of authorities and community, in which the students presented their research and its results. There have been advances in learning with the appropriation of geographical knowledge and positive change of posture as the students started perceiving themselves as agents of transformation and production of the place where they live.

Keywords: We Propose project; Paranoá; learning in Geography.

\section{Introdução}

Este artigo é resultado de análise da implementação do projeto Nós Propomos em uma escola de ensino fundamental da rede pública do Distrito Federal. O aporte teórico, baseado em autores da Geografia Escolar, dentre outros, possibilitou identificar e analisar os desafios inerentes ao cotidiano da sala de aula, especialmente 
aqueles relacionados ao processo de ensino-aprendizagem de Geografia na educação básica.

O projeto Nós Propomos configura uma possibilidade de inovação na aprendizagem em geografia, uma vez que considera, por um lado, a percepção do estudante sobre sua própria realidade, e, por outro, a pesquisa como elemento norteador das ações desenvolvidas e a formação na e para a cidadania. À medida que a centralidade do processo de aprendizagem vai sendo, paulatinamente, deslocada para o estudante, este torna-se sujeito ativo das aulas.

Ao longo de 2017, o Nós Propomos foi desenvolvido no Centro de Ensino Fundamental 03, unidade de ensino da rede pública do Distrito Federal localizada no Paranoá, com 70 estudantes, das turmas dos 9ao $\mathrm{E}$ e $\mathrm{F}$, residentes locais e de idade entre 14 e 16 anos. Esses estudantes foram sujeitos desta pesquisa duplamente, na medida em que, em primeiro lugar, atuaram como protagonistas na adesão ao projeto no âmbito da escola, e, após, como sujeitos que foram analisados na perspectiva do desenvolvimento do raciocínio geográfico.

O Paranoá é uma das 31 Regiões Administrativas - RA - do Distrito Federal e está localizado a sudeste desta unidade da federação, destacando-se, dentre outras razões, por apresentar uma das maiores áreas territoriais do quadrilátero, conforme pode ser observado na figura 1. 


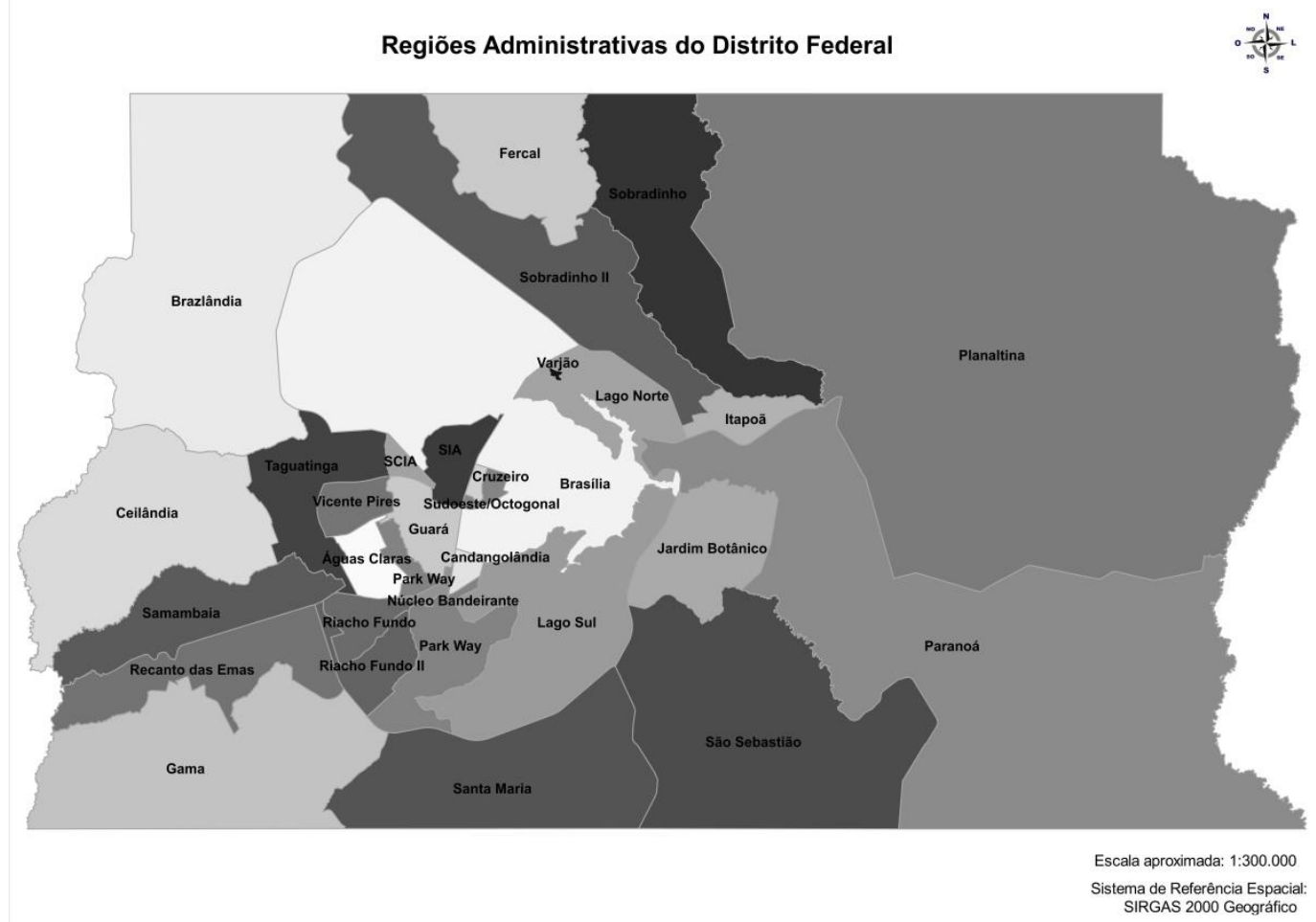

Fonte: Organizado por Daldegan, 2014 (a partir de dados da CODEPLAN)

O planejamento das ações foi norteado pela temática ampla da cidadania na educação geográfica, bem como pelas condições reais da escola e da comunidade, pelas particularidades locais e pelo perfil sociocultural das turmas. O projeto foi desenvolvido, assim, a partir dos seguintes pressupostos teórico-metodológicos: promoção do conhecimento a partir da pesquisa; contribuição para o desenvolvimento do raciocínio geográfico; favorecimento de uma postura cidadã frente às circunstâncias e problemas cotidianos da vida na cidade.

Por apresentar uma configuração político-administrativa distinta das demais unidades da federação, sendo subdividido em regiões administrativas e não em municípios, o Distrito Federal apresenta especificidades com as quais os estudantes devem se familiarizar ao longo da educação básica, a fim de que se apropriem do espaço onde residem. No entanto, são muitos os que, ao concluírem o ensino fundamental, apresentam conhecimento superficial sobre ou mesmo desconhecem essa configuração, suas particularidades e relações entre as escalas local, regional e global. Daí a necessidade de instrumentaliza-los com conhecimentos necessários sobre o seu lugar de vivência, com vistas a uma prática cidadã que só se torna efetiva na medida em que se entende a dinâmica complexa e contraditória inerente a toda e qualquer porção do espaço. 
Tal organização político-administrativa impõe, ainda, uma lógica de representação social que, em detrimento das demais cidades, enaltece a RA Brasília por ser a capital do país. A ocupação desordenada e a ausência de investimentos públicos nas cidades vizinhas a Brasília promovem um arranjo espacial que corrobora a imagem depreciativa que, não raro, os próprios moradores têm de sua cidade. Não obstante, a identidade com o lugar é fundamental para o processo de entendimento e compreensão das contradições e tensões presentes no espaço, que precisa ser mediada pelo trabalho pedagógico desenvolvido pelo professor de Geografia, cujo papel é o de conduzir os estudantes em sua leitura do espaço, a fim de que decodifiquem símbolos e desmascarem a realidade que lhes é apresentada.

Para o desenvolvimento desta pesquisa, foram utilizados os pressupostos da pesquisa qualitativa com a opção pelo estudo de caso, que possibilita a análise aprofundada de um fenômeno sem perder de vista a complexidade e subjetividade inerentes ao campo educacional. Também foi utilizado o diário da pesquisadora para registros de observações que se davam ao longo das aulas, nos encontros fora da sala de aula e até mesmo em mensagens e postagens nas redes sociais como Facebook e Whatsapp.

O artigo organiza-se, assim, em duas partes. Na primeira, consta a descrição dos passos metodológicos utilizados para a implementação do projeto e as observações e análises decorrentes dos registros feitos no diário da pesquisadora, referentes aos resultados obtidos, progressivamente, em cada etapa do projeto. $\mathrm{Na}$ segunda, os resultados são analisados à luz do aporte teórico da Geografia Escolar, na perspectiva do desenvolvimento do raciocínio geográfico por meio da construção de conhecimento que se centra na pesquisa e na formação de postura cidadã frente às circunstâncias e problemas cotidianos da vida na cidade.

\section{A implementação do projeto Nós Propomos no Paranoá-DF: desafios metodológicos da Geografia Escolar}

No início do ano letivo de 2017, o projeto Nós Propomos foi apresentado aos estudantes do 9o ano do ensino fundamental, ao grupo gestor da escola e aos responsáveis que consentiram a participação dos estudantes no âmbito da disciplina de PD, que corresponde ao componente curricular denominado Parte Diversificada, obrigatório no currículo da educação básica brasileira desde a Lei de Diretrizes e Bases da Educação Nacional (LDB) de 1996. A LDB estabelece que a parte 
diversificada do currículo deva articular-se ao contexto histórico, econômico, social, ambiental e cultural da escola (Brasil, 1996), de forma a constituir importante espaço para que aspectos socioculturais que conformam a comunidade escolar sejam inseridos e abordados como conteúdos relevantes na formação básica do estudante. Infelizmente, no entanto, com frequência ela serve apenas para compor matematicamente/burocraticamente a carga horária dos professores. Nesse contexto, a implementação do projeto Nós Propomos permitiu cumprir o papel das aulas de PD definido pela LDB de 1996 e, da mesma forma, atender aos pressupostos teóricometodológicos do Currículo em Movimento do Distrito Federal, orientado pela pedagogia histórico-crítica e a Psicologia histórico-cultural.

Durante as aulas do primeiro bimestre, foi apresentada aos estudantes a organização político-administrativa do Distrito Federal e sua configuração em Regiões Administrativas, com foco na Região Administrativa Paranoá, a partir da leitura de mapas e atividades cartográficas realizadas em sala de aula. O objetivo, nesta primeira etapa, era o de despertar o interesse pelo estudo cartográfico do DF a partir das peculiaridades de se viver na única unidade da federação que não possui municípios nem tampouco bairros. As implicações de ordem jurídica, tal como as especificidades do processo eleitoral, diferenciado das outras unidades da federação, despertaram a curiosidade dos estudantes e produziram questionamentos como: "Então, quem governa o Paranoá, se não tem prefeito aqui?"; "Quem toma conta do DF e da nossa cidade é o presidente?". As perguntas dinamizaram as aulas e contribuíram para que o objetivo da aprendizagem por meio da pesquisa fosse contemplado, na medida em que tais questionamentos constituíram perguntas de pesquisa, configurando-se em "deveres de casa" que foram retomados em aulas posteriores e discutidos coletivamente após os estudantes se apropriarem de informações sobre o assunto por meio de buscas na web e/ou conversas com professores e familiares.

A extensão territorial do Paranoá e sua proximidade com o Plano Piloto ${ }^{2}$, expressão comumente usada para se referir às asas norte e sul de Brasília, despertou a atenção dos estudantes e promoveu participação efetiva, o que permitiu identificar, a partir de questionamentos, as limitações quanto à leitura e compreensão dos elementos presentes nos mapas. As reações dos estudantes - surpresa, incompreensão, estranhamento - evidenciaram fragilidades no processo de letramento imagético e

${ }^{2}$ O Plano Piloto é o projeto urbanístico de Brasília concebido por Lúcio Costa. Contempla as Asas Sul e os Eixos Monumental e Rodoviário. 
alfabetização cartográfica ao longo do ensino fundamental. As dúvidas quanto a elementos como escala, legenda e outras convenções cartográficas exigiram adequações de algumas atividades, bem como a realização de um mapa mental cujo intuito foi identificar a capacidade dos estudantes de representarem o trajeto percorrido diariamente de suas casas à escola. Foram evidentes as dificuldades de utilização de técnicas de perspectiva ou de visão vertical sobre o trajeto representado. Essas noções cartográficas, previstas para serem aprendidas em anos anteriores, denotam limitações no processo de ensino de geografia, especialmente no tocante à cartografia, conforme demonstram os desenhos.

Figuras 2 e 3-Desenhos que demonstram dificuldades de representação em mapas mentais feitos pelos estudantes.
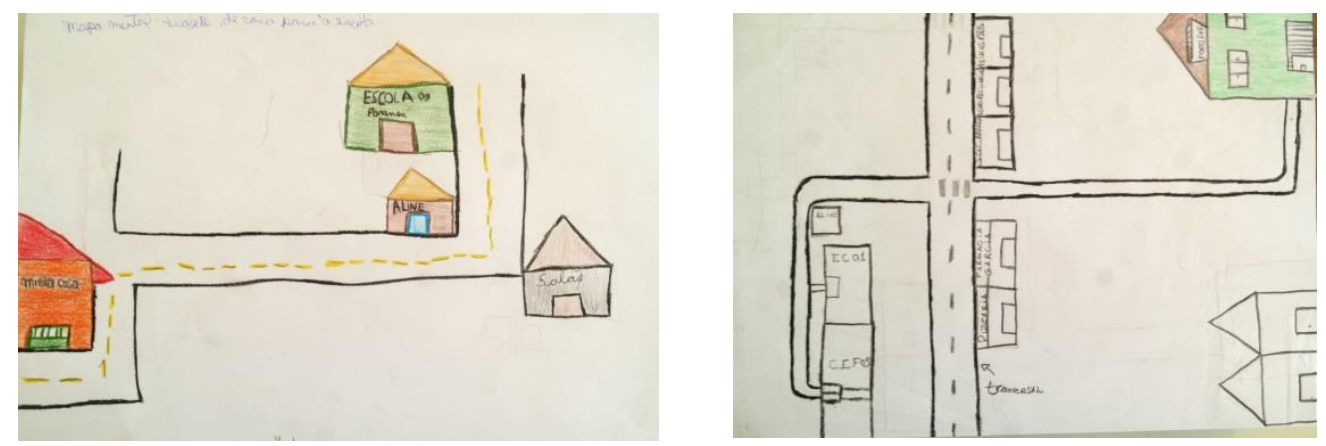

Fonte: Silva, D. M. P.

Ao se analisar o desenho do trajeto de casa para a escola, percebe-se que os estudantes não conseguiram representar uma visão vertical ou em perspectiva das casas e da escola. Os traços assemelham-se aos de crianças em fase de alfabetização, denunciando que não houve evolução dos anos iniciais para os anos finais quanto ao aprimoramento no uso de técnicas de representação do espaço. $O$ processo de alfabetizar cartograficamente tem se mostrado ineficiente, e se apresenta como um caminho difícil para as crianças percorrerem, porque "a única maneira de perceber qualquer área geográfica como um todo é vê-la de uma posição mais alta, e essa perspectiva não é familiar para a criança, nem, talvez, para muitos professores" (Oliveira, 2010, p. 26). Buscou-se, assim, suprir algumas lacunas dos anos/etapas anteriores por meio de atividades cartográficas cuja finalidade era "desenvolver o pensamento espacial, estimulando o raciocínio geográfico para representar e interpretar o mundo em permanente transformação e relacionando componentes da sociedade e da natureza" (Brasil, 2017, p. 358).

A despeito de habilidades não desenvolvidas no campo do letramento cartográfico, os estudantes se apropriaram de elementos que conseguiram decodificar, como a 
identificação do Paranoá, de outras Regiões Administrativas que Ihes eram familiares e dos limites do Distrito Federal com o estado de Goiás e municípios limítrofes ao DF. Afirmações e questionamentos como "eu não sabia que o Paranoá era tão grande!" ou "mas se o Paranoá tem esse território todo, por que todo mundo mora só nesse pedacinho?"(em referência à área urbanizada), e, ainda, "vou sempre pra Ceilândia, na casa da minha tia..." (procurando por Ceilândia atentamente, no mapa), dentre outras reações, explicitaram comparações quanto às distâncias do Paranoá em relação às demais $\mathrm{RA}$, ou aos municípios do estado de Goiás que fazem limite com o DF, como Águas Lindas de Goiás, Planaltina (GO), Formosa, Luziânia, dentre outros. Outra observação registrada foi a surpresa diante da visualização do Lago Paranoá: "Não sabia que o lago era tão grande assim!"; “Aqui do Paranoá não dá pra ver que o lago tem esse tamanho todo"; "Como o lago se formou?". As dúvidas sobre o lago acompanhavam incompreensões sobre Brasília enquanto capital federal planejada e suas relações com a RA Paranoá. Algumas aulas foram destinadas à exposição sobre o concurso que escolheu um plano urbanístico para a nova capital, durante o governo de Juscelino Kubitschek, que deu origem à construção de Brasília. O fato de o Paranoá ter surgido a partir da fixação de trabalhadores, quando da construção da barragem do lago, intensificou o interesse sobre Brasília enquanto cidade planejada e próxima (25 km de distância). As perguntas feitas pelos próprios estudantes converteram-se em temas a serem pesquisados e posteriormente debatidos em sala de aula.

Tendo em vista que pretendia-se promover a identificação do Paranoá no conjunto de cidades que constituem o Distrito Federal, sem exaltar a capital, pode-se dizer que o objetivo foi atingido, pois o uso instrumental dos mapas permitiu aos alunos situaremse enquanto moradores de uma cidade do DF, bem como em relação a outras cidades e a própria Brasília; com efeito, como afirma Oliveira, "o valor do mapa está naquilo que o professor se propõe a fazer com ele" (Oliveira, 2010, p. 23). É o mundo sendo feito através de relações, nas quais se encontra a política: um impulso para o mundo além do torrão de cada um; "um compromisso com essa contemporaneidade radical que é a condição de e para a espacialidade" (Massey, 2012, p. 37). Ao se apropriarem dos novos conhecimentos, os estudantes demonstraram, por meio de relatos ao longo das aulas, compreender o Paranoá para além de um torrão: como cidade que influencia e sofre influências, conectada a uma rede de outras cidades e em relação com culturas próximas ou longínquas, parte de uma densa malha constituída por mais 30 RA e integrada às esferas nacional e internacional. 
No segundo bimestre, com o intuito de perceber a historicidade presente no espaço geográfico, os alunos pesquisaram a história de sua cidade a partir de websites, publicações disponibilizadas pela mídia e instituições governamentais. Em sala de aula, assistiram a vídeos produzidos por moradores do Paranoá, tais como os documentários "Pedras da Vila Paranoá" (Carneiro, 2012), que retrata a resistência e luta dos trabalhadores que construíram a barragem do Paranoá, e "A cidade é uma só?" (Queirós, 2013), que retrata a história dos trabalhadores pioneiros da construção de Brasília que foram forçados a sair da área do Plano Piloto e a se instalar no chamado Centro de Erradicação de Invasores - CEI, que deu origem à Ceilândia, RA mais populosa do DF e expressão da segregação inerente ao processo de construção da capital federal. Foram realizados debates após as sessões e os estudantes expressaram indignação quanto ao embate travado entre o Governo do Distrito Federal e os moradores para garantir o direito destes ao território ocupado. A escolha de um vídeo que retrata outra cidade que não Paranoá, justifica-se pela importância de Ceilândia como polo de produção cultural, inclusive cinematográfica, do DF e referência para as demais cidades quanto à resistência ao processo de exclusão.

Os debates, após os filmes, foram mediados pela professora através de questionamentos sobre as possíveis semelhanças entre o roteiro dos filmes e a história do Paranoá. A participação dos estudantes demonstrou curiosidade e indignação. Questionamentos como "quem permitiu que a polícia expulsasse as pessoas?" ou "por que os trabalhadores não podiam morar em Brasília?" permitiram diálogo qualificado entre os estudantes e, quando necessária, a intervenção da mediadora.

Figura 4 - Fotografia dos estudantes, após assistirem aos filmes.

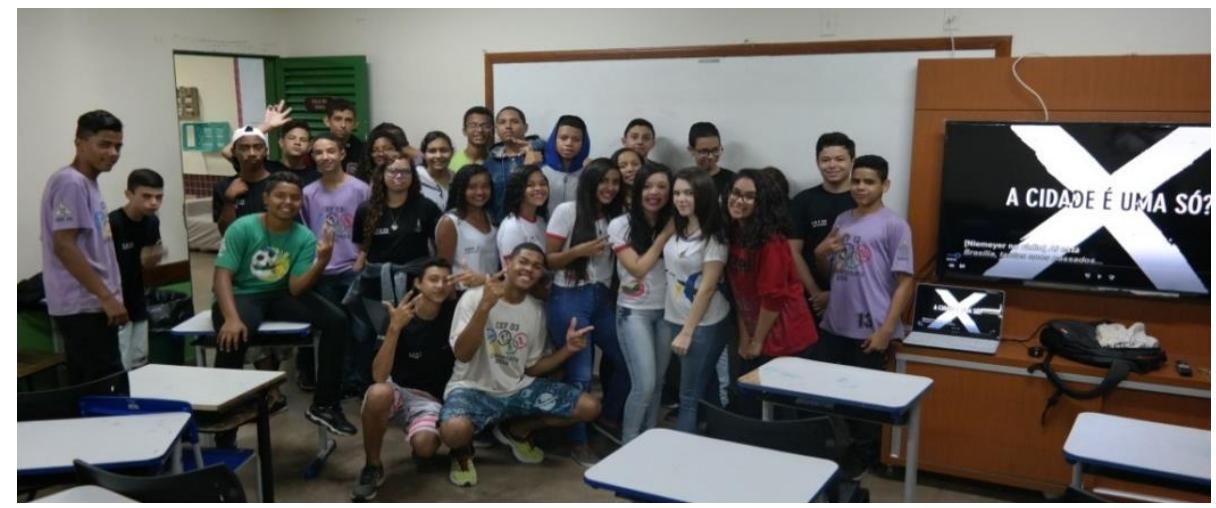

Fonte: Silva, D.M.P.

O uso de linguagens como filmes permitiu que os alunos percebessem que o espaço onde atualmente vivem é produto de 55 anos de história e de luta e que, ao longo do 
tempo, as paisagens da cidade foram se alterando, a área urbanizada cresceu, novas demandas relacionadas ao comércio e serviços foram surgindo e, na mesma medida, problemas urbanos foram aparecendo. As imagens dos filmes acrescidas aos mapas estudados contribuíram para que se compreendesse a evolução histórica e as transformações na paisagem da cidade. Os debates após as sessões permitiram importante exercício da oralidade, da escuta e do diálogo, bem como motivaram os estudantes a buscar outras produções em vídeo sobre a história do Paranoá. Os debates, pouco presentes em aulas expositivas nas quais os estudantes são meros expectadores, impulsionaram a manifestação de opiniões, dúvidas ou comentários sobre um trecho do vídeo, o que permitiu aumento da comunicação oral.

Com o objetivo de levar os estudantes a construir o conceito de paisagem, parte das atividades desenvolvidas no segundo bimestre foi a realização de um concurso de fotografia, com o tema Nós Propomos Paranoá-DF. Os critérios para a produção da fotografia foram: a capacidade de exprimir uma mensagem através da fotografia, a originalidade e a relação com o tema do projeto. Os recortes espaciais definidos pelos estudantes foram variados e houve dificuldades quanto ao planejamento e intencionalidade no exercício de capturar determinada porção do espaço. Estas dificuldades, contudo, favoreceram o processo de construção do conceito de paisagem, na medida em que os estudantes compreenderam que paisagem é "um conjunto de objetos geográficos distribuídos sobre um território, sua configuração geográfica ou sua configuração espacial e a maneira como esses objetos se dão aos nossos olhos, na sua continuidade visível" (Santos, 2012, p. 12). As orientações dadas aos alunos sobre a mensagem que se pretendia transmitir com a fotografia favoreceu debate sobre como a mídia se utiliza de técnicas para enfatizar determinado aspecto de um fenômeno em detrimento de outros, e as implicações da manipulação de imagens e vídeos na formação de opinião dos telespectadores. 
Figura 5 - Fotografia vencedora do concurso. Avenida Paranoá.

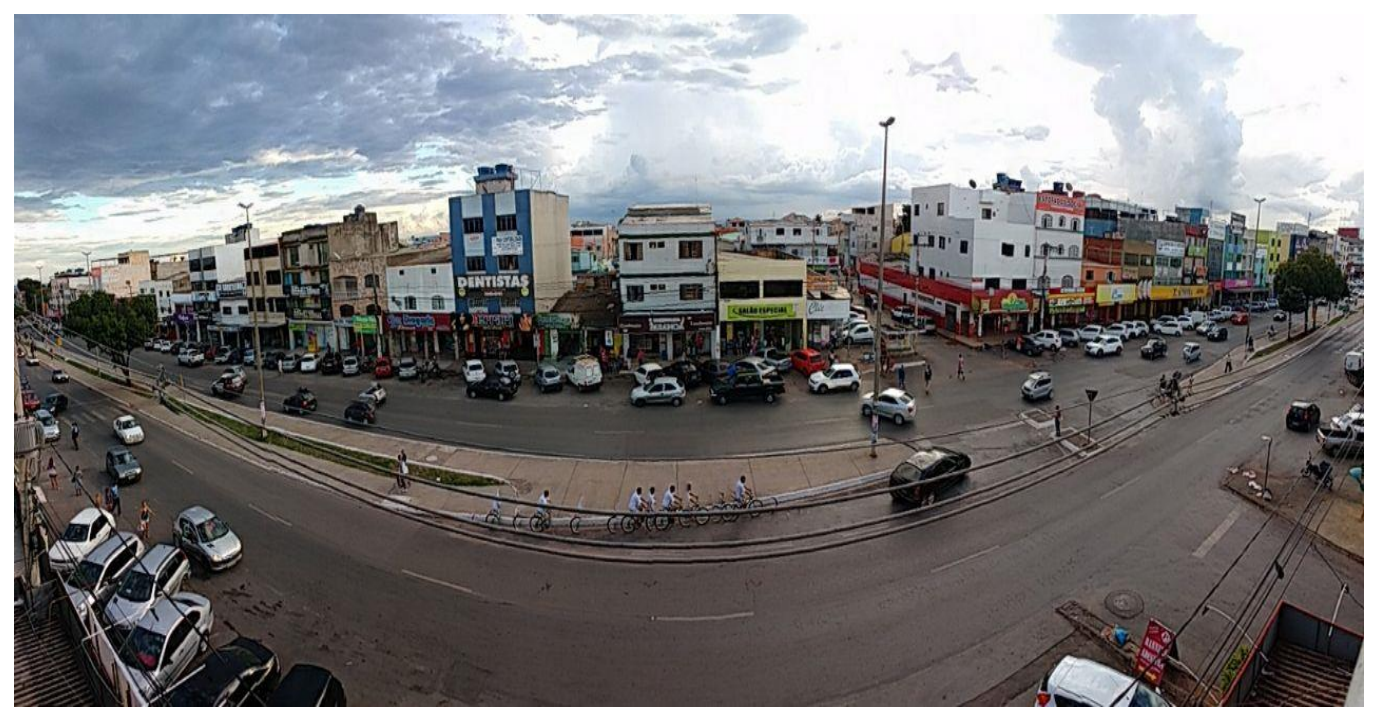

Fonte: SILVA, T. P. 2017 (estudante do 9o ano E).

Em cada atividade desenvolvida, a proposta didática buscou promover a interação entre os alunos e a professora, bem como entre os próprios alunos, por meio de apresentação das atividades desenvolvidas, discussão sobre os resultados parciais e divulgação nas redes sociais para promover integração com os demais envolvidos no projeto, em âmbito nacional ou internacional. Atividades avaliativas, como produção de textos, mapas mentais, interpretação de textos e relatórios também foram realizadas.

No início do terceiro bimestre, foram realizadas saídas a campo com o objetivo de observar a paisagem da cidade e relacioná-la ao estudo teórico, problematizando as paisagens e ensaiando soluções para os problemas identificados. Nessa etapa, após debates sobre os diferentes problemas encontrados, as turmas foram divididas em grupos, cada um dos quais definiu um subtema a ser estudado com mais profundidade, realizando a pesquisa empírica. Os subtemas escolhidos foram: comércio ilegal, utilização de drogas na escola, lixo, vias de circulação para pedestres, acidentes de trânsito, uso lago Paranoá, cultura alimentar de jovens do Paranoá e alimentação escolar. Em razão da diversidade de subtemas, não será viável, neste texto, especificar as perguntas elaboradas pelos estudantes em cada instrumento de pesquisa utilizado. 


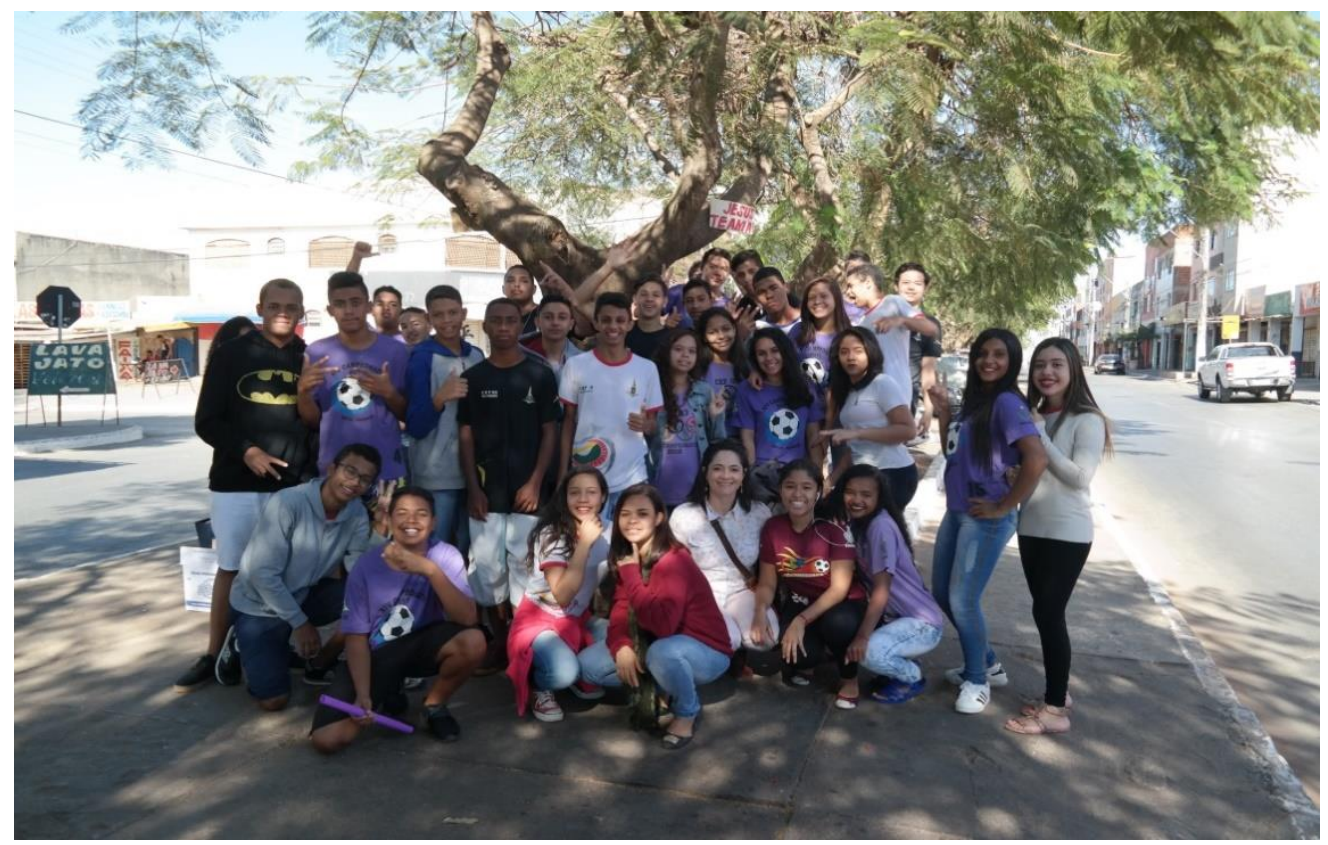

Fonte: Silva, D. M.P.

Para cada grupo, foi definido um professor orientador, escolhido pelos estudantes, considerando-se a familiaridade do professor com a temática e a afinidade do mesmo com o grupo de estudantes. Foram realizadas reuniões do grupo com o orientador, que sugeriu leituras, vídeos e possibilidades de abordagem do problema a ser pesquisado. Embora os professores tivessem demonstrado interesse em orientar os grupos, os mesmos não estavam completamente inteirados das etapas do projeto em razão da própria dinâmica da escola, em que cada professor permanece isolado em sua sala de aula, e por não haver momentos coletivos de diálogo, o que pode ter dificultado uma intervenção mais eficiente.

Durante os terceiro e quarto bimestres, os grupos elaboraram instrumentos de pesquisa, a saber, questionário e entrevista semiestruturada, para a realização da pesquisa empírica. Nessa etapa, foram necessários encontros com os estudantes fora do horário de aulas, para orientação a respeito da pesquisa empírica enquanto meio de produção de dados e da elaboração dos questionários e entrevistas constituídos por perguntas fechadas, no caso dos questionários, e perguntas abertas, no caso das entrevistas. Os grupos focaram na percepção que os sujeitos possuíam sobre os diferentes temas com o intuito de qualificar as representações para que tais dados norteassem, posteriormente, os encaminhamentos das possíveis soluções. Tal processo se apresentou como uma novidade para os alunos, o que levou à necessidade de contato constante com a professora para esclarecimento de dúvidas e 
discussões mais aprofundadas sobre a temática escolhida por cada grupo. Na medida em que os grupos agendavam encontro para orientação quanto às dificuldades que estavam encontrando, esses encontros foram utilizados para identificar em que medida o trabalho desenvolvido estava contribuindo para o desenvolvimento do raciocínio geográfico. Os dados produzidos são analisados na segunda parte deste texto.

A utilização do whatsapp contribuiu para incentivar os estudantes a realizarem suas pesquisas, na medida em que podiam enviar textos, vídeos, áudios, compartilhar alguma informação para se certificarem de que estavam no caminho certo ou tirar dúvidas sobre o formato do trabalho e/ou o conteúdo que estava sendo pesquisado. Também para a divulgação das pesquisas em andamento, as redes sociais como o Facebook permitiram proximidade com o projeto desenvolvido em escolas de outras regiões do Brasil e, principalmente com as pesquisas desenvolvidas pelos estudantes em Portugal, onde o projeto encontrava-se mais adiantado. Visualizar estudantes de outro país pesquisando os problemas dos lugares onde vivem motivou os alunos a se envolverem com o projeto, na medida em que se perceberam parte de uma rede constituída por professores e estudantes cujo ponto comum era a busca por soluções para os diversos desafios identificados na cidade.

A culminância do projeto se deu com a realização de um seminário em que autoridades e personalidades estiveram presentes, quando os grupos de estudantes apresentaram os resultados de suas pesquisas e as proposições/sugestões para os problemas pesquisados. Os grupos entregaram, também, um trabalho escrito seguindo o padrão científico e os slides que nortearam a apresentação oral.

Figura 7 - Fotografia do I Seminário Nós Propomos no Paranoá-DF

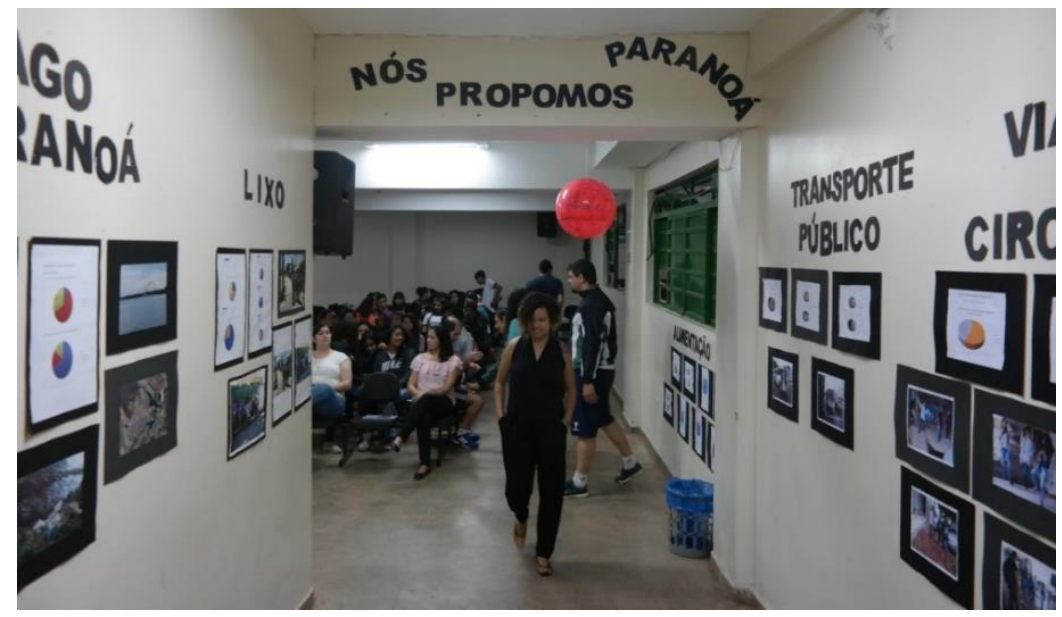

Fonte: Silva, D. M.P. 


\section{Nós Propomos Paranoá-DF: interlocuções com os referenciais teóricos da Geografia Escolar}

As reflexões decorrentes das disciplinas cursadas no âmbito do programa de pósgraduação da UnB, como "Geografia e Educação", bem como a experiência docente da autora permitiram atestar que práticas pedagógicas positivas foram desenvolvidas na implementação do Projeto Nós Propomos em uma escola do Paranoá-DF.

As etapas do projeto, descritas na primeira parte deste trabalho, corresponderam às estratégias de ensino de geografia pensadas para motivar os estudantes, valorizar o seu lugar de vivência e incentivar a produção de novos conhecimentos a partir da pesquisa, com vistas a incorporar uma consciência cidadã. Tal consciência significa compreender a própria existência como uma prática espacial, como afirma Cavalcanti:

(...) há na experiência humana uma relação com o mundo material e imaterial, que resulta em espacialidade. Essa espacialidade é concebida, para além da concepção de um espaço geométrico formal, como materialização dos movimentos e realizações diárias que os sujeitos levam a cabo para produzir a vida, o que significa entender que as relações sociais, econômicas, políticas e culturais estão materializadas na cidade e a configuram (2011, p.16).

No intuito de apresentar aos estudantes uma proposta de estudo da cidade em que vivem, cuidou-se para que o discurso da mídia, marcado por reduzir as cidades da periferia do Distrito Federal à violência urbana e à criminalidade, não fosse reproduzido. Contudo, não se pode desconsiderar as implicações sociais da localização periférica de cidades como o Paranoá, pois, tal como afirma Santos, "o valor do indivíduo depende, em larga escala, do lugar onde está" (1993, p 1110).

A primeira fase do projeto pautou-se pelo estudo do mapa. Ao definir-se como ponto de partida o mapa da unidade da federação onde se localiza a cidade estudada, qual seja, o Distrito Federal e a RA Paranoá, muitas percepções iniciais emergiram desse exercício cartográfico de observação e leitura do mapa. A despeito das dificuldades na interpretação de elementos cartográficos, como a própria legenda e os símbolos convencionais, o mapa que mostrava a cidade onde os estudantes vivem despertou sentimentos e provocou reações que permitiram aos alunos avançar na compreensão do mapa enquanto representação de determinada porção do espaço e que prescindia de complementação verbal, tanto do professor quanto das narrativas dos próprios estudantes. Para Novaes (2017), a linguagem visual e a linguagem verbal se complementam na medida em que possuem limitações semelhantes e, por essa razão, os professores devem promover interações entre textos e imagens nas práticas 
pedagógicas das aulas de geografia. Essa interação permitiu que os estudantes mobilizassem os conhecimentos empíricos que possuíam sobre o Distrito Federal e que só foram acionados a partir da visualização do mapa: "mais ou menos por aqui tem uma cachoeira onde costumo nadar"; "sempre viajo para Goiânia e passo por todas essas cidades pra chegar lá". Os relatos denotam que o mapa adquire significados de acordo com a experiência de cada um, e as falas acabam por suscitar, no outro, memórias de situações vivenciadas nos lugares citados.

Quanto à organização político-administrativa do DF e aos aspectos geográficos e históricos da cidade em que vivem, os estudantes demonstraram nunca tê-los estudado. Prevê-se que os estudantes adquiram tais conhecimentos nos anos iniciais - 1ำ ao $5^{\circ}$ ano - do Ensino Fundamental I, etapa em que o Distrito Federal consta como conteúdo a ser estudado. Em pesquisa realizada por Leite (2015), em uma cidade do DF, demonstrou-se que o material didático utilizado aborda essencialmente Brasília, desconsiderando-se as cidades vizinhas, produzindo um discurso de hegemonia da capital sobre as demais cidades. Para a autora, há um despreparo dos pedagogos, que durante a graduação, cumprem apenas uma disciplina sobre ensino de Geografia e, por esta razão, apresentam dificuldades em considerar o Lugar enquanto realidade mais próxima do estudante e que permitiria contemplar os conteúdos dos livros didáticos. Assim,

(...) os professores participantes da pesquisa em nenhum momento perceberam que os conteúdos deveriam ser aplicados tomando-se como base a sua cidade. Ao contrário, legitimaram um processo de segregação, pela reafirmação da cidade de Brasília, em prejuízo das características locais, jogando fora toda a potencialidade existente na perspectiva do Lugar (Leite, 2015, p. 94).

Os estudantes do Paranoá não tiveram a experiência de estudar sua própria realidade durante os anos iniciais, provavelmente por razões semelhantes àquelas identificadas na pesquisa supracitada. $O$ fato de não conhecerem o processo histórico de formação de sua RA acarretou-lhes ausência de identidade com o lugar onde nasceram e com a dinâmica própria de sua cidade, que é bastante diferente de Brasília e com a qual não possuem os mesmos vínculos, embora conheçam seu processo de formação. Não se trata de desconsiderar a importância de Brasília, mas da "construção da autonomia e a formação da cidadania dos sujeitos de um território, que se conformou espacialmente em lógicas muito diferentes daquelas que produziram a capital da República" (Leite, 2015, p. 97). Por isso, o estudo da cidade do Paranoá apresentou-se como uma revelação para os estudantes que, a cada aula, sentiam-se orgulhosos por fazer parte 
de um território marcado por luta e resistência frente às decisões governamentais. $O$ Paranoá surgiu com os trabalhadores que migraram para o DF com o objetivo de construir a barragem do Lago Paranoá. Ao se fixaram nas suas proximidades, recusaram-se a deixar a área, enfrentando confrontos com a polícia e organizando-se para garantir o direito de permanecer naquelas terras. Conhecer essa história produziu nos estudantes orgulho dos fundadores da cidade e valorização do lugar onde vivem.

O lugar enquanto categoria de análise esteve presente em todas as etapas do projeto, norteando o planejamento das ações e os ajustes necessários. A concepção de lugar da geografia humanística considera que "o lugar é o espaço que se torna familiar ao indivíduo, é o espaço do vivido, do experienciado" (Cavalcanti, 2013, p. 89). Na dinâmica ensino-aprendizagem, o lugar é o ponto de partida, pois o conhecimento adquirido pelo estudante está conformado a partir de sua experiência no lugar.

Com a preocupação de que o lugar não fosse estudado como um conceito pronto a ser memorizado pelos estudantes, buscou-se investir em práticas denominadas metodologias ativas, cujo objetivo é colocar os estudantes em destaque no processo de construção do conhecimento: "entre suas potencialidades estão a de impulsionar o envolvimento dos alunos por meio de atividades lúdicas, como o uso de jogos, e a partir de situações vivenciadas por eles para tratar de temas como cidade ou meio ambiente" (Moraes, 2017, p.80). Nesse sentido, a implementação do projeto em cada etapa ofereceu aos estudantes possibilidades de protagonizarem o processo, gradualmente, na medida em que as incumbências de pesquisa bibliográfica e empírica, produção escrita e comunicação oral foram tornando-se mais rigorosas com o avançar do ano letivo. As turmas corresponderam às propostas realizadas pela professora porque se sentiram motivadas, já que o formato de cada atividade era sempre diferente das aulas tradicionais às quais estavam habituadas. Os estudantes perceberam que o projeto só avançaria se assumissem o compromisso de cumprir, rigorosamente, cada etapa. Mesmo completamente despreparados para realizar as etapas mais difíceis, como entrevistar pessoas para produzir dados, estabeleceu-se uma relação de confiança com a professora e, assim, os estudantes encararam o projeto como uma questão de honra. 


\section{Conclusão}

A implementação do projeto Nós Propomos no Paranoá, uma cidade com diversos problemas e estudantes em condição de vulnerabilidade social, permitiu constatar

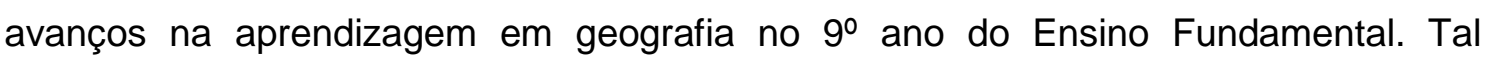
avanço, identificado pela apropriação de conhecimentos geográficos, também se deu na postura dos estudantes frente às contradições da cidade, que exigiu um pensar sobre os problemas urbanos, o trabalho em equipe para propor soluções e a sensibilidade para compreender as dinâmicas sociais inerentes aos lugares desprovidos de atenção. Ao perceberem-se como agentes de transformação e produção do espaço da cidade, os estudantes assumiram a parte que thes cabe na constituição de uma sociedade cidadã, colocando em prática ações como: fiscalização do cardápio da merenda escolar por meio de fotografias encaminhadas à gestão da escola, atuação junto a organizações estudantis como o grêmio estudantil, denúncias nos sites do DETRAN-DF e da Administração Regional do Paranoá sobre o lixo acumulado nas redondezas da escola e sobre a comercialização de produtos ilegais e as más condições de vias de circulação, que oferecem risco de acidentes especialmente para pessoas com alguma deficiência.

Enquanto professora que conduziu os sujeitos/alunos à execução do projeto, percebi, ao longo de sua implementação, que me revesti de uma postura investigadora que foi tornando-se mais rigorosa e sofisticada com o avançar das ações. Observei atentamente suas falas, suas expressões faciais, seus gestos. Entendi que, quando o silêncio prevalecia, o pensamento respondia, com elaboração de hipóteses ou com outra pergunta ao questionamento feito, embora nenhuma palavra fosse dita. Foi necessário estabelecer laços de confiança com os estudantes para que os resultados aparecessem. Esses laços tornaram-se mais afetivos, paradoxalmente, na medida em que as orientações tornaram-se mais científicas e o trabalho adquiriu status de pesquisa científica.

\section{Referências bibliográficas}

A cidade é uma só? Direção: Adirley Queirós. Brasília: 2013. Documentário, 1h13. Disponível em https://www.youtube.com/watch?v=mVI8DiLjMN4. Acesso em: 23 mar. 2017. 
Brasil. Ministério da educação. Base nacional comum curricular-BNCC. Brasília, DF, 2017. Disponível em http://basenacionalcomum.mec.gov.br/abase/. Acesso em: 10 jan. 2018.

Cavalcanti, L.S. (2013). Geografia, escola e produção de conhecimentos. Campinas, SP: Papirus.

Cavalcanti, L.S. \& Morais, Eliana Marta Barbosa. (2011). A cidade, os sujeitos e suas práticas espaciais cotidianas. In E. M. B. Morais \& L. S. Cavalcanti (Orgs.). A cidade e seus sujeitos. Goiânia: Editora Vieira.

Leite, C. M. C. (2015). Considerações sobre o processo de formação dos professores que ensinarão geografia nos anos iniciais de escolarização. In K. S. P. Rabelo \& M. A. Bueno (Orgs.). Currículo, políticas públicas e ensino de Geografia. Goiânia: Ed. da PUC Goiás

Massey, D. (2012). Pelo espaço: uma nova política da espacialidade. Rio de Janeiro: Bertrand Brasil.

Moraes, J. V. (2017). O papel das metodologias ativas no processo de alfabetização científica em Geografia. In V. O. R. Ascenção (Org.) et al. Conhecimentos da Geografia: percursos de formação docente e práticas na educação básica. Belo Horizonte.

Oliveira, L. (2010). Estudo metodológico e cognitivo do mapa. In R. D. Almeida (Org.). Cartografia Escolar. São Paulo: Contexto.

Pedras da Vila Paranoá. (2012). Direção: Tiago Machado Carneiro. Brasília. Documentário, cor, digital, 17min, Livre. Disponível em https://www.youtube.com/watch?v=9LpPmUBykoc. Acesso em: 20 mar. 2017.

Santos, M. (2012). Espaço e método. São Paulo: Edusp. 


\title{
Construindo pensadores espaciais críticos: a importância do Projeto Nós Propomos! e do Concurso de Fotografia em Portugal
}

\author{
DIOGO GASPAR SILVA ${ }^{1}$
}

RICARDO A. C. GARCIA ${ }^{2}$

\section{Resumo}

O Projeto Nós Propomos! tem, ao longo de sete anos, consolidado a sua rede nacional e internacional. Porém, a participação de estudantes, num Projeto onde a promoção da cidadania é um marco inquestionável, pode não apresentar uma correspondência inequívoca com o desenvolvimento de competências de literacia espacial. Partindo da experiência portuguesa, o artigo analisa criticamente de que modo o Projeto Nós Propomos! tem contribuído para a construção de pensadores espaciais críticos. Considerando a participação no concurso de fotografia e os resultados dos inquéritos de avaliação do Projeto entre 2011 e 2018, preenchidos pelos alunos participantes, discutem-se as oportunidades e as limitações experienciadas na afirmação de análises críticas sobre problemas territoriais. No final, apresentam-se recomendações estratégicas que poderão ser implementadas na rede Nós Propomos! com o objetivo de reforçar a importância do pensamento espacial crítico na educação geográfica.

Palavras-chave: Nós Propomos!; pensamento espacial crítico; fotografia; trabalho de campo; educação geográfica

\footnotetext{
1 Mestrando em Geografia Humana: Globalização, Sociedade e Território do Instituto de Geografia e Ordenamento do Território da Universidade de Lisboa, diogosilva4@campus.ul.pt

${ }^{2}$ Professor Auxiliar e Investigador Efetivo do Centro de Estudos Geográficos do Instituto de Geografia e Ordenamento do Território da Universidade de Lisboa, rgarcia@campus.ul.pt
} 


\section{Abstract}

During the last seven years, the We Propose! Project has consolidated its national and international network. However, if the students' involvement in this Project improve their citizenship and territorial concerns, it is not mandatory that there is an unequivocal increase concerning their spatial literacy skills. Taking in consideration the Portuguese experience, the paper critically analyzes how the We Propose! Project has contributed to the construction of critical spatial thinkers. Based on the photography contest participation and the results of the Project evaluation surveys between 2011 and 2018, completed by the participating students, the opportunities and limitations experienced in the affirmation of critical analysis of territorial problems are discussed. At the end, we present some strategic recommendations that could be implemented in the network We Propose! to reinforce the importance of critical spatial thinking in geographic education.

Keywords: We Propose!; critical spatial thinking; photography; fieldwork; geographic education

\section{Introdução}

Ao longo dos últimos sete anos, o Projeto Nós Propomos! tem consolidado a sua rede de participantes em Portugal, incluindo no concurso de fotografia. Esta consolidação pode, em parte, ser explicada pela crescente proliferação, acessibilidade e utilização das tecnologias da informação e da comunicação pelos grupos etários mais jovens (Goodchild \& Janelle, 2010). Consequentemente, tal democratização do acesso a equipamentos digitais tem contribuído para a consolidação de fotógrafos amadores e profissionais. Porém só recentemente se começou a problematizar sobre a eficácia dos métodos fotográficos, assim como a sua utilidade na educação geográfica e na estruturação de pensadores espaciais (Sanders, 2007).

Os métodos fotográficos, em profunda transformação desde a introdução da fotografia digital, têm sido questionados em termos de problematização territorial. Esta crítica parece resultar da aleatoriedade e da transitoriedade de algumas produções fotográficas que não revelam quaisquer critérios geográficos que permitam avaliar a literacia espacial e o espírito crítico do fotógrafo e, neste caso concreto, do pensador espacial (Goodchild, 2009). Este último deve apresentar um conjunto de capacidades na identificação de problemas e nas suas implicações territoriais, recolhendo informação espacial e multidimensional que o demonstrem, como é o caso do método fotográfico enquanto processo de observar com intenção (Sanders, 2007). A ineficácia 
dos métodos fotográficos reside ainda na dimensão estritamente descritiva que a fotografia tende a possuir na generalidade dos trabalhos académicos, reduzindo a dimensão fotográfica a uma captura do mundo conhecido ou da sua transformação enquanto elemento ilustrativo dessa realidade (Rose, 2008).

Considerando a participação dos autores nos processos de avaliação do concurso de fotografia e a experiência portuguesa do Projeto Nós Propomos!, através dos resultados dos inquéritos de avaliação preenchidos pelos alunos participantes, o artigo analisa criticamente de que modo o Projeto e o concurso de fotografia têm contribuído para a construção de pensadores espaciais críticos. Discutem-se ainda as oportunidades e as limitações associadas à afirmação de análises críticas sobre problemas territoriais, objetivo para o qual o Projeto Nós Propomos! pretende contribuir.

\section{Metodologia}

A investigação apresenta uma dimensão teórica e uma dimensão empírica. A primeira dimensão está ancorada na reflexão teórica do conceito de pensador espacial crítico, particularmente das características que devem configurar a problematização do pensamento geográfico. Nesta dimensão é ainda realizado um enquadramento sobre a importância dos métodos fotográficos para a estruturação de pensadores espaciais críticos. Essa reflexão realça os métodos fotográficos enquanto um método substantivo de apoio à reflexão de conceitos teóricos e, naturalmente, à construção de conhecimento territorial crítico. A dimensão empírica está ancorada em métodos quantitativos e qualitativos. A sua conjugação permitirá discutir a importância do concurso de fotografia do Projeto Nós Propomos! para a estruturação de pensadores espaciais críticos.

Em termos de método, a segunda dimensão estrutura-se em duas fases: (i) analisamse os resultados interanuais da avaliação do Projeto Nós Propomos! pelos alunos participantes entre 2011 e 2018, realizados através de inquéritos por questionário no final de cada ano letivo, e a partir dos quais se discutem as perceções dos estudantes relativamente à importância global do Projeto para a sua formação geográfica. Esta mensuração será realizada através de três dimensões analíticas, designadamente inovação na disciplina de Geografia; contributo para o conhecimento local e apresentação de propostas sobre problemas locais; (ii) suportada na experiência dos autores enquanto avaliadores dos projetos finais e das produções fotográficas, tendose selecionado algumas produções avaliadas como "boas práticas" pelo Júri do 
concurso de fotografia de 2017 e 2018. Partindo dessa seleção, discute-se a importância da fotografia enquanto um elemento de conhecimento geográfico. Através da análise e discussão desses exemplos, aborda-se o potencial dos métodos fotográficos na formação de pensadores espaciais críticos.

\section{O Projeto Nós Propomos! e o Concurso de Fotografia em Portugal}

O Projeto Nós Propomos!, com um pendor focado na cidadania e na inovação na educação geográfica, procura estimular a aplicação do estudo de caso enquanto método para a identificação e resolução de problemas locais (Claudino \& Mendonça, 2017). Deste modo, pretende-se reforçar a importância do estudo de caso e do trabalho de campo enquanto métodos na consolidação de cidadãos participativos. $O$ Projeto teve início em Portugal no ano de 2011, integrando as atividades de apoio e serviço à comunidade escolar do Instituto de Geografia e Ordenamento do Território da Universidade de Lisboa (IGOT-UL), alargando-se, posteriormente, ao Brasil, em 2014, e a Espanha, em 2016. Recentemente, tem-se consolidado a rede iberoamericana em países como Moçambique, Colômbia ou Perú.

Conjugando as parcerias entre universidades, escolas, autarquias e outras organizações da sociedade civil, numa primeira fase, os estudantes identificam os problemas que lhes parecem mais significativos na sua área de estudo, mobilizando, numa segunda fase, e se possível, uma entrevista com técnicos da autarquia, permitindo enquadrar as prioridades do Plano Diretor Municipal enquanto instrumento de gestão territorial. Finalmente, os estudantes desenvolvem o seu trabalho de pesquisa, identificando problemas, auscultando a população e produzindo informação geográfica que sustente a formulação de propostas relativamente ao problema identificado. Estes resultados são apresentados no Seminário Nacional, realizado anualmente no IGOT-UL, que congrega todos os participantes do Projeto em Portugal. Em alguns casos, as propostas acabam por ser ponderadas e implementadas pelos municípios. No final do ano letivo, os professores e os alunos são convidados a avaliar o desempenho e a qualidade do Projeto (Claudino \& Mendonça, 2017).

Como se pode observar na figura 1, que representa a evolução espácio-temporal do Projeto, numa fase inicial (2011), a rede de estabelecimentos de ensino circunscrevese à região de Lisboa e abrange meramente as escolas de ensino secundário, objetivo inicial e primordial do Projeto. Entre 2012 e 2016, o Projeto Nós Propomos! expandese até às regiões autónomas e o território continental apresenta uma distribuição geográfica relativamente homogénea, com exceção da região do Alentejo. Esta fase 
de crescimento é ainda marcada pelo alargamento do nível de ensino das escolas

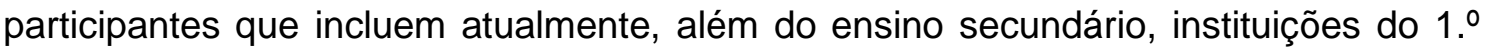
ciclo e ainda escolas profissionais e séniores. Desde 2017, tem-se assistido a uma certa estabilização em Portugal, embora o crescimento internacional se tenha consolidado. Apesar disso, esboça-se uma boa cobertura no território nacional. Contudo, foram-se emancipando alguns constrangimentos logísticos que poderão dificultar a expansão territorial do Projeto, uma vez que o apoio presencial de elementos do IGOT-UL nas escolas se torna complexo, tendência já verificada através da redução do número de escolas participantes no último ano letivo (Figura 1).

Figura 1 - A rede Nós Propomos! em Portugal e as suas fases de expansão entre 2011 e 2017

$2011 / 12$

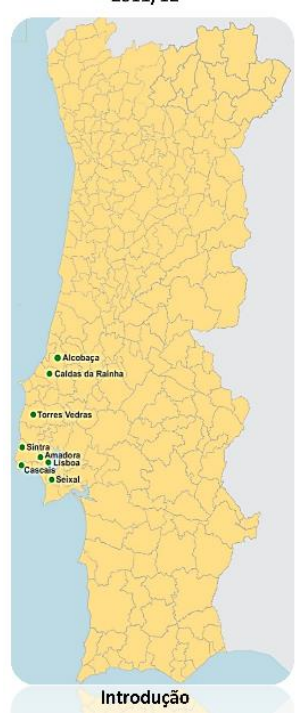

$2013 / 14$

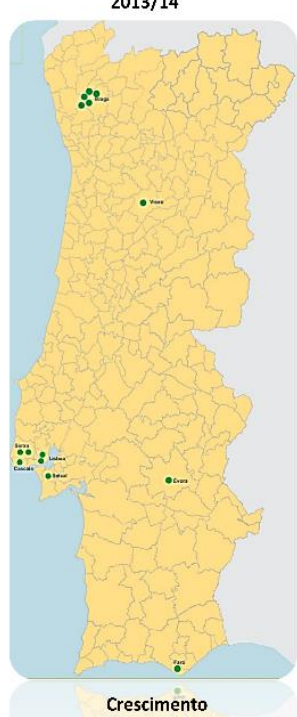

Fonte: adaptado de Projeto Nós Propomos! (2011-17)
$2014 / 15$

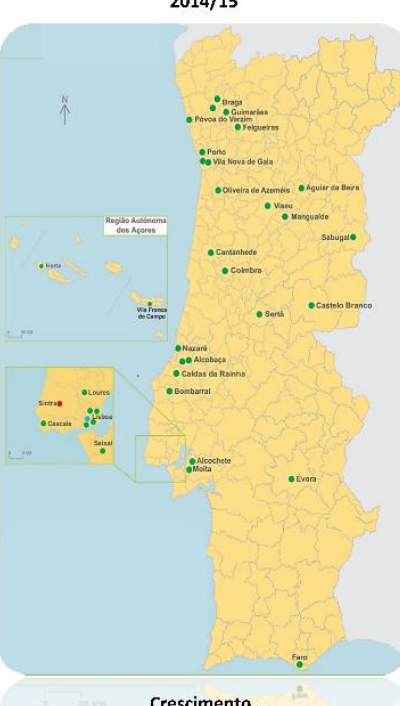

Crescimento

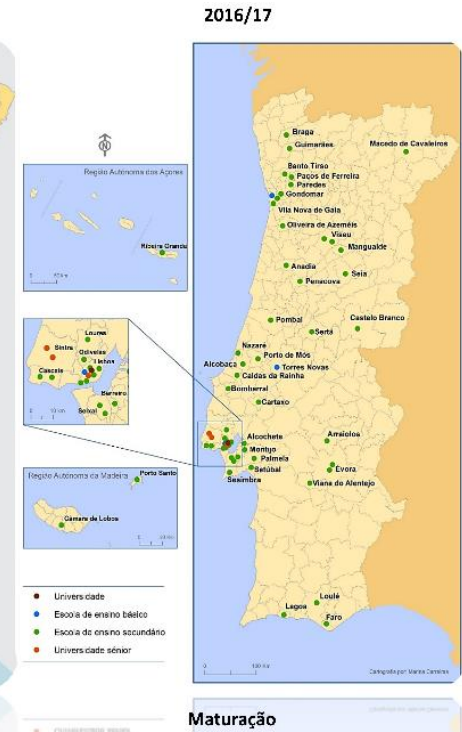

Maturação

Nos últimos anos, no Seminário Nacional, além de se disseminarem as propostas dos estudantes relativamente aos problemas identificados, têm-se premiado as melhores produções fotográficas, através de um concurso nacional de fotografia, as melhores curtas-metragens, através de um concurso de vídeo, e ainda os melhores projetos, através de um concurso de avaliação de projetos.

Especificamente, o concurso de fotografia foi introduzido em 2014, embora em 2015 tenha sido dividido em duas modalidades: trabalho de campo e paisagem. A partir de 2016, as fotografias premiadas foram submetidas independentemente da sua tipologia. As fotografias são produzidas e submetidas a concurso pelos estudantes e são avaliadas por representantes do IGOT-UL segundo três critérios ponderados: a originalidade e a criatividade (15\%); a qualidade da produção fotográfica (40\%) e a qualidade científica (45\%). 


\section{O contributo dos métodos fotográficos para a estruturação de pensadores espaciais críticos}

A proliferação e crescente acessibilidade das tecnologias de informação possibilita que as imagens digitais sejam facilmente recolhidas, partilhadas e georreferenciadas, transformando as ferramentas espaciais em algo ubíquo na vida profissional e académica (Goodchild \& Janelle, 2010), parecendo justificar o surgimento do termo spatial turn (Anselin et al., 2004). Consequentemente, a facilidade de acesso a ferramentas como o Google Earth ou Google Maps democratizou o acesso à informação espacial (Sidaway, 2002). Porém, como salientam Goodchild (2009) e Bearman et al. (2016), o advento e a democratização dos geobrowsers têm contribuído para a redução da literacia espacial, comprometendo uma utilização crítica da informação espacial, designadamente entre os mais jovens que fazem uma utilização intensiva destas plataformas.

Perante esta evidência, a ciência geográfica deve contribuir para o conhecimento teórico e prático dos processos e dos problemas territoriais em diversas escalas (Bearman et al., 2016). Porém, segundo Goodchild \& Janelle (2010) e Bearman et al. (2016), os currículos tendem a privilegiar uma dimensão eminentemente prática, resultando no seguimento pelos estudantes de um conjunto de instruções prévias sem plena compreensão do que significam ou dos seus objetivos. Como esclarece Cachinho (2006, 2010), esta realidade resulta de um modelo pedagógico centrado na transmissão de conhecimento, limitando os processos de questionamento críticos que futuros geógrafos devem ser capazes de desenvolver. Segundo Bearman et al. (2016), a construção de um pensador espacial crítico depende de um conjunto de capacidades que devem ser desenvolvidas nas unidades curriculares dos cursos de Geografia, designadamente a capacidade de identificar problemas e as suas implicações territoriais, recolher informação espacial multidimensional, reconhecendo as suas limitações, e aplicar a teoria da ciência geográfica para a resolução desses problemas (Cachinho, 2010; Goodchild \& Janelle, 2010; Bearman et al., 2016).

Após recolher informação espacial que permita consolidar a problemática, o pensador espacial crítico deve raciocinar e compreender os processos e os efeitos em dimensões espaciais multiescalares e holísticas (Goodchild \& Janelle, 2010). Para tal, o pensador espacial crítico deve discutir as causas dinâmicas, as interações e as tendências que diferentes sistemas (humanos, físicos, locais, globais) apresentam em diferentes territórios. Posteriormente, o pensador espacial deve produzir informação relevante que responda ao problema inicial (Bearman et al., 2016). 
Este ciclo de aprendizagem procura sistematizar as fases que devem ser integradas na estruturação de um pensador espacial crítico na resposta a problemas espaciais (Figura 2), convergindo para o place-based knowledge, sem o qual é impossível intervir sob os territórios (Goodchild \& Janelle, 2010).

Figura 2 - Procedimentos adotados na resposta a questões geográficas

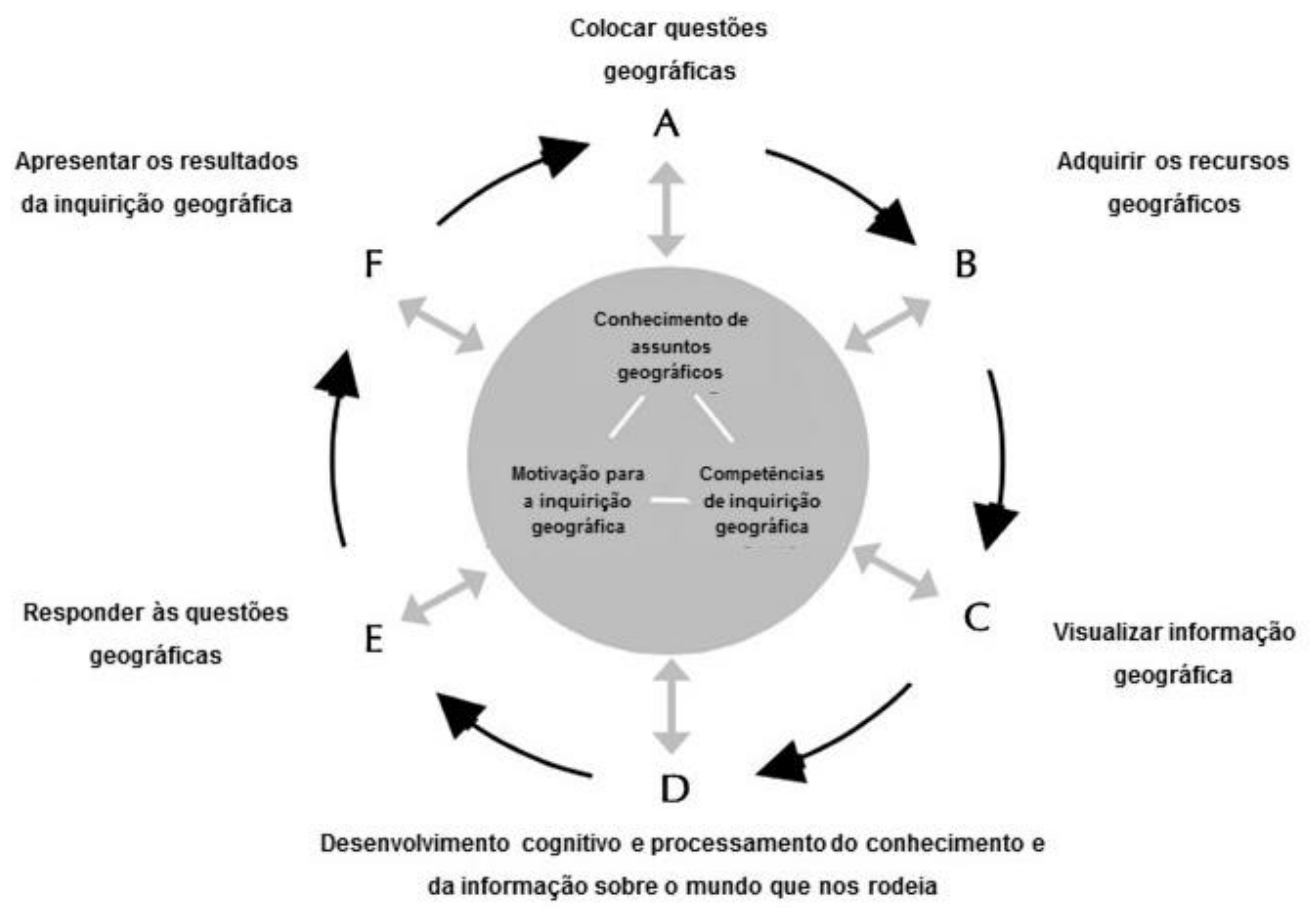

Fonte: adaptado de Bearman et al. (2016)

Assim, o pensador espacial crítico deve refletir criticamente sobre problemas territoriais específicos, envolvendo um permanente questionamento e análise das situações. Goodchild \& Janelle (2010) definem o pensamento espacial crítico como uma capacidade cognitiva que deve ser mobilizada no quotidiano para estruturar problemas, encontrar respostas e propor soluções, mobilizando conceitos e propriedades espaciais, ferramentas de representação e o raciocínio espacial na resolução de problemas, modelo que tende a ser privilegiado no mundo colaborativo do século XXI.

O desenvolvimento de pensadores espaciais críticos pode ser realizado através da fotografia enquanto processo de observar com intenção, estruturando um modelo de aprendizagem que estabelece relações entre os conteúdos teóricos e o mundo real. Uma das vantagens desta abordagem reside no entusiasmo que os estudantes demonstram em responder ativamente aos desafios colocados, mobilizando o visual (Sanders, 2007). Porém, a fotografia tende a ser utilizada enquanto um apoio meramente descritivo da paisagem (Rose, 2008). 
Numa primeira fase, a fotografia pode ser mobilizada para o reconhecimento do território, identificando-se um problema num determinado espaço. Segundo Sanders (2007) e Rose (2008), é o fotógrafo quem decide o que fotografar e com que perspetiva, abrindo o debate sobre as múltiplas interpretações e representações do território e dos seus problemas. Por exemplo, Edensor (2005) mobiliza as suas produções fotográficas para documentar a sua perspetiva sobre os problemas e as consequências causadas pelo processo de arruinamento de áreas industriais. Por isso, e como relembra DeCuyper (1997), a fotografia deve ser usada em termos analíticos e de relevância social e não meramente enquanto um apoio ilustrativo para um texto, permitindo a representação dos aspetos materiais do espaço, o que implica que se reflita sobre ela cuidadosamente (Sanders, 2007; Rose, 2008).

Mobilizando a sua experiência académica, Sanders (2007) reconhece que a fotografia exige aos estudantes a captura da complexidade e a mobilização de conceitos teóricos para responder aos desafios espaciais. Deste modo, os estudantes desenvolvem competências de observação ativa e aprendem que não estão apenas a produzir fotografias (Rose, 2008), mas a capturar parte da realidade que deve prosseguir com uma análise substantiva através da recolha, tratamento e visualização da informação geográfica (Sanders, 2007). Deste modo, as fotografias são agentes ativos na construção de diferentes tipos de conhecimento geográfico (Rose, 2008).

Estas ferramentas que um pensador espacial crítico deve desenvolver vão-se estruturando, tendo a consciência de que o que é fotografado não nos conta toda a história, mas parte dela. Consequentemente, Sanders (2007) reconhece que os estudantes notaram que Ihes foi exigido que pensassem criticamente sobre os problemas territoriais e que não produzissem fotografias aleatórias (Sidaway, 2002; Sanders, 2007). Para a sua estruturação, as competências desenvolvidas durante o trabalho de campo, designadamente a observação crítica, são essenciais, nomeadamente para a discussão e seleção das fotografias pelos estudantes. Deste modo, as lógicas de decisão associadas à escolha das imagens são fundamentais no processo de resolução de problemas, sendo, por isso, vital consolidarem-se objetivos pedagógicos críticos na identificação de problemas espaciais através da prática fotográfica (Sidaway, 2002).

\section{Resultados e Discussão}

Ao longo dos últimos 7 anos, o Projeto Nós Propomos! tem consolidado os seus objetivos de fomentar a cidadania territorial dos estudantes participantes. 
Esse contributo, amplamente desenvolvido através da metodologia ancorada no caso de estudo, é identificada nas perceções dos estudantes participantes entre 2011 e 2018. Primeiramente, mais de metade dos estudantes reconhecem que o Nós Propomos! tem contribuído significativamente ou muito significativamente para a inovação na educação geográfica (Figura 3). Ao longo dos últimos anos, esta evidência tem-se consolidado, não só pela redução da proporção de estudantes que percecionam que o Projeto não tem contribuído para a inovação na aprendizagem geográfica de $6,5 \%$ em 2011/12 para 1,1\% em 2017/18, mas também pela proporção de alunos que percecionam como elevado ou muito elevado o contributo do Projeto nessa dimensão (84,5\%). Estes resultados revelam a importância de uma aprendizagem ancorada em problemas do quotidiano (Cachinho, 2006, 2010). Deste modo, os alunos consideram-se construtores do próprio conhecimento através do aprofundamento de uma realidade que constitui o seu caso de estudo e que é desenvolvida sob a forma de trabalho de grupo e de campo, dimensões que os estudantes destacam enquanto pontos fortes do Projeto.

Considerando as dimensões do conhecimento dos problemas do território local e a formulação de propostas de resolução para os problemas identificados, cerca de $70 \%$ a $80 \%$ dos estudantes reconhecem que o Projeto tem permitido um melhor conhecimento do território local (Sidaway, 2002; Sanders, 2007). Porém, os valores intermédios ("Razoavelmente") registam um valor médio de $16 \%$. Contudo, os valores das classes mais negativas são pouco expressivos, tendo diminuído de 9,5\% em 2011/12 para cerca de $1 \%$ em 2017/18. Por outro lado, os estudantes reconhecem que o Projeto tem desenvolvido a capacidade de formular propostas para os problemas locais (Figura 5). 


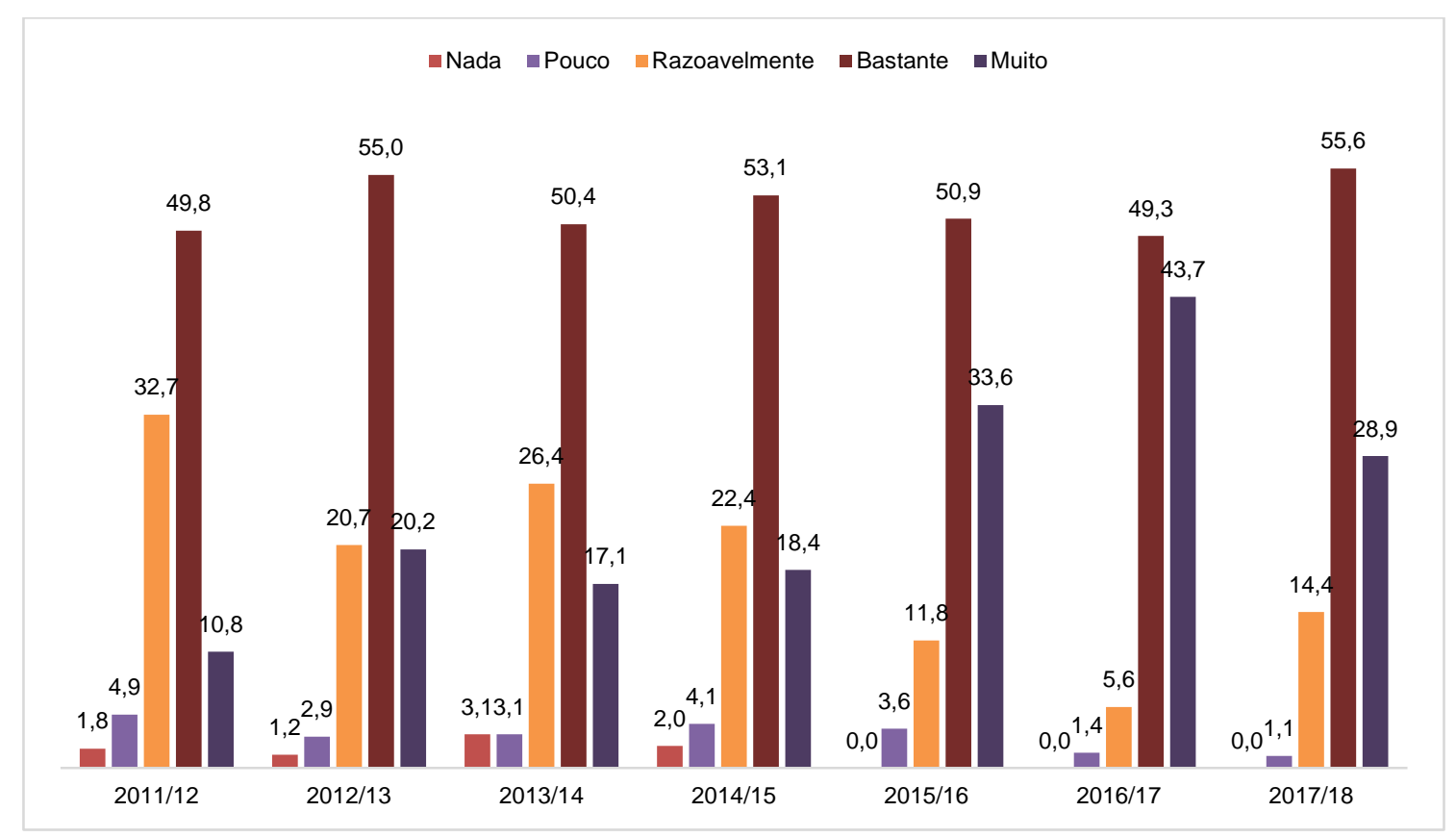

Fonte: Elaboração própria, Inquéritos de Avaliação Global do Projeto Nós Propomos (2011-18)

Figura 4 - Perceções dos estudantes: contributo do Nós Propomos! (2011-18) para o conhecimento do território local (\%)

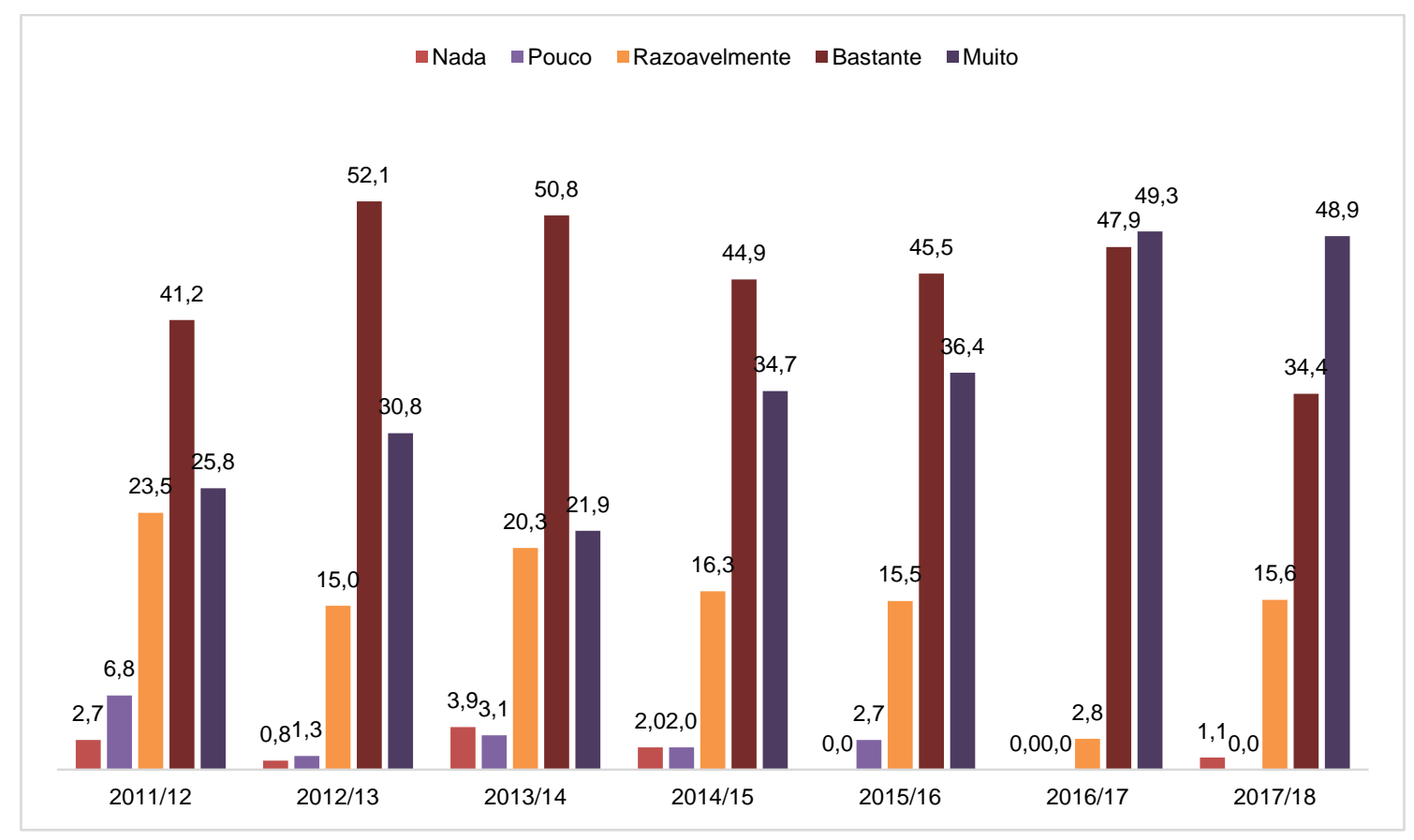

Fonte: Elaboração própria, Inquéritos de Avaliação Global do Projeto Nós Propomos (2011-18)

Figura 5 - Perceções dos estudantes: contributo do Nós Propomos! (2011-18) para a reflexão crítica sobre problemas territoriais e formulação de propostas (\%) 


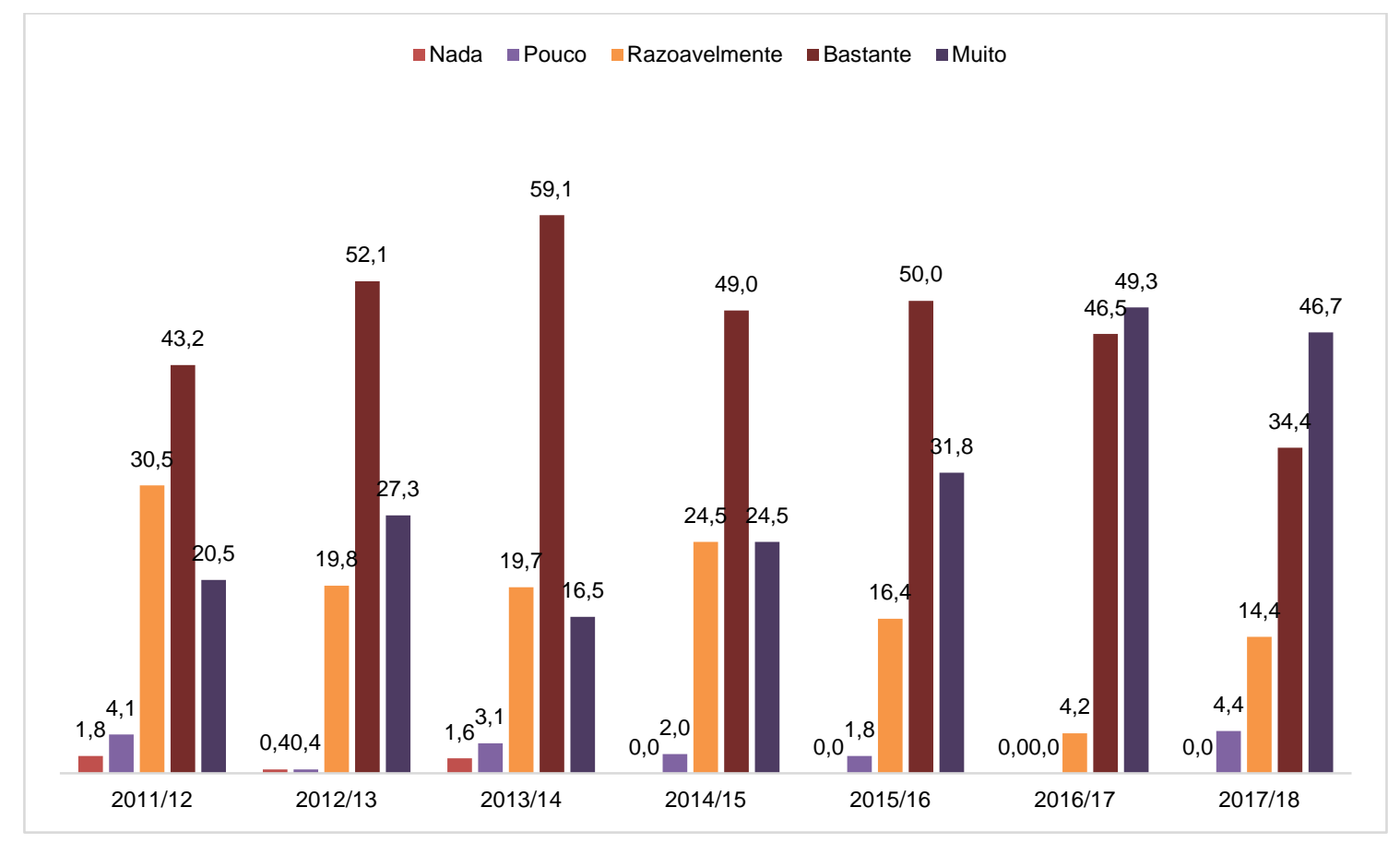

Fonte: Elaboração própria, Inquéritos de Avaliação Global do Projeto Nós Propomos (2011-18)

Porém, a elevada participação dos estudantes num Projeto onde a promoção da participação cívica é inquestionável (Figuras 3 a 5 ) pode não apresentar uma correspondência no desenvolvimento da literacia espacial.

Em primeiro lugar, realça-se que o número de participantes no concurso de fotografia tem recrudescido nos últimos anos. Com a introdução do concurso em 2014/15, apenas $2,5 \%$ do total de estudantes participantes no Projeto submeteram fotografias enquanto que em 2017/18 esse valor atingiu os 5,3\%. Este aumento relativo pode ser, em parte, explicado pela democratização do acesso e da ubiquidade que as tecnologias da informação assumem num contexto de globalização da informação, designadamente através de equipamentos móveis, muitos dos quais com significativa qualidade tecnológica para produção fotográfica (Goodchild \& Janelle, 2010). Ainda assim, globalmente, a participação relativa é fraca (Figura 6), realidade que pode ser explicada pela reduzida mobilização das potencialidades da imagem enquanto veículo para a identificação e aplicação de conceitos espaciais num contexto didático e de aprendizagem ativa.

Contudo, este incremento do nível de participação parece não ter em correspondência a dimensão crítica do pensamento espacial subjacente às produções fotográficas (Bearman et al., 2016; Goodchild, 2009). Assim, o aumento do número de participantes decorre de progressos tecnológicos nas redes móveis e digitais, não sendo sinónimo do desenvolvimento de competências de pensamento espacial crítico, uma vez que, em muitos casos, a produção da fotografia, embora de qualidade técnica 
elevada, não é acompanhada de um processo de observação com intenção (Sanders, 2007).

Figura 6 - Evolução do número de participantes no Projeto Nós Propomos! (2011-18) e no Concurso de Fotografia (2014-18)

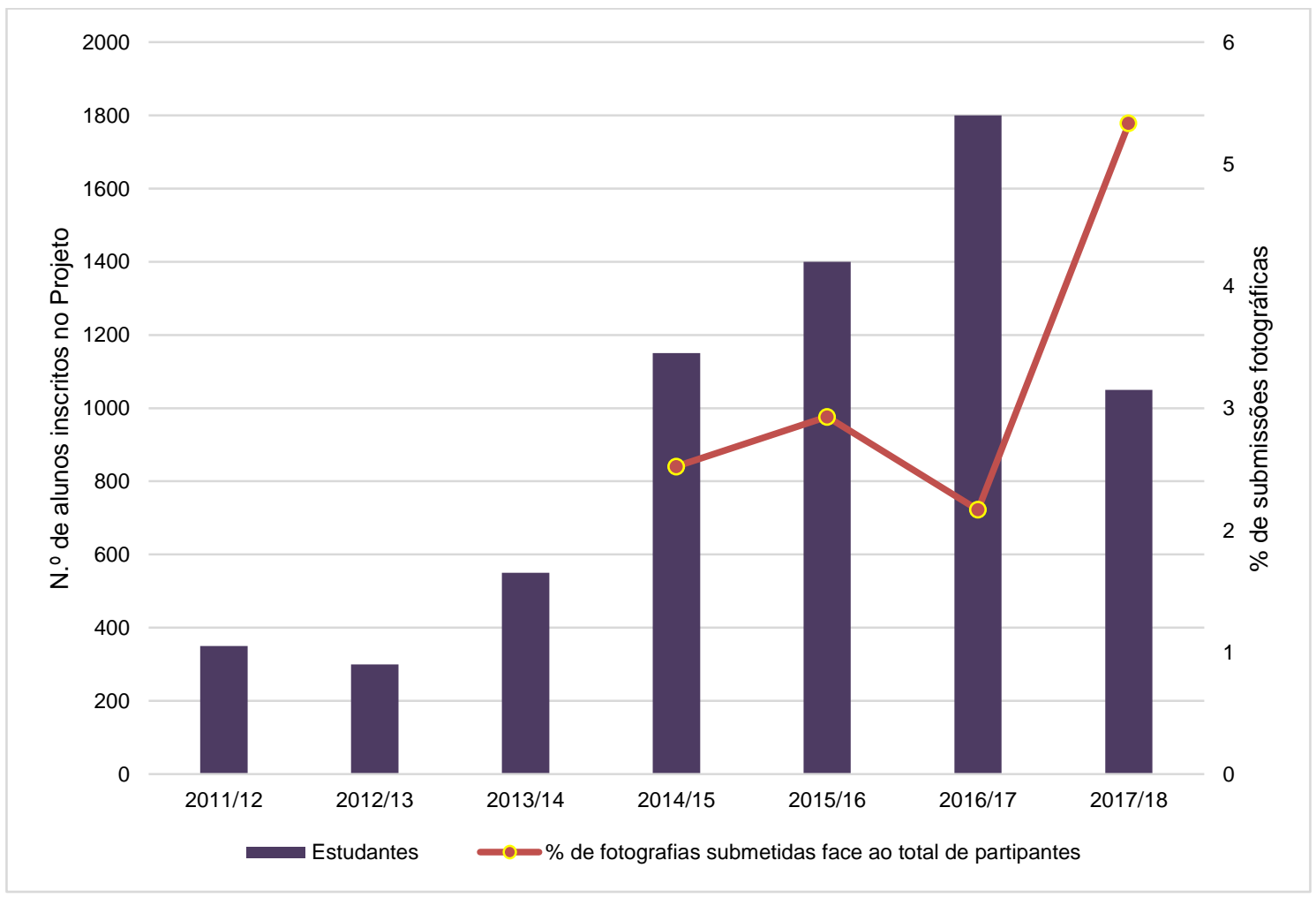

Fonte: Elaboração própria, Projeto Nós Propomos! (2011-18) e Concurso de Fotografia (2014-18)

Consequentemente, uma das limitações da maioria das produções fotográficas traduzse na sua utilização enquanto um mero apoio ilustrativo do trabalho de campo (Rose, 2008), descurando-se o valor simbólico, analítico e crítico que estas podem revelar para a identificação ou resolução de um problema (DeCuyper, 1997). Assim, os participantes tendem a desvalorizar a potencialidade dos métodos fotográficos enquanto métodos de auxílio da representação dos aspetos materiais do espaço (Rose, 2008).

Deste modo, a produção fotográfica só deve ser submetida depois de validadas as etapas do ciclo de aprendizagem de um pensador espacial crítico que pretende identificar e responder a problemas espaciais, objetivos partilhados pelo Projeto Nós Propomos!. Assim, o pensador espacial crítico deve refletir criticamente sobre os problemas locais existentes, escolhendo um caso de estudo. Nesta fase devem ser colocadas questões geográficas que ajudem o fotógrafo a problematizar aquilo que irá ser fotografado. Realça-se que os métodos fotográficos, numa primeira fase, podem ser mobilizados para o reconhecimento do território, esboçando-se uma geografia do 
que acontece ou do que aconteceu. Paralelamente, esta problematização deve estar ancorada em conceitos teóricos que assumem, naquele caso de estudo, uma expressão territorial (Sanders, 2007; Rose, 2008). Posteriormente à identificação do problema, os estudantes devem recolher informação que permita avaliar o seu impacto social. Assim, a fotografia deve representar um problema que, além de identificado pelos estudantes, deve revelar uma dimensão social. Esta fase resulta do tratamento e visualização da informação geográfica (Bearman et al., 2016).

Uma das limitações que se tem identificado no concurso, além da quase-aleatoriedade das produções que revelam défices significativos no desenvolvimento do pensamento espacial crítico, decorre da ausência ou incorreta mobilização dos conceitos teóricos adequados para compreender o mundo envolvente, nomeadamente nos títulos das fotografias e nos projetos finais. Esta (in)capacidade, que deve ser aprimorada durante a construção de pensadores espaciais, é igualmente avaliada pelo júri, aplicando-se penalizações quando o conceito é incorretamente mobilizado.

Depois de aplicados estes procedimentos do pensamento espacial crítico, torna-se possível responder com rigor às questões geográficas. Consequentemente, os métodos fotográficos devem ser permanentemente mobilizados ao longo deste processo, sendo uma das formas de apresentação dos resultados. Esses resultados serão tão melhor consolidados quanto maior for a reflexão crítica em torno da capacidade de inquirição geográfica, incluindo a problematização, a recolha e tratamento da informação e articulação com o mundo real.

Por isso, os métodos fotográficos não devem pertencer a um sistema fechado e circunscrito a uma das fases do processo de construção de um pensador espacial crítico. Primeiramente, a fotografia deve ser mobilizada para o reconhecimento do território através da identificação de um problema espacial. Em fases de maior maturação do pensamento espacial, ou seja, após a análise substantiva da informação estruturada em conceitos geográficos, a fotografia inicialmente produzida pode não documentar a perspetiva total sobre o problema ou sobre as consequências causadas por um determinado processo territorial, sendo necessária a produção de uma nova fotografia, potenciando-se, assim, o seu significado e valor técnico-científico para responder às questões geográficas (Sanders, 2007). Por isso, a produção de fotografias e a sua seleção deve ser criteriosamente justificada e a sua escolha deve refletir os processos teóricos abordados (Sidaway, 2002). Assim, uma fotografia que realce um problema associado ao arruinamento urbano deve associar, no seu título, um conceito que traduza esse processo ou que, enquanto solução, proponha, por 
exemplo, a sua regeneração. No concurso de fotografia é rara a mobilização desses conceitos nos títulos das fotografias, situação que eleva substancialmente o nível de subjetividade da avaliação.

Consequentemente, para a estruturação de um pensador espacial crítico, devem ser desenvolvidas competências de observação durante 0 trabalho de campo, particularmente na discussão das fotografias. Deste modo, devem consolidar-se métodos de observação crítica na identificação e resolução de problemas espaciais através da fotografia (Sidaway, 2002).

Apesar destas limitações, o concurso de fotografia apresenta um conjunto de boas práticas que devem ser realçadas. Além da qualidade técnica da produção fotográfica, avaliada segundo critérios de exposição de luz e impacto visual, a qualidade científica, onde é avaliada a dimensão crítica e a mensagem da fotografia, é, em alguns casos, elevada, sendo possível identificar um problema territorial e, em poucos casos, uma proposta de resolução.

Por exemplo, as fotografias inseridas no projeto "O que fazer em caso de incêndio florestal? A importância da participação comunitária" seguem as etapas do ciclo de aprendizagem estruturante de um pensador espacial crítico (Figuras 7 e 8). Este projeto problematiza a temática dos incêndios florestais que afetaram a região em 2017. Identificando um problema associado às consequências dos incêndios florestais, designadamente a fraca resiliência comunitária, e mobilizando um conjunto de métodos qualitativos e quantitativos, os estudantes procuraram evidenciar a importância da participação comunitária na mitigação e na adaptação a situações de elevada vulnerabilidade social face a incêndios florestais. A proposta apresentada prevê a criação do programa "Aldeias Resilientes" que almeja monitorizar e avaliar o desempenho das comunidades na mitigação de situações de risco. 
Figura 7 - "Angústias", O que fazer em caso de incêndio florestal?: a importância da participação comunitária

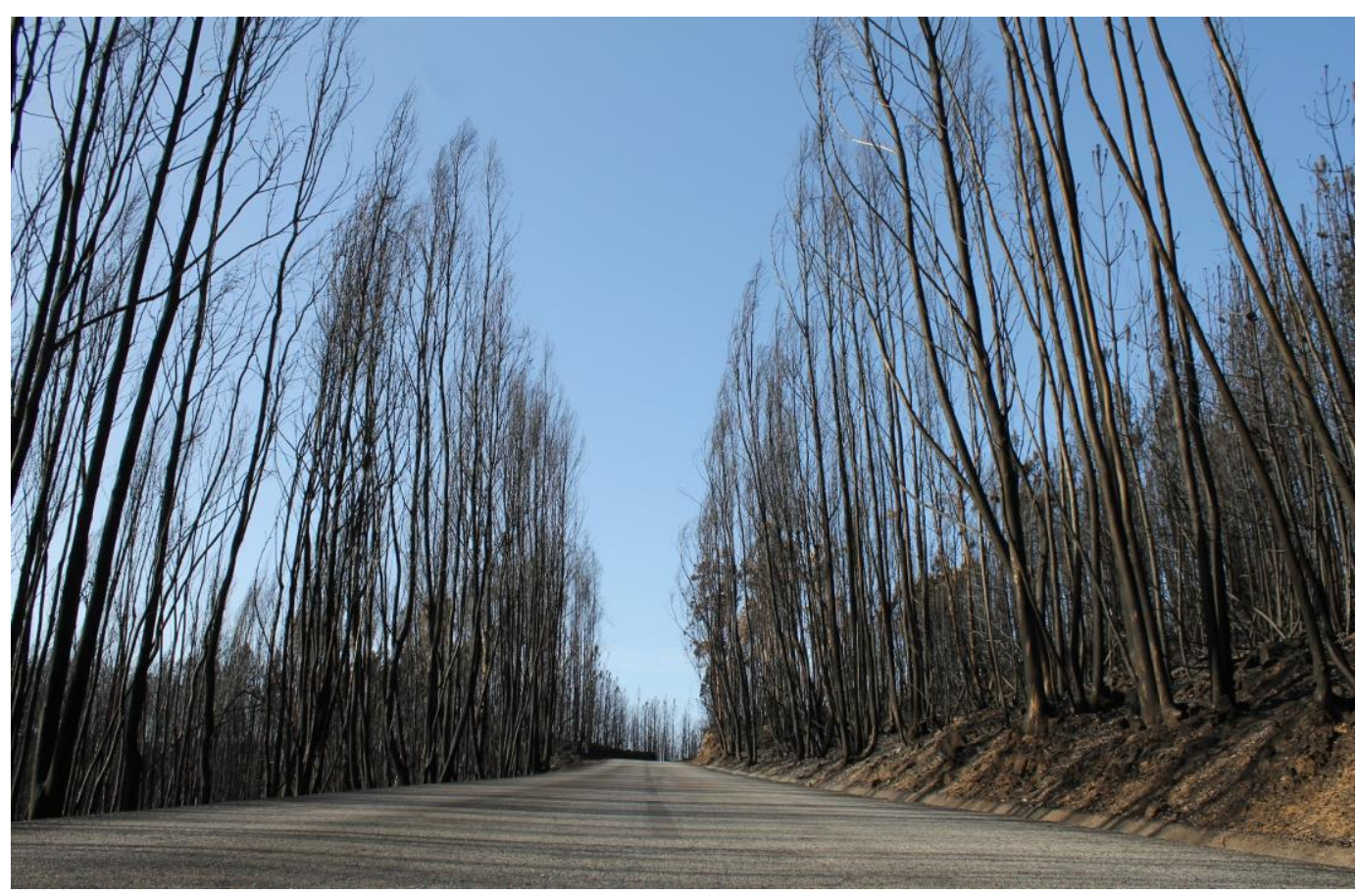

Fonte: Concurso de Fotografia 2018, Fotografia de Rafaela Anaya, Escola Secundária da Sertã (2018)

Figura 8 - "Num simples olhar", O que fazer em caso de incêndio florestal?: a importância da participação comunitária

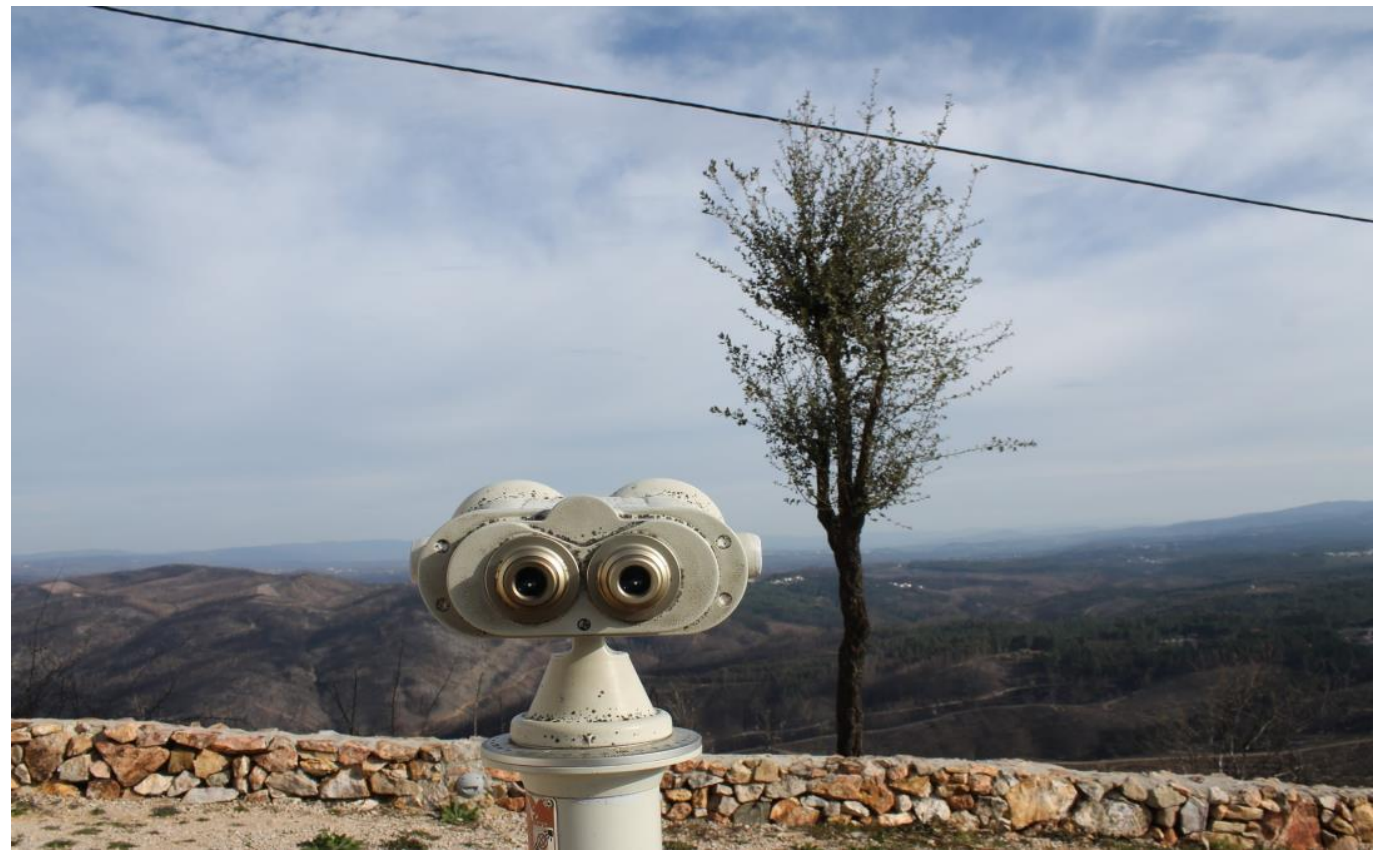

Fonte: Concurso de Fotografia 2018, Fotografia de Rafaela Anaya, Escola Secundária da Sertã (2018).

Apesar dos títulos das fotografias não permitirem uma enunciação clara do conceito central - a resiliência -, a análise das representações permite identificar o problema 
territorial e a sua relação com os objetivos do projeto. Embora não tenhamos acesso à informação temporal em que as fotografias foram produzidas, estas podem ter sido captadas em momentos distintos do processo de aprendizagem. Porém, se não o foram, demonstram claramente dois momentos. A primeira fotografia enquadra-se num período de reconhecimento do território e de identificação do problema e a segunda parece demonstrar uma maior maturação no processo do pensamento espacial, posterior à recolha e análise da informação geográfica, porque, além de incorporar o problema no plano intermédio, apresenta uma solução em primeiro plano: a prevenção através de "um simples olhar", simbolicamente representado por um local de observação. Deste modo, parece haver um reconhecimento da importância da prevenção no planeamento das emergências, o que contribui para a resiliência comunitária.

\section{Considerações finais}

Este artigo procurou discutir criticamente a importância do Projeto Nós Propomos! e do concurso de fotografia em Portugal para a construção de pensadores espaciais críticos. Parece evidente que o Projeto apresenta um elevado potencial para 0 desenvolvimento de cidadãos interventivos nos seus territórios de residência. Contudo, apesar das perceções dos estudantes destacarem o contributo do Projeto na consolidação da inovação na educação geográfica ou para o conhecimento do território local e formulação de propostas para a resolução dos problemas locais, a participação no concurso de fotografia não demonstra uma relação paralela com o desenvolvimento de competências de pensamento espacial crítico e apresenta resultados de participação relativos reduzidos.

Consequentemente, e apesar dos progressivos desenvolvimentos tecnológicos que potenciaram a qualidade e a quantidade das produções fotográficas, parte significativa destas não revelou estruturar-se segundo as etapas do ciclo de aprendizagem de um pensador espacial crítico. Dessas evidências realça-se a ubiquidade e o fraco desenvolvimento de competências associadas à observação com intenção durante o trabalho de campo, factos que limitam o conteúdo teórico-concetual e prático da representação fotográfica.

Deste modo, parte das fotografias submetidas revelou-se um elemento meramente ilustrativo do trabalho de campo realizado, tendo-se desvalorizado o valor social e crítico dos métodos fotográficos que tendem a ser mobilizados numa fase circunscrita do processo de desenvolvimento de pensadores espaciais críticos. Através da 
identificação de "boas práticas", sugere-se que os métodos fotográficos podem ser mobilizados, numa primeira fase, para o reconhecimento e identificação de um problema territorial e posteriormente, após a recolha e tratamento da informação, através da mobilização dos conceitos teóricos adequados para compreender o mundo envolvente. Considerando a experiência portuguesa, verificou-se que os conceitos não são adequadamente mobilizados, por exemplo, no título das produções fotográficas, o que contribui para um elevado nível de subjetividade da avaliação.

Considerando estas evidências e a fim de potenciar a prática fotográfica ancorada no desenvolvimento de pensadores espaciais críticos, afigura-se relevante que, para que sejam minimizados os problemas decorrentes de uma avaliação subjetiva, seja introduzida, enquanto elemento de avaliação do concurso de fotografia, uma memória descritiva de, no máximo, 150 palavras. Nesse elemento, o participante deve destacar o conceito geográfico estruturante, nomeadamente através do seu título, e deve justificar a seleção daquela fotografia para submeter a concurso, indicando qual o problema e qual a intenção da sua representação. Deste modo, seriam desenvolvidas as técnicas de observação com intenção durante o trabalho de campo, além de se considerarem os métodos fotográficos como elementos fundamentais na resposta às questões geográficas "Onde?", "O quê?" e "Porquê aqui?", aclarando-se ainda as especificidades dos territórios e dos problemas locais.

Uma segunda sugestão prende-se com a possibilidade de se incorporarem, nos inquéritos por questionário preenchidos pelos estudantes participantes no final de cada ano letivo, um conjunto de questões específicas que aferisse o interesse relativo aos concursos desenvolvidos, permitindo a realização de ajustes nas edições seguintes e, face aos resultados obtidos, considerar estratégias ativas de promoção da participação nos concursos.

Finalmente, deve ainda consolidar-se a rede ibero-americana Nós Propomos! através do incentivo e implementação de concursos de fotografia em cada país. Com os devidos ajustamentos às realidades de cada membro, os critérios de classificação das produções fotográficas deveriam ser estandardizados, permitindo a realização de uma comparação interanual e internacional do desenvolvimento de competências de observação com intenção que devem ser inerentes à construção de um pensador espacial crítico.

\section{Referências bibliográficas}


Anselin, L., Florax, R. J., Rey, S. J. (eds.) (2004). Advances in spatial econometrics: Methodology, tools and applications. Springer, Berlim.

Bearman, N., Jones, N., André, I., Cachinho, H., \& DeMers, M. (2016). The future role of GIS education in creating critical spatial thinkers. Journal of Geography in Higher Education, 40(3), 394-408. https://doi.org/10.1080/03098265.2016.1144729

Cachinho, H. (2006). Creating wings: The challenges of teacher training in postmodernity. In K. Purnell, J. Lidstone, \& S. Hodgson (Eds.), Changes in geographical education: Past, present and future, Proceedings of the International Geographical Union Commission on Geographical Education (pp. 96-102). Brisbane, Austrália: IGU.

Cachinho, H. (2010). Aprendizagem baseada em problemas: desafios da sua implementação em ambientes de racionalidade técnica. Congresso Internacional - PBL 2010: Aprendizagem Baseada em Problemas e Metodologias Atividades de Aprendizagem, São Paulo, Brasil. DOI: 10.13140/2.1.4509.5365

Claudino, S., Mendonça, S. (2017). “Nós Propomos»: uma proposta alternativa de educação geográfica na Iberoamérica". In J. Bazzoli, S. Claudino, M. Costa e Silva, S. Viana \& W. Silva (Eds.), A extensão universitária como indutora à cidadania: a experiência do "Nós Propomos", 103-112, Palmas, Brasil.

DeCuyper, S. (1997). On the future of photographic representation in anthropology: lessons from the practice of community photography in Britain, Visual Antropology Review, 13(2), 3-17

Edensor, T. (2005). Industrial ruins: aesthetics, materiality and memory, Oxford: Berg.

Goodchild, M. F. (2009). The changing face of GIS. Keynote presentation at the GIS in the humanities and social sciences international conference; October 7-9; Taipei, Taiwan: Research Center for Humanities and Social Sciences, Academia Sinica.

Goodchild, M. F., \& Janelle, D. G. (2010). Toward critical spatial thinking in the social sciences and humanities. GeoJournal. https://doi.org/10.1007/s10708-010-9340-3

Rose, G. (2008). Using photographs as illustrations in human geography. Journal of Geography in Higher Education, 32(1), 151-160. https://doi.org/10.1080/03098260601082230

Sanders, R. (2007). Developing geographers through photography: Enlarging concepts. Journal of Geography in Higher Education, 31(1), 181-195. https://doi.org/10.1080/03098260601033118 
Sidaway, J. D. (2002). Photography as geographical fieldwork. Journal of Geography in Higher Education, 26(1), 95-103. https://doi.org/10.1080/03098260120110395 


\title{
Nós Propomos! Metodologia do Estudo de Caso no ensino da Geografia na UNIOESTE/Pato Branco/PR/Brasil
}

\author{
ELIANE MARIA ROZIN ${ }^{1}$
}

ANA CLAUDIA BIZ

\section{Resumo}

Este artigo apresenta o subprojeto "Nós Propomos! Ensinar e aprender sobre o lugar com significado", realizado com estudantes do ensino médio, no Colégio Estadual Professor Agostinho Pereira, em Pato Branco/PR/BR. O propósito foi identificar as problemáticas com a participação ativa dos estudantes, por meio do Estudo de Caso. Os participantes envolvidos diretamente foram 35 estudantes e quatro professoras, sendo três da Universidade Estadual do Oeste do Paraná e uma da escola, em parceria com o Instituto de Geografia e Ordenamento do Território da Universidade de Lisboa, Portugal- IGOT/UL/PT. Durante o desenvolvimento houve a apresentação do subprojeto aos estudantes pelo Professor Sérgio Claudino. As etapas consistem na decisão das temáticas, elaboração dos logotipos, na realização do diagnóstico e identificação dos problemas, organização e planejamento das ações. Os estudantes se organizaram em cinco grupos com as seguintes temáticas: 1) Placas de informação nos pontos de ônibus urbano; 2) Trânsito; 3) Ração e água para animais de rua; 4) SOS Vida Animal; e, 5) Literatura Cidadã. Para a sua efetivação realizaram estudos, debates para identificar os problemas e apresentar propostas. A pesquisa pretende aproximar universidade-escola-comunidade; concretizar a participação em eventos; promover atividades de participação democrática no município; refletir sobre e o ensino de Geografia no ensino médio; formar o estudante para a cidadania, a partir do conhecimento do lugar, como possibilidade de construção e do comprometimento com

\footnotetext{
Mestranda em Educação pela Universidade Estadual do Oeste do Paraná - UNIOESTE Francisco Beltrão, PR - Brasil, nannebb@hotmail.com

2 Doutoranda em Geografia pela Universidade Estadual do Oeste do Paraná - UNIOESTE Francisco Beltrão, PR - Brasil, anacbiz@gmail.com
} 
- conhecimento; reconhecer as possibilidades de mudanças no ensino e nas vinculadas à vida dos estudantes e ao seu lugar.

Palavras-chave: Ensino e Aprendizagem; Geografia; Lugar; Cidade.

\section{Abstract}

This article presents the We Proposed subproject! Teach and learn about the place with meaning. Held with high school students, at the State College Professor Agostinho Pereira, in Pato Branco / PR / BR. The purpose was to identify the problems with the active participation of the students, through the Case Study. The participants directly involved 35 students and four teachers, three from the State University of the West of Paraná and one from the school, in partnership with the Institute of Geography and Spatial Planning of the University of Lisbon, Portugal - IGOT / UL / PT. During the development there was the presentation of the subproject to the students by Professor Sérgio Claudino. The stages consist in the decision of the themes, elaboration of the logos, in the realization of the diagnosis and identification of the problems, organization and planning of the actions. The students were organized in five groups with the following themes: 1) Information boards at the urban bus stops; 2) Transit; 3) Feed and water for street animals; 4) SOS Animal Life; and, 5) Citizen Literature. For their accomplishment, they carried out studies, debates to identify problems and present proposals. The research intends to approach university-school-community; materialize participation in events; promote activities of democratic participation in the municipality; reflect on and the teaching of Geography in high school; to form the student for citizenship, from the knowledge of the place, as a possibility of construction and commitment to knowledge; recognize the possibilities of changes in teaching and those linked to students' lives and their place.

Keywords: Teaching; Geography; Place; City

\section{Introdução}

Como professores de Geografia, atuando na rede estadual de ensino do estado do Paraná, deparamo-nos com a problemática de que há o distanciamento na aprendizagem entre os conceitos científicos e a realidade. Frente a essa intranquilidade, surgiu o desafio de investigar um ensino significativo. Cabe ressaltar o grande estímulo por parte dos estudantes e de professores, como oportunidade de fazer integração internacional, importante porque possibilita reinventar as fronteiras do 
conhecimento disciplinar por meio da pesquisa e da participação cidadã, bem como oportunizar ao estudante fazer ciência.

Destacamos a parceria entre a Universidade Estadual do Oeste do Paraná, Campus de Francisco Beltrão, Paraná - UNIOESTE/FB, e Instituto de Geografia e Ordenamento do Território da Universidade de Lisboa, Portugal - IGOT/UL/PT, para a realização desta pesquisa que objetivou analisar 0 processo de ensino e aprendizagem dos conteúdos geográficos, por meio do Estudo de Caso, enquanto metodologia de pesquisa, por intermédio do estudo do lugar. Bem como, de compreender como ocorre a apropriação do sentido no contexto da comunidade local, fomentando a participação dos estudantes na identificação dos problemas e na busca de propostas para mudanças. Teve início em outubro de 2017 e envolveu os estudantes com idade entre 15 a 17 anos, uma turma de 35 estudantes, do $1^{\circ}$ Ano do Ensino Médio, em 2017 e do 2 ํ Ano em 2018.

A coleta dos dados foi realizada por meio de questionários, entrevistas e trabalhos de campo. As ações foram realizadas em vários momentos, desde o diagnóstico, até visitas de professores da universidade à escola, realizaram estudos, trabalhos de campo, entrevistas e debates. A formação de grupos pelos estudantes oportunizou o desenvolvimento das propostas dos projetos. Os estudantes decidiram sobre as temáticas, os logotipos representativos, a realização do diagnóstico, a identificação dos problemas, a organização e o planejamento das ações. Organizaram-se em cinco grupos e definiram as seguintes temáticas: 1) Placas de informação nos pontos de lotação; 2) Trânsito; 3) Ração e água para animais de rua; 4) SOS vida animal e, 5) Literatura nas instituições.

A participação dos estudantes se concretizou com o "I colóquio Ensino de Geografia com Significado na Pesquisa Nós Propomos UNIOESTE/PR/BR", realizado em 16 de agosto de 2018. As atividades envolveram a participação e reflexão sobre o ensino de Geografia no Ensino Médio; a formação para a cidadania a partir do conhecimento do lugar.

\section{O ensino de Geografia e o lugar}

O estudo do lugar compreende uma importante contribuição para a construção de conhecimentos. A abordagem das experiências de vida dos estudantes favorece significativamente a produção e o desenvolvimento de saberes úteis, com o significado social dos conteúdos e da participação da escola na sua formação. Para Santos (2008), o lugar assume nova dimensão, é o ponto de encontro de interesses 
longínquos e próximos, locais e globais, com conceito amplamente discutido em Geografia, possui tamanha importância por representar uma categoria geográfica composta de significados próprios além da sua prática social.

Cavalcanti (2002) reafirma a importância de os estudantes abordarem a temática do espaço urbano nos conteúdos de Geografia, por se tratar de uma espacialidade específica, com múltiplos aspectos e características próprias. Desse modo, com o intuito de desenvolver valores e condutas para a vida cotidiana, de contribuir, neste sentido, para a formação da cidadania. Igualmente, fica a evidência do estudo da Geografia baseado na proximidade do estudante. Isto propicia o entendimento dos problemas decorrentes da fragmentação do espaço urbano ou rural, bem como na segregação sócioespacial. Esta seria a contribuição para uma visão crítica do lugar e para a formação de cidadãos autônomos no pensar e agir, vislumbrando uma sociedade mais justa e democrática.

Nesse sentido, destacamos a importância do ensino da Geografia para formação da cidadania. O ensino de Geografia contribui para a formação da cidadania pela prática de construção e reconstrução de conhecimentos, habilidades, valores que ampliam a capacidade dos estudantes compreenderem o mundo em que vivem e atuam, numa escola organizada como um espaço aberto e vivo de culturas. O exercício da cidadania na sociedade atual, por sua vez, requer uma concepção, uma experiência, uma prática de cidade. (Cavalcanti, 2002).

A inquietude frente à educação geográfica fomenta o professor na busca de novas maneiras de ensinar e de perceber o processo de ensino. Compreender que há necessidade, muitas vezes, de mudar o foco da atividade no sentido da aprendizagem, desafiar os estudantes a procurar solução para problemas do cotidiano e tornar a educação um processo emancipatório para ensinar os conceitos em Geografia a partir da realidade.

\section{Ressignificar o ensino do lugar: estudo de caso com Geografia na escola}

O desenvolvimento da pesquisa seguiu algumas fases, mais indicativas do processo. Entre elas destacamos: a) reunião com a direção da escola, professoras da UNIOESTE/FB e a pesquisadora; b) assinatura do protocolo com a direção do Colégio Estadual Professor Agostinho Pereira, Pato Branco/PR, IGOT/UL/PT e UNIOESTE/FB; c) apresentação do projeto aos estudantes pelo Professor Sérgio Claudino; d) incentivo para a inscrição dos estudantes nas redes sociais do projeto e para pesquisas sobre o projeto em outros estados ou países; e) formação de grupos de estudo para discutir sobre os problemas de Pato Branco/PR. 
Os estudantes escolheram temáticas e discutiram quanto a relevância sobre tratar dos problemas no bairro e a importância disso para a cidade. O desenvolvimento dos trabalhos pelos grupos aconteceu em etapas que foram: a) Seleção do nome do grupo e a criação de um logotipo que representou o tema e o problema estudado; b) Análise do Plano Diretor do município; c) Realização do trabalho de campo, em 19 de abril de 2018, por meio de entrevistas à população e às autoridades nas secretarias da Prefeitura Municipal (Secretaria do Meio Ambiente, gabinete do Prefeito, DEPATRAN Departamento de Trânsito, entre outros). O projeto foi apresentado, também, aos empresários de estabelecimentos centrais da cidade; e, d) A elaboração das propostas, que ocorreu concomitante ao trabalho de campo culminando.

Os problemas elencados pelos estudantes vão desde a responsabilidade da administração pública sobre o trânsito, da cidade, até a localização irregular de semáforos. Dois grupos se preocuparam em abordar a questão dos animais abandonados; outro com, a literatura cidadã e a importância da leitura em instituições; Também surgiu o problema da falta de informações nos pontos de lotação na área central. Cabe salientar que os nomes dos estudantes neste artifgo são nomes fictícios. Os estudantes se manifestaram em relação às ações: "Estamos ansiosos para pôr os projetos em prática." (Estudante Larissa, 2017); “Estamos tendo muitas experiências." (Estudante Sabrina, 2017); "Estamos muito contentes por sair do ambiente da escola e conhecer a realidade." (Estudante Larissa, 2017).

É importante destacar a visita na escola, em 30 de outubro de 2017, dos professores da UNIOESTE/FB, do IGOT/UL/PT, desta última do Professor Sérgio Claudino, que apresentou o projeto desenvolvido, sob sua coordenação, desde 2011 em Portugal, se expandiu para outros países e chegou ao Brasil em 2014. No Paraná, a pioneira foi a professora Mafalda Nesi Francischett, na UNIOESTE Francisco Beltrão/PR em 2017. Este subprojeto intitulado "Estudo de Caso no ensino da Geografia na UNIOESTE/Pato Branco/Brasil" é o segundo a ser desenvolvido no Paraná.

Trata-se de um projeto direcionado à discussão de problemas locais e a apresentação de propostas para a comunidade. Muitas propostas interessantes e, em conjunto com a universidade, administração pública e empresas, foram postas em prática. $\mathrm{Na}$ oportunidade, o professor esclareceu sobre o estudo de caso na educação geográfica, como meio para promover uma ativa cidadania territorial, mobilizar os estudantes para conhecer o Plano Diretor Municipal e apresentar propostas de intervenção no bairro, visando um desenvolvimento sustentável. (Claudino, 2017). 
O Estudo de Caso, apresentado como uma modalidade de pesquisa, em suas diferentes abordagens revela sua importância na inovação do ensino. Como metodologia de pesquisa o estudo de caso é usado para contribuir no conhecimento dos fenômenos individuais, grupais, organizacionais, sociais, políticos e relacionados. [...] seja qual for o campo de interesse, a necessidade da pesquisa de estudo de caso surge do desejo de entender fenômenos sociais complexos. Em resumo, permite que os investigadores foquem um "caso" e retenham uma perspectiva holística e do mundo real. (Yin, 2015, p.4).

Para Claudino (2018), se torna obrigatória a realização de Estudo de Caso para que haja a oportunidade de construir o conhecimento da realidade. Ele salienta que no trabalho em Geografia, a metodologia concretiza análises críticas sobre os problemas locais, refletindo e apresentando propostas, "Um trabalho de índole mais prática e muito direcionado para a escala regional/local e para que se preconize a metodologia de trabalho de projeto." (Claudino, 2018, p. 273).

Os estudantes, particoantes deste subprojeto, se reuniram em grupo, por afinidades, isso facilitou a integração de seus membros. Iniciaram seus projetos em 20 de novembro de 2017, com inúmeras ideias e propostas. As temáticas definidas por eles foram: a) Placas de informação nos pontos de lotação; b) Trânsito; c) Ração e água para animais de rua; d) SOS Vida Animal; e) Literatura Cidadã.

Cada grupo organizou o roteiro das atividades previstas, da pesquisa sobre os problemas locais, com a justificativa sobre os motivos da escolha desse tema, da localização e das propostas de soluções. Os estudantes criaram logotipos significativos referenciados aos seus temas. E, no dia 19 de abril de 2018 realizaram os trabalhos de campo, que foram fundamentais para a pesquisa, pela oportunidade de criar sentido para os estudantes em relação aos conteúdos geográficos, pela observação dos problemas, pelo confronto de informações e pela descrição do que acontece no lugar em relação a outros lugares.

A seguir apresentamos a representação de cada grupo.

Figura 11 - Logotipos dos grupos de trabalho.

1 - Placas de informação nos pontos de lotação $\quad 2$ - Trânsito 


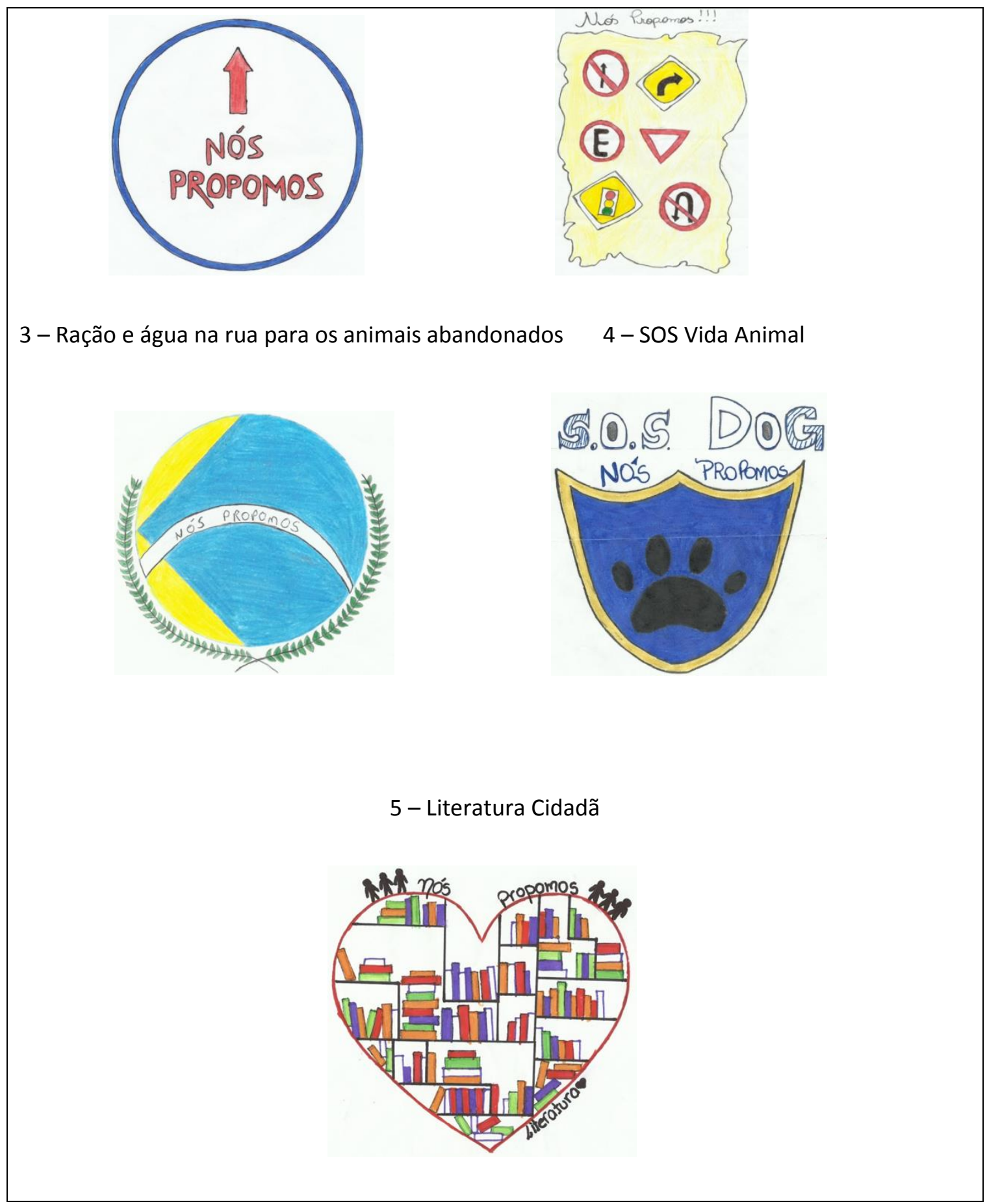

Fonte: Elaboração: Estudantes 2017.

O grupo 1 elegeu o tema placas de informação nos pontos de lotação porque, na visão deles, a comunidade patobranquense precisa saber os horários de lotação nos pontos mais utilizados. Inicialmente a experiência se deu no centro da cidade e mais tarde a ideia será lançada aos demais bairros. Os estudantes realizaram algumas atividades no trabalho de campo como: visitar a empresa que administra as lotações; conhecer o setor da prefeitura que cuida deste segmento; verificar a possibilidade de implantação de placas ou adesivos de informação nos pontos de lotação, inicialmente no Centro; 
criar uma placa modelo para apresentar e se aprovado, apresentar aos presidentes de bairro.

Durante o trabalho de campo entrevistaram em média 15 pessoas, as questões foram sobre o transporte coletivo da cidade; a estrutura de ônibus adequada e as sugestões de melhorias. A professora que acompanhou relata que a iniciativa do grupo foi "incrível": "Era bacana observar que antes de chegarmos, as pessoas estavam em silêncio, não conversavam entre si. Com as perguntas começaram a conversar e ficou um clima agradável de amizade.". (Professora Diane).

Durante as entrevistas, um senhor idoso ressaltou que muita gente não sabe ler ou "não entende", então não adianta placa de horários. Foi nesse momento que surgiu a ideia de, além de placas com informações de horários, propôr um mapa com linhas coloridas. A reclamação maior foi sobre a mudança na concessão do transporte coletivo da cidade, por não ter informação, uma vez que as informações que constam no letreiro luminoso não são suficientes.

Durante o trajeto surgiram novas propostas, houve diálogo e discussão sobre a viabilidade. Há preocupação, inclusive, sobre a quantidade de investimento necessário ao projeto. Em visita ao Transporte Urbano de Pato Branco (TUPA), para a coleta de informações sobre os itinerários surge a informação de que no site da empresa estão disponibilizadas todas as informações. No retorno à escola, eles discutiram sobre o modelo de placa de informação, ou mapa com cores dos itinerários. Também surgiu a ideia de um aplicativo que tenha como base as rotas do transporte, para localizar.

O grupo 2, trabalhou o tema referente ao trânsito, como o mau posicionamento e a localização dos semáforos no centro da cidade, mais especificamente no cruzamento da Avenida Tupi com a Rua Arariboia e o tempo reduzido para a passagem dos pedestres pela faixa. Observaram que a visibilidade, tanto para os pedestres como para os motoristas dos veículos, fica prejudicada e o tempo de passagem para os pedestres é insuficiente, pois comprovaram que é de cerca de três segundos apenas.

No trabalho de campo, as entrevistas foram realizadas com pedestres e com motoristas que transitavam pelo local e com agentes de trânsito. Os assuntos referentes ao trânsito da cidade são direcionados ao DEPATRAN (Departamento de Trânsito de Pato Branco/PR). Ao visitar este departamento, os estudantes foram recebidos pelo diretor, que conversou e esclareceu aos questionamentos deles. Muitas informações foram inéditas, como a da instalação de lombadas no perímetro urbano não estar legalizada na lei municipal; os direitos dos munícipios em relação aos danos causados por má conservação das vias públicas; o número 156 para reclamações e 
denúncias; informações como: na falta de sinalização, é sempre o veículo da direita que possui a preferência; e, na falta de placas de sinalização, a velocidade máxima permitida na cidade é $40 \mathrm{~km} / \mathrm{h}$.

O diretor do DEPATRAN ainda salientou que o maior problema do trânsito é a falta de educação e que para isso, o departamento possui um funcionário que se dedica ao atendimento nas escolas municipais. Porém, nas escolas estaduais não há esse trabalho. Para auxiliar os estudantes pesquisadores, o diretor do departamento, se disponibilizou para a realização de palestra no Colégio. O problema do trânsito é real e não há uma solução imediata, mas pode ser amenizado com ações educativas, segundo o diretor do DEPATRAN. Há a possibilidade de disseminar informações úteis à população pelo projeto dos estudantes.

O terceiro grupo mobilizou-se em favor da causa animal, organizaram entrevistas com a população e ações como propostas.

Entrevistaram dez pessoas, aleatoriamente, no Centro de Pato Branco. Eles queriam saber se elas ajudam aos animais de rua. Todos os entrevistados responderam que sim; desses, nove pessoas responderam que já ajudaram ou ajudariam e uma não ajudou e nem ajudaria, por motivos não citados. Na questão que se refere de que forma foi esse auxílio, as respostas variam entre alimentar animais de rua, ajudar financeiramente ONGs e instituições ou levar algum animal abandonado ao veterinário. $\mathrm{O}$ grupo se propôs a ajudar na venda de ingressos para jantar beneficente em prol da causa e que auxiliaria as ONGs.

As sugestões foram desde a construção de um canil municipal, até o trabalho de conscientização das pessoas, como também mais responsabilidade por parte da prefeitura, pois o problema é social. Os estudantes fizeram apontamentos interessantes, um deles é de que as pessoas têm vontade de ajudar, mas elas não têm iniciativa, também falta tempo para cuidar e se dedicarem à causa animal. Por esse motivo eles preferem ajudar financeiramente alguma entidade que se dispunha a fazer este trabalho, como as ONGs da cidade.

Em visita à Secretaria de Meio Ambiente do município, o objetivo foi verificar se há projetos no município que sejam dedicados à causa dos animais abandonados. Nesse aspecto, eles descobriram que há projetos para os animais de rua, como atendimento veterinário aos acidentados e doentes, castração, realização de feiras de adoção mensais e no auxílio financeiro a um canil particular que acolhe como lar temporário esses animais. Mas, não há nenhum projeto que envolva alimentação como medida 
paliativa do problema. O secretário municipal do meio ambiente indicou que o projeto dos estudantes seria um bom início de trabalho.

Sobre a temática do grupo 4, a ideia surgiu em uma conversa na sala de aula, quando foi solicitado o tema do projeto de pesquisa que seria realizado pelo grupo. $\mathrm{Na}$ oportunidade, os estudantes sugeriram discutir sobre animais abandonados, soltos nas ruas. O grupo, também, trabalhou a busca de soluções para animais de rua e criaram o logotipo.

No trabalho de campo visitaram a Secretaria de Meio Ambiente do município, juntamente com o grupo 3, que trata do tema semelhante.

Para tentar amenizar o problema, em alguns bairros e no centro de Pato Branco, os estudantes sugeriram um modelo de comedouro e bebedouro. A sugestão é instalar comedouros e bebedouros, feitos com cano PVC, pelas ruas da cidade para que os animais possam saciar a sede e a fome a qualquer hora do dia. Os idealizadores relataram que: "A nossa ideia é arrecadar o material no comércio para instalar esses pontos pela cidade. Isso ajudaria bastante os animais abandonados, desde que as pessoas sejam responsáveis na manutenção" (Estudante Geison). O grupo pesquisou as ONGs atuantes na cidade e auxiliaram na divulgação da ONG Anjos Protetores ${ }^{3}$ na programação de um jantar em prol da causa animal.

O grupo 5 se dedicou a superar a dificuldade de aquisição de livros pela Casa abrigo, instituição municipal que abriga 23 crianças. Este grupo desenvolveu o projeto sobre o tema literatura cidadã, preocupados com a falta de leitura das crianças que moram na Casa Abrigo e para fomentar a doação de livros pelos colegas de colégio de colégios próximos. A preocupação principal é promover a leitura, enquanto estratégia de desenvolvimento da cidadania e transformação da sociedade. No trabalho de campo visitaram as salas do colégio Estadual La Salle, na cidade de Pato Branco, apresentaram o projeto e incentivaram os colegas.

Articulados aos grupos de trabalho, os estudantes foram convidados a participar de um programa de rádio local para falar sobre seus projetos para a população. Isso ocorreu em três de maio de 2018. Na oportunidade, foram feitos vários questionamentos sobre a origem e os encaminhamentos do Projeto Nós Propomos, o que resultou na aproximação da escola com a comunidade.

\footnotetext{
${ }^{3}$ A ONG Anjos Protetores, Organização Não Governamental, inscrita no CNPJ sob № 26.639.645/000162, com endereço na Rodovia BR 158, no 6877, Vila Esperança, nesta Cidade de Pato Branco, Paraná, teve sua origem a partir da iniciativa de um grupo de protetores, há mais de cinco anos. Pessoas sensibilizadas e preocupadas com a situação de vulnerabilidade dos animais abandonados nas ruas. Alguns destes animais, antes possuíam tutores, sendo que após fuga ou abandono se tornaram vítimas de acidentes e maus tratos e, ao serem resgatados, estavam doentes e feridos.
} 
No desenvolvimento dos projetos, os estudantes demonstraram o quanto a pesquisa é fundamental na educação geográfica. Eles se declaram como protagonistas construindo o saber no coletivo e pessoal pela pesquisa, pela curiosidade. $O$ fazer pesquisa para eles foi entender um problema e, para o ensino, foi fazer ciência com rigor científico. A curiosidade moveu o processo no seu aspecto formal e instrumental. O estudante maneja o conhecimento e no aspecto político alimenta a cidadania.

\section{Breves considerações}

No desenvolvimento dos trabalhos, os estudantes foram instigados a pesquisar, discutir os roteiros para os problemas elencados, organizar trabalhos de campo, confrontar informações e formar um conceito sobre o problema. A participação efetiva da professora regente, em todo processo foi imprescindível. Seu conhecimento e sua disposição fizeram grande diferença no resultado. Pela opinião dos estudantes ocorreu tomada de consciência e nova visão da Geografia.

Nas palavras dos estudantes, mudou o olhar e fez alguma diferença nas aulas: "Quando você se envolve com os problemas da sua cidade, passa a enxergá-la de outra forma e se sente mais participativo." (Estudante Larissa, 2018); "Com o projeto houve muito aprendizado, mudou muito minha concepção. Além do respeito, quis ajudar mais os outros." (Estudante Muriel, 2018); "Com o projeto ajudamos os animais e aprendemos a ser mais solidários." (Estudante Lucian, 2018); "Significou muito, pois nos descontraiu um pouco do dia-a-dia e por um bom motivo. Fortaleceu nossa relação com os colegas e a professora. Mudou a maneira de olhar para os problemas da sociedade, pois para qualquer problema pode haver solução, com um pouco de esforço nós fazemos a diferença". (Estudante Denise, 2018); "Para nós foi muito importante, nós achamos problemas para resolver em nossa cidade, onde antes ninguém observou, iremos ajudar a população. Aprendemos a ver os problemas e achar soluções, as aulas ficaram bem diferentes. Gostei muito da ideia do projeto e poder participar." (Estudantes Daiana, Diuli e Estela, 2018); "Mostra o comprometimento no assunto, para que nos importemos com a cidade e que buscamos melhorá-la." (Estudante Eder, 2018); "O projeto fez com que eu enxergasse de uma maneira diferente nossa cidade." (Estudante Ana); "O nosso projeto fez com que nós tivéssemos uma visão mais aberta sobre a sociedade e o nosso papel dentro dela." (Estudante Giane).

Ensinar Geografia é uma prática política, na busca da tomada de consciência dos estudantes frente ao mundo, que é marcado pelas contradições e desigualdades. 
Como forma de transformar a organização social e espacial pela consolidação dos direitos e deveres, coletivos e individuais no exercício da cidadania.

O desenvolvimento desta pesquisa gerou mudanças positivas tanto para as professoras como para os estudantes. No decorrer do projeto os estudantes trabalharam em grupos, o diálogo propiciou crescimento e auxiliou na condução de resultados. A aprendizagem pela pesquisa supõe questionamentos, que suscitam 0 interesse coletivo da sala para alcançar os objetivos.

A disposição para desenvolver este projeto em parceria com a escola, a UNIOESTE/FB, O IGOT/UL/PT e a comunidade local justificou o papel social e transformador da Geografia. Isso apareceu nos trabalhos em grupos realizados pelos estudantes, projetos coletivos desencadeados e sensibilizados pela importância do lugar. Eles se reconheceram como seres únicos, mas também como resultado das relações sociais.

Para não concluir, se testam novos caminhos no ensino e aprendizagem da ciência geográfica, o conceito de lugar em sala de aula, como conteúdo, mas também como vivência fora dela. Conhecer o espaço local possibilitou a análise de outros lugares. Os estudantes encontraram nas pesquisas, os conteúdos geográficos, como a utilização dos meios de transporte coletivos, a localização e efetividade dos semáforos na cidade, a preocupação com o problema do abandono de animais e a necessidade de conhecer para atuar por meio da leitura, a literatura cidadã.

A tarefa de concluir este trabalho não está ao nosso alcance. O desafio proposto aos estudantes se mantém vivo e dinâmico como o lugar que descobriram pela pesquisa. Não falamos de uma nova realidade, mas de nova maneira de conhecer, como se refere a escola a respeito do projeto Nós Propomos: "Achei uma iniciativa muito bacana e positiva para nossa instituição. Pois, através destas atividades diferentes do cotidiano dos nossos alunos descobrimos o quanto eles têm potencial e capacidade de ir além da sala de aula. E ainda, oportunizar a eles este contato direto com a sociedade, com os anseios da população, faz com que eles comecem a refletir e se posicionar diante dos problemas e dilemas dos cidadãos patobranquensess, bem como das dificuldades da administração municipal em dar conta de cumprir com as obrigações atribuídas e, ainda conhecer e satisfazer as necessidades dos munícipes. Isso tudo tem um ponto positivo, pois nos mostra que, nem sempre a boa vontade é suficiente, é preciso muito mais, mais atitudes, mais ações, um olhar mais próximo da realidade que nos rodeia e, principalmente, o que eu estou fazendo para melhorar este espaço?" (Ella, equipe diretiva da escola, 2018). 
Ao aprender com significado os conceitos geográficos, o estudante se tornou capaz de relacionar o seu lugar com o mundo, usou leituras anteriores para novas situações. $A$ leitura do lugar auxilia no reconhecimento de eventos em outras escalas, como decodificar espaços simples que fazem o todo.A educação é um campo de transformação e precisamos avançar o quanto pudermos para tornar cada discurso uma prática.

\section{Referências bibliográficas}

Callai, H.C. (2000). Estudar o lugar para compreender o mundo. In Castrogiovanni, A. C. (Org.). Ensino de Geografia: práticas e textualizações no cotidiano. Porto Alegre: Mediação, p. 72-112. CALLAI, H. C. Geografia em sala de aula: prática e reflexões. Porto Alegre: Ed da UFRGS.

Cavalcanti, L. S. (2002). Geografia e práticas de ensino. Goiânia: Alternativa.

Cavalcanti, L. S. (2010). Geografia, Escola e Construção de conhecimentos. 16.ed. Campinas: Papirus.

Claudino, S. (2014). Escola, Educação Geográfica e Cidadania Territorial. Scripta Nova, Revista Electrónica de Geografia y Ciencia Sciales. Universidad de Barcelona, v.18, n.496, p. 01-10.

Claudino, S. (2018). Educação Geográfica Trabalho de Campo e Cidadania. O Projeto Nós Propomos! In Veiga, F.H. O Ensino e a Escola de hoje: Teoria, investigação e aplicação. Lisboa: Climepsi Editores, p. 265-303.

Claudino, S. (2017). As recentes reformas curriculares em Portugal. Os programas mudam as práticas? In: Palestra UNIOESTE, Francisco Beltrão/PR. 30 out. 2017.

PROJETO NÓS PROPOMOS PORTUGAL. Disponível em: < https://sites.google.com/site/nospropomos1213/home> Acesso: jul. 2018.

Santos, M.(1988). Paisagem e Espaço. In: Santos, Milton. Metamorfoses do Espaço Habitado, fundamentos teórico e metodológico da Geografia. São Paulo: Hucitec, 1988.

Santos, M.(2008). A Natureza do Espaço: Técnica e Tempo. Razão e Emoção. 4. ed. São Paulo: Editora da Universidade de São Paulo-EDUSP. (Coleção Milton Santos I).

Santos, M.(2014). Espaço e Método. 5. ed. 2. reimpressão. São Paulo: Editora da Universidade de São Paulo-EDUSP. 


\section{Geografia Escolar e o Projeto Nós Propomos: Construção/ consolidação da cidadania e da justiça espacial ${ }^{1}$}

HUGO DE CARVALHO SOBRINHO

\section{Resumo}

A dinâmica das modificações que ocorrem no mundo contemporâneo origina questionamentos em diversos âmbitos. Em nível educacional, podem ocasionar dificuldades na compreensão da realidade, de maneira que a educação, em geral, e a escola, em particular, assumem relevante função para o alcance dessa compreensão. É nesse contexto que se ressalta a importância das práticas pedagógicas em Geografia para a compreensão da dinâmica espacial, que evidencia a alteração das formas e funções postas no cotidiano vivido dos indivíduos. Partindo dessa premissa, este artigo propõe reflexões sobre a finalidade da Geografia Escolar na contemporaneidade e, nessa perspectiva, destaca o Projeto Nós Propomos!, apontado como alternativa didática e metodológica às aulas de Geografia, capaz de viabilizar a construção/consolidação da cidadania. Pautando-se na abordagem qualitativa, a partir da literatura e da experiência do autor como professor/pesquisador, busca-se avançar na discussão sobre alguns aspectos considerados pertinentes à Educação Geográfica cidadã, em que se destaca a dimensão da justiça espacial. Esta, ao relacionar ideias de democracia, cidadania, direitos, deveres, justiça e liberdade, fundamenta as proposições do Projeto Nós Propomos! e fornece elementos imprescindíveis à compreensão da espacialidade como dimensão da vida dos sujeitos e da busca por uma cidadania ativa.

\footnotetext{
${ }^{1}$ Agradeço à Fundação de Apoio à Pesquisa do Distrito Federal (FAP-DF) e a Universidade de Brasília (UnB) pelo auxílio financeiro concedido para à participação e apresentação deste trabalho.

2 Doutorando e Mestre em Geografia pela Universidade de Brasília (UnB). Professor da Carreira do Magistério Público da Secretaria de Estado de Educação do Distrito Federal SEEDF. Pesquisador do grupo - Ensino, Aprendizagem e Formação de Professores em Geografia da Universidade de Brasília - GEAF/UnB, hugo.carvalhosobrinho@gmail.com
} 
Palavras-chave: Geografia Escolar; Nós Propomos; Cidadania; Justiça Espacial.

\section{Abstract}

The dynamics of the changes in the contemporary world give rise to questions in different areas. At the educational level, they may cause difficulties in reality's understanding, so that education in general and the school in particular play a relevant role in reaching that understanding. It is in this context, then, that pedagogical practices in geography must be considered in the comprehension of the spatial dynamics, which shows the alteration of the forms and functions put in the daily lives of individuals. In this premise, this article proposes some reflections on the purpose of School Geography in the contemporary world and, to this end, highlights the We Propose Project, once considered a didactic and methodological alternative to the Geography classes, which enables the construction/consolidation of citizenship. Thus, based on the qualitative approach, from theory and experience as a teacher/researcher, we seek to advance in some aspects, considered relevant to Citizen Geographic Education, in which the spatial justice dimension is highlighted. This, in relating ideas of democracy, citizenship, rights, duties, justice and freedom, bases the propositions of the Project We Propose and provides indispensable elements to the comprehension of the spatiality, as dimension of the life of the subjects and of the search for an active citizenship.

Keywords: School Geography; We Propose; Citizenship; Spatial Justice.

Escutem a nossa história Vocês que estão no poder Vivemos numa comunidade De um povo sem nenhum lazer Aqui não nos faltam deveres Plantamos os nossos alqueires Pra não faltar o que comer

Nesse espaço tudo é simples Nossa escola é o nosso suporte É lá que nos reunimos

Pra entender o que é ser forte E nessa longa labuta De um povo cheio de luta Lamento por tanta morte

Morte de sonhos perdidos Daqueles que mal sabem ler

Que tiram o pão da boca Pro seu próprio filho comer 
E o que queremos em troca?

Falando você até "choca"

Com a lista que vou escrever

Queremos os nossos direitos

Talvez uma estrada asfaltada

A nossa quadra coberta

Uma vida mais zelada Investimento na educação

Seria a solução

Pra essa comunidade atrasada

Nós propomos tantas coisas

E não nos querem atender

Exigimos os nossos direitos

Mas eles não querem saber

Queremos ter voz e vez

Pormos em prática as leis

Pra nossa história se refazer

Autora: Maria Eduarda Nobre da Silva - Estudante do Centro Educacional Incra 09 - Ceilândia - DF / Brasil, 2018.

\section{INTRODUÇÃO}

O que motiva a escrita deste ensaio é o anseio pela realização de um ensino de Geografia que esteja atrelado ao cotidiano vivido pelos sujeitos. Desde 2011, tenho me debruçado sobre a temática que se relaciona à construção dos conhecimentos geográficos na perspectiva da busca por novas metodologias que se apresentem eficazes para os jovens escolares. Mais recentemente, a educação geográfica vinculada ao Projeto Nós Propomos! apresentou-se como campo fecundo de reflexões. O presente artigo tratará, assim, do que é o Projeto Nós Propomos!, como ele mobiliza as questões que envolvem os sujeitos em suas espacialidades e quais elementos constituem a dimensão da justiça espacial.

O trecho do cordel $^{3}$ que consiste na epígrafe deste trabalho foi escrito por uma estudante do Ensino Fundamental, anos finais, do Centro Educacional Incra 09 Ceilândia/ DF/Brasil, localizado na zona rural, e está carregado de elementos que se reportam às atividades que estão sendo realizadas por intermédio da implementação do Projeto Nós Propomos!. A estudante destaca os problemas corriqueiros da sua comunidade, propondo que o poder público resolva as questões mais urgentes, além de, num tom de denúncia, descrever as adversidades que assolam o espaço em que

\footnotetext{
${ }^{3}$ Este cordel foi apresentado pela autora aos representantes da comunidade e ao deputado distrital Reginaldo Veras na solenidade de aniversário da comunidade escolar no ano de 2018.
} 
ela reside. É nesse sentido que as atividades desse projeto conduzem os estudantes a refletirem sobre a atuação no lugar e a problematizarem questões que se relacionam aos direitos e deveres dos sujeitos numa perspectiva cidadã: reflexiva, crítica e propositiva.

A presente reflexão pretende, assim, evidenciar a finalidade da Geografia Escolar na contemporaneidade, considerando o Projeto Nós Propomos! como uma alternativa didática-metodológica que viabiliza a construção/consolidação da cidadania atrelada aos pressupostos da justiça espacial. Pautando-se na abordagem qualitativa, a partir da literatura e da minha experiência como professor/pesquisador, busco avançar na discussão sobre alguns aspectos considerados pertinentes à Geografia, relevante para a Educação Básica.

\section{GEOGRAFIA ESCOLAR: finalidade na contemporaneidade}

A discussão sobre o significado da Geografia Escolar na contemporaneidade conduz à reflexão sobre a produção científica dessa área ao longo do tempo e à percepção de que ela é uma criação particular e original dos sujeitos da escola em seus contextos práticos (Callai, 2011). Mais do que nunca, hoje, devido às novas reformas curriculares e àquelas que ainda estão em tramitação no Brasil, é necessário compreender e defender o ensino geográfico na Educação Básica.

A Geografia Escolar não pode ser entendida como mera simplificação da ciência geográfica, na medida em que, ainda que se estabeleça entre elas relação direta, a primeira independe das prescrições acadêmicas. Sua perspectiva é a da apropriação de conteúdos que são elaborados no campo acadêmico, escolhidos e ressignificados, tendo em vista a formação da cidadania. Isso ocorre quando as escolas, por meio dos professores, trabalham os conteúdos do arcabouço teórico dessa ciência pertinentes à prática da cidadania, que são transpostos a um contexto específico, conferindo à Geografia Escolar propriedade e peculiaridade em sua abordagem (Cavalcanti, 2012).

Dessa maneira, o trajeto realizado pela Geografia Escolar se vincula aos movimentos da Geografia Acadêmica, mas não se confunde com a mesma. Segundo Cavalcanti (2008), foi a partir de 1980, por meio de novas fundamentações filosóficas, dentre as quais o materialismo histórico dialético, que se buscou superar a Geografia Clássica, denunciando a sua falsa neutralidade e o caráter utilitário e ideológico vinculado ao Estado, fator que redimensionou as reflexões acerca desse componente curricular. Foi na transição do século XX para o XXI, sob a influência da Geografia Crítica, que pesquisadores começaram a refletir sobre as questões de ensino-aprendizagem em 
Geografia na Educação Básica por meio dos programas de pós-graduação em Geografia e Educação (Cavalcanti, 2008).

Tais questões, postas no tocante à reflexão sobre a Geografia Escolar, são complexas porque o ato de ensinar não significa transferência de conhecimento, mas, ao contrário, envolve a consideração de fatores culturais, sociais e econômicos como contextualização para a aprendizagem. Exige-se do professor, ainda, duas particularidades em relação ao conhecimento que ele deve ensinar: o saber e o saber/fazer. Quem ensina deve possuir tanto o conhecimento teórico dos conteúdos a serem trabalhados, como também das formas didáticas e práticas para promover a internalização desses pelos estudantes, no sentido de torná-los aptos a se apropriarem de conhecimento (Libâneo, 1994).

É nesse sentido que são pertinentes as problematizações que conduzam a um entendimento acerca do papel que assume esse campo disciplinar, numa conjuntura mundial marcada pela complexidade, pelas relações e interações instantâneas, simultâneas e assíncronas, decorrentes dos avanços nas redes de comunicação tecnológica (Leite, 2012). Tais considerações têm originado concepções contemporâneas da ciência geográfica e da Geografia Escolar, dentre as quais se destacam aquelas que assinalam importância do lugar e o apresentam como categoria analítica. O lugar, no contexto da Geografia Escolar, se apresenta como possibilidade de aprendizagem que parte do mundo vivido pelo estudante e o conduz à sistematização dos saberes, não só dos geográficos, mas também de outros campos disciplinares, o que reforça sua própria importância na escolarização.

É nessa perspectiva que se faz indispensável a elaboração e proposição de metodologias que tenham a prática social - o lugar - dos sujeitos como uma via de internalização dos conteúdos. Assim, pode-se afirmar que a escola e, neste contexto específico, a educação geográfica se colocam como rumos de democratização e formação da cidadania em um mundo tão confuso, e que suas reflexões devem, necessariamente, buscasr elaborar e propor metodologias condizentes ao período contemporâneo. As ações didáticas e práticas contribuem para a leitura da espacialidade do sujeito e, assim, auxiliam no processo de internalização dos conceitos em Geografia. Por isso, os procedimentos didático-metodológicos que conduzem a implementação do Projeto Nós Propomos! trabalham nesta perspectiva. 


\section{PROJETO NÓS PROPOMOS!: caminhos para (re)significar o ensino de Geografia $^{4}$}

O Projeto Nós Propomos!, reportando-se às reflexões anteriores sobre Geografia Escolar, aposta na compreensão da realidade vivida pelos estudantes e no comprometimento destes com a transformação da sociedade em que vivem. Os jovens são desafiados a retratar o seu cotidiano e a buscar soluções para os problemas locais que Ihes afetam. Partindo de uma inspiração socioconstrutivista da aprendizagem, o Projeto possui dimensões que perpassam a teoria e a prática, já que, quando os estudantes buscam propor, devem investigar tanto no sentido prático como teórico para que as soluções sejam de fato sistematizadas (Carvalho Sobrinho, 2018).

Tendo tomado forma no ano letivo de 2011/12, o Projeto alargou-se a escolas de praticamente todo o território português, também às Regiões Autónomas dos Açores e da Madeira. O fato de se dirigir diretamente à resolução de problemas comunitários, em assumida cidadania territorial local, ajuda a explicar a sua rápida expansão internacional. Contando com o apoio do Ministério da Educação de Portugal, integrou, em 2016, as iniciativas do Ano Internacional do Entendimento Global (Claudino, 2017).

O Projeto consiste em uma alternativa de educação geográfica com forte compromisso social de mobilização dos estudantes para a construção da sua cidade e, assim, constitui uma possibilidade de superação das práticas tradicionais no contexto do ensino em geral e da Geografia em particular (Claudino \& Mendonça, 2017). Ele surge dos desafios que a educação geográfica enfrenta em seus contextos diferenciados em várias localidades, de maneira a apresentar-se como uma oportunidade efetiva de introduzir o conhecimento da realidade no trabalho em Geografia, posto que exige que os estudantes analisem criticamente problemas que afetam a região onde vivem, refletindo sobre soluções possíveis (Alves; Brazão \& Martins, 2001, p. 57).

De acordo com o Regulamento das Atividades, o Projeto Nós Propomos! tem por objetivos:

Promover ativa cidadania territorial junto à população estudantil; aproximar o poder público local das comunidades por meio das escolas; contribuir para o desenvolvimento sustentável das localidades e dos municípios onde se desenvolve; valorizar o estudo de caso como trabalho experimental sobre problemas locais; fomentar redes de cooperação entre atores locais, como universidades, escolas, poderes legislativos e executivos municipais,

\footnotetext{
${ }^{4}$ Esta seção é parte da reflexão já iniciada no artigo intitulado - Práticas pedagógicas em Geografia para uma educação cidadã emancipadora - publicado na Revista Interdisciplinar de Direitos Humanos, vinculado ao Departamento de Ciências Humanas, da Faculdade de Arquitetura, Artes e Comunicação da Unesp, campus de Bauru-SP. Acesso: https://www3.faac.unesp.br/ridh/index.php/ridh/article/view/622.
} 
associações locais e empresas; promover abordagens metodológicas inovadoras no âmbito do ensino das disciplinas do ensino médio, fomentar a utilização de tecnologias de informação em estudos de âmbito prático (IgotUL, 2018, n.p).

Em síntese, tais objetivos vislumbram a elaboração de propostas para a resolução de problemas locais. As ações do Projeto buscam, assim, identificar os problemas por meio de pesquisa de campo e apresentar soluções viáveis. De maneira complementar ao exposto, "Não podemos deixar de destacar o caráter interdisciplinar do projeto, pois mesmo evidenciando a sua contribuição para o ensino de Geografia em específico, ele tem uma amplitude maior que é promover ativa cidadania territorial. Sabe-se, como já foi abordado, a forte relação da Geografia com essa premissa. Entretanto, as demais disciplinas também se voltam para essa perspectiva, assim, o projeto se apresenta como indutor da interdisciplinaridade" (Carvalho Sobrinho, 2018, p. 60).

No regulamento, também se explicita o direcionamento da abordagem para o ensino médio, mas isso não é um impeditivo para que os objetivos sejam ressignificados para atividades do ensino fundamental, tal como sucede em Portugal, através do Nós Propomos! Pequenos Grandes Cidadãos (Claudino, 2018b). É necessário propiciar momentos para se pensar a democracia participativa desde o mais breve possível, pois estamos vivenciando um contexto de afronta à democracia. Assim, a proposta se vincula a uma perspectiva de aprendizagem significativa, cujos temas se relacionam aos interesses dos próprios estudantes, tais como a construção de espaços de lazer e esporte, a recuperação de imóveis abandonados para fins públicos, construção de ciclovias, melhora nos atendimentos públicos de saúde, entre tantos outros problemas (Claudino, 2018).

Pretende-se, portanto, conscientizar os sujeitos acerca da necessidade de criar momentos para debater aspectos da democracia participativa e enfatizar que as transformações dos comportamentos evidenciam potencial para que se promova interação entre a sociedade civil e o poder público e, assim, garanta-se uma participação mais plural na gestão das cidades (Bazzoli, 2017).

As fases do Projeto são: 1) reunião com os docentes envolvidos; 2) assinatura de protocolos com as autarquias; inscrição dos estudantes no sítio do Projeto e na página do Facebook; 3) identificação dos problemas locais pelos estudantes; 4) formação de grupos e definição do tema de projeto; concurso do logótipo do Projeto; 5) sessão da equipe de coordenação com os estudantes nas escolas; sessões de trabalho sobre o Plano Diretor Municipal; 6) realização de trabalho de campo; elaboração das propostas pelos estudantes; 7) autoavaliação intermédia; 8) participação em concursos de 
fotografia de paisagem, fotografia de trabalho de campo, texto, desenho e vídeo; 9) divulgação das propostas dos estudantes; e 10), por último, avaliação do Projeto (Claudino, 2014).

Ainda que, por questões didáticas e institucionais, o procedimento tenha sido sistematizado em fases, sua análise evidencia a sua simplicidade. Observa-se que, metodologicamente, ele não é complexo nem rígido, pois considera as realidades locais de onde será implementado. Dentre as fases descritas, duas merecem atenção por serem essenciais no desenvolvimento das atividades: a identificação dos problemas locais e a elaboração das propostas pelos estudantes. Nesses momentos, os professores podem construir significados aos conteúdos de Geografia por meio do diálogo em sala de aula, bem como levar os estudantes a campo para observarem mais atentamente a manifestação dos fenômenos geográficos (Carvalho Sobrinho, 2018, p. 61).

Ao detectar os problemas e sugerir soluções, os estudantes passam a construir significados e a compreender conceitos e fenômenos essenciais para a Geografia, com enfoque em suas próprias cidades. Por exemplo: ao detectar as questões que envolvem a degradação ambiental, surgirão vários outros questionamentos referentes a ocupações irregulares, segregação urbana, crise hídrica, arquitetura das cidades, o papel dos sujeitos, entre tantos outros temas (Carvalho Sobrinho, 2018). Por isso, essa proposta é fundamental para a constituição do sentido de cidadania, já que os jovens estudantes entenderão e compreenderão os processos e dinâmicas de maneira crítica, ativa e propositiva.

No Distrito Federal, a proposta está sendo acolhida e implementada desde o ano de 2017. A implementação do Projeto Nós Propomos! em escolas públicas do Distrito Federal já é uma realidade, sendo que os professores participantes já possuem produções na área e indicam a grandiosidade das atividades.

\section{RELAÇÃO-PODEROSA: Geografia Escolar, Projeto Nós Propomos! e Justiça Espacial}

A partir das questões aqui levantadas, é possível afimar que a relação entre Geografia Escolar, Projeto Nós Propomos! e a perspectiva da Justiça Espacial se apresenta como uma relação-poderosa (ou ideia-força) na superação das práticas tradicionais no ensino de Geografia. Ao perceber que essas perspectivas se entrelaçam, podemos construir conhecimentos geográficos e interdisciplinares, tendo o Projeto como uma via de mediação pedagógica. 
Pode-se observar no esquema da Figura 1 que a interação entre as partes existe em função do fato de que seus objetivos se entrelaçam. A relação-poderosa faz a ligação de temáticas que conduzem à cidadania territorial ativa no entedimento $e$ pressupostos da Geografia Escolar. A justiça espacial, para Soja (2014), considera as ideias de democracia, justiça, liberdade, cidadania, direitos, deveres, as quais se reportam a questões primordiais para o Projeto Nós Propomos e a Geografia Escolar, isto é, a construção/consolidação do sentido de uma cidadania ativa que busque, de fato, considerar os sujeitos e ouvi-los em seus questionamentos e proposições, ultrapassando os conceitos de direitos e deveres.

Assim, essa relação se apresenta como uma ideia-força para as práticas pedagógicas em Geografia, pois relaciona a espacialidade, por exemplo, contemplada nos conteúdos geográficos, às ideias de democracia, cidadania, direitos, justiça e liberdade, sempre destacando a dimensão da vida humana (Cavalcanti, 2017).

Figura 1 - Relação-Poderosa

\section{RELAÇÃO-PODEROSA}

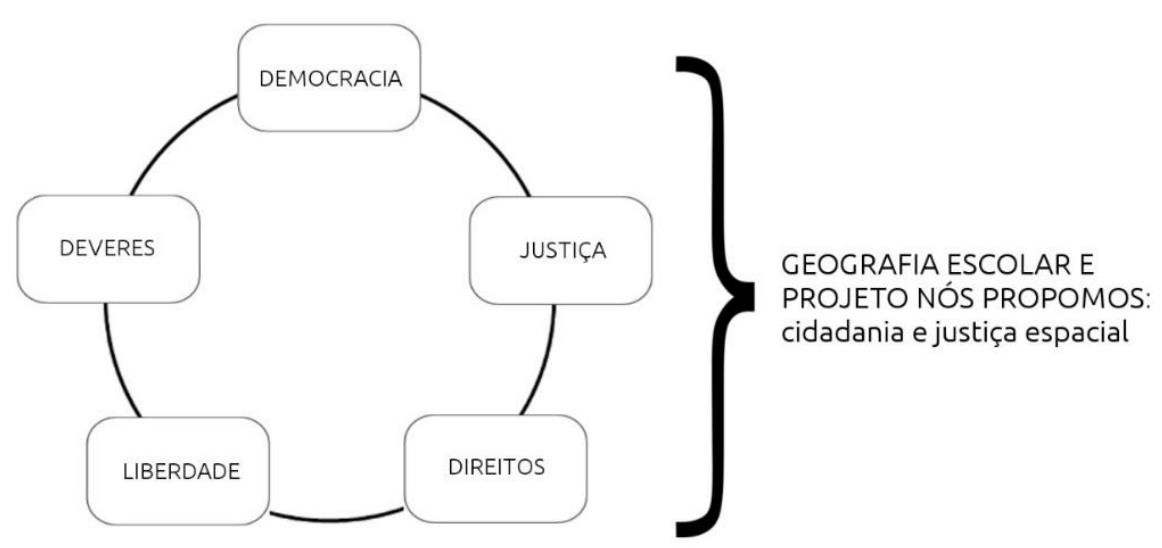

Elaboração: Carvalho Sobrinho, 2018.

A relação-poderosa, no contexto aqui endossado, pode ser relacionada, também, ao conhecimento poderoso que se refere ao que esse pode fazer, no sentido de fornecer explicações sistematizadas e novas formas de se pensar a respeito do mundo (Young, 2007). Dessa maneira, a relação-poderosa está atrelada ao cohecimento poderoso, isto é, um conhecimento que permite que os alunos compreendam o mundo em que vivem. É nesta perspectiva que entendo o ensino de Geografia. Nas palavras de Young, "Para crianças de lares desfavorecidos, a participação ativa na escola pode ser a única oportunidade de adquirirem conhecimento poderoso e serem capazes de 
caminhar, ao menos intelectualmente, para além de suas circunstâncias locais e particulares" (Young, 2007, p. 1297).

Por fim, fazemos referência, novamente, ao cordel composto por uma estudante que constitui a epígrafe deste trabalho, posto que ele possibilita visualizar a concretude dessa relação: é rico em conteúdo, em proposta e busca a justiça espacial. Sendo assim, é uma relação-poderosa que conduz os processos de mediação pedagógica que estejam vinculados à cidadania ativa.

\section{CONSIDERAÇÕES FINAIS}

Como se pode verificar, este ensaio não pretendia esgotar o tema discutido, dada sua grandiosidade, mas tão somente considerar alguns aspectos que avaliamos serem essenciais e que devem ter continuidade nos processos pedagógicos em diferentes contextos.

O Nós Propomos! aborda uma diversidade de temáticas, aspecto que considero importante por promover o processo de interdisciplinaridade. A flexibilidade e dinâmica do projeto possibilitam a abordagem e aplicação em diferentes contextos e realidades, que não se desvinculam do propósito maior: promover uma efetiva cidadania territorial local. Além do mais, percebe-se que o desejo se vincula à superação de uma educação geográfica realizada nos paradigmas da perspectiva tradicional.

A possibilidade de dialogar sobre a relação existente entre Geografia Escolar, Projeto Nós Propomos! e a perspectiva da justiça espacial se apresenta como um caminho didático-metodológico importante e necessário na contemporaneidade. Essa relação, sem sombra de dúvidas, enriquece o processo de ensino-aprendizagem ao frisar a espacialidade dos sujeitos como elemento a ser evidenciado na construção dos conhecimentos.

Como professor/pesquisador, reitero a minha preocupação com os problemas sociais e tenho tentado buscar metodologias que possibilitem que os sujeitos e suas práticas espaciais sejam pontos de saída e chegada para a compreensão das dinâmicas complexas da contemporaneidade nas ações pedagógicas que venho realizando. Por fim, enfatizo que as atividades do Projeto Nós Propomos! vêm ao encontro das defesas travadas pela Geografia Escolar contemporânea.

\section{REFERÊNCIAS}


Alves, M. L., Brazão, M., Martins, O. S. (2001). Programa de Geografia. Lisboa: Ministério da Educação.

Bazzoli, J. A. (2017). "Nós Propomos" e a busca da inovação no campo da extensão universitária. In J. A. Bazzoli e et. al. (Orgs.), A extensão universitária como indutora à cidadania: a experiência do Nós Propomos. Palmas: Eduft.

Callai, H. C. (2011) A Geografia Escolar e os conteúdos da Geografia. Anekumene, $1(1), 128-139$.

Carvalho Sobrinho, H. (2018). A cidade e o ensino de Geografia: significação a partir das atividades do Projeto Nós Propomos. In V. L. C. A. SOUZA \& C. M. C. LEITE, (Eds.), Ensinar e aprender Geografia por meio do Projeto Nós Propomos. Goiânia: C \& A Alfa Comunicação.

Cavalcanti, L. S. (2008). A Geografia escolar e a cidade: Ensaios de Geografia para a vida urbana cotidiana. Campinas, SP: Papirus.

Cavalcanti, L. S. (2012). O ensino de Geografia na escola. Campinas, SP: Papirus.

Cavalcanti, L. S. (2017). O trabalho do professor de Geografia e tensões entre demandas da formação e do cotidiano. In V. O. R. Ascenção e et al (Eds.), Conhecimentos da Geografia: percursos de formação docente e práticas na educação básica. Belo Horizonte: IGC.

Claudino, S. (2017). The Project We propose! Young people discussing and building the territory. In Oosterbeek et al., Transdisciplinary contributions for Cultural Integrated Landscape Management (pp. 175-198). Mação: Apheleia, Erasmus+, Instituto Terra e Memória, Instituto Politécnico de Tomar, V (1).

Claudino, S. (2018a). Educação.Riscos e Currículos Escolares. Territorium, Coimbra, $\mathrm{V}(25), 5-18$.

Claudino, S. (2018b). Educação Geográfica, Trabalho de Campo e Cidadania. O Projeto Nós Propomos! In F. H. Veiga (Eds.), O Ensino na Escola de Hoje. Teoria, Investigação e Aplicação (pp. 265-303). Lisboa: Climepsi Editores.

Claudino, S., Mendonça, S. (2017). "Nós Propomos": uma proposta alternativa de educação geográfica na Iberoamerica. In Bazzoli, et al. (Org.). A extensão universitária como indutora à cidadania: a experiência do "Nós Propomos". Palmas: Eduft, 2017.

IGOT-UL (2018) - Regulamento de Atividades. Disponível em: http://nos propomos.igot.ul.pt 
IGOT-UL. (2018). O processo de ensinar e aprender Geografia por meio do Projeto Nós Propomos: a experiência no Distrito Federal. In V. L. C. A. Souza \& C. M. C. Leite, (Eds.), Ensinar e aprender Geografia por meio do Projeto Nós Propomos. Goiânia: C \& A Alfa Comunicação.

Leite, C. M. C. (2012). O lugar e a construção da identidade: os significados construídos por professor de Geografia do ensino fundamental. (Tese de doutoramento). Faculdade de Educação, Programa de pós-graduação em Educação, Universidade de Brasília.

Libâneo, J. C. (1994). Didática, São Paulo: Cortez.

Soja, E. W. (2014). En busca de la justicia espacial. Valencia, Espanha: Tirant Humanidades.

Young, M. (2007). Para que servem as escolas?.Educ.Soc., Campinas, 28(101), 12871302. 


\title{
Nós Propomos - O verdadeiro papel da extensão universitária
}

\author{
HUGO FABIANO DOMINIQUINI ${ }^{1}$ \\ JOAO APARECIDO BAZZOLI ${ }^{2}$ \\ MARIELA CRISTINA AYRES DE OLIVEIRA ${ }^{3}$
}

\section{Resumo}

As políticas institucionais brasileiras seguem concomitantemente as políticas públicas nacionais, estas em ascensão a partir do início do século XXI. O dialogo da Universidade com a comunidade externa representa um dos quatro pilares da universidade Federal do Tocantins (UFT), segundo seu Plano de Desenvolvimento Institucional (PDI 2016-2020). Mediante o exposto, os projetos de Extensão Universitária são o elo principal de ligação das instituições públicas de ensino superior com a sociedade no fortalecimento da inclusão sociocultural. O Projeto "Nós Propomos" é um projeto de extensão da (UFT) em convênio com a Universidade de Lisboa - IGOT (Instituto de Geografia e Ordenamento do Território) e parceria com a Secretaria estadual de educação, juventude e esporte; sendo a ação voltada aos jovens do Ensino Médio da Rede Pública Estadual de Palmas e Araguaína. No ano de 2017, o projeto concretizou 19 trabalhos relevantes discutindo o Direito à Cidade sob a ótica destes estudantes, locados em 10 escolas diferentes das duas cidades. Os resultados apontaram problemas urbanos observados pelos alunos que com o auxílio da equipe do projeto e professores, apresentaram propostas criativas e viáveis para a resolução desses problemas. O "Projeto Nós Propomos" procura estimular os estudantes ao exercício da cidadania plena através da participação nas decisões locais. Entende-se que a hegemonia e sucesso do projeto estão vinculados ao fato do estado do Tocantins possuir inúmeras demandas, em todas as áreas do conhecimento, ensejando uma atuação conjunta do papel exercido pela UFT no Estado, enfatizando o protagonismo das ações de extensão.

Palavras-chave: Políticas Institucionais Brasileiras, Direito à Cidade

\footnotetext{
${ }^{1}$ Aluno do curso de Direito, Católica do Tocantins, hdominiq@hotmail.com

2 Professor Adjunto DE, UFT, jbazzoli@uft.edu.br

${ }^{3}$ Professora Associada DE, UFT, mariela@uft.edu.br
} 


\section{Abstract}

In Brazil, Institutional Policies follow national public policies concomitantly, which have risen since the beginning of the 21st century. The University's dialogue with the external community represents one of the four pillars of the Federal University of Tocantins (UFT), according to its Institutional Development Plan (PDI 2016-2020). Through the above, the projects of University Extension are the main link between public higher education institutions and society in strengthening socio-cultural inclusion. The "We Proposed" Project is an extension project (UFT) in partnership with the University of Lisbon - IGOT (Institute of Geography and Spatial Planning) and partnership with the State Department of Education, Youth and Sport; being the action directed to young people of the High School of the State Public Network of Palmas and Araguaína. In 2017, the project completed 19 relevant papers discussing the Right to the City from the perspective of these students, located in 10 different schools of the two cities. The results point to urban problems observed by the students and, with the help of the project team and teachers, the students presented creative and feasible proposals for solving these problems. The "We Proposed Project" seeks to encourage students to exercise full citizenship through participation in local decisions. The authors believe that the hegemony and success of the project are possible due to the high demands of the state of Tocantins, in all areas of knowledge, providing a joint action of the role played by UFT in the State, emphasizing the role of extension actions.

Key words: Brazil, Institutional Policies, Right to the city

\section{A Universidade Federal do Tocantins}

O Plano de Desenvolvimento Institucional (PDI) é uma exigência nos processos de avaliação institucional, cursos e órgãos de fomento. Para além dessas condições, o PDI deve ser uma exigência da própria IES estabelecendo um horizonte em relação ao qual deve se orientar num determinado período. Nestas determinações, surgiram diversas normativas legais.

O PDI fundamenta-se na missão da instituição de ensino superior e as estratégias para atingir suas metas e objetivos. A coerência e a articulação entre as diversas ações devem levar em conta os padrões de qualidade e o orçamento da instituição. $O$ cronograma e a metodologia devem ser dimensionados para cinco anos, deixando claro os objetivos, as metas e as ações do Plano da IES. 
A edição do Decreto n. 5.773, de 09 de maio de 2006, que dispõe sobre o exercício das funções de regulação, supervisão e avaliação de instituições de educação superior e cursos superiores de graduação e sequenciais no sistema federal de ensino, exige uma nova adequação dos procedimentos de elaboração e análise do PDI (Plano de Desenvolvimento Institucional).

A Lei no 10.861, de 14 de abril de 2004, que estabelece o Sistema Nacional de Avaliação da Educação Superior (SINAES), o Ministério da Educação iniciou um processo de revisão das atribuições e competências da Secretaria de Educação Superior - SESU, da Secretaria de Educação Profissional e Tecnológica - SETEC, do Conselho Nacional de Educação - CNE e do Instituto Nacional de Estudos e Pesquisa Educacionais - INEP, objetivando consolidar o trabalho realizado e conferir maior eficiência e eficácia aos dispositivos contidos na Lei no 9.394/96 (LDB), o que motivou a alteração anteriormente acorrida.

Como dispositivos legais de orientação à elaboração de PDI, destacam-se: Lei № 9.394/1996 (LDB), Decreto n. 5.773/2006, Lei № 10.861/2004, Decreto № 2.494/1998, Decreto № 5.224/2004; Portaria MEC № 1.466/2001, Portaria MEC № 2.253/2001, Portaria MEC № 3.284/2003, Portaria MEC № 7/2004, Portaria MEC № 2.051/2004, Portaria MEC n 4.361/2004, Portarias Normativas n.1/2007, Portaria Normativa n, 2/2007, Resolução CES/CNE No 2/1998, Resolução CNE/CP No 1/1999, Resolução CES/CNE № 1/2001, Resolução CP/CNE № 1/2002 (art.7º), Parecer CES/CNE № $1.070 / 1999$.

Os dados e informações sobre a IES, constantes do PDI, deverão se organizar em três níveis hierárquicos: Dimensões, Categorias de Análise e Indicadores. Dimensões: agregam os dados e informações das Instituições e de seus cursos em 03 (três) níveis amplos, compreendendo: Organização Institucional e pedagógica, Corpo Docente e Instalações Categorias de Análise: Constituem os desdobramentos das Dimensões, organizadas, cada uma, também em 03 (três) níveis, de acordo com as características consideradas mais pertinentes em função dos processos futuros de análise e avaliação. Indicadores: São os desdobramentos das categorias de análise e também estão organizados em função da sua proximidade e interdependência.

A Universidade Federal do Tocantins (UFT), instituída pela Lei 10.032, de 23 de outubro de 2000, vinculada ao Ministério da Educação, é uma entidade pública destinada à promoção do ensino, pesquisa e extensão, dotada de autonomia didáticocientífica, administrativa e de gestão financeira e patrimonial, em consonância com a legislação vigente. Embora tenha sido criada em 2000, a UFT iniciou suas atividades 
somente a partir de maio de 2003 , com a posse dos primeiros professores efetivos e a transferência dos cursos de graduação regulares da Universidade do Tocantins (UNITINS), mantida pelo Estado do Tocantins. (CONSUNI N 16/2016)

A Universidade Federal do Tocantins divide-se em sete Campi, ocupando de norte a sul do território do estado (Tocantins) com uma distância aproximada de $900 \mathrm{~km}$ entre Tocantinópolis ao Norte e Arraias ao Sul. A UFT vem se estruturando para fortalecer suas áreas de planejamento e gestão, de modo a criar uma cultura administrativa que se aproveite das oportunidades e minimize as ameaças do ambiente externo.

A estrutura multi campi, reforça o papel social da universidade dentro do Estado, pois embora muito extenso o estado situa-se na Região Norte do País, com aproximadamente 1,5 milhões de habitantes. Segundo os dados IBGE, 2018, o estado do Tocantins conta com 139 municípios sendo que Palmas, Araguaína, Gurupi e Porto Nacional são as quatro maiores do estado. As cidades de Miracema, Tocantinópolis e Arraias ocupam a $9^{\circ}, 11^{\circ}$ e $27^{\circ}$ posição. A inserção multi campi da Universidade auxiliam na atuação e representação da UFT dentro do estado. O quadro 01 mostra a representação da população da UFT dentro do estado do Tocantins. Percebe-se a representatividade da instituição dentro do estado.

Quadro 01: Relação da População da UFT com o Estado -TO

\begin{tabular}{|c|c|c|c|c|}
\hline Cidade & $\begin{array}{l}\text { Habitantes } \\
\text { (IBGE) }\end{array}$ & $\begin{array}{c}\text { Professores por } \\
\text { Campi(PD) }\end{array}$ & $\begin{array}{l}\text { Tecnicos por } \\
\text { Campi(PDI) }\end{array}$ & $\begin{array}{c}\text { Alunos } \\
\text { total } \\
\text { (PD) }\end{array}$ \\
\hline Palmas & \pm 217.000 & 453 & 488 & \\
\hline Araguaína & \pm 143.00 & 219 & 137 & \\
\hline Gurupi & \pm 85.000 & 86 & 66 & \\
\hline Porto Nacional & \pm 53.000 & 121 & 61 & 20.541 \\
\hline Miracema & \pm 27.000 & 54 & 27 & \\
\hline Tocantinópolis & \pm 23.000 & 48 & 34 & \\
\hline Arraias & \pm 12.000 & 61 & 35 & \\
\hline \multicolumn{4}{|c|}{ População total (habitantes) da UFT no estado: } & 41.930 \\
\hline
\end{tabular}

Fonte: Elaborado pelos autores, 2018

A Missão da UFT é formar profissionais cidadãos e produzir conhecimento com inovação e qualidade que contribuam para o desenvolvimento socioambiental do Estado do Tocantins e da Amazônia Legal. A Visão da UFT é ser reconhecida nacionalmente até 2022, pela excelência no ensino, pesquisa e extensão. Para a promoção da missão a UFT declara e promove os seguintes valores: Respeito à vida e 
à diversidade; Transparência; Comprometimento com a qualidade; Criatividade e inovação; • Responsabilidade social; Equidade. (CONSUNI Nํ16/2016)

O papel social da instituição está articulação entre as ações de Ensino, Pesquisa e Extensão Com base nas dez dimensões avaliadas pelo Sistema Nacional de Avaliação da Educação Superior (SINAES), elaborou-se o PDI para o período de 2016 a 2020, a missão, visão e valores da UFT, que representam sua identidade institucional com o objetivo de promover a convergência de esforços humanos, materiais e financeiros, regendo e inspirando a conduta e os rumos da Instituição.

No âmbito institucional o projeto Nós Propomos se insere no eixo 3, dentro da dimensão 2 de Políticas para o Ensino, a Pesquisa e a Extensão. Os Eixos do PDI estão relacionados as dimensões do SINAES para a avaliação institucional como mostra o quadro 02. (CONSUNI $N \cong 16 / 2016)$

Quadro 02: Relação dos eixos do PDI as dimensões do SINAES

\begin{tabular}{|l|l|}
\hline \multicolumn{1}{|c|}{ EIXO PDI/UFT } & \multicolumn{1}{c|}{ DIMENSÃO SINAES } \\
\hline $\begin{array}{l}\text { Eixo 1: planejamento e } \\
\text { avaliação institucional }\end{array}$ & Dimensão 8: planejamento e avaliação \\
\hline $\begin{array}{l}\text { Eixo 2: desenvolvimento } \\
\text { institucional }\end{array}$ & $\begin{array}{l}\text { Dimensão 1: missão e plano de desenvolvimento } \\
\text { institucional } \\
\text { Dimensão 3: responsabilidade social da instituição) } \\
\text { do SINAES }\end{array}$ \\
\hline Eixo 3: políticas acadêmicas & $\begin{array}{l}\text { Dimensão 2: políticas para o ensino, a pesquisa e a } \\
\text { extensão (projeto “Nós Propomos") } \\
\text { Dimensão 4: comunicação com a sociedade } \\
\text { Dimensão 9: políticas de atendimento aos discentes }\end{array}$ \\
\hline Eixo 4: políticas de gestão & $\begin{array}{l}\text { Dimensão 5: políticas de pessoal } \\
\text { Dimensão 6: organização e gestão da instituição }\end{array}$ \\
\hline Eixo 5: infraestrutura física & Dimensão 10: sustentabilidade financeira \\
\hline
\end{tabular}

Fonte: Elaborado pelos autores, 2018

\subsection{Políticas de Ensino, Pesquisa e Extensão}

O Projeto Político Pedagógico (PPP) de um curso por der entendido como sua hegemonia. O PPP nasceu após a Constituição de 88, regido pela LDB (Lei de Diretrizes e Bases da Educação) Lei 9394/96, sendo responsável construção de projetos diferenciados de acordo com as necessidades de cada instituição.

Desta maneira compreende-se o Projeto Pedagógico de um determinado curso de graduação como o conjunto de ações de caráter sócio-político-humanístico-ambiental e pedagógico relativo à formação acadêmico-profissional. Para a sua elaboração, 
implementação, avaliação ou reformulação devem ser observados os seguintes princípios: I. Comprometimento com a igualdade de acesso e permanência dos discentes na Universidade, respeitadas as políticas de ações afirmativas; II. Qualidade da educação oferecida nos cursos de graduação; III. Gestão democrática; IV. Autonomia e liberdade para pensar, produzir e divulgar o conhecimento e os saberes, respeitando as concepções e práticas pedagógicas diferenciadas; V. Valorização do magistério (formação inicial e continuada, condições adequadas de trabalho, salários adequados, entre outros); VI. Indissociabilidade entre o ensino, a pesquisa e a extensão; VII. Participação de toda a comunidade acadêmica e de diferentes segmentos sociais; VIII. Avaliação permanente de seus processos e resultados; IX. Considerações às especificidades locais e regionais. O Projeto Pedagógico dos cursos de graduação deve compreender os marcos situacional, teórico, operativo e ações programáticas. (CONSEPE N005/2005)

A resolução CONSUNI № 16/2016 que também contém o Projeto PedagógicoInstitucional (PPI) admite que as políticas de graduação para a UFT requerem clareza de que as variáveis inerentes ao processo de ensino aprendizagem são parte integrante do sistema sócio-político-cultural e econômico do país. Esses sistemas, por meio de articulação dialética, possuem seus valores, direções, opções, preferências, prioridades que se traduzem, e se impõem, nas normas, leis, decretos, burocracias, ministérios e secretarias. Nesse sentido, a despeito do esforço para superar a dicotomia quantidade $X$ qualidade, acaba ocorrendo no interior da Universidade a predominância dos aspectos quantitativos sobre os qualitativos, visto que a qualidade necessária e exigida não deixa de sofrer as influências de um conjunto de determinantes que configuram os instrumentos da educação formal e informal e o perfil do aluno. (CONSUNI $N \cong 16 / 2016)$

A articulação com diferentes áreas de conhecimento, por meio da relação teoria/prática, propicia aos sujeitos da educação formal um rompimento com a linearidade positivista na produção e organização dos "saberes humanos". Dessa forma, superar as adversidades objetivando uma formação híbrida e aberta à articulação entre domínio específico e domínios mais amplos é um dos desafios de cada curso de graduação da UFT, para que os currículos dos cursos possuam a flexibilização necessária para que o discente alcance conhecimentos e "saberes" de forma contínua, cooperativa, superando modelos tradicionais, uma vez que possibilita no percurso da formação escolhas de componentes curriculares optativos. (Consuni, no 16/2016) 
A preocupação com a integração Universidade/sociedade faz parte do compromisso social das Instituições Públicas de Ensino Superior que, como bem público, não devem apenas garantir o ensino gratuito. A concepção deve ser mais ampla, no sentido de garantir também as possibilidades de participação da sociedade de usufruir, de alguma forma, do conhecimento que se produz no âmbito acadêmico. Essa interrelação também favorece a troca de conhecimentos, que enriquece a formação do aluno e as experiências docentes. Essa ligação é estabelecida e estimulada pela Pró Reitoria de Extensão da UFT (PROEX- UFT), responsável direta na instituição pelo desenvolvimento de ações que viabilizem essa proposta. (Consuni, n 16/2016)

O papel da extensão universitária é, portanto, realizar esse compromisso da Universidade, através dos programas, projetos, cursos, consultorias, serviços, seminários, entre outras ações, que são cadastradas, apoiadas e executadas pela PROEX. A extensão da UFT vem buscando consolidar essas políticas acadêmicas de extensão, fortalecendo o projeto da Universidade de interagir com os diversos grupos sociais de forma a contribuir para a construção de uma sociedade mais justa, democrática e solidaria.

No âmbito da Extensão e da Cultura, procura-se incentivar a comunidade acadêmica da UFT a realizar e ampliar sua inserção em programas e projetos, através de ações como: divulgação de editais de extensão e cultura das principais agências de fomento do Brasil.

São diretrizes da PROEX entre outras:

I. Promover a cidadania através da: Articulação dos acadêmicos nas ações de inclusão social. Fortalecimento de ações que promovam a inserção da comunidade na universidade.

II. Promover a arte e a cultura: Diretrizes: Incentivar a participação da comunidade universitária nas ações culturais desenvolvidas pela UFT, Estabelecer políticas culturais permanentes que contemplem as diversidades indenitárias da comunidade universitária.

III. Ampliar a divulgação dando visibilidade da extensão: Diretrizes: Valorizar a extensão no ambiente interno e externo. Consolidar a extensão como fundamental da responsabilidade social da Universidade. Garantir maior participação da comunidade acadêmica nas atividades de extensão. Consolidar a política de extensão da UFT, em consonância com as políticas nacionais de extensão. 
Através da avalição institucional da UFT, ao se consultar o eixo 3: políticas acadêmicas, inserido na Dimensão 2: Políticas para o Ensino, a Pesquisa e a Extensão, junto a Pró Reitoria de Extensão (PROEX) encontrar-se-á o quantitativo de programas, projetos, cursos e eventos cadastrados no Sistema de Informação e Gestão de Projetos (SIGProj) referentes ao triênio 2015-2017. O quadro 03 mostra este quantitativo sendo que o projeto está inserido nestes números.

Quadro 03: Quantitativo de Ações PROEX 2015/2017

\begin{tabular}{|c|c|c|c|}
\hline AÇÕES & QUANT/2015 & QUANT/2016 & QUANT/2017 \\
\hline Programas & 20 & 27 & 37 \\
\hline Projetos & 81 & 170 & 244 \\
\hline Cursos & 37 & 63 & 95 \\
\hline Eventos & 96 & 221 & 261 \\
\hline TOTAL & 234 & 481 & 637 \\
\hline
\end{tabular}

Fonte: Relatório CPA, 2018

Segundo o coordenador do projeto na UFT, João Bazzoli: “... É importante salientar que o Projeto foi contemplado, em 2016, pelo Programa Nacional de Extensão Universitária (PROEXT) do Ministério da Educação, com recursos que permitiram o seu desenvolvimento..." (Bazzoli, 2017, pag54). Todas as ações do Projeto podem ser conferidas no endereço eletrônico: nospropomos.blogspot.com/

\section{Projeto "Nós PROPOMOS"}

Dentro da UFT o Nós PROPOMOS- BRASIL -TO, está dentro da "Pró Reitoria de Extensão", vinculado a um Programa, na esfera ensino é uma ação Inter campi, envolvendo os cursos de: Direito, Arquitetura, Geografia e, na esfera pesquisa possui como resultado de suas ações a publicação de 1 livro e 1 manual no ano de 2017.

No Brasil, o Projeto foi adaptado às diversas vertentes regionais, respeitado o pilar de sustentação da educação, inovação e cidadania. Dentro do plano de expansão do Projeto, a Universidade Federal do Tocantins (UFT). A cerimonia de parceria com a instituição portuguesa foi firmada no ano de 2014, no IGOT, Universidade de Lisboa em Portugal, legitimando sua implantação e execução no Estado do Tocantins, com a formalização de convênio. (Bazzoli et al, 2017)

Dentro de uma realidade social muito diferente do seu país de origem, foi necessário refletir sobre os tipos de formatações possíveis, que viabilizassem a operacionalização deste Projeto no Tocantins. Neste sentido, pensando na contribuição social aos jovens 
do ensino médio, estabeleceu-se parceria com a Secretária da Educação, Juventude e Esportes do Tocantins (SEDUC/TO), formalizada desde 2015. (Bazzoli et al, 2017)

A adequação do projeto para a realidade regional exigiu uma interdisciplinaridade de cursos dentro da UFT, almejando-se diferentes olhares sobre a temática, oportunidade em que se uniram, com o propósito de desenvolver as atividades e ações propostas pelo Projeto, os cursos de: Direito, Arquitetura e Urbanismo, bem como o Programa de Pós-Graduação em Desenvolvimento Regional (PPGDR/UFT/Palmas) e o de Geografia (Araguaína). (Bazzoli et al, 2017)

O programa foi cadastrado junto ao curso de Direito em parceria com a Secretária da Educação, Juventude e Esportes do Tocantins (SEDUC/TO) voltado para a educação cidadã, com o intuito de estimular o desenvolvimento social e o espírito crítico dos estudantes.

Tem como objetivo introduzir o aluno na democracia participativa, através de propostas para resolução de problemas urbanos, explorando a vertente da participação popular nas decisões públicas municipais - gestão democrática da cidade nas cidades de Araguaína, Gurupi e Palmas inicialmente. A estrutura multi campi da Universidade auxiliou na logística dentro do estado. Em 2016 as cidades de Gurupi ao Sul do estado e Araguaína ao Norte do estado participaram do projeto. Em 2017 Araguaína ainda participa do Projeto com uma representação bem expressiva nos trabalhos apresentados no seminário. No ano de 2018 a falta de recursos e auxilio não permitiram que o Projeto pudesse ser realizado em outras cidades.

O I Seminário Estadual ocorreu em dezembro de 2016 na UFT, campus de Palmas. Cabe ressaltar a importância dos múltiplos olhares dos jovens lançado sobre o espaço vivido, o discernimento de onde pretende chegar, a maneira contundente de apresentar o problema e especialmente a visão futura e sustentável de propor suas resoluções. (Bazzoli et al, 2017)

O II Seminário Estadual do projeto de extensão Nós Propomos, ocorreu em novembro de 2017 no auditório do Centro Universitário Integrado de Ciência, Cultura e Arte (CUICA), no Campus de Palmas da UFT, muitas das apresentações ao demonstrarem a metodologia utilizada pelos grupos elucidaram o movimento de aproximação da comunidade realizada pelos jovens, ou seja, estes buscaram informações através de quem vive no local e, consequentemente, convive com os problemas que buscavam solucionar. (Nós Propomos, 2017)

O III Seminário "Nós Propomos - Educação, cidade e cidadania: múltiplos olhares sobre o direito à cidade" aconteceu em novembro de 2018 na defensoria pública do 
estado. Entra várias parcerias o projeto integrou o Circuito Urbano 2018, promovido pela ONU-Habitat Brasil. Sobre o evento merece destaque a qualidade dos trabalhos apresentados pelos estudantes. Prevaleceu nos trabalhos apresentados a pesquisa empírica, com trabalhos de campo e a aproximação com a comunidade para a obtenção de informações para identificar os problemas locais. Os estudantes aplicaram questionários e fizeram vídeos nas comunidades pesquisadas. (Nós propomos, 2018)

O Quadro 04 mostra a distribuição das ações pelas cidades em três anos do programa, neste sentido.

Quadro 04: Distribuição das ações pelas cidades em três anos do programa

\begin{tabular}{|c|c|c|c|}
\hline Ano & 2016 & 2017 & 2018 \\
\hline $\mathbf{N}^{\circ}$ de escolas & 14 & 10 & 6 \\
\hline $\begin{array}{c}\text { Cidade } \\
\mathbf{X} \\
\mathbf{N}^{\circ} \text { Escola }\end{array}$ & $\begin{array}{l}\text { Araguaína -5 } \\
\text { Gurupi - 3 } \\
\text { Palmas - 6 }\end{array}$ & $\begin{array}{l}\text { Araguaína - 4 } \\
\text { Palmas - 6 }\end{array}$ & Palmas - 6 \\
\hline
\end{tabular}

Fonte: Elaborado pelos autores 2018

\section{Conclusão}

Em Novembro de 2017 no II Seminário Estadual do projeto Nós Propomos, as cidades de Palmas e Araguaína elaboraram 17 ações de destaques são elas: "HIDRATAPALMAS", "Praça Nossa de Todo Dia", "Ausência de Sinalização Horizontal e Vertical na Quadra 806 Sul”, "Pavimentação e lluminação Pública da Viela na Quadra 806 Sul", "Limitações aos Direitos de Mobilidade Urbana da Pessoa com Deficiência, Ornamentação de Espaço Público", "Acessibilidade na Escola, Arborização do Espaço Escolar"; "Acondicionamento do Lixo Urbano"; "Acessibilidade na Capital Palmas -TO"; "Casa de Passagem VIVER COM ALEGRIA"; "Poluição do Córrego Neblina"; "Impacto Ambiental da Nascente do Córrego Canindé no Parque Cimba"; "Segurança Pública Comunitária"; "Inclusão Digital e Profissional"; "Praça da Juventude: mais lazer e cultura, mais vida!"

O caráter orgânico-institucional em sintonia com os planos pedagógicos dos cursos envolvidos e no plano de desenvolvimento da instituição consegue através da cidadania, do estimulo do desenvolvimento social e o espírito crítico dos estudantes da UFT elaborar propostas para resolução de problemas urbanos nas cidades tocantinenses através dos jovens estudantes do ensino médio da rede pública estadual. Consegue-se assim, plantar uma semente da educação para a democracia 
participativa, com a colaboração entre a universidade e as escolas de ensino médio, no âmbito da identificação e da pesquisa, de problemas urbanos, e essencialmente socializar as propostas de resoluções por meio de um seminário estadual. Cabe ressaltar que o projeto "Casa de Passagem VIVER COM ALEGRIA" foi executado com auxílio de uma ONG.

Em novembro de 2018, a equipe do projeto realizou onze oficinas nas cinco escolas públicas de ensino médio integrantes do Projeto, numa medeia de 120 participantes, entre professores e alunos. Merece destaque que o trabalho sobre a revitalização do Centro Comunitário Viver com Alegria, "Protagonismo entre gerações" desenvolvido pela acadêmica Nathalia Patrícia Leão com a orientação do Prof. Dr. João Aparecido Bazzoli, apresentado no V Seminário Integrado de Ensino, Pesquisa e Extensão, foi premiado com o $1^{\circ}$ lugar na categoria Extensão, Cultura e Assuntos Comunitários. Isto frisa o crescimento e importância do projeto dentro do âmbito da Universidade, Conforme colocado no quadro 3 , dentro de tantas ações o Projeto de destaca e recebe um primeiro lugar dentro da UFT.

A terceira edição do Congresso contou com 189 participantes com participação de alunos do ensino médio da rede pública estadual da cidade de Palmas, com propostas de resoluções de problemas urbanos formulados pelos estudantes do ensino médio, resultantes de estudo de casos. Foram apresentados 9 projetos "Uma praça em minha vida: proposta de mudança na praça Brasília, no bairro Aureny I, Palmas - TO", "lluminar", "Horta de escambo", "Tocando em frente", "Reativação e restituição da Associação Comunitária do Cidadão do Aureny I", "Lixo no lugar certo", "Criação da praça da quadra 407 Norte", "Hidrata Palmas", "Centro de assistência a mulher"

Através um projeto de extensão, o Projeto Nós Propomos!, busca no protagonismo juvenil, o elemento central da prática educativa. Na metodologia do projeto o jovem participa de todas as fases da prática educacional, desde a elaboração, execução até a avaliação das ações propostas reforçando o protagonismo juvenil e estimulando a participação social.

\section{Referências}

Bazzoli, J. A. (2017). Nós propomos? Multiplicidade de atores e diversidade na educação cidadã. In J. A. Bazzoli, S. Claudino, M. V. Costa e Silva, S. F. R. Viana \& W. C. Silva. (Org.). A extensão universitária como indutora à cidadania: a experiência do "Nós Propomos", ISBN 978.85.60487.26.4 Palmas: Editora UFT - EDUFT, v. 1, p. 47-67 
Bazzoli, J. A., Claudino S. L., Costa e Silva, M. V.; Viana S. F. Rocha \& Silva W. C. (2017). A extensão universitária como indutora à cidadania: a experiência do "Nós Propomos", ISBN 978.85.60487.26.4 .Palmas: Editora UFT - EDUFT.

Brasil. Casa Civil. Subchefia para Assuntos Jurídicos. Constituição da república federativa do Brasil de 1988. Disponível em < http://www.planalto.gov.br/ccivil_03/constituicao/constituicao.htm> Acessado em $28 / 12 / 2018$

Brasil. Casa Civil. Subchefia para Assuntos Jurídicos lei no 9.394, de 20 de dezembro de 1996. Estabelece as diretrizes e bases da educação nacional. Disponível em < http://www.planalto.gov.br/ccivil_03/leis/L9394.htm >. Acessado em 19/03/2018

Brasil. Ministério da Educação. Decreto $n^{\circ}$ 5.773, de 9 de maio de 2006. Dispõe sobre o exercício das funções de regulação, supervisão e avaliação de instituições de educação superior e cursos superiores de graduação e sequenciais no sistema federal de ensino. Disponível em < http://www2.mec.gov.br/sapiens/portarias/dec5773.htm>. Acessado em 20/02/2018

Brasil. Casa Civil. Subchefia para Assuntos Jurídicos. Lei $n^{\circ} 10.861$, de 14 de abril de 2004. Institui o Sistema Nacional de Avaliação da Educação Superior - SINAES e dá outras providências. Disponível em < http://www.planalto.gov.br/ccivil_03/_ato20042006/2004/lei//10.861.htm >. Acessado em 22/02/2018

Brasil. Ministério da Educação. Decreto $n^{\circ}$ 2.494, de 10 de fevereiro de 1998. Disponível em < http://portal.mec.gov.br/seed/arquivos/pdf/tvescola/leis/D2494.pdf >. Acessado em 19/02/2018

Brasil. Ministério da Educação. Portaria no 1.466, de 12 de julho de 2001. Disponível em < http://www.uesb.br/pdi/downloads/legislacao/Portaria\%201466\%202001.pdf >. Acessado em 09/03/2018

Brasil. Ministério da Educação. Portaria no 2.253, de 18 de outubro de 2001. Dispõe sobre a introdução nas instituições de ensino superior do sistema federal de ensino, na organização pedagógica e curricular de seus cursos superiores reconhecidos, a oferta de disciplinas que, em seu todo ou em parte, utilizem método não presencial, com base no art. 81 da Lei n. 9394, de 1996. Disponível em < http://www2.camara.leg.br/legin/marg/portar/2001/portaria-2253-18-outubro-2001-

412758-publicacaooriginal-1-me.html >. Acessado em 09/03/2018 
Brasil. Ministério da Educação Portaria nº 3.284, de 7 de NOVEMBRO de 2003. DOU 11/11/2003 p. 12, Seção 1. Dispõe sobre requisitos de acessibilidade de pessoas portadoras de deficiências, para instruir os processos de autorização e de reconhecimento de cursos, e de credenciamento de instituições. Disponível em < http://portal.mec.gov.br/sesu/arquivos/pdf/port3284.pdf >. Acessado em 09/04/2018

Brasil. Ministério da Educação. Portaria n 7, de 19 de março de 2004. Disponível em < http://porteiras.s.unipampa.edu.br/pdi/files/2017/12/portaria-n-7-de-19-de-marco-de2004.pdf >. Acessado em 09/04/2018

Brasil. Ministério da Educação. Portaria MEC no 2.051/2004. Regulamenta os procedimentos de avaliação do Sistema Nacional de Avaliação da Educação Superior (SINAES), instituído na Lei no 10.861, de 14 de abril de 2004. Disponível em $<$ http://portal.mec.gov.br/arquivos/pdf/PORTARIA_2051.pdf>. Acessado em 09/04/2018

Brasil. Ministério da Educação. Portaria no 4.361, de 29 de dezembro de 2004. DOU de 30 de dezembro de 2004, Seção 1, páginas 66/67. Disponível em < http://portal.mec.gov.br/seed/arquivos/pdf/port_4361.pdf >. Acessado em 09/04/2018

Brasil. Ministério da Educação. Lei no 10.032, de 23 de outubro de 2000. Autoriza o Poder Executivo a instituir a Fundação Universidade Federal do Tocantins. Diário Oficial da União - Seção 1 - Eletrônico - 24/10/2000, Página 1. Coleção de Leis do Brasil - 2000, Página 7215 Vols. 10 (Publicação Original). Disponível em < http://www2.camara.leg.br/legin/fed/lei/2000/lei-10032-23-outubro-2000-374833norma-pl.html >. Acessado em 04/02/2018

Consuni, № 11/2010. Resolução do conselho universitário (CONSUNI) Fundação Universidade Federal do Tocantins $n^{\circ} 11 / 2010$. Dispõe sobre o Plano Institucional (PDI) da Universidade Federal do Tocantins (UFT) - 2011-2015

Consuni, № 16/2016. Resolução do conselho universitário (CONSUNI) fundação universidade federal do Tocantins. Plano de desenvolvimento institucional 2016 2020. Aprovado pelo Conselho Universitário 05 de abril de 2016 (Resolução $n^{\circ}$ 06/2016-Consumi)

Consope, $\mathrm{N}^{\circ}$ 005/2005.resolução do conselho de ensino, pesquisa e extensão (CONSEPE). Aprova a sistemática orientadora de elaboração e reformulação do Projeto Político-Pedagógico dos Cursos de Graduação da UFT. 
CPA -Comissão Própria de Avaliação. Relatório de avaliação institucional uft_2017. 155 págs. Editora UFT, publicado em 2018. Disponível em: http://download.uft.edu.br/?d=007af53c-9787-4b24-a31f-

37871dc25328;1.0:Relat\%C3\%B3rio\%20de\%20Avalia\%C3\%A7\%C3\%A30\%20Instituci onal\%202017.pdf. Acessado em 28/12/2018.

Instituto Brasileiro de Geografia e Estatística (IBGE), Estimativas da população residente no Brasil e unidades da Federação com data de referência em $1^{\circ}$ de julho de 2018.

Disponível

em

$\mathrm{ftp} / / / \mathrm{ftp}$. ibge.gov.br/Estimativas_de_Populacao/Estimativas_2018/estimativa_TCU_201 8_20181212.pdf; Acessado em: 28/12/2018

Nós Propomos. III Seminário Estadual Nós Propomos participa do Circuito Urbano 2018. Blog Nós Propomos. Sexta-feira, 21 de dezembro de 2018 Disponível em: <http://nospropomos.blogspot.com/> Acesso em: 28 de dezembro de 2018.

Nós Propomos. II Seminário Estadual do projeto Nós Propomos. Sexta-feira, 17 de novembro de 2017. Disponível em: <http://nospropomos.blogspot.com/> Acesso em: 20 de dezembro de 2017. 


\title{
O Projeto Nós Propomos! A construção de uma cidadania territorial. A experiência da Sertã
}

\author{
ILDA BICACRO ${ }^{1}$ \\ SÉRGIO CLAUDINO
}

\section{Resumo}

Os alunos de Geografia da Escola Secundária da Sertã, desde 2014/15, encontraram no Projeto "Nós Propomos!" a possibilidade de realizar o Estudo de Caso e, em simultâneo, de desenvolver uma cidadania ativa, contribuindo para a melhoria do seu território, numa perspetiva de melhores condições de vida e de bem-estar. Depois de aceite a candidatura desta escola ao Projeto, dinamizado pelo Instituto de Geografia e Ordenamento do Território da Universidade de Lisboa (IGOT-UL), este foi apresentado aos alunos e celebrados protocolos entre a Escola, a Universidade e o Município da Sertã. Em cada ano letivo, os alunos, em pequenos grupos, coordenados pela professora de Geografia, percorrem o seu território, identificam problemas a estudar, planificam o seu projeto e desenvolvem os seus trabalhos durante sete meses. A metodologia utilizada privilegia o trabalho colaborativo, recorrendo sistematicamente a trabalho de campo, com observação local, realização de inquéritos e entrevistas, manuseamento de mapas digitais, utilização de bases de dados e outra informação. Por fim, depois de tratada toda a informação recolhida, os alunos elaboram relatórios e apresentam publicamente as suas propostas de resolução dos problemas e de melhoria de condições, numa perspetiva de intervenção cidadã. Os projetos são, depois, partilhados com autarcas ou instituições e em outros fóruns de participação. A experiência do Projeto na Sertã tem sido muito marcante e adquirido grande visibilidade no país e na rede internacional do Projeto Nós Propomos! Têm sido atribuídas diversas distinções nacionais ao Projeto, testemunho do compromisso escolar e cidadão de alunos e docente.

\footnotetext{
${ }_{1}^{1}$ Professora do Agrupamento de Escolas da Sertã, ilda.bicacro@gmail.com

2 Professor do Instituto de Geografia e Ordenamento do Território da Universidade de Lisboa, Investigador Efetivo do Centro de Estudos Geográficos, sergio@campus.ul.pt
} 
Palavras-chave: Cidadania; Geografia; Território; trabalho colaborativo; Estudo de Caso.

\section{Resumen}

Los alumnos de Geografia de la Escuela Secundária de Sertã, desde 2014/15, encontraron en el proyecto "Nosotros Proponemos!" la posibilidad de hacer el Estudio de Caso y, en simultaneo, desenvolver una ciudadanía activa, contribuyendo para la mejoría de su territorio, en una perspectiva de mejores condiciones de vida y de bienestar. Después de aceptada la candidatura de esta escuela al Proyecto, dinamizado por el Instituto de Geografia e Ordenamento do Território de la Universidad de Lisboa (IGOT-UL), este fue presentado a los alumnos y fueron celebrados protocolos entre la Escuela, la Universidad y el Municipio de Sertã. En cada año lectivo, los alumnos, en pequeños grupos, coordenados por la profesora de Geografia, recorrem su território, identifican problemas a estudiar, planifican su proyecto y desenvuelven sus trabajos durante siete meses. La metodologia utilizada privilegía el trabajo colaborativo, recorriendo sistematicamente al trabajo de campo, con observación local, realización de inqueritos y entrevistas, manoseamiento de mapas digitales, utilización de bases de datos y otra información. Por fin, después de tratada toda la información recogida, los alumnos elaboran relatórios y presentan publicamente sus propuestas de resolución de problemas y de mejoría de condiciones, en la perspectiva de intervención ciudadana. Los proyectos son, después, compartidos con las entidades o instituiciones y en otros foruns de participación. La experiencia del Proyecto en Sertã ha sido muy marcante y ha adquirido gran visibilidad en el país y en la red internacional del Proyecto Nosotros Proponemos! han sido atribuídas diversas distinciones nacionales al Proyecto, testimonios del compromiso escolar y ciudadano de alumnos y docentes.

Palabras-Ilaves: Ciudadania; Geografia; Territorio; Trabajo Colaborativo; Estudio de Caso.

\section{Introdução}

O Projeto "Nós Propomos! Cidadania e Inovação na Educação Geográfica" apresentase, hoje, como o único projeto de inovação na educação Geográfica em Portugal. Na Escola Secundária da Sertã, nos últimos quatro anos, afirmou-se como um projeto que colocou os alunos de Geografia a ultrapassar os muros impostos pela sala de aula e a fazer verdadeira geografia e cidadania territorial ativa, consciente e interveniente. 
Sendo um verdadeiro Estudo de Caso, foi também o motivo para colocar jovens dos 15 aos 18 anos a observar o seu território, a enunciar verdadeiros problemas e, depois de um percurso de investigação, a encontrar soluções para os problemas enunciados. Pretende-se realçar como este projeto, coordenado pelo Instituto de Geografia e Ordenamento do território da Universidade de Lisboa (IGOT-UL), tem sido o ambiente em que os alunos se encontram motivados, quer pelo sentido de verdadeiros participantes na construção do seu território, da sua comunidade (Bazzoli, 2017), quer pela competitividade que se gera dentro dos desafios do Projeto. Havendo todo um conjunto de desafios com prémios de melhor projeto nacional, melhor fotografia de trabalho de campo, melhor vídeo ou outros desafios que têm rodeado este Projeto, podem encontrar-se motivações várias para o prosseguimento de algumas verdadeiras aventuras dentro do mesmo. O processo de aprendizagem revelou-se de grande importância, quer pelas competências científicas, quer pelas competências sociais que foram desenvolvidas. O trabalho colaborativo surgiu como metodologia mais apropriada para estes ambientes de aprendizagem, tornando as aprendizagens mais consistentes.

Este texto pretende mostrar também como nestes quatro anos, os alunos de Geografia da Escola Secundária da Sertã foram verdadeiros cidadãos ao apresentarem propostas de melhoria do seu Concelho, mas também ao serem protagonistas da sua aprendizagem, ao apresentar os seus trabalhos publicamente na Escola, na Câmara Municipal da Sertã e na Universidade de Lisboa.

\section{Projeto “Nós Propomos!”}

\subsection{O Projeto e o Estudo de Caso de Geografia no ensino secundário em Portugal}

No ano letivo 2011/12, depois de uma (mal sucedida) caminhada junto das instâncias do Ministério da Educação para a implementação do Estudo de Caso contemplado nos currículos do ensino secundário (Alves, Brazão, Martins, 2001), Sérgio Claudino, no Instituto de Geografia e Ordenamento do território da Universidade de Lisboa (IGOTUL), vê aprovada pelos núcleos de investigação de que fazia parte, no Centro de Estudos Geográficos, uma pequena verba que vai fazer arrancar o Projeto "Nós Propomos! Cidadania e Inovação na Educação Geográfica”. Lançado o Projeto, juntase ao IGOT a Esri Portugal, que apoiava a utilização dos Sistemas de Informação Geográfica e a deslocação às escolas. 
Operacionalizando o estudo de caso, o Projeto prevê que os alunos identifiquem problemáticas no contexto da Geografia e, através de trabalho de campo, o estudo e avaliação dos mesmos problemas junto da comunidade local, a elaboração de propostas de ação e/ou solução/atenuantes para a problemática identificada, sempre que possível em diálogo com as autarquias (Claudino, 2018). Com uma inspiração construtivista, e assumindo que a educação cidadã se desenvolve na resolução de problemas concretos da comunidade (Figueiredo, 2005) é, assumidamente, um Projeto de cidadania territorial, em que a escola presume contribuir para a melhoria das condições da comunidade local, atendendo ao envolvimento com as autarquias preconizado na sua metodologia.

\subsection{Domínios e metodologia}

O Projeto Nós Propomos! assenta em dois domínios fundamentais:

1) A cidadania territorial, através da participação publica, informada e consciente na tomada de decisões;

2) A inovação educativa, no âmbito da disciplina de Geografia.

Atualmente, o Projeto alargou-se a várias modalidades de ensino (secundário, profissional, academias seniores etc.) e está presente em escolas de todo o país (continente e ilhas). Tem as seguintes fases principais:

a) Candidaturas, em julho ou setembro;

b) Assinatura do Protocolo de Colaboração entre a Universidade de Lisboa, a Escola e a Autarquia a que pertence;

c) Os alunos, com apoio de um professor coordenador (Geografia), identificam um problema local e constituem um grupo de trabalho;

d) Realização de trabalho de campo (inclui contacto com a autarquia e outras instituições responsáveis pela problemática em estudo);

e) Apresentação de propostas de intervenção até finais de abril;

f) Partilha de propostas: na Universidade de Lisboa, no "Seminário Nacional Nós Propomos!"; na Comunidade (ex. na Câmara Municipal, na Escola, numa organização relacionada com a problemática). 
Na Escola Secundária da Sertã, o projeto "Nós Propomos!" desenvolve-se segundo a metodologia do estudo de caso e em trabalho colaborativo, onde os alunos são os grandes condutores das suas aprendizagens.

Figura 1- Aplicação de Inquérito

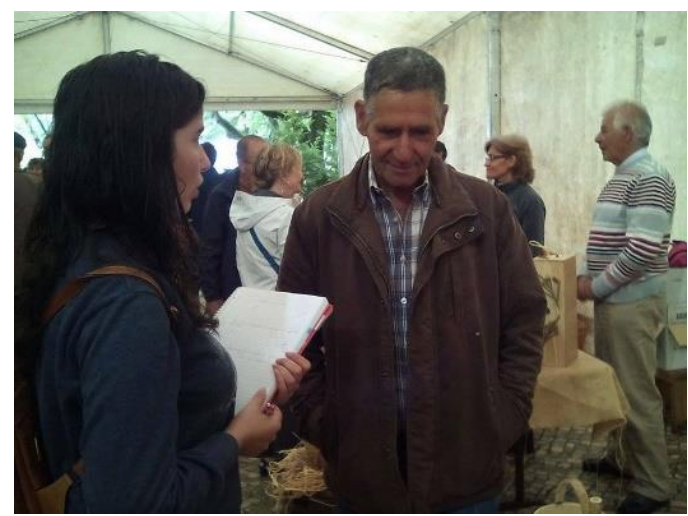

Figura 2 - Entrevista a autarca

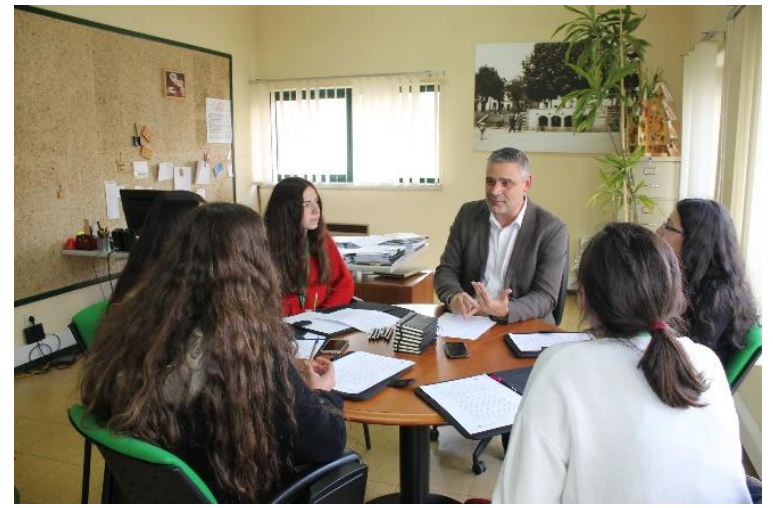

Desde o lançamento do projeto e no início de cada ano letivo, logo que os grupos se constituem e escolhem a sua temática/problema a estudar, passam à planificação de todo o trabalho a desenvolver ao longo de cerca de sete meses. Há datas que são imediatamente comunicadas e assumidas por todos: a apresentação e votação dos projetos na Escola e a sua apresentação na Universidade de Lisboa (IGOT-UL). Consoante os problemas, são escolhidas as pessoas/instituições a envolver e os grupos adotam como técnicas privilegiadas de recolha de informação: a entrevista, o inquérito e outras formas de abordagem das questões. Tudo é passado para o plano de trabalho do grupo e todos os alunos sabem que papel é preciso desempenhar neste trabalho colaborativo. As formas de divulgação do projeto, a apresentação e o poster, são produtos finais obrigatórios e fazem parte integrante da planificação dos projetos. A participação nos concursos de fotografia e vídeo de trabalho de campo são também divulgados e incentivados junto de todos os grupos de alunos e para todos os temas/problemas abordados. 


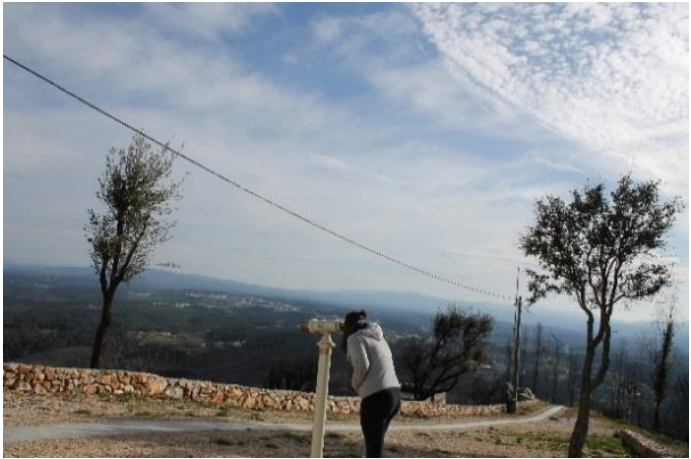

Figura 5 - Exposição de pósteres na Universidade de Lisboa

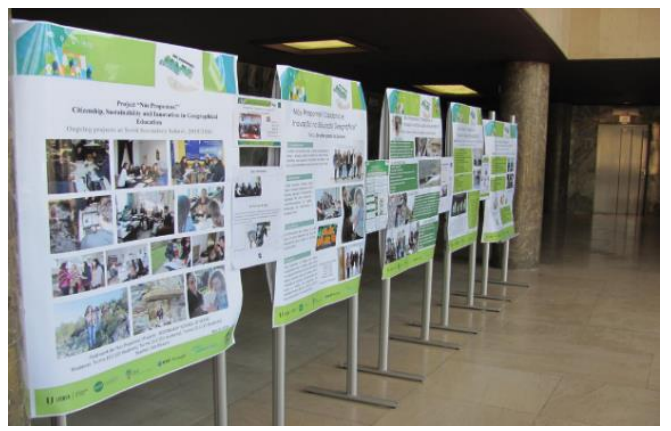

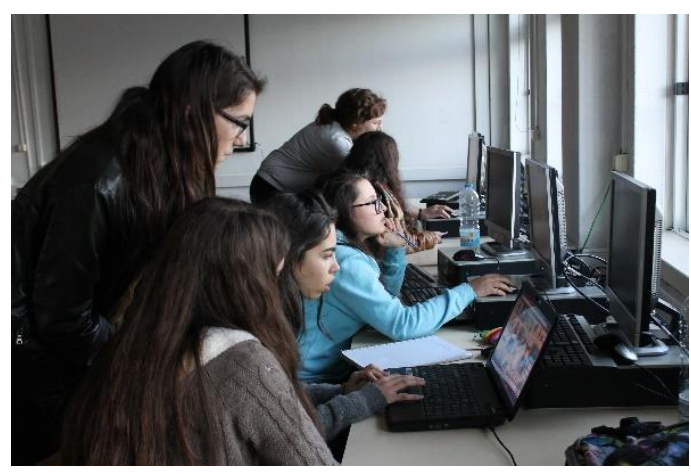

Figura 6 - O projeto na comunicação social da Sertã

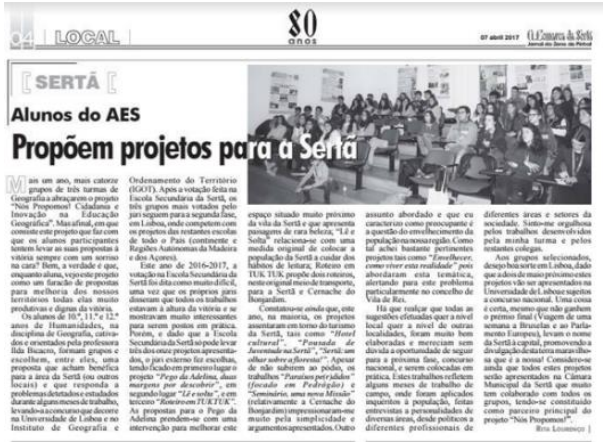

\section{O Projeto “Nós Propomos!" na Escola Secundária da Sertã}

\subsection{Quatro anos de "Nós Propomos!"}

No ano escolar de 2014, depois da aceitação da lecionação das turmas e anos de Geografia do ensino secundário, considerando a pertinência do Estudo de Caso, fezse a candidatura à participação da Escola Secundária da Sertã ao projeto nacional, à época, e agora internacional. Neste momento, contam-se com quatro anos de participação empenhada e ininterrupta.

\subsubsection{Ano escolar de 2014 - 2015}

Em maio de 2015, a Escola da Sertã participou pela primeira vez no Seminário Nacional do Projeto, num universo de 1300 alunos e seus professores, onde foram discutidas políticas para o território. As turmas de Geografia dos $10^{\circ}$ e $11^{\circ}$ anos, num total de 44 alunos apresentaram 8 projetos. A par da distinção de melhor projeto na Escola, "Hotel da Foz da Sertã, um Fantasma do Passado?" foi desenvolvido e apresentado por um grupo de alunos de $11^{\circ}$, permitindo que estes tivessem sido 
selecionados para participarem na viagem ao Parlamento Europeu e a Paris. Outros alunos da Escola Secundária da Sertã foram também premiados com num estágio sobre ciência polar, na paisagem de origem glaciária da Serra da Estrela. Além deste reconhecimento, também foram agraciados com uma visita a um Centro Ciência Viva (em Proença-a-Nova) e receberam livros de Geografia do Centro de Estudos Geográficos/IGOT-UL e da Plátano Editora e da Didática Editora.

Em junho de 2015, a convite do Senhor Presidente da Câmara Municipal da Sertã, os alunos do $10^{\circ}$ e $11^{\circ}$ anos apresentaram as suas propostas, na sessão pública da Câmara Municipal sobre o Plano Estratégico do Município da Sertã. Os alunos do Projeto Nós Propomos! foram "parceiros" nesta sessão e fizeram a apresentação dos seus trabalhos ao Presidente da Assembleia Municipal, ao Senhor Presidente da Câmara Municipal, Senhores Vereadores, Senhores Deputados da Assembleia Municipal, Presidentes de Junta de Freguesia, Diretor do Agrupamento de Escolas, representantes de outras entidades oficiais e civis, comunicação social e munícipes. Nesta sessão, esteve ainda presente a equipa de investigadores da Universidade de Aveiro que coordenou os estudos para o Plano Estratégico do concelho da Sertã, tendo havido debate das propostas apresentadas pelos alunos nos diversos projetos.

\subsubsection{Ano escolar de 2015 - 2016}

Em abril de 2016, participaram 64 alunos, tendo sido apresentados 11 projetos na Universidade de Lisboa (IGOT), onde foram premiados pelo segundo ano consecutivo. A Escola Secundária da Sertã foi premiada nas categorias de "Melhor Fotografia de Trabalho de Campo (10 lugar)", "Melhor Texto" (1 $1^{\circ}$ e $2^{\circ}$ lugar) e "Melhor Desenho/Caricatura" ( $1^{\circ}$ lugar). Os alunos vencedores foram contemplados com uma viagem a Bruxelas, ao Parlamento Europeu, que se realizou em abril de 2017.

Na sequência deste prémio, um grupo de sete alunas, acompanhadas pela professora de Geografia, integraram o grupo de premiados de mais dezasseis Escolas Secundárias de todo o país e das regiões autónomas, e realizaram uma viagem ao Parlamento Europeu entre 24 a 29 de abril de 2017. A viagem contemplou ainda, uma visita à cidade de San Sebastian em Espanha, no País Basco, e dois dias de percurso e visitas na cidade de Paris. Desta experiência, cita-se o testemunho de uma aluna da Sertã que nela participou:

A Sertã representou Portugal e defendeu-se além-fronteiras com muito orgulho, trabalho e dedicação. Esta experiência de vida única, permitiu aos alunos premiados e professores acompanhantes um novo e mais rico olhar sobre o mundo, numa abordagem à geografia dos sentimentos. 


\subsubsection{Ano escolar de 2016 - 2017}

Em maio de 2017, participaram cerca de 60 Escolas de todo o país, num universo de mais de 1200 alunos e professores. A Escola Secundária da Sertã fez-se representar, nesse ano, com 65 alunos e 11 projetos.

O Projeto "Lê e Solta", defendido por um grupo de alunas do $11^{\circ}$ ano, obteve o $2^{\circ}$ Lugar para "Melhor Projeto Nacional". A sua proposta refere-se às práticas de "Bookcrossing" transmunicipal entre as Vilas da Sertã, de Cernache do Bonjardim, e sedes dos municípios de Proença-a-Nova, Oleiros e Vila de Rei, nesta região do Pinhal Interior. A Escola recebeu, ainda, o prémio de "Melhor Fotografia de trabalho de campo" e uma "Menção Honrosa" pelos trabalhos "Lê e Solta" e "Pego da Adelina, duas margens por descobrir". Este último trabalho obteve, também, prémio de melhor projeto escolar (em parceria com outro projeto Nós Propomos!, ambos considerados $2^{\circ}$ prémios) da Associação Portuguesa de Geógrafos.

\subsubsection{Ano escolar de 2017 - 2018}

O ano escolar de 2017-2018 foi o ano de consolidação do Projeto "Nós Propomos!" na Escola Secundária da Sertã. Os parceiros estiveram na linha da frente do apoio, as metodologias estavam implementadas e percecionadas pelos intervenientes, os alunos perceberam que era importante o seu empenho e o desenvolvimento dos seus projetos era frutífero para todos.

Foram apresentados à comunidade e depois no IGOT-UL cinco projetos que traduziram sete meses de trabalho consistente, onde destacamos o trabalho de campo, a ligação às instituições e à comunidade. O Projeto "Saberes e sabores do coração de Portugal" obteve, com Rita Lourenço, o $1^{\circ}$ lugar no Prémio de Texto, e o Projeto "O que fazer em caso de incêndio florestal" o $2^{\circ}$ Lugar no Prémio de Fotografia de trabalho de campo. Este foi o ano em que os alunos se empenharam para a participação nos desafios lançados pelo I Congresso Iberoamericano Nós Propomos!, onde a Escola Secundária da Sertã participou, tendo ganho o 1ํㅜㄹémio de Desenho/ Caricatura e o $1^{\circ}$ Prémio de Texto. A participação neste congresso foi marcante para os alunos da Escola Secundária da Sertã.

Em resenha, a Tabela I sintetiza o número de alunos e as temáticas escolhidas pelos grupos de alunos em cada um dos anos letivos. 
Tabela 2 - Quatro anos de "Nós Propomos!" na Escola Secundária da Sertã

\begin{tabular}{|c|c|c|c|}
\hline $\begin{array}{l}\text { Ano } \\
\text { letivo }\end{array}$ & $\begin{array}{l}\text { № de alunos } \\
\text { participantes/anos } \\
\text { de escolaridade }\end{array}$ & Temas abordados & Prémios alcançados \\
\hline $\begin{array}{l}2014- \\
2015\end{array}$ & $\begin{array}{c}45 \text { alunos } \\
\left(10^{\circ}, 11^{\circ}\right)\end{array}$ & $\begin{array}{l}\text { Reabilitação de Hotel termal; Construção e } \\
\text { funcionamento de núcleo museológico; } \\
\text { Reabilitação do centro histórico da vila; } \\
\text { Potencialização do Turismo na região; } \\
\text { Preservação e dinamização de Espaços } \\
\text { verdes/Jardim; Mobilidade em espaços } \\
\text { públicos na vila. } \\
\text { Planeamento de espaços públicos e } \\
\text { acessos na Vila. }\end{array}$ & $\begin{array}{l}\text { - Melhor projeto de } \\
\text { Escola; } \\
\text { Viagem ao } \\
\text { Parlamento Europeu } \\
\text { (Bruxelas com } \\
\text { passagem por Paris - } \\
4 \text { alunos) }\end{array}$ \\
\hline $\begin{array}{l}2015- \\
2016\end{array}$ & $\begin{array}{c}70 \\
\left(10^{\circ}, 11^{\circ} \text { e } 12^{\circ}\right)\end{array}$ & $\begin{array}{l}\text { (Des)localização do novo Centro de } \\
\text { Saúde; Cartaz cultural ligado à música; } \\
\text { Criminalidade; Revitalização do Centro de } \\
\text { Geodesia de Vila de Rei; Horta biológica e } \\
\text { Quinta pedagógica; Reabilitação do Clube } \\
\text { cultural; Empreendedorismo local, o } \\
\text { comércio online; Acolhimento de } \\
\text { Refugiados; Reabilitação de parque } \\
\text { arqueológico; Envelhecimento e lares de } \\
\text { terceira idade; Redimensionamento da } \\
\text { ETAR/ Poluição na Ribeira da Sertã. }\end{array}$ & $\begin{array}{l}\text { - 1ํ Prémio de } \\
\text { Fotografia - "Pelas } \\
\text { linhas da História"; } \\
\text { - 1ํPrémio de } \\
\text { desenho/caricatura; } \\
\text { - 1o Prémio de texto } \\
\text { Viagem ao } \\
\text { Parlamento Europeu } \\
\text { (Bruxelas com } \\
\text { passagem por Paris - } \\
6 \text { alunas e a } \\
\text { professora de } \\
\text { Geografia) }\end{array}$ \\
\hline $\begin{array}{l}2016- \\
2017\end{array}$ & $\begin{array}{c}70 \\
\left(10^{\circ}, 11^{\circ} \text { e } 12^{\circ}\right)\end{array}$ & $\begin{array}{l}\text { Roteiro pelas estações arqueológicas do } \\
\text { concelho; Reordenamento da Floresta; } \\
\text { Roteiro turístico em TUK TUK; } \\
\text { Envelhecimento populacional; Praia Fluvial } \\
\text { e de Barragem; Promoção da leitura; } \\
\text { Reabilitação do Seminário das Missões; } \\
\text { Hotel Cultural de aldeia; Promoção do } \\
\text { trabalho para jovens estudantes; } \\
\text { Reabilitação/construção de parque de } \\
\text { lazer com campismo, }\end{array}$ & $\begin{array}{l}\text { - 1 Prémio de } \\
\text { Fotografia - "Nas } \\
\text { margens da leitura"; } \\
\text { - Menção Honrosa de } \\
\text { Fotografia - "Espelho } \\
\text { de Água"; }\end{array}$ \\
\hline $\begin{array}{l}2017- \\
2018\end{array}$ & $\begin{array}{c}30 \\
\left(11^{\circ}, 12^{\circ}\right)\end{array}$ & $\begin{array}{l}\text { Prevenção de risco de incêndio florestal; } \\
\text { Potencialização do Turismo na região; } \\
\text { Ordenamento das margens da Ribeira; } \\
\text { Prevenção do risco de seca; Divulgação } \\
\text { da Gastronomia e cultura da região. }\end{array}$ & $\begin{array}{l}\text { - } 2^{\circ} \text { Prémio de } \\
\text { Fotografia; } \\
\text { - Menção Honrosa de } \\
\text { Fotografia; } \\
\text { - 1o Prémio de } \\
\text { Desenho (I } \\
\text { Congresso } \\
\text { Iberoamericano); } \\
\text { - 1ํ Prémio de Texto } \\
\text { (I congresso } \\
\text { Iberoamericano) } \\
\text { Participação da aluna } \\
\text { Rita Mateus nas } \\
\text { viagens por Portugal } \\
\text { do I Congresso } \\
\text { lberoamericano }\end{array}$ \\
\hline
\end{tabular}

\section{Conclusão}


Percorridos quatro anos do Projeto "Nós Propomos! Cidadania e Inovação na Educação Geográfica" na Escola Secundária da Sertã, surge o momento de fazer uma reflexão sobre o trabalho desenvolvido, os grandes desafios e as conquistas alcançados e os constrangimentos sentidos. É justo referir-se que este Projeto foi capaz de colocar a educação geográfica na agenda curricular, trazendo o trabalho de projeto e colaborativo para as discussões pedagógicas: a Geografia tornou-se uma disciplina a escolher para a formação de cidadãos informados, conscientes e participativos na governança dos territórios ao nível local e nacional.

As metodologias ativas, as ferramentas digitais, o manuseamento de sistemas de informação geográfica, a capacidade de equacionar problemas, de planificar e gerir projetos, as competências ao nível da produção de texto, da apresentação oral e pública de trabalhos escolares são formas de inovação pedagógica agora testadas e que urge continuar a desenvolver.

Este Projeto marca um momento na pedagogia em Portugal, está a dar frutos no campo da Geografia e julga-se que pode ainda trazer novos contributos, quer como projeto de inovação didática da geografia em Portugal, quer nos diferentes países do mundo onde está a ser acolhido e desenvolvido. As competências que estão a ser preconizadas para os jovens do século XXI pedem que a metodologia do Projeto Nós Propomos! seja desenvolvida transversalmente aos currículos escolares. Urge formar cidadãos!

\section{Referências Bibliográficas}

Alves, M. L., Brazão, M. \& Martins, O. S. (2001). Programa de Geografia A. Lisboa: Ministério da Educação.

Bazzoli, J. A. (2017). Nós Propomos! e a busca inovação no campo da extensão universitária. In J. A. Bazzoli, S. Claudino, M. V. C Silva, S. F. R. Viana, W. C. Silva, A Extensão Universitária como indutora à cidadania: a experiência do "Nós Propomos" (pp. 13-27). Palmas: EDUFT.

Claudino, S. (2018). Educação Geográfica, Trabalho de Campo e Cidadania. O Projeto Nós Propomos! In F. H. Veiga (Coord.) O Ensino na Escola de Hoje. Teoria, Investigação e Aplicação (pp. 265-303). Lisboa: Climepsi Editores.

Figueiredo, C. C. (2005). Formação Cívica. E agora, um tempo para reflectir? In C. Carvalho, F. de Sousa, J. Pintassilgo, A educação para a cidadania como dimensão transversal do currículo escolar (pp. 23-47). Porto: Porto Editora. 


\section{Nós propomos!: uma análise sob a ótica da gestão social}

JOÃO APARECIDO BAZZOLI ${ }^{1}$

AIRTON CARDOSO CANÇADO²

\section{Resumo}

Este estudo objetiva construir uma proposta metodológica para avaliar os resultados das atividades do Projeto Nós Propomos! que se apresenta como modo alternativo de inserção dos estudantes secundários nos debates sobre a cidade. Pretende-se com o estudo analisar documentos produzidos e compreender a percepção de agentes e atores que atuam diretamente e indiretamente no Projeto, com a finalidade de observar qualitativamente se há efetividade dos resultados sob a ótica da Gestão Social na tradição de pesquisa brasileira. Este Projeto desenvolvido em dez escolas das cidades de Palmas e Araguaína, Tocantins, acumulou um acervo de propostas resultantes de suas atividades de três edições, que possibilita estruturar uma proposta metodológica para padronizar a métrica de avaliação dos resultados pretendidos com a sua execução. O Nós Propomos!, na sua concepção, busca compreender a extensão universitária como meio de instigar estudantes do ensino médio a participação social e despertar a cidadania a partir da identificação de problemas urbanos e proposições de resoluções para estes problemas.

Palavras-chave: Projeto Nós Propomos!; Gestão Social; Participação cívica; Extensão universitária.

\section{Abstract}

This study aims to build a methodological approach to assess the results of the activities we propose that present themselves as alternative mode secondary students ' insertion in the debates about the city. This study aims to analyze documents and

1 Professor Doutor, Universidade Federal do Tocantins (UFT), Curso de Direito, jbazzoli@uft.edu;br

2 Professor Doutor, Universidade Federal do Tocantins (UFT), Curso de Administração, airtoncardoso@yahoo.com.br 
understand the perception of agents and actors involved directly and indirectly in the project, with the purpose of observing qualitatively if there is effectiveness of results from the perspective of social management in the tradition of brazilian research. This project developed in ten schools of the cities of Araguaína, Tocantins and Palms he amassed a collection of proposals resulting from its three editions, that allows structure methodological proposal to standardize the metric for the evaluation of expected results with your implementation. What we propose in your design tries to understand the University extension as a means of instigating high school students middle social participation and citizenship from the identification of urban problems and propositions of resolutions to these problems.

Keywords: We Proposed; Social Management; Civic Participation; University Extension.

\section{Introdução}

Este estudo objetiva construir uma proposta metodológica para avaliar os resultados das atividades do Projeto Nós Propomos! que se apresenta como modo alternativo de inserção dos estudantes secundários nos debates sobre participação social na cidade. Busca-se com o estudo discutir as açoes desenvolvidas durante a execução das atividades do Nós Propomos! a partir da contextualização do atual estágio do campo da Gestão Social no Brasil. Essa proposta se justifica pelo processo de intenso desenvolvimento do constructo Gestão Social no Brasil, o avanço de pesquisas e a dissiminação de atividades voltadas para o tema, especialmente a criação do Programa de Estudos em Gestão Social. Diversos atores fizeram parte desse processo e hoje pode-se dizer que existe um profícuo campo de estudos sobre a temática na academia brasileira. A Gestão Social como será apresentada neste texto se configura como um conceito brasileiro por excelência (Cançado; Pereira; Tenório, 2015; Pereira; Cançado, 2018).

A tradição da pesquisa em Gestão Social no Brasil está fortemente ligada a Escolas de Administração, como por exemplo a Fundação Getúlio Vargas - FGV, Universidade Federal do Rio Grande do Sul - UFGRS, Universidade Federal da Bahia - UFBA, dentre outras. Entretanto há também trabalhos oriundos do Serviço Social, porém em ambos os campos a Gestão Social aproxima-se da Gestão Pública. Outra característica desse campo de estudos é que parte dos pioneiros do campo no país iniciaram seus trabalhos pesquisando sobre terceiro setor em vários núcleos de pesquisa de Universidades brasileiras. (Cançado; Pereira; Tenório, 2015). 
Trazendo para o contexto de nosso objeto de estudo, o Projeto Nós Propomos! de origem portuguesa foi implantado em 2011 pelo Instituto de Geografia e Ordenamento do Território da Universidade de Lisboa (IGOT-UL), expandiu-se para a Espanha, Colômbia, Peru, Moçambique, México e Brasil, "por representar um instrumento que busca despertar a cidadania ativa com enfoque na gestão democrática das cidades". (Bazzoli, 2017, p. 5-6).

O Projeto veio para o Tocantins em 2015 e foi implantado pela Universidade Federal em 2016, "para ser desenvolvido nas escolas de ensino médio das cidades de Palmas e Araguaína, por meio da parceria firmada com a Secretaria de Educação, Juventude e Esportes do Estado". (Bazzoli, 2017, p. 13-27).

Neste contexto buscamos neste trabalho iniciar com um resgate histórico sobre a construção do campo da Gestão Social no país. Posteriormente apresentaremos a teoria que sustenta este conceito, em especial as contribuições da Rede de Pesquisadores em Gestão Social - RGS e seus atuais desdobramentos. Ao final tentaremos demonstrar o desenvolvimento de nossos esforços de integração na busca da conciliação de uma agenda de pesquisa experimental desenvolvida pela Universidade Federal do Tocantins - UFT - para identificar a gestão social na dinâmica do desenvolvimento das atividades do Nós Propomos!. Este trabalho piloto esta sendo realizado a partir da observação das atividades do Nós Propomos! dentro da sua concepção de buscar compreender a extensão universitária como meio de instigar os estudantes do ensino médio a participação social e de despertar a cidadania por meio da identificação de problemas urbanos e de proposições de resoluções para estes problemas. Este trabalho tem como finalidade estruturar uma proposta metodológica para padronizar uma métrica de avaliação de resultados pretendidos com a execução do Projeto.

\section{Histórico da evolução Gestão Social no Brasil}

O marco inicial dos estudos em Gestão Social no Brasil foi a criação do Programa de Estudos em Gestão Social, vinculado à escola Brasileira de Administração Pública e de Empresas da Fundação Getúlio Vargas do Rio de Janeiro (PEGS/EBAPE/FGV) em 1990. (Tenório, 1998). Neste mesmo ano o Instituto Interamericano para o Desenvolvimento Social do Banco Interamericano de Desenvolvimento - INDES/BID passou a fomentar cursos sobre Gestão Social para pesquisadores da América Latina, conforme relata Tenório (2010) e nesses espaços, a Gestão Social era entendida como Gestão de Políticas Públicas Sociais. 
Porém, nesses cursos, parte dos pesquisadores presentes passaram a contestar limitação da abrangência do conceito de Gestão Social apresentada. No início dos anos 2000, diversos pesquisadores brasileiros começam a discutir a criação de uma rede para estudos em Gestão Social e desenvolvimento local. Em 2003 foi realizada uma reunião em São Paulo para dar contornos mais precisos à proposta. Nessa ocasião a rede decide permanecer informal.

A partir daí algumas ações são realizadas como a criação do Centro Interdisciplinar de Desenvolvimento e Gestão Social na Escola de Administração da Universidade Federal da Bahia - CIAGS/EAUFBA. O CIAGS passa então a oferecer cursos de extensão e especialização. Em 2005 o Mestrado Multidisciplinar e Profissionalizante em Desenvolvimento e Gestão Social é proposto e a primeira turma se inicia em junho de 2006 (Ciags, 2016). Em 2007 o CIAGS lança o periódico Cadernos Gestão Social, o primeiro periódico brasileiro específico para a Gestão Social e surge a Rede de Pesquisadores em Gestão Social - RGS com a realização do I Encontro Nacional de Pesquisadores em Gestão Social - I ENAPEGS na cidade de Juazeiro do Norte, Ceará e a partir daí passa a realizar reuniões anuais.

Após esta breve instrodução histórica mostraremos a seguir a evolução conceitual da Gestão Social no Brasil, bem como os debates suscitados pela temática.

\section{Gestão Social no Brasil: evolução e uma aproximação teórica}

A Gestão Social parece se aproximar mais do chamado "Campo de Públicas" (Pires et al., 2014; Cançado, 2016), que recentemente vem sendo configurado no país. O "Campo de Públicas" é formado pelo imbricamento entre Direito, Administração, Economia e Ciências Sociais e se configura como um lócus multi ou interdisciplinar de ensino e pesquisa que englobaria, além da Gestão Social, a Gestão Pública e as Políticas Públicas.

As origens da terminologia Gestão Social em português remontam aos trabalhos de Tenório. O primeiro contato do autor com o termo foi em um texto de Rovida (1985) que trata de experiências autogestionárias na guerra civil espanhola (Tenório, 2010). No referido texto, Gestão Social aparece com o significado de democracia proletária de caráter local (Rovida, 1985). Porém, o termo também é usado para descrever a gestão do Sovkhoz (fazendas coletivas na União Soviética) (Dicionário..., 2016).

A gestão social contrapõe-se à gestão estratégica na medida em que tenta substituir a gestão tecnoburocrática, monológica, por um gerenciamento 
mais participativo, dialógico, no qual o processo decisório é exercido por meio de diferentes sujeitos sociais (Tenório, 1998, p.15).

A posição de Tenório (1998) é embasada na Teoria Crítica Frankfurtiana (Adorno, Horkheimer e Habermas), em especial na Teoria da Ação Comunicativa de Habermas (Tenório, 1998). Outra referência importante é a obra de Guerreiro Ramos, principalmente sua crítica ao status quo dos estudos organizacionais e a hegemonia da racionalidade utilitária (Tenório, 1997).

[A] gestão social [pode ser definida] como o processo gerencial dialógico no qual a autoridade decisória é compartilhada entre os participantes da ação (ação que possa ocorrer em qualquer tipo de sistema social - público, privado ou de organizações não-governamentais). $O$ adjetivo social qualificando o substantivo gestão será entendido como o espaço privilegiado de relações sociais em que todos têm o direito à fala, sem nenhum tipo de coação (Tenório, 2005, p.105, grifos do original).

Tenório (2010) argumenta que a demarcação da Gestão Social como um novo conceito tem a intenção de enfatizar que o determinante da ação dos gestores deve ser a sociedade e não o mercado, "perspectiva que acompanha não só o pensamento crítico frankfurtiano como o santoamarense, configuração que assume que o mercado é apenas um dos enclaves da sociedade, da totalidade" (Tenório, 2010, p.57).

No caminho da evolução conceitual da Gestão Social é importante destacar que as contribuições, de certa forma vão se sobrepondo em alguns aspectos e se complementando em outros. França Filho (2003), por exemplo, usa o caminho da desconstrução e reconstrução do conceito de Gestão Social. Esse percurso metodológico traz dois resultados importantes. Permite ao autor comparar Gestão Social, gestão pública e gestão estratégica; e caracterizar a Gestão Social enquanto um fim e enquanto um processo. Nesse caso, a Gestão Social, enquanto finalidade busca a gestão das demandas e necessidades do social, aproximando-se da gestão pública. Por outro lado, ela se afasta da gestão pública enquanto processo, pois ao buscar subordinar lógicas instrumentais a outras lógicas mais sociais, políticas, culturais ou ecológicas se afasta da lógica burocrática-instrumental característica da gestão pública (França Filho, 2003).

Cançado, Sausen e Villela (2013) fazem uma comparação entre Gestão Social e gestão estratégica, no sentido da contra-indução proposta por Feyerabend (2007). Segundo Feyerabend (2007) "[...] algumas das mais importantes propriedades formais de uma teoria são descobertas por contraste, e não por análise", pois as teorias devem ser comparadas antes com outras teorias "[...] do que com a 'experiência' e tem 
de tentar aperfeiçoar, em vez de descartar, as concepções que fracassaram nesta competição" (Feyerabend, 2007, p.46).

Algumas novas abordagens têm surgido no intuito de ampliar a discussão conceitual na temática. Exemplos dessas novas abordagem podem ser vistas em textos como Cançado e Oliveira (2015) que buscam na obra "A República" de Platão, aportes para a Gestão Social. Outro texto, Cançado, Tavares e Dallabrida (2013), aproxima os conceitos de Gestão Social e governança territorial. Esses exemplos ilustram o desenvolvimento do campo a partir de outras abordagens.

Após a apresentação do histórico e das discussões iniciais, propomos na seção seguinte a aproximação teórica para a Gestão Social.

\subsection{Aproximação Teórica para a Gestão Social}

Cançado, Tenório e Pereira (2011) apresentam, baseados em uma revisão de literatura as características da Gestão Social. Esse esforço teórico contempla a preocupação de França Filho (2003). O autor apresenta a necessidade de referenciais teóricos e metodológicos mais consistentes, sob pena da banalização da termininologia Gestão Social. No mesmo sentido, Fischer (2002) e Fischer e Melo (2006) argumentam que é necessária a "construção de um mapa" que dê significado à Gestão Social.

Em síntese, a gestão social pode ser apresentada como a tomada de decisão coletiva, sem coerção, baseada na inteligibilidade da linguagem, na dialogicidade e no entendimento esclarecido como processo, na transparência como pressuposto e na emancipação enquanto fim último (Cançado; Tenório; Pereira, 2011, p.697).

A partir dessas características e baseado em uma extensa revisão de literatura, Cançado (2011) apresenta uma aproximação teórica para a Gestão Social. Essa aproximação teórica é sustentada pela construção de categorias e sub-categorias teóricas que delineiam a Gestão Social. Posteriormente essa primeira aproximação teórica é aprimorada pelo próprio autor (Cançado, 2013b). Em seguida, chega-se a novo refinamento em Cançado, Pereira e Tenório (2015), conforme Figura 1.

A aproximação teórica proposta foi baseada em três grandes categorias teóricas: Interesse Bem Compreendido - IBC, Esfera Pública e Emancipação. Segundo os autores, as categorias devem ser interpretadas como tipos ideais weberianos, pois não é possível satisfazê-las plenamente. Elas são um "norte", uma situação a ser alcançada que se mantém em constante reconstrução por meio de uma relação dialética negativa (Adorno, 2009). A dialética negativa adorniana se alicerça na inter- 
relação entre tese e antítese, sem síntese (ou sem falsas sínteses, como prefere o autor).

Figura 1 - Aproximação Teórica para a Gestão Social

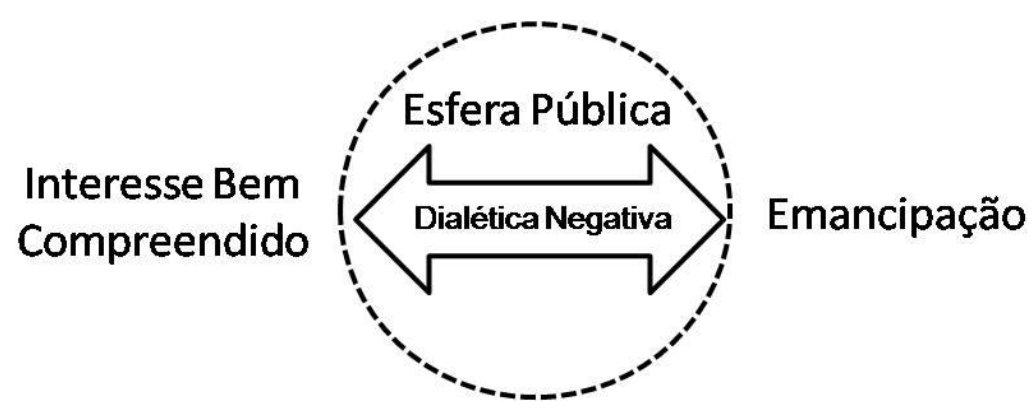

Fonte: Adaptado de Cançado, Pereira e Tenório (2015, p.161).

Essa aproximação teórica pode ser considerada como uma situação dinâmica, onde se busca o aperfeiçoamento da relação dialógica na esfera pública. Os autores alertam ainda que esta aproximação (já na sua terceira versão) está em construção, por meio da interação entre os membros da RGS e de outros pesquisadores.

Para melhor entendimento, nos subitens seguintes serão discutidas as categorias da aproximação teórica.

\subsubsection{Interesse Bem Compreendido}

O Interesse Bem Compreendido - IBC é um conceito adaptado de Tocqueville (1987), que o usa para descrever a sociedade norte-americana no Século XIX. O autor parte do contraste entre aristocracia (marcada pela desigualdade natural e a hierarquia) e democracia (marcada pela igualdade, sem hierarquia). O IBC só pode acontecer em um contexto democrático (Jasmin 2005). Ainda segundo Jasmin (2005, p.51) a "[...] participação na esfera pública [é] o que define a natureza política do governo democrático e não o conteúdo popular de suas medidas ou as 'formas exteriores' de suas instituições".

O IBC parte da premissa que o bem-estar coletivo é pré-condição para o bem-estar individual (e vice-versa), dessa forma, ao defender os interesses coletivos, em última instância, o indivíduo está defendendo seus próprios interesses. Em outras palavras, utilizando a terminologia do autor, "a virtude é útil” (Tocqueville, 1987).

O IBC reforça a questão da interdependência entre os indivíduos no sentido de perceber a dinâmica da sua própria atuação na Esfera Pública, não no sentido de ser altruísta ou mesmo assistencialista, mas no sentido de (re)construção coletiva da Esfera Pública com a intenção clara de conseguir o bem-estar coletivo e por 
consequência o bem-estar individual. São, na verdade, ocasiões onde os indivíduos percebem "[...] que dependem uns dos outros, afastando aquele sentimento egocêntrico e de independência que os induz a confundir liberdade com autossuficiência privada" (BARBACENA, 2009, p.23).

\subsubsection{Esfera Pública}

O conceito de Esfera Pública remonta aos gregos e romanos. A diferença, em termos gerais se refere à precedência de uma esfera sobre a outra. Enquanto na Grécia o homem se realiza na Esfera Pública, após sua "vitória" na esfera privada o libertar do cotidiano do lar e o qualificar para a Esfera Pública, em Roma a Esfera Pública é tão importante quanto a esfera privada, a vida em família. Cabe ressaltar que, em ambos os lugares, poucos tinham acesso à Esfera Pública, apenas os homens considerados cidadãos tinham acesso a este espaço (Arendt, 2010; Habermas, 2003b).

Com o surgimento da sociedade de massas, o domínio social atingiu seu ápice e passa a controlar todos os membros de determinada comunidade, ela "[...] não apenas destrói o domínio privado tanto quanto o domínio público; priva ainda os homens não só de seu lugar no mundo, mas também do seu lar privado" (Arendt, 2010, p.72). 0 domínio social, por meio da padronização do comportamento, conquistou o domínio público. A partir daí, a distinção e a diferença passaram a ser assuntos privados do indivíduo. Antes o domínio público era o espaço onde o indivíduo tinha espaço para sua individualidade (Arendt, 2010).

No caso da Gestão Social, busca-se uma nova Esfera Pública que consiga aproximar a população da política. Nesse sentido, pode-se dizer que a Gestão Social busca uma Esfera Pública ampliada em relação à Esfera Pública Burguesa. Para que a Gestão Social aconteça efetivamente é necessário um espaço onde, novamente (mas com diferentes intenções), as pessoas privadas (todas, não apenas aquelas que participavam da Esfera Pública Burguesa) se encontrem em um espaço público a fim deliberarem sobre suas necessidades e futuro.

De acordo com a aproximação teórica proposta, precisa-se apresentar agora, em mais detalhes, a redefinição desta Esfera Pública. Começa-se com o conceito de público. Segundo Habermas (2003b, p.14), “chamamos de 'públicos' certos eventos quando eles, em contraposição às sociedades fechadas, são acessíveis a qualquer um assim como falamos de locais públicos ou de casas públicas". 
A Esfera Pública se entrelaça com a esfera privada nas "[...] densas redes de interação da família e do círculo de amigos e os contatos mais superficiais com vizinhos, colegas de trabalho, conhecidos, etc" (Habermas, 2003a, p.98).

A nova Esfera Pública proposta tem no diálogo e na intersubjetividade seu cerne. Esse espaço pode ser considerado novo, na medida em que as pessoas se afastaram da política e são guiadas pelo comportamento e não pela ação. O que se busca é que o indivíduo se reconheça enquanto tal em uma relação dialética negativa entre Interesse Bem Compreendido e Emancipação.

\subsubsection{Emancipação}

Emancipação aqui é entendida como "livrar-se da tutela de alguém", "libertar-se" (Michaelis, 2016a), buscar autonomia. A Emancipação enquanto categoria teórica da Gestão Social pode ser percebida no sentido de ser a libertação de uma dominação opressora, baseada nas relações de produção e reprodução da vida. Emancipação é a ruptura com a subalternidade e a recusa à manipulação (Nogueira, 2011).

Muitas vezes pode-se ter a sensação de que não há o que fazer em relação a uma realidade dada, pela sua própria força e onipresença. Porém, a Teoria Crítica pensa de maneira diferente, pois "se o pensamento não se limita a registrar e classificar as categorias da forma mais neutra possível, isto é, se não se restringe às categorias indispensáveis, à práxis da vida nas formas dadas, surge imediatamente uma resistência" (Horkheimer, 1991a, p.61, grifos do autor), tanto dos acomodados que não querem sair desta condição, quanto dos dominantes que se sentem ameaçados.

O homem se emancipa quando se percebe enquanto indivíduo, com suas potencialidades individuais (forces propes) como motor das forças sociais, por fim, quando se percebe como ser político.

Finalizando a categoria teórica da Emancipação, acrescenta-se outra característica a esta categoria teórica. Sugere-se que a Emancipação se presta também a reforçar a percepção do IBC (e vice versa). Ao se libertar, escapando da manipulação, o ser humano pode passar a ter mais claro para si que ele vive em comunidade, as questões referentes à solidariedade podem se tornar óbvias, de certa forma.

Por outro lado, se o espaço da nova Esfera Pública não está disponível, ele precisa primeiro ser (re)construído, para depois ser vivenciado. A chave para a aproximação teórica é a noção de equilíbrio e interdependência entre as categorias teóricas (dialética negativa adorniana), bem como seu caráter de tipo ideal weberiano. 
Essa contribuição ainda carece de avanços, pode-se dizer que ainda estamos em busca do primeiro paradigma (Khun, 1978) ou consolidação de um programa de investigação científica (Lakatos, 1999). Nesse sentido, apresenta-se uma agenda de pesquisa proposta para a área na Tabela 1.

Tabela 01 - Síntese da Agenda de Pesquisa proposta.

\section{Agenda de Pesquisa Objetivo(s)}

Desenvolvimento de Interorganizações e Comunidades de Prática
Desenvolver caminhos para "incentivar" a constituição de Interorganizações e de Comunidades de Prática, preferencialmente de forma complementar

Primeiro paradigma para a Gestão Construir o primeiro paradigma para a gestão Social

Social

Demonstrar que a Gestão Social é multiparadigmática

Escalaridade da Gestão Social

Identificar as possibilidades de escalaridade da Gestão Social com relação à participação direta e indireta

Identificar possibilidade de uso de tecnologias da informação e comunicação para participação direta no âmbito da Gestão Social

Quadro de Análise para identificar a Gestão Social
Aprimorar o quadro de análise

Criar ferramentas e mecanismos para utilização do quadro de análise

Utilizar o quadro de análise em diferentes organizações de forma a verificar suas possibilidades de Gestão Social

Fonte: Cançado, Pereira e Tenório (2015, p. 195).

Essa agenda de pesquisa está em curso no Brasil nos diversos programas de pósgraduação, grupos de pesquisa, eventos e periódicos. O campo é bastante profícuo no país e passa por um momento de consolidação, tanto teórica, quanto empírica. No caso do Projeto Nós Propomos! tratar-se-á diretamente do $1^{\circ}$ e $3^{\circ}$ itens da Agenda de Pesquisa.

\section{Esforços na construção de proposta metodológica para avaliar o Nós Propomos!}

Detecta-se desde a sua implantação a relevância do Nós Propomos! como instrumento de articulação da participação popular. Os estudantes tem estreitado os laços comunitários, tomam conhecimento dos problemas sociais, culturais e da 
realidade econômica de sua região. Desta maneira, passam a se inserir e reconstruir a consciência de "pertencimento", ou seja, sentem-se parte desse processo de mudança e começam a verificar que podem, por meio da educação e do trabalho coletivo, encontrar possíveis resoluções para a melhoria da qualidade dos serviços públicos locais.

Ressalta-se a importância de o estudante atuando como pesquisador, no estabelecimento destes laços comunitários, esteja desprovido de preconceitos para reconhecer o protagonismo dos sujeitos locais, independentemente de níveis de escolaridade. Assim sendo, torna-se primordial se orientar pelo respeito a diversidade. Cada sujeito será dono de uma história de vida, mesmo que pareça anônima ao olhar do volume de informações produzidos na modernidade, porém, em regra geral ela terá profundidade maior que se poderia imaginar.

Este importante contato com a população local permite a elaboração de diagnósticos e o mapeamento dos pontos nevrálgicos e primordiais da comunidade a serem trabalhados e estudados nas rodas de palestras, reuniões de trabalho e seminários, que são realizados nas próprias escolas ou na universidade e/ou pela coordenação e equipe técnica do projeto.

Identificou-se como ponto forte do Projeto nas três edições o ativismo criativo dos estudantes, ao apontar resoluções viáveis e inovadoras para os problemas apontados nas comunidades, ouvindo a população interessada.

Diante deste contexto e em razão da visão empirica da forte tendência do conjunto de ações e reações observadas durante as três edições do Nós Propomos!, que possibilitou acumular um acervo de propostas resultantes de atividades, foi possivel encontrar evidências de Gestão Social, busca-se então, com esta agenda em andamento, estruturar uma proposta metodológica objetivando padronizar uma métrica de avaliação dos resultados pretendidos na execução do Nós Propomos!, tendo algumas direções básicas: Identificar se as Categorias Teóricas (CT) apresentadas por este estudo exploratório inicial acontecem e são fomentadas no Nós Propomos!; fomentar o uso de instrumentos avaliativos, como questionários, entrevistas e Grupos Focais; proceder análise baseada no referencial teórico, na percepção dos observados e nos documentos produzidos durante a execução do Projeto (triangulação).

Desta maneira a avalição almejada nos permitirá ver como o Nós Propomos! influencia na construção do processo da Gestão Social. Permitirá também, melhorar as novas intervenções decorrentes de trabalhos futuros, bem como, comparar ações em 
distintos lugares, estados e países, resguardando suas diferenças, especialmente as culturais.

\section{Considerações finais}

Contata-se com este estudo que a educação se constitui mecanismo de empoderamento de sujeitos de direito nas comunidades em que vivem a partir de uma contemporaneidade marcada por intensas transformações e exigências crescentes de acesso ao conhecimento.

Desta maneira, observa-se que as transformações básicas na pesquisa não se efetivam na velocidade desejada em razão dos efeitos de mudanças se revelarem por exposições relegadas a importância secundária e de proporcionarem resistências conservadoras. É necessário primordialmente entender a importância do estabelecimento de métricas e de condensar estruturas fundadas na produção do conhecimento que possibilitem aplicar instrumentos eficazes de tecnologia social e de novas descobertas acopladas aos processos educacionais locais na execução do Nós Propomos!.

Buscou-se neste estudo contextualizar a ideia da construção e estruturação de proposta metodológica para padronizar uma métrica de avaliação dos resultados pretendidos com a execução do Nós Propomos! e ficou demonstrado a possibilidade e a utilidade desta mensuração, que, além de melhorar as novas intervenções decorrentes de trabalhos futuros propostos pelo Projeto, possibilitará comparar ações ocorridas em distintos lugares, estados e países.

\section{Referências bibliograficas}

Adorno, T. W. (2009). Dialética negativa. Tradução: Marco Antonio Casanova; revisão técnica: Eduardo Soares Neves Silva. Rio de Janeiro: Jorge Zahar.

Arendt, H. (2010). A condição humana. 11 Ed. Tradução Roberto Raposo. Rio de Janeiro: forense Universitária.

Barbacena, J. M. (2009). Ação Popular e participação política: um diálogo com a teoria democrática de Aléxis de Tocqueville. Revista Urutágua, n. 17, dez. 2008/ mar., p.1828.

Bazzoli, J.A.; Nunes, S. C. L.; et al. (2017). A extensão universitária como indutora à cidadania: a experiência do Nós propomos. Palmas: Eduft. 
Cançado, A. C. (2016). Gestão Social e Economia Solidária - para além do mimetismo: outra gestão é possível? Revista Economia Solidária, V.10, dez.

Cançado, A. C. (2013). Gestão social: um debate para a construção do campo. NAU A Revista da Residência Social, v.4, n.6, p.191-209, mai./out.

Cançado, A. C. (2013). Gestão social: aprofundando a discussão. Relatório (Estágio Pós-doutoral em Administração) EBAPE/FGV. Rio de Janeiro: FGV, 2013b.

Cançado, A. C. (2011). Fundamentos teóricos da gestão social. 2011. Tese (Doutorado em Administração) - Universidade Federal de Lavras, Lavras, 2011.

Cançado A. C.; Pozzebon, M. (2016). Social management: the potential contribution of a Brazilian research tradition to the international nonprofit debate In ISTR's 12th International Conference: The Third Sector in Transition: Accountability, Transparency, and Social Inclusion, 12, Stockholm, Anais...,. Stockholm: ISTR. p.1-15.

Cançado, A. C.; MARINHO, F. A.; IWAMOTO, H. M. (2018). Social Management: An Anglophone Perspective. International Conference on Democratic Governance in Developing World, 4, 2018, Rio de Janeiro, Anais..., Rio de Janeiro: EBAPE/FGV.

Cançado, A. C.; PEREIRA, J. R.; TENÓRIO, F. G. (2015). Gestão social: epistemologia de um paradigma. 2 Ed. Curitiba: CRV.

Cançado, A. C.; Rigo, A. S.; Iwamoto, H. M.; Pinheiro, L. S. (2016). Gestão social, autogestão e gestão democrática pela Navalha de Occam : uma abordagem conceitual baseada na teoria dos conjuntos. In Encontro de Administração Pública e Governança, 6, 2016, São Paulo. Anais..., Rio de Janeiro: ANPAD.

Cançado, A. C.; Rigo, A. S.; Pinheiro, L. S. (2016). Por una agenda de investigación para la gestión social: control social, paradigma, escala y cuadro de análisis. Práxis Sociológica, V. 21, p.63-94.

Cançado, A. C.; Tavares, B.; Dallabrida, V. R. (2013). Gestão social e governança territorial: interseções e especificidades teórico-práticas. Revista Brasileira de Gestão e Desenvolvimento Regional, v.9, n.3, p.313-353, set/dez.

C Cançado, A. C.; Tenório Fernando G.; Pereira, José Roberto (2011). Gestão social: reflexões teóricas e conceituais. Cadernos EBAPE.BR, Rio de Janeiro, v. 9, n. 3, p. 681-703.

Feyerabend, P. K. (2007). Contra o método. Tradução: Cezar Augusto Morari. São Paulo: UNESP. 
Fischer, T. (2002). Poderes locais, desenvolvimento e gestão: uma introdução a uma agenda. In Fischer, T. (org.). Gestão do desenvolvimento e poderes locais: marcos teóricos e avaliação. Salvador: Casa da Qualidade, p.12-32.

Fischer, T.; Melo, V. P. (2006). Programa de desenvolvimento e gestão social: uma construção coletiva. In Fischer, T.; Roesch, S.; Melo, V. P. Gestão do desenvolvimento territorial e residência social: casos para ensino. Salvador: EDUFBA, CIAGS/UFBA, p.13-41.

França Filho, G. C. (2003). Gestão Social: um conceito em construção. In Colóquio Internacional sobre Poder Local, 9, Salvador. Anais..., Salvador: CIAGS/UFBA.

Habermas, J. (2003). Direito e democracia: entre a facticidade e a validade, volume II. 2 Ed. Tradução Fábio Beno Siebeneichler. Rio de Janeiro: Tempo Brasileiro.

Habermas, J. (2003). Mudança estrutural na esfera pública: investigações quanto a uma categoria da sociedade burguesa. 2 Ed. Tradução de Flávio R. Kothe. Rio de Janeiro: Tempo Brasileiro.

Horkheimer, M. (1991). Filosofia e teoria crítica. In Horkheimer, M.; Adorno, T. W. Textos escolhidos. 5 Ed. São Paulo: Nova Cultural.

Horkheimer, M. (1991). Teoria tradicional e teoria crítica. In Horkheimer, Max; Adorno, Theodor W. Textos escolhidos. 5 Ed. São Paulo: Nova Cultural.

Jasmin, M. G. (2005). Alexis de Tocqueville: a historiografia como ciência da política. 2 Ed. Belo horizonte: UFMG; IUPERJ.

Khun, T. S. (1978). A estrutura das revoluções científicas. 2 Ed. São Paulo: Perspectiva.

Lakatos, I. (1999). Falsificação e metodologia dos programas de investigação científica. Tradução de Emília Picado Tavares Marinho Mendes. Edições 70.

MarinhO, F. A.; Cançado, A. C. (2018). Icelandic Crowdsourced Constitution and Social Management: Practice and Theory in Citizens Democratic Participation In International Conference of the International Society for Third-Sector Research (ISTR), 13, Amsterdam. Annals..., Amsterdam: ISTR.

Michaelis - Moderno Dicionário da Língua Portuguesa. Emancipar. Disponível em <http://michaelis.uol.com.br/moderno/portugues/index.php?lingua=portuguesportugues\&palavra=emancipar>. Acesso em 12 maio 2018. 
Nogueira, M. A. (2011). Um Estado para a sociedade civil: temas éticos e políticos da gestão democrática. 3 Ed. São Paulo: Cortez.

Oliveira, A.; Cançado, A. C. (2015). Platão e a gestão da sociedade: contribuições da politeia à Gestão Social. RIGS, v.4, n.1, jan/mar, p.13-36.

Pereira, J. R.; Cançado, A. C. (2018). Gestão Social de Cooperativas. Curitiba, Editora Appris.

Pires, V. et al. (2014). Dossiê - Campo de Públicas no Brasil: definição, movimento constitutivo e desafias atuais. In: Revista de Administração Pública e Gestão Social, v. 6, n. 3, jul./set., p. 110-126.

Ramos, A. G. (1981). A nova ciência das organizações: uma reconceituação da riqueza das nações. Tradução de Mary Cardoso. 2 ed. Rio de Janeiro: Editora FGV.

Rovida, G. (1985). A revolução e a guerra na Espanha. In: Hobsbawn, Eric J. (Org.) História do marxismo $\mathrm{Vl}$ : o Marxismo na época da Terceira Internacional; A Internacional Comunista de 1919; As Frentes Populares. Rio de Janeiro: Paz e Terra.

Tenório, F. G. (2010). Gestão Social: uma réplica. In Rigo, A. S.; Silva JR, J. T.; Cançado, A. C.; Schommer, P. C. Gestão Social e Políticas Públicas de Desenvolvimento: Ações, Articulações e Agenda. Recife: UNIVASF.

Tenório, F. G. (2005). (Re)visitando o conceito de gestão social. Desenvolvimento em Questão, v. 3, n. 5, jan./jun., p.101-124.

Tenório, F. G. (1998). Gestão social: uma perspectiva conceitual. Revista de Administração Pública, v.32, n.5, p. 7-23, set./out.

Tenório, F. G. (1997). Superando a ingenuidade: minha dívida a Guerreiro Ramos. Revista de Administração Pública, v.31, n.5, p.29-44, set./out.

Tocqueville, A. (1987). Democracia na América. Traduzido e notas Neil Ribeiro da Silva. 2 Ed. Belo Horizonte: EDUSP; Itatiaia. 


\section{Trilhas Palmarinas: contribuição para educação geográfica de União dos Palmares, Alagoas, Brasil}

JOSÉ LIDEMBERG DE SOUSA LOPES ${ }^{1}$

MARIA EDINEY FERREIRA DA SILVA ${ }^{2}$

\section{Resumo}

Com o intuito de compreender a importância do trabalho de campo no contexto geográfico, o presente artigo tratará do Projeto de Extensão Universitária intitulado: Trilhas palmarinas: metodologias de ensino em espaços socioculturais, históricos e ambientais da cidade de União dos Palmares - Al. Projeto de grande valia na complementação dos estudos da ciência geográfica na escola, fazendo parte, assim como tantos outros do Projeto Nós Propomos!. Partimos do pressuposto de que o trabalho de campo se constitui em uma importante ferramenta metodológica, pois fornece ao aluno a possibilidade de construir o conhecimento na prática, aproximando a realidade concreta e o conhecimento disposto em sala de aula, ação que colabora na tomadas de decisões de forma critica e consciente por parte do aluno. Neste caso, o trabalho de campo representa a união entre a teoria, discutida em sala de aula, e a prática, ação que rompe o limite dos bancos escolares. No presente projeto, o aluno possui como aporte para discussão a ida a importantes espaços socioculturais onde, por meio de visitas guiadas, fatos relevantes da história local são resgatados, identificando as mudanças ocorridas no espaço geográfico, bem como os possíveis dilemas ambientais enfrentados no cotidiano pela população. A importância de abordagens como esta reflete-se diretamente na capacidade percetiva e atitudinal com que os alunos aprofundam os conhecimentos dispostos nos conteúdos abordados em sala de aula, pois facilitam o entendimento a partir da análise da realidade do espaço vivido.

\footnotetext{
1 Professor de graduação em Geografia e do programa de Pós-graduação em Dinâmicas Territoriais e Cultura, Universidade Estadual de Alagoas, jlidemberg@yahoo.com.br.

${ }^{2}$ Professora de graduação em Geografia, Universidade Estadual de Alagoas, maredy08@.
} 
Palavras-chave: Educação geográfica; trabalho de campo; extensão universitária; Cidade de União dos Palmares.

\section{Abstract}

In order to understand the importance of fieldwork in the geographic context, the present article will deal with the University Extension Project entitled: "Trilhas palmarinas": methodologies of teaching in sociocultural, historical and environmental spaces of the city of "União dos Palmares - Alagoas- Brazil". Project of great value in the complementation of the studies of the geographic science in the school, being part, as well as so many others of the Project We propose. We start from the assumption that the fieldwork constitutes an important methodological tool, since it provides the student with the possibility of constructing knowledge in practice, approaching the concrete reality and the knowledge arranged in the classroom, an action that contributes to decision making in a critical and conscious way on the part of the student. In this case, the fieldwork represents the union between the theory, discussed in the classroom, and the practice, action that breaks the limit of the school benches. In the present project, the student learning about the important socio-cultural spaces of the municipality, through guided visits, where are rescued facts local the history, being possible to identify the changes occurred in the geographic space, as well as the possible environmental dilemmas faced by the population. The importance of such approaches directly reflects the perceptive and attitudinal ability with which students deepen the knowledge of the content addressed in the classroom, since it facilitates the understanding from the analysis of the reality of the lived space.

Keywords: Geographical Education, Fieldwork, University extension, União dos Palmares city.

\section{Introdução}

Os diferentes significados que determinadas atividades, voltadas a aprendizagem, poderão proporcionar aos sujeitos estão intimamente atreladas à maneira como cada ser humano vivencia esta produção social. Ou seja, a maneira como cada indivíduo participa, vivencia e por conseguinte se apropria do espaço geográfico. Este fato conduz a uma compreensão mais profunda de sua realidade, proporcionando significados únicos às relações cotidianas. Concordamos com Becker (1993, p. 25) quando declara que todo conhecimento surge da interação que cada indivíduo 
estabelece no decorrer de sua existência. A dimensão do vivido, do experimentado estabelece relações subjetivas que proporcionam a construção de relações de pertencimento, identidades ou mesmo estranhamentos e repulsas. $\mathrm{O}$ indivíduo amplia sua visão de mundo a medida em que experimenta, vive e produz suas relações sociais.

Entretanto, quando nos propomos a romper com os espaços característicos da sociedade disciplinar (Foucault, 1977) como os presentes na escola, necessitamos olhar atentamente as dinâmicas sociais que nos cercam. A realidade inúmeras vezes não se revela da forma como percebemos, questiona-la, bem como compreende-la, exige desvelar tramites sutis presentes no cotidiano. Quando centramos a análise desta realidade a partir de determinados conhecimentos ministrados na instituição escolar, o cotidiano se torna palco para o entendimento dos conteúdos ministrados em sala de aula. Porém se faz imprescindível materializar a teoria a partir da ação humana, utilizando do meio em que estamos inseridos para agregar significância e sentido ao que se ensina na escola.

Diante desta compreensão, o presente artigo apresenta o Projeto de Extensão Universitária intitulado: Trilhas Palmarinas: metodologias de ensino em espaços socioculturais, históricos e ambientais da cidade de União dos Palmares - Al que tem como premissa contribuir com estudo da geografia, utilizando como recurso metodológico aulas de campo em espaços socioculturais, históricos e ambientais da cidade Palmarina, contribuindo não apenas com o romper dos muros da escola, mas com a aproximação da comunidade escolar com a realidade local, seus dilemas e suas possibilidades. Neste sentido, a proposta aqui disposta possui como um dos parâmetros as diretrizes dispostas pelo Plano Nacional de Educação 2014-2024 (Brasil, 2014), quando dispõem nos incisos do art. 2 ao tratar sobre a melhoria da educação básica, bem como a promoção humanística, promovendo princípios do respeito aos direitos humanos, à diversidade e à sustentabilidade socioambiental. Buscando assim, proporcionar um maior envolvimento da Universidade com a comunidade escolar (professores, alunos, funcionários, familiares dentre outros).

Sabemos que o homem, desde os primórdios, sempre explorou os espaços, fosse a busca de alimento, proteção dentre outras necessidades; todavia a necessidade de deslocamento assumiu diferentes motivações. Segundo Andrade e Rocha (1990) a exploração dos lugares a partir de atividades como as trilhas assumem novos e relevantes significados que priorizam experiências, suas sensações, percepções sobre o que cerca o sujeito. As trilhas utilizadas enquanto recurso didáticos possibilitam aos 
sujeitos vivenciar nos trajetos diferentes percepções, surgindo com um forte recurso na aproximação da teoria com a prática.

Para Xavier (2002) o ensino de geografia enquanto prática deve assegurar espaços que possibilitem o aprendizado adequados a realidade, buscando no cotidiano do aluno o seu envolvimento com o meio natural, construído assim, exemplos concretos e perceptíveis que colaborem em uma aprendizagem capaz de ser significativa ao aluno. Desta forma a comunidade escolar pode obter com as trilhas um modo não apenas de enriquecer os conhecimentos ministrados em sala de aula, mas podem contar com um instrumento pedagógico capaz de despertar o olhar de forma a conscientizar através das diferentes paisagens naturais e construídas presentes no município de União dos Palmares.

Com o intuito de compreender a importância do trabalho de campo no contexto geográfico, partimos do pressuposto de que essa atividade, trilhas palmarinas, será de grande valia para complementação de ensino, correspondendo uma metodologia fundante para a construção do conhecimento geográfico, e neste caso, a mesma não deve ser menosprezada nem na educação básica e pincipalmente no ensino superior. O trabalho de campo fornece ao aluno a possibilidade de construir o conhecimento na prática, já que este terá a oportunidade de se aproximar da realidade concreta, onde realizará observações de inúmeros aspectos além de análises críticas desta realidade. Nesse caso o trabalho de campo representa a união entre a teoria que é discutida em sala e a prática além dos bancos escolares, onde acontece o aprofundamento dos conteúdos abordados, além da possibilidade de levantar novos conhecimentos através das inúmeras alternativas de análise do real.

\section{$1 \quad$ Para quer trilhar?}

Desde o início da ciência geográfica no século XIX com Alexander Von Humboldt o trabalho de campo já estava presente. Segundo Figueiredo (2001) Humboldt, assim como Charles Darwin (1809-1882), realizou longas viagens, percorrendo grandes porções das áreas continentais e insulares, coletando dados empíricos que, posteriormente, sustentaram suas formulações científicas. Analisando o contexto histórico o trabalho de campo é colocado para a Geografia científica como um método para a coleta de dados, desde a sua origem em meados do anos de 1800.

Atualmente o trabalho de campo é objeto de discussões e indagações na realidade acadêmica e escolar. Onde muitas questões são levantadas, como: Qual a melhor forma de realizar? Existe diferença entre as práticas de campo realizadas na realidade 
acadêmica e na escolar? Como relacionar de maneira correta a teoria e a prática? Os inúmeros questionamentos nos possibilitam reconhecer que estas indagações, bem como as que possivelmente venham a surgir podem encontrar na proposta aqui apresentada uma resposta, pois ao unir teoria e prática possibilitamos a materialidade do teórico, dando forma ao que o conhecimento cientifico se propõe. Desta forma a linguagem acadêmica se transpõe para a escola de uma forma didática e acessível, o que possibilita uma melhor compreensão da realidade por parte dos alunos, professores e demais envolvidos.

Nesse sentido, conceituar aula de campo é importante, onde Oliveira e Assis (2009, p.196) o trabalho de campo consiste em: uma atividade extra-sala/extra-escola que envolve, concomitantemente, conteúdos escolares, científicos (ou não) e sociais com a modalidade espacial; realidade social e seu complexo amalgamado material e imaterial de tradições/novidades. É um movimento que tende elucidar sensações de estranheza, identidade, feiura, beleza, sentimento e até rebeldia do que é observado, entrevistado, fotografado e percorrido.

O trabalho de campo contribui para que seja trabalhada de maneira conjunta, contribuindo para desmitificar a dicotomia que embutiram na disciplina. "O trabalho de campo é um instrumento chave para a superação dessas ambiguidades, não priorizando nem a análise dos chamados fatores naturais nem dos fatores humanos (ou 'antrópicos')" (Serpa, 2006, p. 9-10).

O estado alagoano é um museu vivo de arte popular, só basta nos remontar do filé do Pontal da barra (tipo de bordado mais antigo de Alagoas) ou até mesmo do saboroso sururu (tipo de molusco para alimentação) catado nas margens da lagoa do Mundaú, expressões típicas da terra de Deodoro (referência ao Marechal Deodoro da Fonseca, o presidente da Proclamação da República do Brasil), Graciliano (Graciliano Ramos escritor alagoano), Maria Mariá (professora e historiadora) e de Jorge de Lima (Poeta, escritor e pintor), e tantos outros vultos que deixaram rastro de história imensurável.

Nesse contexto, o presente projeto está imbricada em fazer uma viagem aos patrimônios edificados da cidade de União dos Palmares, dando ênfase a rua Correia de Oliveira, conhecida como rua da Batata (essa rua ficou conhecida com esse epiteto devido os transeuntes ir e vir da feira com sacos de batatas, macaxeira constantemente nesse logradouro), tais inquietações para se produzir essa pesquisa foram as mais diversas, pois percebeu-se que os prédios ali instalados estão sofrendo das mais diversas depredações (modificações em suas fachadas, pichações) deixando a paisagem secular e bucólica em vias da chamada "modernização". O objeto de 
estudo encontra-se localizado no bairro Centro, conhecido também por bairro do comércio, que é delimitado por um quadrilátero formado pela Av. Monsenhor Clóvis Duarte, pela rua Tavares Bastos, rua Dr. Antônio Arecipo e a travessa Santa Maria Madalena.

Para melhor situar o objeto de estudo deste trabalho, a rua Correia de Oliveira/Batata, tem como paralelas as travessas Costa Rêgo, Marechal Floriano Peixoto, Leão Veloso e a do Mercado, vias estreitas, entretanto de grande importância para a cidade em termos de circulação de pessoas e serviços públicos e privados (Figura 1).

Figura 1- Localização da Rua Correia de Oliveira, União dos Palmares, Alagoas.

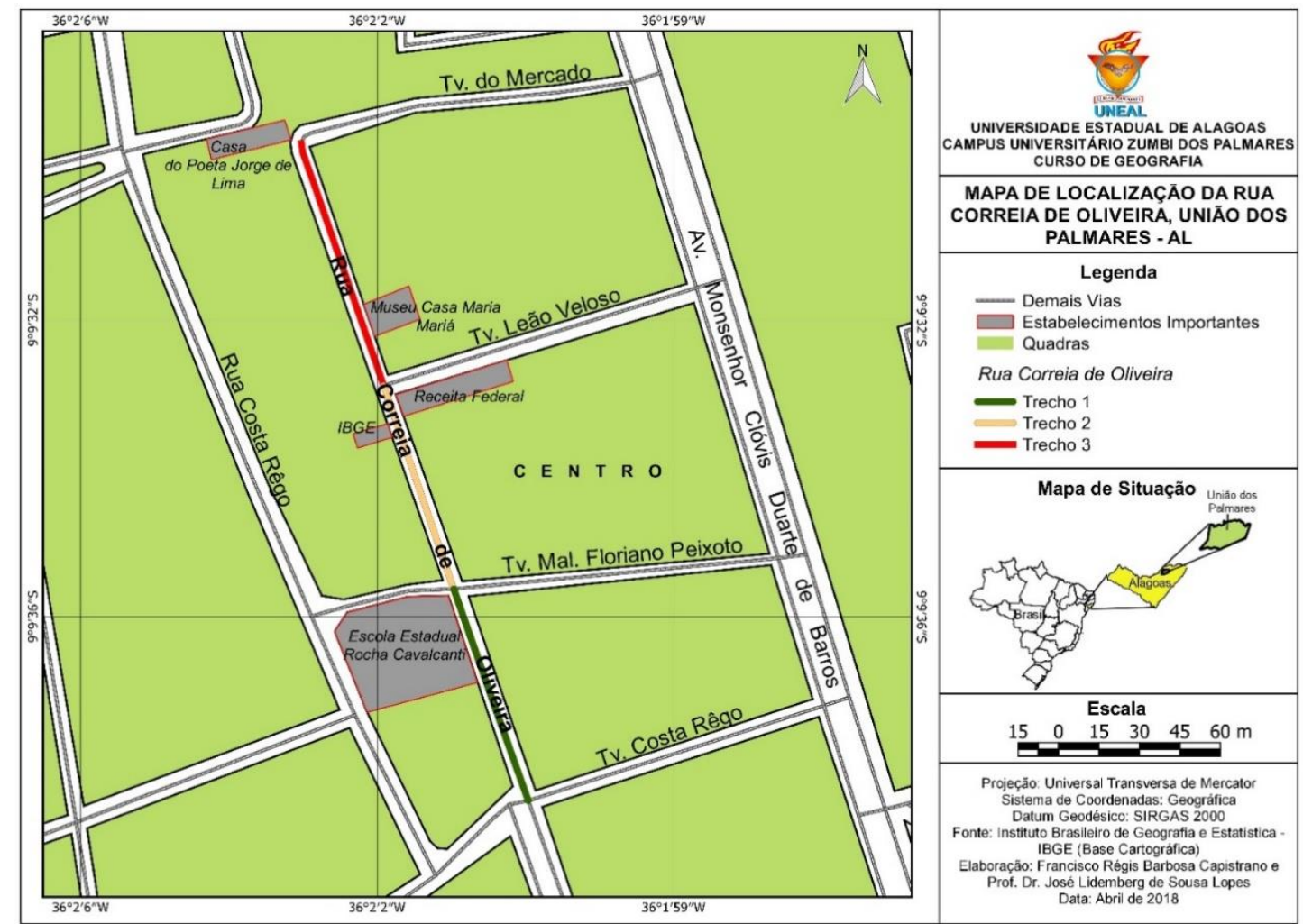

Fonte: Elaborado pelos autores, 2018.

Nesse rua, encontramos os mais variados tipos de prédios históricos e culturais da cidade de União dos Palmares. E é nesse logradouro que as trilhas palmarinas se apresenta com uma maior conotação para os alunos que vão desbravar a história de União dos Palmares. A seguir, segue as figuras dos principais pontos de visitação do projeto.

Figuras 2, $2 a$ e 2b-Mosaico dos pontos de visitações das Trilhas Palmarinas: a. Escola Estadual Rocha Cavalcante; b. Casa-Museu Maria Mariá de Castro Sarmento e c. Casa do Peta Jorge de Lima, União dos Palmares, Alagoas. 


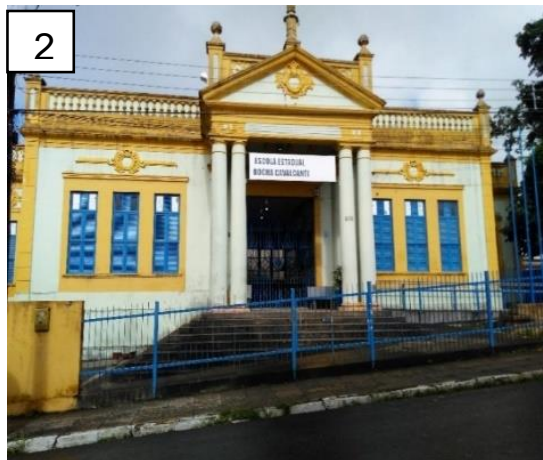

Fonte: arquivo dos autores, 2018.
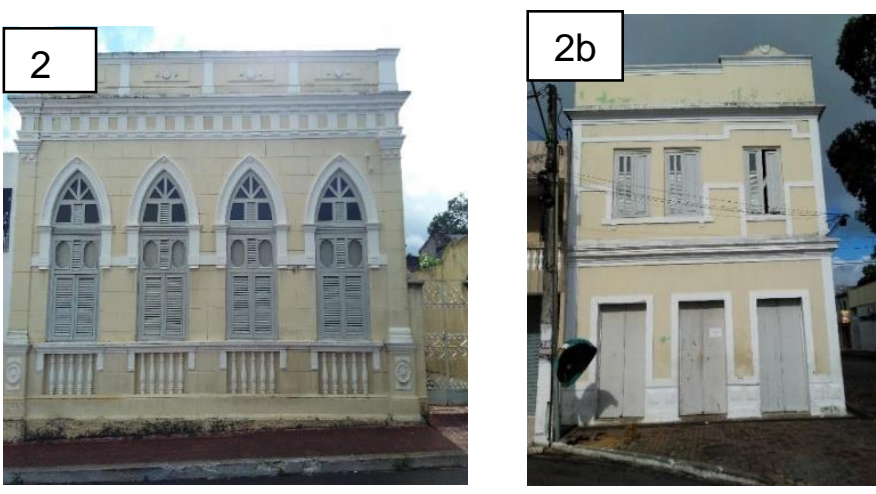

Algumas edificações visitadas possuem estilo da arquitetura predominante eclético, com predomínio de linhas neoclássicas, proveniente dos tempos áureos da comercialização do algodão. Uma arquitetura que apresenta cornijas e platibandas ricamente ornamentadas, não só exercendo a função de esconder os telhados de telhas de barro como também para embelezar ainda mais a edificação, típico da arquitetura do final do século XIX e início do século XX, exemplo claro temo a Escola Estadual Rocha Cavalcanti.

Em outro trecho de visitação da rua, os equipamentos são de utilidades mistas, seja na parte cultural (onde se localiza a Casa-Museu Maria Mariá e a Casa do Poeta Jorge de Lima); seja para fins comerciais (cartórios, lojas, academias).

Entretanto, o que mais chama a atenção dos alunos na visitação são os casarões antigos (figura 3 e $3 a$ ) onde se nota a má preservação das fachadas das casas por parte dos órgãos gestores e dos moradores.

Figuras 3 e 3a-Residências má conservadas na rua Correia de Oliveira, União dos Palmares, Alagoas.
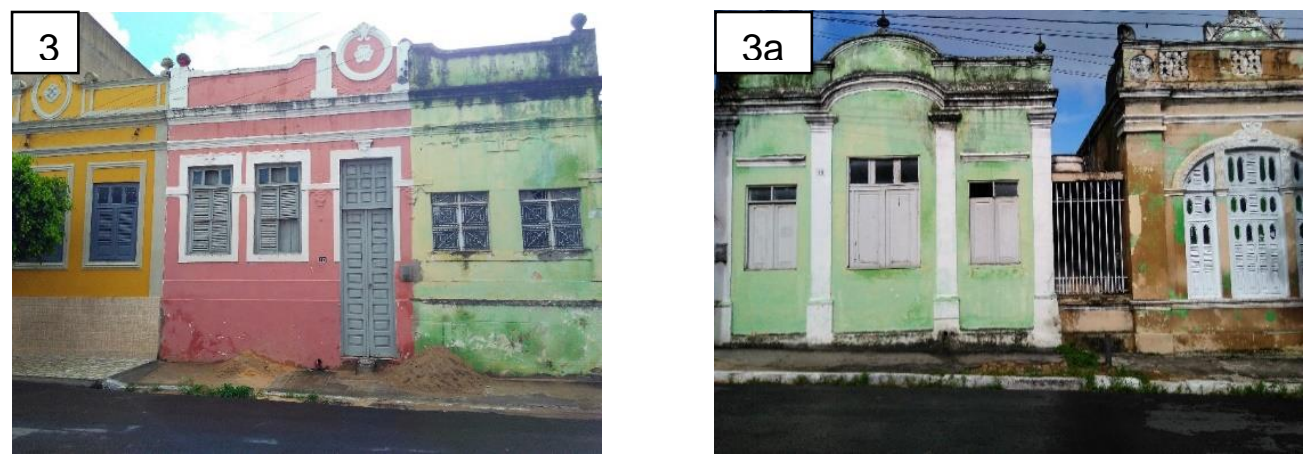

Fonte: arquivo dos autores, 2018.

Nesse sentido, a percepção dos alunos sobre esses prédios dos patrimônios e sua deterioração ao longo do tempo é que mais nos chamou a atenção. Os discentes, já 
com uma noção de memória e conservação desses equipamentos é que veio a noção de propor um corredor cultural nessa rua, juntamente com os moradores, órgãos gestores, universidade. A seguir, segue a metodologia aplicada na pesquisa.

\section{Metodologia}

O projeto Trilhas Palmarinas: metodologias de ensino em espaços socioculturais, históricos e ambientais da cidade de União dos Palmares- Alagoas privilegia a educação pela indagação e o questionamento, proporcionando a ressignificação constante da realidade local através da problematização dos dilemas históricos, ambientais e culturais.

A seleção dos trajetos foi realizado como fundamentação dos conteúdos ministrados no currículo escolar, entretanto a intenção é que sejam trabalhados dentro de uma proposta maleável e dinâmica que permita estabelecer relações entre as disciplinas presentes na estrutura curricular, seus respectivos conteúdos e o cotidiano do município. Desta forma, o conhecimento passa a ser tratado através de uma metodologia pautada na integração, priorizando a prática interdisciplinar pautada na pesquisa, fator que propicia a construção de ferramentas didáticas por meio de atividades permanentes.

É de entendimento que a produção de conhecimentos caracteriza os processos de pesquisa possuindo como fundamento metodologias que, historicamente, se abrigam sob paradigmas da ciência moderna, clássica e tradicional. Assim, como forma de se verificar a potencialidade da área quanto ao traçado e mapeamento das trilhas a metodologia será dividida em etapas: levantamento bibliográfico e atividade de campo para reconhecimento das trilhas priorizando o contexto histórico, cultural e ambiental. Outra etapa foi aplicado um questionário contendo 04 perguntas simples para ver 0 interesse dos alunos no projeto. Os questionários foi aplicado no decorrer do percurso. Inicialmente foi selecionado 04 escolas municipais (duas da área urbana e duas rurais). Os alunos contemplados para a sua passeio foram do $9^{\circ}$ ano de cada escola. As escolas urbanas foram: Escola Municipal Dr. Paulo Sarmento, a escola Pe. Donaldo Macgillivray. As escolas da área rural foram: Escola Pedro Cândido da Silva (escola de assentamento rural) e a escola Pedro Pereira da Silva (escola quilombola). Todas as escolas foram contempladas com 40 vagas. No resultado da pesquisa estão as respostas das escolas contempladas com o projeto. Com a sistematização dos possíveis dados coletados, possibilitou a elaboração de gráficos que auxiliaram no conhecimento disposto nas trilhas. 


\section{Resultados e Discussão}

Como resultado da pesquisa foi traçado roteiros geohistóricos, culturais e ambientais para os alunos de quatro escolas do município de União dos Palmares, Alagoas. A seguir as respostas de 04 perguntas realizadas para a captação do interesse pelos alunos para essa ferramenta didática: 1 ) Você achou importante essa aula?; 2) Qual o grau de satisfação da aula de campo?;3) O que se aprendeu nessa aula, se aprende na disciplina Cultura Palmarina?; e 4 ) Você acha importante a proteção dos prédios antigos da cidade?

Respostas da Escola 1 - Escola Municipal Dr. Paulo de Castro Sarmento

Resposta da pergunta 1

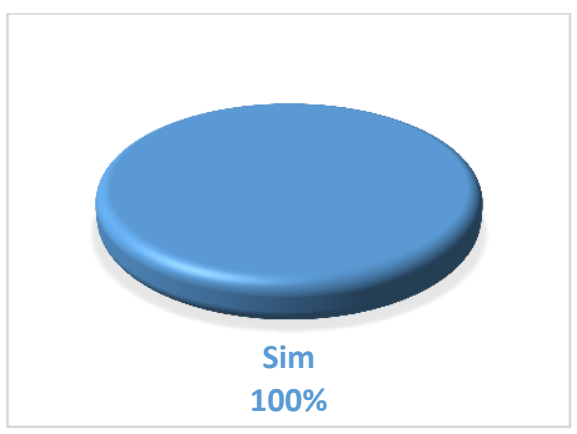

Fonte: elaborado pelos autores, 2018.

Resposta da pergunta 2

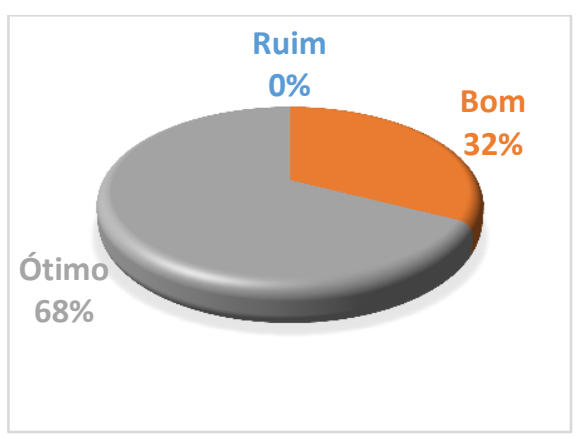

Fonte: elaborado pelos autores, 2018.
Resposta da pergunta 3

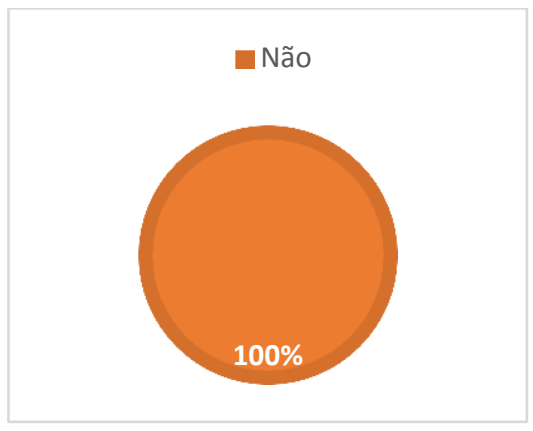

Fonte: elaborado pelos autores, 2018.

Resposta da pergunta 4

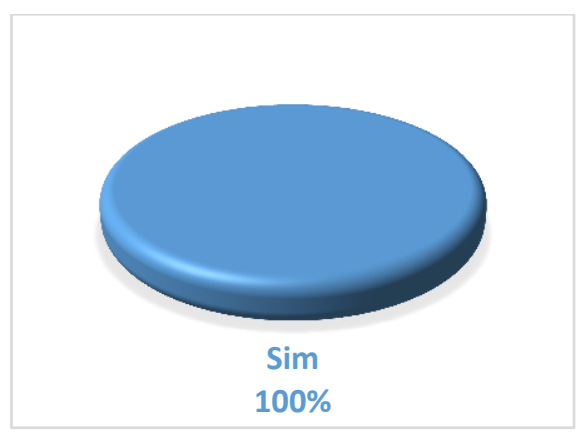

Fonte: elaborado pelos autores, 2018

Conforme as respostas dos discentes da Escola Municipal Dr. Paulo de Castro Sarmento, os gráficos mostram que em relação a importância da aula, 100\% dos alunos foram convictos que a aula é importante para seus conhecimentos; em relação ao grau de satisfação, $68 \%$ dos alunos/as responderam que a aula de campo é ótima; $32 \%$ a aula de campo foi boa e $0 \%$ responderam que é ruim. Quando se fala o que se aprendeu na aula de campo, se aprende na disciplina cultura palmarina, os discentes 
foram unânimes (100\%) resonderaão que não; e a última questão em relação a preservação/conservação dos prédios antigos, 100\% responderam que sim, os patrimônios históricos precisam serem preservados para a memória histórica do município de União dos Palmares, Al.

Respostas da Escola 2 - Escola Municipal Padre Donald Macgillivray

Resposta da pergunta 1

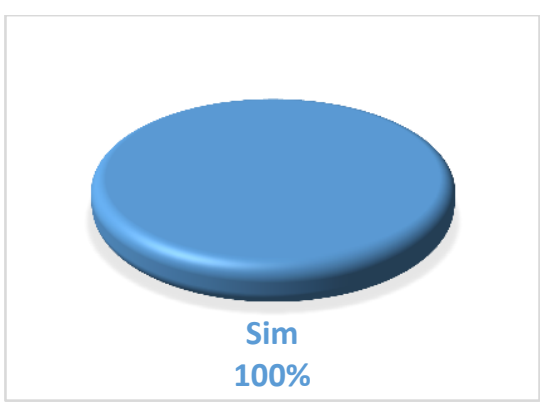

Fonte: elaborado pelos autores, 2018.

Resposta da pergunta 2

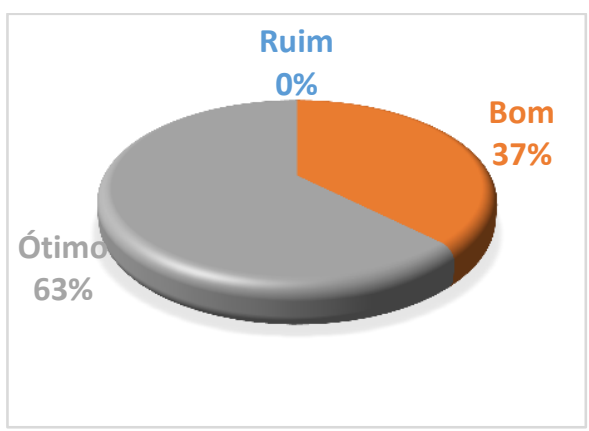

Fonte: elaborado pelos autores, 2018.
Resposta da pergunta 3

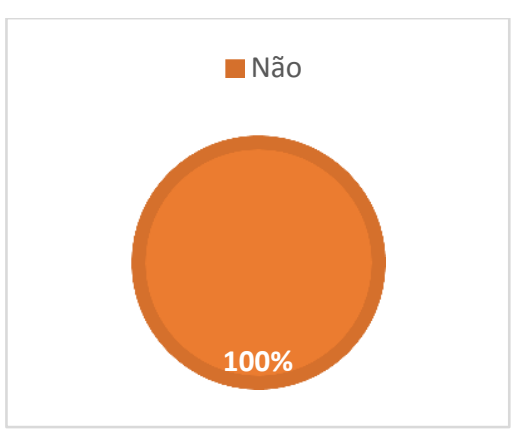

Resposta da pergunta 4

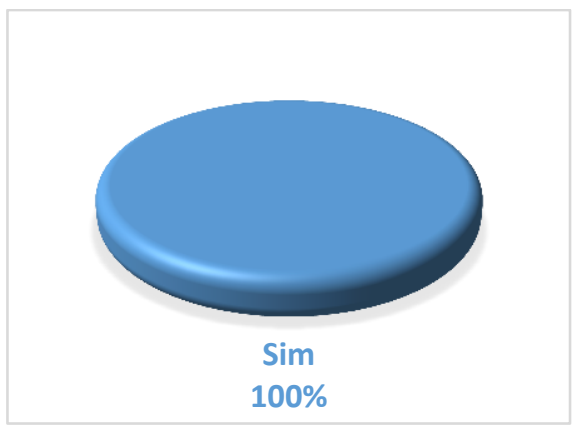

Fonte: elaborado pelos autores, 2018.

Os discentes da Escola Municipal Padre Donald Macgillivray, conforme mostram os gráficos responderam que em relação a importância da aula, 100\% dos alunos responderam que a aula é importante, e que a mesma retiram eles da sala de aula; em relação ao grau de satisfação, $63 \%$ dos alunos/as responderam que a aula de campo é ótima; $37 \%$ a aula de campo foi boa e $0 \%$ responderam que é ruim; em relação a terceira pergunta $100 \%$ responderam que o que eles aprenderam nessa aula/trilha não é o que se aprende na disciplina cultura palmarina; e em relação a questão sobre os prédios antigo, sua preservação/conservação, 100\% responderam que sim, os prédios antigos precisam serem preservados/conservados, pois mostra a história da cidade. 
Resposta da pergunta 1

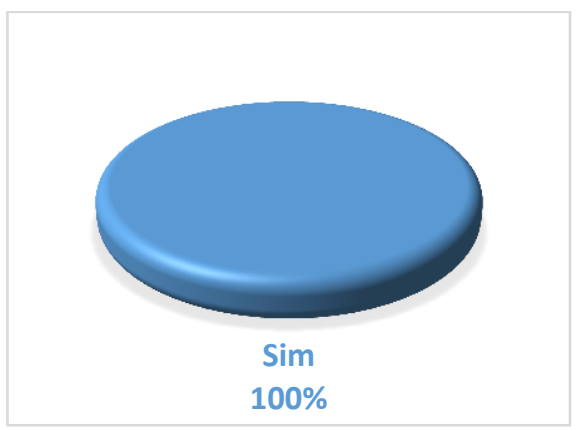

Fonte: elaborado pelos autores, 2018.

Resposta da pergunta 2

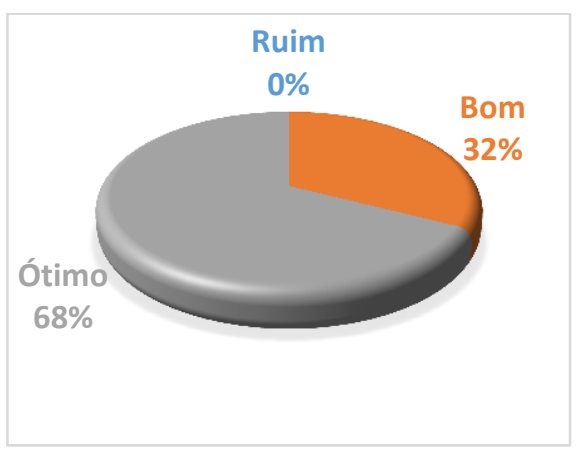

Fonte: elaborado pelos autores, 2018.
Resposta da pergunta 3

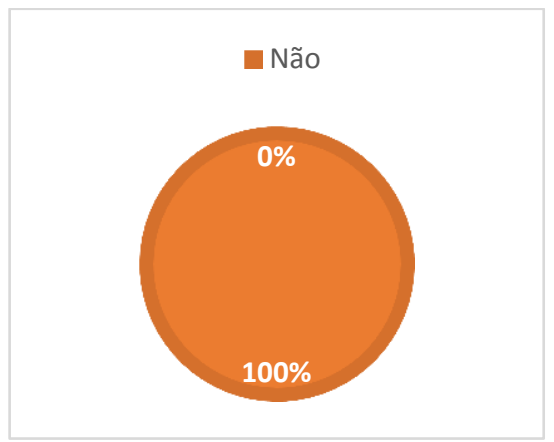

Fonte: elaborado pelos autores, 2018.

Resposta da pergunta 4

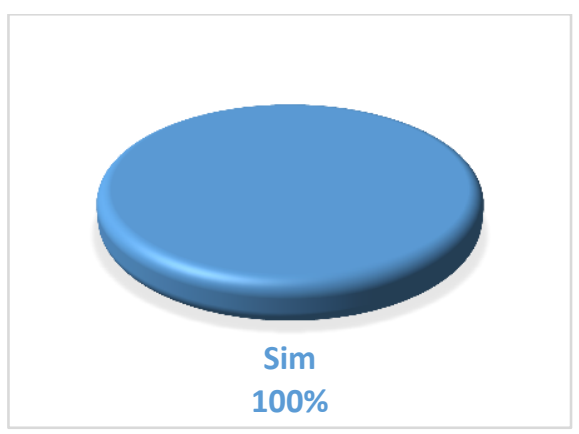

Fonte: elaborado pelos autores, 2018.

Conforme as respostas dos discentes da Escola Municipal Pedro Cândido da Silva, $100 \%$ dos alunos/as responderam que a aula é importante para conhecerem a cidade, pois muitos alunos/as ainda não haviam ido conhecer o centro de União dos Palmeares; conforme o grau de satisfação, 68\% dos alunos/as responderam que a aula de campo a satisfação foi ótima; $37 \%$ a aula de campo foi satisfatoriamente boa e $0 \%$ responderam que é ruim ou insatisfatória; em relação a terceira pergunta 100\% responderam que o que eles aprenderam nessa aula/trilha não é o que se aprende na disciplina cultura palmarina; e em relação a questão sobre os prédios antigo, sua preservação/conservação, 100\% responderam que sim, os prédios antigos precisam serem preservados/conservados pois embelezam a cidade de União dos Palmares. 


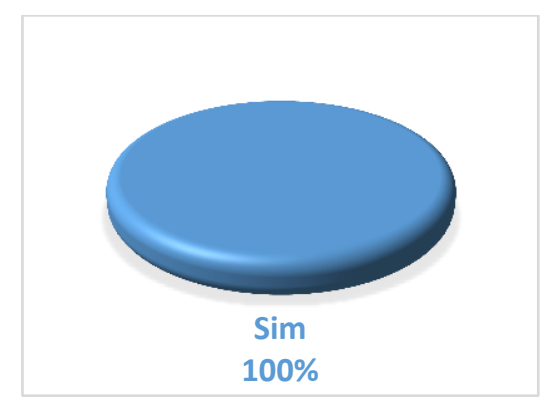

Fonte: elaborado pelos autores, 2018.

Resposta da pergunta 2

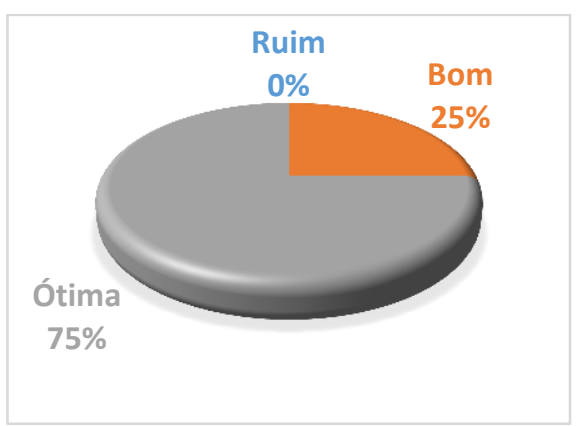

Fonte: elaborado pelos autores, 2018.
Resposta da pergunta 3

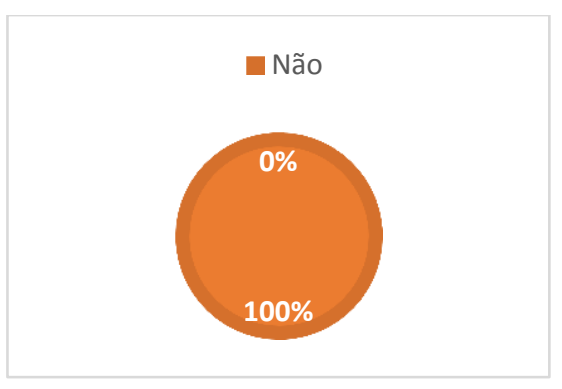

Fonte: elaborado pelos autores, 2018.

Resposta da pergunta 4

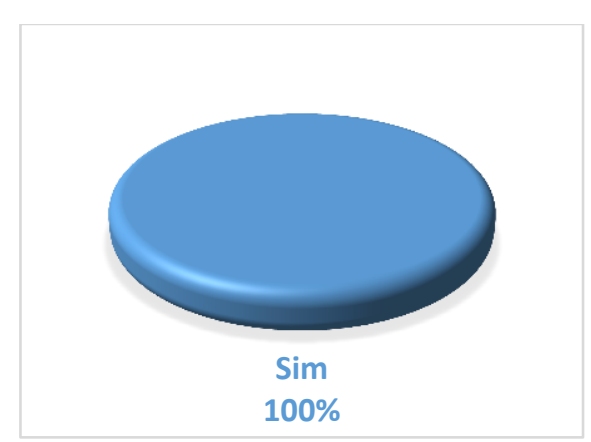

Fonte: elaborado pelos autores, 2018.

Conforme as respostas dos discentes da Escola Municipal Pedro Pereira da Silva, essa escola é de remanescentes quilombolas, dos alunos/as pesquisados no momento da aula, 100\% dos responderam que a aula é importante para conhecerem história da cidade; em relação pergunta seguinte, sobre o grau de satisfação dos alunos em relação a aula/trilha, $75 \%$ dos alunos/as responderam que a aula de campo a satisfação foi ótima; $25 \%$ a aula de campo foi satisfatoriamente boa e $0 \%$ responderam que é ruim ou insatisfatória; em relação a terceira pergunta $100 \%$ responderam que o que eles aprenderam nessa aula/trilha não é o que se aprende na disciplina cultura palmarina; e em relação a questão sobre os prédios antigo, sua preservação/conservação, $100 \%$ responderam que sim, os prédios antigos precisam serem preservados/conservados pois embelezam União dos Palmares, além de mostrar

a

história

da

cidade. 


\section{Conclusão}

Como conclusão podemos entender que a teoria e a prática necessitam convergirem. Nessa perspectiva o projeto trilha palmarinas mostrou a necessidade de quebramos 0 paradigma que prendam os discentes nas salas de aulas. Após analisarmos as respostas proferidas pelos discentes, verificamos que o grau de satisfação dos mesmos foram tremenda, onde os mesmos nas discussões ao final das aulas, indagavam que as trilhas/aulas os professores deveriam implantar essa ideia na disciplina Cultura Palmarina, pois as aulas os deixam cansados e desestimulados. As aulas, só relatam questões do negro, pois estão na terra de Zumbi, isso mostrando que tem mais assuntos para aprenderem sobre a história da cidade.

O estudo do meio é uma ferramenta didática importante e contribuidora para fortalecer o aprendizado dos alunos. Com isso, fica nítido respostas dos questionários que uma dinâmica diferenciada e tirando os discentes daqueles engessamento escolar é a importância desse projeto para as escolas municipais de União dos Palmares, no estado alagoano.

\section{Referências bibliográficas}

Andrade, W. J.; Rocha, L. M. Planejamento, implantação e manutenção de trilhas. In: Congresso Florestal Brasileiro, Campos do Jordão, 1990. Anais. São Paulo, SBS/sbef, 1990. Vol.3. p. 86-93.

Becker, F (1993). A epistemologia do professor: o cotidiano da escola. 8. ed. Petrópolis, RJ: vozes.

Brasil. Lei oํ 13.005, de 25 de junho de 2014. Aprova o Plano Nacional de Educação PNE e da outras providencias. Diário Oficial da Uniao, Brasilia, DF, 26 jun 2014a. Secao 1 (ed. extra), p. 1. Disponível em: .Acesso em: 08 de agosto de 2018.

Figueiredo, P. H (2011) O. O trabalho de campo na geografia escolar como estratégia para a percepção da dimensão socioespacial do real. (Dissertação de mestrado). Centro Universitário UNA. Programa de Mestrado em Gestão Social, Educação e Desenvolvimento Local.

Foucault, M. (1977). Vigiar e punir. Petrópolis, RJ: Vozes.

Oliveira, C. D.M. de; ASSIS, Raimundo Jucier Sousa de (2009). Travessias da aula em campo na Geografia escolar: a necessidade convertida para além da fábula. Educação 
e Pesquisa, São Paulo, v.35, n.1, p. 195-209, jan./abr. Disponível em: < http://www.scielo.br/pdf/ep/v35n1/a13v35n1.pdf >. Acesso 02 Jun. de 2018.

Serpa, Â. (2006). O trabalho de campo em Geografia: Uma abordagem teóricometodológica. In: Boletim Paulista de Geografia. São Paulo: Xamã Editora.

Xavier, H. (2002). A incorporação do turismo do ensino da geografia. In: Pontuschka, Nidia Nacib e Oliveira, Ariovaldo Umbelino de (orgs.) Geografia em Perspectiva (pp. 59-68). São Paulo: Contexto. 


\title{
Nós Propomos! Paraíba e o patrimônio histórico, artístico e cultural do centro do município de João Pessoa, Paraíba, Brasil
}

\author{
JOAZADAQUE LUCENA DE SOUZA ${ }^{1}$ \\ REGINA CELLY NOGUEIRA DA SILVA ${ }^{2}$ \\ RAQUEL SOARES PEREIRA ${ }^{3}$
}

\section{Resumo}

O Projeto Nós Propomos! Paraíba: revitalizando a cidadania através da educação foi implementado no ano de 2018, através de um convênio institucional entre o Centro Estadual Experimental de Ensino-Aprendizagem Sesquicentenário, escola pública da Rede Estadual de Ensino, e a Universidade Estadual da Paraíba. Tem o objetivo de compreender o processo de revitalização do centro histórico de João Pessoa e o conceito de patrimônio, que pode ser classificado como material ou imaterial devidamente identificado, preservado, tombado e fiscalizado por órgãos ligados a união, estados e municípios por meio de legislações específicas. As leituras, pesquisas, coleta de dados e discussões desenvolvidas nos encontros do projeto identificaram o processo de sucateamento e degradação do espaço urbano, posteriormente ocorreram trabalhos de campo na área central da cidade e uma visita técnica ao Instituto do Patrimônio Histórico e Artísitico Nacional (IPHAN) com o intuito de compreender a identificação, tombamento, preservação e revitalização do patrimônio arquitetônico, artísitico e cultural, os impactos nas populações residentes por meio de uma exposição e um amplo dabate conduzido por pesquisadores do Ministério da Cultura. As impressões dos discentes foram compiladas em relatórios

\footnotetext{
${ }^{1}$ Professor do Centro Estadual Experimental de Ensino-Aprendizagem Sesquicentenário, Rede Estadual de Ensino da Paraíba - joazadaque@hotmail.com

${ }_{2}$ Professora da Universidade Estadual da Paraíba - recelly51@hotmail.com

3 Estudante do $3^{\circ}$ Ano do Ensino Médio do Centro Estadual Experimental de Ensino-Aprendizagem Sesquicentenário, Rede Estadual de Ensino da Paraíba - rachelsoarespereira@gmail.com
} 
contendo o diagnóstico dos problemas socioambientais e as propostas dos estudantes para a resolução de tais problemáticas. O desenvolvimento de uma consciência cidadã fomentadas pelo Nós Propomos! Paraíba vem contribuíndo de forma substancial com o incentivo à autonomia intelectual e a iniciação científica dos estudantes do ensino médio, cumprindo a função primeira da educação.

Palavras-chave: Nós Propomos!; Educação; Patrimônio; Centro Histórico; João Pessoa

\section{Abstract}

The project "Nós Propomos!" Paraiba: revitalizing citizenship through education was implemented in the year 2018, through an institutional agreement between experimental state teaching-learning center Sesquicentenário, public school of the state education network, and the state university of Paraiba. It's the objective of understanding the revitalization process of the historical center of João Pessoa, Paraíba, Brazil and the concept of patrimony that can be classified as material or intangible, duly identified, preserved, "tombados", and supervised by bodies linked to the union, states and municipalities through specific legislation. The readings, surveys, data collection and discussions developed in the project meetings identified the process of scrapping and degradation of the urban space. Later field works in the central area of the city and a technical visit to the Institute of National Historical and Artistic Heritage (IPHAN) with the aim of understanding the identification, preservation and revitalization of the architectural, artistic and cultural heritage, the impacts on the resident populations through an extensive exposure and debate conducted by researchers at the ministry of culture. Student's impressions were compiled in reports containing the diagnosis of socio-environmental problems and the students' proposals for solving such problems. The development of a citizen conscience fostered by the "Nós Propomos!" has contributed substantially to the incentive to intellectual autonomy and the scientific initiation of middle school students, fulfilling the primary function of education.

Keywords: “Nós Propomos!”; Education; Patrimony; Historical Center; João Pessoa

\section{Introdução}

A iniciativa Nós Propomos! Paraíba: revitalizando a cidadania através da educação é um projeto de extensão da Universidade Estadual da Paraíba (UEPB) com 
coordenação geral da Universidade de Lisboa, Portugal. É desenvolvido no Centro Estadual Experimental de Ensino-Aprendizagem Sesquicentenário desde março de 2018 em parceria com o Programa Ensino Médio Inovador (PROEMI), Programa do Governo Federal, através do Campo de Integração Curricular voltado a Iniciação Científica e Pesquisa. Os encontros são realizados semanalmente nas quintas-feiras no turno da tarde, horário oposto às aulas regulares, com a participação da Professora da Universidade Estadual da Paraíba Regina Celly Nogueira da Silva; dos Professores do Sesquicentenário Joazadaque Lucena de Souza e Lara Torezzan Gonçalves Ramalho Nitão e uma média de 25 estudantes do $1^{\circ}$. 2ำ e $3^{\circ}$ anos do Ensino Médio. $O$ projeto conta com uma rede de parceiros como o Departamento de História da Universidade Federal da Paraíba (UFPB), na figura da Professora Regina Célia Gonçalves e o Projeto Memória João Pessoa um projeto de extensão do Departamento de Arquitetura e Urbanismo da UFPB, representado pela professora Maria Berthilde de Barros Lima e Moura Filha.

Tem como objetivo principal estudar o processo de revitalização do centro histórico de João Pessoa, capital do estado da Paraíba a partir da leitura de material bibliográfico, coleta de dados e realização de visitas de estudos e trabalhos de campo, com o intuito de fomentar práticas educativas exitosas entre docentes e discentes, intercâmbio entre escola e universidade; difusão de práticas cidadãs a partir da identificação de problemas socioambientais existentes no espaço urbano e a respectiva formulação de propostas para as resoluções dos mesmos. Se propõe a fomentar a consciência cidadã e incentivar uma efetiva cultura de cidadania territorial entre os jovens estudantes, estimulando à participação popular democrática com a finalidade de se garantir o direito à cidade e uma gestão democrática do espaço urbano. As práticas educativas desenvolvidas consistem no levantamento de material bibliográfico e iconográfico sobre as temáticas escolhidas; leitura de livros, artigos científicos e matérias jornalísticas; realização de trabalhos de campo e visita de estudos às localidades e instituições; elaboração de relatórios, comunicações para congressos, capítulos de livro e artigos científicos a serem publicados em periódicos nacionais e internacionais.

O centro histórico de João Pessoa remonta 433 anos de história, sendo a área de ocupação mais antiga da cidade. Dispõe de um patrimônio histórico bastante pujante, com cerca de 700 edificações no estilo barroco no caso das igrejas, e Art Decó, que está na maior parte dos casarões dispostos em uma área de 117 hectares e registrada na arquitetura de ruas, praças e edificações que resistem ao tempo e remetem ao passado da criação da cidade. Em contrapartida, vem passando por um processo de 
sucateamento de suas funções urbanas, degradação do patrimônio arquitetônico edificado e a falta de valorização aos aspectos artísticos e culturais, que por conseguinte são peças de extrema relevância à consolidação da memória, identidade e sentimento de pertencimento à toda herança cultural acumulada durante séculos no imaginário coletivo e relações sociais da população. No Brasil as legislações que norteam o patrimônio histórico, artísitico e cultural são os Decretos-leis n²5/1937 e no 3.551/2000; Lei: 3.924/1961 e artigo 216 da Constituição Federal de 1988 e o órgão responsável por identificar, preservar, tombar e fiscalizar as questões relativas ao patrimônio é o Instituto do Patrimônio Histórico e Artísitico Nacional (IPHAN).

As problemáticas envolvidas na produção e reprodução das relações socioespaciais existentes na região central da capital paraibana são inúmeras e possuem um elevado nível de complexidade, envolvendo questões sensíveis ao diálogo e mobilização popular como a deterioração do patrimônio público, falta de incentivo à cultura popular, equívocos nas políticas de incentivo ao turismo, escalada do processo de gentrificação e expulsão das comunidades residentes no local, aumento da violência e precarização das relações de trabalho, intervenções antrópicas no meio ambiente e modificação dos processos naturais entre outros temas de igual relevância, que não são objeto de estudo nesse momento da pesquisa, mas que serão objeto de estudo nas próximas etapas do projeto.

\section{Aspectos teóricos}

Estudos de Scocuglia (2004) apontam que foi na França que surgiu a noção de interesse público de proteção legal de determinados bens e símbolos da nação e o conceito de patrimônio histórico e artístico nacional. Nesse sentido Millet (1988) afirma que a efetivação da preservação dos bens culturais só se encontra socialmente definida a partir do momento em que o Estado assume sua proteção e, através da ordenação jurídica, os instrui e delimita oficialmente enquanto bem cultural, regulamentando o seu uso, a finalidade e o caráter desses bens dentro de leis específicas de propriedade e zoneamento, uso e ocupação do solo. Embora as categorias envolvendo valores históricos e artísticos terem sido formuladas desde o Renascimento, foi somente a partir da formação do Estado Nacional que os monumentos ganharam um estatuto ideológico e foram asseguradas práticas específicas de preservação. E portanto foi a partir da noção moderna de monumento histórico e artístico que se constituiu a noção de patrimônio como categoria 
socialmente definida, regulamentada e delimitada, e com o sentido de herança coletiva especificamente cultural.

Para Scocuglia (2004) o modelo francês, de caráter estatal e centralizador foi exportado para o Brasil e outros países da América Latina em meados do século XX, ampliando a noção de patrimônio que se sobrepõe a ideia de bem patrimonial e elevando as práticas de preservação muito além da ideia da guarda de bens excepciconais para serem objetos de contemplação e fonte de conhecimento, considerada hoje uma postura museológica, anacrônica, elitista, tanto em termos mercadológicos quanto em termos políticos. De acordo com Scocuglia (2004) a criação de órgãos internacionais voltados para a cultura no pós II Guerra Mundial e incorporação dos direitos culturais pela Organização das Nacões Unidas (ONU) e da figura de Patrimônio Cultural da Humanidade pela Organização das Nações Unidas para a Educação, a Ciência e a Cultura (UNESCO), vem implícita uma noção de cidadania cada vez mais fundada em direitos diversificados e a partir de então, vem legitimar as atividades de revitalização urbana que advoga em favor de modificações arquitetônicas no espaço urbano em favor de atividades turísticas e econômicas em detrimento de uma série de territorialidades decorrentes ocupações humanas que ali habitavam no espaço urbano num momento anterior e, que frequentemente são relocadas para outros espaços, gerando segregação socioespacial.

Escritos de Cury (2000) evidenciam que a noção de monumento histórico compreende a criação arquitetônica isolada, bem como o sítio urbano que dá testemunho a uma civilização particular, de uma evolução significativa ou de um acontecimento histórico, compreendendo não só as grande criações, mas também às obras modestas, que tenham adiquirido, com o tempo, uma significação cultural. Deste modo Choay (1992) exalta que o turismo cultural é a origem da expansão mais significativa do público das áreas históricas: dos pequenos grupos iniciais de conhecedores eruditos, até a formação de uma rede mundial, uma audiência que chega a milhões de habitantes. Iniciam-se as experiências de revitalização do patrimônio cultural urbano contemporêneas, inserindo-o na lógica econômica do mercado. Hoje, os museus consagram a cultura frente aos monumentos históricos. A Cultura perde seu caráter de realização pessoal, para se tornar empresa. Os bens culturais adiquirem um novo status: são colocados a disponsição de todos como produto cultural, fabricado, embalado e difundido com vistas ao consumo. A metamorfose de seu valor de uso em valor econômico é realizada com o objetivo de explorar os monumentos e uma ambiência por todos os meios, multiplicando seus visitantes. 
Silva (2016) aponta que em meados na década de 1980 se intensificaram as políticas de revitalziação/requalificação da área central de João Pessoa, fazendo com que a área passasse a ser objeto de ações urbanísticas por meio do Convênio Brasil/Espanha, através o Projeto de Revitalização do Centro Histórico de João Pessoa, que visava a retomada do desenvolvimento econômico da área e o resgaste da sua importância histórica a partir do ano de 1987. As intervenções urbanísiticas nos centros históricos das cidades brasileiras, por meio de processos de revitalização/requalificação, apontam a complexa relação entre os sujeitos: Estado, capital privado; consultores internacionais, empreendedores culturais, comerciantes e moradores, de tal forma que expressam as diversas formas de apropriação do espaço urbano e os tipos de disputa por esse espaço. Nesse sentido Carlos (2004) discorre que a normatização do espaço se materializa a partir da construção de planos diretores, que se direciona e hierarquiza o investimento na cidade. Mas também existem os interesses privados dos diversos setores econômicos da sociedade que veêm no espaço, a condição de realização da reprodução econômica, fazendo com que os lugares apareçam enquanto lugares da infraestrutura necessária ao desenvolvimento de cada atividade de modo a permitir uma equação favorável à realização do lucro e em todos esses momentos da reprodução do capital, a interferência do Estado é fundamental e sua ação desencadeia, como aspirações, um proceso de revalorização/desvalorização dos lugares da metrópole produzindo o fenômeno da implosão-explosão.

Existe no Brasil uma preocupação para a preservação dos bens históricos, percebidos através das políticas culturais existentes que incentivam a proteção e restauração de tais bens. Santos et. al. (2011) relatam que no ano de 1935 foi criado o Serviço do Patrimônio Histórico e Artístico Nacional (SPHAN), atual Instituto do Patrimônio Histórico e Artístico Nacional (IPAHN), com a finalidade de promover o tombamento, preservar, identificar, fiscalizar, revitalizar, restaurar o conhecimento do patrimônio nacional e divulgar os bens culturais do Brasil. A partir da implementação dessas políticas públicas o patrimônio pode ser classificado como material no caso de edificações, documentos, objetos, escossistemas e paisagens; e imaterial no caso de celebrações, costumes, crenças e manifestações artísticas, e ambos devem vir a ser devidamente identificados, preservados, tombados e fiscalizados pelo IPHAN na esfera federal e órgãos correlatos a nível estadual e, em alguns casos, municipal, sendo regido por um conjunto de legislações, dentre as quais destacam-se o DecretoLei $n^{\circ}$. 25/1937, que organiza a proteção do patrimônio histórico e artístico nacional (Brasil, 1937); a Lei $n^{\circ}$. 3.924/1961, que dispõe sôbre os monumentos arqueológicos e 
pré-históricos (Brasil, 1961) e o Decreto-Lei $n^{\circ}$. 3.551/2000, que institui o registro de bens culturais de natureza imaterial que constituem patrimônio cultural brasileiro, cria o programa nacional de patrimônio imaterial e dá outras providências (Brasil, 2000). Está previsto no artigo 216 da Constituição Federal de 1988 (Brasil, 1988) que o patrimônio cultural brasileiro e todos os bens de natureza material e imaterial, sendo estes tomados individualmente ou em conjunto, portadores de referência, identidade, ação, memória dos diferentes grupos formadores da sociedade brasileira, nos quais se incluem as diversas formas de impressões, o procedimento de criar, fazer e viver, as produções artísitcas, científicas e tecnológicas e ainda reconhece os espaços destinados as manifestações culturais e os conjuntos urbanos e sítios arqueológicos, ecológicos e paisagísiticos.

O Decreto Estadual no 5.255, em 1971 (BRASIL, 1971), cria o Instituto do Patrimônio Histórico e Artístico da Paraíba (IPHAEP) com o estimulo do Governo Federal aos estados e municípios no sentido de criar legislações para a proteção de monumentos de interesse regional e local. O IPHAEP tem como finalidade preservar os bens culturais, artísticos e históricos do estado que não se encontravam sob proteção e guarda do IPHAN. Levantamentos da PMJP (2017) dão conta que o núcleo do centro histórico do município de João Pessoa tombado pelo IPHAEP, possui CERCA DE 700 edificações, além de ruas, praças e parques históricos dispostos em uma área de 117 hectares, com destaque para o Hotel Globo (figura 1); Igreja de São Francisco (figura 2); Casa da Pólvora (figura 3) e a praça Antenor Navarro (figura 4).

Figura 1 - Hotel Globo

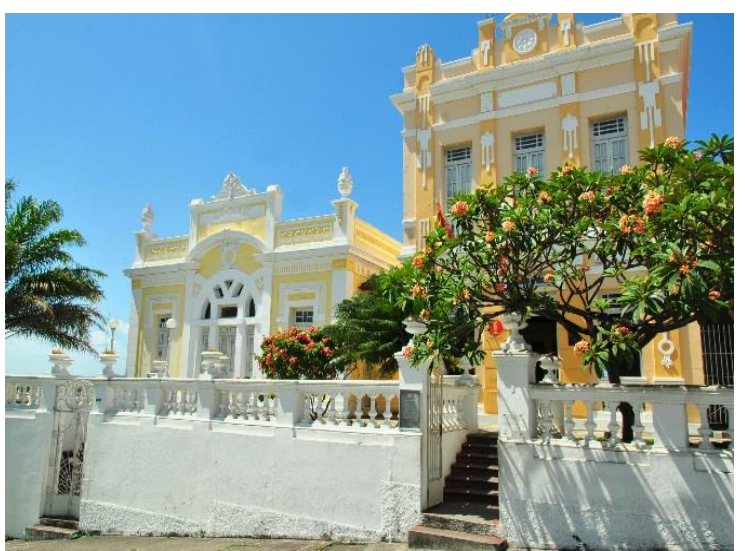

Fonte: http://www.conexaoboasnoticias.com.br/
Figura 2 - Igreja de São Franscisco

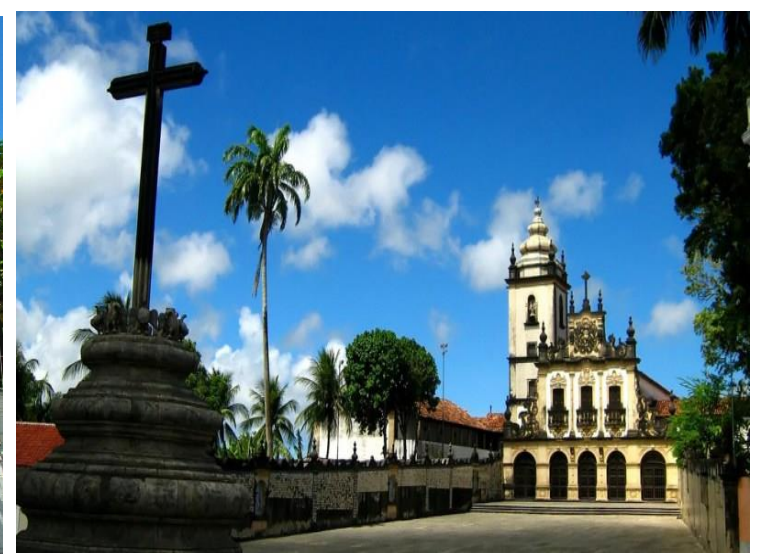

Fonte: http://www.joaopessoa.pb.gov.br/ 
Figura 3 - Navarro Casa da Pólvora

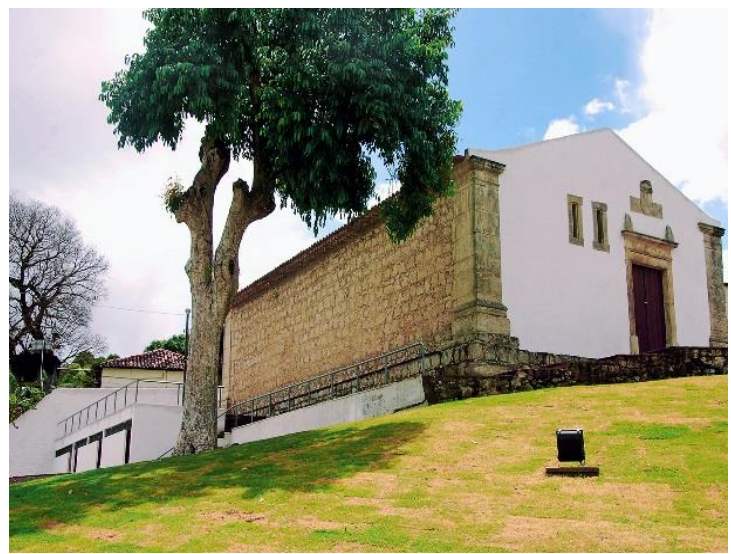

Fonte: https://turismo.joaopessoa.pb.gov.br/
Figura 4 - Praça Antenor

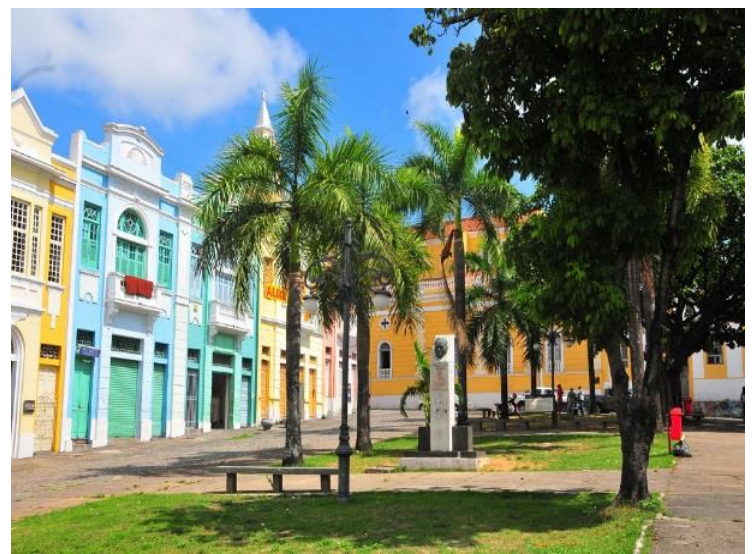

Fonte: https://portalcorreio.com.br/

De acordo com Santos et. al. (2011) o patrimônio histórico e artístico assume um papel importante na sociedade por representar bens de herança cultural guardam a essência da história e o entendimento do modo de vida dos nossos antepassados, nos fornecendo memória da constução de nossa cultura, constituindo elementos de afirmação da dentidade e sentimento de pertencimento por uma lado, e é utilizado economicamente para impulsionar o turismo, desenvolver a economia, produzir lucro e gerar emprego e renda por outro. Contudo, a atual situação estrutural das edificações históricas município do centro histórico de João Pessoa encontram-se em um acelerado processo de descaracterização (figura 5), ocasionando uma perda cultural bastante significativa.

Figura 5 - Ddegradação do patrimônio histôrico do centro histórico de João Pessoa

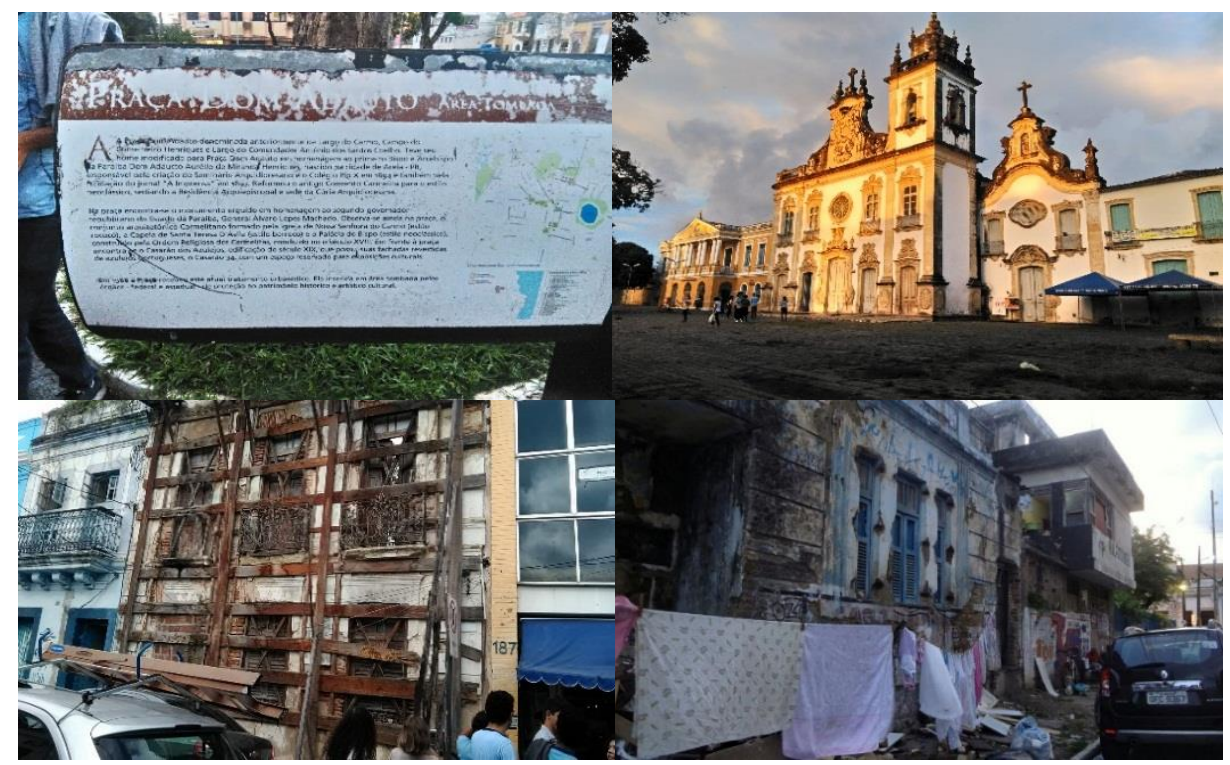

Fonte: Elaboração própria 


\section{Descrição das atividades}

As atividades pedagógicas e cidadãs desenvolvidas pelo projeto Nós Propomos! Paraíba: revitalizando a cidadania através da educação durante o ano de 2018 buscaram atingir os seguintes objetivos:

- Ampliar o diálogo entre estudantes e professores da educação básica e ensino superior, estabelecendo parcerias entre a escola, universidade, poder público, entidades civis e a comunidades;

- Identificar os principais problemas socioambientais existentes no centro histórico de João Pessoa e produzir estudos sobre as temáticas mais relevantes;

- Realizar trabalhos de campo e visitas de estudo com o intuito de fazer registros fotográficos, aplicar questionários e/ou entrevistas com população e aos principais atores locais;

- Estabelecer contato entre os técnicos e representantes de órgãos ligados ao poder público municipal, estadual e federal com o intuito de aprofundar 0 conhecimento sobre a política pública de planejamento urbano;

- Elaborar propostas com as resoluções dos problemas urbanos, contemplando as opiniões da população, as justificativas dadas pelo poder público e as considerações tecidas pela universidade e socializá-las em seminários e instâncias comunitárias.

- Construção de relatórios com o balanço das atividades realizadas, as dificuldades encontradas e a projeção de atividades futuras;

- Produção de artigos científicos e comunicações endereçados a periódicos, congressos e participação no Congresso Ibero-Americano Nós Propomos! Geografia, Cidadania e Educação em Lisboa, Portugal no mês de setembro de 2018.

As problemáticas identificadas pelos discentes do ensino médio tornaram-se eixos de pesquisa e tiveram um foco na falta de conservação e sucateamento das estruturas e equipamentos urbanos que compõem a região central de João pessoa, as questões sociais decorrentes desse processo e o que pode ser feito para melhorar a atual situação. Nesse sentido foram estabelecidos seis grupos de trabalho temáticos com direcionamento específicos em suas linhas de pesquisa.

Eixo 01. O Patrimônio histórico artístico e cultural de João Pessoa; 
Eixo 02. O Processo de revitalização do centro histórico de João Pessoa;

Eixo 03. Processo de revitalização e histórico de lutas da comunidade do Porto do Capim;

Eixo 04. Manifestações culturais da comunidade Porto do Capim;

Eixo 05. Práticas educativas e fortalecimento da cidadania no Sesquicentenário;

Eixo 06. Memória e Identidade: um olhar digital sobre a cultura regional.

No primeiro momento ocorreram leituras de material bibliográfico, pesquisa e levantamento de dados, realização de debates e rodas de discussão (figura 6) que renderam muitas reflexões sobre a preservação do patrimônio material e imaterial do município de João pessoa durante os encontros do projeto. Num segundo momento foi agendado um visita de estudos ao IPHAN e dois trabalhos de campo nos meses de abril e julho, respectivamente.

Figura 6 - Encontros semanais do Nós Propomos! Paraíba

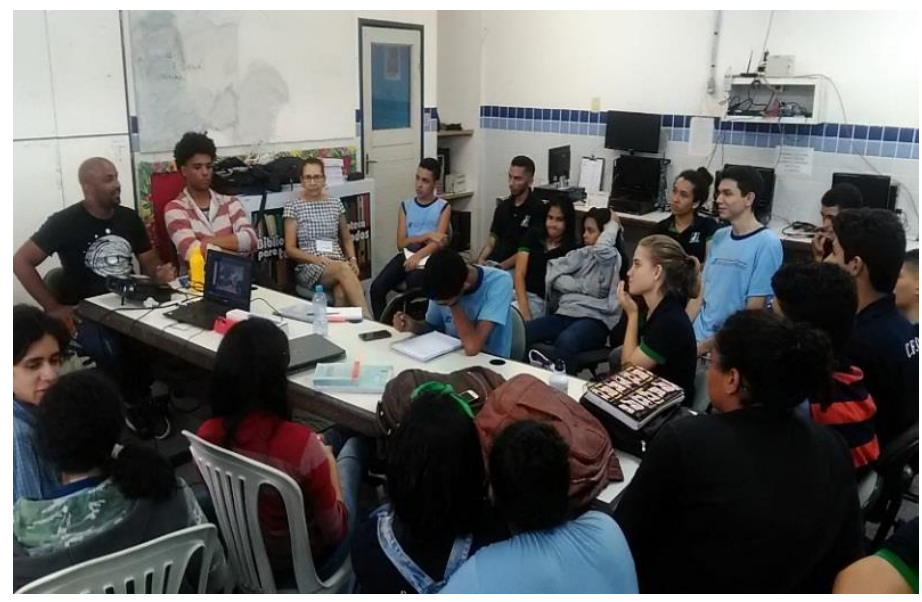

Fonte: Elaboração própria

Figura 7 - Exposição das funções do IPHAN

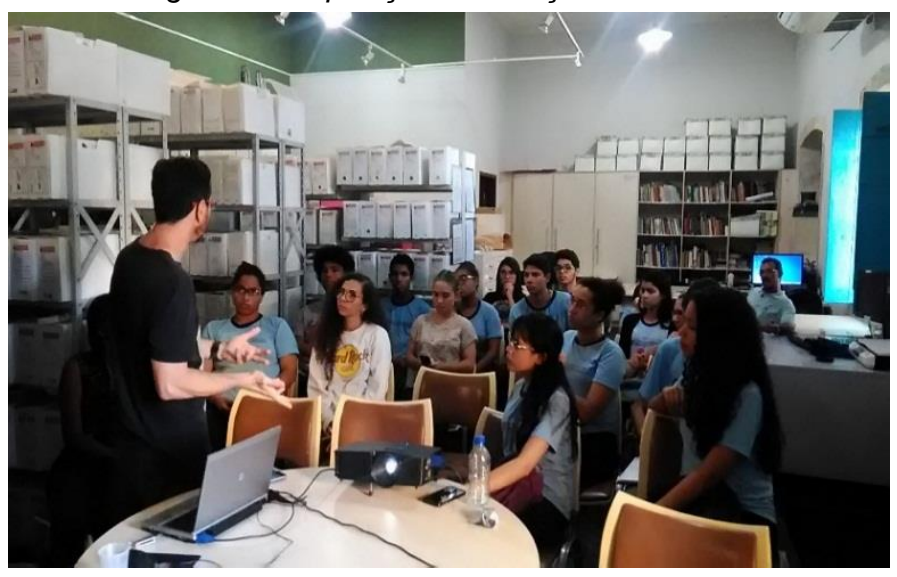

Fonte: Elaboração própria 
Durante a visita técnica à Casa do Patrimônio do IPHAN, ocorrida em 12/04/2018 foi possível compreender o funcionamento da dinâmica de identificação, tombamento, preservação e propostas de revitalização do patrimônio histórico, arquitetônico, artísitico e cultural; os marcos legais envolvidos no processo, as modificações na configuração do sitio urbano e os impactos nas populações residentes no centro da cidade. Após a realização de uma exposição sobre o patrimônio material e imaterial da Paraíba (figura 7) realizada por Átila Tolentino, pesquisador do Ministério da Cultura, ocorreu um amplo debate acerca da função que o órgão desempenha na conservação da história, cultura e memória de João Pessoa e a formulação de diversas questões pelos estudantes.

Durante os rabalhos de campo pelas ruas e demais logradouros do centro histórico de João Pessoa foi possível verificar in loco os seguintes aspectos:

- O estado de conservação/degradação do patrimônio histórico e a infraestrutura das construções, ruas, praças, parques e demais logradouros públicos;

- Circulação de pessoas, a condição do trânsito, transporte público e a mobilidade urbana;

- $\quad$ O quadro do comércio informal e a situação bastante vulnerável econômicasocialmente dos trabalhadores informais da região central de João Pessoa;

- $\quad$ Os pontos positivos e negativos da reforma do parque Solón de Lucena;

- A degradação da natureza, a artificialização dos espaços e os impactos ambientais decorrentes da ação antrópica.

A partir de então cada grupo de trabalho ficou responsável por registrar as informações e dados relevantes, adquiridos durante a visita técnica do IPHAN e fazer um relatório dos problemas identificados na pesquisa de campo e elaborar propostas de resolução dos mesmos sobre os seguintes aspectos:

1. Relativa ao patrimônio histórico, voltada para a conservação e melhoria da infraestrutura, a degradação de praças, parques, monumentos históricos e demais equipamentos urbanos; quais as funções do patrimônio histórico; o andamento e eficácia das reformas e o nível do processo de revitalização e a importância histórica e/ou turística da região para a cidade;

2. Acerca da expressão cultural desenvolvida no centro histórico (música, dança, pintura, artesanato etc.); se os espaços utilizados são adequados a prática artística; 
como o IPHAN fomenta a cultura da região; as funções dos órgãos públicos das diferentes esferas de governo nesse processo;

3. Sobre a valorização da cultura popular e dos artistas locais.

Em seguida ocorreu um trabalho de campo pelas ruas do centro da capital paraibana (figura 8), ainda no dia 12/04/2018 sob a coordenação da Professora Regina Celly Nogueira da Silva da UEPB unindo o conhecimento teórico da estrutura e funcionamento do processo de preservação do patrimônio com a vivência prática de identificação do processo de degradação e as iniciativas de revitalização. Foram realizadas observações, anotações, registros fotográficos que estimularam as reflexão dos discentes sobre a real dimensão dos problemas previamente analisados de forma teórica.

Figura 8 - Trabalho de campo - Centro histórico de João Pessoa

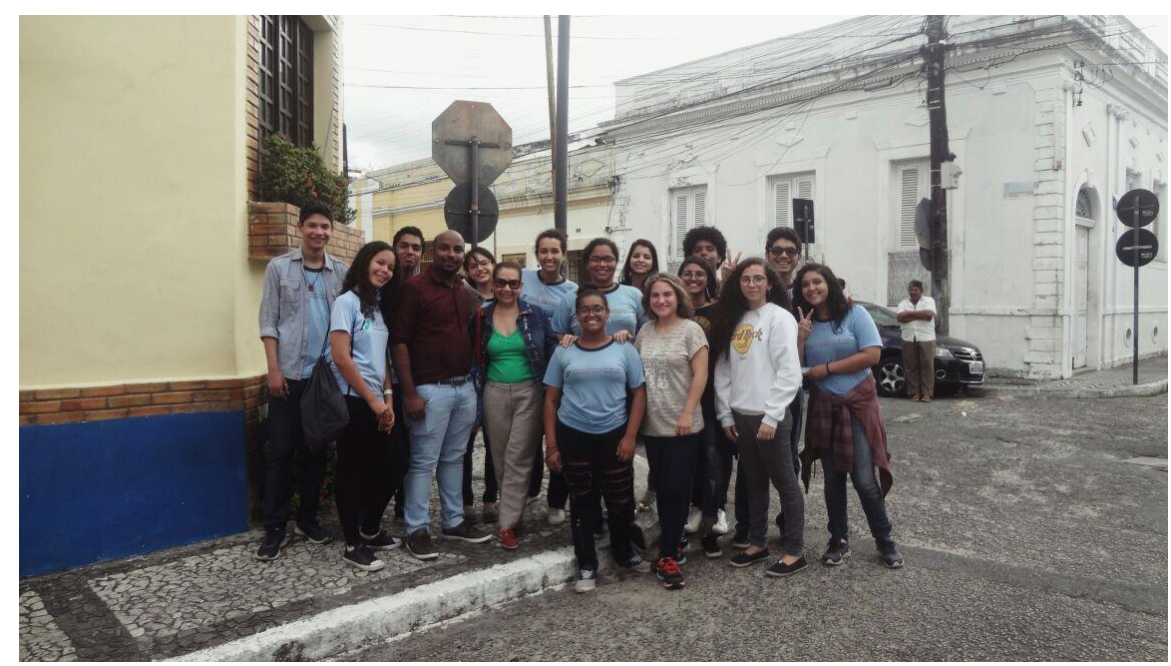

Fonte: Elaboração Própria

No dia 26/07/2018 foi realizado uma aula de campo (figura 9) ministrada pela Professora Regina Célia Gonçalves da UFPB que teve como objetivo a compreensão do processo de construção e evolução da urbanização do centro histórico de João Pessoa através da visualização das memórias históricas representadas por edificações, monuumentos, ruas, largos, praças e logradouros da parte alta da cidade. 
Figura 9 - Trabalho de Campo Cidade centro histórico de João Pessoa

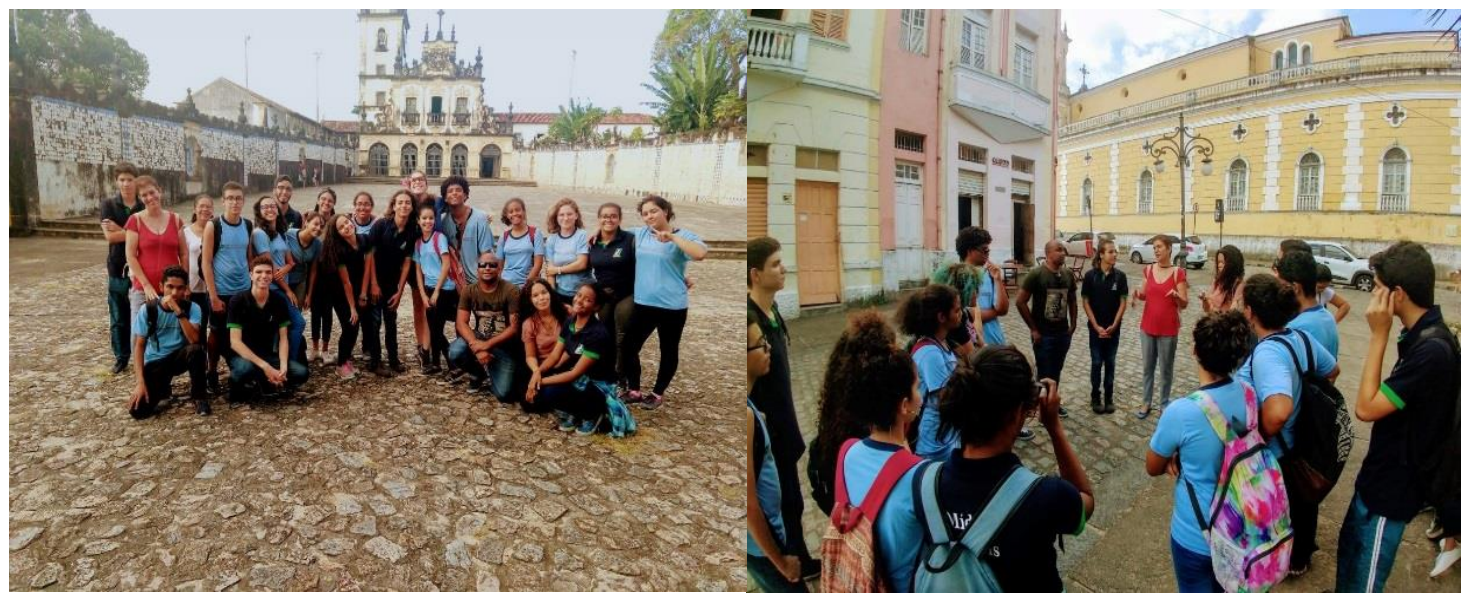

Fonte: Elaboração Própria

\section{Resultados}

Os resultados das impressões dos discentes após as atividades listadas anteriormente foram descritas em relatórios produzidos em conjuntos pelos grupos de trabalho que compõem o projeto e do compilado desses documentos foram identificados os seguintes problemas urbanos:

\subsection{Impressões dos estudantes}

1. Degradação dos monumentos, igrejas e imóveis com valor histórico pertencentes ao estado, ausência de calçamento e asfalto adequado nas ruas praças, parques e demais logradouros dificultando a acessibilidade de idosos e pessoas com mobilidade reduzida.

2. Abandono e degradação de imóveis particulares tombados pelo IPHAN devido a negligência dos proprietários por conta da especulação imobiliária e a possibilidade de novas construções serem feitas após a antiga ser condenada;

3. Ineficiência da utilização do patrimônio histórico, artístico e cultural como fomento ao turismo juntamente com deterioração das placas informativas dos monumentos e falta de disponibilidade em relação a traduções para línguas estrangeiras;

4. Ocorrência do processo de gentrificação, que além de promover a expulsão progressiva das populações da região central da cidade para áreas periféricas com a instalação de atividades comerciais em detrimento das moradias e locais 
de cultura, utilizam esses espaços para a expansão do capital especulativo voltado a indústria de grandes eventos e por fim a não oferta dos serviços públicos de infraestrutura e saneamento de forma adequada às comunidades que, a duras penas, ainda resistem a essa ação do Estado e capital privado;

5. Expansão do comércio informal realizado, principalmente, por ambulantes que se espraiam pelas calçadas em subempregos e bicos que visam atender apenas os anseios do capital especulativo da indústria de grandes eventos;

6. Degradação ambiental a artificialização dos espaços com a gradativa substituição da área verde e solo exposto por áreas com concreto, asfalto, pavimento; verticalização das construções e poluição do ar causada pelo grande fluxo de veículos automotores, gerando o aumento da temperatura local e o fenômeno das ilhas de calor;

7. Acúmulo de resíduos sólidos próximos aos corpos hídricos, causando o assoreamento, a redução do escoamento superficial, culminando na ocorrência de enchentes e a progressiva instalação de pontos de alagamento nas áreas que sofreram um processo de intervenção antrópica mais acentuado, tais como canalização, aterros entre outros.

\subsection{Propostas dos estudantes}

As propostas dos estudantes do Nós Propomos! Paraíba para a resolução dos problemas demandam:

A. Criação de linhas de crédito nos bancos públicos para financiamento do reparo, restauração e reconstrução de monumentos históricos, manutenção de parques, praças e demais equipamentos urbanos visando uma requalificação mais consciente do patrimônio histórico do município de João Pessoa;

B. Fiscalização mais eficaz por parte do IPHAN e IPHAEP quanto ao estado das edificações e solicitação de reformas estruturais nos imóveis tombados com algum grau de deterioração e mais rigor na punição para os proprietários particulares que não cumprirem os marcos legais;

C. Maior incentivo ao turismo a partir de campanhas de massificação das atividades culturais na mídia tradicional, melhoria estrutural dos conjuntos arquitetônico do centro histórico de João Pessoa e a fixação de placas instrutivas em inglês e outras línguas estrangeiras de acordo com o perfil linguístico dos turistas internacionais que visitam o território paraibano; 
D. Palestras e oficinas de educação patrimonial em turmas do ensino fundamental em escolas da rede pública com o intuito de incentivar o desenvolvimento de práticas pedagógicas voltadas ao fomento da cidadania desde a infância, formando uma geração de indivíduos preocupados com o estado de conservação do patrimônio histórico, arquitetônico, artístico e cultural;

E. Manutenção do calçamento e melhoria da acessibilidade nas ruas e logradouros de maior circulação de pedestres.

F. Desenvolvimento de uma política ambiental que vise o reflorestamento com mudas de árvores frutíferas típicas do bioma de mata atlântica, incentivo a criação de hortas verticais, diminuição da área coberta com concreto, asfalto e pavimento nas proximidades dos parques e praças do centro histórico, promovendo a naturalização dos espaços e visando à diminuição da temperatura e aumentar a circulação de ar e melhorando o conforto ambiental.

\section{Conclusão}

A compreensão e o desenvolvimento de uma consciência cidadã fomentadas e desenvolvidas com as atividades do Projeto Nós Propomos! Paraíba: revitalizando a cidadania através da educação vem contribuíndo de forma substancial com o desenvolvimento da autonomia intelectual, incentivo à pesquisa e iniciação científica dos alunos do ensino médio, dando a motivação necessária para seguir acreditando nas mudanças sociais, políticas e econômicas e, principalmente, na capacidade de cada cidadão em trasformar o meio em que vive, elencando os problemas socioambientais urbanos e produzindo propostas de intervenção para resolução dos mesmos e encaminhando-as para ciência das autoridades competentes, completando a função social da educação: a de formar cidadãos capazes de transformar a realidade social em que vivem. Os resultados obtidos no primeiro ano de implantação do projeto foram apresentados no Congresso Ibero-Americano Nós Propomos! Geografia, Cidadania e Educação ocorrido na Universidade de Lisboa, Portugal entre 07 e 12 de setembro de 2018 e também foram compartilhadas no II Encontro de Geografia do Sesquicentenário (II GEOSESQUI) ocorrido em João Pessoa na data de 29 de novembro de 2018.

\section{Referências bibliográficas}

Brasil. (1988) Constituição da República Federativa do Brasil. Brasília, DF: Senado Federal: Centro Gráfico. 
Decreto-Lei ํㅜ 25, de 30 de Novembro de 1937. Organiza a proteção do patrimônio histórico e artístico nacional.

Decreto no 5.255 de 31 de março de 1971. O Governo do Estado cria na secretaria de Educação e Cultura o Instituto do Patrimônio Histórico e Artístico do Estado da Paraíba.

Decreto no 3.551, de 4 de agosto de 2000. Institui o Registro de Bens Culturais de Natureza Imaterial que constituem patrimônio cultural brasileiro, cria o Programa Nacional do Patrimônio Imaterial e dá outras providências.

Carlos, A. F. (2004). O Espaço Urbano: novos escritos sobre a cidade. São Paulo: Contexto.

Centro Histórico de João Pessoa completa dez anos de tombamento e recebe investimentos da PMJP (2017, dezembro). Público. Disponível em: http://www.joaopessoa.pb.gov.br/centro-historico-de-joao-pessoa-completa-dez-anosde-tombamento-e-recebe-investimentos-da-pmjp/

Choay, F. (1979). O urbanismo: utopias e realidades - Uma antologia. São Paulo: Editora Perspectiva.

Cury, I. (2000). Cartas Patrimoniais. Rio de Janeiro: Ed. do Patrimônio/IPHAN.

Lei $n^{0}$ 3.924, de 26 de julho de 1961. Dispõe sobre monumentos e arqueológicos e pré-históricos.

Millet, V. (1988) A teimosia das pedras: um estudo sobre a preservação do patrimônio ambiental no Brasil. Olinda: Prefeitura de Olinda.

Santos, L. R. D.; Ramos, A. R. D.; Badiru, A. I. Z.; Beppler, M.; Neves, D. J. D.; Araújo, A. L. (2011, Julho) Cadastro Técnico do patrimônio histórico da cidade de João Pessoa-PB utilizando técnicas de Geoprocessamento. In: Simpósio Brasileiro de Sensoriamento Remoto, Curitiba. Anais XV Simpósio Brasileiro de Sensoriamento V. XV. doi: http://marte.sid.inpe.br/col/dpi.inpe.br/marte/2011/07.22.15.42/doc/p1553.pdf

Silva, R. C. N. (2016) A revitalização do Centro Histórico de João Pessoa: uma estratégia para a reprodução do capital. (Tese de Doutorado). Disponível em: http://www.teses.usp.br/teses/disponiveis/8/8136/tde-10032016-144330/pt-br.php

Scoguglia, J. B. C. (2004) Revitalização Urbana e (Re) Invenção do Centro Histórico na Cidade de João Pessoa. João Pessoa: Editora Universitária. 


\title{
Nosotros Proponemos: un proyecto globalizador para la enseñanza
}

\author{
JUAN MARTIN MARTÍN ${ }^{1}$ \\ MARIA LUISA VÁZQUEZ SÁNCHEZ
}

\section{Resumen}

La enseñanza en las aulas debe estar en un proceso de permanente renovación tratando de acercar el conocimiento, la sociedad y el mundo que nos rodea a los alumnos y a ser posible que estos sean partícipes de esos cambios. Es difícil encontrar un proyecto educativo que ilusione y cuyos protagonistas principales no sean los adultos sino los jóvenes. Este es el caso del Proyecto Nosotros Proponemos que es un ejemplo de participación del alumno en la sociedad, en la ciudadanía, tratando de aportar sus ideas y soluciones. El curso 2016-2017 el "Proyecto Nós Propomos! llegó por primera vez a España", siendo Ciudad Real la primera ciudad española en acoger dicho Proyecto. Debido al éxito de participación, al esfuerzo del profesorado de primaria y secundaria, a la Universidad de Castilla La Mancha (UCLM) y al Ayuntamiento se volvió a celebrar una segunda edición en el que se mejoraron los resultados. El Departamento de Geografía e Historia del IES Hernán Pérez del Pulgar, a través de sus profesores de geografía, ha participado en las dos ediciones desarrolladas en España (Ciudad Real) con unos proyectos variados en su temática y que han servido para conocer y mejorar su ciudad y planteando interesantes soluciones a ésta. El Projeto Nós propomos! se puede considerar un proyecto globalizador con características geográficas mundiales (Portugal, España, Brasil, Colombia, Mozambique...) y cuyos protagonistas son los estudiantes.

Palabras clave: Nosotros Proponemos, proyecto educativo, didáctica de la Geografía, Geografía urbana, Educación Secundaria

\section{Resumo}

O ensino em sala de aula deve estar em um processo de renovação permanente, tentando trazer o conhecimento, a sociedade e o mundo ao nosso redor para os

\footnotetext{
${ }^{1}$ Profesor del Departamento de Geografía e Historia del IES Hernán Pérez del Pulgar de Ciudad Real, juanmartinmartin@gmail.com, geografia.ies.hernan@gmail.com

${ }_{2}$ Profesora del Departamento de Geografía e Historia del IES Hernán Pérez del Pulgar de Ciudad Real, luisavazquezsanchez@hotmail.com,
} 
alunos, permitindo que eles sejam participantes dessas mudanças. É difícil encontrar um projeto educativo do qual os principais protagonistas não sejam adultos, mas jovens. Este é o caso do "Projeto Nós Propomos!". Propomos que seja um exemplo de participação estudantil na sociedade, na cidadania, procurando contribuir com suas idéias e soluções. O curso 2016-2017 o "Projeto Nós Propomos! chegou pela primeira vez na Espanha ", sendo Ciudad Real a primeira cidade espanhola a sediar este projeto. Devido ao sucesso da participação, ao esforço do corpo docente, à Universidade de Castilla La Mancha (UCLM) e à Câmara Municipal, uma segunda edição foi realizada novamente com melhores resultados. O departamento de Geografia e História do IES Hernán Pérez del Pulgar, através de seus professores de geografia, participou das duas edições desenvolvidas na Espanha (Ciudad Real) com vários projetos em seu tema que serviram para conhecer e melhorar sua cidade e levantando soluções interessantes para isso. O "Projeto Nós propomos!" pode ser considerado um projeto globalizante com características geográficas globais (Portugal, Espanha, Brasil, Colômbia, Moçambique...) e cujos protagonistas são os estudantes.

Palavras-chave: Nos Propomos!, projeto educativo, Geografia didática, Geografia Urbana, Ensino Secundário.

\section{Introducción}

Durante muchos siglo hemos vivido en una sociedad donde parte del conocimiento era difícil que traspasara las fronteras. Poco a poco la globalización ha ido diluyendo esas fronteras y cualquier hecho o acontecimiento por muy lejos que se produzca, puede tener una difusión en cualquier rincón del mundo.

Esta situación se ha visto beneficiada por la irrupción de Internet, el uso de las redes sociales, las webs, etc. que han hecho que las nuevas tecnologías puedan formar parte de nuestras vidas.

El Proyecto ¡Nosotros Proponemos!: geografía, educación y ciudadanía. Empezó siendo un proyecto de ámbito local / nacional en Portugal, pero pronto se vio que tenía un espíritu transnacional y globalizador con implantación no solo en Europa (Portugal y España), sino también en América (Brasil, Perú, Colombía y próximmente México) y África (Mozambique)

Es probable que a lo largo del curso 18-19 y 19-20 se integren más países haciendo el proyecto más internacional y global.

Figura 12 - Países participantes en el Proyecto Nosotros Proponemos. 2018 


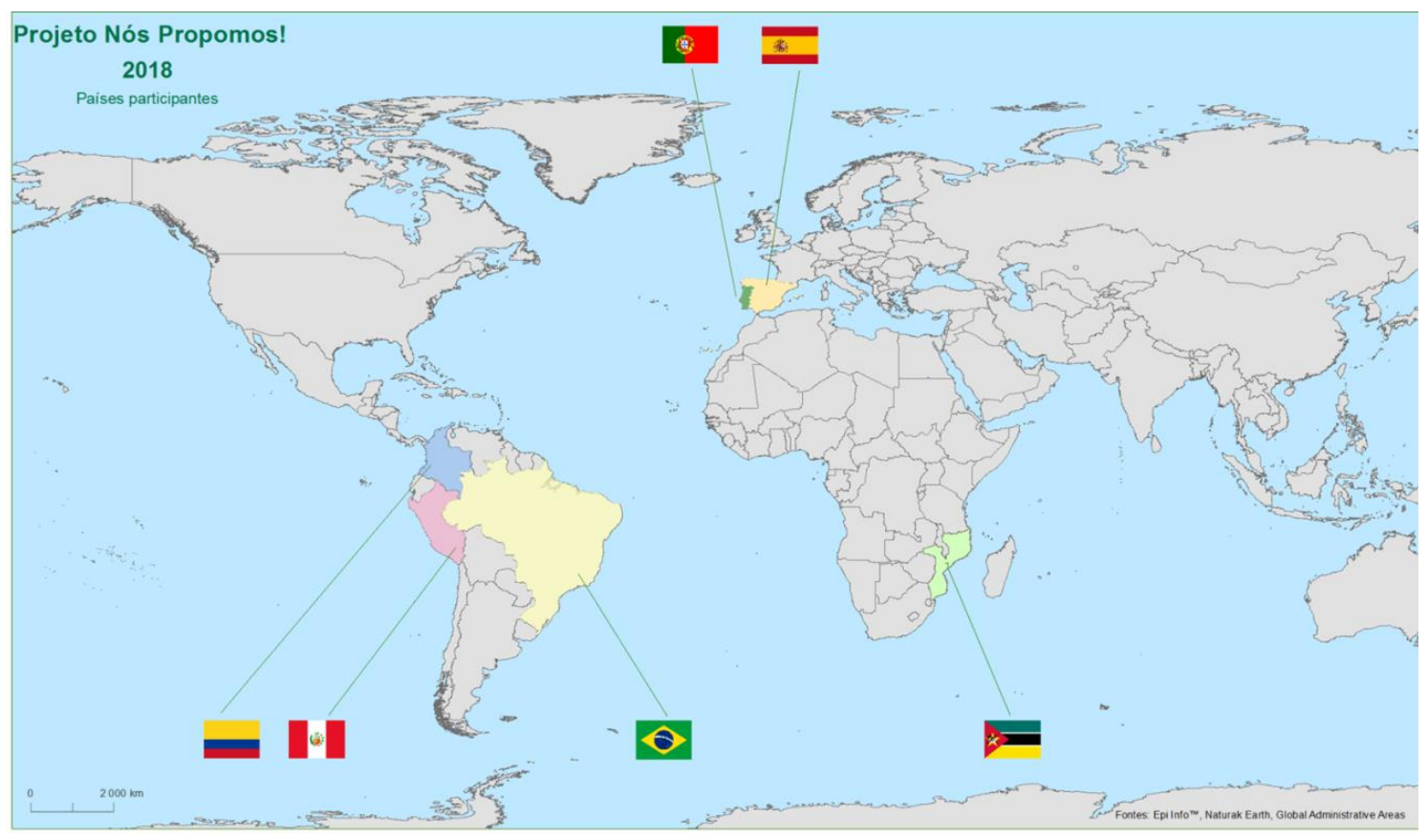

Fuente: http://www.nosotrosproponemos.com/donde-estamos/

\section{Un proyecto globalizador para la enseñanza.}

La enseñanza no entiende de fronteras, y por tanto debe superar esos límites artificiales, para hacerse más global, donde profesores y alumnos se ayuden e intercambien conocimientos y metodología y conseguir así una sociedad más justa y avanzada.

El objetivo principal del proyecto era incorporar a los alumnos de primaria y secundaria para que estos detectaran e identificaran problemas cotidianos de su ciudad y de su entorno y plantearan unas soluciones a la administracion, (preferentemente a los ayuntamientos). De esta forma se sentirían protagonistas de su ciudad, haciéndola más habitable y asumiendo una mayor concienciación social, además de fomentar la participación en grupos de trabajo multidisciplinares. (Rodriguez-Domennech, M.A y Claudino. S. 2018)

\section{Congreso Iberoamericano Nosotros Proponemos.}

Ante el crecimiento del proyecto en diversos países y continentes y con la finalidad de consolidar el Proyecto Nos Propomos!, se ha organizado en Lisboa entre el 7 y el 12 de octubre de 2018 el $1^{\circ}$ Congreso Iberoamericano "Nosotros Proponemos: geografía, educación y ciudanía" con la finalidad consolidar la red de profesores, investigadores 
y estudiantes que, en el espacio iberoamericano, han construido el proyecto ¡Nosotros Proponemos!

Otro de los objetivos que se planteaban era la difusión del proyecto ¡Nosotros Proponemos! demoestrando que era posible innovar la enseñanza promoviendo la realización de "estudios de caso" locales, siendo los alumnos los que den soluciones a dicha problemática.

En este primer congreso se ha buscado consolidar el conocimiento personal y las redes de colaboración entre profesores (a través de Geoforo), investigadores y estudiantes de los distintos países y regiones.

\section{Cosolidación del proyecto en España.}

El crecimiento del proyecto Nosotros Proponemos no ha consistido sólo en la presencia de más países, sino también en número de universidades y alumnos que se han unido al proyecto.

La labor de las universidades, de los ayuntamientos y el trabajo de los centros educativos de primaria y secunadria con sus profesores, ha sido fundamental para asentar los proyectos en sus localidades, consiguiendo unos resultados importantes en la resolución de problemas en su ciudad.

En Potugal ha sido la univesidad de Lisboa, con el IGOT, la que ha organizado los proyectos en el país, además, en gran medida, ha sido la "madre" del proyecto inicial, marcando las pautas de trabajo, la metodología, etc.

Brasil, debido a sus dimensiones, se ha convertido en el país con mayor implantación, participando la universidad Federal de Tocantis y la universidad Federal de Santa Catalina. (Rodriguez-Domennech, M.A y Claudino. S. 2018)

En España, la primera universidad que implantó el proyecto fue la Universidad de Castilla la Mancha (UCLM) y posteriormente la de Valencia (UV), aunque próximamente se unirán más universidades como la de Andalucía y Extremadura entre otras.

\section{Ciudades participantes:}

a) Provincia de Ciudad Real: Ciudad Real, Alcázar de San Juan y Bolaños

b) Provincia de Valencia: Valencia y Ontiyent (Onteniente)

c) Provincia de Alicante: Xàbia (Jávea) 
d) Las próximas incorporaciones serán Córdoba y Badajoz

Con el fin de centralizar toda la información en España, se ha creado una web http://www.nosotrosproponemos.com/. En esta web aparecen todas las universidades y ciudades participantes, cada una de ellas con un espacio diferenciado, en la que una vez registrado se pueden consultar noticias, fotografías, vídeos, etc. de carácter general y específicas de cada ciudad.

\section{El proyecto y su implantación en Ciudad Real}

La Universidad de Castilla la Mancha (UCLM), a través de la Facultad de Educación de Ciudad Real y el ayuntamiento de la localidad, han organizado la segunda edición del Proyecto Nosotros Proponemos pretendiendo la consolidación del proyecto y buscando la mejora de la ciudad a través de la localización de problemas concretos y la resolución de estos por los alumnos.

Durante el mes de octubre se dio formación a los profesores y centros participantes en la segunda edición. Esta formación se impartió desde la universidad ( en la que también colaboró el profesor de secundaria Juan Martín Martín), junto con el ayuntamiento de Ciudad Real.

Figura 2 - Fechas claves del Proyecto Nosotros proponemos en Ciudad Real, 2017-2018.

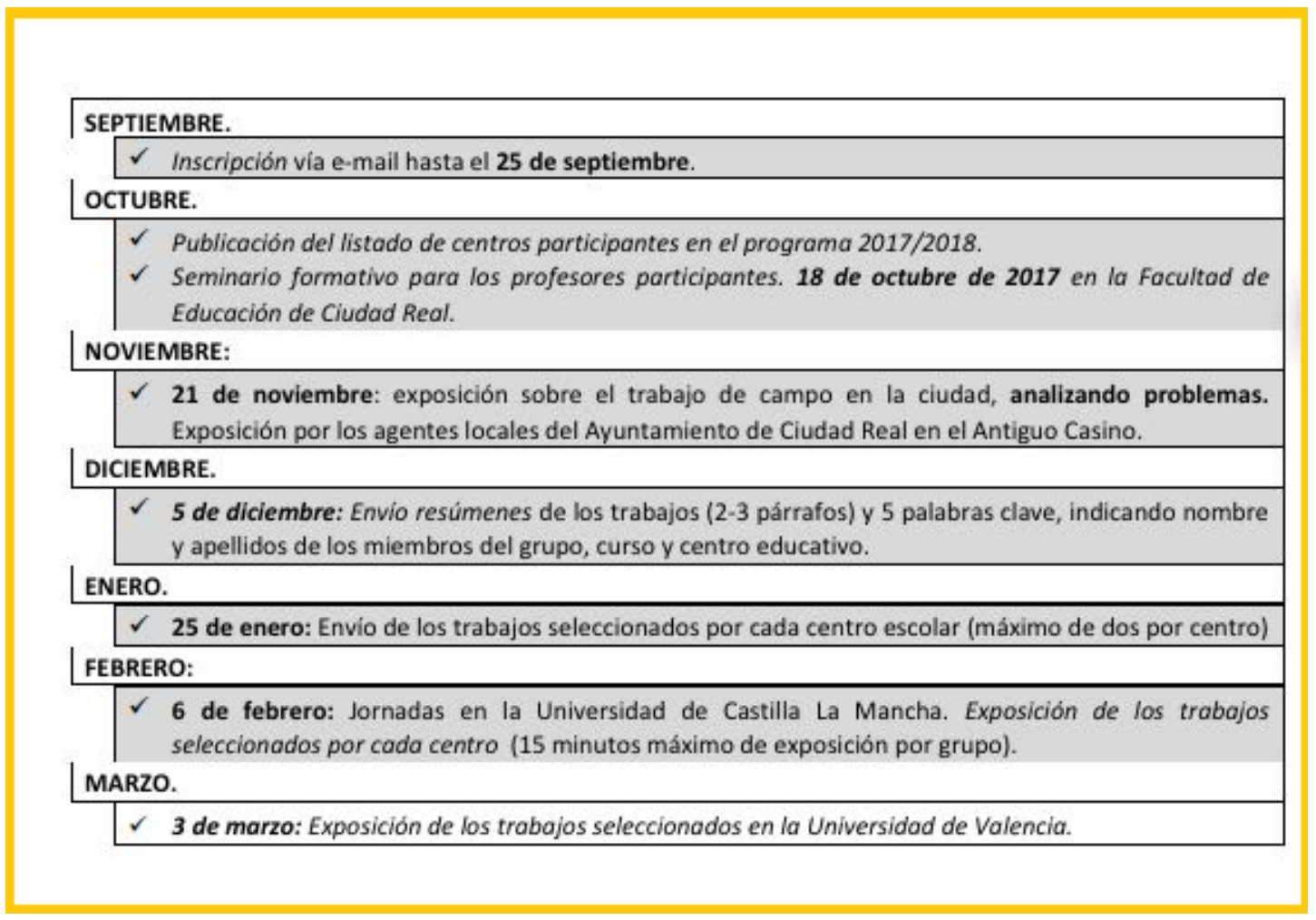

Fuente: Proyecto Nosotros Proponemos 2017-2018. 
El compromiso del profesorado de primaria y secundaria con el proyecto, ha hecho que la mayoría de los centros participantes volvieran a participar este año, a pesar de la complicación de incluirlo en sus respectivos curriculos educativos y en sus programaciones de aula.

\subsubsection{Centros participantes en la $2^{\text {a }}$ edición:}

A) Enseñanza Primaria:

$\checkmark$ CEIP Alcalde José Maestro

$\checkmark$ CEIP Cristóbal Colón

$\checkmark$ CEIP Ferroviario

$\checkmark$ CEIP Miguel de Cervantes

$\checkmark$ CEIP Pío XII

B) EnseñanzaSecundaria:

$\checkmark$ CPC San José

$\checkmark \quad$ IES Hernán Pérez del Pulgar

$\checkmark$ IES Maestro Juan de Ávila

$\checkmark \quad$ IES Torreón del Alcázar

De todos los proyectos realizados por los respectivos centros educativos, fueron seleccionados dos de cada centro. Estos 18 trabajos se tuvieron que exponer y defender en una sesión conjunta, celebrada en la Facultad de Educación de Ciudad Real y en la que posteriormente un jurado formado por miembros de la UCLM y del ayuntamiento seleccionaron a los respectivos finalistas de cada centro.

Los trabajos finalistas fueron premiados con un viaje a Valencia donde además de participar en diferentes actividades culturales, tuvieron que exponer dichos proyectos en el Paraninfo de la Universitat de Valencia donde también participaron alumnos de otras localidades valencianas.

\section{EI Proyecto Nosotros proponemos en el IES Hernán Pérez del Pulgar}

El Departamento de Geografía del IES Hernán Perez del Pulgar de Ciudad Real decidió volver a participar en la segunda edición del Proyecto Nosotros Proponemos en Ciudad Real, bajo la dirección de los profesores del Departamento Juan Martín Martín y Mํㅡㄴ Luisa Vázquez Sánchez. 
Se pensó que podrían participar tanto alumnos de segundo y tercero de ESO, pero que sería de forma voluntaria y por tanto la mayor parte de los trabajos tendría que ser realizado fuera del horario lectivo con el fin de no ralentizar las clases.

Los alumnos fueron informados de los objetivos del proyecto, de los agrupamientos, de los plazos, etc.

La participación fue masiva, suponiendo un esfuerzo extra para los profesores responsabbles de los proyectos, que han tenido que realizar su labor de dirección y coordinación fuera del horario lectivo no interfiriendo en el temario, ni en los alumnos no participantes.

\section{Los proyectos del iES Hernán Pérez del Pulgar. Curso 2017-2018.}

En el curso 2017-2018 han participado un total de 12 grupos con un total de 42 alumnos, de los cuales 5 eran de $2^{\circ}$ de la ESO y 7 de $3^{\circ}$ de la ESO.

La temática y composición de los grupos que han participado este curso ha sido muy variada, desde app para mejorar la accesibilidad, a la realización de Jardines Vericales o la rehabilitación de edificios.

A continuación se muestra de forma esquemática las características de cada uno de los proyectos realizados por los alumnos, así como sus componentes:

Figura 3 - Grupo 1. Proyecto Nosotros Proponemos. IES Hernán Perez del Pulgar 2017-2018

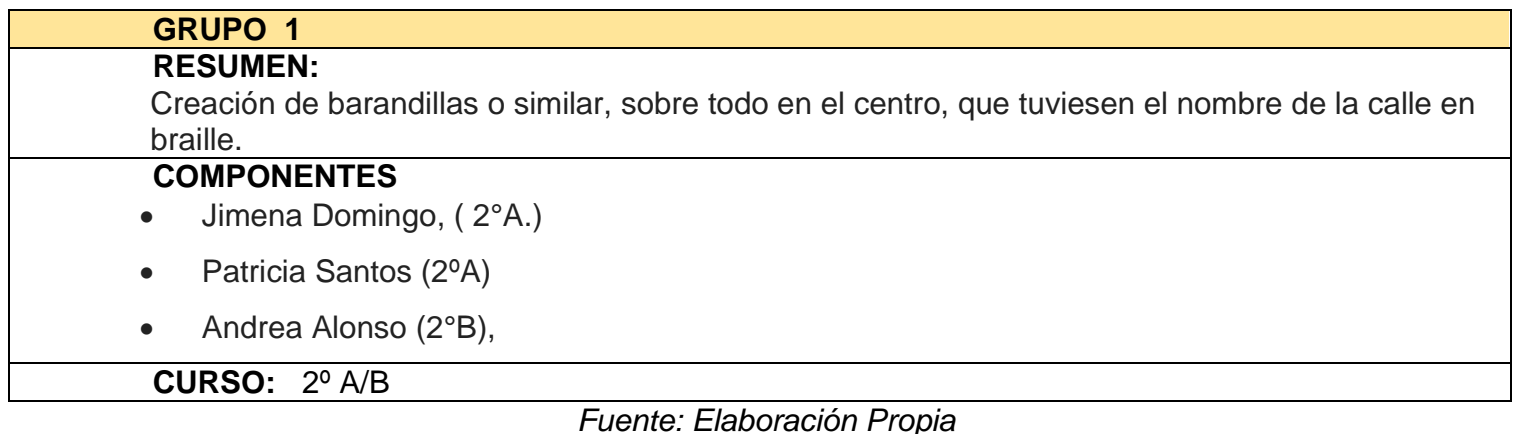

Figura 4 - Grupo 2. Proyecto Nosotros Proponemos. IES Hernán Perez del Pulgar 2017-2018

\begin{tabular}{|l|}
\hline GRUPO 2 (GANADOR. Premiado con Viaje a Valencia) \\
\hline RESUMEN \\
Mejorar el aspecto de la ciudad y a la vez controlar la contaminación. Conseguimos esto gracias \\
a los jardines verticales en los edificios \\
\hline COMPONENTES \\
Nuria Calle González \\
Elisabet Carrillejo Isasi
\end{tabular}




\begin{tabular}{|c|}
\hline $\begin{array}{ll}\text { - } & \text { Marina García de León } \\
\text { - } & \text { Paula Serrano Castro }\end{array}$ \\
\hline CURSO $2^{\circ}$ ESO C \\
\hline
\end{tabular}

Fuente: Elaboración Propia

Figura 5 - Grupo 3. Proyecto Nosotros Proponemos. IES Hernán Perez del Pulgar 2017-2018

\begin{tabular}{|l|}
\hline GRUPO 3 \\
\hline RESUMEN \\
Rehabilitación del hospital abandonado, que lo queremos convertir en una residencia de \\
estudiantes \\
\hline COMPONENTES \\
- Mario Vargas Serrano, \\
- Diego Zafra Sanchez, \\
- $\quad$ Saberto Carlos Cordoba Cano, \\
- Yolanda Expósito Gutiérrez \\
\hline CURSO: $2^{\circ}$ ESO C \\
\hline
\end{tabular}

Fuente: Elaboración Propia

Figura 6 - Grupo 4. Proyecto Nosotros Proponemos. IES Hernán Perez del Pulgar 2017-2018

\begin{tabular}{|l|}
\hline GRUPO 4 (FINALISTA) \\
\hline RESUMEN: \\
Crear una “especie de Red Social” para ayudar a los discapacitados donde los propios usuarios \\
van a poder reportar defectos que llegarían directamente al ayuntamiento o la entidad elegida \\
para intentar corregirlos. \\
COMPONENTES. \\
Rodrigo Palomares Céspedes \\
\hline CURSO: $2^{\circ}$ ESO D \\
\hline
\end{tabular}

Fuente: Elaboración Propia

Figura 7- Grupo 5. Proyecto Nosotros Proponemos. IES Hernán Perez del Pulgar 2017-2018

\begin{tabular}{|l|}
\hline GRUPO $\mathbf{5}$ \\
\hline RESUMEN \\
Rehabilitación del antiguo hospital Nuestra Señora de Alarcos \\
\hline COMPONENTES \\
- Juan Lucas Rey. \\
- Álvaro Ramos Sánchez \\
Aitor Ruiz Ruiz \\
\hline CURSO: $2^{\circ}$ ESO D \\
\hline
\end{tabular}

Fuente: Elaboración Propia

Figura 8- Grupo 6. Proyecto Nosotros Proponemos. IES Hernán Perez del Pulgar 2017-2018

\begin{tabular}{|l|}
\hline GRUPO 6 \\
\hline RESUMEN: \\
Mejora de diferentes aspectos de la pedanía de Las Casas \\
\hline
\end{tabular}




\begin{tabular}{|l|}
\hline COMPONENTES \\
- Aitana Arranz Carrasco \\
- Inés Velasco Aponte \\
- Carolina Lezana Plaza \\
\hline CURSO 3ํES A \\
\hline
\end{tabular}

Fuente: Elaboración Propia

Figura 9 - Grupo 7. Proyecto Nosotros Proponemos. IES Hernán Perez del Pulgar 2017-2018

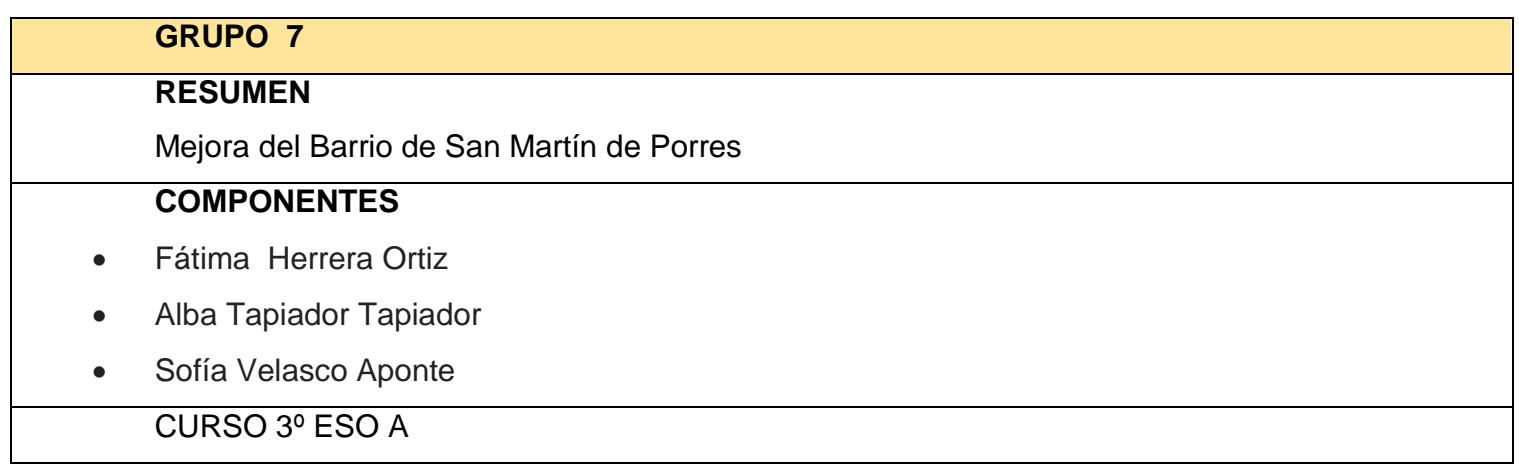

Fuente: Elaboración Propia

Figura 10 - Grupo 8. Proyecto Nosotros Proponemos. IES Hernán Perez del Pulgar 2017-2018

\begin{tabular}{|l|}
\hline GRUPO 8 \\
\hline RESUMEN \\
Errores Ecológicos de nuestra Ciudad: \\
Se trataría de ver los problemas Medioambientales y aportar soluciones ecológicas: \\
- El agua (Gran consumo de agua y como administrarla...) \\
- Electricidad (Consumo innecesario de energía y como evitarlo....) \\
- etc \\
\hline COMPONENTES \\
- Alejandro Cerro Diaz Ropero \\
- Ernesto Hernandez Areas \\
- Jaime Moraga Pérez \\
- María Sanchez Paulete \\
CURSO 3 3onso Zazo Castellanos \\
\hline
\end{tabular}

Fuente: Elaboración Propia

Figura 11 - Grupo 9. Proyecto Nosotros Proponemos. IES Hernán Perez del Pulgar 2017-2018

\begin{tabular}{|l|}
\hline GRUPO $\mathbf{9}$ \\
\hline RESUMEN: \\
Mejorar la seguridad vial en las calles, mediante carril bici y recolocación de los obstaculos, \\
como papeleras, etc. \\
\hline COMPONENTES: \\
- Marta Gómez Aliseda \\
- Patricia Gómez Naranjo \\
Lydia Lucas Ruiz, \\
\hline
\end{tabular}




\begin{tabular}{|l|}
\hline Elisa Rodríguez Turrillo \\
\hline CURSO: $\quad 3^{\circ} \mathrm{C}$ \\
\hline
\end{tabular}

Fuente: Elaboración Propia

Figura 12 - Grupo 10. Proyecto Nosotros Proponemos. IES Hernán Perez del Pulgar 2017-2018

\begin{tabular}{|l|}
\hline GRUPO $\mathbf{1 0}$ \\
\hline RESUMEN \\
Restauración de aceras y adaptación para personas minusválidas. \\
\hline COMPONENTES \\
- $\quad$ Andrés Alañón Ruiz \\
- Jorge Arroyo Díaz \\
- Jerardo Mora Domínguez Sánchez Peñuela \\
- Ismael Zúñiga Sánchez \\
\hline CURSO: $3^{\circ}$ ESO C \\
\hline
\end{tabular}

Fuente: Elaboración Propia 
Figura 13 - Grupo 11. Proyecto Nosotros Proponemos. IES Hernán Perez del Pulgar 2017-2018

\begin{tabular}{|l|}
\hline GRUPO 11 \\
\hline RESUMEN: \\
Realización de Códigos QR para que las personas conozcan la historia de la calle, origen del \\
nombre y fotografías antiguas de esa calle \\
\hline COMPONENTES: \\
- Elena Castañeda.Rodríguez \\
- Jihan Ibnechaychk \\
- Paula Ortiz Herrera \\
\hline CURSO: $3^{\circ}$ ESO C \\
\hline
\end{tabular}

Fuente: Elaboración Propia

Figura 14 - Grupo 12. Proyecto Nosotros Proponemos. IES Hernán Perez del Pulgar 2017-2018

\begin{tabular}{|l|}
\hline GRUPO 12 \\
\hline RESUMEN \\
-Facilitar y mejorar la accesibilidad \\
-Mejora de las líneas de Autobús en las zonas de viviendas retiradas \\
-Habilitar el edificio de la calle Camino de la Guija \\
\hline COMPONENTES \\
- Ana Ros De Lope \\
- Sarah Martín-Llorente Hamed \\
\hline CURSO $3^{\circ}$ ESO C \\
\hline
\end{tabular}

Fuente: Elaboración Propia

\section{Los proyectos Finalistas. Curso 2017-2018.}

Los trabajos seleccionados por el jurado del IES Hernán Pérez del Pulgar para la Fase Final fueron:

- Los Jardines Verticales realizado por las alumnas de $2^{\circ}$ de la ESO C (Nuria Calle, Elisabeth Carrillejo, Marina García de León y Paula Serrano).

$<$ https://es.slideshare.net/juanmartin1/nosotros-proponemos-cr-los-jardines-

verticales-ies-hernn-prez-del-pulgar-de-ciudad-realproyecto-finalista-2018>

- App Ciudad Real + realizado por Rodrigo Palomares Céspedes alumno de $2^{\circ}$ ESO D $<$ https://www.youtube.com/watch?v=tnao5U0SE58>

Dichos trabajos fueron expuestos en el Salón de Actos de la Facultad de Educación de la UCLM de Ciudad Real, con la presencia de la Alcaldesa de Ciudad Real, la Decana de la Facultad de Educación, la Concejala de Educación y la Coordinadora del 


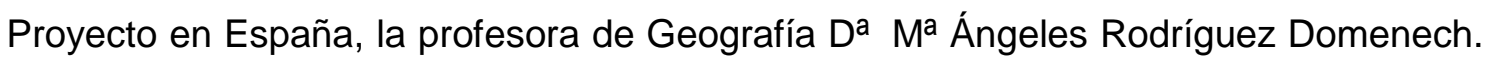
También participaron en este acto el resto de centros participantes en esta $2^{\mathfrak{a}}$ edición "Nosotros Proponemos de Ciudad Real"

El trabajo ganador del IES Hernán Pérez del Pulgar fueron "Los Jardines Verticales" que viajaría a Valencia para representar a Ciudad Real (junto a otros centros finalistas). $\mathrm{Y}$ que trataba sobre

La importancia de usar las plantas y en general la vegetación de forma vertical sobre fachadas preferentemente públicas como colegios, oficinas del ayuntamiento, edificios con paredes deterioradas, etc, mostrando así su importancia ecológica, medioambiental, de ahorro energético, así como sus posibilidades turísticas en el paisaje urbano, y su propuesta de aplicación en Ciudad Real.

Figura 15- Finalistas de la $2^{a}$ Edición del proyecto Nosotros Proponemos

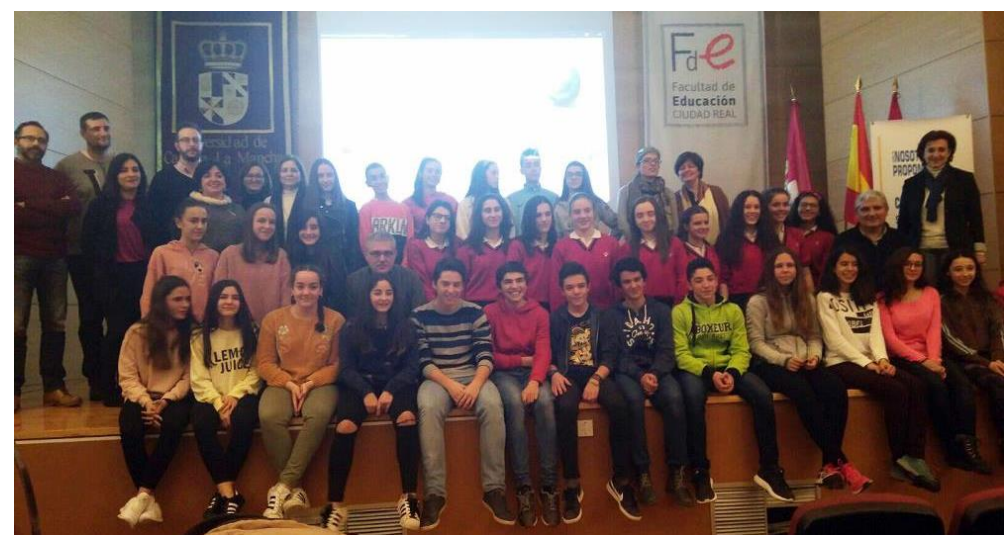

Fuente: Organización 2ª Edición 2018

Los alumnos y profesores de los proyectos ganadores, fueron recibidos con posterioridad en el salón de plenos del ayuntamiento de Ciudad Real, presidido por la alcaldesa y parte de la corporación municipal, así como miembros de la UCLM de la $2^{\underline{a}}$ Edición del Proyecto Nosotros Proponemos. 
Figura 16- Alumnas premiadas, el profesor Juan Martín Martín y la alcaldesa Pilar Zamora en el Salón de Plenos del ayuntamiento

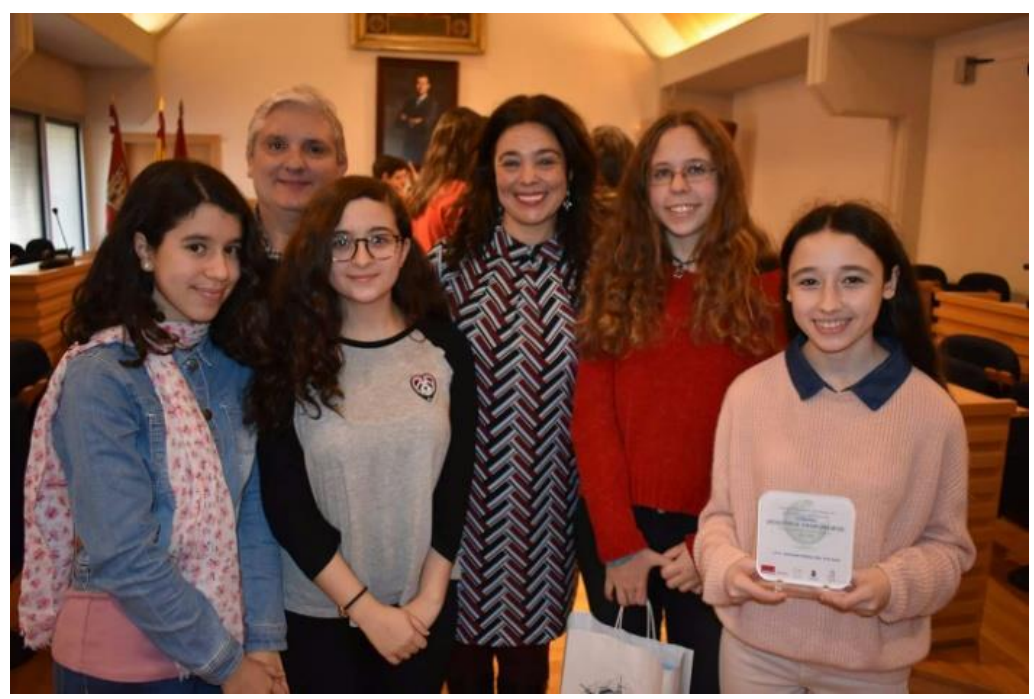

Fuente: Autores

\section{Viaje a Valencia.}

Las alumnas premiadas del IES Hernán Pérez del Pulgar viajaron, junto al resto de centros premiados, los días 2 y 3 de marzo a Valencia (que se incorporaba por primera vez al proyecto) para presentar y defender sus trabajos.

El acto se desarrolló en el Paraninfo de la Universitat de Valencia y estuvo presidido por el Vicerrector de Políticas de formación de la Universidad de Valencia, Ramón López; y los concejales de Educación de Ontinyent y Ciudad Real, el Director del proyecto en Lisboa, Sergio Claudino y los coordinadores Xose Manuel Souto por la Universidad de Valencia y $\mathrm{M}^{\mathrm{a}}$ Ángeles Rodríguez Domenech por parte de de Universidad de Castilla La Mancha.

Las alumnas finalistas del IES Hernán Pérez del Pulgar defendieron su proyecto que trató sobre "Los Jardines Verticales", destacando su importancia ecológica, medioambiental, de ahorro energético, así como sus posibilidades turísticas en el paisaje urbano, y su propuesta de aplicación en Ciudad Real. 
Figura 16- Las alumnas finalistas del IES Hernán Pérez del Pulgar.

El profesor Juan Martín, Sergio Claudino y Mª Ángeles Rodríguez.

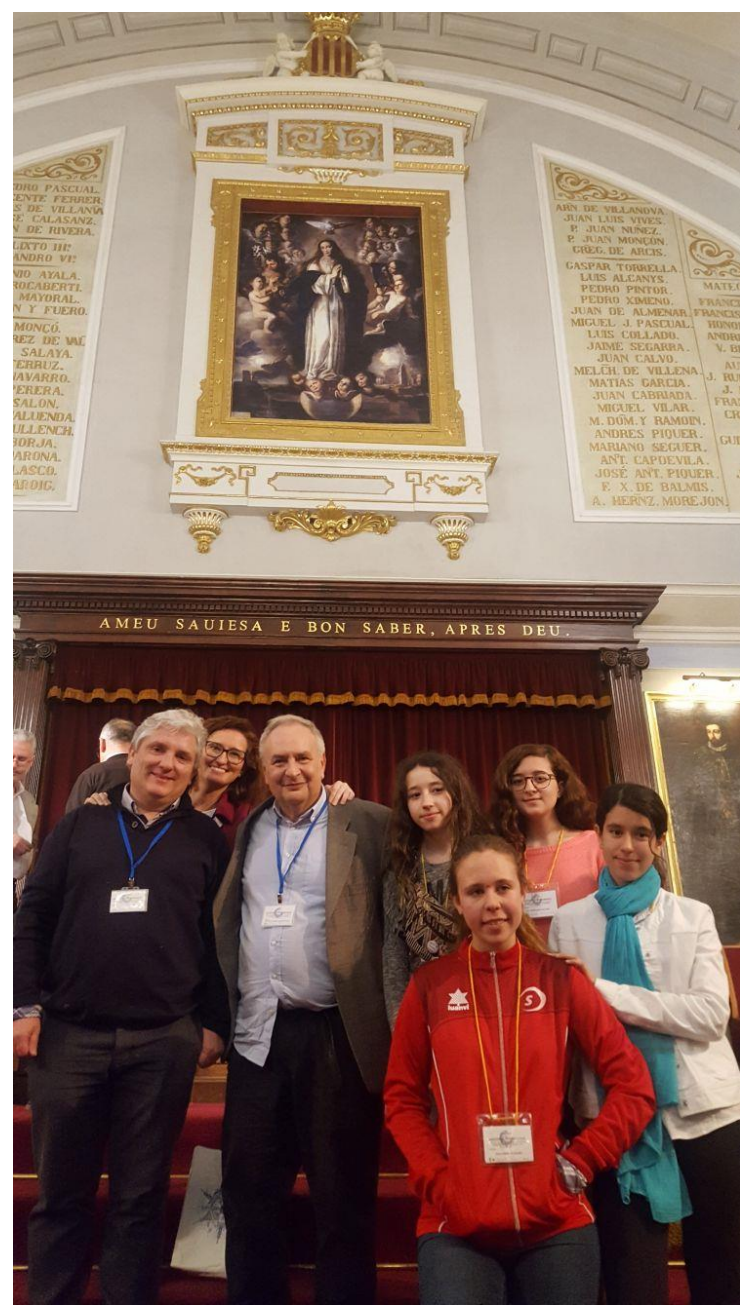

Fuente: Autores

\section{Objetivos y metodología del Proyecto.}

Durante el curso 2017-2018 se realizó un curso de formación a través del Centro Regional de Formación de Castilla La Mancha para los profesores participantes en la 2ํo Edición.

En dicho curso se establecieron una serie de items para mejorar el rendimiento a la hora de trabajar con los alumnos participantes en el proyecto.

Los objetivos trabajados con los proyectos finalistas (Los Jardines verticales y app Ciudad Real+), han sido:

1. Profundizar en cómo es la ciudad en la que viven.

2. Descubrir la problemática de ciertos espacios o ámbitos en la ciudad

3. Valorar la opinión de los ciudadanos 
4. Presentar la propuesta de resolución a una de las problemáticas detectadas. Junto a los 4 objetivos marcados se trabajaron otros items como: la actividad, los contenidos, la metodología, la duracción (sesiones) y el material empleado.

Tabla 3 - Objetivo 1

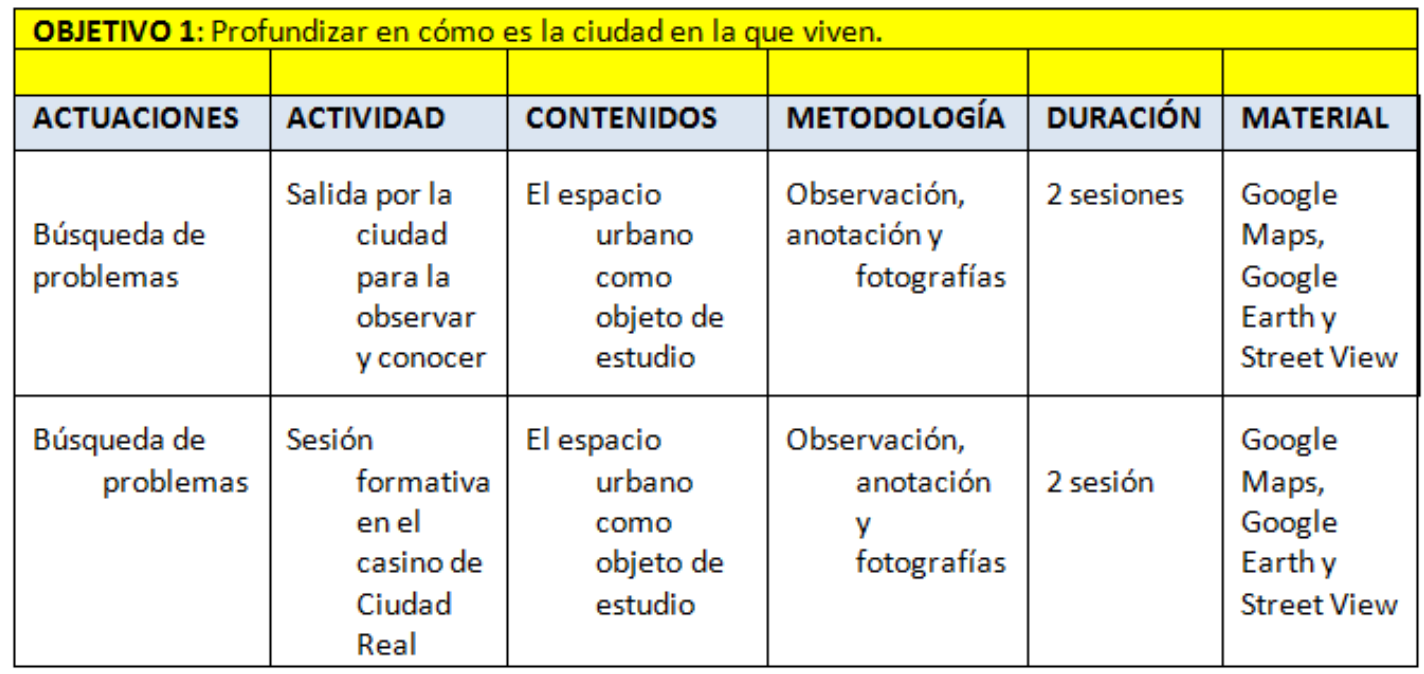

Fuente: Elaboración propia

Tabla 2 - Objetivo 2

\begin{tabular}{|l|l|l|l|l|l|}
\hline \multicolumn{2}{|l|}{ OBJETIVO 2: Descubrir la problemática de ciertos espacios o ámbitos en la ciudad. } \\
\hline ACTUACIONES & ACTIVIDAD & CONTENIDOS & METODOLOGÍA & DURACIÓN & MATERIAL \\
\hline $\begin{array}{l}\text { Analizar } \\
\text { posibles } \\
\text { problemas de la } \\
\text { ciudad }\end{array}$ & $\begin{array}{l}\text { Seleccionar las } \\
\text { deficiencias } \\
\text { detectadas }\end{array}$ & $\begin{array}{l}\text { La ciudad: el } \\
\text { espacio urbano } \\
\text { y su utilización }\end{array}$ & $\begin{array}{l}\text { Observación, } \\
\text { investigación y } \\
\text { debate de } \\
\text { problemas }\end{array}$ & 2 sesiones & $\begin{array}{l}\text { Soportes } \\
\text { digitales y } \\
\text { cuaderno } \\
\text { de campo }\end{array}$ \\
\hline $\begin{array}{l}\text { Seleccionar las } \\
\text { ideas }\end{array}$ & $\begin{array}{l}\text { Búsqueda de } \\
\text { información } \\
\text { sobre los } \\
\text { "Jardines } \\
\text { verticales" }\end{array}$ & $\begin{array}{l}\text { El espacio } \\
\text { urbanoy } \\
\text { actividades } \\
\text { humanas como } \\
\text { objeto de } \\
\text { estudio }\end{array}$ & $\begin{array}{l}\text { Contactar con } \\
\text { empresas } \\
\text { especializadas } \\
\text { en preparación } \\
\text { de Jardines } \\
\text { Verticales }\end{array}$ & 2 sesión & $\begin{array}{l}\text { Soporte } \\
\text { digital }\end{array}$ \\
\hline $\begin{array}{l}\text { Búsqueda de } \\
\text { información } \\
\text { técnica de los } \\
\text { edificios a } \\
\text { rehabilitar }\end{array}$ & $\begin{array}{l}\text { Búsqueda de } \\
\text { información } \\
\text { sobre } \\
\text { soluciones del } \\
\text { deterioro del } \\
\text { material } \\
\text { urbano a } \\
\text { través de una } \\
\text { App }\end{array}$ & $\begin{array}{l}\text { El espacio } \\
\text { urbanoy } \\
\text { actividades } \\
\text { humanas como } \\
\text { objeto de } \\
\text { estudio }\end{array}$ & $\begin{array}{l}\text { Búsqueda de } \\
\text { información } \\
\text { para la } \\
\text { preparación de } \\
\text { una App }\end{array}$ & 2 sesión & $\begin{array}{l}\text { Soporte } \\
\text { digital }\end{array}$ \\
\hline
\end{tabular}

Fuente: Elaboración propia 


\begin{tabular}{|l|l|l|l|l|l|}
\hline \multicolumn{6}{|l|}{ OBJETIVO 3: Valorar la opinión de los ciudadanos. } \\
\hline ACTUACIONES & ACTIVIDAD & CONTENIDOS & METODOLOGÍA & DURACIÓN & MATERIAL \\
\hline $\begin{array}{l}\text { Conocer la } \\
\text { opinión de los } \\
\text { ciudadanos }\end{array}$ & $\begin{array}{l}\text { Realizar } \\
\text { encuestas y } \\
\text { entrevistas }\end{array}$ & $\begin{array}{l}\text { El espacio } \\
\text { urbanoy } \\
\text { actividades } \\
\text { humanas como } \\
\text { objeto de } \\
\text { estudio }\end{array}$ & $\begin{array}{l}\text { Preparación de } \\
\text { entrevistas y } \\
\text { encuestas }\end{array}$ & 2 sesiones & $\begin{array}{l}\text { Grabación } \\
\text { de vídeo y } \\
\text { fotografías }\end{array}$ \\
\hline $\begin{array}{l}\text { Conocer la } \\
\text { opinión de los } \\
\text { ciudadanos }\end{array}$ & $\begin{array}{l}\text { Realizar } \\
\text { entrevistas } \\
\text { sobre el } \\
\text { deterioro del } \\
\text { mobiliario } \\
\text { urbano }\end{array}$ & $\begin{array}{l}\text { El espacio } \\
\text { urbanoy } \\
\text { actividades } \\
\text { humanas como } \\
\text { objeto de } \\
\text { estudio }\end{array}$ & $\begin{array}{l}\text { Realización de } \\
\text { una App en } \\
\text { función de las } \\
\text { aportaciones } \\
\text { ciudadanas }\end{array}$ & 2 sesión & $\begin{array}{l}\text { Soporte } \\
\text { digital }\end{array}$ \\
\hline
\end{tabular}

Fuente: Elaboración propia

Tabla 4 - Objetivo 4

\begin{tabular}{|l|l|l|l|l|l|}
\hline \multicolumn{2}{|l|}{ OBJETIVO 4: Presentar la propuesta de resolución a una de las problemáticas detectadas. } \\
\hline ACTUACIONES & ACTIVIDAD & CONTENIDOS & METODOLOGÍA & DURACIÓN & MATERIAL \\
\hline $\begin{array}{l}\text { Presentar la } \\
\text { solución al } \\
\text { problema }\end{array}$ & $\begin{array}{l}\text { Realización de } \\
\text { un ppt con las } \\
\text { soluciones } \\
\text { propuestas }\end{array}$ & $\begin{array}{l}\text { Realización de } \\
\text { "Jardines } \\
\text { verticales" en } \\
\text { algunos edificios } \\
\text { de la ciudad }\end{array}$ & $\begin{array}{l}\text { Presentación } \\
\text { digital de las } \\
\text { soluciones } \\
\text { planteadas }\end{array}$ & 2 sesiones & $\begin{array}{l}\text { Soporte } \\
\text { digital e } \\
\text { informes } \\
\text { de } \\
\text { empresas }\end{array}$ \\
\hline $\begin{array}{l}\text { Presentar la } \\
\text { solución al } \\
\text { problema }\end{array}$ & $\begin{array}{l}\text { Realización de } \\
\text { un vídeo con } \\
\text { el contenido } \\
\text { de la App para } \\
\text { móvil }\end{array}$ & $\begin{array}{l}\text { Utilización de } \\
\text { una App para } \\
\text { soluciones } \\
\text { deterioro del } \\
\text { mobiliario } \\
\text { urbano }\end{array}$ & $\begin{array}{l}\text { Presentación } \\
\text { digital de las } \\
\text { soluciones } \\
\text { planteadas }\end{array}$ & 2 sesiones & $\begin{array}{l}\text { Soporte } \\
\text { digital para } \\
\text { teléfonos } \\
\text { móviles }\end{array}$ \\
\end{tabular}

Fuente: Elaboración propia

Tabla 5 - Grupos Finalistas del IES Hernán Pérez del Pulgar

\begin{tabular}{|l|ll|l|}
\hline GRUPOS & & INTEGRANTES & CONTENIDOS \\
\hline $2^{\circ}$ ESO C & - & Nuria Calle González. & Proyecto : "Los Jardines \\
& - & Elisabet Carrillejo Isasi. & Verticales" \\
& - & Marina García de León Pintado. & \\
& - & Paula Serrano Castro. & \\
\hline $2^{\circ}$ ESO D & - & Rodrigo Palomares Céspedes & Proyecto: “App Ciudad \\
\hline
\end{tabular}

Fuente: Elaboración propia 


\section{Estándares trabajados.}

Se entiende por competencia la capacidad de poner en práctica de forma integrada, en contextos y situaciones diferentes, los conocimientos, las habilidades y las actitudes personales adquiridos. Las competencias tienen tres componentes: un saber (un contenido), un saber hacer (un procedimiento, una habilidad, una destreza, etc.) y un saber ser o saber estar (una actitud determinada), (Martín y Vázquez, 2017)

El trabajo con los alumnos ha supuesto el trabajo de las siguientes competencias:

1.-Comunicación lingüística $(\mathrm{CCL})$

2.-Competencia matemática y competencias básicas en ciencia y tecnología (CMCT)

3.-Competencia digital (CD)

4.-Aprender a aprender (AA)

5.-Competencias sociales y cívicas (CSC)

6.-Sentido de iniciativa y espíritu emprendedor (SIEE)

7.-Conciencia y expresiones culturales (CEC)

Igualmente se han conseguido superar diversos de estándares relacionados con las competencias adquiridas y los contenidos trabajados como ha quedado de manifiesto en los diferentes trabajos realizados.

Tabla 5 - Estándares trabajados

\begin{tabular}{|c|c|c|}
\hline & ESTÁNDARES TRABAJADOS DE LAS DISTINTAS ÁREAS & COMPETENCIAS \\
\hline 1. & $\begin{array}{l}\text { Analiza y compara a través de tablas estadísticas, gráficos y mapas } \\
\text { los indicadores demográficos necesarios para el estudio de la } \\
\text { población en Ciudad Real }\end{array}$ & СMCT \\
\hline 2. & $\begin{array}{l}\text { Comenta y utiliza gráficos de distinto tipo (lineales, de barra y de } \\
\text { sectores) y mapas temáticos. }\end{array}$ & CMCT y CCL \\
\hline 3. & $\begin{array}{l}\text { Investiga utilizando las Tic's sobre un tema histórico o geográfico } \\
\text { siguiendo el método científico. }\end{array}$ & CD \\
\hline 4. & $\begin{array}{l}\text { Utiliza mapas digitales para localizar puntos geográficos y } \\
\text { solucionar problemas de tipo geográfico. }\end{array}$ & CD \\
\hline 5. & $\begin{array}{l}\text { Realiza trabajos y presentaciones a nivel individual y grupal que } \\
\text { suponen la búsqueda, selección y organización de textos o } \\
\text { herramientas }\end{array}$ & CAA, CD y CCL \\
\hline 6. & $\begin{array}{l}\text { Elabora gráficos de distinto tipo (lineales, de barra y de sectores) y } \\
\text { mapas temáticos en soportes virtuales o analógicos que reflejen } \\
\text { información de países o áreas geográficas a partir de los datos }\end{array}$ & CMCT \\
\hline
\end{tabular}




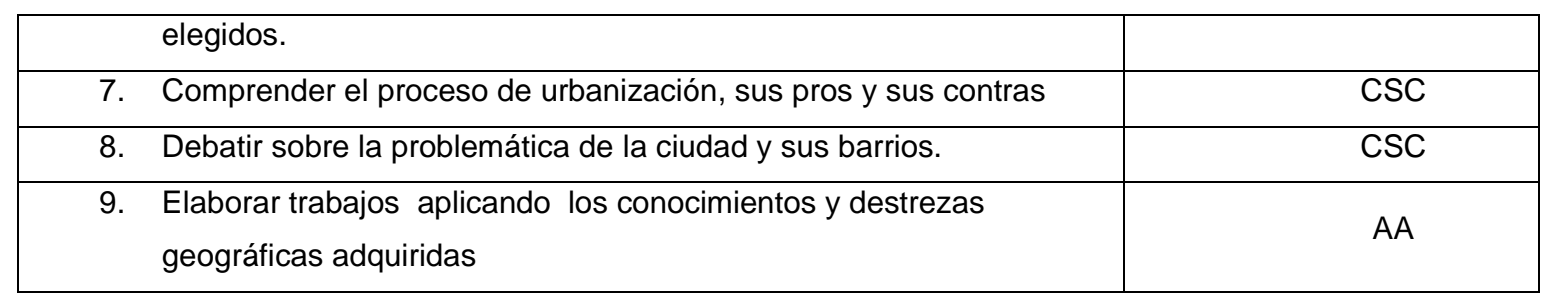

Fuente: Elaboración propia

\section{Conclusión}

Si la primera edición del Proyecto Nosotros Proponemos fue muy enriquecedora, esta segunda afianza el proyecto, siendo la experiencia un elemento muy importante para poder mejorar los estudios de casos de nuestra ciudad y sus posibles soluciones.

El tabajar de forma grupal, entre compañeros de clase, con la supervisión de los profesores, ha supuesto una mayor imbricación y conocimiento de la ciudad, pudiendo ver de cerca la problemática del espacio que nos rodea y la preocupación por encontrar soluciones.

Los alumnos han tenido que exponer sus trabajos ante alumnos de otros centros, hablar en público en el Ayuntamiento, exponer sus trabajos en la universidad de Castilla la Mancha y en el paraninfo de la Universitat de Valencia. Durante un fin de semana han convivido con alumnos de otros centros de distintas edades y con profesores, han visitado la ciudad de Valencia, etc.

Además, para la realización del trabajo han tenido que hacer uso de las TIC: Google maps, Google Earth, fotografías, móviles etc., que les ha permitido conocer mejor su ciudad y el espacio que les rodea (Geografía del Entorno).

Todo el proyecto ha sido bastante seguido por la prensa y televisión local, lo que ha estimulado también a los alumnos, puesto que sus trabajos no han quedado sólo en sus centros, sino que han tenido una mayor difusión.

\section{Bibliografía}

Claudino, S. (2013), “A Cidade, um laboratório para a educação geográfica” , O Projeto “ Nós Propomos! Cidadania e inovação na educação geográfica 2012/13” E a mobilização do "estudo de caso" do $11^{\circ}$ ano, en Atas do VI Congresso Ibérico de Geografia, Lisboa., pp. 151-164

Claudino, S. (2016) "Projeto nós propomos!: tentar mudar a educação geográfica em pequenos passos" en Rafael Sebastiá Alcaraz y Emilia María Tonda Monllor: La 
investigación e innovación en la enseñanza de la geografía. Universidad de Alicante. pp. $661-668$

Martín, J. y Vázquez, M.L., (2017). "Nosotros Proponemos: Un proyecto lbérico para la enseñanza Secundaria" en A.C. Câmara; E. Sande; M.H. Nagro, eds. Educação Geográfica na Modernidade Líquida. Lisboa: Associação de Professores de Geografia, pp. 260-270

Martín, J y Vazquez M.L. (2018) "La experiencia educativa en el aula"en Rodríguez Domenech, M.A. y Claudino, S. Coords. "Nosotros Proponemos!. Ciudadanía, sostenibilidad e onnovación geográfica ante los desafíos educativos de la sociedad". Barcelona. Ed. Graó. pp. 107-116.

Rodríguez-Domenech, M.A. y Claudino, (2018) S. "Principios y base metodológica del proyecto “¡Nosotros Proponemos”! en Rodríguez Domenech, M.A. y Claudino, S. Coords. “iNosotros Proponemos!. Ciudadanía, sostenibilidad e onnovación geográfica ante los desafíos educativos de la sociedad”. Barcelona. Ed. Graó. pp.19-38.

\section{Webgrafía}

Martín, J., "Blog de Geografía del profesor Juan Martín Martín":

http://blogdegeografiadejuan.blogspot.com/p/proyecto-nosotros-proponemos.html [Último acceso 20 de octubre 2018]

Nos Propomos. Portugal: http://nospropomos2016.weebly.com/ [Último acceso 20 de octubre 2018]

Nosotros Proponemos. España: http://www.nosotrosproponemos.com/ [Último acceso 20 de octubre 2018] 


\title{
Potencialidades del dron (drone) en el Proyecto Nosotros Proponemos
}

\author{
JUAN MARTín MARTíN ${ }^{1}$ \\ MARÍA LUISA VÁZQUEZ SÁNCHEZ
}

\section{Resumen}

Desde hace años venimos presenciando como la tecnología está extendiéndose por todos los ámbitos., lo que nos obliga a los docentes a sacarle toda la utilidad posible para el ámbito de la educación y, especialmente en nuestro caso, para la Geografía. La educación y los profesores no podemos mantenernos al margen y debemos adaptarnos a esta revolución tecnológica que vive nuestra sociedad, además nuestros alumnos son cada vez más tecnológico y por ello las TIC forman parte de sus vidas. No se trata de saber manejar los distintos aparatos tecnológicos que a un ritmo vertiginoso irrumpen casi a diario en el mercado, sino de saber utilizar y aplicar a la Geografía para un mejor conocimiento de ésta. Uno de los últimos dispositivos tecnológicos que ha irrumpido con fuerza en el mundo de la información, comunicación y estudio del espacio geográfico ha sido el dron o drone (vehículo aéreo no tripulado). El uso del dron y la aplicación de la dronegeografía nos debe ayudar a identificar mejor los problemas territoriales o socio territoriales contribuyendo así al trabajo de campo desarrollado por el Proyecto Nos Propomos!.

Palabras clave: Nosotros Proponemos, dron, TIC, didáctica de la Geografía, enseñanza secundaria

\section{Resumo}

Durante anos, temos visto como a tecnologia se está difundindo em todas as áreas, fazendo com que os professores tirem o maior proveito no ámbito da educação, especialmente, no nosso caso, para a Geografia. A educação e os professores não podem ficar à margen e temos de nos adaptar a esta revolução tecnológica que afeta a sociedade, visto que nossos alunos estão cada vez mais tecnológicos e, portanto, as

\footnotetext{
${ }^{1}$ Profesores del Departamento de Geografía e Historia del IES Hernán Pérez del Pulgar de Ciudad Real, juanmartinmartin@gmail.com, geografia.ies.hernan@gmail.com luisavazquezsanchez@hotmail.com,
} 
TIC fazem parte de suas vidas. Não se trata de saber como lidar com os diferentes dispositivos tecnológicos que surgem diariamente no mercado, a um ritmo frenético, mas de como usar e aplicar a Geografia para a entender melhor. Um dos mais recentes dispositivos tecnológicos que surgiram no mundo da informação, comunicação e estudos da área geográfica tem sido o Drone (veículo aéreo não tripulado). O uso de drones e a aplicação na dronegeografia debe-nos ajudar a identificar melhor os problemas territoriais ou sócio-territoriais, contribuindo, assim, para o trabalho de campo desenvolvido no Projeto Nós Propomos!

Palavras-chave: Nós Propomos, drone, TIC, Didática da Geografia, ensino secundário,

\section{Introducción}

La preocupación por incorporar las TIC en nuestra vida cotidiana y sobre todo en la educación ha sido tal, que la Comisión Europea adoptó en enero de 2018 un Plan de Acción de Educación Digital que incluía 11 iniciativas para apoyar el uso de la tecnología y el desarrollo de competencias digitales en educación.

El plan de acción tiene tres prioridades, que establecían medidas para ayudar a los Estados miembros de la UE a afrontar los desafíos y las oportunidades de la educación en la era digital:

- Prioridad 1: Hacer un mejor uso de la tecnología digital para la enseñanza y el aprendizaje

- Prioridad 2: Desarrollar competencias y habilidades digitales

- Prioridad 3: Mejorar la educación a través de un mejor análisis de datos y previsión.

El uso del dron potencia la aplicación de las TIC en el aula y con el tiempo su uso se va a convertir en una herramienta cada vez más utilizada y con mayor proyección en las aulas debido las aplicaciones en diferentes campos educativos. (Martín y Vázquez 2017)

El interés por el desarrollo y la aplicación de los drones en educación y en las aulas ha ido en aumento. La Organización Internacional para la Innovación y Tecnología en Educación (IOITE) puso en marcha en el año 2014 un proyecto mundial para desarrollar robots y drones que puedan tener utilidad en las aulas. La idea es que estas herramientas facilitaran la tarea de proceso enseñanza-aprendizaje a los docentes, alumnos y padres, y además, que ayudaran a aprender con herramientas digitales de nuestro tiempo. También se puso en práctica el denominado Plan de 
Acción y Apertura a la Educación (Opennig up education) elaborado por la Comisión Europea, cuyos objetivos buscaban:

1. Crear oportunidades de innovación para las organizaciones, los profesores y los alumnos.

2. Aumentar el uso de los recursos educativos abiertos (REA), garantizando así que los materiales producidos con financiación pública sean accesibles a todos;

3. Mejorar la infraestructura en materia de TIC y de conectividad en los centros de enseñanza.

La aplicación de los drones y los robots en el aula como elemento educativo están en proceso de adaptación en muchos países. En el caso de Finlandia, se ha comprobado ya su éxito, razón por la cual se pretende continuar su expansión en otros países, pudiendo ser España uno de los países en la vanguardia, siempre que Administración y profesorado colaboren de forma conjunta. (Martín y Vázquez 2017)

\section{Qué es un dron (drone)}

Un dron es un vehículo aéreo no tripulado, que se dirige mediante un control remoto y que puede elevarse y girar en todas las direcciones. En funcón de sus hélices pueden ser cuadricópteros (los más usados), hexacópteros y octacópteros. Para mantener el equilibrio unas hélices giran en sentido de las agujas del reloj y las otras en sentido contrario.

\section{Partes y elementos de las que se compone un dron}

El dron cuenta con un cuerpo central, muy ligero, al que le añadimos unas baterias específicas para cada modelo (es la parte más pesada). La duración de las bateriás puede oscilar entre los 10 y los 30 minutos, según la calidad del dron.

El cuerpo central suele tener diferentes sensores, como varios gps, y otros que permiten esquivar obstáculos en todas las direcciones, una cámara para fotografía y vídeo., etc.

Los sensores del gps son tan exactos que son capaces de indicar la altura, la velocidad e incluso están preparados para poder volver automáticamente al punto de partida y aterrizar solos, en caso de ser necesario.

Respecto a la velocidad y altura que pueden alcanzar, hay que comentar que depende de la complejidad y calidad del dron, pudiendo alcanzar los $70 \mathrm{~km} / \mathrm{h}$, altura de hasta 500 metros y distancia de vuelo controlado de varios $\mathrm{km}$. Algunos modelos vienen 
limitados de fábrica según la legislación del país. De no ser así, bajo ningún concepto debemos infringir la normativa vigente en cada país o CCAA.

El continúo avance de la tecnología está permitiendo incorporar cámaras (para fotografía y vídeo) cada vez más completas y complejas pudiendo usar zoom (sin necesidad de acercarnos a un objeto), grabar en full HD y $4 \mathrm{k}$ y poder seleccionar en la cámara desde la sensibilidad, el obturador, tecnología HDR, incorporar filtros, etc casi como una cámara reflex. Todas las imágenes y grabaciones de vídeos quedan recogidas en la memoria interna o en una tarjeta extraible (SD, micro...) que puede ser descargada posteriormente en un ordenador.

Finalmente el dron necesita una emisora inalambrica para poder manejarlo y transmitir lás órdenes a distancia al dron, para ello necesita crear una red wifi ayudado de unas potentes antenas que usan unas frecuencias específicas. Últimamente se está utilizando el smarphone como emisora, pudiendo visulaizarse en él el vuelo en directo, como si fuera un monitor y usando su sistema táctil para manejarlo gracias a unos programas y app específicos.

Como complemento para un mejor manejo y pilotaje del dron podemos usar gafas de Realidad Virtual pudiendo visualizar en primera persona y en tiempo real como si estuviéramos manejado el dron desde su interior. Este tipo de pilotaje y visión se denomina FPV (First Person View). Su uso debe estar acomodado a una normativa específica.Todos los vuelos quedan geolocalizados en una app (altura, velocidad, mapa del vuelo, etc)

\section{Potencialidades del dron}

¿Se puede usar en el dron con la metodolgía del Proyecto Nosotros Proponemos? ¿Como podemos incorporar toda esta tecnología tan moderna y al mismo tiempo tan de actualidad al Proyecto Nosotros Proponemos?

Desde los orígenes del Proyecto Nosotros Proponemos en Portugal en el curso 20112012, éste ha crecido exponencialmente, no solo en centros, profesorado y alumnos, sino también en universidades, ciudades y países, con presencia en tres continentes. Seguramente cuando el IGOT (Instituto de Ordenación del Territorio de Lisboa) inició su andadura era dificil imaginar la dimensión que podía obtener en tan poco tiempo.

El objetivo principal del proyecto era incorporar a los alumnos de primaria y secundaria para que éstos detectaran e identificaran problemas cotidianos de su ciudad y de su entorno y plantearan unas soluciones a la administracion, (preferentemente a los ayuntamientos). De esta forma se sentirían protagonistas de su ciudad, haciéndola más habitable y asumiendo una mayor concienciación social, además de fomentar la 
participación en grupos de trabajo multidisciplinares. (Rodriguez-Domennech, M.A y Claudino. S. 2018)

El paso de los años nos ha llevado a una renovación pedagógica en las aulas. La incorporación de las TIC, y el aumento de de las tecnologías en nuestra vida cotidiana ha influido directamente en la forma de dar las clases, trabajar con los alumnos y abordar los trabajos grupales de forma diferente. Todos estos motivos nos ayudado a incorporar paulativamente estas cuestiones al Proyecto Nosotros Proponemos.

Desde hace algunos años venimos trabajando en el aula, y difundiendo en diferentes Congresos de geografía las potencialidades de los drones a la enseñanza de la geografía. Por ello consideramos que era factible la incorporación de la dronegeografía al Proyecto Nosostros proponemos.

A esta herramienta que trata de relacionar el uso de los drones con la geografía, pero con un uso didáctico y de investigación se le ha denominado dronegeografía (Martín y Vázquez 2016.).

\section{Potencialidades del dron y su aplicación al Proyecto Nosotros Proponemos.}

La proliferación de los drones ha hecho que éstos empiecen a formar parte de nuestras vidas y ya no nos resulten tran extraño su uso en multitud de actividades.

La dronegeografía puede suponer no sólo una motivación para los alumnos, sino también una innovación y una revolución para la enseñanza de la geografía y para el Proyecto Nosotros Proponemos.

El ambito de aplicación de la dronegeografía abarca toda la enseñanza, desde la primaria hasta la secundaria (en primaria en menor medida), pero será en la enseñanza universitaria, donde se pueda obtener mejores resultados a partir de la investigación, siendo una herramienta muy útil tanto para el profesorado como para los alumnos.

Una de las ventajas del uso del dron en la enseñanza es la posibilidad de conocer y profundizar en la geografía del entorno, es decir, la geografía más cercana y así conocer y comprender el espacio que nos rodea.

El Proyecto Nosotros Proponemos trata precisamente de eso, de conocer el espacio que nos rodea con el fin de dar respuestas y soluciones a problemas muy concretos, convirtiéndose el dron en una ayuda indispensable y complementaria.

Con el uso del dron, el alumno va a poder comprobar de primera mano una perspectiva aérea hasta ahora solo posible a través de documentales o contratando un helicóptero u otros sistemas extremadamnete caros. Además las imágenes del dron nos dan una visión actualizada y real del momento. 
Como antes comentábamos, el dron lleva incorporado una cámara con la que puedes realizar grabaciones de vídeo o bien fotografías, pudiendo mover el objetivo y dirigirlo al punto de interés. Algunos drones están ya incorporando la función de zoom, lo que puede ayudarnos a grabar o fotografiar sin necesidad de acercarnos al espacio deseado (muy útil en espacios urbanos, donde no se debe sobrevolar por su peligrosidad sobre las personas). De esta forma se puede recoger información y visualizarla en directo o bien con posterioridad una vez descargados los archivos.

Las actividades y temática que se pueden trabajar con drones para geografía y para el Proyecto Nosotros Proponemos puede ser amplia y diversa, entre las que puede destacar:

\subsubsection{Espacio urbano}

Uno de los espacios con más posibilidades para trabajar con los alumnos es el relacionado con la ciudad, que es el espacio más cercano y donde se detectan los problemas que más importan a los alumnos.

En este mundo urbano pueden trabajar el patrimonio artístico, estudiar y conocer la morfología de la ciudad, la altura de los edificios o la situación de los barrios marginales, con elfin de llegar a establecer unas conclusiones y ofrecer posibles soluciones.

Vamos a mostrar diversas fotografías que hemos tomado con el el dron y que pueden servir de ejemplo para ver las posiblidades de trabajo con los alumnos:

Conocer la morfología de barrios, espacios verdes, altura de los edificios, etc.

Imagen 1- Barrio de la Granja. Ciudad Real

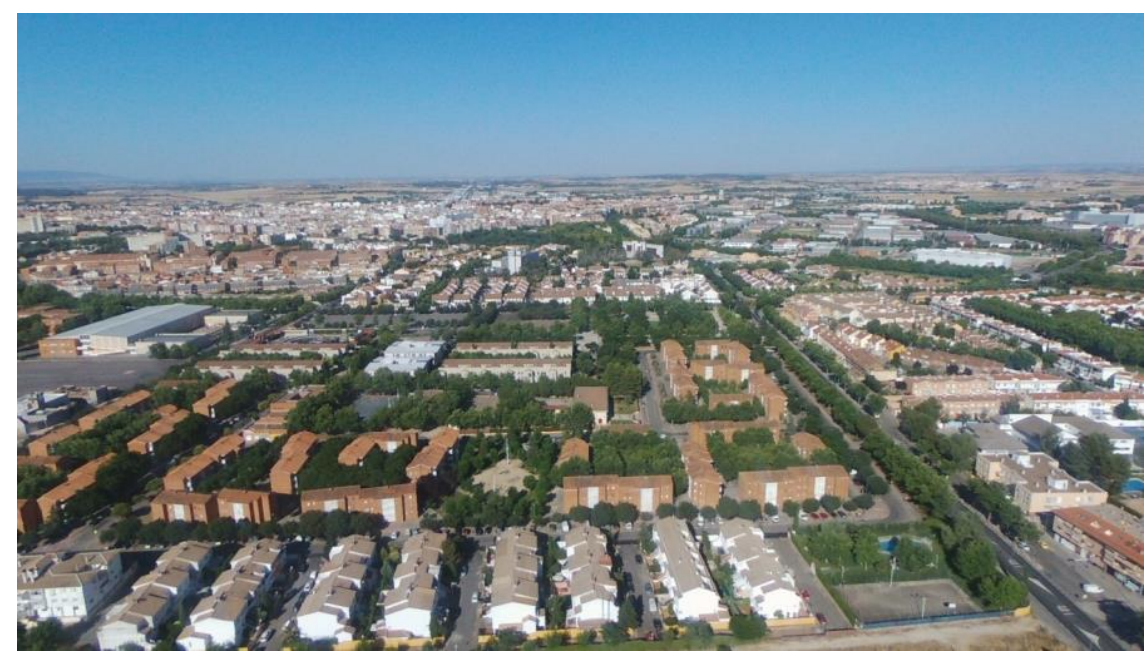

Fotografía de los autores 


\subsubsection{Infraestructuras y comunicaciones}

Las grandes infraestructuras y las comunicaciones son aspectos de gran importancia para la vida, como las carreteras, puertos, aeropuertos, etc., que ocupan un espacio importante y que a veces generan edificios, hangares, $u$ otras instalaciones que quedan desocupadas y abandonadas y que pueden ser recuperadas para la ciudad, dando soluciones, por parte de los alumnos, tal y como pretende el Proyecto de Nosotros Proponemos.

Imagen 2- Puerto de Gandía con parte sus instalaciones

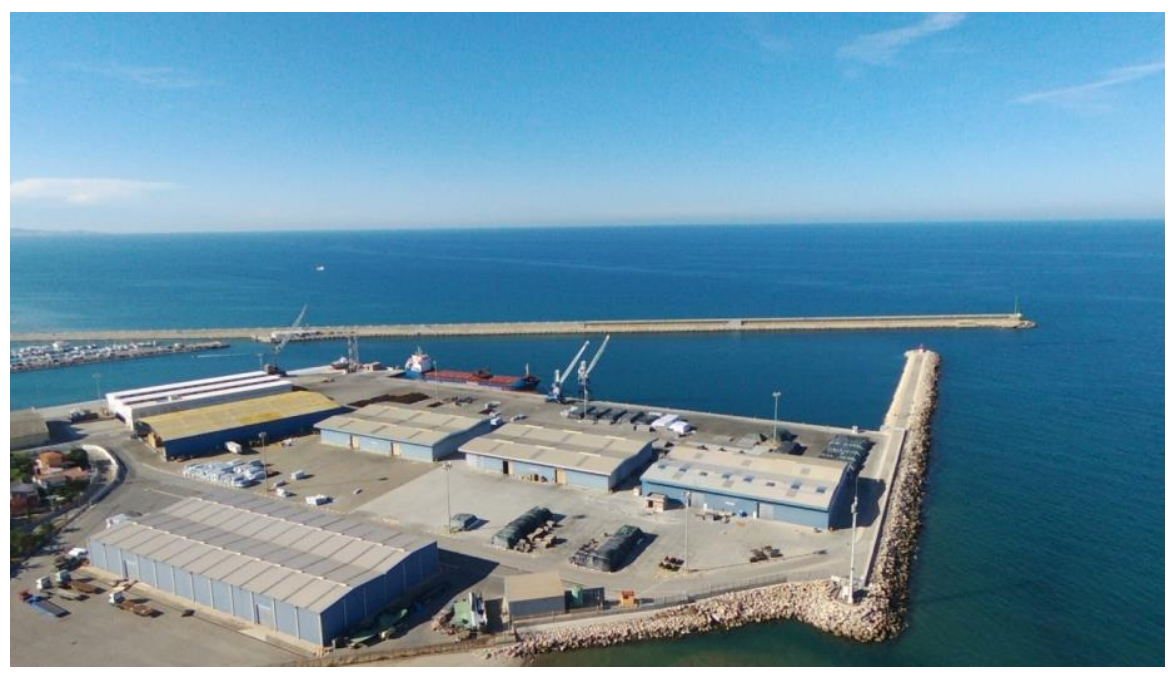

Foto de los autores

\subsubsection{Patrimonio artístico, cultural y arqueológico}

Otro de los usos del dron y que nos ofrece grandes potencialidades es la posibilidad de comprender y conocer mejor nuestro patrimonio artístico, cultural y arqueológico.

El uso del dron nos permite una visión aérea, real y en el momento, pudiendo ser una ayuda para detectar problemáticas y poder proponer posibles soluciones (como en iglesias, ermitas, palacios, castillos, yacimientos arqueólogicos, etc.). 
Imagen 3- Restos arqueológicos en el cerro de Alarcos (Ciudad Real).

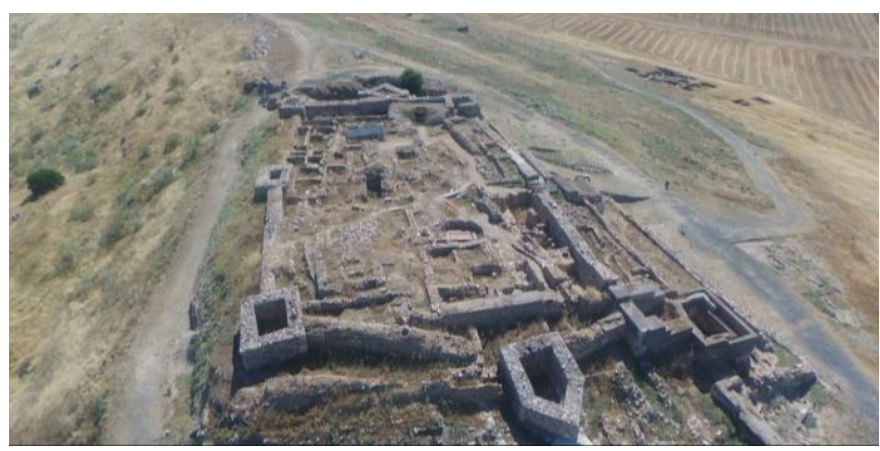

Foto de los autores

\subsubsection{Control y protección del medioambiente, ríos, embalses, vegetación,} cultivos...

La utilidad y potencialidad del dron es casi infinita, pues puede actuar en casos de incendios, evaluando al terreno y evitando pérdidas de vidas humanas.

Es también importante conocer el estado de nuestro ríos y embalses y del espacio que le rodea como la vegetación, tipos de suelo, etc.

Desde el aula hemos trabajado con los alumnos en el conocimiento y análisis de espacios protegidos en zonas de playa como las dunas y su vegetación autóctona que, en muchas ocasiones, había sido eliminada por el "consumo excesivo" del suelo como consecuencia del turismo.

Nuestros alumnos en algunos de sus proyectos han evaluado la importancia de nuestros ríos, embalses y aguas en general como elemento imprescindible para el desarrollo de la vida y han detectado cómo un mal uso puede tener graves consecuencias para el ecosistema.

Imagen 4 - Embalse del Vicario sobre el río Guadiana. Ciudad Real

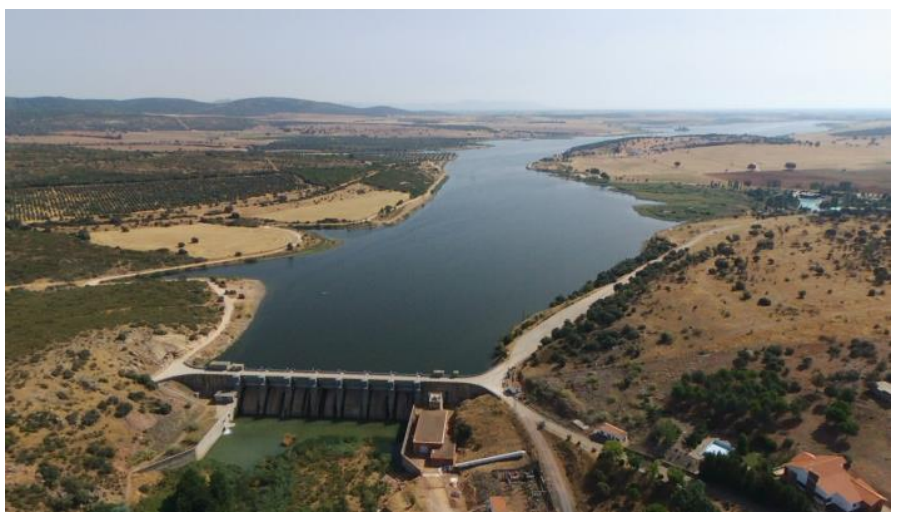

Foto de los autores 
Los espacios rurales y agrícolas ocupan la mayor parte de nuestro territorio español y en ellos se produce la mayoría de nuestro alimentos. En ellos se encuentra una rica biodiversidad que tiene un gran impacto en el medioambiente.

Uno de los problemas en el espacio rural es el abandono de las actividades agrícolas, debido tanto a su bajo rendimiento como a la competencia con otros mercados exteriores de menor coste, lo que ha supuesto un aumento del envejecimiento de la población agrícola en España.

Hemos seleccionado algunas imágenes que han sido analizadas por los alumnos para un mejor conocimiento del espacio rural y agrícola, las características de los espacios de regadío, de secano, el latifundismo, minifundismo, su productividad, la protección del monte, etc.

Imagen 5 - Las huertas y el uso del regadío.

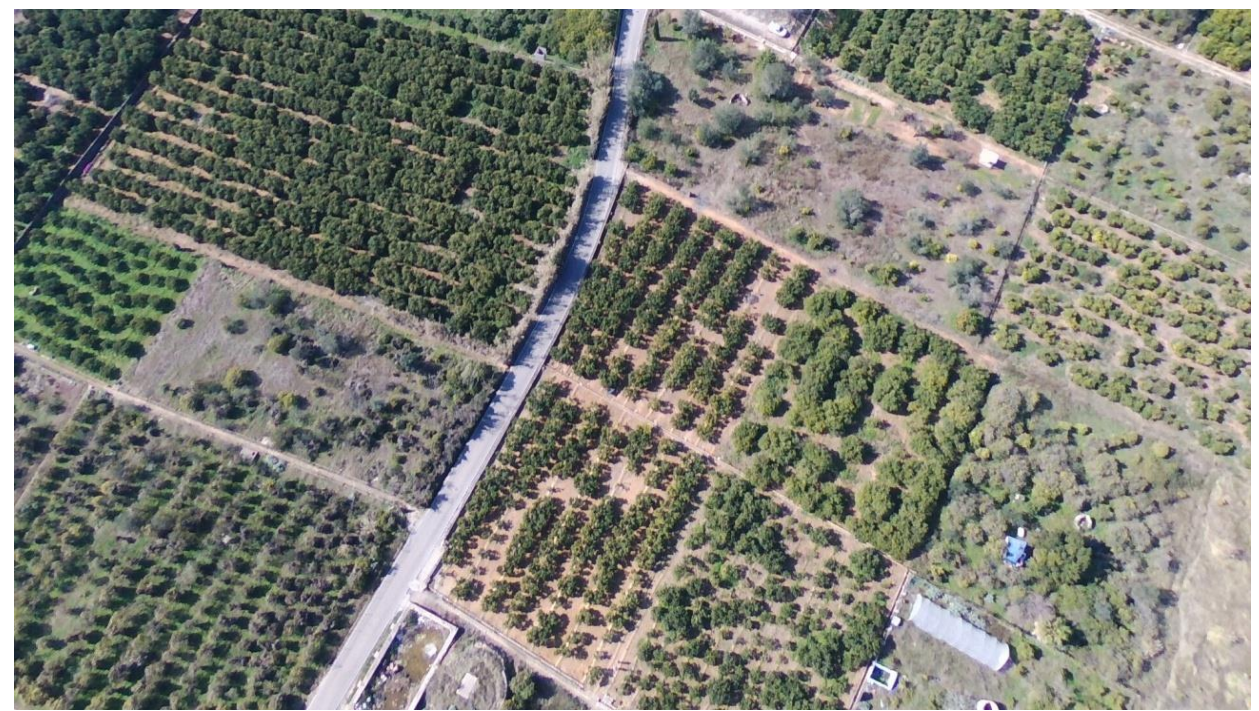

Foto de los autores 
Imagen 6- Cultivo del cereal, dehesas y monte de encinas.

Campo de Montiel. Alhambra. Ciudad Real.

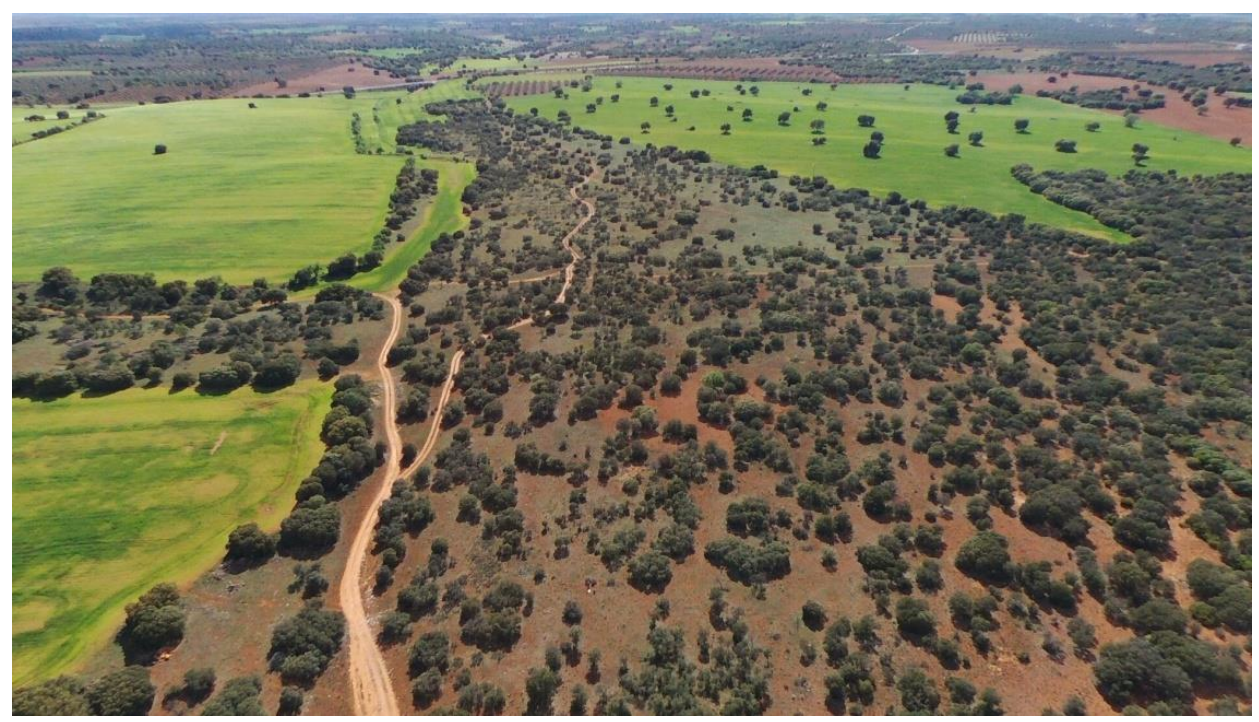

Foto de los autores

\subsubsection{Estudios y análisis de conjunto (Vegetación, acantilados, erosiones, playas, espacios turísticos de recreo, edificaciones). Turismo sostenible...}

A veces el dron nos ayuda a poder realizar un estudio de conjunto en el que se valoran multiples elementos y variables con el fin de dar soluciones por parte de los alumnos para posibles Proyectos de Nosostros Proponemos.

A continuación ponemos un ejemplo de la localidad de Xàbia (Jávea) en Alicante, junto al Mediterráneo, en la zona conocida como el Portixol, cercano al cabo de la Nao, al cap Negre, cap Prim, donde podemos estudiar desde la vegetación, el relieve de los Sistemas Béticos con sus acantilados, la erosión producida por las cárcavas sobre una litología caliza, el retroceso de sus playas, la vegetación de pinos carrasco. Las actiividades recreativas en el mar (alquiler de yates, motos de agua y otro tipo de embarcaciones), las abundantes urbanizaciones diseminadas (muchas de ellas para extranjeros) que colonizan gran parte del término municipal de Jávea (Xàbia), con un clima agradable todo el año

En esta ocasión el uso de la dronegeografía en el aula, nos ofrece una visión de conjunto excepcional, y sobre todo la importancia de que nuestros alumnos puedan aportar ideas para mejorar un turismo sostenible, que no altere el medioambiente en esta zona del Mediterráneo a veces frágil. 


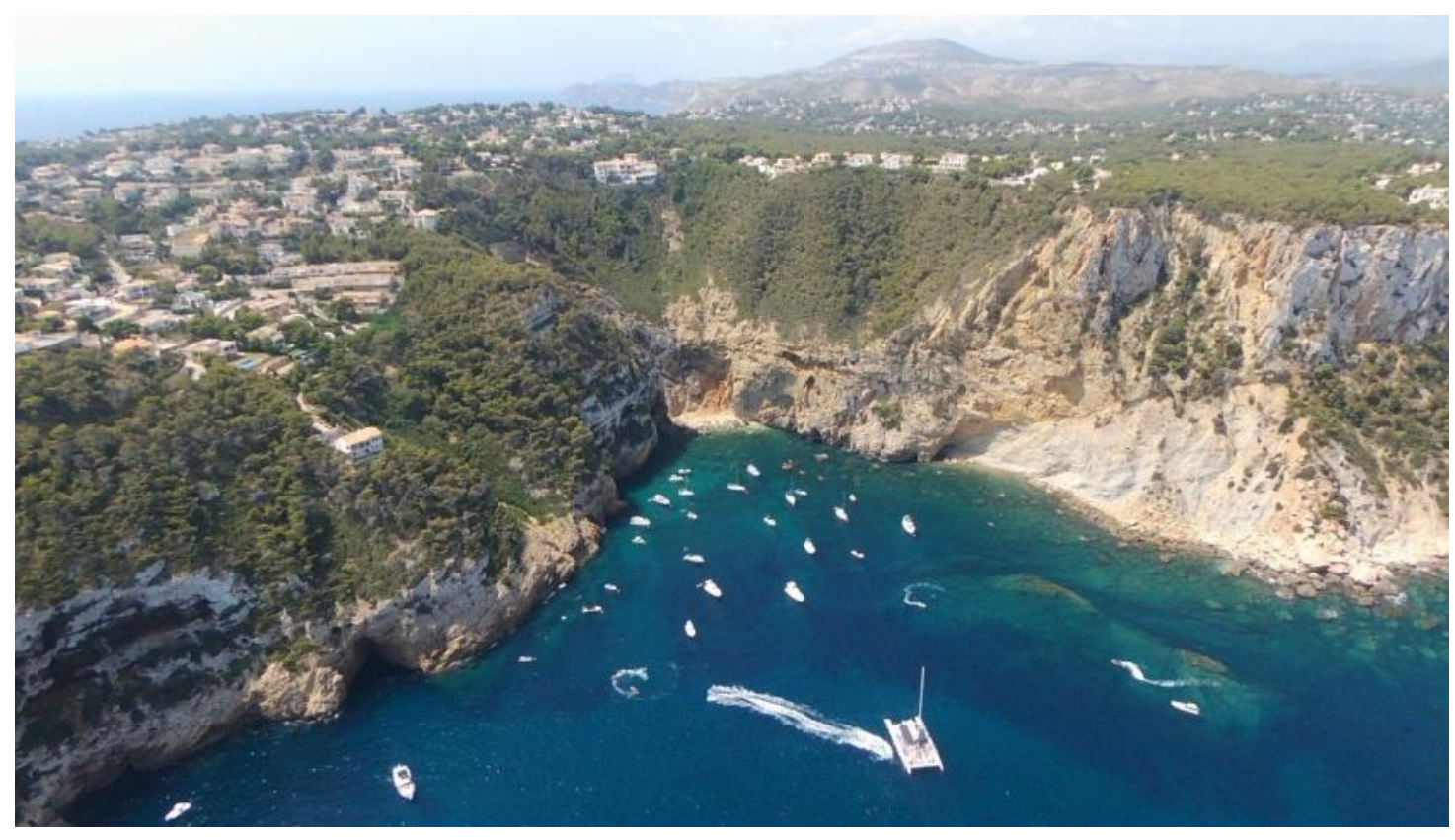

Foto de los autores

En las siguientes imágenes (18 y 19) tomadas con un dron podemos comparar y comentar con los alumnos la disposición de los cabos, de los acantilados, su litología, las bahías y pequeñas calas que se forman, características de los Sistemas Béticos y su relación con el litoral mediterráneo, la vegetación y cómo ésta puede frenar los procesos erosivos. etc.

Igualmente se pueden estudiar las características del turismo, tipos de urbanizaciones, tipología de las viviendas y su disposición, la localización del núcleo de población de Jávea, las actividades naúticas, consecuencias positivas y negativas del turismo, etc.

En la segunda imagen (19) aparecen indicaciones didácticas para ayudar a comprender mejor este paisaje alicantino. 
Imagen 8. El Portixol. Jávea (Xàbia) Alicante

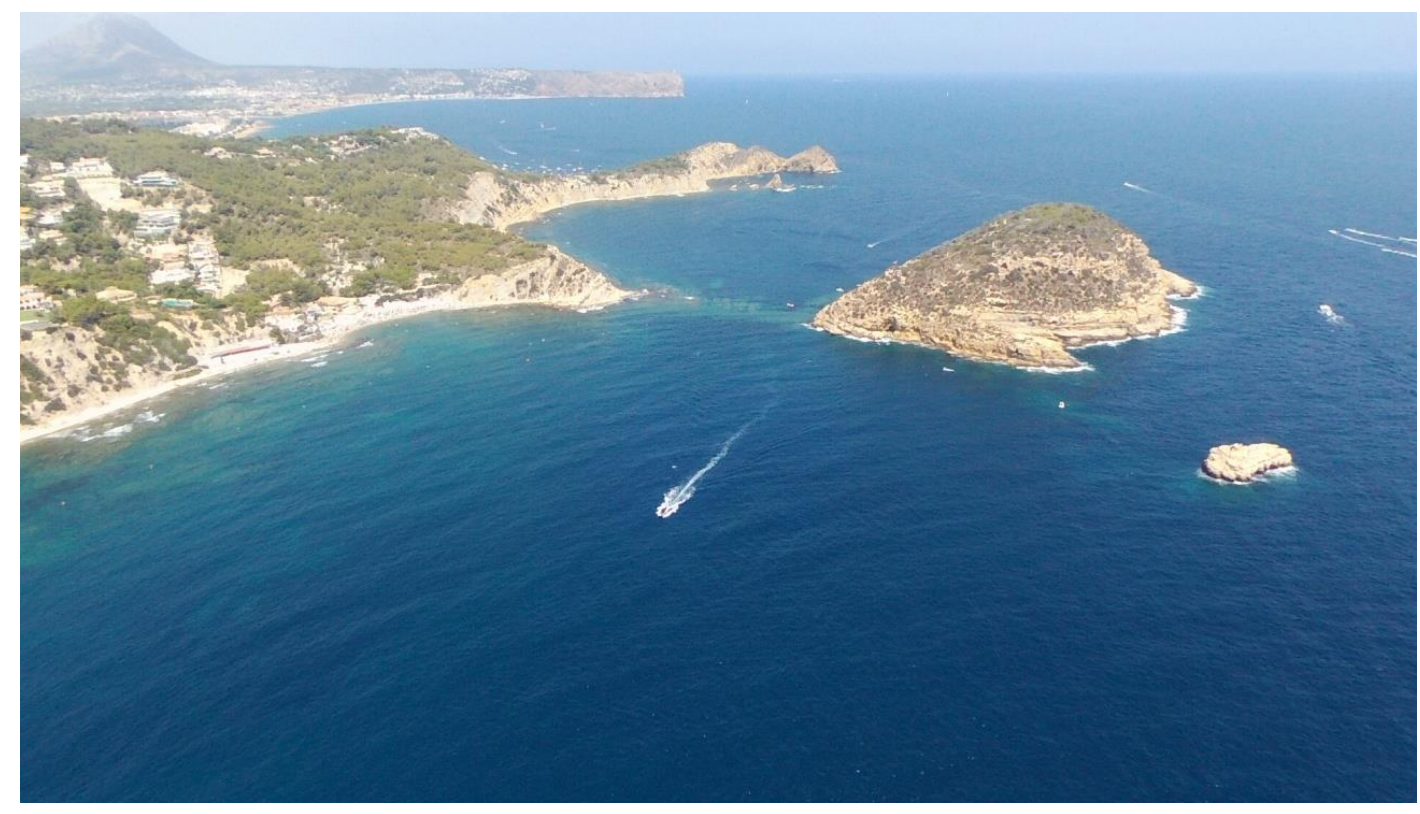

. Foto de los Autores.

Imagen 9 - Explicación didáctica del Portixol. Jávea (Xàbia) Alicante

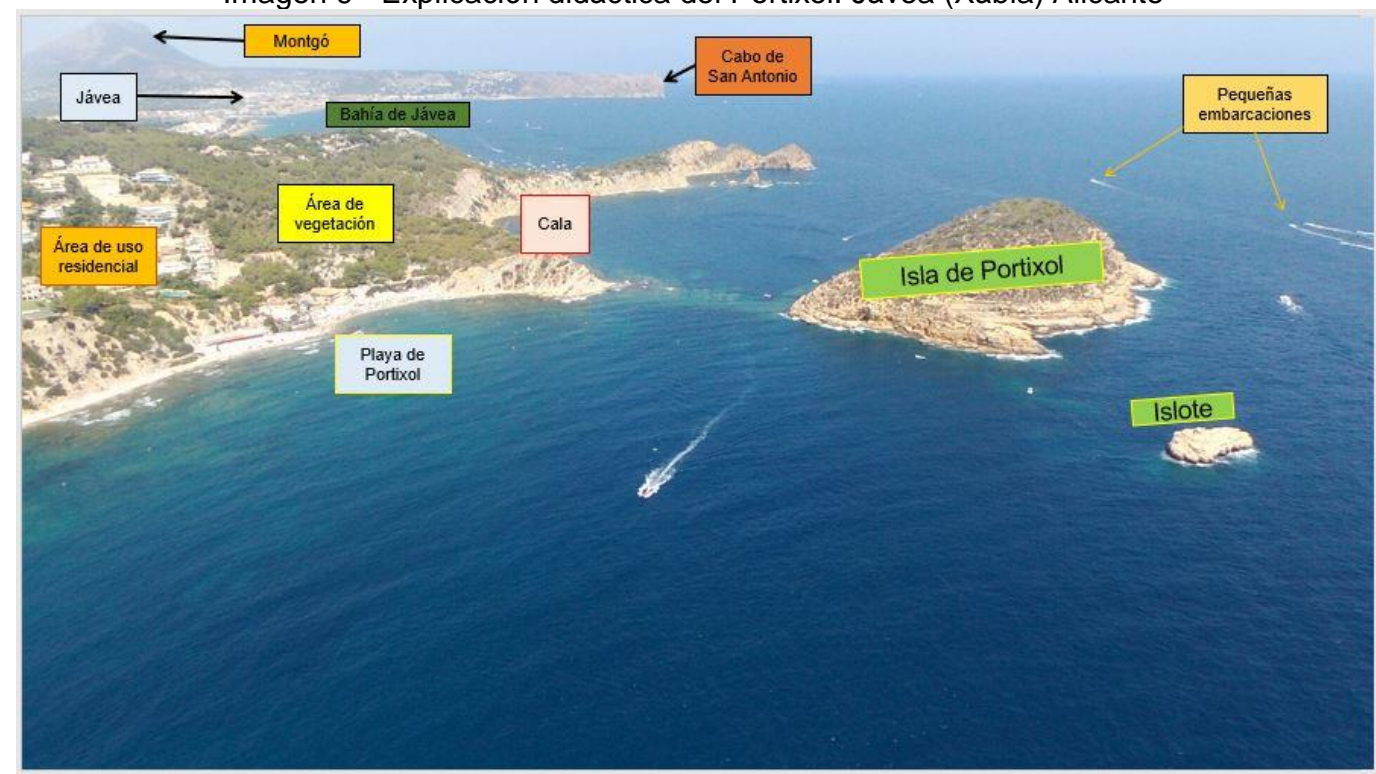

. Fuente: Juan Martín y Rafael Fdez. 


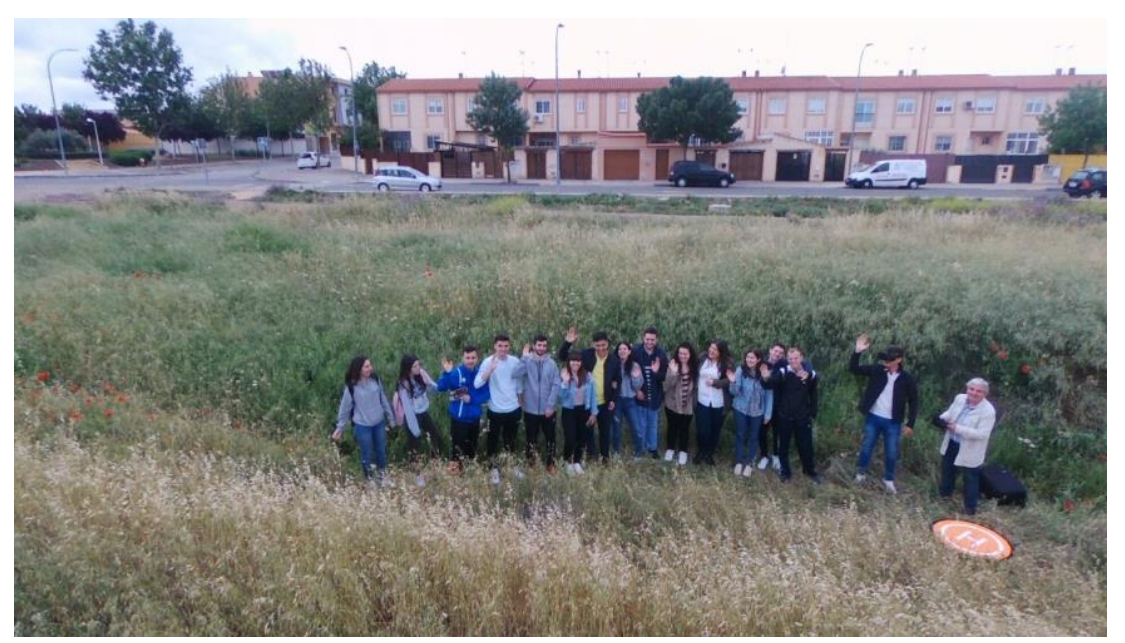

Foto de los Autores.

\section{Legislación}

Probablemente una de las preguntas que nos podemos hacer es si uno puede volar libremente el dron o hay unas limitaciones.

Antes de usar un dron o un dispositivo similar debemos de conocer la normativa vigente en cada momento y en cada país.

El uso de estos aparatos estaba regulado (hasta hace unos meses) en España por el R.D. 57/2002 y el R.D. 552/2014. sin embargo, desde finales de 2017, debemos remitirnos al Real Decreto 1036/2017, de 15 de diciembre, por el que se regula la utilización civil de las aeronaves pilotadas por control remoto y se modifican los dos anteriores. Para el uso en el Proyecto Nosotros Proponemos tendríamos que tener en cuenta todas las cuestiones referidas al uso recreativo de estos dispositivos, pues el fin es didáctico y no comercial o profesional.

Por ejemplo, no se puede realizar vuelos sobre núcleos urbanos o núcleos de población diseminados, o reuniones de personas al aire libre, salvo que la aeronave tenga un máximo de 250 gramos de peso y no opere a más de 20 metros de altura. Asimismo, no se podrá sobrevolar las zonas reservadas, prohibidas o restringidas a la navegación aérea (seguridad del Estado, centrales nucleares, etc), tal y como indica el artículo 23 del R.D. 1036/2017. Finalmente, no podemos dejar de mencionar el artículo 25 que autoriza la realización de vuelos nocturnos, siempre y cuando se solicite una autorización a la Agencia Estatal de Seguridad Aérea (AESA).

Uno de los aspectos más importantes es el de mantener la seguridad de las personas y enseres, por ello se podrá volar a una distancia horizontal del piloto, o en su caso de los observadores, no mayor de $500 \mathrm{~m}$ y a una altura sobre el terreno no mayor de 400 
pies $(120 \mathrm{~m})$ sobre el obstáculo más alto situado dentro de un radio de $150 \mathrm{~m}$ (500 ft) desde la aeronave.

Para facilitar el conocimiento del espacio donde se pretende volar y sus posibles restricciones hay webs, apps, etc que nos ayudan y orientan, como es el caso de la app Icarus RPA 0 similares (tanto para Andrid ó IOS) https://www.icarusrpa.info/mapa.php?opt=all que nos informan en un mapa con localización GPS sobre :

- Zonas prohibidas

- Zonas Peligrosas

- Zonas restringidas

- Zonas prohibidas al vuelo fotográfico.

- Zonas temporalmente segregadas

- Otras zonas protetegidas

- CTR

- Zepas.

- Etc.

\section{Blog y canal de YouTube}

\section{Blog de Geografía}

Todas las actividades realizadas en el Proyecto Nosotros Proponemos se recogen en el Blog de Geografía del profesor Juan Martín Martín, donde además de tener un espacio reservado a dicho proyecto y a la dronegeografía podemos encontrar información variada, con más de 2.000 post (artículos) y 600 vídeos sobre geografía en la enseñanza secundaria (ESO y Bachillerato), ejercicios diversos, resolución de exámenes, vídeos, etc.

\section{Canal de YouTube}

Las nuevas tecnologías y el interés por difundir la geografía en todos los ámbitos nos ha llevado a crear un Canal de YouTube con vídeos didácticos, algunos de ellos dedicados a la dronegeografía entre los que destacan:

\subsubsection{Vídeos con drones}


$\checkmark$ Intro canal YouTube: https://www.youtube.com/watch?v=KcjrprMV9GE

$\checkmark$ Los alumnos de geografía de bachillerato a vista de dron: https://www.youtube.com/watch?v=UVY5u1LrcPw

$\checkmark$ El Portixol de Jávea (Xàbia): https://www.youtube.com/watch?v=PwWZpPQGIY

$\checkmark$ El castillo de Bayren y las huertas de Gandía: https://www.youtube.com/watch?v=xs59GXgyVrk

$\checkmark$ Cantera del Arzollar: https://www.youtube.com/watch?v=s245mOnhBtw

$\checkmark$ Potencialidades del dron: https://www.youtube.com/watch?v=Vh$z 3 z 3 W 9 v w \& t=604 s$

\subsubsection{Vídeos de alumnos}

$\checkmark$ Paseo por Alcolea: https://www.youtube.com/watch?v=nB7zbT0kObs

$\checkmark$ Vía Verde de Ciudad Real: https://www.youtube.com/watch?v=A5WyHzVZgoQ

\section{Conclusión}

La llegada de nuevas tecnologías y de las aeronaves no tripuladas (drones) deben convertirse en una de las herramientas complementarias para el Proyecto Nosotros Proponemos, así como de materias como la geografía, la historia, las ciencias medioambientales, etc. facilitando un acercamiento y una motivación con el alumnado, y por lo tanto con la ciudadanía, la sostenibilidad y la innovación geográfica.

La utilización de estos dispositivos está generando un cambio en la forma de impartir Geografía en las aulas. La dronegeografía no se limita a realizar vídeos e imágenes para que el alumno pueda comentarlas sino que las posibilidades que oferta son muy amplias. Muchos de estos dispositivos llevan incorporado la función FPV (First Person View) que permite pilotar los drones en primera persona, pues a partir de la cámara se ve en tiempo real las imágenes y vídeos que se están realizando.

Pensamos que, su aplicación al aula y al Proyecto Nosotros Proponemos puede ser de gran utilidad pudiendo realizar salidas de campo con los alumnos, donde podrán manejar y ver en tiempo real el estudio a realizar.

Es probable que en un futuro no muy lejano muchos centros de secundaria y Departamentos universitarios cuenten con drones como método de estudio e investigación. 


\section{Bibliografía}

Buzo, I., 2015. "Aplicación de la metodología del aprendizaje geográfico por descubrimiento basado en SIG en proyectos didácticos para $2^{\circ}$ de Bachillerato" en Sebastiá R. y Tonda E. M., eds. La investigación e innovación en la enseñanza de la Geografía. Alicante: Universidad de Alicante, pp. 477-489.

Cálciz Baro, A., 2011: "Metodologías activas y aprendizaje por descubrimiento". Innovación y experiencias educativas, 40. CSIF. Granada

Martín, J. y Vázquez, M. L., 2016: “La Dronegeografía” en L. Alanís, J. A. Palma, G. de Oliveira, R. Iglesias y B. Pedregal, eds. Nativos digitales y geografía en el siglo XXI: Educación geográfica y sistemas de aprendizaje. Sevilla: Grupo de Didáctica de la Geografía. Universidad Pablo de Olavide, pp. 637-649.

Martín, J. y Vázquez, M.L., 2017. "El uso del dron como recurso didáctico en geografía: Experiencia en el aula“ en A.C. Câmara; E. Sande; M.H. Nagro, eds. Educação Geográfica na Modernidade Líquida. Lisboa:Associação de Professores de Geografia, pp. 146-158

Martín, J y Vázquez ML., 2018. "La experiencia educativa en el aula en el Proyecto Nosotros Proponemos" en Rodríguez Domenech, M.A. y Claudino, S. Coords. "iNosotros Proponemos!. Ciudadanía, sostenibilidad e onnovación geográfica ante los desafíos educativos de la sociedad”. Barcelona. Ed. Graó. pp 107-116.

Rodríguez Domenech, M.A. (2015): "La Geografía en la LOMCE ¿una ocasión perdida?" Boletín de la Asociación de Geógrafos Españoles. №67. pp 403-433.

Rodríguez Domenech, M.A. y Claudino, S. (2018) "Principios y base metodológica del proyecto “¡Nosotros Proponemos”! en Rodríguez Domenech, M.A. y Claudino, S. Coords. "iNosotros Proponemos!. Ciudadanía, sostenibilidad e onnovación geográfica ante los desafíos educativos de la sociedad". Barcelona. Ed. Graó. pp19-38.

\section{Webgrafía}

App Icarus RPA https://www.icarusrpa.info/mapa.php?opt=all

BOE. Legislación drones. https://www.boe.es/buscar/doc.php?id=BOE-A-2017-15721

Controldrom.com https://www.controldron.com/tag/real-decreto-10362017/ [Último acceso 15 de octubre 2018]

Martín, J., "Blog de Geografía del profesor Juan Martín Martín": 
http://blogdegeografiadejuan.blogspot.com.es/ [Último acceso 15 de octubre 2018] Nos Propomos. Portugal: http://nospropomos2016.weebly.com/ Nosotros Proponemos. España: http://www.nosotrosproponemos.com/ Pérez, J., "Política de Uso del Espacio Aéreo por parte las RPAS": https://es.slideshare.net/copacp/poltica-de-uso-del-espacio-areo-por-parte-de-rpasjess-prez-blanco-dgac [último acceso 15 de octubre 2018] 


\title{
Nós Propomos! Ensino e pesquisa de Geografia desde o estudo de caso
}

\author{
MAFALDA NESI FRANCISCHETT ${ }^{1}$ \\ SÉRGIO CLAUDINO² \\ ROSANA BIRAL LEME ${ }^{3}$
}

\section{Resumo}

Em resultado de uma parceria entre o IGOT-UL/PT e a UNIOESTE/BR, no âmbito do Projeto Nós Propomos!, está em desenvolvimento um conjunto de pesquisas centradas na prática dos professores e alunos de Geografia mobilizados no Projeto. Adotando uma perspectiva centrada da formação do sujeito e apostando na metodologia do Estudo de Caso, os estudantes são desafiados a identificarem problemas/desafios significativos da sua cidade; a pesquisarem sobre os mesmos, dando corpo a um trabalho de campo que deve ser caraterizador da educação geográfica e, por fim, a apresentarem propostas de ação - que se pretende, afinal, contribuir para a formação de cidadãos intervenientes, numa sociedade democrática e participativa. Desde 2017, o Projeto Nós Propomos! está se desenvolvendo em dois municípios da região Sudoeste do Paraná, Itapejara do Oeste e Pato Branco. No primeiro com estudantes do $8^{\circ}$ ano do Fundamental e, no segundo, com o $1^{\circ}$ ano do Ensino Médio. O lugar, a comunidade, constituem categorias extraordinariamente importantes, numa educação geográfica que se quer comprometida com a formação cidadã dos jovens. Assim, perpassa a necessidade de um olhar aprimorado sobre uma didática do ensino de Geografia comprometida em: a) idealizar uma concepção inovadora de currículo; a) estimular uma leitura crítica do mundo e, complementarmente, b) promover encaminhamentos metodológicos alternativos para

\footnotetext{
1 Professora, Universidade Estadual do Oeste do Paraná/UNIOESTE-Francisco BeltrãoParaná - Brasil, mafalda@wln.com.br.

2 Professor, Instituto de Geografia e Ordenamento do Território / IGOT-Universidade de Lisboa-Portugal, sergio@campus.ul.pt.

3 Professora, Universidade Estadual do Oeste do Paraná/UNIOESTE-Francisco BeltrãoParaná-Brasil, rosanabiral@hotmail.com.
} 
a compreensão do lugar; c) confundir a condição de estudante com a de cidadão e, e) de pesquisar e ensinar, como ações complementares, não excludentes.

Palavras-chave: Geografia; lugar, Projeto; estudo de caso; pesquisa

\section{Resumen}

La propuesta establecida en asociación con IGOT/PT y UNIOESTE/BR revisa las investigaciones y estudios realizados en la práctica de los profesores de Geografía, con la participación efectiva de los estudiantes. El objetivo es trabajar junto a la realidad de la escuela y del entorno, en el abordaje del proceso de enseñanza y aprendizaje, centrado en la formación del sujeto, en la perspectiva de la investigación pedagógica señalada por la metodología del estudio de caso. Ha empezado en 2017 y hoy se está desarrollando en dos municipios de la región Sudoeste del Paraná, a saber: Itapejara do Oeste y Pato Branco. En el primer municipio con estudiantes de octavo año de la Primaria y, en el segundo, con el primer año de la Secundaria. En coherencia con las necesidades geográficas educativas presentes en la escuela, el lugar continúa siendo una categoría extraordinariamente importante, pero muy compleja para ser contextualizada por los contenidos escolares en estos niveles de enseñanza. Así que, la mediación cultural en esta investigación sobrepasa la necesidad de la función de enseñar, para alcanzar qué y cómo enseñar. Ello exige una mirada profunda sobre la didáctica de enseñanza de la Geografía en la amplitud de: a) proceder la lectura del mundo; b) Idealizar una concepción de currículo oficial y práctico; c) proceder con estrategias metodológicas para la comprensión del lugar; d) adjudicar la condición de la actuación al estudiante ciudadano; e) Y además investigar y enseñar sin que sean acciones necesarias excluyentes.

Palabras-clave: Geografía. Lugar, Proyecto, Investigación. Estudio de caso

\section{Introdução}

"Nós Propomos! Ensino e pesquisa de Geografia desde o estudo de caso com significado na pesquisa" é o projeto em desenvolvimento na Universidade Estadual do Oeste do Paraná - UNIOESTE/FB/BR desde 2017. O Curso de Geografia da UNIOESTE de Francisco Beltrão é pioneiro no Projeto no Paraná. Trata-se de uma parceria com o Instituto de Geografia e Ordenamento do Território da Universidade de Lisboa - IGOT/UL, idealizado e coordenado pelo Professor Sérgio Claudino. O 
objetivo principal é promover estudos e pesquisas mediante a prática pedagógica entre professores e estudantes trabalhando com a realidade do lugar, como retomaremos a seguir. Assumimos uma perspetiva de aprendizagem em que há a valorização dos interesses prévios, na linha de Souto González (1998). Em consonância, entendemos que a principal concepção do processo de ensinoaprendizagem é a formação do sujeito. Esse entendimento se baseia na teoria vigotskiana e na interpretação da fala dos sujeitos com enfoque no sentido e no significado da teoria bakhtiniana. No decorrer do processo são apresentados dados e análises por meio dos depoimentos e das ações realizadas pelo Estudo de Caso, na condição de entendê-lo e interpretá-lo como uma metodologia de pesquisa e proposta a contribuir para uma educação geográfica comprometida com a inserção escola/comunidade/lugar, numa perspetiva de educação para a cidadania.

$\mathrm{Na}$ realidade, este constitui um desafio cada vez mais relevante para a escola, quando a sociedade tende a transferir para aquela a socialização primária dos mais jovens (Tedesco, 1997). Neste contexto, convém lembrar que a educação para a cidadania não é mais um saber disciplinar, feito de transmissão de conhecimentos e valores, reduzida a mais um tema escolar (Parra Monserrat, Souto González, 2015). A educação para a cidadania significa ação na comunidade, num exercício afetivo e moral diante de desafíos do cotidiano. Educar para a cidadania é educar na cidadania e pela cidadania (Figueiredo, 2005), no pertencimento à comunidade, na partilha da forma como os seus membros perspectivam os problemas comuns e tendo em vista a tomada de decisões. Assim, esta educação tem de estar vinculada à participação dos estudantes, como cidadãos, na vida escolar, nos espaços e nos tempos em que tenham possibilidades de intervir (García-Perez, Alba-Fernandez, Navarro-Medina, 2015, p. 138). E este é um desafio fundamental.

\section{O Projeto Nós Propomos!}

O Projeto "Nós Propomos! Cidadania e Inovação na Educação Geográfica" surgiu em Portugal, no Instituto de Geografia e Ordenamento do Território da Universidade de Lisboa - IGOT/UL, em 2011/2012, com estudantes do 11ํano (16/17 anos de idade) da educação básica/ensino secundário, na disciplina de Geografia (Claudino, 2018). Presentemente, encontra-se difundido, para além de Portugal, por Espanha, Moçambique, Perú, Colômbia, México (em fase de implementação) e, naturalmente, no Brasil, onde assume uma verdadeira dimensão nacional. Trata-se, assim, de um projeto dominantemente iberoamericano. 
O objetivo do Projeto é desafiar os alunos a identificarem problemas locais, realizarem trabalho de pesquisa de campo e apresentarem propostas de solução para problemas encontrados, numa perspetiva de cidadania territorial. O projeto original - assim denominamos o mencionado acima, de Portugal - aborda 14 tópicos principais a serem almejados, que são: 1) Cidadania territorial; 2) Simplicidade metodológica; 3) Inclusão; 4) Construtivismo; 5) Diálogo/horizontalidade; 6) Afetividade; 7) Parcerias; 8) Valorização de diferentes competências; 9) Autoemulação; 10) Multidisciplinaridade; 11) O trabalho em rede; 12) Mobilidade; 13) Investigação; e 14) Divulgação (Claudino, 2019).

O movimento direcionador do Projeto em Geografia da Unioeste/FB conta com a participação de professores e de estudantes da educação básica e tem seu desenvolvimento em ações como: a) a identificação de problemas locais; b) o trabalho de estudo de campo sobre os problemas; e c) a apresentação de propostas de intervenção. O propósito é o de investigar e discutir as soluções dos problemas, o que, metodologicamente, se apresenta em seis fases principais, que são: 1) reunião com os docentes envolvidos; 2) assinatura de protocolos com as autarquias; 3) identificação dos problemas locais pelos alunos; 4) pesquisa de informação sobre os problemas identificados; 5) apresentação de propostas sobre os problemas identificados pelos alunos; e 6) divulgação pública das mesmas propostas. O Projeto se vincula intrinsecamente às atividades de pesquisa e ensino de Geografia, na formação do professor e do estudante cidadão. Aborda concepções de sujeito a partir da teoria de Vigotski (1998) e na interpretação do sentido e significado na teoria de Bakhtin (2002), com enfoque no ensino de Geografia, por meio da pesquisa pelo estudo de caso do lugar.

O Projeto segue as caracteríticas do projeto original do IGOT/UL. Porém apresenta, obviamente, as especificidades da região Sudoeste do Paraná. Iniciou com professores da rede pública estadual de educação básica de ensino, que procuraram, na UNIOESTE/FB, o setor de Pós-Graduação em Geografia e em Educação, na linha de pesquisa em Educação e Ensino de Geografia e na linha de pesquisa de Cultura, Processos Educativos e Formação de Professores, respectivamente, com a esperança de formação e de mudança na prática pedagógica.

Um projeto de ensino e pesquisa de Geografia desde o estudo de caso se justifica por dois principais fatores: 1) porque há carência de pesquisa na formação do professor de Geografia e porque, 2) além da formação específica, o professor, pela sua mediação, vai promover o conhecimento de Geografia entre os estudantes e a 
comunidade. Então, pretende a integração de professores que procuram os cursos de Pós-Graduação para continuarem a formação na área da docência.

Esse Projeto foi iniciado, na prática, no mês de julho de 2017, no município de Itapejara do Oeste, pioneiro, e, em agosto, em Pato Branco. O principal desafio é a construção do conhecimento geográfico na representação investigativa dos próprios estudantes, tendo como principal referência a escola. Destaca a metodologia do Estudo de Caso como procedimento investigativo na prática pedagógica, para o estudo, a pesquisa e a comunicação de fatos geográficos, visando alcançar uma compreensão com sentido e significado do lugar.

\subsection{Aspectos fundamentais da proposta}

A prática pedagógica é uma ação política, de decisão e de compromisso, um modo de intervir dialeticamente no mundo em transformação. Nesta pesquisa a intenção é a de que a formação de estudantes, e também a de professores, seja um processo de investigação e de análise crítica a partir de significativas situações de vivências que contemplem a ampliação de seus conhecimentos. Garantir a qualidade educacional, cultural e científica, principalmente nas escolas de educação básica, exige a manutenção e a continuidade da formação de seus profissionais, principalmente considerando que essa formação profissional é um processo contínuo, que envolve transformações nas formas de relação com o mundo e entre os sujeitos, mediante profícuas interações com o conhecimento. De tal modo que, o projeto fundamenta-se na teoria sócio-histórica da formação humana de base em Vigotski (1998), por apresentar como proposta a aprendizagem pela troca de experiências no social dos sujeitos.

A escola necessita ser abordada a partir de uma concepção local de desenvolvimento para que possa se tornar espaço social privilegiado para tratar de questões complexas que se apresentam ao mundo, ultrapassando uma visão adaptativa dos sujeitos aos processos formativos hegemônicos (Calazans, 1993).

Nesse sentido, o encaminhamento das ações que qualificam o trabalho desenvolvido pelos professores busca construir relação entre os profissionais das escolas e os professores da universidade, num processo permanente de reflexão e no qual teoria e prática se complementem dialogicamente, direcionando um fazer pedagógico consciente. Busca, também, apontar caminhos diversos aos programas de formação continuada, com elementos sócio-históricos envolvidos na relação. A formação de 
professores de Geografia se faz pelo curso de licenciatura. Essa formação é de muita importância e estritamente necessária para potencializar esses profissionais para atuarem na educação básica do ensino fundamental. A atuação desses professores há de se constituir em diálogos constantes entre conhecimentos, saberes e práticas, da universidade e da escola, para promover e garantir o desenvolvimento cultural dos escolares e assegurar-Ihes uma educação que lhes permita a ampliação dos conhecimentos e das capacidades imprescindíveis para a plena participação. Assim, o elo entre universidade-escola-comunidade precisa ser mantido. O Projeto Nós Propomos! tem a pretensão de, além de fortalecer os laços, ampliar a rede de experiências pedagógicas e de conhecimentos.

O planejamento das ações se delineia a partir das demandas apresentadas pela escola e se focaliza na demanda pedagógica, em ações como elaboração de material didático construído pelas ações do próprio Projeto, com a participação dos estudantes e na formação dos professores para a produção e utilização de recursos. Essas ações têm o pressuposto de que esses recursos são importantes para subsidiar a prática educativa e auxiliar o processo de ensino-aprendizagem. Para Francischett (2004), os materiais didáticos se constituem mediadores da prática educativa e servem de apoio às atividades curriculares, às experiências didáticas de sala de aula e ao processo de ensino-aprendizagem. Com eles é possível trabalhar satisfatoriamente os conteúdos das áreas de conhecimento da educação básica. Mesmo assim, porém, não basta ficar neles.

Os aspectos fundamentais da proposta consistem em: a) desenvolver a prática de ensino de Geografia do lugar pela pesquisa, na organização do espaço-tempomovimento; b) desenvolver o estudo de caso como proposta metodológica de pesquisa no ensino de Geografia do lugar na educação básica; c) investigar o significado da pesquisa na vida pessoal-profissional do professor e na formação do estudante no conhecimento em Geografia; d) contribuir para a formação docente com ênfase na pesquisa voltada para a experiência prática; e) investigar e identificar os problemas do espaço geográfico urbano de vivência dos estudantes inseridos no projeto; f) estudar e reconhecer as possibilidades de contribuir conjuntamente escolacomunidade com a proposta dos alunos ao poder público do município/cidade; g) promover a troca de experiências da realidade, por meio de trabalho em rede nacional e internacional, discutir o ensino de Geografia por meio da pesquisa e ação; $h$ ) promover seminários, oficinas, cursos de curta duração e palestras, entre outros, sobre o ensino de Geografia para escolares da educação básica; i) contribuir com a criação e/ou fortalecimento de políticas públicas voltadas para a educação básica; j) 
promover integração e troca de experiências dos acadêmicos, pesquisadores, professores e alunos da rede pública e particular de ensino, dos do curso de graduação, de mestrado e de doutorado em Educação e em Geografia, com outros cursos da instituição, de outras instituições, e da sociedade, que possam contribuir com o projeto; k) motivar e potencializar os alunos da educação básica para concorrerem à frequência de cursos do ensino superior; e l) construir materiais didáticos, no contexto do projeto, tarefa que pretende estimular professores e alunos a trabalhar diferentes possibilidades na produção do saber em Geografia.

O método de estudo de caso se caracteriza por aproximar situações reais e práticas na formação do sujeito e "[...] desenvolver capacidades de pensamento e aprendizagem estratégicos que Ihes permitam [aos alunos] entender, sentir, relacionar-se, intervir e sobreviver neste mundo em mudança e transformação rápida, desconcertante" (Tavares, 1996, p. 24). Também evidencia aspectos dinâmicos e imprevisíveis da sala de aula, da escola, da comunidade e abrange o contexto social. Evidencia aspectos particulares da relação entre a percepção de fenômenos geográficos e da dinâmica curricular relacionada ao aspecto formativo dos sujeitos envolvidos.

Esta proposta "Nós Propomos! Ensino e pesquisa de Geografia desde o estudo de caso com significado na pesquisa" se desenvolve: a) na universidade (UNIOESTEFB), nos Programas de Pós-graduação em Geografia (mestrado e doutorado) e no de Educação (mestrado), atuando com professores, nas escolas públicas estaduais de educação básica, que desenvolvem subprojetos nos municípios, nas escolas com as quais eles têm relações profissionais, afetivas ou de colaboração mútua possível.

Cada um dos subprojetos terá duração de dois anos, podendo ser alongado conforme necessidade, devendo seguir indicativos de clareza, com: a) objetivos; b) metodologia; e c) etapas explicitadas de acordo com as necessidades e as especidicidade de cada lugar. O objetivo comum a todos os subprojetos está explicitado nos mesmos 14 pilares indicados no Projeto original português, sendo que os objetivos e as etapas seguem a natureza da realidade e das necessidades específicas de cada lugar.

Nesse âmbito seguem algumas das principais etapas idealizadas para a prática, em Portugal, que são: $1^{a}$ Fase: Identificação da escola, da/s turma/s e dos sujeitos, mais a apresentação da proposta e pedido de anuência, de consentimento da direção; $2^{\underline{a}}$ Fase: Apresentação da proposta para os estudantes, com discussão dos objetivos, da metodologia e da formulação das diretrizes e do cronograma do subprojeto; $3^{\underline{a}}$ Fase: Apresentação da proposta aos pais: discussão dos objetivos, da metodologia e as 


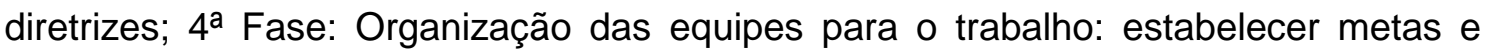
cronograma; 5 ${ }^{\text {a }}$ Fase: Reconhecimento e estudo do Plano Diretor Municipal: estudar o documento e estabelecer o/s pilar/es norteador/es do planejamento das ações; $6^{\underline{a}}$ Fase: Planejamento de trabalho de campo: traçar roteiro para a identificação dos problemas; 7aㅗ Fase: Escolha do logotipo: organizar e proceder à seleção; 8 ${ }^{\underline{a}}$ Fase: Apresentação do diagnóstico: socializar o diagnóstico; 9a Fase: Fórum de socialização: apresentação das propostas de intervenção para a solução dos problemas diagnosticados e estudados pelos alunos; 10ª Fase: Relatório das ações realizadas; $11^{\underline{a}}$ Fase: Socialização dos resultados; $12^{\underline{a}}$ Fase: Avaliação da proposta; e 13ํㅡㄹ Fase: Elaboração de registro de material didático do Projeto (Claudino, 218).

\section{Caracterização da área da pesquisa}

Pela Lei Estadual № 9.663, de 16 de julho de 1991, a UNIOESTE foi transformada em autarquia e vinculada à Secretaria de Estado de Ciência, Tecnologia e Ensino Superior - SETI/PR, nos termos das leis estaduais pertinentes, consolidando a sua condição de instituição pública de qualidade, dedicada aos fins do ensino, da pesquisa e da extensão. O 5 Campus da UNIOESTE está localizado na cidade de Francisco Beltrão, cujo município, juntamente com outros 41 , forma a Região Sudoeste do Paraná.

Figura 1 - Mapas do país-estado-região

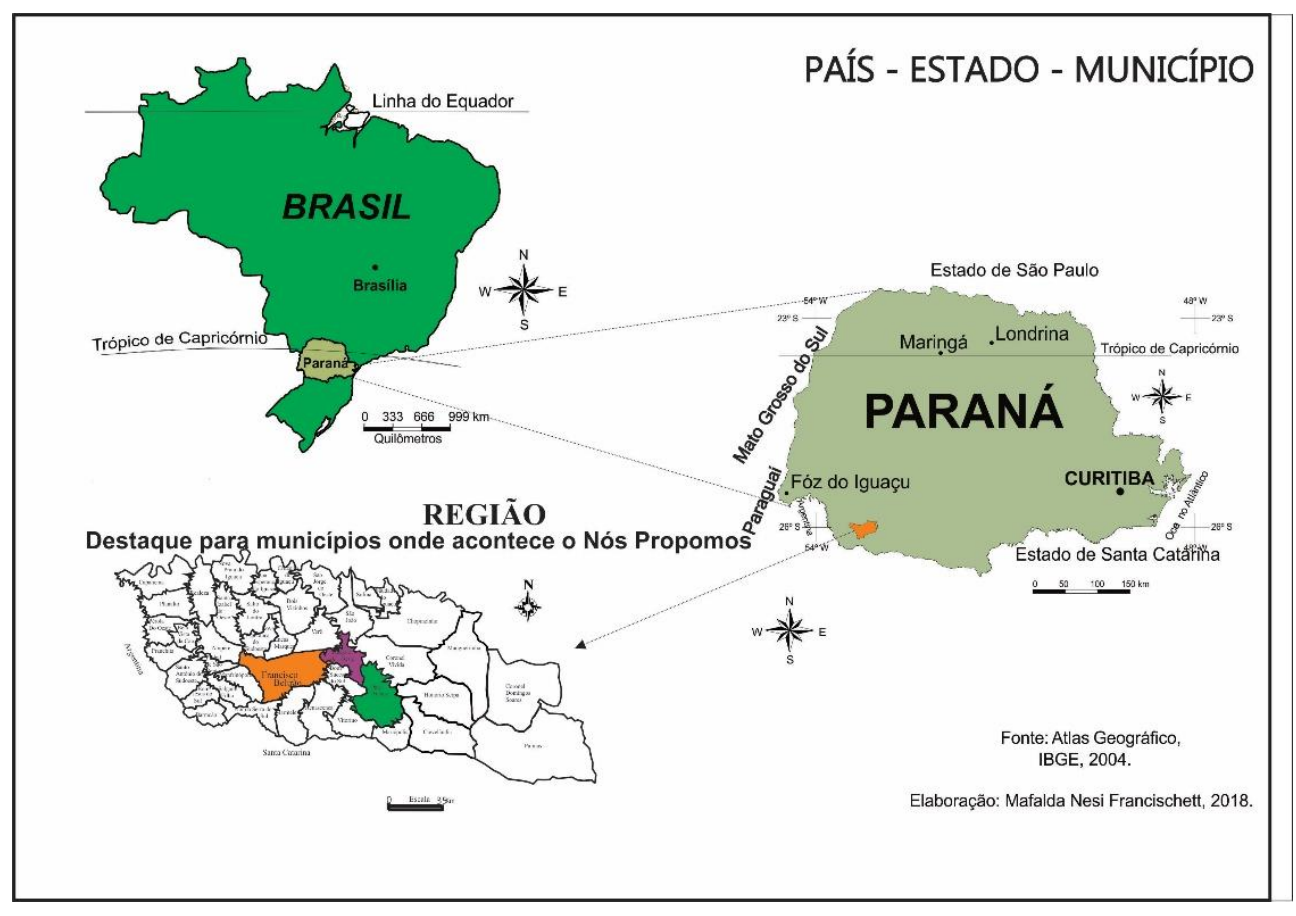

Elaboração: Francischett,2018. 
Assim, "Nós Propomos! Ensino e pesquisa de Geografia desde o estudo de caso com significado na pesquisa" é um Projeto que mobiliza, até ao momento, três municípios, incluindo o de Francisco Beltrão, onde está o campus da UNIOESTE. As escolas que participam demonstram grande interesse em oportunizar transformações, modificanado as práticas educativas no sentido de valorizar a formação geográfica e cidadã dos estudantes. A primeira escola a participar no Projeto, pela UNIOESTE, foi a Escola Estadual Isidoro Dumont, no município de Itapejara do Oeste, e a segunda foi a Escola Estadual Prof. Agustinho Pereira, no município de Pato Branco.

Figura 2- Mapa dos municípios da região Sudoeste do Paraná

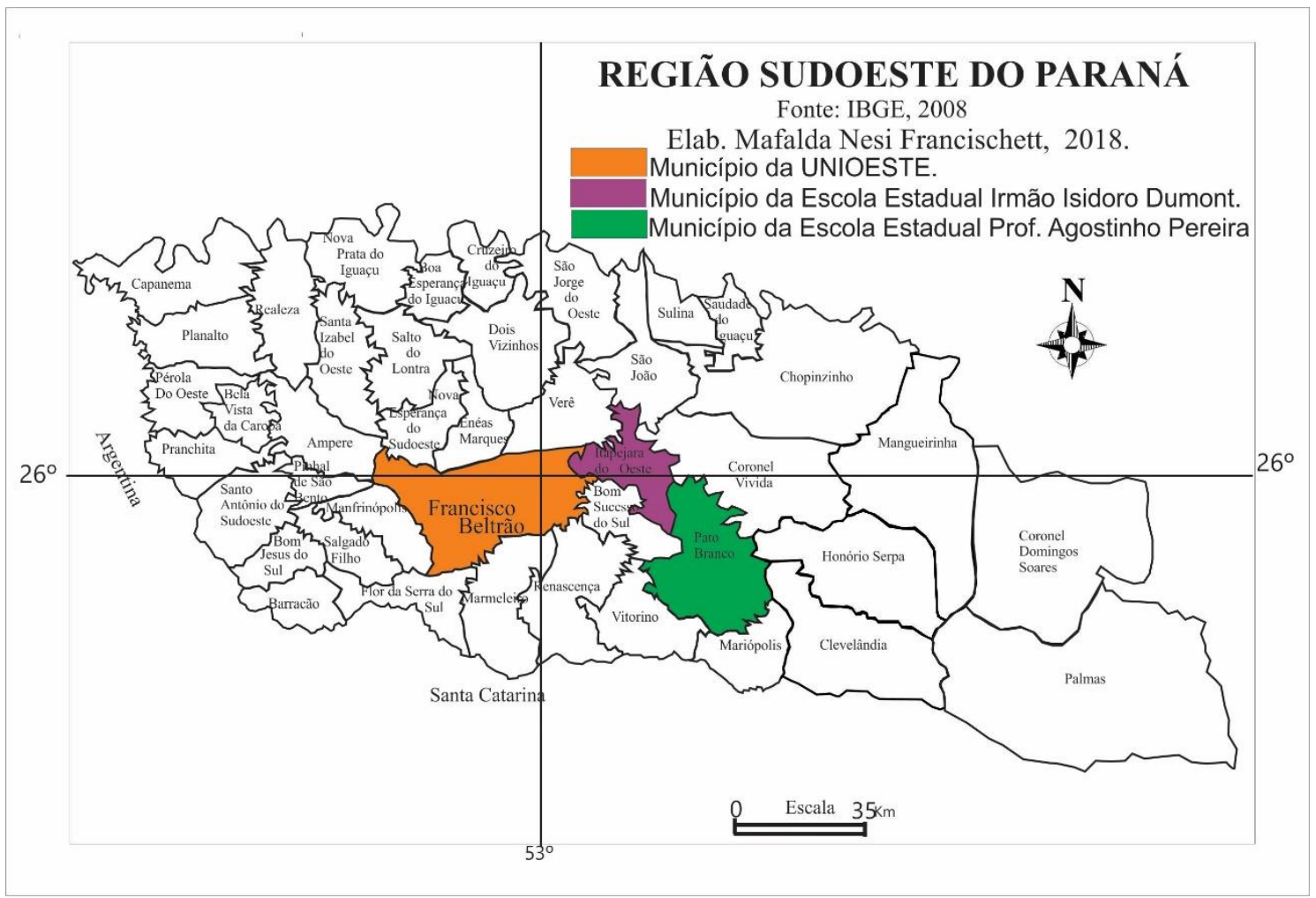

Elaboração: Francischett,2018.

Melhor especificando o primeiro subprojeto, esta pesquisa - que se caracteriza como um estudo de caso realizado na educação básica na disciplina de Geografia - está acontecendo na Escola Estadual Irmão Isidoro Dumont - Ensino Fundamental, no município de Itapejara D'Oeste, com a turma do $7^{\circ}$ ano B, com 40 estudantes.Tem como objetivo investigar e identificar os problemas do espaço geográfico urbano e propor ações que viabilizem eventuais soluções. O projeto tem o propósito de contribuir significativamente para a formação cidadã, no desenvolvimento cognitivo dos estudantes, por meio do estudo dos problemas da cidade que, muitas vezes, são ignorados pelo poder público e pela comunidade em geral. A temática principal desse subprojeto é a de pensar a Geografia por meio da participação investigativa com os 
estudantes. No ano de 2017 foram desenvolvidas ações indicativas do subprojeto, sendo elas: 1) Identificação da escola, da turma, dos sujeitos da pesquisa; 2) Apresentação da proposta, o pedido de anuência, de consentimento da direção e da Secretaria de Estado da Educação do Paraná; 3) Apresentação da proposta para os dirigentes e estudantes; 4) Organização das equipes de trabalho, na escola; 5) Escolha do logotipo; 6) Definição dos temas da pesquisa; 7) Planejamento do trabalho de campo. Os resultados demonstram que os estudantes, as famílias e a comunidade estão envolvidos diretamente com a escola, no desenvolvimento do projeto. Isso despertou interesse nos participantes e os pais demonstraram satisfação e responsabilidade em contribuir na efetivação da atividade.

Quanto ao segundo subprojeto, o de Pato Branco, o objetivo estabelecido é o de ensinar e aprender sobre o lugar com significado. Está sendo realizado com estudantes do ensino médio do Colégio Estadual Prof. Agostinho Pereira, com o propósito de identificar as problemáticas na comunidade escolar, nas famílias e na cidade. Os participantes envolvidos diretamente são 35 estudantes e quatro professoras, sendo três da Universidade Estadual do Oeste do Paraná e uma da escola. As etapas consistem na decisão das temáticas, dos logotipos, na realização do diagnóstico, identificação dos problemas, organização e planejamento das ações. Os estudantes se organizaram em sete grupos e as temáticas são: 1) Placas de informação nos pontos de lotação; 2) Muros da cidade; 3) Trânsito da cidade; 4) Ração e água para animais de rua; 5) SOS vida animal; 6) Literatura nas instituições e 7) Ciclovias. Para a sua efetivação dos estudos nesses temas buscam informações qualitativas e quantitativas, realizaram debates para identificar os problemas e visam apresentar propostas.

\section{Conclusão}

Salientamos que a pertinência científica do Projeto consiste em explorar as possibilidades da pesquisa pela metodologia do estudo de caso, em trazer respostas aos temas escolhidos e estudados e em qualificar o processo de ensino-aprendizagem da Geografia Escolar na educação báscia.

Como se pode deduzir pelo desenvolvimento dos subprojetos até este momento, essas atividades têm aproximado universidade-escola-comunidade e já concretizou a participação em eventos, uma vez que promoveu o "I Colóquio Ensino de Geografia com Significado na Pesquisa - Nós Propomos - Unioeste/PR/BR", que aconteceu em 
16 de agosto de 2018, evento que possibilitou aos estudantes apresentarem as propostas ao público.

Cabe enfatizar que as diversas atividades dos subprojetos têm promovido atividades de participação democrática nos municípios, tem feito os estudantes refletirem sobre o ensino de Geografia no ensino médio (no caso do segundo subprojeto) e sobre a importância da formação para a cidadania. Enfim, a partir do conhecimento do lugar e com possibilidade de proposição de soluções para problemas, os estudantes passam a reconhecer as possibilidades de mudanças no ensino e na vida no próprio lugar e com isso se comprometem.

\section{Referências Bibliográficas}

Bakhtin, M. (2002). Marxismo e filosofia da linguagem. 9. ed., São Paulo: Hucitec; Annablume.

Calazans, M. J. C. (1993). Para compreender a educação do Estado no meio rural. In: J. Therrien \& M. N. Damasceno (Orgs.). Educação e escola no campo (pp. 14-40). Campinas, SP: Papirus.

Claudino, S. (2018). Educação Geográfica, Trabalho de Campo e Cidadania. O Projeto Nós Propomos! In F. H. Veiga (Coord.) O Ensino na Escola de Hoje. Teoria, Investigação e Aplicação (pp. 265-303). Lisboa: Climepsi Editores.

Claudino, S. (2019). Project We Propose! Building Territorial Citizenship From School. In José A. Pineda-Alfonso, N. De Alba-Fernández \& E. Navarro-Medina (Eds). Handbook of Research on Education for Participative Citizenship and Global Prosperity (pp. 350-382). Hershey: IGI Global.

Figueiredo, C. C. (2005). Formação Cívica. E agora, um tempo para reflectir? In C. Carvalho, F. Sousa \& J. Pintassilgo (Org.), A educação para a cidadania como dimensão transversal do currículo escolar (pp. 23-47). Porto: Porto Editora.

Francischett, M. N. (2004). A cartografia no ensino de geografia: a aprendizagem mediada. Cascavel, PR: Editora da UNIOESTE,

García-Pérez, F. F., Alba-Fernández, N. \& Navarro-Medina, E. (2015). La formación inicial del professorado para enseñar ciudadanía. Experinecias en los neveles de grado e de máster. In B. Borghi, F. F. García-Pérez, O. Moreno-Fernández, Novi Cíves. Cittadini dall infanzia in poi (pp. 137-148). Bologna: Pàtron Editores. 
Garrido, E.; Pimenta, S. G.; Moura, M. O. de. (2000). A pesquisa colaborativa na escola como abordagem facilitadora para o desenvolvimento da profissão do professor. In: A. J. Marin, Educação continuada: reflexões, alternativas (pp. 89-112). Campinas, SP: Papirus.

Garrido, E. Pesquisa universidade-escola e desenvolvimento profissional do professor. (2000). Tese (Livre-docência). Faculdade de Educação, Universidade de São PauloUSP, São Paulo.

Giovanil, L. M. Do professor informante ao parceiro: reflexões sobre o papel da universidade para o desenvolvimento profissional de professores e as mudanças na escola. (1998). Cadernos Cedes (O professor e o ensino: novos olhares), Campinas/SP, no 44, p. 46-58.

Parra Monserrat, D. \& Souto González, X. (2015). La construcción de la Ciudadania en el marco escolar español. In B. Borghi, F. F. García-Pérez, O. Moreno-Fernández, Novi Cíves. Cittadini dall infanzia in poi (pp. 159-171). Bologna: Pàtron Editores.

Saccristán, J. G. (1996). Escolarização e cultura: a dupla determinação. In: L. E. Silva Reestruturação curricular: novos mapas culturais, novas perspectivas educacionais (pp. 34-57). Porto Alegre, RS: Sulina.

Souto X. M. (1998). Didáctica de la Geografia. Problemas sociales e conocimiento del medio. Lisboa: Ediciones del Serbal.

Tavares, J. (1996). Uma sociedade que aprende e se desenvolve: relações interpessoais. Porto: Editora Porto.

Tedesco, J. C. (1997) The New Educational Pact; Education, Competitiveness and Citizenship in Modern Society. Genève: UNESCO-IBE.

Vigotsky, L. S. (1998). A formação social da mente. São Paulo: Martins Fontes. 


\title{
Evolución y Análisis de la Participación en el Proyecto Educativo ¡Nosotros Proponemos! en Ciudad Real
}

\author{
MIGUEL GONZÁLEZ-MOHINO SÁNCHEZ ${ }^{1}$ \\ MARÍA DE LOS ÁNGELES RODRÍGUEZ-DOMENECH² \\ ANA ISABEL CALLEJAS-ALBIÑANA ${ }^{3}$
}

\section{Resumen}

El principal objetivo de la investigación en el Proyecto Educativo: ¡Nosotros Proponemos! es conocer la valoración de la ciudad y la relación con su entorno educativo, por parte de los alumnos/as de los centros educativos de Ciudad Real. Para ello se realiza una comparativa de las dos ediciones realizadas en Ciudad Real (España), analizando la temática de los trabajos presentados por los alumnos/as, el número de participantes, el conocimiento y valoración de los espacios de la ciudad. Se realizó un cuestionario para medir la satisfacción de los alumnos/as con el proyecto y su grado de implicación con la ciudad. Con este proceso se pretenden dos objetivos principales, por un lado, reconocer los espacios que deben mejorarse en la ciudad, y por otro observar si en ese proceso de "análisis" de la ciudad por parte de los alumnos, puede existir una mejora en sus percepciones.

Palabras clave: participación, evolución, conocimiento, preferencia, Ciudad Real.

\section{Resumo}

O principal objetivo da pesquisa no Projeto Educacional: Propomos! é conhecer a avaliação da cidade e a relação com seu ambiente educacional, pelos alunos dos

\begin{tabular}{llllllll}
\hline 1 Doctorando & Economía y & Empresa, & Univ. & de & Castilla-La & Mancha, \\
Miguel.Gonzalezmohino@alu.uclm.es & Profesora departamento & Geografía, & Universidad & Castilla- & La & Mancha, \\
$\begin{array}{l}\text { Mangeles.Rodriguez@uclm.es } \\
3 \quad \text { Profesora departamento }\end{array}$ & Psicología, & Universidad & Castilla & -La & Mancha, \\
Analsabel.Callejas@uclm.es & & & & &
\end{tabular}


centros educativos de Ciudad Real. Para fazer isso, uma comparação das duas edições feitas em Ciudad Real (Espanha) é feita, analisando o tema dos trabalhos apresentados pelos alunos, o número de participantes, o conhecimento e avaliação

dos espaços na cidade. Para tanto, foi realizado um questionário para medir a satisfação dos alunos com o projeto e o grau de envolvimento deles com a cidade. Este processo visa atingir dois objetivos principais, por um lado, reconhecer os espaços que devem ser melhorados na cidade e, por outro lado, observar se, nesse processo de "análise" da cidade pelos alunos, pode haver uma melhoria em suas percepções.

Palavras-chave: participação, evolução, conhecimento, preferência, Ciudad Real.

\section{Introducción}

El proyecto educativo ¡Nosotros Proponemos! es un programa de ámbito universitario escolar internacional que surge en la Universidad de Lisboa, en el que se ofrece metodología para trabajar con escolares sobre los problemas de la ciudad y abordar propuestas de resolución de problemas sociales desde un enfoque participativo (Rodríguez- Domenech y Claudino, 2018).

Este proyecto ha sido trasladado a Ciudad Real, donde se establecieron los canales necesarios de colaboración entre el Ayuntamiento de Ciudad Real y la Universidad de Castilla-La Mancha (UCLM), mediante un convenio de colaboración firmado por ambas entidades con el fin de trabajar de forma coordinada en el proyecto.

Este proyecto inicialmente nace en Portugal con el profesor de Geografía D. Sergio Claudino, para posteriormente expandirse a otros países como España, Brasil, Perú, Colombia y Mozambique. En este trabajo, estudiaremos la evolución del proyecto en la ciudad de Ciudad Real (España), que fue la pionera en poner en marcha este proyecto en el país (Recuperado de: http://www.nosotrosproponemos.com/, 2018).

\section{Objetivo de la Investigación}

El principal objetivo de la investigación en el Proyecto Educativo: ¡Nosotros Proponemos! es conocer la valoración de la ciudad y la relación con su entorno educativo, por parte de los alumnos/as de los centros de Ciudad Real.

Para ello, en la primera edición del programa, se realizó un primer cuestionario a los alumnos/as en septiembre de 2016 antes de que los alumnos/as realizaran los 
trabajos de la ciudad, y posteriormente se lanzó un segundo cuestionario final, en marzo de 2017, después de haber realizado los trabajos y exposiciones. Con este proceso se pretende dos objetivos principales, por un lado, reconocer los espacios que deben mejorarse en la ciudad, y por otro observar si en ese proceso de "análisis" de la ciudad por parte de los alumnos, puede existir una mejora en sus percepciones. En la segunda edición, solo se lanzó un cuestionario a los estudiantes tras la finalización del programa, realizando algunas modificaciones en el cuestionario de la primera edición.

Con dos ediciones finalizadas con éxito en Ciudad Real, se antojaba necesario realizar una comparativa de la participación y evolución sufrida en este proyecto en estos dos años de andadura. Para ello se reunieron los datos de los dos cuestionarios principales, el de marzo de 2017 y el de marzo de 2018.

\section{Metodología}

La metodología empleada en la investigación del proyecto ¡Nosotros Proponemos!, se divide en varias partes: procedimiento, herramientas, diseño y medición del cuestionario, y muestra empleada. Siguiendo el trabajo de González-Mohíno y Callejas (2018), analizaremos su evolución:

\subsection{Procedimiento}

El procedimiento de realización del estudio del cuestionario consta de las siguientes fases:

- Diseño del cuestionario inicial de prueba por parte de los profesores de la Facultad de Educación de Ciudad Real, de la Universidad de Castilla-La Mancha.

- Lanzamiento de dicho cuestionario a los centros educativos participantes en el proyecto.

- Recolección de datos de dicho cuestionario en bases de datos mediante el programa Microsoft Excel.

- Medición y análisis de los datos recogidos.

- Búsqueda y corrección de errores en el cuestionario.

- Diseño del cuestionario final, corrigiendo los errores del cuestionario previo.

- Visita a los centros educativos participantes para la explicación y realización del cuestionario.

- Posteriormente los datos fueron trasferidos de formato papel a digital mediante la herramienta Google Formularios. 
- Tratamiento y análisis de los datos mediante el programa Microsoft Excel y SPSS.

- Realización de cálculos y gráficas para lograr unos resultados visibles.

\subsection{Herramientas utilizadas}

Las herramientas empleadas para el desarrollo del proyecto, así como su medición y valoración ha sido el diseño de un cuestionario en formato papel y otro en formato digital a través de la herramienta de Google Formularios, que permite registrar de forma rápida y automática las respuestas. Posteriormente se han utilizado otra serie de programas como Microsoft Excel o SPSS, para realizar las gráficas y tablas.

\subsection{Diseño y medición del cuestionario}

Para la medición del proyecto, se lanzó un cuestionario inicial de prueba y otro final que constan de unas preguntas de carácter demográfico identificativo relacionadas con: género, centro, edad, curso, ciudad de residencia, situación familiar.

Con respecto a las preguntas sobre el proyecto, se estableció el siguiente criterio de medición: en la pregunta uno (Conocimiento de la ciudad) los encuestados/as marcaban con una cruz los espacios que desconocen de Ciudad Real, y en la segunda (Valoración de los espacios) señalaban los espacios más valorados por cada alumno, eligiendo un máximo de 5 espacios en esta pregunta, sin marcar ningún mínimo.

La pregunta número tres (evaluación de la ciudad) mide la valoración o importancia que le da cada alumno a una serie de ítems, (servicios comerciales, movilidad en la ciudad, actividades culturales, limpieza de la ciudad y medio ambiente).

En lo que respecta a la pregunta número cuatro (satisfacción del proyecto) consta de cuatro apartados: el primero pregunta sobre la satisfacción del proyecto; el segundo trata la utilidad del proyecto para la ciudad; el tercero cuestiona su utilidad para la educación; y el cuarto y último está formado por una pregunta abierta sobre los aspectos a mejorar del proyecto en los próximos años.

El resto de preguntas tratarían otros temas como la calidad de vida en la ciudad, pero al ser preguntas nuevas y no realizarse en la anterior edición, no se tratarán en este trabajo. 


\section{Resultados}

Se ha realizado un estudio estadístico dividido en dos partes bien diferenciadas, por un lado, los resultados que englobarían preguntas como la edad, el género, el curso, etc. $Y$ por otra parte los resultados de las preguntas del cuestionario.

\subsection{Respecto a la muestra}

La primera parte trataría los resultados de la muestra, cuyo contenido está formado por preguntas que tratan la demografía de los estudiantes, por ejemplo, el sexo, centro, curso, etc.

La población participante en la segunda edición está formada por un conjunto total de 9 centros educativos de la capital de Ciudad Real. Cinco de ellos se han tomado de centros de infantil y primaria y cuatro de ellos de centros de secundaria, de estos cuatro, uno es un centro concertado. En total en este segundo cuestionario han participado un total de 260 alumnos/as, pudiéndose desglosar por varios criterios:

- Del total de los participantes 153 pertenecen a Educación Secundaria y 107 a Educación Primaria.

- Del total de los participantes 131 corresponderían a mujeres y 129 a hombres.

- Con respecto a la ciudad de residencia 232 residen en Ciudad Real Capital, mientras que 28 residirían en otras ciudades.

- En relación a la situación de los miembros de la familia, 15 respondieron que ningún miembro de su familia trabaja, 60 contestaron que tienen algún desempleado en su familia, 160 que se encuentran todos empleados y 25 respuestas en blanco.

Si comparásemos las cifras de la segunda edición con las del primer año, nos encontraríamos con la siguiente tabla:

Tabla 1- Evolución del proyecto en Ciudad Real

\begin{tabular}{|c|c|c|}
\hline & $\mathbf{1}^{\mathbf{a}}$ edición del proyecto & $\mathbf{2}^{\mathbf{a}}$ edición del proyecto \\
\hline $\begin{array}{c}\text { Participantes } \\
\text { (estudiantes) }\end{array}$ & 200 & 260 \\
\hline $\begin{array}{c}\text { Alumnos/as de } \\
\text { Educación Primaria y } \\
\text { Secundaria }\end{array}$ & $\begin{array}{c}103 \text { Educación Primaria y 97 Educación } \\
\text { Secundaria }\end{array}$ & $\begin{array}{c}107 \text { Educación Primaria y } 153 \\
\text { Educación Secundaria }\end{array}$ \\
\hline Sexo & 90 mujeres y 110 hombres & 129 hombres, 131 mujeres \\
\hline Ciudad de residencia & $\begin{array}{c}180 \text { en Ciudad Real capital y 20 en otras } \\
\text { poblaciones }\end{array}$ & $\begin{array}{c}232 \text { en Ciudad Real capital, 28 } \\
\text { en otras poblaciones }\end{array}$ \\
\hline
\end{tabular}




\begin{tabular}{|c|c|c|}
\hline $\begin{array}{l}\text { Situación de los } \\
\text { miembros de la familia }\end{array}$ & $\begin{array}{c}7 \text { respondieron ningún miembro de su } \\
\text { familia trabaja, } 60 \text { que tienen algún } \\
\text { desempleado en su familia, } 122 \text { que } \\
\text { todos empleados y } 11 \text { respuestas en } \\
\text { blanco. }\end{array}$ & $\begin{array}{c}15 \text { respondieron ningún } \\
\text { miembro de su familia trabaja, } \\
60 \text { que tienen algún } \\
\text { desempleado en su familia, } \\
160 \text { que todos empleados y } 25 \\
\text { respuestas en blanco. }\end{array}$ \\
\hline Centros participantes & 7 & 9 \\
\hline $\begin{array}{c}\text { Centros de primaria o } \\
\text { secundaria }\end{array}$ & $\begin{array}{l}4 \text { centros de educación primaria y } 3 \text { de } \\
\text { secundaria }\end{array}$ & $\begin{array}{l}5 \text { centros de educación } \\
\text { primaria y } 4 \text { de secundaria }\end{array}$ \\
\hline Centros concertados & 2 & 1 \\
\hline $\begin{array}{c}\text { Profesores de primaria } \\
\text { y secundaria }\end{array}$ & $\begin{array}{c}11 \text { (6 de Ed. Primaria y } 5 \text { Ed. } \\
\text { Secundaria) }\end{array}$ & $\begin{array}{c}15 \text { ( } 9 \text { de Ed. primaria y } 6 \text { Ed. } \\
\text { Secundaria) }\end{array}$ \\
\hline
\end{tabular}

\section{Fuente: Elaboración propia}

En esta tabla podemos apreciar, un incremento de sesenta participantes, dos centros educativos y cuatro profesores más respecto a la primera edición.

Tabla 2- Participantes por centros educativos y sexo-2ª edición

\begin{tabular}{|c|c|c|c|c|c|c|c|c|c|c|}
\hline & $\begin{array}{c}\text { Alcalde } \\
\text { José } \\
\text { Cruz } \\
\text { Prado }\end{array}$ & $\begin{array}{c}\text { Cristób } \\
\text { al Colón }\end{array}$ & $\begin{array}{c}\text { Ferrovi } \\
\text { ario }\end{array}$ & $\begin{array}{c}\text { Pérez } \\
\text { del } \\
\text { Pulgar }\end{array}$ & $\begin{array}{c}\text { Maestr Juan } \\
\text { de } \\
\text { Ávila }\end{array}$ & $\begin{array}{c}\text { Miguel } \\
\text { de } \\
\text { Cervan } \\
\text { tes }\end{array}$ & $\begin{array}{c}\text { Pío } \\
\text { XII }\end{array}$ & $\begin{array}{c}\text { San } \\
\text { José }\end{array}$ & $\begin{array}{c}\text { orre del } \\
\text { Alcáz } \\
\text { ar }\end{array}$ & $\begin{array}{c}\text { Tota } \\
\text { I }\end{array}$ \\
\hline Hombres & 14 & 4 & 22 & 18 & 18 & 13 & 4 & 16 & 20 & 129 \\
\hline Mujeres & 7 & 3 & 27 & 18 & 10 & 9 & 4 & 23 & 30 & 131 \\
\hline Total & 21 & 7 & 49 & 36 & 28 & 22 & 8 & 39 & 50 & 260 \\
\hline
\end{tabular}

\section{Fuente: Elaboración propia}

Los centros educativos que más alumnado aportan al proyecto son: el I.E.S. (Instituto de Educación Secundaria) Torreón del Alcázar con 50 alumnos/as, seguido de uno por el C.E.I.P. (Centro de Educación Infantil y Primaria) Ferroviario con 49, consecutivamente iría el Centro Concertado (C.C) San José con 39, el I.E.S. Hernán Pérez del Pulgar (36) y el I.E.S. Maestro Juan de Ávila (28), cerrarían este grupo de centros con mayor volumen de alumnado. El dato destaca que los centros con mayor alumnado participante en el proyecto provienen de los centros de secundaria, ya que de todos los anteriores centros nombrados solamente uno (C.E.I.P Ferroviario) pertenece a primaria. 


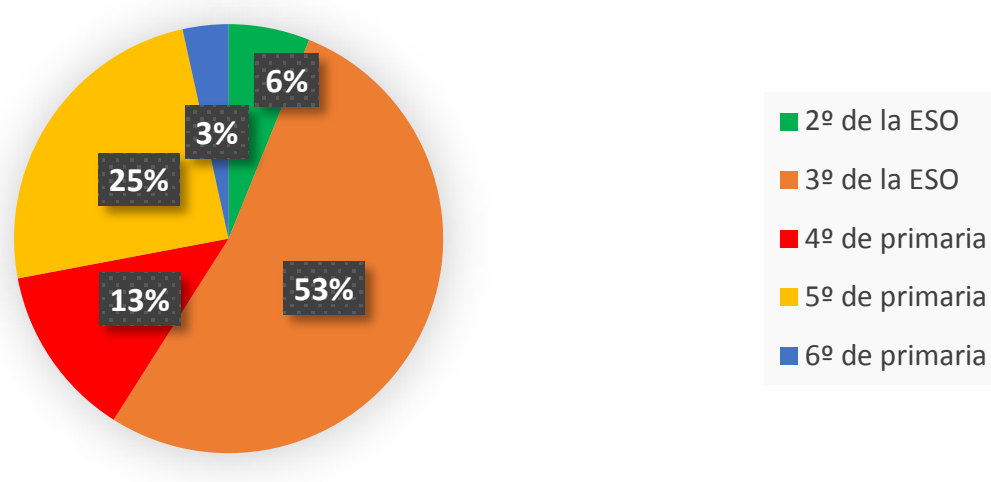

Fuente: Elaboración propia

Respecto al curso en el que se encontraban los/as alumnos/as participantes fue muy heterogéneo, siendo 16 alumnos/as de segundo curso de la E.S.O. (Educación Secundaria Obligatoria), 137 de tercero de la E.S.O., 34 de cuarto de primaria, 64 de quinto de primaria y 9 de sexto de primaria. Sin embargo, las cifras del año anterior reflejaban una amplia mayoría formada por el grupo de $5^{\circ}$ de primaria que contaba con 87 participantes que representaron el $43,71 \%$ del total, seguido de $2 \circ$ de la E.S.O. que representaría el $26,13 \%$, 3ํ de la E.S.O. un 22,61 \% y por último el grupo menos numeroso de 6 o de primaria $6,5 \%$.

\subsection{Respecto al cuestionario}

Los resultados respecto al cuestionario tratan preguntas sobre el conocimiento y preferencia de los espacios/lugares de la ciudad, prioridades de mejora para los alumnos en la ciudad y la satisfacción del proyecto (González-Mohíno y Callejas, 2018). En los siguientes apartados podremos ver los distintos resultados obtenidos en las dos ediciones realizadas en Ciudad Real.

\section{a) Conocimiento de la ciudad-1 $1^{\text {a }}$ edición}

Una de las primeras preguntas que se realizaron a los participantes consistía en el grado de conocimiento de los diferentes espacios/lugares que componen la ciudad. Los participantes tenían que elegir o marcar aquellos que desconocían o tenían dudas sobre su ubicación exacta. Así de este modo en la primera edición, los espacios más desconocidos quedarían resumidos en el siguiente gráfico: 


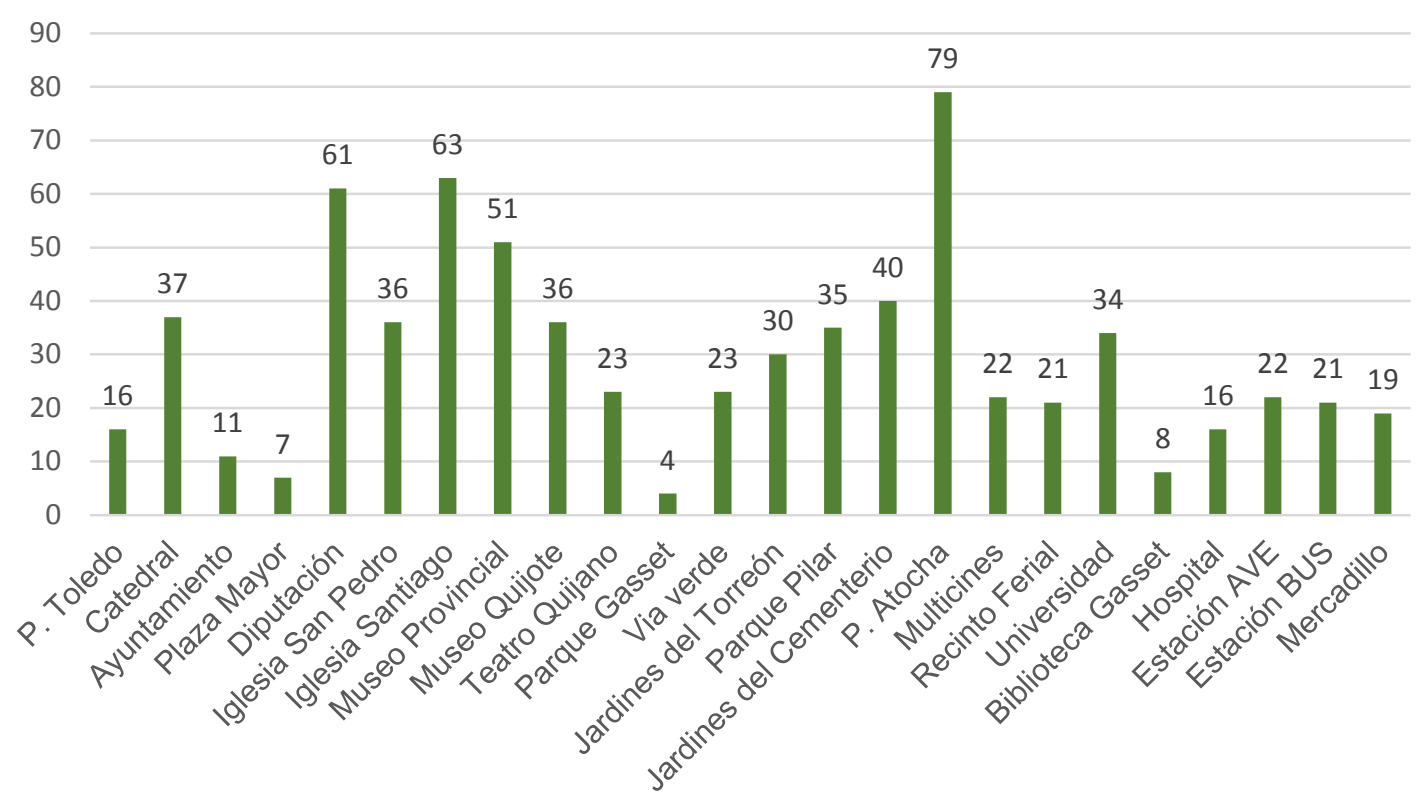

Fuente: Elaboración propia

Analizando los resultados obtenidos por González-Mohíno y Callejas (2018) respecto al patrimonio cultural destacar que más del $90 \%$ de los participantes conocen la Plaza Mayor situada en el centro de la ciudad seguida del Ayuntamiento, situado en la misma plaza (sorprende que haya 3 que no ubican el ayuntamiento en la plaza). En torno al $80 \%$ sitúan la Puerta de Toledo, Iglesia de San Pedro y la Catedral. Los menos conocidos, aunque lo son por el $70 \%$ de los participantes son la Iglesia de Santiago y la Diputación Provincial.

El conocimiento del patrimonio natural destaca, casi con el $100 \%$ de los participantes, el Parque de Gasset, seguido por la Vía Verde, el Parque de la Atalaya en un $90 \%$ y en torno al 80\% Parque del Pilar, Jardines del Torreón y Jardines del Cementerio. El espacio menos conocido es el Parque de Atocha con menos del 60\%.

El espacio de ocio más conocido por los participantes es el teatro seguido del Recinto Ferial y los Multicines que suponen más del $90 \%$, y más del $80 \%$ conoce el Museo de Don Quijote, siendo el menos conocido el Museo Provincial.

Por último, en el conocimiento de servicios de la ciudad superan el $90 \%$, la Biblioteca Pública, el Hospital, la Estación de AVE y la Estación de Autobuses, seguido en un $80 \%$ por el Mercadillo y la menos conocida, el 70\%, la Universidad de Ciudad Real. 


\section{b) Conocimiento de la ciudad- $2^{\text {a }}$ edición}

Respecto a la segunda edición de ¡Nosotros Proponemos! se realizaron los siguientes cambios en el estudio:

En el patrimonio cultural se añadió el Antiguo Casino, Museo López Villaseñor, Museo de la Merced y Museo Diocesano. Se realizó un ajuste en los espacios del Museo del Quijote y Museo Provincial incluyéndolos en patrimonio cultural en lugar de ocio.

En el patrimonio natural se añadió el Parque Juan Pablo II y las Playas de Vicario. En ocio, se añadieron los espacios Pabellón Rey Juan Carlos I, Pabellón Quijote Arena y Ciudad Deportiva Sur. Además, se eliminó de esta categoría los espacios del Museo del Quijote y Museo Provincial. En Servicios se añadió el Mercado de Abastos de la ciudad, edificio céntrico y emblemático de la ciudad.

Gráfico 3- Lugares más desconocidos en Ciudad Real, $2^{\underline{a}}$ edición

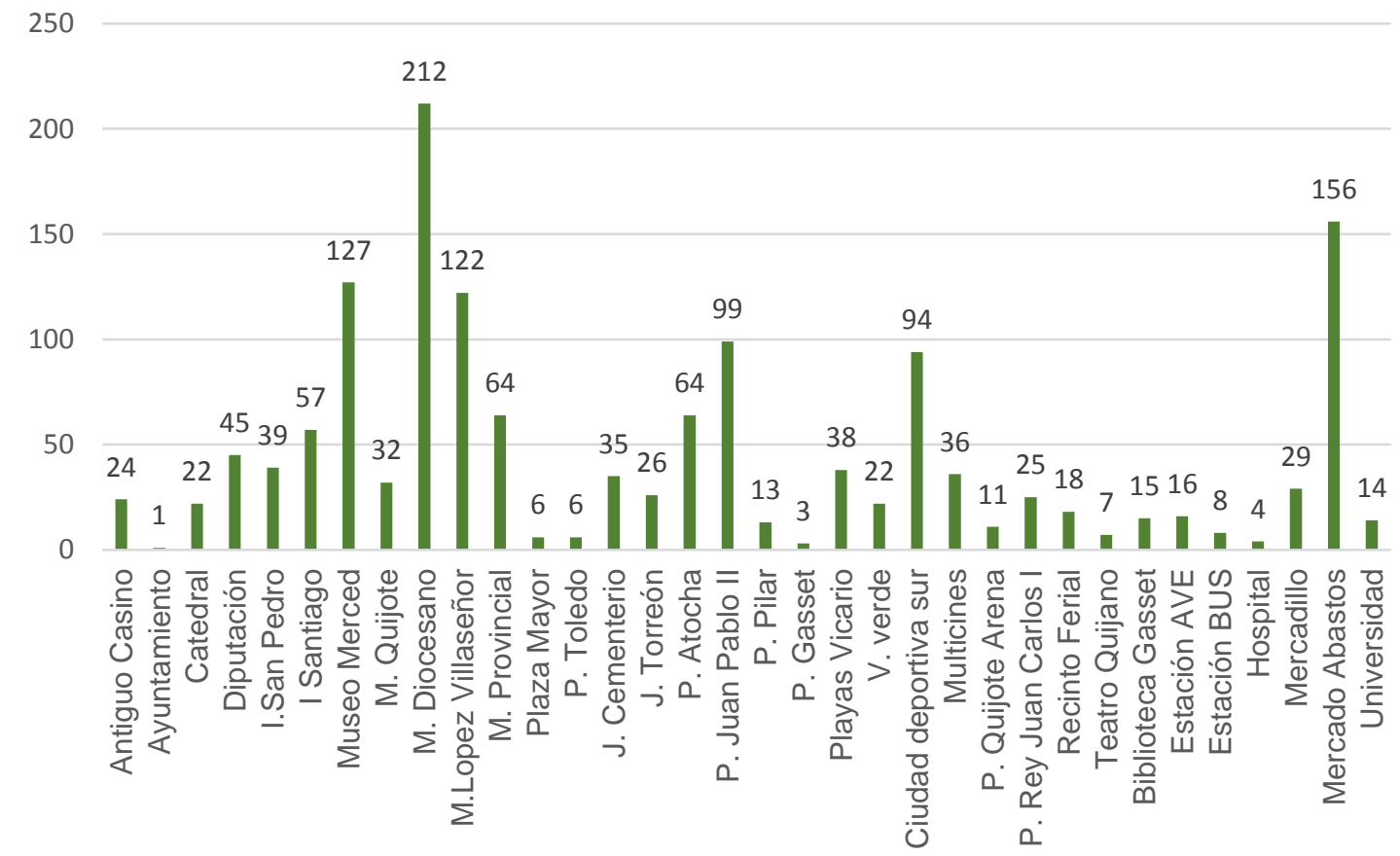

Fuente: Elaboración propia

Los resultados indican que los lugares más desconocidos para los participantes de esta edición son, con más de un $90 \%$ de desconocimiento el Museo Diocesano (patrimonio cultural) y el Mercado de Abastos (espacio de servicios); Con más del $80 \%$ el Museo de la Merced y el Museo López Villaseñor, ambos incluidos en el espacio de ocio. El 70\% aproximadamente desconoce el Parque S. Pablo II y la Ciudad Deportiva Sur (patrimonio natural y ocio respectivamente) y en torno al $50 \%$ desconocen la 
Iglesia de Santiago (patrimonio cultural), el Museo Provincial (patrimonio de cultural); y el Parque de Atocha (patrimonio natural).

Los casos del Museo de la Merced, el Museo Diocesano, el Museo López Villaseñor y el Mercado de Abastos destacan sobre el resto y resulta curioso al ser edificios ubicados en el centro histórico de la ciudad y con un tamaño considerable sobre el resto de edificios de la ciudad.

Tabla 3- Lugares más desconocidos por patrimonio y educación-2 $2^{a}$ edición

\begin{tabular}{|c|c|c|c|c|}
\hline & & PRIMARIA & SECUNDARIA & TOTAL \\
\hline \multirow{13}{*}{$\begin{array}{l}\text { PATRIMONIO } \\
\text { CULTURAL }\end{array}$} & Antiguo Casino & 17 & 7 & 24 \\
\hline & Ayuntamiento & 1 & 0 & 1 \\
\hline & Catedral & 13 & 9 & 22 \\
\hline & Diputación Provincial & 23 & 22 & 45 \\
\hline & Iglesia San Pedro & 32 & 7 & 39 \\
\hline & Iglesia Santiago & 35 & 22 & 57 \\
\hline & Museo Merced & 65 & 62 & 127 \\
\hline & Museo del Quijote & 12 & 20 & 32 \\
\hline & Museo Diocesano & 93 & 119 & 212 \\
\hline & Museo López Villaseñor & 74 & 48 & 122 \\
\hline & Museo Provincial & 31 & 33 & 64 \\
\hline & Plaza Mayor & 5 & 1 & 6 \\
\hline & Puerta de Toledo & 6 & 0 & 6 \\
\hline \multirow{8}{*}{$\begin{array}{c}\text { PATRIMONIO } \\
\text { NATURAL }\end{array}$} & Jardines del Cementerio & 30 & 5 & 35 \\
\hline & Jardines del Torreón & 24 & 2 & 26 \\
\hline & Parque de Atocha & 50 & 14 & 64 \\
\hline & Parque Juan Pablo II & 69 & 30 & 99 \\
\hline & Plaza del Pilar & 10 & 3 & 13 \\
\hline & Parque Gasset & 3 & 0 & 3 \\
\hline & Playas Vicario & 31 & 7 & 38 \\
\hline & Vía verde & 17 & 5 & 22 \\
\hline \multirow{6}{*}{ OClO } & Ciudad deportiva sur & 57 & 37 & 94 \\
\hline & Multicines & 32 & 4 & 36 \\
\hline & Pabellón Quijote Arena & 10 & 1 & 11 \\
\hline & Pabellón Rey Juan Carlos I & 19 & 6 & 25 \\
\hline & Recinto Ferial & 15 & 3 & 18 \\
\hline & Teatro Quijano & 5 & 2 & 7 \\
\hline \multirow{5}{*}{ SERVICIOS } & Biblioteca Gasset & 11 & 4 & 15 \\
\hline & Estación AVE & 11 & 5 & 16 \\
\hline & Estación BUS & 5 & 3 & 8 \\
\hline & Hospital & 4 & 0 & 4 \\
\hline & Mercadillo & 12 & 17 & 29 \\
\hline
\end{tabular}




\begin{tabular}{|c|c|c|c|c|}
\hline & Mercado Abastos & 78 & 78 & 156 \\
\cline { 2 - 4 } & Universidad & 12 & 2 & 14 \\
\hline
\end{tabular}

Fuente: Elaboración propia

En la tabla anterior se puede apreciar que no existen diferencias significativas entre las distintas etapas respecto al desconocimiento de espacios y lugares. Podríamos destacar que dentro de esos espacios desconocidos, en el caso del Museo Diocesano, lo desconocen más los alumnos/as de secundaria que los alumnos/as de primaria, caso contrario ocurre con el Museo López Villaseñor, más desconocido para los alumnos/as de primaria que para los de secundaria. No obstante, no son diferencias que podamos indicar como detonantes de resultados diferenciadores por etapas.

\section{c) Espacios favoritos de la ciudad $-1^{\text {a }}$ edición}

La segunda pregunta que se realizaba a los participantes consistía en analizar el grado de preferencia de los mismos espacios propuestos en la pregunta de conocimiento, pero esta vez preguntando por sus cinco favoritos, resultando en la primera edición las siguientes cifras:

\section{Gráfico 4- Lugares favoritos en Ciudad Real, 1a edición}

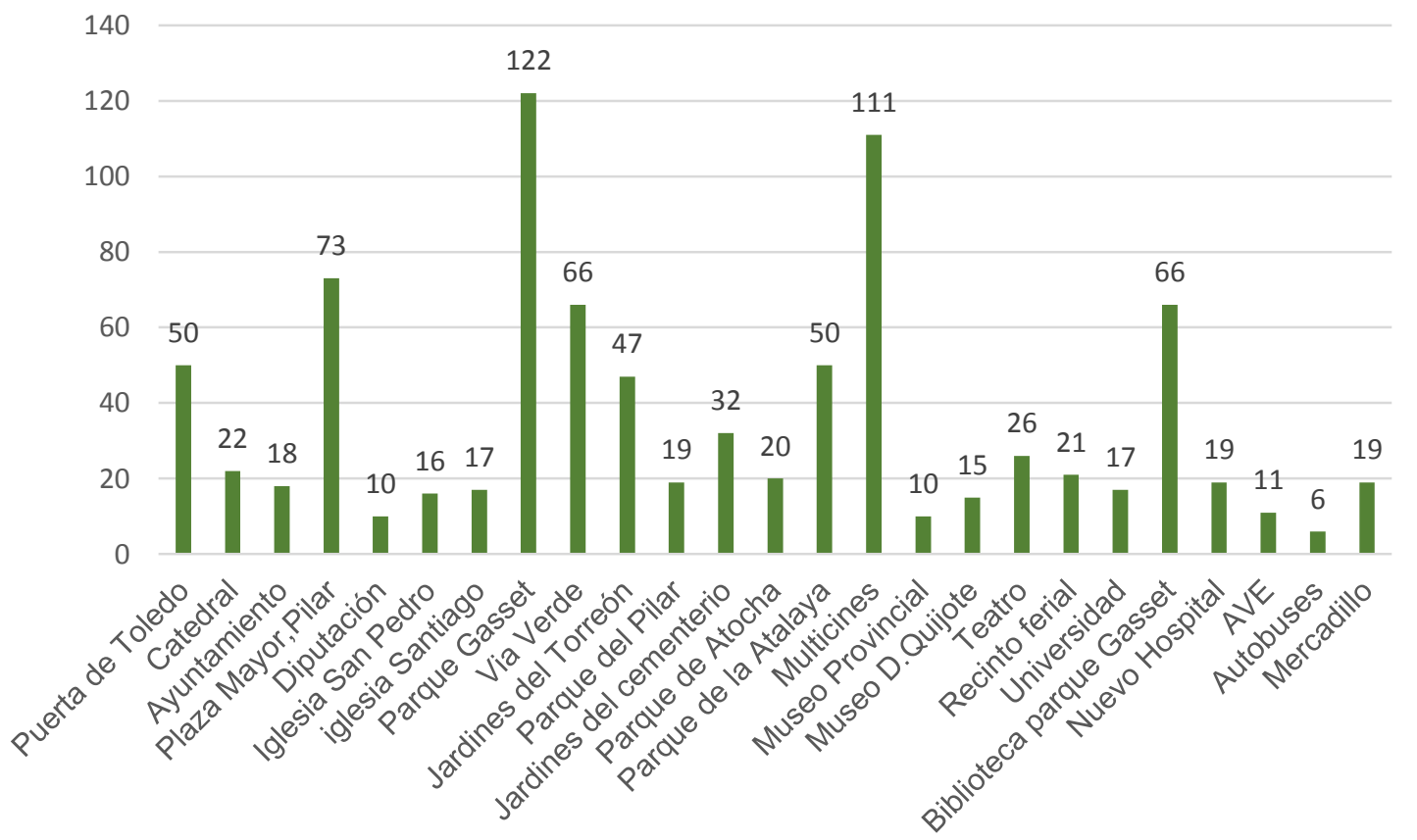

Fuente: Elaboración propia

Los espacios que más gustan a nuestros participantes son, por orden de preferencia: el Parque de Gasset (57\%), los Multicines (51\%), Plaza Mayor y Plaza del Pilar (34\%), Vía Verde y Biblioteca Parque de Gasset (30\%); y los menos favoritos son la Estación 
de Autobuses (2\%), Diputación Provincial y Museo Provincial (4\%) y Estación del AVE (5\%). El resto de los espacios se encuentran en valores menores del $25 \%$ de preferencia.

Es importante destacar que la mayoría de los espacios favoritos son parques que cuentan con zonas de ocio y juego, quizás esta sería una de las posibles causas de su preferencia por estos lugares.

\section{d) Espacios favoritos de la ciudad $-2^{a}$ edición}

Por otro lado, se analizaron los mismos espacios propuestos que en la pregunta de conocimiento (ver punto b, conocimiento de la ciudad- $2^{\underline{a}}$ edición), pero esta vez preguntando por sus cinco favoritos, resultando en la segunda edición las siguientes cifras:

Gráfico 5- Lugares favoritos en Ciudad Real, 2ªํㅡㄹ edicion

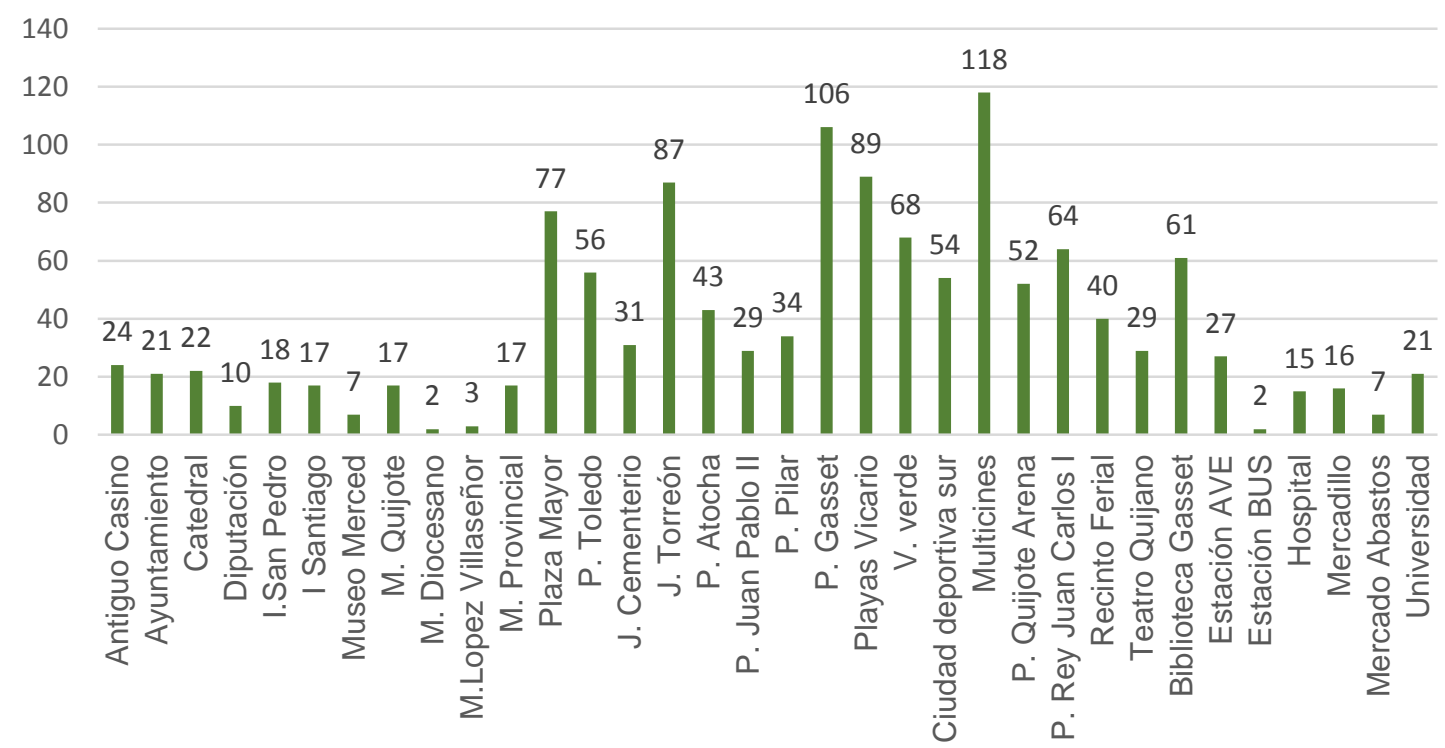

Fuente: Elaboración propia

Los participantes de la $2^{\mathrm{a}}$ edición destacan como lugares favoritos, en torno al $50 \%$ el Parque de Gasset (patrimonio natural) y los Multicines (espacio ocio); con un 35\% Jardines del Torreón y Playas del Vicario ambos relacionados con el patrimonio natural y con un $30 \%$ la Plaza Mayor (patrimonio cultural) y la Vía Verde (patrimonio natural). En general se aprecia una tendencia a elegir como lugares favoritos los espacios naturales.

Si comparásemos estos datos con los expuestos en la 1aㅡ edición (Gráfico 4), observamos que se repiten las mismas preferencias, dejando claro que Multicines y Parque Gasset son los espacios favoritos por los jóvenes de Ciudad Real. 
Tabla 4- Lugares favoritos por patrimonio y educación-2ª edición

\begin{tabular}{|c|c|c|c|c|}
\hline & & PRIMARIA & SECUNDARIA & TOTAL \\
\hline \multirow{13}{*}{$\begin{array}{l}\text { PATRIMONIO } \\
\text { CULTURAL }\end{array}$} & Antiguo Casino & 12 & 12 & 24 \\
\hline & Ayuntamiento & 14 & 7 & 21 \\
\hline & Catedral & 7 & 15 & 22 \\
\hline & Diputación Provincial & 5 & 5 & 10 \\
\hline & Iglesia San Pedro & 5 & 13 & 18 \\
\hline & Iglesia Santiago & 9 & 8 & 17 \\
\hline & Museo Merced & 4 & 3 & 7 \\
\hline & Museo del Quijote & 12 & 5 & 17 \\
\hline & Museo Diocesano & 2 & 0 & 2 \\
\hline & Museo López Villaseñor & 3 & 0 & 3 \\
\hline & Museo Provincial & 14 & 3 & 17 \\
\hline & Plaza Mayor & 41 & 36 & 77 \\
\hline & Puerta de Toledo & 31 & 25 & 56 \\
\hline \multirow{8}{*}{$\begin{array}{l}\text { PATRIMONIO } \\
\text { NATURAL }\end{array}$} & Jardines del Cementerio & 9 & 22 & 31 \\
\hline & Jardines del Torreón & 13 & 74 & 87 \\
\hline & Parque de Atocha & 6 & 37 & 43 \\
\hline & Parque Juan Pablo II & 4 & 25 & 29 \\
\hline & Plaza del Pilar & 7 & 27 & 34 \\
\hline & Parque Gasset & 45 & 61 & 106 \\
\hline & Playas Vicario & 38 & 51 & 89 \\
\hline & Vía Verde & 27 & 41 & 68 \\
\hline \multirow{6}{*}{$\mathrm{OCIO}$} & Ciudad Deportiva Sur & 20 & 34 & 54 \\
\hline & Multicines & 36 & 82 & 118 \\
\hline & Pabellón Quijote Arena & 24 & 28 & 52 \\
\hline & Pabellón Rey Juan Carlos I & 24 & 40 & 64 \\
\hline & Recinto Ferial & 18 & 22 & 40 \\
\hline & Teatro Quijano & 18 & 11 & 29 \\
\hline \multirow{7}{*}{ SERVICIOS } & Biblioteca Gasset & 24 & 37 & 61 \\
\hline & Estación AVE & 14 & 13 & 27 \\
\hline & Estación BUS & 1 & 1 & 2 \\
\hline & Hospital & 5 & 10 & 15 \\
\hline & Mercadillo & 9 & 7 & 16 \\
\hline & Mercado Abastos & 5 & 2 & 7 \\
\hline & Universidad & 12 & 9 & 21 \\
\hline
\end{tabular}

Fuente: Elaboración propia

Respecto a la preferencia diferenciada por la etapa educativa de los participantes podemos destacar que se establecen diferencias poco significativas, ya que los estudiantes de secundaria han secundado en mayor medida los espacios 
seleccionados por todos como favoritos, como son: el Parque de Gasset, los Jardines del Torreón, Multicines.

\section{e) Mejora en la ciudad}

Se preguntó a los participantes por cuatro posibilidades de mejora en la ciudad. Tenían que ordenar correlativamente del 1 al 4 cada una de las cuatro opciones, obteniendo los siguientes resultados:

\section{Gráfico 6- Prioridad de mejora en Ciudad Real}

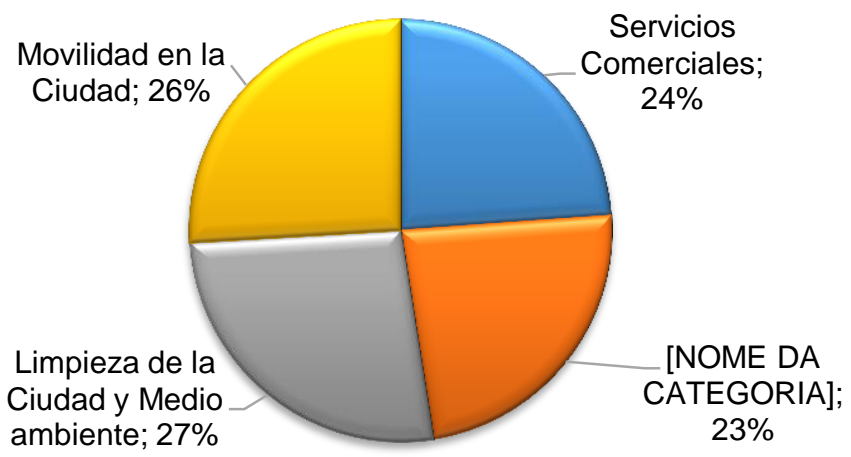

$\square$ Servicios Comerciales

๑actividades Culturales

$\square$ Limpieza de la Ciudad y Medio ambiente $\square$ Movilidad en la Ciudad

\section{Fuente: Elaboración propia}

Como se puede observar en la imagen anterior, las mejoras en la ciudad planteadas están muy igualadas, aunque destaca la mejora relacionada con la limpieza de la ciudad y el medio ambiente, que obtuvo un $27 \%$ de respuestas que priorizan la mejora en este apartado, seguida de la movilidad de la ciudad con un $26 \%$, servicios comerciales con un $24 \%$ y actividades culturales con otro $23 \%$.

Esta pregunta fue novedosa respecto a la primera edición del programa, donde se trataba las actuaciones del ayuntamiento y su satisfacción. Se recogía un apartado de sugerencias de mejora, las cuales se encontraban en una línea muy similar al de este año con mejora en limpieza, y más actividades para los jóvenes.

\section{f) Evaluación del proyecto}

En esta última parte se evalúa el proyecto completo de Ciudad Real durante todo el año con los centros educativos. La primera parte de la evaluación del proyecto es la general, que consiste en tres preguntas:

- ¿Te parece interesante el proyecto? 
- ¿Piensas que puede ser útil para la ciudad?

- ¿Piensas que tiene utilidad para la educación?

Estas preguntas las respondían solo los participantes que llegaron a la final del proyecto. Se midieron con una escala de: muy satisfecho, de acuerdo (4), satisfecho, de acuerdo (3), insatisfecho, en desacuerdo (2), muy insatisfecho, muy en desacuerdo (1). Agrupando las opciones de muy satisfechos (4) con satisfecho (3) por un lado, e insatisfecho (2) con muy insatisfecho (1) por otro, podemos calcular el siguiente gráfico, donde el porcentaje resultante indica el grado de satisfacción:

Gráfico 7- Satisfacción de la 2ª edición del proyecto en Ciudad Real

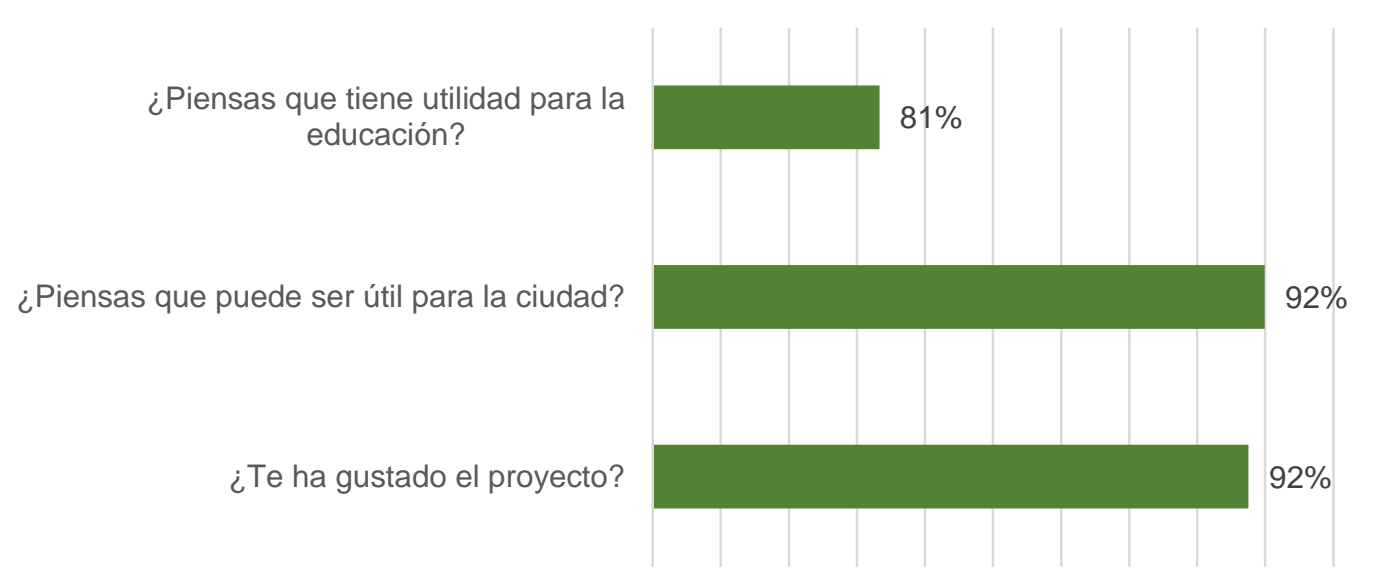

$74 \% 76 \% 78 \% 80 \% 82 \% 84 \% 86 \% 88 \% 90 \% 92 \% 94 \%$

Fuente: Elaboración propia

Respecto a la satisfacción del proyecto todos los indicativos cuestionarios superan el $80 \%$ por lo que podemos afirmar que existe una satisfacción alta. Únicamente destacar la diferencia entre la utilidad para la ciudad y en menor medida como proyecto educativo.

Si comparásemos estas cifras respecto a la primera edición, encontramos que a más de un $75 \%$ les gustó el proyecto en su primera edición, un 73,3\% consideraron que tenía mucha utilidad para la educación y un 73,40\% pensaron que era importante para la ciudad. Estas cifras comparadas con las de la segunda edición reflejan una mejoría en la opinión de los participantes. Posteriormente se evaluó la satisfacción de las etapas del proyecto: 


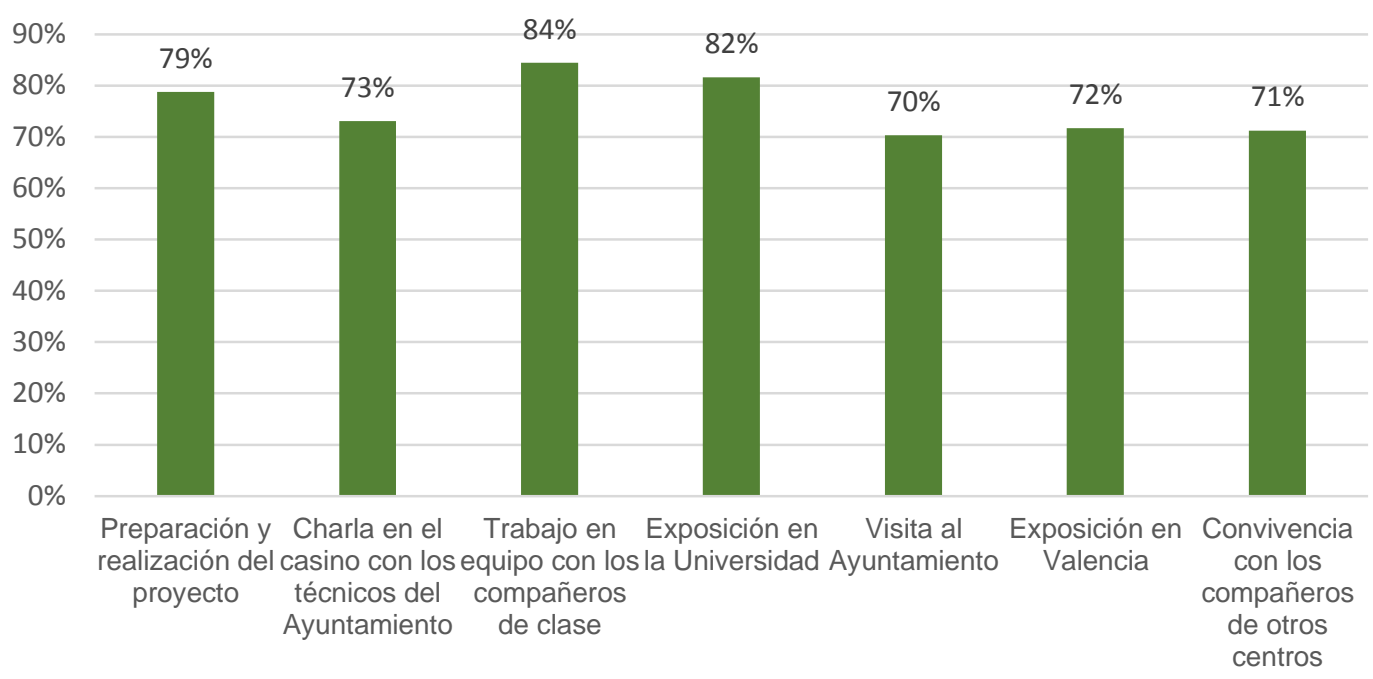

Fuente: Elaboración propia

Como podemos observar en el gráfico anterior, lo más enriquecedor para los participantes es poder trabajar en equipo con los compañeros/as de clase y la exposición en la Universidad, ambos superan el $80 \%$. Todas las etapas restantes superan el $70 \%$.

\section{Conclusiones}

El proyecto ¡Nosotros Proponemos! ha evolucionado favorablemente en todas sus facetas en estos dos años. Aunque el proyecto lleva poco tiempo en funcionamiento, se puede apreciar un fuerte desarrollo desde la primera edición (2016-2017) con la segunda edición (2017-2018), tanto a nivel de participación, como de desarrollo metodológico o apoyo institucional. El proyecto que nació en Portugal y se trasladó a España, concretamente a Ciudad Real de forma experimental, continua expandiéndose al resto de ciudades de España y del mundo.

El proyecto se convierte así en un elemento clave para que los alumnos/as más jóvenes de la ciudad, instituciones y educación se unan, combinen e intercambien conocimientos con el fin de aportar ideas que mejoren la situación de la ciudad. La implicación por parte de todos los agentes interesados se ha visto aumentada de una edición a otra, superándose en cada una de las facetas.

La ilusión de los jóvenes alumnos y alumnas en ser partícipes en las decisiones de la ciudad, la implicación por parte de toda la comunidad educativa (centros educativos y Universidad) en el funcionamiento del proyecto, y el compromiso real y serio por parte de las instituciones (Ayuntamiento) han hecho posible que Ciudad Real sea vista como 
una ciudad viva, participativa e implicada en la sociedad. Si analizásemos la evolución del proyecto en estas dos ediciones observamos:

\section{Respecto a los espacios de preferencia.}

- Se aprecia que siguen siendo desconocidos algunos espacios de la ciudad y casi en los mismos porcentajes en las dos ediciones; como son la Iglesia de Santiago (patrimonio cultural), el Parque de Atocha (patrimonio natural), el Museo Provincial (espacio de ocio). Cabe destacar que la Diputación Provincial (patrimonio cultural) era la gran desconocida en la primera edición y aunque sigue siendo desconocida en la segunda edición, el porcentaje baja del $90 \%$ al $50 \%$.

- Se evidencia una clara tendencia a seleccionar espacios que tienen relación con el patrimonio natural (parques, jardines,) y el ocio (Multicines), en detrimento de los otros dos, patrimonio cultural y servicios.

\section{Respecto a las mejoras de la ciudad}

- Se detecta interés por los aspectos que atañen directamente al mantenimiento de la ciudad como es la limpieza y el cuidado del medio ambiente como aspecto a mejorar seguido de la movilidad y en un plano inferior, aunque con poca diferencia aparecerían los servicios comerciales y las actividades culturales.

- Existe, por tanto, una coincidencia ya que si los espacios preferidos por los participantes se relacionan con el espacio natural tiene lógica que se preocupen por ellos y manifiesten su necesidad de mejora.

\section{Respecto a la evaluación del Proyecto}

- Existe una satisfacción generalizada hacia el Proyecto respecto a su utilidad y el gusto por participar en él. Sin embargo, hay que potenciar la relación entre la utilidad no solo para la mejora de la ciudad, sino también para la eficacia como Proyecto educativo.

\section{Respecto a la las etapas del Proyecto}

- Los aspectos relacionados con el trabajo cooperativo como son: trabajo en equipo con compañeros/as de clase, exposición en la Universidad, preparación y realización del Proyecto, son las etapas más satisfactorias para los participantes, seguida de las relacionadas con aspectos de carácter social y de divulgación (charla con los técnicos, exposición en otra ciudad (Valencia), 
convivencia con otros compañeros/as de otros centros educativos y visita al Ayuntamiento.

Como conclusión final y atendiendo al objetivo de estudio, podemos afirmar, que tras analizar los resultados de cada una de las partes trabajadas en el Proyecto Educativo: ¡Nosotros Proponemos! en cada una de las ediciones, aunque manteniendo lugares y espacios similares tanto en preferencia como en desconocimiento aporta un indicativo de mejora y satisfacción que son evidencia del buen funcionamiento del Proyecto.

\section{Referencias bibliográficas}

González-Mohíno, M., y Callejas, A. I. (2018). Resultados estadísticos y conclusiones del proyecto "¡Nosotros proponemos!" en Ciudad Real. En M. A. Rodríguez Domenech, y S. Claudino (Edits.), iNosotros proponemos! Ciudadanía, sostenibilidad e innovación geográfica ante los desafíos educativos de la sociedad (1 ed., págs. 235258). Barcelona, España: GRAÓ.

Rodríguez Domenech, M. A., y Claudino, S. (Edits.). (2018). ¡Nosotros proponemos! Ciudadanía, sostenibilidad e innovación geográfica ante los desafíos educativos de la sociedad. (1 ed.). Barcelona: GRAÓ.

http://www.nosotrosproponemos.com/. (29 de octubre de 2018). Obtenido de http://www.nosotrosproponemos.com/ 


\section{A problematização da qualidade do abastecimento de água da área rural de Francisco Beltrão - Paraná, Brasil - por meio do ensino de Geografia}

Rosana CRISTINA BIRAL LEME ${ }^{1}$

\section{Resumo}

A presente pesquisa possui como principal objetivo a problematização dos dados referentes a qualidade da água existente nas Soluções Alternativas Coletivas (SACs) localizadas no perímetro rural do município de Francisco Beltrão, estado do Paraná, Brasil. Nesse sentido, o resumo se integra ao eixo 4: Geografia e Cidadania. Três sequências didáticas foram elaboradas para discutir os elementos que geram a perda da qualidade da água consumida na área rural do município vinculando-as aos conteúdos propostos pelas Diretrizes Estaduais de Ensino de Geografia. As atividades didático pedagógicas foram elaboradas para esclarecer aos alunos sobre o conceito de qualidade, contaminação e poluição da água; sobre os mecanismos e agentes desencadeadores da degradação da qualidade da água e a discussão a respeito das ações necessárias para minimizar ou evitar o problema de contaminação da água potável. Os recursos didáticos utilizados foram: a análise dos dados do Sistema Vigiágua; a produção de textos dos alunos; a elaboração de jogo de tabuleiro e a redação de cartas com sugestões dos alunos endereçadas às lideranças municipais. Consideramos que tais ações ajudam no estreitamento do ensino de Geografia com a abordagem de problemas que fazem parte do espaço local dos alunos; na promoção da discussão da importância da Educação Ambiental, bem como, na criação de

\footnotetext{
1 Professora Associada do Curso de Graduação e Pós-graduação em Geografia da Universidade Estadual do Oeste do Paraná - UNIOESTE - Campus de Francisco Beltrão/ PR, Brasil. Endereço eletrônico: rosanabiral@hotmail.com.
} 
políticas que visem a sustentabilidade e a diminuição de impactos das atividades antrópicas em suas comunidades locais.

Palavras-chave: Educação ambiental; qualidade de vida; educação geográfica; desenvolvimento regional; ensino de Geografia.

\section{Abstract}

The present research has as main objective the problematization of the water quality data existing in the Collective Alternatives Solutions (SACs) located in the rural perimeter of the municipality of Francisco Beltrão, state of Paraná, Brazil. In this sense, the abstract is integrated into axis 4: Geography and Citizenship. Three didactic sequences were elaborated to discuss the elements that generate the loss of the quality of the water consumed in the rural area of the municipality, linking them to the contents proposed by the State Directives of Geography Teaching. The pedagogical didactic activities were elaborated to clarify the students about the concept of quality, contamination and water pollution; on the mechanisms and agents that trigger water quality degradation and the discussion about the actions necessary to minimize or avoid the problem of contamination of drinking water. The didactic resources used were: the analysis of the VIGIAGUA System data; the production of student texts; the elaboration of board game and the writing of letters with suggestions of the students addressed to the municipal leaderships. We believe that such actions help narrow the teaching of Geography by approaching problems that are part of the local space of students; in promoting the discussion of the importance of Environmental Education, as well as in the creation of policies aimed at sustainability and the reduction of impacts of anthropic activities in their local communities.

Keywords: Environmental education; quality of life; geographical education; regional development; Geography teaching.

\section{Introdução}

A diversidade de usos atribuídos à água, converte sua gestão em um tema econômico e geoestratégico de extrema relevância para o desenvolvimento das nações. Provém das universidades e instituições governamentais, via de regra, as principais fontes de informação e monitoramento das fontes de abastecimento de água potável da população. Verificamos por meio de pesquisas que, a maioria das pessoas residentes na área rural do município de Francisco Beltrão, região Sudoeste do estado do Paraná/Brasil, não conhecem a qualidade da água que consomem e dependem 
totalmente do processo de monitoramento realizado pelo departamento de Vigilância em Saúde Municipal - órgão ligado ao governo estadual. Verificamos que, os dados resultantes deste monitoramento municipal não são do conhecimento da população a eles diretamente afetos.

A abordagem concernente a Educação Geográfica, tema central do presente Congresso, vincula-se à capacidade de formação de cidadãos que sejam capazes de compreender os elementos de composição da dinâmica sócio espacial e intervir nessa configuração de modo proativo. Existe uma grande interface entre a Educação Geográfica e a compreensão e resolução dos problemas socioambientais, uma vez que estes - aqui exemplificados pela análise da qualidade da água - são deflagrados por consequências diretas e indiretas do modo de produção e consumo determinados por setores específicos das sociedades que, historicamente, se tornaram dominantes e disseminaram um formato de vivência, produção e consumo, ou seja, produção e ocupação territorial, cujas consequências, em última instância, são problemas socioambientais, via de regra, compartilhados por todos.

Não obstante, dados que explicam e/ou contextualizam as questões ambientais locais são pouco difundidos nos ambientes escolares, perdendo um importante locus de discussão e iniciativas de resolução de tais problemas. Por este motivo, a presente pesquisa visa a realização de trabalho vinculado a aplicação dos dados da qualidade de água do perímetro rural do município de Francisco Beltrão para discussões didáticas inerentes à Educação Geográfica.

Os dados utilizados são do período de 2008 a $2015^{2}$ e compõem o Sistema de Informação de Vigilância da Qualidade da Água para Consumo Humano (Sisagua) obtidas nos trinta e um Sistemas Alternativos Coletivos (SACs) existentes no perímetro rural de Francisco Beltrão. Na área rural de Francisco Beltrão onde não ocorre o fornecimento de água via sistemas de abastecimento de água e saneamento estadual (Sanepar), as fontes de abastecimento são diversificadas (minas; poços livres individuais; poços profundos e artesianos individuais, poços artesianos coletivos) entretanto, o que o predomina são os SAC, poços perfurados em áreas que concentram um número expressivo de famílias e que está sob o monitoramento do Departamento de Vigilância em Saúde. Dentre o conjunto de informações obtido junto ao Sisagua estão vinculadas a indicadores que discriminam presença ou ausência de

\footnotetext{
${ }^{2}$ Cumpre informar que nova etapa de coleta e atualização dos dados está sendo realizada, com previsão de publicação de resultados no ano de 2019.
} 
Coliformes Totais e a presença ou a ausência de Escherichia coli (Ec) ou Coliformes Termotolerantes e índices de Turbidez.

Três sequências didáticas foram elaboradas visando a problematização dos dados fornecidos pela Vigilância da Qualidade da Água para Consumo Humano - Vigiagua, bem como sobre a noção de qualidade, contaminação; poluição da água e medidas mitigadoras dos processos de contaminação mais frequentes para alunos a partir do 6 ano do Ensino Fundamental. Outrossim, somos convictos que tais conteúdos podem ser adaptados aos demais anos das séries finais do Ensino Fundamental, como também aos alunos do Ensino Médio das escolas inseridas neste município, uma vez que o tema apresenta valor inequívoco à qualidade de vida de todos os cidadãos.

\section{Qualidade da água potável em áreas rurais e seu estudo por meio da Educação Geográfica}

Consideramos oportuna a apresentação de noções exordiais sobre os conceitos e dados com os quais trabalhamos para a elaboração das sequências didáticas. Para tanto, são dadas a conhecer informações primordiais sobre o cumprimento de responsabilidade no que tange a gestão das águas potáveis e dos principais parâmetros físico, químicos e microbiológicos utilizados para esta análise.

\subsection{Parâmetros legais para a qualidade da água}

A análise da qualidade da água no Brasil é sujeita às diretrizes do Ministério da Saúde, por meio da Portaria do Ministério da Saúde ํo 2.914/2011. O processo de monitoramento da qualidade da água potável em todo território nacional se dá por meio da manutenção do Programa Sisagua (Sistema de Informação de Vigilância da Qualidade da Água para Consumo Humano). No âmbito local, esta análise é submetida ao departamento de Vigilância em Saúde, integrante da Secretaria de Saúde municipal.

A Portaria № 518/2004 do Ministério da Saúde, obriga o poder público a realizar o monitoramento da qualidade da água após a abertura de poços artesianos ou semi artesianos de uso coletivo para o exercício do controle da qualidade da água para 
consumo humano ${ }^{3}$. No caso do estudo da qualidade das águas rurais, o controle sistemático por parte do estado ocorre por meio da análise da água existente nas Soluções Alternativas Coletivas (SACs) que são modalidade de abastecimento coletivo destinada a fornecer água potável, com captação subterrânea ou superficial, com ou sem canalização e sem rede de distribuição (Brasil, 2011). As SACs são preferencialmente analisadas dada a abrangência de pessoas atendidas por este tipo de abastecimento, podendo chegar a oitenta famílias no município de Francisco Beltrão.

O número de amostras coletadas para a análise oscila consoante o número de pessoas abastecidas pela SAC, bem como o tipo de manancial que lhe dá condição de existência. No que tange as SACs analisadas em Francisco Beltrão a Portaria MS no 2.914/2011 exige a realização de no mínimo 1 coleta mensal a cada 500 habitantes.

Após coletada a água, as amostras são enviadas para laboratórios cadastrados ao Sisagua (programa do Ministério da Saúde) e seus resultados vão compor o banco de dados do Programa Vigiagua. Os parâmetros registrados junto ao programa são: Turbidez, Coliformes Totais e Escherichia coli.

Do ponto de vista da tolerância de contaminação permitida, a Portaria Federal assevera que, em SACs que abastecem número menor do que 20.000 habitantes, apenas uma das amostras examinadas no mês, poderá apresentar resultado positivo para Coliformes totais. No que tange a observância do parâmetro vinculado a Escherichia coli, é importante ressaltar que a Portaria 2.914/2011, é vigorosa ao determinar que não pode haver presença deste bio-indicador em nem uma amostra coletada na SAC. Este deve ser ausente em todas as análises das amostras consideradas potáveis.

No que tange a Turbidez, os valores culminantes outorgados à Turbidez ${ }^{4}$ são de 1,0 NTU para águas subterrâneas em 95\% das amostras coletadas, Enquanto o dígito máximo permitido em qualquer amostra pontual é de 5,0 NTU.

\footnotetext{
${ }^{3}$ Considerado neste estudo como sendo: "conjunto de atividades exercidas regularmente pelo responsável pelo sistema ou por solução alternativa coletiva de abastecimento de água, destinado a verificar se a água fornecida à população é potável, de forma a assegurar a manutenção desta condição" (Brasil, Portaria do Ministério da Saúde no 2.914/2011).

${ }^{4}$ O parâmetro vinculado características físicas da água é o índice de turbidez da água que indica a quantidade de partículas sólidas em suspensão na água e sua mensuração vincula-se a propriedade ótica de absorção e reflexão da luz incidente sobre um corpo de água. A grandeza aplicada a este parâmetro é o Nephelometric Turbidity Unit - NTU e pode indicar a
} 
$\mathrm{Na}$ análise microbiológica é permitida a presença de Coliformes Totais em apenas uma das amostras coletadas, desde que as mesmas não tenham sido coletadas diretamente no poço, mas junto a rede de distribuição ou reservatório da SAC. No caso de resultados positivos, a Portaria assevera a adoção imediata de ações corretivas. Tais ações envolvem a ampliação do número mínimo de amostras; o aumente a frequência de amostragem; a realização de análises laboratoriais de parâmetros adicionais e encaminhar ao responsável pela SAC informações sobre os resultados das análises para tentar evitar a ocorrência de surtos e agravos à saúde relacionados à qualidade da água.

Essa análise é crucial para o reconhecimento de ameaça de patógenos presentes no sistema gastrointestinal o que torna essa água um risco à saúde de humanos e animais.

\subsection{Problematização dos dados por meio da Educação Geográfica}

A primeira etapa para a organização das sequências didáticas versando sobre a qualidade da água na área rural do municipio de Francisco Beltrão foi a organização da caracterização espacial do município.

Francisco Beltrão, localizado no Sudoeste do estado do Paraná, possui, conforme dados estimados pelo IBGE (2018), uma população de 89.942 pessoas distribuídas na área de $735,111 \mathrm{~km}^{2}$. Segundo dados disponibilizados pelo Ipardes ${ }^{5}$ (2015), o município possui cinco distritos administrativos ${ }^{6}$ totalizando 27.909 domicílios. Destes, 24.068 residências urbanos e 3.841 residências rurais, apresentando, portanto, um grau de Urbanização de 85,44\%. Em 30.699 unidades atendidas, são ativas 23.839 ligações de água. Embora a maioria absoluta destas ligações ocorra em unidades urbanas atendidas pela SANEPAR ${ }^{7}$, aproximadamente $13 \%$ são atendidas por outras fontes de abastecimento de água e saneamento ${ }^{8}$ (Ipardes, 2015).

Nesta caracterização buscamos apresentar as dimensões espaciais do município, por meio de mapas e figuras. Por conseguinte, iniciamos a problematização a respeito de

presença de matéria orgânica em suspensão. Geralmente as técnicas utilizadas para a diminuição da turbidez são o processo de filtração e decantação da água.

${ }^{5}$ Instituto Paranaense de Desenvolvimento - Ipardes.

${ }^{6}$ Francisco Beltrão, Jacutinga, Nova Concórdia, São Pio X e Secção Jacaré Comarca a que pertence Francisco Beltrão (Ipardes, 2015).

5 SANEPAR significa: Companhia de Saneamento do Paraná.

${ }^{8}$ De acordo com o Ipardes (2015) são consideradas outras fontes de saneamento: CAGEPAR, CASAN, DEMAE, Prefeitura Municipal, SAAE, SAAEM, SAEMA e SAMAE 
como seria o abastecimento de água que não era fornecido pela SANEPAR. As respostas vinculadas ao abastecimento via fontes e poços predominaram. Não relataram conhecimento aos locais em que estes poços existiam, quem os construiu e quem geria a qualidade de suas águas.

Iniciamos uma discussão sobre o que era a qualidade da água e como esta qualidade poderia ser prejudicada. Discutimos como a água se forma, os meios de infiltração na natureza e as formas de contaminação. Os materiais vinculados com esta discussão foram pautados para a realidade concernente a alunos da faixa etária de 10 a 11 anos - entretanto, consideramos que seu aprofundamento e detalhamento é possível tanto para os anos subsequentes, quanto para os posteriores.

$\mathrm{Na}$ segunda sequencia didática, foram apresentados os dados da Vigilância em Saúde, que relatava que o município de Francisco Beltrão possui trinta e uma (31) Soluções Alternativas Coletivas (SACs) no seu área rural, sendo elas distribuídas nas comunidades de: Associação Assentamento Missões Barra Escondida, Assoc. Linha Pedreirinho, Barra Bonita, Linha Divisor, São Pio X, Km 30, Linha Formiga, Linha Freire, Linha Macagnam, Linha Menino Jesus, Linha Nova União, Linha Palmerinha, Linha Rio Macaco, Linha Santa Bárbara, Linha São Braz, Linha São Marco, Linha São Paulo, Planalto Jacutinga, Ponte Nova do Cotegipe, Posto Panorâmico, Rio do Mato, Linha Rio Serrinho, Associação Rio Tuna, Seção Jacaré, Seção Progresso, Linha São Miguel, Vila Lobos, Vila Rural Água Viva, Vila Rural Gralha Azul e Linha Piracema (Vigiagua, 2015).

Uma das formas como os dados foram apresentados foi por meio de jogos de tabuleiro. Os dados foram apresentados no mapa (tabuleiro) do município e explicamos rapidamente porque o município tinha a obrigação de controlar a qualidade da água destas SACs (que somavam ou perdiam pontos para avançar na corrida da qualidade da água municipal).

O primeiro aspecto foi mostrar a responsabilidade do departamento de Vigilância em Saúde pela produção destes dados, bem como indicar que, comparando as determinações legais com os dados oficialmente disponibilizados pelo municipio, verifica-se que em Francisco Beltrão não existe sistema de monitoramento que atenda ao número de amostras orientadas pela Portaria MS, que seria de 372 amostras anuais no contexto das 31 SACs por possuírem até 500 habitantes devem ter suas águas coletadas pelo menos uma vez ao mês. O que totalizaria dentro do 
período compreendido pelo estudo (oito anos) no mínimo 2.976 análises, não apenas 432 conforme o praticado 9 .

Mostramos por meio de gráficos e figuras o que foram os resultados da qualidade da água analisada nestes locais. De acordo com dados levantados, no período de abril de 2008 a maio de 2011, foram realizadas 199 análises de Coliformes Totais e de Escherichia coli, destas $60 \%$ apresentam resultados com presença de coliformes em composição na água, e 40\% apresentam resultados satisfatórios.

No que tange a presença da Escherichia coli, verificou-se que $79 \%$ das análises obtiveram resultados satisfatórios e $21 \%$ das análises obtiveram resultados insatisfatórios no que tange a adequação à potabilidade. A turbidez durante o período analisado na pesquisa esteve sempre dentro dos padrões estabelecidos pela portaria $518 / 04$.

Já no período subsequente, junho de 2011 a novembro de 2015 , que das trinta e uma comunidades monitoradas, das 233 análises realizadas, 154 apresentam contaminação. As análises realizadas nas comunidades, dezoito destas, acusam presença de Coliformes Termotolerantes do tipo Escherichia coli e as trinta e uma SACs apresentaram Coliformes Totais acima de $40 \%$ das amostras coletadas.

De 2008 a 2015 verificou-se que no que tange ao parâmetro de Coliformes (Escherichia coli e Total) das 432 amostras coletadas, 266 análises foram positivas para Coliformes Totais; 164 foram positivas para $E c$; enquanto que no aspecto Turbidez, das 516 análises realizadas, 51 estavam acima do preconizado na Portaria MS no 2.914/2011.

Após revelarmos que existe um grande número de famílias que consomem água de má qualidade, começamos a terceira etapa das sequências didáticas propostas. Esta etapa envolveu a realização da produção de texto sobre o tema: qualidade da água da área rural de Francisco Beltrão; elaboração de questionário para a realização de trabalho de campo à uma das SACs. É oportuno informar que a SAC visitada, foi uma das poucas localidades que apresentaram boa qualidade de água. Esta seleção se deu pela proximidade da área urbana, mas também por receio de, ao inquerir aos moradores sobre o consumo de água de má qualidade, pudéssemos causar alarme e desconforto aos moradores sem a proposição de nenhuma solução ou saída para o

\footnotetext{
${ }^{9}$ A respeito destas SACs foram coletadas informações referentes a 432 amostras coletadas durante o período compreendido por nossa pesquisa. O número resulta do processo irregular de monitoramento realizado pelo Departamento de Vigilância em Saúde municipal.
} 
problema. Neste trabalho de campo, os alunos questionaram o presidente da associação de moradores a respeito de vários aspectos, dentre os quais: qual a profundidade do poço; para que utilizavam a água; se tinham outras fontes de abastecimento; quantas famílias eram abastecidas e o que faziam para manter a qualidade da SAC. Após a visita entramos na fase de discutir por que isso ocorria e como poderíamos auxiliar na minimização deste impacto.

As crianças elaboraram uma série de sugestões que envolveram a comunidade escolar; a elaboração de carta ao departamento municipal de Vigilância em Saúde e proposições de trabalhos de Educação ambiental nas comunidades tais como visitas aos moradores, entrega de panfletos, criação de calendários com dias de lavagem das caixas d'água, além de sugerir a adoção do uso do hipoclorito de sódio nas águas consumidas diariamente e o maior cuidado com a instalação das fossas sépticas utilizadas na área rural.

As três sequências didáticas foram elaboradas, tendo como base no $6^{\circ}$ ano do Ensino Fundamental e nestas sequências, conceitos e problemas vinculados à qualidade da água foram abordados de modo a propiciar aos alunos a compreensão sobre potabilidade; qualidade; contaminação e poluição da água. Também foram abordadas as formas de abastecimento de água na área rural, a importância da participação da população no processo de controle, bem como a gestão da qualidade da água consumida na área rural. As sequências didáticas contribuíram com a apresentação de dados locais das SAC da área rural de Francisco Beltrão, uma vez que subsidiaram e estimularam a discussão de como as normas de potabilidade da água consumida é gerida pelos órgãos responsáveis. Embora os dados apresentados não tenham indicado, em nenhum momento, a personificação de "um culpado" para o problema, estes dados e sua análise demonstraram que a qualidade da água consumida pela população rural de Francisco Beltrão está aquém do preconizado pelo Ministério da Saúde. Este fato, na análise dos alunos, indicou que este assunto requer por parte dos responsáveis, uma nova atenção, sobretudo, para o número de coletas realizados nas SACs, bem como a necessidade de realizar trabalhos formativos para com a população. Dessa forma, contribuíram com a análise geográfica do problema, uma vez que envolveram os alunos e os estimularam a abordar os problemas locais.

\section{Conclusão}


No que tange a realização deste estudo, foi possível ratificar a importância da Educação Geográfica a partir da problematização de dados socioambientais locais, neste caso, com as questões vinculadas a qualidade da água que ainda são pouco conhecidas da maior parte da população local. Na classe com a qual trabalhamos, compreendemos que a maior parte dos alunos, como senso comum, considerava que a boa qualidade da água estava vinculada à perfuração de poços artesianos ou poços profundos, sendo a água subterrânea considerada superior no que tange a qualidade em relação a água subsuperficial, os conceitos advindos do conhecimento científico demonstraram aos alunos que existem inúmeros aspectos a serem considerados, ante a conclusão de potabilidade da água.

O questionário, bem como o trabalho de campo propostos nas sequências didáticas promoveram o envolvimento dos alunos com o tema e aproximou o conhecimento escolar abordado anteriormente, com os conhecimentos de origem local, coletados e analisados diretamente por eles. Este processo foi primordial para que os alunos atribuíssem sentido e significado ao processo de aprendizado, bem como criassem identidade com o tema, sem o qual não poderíamos requerer a terceira etapa das sequências didáticas, que previa propostas para a resolução dos problemas.

Há necessidade de que se construa a compreensão sobre a importância dos papeis sociais para acompanhar de forma crítica e participativa todas as esferas da vida. No caso da análise realizada pelos alunos, estes indicaram a premência de que não haja apenas um responsável pelo processo de manutenção do equipamento e cloração da água, mas a necessidade de envolvimento de toda a comunidade abastecida por SAC de seu processo de manutenção e gestão. Tal reflexão conduz ao indicativo de que é prioritário o processo formativo não apenas do técnico responsável pela SAC na comunidade, mas de todos os usuários da SAC. A vista disso, consideramos muito significativa a indicação apresentada pelos alunos acerca da formação de cidadãos que monitorem as ações. Para tanto, eles (alunos) indicam a criação e o envolvimento dessa população com projetos educativos que abordem a questão ambiental de modo integrado e assim a população possa compreender e valorizar ações e infraestruturas que ajudem a ter uma boa conservação desses poços na qualidade da água. Ao dar potência a este tipo de crítica sobre a qualidade da água, expecta-se o surgimento de exigências de contrapartidas que auxiliem na proteção e manutenção das fontes de água permanentemente.

A qualidade de água é um aspecto muito importante para o êxito da qualidade de vida de qualquer cidadão e, na área rural de Francisco Beltrão as SACs são extremamente 
importantes para o abastecimento e dessedentação das propriedades rurais, por isso foram utilizadas como base para os processos de discussão crítica. Outrossim, o que apresentamos aos alunos foi uma pequena parcela referente a realidade, e inúmeras outras questões poderiam ser problematizadas. O que queremos evidenciar neste trabalho é que a Educação Geográfica contribui com a proposta de discussão de inúmeros temas mediante ao questionamento sobre a realidade e ao esclarecimento sobre a necessidade de que os cidadãos se conectem com os problemas locais por meio dos dados reais.

Ao formarmos nosso aluno um cidadão capaz de erigir questionamentos sobre a realidade na qual vive, efetivamos o objetivo primordial da Educação Geográfica que é promover a capacidade de leitura e compreensão da realidade socioespacial. Nesse intento, a Geografia ajuda o indivíduo na conquista da cidadania a um só tempo em que fortalece seu papel na busca da construção de pontes que aproximem cada vez mais a sociedade e a universidade, objetivo comum aos participantes do Congresso Nós Propomos!

\section{Referências}

BRASIL, MINISTÉRIO DA SAÚDE. (2015). SISAGUA - Sistema de Informação de Vigilância da Qualidade da Água para Consumo Humano. Disponível em: http://www.saude.pr.gov.br/modules/conteudo/conteudo.php?conteudo=1433> Acesso em: 20 de novembro de 2015.

BRASIL, MINISTÉRIO DA SAÚDE. (2011). Portaria nº 2.914/ 12/ 2011. Disponível em: < http://bvsms.saude.gov.br/bvs/saudelegis/gm/2011/prt2914_12_12_2011.html. Acesso em: 06 de agosto de 2015.

BRASIL, MINISTÉRIO DA SAÚDE. (2004). Portaria nº 518/2004 do Ministério da Saúde. Acesso em: 06 de agostos de 2015.

FIO CRUZ. (2015). Observatório dos Técnicos em Saúde. Disponível em: <http://www.observatorio.epsjv.fiocruz.br/index.php?Area=Trabalhador\&Num=9> Acesso em: 15 de dezembro de 2015.

IBGE - Instituto Brasileiro de Geografia e Estatística (2018).. Panorama municípios Paraná - Disponível em: https://cidades.ibge.gov.br/brasil/pr/franciscobeltrao/panorama. Acesso em: 15 de outubro de 2018. 
IPARDES - Instituto Paranaense de Desenvolvimento. (2015). Caderno Estatístico Município De Francisco Beltrão. Disponível em: < http://www.ipardes.gov.br/cadernos/MontaCadPdf1.php?Município=85600\&btOk=ok> Acesso em:14 de janeiro de 2015.

IPARDES - Instituto Paranaense de Desenvolvimento. (2018). Caderno Estatístico Município De Francisco Beltrão. Disponível em: < http://www.ipardes.gov.br/cadernos/MontaCadPdf1 .php?Município=85600\&btOk=ok>. Acesso em:15 de outubro de 2018.

JB - JORNAL DE FRANCISCO BELTRÃO. (2015, Janeiro). Assentamento Missões é a comunidade que mais produz leite em Beltrão: Publicado em 21 janeiro 2015. Disponível em: <http://franciscobeltrao.pr.gov.br/noticias/desenvolvimentorural/assentamento-missoes-e-a-comunidade-que-mais-produz-leite-em-beltrao> Acesso em: 18 de janeiro de 2016.

LUÍZ, Â. M.; EWERLING, P. M. L. C. \& SCHEFFER, E. W. O. (2016). Parâmetros de cor e turbidez como indicadores de impactos resultantes do uso do solo, na bacia hidrográfica do rio Taquaral, São Mateus do Sul-PR. Disponível em: <http://ojs.c3sl.ufpr.br/ojs/index.php/raega/article/view/26264>. Acesso em: 18 de janeiro de 2016.

SANTOS, L. C. (1999). Laboratório Ambiental. Cascavel: Edunioeste (323 p.).

SILVA, N. (et al.). (2010). Manual de Métodos de Análise Microbiológica de Alimentos e Água. São Paulo: Varela, 2010. Acesso em: 15 de dezembro de 2015.

VIGIÁGUA. Vigilância Ambiental em Saúde relacionada à Qualidade da Água para Consumo Humano. (2015). Dados da qualidade da água das SACs de Francisco Beltrão 2008-2015. Departamento de Vigilância em Saúde da Prefeitura Municipal de Francisco Beltrão, PR. 


\title{
Aprendizagem na Educação Geográfica à luz da neurociência - as experiências "A escola faz o vídeo", "Com-vida" e "Nós Propomos!"
}

\author{
ROSEMY DA SILVA NASCIMENTO ${ }^{1}$ \\ RODRIGO SARTORIO ${ }^{2}$ \\ SÉRGIO CLAUDINO ${ }^{3}$
}

\section{Resumo}

A ciência geográfica estimula análises integradoras e fundamentais para a formação cidadã, dando suporte epistemológico e estimulando uma compreensão de políticas públicas e da gestão dos territórios, contibuindo para uma educação socialmente comprometida. E o processo educativo, como o mundo, se modificam, reivindicando mudanças e novos paradigmas nos métodos de ensino, promovendo as competências e habilidade que os estudantes devem desenvolver na educação básica, conforme as legislações e propostas curriculares para processos de combinações complexas de conhecimentos, capacidades e atitudes, que permitem uma efetiva ação humana em contextos diversificados. À luz dessa reivindicação, este texto apresenta algumas experiências de protagonismo estudantil, desde as pontuais como a "Escola faz o vídeo" em Florianópolis-SC/Brasil; o programa brasileiro do Ministério do Meio Ambiente (MMA), denominado "Comissão de Meio Ambiente e Qualidade de Vida (Com-vida)" até à experiência de expansão internacional, originário em Portugal, o "Projeto Nós Propomos!! Cidadania e Inovação na Educação Geográfica". Pretende-se abordar como essas propostas tornam a aprendizagem eficaz, a partir dos estudos do desenvolvimento neural e cognitivo, em especial no que tange à neuroplasticidade, as alterações neurais decorrentes do treino cognitivo - demonstradas atualmente por

\footnotetext{
Docente da Universidade Federal de Santa Catarina/Brasil, rosemy.nascimento@gmail.com

${ }^{2}$ Biólogo Neurocientista http://rodrigosartorio.com.br, sartoriobio@gmail.com

${ }^{3}$ Docente do Instituto de Geografia e Ordenamento do Território da Universidade de Lisboa, sergio@campus.ul.pt
} 
técnicas de neuroimagem e estudos de neuromorfologia, bem como de estudos das ciências cognitivas para aspectos motivacionais e emocionais. Os resultados dos trabalhos dos estudantes como protagonistas em seus espaços imediatos demonstram que os aportes teóricos da Educação Geográfica e neurociência, permitem a construção de seu conhecimento e concretização de uma educação para a vida.

Palavras-chave: Neurociência. Trabalho de campo. Educação Geográfica.BNCC.

\section{Resumen}

La ciencia geográfica estimula análisis integradores y fundamentales para la formación ciudadana, dando soporte epistemológico y estimulando una comprensión de políticas públicas y de la gestión de los territorios, contiguando para una educación socialmente comprometida. $\mathrm{Y}$ el proceso educativo, como el mundo, se modifican, reivindicando cambios y nuevos paradigmas en los métodos de enseñanza, promoviendo las competencias y habilidad que los estudiantes deben desarrollar en la educación básica, conforme a las legislaciones y propuestas curriculares para procesos de combinaciones complejas de conocimientos, capacidades y actitudes, que permiten una efectiva acción humana en contextos diversificados. A la luz de esta reivindicación, este texto presenta algunas experiencias de protagonismo estudiantil, desde las puntuales como la "Escuela hace el vídeo" en Florianópolis-SC / Brasil; el programa brasileño del Ministerio de Medio Ambiente (MMA), llamado el "Comité de Medio Ambiente y Calidad de Vida (con vida)" a la experiencia de expansión internacional, originarios de Portugal, el "Proyecto Proponemos! Ciudadanía e Innovación en la Educación Geográfica ". Se pretende abordar cómo estas propuestas hacen el aprendizaje eficaz, a partir de los estudios del desarrollo neural y cognitivo, en especial en lo que se refiere a la neuroplasticidad, las alteraciones neurales derivadas del entrenamiento cognitivo - demostradas actualmente por técnicas de neuroimagen y estudios de neuromorfología, así como como de estudios de las ciencias cognitivas para aspectos motivacionales y emocionales. Los resultados de los trabajos de los estudiantes como protagonistas en sus espacios inmediatos demuestran que los aportes teóricos de la educación geográfica y la neurociencia, permiten la construcción de su conocimiento y concreción de una educación para la vida.

Palabras clave: Neurociencia. Trabajo de campo. Educación geográfica. BNCC. 
O ser humano possui a natural curiosidade de querer compreender-se como espécie e tudo o que está a sua volta. Esse processo acontece por meio das suas faculdades mentais, conforme os recursos intelectual e psíquico, os quais já os tem ou são adquiridos, como a percepção, memória, razão, emoção, intuição, força de vontade, imaginação, entre outras. E, no processo de querer entender-se, entra a esfera do conhecimento, que do latim cognoscere significa "ato ou efeito de conhecer", em que há duas entidades; o sujeito (cognoscente) capaz de adquirir conhecimento e o objeto (cognoscível) que é o que se pode conhecer (Santos, 2013). Santos, em consonância com Bungue (1974), descrevem que o conhecimento pode ser construído de várias formas, como através do empirismo (experiência), da teologia (aceitação), filosofia (razão) e pela ciência (experimentação). Todo esse processo de produção de conhecimento ocorre através da cognição que se utiliza das várias faculdades mentais captadas pelos cinco sentidos, como a visão, audição, tato, olfato e paladar. E na esfera do conhecimento, o processo educacional está intimamente ligado. Haja vista a palavra educar que, na língua portuguesa, tem sua origem do latim EDUCARE, que "E" deriva-se de EX, que significa "fora" ou "exterior", e DUCERE, significa guiar, conduzir, instruir. No latim literal, educação significa "guiar para fora", que pode ser entendido como instruir para o mundo ou para fora de si mesmo. E a educação como processo, visa promover nas pessoas o desenvolvimento de habilidades intelectuais para assimilação de dados e informações na geração de conhecimento de forma integrada no campo da matemática, linguagem, história, ciências, artes, tecnologias e inclusive no campo da ciência geográfica.

Na Educação Geográfica, teorias advindas de diversos aportes teórico metodológicos sustentam o conhecimento dos componentes naturais e sociais e suas relações e como estas constroem e reconstroem o espaço geográfico, ou seja, o conhecimento do mundo (geo-terra+grafia-descrição) tem o seu histórico na análise da relação da sociedade com a natureza. Porém, ao longo da trajetória da geografia científica, o conhecimento gerado delineou definições específicas conforme seus entendimentos da sociedade e da natureza no espaço geográfico. Mas é interessante observar, como ocorre a transição da geografia universitária para a geografia da educação básica pois, no resultado educativo, esses entendimentos também influenciarão como a sociedade entende a Geografia. E quem permite entender essa geografia formadora e em formação é o processo educacional, com sua episteme e metodologias desenvolvidos na esfera universitária, estimulando raciocínios, provocando as concepções articuladas e aprofundadas a respeito desse espaço geográfico. O resultado esperado é fazer com que o estudante entenda esses conceitos científicos e consiga ampliá-los 
para o seu cotidiano, permitindo o seu desenvolvimento intelectual e ampliando a sua capacidade de estimular a cognição. Ou seja, aprender e gerar conhecimento requer ir além da metodologia de ensino e didática, requer refletir e utilizar estratégias de resolução de problemas para o cotidiano (Cavalcanti, 2006, p. 24 e 28).

Nóvoa (2016), em entrevista à Revista Educação, acrescenta que, para efetivar o aprendizado o professor deve combinar três tipos de conhecimento: dominar o conteúdo científico que vai ensinar; entender e aplicar as bases pedagógicas e as teorias da aprendizagem para o público específico e saber como esse conhecimento se aplica no cotidiano do estudante. Caso falte um deles, perde-se a dimensão do processo educativo. Outro aspecto que complementa a etapa da aprendizagem é o estudante ser ativo e interativo dentro da sala de aula. Nesse processo, o professor deve estar atento às etapas de seu desenvolvimento, facilitando a aprendizagem com base no respeito mútuo, na confiança e afeto. Gratiot-Alfandéry (2010) descreve que Henri Wallon sugere que deve haver uma relação de cooperativismo entre professor (educador) e estudante (educando), pois sem esta cumplicidade não é possível estabelecer um aprendizado mútuo, pois o professor também aprende. E Luckesi (2011, p. 109) é muito brilhante quando afirma que todo esse esforço é para que o estudante obtenha sua autonomia, afinal quem aprende é ele e deve ser responsável por si.

A luz dessa descrição, este artigo apresenta algumas experiências de protagonismo estudantil, desde as pontuais como a "Escola faz o vídeo" em Florianópolis-SC/Brasil; o programa brasileiro do Ministério do Meio Ambiente (MMA) denominado "Comissão de Meio Ambiente e Qualidade de Vida (Com-vida)" e a experiência de expansão internacional, originária em Portugal, o "Projeto Nós Propomos!! Cidadania e Inovação na Educação Geográfica" - debruçando-se sobre como estas propostas tornam a aprendizagem eficaz, explicadas pelos estudos do desenvolvimento neural e cognitivo, em especial no que tange à neuroplasticidade, as alterações neurais decorrentes do treino cognitivo, demonstradas atualmente por técnicas de neuroimagem e estudos de neuromorfologia, bem como por estudos das ciências cognitivas para aspectos motivacionais e emocionais. Observa-se que propostas em que os estudantes são protagonistas no processo educacional na escala local demonstram que a Educação Geográfica permite a construção de seu conhecimento e aprendizagem a vida.

\section{Projeto "A Escola faz o vídeo"}


Em setembro de 1997, o governo brasileiro, através da Secretaria de Recursos Hídricos e Qualidade Ambiental, do Ministério do Meio Ambiente, criou um Programa chamado "Adote uma Bacia", que fazia parte do Programa Nacional do "Plano Municipal de Desenvolvimento Sustentável". Tinha como propósito adotar medidas sustentáveis relacionados ao uso adequado dos recursos hídricos, partindo da mobilização social das comunidades inseridas nas bacias hidrográficas. Naquela época, o Instituto LARUS - Pesquisa, Proteção e Educação Ambiental, em parceria com pesquisadores da Universidade Federal de Santa Catarina e Universidade Federal do Paraná, foi nomeado como Centro de Referência do Movimento de Cidadania pelas Águas de Florianópolis e adotou a Bacia Hidrográfica Litorânea do Pântano do Sul (BHLPS), devido na mesma época ter ocorrido um surto de Hepatite A, que atingiu 10\% da população local (Araújo, 2000), por causa da água contaminada do canal sangradouro da Lagoa do Peri e do Rio da Bacia Hidrográfica Litorânea do Pântano do Sul, o Quinca Antônio.

Uma das estratégias que o LARUS adotou, em consonância a metodologia de tese de Nascimento (2003), foi a mobilização da comunidade local em defesa das suas águas junto as escolas levando o tripé da Educação Ambiental: Informação, sensibilização e mobilização social. Foram realizadas atividades para a educação infantil até os anos finais do fundamental. $\mathrm{Na}$ educação infantil, usou-se teatro de bonecos com base na Cartilha "A Água Nossa de Cada Dia", do cartonista Ziraldo, doada pela Secretaria de Recursos Hídricos do MMA, em que os familiares foram também convidados. Para os anos finais do fundamental, foi elaborado o projeto "A escola faz o vídeo" (https://www.youtube.com/watch?v=kPZWZfEPrUU\&t=21s) em parceria com diretores, professores e estudantes, em que foram convidados a elaborarem vídeos sobre a saúde da água potável da sua localidade. O método foi apresentar a problemática sobre os recursos hídricos e promover o protagonismo nos estudantes. Nessa época não existia celular com câmeras, pelo que foi usado o material de produção audiovisual do Instituto LARUS. Na escola municipal local, foram constituídos dois grupos que durante o processo realizaram pesquisas bibliográficas, visitas técnicas à Companhia Catarinense de Águas e Saneamento (Casan) e expedições científicas a alguns lugares da Bacia. Os trabalhos acadêmicos foram a base do argumento dos vídeos, que subsidiou os roteiros, os cronogramas de cenas e as demais etapas. Todas as ideias foram dos estudantes que ao final realizaram dois vídeos: "O Uso da Água Potável" (https://www.youtube.com/watch?v=qvuZZkq0uQk) e "O Caminho dos Rios", (https://www.youtube.com/watch?v=b7Raqr7vSMA\&t=24) Há imagens da flora, dos rios, das cachoeiras, piscinas naturais, entrevistas com pessoas antigas da 
comunidade que relembram as paisagens do passado e como se transformou ao longo tempo, principalmente pela degradação ambiental. O lançamento dos vídeos foi em dois momentos, um no único cinema da cidade na época, convidando a comunidade escolar da BHLPS, autoridades e imprensa. O segundo, foi na própria comunidade. Ao final da apresentação, estudantes, professores e diretora abriram o debate com a comunidade sobre as questões que foram levantadas sobre as águas.

Nas diversas reuniões, foram levantadas várias questões como lixo nos rios, nos canais, o aumento da área de inundação atingindo casas que nunca tinham sido afetadas e as doenças. Nesse momento, os estudantes se apoderaram como protagonistas da sua realidade permitindo sensibilizar a comunidade na participação dos movimentos sociais em defesa das águas. Em 15 de outubro de 2003, foi realizada uma Audiência Pública organizada pelo órgão de planejamento do Município de Florianópolis para a discussão participativa do novo Plano Diretor para o distrito, trazendo também as questões dos estudantes como estratégias de melhoria da saúde das águas. Atualmente com a coleta regular e seletiva de lixo, campanhas nas escolas e nas mídias houveram vários benefícios que contribuíram com a diminuição do lixo nos rios da localidade, incremento da construção de fossas sépticas, entre outras conquistas ambientais reflexo também do protagonismo estudantil. $O$ trabalho teve repercussão, que foi realizado no Distrito de Ingleses, norte do Município de Florianópolis com o vídeo "Ingleses - Educar para preservar" (https://www.youtube.com/watch?v=plxF9FJuRvY).

\section{Programa Brasileiro "Comissão de Meio Ambiente e Qualidade de Vida (Com- vida)"}

Em 2003, o Governo Federal brasileiro organizou a I Conferência Nacional Infantojuvenil pelo Meio Ambiente com a adesão espontânea das escolas do país, para saber quais eram opiniões e sugestões dos estudantes que o Brasil deveria providenciar sobre as questões ambientais, ou seja foi a primeira vez que crianças e adolescentes foram convidadas a elaborar políticas públicas. Desse evento, eles propuseram criar conselhos de jovens de meio ambiente e de elaboração da Agenda 21 nas escolas, que desdobrou com a criação do programa brasileiro "Comissão de Meio Ambiente e Qualidade de Vida, denominado Com-vida.

O Com-vida é uma ação de fomento para educação ambiental nas escolas que visa empoderar os estudantes dos $6^{\circ}$ ao $9^{\circ}$ anos do ensino fundamental e do médio em intercâmbio com a comunidade, para realizar ações voltadas à melhoria do meio 
ambiente e da qualidade de vida na escola e sua comunidade. Tendo em vista a sua relevância no processo de construção e reflexão de conhecimento local, e a sua missão de (re)aproximação escola-comunidade, tendo como fio condutor a questão socioambiental, o projeto visa a criação, consolidação e ampliação destas Comissões nas escolas, numa perspectiva de rede, ou seja, Com-vidas estabelecendo intercâmbios entre si.

Conforme a Secretaria de Educação do Paraná (2017), o Ministério de Educação (MEC) já realizou cinco conferências, mobilizando milhares de escolas e milhões de participantes, desde 2003. Em 2018, foi realizada a V CNIJMA com a temática "Vamos Cuidar do Brasil Cuidando das Águas".

Outra iniciativa são os Coletivos Jovens de Meio Ambiente, que constituem mais um estímulo a participação e mobilização do estudante jovem no Brasil.

\section{Projeto Nós Propomos!}

Em 2011/12, foi criado no Instituto de Geografia e Ordenamento do Território da Universidade de Lisboa/IGOT-UL o Projeto Nós Propomos! Cidadania e Inovação na Educação Geográfica, que hoje se estende a todo o Portugal, Espanha, Brasil, Perú, Colômbia, Perú e inicia-se no México.

Em Portugal, no $11^{\circ}$ ano de Geografia do Ensino Secundário (16/17 anos), é obrigatória a realização do Estudo de Caso: um trabalho de caráter mais prático, dirigido preferencialmente para a resolução de problemas regionais. Entre as competências que se pretendem desenvolver, contam-se Analisar criticamente problemas que afetam a região onde vive, refletindo sobre soluções possíveis para os problemas detetados (Alves, Brazão \& Martins, 2002, p. 57).

Contudo, o Estudo de Caso não é objeto de avaliação nos exames nacionais do ensino secundário - pelo que acaba por não ser implementado na generalidade das escolas. O Projeto Nós Propomos! pretendeu, precisamente, estimular as escolas a concretizar o referido Estudo de Caso, dirigindo-o para a identificação de problemas sociais e ambientais locais e para a apresentação de propostas concretas de resolução daqueles. Entretanto, o Projeto alargou-se a outros públicos escolares, desde as universidades de terceira idade, para população mais idosa, até crianças de 8/9/10 anos. O princípio fundamental é sempre o mesmo: identificar problemas locais, pesquisar sobre os mesmos e apresentar propostas de intervenção, partilhando as mesmas com a população. 
O Projeto tem um caráter eminentemente prático, estimula a reflexão a partir dessa prática e adota uma metodologia relativamente simples - o que talvez ajude a explicar a adesão que tem registado.

No começo do ano escolar, a primeira fase é de sensibilização/motivação dos estudantes para as questões da cidadania e dos desafios locais. O professor de Geografia apresenta o Projeto nos seus grandes objetivos e linhas gerais.

Entretanto, os estudantes inscrevem-se no site do Projeto (www.nospropomos.igot.ul.pt) e na página do Facebook. É uma forma de identificação com o projeto, a nível nacional (e internacional) e de receberem mensagens da coordenação nacional. Habitualmente, uma ou mais pessoas da Coordenação Nacional desloca-se a cada escola, onde faz uma sessão de divulgação dos objetivos e da metodologia do Projeto, mas há um problema crescente em realizar essas deslocações, por falta de recursos humanos e financeiros.

$\mathrm{Na}$ motivação dos estudantes, em muitas escolas aplica-se um inquérito de sensibilização para a participação cidadã. Nele, questiona-se o estudante sobre a sua participação na comunidade, os problemas locais e sobre a sua própria expetativa do estudante em relação ao Projeto Nós Propomos!, que está a iniciar. Nos primeiros anos, muitas das respostas dos estudantes no sentido de que os problemas locais deveriam ser resolvidos pelos políticos locais e, por outro lado, um número significativo de estudantes indicava que não havia problemas locais. Com o avançar do Projeto e da sua divulgação nas escolas, os estudantes assumem, de forma mais clara, que os problemas existentes na comunidade são da responsabilidade de todos e a afirmação de que "não há problemas" torna-se mais rara. Por outro lado, alguns professores vêm com os seus estudantes para a rua ou pedem a estes para realizarem itinerários urbanos, a fim de estes identificarem problemas locais que possam ser objeto de estudo. Enfim, a forma mais frequente de identificação dos problemas locais residirá na discussão em sala de aula.

Em qualquer caso, ao encontro da abordagem construtivista da aprendizagem (Souto, 1998), sem negar a influência que as opiniões sempre têm sobre os estudantes, há um princípio claro: são os estudantes que, em grupos, definem o problema sobre que vão trabalhar. Estes grupos têm uma dimensão que varia entre um mínimo e um máximo de seis estudantes. Os temas/problemas são muito diversos, da recuperação de um edifício abandonado à alteração do percurso de uma carreira de transportes públicos, passando pela instalação de equipamentos de lazer num espaço público ou pela criação de um museu virtual das produções locais, para dar alguns exemplos. Em 
número crescente, os estudantes apostam em projetos que mobilizam as tecnologias de informação, como seria expectável.

A identificação do problema a pesquisar constitui uma fase demorada e fundamental. Pretende-se, cada vez mais, que o mesmo seja bem delimitado e concreto. Em novembro (as aulas começam em setembro), os estudantes inscrevem no site do Projeto o tema selecionado e o nome dos elementos do grupo; contudo, há grupos que ainda reformulam os seus temas de projetos e outros que o definem, ainda.

Os estudantes habitualmente selecionam um problema na área da escola. Na sala de aula e na escola, os estudantes reúnem em grupo e preparam inquéritos à população, que depois discutem com os seus professores. Sempre que possível estudantes e professores têm uma reunião com técnicos do Município, que lhes transmitem as principais orientações e preocupações do Plano Diretor Municipal.

Segue-se, então, um momento particularmente marcante do Projeto: em grupo, os estudantes vêm para a rua, fazem fotografias, realizam inquéritos à população ou entrevistam os principais atores locais. Ao escutarem publicamente a população sobre um problema, colocam o mesmo na agenda pública local (Claudino, 2018) - o que é um passo relevante para a sua discussão e, eventualmente, resolução. A diversidade de enfoques dos projetos dos estudantes reflete a própria diversidade de contextos socio-económicos.

As propostas dos estudantes são geralmente concluídas no final do $2^{\circ}$ período escolar. Antes, em fevereiro, respondem a um inquérito nacional lançado pela Comissão de Coordenação, em que indicam o trabalho que já realizaram, o trabalho que lhes falta realizar e os problemas que estão a ter. A cada grupo, responde um membro da Comissão de Coordenação, dando algumas indicações - e os estudantes valorizam muito essa opinião, até pela insegurança sempre associada a um trabalho inédito nas suas vidas.

A proposta final dos estudantes é apresentada por três formas: um recurso multimédia, geralmente um power point (mas pode ser prezzi, vídeo...); uma breve memória descritiva (muitos professores defendem que os estudantes têm de treinar a competência escrita); cada vez mais, a Coordenação do Projeto apela a que os estudantes elaborem cartazes, pela visibilidade que os mesmos dão aos problemas locais em exposições, nas próprias escolas ou nas autarquias. A partir de 2018/19, vai-te tentar que os estudantes elaborem ainda um pequeno vídeo de propagando ao seu Projeto. 
A reação da população aos inquéritos dos jovens é muito positiva. Geralmente, ficam surpreendidos, mas depois respondem e os estudantes ficam contentes com a adesão. Como se referiu, a recetividade dos poderes locais ao Projeto tem sido positiva. Pontualmente, são as próprias autoridades municipais a desafiarem as escolas a participarem no Projeto e assumirem o patrocínio do mesmo. Este patrocínio ocorre em Ciudad Real, em Espanha, em que as autoridades apoiam diretamente o Projeto Nós Propomos!, coordenado pela Faculdade de Educação da Universidade de Castilha-La Mancha (Figura 4). Em Portugal, a partir de 2018/18, a Câmara Municipal de Cascais também decidiu apoiar a divulgação do Projeto Nós Propomos! no respetivo município, aguardando-se com expetativa os resultados desta experiência.

Os estudantes apresentam as suas propostas, tanto no Seminário Nacional (ou local), como sucede na Universidade de Lisboa, como, depois, junto das populações. Algumas propostas têm sido adotadas pelas autarquias locais ou sujeitos a votação, no âmbito do Orçamento Participativo. Em qualquer caso, a experiência demonstra que muitos políticos locais não assumem, imediatamente, que adotam propostas dos estudantes, mas ao longo dos anos verificamos como trabalho de campo dos estudantes sobre um problema local dá visibilidade a esse problema e, não raro, ele é resolvido nos anos subsequentes.

Em Portugal, o Projeto tem mobilizado estudantes de diferentes níveis e, em 2016/17. Em Espanha, o Projeto Nós Propomos! é implementado por estudantes dos 6 aos 15 anos - demonstrando, uma vez mais, que o Estudo de Caso pode ser adaptado às diversas idades; já no Brasil, os estudantes mobilizados frequentam, na sua quase totalidade, o ensino secundário.

O I Congresso Iberoamericano Nós Propomos: Geografia, Educação e Cidadania (IGOT-UL, 7 a 12 de setembro de 2018) traduziu-se na partilha de experiências e na consolidação da rede iberoamericana do Projeto.

\section{Neurociência e ciências cognitivas - 0 protagnismo estudantil e eficácia na aprendizagem}

Promovem-se aprendizagens e as neurociências e as ciências cognitivas têm possibilitado, desde Piaget, Vigotsky, Luria e Wallon, aportes teóricos e práticos que se refletem em melhorias nos métodos de ensino-aprendizagem. Os projetos aqui analisados são ótimos exemplos do que Vigotsky denominou "zona de desenvolvimento real" aquele lugar cognitivo onde o ser aprendente interage com seu 
entorno para estabelecer o desenvolvimento. Por outro lado, as propostas se baseiam em necessidades, anseios e conceitos pré formulados, que muito recebem do aporte teórico construtivista, em especial, a partir das concepções alternativas dos estudantes. A aprendizagem geográfica se estabelece como uma aprendizagem do corpo, a ação, o ato motor precede e amplifica o ato mental, como preconiza Wallon (Galvão, 1995). Há uma forte relação entre o ensino de geografia, as práticas de campo que esta disciplina exige e oferece e o desenvolvimento cognitivo e intelectual, bem como, uma forma de ensinança mais alinhada com a velocidade e disponibilidade de informação no presente século, que são as metodologias ativas de aprendizagem, suportadas fortemente pelos estudos das neurociências.

$\mathrm{Na}$ interface entre neurociências e a Educação Geográfica tem-se diferentes abordagens, a maioria dos estudos estão situados nos mecanismos e nas áreas do cérebro responsáveis pela aprendizagem de questões relacionadas ao espaço e tempo (Denis e Loomis, 2007; Stea, 2015).

Gersmehl e Gersmehl (2006) fazem uma revisão acerca dos distintos modos do pensamento espacial, distintos modos de pensar acerca dos fatos básicos da geografia escolar, particularmente porque o cérebro parece adquirir e armazenar informações sobre lugares (condições) e sobre movimento (conexões) de diferentes maneiras e em diferentes áreas. Neste estudo os autores listam alguns destes modos pelos quais as pessoas organizam seus pensamentos abstratos, em especial as habilidades espaciais. As informações são processadas por comparação, pensar sobre as condições e conexões de novos lugares por meio de comparação com lugares já conhecidos, o processo de comparação parece ser um traço inato da apredizagem humana; há uma aura sobre os conhecimentos espaciais, uma zona de influência para cada lugar, como aeropostos, rios, praias; a ideia de uma região, enquanto um lugar que carreca semelhanças com outros locais nas proximidades e que mostra diferenças para outras regiões, no caso, o cérebro é uma estrutura especializada em classificar objetos e situações a partir das suas semelhanças e diferenças com outros; hierarquia, o cérebro parece colocar as informações a partir de um ranking hierárquio a partir de tamanho, dimensões, capacidade de produção, sendo importantes tanto a geografia física quanto política; analogias, como as que podemos perceber entre as savanas africanas e o cerrado brasileiro, cujo cérebro terá facilitada capacidade de reconhecimento; a transição entre os espaços, como a transição entre as regiões centrais e periféricas de uma área urbana; associações, quando crianças em tenra idade já são capazes de identificar traços associativos entre 
fotos e mapas de um determinado local. Todos estes componentes serão facilitadores de memorização para fatores semânticos relacionados à Educação Geográfica.

Hofmann e Crutch (2015), utilizando de estimulação magnética transcraniana, determinaram que quando este estímulo era aplicado no lobo temporal anterior, uma região de decodifica conhecimento conceitual para palavras e objetos não apresentou efeitos em tarefas geográficas; por outro lado, a estimulação no sulco intraparietal, envolvida na codificação de informações espaciais e numéricas, teve um efeito positivo significativo em tomadas de decisões geografico espaciais, mas não afetaram o discernimento taxonomico destas decisões. O estudo sugere que as habilidades necessárias para o entendimento de geografia residem na intersecção entre estas duas áreas.

Dados sobre o desenvolvimento neural e cognitivo têm demonstrado como as diferentes áreas do cérebro são estruturadas e em quais fases do desenvolvimento ocorrem as mudanças. Giedd et. al. (1999) realizaram um estudo longitudinal, utilizando imageamento por ressonância magnética em crianças e adolescentes e demonstraram que durante a infância há um aumento da massa cinzenta do cérebro, denominado de exuberância sináptica, importante momento de formação intensa de novas conexões sinápticas a partir dos estímulos que as crianças recebem, as áreas do cérebro que receberem mais treino e estimulação serão aquelas que terão maior crescimento do tecido. No que tange ao aprendizado de habilidades espaciais e temporais, muitas áreas do cérebro estarão envolvidas e parece haver um módulo mental inato para a aprendizagem geográfica, uma geografia intuitiva, tendo em vista crianças bem pequenas já apresentarem representações do espaço e reconhecimento de padrões em fotos e mapas.

Parece haver uma sinergia entre treinos cognitivos (ler, escrever, jogos de tabuleiros e eletrônicos, quebra cabeças, leitura de mapas), treinos motores (atividades físicas em geral, atividade física funcional, pilates, esportes) e treino de habilidades sociais (rodas de conversas, sair com os amigos, partilhar uma refeição) enquanto a melhor maneira de aumentar e preservar a reserva neural, diminuíndo os efeitos deletérios do declínio cognitivo próprios da idade ou do estresse (Fernandez et. al. 2013). A aprendizagem de diferentes disciplinas está diretamente relacionada com esta sinergia. No que tange à geografia, aprendemos muitos dos fundamentos desta disciplina tendo como referência nossos próprios corpos, o lugar que eles ocupam no espaço, bem como, a formação de conceitos básicos, como em cima, embaixo, atrás, na frente, do lado, do outro lado são aprendizados que elaboramos com o corpo, e que abrem as 
possibilidades de estabelecimento dos conceitos formais como sequenciação, seriação, unidade, conjunto, multiplicidade, conceitos fundamentais para aprendizagem em geografia, mas também para matemática, linguagens (Caseiros e Lomônaco, 2011).

No que tange à Neuroplasticidade, a mesma pode ser compreendida como qualquer alteração química ou estrutural no sistema nervoso decorrente de aprendizagens, experiências, após lesões (Lent, 2004). Esta alteração pode ocorrer pelo aumento do número de conexões entre células nervosas e, até mesmo, do tecido nervoso (Jenkins et. Al. 1990). A neuroplasticidade química pode ser percebida pelo número de substâncias neurotransmissoras produzidas e/ou liberadas na fenda sináptica, mas, também, pelo número de receptores para estas substâncias presentes nas membranas plasmáticas dos botões pré e pós sinápticos. Em um estudo clássico realizado com macacos submetidos à dependência com cocaína, com possibilidades de se autoadministrarem a droga, foi verificado que indivíduos que gozavam de melhores estatus na hierarquia, em especial aqueles que ascendiam no ranking social, apresentavam diminuição no uso da droga, em detrimento daqueles que desciam ou que estavam em posições mais subalternas (Kuhar, 2002). A maneira como o sujeito se percebe no ambiente parece refletir na quantidade de receptores para dopamina, o neurotransmissor envolvido no sistema de recompensa ou prazer, no cérebro. Práticas pedagógicas inovadoras, que transformam os estudantes em protagonistas da aprendizagem, sugerem alta eficácia na melhoria da percepção do sujeito ao seu entorno e nas suas capacidades de transformação social.

Para Sapolsky (2005), existem fatores estressores na pobreza que diminuem a imunidade, mas ainda mais importante notar que o fato de ser pobre não é tão estressor quanto o fato de sentir-se pobre, a percepção do sujeito frente a sua realidade é o fator adoecedor, e que gera impacto direto sobre os riscos que o sujeito está disposto a correr para garantir sua vida, diminuíndo os mesmos (Wilson e Daly, 2006).

De alguma maneira, a percepção que o sujeito constrói da sua realidade é também um fator que sugere tirá-lo daquela condição, ou de visualizar a solução de problemas, melhorando a percepção de si mesmo no mundo, e suas chances de ascenção social, diminuíndo o estresse atrelado às condições sociais, políticas e geográficas, bem como, diminuição dos comportamentos de risco e uso de drogas recreativas. Nesse aspecto, projetos na Educação Geográfica que remetam o estudante verificar e analisar a realidade do seu entorno, além de diminuir os efeitos do estresse e da 
pobreza, podem ser mediadores do aumento de habilidades cognitivas e físicas e proponentes de soluções para os problemas levantados.

Aprendizagens com metodologias ativas melhoram o desempenho de aprendizagem quando comparado com aprendizagens tradicionais, onde o estudante é passivo no processo (Freeman et. al., 2014). Os estudos aqui analisados constituem exemplos amplos de formas ativas e construtivistas de aprendizagem, são organizados a partir de questionamentos formulados pelos estudantes, com coleta e análise de dados, produção de material didático e audio-visual, além de proponente de soluções para os problemas apontados.

Por último, como sugere Gagen (2013), os ambientes educacionais e seus curriculos são ótimos espaços para trabalhar o entendimento e o controle das emoções, práticas de campo e estudos de caso do entorno emocional dos estudantes parecem oferecer suporte extra no controle dos impulsos, na mediação de conflitos e ainda um entendimento mais sofisticado da natureza emocional das relações interpessoais.

\section{Conclusão}

Conforme o que foi explicitado, a escola tem um papel fundamental na relação entre a comunidade e os desafios da Educação Ambiental, tendo em vista a promoção da cidadania e da sustentabilidade. O chão da sala de aula torna-se um palco em que os temas mundiais e nacionais são apresentados. E, no âmbito local, os estudantes podem perceber as suas conexões com as temáticas, e também estabeler alianças transformadoras nas suas comunidades para ambientes melhores. Pois na escola, analisar o seu ambiente é desenvolver o senso crítico, permitir atitudes emancipatórias para mudanças de comportamento, incentivando o respeito à vida e disseminando novas ações para o uso dos recursos naturais.

Os resultados dos trabalhos dos estudantes como protagonistas em seus espaços imediatos demonstram que os aportes teóricos da educação geográfica e neurociência, permitem a construção de seu conhecimento e concretização de uma educação para a vida 


\section{Referências Bibliograficas}

Alves, M. L.; Brazão, M. \& Martins, O. S. (2001). Programa de Geografia A. Lisboa: Ministério da Educação.

Araújo, C. D. P. de. Saúde, ambiente e território: Distrito do Pântano do Sul, em Florianópolis, Santa Catarina. (2000). Dissertação (Mestrado em Administração e Planejamento de Serviços de Saúde) - Curso de Pós-Graduação em Saúde Pública, Universidade Federal de Santa Catarina, 2000.

Cavalcanti, L. de S.. Geografia, escola e construção de conhecimentos. (2006). 9a edição, Ed. Papirus, São Paulo.

Cazeiro, A. P. M., \& Lomônaco, J. F. B. (2011). Formação de conceitos por crianças com paralisia cerebral: um estudo exploratório sobre a influência de atividades lúdicas. Psicologia: Reflexão e Crítica, 24(1), 40-50. doi: https://dx.doi.org/10.1590/S0102-79722011000100006.

Claudino, S. (2014). Escola, Educação Geográfica e Cidadania Territorial. Scripta Nova Revista Electrónica de Geografía y Ciencias Sociales, 494 (09), 1-10. Disponível em http://www.ub.edu/geocrit//sn/sn-496/496-09.pdf

Claudino, S. (2018). Educação Geográfica, Trabalho de Campo e Cidadania. O Projeto Nós Propomos! In Feliciano H. Veiga (Coord.) O Ensino na Escola de Hoje. Teoria, Investigação e Aplicação (pp. 265-303). Lisboa: Climepsi Editores.

Daly, M.. \& Wilson, M. (2001). Risk-taking, intrasexual competition, and homicide. Nebraska Symposium on Motivation. 47:1-36.

Denis, M.; Loomis, J. M. (2007). Perspectives on human spatial cognition: memory, navigation and environmental learning. Psychological Research (2007) 71:235-239 DOI 10.1007/s00426-006-0079-x.

Fernandez, A.; Goldberg, E.; Michelon, P. (2013). The Sharp Brains Guide to Brain Fitness: How to Optimize Brain Health and Performance at Any Age. Washington, DC: SharpBrains. http://mybook.to/brainfitness. Retrieved January 15, 2015.

Freeman, S.; Eddy, S. L.; McDonough, M.; Smith, M. K.; Okoroafor, N.; Jordt, H.; Wenderoth, M. P. (2014). Active learning boosts performance in STEM courses. Proceedings of the National Academy of Sciences, 111 (23) 84108415; DOI:10.1073/pnas.1319030111.

Gagen, E. A. (2013) Governing emotions: citizenship, neuroscience and the education of youth. Transactions of the Institute of Britsh Geographers, 40:140-152 doi: 10.1111/tran.12048.

Galvão, I.. Wallon, Henri: uma concepção dialética do desenvolvimento infantil. (1995) Petrópolis, RJ, Ed. Vozes.

Gazzaniga, M. S. \& Heatherton, T. F. (2005). Ciência psicológica: mente, cérebro e comportamento. 2. imp.rev. Porto Alegre: Artmed. 
Gersmehl, P. J.; Gersmehl, C. A. (2007) Spatial Thinking by Young Children: Neurologic Evidence for Early Development and "Educability", Journal of Geography, 106:5, 181-191, DOI: 10.1080/00221340701809108.

Giedd, J. N., Blumenthal, J., Jeffries, N. O., Castellanos, F. X., Liu, H., Zijdenbos, A., Paus, T., Evans, A. C. \& Rapoport, J. L. (1999). Brain development during childhood and adolescence: a longitudinal MRI study. Nature Neuroscience 2:861-863.

Gratiot-Alfandéry, H.. Henri Wallon. (Tradução e organização Patrícia Junqueira), Recife - Fundação Joaquim Nabuco, Editora Massangana, 2010.

Hoffman, P.; Crutch, S. (2016) Knowing what and where: TMS evidence for the dual neural basis of geographical knowledge. Cortex 75 (2016) 151-159.

http://www.educadores.diaadia.pr.gov.br/modules/conteudo/conteudo.php?conteudo=8 53.

Kuhar, M. (2002). Social rank and vulnerability to drug abuse. Nature Neuroscience 2(5):88-90.

Lent, R. (2004). Cem bilhões de neurônios: conceitos fundamentais de neurociências. São Paulo: Atheneu.

Luckesi, C.C.. Avaliação da aprendizagem: componente do ato pedagógico. 1 ed, São Paulo, Cortez, 2011

Nascimento, R. da S. (2003). Instrumentos para prática de educação ambiental formal com foco nos recursos hídricos. Florianópolis. Dissertação de doutoramento. Disponível em: <http://www.tede.ufsc.br/teses/PEPS3789.pdf.

Nóvoa, A.. O lugar da licenciatura. Ensino Superior. Em 8 de novembro de 2016 Disponível em http://www.revistaeducacao.com.br/o-lugar-da-licenciatura/. Acesso em: $04 / 11 / 2018$

Santos, I. E.. Manual de métodos e técnicas de pesquisa científica (2013). 10 Ed., ver., atual. e ampliada, Niterói, RJ, Impetus.

Sapolsky, R. (2005). Sick of Poverty: New studies suggest that the stress of being poor has a staggeringly harmful influence on health. Scientific American. 293 (6): 92-99.

Secretaria da Educação do Paraná - SED-PR (2017). Conferências Nacionais Infantojuvenis pelo Meio Ambiente. Disponível em: http://conferenciainfanto.mec.gov.br/. Acesso em: 04/11/2018.

Souto, X. M. (1998). Didáctica de la Geografía. Problemas sociales e conocimiento del medio. Lisboa: Ediciones del Serbal.

Stea, D. (2015): Space in Mind: Concepts for Spatial Learning and Education, Journal of Geography, DOI: 10.1080/00221341.2015.1041415. 
Wilson, M. \& Daly, M. (2006). Are juvenile offenders extreme future discounters? Psychological Science. 17(11):989-994. 


\title{
Práticas educativas e a formação cidadã no Brasil
}

\author{
Thais Angela Cavalheiro de Azevedo ${ }^{1}$ \\ ANDREA COELHO LASTÓRIA ${ }^{2}$ \\ SilVia Aparecida de SoUsa FERNANDES ${ }^{3}$
}

\section{Resumo}

Neste trabalho apresentamos práticas educativas desenvolvidas no Brasil, vinculadas ao Projeto Nós Propomos!, realizadas no estado de São Paulo. O referencial teórico é composto por autores que discutem formação de professores, currículo para a Educação Básica, ensino de Geografia e História, formação cidadã, políticas públicas, além das bases legais que sustentam as diretrizes nacionais voltadas à formação docente no Brasil. Dentre os documentos destacamos as Diretrizes Curriculares Nacionais para a Formação Inicial no Ensino Superior cujo princípio central reside na formação para a cidadania. Tal aspecto também é contemplado nos Parâmetros Curriculares Nacionais para o ensino de Geografia, documento que direcionou os currículos brasileiros a partir de 1997. Além dos citados, nosso trabalho também expõe considerações a respeito do mais recente documento curricular educacional, a Base Nacional Comum Curricular, homologada em dezembro de 2017. Para além dos documentos de âmbito formal, o presente trabalho busca refletir sobre o currículo real executado nas escolas brasileiras, ressaltando as práticas educativas desenvolvidas no âmbito do Projeto Nós Propomos! As práticas revelam, portanto, exemplos bemsucedidos de ações que podem transformar, de forma efetiva, o currículo real, o cotidiano escolar e a vida de centenas de estudantes da educação básica no Brasil.

Palavras-chave: Práticas educativas; formação cidadã; ensino de Geografia e História; Nós Propomos!.

Profa. Ms. no Instituto de Ciências Humanas, Universidade Paulista, thais.deazevedo@hotmail.com

${ }^{2}$ Profa. Dra. na Faculdade de Filosofia Ciências e Letras de Ribeirão Preto, Universidade de São Paulo, lastoria@ffclrp.usp.br.

${ }_{3}^{3}$ Profa. Dra. na Universidade Estadual Paulista (UNESP), Faculdade de Filosofia e Ciências, Marília-SP, silvia-sousa@uol.com.br; sas.fernandes@unesp.br 


\section{Abstract}

In this work we present and we reflect on educational practices developed in Brazil, linked to the We Propose Project! The theoretical framework is composed by authors who specialize in teacher education, curriculum for Basic Education, Geography and History teaching, citizen training, public policies and national guidelines for teacher education in Brazil. Among the documents we highlight the National Curricular Guidelines for Initial Formation in Higher Education whose central principle is training for citizenship. This aspect is also contemplated in the National Curricular Parameters for the teaching of Geography, document that directed the Brazilian curriculum from the year of 1997. Our work also exposes considerations about the most recent curricular educational document, the National Curricular Common Base, homologated in December 2017. In addition to the formal documents, this paper reflects on the real curriculum implemented in Brazilian schools, highlighting the educational practices developed within the scope of the We Propose Project! The practices reveal, therefore, successful examples of actions that can effectively transform the real curriculum and the lives of hundreds of students of basic education in Brazil.

Keywords: Educational practices; Teaching for citizenship; Teaching of Geography and History; We Propose Project.

\section{Introdução}

O projeto Nós Propomos! é uma ação ibero-americana que consiste em desenvolver práticas educativas que têm como objetivo promover a educação geográfica centrada na cidadania territorial local e proporcionar a investigação sobre o ensino de Geografia. Tal projeto está vinculado ao Instituto de Geografia e Ordenamento do Território da Universidade de Lisboa (IGOT-UL), coordenado pelo Prof. Dr. Sérgio Claudino e realizado em parceria com vários países ibero-americanos. No Brasil, o projeto se realiza em várias unidades da federação e conta com a participação universidades, institutos de ensino e escolas da educação básica ${ }^{4}$.

As ações educativas iniciam-se pela sensibilização dos alunos para os desafios locais. Os estudantes, em pequenos grupos, identificam problemas e situações, em sua localidade, que Ihes são tocantes e que Ihes causam incômodo. Para esta sensibilização, o projeto Nós Propomos! considera imprescindível o trabalho de campo

\footnotetext{
${ }^{4}$ Para conhecer o histórico do Projeto Nós Propomos sugere-se a consulta ao Foro 24 do Geoforo lberoamericano de Educação. Disponível em: https://drive.google.com/file/d/1yG9L9WXjfKwMQXbF9P7L93dgjIAMxvFY/view>
} 
para identificação dos problemas locais e para coleta de dados que serão investigados. Ou seja, é pressuposto do projeto, que os estudantes tenham um contato direto com o entorno e com os seus dilemas, sociais, ambientais e culturais.

Outro princípio educativo do projeto é que os professores envolvidos reflitam sobre os problemas detectados pelos estudantes, trazendo contextualizações e produzindo conhecimentos sobre o tema local escolhido. Os trabalhos de campo, as reflexões em sala de aula, dentre outras ações vinculadas às práticas educativas, compõem um processo que visa à construção de uma proposta para a resolução do problema que foi escolhido, pelos estudantes. A proposta construída pelos alunos deverá ser exposta e poderá contar com parcerias, como com as universidades, as escolas, as autarquias, as empresas e as associações. Vislumbrando as resoluções sustentáveis e pautando-se em um protocolo de cooperação.

Tendo em vista a formação para a cidadania, objetivo maior do Nós Propomos! e as ações do projeto realizadas em duas localidades do Estado de São Paulo que integram diferentes grupos de pesquisa, buscamos neste texto construir reflexões que envolvem a análise de documentos curriculares nacionais, a formação de professores e as experiências realizadas no âmbito da formação de professores e de práticas educativas da educação básica. Tais práticas estão sendo realizadas por professores da educação básica e da universidade, membros pesquisadores de dois grupos de estudo e pesquisa da Universidade de São Paulo/USP e da Universidade Estadual Paulista/UNESP. São eles, o Grupo de Estudos da Localidade - ELO/USP e o Centro de Pesquisas e Estudos Agrários e Ambientais - CPEA/UNESP.

O Grupo de Estudos da Localidade - ELO é vinculado ao Laboratório Interdisciplinar de Formação do Educador - LAIFE, localizado na Faculdade de Filosofia, Ciências e Letras de Ribeirão Preto - FFCLRP da Universidade de São Paulo - USP e está inserido no Diretório dos Grupos de Pesquisa do Brasil (CNPq), desde o ano de 2006. É uma comunidade de aprendizagem profissional da docência. Compartilha saberes da prática pedagógica e das áreas específicas do conhecimento. Reflete sobre as permanências e mudanças realizadas pela sociedade ao longo do tempo. Produz materiais didáticos, pesquisas em ensino e novos saberes docentes.

Fazem parte deste coletivo estudantes de graduação e pós-graduação, professores das redes municipal, estadual e privada, além de professores de instituições de ensino superior público e privado. Tais profissionais são, em sua maioria, professores de História e Geografia e pedagogos. As diversas áreas de formação contempladas no 
ELO proporcionam uma pluralidade de perspectivas educacionais que enriquecem as reflexões educacionais construídas nos encontros que ocorrem semanalmente.

O Projeto Nós Propomos! foi apresentado, formalmente, aos membros do Grupo de Estudos da Localidade - ELO pelo Professor Sérgio Claudino no evento denominado "I Colóquio de Formação de Professores do LAIFE: Contextos e Perspectivas", que ocorreu em novembro de 2017. De imediato membros do Grupo ELO se interessaram em desenvolver práticas vinculadas ao projeto Nós Propomos!. Tais práticas estão sendo desenvolvidas nas cidades de Ibitinga/SP, Mococa/SP, Serrana//SP, Americana/SP e Ribeirão Preto/SP.

Os princípios educacionais apreciados pelo Grupo ELO corroboram com os princípios do projeto Nós Propomos!, entre os pontos de convergência destacamos o interesse em desenvolver práticas educativas inovadoras e o foco em uma formação ampla e cidadã para os estudantes da educação básica.

O Centro de Pesquisas e Estudos Agrários e Ambientais (CPEA) tem sede na Universidade Estadual Paulista (UNESP), campus de Marília. É um grupo de pesquisa reconhecido pelo CNPq. O CPEA foi criado em 1988 e realiza pesquisas que contemplem a discussão sobre relação cidade-campo, políticas públicas em diversas áreas: políticas ambientais, Reforma Agrária, Soberania e Segurança Alimentar e Nutricional, Educação. Reúne professores de diferentes universidades, estudantes da Pós-Graduação e estudantes da graduação. Ao longo desses 30 anos, vários projetos foram desenvolvidos a partir dessas temáticas.

Os primeiros projetos desenvolvidos no final da década de 1980 e ao longo da década de 1990 tiveram como preocupação a pesquisa sobre alfabetização em áreas rurais e a territorialização dos movimentos sociais. Foram realizadas inúmeras oficinas de alfabetização em assentamentos da reforma agrária da região de Marília. Uma preocupação recorrente nos projetos desenvolvidos é a questão ambiental e a questão agrária e mais recentemente, as políticas públicas de educação. Entre 2014 e 2016 foi desenvolvido o projeto "Cinema, Juventude e Ruralidades" que propôs a formação de jovens em oficinas vídeo e fotografia, com o intuito de resgatar a trajetória e experiências de vida de moradores de assentamentos.

Seguindo essa tradição em pesquisas e atividades de extensão universitária, em 2017 foi proposto por meio do CPEA em parceria com o Grupo ELO, o IGOT/Universidade de Lisboa e a Secretaria da Educação de São Paulo, a realização do projeto "Nós Propomos!: observatório do meio ambiente em Marília", que teve continuidade em 2018. Nas duas edições, o projeto foi desenvolvido na Escola Estadual Oracina Corrêa 
de Moraes Rodini, escola pública estadual, localizada na cidade de Marília. A coordenação do projeto na escola foi do Prof. Gabriel Grazzini e contou com a participação de estudantes da graduação em Ciências Sociais, o que atribui ao projeto a dimensão formativa em educação superior, além das práticas na educação básica.

O presente trabalho busca refletir sobre o currículo real executado nas escolas brasileiras, ressaltando as práticas educativas desenvolvidas no âmbito do Projeto Nós Propomos! As práticas revelam, portanto, exemplos bem-sucedidos de ações que podem transformar, de forma efetiva, o currículo real, o cotidiano escolar e a vida de centenas de estudantes da educação básica no Brasil.

\title{
2. A educação cidadã no currículo de formação inicial e continuada de professores
}

No Brasil a formação inicial e continuada de professores é regulamentada pelo documento educacional denominado "Diretrizes Curriculares Nacionais para a Formação Inicial no Ensino Superior (cursos de licenciatura, cursos de formação pedagógica para graduados e cursos de segunda licenciatura)", que entrou em vigor em julho de 2015. Em tal legislação buscamos afirmações que se relacionem diretamente com o objetivo de formar estudantes para a atuação cidadã. Encontramos tal pressuposto em vários trechos. O Art. 3 , segundo parágrafo, estabelece que:

\begin{abstract}
$\S 2^{\circ}$ Para fins desta Resolução, a educação contextualizada se efetiva, de modo sistemático e sustentável, nas instituições educativas, por meio de processos pedagógicos entre os profissionais e estudantes articulados nas áreas de conhecimento específico e/ou interdisciplinar e pedagógico, nas políticas, na gestão, nos fundamentos e nas teorias sociais e pedagógicas para a formação ampla e cidadã e para o aprendizado nos diferentes níveis, etapas e modalidades de educação básica. (Brasil, 2015, p.4).
\end{abstract}

Tendo em vista este excerto podemos apontar que, neste documento, a formação cidadã é apresentada como objetivo central para todo o ensino básico. Este documento traz no sétimo artigo:

formação inicial e continuada deverá possuir um repertório de informações e habilidades composto pela pluralidade de conhecimentos teóricos e práticos, resultado do projeto pedagógico e do percurso formativo vivenciado cuja consolidação virá do seu exercício profissional, fundamentado em princípios de interdisciplinaridade, contextualização, democratização, pertinência e relevância social, ética e sensibilidade afetiva e estética, de modo a lhe permitir: I - o conhecimento da instituição educativa como organização complexa na função de promover a educação para e na cidadania. (Brasil, 2015, p. 7).

Notamos que ao longo do documento estudado a formação cidadã é tida como fundamental para o processo formativo, seja no âmbito da docência ou no ensino 
básico. Consideramos a presença deste pressuposto como um ponto positivo e que pode fundamentar as práticas educativas, voltadas para a cidadania.

O desenvolvimento de práticas educativas voltadas para a cidadania e que contemplam aspectos da localidade corroboram com os princípios do Grupo ELO, assim como os do projeto Nós Propomos!. Para um pleno desenvolvimento de práticas educativas, que visam a formação cidadã, os autores Santos e Lastória (2013, p. 19) acrescentam que a interdisciplinaridade tem papel fundamental "o objetivo de formação para a cidadania [...] deve ser alcançado por meio da colaboração das diversas áreas do saber, nesse sentido é que acreditamos que cada disciplina escolar deva dar uma contribuição específica".

As Diretrizes Curriculares Nacionais para a formação de professores (2015), documento analisado por nós nesta seção, também cita a interdisciplinaridade como central para o pleno desenvolvimento educacional. Em seu quinto artigo é tido como obrigação assegurar "à integração e interdisciplinaridade curricular, dando significado e relevância aos conhecimentos e vivência da realidade social e cultural, consoantes às exigências da educação básica e da educação superior para o exercício da cidadania e qualificação para o trabalho". (Brasil, 2015, p.6).

A relação entre a interdisciplinaridade e a formação cidadã deve extrapolar o currículo prescrito e estar presente de forma efetiva no cotidiano escolar. Ao desenvolvermos práticas educativas que envolvem as diversas áreas do conhecimento temos a oportunidade de ampliar as perspectivas e enriquecer as reflexões, construindo panoramas mais amplos e vislumbrando a formação para a cidadania. Pontuscka et al (2009, p.145) afirmam que "A interdisciplinaridade pode criar novos saberes e favorecer uma aproximação maior com a realidade social mediante leituras diversificadas do espaço geográfico e de temas de grande interesse e necessidade para o Brasil e para o mundo".

Não podemos deixar de apontar que a análise de tal legislação descreve somente o âmbito formal do currículo educacional. Segundo Libâneo (2001, p. 99) "O currículo formal ou oficial é aquele conjunto de diretrizes normativas prescritas institucionalmente." Porém, este não é o único âmbito, outras esferas também estão presentes na construção curricular educacional. Libâneo, Oliveira e Tochi (2003, p.363) conceituam os três níveis de currículo:

O currículo formal, ou oficial é aquele estabelecido pelos sistemas de ensino, expresso em diretrizes curriculares, nos objetivos e nos conteúdos das áreas ou disciplinas de estudo. [...] O currículo real é aquele que, de fato, acontece na sala de aula, em decorrência de um projeto pedagógico e 
dos planos de ensino. É tanto o que sai das ideias e da prática dos professores, da percepção e do uso que eles fazem do currículo formal, como o que fica na percepção dos alunos. [...] O currículo oculto refere-se àquelas influências que afetam a aprendizagem dos alunos e o trabalho dos professores e são provenientes da experiência cultural, dos valores e dos significados trazidos de seu meio social de origem e vivenciados no ambiente escolar - ou seja, das práticas e das e experiências compartilhadas em sala e aula. É chamado de oculto porque não se manifesta claramente, não é prescrito, não aparece no planejamento, embora constitua importante fator de aprendizagem.

O documento investigado, nesta seção, regulamenta cursos de formação inicial e continuada de professores, passamos então a analisar se os pressupostos da formação cidadã estão presentes, também, nos documentos curriculares dedicados à educação básica no Brasil.

\section{O Currículo Educacional brasileiro: mudanças e permanências tendo em vista a formação para a cidadania}

Nesta seção analisamos os documentos curriculares educacionais, direcionados à educação básica e buscamos afirmações que apontem para os princípios educacionais relacionados à formação cidadã. Não podemos deixar de citar que tal pressuposto é previsto no artigo 205 da Constituição Federal (1988) que reconhece a educação como direito fundamental compartilhado entre Estado, família e sociedade ao determinar que

a educação, direito de todos e dever do Estado e da família, será promovida e incentivada com a colaboração da sociedade, visando ao pleno desenvolvimento da pessoa, seu preparo para o exercício da cidadania e sua qualificação para o trabalho (BRASIL, 1988).

Dessa forma apontamos que a formação para a cidadania está presente na Carta Magna na qual estão previstos os princípios que nortearão toda a produção legislativa infraconstitucional inclusive em matéria de educação. Apesar disso, a educação básica no Brasil tem sido constantemente impactada por mudanças estruturais, por exemplo, com o fechamento de escolas na cidade e no campo, exiguidade na oferta de ensino noturno, mudanças curriculares nacionais. No âmbito curricular destacamos a elaboração, aprovação e implantação da Base Nacional Curricular Comum (BNCC).

A BNCC propõe-se a direcionar os conteúdos a serem desenvolvidos na Educação Infantil e no Ensino Fundamental, em todo o território brasileiro. O texto de apresentação do documento informa que a Base Nacional Comum Curricular está:

Prevista na Constituição de 1988, na LDB de 1996 e no Plano Nacional de Educação de 2014, a BNCC foi preparada por especialistas de cada área do conhecimento, com a valiosa participação crítica e propositiva de 
profissionais de ensino e da sociedade civil. Em abril de 2017, considerando as versões anteriores do documento, o Ministério da Educação (MEC) concluiu a sistematização e encaminhou a terceira e última versão ao Conselho Nacional de Educação (CNE). A BNCC pôde então receber novas sugestões para seu aprimoramento, por meio das audiências públicas realizadas nas cinco regiões do País, com participação ampla da sociedade. (Brasil, 2017, p. 5).

Importante destacar que esse documento passou por inúmeras reformulações desde a proposição inicial em 2016 e o excerto acima corresponde à apresentação da terceira versão da BNCC, homologada em pelo Ministério da Educação (MEC) em dezembro de $2017^{5}$.

É necessário mencionar que mudanças curriculares desta magnitude provocam instabilidades e adequações são necessárias. Não podemos deixar de citar que a conjuntura política na qual a BNCC foi homologada era instável. Neste trabalho, não pretendemos nos aprofundar neste aspecto e nem nas incoerências que estiveram presentes no que diz respeito ao diálogo com os professores e pesquisadores educacionais no tocante à construção do referido documento. Detemo-nos às análises relacionadas à presença da formação cidadã na BNCC e a comparações com os Parâmetros Curriculares Nacionais - PCNs, que guiavam as práticas educativas, até então.

Os Parâmetros Curriculares Nacionais foram instaurados no ano de 1997 e se dedicavam a indicar conteúdos, temas, pressupostos e habilidades a serem desenvolvidos no ensino básico no Brasil. No ano de 2013, as autoras Lastória e Fernandes (2013) apontaram que os PCNs poderiam ser analisados como 0 documento de maior abrangência escolar, pois tratavam de uma política pública implementada pelo próprio governo federal para todo o país. Um documento importante, um divisor de águas se considerarmos a trajetória do ensino História e Geografia no Brasil.

Podemos considerar que os PCNs consolidaram a presença da Geografia no currículo dos anos iniciais do Ensino Fundamental em nosso país. Tal área do conhecimento é apontada pelo referido documento curricular educacional como essencial para a construção da cidadania, como evidenciado no seguinte excerto:

A Geografia é uma área de conhecimento comprometida em tornar o mundo compreensível para os alunos, explicável e passível de transformações. Neste sentido, assume grande relevância dentro do contexto dos

5 O documento na íntegra pode ser encontrado no endereço: http://basenacionalcomum.mec.gov.br/a-base <acesso em 07 de janeiro de 2019>. 
Parâmetros Curriculares Nacionais, em sua meta de buscar um ensino para a conquista da cidadania brasileira. (Brasil, 1997, p.26).

O objetivo dos PCNs era garantir que todas as crianças e jovens brasileiros, mesmo em locais com condições socioeconômicas desfavoráveis, tivessem o direito de usufruir do conjunto de conhecimentos reconhecidos como necessários para o exercício da cidadania. O documento não possuía caráter de obrigatoriedade e, portanto, pressupunha adaptações às peculiaridades locais (Morais, 2014). Lastória et al (2015, p. 26) afirmam que "Nos PCNs, foi possível identificar a participação política como uma dimensão importante para a formação para a cidadania e o papel da escola e da educação nesse processo. (tradução nossa)".

Nos Parâmetros Curriculares Nacionais (1997) a formação para a cidadania está posta como eixo central para o desenvolvimento da educação brasileira. As práticas educativas, que se fundamentam nos PCNs, devem considerar a formação cidadã como o seu principal objetivo. Tal objetivo deveria relacionar-se com a localidade do estudante, construindo um ensino básico mais contextualizado.

Com as mudanças curriculares recentes, nos perguntamos qual o "lugar" ocupado pela formação cidadã para a área de Geografia na BNCC? No capítulo dedicado à Geografia é exposto que:

Essa é a grande contribuição da Geografa aos alunos da Educação Básica: desenvolver o pensamento espacial, estimulando o raciocínio geográfco para representar e interpretar o mundo em permanente transformação e relacionando componentes da sociedade e da natureza. Para tanto, é necessário assegurar a apropriação de conceitos para o domínio do conhecimento fatual (com destaque para os acontecimentos que podem ser observados e localizados no tempo e no espaço) e para o exercício da cidadania. (Brasil, 2017, p. 358).

Nota-se que a formação cidadã é prontamente apresentada como objetivo do ensino de Geografia na Educação Básica, ou seja, a relação estabelecida nos PCNs entre a Geografia e a formação para a cidadania também pode ser identificada na BNCC.

A formação para a cidadania se destaca, também, quando o documento apresenta as unidades temáticas do Ensino Fundamental:

Em todas essas unidades, destacam-se aspectos relacionados ao exercício da cidadania e à aplicação de conhecimentos da Geografa diante de situações e problemas da vida cotidiana, tais como: estabelecer regras de convivência na escola e na comunidade; discutir propostas de ampliação de espaços públicos; e propor ações de intervenção na realidade, tudo visando à melhoria da coletividade e do bem comum. (Brasil, 2017, p. 362).

A BNCC, no trecho em que destacamos, postula que a Geografia é fundamental para formarmos estudantes capazes de compreender a realidade na qual estão inseridos e 
promover ações que podem transformar o seu em torno, visando o bem-estar coletivo e a justiça social.

A partir desta análise documental, na qual estudamos os Parâmetros Curriculares Nacionais, que guiaram o currículo educacional desde o ano de 1997, e a Base Nacional Comum Curricular, que entrou em vigência em dezembro de 2007, constatamos que a formação para a cidadania é posta, nestes dois documentos curriculares educacionais nacionais, como eixo central no desenvolvimento da educação básica no Brasil.

A Geografia é exposta como essencial para o desenvolvimento da formação para a cidadania. Consideramos relevante refletirmos acerca do ensino da referida área do conhecimento, que além de explicitada como central para a formação cidadã, nos documentos estudados, também é precursora das práticas educativas vinculadas ao projeto Nós Propomos!.

\section{O Ensino de Geografia e a formação cidadã: as ações do Projeto Nós Propomos!}

O Projeto Nós Propomos!, no âmbito dos grupos de pesquisa apresentados na introdução deste texto, está sendo realizado em diferentes municípios do interior do Estado de São Paulo. Nesta seção apresentamos as ações desenvolvidas e tecemos considerações sobre a relevância das mesmas para a educação geográfica.

As práticas educativas do Nós Propomos! estão sendo desenvolvidas por membros dos grupos de pesquisa, em parceria com escolas estaduais e municipais, públicas e privadas nos municípios de Ibitinga, Serrana, Americana Mococa e Ribeirão Preto e Marília.

Na cidade de Marília o projeto teve início em 2017, envolvendo cerca de 70 estudantes de duas turmas do $8^{\circ}$ ano, abordando a temática "Observatório do Meio ambiente: a questão ambiental em Marília". Seguindo a metodologia do projeto, as ações iniciaram-se com a identificação dos problemas ambientais urbanos para reflexão em sala de aula. Na segunda etapa realizamos o trabalho de campo em diferentes pontos da cidade, contemplando os temas escolhidos pelos estudantes que, organizados em grupos, analisaram as situações de investigação e elaboraram propostas de intervenção urbana. Destaca-se a proposta de remoção de áreas de favelização ao entorno da escola e revitalização urbana. 
Em 2018 as atividades foram realizadas com estudantes do 2ํㅡㄹ Ano do Ensino Médio, com a temática relação cidade-campo e a agricultura brasileira. Nesta etapa de escolarização os estudantes têm entre 15 e 17 anos, o que tornou o trabalho mais profícuo, pois permitiu maior reflexão e aprofundamento do tema de estudo. O campo foi realizado em um assentamento da reforma agrária, o que causou grande impacto por ser uma experiência inovadora. Nenhum dos estudantes conhecia assentamentos rurais, embora muitos relatassem que os pais ou avós tinham morado no campo. $\mathrm{Na}$ visita de estudo a ênfase foi aos modelos de produção agrícola e circulação das mercadorias, o que possibilitou refletir sobre circuitos curtos de produção, valorização do comércio local e a comercialização dos produtos orgânicos em feiras de produtores. Os resultados foram apresentados em seminário na biblioteca da escola, com a participação de um representante do poder público local.

$\mathrm{Na}$ cidade de Ibitinga, a prática está sendo desenvolvida por três professores de diferentes áreas, em turmas do $8^{\circ} \mathrm{Ano}$ do ensino fundamental, envolvendo 105 alunos. Neste caso, o diferencial do projeto está na interdisciplinaridade e da parceria com o governo municipal, que disponibilizou materiais cartográficos do projeto "cidades inteligentes" e colaborou com atividades na escola, por meio de entrevistas/palestras de representantes da secretaria de planejamento urbano.

Em Americana o projeto está em processo inicial e tem como característica específica o fato de que será desenvolvido com estudantes de um $5^{\circ}$ ano do ensino fundamental, nomeados no projeto como "pequenos grandes cidadãos". Isso torna esta experiência inovadora no grupo, pois o trabalho com crianças com idade entre 9 e 10 anos requer atenção diferenciada na preparação do trabalho de campo.

No município de Serrana a ação vinculada ao projeto Nós Propomos! é parte dos trabalhos dos $3^{\circ} \mathrm{s}$ Anos do Ensino Médio. Nesta cidade, destacamos que o projeto está ocorrendo em parceria com a professora de Artes, o que agrega interdisciplinaridade à ação. Os estudantes conheceram o projeto por meio de slides e construíram uma entrevista estruturada que será realizada com a comunidade.

Mococa está desenvolvendo o projeto em duas instituições de ensino, uma delas é pública e a outra privada, em turmas de $8^{\circ} \mathrm{s}$ anos do ensino fundamental e totalizando 80 alunos envolvidos. O tema escolhido, em uma das instituições foi o funcionamento do Sistema Único de Saúde - SUS e em outra a arborização de espaços urbanos.

Em Ribeirão Preto o projeto ocorre, atualmente, em uma turma de $1^{\circ}$ Ano do Ensino Médio, os alunos realizaram trabalhos de campo, entrevistas, em seis bairros da cidade, dedicando-se, especialmente a aspectos socioambientais. 
Ressaltamos que em Serrana, Ibitinga, Americana, Mococa e Ribeirão Preto as práticas educativas vinculadas ao projeto Nós Propomos! foram iniciadas em 2018 e estão em realização, o que não nos permite descrever os resultados. Consideramos que tais práticas podem colaborar com uma formação cidadã por contemplarem a localidade do aluno, envolverem estratégias de ensino diferenciadas e dedicarem-se à construção de propostas que vislumbram transformações e melhorias no cotidiano coletivo.

A ação educativa que envolve o componente curricular da Geografia pode contribuir para que os estudantes desenvolvam subsídios importantes para a leitura e interpretação do mundo (Callai, 2013). A autora enfatiza que ensinar Geografia é ensinar a "Ler o mundo da vida, ler o espaço e compreender que as paisagens que podemos ver são resultado da vida em sociedade, dos homens na busca da sua sobrevivência e da satisfação das suas necessidades. Em linhas gerais, esse é o papel da geografia na escola." (Callai, 2005, p.228).

A leitura e a compreensão do mundo estão diretamente relacionadas à uma formação cidadã. É necessário que o estudante compreenda as relações presentes a sua volta, as características ambientais e sociais do seu entorno, além de perceber-se como autor da própria realidade (Pontuschka, Paganelli e Cacete, 2009). Para que as práticas educativas, que contemplem a Geografia, se voltem para compreensão das realidades vividas pelos alunos e para uma formação cidadã, entendemos que é preciso levar em conta os aspectos da localidade. Consideramos que as práticas voltadas para a localidade, também, podem ser desenvolvidas de forma a tornar os conceitos geográficos mais significativos e contextualizados. A presença da localidade no ensino de Geografia é valorizada por Oliveira (2009, p.174), quando afirma que

no processo de ensino e formação é importante considerar a localidade e a cidade como objetos de ensino que podem se tornar propostas concretas e ao mesmo tempo singulares, pois permitem operar com a complexidade que é o lugar e o cotidiano, temas centrais de caráter geográfico, histórico e social que são reais, concretos e tangíveis.

As práticas educativas que se dedicam a compreender a localidade, assim colaborando para a leitura e compreensão de mundo, corroboram, diretamente com os propósitos do Projeto Nós Propomos!. Além de compreender o mundo, é essencial que os alunos possam formar-se transformadores da realidade, autores da sua própria história.

A despeito do currículo nacional elaborado pelo Estado, as inovações educativas só são possíveis em um contexto de autonomia docente. 
Las evidencias que podemos encontrar en la historia escolar de algunos países nos indican que las innovaciones son consecuencia de planteamientos pedagógicos que buscan la legitimidad en la construcción de un espacio público educativo, donde los miembros de la comunidad escolar puedan ejercer su autonomía racional. La posición del poder institucional, o no, de los grupos pedagógicos implica el diferente rol en la difusión y persuasión de la legitimidad de dicho discurso. (Souto González, 2012).

Assim, consideramos que o desenvolvimento de práticas educativas que se voltem para a formação cidadã só são possíveis com o exercício da autonomia docente. As práticas aqui relatadas só se tornaram possíveis porque os professores envolvidos exercem e exerceram o trabalho docente com autonomia e com análise crítica do currículo e do contexto escolar em que realizam suas práticas. A valorização da localidade e o estudo dos problemas locais é um traço característico desse processo e contribui para a formação autônoma e crítica dos estudantes. Como afirmam Fernandes, Monteagudo e Souto Gonzáles (2016), esta valorização é possível por meio da realização de trabalhos de campo como possibilidade de investigação na educação básica.

\section{Considerações Finais}

Nosso trabalho construiu reflexões a respeito da formação cidadã no Brasil por meio da análise de documentos curriculares e das práticas educativas desenvolvidas na educação básica. Nos documentos curriculares brasileiros a formação cidadã ocupa lugar central. Apesar disso, a formação voltada para a cidadania só se faz presente, no cotidiano escolar, quando são priorizados projetos inovadores.

Descrevemos as ações de dois grupos de ensino e pesquisa. Enfatizamos que a participação em tais coletivos colabora para que os participantes, membros pesquisadores, construam reflexões a cerca do ensino de geografia, da localidade e possam, por meio da reflexão sobre a prática docente, construir práticas inovadoras no exercício da docência.

Consideramos que as práticas educativas vinculadas ao projeto Nós Propomos! compõem o currículo educacional em seu âmbito real, ou seja, é por meio de tais práticas educativas, que determinados preceitos educacionais, neste caso a formação cidadã, se torna efetiva no ensino básico brasileiro. 


\section{Referências bibliográficas}

Brasil. (1988). Constituição da República Federativa do Brasil. Brasília, DF: Senado Federal.

Brasil. (1997). Parâmetros Curriculares Nacionais: História e Geografia 1ํ e $2^{\circ}$ Ciclos do Ensino Fundamental. Brasília: MEC/SEF. Secretaria de Educação Fundamental.

Brasil. (2015) Diretrizes Curriculares Nacionais para a formação inicial em nível superior (cursos de licenciatura, cursos de formação pedagógica para graduados e cursos de segunda licenciatura) e para a formação continuada. Brasília, DF: Conselho Nacional de Educação.

Brasil. (2017). Base nacional comum curricular. Brasília, DF: Ministério da Educação. Secretaria da Educação Básica.

Callai, H. C. (2005). Aprendendo a ler o mundo: a Geografia nos anos iniciais do Ensino Fundamental. Cadernos Cedes, vol 25, n. 66, maio /ago. Campinas.

Callai, H. C. (2013). A formação do profissional da geografia: o professor. Ijuí: Ed. Unijuí.

Fernandes, S. A. S.; Monteagudo, D. G; Souto Gonzales, X. M. Educación Geográfica y las salidas de campo como estratégia didáctica: um estúdio comparativo desde El Geofoto Iberoamericano. Biblio 3W (Barcelona), v. XXI, p. 1-22, 2016. Disponível em: $<$ http://www.ub.edu/geocrit/b3w-1155.pdf>

Lastória. A. C.; Fernandes, S. A. S. (2013). Cartografia escolar na formação inicial de professores dos anos iniciais do ensino fundamental: ficção ou realidade? In: Oliveira, P. (Org.). (Geo) grafias e linguagens: concepções, pesquisas e experiências formativas. 1 ed. v. 1, p. 53-68. Curitiba- PR.

Lastoria, A. C.; Callai, H.; Cavalcantil, L. S. ; Souza, V. C. (2015). School education in Brazil and the goal of citizen formation: indicators in official proposals and in formative pratices.. In: Beatrice B.; Francisco F.; García P.; Olga M. F. (Org.). Nóvi cíves: cittadini dallinfanzia in poi v. 1. 1ed. p. 43-52. Bologna: Pàtron editore.

Libâneo, J. C. (2001). Pedagogia e pedagogos... Revista Educar, n.17, Curitiba: Editora da UFPR.

Libâneo, J. C.; Oliveira, J. F. de; Toschi, M. S. (2003). Educação Escolar: políticas, estrutura e organização. São Paulo: Cortez, 2003. 
Morais, C.C. (2014). Cartografia Escolar nos anos iniciais: o letramento cartográfico nas práticas das professoras. 183 f. Dissertação (Mestrado) - Faculdade de Filosofia Ciências e Letras de Ribeirão Preto, Universidade de São Paulo, São Paulo.

Oliveira, T. M. L. (2009). Ensino de Geografia na contemporaneidade: O Uso de recursos didáticos na sua abordagem. URCA. Porto Alegre.

Pontuschka, N. N.; Paganelli, T I..; Cacete, N. H. (2009). Para ensinar e aprender Geografia - 3ํo ed. - São Paulo: Cortez.

Santos, J. F. A.; Lastória, A. C. (2013) Coronelismo e o ensino de História: reflexões para a formação cidadã. Dialogus (Ribeirão Preto), v. 9, p. 157-174.

Souto González, J. M. (2012). Didáctica de la Geografía y currículo escolar. In: DE MIGUEL GONZÁLEZ, R.; DE LÁZARO Y TORRES, M. L.; MARRÓN GAITE, M. J. (editores) La educación geográfica digital. Zaragoza: Grupo de Didáctica de la Geografía de la Asociación de Geógrafos Españoles, p. 73-92. 


\section{DOMÍNIO B \\ Experiências Educativas Alternativas}




\section{O mapa no ensino de geografia: um olhar para as transformações no espaço}

BIZ, ANA CLAudia ${ }^{1}$

\section{Resumo}

O texto aborda proposta de pesquisa de doutoramento desenvolvida, na Universidade Estadual do Oeste do Paraná (UNIOESTE/FB), cujo objetivo é identificar as transformações ocorridas no território, ao longo do tempo, por meio do registro em mapas, no município de Francisco Beltrão, Paraná, Brasil. As mudanças ocorridas no espaço, pelo tempo, trazem a leitura de lugar por meio das representações gráficas e cartográficas, no contexto da linguagem para o ensino de Geografia na formação do estudante cidadão, enquanto usuário de mapa. O propósito é de resgatar e registrar o contexto histórico-geográfico do município com as representações cartográficas, na relação com o contexto político-econômico-social (sociedade/natureza), para estabelecer relações entre o conhecimento - representação espacial - espaço geográfico e Geografia escolar na formação do estudante enquanto cidadão crítico.

Palavras-chave: Ensino de Geografia; cartografia escolar; mapa.

\section{Abstract}

The text starts approaches aspects of the doctorate development's projects, at Universidade Estadual do Oeste do Paraná (UNIOESTE/FB), whose objective is identify the territory's transformations, a long time, through of the maps register, in Francisco Beltrão, Paraná, Brazil. The changes occurred in space, for the time, bring a read of the places through graphical and cartographic representations, in the language context to the Geography teaching in the student citizen formation, as map user. The

\footnotetext{
${ }^{1}$ Doutoranda em Geografia pela Universidade Estadual do Oeste do Paraná - UNIOESTE Francisco Beltrão, PR - Brasil. Membro do Grupo de Pesquisa RETLEE, anacbiz@gmail.com. Co-autoria: Mafalda Nesi Francischett - Doutora em Geografia pela UNESP/SP. Professora do curso de Graduação em Geografia e do Programa de Mestrado e Doutorado em Geografia da UNIOESTE - Campus de Francisco Beltrão/PR. Membro do Grupo de Pesquisa RETLEE. Pesquisadora Colaboradora da UNICAMP/SP, mafalda@wln.com.br.
} 
project objective is recue the context historic-geographic of municipality and identify changes in the cartographic representation himself, in relation with the context politicaleconomic-social (society/nature) to establish relationship between the knowledge spatial representation - space geographic and Geography school in student formation as critical citizen.

Keywords: Geography Teaching; cartography school; map.

\section{Introdução}

O mapa é um recurso indispensável na Geografia e nas demais áreas do conhecimento, porque compõe o contexto da linguagem geográfica e, como representação, tem grande significado no ensino. Especificamente para na Educação Geográfica o mapa é identificado como importante meio de comunicação e, de acordo com Duarte (2006), desde as primeiras civilizações, elas desenvolveram formas de mapear o espaço, algumas com maior destaque, como os europeus, chineses, gregos, hindus. Com as mudanças ocorridas no tempo histórico no espaço, a leitura de mundo pelas representações se tornaram fundamentais.

Não concebemos a Geografia, sem o entendimento do espaço e isto começa na escola: "Vai-se à escola para aprender a ler, a escrever e a contar. Por que não para aprender a ler uma carta? (Lacoste, 1998, p.55). Por meio das representações cartográficas fica possível conhecer as diversidades espaciais. De acordo com Francischett (2014) a linguagem cartográfica medeia o uso e a elaboração do mapa como elementos de um mesmo processo: a semiose. Ou seja, o mapa, como meio de comunicação, é a própria comunicação; incorporado na linguagem cartográfica, é um veículo na transmissão e na leitura da informação.

No ensino de Geografia, o mapa é um recurso indispensável. Partimos da premissa de que as representações cartográficas, compõem o contexto de linguagem no ensino. Portanto, neste texto, trabalharemos na perspectiva da leitura de mundo a partir da representação do espaço, fundamentada no campo da Semiologia Gráfica, com os seguintes autores basilares: Martinelli (1991; 2009; 2011); Francischett (2004; 2007; 2011 e 2011(a); e Matias (1996), Bertin (1986; 1988), Joly (1990), Archela (2001), Archela e Théry (2008); Oliveira (2011), nas categorias: forma, estrutura, função e processo, em Santos (2008). Nos conceitos de espaço e tempo em Santos (2008) e Bakhtin (1992; 2002); na metodologia do estudo de caso, fundamentada em Yin 
(2015); na Teoria da Atividade de Leontiev (1988) e no processo de mediação pedagógica em Vygotsky (1987).

A proposta segue na perspectiva da leitura de mundo, a partir da representação do espaço, com objetivo de resgatar o conteúdo-forma nas representações cartográficas do espaço, pelo registro em mapas do município de Francisco Beltrão, por meio de levantamento da Cartografia da região do Sudoeste do Paraná e da identificação dos mapas e representações cartográficas construídas ao longo do processo histórico.

Os conceitos de espaço e de tempo serão norteadores no desenvolvimento da pesquisa, por isso, consideramos importante a revisão bibliográfica de Mikhail Bakhtin e Milton Santos, os autores fazem importantes contribuições sobre a relação indissociável dos dois conceitos.

\section{Cartografia escolar e semiologia gráfica}

É consentimento entre os autores da Cartografia Escolar que o mapa é importante forma de comunicação. De acordo com Duarte (2006) as mais variadas civilizações desenvolveram formas de mapear o espaço, algumas com maior destaque, como os europeus, chineses, gregos, hindus, entre outros. Com as mudanças ocorridas, pelo tempo histórico no espaço, a leitura de mundo pelas representações se tornaram fundamentais.

O desenvolvimento desse processo de espacialidade diferencia se traduz por essa proliferação das representações espaciais, pela multiplicação das preocupações concernentes ao espaço (nem que seja por causa da multiplicação dos deslocamentos). Mas esse espaço do qual todo mundo fala, ao qual nos referimos todo tempo, é cada vez mais difícil de apreender globalmente para se perceber suas relações com uma prática global (Lacoste, 1998, p.50).

Por meio das representações cartográficas é possível conhecer as diversidades espaciais. De acordo com Francischett (2014) a linguagem cartográfica trata o uso e a elaboração do mapa como elementos de um mesmo processo, na semiose. Ele é a própria comunicação; incorporado na linguagem cartográfica, é um veículo na transmissão e na leitura da informação.

Para compreender o desenvolvimento cognitivo proporcionado pelo mapa na Semiologia Gráfica, importante é compreender a linguagem cartográfica por meio de um sistema de signos que, de acordo com Francischett (2011), corresponde às relações dos objetos e de sua natureza, com as informações que representam, permitindo que o leitor realize a leitura da representação gráfica. Uma linguagem que 
exprime, pelo emprego de signos, pensamento e desejo de comunicação com o outro. Assim, a Cartografia é considerada uma linguagem universal, no sentido de uma gama de símbolos. "Conhecer as propriedades dessa linguagem para melhor utilizá-la é o objeto da semiologia gráfica". (Joly, 1990, p.13).

Surgida na França, na década de 1960, a Semiologia Gráfica se desenvolveu, no Brasil, a partir da década de 1980. Consiste numa orientação na elaboração de mapas temáticos, com o uso de símbolos que caracterizam a informação. Ou seja: "Aplicada à cartografia, ela permite avaliar as vantagens e os limites das variáveis visuais empregadas na simbologia cartográfica e, portanto, formular as regras de uma utilização racional da linguagem cartográfica" (Joly, 1990, p.13).

A Semiologia Gráfica propõe o estudo do mapa a partir das variáveis visuais, tamanho, textura, cor, orientação e forma, e componentes, diversidade, ordem e proporcionalidade. Linguagem gráfica com um sistema de signos gráficos constituídos de significado (conceito) e significante (imagem gráfica). Através da percepção, por meio da leitura, o leitor identifica e interpreta os signos presentes na representação (Bertin, 1980).

Existem dois tempos na percepção gráfica a leitura e a interpretação dos mapas.

Primeiro tempo: a identificação externa, a percepção isola os conjuntos, por exemplo, um conjunto de países, um conjunto de produtos (2), entre todos os possíveis. É o tempo do "sinal", ou seja, das convenções verbais ou de convenções mais ou menos analógicas ao grafismo. [...] segundo tempo: a identificação interna, a percepção descobre as relações. E o domínio da neográfica. A transcrição das relações não utiliza "o sinal". Ela utiliza a relação entre os sinais. Ela utiliza as variações visuais. A neográfica transcreve uma semelhança entre duas coisas por uma semelhança visual entre dois sinais, uma ordem entre três coisas por uma ordem entre três sinais (Bertin, 1986, p.177).

Bertin (1986) salienta que a Cartografia consiste numa linguagem potencialmente monossêmica, pois trata da relação entre: a semelhança, a ordem e a proporcionalidade e as variáveis visuais.

O mapa como linguagem é entendido a partir do sistema cognitivo, em que a percepção do leitor é o principal elemento. "A semiologia gráfica está ao mesmo tempo ligada às diversas teorias das formas e de sua representação, desenvolvidas pela psicologia contemporânea, e às teorias da informação" (Joly, 1990, p.13).

Há relação da Semiologia Gráfica com teorias de psicologia da aprendizagem, que estão ligadas ao cognitivo. As ações-atividades, na pesquisa, serão fundamentadas na 
Teoria da Atividade de Leontiev (1988), que propõe que, elas devem ter uma intenção, uma finalidade ao ser executada enquanto ação.

Essa teoria é busca resultados principalmente,

[...] da relação entre a estrutura objetiva da atividade humana e a estrutura subjetiva da consciência. Entre as várias e decisivas implicações da análise que Leontiev faz dessa relação, destaco duas: em primeiro lugar, o avanço no campo da teoria marxista no que se refere às complexas relações entre indivíduo e sociedade; em segundo lugar, mas com igual grau de importância, o enriquecimento dos instrumentos metodológicos de análise dos processos de alienação produzidos pelas atividades que dão o sentido (ou o sem-sentido) da vida dos seres humanos na sociedade capitalista (Duarte, 2002, p. 284).

Metodologias investigativas para o ensino da Geografia, na educação básica, partem do pressuposto de que, ao serem realizadas elas têm como finalidade trabalhar 0 conteúdo almejado, para proporcionarem a construção dos conhecimentos geográficos, o que ocorre a partir da compreensão dos signos da representação gráfica, da leitura e do entendimento do mapa, por exemplo.

\section{O mapa como recurso para identificação cidadã}

O espaço representado no mapa do município, por exemplo, apresenta interações da sociedade de ordens econômicas, culturais e ideológicas, de acordo com Santos (2008) isso significa que ao passo que o espaço contém, ele é contido por todas estas instâncias. Pois, o espaço não se refere apenas às coisas, mas também por objetos geográficos, naturais e artificiais, além da sociedade. Assim esses é dinâmico e sofre alterações variadas, em variados períodos, de acordo com as interações que nele acontecem.

Neste contexto, o Sudoeste do Paraná, região com 42 municípios, conforme a Lei Estadual $n^{\circ} 15.825$, de 28 de abril de 2008, apresenta a ocupação mais recente do estado do Paraná. Com municípios, como Palmas, que é o mais antigo, criado em 1879 e o mais recente, Pinhal de São Bento fundado em 1990. Está presente na história desta região a criação de municípios que foram sendo desmenbrados de outros maiores, o caso do município de Francisco Beltrão. Em 12/03/1943 o então presidente Getúlio Vargas criou e implantou a CANGO (Colônia Agrícola Nacional General Osório), que objetivou, inicialmente, promover a ocupação física da faixa de fronteira com a Argentina quase que deserta totalmente naquela época. Essa colônia foi provisoriamente implantada naquele mesmo ano, numa pequena localidade que 
aos poucos começava a se desenvolver, território de Pato Branco, que anteriormente pertencia à Clevelândia. (Francischett; Toffolo, Biz; Geron, 2018).

Historicamente o município de Francisco Beltrão foi criado efetivamente em 1948, apresenta mudanças na delimitação de seu território. Fazendo um contraponto entre os dois mapas, a seguir, é possível perceber que em 77 anos, de diferença entre as representações, o território de Clevelândia se reduziu praticamente em $90 \%$ de sua área. Outro aspecto a considerar é o fato de que a ocupação paranaense se deu de Leste para Oeste, visivelmente no mapa, explicada por muitos fatores como por exemplo o acesso oportunizado pelo mar no descobrimento, pelo comércio etc. O que ocorreu para que Palmas e Clevelândia tenham reduzido seu território?

Mapa 4 - Paraná - divisão administrativa do ano de 1940.

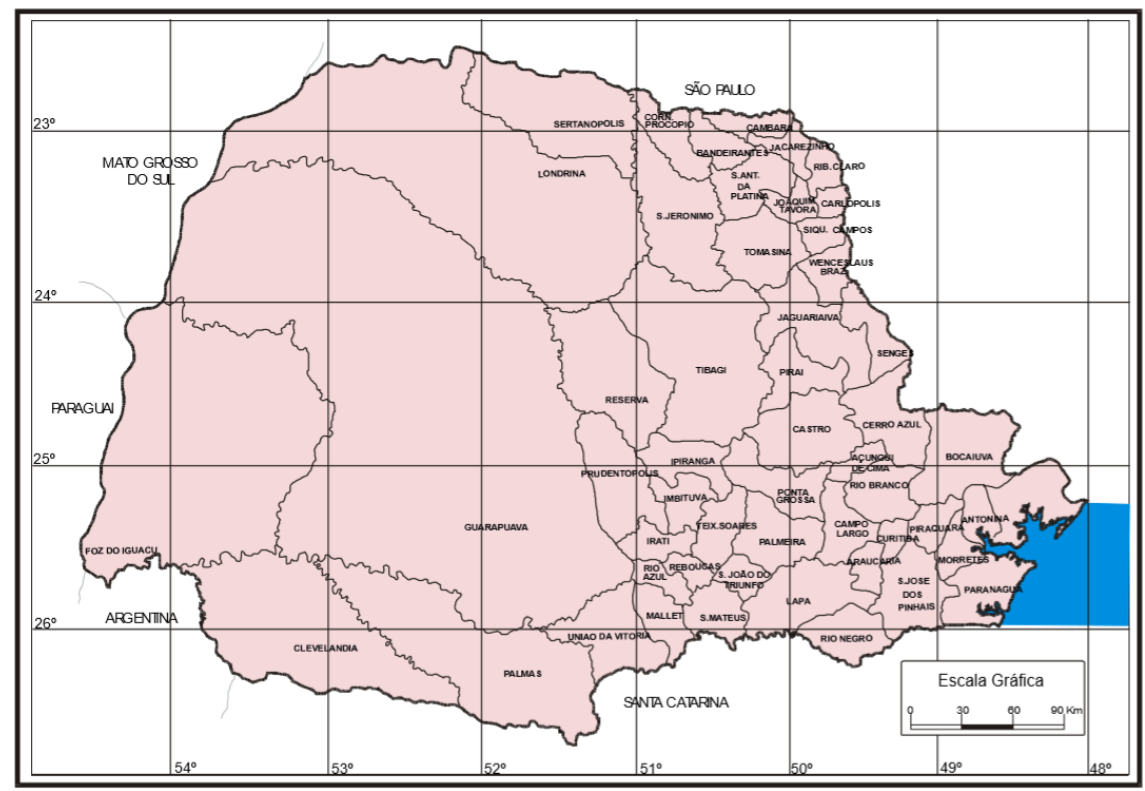

Fonte: Paraná, 2003. 


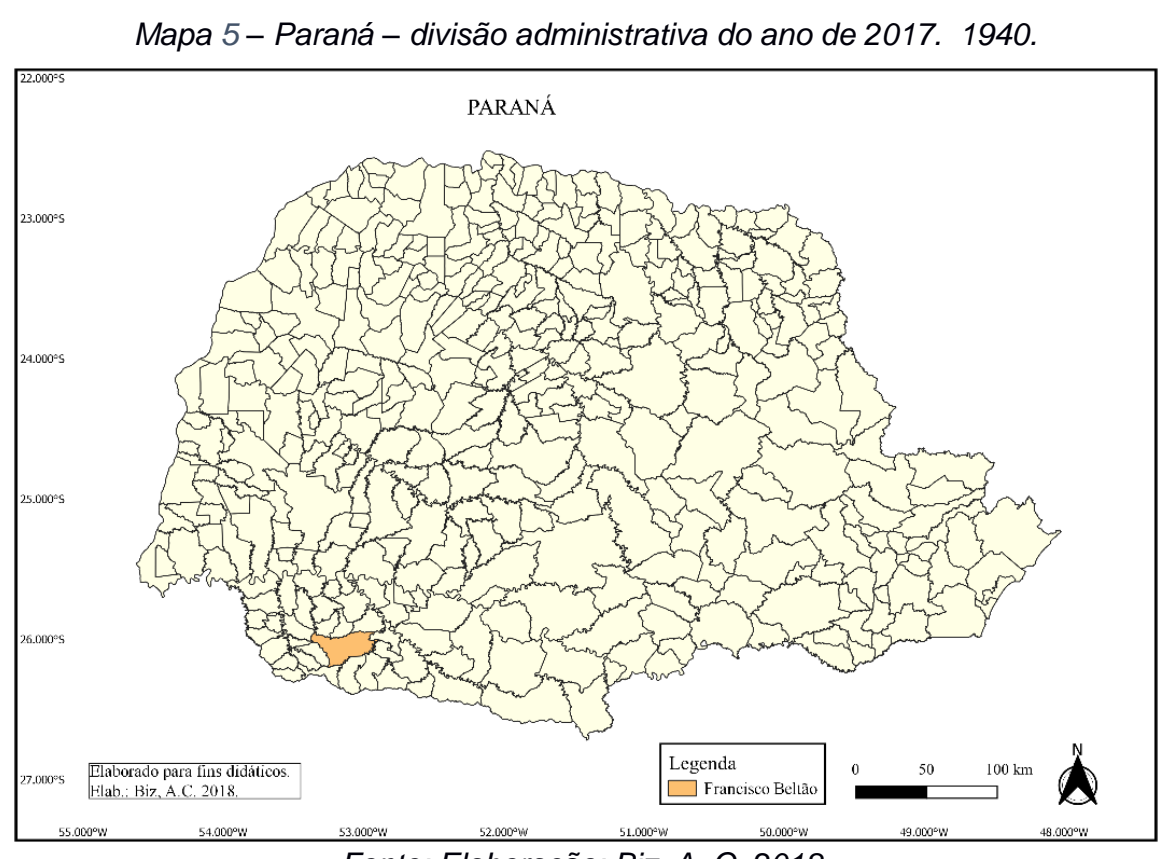

Fonte: Elaboração: Biz, A. C. 2018.

O processo de mudança territorial que ocorreu no estado do Paraná, na região Sul do Brasil, também é percebido na região Sudoeste, como visualizado nos mapas anteriores. Conforme Cortesão (1965), é uma característica do país, que tem variada e complexa história das fronteiras e consequentemente de representação espacial. Este processo nos instiga a olhar com cuidado para os acontecimentos históricos do município. Daí brota a fonte dessa proposta de tese.

De acordo com Callai (2016) uma pesquisa que se caracteriza numa perspectiva cidadã envolve a participação dos sujetiros envolvidos, interrelacionando sujeitos e objetos numa construção de conhecimentos. Neste sentido buscamos traçar o ensino de Geografia na formação do estudante cidadão, enquanto usuário de mapa. $O$ sujeito/estudante de Francisco Beltrão ao ler os mapas do município, de diferentes tempos históricos, compreende que o espaço que ele vive foi palco de mudanças espaço-temporais que, além do mapeamento, alteraram a sociedade e o lugar. Também de que como as mudanças espaciais ocorreram no município de Francisco Beltrão e significa compreender o processo em movimento no espaço geográfico, na sua abstração pelos sujeitos que registram nestes grafismos. Com o resgate das representações indicativas do processo, faremos análise com um grupo de professores, da rede de ensino municipal e estadual, para responder ao propósito da tese: para que se valem estudos históricos-geográficos e registros cartográficos de um lugar no ensino de Geografia na escola? 
Os procedimentos metodológicos consistem em revisão de fontes bibliográficas e na busca de pesquisas realizadas sobre a Cartografia na constituição histórica-geográfica da região Sudoeste do Paraná. Para tal serão consultados os bancos de dados do IBGE (Instituto Brasileiro de Geografia e Estatísticas) e do ITCG (Instituto de Terras, Cartografias e Geociências), dos mapas e de documentos, em períodos variados, do munícipio. A partir da análise pautada nas categorias teóricas de Santos (2008): Forma, Estrutura, Função e Processo. Assim, buscamos explicar os fenômenos que configuram as mudanças espaciais.

\section{Referências bibliográficas}

Bertin, J. (1986). A Neográfica e o tratamento gráfico da informação. Curitiba: Editora da UFPR.

Callai. H. C., Moraes, M. M. de. (2016). Pesquisa, educação e cidadania: percursos teóricos e metodológicos. ljuí: Ed. Unijuí, 2016.

Cortesão, J. (1965). História do Brasil nos velhos mapas. Tomo I. Rio de Janeiro: Departamento de Imprensa Nacional.

Duarte, N. (2002). A teoria da atividade como uma abordagem para a pesquisa em educação. Revista Perspectiva. Florianópolis, V (20), n. 02, 279-301.

Duarte, P. A. (2006). Fundamentos da cartografia. Florianópolis: Editora da UFSC.

Francischett, M. N. (2011). O significado das Representações Gráficas cartográficas no Ensino. Biblioteca On-line de Ciências da Comunicação. http://www.bocc.ubi.pt/pag/franchischett-mafalda-o-significado-das-representacoesgraficas.pdf.

Francischett, M. N (2014). Construindo elos metodológicos na linguagem cartográfica. Revista Brasileira de Cartografia. № 66/4: 843-859. http://www.Isie.unb.br/rbc/index.php/rbc/article/viewFile/926/714. Acesso em 07 de jun. 2016

Francischett, M. N.; Toffolo, G.; Biz, A. C.; Geron, G. (2018) A geografia nos anos iniciais: ensino Fundamental: Município de Francisco Beltrão. Francisco Beltrão: Calgan.

Joly, F. (1990). A cartografia. Campinas: Papirus. 
Lacoste. Y. ( 1988). A geografia: isso serve, em primeiro lugar para fazer a guerra. Campinas: Papirus.

Paraná. (2003). Instituto de Terras Cartografia e Geociências - ITCG. Arquivo gráfico municipal do estado do Paraná.

Santos, M. (2008). Espaço e método. São Paulo: EDUSP.

Vygostky, L. S.; Luria, A. R.; Leontiev, A. N. (1988) Linguagem, desenvolvimento e aprendizagem. São Paulo: Ícone EDUSP. 


\title{
Ações educativas e fortalecimento da cidadania na escola Sesquicentenário, João Pessoa, Paraíba, Brasil
}

\author{
ANNA THERESA ROSENHAIM ${ }^{1}$ \\ MARIA EDUARDA VIANA PONTES DOS SANTOS ${ }^{2}$ \\ REGINA CELLY NOGUEIRA DA SILVA ${ }^{3}$
}

\section{Resumo}

O Projeto "Nós Propomos! Paraíba: revitalizando a cidadania através da educação" iniciou suas atividades em 2018 através de uma parceria entre o Centro Estadual Experimental de Ensino-Aprendizagem Sesquicentenário e a Universidade Estadual da Paraíba visando o desenvolvimento de práticas pedagógicas exitosas que busquem fomentar a consciência cidadã de jovens estudantes dos diferentes níveis e modalidades de ensino. Uma das ações do projeto consiste na realização de práticas educativas nas turmas do Ensino Fundamental II (anos finais) do Sesquicentenário ligadas a importância da preservação do patrimônio arquitetônico, histórico, artístico, cultural e ambiental que fazem parte do espaço vivido e imaginário das crianças dessa faixa etária em conjunto com discentes do curso de pedagogia da Universidade Federal da Paraíba (UFPB). As ações incluem: Palestras sobre patrimônio e a importância de preservar as memórias da cultura local; oficinas de desenho, pintura e jogos com as temáticas do patrimônio local; rodas de conversa sobre as potencialidades locais, identificação das maiores problemáticas que afetam a comunidade e quais seriam as possíveis soluções na ótica dos alunos da escola Padre João Félix. As atividades desenvolvidas são parte integrante de ações cidadãs propostas pelo art. 182 da Constituição Federal e Estatuto da Cidade que pretendem,

\footnotetext{
1 Estudante do $3^{\circ}$ Ano do Ensino Médio do Centro Estadual Experimental de Ensino-Aprendizagem Sesquicentenário - annatheresarosenhaim@gmail.com

2 Estudante do 2을 Ano do Ensino Médio do Centro Estadual Experimental de Ensino-Aprendizagem Sesquicentenário - mariaeduardapontes69@gmail.com

3 Professora da Universidade Esatdual da Paraíba - recelly51@hotmail.com
} 
por sua vez, ordenar o pleno desenvolvimento das funções sociais da cidade e garantir o bem-estar de seus habitantes.

Palavras-chave: Educação; Cidadania; Ações Pedagógicas; João Pessoa; Sesquicentenário

\section{Resumen}

El proyecto "Nosotros proponemos! Paraíba: revitalizando la ciudadanía a través de la educación" inició sus actividades en 2018 a través de una asociación entre el Centro Estadual Experimental de Enseñanza-Aprendizaje Sesquicentenario y la Universidad Estadual de Paraíba con el objetivo de desarrollar prácticas pedagógicas exitosas que busquen fomentar la comunicación conciencia ciudadana de jóvenes estudiantes de los diferentes niveles y modalidades de enseñanza. Una de las acciones del proyecto consistió en realizacion de prácticas educativas en las clases de la Enseñanza Fundamental I (años finales) En Sesquicentenário ligadas a la importancia de la preservación del patrimonio arquitectónico, histórico, artístico, cultural y ambiental que forman parte del espacio vivido e imaginario de los niños de esa franja etaria en conjunto con discentes del curso de pedagogía de la Universidad Federal de Paraíba (UFPB). Las acciones incluyen: Palestras sobre patrimonio y la importancia de preservar las memorias de la cultura local; talleres de dibujo, pintura y juegos con las temáticas del patrimonio local; las ruedas de conversación sobre las potencialidades locales, identificación de las mayores problemáticas que afectan a la comunidad y cuáles serían las posibles soluciones en la óptica de los alumnos de la escuela Padre João Félix. Las actividades desarrolladas son parte integrante de acciones ciudadanas propuestas por el art. 182 de la Constitución Federal y Estatuto de la Ciudad que, a su vez, ordenan el pleno desarrollo de las funciones sociales de la ciudad y garantizar el bienestar de sus habitantes.

Palabras clave: Educación; Ciudadanía; Acciones Educativas; João Pessoa; Sesquicentenário

\section{Introdução}

O desenvolvimento de ações voltadas à educação patrimonial foi um dos maiores objetivos do projeto Nós Propomos! Paraíba: revitalizando a cidadania através da educação durante o ano de 2018, por esse motivo um dos grupos de trabalho do projeto se propôs a desenvolver práticas de educação patrimonial numa turma do $6^{\circ}$ 
ano do Ensino Fundamental II (anos finais) no Centro Estadual Experimental de Ensino-Aprendizagem Sesquicentenário.

As oficinas de educação patrimonial ocorreram com uma exposição dialogada dos estudantes participantes do projeto Nós Propomos! Paraíba que abordaram os conceitos de patrimônio histórico material e imaterial; a importância do Instituto do Patrimônio Histórico e Artístico Nacional (IPHAN) na conservação, fiscalização, tombamento e preservação do patrimônio histórico, arquitetônico, artístico, cultural e natural a nível nacional, estadual e, em alguns casos municipal; utilização das lendas e contos antigos relacionados aos monumentos históricos com o objetivo de trazer a questão lúdica para o debate com crianças e adolescentes e assim intensificar a aprendizagem de tais conceitos e, sobretudo, despertar o diálogo e uma interação mais ativa entre os alunos do ensino fundamental II (anos finais) e do ensino médio, que estão ministrando as oficinas; e por fim foi proposto a produção de cartazes em cartolina se utilizando de desenhos e pinturas que aliassem a representação dos monumentos históricos de João Pessoa com as lendas de sua fundação.

\section{Conceito de Educação Patrimonial e suas discussões}

Estudos de Pelegrini (2006) apontam que a educação patrimonial no Brasil tem sido praticada de modo não sistemático desde a década de 1940, principalmente nas cidades em que o Instituto do Patrimônio Histórico e Artístico Nacional (IPHAN) mantém áreas tombadas, tratando-se apenas de atividades extracurriculares $\mathrm{e}$ interdisciplinares que se propõem a reconhecer e valorizar as referências culturais locais, regionais ou nacionais. Na América Latina, de modo geral, essa atividade educacional é muito recente, mas vem se intensificando desde as décadas de 1980 e 1990. A definição de Horta et. al. (1999) descreve as práticas de educação patrimonial como um processo permanente e sistemático de trabalho educacional centrado no patrimônio cultural como fonte primária de conhecimento e enriquecimento individual e coletivo. É a partir da experiência e do contato direto com as evidências e manifestações da cultura, em todos os seus múltiplos aspectos, sentidos e significados, que o trabalho de educação patrimonial ganha relevância e busca levar as crianças, os jovens e adultos a um processo ativo de conhecimento, apropriação e valorização de sua herança cultural, conscientizando-os da importância destes bens e de seu usufruto, propiciando a geração e a produção de novos conhecimentos, num processo permanente de criação cultural. 
Nesse sentido o Decreto-Lei n 25, de 30 de novembro de 1937 atribui poderes ao Instituto do Patrimônio Histórico e Artístico Nacional (IPHAN ) para denominar como patrimônio cultural todas as expressões culturais criadas pela sociedade ao longo da história que, com o tempo, são agregadas às das gerações anteriores. Takada et. al. (2010) discorre que esse conceito, na atualidade, se estendeu a imóveis particulares, trechos urbanos e até ambientes naturais de importância paisagística, além de imagens, utensílios e outros bens móveis. A própria comunidade pode indicar como classificar seus bens, de acordo com o que julga ser representativo, e cabe ao Conselho Consultivo do IPHAN determinar como tal propriedade será registrada oficialmente. Um prédio histórico pode estar integrado a uma área tombada - o tombamento é um ato do poder público para impedir a destruição ou a descaracterização de um bem -, assim como um parque natural pode carregar consigo lendas e práticas econômicas marcantes. É por isso que um mesmo local pode ser estudado e pesquisado com diferentes abordagens.

Assim, o patrimônio histórico é um bem cultural que simboliza a formação de um povo e carrega testemunhos de sua história. Na paisagem está impressa as relações entre passado e presente e as mudanças ocorridas em uma cidade ao longo do tempo, por exemplo, que são representadas no centro histórico - suas diferentes arquiteturas, seu traçado urbano, o desenho das ruas, seus prédios, monumentos, tudo pode ser uma referência para que se compreenda o modo de vida dos antigos e atuais habitantes de um lugar, independentemente da beleza artística. Da mesma maneira, arquivos históricos, imagens, jardins, parques, praças e artefatos de época podem ser considerados patrimônios históricos por sua importância como documentos de uma época.

A Educação Patrimonial é um instrumento junto a escola, a comunidade e demais sujeitos que desejem trabalhar nessa perspectiva. Essa ação possibilita ao indivíduo fazer a leitura do mundo que o rodeia, levando-o assim à compreensão do universo sociocultural e da trajetória histórico-temporal em que está inserido. Prática educativa extremamente importante para o despertar acerca da cultura do lugar, de suas especificidades, da riqueza que cerca o indivíduo. Nesse sentido, a educação patrimonial leva ao reforço da autoestima e valores dos indivíduos e comunidades, a construção da identidade, à valorização da cultura brasileira, compreendida em âmbito geral como múltipla e plural. Segundo o Horta et. al. (1999) a metodologia da Educação Patrimonial pode ser aplicada e desenvolvida, a qualquer evidência material ou manifestação da cultura, seja um objeto ou conjunto de bens, um monumento ou um sítio histórico ou arqueológico, uma paisagem natural, assim como um parque ou 
uma área de proteção ambiental, um centro histórico urbano ou uma comunidade da área rural, uma manifestação popular de caráter folclórico ou ritual, um processo de produção industrial ou artesanal, tecnologias e saberes populares, e qualquer outra expressão resultante da relação entre indivíduos e seu meio ambiente.

Através das ações de Educação Patrimonial a escola deverá promover de forma sistemática situações que trabalhem as evidências materiais ou manifestações culturais de uma comunidade. Neste processo dinâmico de sociabilização e aquisição de conhecimento em que se aprende a fazer parte de um grupo social o indivíduo constrói a própria identidade. As ações desenvolvidas pela Educação Patrimonial na escola devem provocar situações de aprendizado sobre o processo cultural e seus produtos e manifestações, que despertem nos alunos o interesse em compreender 0 universo cultural e social em que estão inseridos, como também, resolver questões significativas para sua própria vida, pessoal e coletiva. Nesse sentido Dermarchi (20016) chama atenção para a importância que a educação patrimonial deva ser apreendida e assumida como um processo com perspectiva de longa duração e de ampliação, com a garantia de continuidade e de rebatimento para o planejamento e reformulação das práticas das instituições comprometidas com a preservação cultural.

Muitas são ações que os professores podem realizar com seus alunos em sala de aula e fora dela. Durante as aulas é comum a utilização de fontes como os objetos materiais, mensagens escritas e orais gravadas, imagens, esculturas, paisagens, arquiteturas e centros urbanos são, em geral, consideradas bens culturais. Todas essas fontes, antes de serem usadas para a produção de informação, são coisas em sua origem e, no presente, se tornam vestígios de atividades humanas no passado. Assim, nas aulas temos que superar a visão de que a história é apenas a que está nos livros. Se agirmos assim os alunos perdem a chance de relacionar o conhecimento histórico aos vestígios expressos na paisagem, o simbolismo dos objetos, a importância dos artefatos. Aprender a utilizar as fontes é essencial pois com isso os alunos terão oportunidade de aprender a interpretá-las.

Os Centros Históricos de muitas cidades brasileiras são excelentes exemplares para estimular os alunos a estabelecer e compreender as relações fundamentais entre 0 presente, o passado, e as mudanças ocorridas nos modos de vida das pessoas que neles viveram ou ainda vivem, assim como nas próprias cidades. Depois de uma aula sobre a história da cidade, pesquisa em sala de aula e na biblioteca da escola, o essencial é fazer com que os alunos compreendam a necessidade de preservar um bem arquitetônico, uma obra, o patrimônio, visto que eles revelam informações sobre a 
formação da cidade. Através de idas ao Centro Histórico, conduzir uma investigação sobre o patrimônio cultural da área é fundamental. Entre outros aspectos, deve ser explorado pelos professores as construções históricas, o ambiente natural, aspectos que apontam as relações com o meio ambiente, as necessidades de certa época e as inspirações artísticas.

Além disso, professores e alunos tem a possibilidade de aprender juntos sobre o Centro Histórico e sua importância para a construção da identidade. A área permite um amplo campo de investigação e pesquisa que desperta interesse tanto nos alunos menores nos primeiros anos de aprendizagem como no adolescente do ensino médio. Ao mesmo tempo em que permite a troca de conhecimento entre as disciplinas, envolvendo os alunos em trabalhos interdisciplinares fora da sala de aula, a troca de ideias, além de possibilitar a compreensão do patrimônio, da história, do meio ambiente.

Nesse sentido o trabalho de campo com os alunos torna-se uma atividade fundamental para que os estudantes tenham a oportunidade de explorar as ruas a pé, observar as construções, os monumentos e a dinâmica da área e conheçam personagens que frequentam o centro histórico. O valor cultural de cada obra abre um debate sobre o significado da arte e como ela está inserida na comunidade. O contato com monumentos, ruas, prédios, praças, marcam a identidade da paisagem urbana acabam por estimular a apreciação artística e acentuar o diálogo entre as produções regionais e a diversidade da arte universal. A ação deve ser interdisciplinar, envolver o máximo de área de conhecimento, assim professores de História, Geografia, Artes, Biologia, Língua Portuguesa, Matemática, Sociologia, etc. apontam as diferenças entre prédios comuns e tombados e mostram como o edifício histórico está relacionado à origem daquela comunidade. A paisagem da área central da cidade reflete a história da cidade e seu contínuo e permanente processo de transformação ao longo do tempo.

Os professores devem proporcionar aos alunos um diálogo com moradores que conhecem bem as tradições da comunidade, realizar entrevistas com moradores, conhecer os artistas populares, os artesões, as festas. A experiência é importante porque permite aos estudantes ter contato e acesso ao modo de vida de uma época histórica desconhecida e comparar com os dias atuais, assim os discentes estabelecem contato com valores e costumes de outras épocas. Um erro cometido pelos que estudam o patrimônio é abordar manifestações típicas só em datas comemorativas. Essa atitude esvazia o significado da memória de um povo. Deve-se 
entender as produções como parte integrante de uma comunidade. A prática da educação patrimonial é construir a sensação de pertencimento a uma cultura sendo esse um dos principais objetivos quando se trabalha com o patrimônio cultural.

Assim investigar as relações que se estabelecem no lugar e cria uma rede de significados e relações é o que motiva a prática da educação patrimonial, como ressalta Horta et. al. (1999):

Descobrir esta rede de significados, relações, processos de criação, fabricação, trocas, comercialização e usos diferenciados, que dão sentido às evidências culturais e nos informam sobre o modo de vida das pessoas no passado e no presente, em um ciclo constante de continuidade, transformação e reutilização é a tarefa especifica da Educação Patrimonial. Neste processo de descobrimento da realidade cultural de um determinado tempo e espaço social é possível se aplicar uma metodologia apropriada que facilite a percepção e a compreensão dos fatos e fenômenos cultural.

A prática da Educação Patrimonial irá trabalhar também com o conjunto de práticas e saberes transmitidos de geração em geração que diferenciam determinado povo ou região. Comidas, vestimentas, danças, músicas, expressões, lendas, festas, celebrações, conhecimentos e técnicas, assim como instrumentos, artefatos e lugares, carregam em si uma memória coletiva, a história do lugar, os valores de uma época.

Vale ressaltar ainda que os professores devem trabalhar os aspectos ambientais da área, pois todo local cuja natureza tenha relevância para uma população deve ser preservado enquanto patrimônio ambiental. Os rios, lagoas, mangues, litoral, florestas, são lugares que também apresentam relações significativas com a sociedade, por causa da história e da economia a ele associada. A raridade, a importância de um bioma ou a beleza de seu conjunto também recebe a classificação de patrimônio natural. As ações da Educação Patrimonial visam levar o aluno a compreender o espaço onde vive com conhecimentos históricos e geográficos, sendo apresentado às manifestações folclóricas e às atividades econômicas ou turísticas do local. O estudo sobre a flora e a fauna típicas da região incentiva a preservação, pois assim o aluno se considera parte desse ambiente.

\section{Experiência de participação no I Congresso Ibero-Americano Nós Propomos! Geografia, Cidadania e Educação}

Os resultados das práticas de educação patrimonial desenvolvidas no Centro Estadual Experimental de Ensino-Aprendizagem Sesquicentenário foram apresentados durante o I Congresso Ibero-Americano Nós Propomos! Geografia, Cidadania e Educação, que ocorreu no Instituto de Geografia e Ordenamento de Território (IGOT) da Universidade 
de Lisboa, Portugal. Onde foi possível também assistir diversas apresentações de professores e estudantes presentes no evento acerca do andamento do projeto em Portugal, Espanha, Colômbia, Peru e diversos estados brasileiros que conseguiam retratar os problemas socioambientais urbanos em diversos contextos geográficos. E, através desta oportunidade foi possível apresentar os estudos realizados pelo projeto Nós Propomos! Paraíba: revitalizando a cidadania através da educação no que concernem as problemáticas existentes no Centro Histórico de João Pessoa, que apesar de muito belo e detém um grau de importância elevada como patrimônio histórico, arquitetônico, artístico e cultural por representar 433 anos de história, também passa por um processo de sucateamento de suas funções urbanas nas últimas décadas, com um elevado estado de degradação, abandono por parte do poder público e o fortalecimento do processo de gentrificação contra as comunidades que ali residem. Foi enfatizada a importância da preservação do patrimônio histórico com ênfase na multiplicação da oferta de ações educativas aos mais jovens nas escolas, visando tratar da importância dos monumentos históricos e suas representações no imaginário coletivo como ferramenta de fomento preservação da história, memória e cultura do Centro histórico de João Pessoa e sua função de fonte de informação às gerações futuras.

Ainda em Portugal, o referido congresso ofertou um leque de atividades, sendo possível realizar visitas de estudos e trabalhos de campo em oito cidades portuguesas: Lisboa, Évora, Cascais, Braga, Porto, Coimbra, Fátima e Belém. Onde foi possível tomar nota sobre o andamento de projetos exitosos e premiados do mundo ibérico, experimentar a culinária e conviver com os costumes e a cultura local de cada uma das cidades que visitadas. Ao longo do trajeto ocorreu a exposição das características geográficas de cada cidade, tais como: condições climáticas, aspectos do mundo físico e os condicionantes históricos, econômicos, sociais e culturais de cada região com a coordenação e orientação do Professor Sérgio Claudino e Luís Mendes, juntamente com a colaboração de diversos professores e pesquisadores de diversas instituições, estudantes de escolas e representantes do poder público.

\section{Oficinas de Educação Patrimonial}

A equipe de estudantes do responsáveis pelo eixo temático do Projeto Nós Propomos! Paraíba voltado à Educação Patrimonial realizaram oficinas para alunos do $6^{\circ}$ ano do ensino fundamental II (anos finais) do Centro Estadual Experimental de EnsinoAprendizagem Sesquicentenário durante o ano de 2018, em cumprimento ao que 
versa o artigo 182 da Constituição Federal disponível em Brasil (1988), que discorre sobre a importância da efetivação de práticas de educação patrimonial e a importância da cidadania para a valorização e preservação do patrimônio histórico. O principal objetivo das oficinas foi realizar uma discussão sobre o conceito de patrimônio histórico material e imaterial, e por fim realizar a interação com os discentes sobre os monumentos históricos tombados que apresentam maior significância no centro histórico de João Pessoa.

A exposição iniciou-se com a apresentação dos integrantes do grupo de trabalho e uma explanação geral obre o funcionamento do Projeto Nós Propomos! E sua relação com o patrimônio histórico, artístico e cultural do Centro Histórico de João Pessoa. Após o momento inicial os alunos foram questionados a responderem três perguntas iniciais (figura 1): O que é patrimônio? O que vocês consideram como patrimônio? Se Já visitou, comeu, ouviu ou dançou algum patrimônio histórico? Foi entregue folhas em branco, para que com suas ideias e conhecimentos respondessem esses questionamentos.

Figura 1 - Questionário sobre educação patrimonial

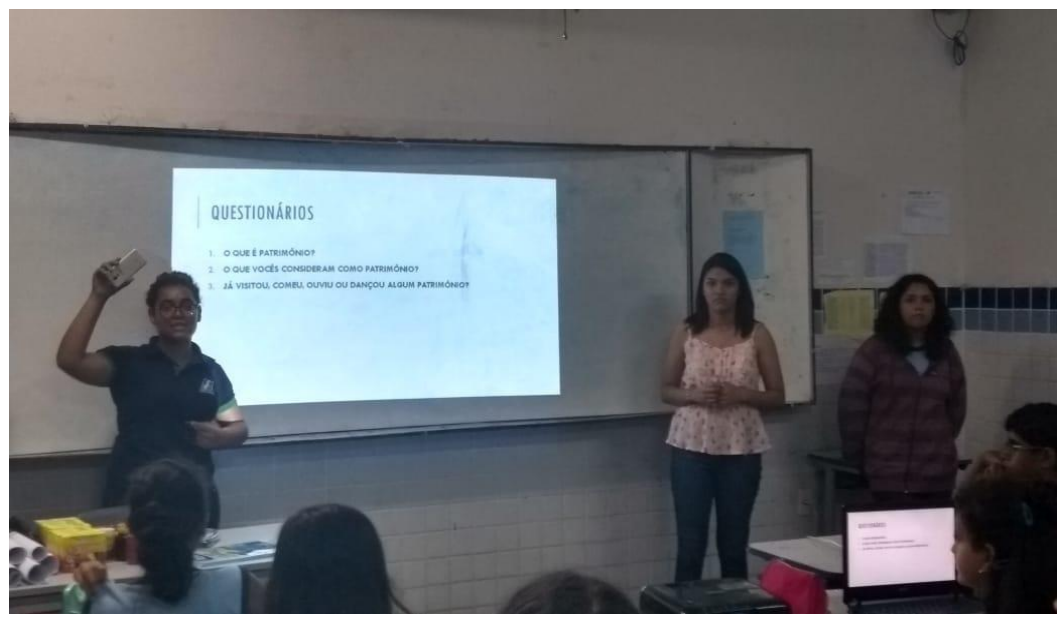

Fonte: Lucas Eduardo Melo Alves

Posteriormente, foram retomadas às discussões sobre o conceito de patrimônio pelos integrantes do projeto com as diferenciações dos conceitos de bem material, imaterial e natural que possuem algum significado para um povo ou nação. Os estudantes Ana Lívia de Lima Borges e Yan de Lima Ribeiro fizeram a exposição das perguntas do questionário; seguiu-se com a apresentação com Maria Heloísa Ferreira da Costa, Maria Eduarda Sousa Ismael e Anna Theresa Rosenhaim sobre a função e as atribuições do Instituto do Patrimônio Histórico e Artístico Nacional (IPHAN), órgão governamental, ligado ao Ministério da Cultura (figura 2), que age para preservar e 
tombar imóveis públicos e particulares, edifícios, praças, parques, vilas e outros que representem um povo e sua história. 
Figura 2 - Exposição das funções do IPHAN

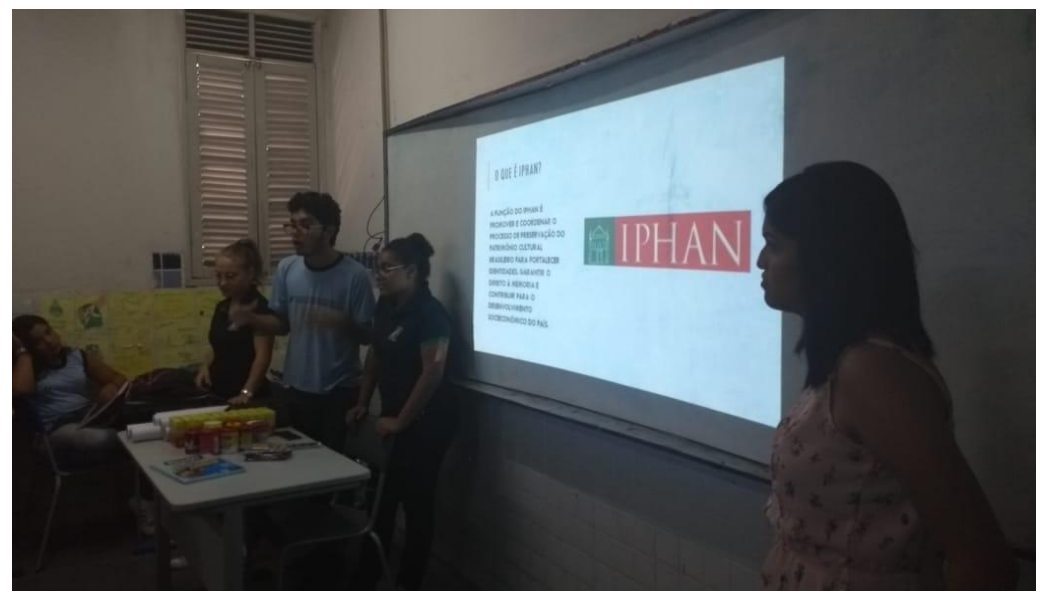

Fonte: Lucas Eduardo Melo Alves

Em seguida foram mostradas imagens dos monumentos históricos selecionados para oficina: Hotel Globo e o Theatro Santa Roza, ambos patrimônios materiais; o Parque Arruda Câmara, conhecido popularmente como Bica (figura 3) e o Parque Sólon de Lucena, chamado comumente de "Lagoa", um patrimônios naturais da cidade; também foram mostrados alguns exemplos de patrimônio imaterial como a rapadura e o forró, típicos da região Nordeste do Brasil.

Figura 3 - Exposição da "Lenda" de fundação do Parque Arruda Câmara

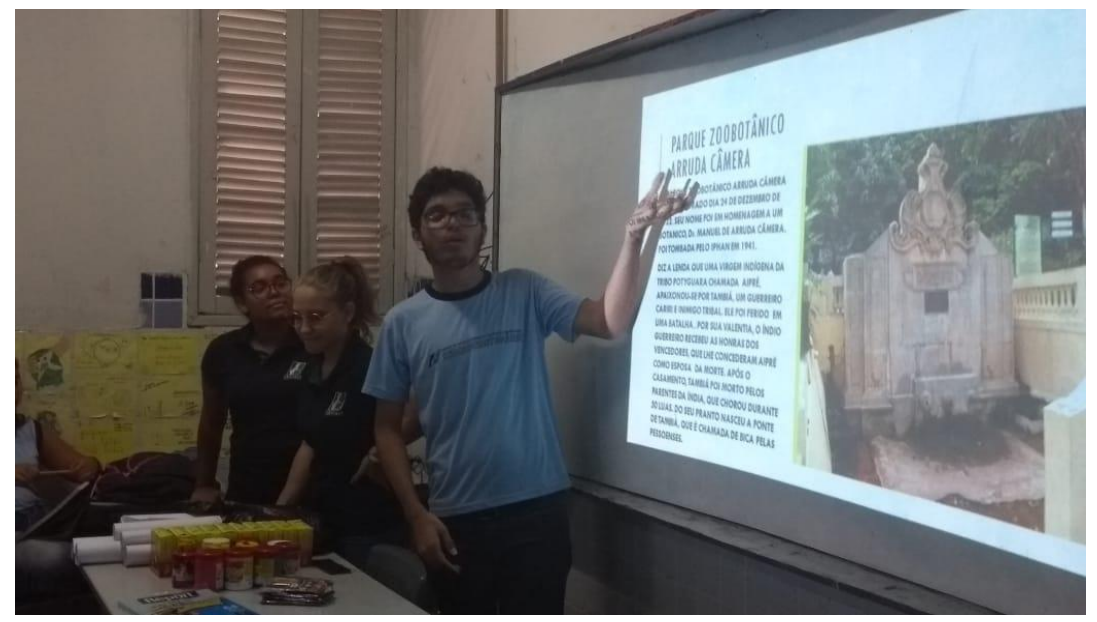

Fonte: Lucas Eduardo Melo Alves

Com o fim da apresentação foram iniciadas as atividades de pintura criativa com a utilização de cartolinas brancas, tintas e canetas coloridas (Figuras 4 e 5). 
Figura 4 - Alunos do $6^{\circ}$ ano trabalhando em suas representações do patrimônio

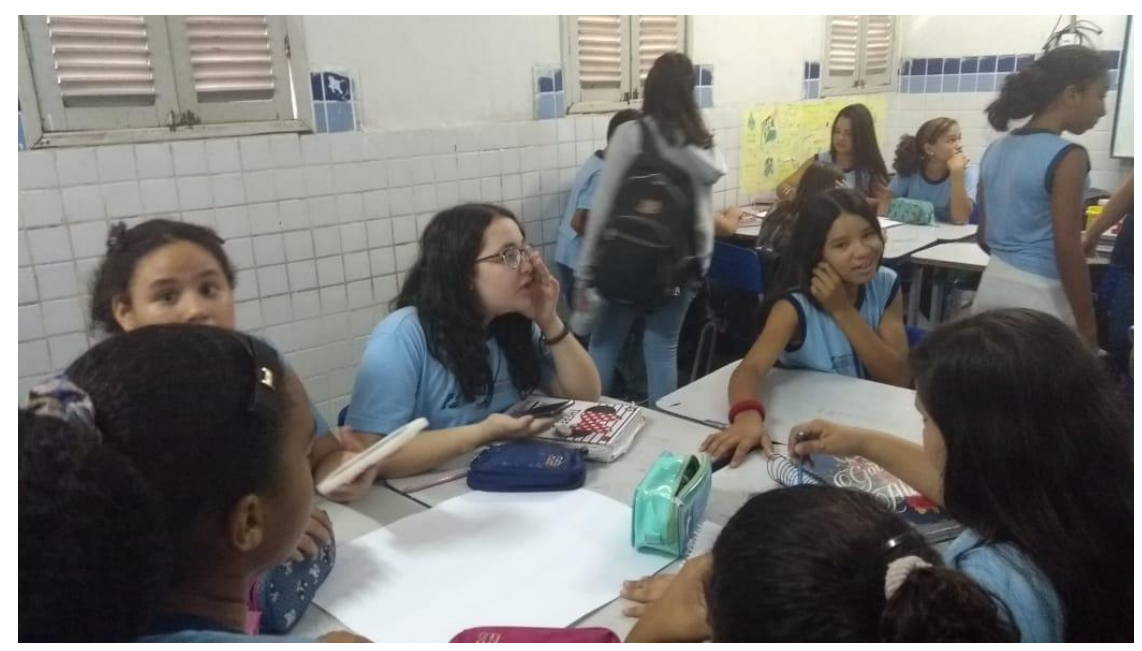

Fonte: Lucas Eduardo Melo Alves

Foram propostas pelos alunos as temáticas de criação de desenhos baseados nas lendas acerca dos patrimônios citados na apresentação. Ao final de cada oficina foi percebido que muitos alunos não tinham uma ideia previa do conceito de patrimônio histórico, mas que os mesmos tinham histórias e que carregavam consigo relatos e vivências intimamente ligadas monumentos históricos, bens arquitetônicos, culturais e naturais que carregam a identidade do povo paraibano e que pulsa cultura a todo instante, assim, revelando ainda mais a importância de aliar os conceitos patrimônio histórico com o sentimento de pertencimento e identidade cultural a partir de práticas pedagógicas que estimulem a cidadania, principalmente com os mais jovens.

Figura 5 - Orientação das atividades de educação patrimonial

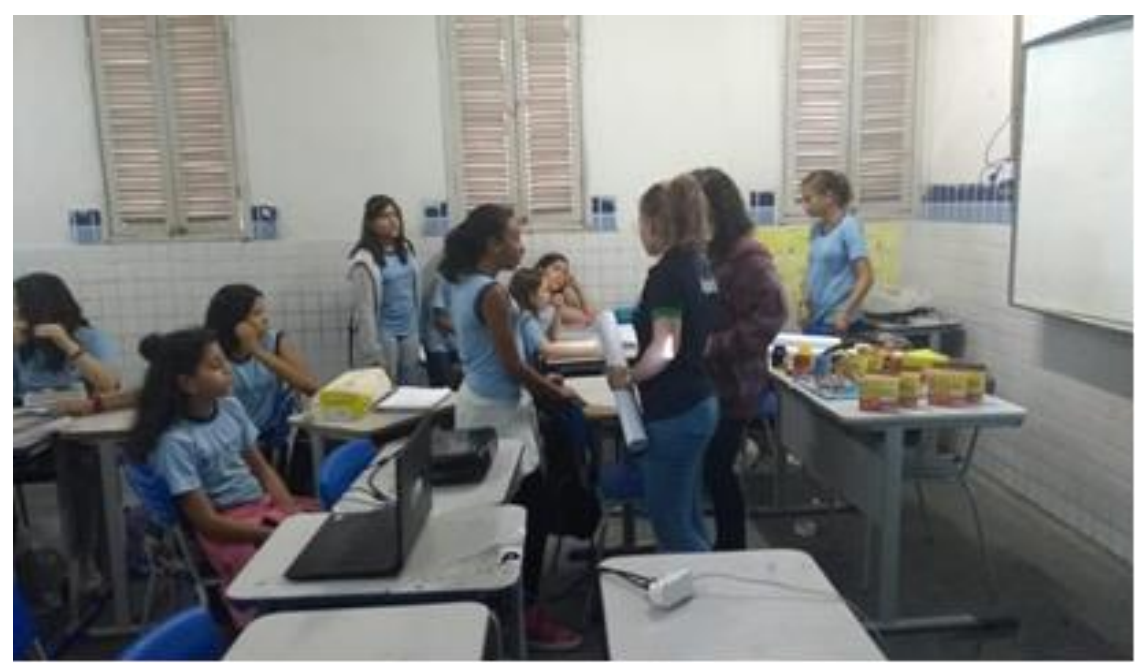

Fonte: Lucas Eduardo Melo Alves 


\subsection{Respostas dos estudantes}

Ao longo das oficinas pedimos aos alunos dos $6^{\circ}$ ano para responderem algumas indagações feitas sobre patrimônio histórico, com a finalidade de acompanhar o desenvolvimento dos estudantes ao decorrer das atividades, analisando o nível de dificuldade para que possamos abordar a temática de maneira mais apropriada. Logo abaixo podemos observar algumas respostas vinda dos estudantes sobre 0 questionário:

O questionário foi composto pelas seguintes perguntas:

1. o que é patrimônio?

2. o que vocês consideram patrimônio?

3. já visitaram, comeram, ou ouviram algum patrimônio?

Abaixo é possíveis verificar algumas respostas dos estudantes que participaram das oficinas:

1. "Bom para mim patrimônio histórico é algo antigo de uma cidade que nos tempos atuais torna-se parte da história de um lugar".

2. "Casa da pólvora".

3. "Já".

1. "Um lugar importante e especial para uma cidade ou país".

2. "Um lugar bastante visitado e conhecido".

3. "Sim, já fui no Parque Solon de Lucena"

Gráfico das respostas dos alunos do $6^{\circ}$ ano

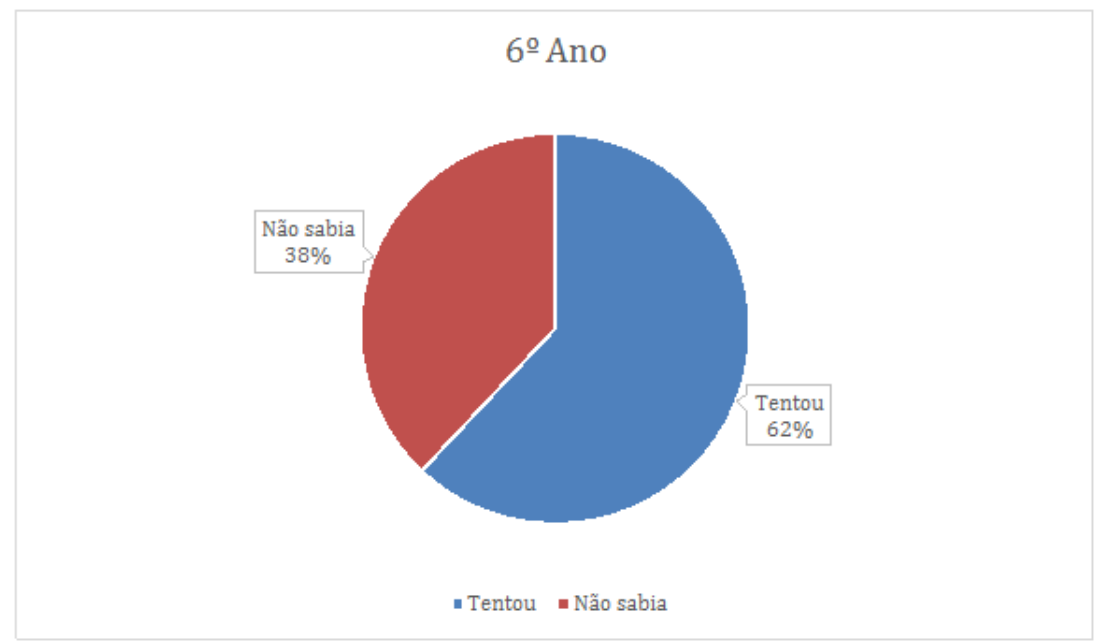

Fonte: Maria Heloísa Ferreira da Costa 
O gráfico abaixo (Figura 6) mostra que cerca de 21 alunos participantes das oficinas de educação patrimonial responderam os questionários. Cerca de $62 \%$ dos discentes reponderam as perguntas com relatos sobre experiências anteriores com algum tipo de patrimônio histórico, arquitetônico, natural, cultural e/ou artístico, enquanto 38\% dos estudantes presentes responderam "não sei”, não" ou deram respostas insatisfatórias.

Tais resultados evidenciam o fato de que a maioria dos alunos tiveram algum tipo de acesso ao patrimônio e apesar de conseguirem associar as lembranças anteriores com as temáticas discutidas durante as oficinas, de alguma forma no momento do contato não entenderam essa experiência prévia com uma praça, igreja, casa ou pédio antigo, parque, ambiente florestal, rio, lagoa ou alguma apresentação cultural como algo que necessitasse ser preservado a partir de políticas públicas e fortalecimento da cidadania, passando a ter essa noção, apenas após a realização das oficinas. É Bastante urgente a necessidade da realização de projetos de educação patrimonial nas escolas públicas e privadas visando a difusão do conhecimento científico sobre o tema, aliado a incorporação da Educação patrimonial nos currículos das redes de ensino desde os primeiros anos da educação básica no Brasil.

\section{Conclusão}

A realização das oficinas de Educação Patrimonial é o primeiro passo para a retomada da importância do patrimônio histórico, arquitetônico, natural, artístico e cultural no século XXI. Aos poucos, esse tipo de conhecimento deve ser integrado a realidade dos estudantes do ensino fundamental e médio, durante as aulas regulares, de forma interdisciplinar, multidisciplinar e transdisciplinar. Ter jovens estudantes do Ensino Médio, engajados com essa temática e atuanto como multiplicadores do conhecimento para as novas gerações através do projeto Nós Propomos! é uma importante prática da cidadania que, sem dúvida, contribuirá para a formação de indivíduos mais conscientes do seu papel ativo na sociedade, sendo capazes de pensar criticamente sobre a sua história e cultivarem o embrião de uma sociedade mais justa para as próximas gerações.

\section{Agradecimentos}

Gostaríamos de agradecer a colaboração do Professor Radamés em ceder às aulas apra realização das oficinas, o apoio da professora Regina Célia Valença na organização das temáticas na construção dos Artigos e o incansável empenho de 
Lucas Eduardo Melo Alves no registro das fotos e vídeios da oficina. É muito importante a participação de Yan de Lima Ribeiro, Ana Livia Borges de Lima, Maria Heloisa Ferreira da Costa e Maria Eduarda Isamael, tanto na realziação das oficinas, quanto na construção dos textos desse capíutulo de livro.

\section{Referências bibliográficas}

Brasil. (1998). Constituição da República Federativa do Brasil. Brasília, DF: Senado Federal: Centro Gráfico.

Decreto-Lei $n^{\circ}$ 25, de 30 de Novembro de 1937. Organiza a proteção do patrimônio histórico e artístico nacional.

Demarchi, J. (2016). Para atuação em educação patrimonial. Revista CPC, São Paulo, n.22, p.267-291, jul./dez.

Horta, M. L. P.; Grumberg, E.; Monteiro, A. Q. (1999). Guia Básico de Educação Patrimonial. Instituto do Patrimônio Histórico e Artístico Nacional. Brasília: Museu Imperial.

Pelegrini, S. C.A. (2006) Cultura e natureza: os desafios das práticas preservacionistas na esfera do patrimônio cultural e ambiental. Revista Brasileira de História, vol. 26, no 51.

Takada, P.; Castro J.; Pelegrini, D. (2010). É hora de valorizar nosso patrimônio cultural: o trabalho com as heranças culturais de sua região permite que o aluno aprenda a resguardar a memória da comunidade e se sinta parte dela. Disponível em: https://novaescola.org.br/conteudo/1682/e-hora-de-valorizar-nosso-patrimonio-cultural. 


\title{
Aprender Geografia simulando uma intervenção espacial na cidade
}

\author{
ARMSTRONG MIRANDA EVANGELISTA ${ }^{1}$
}

\section{Resumo}

O trabalho descreve uma experiência da disciplina "Metodologia da Geografia para a Pedagogia" realizada na Universidade Federal do Piauí, em Teresina no Nordeste do Brasil. O estudo traz contribuições da Didática da Geografia ao integrar conteúdo e método de ensino. Procura relacionar teoria e realidade a partir do estudo sistemático do conceito de espaço geográfico através do desenvolvimento de uma atividade simulada de intervenção espacial. Contou com a participação de três turmas de alunos do curso de Pedagogia. Primeiro fez-se um estudo teórico do conceito de espaço geográfico à luz de autores atuais da Geografia. Depois, foram planejados e apresentados os projetos dos alunos sob supervisão docente, em forma de grupo de discussão. Os alunos formaram grupos de trabalho, sugerindo modificações espaciais em diversas áreas da cidade de Teresina no sentido de melhorar a qualidade de vida da população, elaborando um relatório articulando elementos empíricos e teóricos. A experiência foi bastante proveitosa e estimulante, aumentando o interesse dos alunos pelo tema, bem como facilitando a compreensão de conceitos, como os de espaço absoluto e espaço relativo. Ademais, demonstrou a capacidade criativa e crítica dos alunos ao raciocinarem sobre o lugar de vivência, utilizando categorias do saber geográfico no exercício da cidadania.

Palavras-chave: Didática da Geografia; ensino de Geografia; saberes geográficos; conceitos espaciais.

\section{Resumen}

El trabajo describe una experiencia de la disciplina Metodología de la Geografía para la Pedagogía realizada en la Universidad Federal de Piauí, en Teresina en el Nordeste de Brasil. El estudio trae contribuciones de la Didáctica de la Geografía al integrar

\footnotetext{
${ }^{1}$ Professor Associado, Universidade Federal do Piauí, armstrong@ufpi.edu.br
} 
contenido y método de enseñanza. Se busca relacionar teoría y realidad a partir del estudio sistemático del concepto de espacio geográfico a través del desarrollo de una actividad simulada de intervención espacial. Participaron del proyecto tres clases de alumnos del curso de Pedagogía. Primero se hizo un estudio teórico del concepto de espacio geográfico a la luz de autores actuales de la Geografía, después de que se planificaron y presentar los proyectos de los alumnos bajo supervisión docente, en forma de grupo de discusión. Los alumnos formaron grupos de trabajo, sugiriendo modificaciones espaciales en diversas áreas de la ciudad de Teresina en el sentido de mejorar la calidad de vida de la población, elaborando un informe articulando elementos empíricos y teóricos. La experiencia fue muy provechosa y estimulante aumentando el interés de los alumnos por el tema, así como facilitando la comprensión de conceptos, como los de espacio absoluto y espacio relativo. Además, demostró la capacidad creativa y crítica de los alumnos al razonar sobre el lugar de vivencia utilizando categorías del saber geográfico en el ejercicio de la ciudadanía.

Palabras clave: Didáctica de la Geografía; enseñanza de Geografía; conocimientos geográficos; conceptos espaciales.

\section{Introdução}

Uma das questões problemáticas enfrentadas pelos alunos do curso de Pedagogia e, por conseguinte, pelos professores da área, diz respeito ao domínio do conteúdo ensinado. Isso porque tem apenas uma disciplina no currículo referente ao ensino de Geografia, mais voltada para a dimensão metodológica, ao como ensinar. Em razão disso, temos procurado equacionar essa dificuldade aumentando a carga horária da disciplina Metodologia da Geografia e dotando-Ihe de uma maior carga de conteúdo teórico-conceitual. Assim sendo, neste texto relatamos uma experiência desenvolvida com graduandos dessa disciplina acadêmica acerca de conteúdos fundantes de Geografia, principalmente quanto ao seu foco de estudo, o espaço geográfico. Buscamos através dessa experiência simplificar a compreensão dos conceitos a partir dos conhecimentos prévios dos alunos e aproveitamento de sua vivência espacial em Teresina-PI, introduzindo no processo de ensino-aprendizagem elementos indutivos e heurísticos. Para tanto, o texto divide-se em duas partes que se complementam evidenciando as principais etapas de um trabalho voltado para a reflexão, discussão e produção escrita acerca da estrutura dos espaços dessa cidade. 


\section{A propedêutica da proposta de ensino geográfico}

Antes de propor a atividade de estudo sobre as possibilidades de reordenamentos do espaço local preparamos alguns encontros para explicar aos alunos de Metodologia da Geografia do curso de Pedagogia o significado dos conceitos estruturantes do trabalho, Geografia e Espaço Geográfico. Buscou-se fundamentar a abordagem em referências teóricas atuais da ciência geográfica, notadamente os trabalhos de Santos $(1987,1997)$.

As explicações partiram da visão clássica de Geografia, comparando-a ao ponto de vista contemporâneo. Considerou-se importante conhecer a formulação primeira do que seria Geografia através do seu entendimento como estudo da superfície terrestre. Aliado a isso assinalar a ênfase que era dada ao estudo da natureza e ao método descritivo, conforme a própria etimologia do vocábulo Geografia, ou seja, descrição da terra. Procuramos evidenciar que uma ciência é construída historicamente e que as mudanças são contínuas. A Geografia tem muitos conhecimentos do passado que ainda hoje são estudados, alguns com poucas alterações, outros revisados. Tais mudanças se operam nos processos de embate e renovação das ideias conforme o contexto das relações realizadas na sociedade.O estudo das categorias geográficas denotam isso, pois na história do pensamento geográfico mudaram os paradigmas hegemônicos e, relacionado aos mesmos o protagonismo dos conceitos. As verdades de uma ciência tende a ser provisória devido ao movimento do real e ao movimento do pensar dos cientistas, não sendo diferente com a Geografia, sobretudo porque envolve a dinâmica social no processo histórico.

Consideramos pertinente examinar o saber experiencial do aluno sugerindo a eles que escrevessem um pouco sobre a Geografia antes das explicações. A partir dos textos produzidos identificamos as ideias recorrentes e passamos a problematizá-las no contexto da evolução do pensamento geográfico acadêmico e escolar, buscando organizar melhor essas ideias com o aporte da visão científica. Constatamos a dificuldade dos alunos em delinear uma definição de Geografia, já que havia dispersão do entendimento. Essa situação nos instigou a refletir sobre o debate acerca da definição dos objetos de estudo das ciências e que isso não era diferente em relação à Geografia. Indagamos: afinal, o que a Geografia estuda? As respostas dadas expressaram uma visão fragmentada, desprovida de um ordenamento conceitual, momento em que buscamos o apoio das ideias de Morin (2014), ao dizer que mais vale uma cabeça bem feita do que uma cabeça cheia, ainda mais no mundo atual pela facilidade de acesso à informação, através de diferentes meios. Facilitação que exige 
orientação docente e o aprendizado de habilidades para obtê-las, frente a sua quantidade excessiva, para não incorrer no risco de acessar o que é superficial e pouco significativo cientificamente, e, portanto, de pouca valia para a formação escolar do aluno.

$\mathrm{Na}$ verdade os alunos não atentavam para o fato nomeadamente antigo de que a Geografia orienta seu foco para o estudo do planeta Terra; vários deles associaram o conteúdo dessa disciplina escolar a saberes clássicos que se sobressaiam na programação pretérita de Geografia, vinculadas, por exemplo, a noções de astronomia, geometria e cosmografia, e a aspectos físicos e politico-administrativos. Além disso, valeram-se de uma forma de pensar generalizante, como se tudo que diz respeito à categoria espaço fosse foco dessa matéria. A esse respeito, ressaltamos com Spósito (2004), que o espaço pode ser apreendido enquanto categoria ontológica do humano, dada a sua imanência e essencialidade, e que deveria ser objeto de reflexão do professor de Geografia, em extensão, qualidade e relatividade, para que seja possível avançar na própria compreensão do que trata mais diretamente essa ciência. Entretanto, os cientistas reclamam a delimitação do objeto de estudo de cada ciencia com a intenção de apreender melhor o que pesquisam, fato que suscita os debates epistemológicos e ideológicos, conforme os diversos pressupostos teóricosconceituais a serem adotados. Esse tipo de preocupação levou no decurso da Geografia Moderna à elaboração de um conjunto de princípios geográficos com vistas a embasar a produção do conhecimento e dar coerência ao trabalho do geógrafo. Para Moraes (2005), os princípios geográficos (localização, extensão, comparação, conexão, diferenciação, individualização), durante muito tempo, concederam-lhe um caráter de unidade, mesmo que emanados de uma visão positivista de ciência.

Ademais, constatamos os efeitos da tradição da cultura geográfica escolar ao relacionar Geografia ao estudo dos aspectos naturais da superfície da Terra, secundarizando a importância do papel da sociedade nas transformações do espaço terrestre. Em razão disso, debatemos que a presença humana na Terra torna a abordagem da Geografia bem mais complexa, não obstante a importância de se levar em conta o quadro natural da superfície da Terra. Porém, avertindo que compreendêlo isoladamente podería nos distanciar da conceituação contemporânea dada a essa ciência.

Nesses momentos iniciais utilizamos principalmente a técnica de narrativa oral e suas variantes; a exposição sistemática das ideias, com auxilio do data-show, explorando o uso de diversos tipos de figuras, com exemplos próximos da realidade cotidiana da 
turma; e fotografias diversas, permeadas pela contínua dialogia. O objetivo era propiciar a construção de esquemas cognitivos reestruturados a respeito do saber geográfico, buscando integrar com logicidade as cognições fragmentadas.

Em continuidade, passamos a explicar que no Brasil a discussão em torno do conceito de espaço na Geografia tem valorizado uma perspectiva relativa, na qual são valorizadas as relações dos objetos constituintes do espaço. Partimos da noção absoluta de localização e extensão dos objetos geográficos do espaço, buscando-se maneiras simples e didáticas de ilustrar essas ideias. Após, avançamos na explicação de que as localizações espaciais são afetadas por situações, por contextos em que atuam múltiplos fatores, sejam eles políticos, sociais, econômicos e culturais. Fatores responsáveis por conferir ao espaço determinadas organizações ao longo do tempo.

Por isso a pertinência de compreender e analisar o espaço geográfico de maneira sistêmica. Assim, o que homem constrói ou modifica se dá através de um sistema de relações que se manifesta em diferentes escalas de tempo e espaço, do lugar ao mundo. O espaço está em parmanente estruturação dinamizada por diversos tipos de força em ritmos variados, expressando-se em configurações diferenciadas de acordo com o grau e o caráter das forças operantes. Assim, tem-se nos territórios a presença de sistemas técnicos e sistemas ações coordenados produtores de arranjos complexos e dinâmicos distribuídos diferenciadamente. Destacamos que o meio geográfico acompanha as alterações nas formas de produção da sociedade, citando as eras do meio geográfico conforme o esquema elaborado por Moreira (1995), inspirado em Milton Santos (1994): Meio Natural, Meio Técnico, Meio Técnicocientífico e Meio Técnico-científico-informacional.

À ideia de dinâmica espacial relacionamos os processos sociais e, por conseguinte, as possibilidades de mudança das paisagens humanas, sobretudo quando o interesse for favorecer a qualidade de vida das pessoas. Ainda ressaltou-se a necessidade de raciocinar sobre o espaço com um pensar dialético, relacional, atentando para os binômios: Sociedade-Espaço e Forma-Conteúdo, pois há uma ação reciproca entre eles. O espaço não é apenas produto da ação social, ele também é fator. $E$ além do mais é preciso compreender a finalidade das formas espaciais no complexo de relações que se desenvolve no sistema capitalista, o que torna pertinente na investigação do espaço dispor de algumas categorias analiticas indispensáveis, mencionadas por Santos (1997): Estrutura, Processo, Função e Forma. 


\section{A proposta de intervenção espacial}

Pressupomos na elaboração dessa proposta de ensino a indissociabilidade entre sociedade e território, entre cidadania e espaço, pois o espaço deve ser do cidadão. Posicionamos-nos aqui favorável à ideia de que o espaço materializa uma cidadania efetiva, além da mera abstração do conceito. Ciente da dinâmica do tempo social e das trocas espaciais compreendemos que a paisagem geográfica pode mudar qualitativa e quantitativamente, contribuindo para o bem-estar das pessoas que habitam o espaço. E que isso depende da organização da sociedade e de sua mobilização, que principia na escola, locus especial, sobretudo nas aulas de Geografia, investigando-se o que ela trata e de que forma, posto que como explicita Santos (2011), o espaço deve ser produzido por todos os habitantes, eles têm direito à cidade, contemplando suas particularidades e diferenças, pois cidadania se aprende.

A partir da observação e relatos sobre o espaço de vivência dos alunos, constatamos as necessidades de mudanças espaciais, no que é mais essencial para a vida das pessoas que fazem parte da cidade. Baseando-se nisso, propomos que desenvolvéssemos uma atividade sugerindo modificações geográficas na cidade de Teresina-PI. Em um primeiro momento faríamos uso da técnica de descrição para evidenciar os objetos geográficos presentes nas áreas selecionadas, considerando as suas idades, vantagens e limitações. Uma descrição pormenorizada das características das ruas, trânsito, comércio e serviços, dos enquadramentos sociais, dos arranjos estruturais criados por uma sociedade desigual, para habituar as pessoas a um determinado do modo de viver e ocupar o espaço, no qual as profundas diferenças são encaradas como naturais. Em atenção ao fato de que o ordenamento do espaço em seus fixos sociais, como vias de circulação, habitações, prédios públicos, praças, parques, reproduz o tipo de sociedade vigente. Ciente também de que o espaço não é só enquadramento das pessoas a modelos tradicionais e excludentes de disposição dos seus objetos, mas pode ser modificado de modo a contribuir para a melhoria da condição geral de vida dos habitantes.

Dessa maneira, concebíamos que a cidade precisava ser vista em sua globalidade, em suas inter-relações diversas. Mudar um setor da mesma poderia provocar consequências mais amplas na forma como os habitantes interagiam com o espaço. Seguindo Santos (2011), introduzimos conceituamos fixos sociais e fluxos espaciais. $O$ espaço é composto de formas fixas e de movimentos entre estas. Possui ritmos diferenciados, conforme a disponibilidade de energia, informação e densidade técnica, o que lhes confere aceleração variável dos processos operantes. A consequência 
disso é um uso diferenciado do espaço pelos habitantes, sendo que parte deles não aproveitam ao máximo a sua condição de cidadania, havendo inclusive cidadãos sem espaço, ou em espaços periféricos, geográfica e simbolicamente. Nesse sentido, nos apoiando nos estudos de Cavalcanti (2005, p. 41), insistimos na noção de que "O exercício da cidadania na sociedade atual, por sua vez, requer uma concepção, uma experiência, uma prática - comportamentos, hábitos, ações concretas de cidade".

Procuramos demonstrar que a escola é lócus privilegiado para a formação da cidadania ativa, onde as pessoas compreendam sistematicamente a possibilidade de reconhecer seus direitos sociais, fazendo-se isso de várias maneiras. A prioridade foi a formação intelectual e moral dos alunos, e a mudança de comportamento através de uma prática criativa em que pudessem se expressar ética e esteticamente sobre os lugares de sua cidade. Criar as condições para perceberem como a sociedade se organiza e as prioridades existentes no processo de produção do espaço, visto que a paisagem urbana está intrinsecamente relacionada ao caráter das interações sociais, à sua dinâmica interna, manifesta nos aspectos econômicos, políticos e culturais. Com efeito, resultaria daí a divisão territorial do trabalho, o conjunto de normas de uso e ocupação do espaço, bem como a segregação socio-espacial, fatores responsáveis pelas diferenciações internas nas áreas urbanas.

Portanto, queríamos que os alunos se dessem conta que é possível mudar a realidade sócio-geográfica, exercer a cidadania ativa, raciocinar sobre o espaço, propor alterações e soluções criativas para os problemas encontrados nas áreas estudadas. Por entender, como sugere Santos (2011, p. 46), que "[...] o direito de habitar a cidade é mais do que de morar, é morar bem, frequentar a cidade, morar com dignidade, ter acesso aos bens da cidade [...] de produzir culturas, construir identidades". Para que acreditassem que a produção do espaço urbano pode ser mais democrática, contando com a participação individual e coletiva dos seus habitantes, de modo propositivo e crítico, considerando a existência de espaços de exclusão carentes dos serviços públicos mínimos.

Com o desenvolvimento da atividade pretendia-se relacionar o teórico e o empírico, de maneira que os alunos identificassem em situações concretas do cotidiano os conceitos abordados nas aulas expositivas e reflexivas realizadas. Em que fosse possível pensar a cidade com o devido embasamento, em um movimento dialético entre a teoria e prática, para atingir os objetivos básicos da sequência de ensino proposta, ressignificando assim a concepção que tinham do objeto de estudo da Geografia. Prosseguimos orientando detalhadamente as turmas sobre os 
procedimentos a serem seguidos, formando grupos de trabalho, com no máximo cinco componentes. Foi exibido e entregue às turmas um roteiro escrito com as recomendações básicas para a realização da atividade. O roteiro continha como exemplo uma área da cidade de Teresina que passou por mudanças importantes em termos de valorização econômica e cultural. $\mathrm{Na}$ oportunidade refletimos sobre o porquê de tais mudanças e sobre a possibilidade de reequipá-la com a oferta de serviços de públicos, ações da comunidade e do setor privado, de modo a impactar o

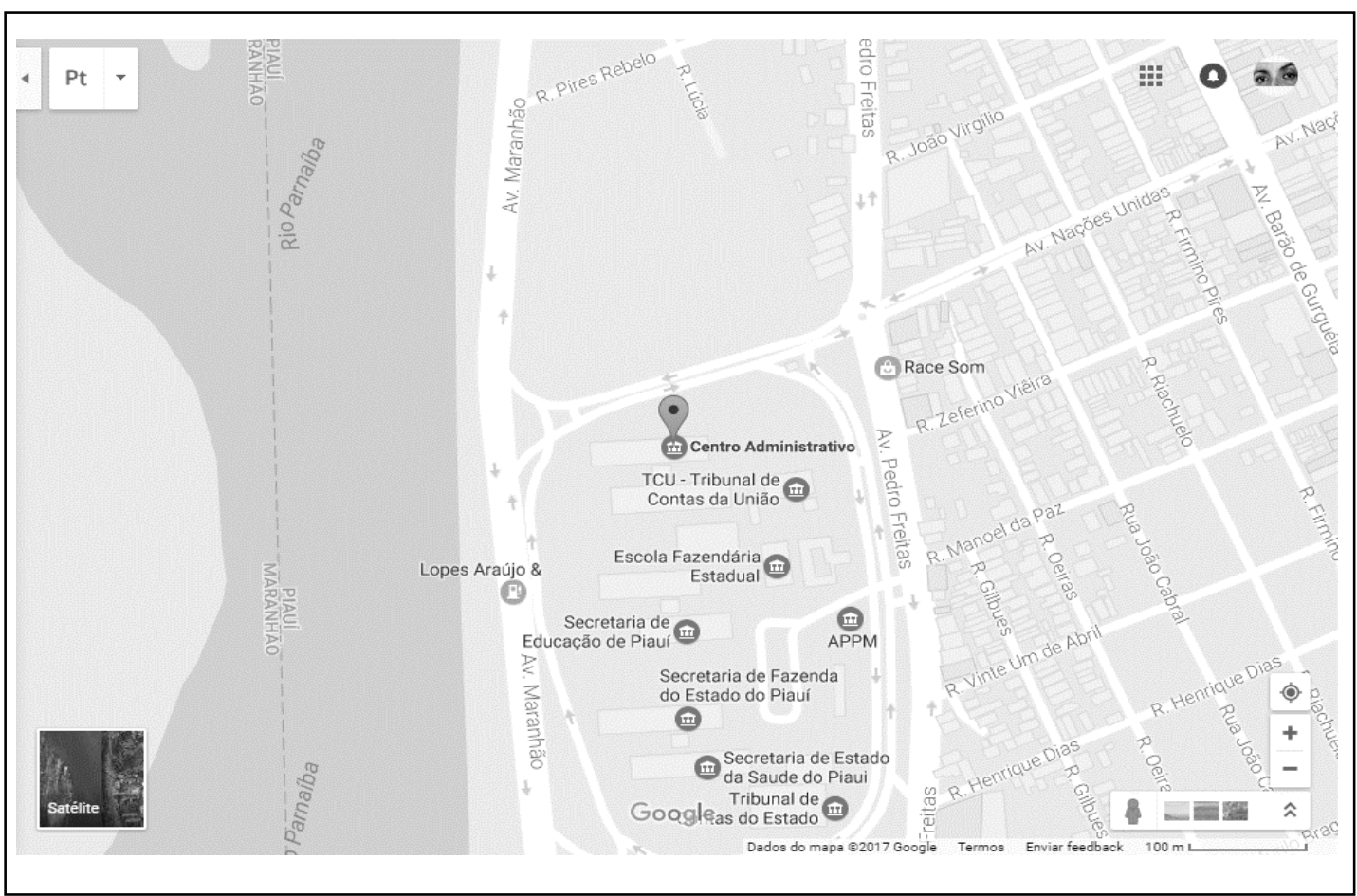

seu entorno e até em outras regiões do estado do Piauí. Na figura 1 expomos objetivamente o roteiro divulgado aos alunos.

Fonte: pesquisa direta, 2018

A expectativa era de que surgissem muitas ideias interessantes, desencadeadas pelo aprendizado dos conceitos expostos e debatidos em sala de aula. Cada grupo elaborou sua proposta e apresentou ao coletivo para discussão e incorporação das possíveis sugestões dos presentes, sempre procurando fundamentar a experiência no quadro teórico sobre 0 assunto. A seleção das áreas da cidade, objetos de intervenção, coube a cada grupo, tendo como critério ser um espaço que fosse conhecido dos alunos e com necessidades de melhoria evidentes. Baseado nisso, foram identificados locais diversos, sendo criadas diversas propostas de intervenção: edificação de praças, criação de parques, construção de ciclovias, mudanças no trânsito, construção ou reforma de mercados públicos e espaços culturais, construção de pontes, dentre outros. Verificamos que as ideias surgidas foram bastante criativas, 
com alternativas interessantes de implantação de "fixos sociais" (Santos, 1997) nos espaços analisados, atentos ao fato de que as transformações espaciais influenciam as interações sociais quantitativa e qualitativamente, que o espaço não é passivo, somente reflexo do social ocupando determinada extensão material, mas é condicionante e condicionado.

Com a situação prática notamos que os alunos se sentiram mais confiantes em problematizar os conceitos abordados na aula teórica e em entender a lógica dos textos recomendados para a disciplina de Metodologia da Geografia. Posteriormente, observamos que isso repercutiu positivamente na capacidade de verbalização e na elaboração do trabalho escrito dos membros dos grupos; igualmente em uma prova escrita individual que avaliava os conceitos relativos a Geografia e Espaço geográfico estudados ao longo do conjunto de aulas desenvolvidas.

\section{Conclusão}

O relato que propomos acima atesta que há alternativas possíveis durante o ensino de conteúdos geográficos aparentemente abstratos, visando objetivar respostas a questões básicas feitas por qualquer aluno do ensino fundamental referente ao estudo de Geografia. É preciso que esteja claro para o professor o escopo de sua abordagem e quais são os conceitos mais importantes da disciplina, evitando a tergiversação ou a dispersão excessiva, indutores de incompreensão dos temas tratados.

Consideramos que o movimento do conteúdo para o método, e vice-versa, dá consistência à formação do graduando, porque passa a integrar forma e conteúdo no ensino, porque não se trata apenas do como ensinar, mas também do que ensinar. Raciocinio semelhante ao que foi feito no tocante à abordagem da Geografia, porque o enfoque sobre o espaço geográfico não consiste somente no estudo morfológico devendo incluir o seu conteúdo, o que significa reconhecer as finalidades dessas formas.

Portanto, constatamos que a metodologia adotada nessa experiência nos pareceu promissora, tendo em vista o caráter da participação dos alunos e a facilidade do aprendizado do assunto abordado, expresso nos relatos orais e escritos e em prova escrita posterior, culminância do processo de avaliação. O que no inicio parecia abstrato foi aos poucos se esclarecendo e se incorporando no léxico científico dos alunos em relação a Geografia. 


\section{Referências bibliográficas}

Cavalcanti, L. S. (2005). A cidadania, o direito a cidade e a Geografia Escolar: elementos de geografia para estudo do espaço urbano. Revista Geousp, n. 5, p. 4155.

Moraes, A. C. R. (2005). Geografia: pequena história crítica. São Paulo: Annanblume.

Moreira, R (1995). Inovações Tecnológicas e Novas Formas de Gestão do Trabalho. Palestra promovida no Dpto de Geografia da Universidade Federal Fluminense, em 24.10.1995-AGBNiterói.

http://profwladimir.blogspot.com/2013/04/ruy-moreira-inovacoes-tecnologicas-e.html

Morin, E. (2003). A cabeça bem-feita: repensar a reforma, reformar o pensamento. $8^{\text {a }}$ edição. Rio de Janeiro: Bertrand Brasil.

Santos, M. (1987). O Espaço do Cidadão. São Paulo: Editora Nobel. informacional. São Paulo: Hucitec. . (1997). A Natureza do Espaço. São Paulo: Difel.

Spósito, E. S. (2004). Geografia e filosofia: contribuição para o ensino do pensamento geográfico. São Paulo: Editora da UNESP. 


\section{A Geografia no Ensino Médio na América Latina: o caso do Brasil e da Argentina}

CLÉZIO DOS SANTOS ${ }^{1}$

\section{Resumo}

A transição do pensamento social contemporâneo na América Latina se vê atropelado por aceleradas transformações sociais, econômicas, políticas, tecnológicas do mundo atual. Essa situação impõe desafios constantes para toda a educação e também para o ensino de geografia engajado na formação de cidadãos responsáveis, reflexivos e comprometidos. Desde a década de 1990 temos inúmeras reformas curriculares implementadas nos países ditos "em desenvolvimento", relacionadas à educação básica. O objetivo principal do texto é a análise e reflexão de como a disciplina escolar geografia permanece nas novas políticas para educação básica e educação profissional no ensino médio no Brasil e na Argentina. A metodologia qualitativa, fundamentada no referencial teórico e em entrevistas com professores de geografia do ensino médio do Brasil e da Argentina. O contexto atual das reformas no ensino médio que tem ocorrido o Brasil e na Argentina, repercutindo diretamente na Educação Básica e na Educação Profissional e deve ser contextualizado porque repercuti na inserção destes países no mundo do trabalho.

Palavras-chave: Geografia; ensino médio; escola; currículo; política educacional.

\section{Abstract}

The transition from contemporary social thinking in Latin America finds itself run over by accelerated social, economic, political, technological transformations of the present world. This situation poses constant challenges for all education and also for the teaching of geography engaged in the formation of responsible, reflective and committed citizens. Since the Decade of 1990 we have had numerous curriculum reforms implemented in the said ' developing ' countries, related to basic education. The main objective of the text is the analysis and reflection of the school discipline

\footnotetext{
${ }^{1}$ Prof. Dr. de Ensino de Geografia, Universidade Federal Rural do Rio de Janeiro, Programa de Pós-Graduação em Geografia (PPGGEO/UFRRJ), e pesquisador CNPq e JCNE da FAPERJ. cleziogeo@yahoo.com.br
} 
Geography remains in the new policies for basic education and professional education in high school in Brazil and Argentina. The qualitative methodology, based on the reference Theoretical and in interviews with teachers of geography of the high School of Brazil and Argentina. The current context of the reforms in the middle Enisno that has occurred in Brazil and Argentina, reflecting directly on basic education and Saltsjöbaden education and should be contextualized because it resonates in the insertion of these countries in the world of Work.

Keywords: Geography; high school; college; curriculum; educational policy.

\section{Introdução}

A estancia de pós-doutorado realizada em 2016 no Instituto de Geografía "Romualdo Ardissone" da Faculdad de Filosofia y Letras da Universidad de Buenos Aires (FFyL/UBA), permitiu a aproximação com o trabalho do grupo de pesquisa em Ensino de Geografia coordenado pela professora María Victoria Fernandéz Caso denominado de Investigación y Desarrollo en Enseñanza de la Geografía (INDEGEO) e do Departamento de Geografía da Universidad de Buenos Aires. Essa aproximação propiciou o diálogo com o Programa de Pós-Graduação em Geografia (PPGGEO/UFRRJ).

O objetivo principal da pesquisa é a análise e reflexão de com a disciplina escolar geografia permanece nas novas políticas para educação básica e educação profissional no ensino médio no Brasil e na Argentina.

A metodologia se apoia nas pesquisas educacionais de cunho qualitativo, destacando a leitura de autores latinoamericanos relacionados ao Ensino de Geografia como Reboratti (1993), Cavalcanti (2012), Pontuschka, Paganelli e Cacete (2007), Gurevich (2006), Fernandéz Caso (2008), Fernandéz Caso e Gurevich (2007), Villa e Zenobi (2011), Hollman (2008). Zenobi (2011), Busch (2013); e entrevistas com professores de Geografia da Escola Secundária na Ciudad Autonoma de Buenos Aires (CABA) na Argentina e professores de Geografia do Ensino Médio na Baixada Fluminense no Brasil.

\section{As reformas educacionais na América Latina}

O contexto das reformas educacionais da América Latina segue dois momentos chaves para pensar o desenrolar dos rumos das políticas públicas educacionais de acordo com Sene (2008) ocorre em dois ciclos. 
O primeiro ciclo de reformas educacionais esteve orientado fundamentalmente para a expansão dos sistemas educativos visando à ampliação do número de estudantes nos bancos escolares. Deu-se, na maior parte dos casos, sob regimes militares de exceção no contexto das disputas geopolítico-ideológicas da Guerra Fria. Além do controle ideológico e da formação cívico-patriótica, deve ser considerada também a necessidade de formação de mão-de-obra, especialmente nos países que se industrializavam no contexto da segunda revolução tecnológica e ao mesmo tempo passavam por acelerada urbanização.

O segundo ciclo, ainda em andamento, é bem mais complexo. Apresenta um caráter de reconversão, de refundação de todo o sistema educativo; está muito mais orientado para a organização e gestão, a busca de qualidade e equidade. Insere-se num mundo pós-Guerra Fria, num contexto regional em que se busca consolidar a democracia e ao mesmo tempo adaptar-se à atual revolução técnico-científica, ao atual momento do sistema capitalista.

As recentes reformas educacionais na América Latina são bastante complexas e apresentam várias dimensões normativas, avaliativas, curriculares, financeiras, administrativas, etc.

Uma característica comum a todas elas, é o processo de descentralização. Apesar de Cassassus (2001) apresentar o quadro com vários países (Argentina, Brasil, Chile, Colômbia e México), optamos por reorganizá-lo apenas com as informações referentes à Argentina e Brasil para análise comparativa. Desta forma, o Quadro 01, mostra as dimensões implicadas nas reformas e o grau de descentralização, segundo as esferas de poder na Argentina e no Brasil. Nesse quadro, utilizamos de forma equivalente o termo poder provincial na Argentina e poder estadual no Brasil.

Quadro 6 - Descentralização educacional na Argentina e no Brasil segundo Cassassus (2001)

\begin{tabular}{l|l|l}
\hline Dimensões & Argentina & Brasil \\
\hline Política Educacional & Nacional & Nacional \\
\hline Sistema de Avaliação & Nacional e Provincial & Nacional \\
\hline Normas & Nacional & Nacionais \\
& & $\begin{array}{l}\text { Estaduais } \\
\text { Municipais }\end{array}$ \\
& & Nacional (Ajuste Provincial) \\
\hline Currículo & & Estaduais \\
& & Municipais \\
\hline Financiamento & Co-participação Federal & Federal \\
& Tributos provinciais & Estadual \\
& & Municipal
\end{tabular}




\begin{tabular}{l|l|l} 
Supervisão & Provincial & Compartilhada \\
\hline Administração de Escolas & Provincial & $\begin{array}{l}\text { Estadual } \\
\text { Municipal }\end{array}$ \\
\hline Contratação de docente & Provincial & Eunicipal (Buenos Aires) \\
& Nacional & Municipal \\
\hline Planejamento & $\begin{array}{l}\text { Provincial } \\
\text { Escola }\end{array}$ & $\begin{array}{l}\text { Federal } \\
\text { Estadual } \\
\text { Fonte: Elaboração própria Santos (2016). }\end{array}$
\end{tabular}

Percebe-se que a descentralização varia entre Argentina e Brasil segundo a dimensão considerada. No entanto, de maneira geral, a política educacional, as avaliações e a definição de normas em ambos os países são feitas de forma centralizada. Já o currículo, o financiamento e o planejamento são definidos de forma compartilhada entre as três esferas de poder no Brasil e na Argentina entre o Federal e o Provincial. Assim, as estruturas mais descentralizadas são aquelas que têm maior vínculo com o cotidiano da escola, que têm um caráter mais operacional: a supervisão, a administração escolar e a contratação de professores. Isso indica que apesar de um "discurso" em defesa da descentralização, os governos centrais não abrem mão das decisões estratégicas em termos de políticas educacionais.

Concordamos com Reboratti (1993) e Sene (2008), ambos destacam que nos anos 1990, as reformas educacionais realizadas na América Latina apresentavam muitas semelhanças entre si, havia uma grande homogeneidade nas propostas. Com exceção da chilena, todas as outras reformas foram feitas sob regimes democráticos, alguns muitos jovens, e a busca da consolidação da democracia era constantemente destacada. Todas, sem exceção, foram elaboradas sob a égide de governos neoliberais, então dominantes na região.

Ao mesmo tempo, destacavam a importância do Estado na gestão e no financiamento do sistema escolar, perseguiam a equidade e propunham mecanismos compensatórios, objetivos que não coadunam plenamente com a ideologia liberal em educação. Mesmo o processo de descentralização é diverso e no nível estratégico as decisões se mantêm nas mãos dos governos centrais. Enfim, são reformas complexas, multidimensionais, portanto, não é trivial classificá-las simplesmente como neoliberais. Talvez a melhor forma de qualificar essas reformas seja associá-las à ideologia pluralista, como propuseram Álvaro Marquesi e Elena Martín (Sene, 2008, p.12).

Nos anos 2000, estão sendo elaboradas novas reformas educacionais na América Latina, tanto na Argentina com a Nueva Escuela Secundaria na Ciudad Autonoma de Buenos Aires (2014), como no Brasil com a Novo Ensino Médio, aprovado no início do 
ano de 2017. O que poderíamos chamar de uma outra onda reformista. Essas reformas e essas novas leis educacionais não são os únicos instrumentos de garantia de mudança. Elas têm ocorrido de vária maneiras e em diferentes instâncias.

Las ofertas de actualización vinieron la mano de la Reforma Educativa de los noventa y em general fueron convocados profesores universitarios para el dictado de cursos y seminários cuyo objetivo central era acercar a los docentes nuevos enfoques y temáticas propios del campo académicos en que mediara alguna conexión con las prácticas de enseñanza de la disciplina. Por otra parte, es importante tener en cuenta que las precarias condiciones de trabajo de la mayor parte de los docentes impiden su crecimiento como profesionales, a lo que se agrega la escasa producción de materiales destinados a su actualización. (Zenobi, 2011, p. 17).

Entretanto, agora como antes, o problema não está apenas nas leis, mas em sua aplicação. Tanto Sene (2008) como Zenobi (2011) destacam as Reformas, o envolvimento dos professores universitários e da Academia, porém não encontram ressonância direta na escola pois ainda essas políticas falam de uma escola pouco conhecida e não levam em consideração a real situação dessa escola, de seus docentes e de seus alunos.

\subsection{A Proposta Curricular da Nueva Escuela Secundaria (NES) e o Ensino de Geografia}

A análise do Nuevo Diseño Curricular de Geografía da Escuela Secundaria da CABA nos possibilitou inúmeros pontos de vista comuns e distintos para soluções de problemas enfrentados na implantação curricular permitindo distintas leituras de outros pesquisadores de ensino de Geografia da América Latina.

De acordo com Fernandéz Caso (2008):

Las geografías académicas nos ofrecen pistas teórico-conceptuales para
una transmisión significativa de los contenidos implicados en un temario
como este. Por ejemplo, los conceptos de lugar, región y fragmentación
permiten pensar lo local como el lugar donde se condensan tensiones y
diferencias, y en cuyo estudio confluirán múltiples escalas de análisis y
variedad de atributos no locales, y que colaboran en el desdibujamiento de
las pinturas homogéneas que postulaban las geografías sistemáticas,
continentales, regionales o nacionales. (Fernandéz Caso, 2008, p. 5).

Quando a autora retoma conceitos chaves da Ciência Geográfica e os contextualizam demonstrando as inúmeras escalas de abordagem geográfica e necessidade e relevância desses pontos de vista que somam ao significado de ensinar e aprender Geografia na Escola não de forma homogênea e sim tendo uma clareza de que essas 
escalas permitem entender e reconhecer a não heterogeneidade, a fragmentação e a diferença dos diferentes lugares.

\begin{abstract}
Una propuesta de trabajo que articule aspectos disciplinares de una geografía renovada y aspectos didácticos de una pedagogía crítica, nos permite acercar a los jóvenes una perspectiva que no asigna rasgos de fijeza e inmutabilidad a los procesos que analizamos y a los grupos, personas y comunidades con las que intercambiamos, y nos aleja de la idea de un destino preestablecido, tanto a nivel personal como colectivo. En fin, nos permite colocar en el horizonte de la comprensión y de la acción, la posibilidad de reorientar el rumbo, de elegir el derrotero, de imaginar nuevos comienzos (Gurevich, 2005, p. 8).
\end{abstract}

Concordamos com Gurevich (2005) quando defende um ensino de Geografia que articule questões disciplinares de uma geografia renovada com aspectos didáticos numa perspectiva educacional crítica, permitindo aos jovens o entendimento das possibilidades e não um entendimento fixo e imutável. Oferecer um horizonte de compreensão e ação, acima de tudo, da possibilidade de reorientação do curso, escolher o curso e imaginar novos começos. Porém, esse entendimento de Ensino de Geografia tem dificuldade de ser materializado nas propostas curriculares em andamento.

O novo diseño curricular de Geografia feito pelo Ministério de Educación da Ciudade Autónoma de Buenos Aires (CABA) se encontra no documento denominado Nueva Escuela Secundaria (NES) editado em 2014 e tem como política um período que pretende ser de 2014-2020, portanto entre a discussão do novo diseño e sua implementação estamos nos primeiros anos.

A Nueva Escuela Secundaria (NES) não pretende ser apenas uma reforma curricular e sim uma repensar dos espaços e da estrutura de funcionamento institucional das escolas atuais

O documento da Nueva Escuela Secundária foi construído para os dois anos iniciais dos cinco anos que compõe a Escuela Secundária na CABA. O ciclo inicial (composto pelo primeiro e segundo anos) é oferecido a toda Escuela Secundária na CABA pois tem diferentes propostas de especialização no ciclo final de formação.

O documento de Geografia está dividido nas seguintes partes: Objetivos y contenidos troncales para la finalización de la escuela secundaria; Apresentación; Propósitos de enseñanza; Primer Año; Segundo Año; e Orientaciones generales para la evaluación.

O diseño curricular de Geografia da Escuela Secundária reforça as ideais que vem sendo efetivada após as reformas de 1990 na América Latina e também na Argentina cujos objetivos são: 
Esta propuesta curricular considera que la enseñanza de la Geografía en la escuela secundaria constituye un aporte valioso para la formación de ciudadanos en y para la democracia, así como para el desarrollo de capacidades intelectuales que permiten comprender y explicar cuestiones territoriales que son relevantes en el mundo actual, en sus diferentes regiones y en la escala local. A la vez, favorece a que los estudiantes asuman su protagonismo en los procesos de cambio social a partir del desarrollo de actitudes fundamentadas, críticas y comprometidas con los valores de una sociedad cada vez más democrática, solidaria y justa. (Caba/Nes, 2014, p.379).

Porém para aprender por meio de conceitos, implica uma relação distinta entre a produção de saber na escola, implicando que alunos e professores construam os conceitos e não os reproduzam. O papel do professor de geografia é fundamental nesse processo de construção e suas práticas podem assegurar, auxiliar ou dificultar a construção desse processo, para tal recorremos aos professores da escola secundária da CABA para entender um pouco mais como efetivam suas práticas docentes no cotidiano da escola.o en Educación Especial y Profesorado en Educación Primaria, respectivamente.

\subsection{O "Novo Ensino Médio" no Brasil}

Com base na leitura e discussões sobre a Medida Provisória nำ746/16 e da Lei 13.415/2017, reiteramos a discussão realizada e divulgadas em notas públicas pela Associação Nacional de Pós-Graduação e Pesquisa em Educação (Anped), Anpuh, Associação dos Geógrafos Brasileiros (AGB) e Associação Nacional de História (Anpuh). Vemos com muita preocupação a fragmentação dos "percursos formativos" que podem levar a um empobrecimento ou reducionismo curricular, bem como aponta uma tendência tecnicista, focada na inserção profissional sobre os aspectos humanistas.

O novo Ensino Médio aponta os seguintes percursos formativos: 1) Linguagens e tecnologia; 2) Matemática e suas tecnologias; 3) Ciências Naturais e suas tecnologias; 4) Ciências Humanas e Sociais Aplicadas; e 5) Formação técnica e profissional.

Consideramos que o acelerado trâmite para a aprovação da MP 746/16 impediu o diálogo com as entidades ligadas à educação e reforça o cunho conservador dessa proposta, já bastante questionada inclusive pelo Procurador Geral da República em uma ADIN (Ação Direta de Inconstitucionalidade) junto ao STF.

Devemos ressaltar as inúmeras manifestações estudantis contrárias a esta Reforma que sofreram repressão ao longo do ano de 2016. 
De acordo com o texto aprovado, o currículo do Ensino Médio será composto pela Base Nacional Comum Curricular (BNCC), cuja 3ª versão ainda não foi divulgada. Em razão das informações pouco esclarecedoras apresentadas pelo MEC a respeito do "Novo Ensino Médio", consideramos incerto o lugar das disciplinas de História e Geografia na reformulação do Ensino Médio, etapa final da Educação Básica.

Com base no artigo 22 da Lei de Diretrizes e Bases (LDB) 9394/96, "a Educação Básica tem por finalidades desenvolver o educando, assegurar-lhe a formação comum indispensável para o exercício da cidadania (...)". Ao prever "diferentes arranjos curriculares" e variados itinerários formativos, que terão seus critérios estabelecidos em cada sistema de ensino, a nova proposta desobriga o poder público quanto à oferta de um ensino equânime para todos. Reiteramos que a Lei 13.415/2017 tornou obrigatórias nos três anos de Ensino Médio apenas as matérias de matemática, língua portuguesa e inglês, fazendo com que o currículo fique dividido em duas partes, uma que será aplicada a todos os estudantes e outra voltada aos itinerários formativos. Ferindo a própria LDB de 1996.

Por meio dessas rápidas considerações e com base numa leitura que pensa a Geografia como saber acadêmico e como Prática de Ensino, demonstrar a insatisfação em relação à indefinição dessa disciplina na atual política educacional.

\section{O desafio da Geografia no Ensino Médio na Argentina e no Brasil: entre práticas docentes disciplinares e interdisciplinares}

A visão sobre o ensino de geografia vem sofrendo mudanças significativas ao longo do tempo e há muito se fala de uma geografia relacionada com a realidade do aluno, em formação do cidadão, ou seja, do sujeito pronto para exercer sua cidadania. Discussões sobre o ensino de geografia nesse sentido avançam, gerando inúmeras pesquisas, mudanças nos documentos que regem a educação como os Parâmetros Curriculares Nacionais e também mudanças nos cursos de formação, entre outras. No entanto, a realidade da geografia escola ainda é de uma disciplina fortemente presa ao livro didático, desconectada à realidade do aluno e de cunho memorizador, que dificulta o interesse por esta disciplina por parte dos alunos, já que não vêem nesta aplicação prática a sua vida.

Apesar de ser um recurso bastante utilizado nas aulas de geografia, o livro didático não está presente em todas as salas de aula do ensino básico, apresentando maior ausência nas turmas noturnas, o que faz com que os textos impressos pelos próprios 
professores e a escrita de extensos textos no quadro faça parte do cotidiano do professor de geografia. A realização de questionários é também muito comum na sala de aula com a finalidade de preparar o aluno para a prova, estimulando-o a memorização dos conteúdos.

Alguns professores de geografia dispõem de métodos que são capazes de facilitar o processo de ensino aprendizagem, no entanto, necessita-se do emprego destes em metodologias que estimulem a participação do aluno, para que este faça parte da aula enquanto sujeito ativo. Um destes métodos, que apesar de não ser peculiar da geografia, desde o princípio dá aporte a compreensão do espaço geográfico é o uso de mapas, ou seja, a cartografia. Entende-se que o aluno deve ser capaz de ler a realidade, interpretá-la e agir sobre ela. Para isso o uso de mapas pode colaborar para o alcance de tais objetivos, pois este é uma forma de representação, que pode esclarecer fenômenos por vezes não compreendidos. No entanto, o que se encontra na sala de aula é um professor de geografia que apresenta de forma tímida os mapas, fazendo uso de forma rápida dos mapas ilustrados nos livros didáticos, perdendo, desta forma a essência da disciplina distanciando-se de seu objetivo, de facilitar a leitura do mundo.

A tentativa de mudança na realidade é encontrada na prática de professores engajados em sua missão de contribuir para a construção do conhecimento, através do desenvolvimento de metodologias que permitam a troca de saberes, a valorização do aluno, o trabalho em equipe e a valorização da geografia enquanto disciplina capaz de contribuir para a compreensão da realidade vivida. Essa seria uma contribuição da prática disciplinar, mas o conhecimento deve caminhar rumo a novos horizontes.

A interdisciplinaridade surge no século $X X$ como um esforço de superar a especialização da ciência, além de superar a fragmentação do conhecimento em diversas áreas do estudo e pesquisa. Em síntese, podemos dizer que a interdisciplinaridade é a integração de duas ou mais áreas curriculares com o objetivo de gerar conhecimento, formulando assim um saber crítico-reflexivo no processo de ensino-aprendizagem.

$\mathrm{Na}$ Argentina e no Brasil a difusão desta metodologia se deu a partir dos anos 90 e de forma mais eficaz com as reformas educacionais por meio das políticas educacionais centralizadoras e de âmbito nacional. No ensino da Geografia, a interdisciplinaridade pode se materializar em diversos ramos do conhecimento como a arte, a música, o cinema e a literatura.

De acordo com Frederico e Teixeira (2009, p. 2): 
[...] a interdisciplinaridade deveria ser uma proposta curricular elaborada em conjunto com todo o corpo escolar objetivando algo único que venha a oferecer perspectivas positivas na vida do aluno e melhorias no ensino e em sua qualidade de vida refletindo-se na comunidade em que este está inserido, sendo uma constante no cotidiano educacional. Dessa forma acreditamos que a utilização de recursos como os textos literários e as composições músicas em suas diferentes expressões são importantes instrumentos para a aproximação do conteúdo geográfico do cotidiano do aluno e que o mesmo pode ser oferecido com uma abordagem interdisciplinar.

Ao se apropriar de conhecimentos de outras áreas, que não são do domínio do professor, ele tende a encontrar dificuldades para a elucidação do caso em questão. Porém, na busca pelas respostas, o professor pode sanar esse déficit de conhecimento com seus colegas, fato este que pode estimular ainda mais o processo.

$\mathrm{Na}$ busca pela prática interdisciplinar, o professor acaba por se tornar pesquisador, sendo a pesquisa interdisciplinar diferente das demais, pois, segundo Fazenda (2005, p. 5):

[...] a pesquisa interdisciplinar distingue-se das demais por revelar na sua forma de abordagem a marca registrada do pesquisador. O exercício de buscar a marca registrada envolve uma viagem interior, um retrocesso no tempo, em que o autor ao tentar descrever a ação vivenciada em sua história de vida identifica-se com seu próprio modo de ser no mundo, no qual busca o encontro com sua metáfora interior.

Portanto, pesquisa interdisciplinar é um ato que surge de dentro para fora, pois antes de pesquisar o pesquisador irá descobrir qual o seu papel na sociedade. Assim percebe-se pesquisador aquele que cria os instrumentos, conhece suas funcionalidades, sabe o propósito para o qual aquele instrumento foi criado. Assim ao descobrir as suas particularidades, o professor acaba transmitindo essa metodologia e também estimula o aluno a aflorar sua real identidade, tendo como consequência o afloramento das aptidões destes alunos.

Neste tipo de pesquisa, descobrimos que o todo é maior que a soma das partes, descobrimos novas formas de conhecimento. Renovamos nossas práticas e nos tornamos mais críticos de nós mesmos, terminamos por tornamo-nos um professor reflexivo.

Ao longo do presente texto, discutimos a ideia de interdisciplinaridade na pesquisa e no ensino essencialmente a partir dos estudos de 2005 e 2008 de Ivani Catarina Arantes Fazenda. No decorrer do texto, percebemos que várias ideias apontadas pelos autores convergem ao considerarem a interdisciplinaridade como um conceito que contribui em vários aspectos para superar a fragmentação dos conhecimentos. Em vista do que foi aqui discutido, portanto, não se pode negar que o movimento pela 
interdisciplinaridade - em curso desde a década de 1960 - possibilitou uma importante reflexão sobre a falta de interligação entre as disciplinas que compõem tanto o currículo escolar quanto o universo da pesquisa científica.

Para se trabalhar em uma perspectiva interdisciplinar, portanto, os saberes já produzidos - que muitas vezes permanecem separados uns dos outros - A interdisciplinaridade como possibilidade de diálogo e trabalho coletivo no campo da pesquisa e da educação devem integrar-se. Diante disso, o movimento pela interdisciplinaridade pode ser visto como uma forma de promover o diálogo entre conhecimentos, que não mais são tomados de maneira fragmentada e passam a colaborar mutuamente para o enfrentamento dos problemas complexos que nos são colocados pela realidade.

Esse diálogo refere-se não apenas à interação entre duas ou mais disciplinas, mas pressupõe o trabalho em conjunto, que pode ocorrer tanto entre pesquisadores quanto entre professores na escola. Esse trabalho coletivo é, ao mesmo tempo, uma maneira de reconhecer as limitações dos campos disciplinares e uma forma de buscar um conhecimento que só pode ser produzido a partir da articulação.

O princípio que embasa essa concepção de interdisciplinaridade é o de que nenhuma área do conhecimento pode ser considerada completa por si só. Tal princípio, no entanto, não significa que o movimento pela interdisciplinaridade é anti-disciplina ou que tem por objetivo integrar todos os saberes existentes em busca de um conhecimento completo. Essas são visões dicotômicas que frequentemente ocasionam mais confusão do que esclarecimentos sobre 0 conceito de interdisciplinaridade.

A interdisciplinaridade, abre caminho para o trabalho coletivo, que fornece as bases para um trabalho pedagógico cujo objetivo é a aproximação entre as disciplinas escolares e as questões relacionadas à vida cotidiana de alunos e alunas. É esse trabalho coletivo que pode ajudar a conectar as disciplinas curriculares com a vida das pessoas, mantendo a escola aberta à complexidade e disponível às questões transversais presentes na sociedade em que vivemos. Embora apresente limites, a interdisciplinaridade pode nos ajudar, portanto, a considerar uma dupla necessidade de reorganização das práticas $A$ interdisciplinaridade como possibilidade de diálogo $\mathrm{e}$ trabalho coletivo no campo da pesquisa e da educação escolares. Ao mesmo tempo em que é importante favorecer a interligação metodológica entre os saberes disciplinares - tanto na escola quanto na pesquisa -, também é essencial questionar 
quais os tipos de conhecimento a ciência vêm produzindo, em seus aspectos epistemológicos.

\section{Conclusão}

As mudanças ocorridas tanto na Nueva Escuela Secundaria (NES) na Ciudad Autónoma de Buenos Aires (CABA) na Argentina, como no "Novo Ensino Médio" do Brasil, tem alterado bastante a estrutura educacional, apresentando um direcionamento para a formação específica nas grandes áreas do conhecimento. A escola passa a ofertar uma ou mais áreas de conhecimento, podendo aser na CABA: Ciencias Exatas y tecnologia; Ciencias Naturales; Ciencias Sociales e Humanidades; Literatura; Agronomia; Turismo; entre outras áreas. No Brasil com o "Novo Ensino Médio" os seguintes percursos formativos: Linguagens e tecnologia; Matemática e suas tecnologias; Ciências Naturais e suas tecnologias; Ciências Humanas e Sociais Aplicadas; e Formação técnica e profissional. Entre as duas propostas a Argentina apesar de contemplar um leque mais diversificado de formações, caminha para a especialização da formação.

Os primeiros anos sempre básicos. Na CABA, os dois primeiros anos, dos cinco anos da Escuela Secundaria, mantém inalterada a carga horária da disciplina de Geografia, já nos demais anos a carga se mantém apenas nas escolas que ofertam a área de Ciencias Sociales e Humanidades e nas demais é reduzida ou não é ofertada. Isso acarreta numa diminuição a curto e médio prazo das aulas de Geografia na Escuela Secundaria, bem como de toda área de Ciências Humanas. Já no Brasil a disciplina de Geografia desaparece como disciplina obrigatória permanecendo apenas matemática, língua portuguesa e inglês, demonstrando um empobrecimento maior do campo curricular. Tanto a "Nueva Escuela Secundaria" na Argentina, como o "Novo Ensino Médio" no Brasil, reproduzem um modelo de ensino médio que passa a ser implantado em toda América Latina e um modelo preocupante, tecnicista e acrítico.

Destacamos também que não se trata, de considerar o pensamento interdisciplinar como uma salvação para os problemas presentes na educação, mas como uma perspectiva que oferece caminhos e reflexões para superar certos modelos de ciência e de educação fortemente influenciados pelo pensamento cartesiano e simplificante, presente nas práticas disciplinares, porém esse movimento necessita de tempo e as reformas subtraem um tempo significativo para se trabalhar com a Geografia, por meio da redução da carga horária. Surgindo nitidamente uma contradição entre o discurso 
implantado e o tempo para se efetivar a construção de conhecimento proposto. Temos clareza de que o caminho entre as

A Geografia Escolar enquanto parte ativa e crítica do sistema educacional deve estar atenta e sensível as transformações ocorridas neste sistema e no mundo, sendo fundamental no momento atual um movimento de defesa e resistência, seja na Argentina, no Brasil e nos demais países latino-americanos da Geografia e das Ciências Humanas e Sociais na Educação básica pública.

\section{Referências bibliográficas}

Busch, S. I. (2013). La geografia em la reforma currcilar del "compromisso entre lo nuevo y las tradiciones". Revista del IICE, 34, p.99-110.

Casassus, J. (2001). A reforma educacional na América Latina no contexto da globalização. Cadernos de Pesquisa. [On-line]. São Paulo: Fundação Carlos Chagas. n. 114, nov. 2001. p. 7-28. <http://www.scielo.br/pdf/cp/n114/a01n114.pdf>. [2 de setembro de 2016].

Castells, M. (1999). A sociedade em rede. 3 ed. São Paulo: Paz e Terra, (A era da informação: economia, sociedade e cultura. v. 1).

Ciudad Autónoma de Buenos Aires - Secretaría de Educación (2014). Documentación acerca de la Nueva Escuela Secundaria de Calidad. Buenos Aires, Disponible en: www.buenosaires.gob.ar/areas/educacion

Fazenda, I. C. (2008) O que é Interdisciplinaridade? São Paulo: Cortez.

Fazenda, I. C. (2005) Formação do Professor Pesquisador -30 anos de pesquisa. Revista e-Curriculum, v. 01, número 01, PUC/ SP, pp.1-23.

Fernández Caso, M. V. (coord.) (2008). Geografía y territorios en transformación. Noveduc, Buenos Aires.

Fernández Caso, M. V. e Gurevich, R. (2007). Geografía: Nuevos temas, nuevas preguntas. Um temário para su enseñanza. Buenos Aires, Biblos.

Frederico, I. da C; Teixeira A. L. (2009). Práticas Interdisciplinares no Ensino da Geografia. Anais. Encontro Nacional de Professores de Ensino de Geografia, AGB, 2009. 
Gurevich, R. (2005). Sociedades y territorios en tiempos contemporáneos. Una introducción a la enseñanza de la Geografía. Buenos Aires: Fondo de Cultura Económica.

Marquesi, A. Martín, E. (2003). Qualidade do ensino em tempos de mudança. Porto Alegre: Artmed, 2003.

Brasil - Ministério da Educação (2015). Base Nacional Comum Curricular (BNCC). Segunda Versão do Texto. Brasília.

Riboratti, C. E. (1993). La geografía em la esculea secundaria: de inventario intrascendente a herramienta de comprensión. Geographikós - Uma Revistta de Geografía. Buenos Aires, 3 (4), 7-33.

Santos. C. (2016). Las Prácticas Pedagógicas de los Profesores de Geografía en la Educación Pública Secundaria en la Ciudad de Buenos Aires: los desafíos de la formación ciudadana en la escuela. Buenos Aires, IGGEO/FFyL/UBA.

Sene, J. E. (2008). Reformas educacionais na América Latina. Ar@cne. Revista electrónica de recursos en Internet sobre Geografía y Ciencias Sociales. [En línea. Acceso libre]. Barcelona: Universidad de Barcelona, no 105 , <http://www.ub.es/geocrit/aracne/aracne-105.htm>.[2 de setembro de 2016].

Villa, A; Zenobi, V. (2011, Novembro). Seminário "Situación y Perspectivas de la Enseñanza de la Geografía”, realizado no Ministério de Educación, Buenos Aires AR.

Villa, A. (2011). La escuela y la construcción del currículo de ciências sociales. Los circuitos productivos regionales em la Argentina. . In M. insaurralde (Comp.). Ciencias Sociales: líneas de acción didáctica y perspectivas epistemológicas. Buenos Aires, Noveduc.

Zenobi, V (2013). El lugar de los materiales curriculares en la renovación de las prácticas de enseñanza de la geografía. In M. insaurralde (Comp.). Enseñanza de las Ciencias Sociales, Buenos Aires, Noveduc 13-26

Zenobi, V. (2011). Las tradiciones de la geografía su relación con la enseñanza tradiciones disciplinaresv y geografía escolar. In INSAURRALDE, Mónica (Comp.). Ciencias Sociales: líneas de acción didáctica y perspectivas epistemológicas. Buenos Aires, Noveduc. 


\title{
Geoprocessamento como instrumento na educação geográfica usando a metodologia ativa do Projeto Nós Propomos!
}

\author{
EduARdo S. HEUSSER ${ }^{1}$ \\ ROSEMY S. NASCIMENTO
}

\section{Resumo}

Este artigo faz parte da divulgação da pesquisa de mestrado em Geografia do Programa de Pós-Graduação em Geografia da Universidade Federal de Santa Catarina (UFSC), durante 2018 e 2019. Objetiva propor que o estudante do Ensino Médio se torne um agente ativo no processo de ensino e aprendizagem, identificando problemas ambientais e propondo intervenção sobre os mesmos. Destaca a potencialidade de uma parceria entre escola, poder local e comunidade na construção de um ambiente geográfico sustentável. O estudante deve ser capaz de conhecer, compreender e analisar o ambiente em que vive, para então sensibilizar uma governança ambiental eficiente. Trata-se de uma pesquisa qualitativa de caráter exploratório, por meio de pesquisa-ação, com dados obtidos a partir da análise de uma turma de Ensino Médio de uma escola da Região Sul do Brasil aplicando a metodologia ativa do Projeto Nós Propomos! A análise dos dados é por meio da análise do discurso, utilizando dados locais textuais, da Cartografia, Sistemas de Informações Geográficas (SIG) e Sensoriamento Remoto para a elaboração de mapas de susceptibilidade ambiental utilizando um software livre de geoprocessamento em laboratório de informática escolar. Esta pesquisa justifica o geoprocessamento como um recurso didático para a educação geográfica, podendo ser implementado com sucesso no Ensino Médio possibilitando que o estudante faça uma análise ambiental da sua realidade e se torne sensibilizador e mobilizador de ações públicas sustentáveis.

\footnotetext{
${ }^{1}$ Mestrando em Geografia, PPGG-UFSC, eduardo.heusser@gmail.com.

2 Doutora em Engenharia de Produção, PPGG-UFSC, rosemy.nascimento@gmail.com. O presente trabalho foi realizado com apoio da Coordenação de Aperfeiçoamento de Pessoal de Nível Superior - Brasil (CAPES) - Código de Financiamento 001.
} 
Palavras-chave: Geografia; Geotecnologias; Análise Ambiental; Metodologia Ativa; Cidadania.

\section{Abstract}

This article is part of the dissemination of the master's degree research in Geography of the Postgraduate Program in Geography of the Federal University of Santa Catarina (UFSC) during 2018 and 2019. It aims to propose that the student of High School become an active agent in the process teaching and learning, identifying environmental problems and proposing intervention on them. It highlights the potential of a partnership between school, local power and community in building a sustainable geographic environment. The student must be able to know, understand and analyze the environment in which he or she lives, to sensitize efficient environmental governance. This is a qualitative exploratory research, through action research, with data obtained from the analysis of a High School class of a school in the Southern Region of Brazil applying the active methodology of the Nós Propomos Project! Data analysis is based on discourse analysis using local textual data from Cartography, Geographic Information Systems (GIS) and Remote Sensing for the preparation of maps of environmental susceptibility using a geoprocessing free software in a school computer laboratory. This research justifies geoprocessing as a didactic resource for geographic education, and can be successfully implemented in High School, enabling the student to make an environmental analysis of their reality and become a sensitizer and mobilizer of sustainable public actions.

Keywords: Geography; Geotechnology; Environmental Analysis; Active Methodology; Citizenship.

\section{Introdução}

Vivemos cada vez mais em uma sociedade desafiadora em lidar com o meio natural. Segundo Porto-Gonçalves (2017, p. 18):

"Estamos diante, nestes últimos 30-40 anos de globalização neoliberal, de uma devastação do planeta sem precedentes em toda a história da humanidade, período em que, paradoxalmente, mais se falou de natureza e em que o próprio desafio ambiental se colocou como tal. Daí ser fundamental entendermos a natureza do processo de globalização e de que modo esse processo implica ou não a globalização da natureza."

Para lidar eficazmente com este desafio, se faz necessário preparar os jovens cidadãos ainda na sua formação, especialmente durante o processo de educação 
geográfica. Como podemos ensinar e motivar estudantes a desenvolver um senso de análise e de resolução de problemas ambientais? De acordo com Fitz (2008, p. 11):

"O estudo do espaço geográfico e dos aspectos ambientais nele inseridos pressupõe uma série de conhecimentos e informações que podem ser trabalhados de maneira mais ágil, fácil e rápida com as novas tecnologias. Inseridos nesse contexto, as geotecnologias tendem a ocupar um lugar de destaque em virtude de sua funcionalidade."

Desta forma, podemos aliar o geoprocessamento com uma proposta de metodologia ativa, onde estudantes e professores trabalham juntos. Neste sentido, Claudino (2018, p. 265) afirma que "o trabalho de campo constitui uma das marcas distintivas da disciplina de Geografia." Ele ainda acrescenta que a sua proposta de projeto "pretende responder ao duplo desafio de inovar a educação geográfica e de promover uma renovada cidadania local, ao estimular os alunos a identificarem problemas locais e a apresentarem propostas de solução." Diante deste pressuposto, como a articulação entre o geoprocessamento e uma metodologia ativa de ensino viabiliza a análise ambiental na educação geográfica?

$\mathrm{Na}$ busca por respostas, a pesquisa a ser compartilhada neste artigo pautou-se nas contribuições de Bogdan e Biklen (1994), Coll (1996), Demo (1996), Quivy e Campenhoudt (1998), Prensky (2001), Fitz (2008), Ab'Saber (2009), Miranda (2010), Thiollent (2013), Young Digital Planet (2016), Gomes (2017), Porto-Gonçalves (2017) e Claudino (2018).

Este artigo faz parte da divulgação da pesquisa de mestrado em Geografia do Programa de Pós-Graduação em Geografia da Universidade Federal de Santa Catarina (UFSC), durante 2018 e 2019. Desta forma, neste primeiro ano, trata-se de um trabalho mais exploratório, principalmente de revisão bibliográfica. Este estudo de natureza qualitativa (Bogdan \& Biklen, 1994) objetiva propor que o estudante do Ensino Médio se torne um agente ativo no processo de ensino e aprendizagem, identificando problemas ambientais e propondo intervenção sobre os mesmos. Destaca a potencialidade de uma parceria entre escola, poder local e comunidade na construção de um ambiente geográfico sustentável. O estudante deve ser capaz de conhecer, compreender e analisar o ambiente em que vive, para então sensibilizar uma governança ambiental eficiente.

\section{Fazer análise ambiental através da educação geográfica}

Naturalmente, para que o jovem estudante se torne capaz de fazer análise ambiental significativa, ele deve ser educado para tal habilidade. Para ajudar-nos, existe a 
Geografia. Neste sentido, Gomes (2017) fala de sua "convicção de que a Geografia é uma disciplina consistente, relevante e de resultados surpreendentes." Ele considera a Geografia como "uma forma de pensar", e ainda mais além, "uma maneira, original e potente, de organizar o pensamento." Essa é a tese defendida por Gomes, e que gostaríamos de nos apropriar neste momento.

Gomes (2017) identifica "três domínios ou três formas que hoje correspondem ao que compreendemos como geográfico, ou seja, a qualidade de ser da Geografia." O primeiro tem a ver com "a capacidade de situar coisas no espaço e de nos situarmos nele. [...] A capacidade de saber se orientar". Para exemplificar, Gomes cita Kant quando diz que "a existência da dimensão espacial é anterior à percepção." O segundo refere-se à inteligência, que produz cultura e conhecimentos que são estabilizados e transmitidos. Esse processo é responsável por agrupar humanos, que por sua vez detêm conhecimento do ambiente onde vivem. Esse tipo de Geografia é tido por alguns geógrafos (Paul Claval, por exemplo) como vernacular. O terceiro domínio dito geográfico trata das causas e formas de entendimento da dispersão, da lógica das localizações. Corresponde hoje ao que entendemos como ciência geográfica. Para Gomes, "é o campo de estudos que interpreta as razões pelas quais coisas diversas estão situadas em posições diferentes ou por que as situações espaciais diversas podem explicar qualidades diferentes de objetos, coisas, pessoas e fenômenos." Gomes finaliza esse raciocínio dizendo que "essas três acepções constituem o preâmbulo para a formulação de uma quarta possibilidade a orbitar o mesmo interesse: a de que a Geografia é também uma forma autônoma de estruturar o pensamento, uma forma original de pensar."

A seguir, Gomes (2017) lança uma afirmação interessante quando diz que "o instrumento básico do pensar geográfico é o quadro. O mapa é um tipo de quadro dentre outros: desenhos, croquis, cartogramas, blocos-diagramas, fotos, esquemas, pinturas, descrições etc." Citando Humboldt, Gomes fala sobre a Naturgemälde, termo que pode ser traduzido como "pintura da natureza". Esta imagem foi publicada no famoso "Ensaio sobre a Geografia das plantas" de Humboldt (1805). Trata-se do perfil de montanhas, com uma série de descrições sobre os elementos bióticos e abióticos daquele lugar. De acordo com Gomes, "podemos sem qualquer sombra de dúvida dizer que são informações geográficas oferecidas ao exame por meio dessa imagem. [...] Na prática e de maneira muito própria, Humboldt construiu aí um sistema original de informações geográficas." Não é à toa que ele é considerado por muitos historiadores da Geografia como o pai da Geografia moderna. Talvez isso "se situa no 
fato de ele ter feito a plena demonstração da utilidade desse instrumental imagético para desenvolver um raciocínio geográfico."

Gomes (2017) reconhece "que os princípios dessa forma de organizar dados, de tratálos e de visualizá-los estão presentes na proposta e na apresentação feita por Humboldt da Naturgemälde." Podemos dizer então "que essa forma de pensar e de correlacionar informações compõe um quadro geográfico." Gomes (2017) destaca:

"Os quadros devem falar ao espírito e à imaginação, insistiu Humboldt mais
de uma vez no seu texto. [...] São também capazes de sensibilizar e
proporcionar prazer indiferentemente a todos os que os apreciem, e ainda
aqueles que não sejam iniciados nas ciências poderão admirá-los e
facilmente se persuadirem pelo interesse e pela importância do seu estudo." Continuando, Gomes (2017) enfatiza que Humboldt foi fiel ao apelo da ideia de "quadro" em suas obras, até a última, o Cosmos. "O recurso às imagens, sejam elas desenhadas ou evocadas, é apresentado explicitamente como instrumento básico para o desenvolvimento de um raciocínio geográfico na obra de Humboldt. Em 1808, por exemplo, ele publica o livro [...] Quadros da natureza", onde "os quadros" são construídos muito mais pela descrição textual do que por imagens. Como ele mesmo afirmou mais tarde no Cosmos, a melhor descrição "converte o ouvido em olho". Segundo Gomes, "Humboldt sustenta que ao prazer da contemplação da variedade da natureza em geral deve se seguir o prazer pelo caráter individual de uma paisagem, que é a configuração de uma região determinada."

Desse modo, partimos do conceito de "quadros geográficos" para conduzir o lugar da análise ambiental dentro do processo de educação geográfica. Para tal tarefa, professor e estudantes precisam estar bem instrumentalizados conceitualmente.

Segundo Demo (1996), existe uma forma de fazer a diferença na educação. Se trata de "educar pela pesquisa". De acordo com ele, "educar pela pesquisa tem como condição essencial primeira que o profissional da educação seja pesquisador, ou seja, maneje a pesquisa como princípio científico e educativo e a tenha como atitude cotidiana." O professor precisa estar instrumentalizado da pesquisa como um princípio educativo para que se possa ser feita educação. Demo afirma ainda que "não se faz antes pesquisa, depois educação, ou vice-versa, mas, no mesmo processo, educação por através da pesquisa." Demo trata também das relações entre pesquisa, aluno e professor, definindo o papel do professor como o orientador do trabalho conjunto, coletivo e individual. O aluno é o parceiro na construção do conhecimento e deve ser estimulado para saber argumentar e questionar. Isso vai bastante de encontro com a proposta apresentada nesta pesquisa. 
Por outro lado, devemos considerar o fato de que boa parte das crianças e adolescentes do século XXI são nativos digitais, amplamente discutido por Prensky (2001). Em primeira análise, parece fácil nosso trabalho enquanto educadores geográficos quando apresentamos as geotecnologias aos nossos estudantes do século XXI. É fácil logo concluir que eles rapidamente aprenderão a utilizar as ferramentas de geoprocessamento, por exemplo. No entanto, precisamos considerar importantes questões: Como habilitar os estudantes a se apropriarem das geotecnologias que temos hoje livremente a disposição? Como desenvolver a capacidade de fazerem uma análise ambiental eficiente através do geoprocessamento, sendo críticos da sociedade em que vivem?

\section{Geoprocessamento na educação geográfica}

A gente pode começar a estudar as imagens de satélites por processos metodológicos gráficos, chamados geoprocessamentos, e tentar interpretar as coisas que se obtêm. Mas, no meu modo de entender, sem a comparação entre o que se obtêm com o geoprocessamento e o que se obtêm pelo estudo direto, no campo, é impossível fazer uma ciência interdisciplinar completa. Ou seja, a imagem de satélite por si só não pode substituir os estudos de campo (Ab'Saber, 2009, p. 118).

Para contribuir com esse debate, Young Digital Planet (2016, p. 54), ao abordar a questão da tecnologia na sala de aula, diz que "a personalização na educação significa ter acesso aos conteúdos sempre que necessário. Além disso, pressupõe fornecer aos alunos materiais adaptados utilizando as ferramentas mais adequadas para eles. Graças a tecnologia, essas diretrizes podem ser seguidas com a ajuda dos dispositivos móveis". Isso mostra a importância da boa instrumentalização do professor e do estudante nas ferramentas digitais que pretendem usar.

Pensando nisso, Fitz (2008) deixa claro que "as tecnologias por si sós são incapazes de trazer reais benefícios para o ser humano." Por isso, ao longo de seu livro ele procura "apresentar a dinamicidade e a aplicabilidade das geotecnologias." Relacionando tomada de decisões e o uso de um Sistema de Informações Geográficas (SIG), Fitz (2008, p. 140-141) faz uma importante consideração que muito nos interessa aqui:

A manipulação de um SIG perpassa por uma longa trajetória que envolve distintos aspectos. O cruzamento de informações derivadas de bases de dados georreferenciados, por exemplo, necessita de critérios consistentes, o que remete a um processo decisório que deve ser visto como um caminho a ser trilhado ao longo desse procedimento.

Para auxiliar nesta tarefa recorremos a Miranda (2010), que nos apresenta os fundamentos de Sistemas de Informações Geográficas. Embora não privilegie nenhum 
sistema em especial, ele informa a existência de softwares livres (SL) de geoprocessamento, que apresentam um desempenho eficiente. Isso muito nos interessa em educação geográfica, por serem gratuitos e funcionais para a metodologia proposta nesta pesquisa. Dentre os indicados por Miranda (2010, p. 408), destacamos o QGIS:

Desenvolvido inicialmente para o ambiente Linux, dispõe de versões para Unix, Windows e MacOS. Desenvolvido em cima do software QT, para produção de interface gráfica, o mesmo usado para desenvolver a interface gráfica do Google Earth. É um SL que suporta vários formatos e funcionalidades vetorial, matricial e de banco de dados, incluso o PostGIS. Usa a biblioteca OGR para importação de dados. Atualmente, é um produto com boa aceitação para os usuários de SIG livre. URL: $<$ http://www.qgis.org>.

Portanto, adotaremos o software livre de geoprocessamento QGIS para desenvolver mapas temáticos a partir das observações dos estudantes sobre os problemas ambientais locais. Deixaremos para discutir essa função mais adiante, quando falarmos sobre metodologia. Agora, veremos a relação à que se dispõe esta pesquisa entre o geoprocessamento com uma metodologia ativa de educação geográfica.

\section{O Projeto Nós Propomos! como metodologia ativa de educação geográfica}

Para termos mais chances de fazer uma Geografia mais útil na vida do estudante, precisamos nos aproveitar de todas as ferramentas que a ciência geográfica nos oferece. É óbvio que não se pode alcançar todas essas ferramentas apenas ficando dentro de quatro paredes, com uma turma de 30 ou 40 alunos em geral. É grande a necessidade de ensinar o estudante a fazer Geografia fora da sala de aula. Para Claudino (2018), "o trabalho de campo constitui das experiências mais motivadoras e marcantes para os alunos, um importante estímulo ao trabalho de parceria entre alunos e favorece a aproximação e o diálogo entre professores e alunos."

Nesse sentido, introduzimos a metodologia ativa de educação geográfica do Projeto Nós Propomos! (Claudino, 2018). De acordo com Claudino, "o trabalho de campo não deve constituir um fim em si mesmo, mas responder às solicitações de cidadania territorial." Dessa forma, Claudino (2018) destaca:

O Projeto Nós Propomos! Cidadania e Inovação na Educação Geográfica, que aqui iremos apresentar quanto aos seus princípios, metodologia e propostas elaboradas por alunos, pretende responder à necessidade de mobilizar a disciplina de Geografia para a realização de um trabalho de campo local que contribua para a melhoria das condições da comunidade.

Claudino (2018) explica que o Projeto Nós Propomos! surge diretamente do desafio educativo colocado pelo Ministério da Educação de Portugal de introduzir um Estudo 
de Caso na Geografia do ensino secundário, "como uma oportunidade efetiva de introduzir o conhecimento da realidade no trabalho em Geografia e concretiza-se que os estudantes devem analisar criticamente problemas que afetam a região onde vivem, refletindo sobre soluções possíveis para os problemas percebidos."

Sobre as fases do projeto, Claudino (2018, p. 274) apresenta:

O desenvolvimento do Projeto não é realizado de forma rígida e tenta respeitar diferentes ritmos de escolas, professores e alunos através das seguintes fases: 1) reunião com os docentes envolvidos; 2) assinatura de protocolos com as autarquias; inscrição dos alunos no sítio do Projeto e na página do Facebook; 3) identifcação dos problemas locais pelos alunos; 4) formação de grupos e definição do tema de projeto; concurso do logótipo do Projeto; 5) sessão da equipa de coordenação com os alunos nas escolas; sessões de trabalho sobre o Plano Diretor Municipal; 6) realização de trabalho de campo; elaboração das propostas pelos alunos; 7) autoavaliação intermédia; 8) participação em concursos de fotografia de paisagem, fotografia de trabalho de campo, texto, desenho e vídeo; 9) divulgação das propostas dos alunos; e 10), por último, avaliação do Projeto. Metodologicamente, é um projeto relativamente simples.

Diante desta proposta de metodologia ativa, passamos agora a metodologia que elaboramos para observação e análise de dados.

\section{$5 \quad$ Metodologia}

\subsection{Observar o quê?}

Quivy e Campenhoudt (1998) destacam que é indispensável tomar em consideração variáveis de controle, dado que as correlações observadas podem resultar de outros fatores implicados no mesmo sistema de interação. Será então necessário recolher um certo número de dados relativos a outras variáveis, para além das que estão explicitamente previstas nas hipóteses principais.

Quivy e Campenhoudt (1998) dão uma importante palavra de cautela. Eles colocam que é possível recolher uma infinidade de dados sobre qualquer fenômeno. Mas que significado Ihes atribuir se não se inscreverem no âmbito de um modelo de análise? 0 correto é recolher apenas os dados úteis à verificação das hipóteses, com exclusão dos outros. São os chamados dados pertinentes.

Assim, pretende-se observar o desempenho de uma proposta de metodologia ativa de educação geográfica para a análise ambiental, que conjugue geoprocessamento com trabalho de campo. De forma complementar, observar o impacto dessa metodologia na comunidade local. 


\title{
5.2 Observar em quem?
}

Neste ponto fica bem claro a importância de definir o campo das análises empíricas no espaço, geográfico e social, e no tempo. Quivy e Campenhoudt (1998) definem aqui duas possíveis situações:

\begin{abstract}
Na primeira, o trabalho tem por objeto um fenômeno ou um acontecimento singular. Neste caso, é necessário precisar explicitamente os limites do campo de análise: período de tempo tido em conta, zona geográfica considerada, organizações e atores aos quais será dado relevo, etc. Já na segunda situação, o investigador não dá relevo a fenômenos singulares, mas a processos sociais. Neste caso deve-se fazer escolhas ponderadas em função de vários critérios, envolvendo as hipóteses de trabalho, os prazos e recursos de que dispõe, etc. Na maioria das vezes, o campo de investigação na própria comunidade onde vive o investigador. Uma dica é não escolher um campo demasiado amplo.
\end{abstract}

Interessante considerar aqui que, para Quivy e Campenhoudt (1998), após ter circunscrito o seu campo de análise, deparam-se três possibilidades ao investigador: ou recolhe dados e faz incidir as suas análises sobre a totalidade da população coberta por esse campo, ou a limita a uma amostra representativa desta população, ou estuda apenas algumas componentes muito típicas, ainda que não estritamente representativas, dessa população.

Portanto, definiremos aqui como unidade de observação uma turma de Ensino Médio, com cerca de 30 alunos, de uma escola do interior de Santa Catarina. A zona geográfica será um bairro próximo a escola, senão o próprio bairro da escola. Quanto ao período de tempo, julgamos necessário e suficiente um semestre letivo, sendo o primeiro de 2019.

\subsection{Observar como?}

Quivy e Campenhoudt (1998) dizem que agora é o momento de conceber o instrumento capaz de fornecer as informações adequadas e necessárias para testar as hipóteses, por exemplo, um questionário de inquérito, um guia de entrevista ou uma grelha de observação direta. Aplicá-lo sistematicamente e proceder, assim, a recolha dos dados pertinentes.

Para esse fim, adota-se aqui a metodologia da pesquisa-ação (Thiollent, 2013), desenvolvendo um projeto participativo que contextualize conteúdos geográficos estudados em sala de aula com trabalho de campo. Será utilizado o método de entrevista semiestruturada, ou semidirectiva (Quivy \& Campenhoudt, 1998), por amostragem sistemática, sobre problemas ambientais que mais preocupam a 
comunidade. Também será feito o uso do método de observação direta, para coleta de dados complementares (croquis, fotos, georreferenciamento). Como técnica, criação de mapa de susceptibilidade ambiental local e formulação de propostas de intervenção usando um software livre de geoprocessamento. Por fim, apresentação das propostas de intervenção à comunidade pelos estudantes.

Naturalmente, todo esse processo envolve avaliação de aprendizagem. Conforme as contribuições de Coll (1996, p. 151), a avaliação pode ser feita em três modalidades: inicial, formativa e somatória. A avaliação inicial é feita no início de uma nova fase de aprendizagem, a avaliação formativa permeia todo o processo de aprendizagem e a avaliação somatória é feita no final de uma etapa de aprendizagem. Ainda, Coll (1996, p. 152) enfatiza que "a aprendizagem escolar deve ser, por definição, significativa, e que pode referir-se tanto a fatos, conceitos e princípios, quanto a procedimentos, valores, normas e atitudes." Portanto, no proposto modelo de metodologia ativa de ensino, cabe ao professor de Geografia avaliar o trabalho desenvolvido de acordo com seu planejamento e proposta junto aos estudantes, ficando a seu critério o estabelecimento da valoração das notas nos conteúdos trabalhados, sendo conceituais, procedimentais e atitudinais.

\section{Resultados esperados}

Esperamos que, a partir da metodologia de observação e análise dos dados apresentada, tenhamos resultados que comprovem a aplicabilidade desta proposta de educação geográfica voltada para uma metodologia ativa que reúna ferramentas de geoprocessamento com trabalho de campo.

Dessa forma, os estudantes poderão se tornar cidadãos capazes de relacionar conceitos geográficos construídos em sala de aula de forma interdisciplinar e contextualizada com a vida em sociedade. Devem estar aptos a fazer análise ambiental conciente e eficiente, propondo soluções cooperativas para as susceptibilidades ambientais verificadas localmente.

É evidente que além de os estudantes necessitarem da mediação pedagógica eficaz, o professor deve proporcionar o acesso às diversas geotecnologias em questão no ambiente escolar. Além disso, ele necessita instrumentalizar-se no uso destes recursos.

E o que dizer do "ensinar pela pesquisa"? Nesse sentido, quando fala do "desafio de educar pela pesquisa na Educação Básica", Demo (1996) passa a ideia de que é 
preciso repensar a educação guiada pela simples reprodução do conhecimento, estruturada na aula repassada pelo professor e copiada pelo estudante. Assim, questiona o poder transformador da educação, que se mantido nessa perspectiva, impede o cidadão da construção da sua própria história. Na concepção de Demo, a educação não é só ensino, instrução, treino, mas, sobretudo, formação da autonomia crítica e criativa do sujeito histórico competente. Portanto, observou-se que a proposta apresentada nesta pesquisa caminha nessa direção, incentivando a autonomia do estudante diante da construção do conhecimento por meio da pesquisa.

\section{Conclusão}

Esta pesquisa espera justificar o geoprocessamento como um recurso didático para a educação geográfica, podendo ser implementado com sucesso no Ensino Médio possibilitando que o estudante faça uma análise ambiental da sua realidade e se torne sensibilizador e mobilizador de ações públicas sustentáveis.

\section{Referências bibliográficas}

Ab’Saber, A. N. (2009). O que é ser geógrafo. 2. ed. Rio de Janeiro: Record.

Bogdan, R. C., \& Biklen, S. K. (1994). Investigação qualitativa em educação: uma introdução à teoria e aos métodos. Lisboa: Porto Editora.

Coll, C. (1996). Psicologia e Currículo: uma aproximação psicopedagógica à elaboração do currículo escolar. São Paulo: Ática.

Claudino, S. (2018). Educação Geográfica, Trabalho de Campo e Cidadania. O Projeto Nós Propomos! In F. H. Veiga (Cood.), O ensino na escola de hoje: teoria, investigação e aplicação (pp. 265-303). Lisboa: Climepsi Editores.

Demo, P. (1996). Educar pela pesquisa. Campinas: Editora Autores Associados.

Fitz, P. R. (2008). Geoprocessamento sem complicação. São Paulo: Oficina de Textos.

Gomes, P. C. C. (2017). Quadros geográficos: uma forma de ver, uma forma de pensar. Rio de Janeiro: Bertrand Brasil.

Miranda, J. I. (2010). Fundamentos de Sistemas de Informações Geográficas. 2. ed. Brasília: Embrapa.

Porto-Gonçalves, C. W. (2017). A globalização da natureza e a natureza da globalização. 7. ed. Rio de Janeiro: Civilização Brasileira. 
Prensky, M. (2001). Digital Natives, Digital Immigrants. On the Horizon, V(9), 1-6. Disponível em: https:/www.marcprensky.com/writing/Prensky\%20\%20Digital\%20Natives,\%20Digital\%20Immigrants\%20-\%20Part1.pdf

Quivy, R., \& Campenhoudt, L. V. (1998). Manual de Investigação em Ciências Sociais. 2. ed. Lisboa: Gradiva.

Thiollent, M. (2013). Metodologia da pesquisa-ação. 18.ed. São Paulo: Cortez.

Young Digital Planet. (2016). Educação no Século 21: tendências, ferramentas e projetos para inspirar. São Paulo: Moderna. 


\title{
A charge como recurso didático: relato de experiência do CETI Governador Freitas Neto, município de Teresina, Piauí, Brasil
}

\author{
EMANUEL LINDEMBERG SILVA ALBUQUERQUE ${ }^{1}$ \\ MAICON HENRIQUE MARQUES BATISTA ${ }^{2}$ \\ MARCONDES E SILVA SOUSA ${ }^{3}$ \\ SIMONE MIRANDA FONTINELES DA SILVA ${ }^{4}$
}

\section{Resumo}

Ao considerar as mais diversas abordagens didáticas na geografia, este trabalho objetiva analisar a capacidade de produção do conhecimento a partir do uso de charges no aprendizado escolar, aproveitando o poder de inovação que o Programa Institucional de Bolsas de Iniciação à Docência (PIBID) propicia no processo de ensino-aprendizagem. Para tanto, a charge foi utilizada como recurso didático, na perspectiva de abordar com mais dinamicidade o conteúdo de globalização e industrialização, tendo como público-alvo os alunos do $1^{\circ}$ ano do Ensino Médio do CETI Governador Freitas Neto, localizado no município de Teresina, estado do Piauí, Brasil. Desse modo, observa-se a importância da utilização das charges no processo de ensino-aprendizagem de geografia, pois a partir desta torna-se mais fácil à assimilação do conteúdo trabalhado em sala de aula de acordo com a realidade do aluno. Portanto, a charge potencializa a aprendizagem dos alunos por meio da construção de uma reflexão voltada à produção geográfica e educativa, trazendo temas complexos da realidade cotidiana e da comunidade escolar, a exemplo das

\footnotetext{
${ }_{1}^{1}$ Professor do Curso de Geoografia, Universidade Federal do Piauí, lindemberg@ufpi.edu.br.

2 Aluno do Curso de Geografia, Universidade Federal do Piauí, henrykimarques@gmail.com.

${ }^{3}$ Aluno do Curso de Geografia, UFPI, marcondes.sousa2014@hotmail.com.

${ }^{4}$ Aluna do Curso de Geografia, Universidade Federal do Piauí, sisi.fontineles@hotmail.com.
} 
características da globalização e industrialização. Pode-se concluir que este recurso ilustrativo apresenta-se com grandes potencialidades no âmbito educacional, pois além de despertar a curiosidade do aluno, faz com que este se interesse pelo conteúdo que está sendo trabalhado em sala de aula, bem como possibilita uma maior articulação e mobilização dos alunos na construção da cidadania.

Palavras-chave: charge; recurso didático; geografia.

\section{Abstract}

In considering the most diverse didactic approaches in geography, this work aims to analyze the capacity of knowledge production from the use of cartoons in school learning, taking advantage of the innovation power that the Institutional Program of Initiation to Teaching (PIBID) teaching-learning process. In order to do so, the cartoon was used as a didactic resource, with a view to more dynamically addressing the content of globalization and industrialization, targeting CETI Governor Freitas Neto's 1st year high school students, located in the municipality of Teresina, state of Piauí, Brazil. Thus, it is observed the importance of the use of cartoons in the teachinglearning process in geography, since from this it becomes easier to assimilate the content worked in the classroom according to the with the reality of the student. Therefore, the charge enhances the students' learning through the construction of a reflection geographic and educational production, bringing complex themes of everyday reality and the school community, such as the characteristics of globalization and industrialization. It can be concluded that this illustrative resource presents great potential in the educational field, because in addition to arousing the curiosity of the student, makes him interested in the content that is being worked in the classroom, as well as enables greater articulation and mobilization of students in the construction of citizenship.

Keywords: cartoons; didactic resource; geography.

\section{Introdução}

Ao considerar as mais diversas abordagens didáticas na geografia, menciona-se que a charge tem sido um instrumento didático-pedagógico que envolve habilidades no campo teórico e prático, em virtude de proporcionar nossas possibilidades no ensinar e no aprender da ciência geográfica, pois é através das representações que se 
estabelecem as relações com o que é observado e apreendido (Silva e Cavalcanti, 2008).

É importante salientar que a charge é um gênero textual imagético, que permite rápida leitura e transmite diversas informações de forma sucinta, exigindo conhecimentos prévios e faz sua crítica utilizando sempre o humor (Lessa, 2007). Destaca-se a charge como uma possibilidade de intermediar o aprendizado do aluno, auxiliando na fixação e na compreensão de conteúdos escolares, como também dos assuntos que envolvem a sociedade na qual estão inseridos, além de propiciar e trabalhar diversas competências do ambiente escolar, como interpretação, interdisciplinaridade, escrita/redacional, dentre outras habilidades educacionais.

Conforme Torres e Moura (2012), o emprego da charge nos assuntos da disciplina de geografia torna-se viável, didaticamente, pela mesma ter funcionalidades interrelacionais e fenomenológicas, pois relata um fato ocorrido em uma época definida no espaço e no tempo, dentro de um determinado contexto cultural, econômico e social específico e que depende do conhecimento desses fatores para ser entendida, tendo em vista que as ações se materializam no espaço geográfico.

A utilização das charges nas aulas de geografia tende a propiciar mudanças no ensino, rompendo com o modelo tradicional de somente seguir os conteúdos abordados e exemplificados no livro didático (Zanatta, 2011). Meirelles e Vilar (2017) explicam que o objetivo é demonstrar que essas aulas possam ser mais prazerosas e que possam transmitir mais conhecimentos, a partir da materialização dos conceitos.

Através de suas características humorísticas e satíricas, a charge proporciona uma visão mais crítica dos problemas vivenciados na contemporaneidade. Ao depender do contexto, desperta o interesse e a capacidade de interpretação de diversos assuntos, através das mensagens implícitas e explícitas da realidade, favorecendo a socialização do conhecimento e o sucesso no ensino e na aprendizagem, quando bem trabalhado pelo profissional docente (Castrogiovani, 2001).

Diante do exposto, objetiva-se no estudo em epígrafe analisar a capacidade de produção do conhecimento a partir do uso de charges no aprendizado escolar, aproveitando o poder de inovação que o Programa Institucional de Bolsas de Iniciação à Docência (PIBID) propicia no processo de ensino-aprendizagem. Portanto, a mesma foi utilizada na perspectiva de abordar com mais dinamicidade o conteúdo de globalização e industrialização, tendo como público-alvo os alunos do $1^{\circ}$ Ano do Ensino Médio do CETI Governador Freitas Neto, localizado no município de Teresina, estado do Piauí, Brasil. 
Portanto, corrobora-se que este recurso ilustrativo apresenta-se com grandes potencialidades no âmbito educacional na geografia escolar, pois além de despertar a curiosidade do aluno, faz com que este se interesse pelo conteúdo que está sendo trabalhado em sala de aula, bem como possibilita uma maior articulação e mobilização dos alunos na construção da cidadania, considerando a sua realidade.

\section{Material e Método}

A atividade em pauta consistiu na realização de uma prática didática com os alunos do 1ํ Ano do Ensino Médio do CETI Governador Freitas Neto, localizado no município de Teresina, estado do Piauí, Brasil, de modo que os alunos pudessem observar e compreender o espaço geográfico a partir da utilização do uso da charge, na perspectiva de abordar com mais dinamicidade o conteúdo de globalização e industrialização.

A referida atividade foi planejada e desenvolvida pelos bolsistas do Programa Institucional de Bolsas de Iniciação à Docência (PIBID), da área de geografia da Universidade Federal do Piauí (UFPI), em conjunto com a professora supervisora da unidade escolar, no intuito de compartilhar com os alunos os conhecimentos a partir da mediação com a charge, enquanto instrumento de ensino e aprendizagem dos conteúdos geográficos.

Deu-se início ao trabalho com um diálogo sobre a atividade a ser realizada com a turma, na perspectiva de contextualizar o conteúdo (globalização e industrialização) e o instrumento a ser utilizado (charge). Ao apresentar a charge, como um recurso didático, objetivou-se instigar a curiosidade e a criatividade dos alunos para o assunto a ser trabalhado, no intuito de materializar os conceitos de forma intuitiva e atraente para o público escolar, considerando a realidade dos alunos. A partir do planejamento didático, foram traçados os objetivos a serem alcançados com a produção e utilização do material a ser produzido.

Após revisar com os alunos o que são charges e o que é linguagem verbal e nãoverbal, apresentaram-se os conceitos para os alunos, partindo dos seguintes questionamentos: Qual mensagem está sendo transmitida, por meio da linguagem não-verbal da charge? E pela linguagem verbal? Qual a relação existente entre a mensagem em linguagem verbal e não-verbal? Qual efeito de sentido é provocado pela mensagem em linguagem não-verbal? 
Em seguida, solicitou-se que os alunos fizessem uma apresentação de suas análises e reflexões a partir do conteúdo a ser abordado e, logo após, coletivamente, foram explorados aspectos das charges que não foram contemplados nas falas dos alunos, considerando a temática globalização e industrialização e suas relações com as charges. Para finalizar, foi solicitado aos alunos (equipes com 4 membros) que produzissem suas próprias charges e construíssem um pequeno livreto, abordando os conhecimentos adquiridos em relação à unidade estudada.

Não obstante, corrobora-se que o momento mais interessante durante a realização da atividade foi a criação das charges e a exposição dos livretos pelos alunos, oportunidade em que todos tiveram contato com as produções dos colegas e pela possibilidade de verificar a percepção que eles conseguiram materializar sobre os acontecimentos retratados no cotidiano.

Portanto, no intuito de assegurar o sucesso da atividade, destacam-se as assertivas apresentadas por Antunes (2010), ao mencionar que o planejamento didático na geografia é uma etapa fundamental para o sucesso do trabalho, uma vez que, com a realização de um bom planejamento, pode-se assegurar que os objetivos traçados sejam realmente alcançados durante a aula, enfatizando a importância da assimilação e aplicação da aprendizagem significativa, na qual o aluno é visto como principal agente.

Nesta perspectiva, Rodrigues e Otaviano (2001) comentam que quando se relaciona os conteúdos vistos em sala de aula com a situação vivenciada pelos alunos, tem-se uma forte tendência em desenvolver neles uma sensibilização maior nas características teórico-prática, além de propiciar o enriquecimento harmonioso do aluno na aquisição de novos conhecimentos.

Salienta-se que o conteúdo, globalização e industrialização, foi escolhido pelo fato de ser o assunto constante no livro didático naquele momento do trabalho em sala de aula, sendo que o mesmo tem o intuito de instruir o professor no conteúdo curricular, mas o docente pode aproveitar o potencial que tem, em conjunto com seus alunos, e desenvolver ferramentas e estratégicas mais exitosas no ensino, como a utilização da charge como recurso didático.

\section{Resultados e Discussões}

Diante das complexidades que imperam no ambiente escolar, sobretudo em relação aos conteúdos que trazem consigo a necessidade de uma ampla abordagem teórica 
para a sua completa compreensão, como é o caso do tema globalização e industrialização, considerando o viés de suas aplicabilidades na realidade dos estudantes, torna-se de fundamental importância o desenvolvimento de estratégias didáticas que buscam atrair o interesse pela temática (Pontuschka, Paganelli, e Cacete, 2009).

Diante deste contexto, a charge surge como uma ferramenta educativa que torna 0 ensino mais instigante em sala de aula, pois o mesmo visa despertar a curiosidade, a criticidade e o questionamento de forma mais atrativa e dinâmica, tendo em vista o caráter envolvente que há para o pleno desenvolvimento de suas ações.

A forma humorística como a mesma é apresentada torna um fator motivador para compreender a realidade, pois é possível fazer uma análise geográfica a partir de vários contextos, de forma mais dinâmica e atraente para os alunos, seja para os alunos do ensino básico ou superior. De acordo com Silva e Cavalcanti (2008), a inserção de charges na escola amplia a capacidade de observação e de expressão, estimulando a fantasia e despertando o prazer estético, o senso de humor e a crítica, tornando a leitura prazerosa e seu hábito saudável de interação em sala de aula.

Diante disso, utilizou-se a charge como um meio didático para intermediar o ensino de geografia no CETI Governador Freitas Neto, localizado no município de Teresina, estado do Piauí, Brasil, aproveitando o contexto e o viés de inovação que o Programa Institucional de Bolsas de Iniciação à Docência (PIBID) propicia para o ensinoaprendizado, particularmente para a área de geografia. Destaca-se que o público-alvo foram os alunos do 1ำ Ano do Ensino Médio da mencionada unidade escolar (figura 1).

Figura 13 - Turma de 1ํAno do Ensino Médio no CETI Governador Freitas Neto, Teresina, Piauí, Brasil.

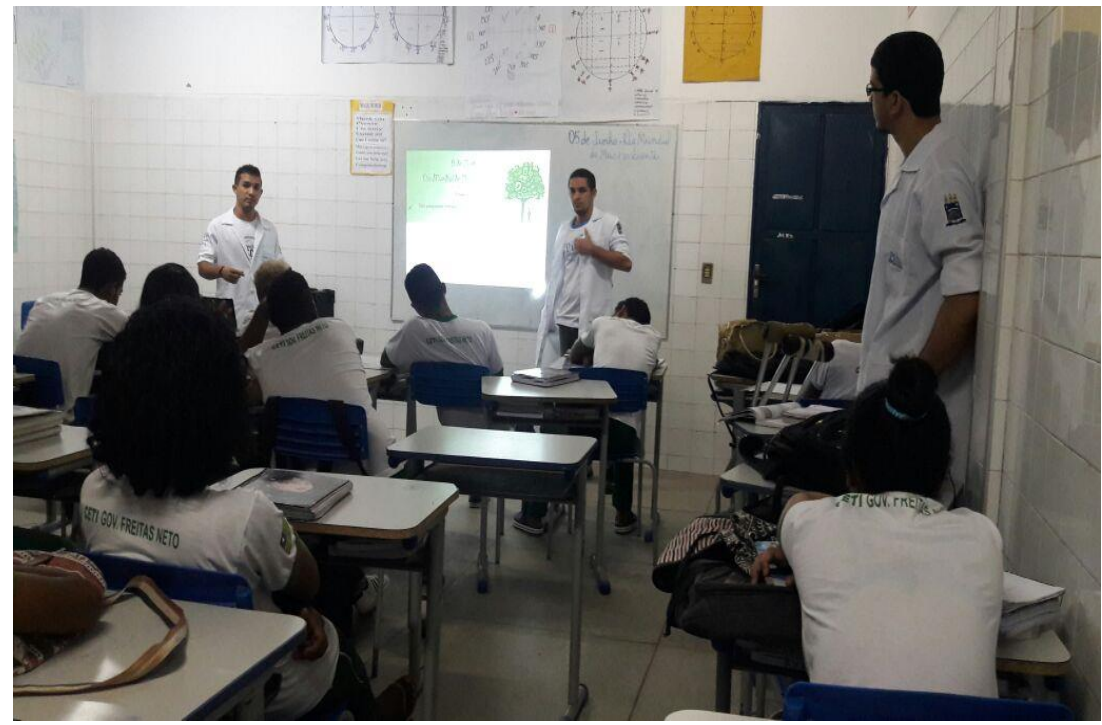


Ao considerar o conteúdo presente no livro didático (primeiro semestre do ano de 2017 - Livro: Geografia o mundo em transição/Geografia Geral: conceitos principais, de José William Vesentini), associado a um desisteresse perceptível por parte dos estudantes, considerando o conteúdo globalização e industrialização, conforme foi constatado em sala de aula, optou-se em trabalhar esta temática por meio da charge, tendo em vista que a mesma apresenta-se como um recurso atrativo no ambiente escolar e que pode ser explorado didaticamente, pois trabalha a prática de leitura e aumenta o leque de conhecimento de mundo, pois este aborda a intertextualidade do espaço geográfico de forma conjunta, indissocializando o espaço e o tempo.

Portanto, dentre as várias alternativas de leitura e interpretação do espaço geográfico, escolheu-se trabalhar com as charges por serem ricas nos aspectos da intertextualidade, permitindo que o aluno, através da linguagem verbal e não verbal, raciocine e analise o que é subentendido nas mesmas, a partir do tema em pauta na sala de aula.

Nesse sentido, a atividade foi iniciada com a explanação do conceito de charge (figura 2), na tentativa de materializar no assunto abordado o seu viés conceitual, trazendo exemplificações que se aproximam da realidade dos alunos, objetivando instigar a curiosidade e a criatividade por meio deste instrumento didático.

Figura 2 - Apresentação das charges para os alunos do CETI Governador Freitas Neto.

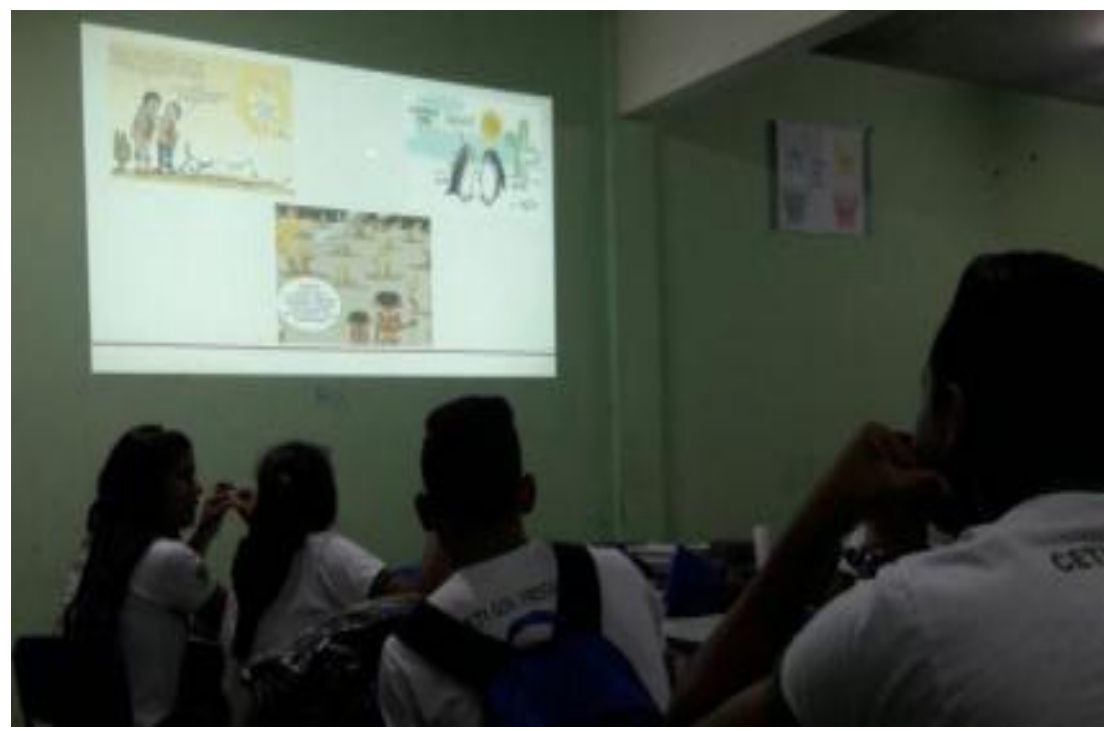

Fonte: Autores 2017. 
Com base em exemplos práticos, a atividade trabalhada em sala de aula contemplou os seguintes questionamentos, sempre sistematizando as ideias por meio de perguntas delineadoras, tais como: Qual mensagem está sendo transmitida, por meio da linguagem verbal e não-verbal da charge? Qual a relação existente entre a mensagem em linguagem verbal e não-verbal? Qual efeito de sentido é provocado pela mensagem em linguagem não-verbal?

A partir destas perguntas guias, foi possível estruturar o diálogo em sala de aula e, consequentemente, instruir as orientações para a construção das charges pelos próprios alunos, na perspectiva que as equipes pudessem elaborar e apresentar, na aula seguinte, os seus produtos, que era a construção de um livreto pautado no tema globalização e industrialização, e suas relações com o seu cotidiano.

Neste contexto, tratando-se da geografia, foi possível trabalhar várias possibilidades temáticas com esse recurso didático, devido ao volume de temas sociais, econômicos, políticos e ambientais que permeiam o ambiente da globalização e da industrialização, tais como os que são apresentados nas figuras 3, 4, 5 e 6 .

Figura 3 - Livreto 1 elaborado pelos alunos do $1^{\circ}$ ano do CETI Governador Freitas Neto.
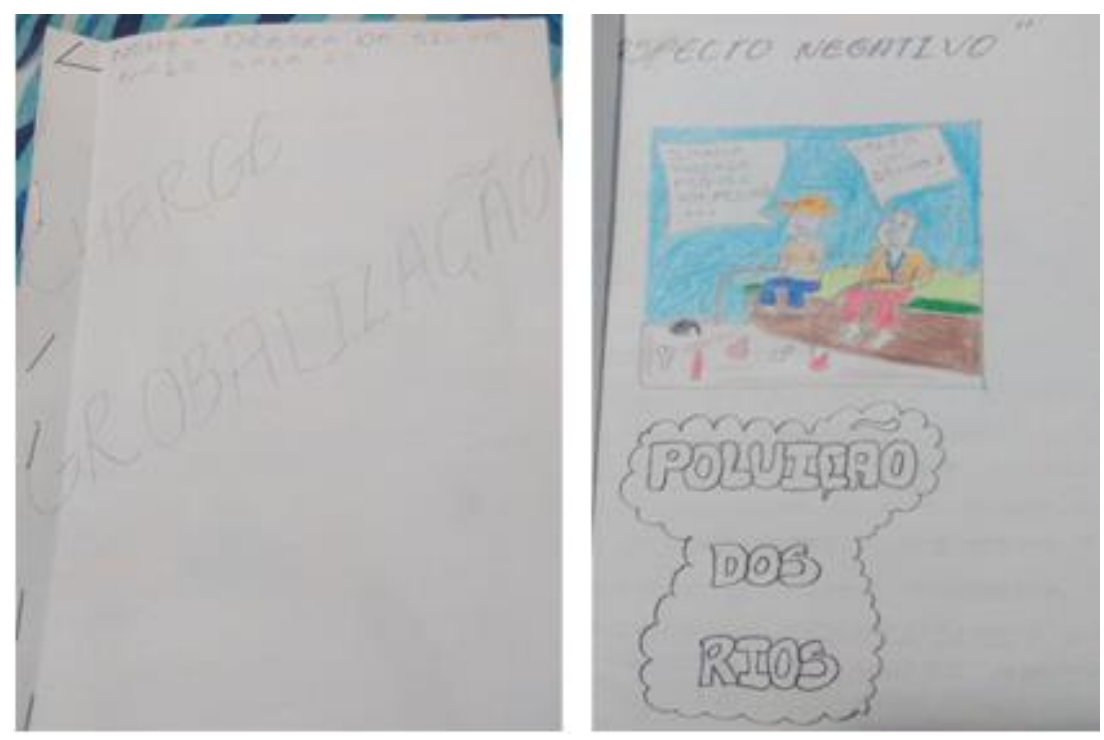

Fonte: Autores 2017. 
Figura 4 - Livreto 2 elaborado pelos alunos do $1^{\circ}$ ano do CETI Governador Freitas Neto.

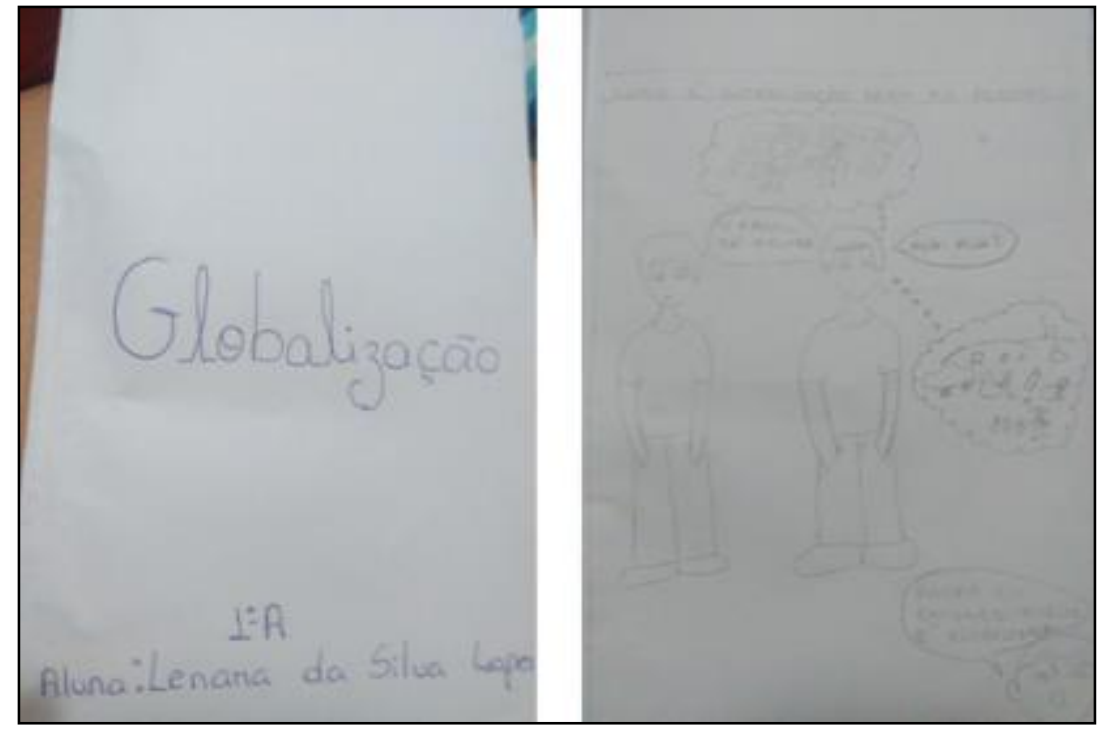

Fonte: Autores 2017.

Figura 5 - Livreto 3 elaborado pelos alunos do $1^{\circ}$ ano do CETI Governador Freitas Neto.

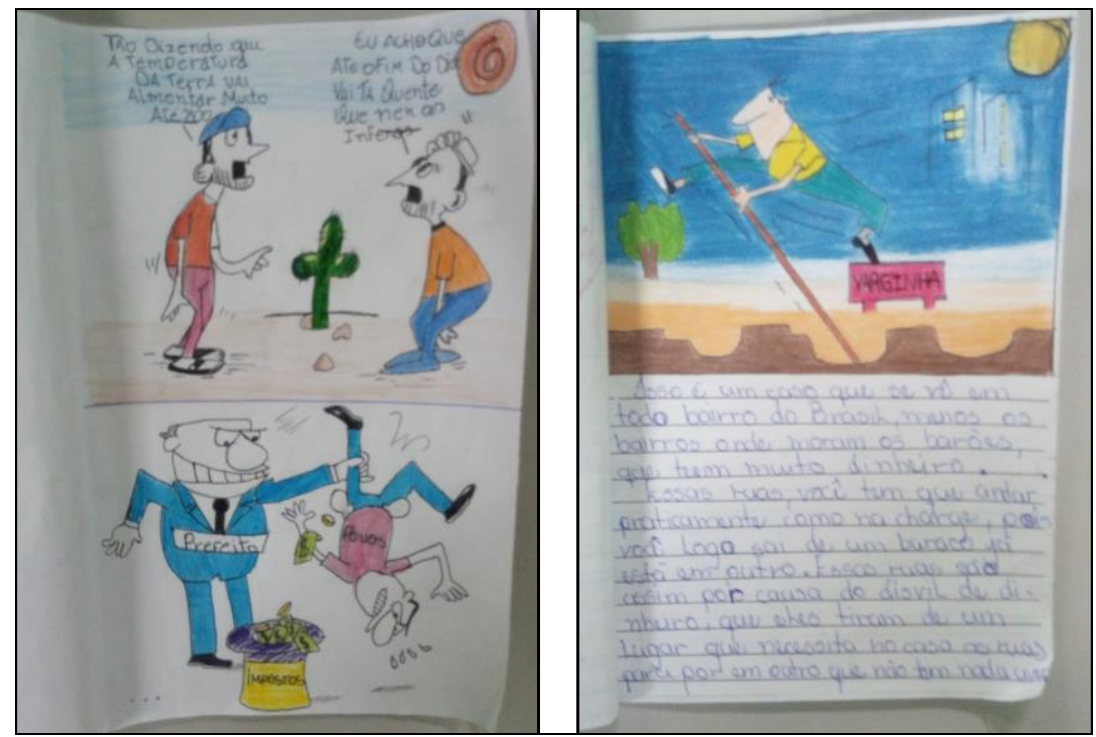

Fonte: Autores 2017. 
Figura 6 - Livreto 4 elaborado pelos alunos do $1^{\circ}$ ano do CETI Governador Freitas Neto.

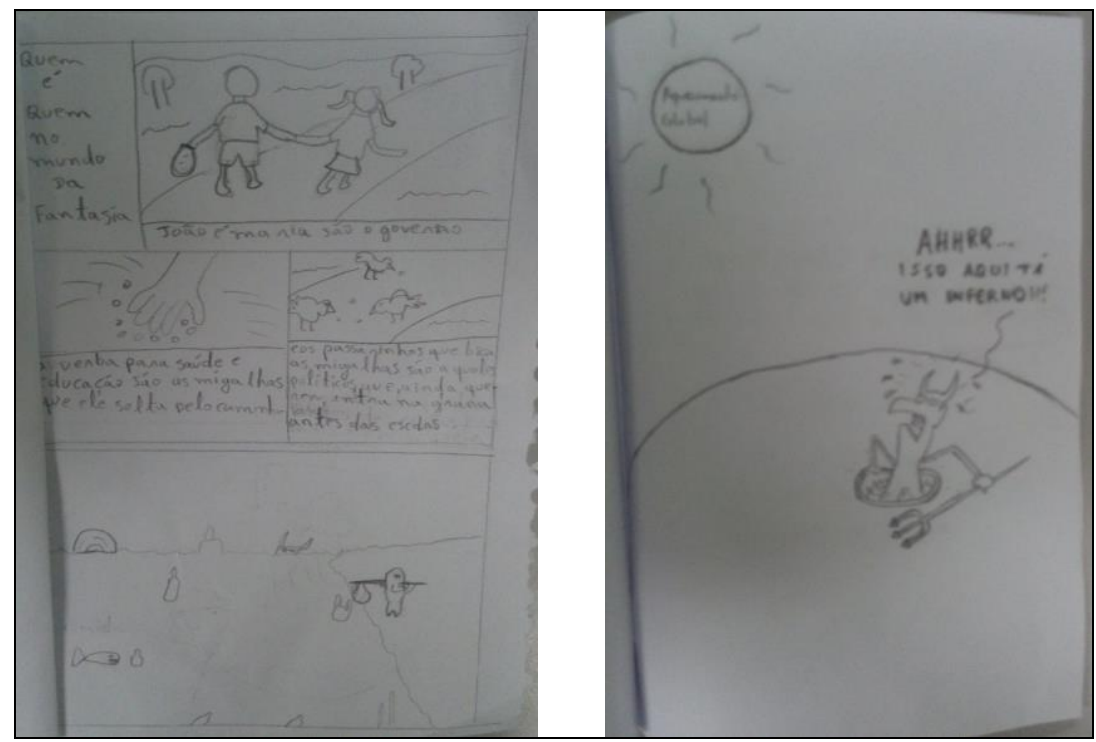

Fonte: Autores 2017.

Diante do que foi apresentado, é evidente que os principais eixos de discussões em sala de aula, com base no viés central da globalização e industrialização, foram pautados nas charges a partir dos seguintes temas: poluição ambiental; relações de poder; classes sociais; disparidades socioeconômicas; questões infraestruturais entre o urbano e o rural; taxa de impostos; mudanças climáticas e; casos de corrupções na política, particularmente nas empresas estatais.

Nessa perspectiva, considerando a culminância exitosa das apresentações, foi possível vislumbrar os elementos que compõem o espaço geográfico a partir de diversas escalas de análises e percepções, sendo que esta abordagem foi realizada pelos alunos de forma clara e concisa, expondo questões de extrema importância que, muitas das vezes, não são apresentadas a contento no livro didático.

Nesse sentido, o professor tem que conhecer os delineamentos da aprendizagem a partir das mais diversas realidades onde se encontra a unidade escolar, no intuito de desenvolver estratégias e técnicas capazes de instigar o interesse dos alunos e, consequentemente, de demonstrar a importância do conteúdo didático em sua formação, enquanto cidadão e ciente de seus direitos e deveres, possibilitando, via de regra, uma maior articulação e mobilização destes na construção da cidadania.

É válido enfatizar a importância da assimilação e aplicação da aprendizagem significativa no ambiente escolar, na qual o aluno tem que ser visto como o principal agente de transformação do conhecimento, tendo em vista as aprendizagens já 
enraigadas em suas vivências e práxis cotidiana (Callai, 2013). Por isso, os livretos produzidos contemplam um pouco de sua história e de seu aprendizado, tendo em vista que os mesmos são constructos de vivências e experiências.

Desta forma, os elementos apresentados potencializaram o entendimento da realidade por parte dos estudantes, tendo em vista as necessidades e estratégias didáticas que facilitam a relação entre o conteúdo formal e não formal da sala de aula. Por sua vez, os alunos demonstraram interesse e compreensão da temática em pauta com 0 instrumento didático utilizado, construindo textos coerentes e representações ricas em detalhes intertextuais que estão materializados no espaço geográfico.

Desse modo, observa-se a importância da utilização das charges no processo de ensino-aprendizagem na geografia, pois a partir desta torna-se mais fácil à assimilação do conteúdo trabalhado em sala de aula com a realidade do aluno. Portanto, a charge potencializa a aprendizagem dos discentes por meio da construção de uma reflexão voltada à produção geográfica e educativa, trazendo temas complexos da realidade cotidiana e da comunidade escolar, a exemplo das características emanadas pela globalização e industrialização.

Corrobora-se que a charge, enquanto recurso didático, apresenta-se com grandes potencialidades no âmbito educacional, pois além de despertar a curiosidade do aluno, faz com que este se interesse pelo conteúdo que está sendo trabalhado em sala de aula, conforme foi constatado com os alunos do $1^{\circ}$ ano do Ensino Médio do CETI Governador Freitas Neto, localizado no município de Teresina, estado do Piauí.

\section{Conclusão}

O estudo foi realizado com o objetivo de relatar a experiência vivenciada em sala de aula com a utilização da charge como instrumento mediador do ensino-aprendizagem de conteúdos da geografia, dando ênfase ao tema globalização e industrialização. Salienta-se que esta atividade foi fruto da proposta desenvolvida pelos bolsistas do Programa Institucional de Bolsas de Iniciação à Docência (PIBID), do Curso de Geografia da Universidade Federal do Piauí (UFPI).

O motivo da escolha desse gênero foi pela possibilidade de se trabalhar com outras linguagens educativas, fugindo do tradicionalismo ainda bem comum no ambiente escolar, que pauta a aula somente no quadro, no giz/pincel e no livro didático. Não obstante, é de suma importância que o professor possa ter a liberdade e a autonomia 
de utilizar ou criar os recursos que melhor se adequem à sua realidade e a de seus alunos, na perspectiva de um melhor ensinar e aprender.

Ao considerar os resultados alcançados com os alunos do $1^{\circ}$ ano do Ensino Médio do CETI Governador Freitas Neto, localizado no município de Teresina, estado do Piauí, Brasil, destaca-se que a charge mostrou-se importante no processo de ensinoaprendizagem, pois além de possuir uma boa aceitação entre os alunos, faz com que eles se identifiquem e a utilizem para expressar seu conhecimento.

Dessa forma, ao ensinar a partir da mediação da charge, o trabalho do professor passa a ter outra função, que é a de cooperar de maneira significativa na aprendizagem dos seus alunos, contribuindo para a formação de cidadãos críticos, aptos a transformar a realidade na qual estão inseridos, tendo em vista a proximidade que se materializa entre teoria e prática.

Ao longo do trabalho realizado, percebeu-se que os alunos demonstraram domínio na leitura das charges apresentadas, o que requer diversas habilidades e domínio dos conteúdos geográficos, ao elaborarem suas próprias charges, permitindo afirmar que a utilização desse gênero textual nas aulas pode torná-las mais motivadoras e instigantes, fazendo com que os mesmos compreendam a realidade geográfica de forma prazerosa e interessante.

Em síntese, os alunos demonstraram muito interesse pelo tema trabalhado e rapidez na assimilação do conteúdo, bem como enriquezeram o debate com suas opiniões, tirando dúvidas e falando de suas experiências, comprovando que quando bem trabalhada em sala de aula a charge pode instigar os alunos a pensarem mais criticamente sobre a sua realidade.

Portanto, a utilização desse gênero é muito importante no ambiente escolar, pois permite que os alunos utilizem o humor para alertar, criticar e gerar posicionamentos diante da realidade, possibilitando uma maior articulação e mobilização dos alunos na construção da cidadania.

\section{Referências bibliográficas}

Antunes, C. (2010). Geografia e Didática. Petrópolis: Vozes.

Callai, H. C. (2013). A formação do profissional de geografia: o professor. ljuí: Unijuí.

Castrogiovani, A. C. (2001). E agora, como fica o ensino da Geografia com a globalização? In Castrogiovanni, A. C., Callai, H. C., Schäffer, N. O., \& KAERCHER, N. 
A. (Eds), Geografia em sala de aula: práticas e reflexões. (pp. 81- 83). Porto Alegre: Editora da UFRGS/AGB-Seção Porto Alegre.

Lessa, D. P. (2007). Gênero textual charge e sua aplicabilidade em sala de aula. Revista Travessias, V(1), 1237-1253.

Pontuschka, N. N., Paganelli, T. I. P., \& Cacete, N. H. (2009). Para ensinar e aprender Geografia. São Paulo: Cortez.

Rodrigues, A. B., \& Otaviano, C. A. (2001). Guia metodológico de trabalho de campo em Geografia. Revista do Departamento de Geociências, V(10), 35-43.

Silva, E. I., \& Cavalvanti, L. (2008). A mediação do ensino-aprendizagem de Geografia, por charges, cartuns e tiras de quadrinhos. Boletim Goiano de Geografia, Goiânia, V(28), 141-156.

Torres, P. S., \& Moura, J. D. P. (2012). A charge como linguagem no ensino de geografia. In A. Y. Asari \& J. D. P. Moura (Eds). Múltiplas Geografias: Ensino, Pesquisa e Reflexão (pp. 291-342). Londrina: UEL.

Meireles, P. S., \& Vilar, M. J. L. (2017, Dezembro). A utilização de charges como recurso didático no ensino da geografia. In VI Encontro de Iniciação à Docência da UEPB \& IV Encontro de Formação de Professores. Realizado pelo Programa Institucional de Bolsas de Iniciação à Docência - PIBID, Universidade Estadual da Paraíba, Campina Grande, BR.

Zanatta, D. R. S. A. (2011). Charges, Cartuns e Tiras Humorísticas a Leitura através das Imagens. Projeto de pesquisa PDE (Inglês). Londrina: SEED e UEL. 


\title{
El paseo geoliterario: una experiencia propedéutica para una ciudadanía competencial
}

\author{
JOSÉ RAMÓN PEDRAZA SERRANO ${ }^{1}$ \\ RICARDO MANUEL LUQUE REVUELTO²
}

\begin{abstract}
El pretender hacer un estudio geográfico de Córdoba y su provincia utilizando la información aportada por los relatos viajeros, plantea en principio dos problemas matizadamente distintos aunque interrelacionados: reflexionar, aunque sea brevemente, sobre las relaciones entre Geografía y Literatura, puesto que aquéllos constituyen un género literario, pero también no olvidar -y sobre ello hay que reflexionar de igual modo- que el relato viajero tiene por objeto esencialmente la descripción de paisajes en el sentido global que los entiende la geografía, y que ello erige a este corpus en una fuente geográfico stricto sensu o en sentido primario.
\end{abstract}

Respecto al primer problema, dentro de una concepción geográfica no reduccionista ni simplificadora, sino inserta en sus clásicos orígenes modernos, los que le trazaron Humboldt, Ritter y sus seguidores, nadie duda de la conexión útil y enriquecedora entre literatura y geografía. Es consustancial a esta última «tomar prestado» cuanto puede ayudar al esclarecimiento de la relación armónica hombre-medio, objeto principal de su análisis, y sin duda la literatura es pródiga en aportaciones de este tipo. Veamos por qué.

No es ajeno a la literatura cuando ayuda a esclarecer la condición humana, que difícilmente es comprensible sin la consideración de que «somos seres-en-un-lugar», de que «necesitamos el paisaje», de que todos estamos «impregnados» por éste, somos «funciones» 0 «hijos» del paisaje, existe una «simbiosis lugar-persona».

Antonio López Ontiveros $(1991 ; 13)$

1 Profesor del Departamento de Ciencias Sociales. I.E.S. Averroes (Córdoba), joserramonps@gmail.com

${ }^{2}$ Profesor del Dpto. de Didáctica de las Ciencias Sociales. Universidad de Córdoba, ch1lurer@uco.es 


\section{Resumen}

Dentro de la Semana Cultural, desde el Departamento de Ciencias Sociales hicimos la propuesta al cercano Departamento de Literatura de realizar el "Paseo Geoliterario por Villaviciosa". Un precedente explica dicha actuación: el "Rally fotográfico Miradas de Villaviciosa" ${ }^{3}$, que nos sirvió para echar a la calle al alumnado de Secundaria a buscar en un tiempo limitado un objeto de atención anunciado por sorpresa en la salida, así como al sector docente y familiar en sus respectivas categorías. Ese espíritu intrépido, desenfadado, competitivo, individual y sensitivo, sirvió para optar por una vía literaria y aprehender el territorio vivido siguiendo un ejemplo textual dado. Objetivo: describir un itinerario en un tiempo marcado en el que, por sorpresa, había que desarrollar algunos aspectos formales que se incluirían en un formato diseñado al efecto y dado en la salida. Nos proponemos puede ser un perfecto marco académico para compartir una experiencia en la que la Geografía coadyuva a generar una ciudadanía comprometida y geográfica.

Palabras clave: Geografía / Literatura / Semana Cultural / Significatividad / / I Ciclo de Secundaria

\section{Abstract}

Within the frame of the Cultural Week, the Department of Social Sciences made a proposal to the close Department of Literature, that of going for a 'Geoliterary walk around the town of Villaviciosa'. A precedent explains such an intervention: the 'Glances of Villaviciosa photography rally', which helped to work outside the classroom with our Secondary School students, as well as with the teaching and family sectors in their corresponding categories, the goal being to look for an object to photograph which was revealed by surprise at the starting line within a limited amount of time. That intrepid, relaxed, competitive, personal and sensitive spirit served to opt for a literary route and aprehend the lived territory following a given textual example. The aim was to describe an itinerary in an established period of time during which participants had to develop certain formal aspects which would be included in a format previously designed to that effect and given at the starting point by surprise. Nos proponemos can

\footnotetext{
${ }^{3}$ Pedraza Serrano, José R. (2009): "El 'rally' fotográfico: un recurso interdisciplinar para el conocimiento del entorno" (Aula de Innovación Educativa, 186); 56-60. Barcelona: Graó.

${ }^{4}$ García de la Vega, Alfonso (2011): "El paisaje: un desafío curricular y didáctico" (Revista Didácticas Específicas, 4); 1-19: "También Vygotsky (2003) afirmó que la lectura y la escritura deben poseer un significado para los niños. $Y$, continuando con su argumento, consideraba que la escritura se enseñaba como una habilidad motora y no como una actividad cultural compleja. Esto quiere decir que hay que darle significado a aquellas producciones literarias, orales $o$ escritas, que los niños realizan".
} 
be the perfect academic framework to share an experience in which Geography contributes to create a committed geographic citizenship.

Key words: Geography / Literature / Cultural Week / Significance / Upper Secondary Level of Secondary School

\section{Introducción}

En las VI Jornadas de intercambio de experiencias didácticas en Ciencias Sociales (CEP Luisa Revuelta, Córdoba, 2014) presentamos la comunicación "Recursos complementarios en la enseñanza geográfica" ${ }^{5}$ (Pedraza, 2015), en la que quisimos exponer algunos ejemplos de la riqueza de posibilidades didácticas con las que puede contar la ciencia geográfica en Secundaria a pesar de las innumerables dificultades que impiden desplegar todo el potencial educativo que debiera tener el conocimiento, el pensamiento y la vivencia espacial (Hernández, 2011).

Figura $n^{\circ}$ 1. Mapa conceptual de recursos complementarios en la enseñanza geográfica

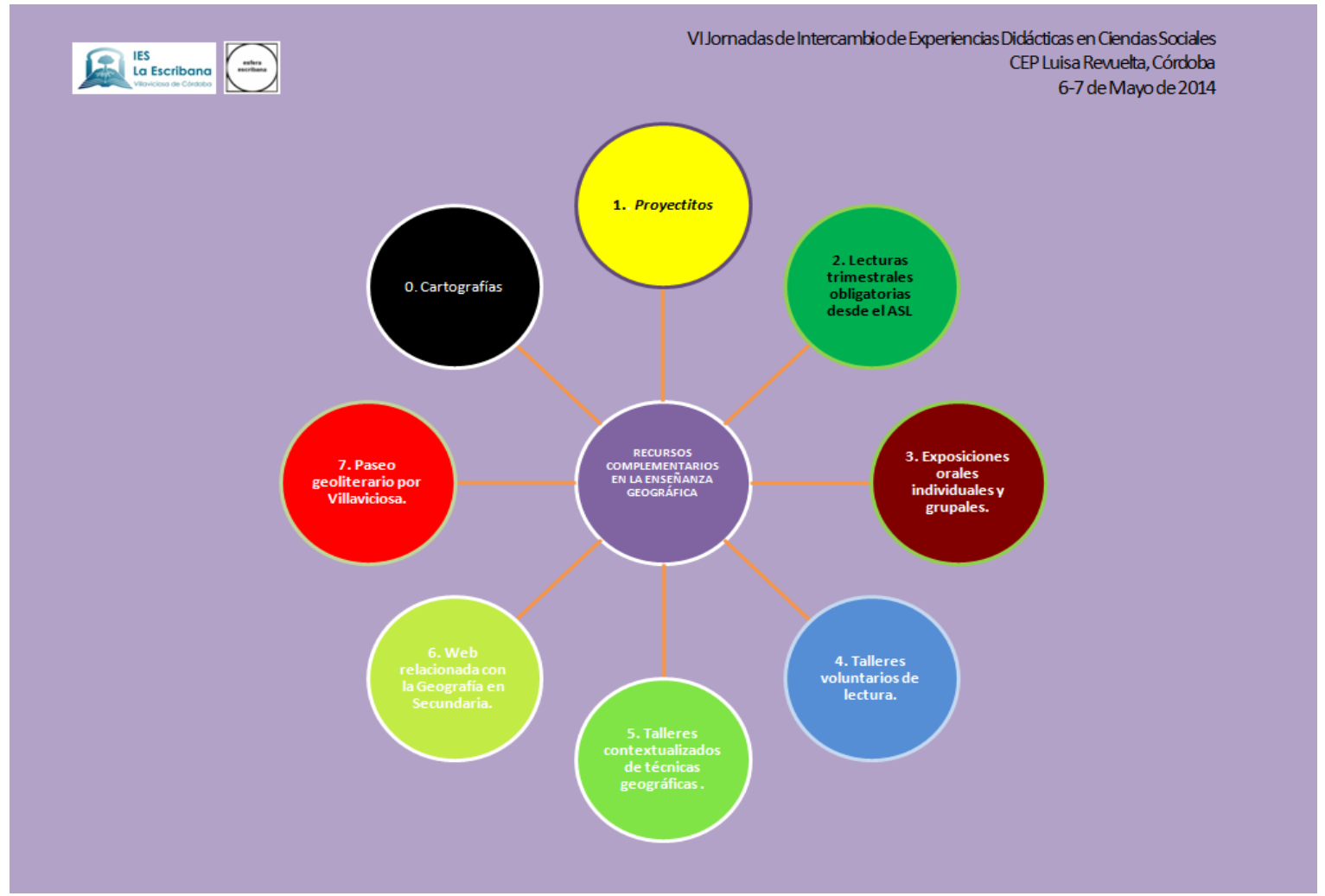

Fuente: Elaboración propia

\footnotetext{
${ }^{5}$ También disponible en <blogdepaisaje.blogspot.com>/ Paseo geoliterario...
} 
En aquella ocasión fueron varios y variados recursos los que quisimos compilar y desarrollar con el objetivo de dimensionar y enriquecer el repertorio de actividades (muchas de ellas competencialmente bien diseñadas e interconectadas con los contenidos teóricos), incluyendo los talleres específicos que sirven para dar a conocer y practicar con el corpus textual o gráfico que ayuda a adaptar ese trabajo procedimental al contexto territorial y social, y para ejemplificar técnicas propias del método científico por medio de esas estrategias de elaboración (confección e interpretación de gráficos, análisis de fotografías de componente paisajística, trabajo cartográfico,...). Enumerativamente, la propuesta de recursos que llamamos complementarios (en su acepción de incrementar la oferta y tiempos convencionales aproximándonos a la metodología de 'flipped classroom', más una tarea telemática, ora interdepartamental, ora voluntaria, ora doméstica) fueron:

- "Proyectitos" de ampliación: investigación de un aspecto de detalle a través de un documento gráfico elegido de todos los contenidos en cada una de las unidades, y ajuste riguroso a un formato resultado de la aplicación de unas pautas; digital y telemático en la remisión dentro del plazo establecido en cada caso.

- Exposiciones orales, individuales y grupales, siguiendo igualmente los objetivos, indicadores y criterios de evaluación dados a conocer a los discentes, así como la estructura o índice compositivo.

- Lecturas trimestrales obligatorias por ámbitos didácticos en las que la presencia geográfica se materializa en base a los temas seleccionados, 0 convirtiéndose junto a nuestro tema (paseo geoliterario) en otro ejemplo de conectividad disciplinar.

- Cartografías físico-políticas: trabajo extralectivo para conocer la localización, fundamentalmente descriptivo-política, de estados y regiones mundiales a lo largo del I trimestre.

- Talleres voluntarios de lectura, con ofrecimiento de materiales

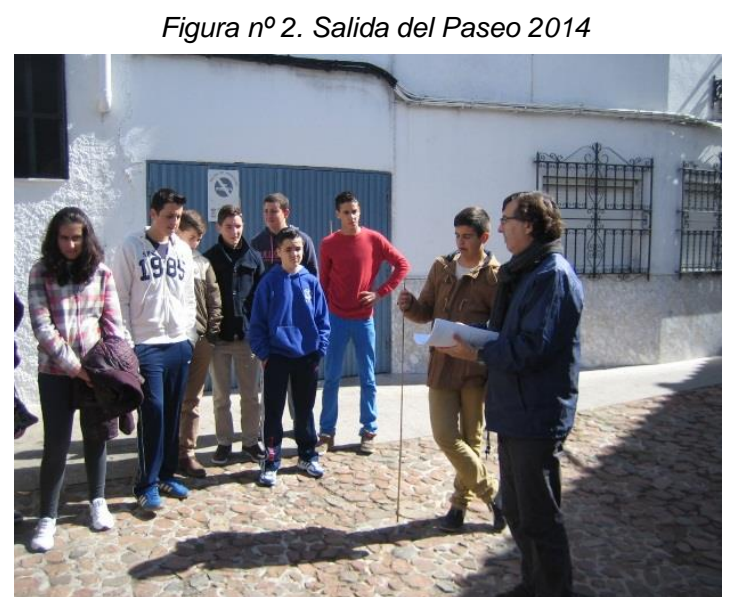

Fuente: Rafael Murillo Infante narrativos, ensayísticos,...que complementen las programaciones. 
- Talleres con técnicas de corte competencial y contextual, reservando una parte sustancial de las pruebas escritas (último apartado o D) para tal fin (escala en el mapa topográfico, análisis de fotografía agraria o planos industriales, disección de la publicidad turística, comentario y realización de mapas de flujos y anamórficos, desequilibrios territoriales a través del valor 100 y su representación en gráficos radiales,...).

- Webs de temática geográfica: esquematización de contenidos ad hoc a cada desarrollo sinóptico, y defensa pública de tal interpretación.

De otro lado, aquel artículo tiene en el último de sus recursos complementarios, que titulamos "Paseo geoliterario por Villaviciosa" y que fue un sillar más en aquel edificio expositivo abocetado de aquellas jornadas, una mera presentación genérica. No conformes con el grado de análisis y confiados en la potencialidad que tiene y puede tener, insistimos en esta acción, lo cual nos sirvió para amplificarla en las VII Jornadas sobre la enseñanza de la Geografía en Secundaria (Universidad Carlos III, Getafe, 13.7.2014) bajo el título "Paseo geoliterario por Villaviciosa (Córdoba): taller paisajístico en una Semana Cultural de temática local", que como en las cinco ediciones anteriores ${ }^{6}$ no tuvo su fragua negro sobre blanco, cosa que ahora hacemos.

Para entender de manera exhaustiva y matizada el entorno sociolaboral sería recomendable la lectura de la introducción y conclusiones del artículo "Recursos complementarios en la enseñanza geográfica" (Pedraza, 2015), en resumidas cuentas, circunstancias condicionantes que, dependiendo del lector, puede hallar próximas, ignotas, y en cualquier caso explicativas ${ }^{8}$.

Por último, y siguiendo la línea pedagógica de excursionar (Martínez de Pisón; Benejam y Pagès, 2004,...) a fin de ejercitarse en el arte del relato viajero por itinerarios o sendas paisajísticas, manifestar la intención de mantener, por un lado, sin modificación el ejercicio a fin de conseguir el cotejo interpromocional, y, de otro, hacer propuestas diferentes en función del nivel psicoevolutivo y curricular de la etapa.

\footnotetext{
${ }^{6} \mathrm{Cf} . \mathrm{http}: / /$ www.age-geografia.es/site/cursos-de-profesores/ [ultimo

Fuente: JRPS

7 También disponible en <blogdepaisaje.blogspot.com>/ Paseo geoliterario...

${ }^{8}$ Apostillar solamente el condicionamiento que ha supuesto históricamente el aislamiento de la población en un vacío demográfico propio de la Sierra Morena andaluza, con toda la incidencia que ello tiene a nivel sociológico y antropológico, mentalidades, niveles de renta, conservación de la naturaleza, etc.
}

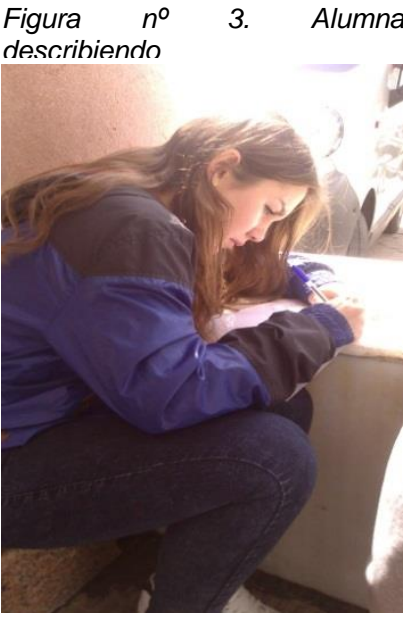


La adaptación al contexto, sea cual sea la temática de la Semana Cultural, también es un reto estimulante como se verá en epígrafe posterior.

\section{La descripción como recurso geográfico}

Describir tiene en esencia, definitoriamente, la espacialidad. Carmen León González, profesora de Lengua y Literatura ( $L Y L)$, arguye que "al describir hay que situar los objetos en el espacio con precisión". Es el reflejo de cómo son las personas, los paisajes, las cosas, explicando sus cualidades, su ubicación. La observación atenta, la selección de los detalles, la organización en un orden elegido de los datos, y las coordenadas geográficas, el dónde. Lo normal es presentar una visión general del lugar, luego se localizan los elementos y trufadamente se transmite la impresión que produce el sitio con todo aquello que lo ocupa y forma.

Teóricamente, la descripción, de manera dual, se agrupa en objetiva (la realidad como es) y en subjetiva (reflejo de sentimientos y emociones). Entroncada a esta figura literaria está la narración, esto es, el relato de un narrador de hechos reales o imaginarios de personajes (historia o trama de actores principales o secundarios) en unos escenarios o marco ("hay que situar la acción en el espacio y el tiempo (...) para que la historia parezca real e interesante").

Programáticamente, la susodicha lo plantea del siguiente tenor:

Ejercicio de escritura

Para esta actividad el alumno deberá conocer y utilizar técnicas de expresión escrita correspondientes a la expresión de textos descriptivos y narrativos ya que se aúnan dichos procesos en la creación de un texto que recoge las experiencias extraídas de un paseo por la localidad.

Se siguen las indicaciones de la descripción para lugares y personas, y se obtiene la parte narrativa de las acciones que se producen. En este caso el narrador escogerá el punto de vista de la $1^{\circ}$ persona y las acciones podrán ser expresadas en orden lineal o establecer una orden subjetiva dada su intención literaria.

La finalidad estética de los textos literarios, con el uso peculiar del lenguaje, es lo que Figura $n^{\circ}$ 4. Dos alumnos en plena actividad motivó y justificó esta aventura. La narración como "avance" de la historia en una determinada sucesión temporal permite la conjunción geográfica en un único ejercicio intelectual. Es necesario describir, "pintar" ambientes o lugares que den cuerpo a la

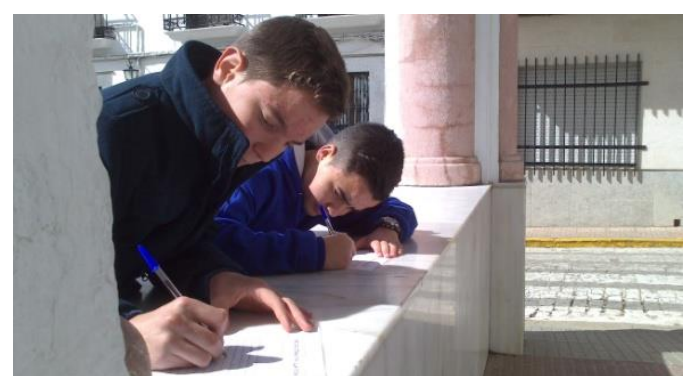

Fuente: JRPS 
narración, para nosotros de un itinerario. La dimensión espacio-temporal, literalmente, siempre es indispensable para albergar la virtud de la verosimilitud.

El paseo precisa de narración y descripción, pintura dinámica con palabras ${ }^{9}$. No es éste el lugar de hacer teoría lingüística, rasgos o tipos. Todo ello el alumnado lo estudia y repasa como preparación antes de acometer su andadura. Y no sólo estos textos literarios puros como la narración o la descripción, también algunos periodísticos o mixtos como el reportaje o la crónica, siempre útiles para el relato viajero, por la observación, selección, variedad, enfoque, documentación, diacronía, valoraciones, libertad.

Si el Rally fotográfico "Miradas de Villaviciosa" fue el claro precedente del paseo geoliterario a lo largo de cuatro ediciones (Pedraza, 2009b), el otro eje que permite sostener la propuesta actual fue la exposición "El viaje a la imagen y a la imaginación: descripciones y visiones" (2010/2011), colgada en la Galería de Paisaje del instituto La Escribana (Villaviciosa, Córdoba), y que marcó un precedente y una tendencia para apostar por hibridar currículos y generar nuevos productos escolares ${ }^{10}$. En dicha

\footnotetext{
${ }^{9}$ García de la Vega, Alfonso (2011): Art. Cit.: "Asimismo, la expresión oral y escrita es una fuente de fortalecimiento de otras habilidades relacionadas con la lengua, así como el procesamiento de información y la elaboración de informes y documentos para el análisis de los procesos geográficos. Canals (2001) ofrece un caso práctico en educación secundaria, donde la producción de textos genera y promueve la adquisición de conceptos, habilidades, estrategias, así como de recursos y valores relacionados con la geografía. El objetivo de estas actividades gira en torno al conocimiento real del territorio". (9)
}

10 En la Gala de entrega de premios de "P.a.i.s.a.j.e. IV Concurso educativo de fotografía paisajística andaluza", sobre ese mestizaje disciplinar en el que el paisaje geográfico se convierte en imán para el trabajo integrado, expusimos: "Buenas tardes a todas y todos, daros la bienvenida y las gracias por asistir a esta Gala de Entrega de los Premios de "P.a.i.s.a.j.e. IV Concurso educativo de fotografía paisajística", organizado por Esfera Escribana, dentro y desde el IES La Escribana de Villaviciosa de Córdoba. Desde hace tres años, esta entrega la queremos hacer coincidir con el Día Mundial del Medio Ambiente que se celebró el pasado martes día 5 de junio.

El pasado 14 de marzo Paisaje comenzó a llamarse y a verse en la televisión como "Proyecto Paisaje", algo más que un concurso del motón que empieza y termina y se repite. Canal Sur TV, en ese magnífico "Club de las ideas" puso su mirada en La Escribana, como en otras ocasiones, y pregonó una seña identitaria joven, sin arrugas, fresca: el paisaje, ése que desborda su Galería de Paisaje, que excede al Concurso en sí o a los temas geográficos propios del curriculum de $1^{\circ}$ o $3^{\circ}$. De entrada, mejor ahora que después, mis gracias a Paco [García Rueda] por su ahínco, por la ilusión por defender lo que es esencia, lo que nos hace ser diferentes, no mejores, sí escribanos/as; ánimo en discernir lo que haya que discernir. Y sin cejar en la mejora, seguir discerniendo, cerniendo sin parar para evitar en lo posible visajes.

El desbordamiento del paisaje significa que Comenius, el intercambio internacional mayúsculo y sin precedentes en este pueblo, ha sido paisaje: el pueblo, Córdoba capital, la provincia, el miniconcurso que hicimos en el camping y que fallamos en la Casa de la Cultura; desbordamiento es la petición de Carmen [León González] en 
muestra compartida se trabajó la etimología (describere), la definición castellana (DRAE, representar lingüísticamente) y políglota (francés, inglés, portugués, alemán, italiano), la clasificación (según actitud -objetiva, subjetiva-; según el objeto abstracciones, concreciones $-\mathrm{y}$ ahí, además de personas o hechos, "lugares, topografía y locus amoenus").

El texto de presentación de dicha exposición, a modo de cancel, ya fue demostrativo:

El trabajo interdepartamental debe ser el camino adecuado para conseguir la educación por competencias. En esta exposición sobre la DESCRIPCIÓN, los Departamentos de Lengua y Literatura y Ciencias Sociales. Geografía e Historia pretenden mostrar una exposición con algunos materiales en los que, textual, gráfica y plásticamente, se descubren algunos ejemplos descriptivos. Un ejercicio para el intelecto y el corazón.

Departamentos de Lengua y Sociales

"Rutas Literarias", proyecto que titula "Apre-he-nder otros paisajes y figuras"; desbordamiento es seguir defendiendo comunicaciones en varios congresos 0 seminarios nacionales o internacionales, geográficos o pedagógicos, en los que La Escribana suena a paisaje; desbordamiento es la Formación en Centros en la que el paisaje inunda el proyecto y la acción, como ahora veremos; desbordamiento es la Escuela de Madres, en la que amagamos - más que otra cosa- con un proyecto que está a medio hacer y que gira sobre el conocimiento competencial y digital de Villaviciosa; desbordamiento es Sophía, esa aventura inacabada, preciosa y creciendo, en la que estamos aplicando el método científico al territorio pateado con afán de mejorarlo, intentando "circular con cabeza" para no darnos de frente; desbordamiento es una amagante Patrulla Verde en el programa convivencial del instituto. El desbordamiento es defender la Educación para la Ciudadanía participando en el Concurso "El País de los Estudiantes", vertebrando dicha reivindicación desde el paisaje a través de una entrevista en un proyecto conjunto de Paco, Antonio [Estrada Parra] y éste que os habla, defendiendo el paisaje como el derecho de las gentes a participar en la gestión, ordenación y protección de su territorio antes que las decisiones tecnocráticas que, por otra parte, son necesarias y a veces insustituibles.

El colmo del desbordamiento llega cuando en la Prueba andaluza de Diagnóstico, para alumnado de $2^{\circ}$ en la Competencia Cultural y Artística, nos encontramos con el siguiente ejercicio: "Como actividad de fin de curso, se ha convocado en el instituto un concurso de fotografía de paisajes. De todas las fotografías presentadas se han elegido tres, por su colorido y las sensaciones que éstas producen en las personas del jurado. El color puede transmitirnos sensación de calor o frío, podemos asociarlo con el agua o el fuego, con el hielo o la sed,.... Pregunta 6. Escribe al menos dos sensaciones que te produce mirar cada imagen y explica por qué. Pregunta 7. Cada color puede asociarse a ideas y significados que varían según cada pueblo o cultura. Por ejemplo, en la India la muerte se asocia con el blanco, mientras que para el mundo occidental la muerte se asocia con el color negro. Une con una flecha cada color con el significado que se le atribuye en nuestra cultura".

El desbordamiento va empapando, lluvia fina e incesante. Mi alumnado de 3으, aprendices geógrafos -harticos de mapas, gráficas y talleres insospechados-, puede ser un botón de muestra. Con la ayuda, sutileza y gentileza de la profesora Carmen León, con la que compartí experiencia y aprendizaje, así se mostró en el mediodía peninsular por las ondas de Canal Sur, en nuestra querida Andalucía (y en Marruecos, Gibraltar o Portugal, y en el mundo entero por el Canal Internacional e Internet)". 
Figura $n^{\circ}$ 5. Una profesora recibiendo las

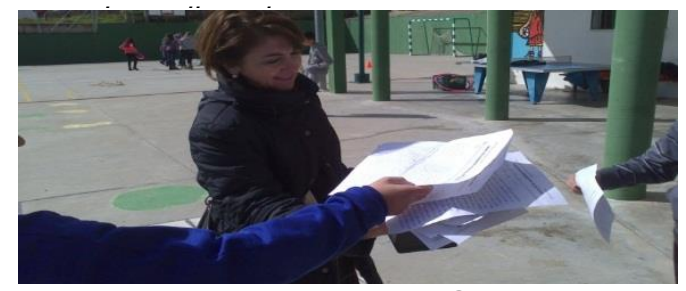

Fuente: JRPS

Numerosos trabajos murales proyectados por el alumnado sirvieron para componer una exposición excepcional, en la que tuvo relumbrante presencia la Geografía a través de una selección de imágenes de "P·a·i·s·a·j·e. Concurso educativo de fotografía paisajística andaluza", que fueron presentadas en secciones con textos de Alejandro López Andrada ${ }^{11}$, Juan G. Nevado Calero ${ }^{12}$ y José R. Pedraza Serrano ${ }^{13}$.

Nuestra aportación a aquella pionera narrativa competencial, en la que el medio geosocial era el necesario trasunto de asépticas y universales teorizaciones, con presencia de retratos de paisanos, hechos sociales, vocabulario del argot, gastronomía corchúa ${ }^{14}$, parajes conocidos,...decía así, inédita hasta ahora y premonitoria de lo que es ya el paseo geoliterario:

La descripción, como la recreación de un paisaje mental o real, debe ser objeto de atención didáctica. Algo aparentemente tan fácil como contar lo visto, o mejor, lo mirado, con los ojos de un observador ávido de dejar indeleble el efímero instante de colores, elementos, formas, movimientos,...no se conseguirá si no es enseñando la técnica descriptiva

\footnotetext{
${ }^{11}$ Alejandro López Andrada: "Villaviciosa: rincón ecológico" (Diario Córdoba, 29.7.1991); 9-11: "...busco el corazón del pueblo blanco. Me adentro en él, disfrutando de un tibio paisaje rural y armonioso, conformado por huertecillos, casitas bajas, corralillos donde se espesan flores y árboles. Después cruzo un laberinto de callejas que suben y bajan, urdiendo un cañamazo sereno y bellísimo. Hay en algunas aceras hermosísimos arriates florecidos, aromados de rosalillos y geranios, que se tienden como sierpes olorosas desde el inicio hasta el final de la calle plácida. Camino perdido, desorientado, por el pueblo,..."

12 Juan G. Nevado Calero (1985): "Una población del siglo XVIII en la Sierra de Córdoba: Villaviciosa", en VV. AA.: Actas I Congreso Histórico Las "Nuevas Poblaciones" de Carlos III en Sierra Morena y Andalucía. Córdoba. UCO - Seminario de Estudios Carolinenses.; 295: "Ubicada entre dos montañas se encuentra la actual población de Villaviciosa de Córdoba, en un paraje frío en invierno y no excesivamente caluroso en el verano, abrigado por la disposición orográfica de las montañas que lo rodean en todas las direcciones menos en la SO, hacen que sea un lugar que reúna las condiciones geográficas idóneas para el asentamiento de pobladores,...".

${ }^{13}$ José R. Pedraza Serrano: Palabras del acto de entrega de premios del Concurso fotográfico de Paisaje (24.6.2009): "No queremos pensar que estuviésemos rompiendo el frágil silencio de un equilibrio sostenible y secular, en el que la naturaleza huele, se escucha, y el verde estalla en verdes dehesas de verdeante pasto salpicado de encinas y manchas de pinares al fondo. En las cercas, ovejas, algún caballo. Viñas y olivos entrecallados. Celeste monocromía de telón, inmaculado azul de fondo escénico.

Pestañeo, pulso, imprimación de luz. Clic, clic.".

${ }^{14}$ Gentilicio oficioso de Villaviciosa de Córdoba; oficialmente, villaviciosano.
} 
desde las edades pueriles. En la mocedad se comienza a describir con cierta precisión. A las pruebas nos remitimos. En la adultez, la descripción debe forjar una manera de ser, el disfrute de dominar el lenguaje preciso que, como excelso escultor, ha estructurado y figurado nuestro pensamiento, a nosotros como tales. Hacer propias las palabras con sus significados nos hace seres únicos, y el manejo de dichos mensajes nos proyecta como somos. Socialmente somos, de manera descriptiva, lenguaje.

José R. Pedraza Serrano

\section{Objetivos}

1. Idear recursos y estrategias espaciales que complementen el contenido curricular geográfico a lo largo de la etapa Secundaria, especialmente en $3^{\circ}$ ESO.

2. Adecuar la variada oferta de actividades a la idiosincrasia y momento educativo que se viva, anteponiendo al aula en tiempo e intensidad a otras situaciones académicas complementarias y extraescolares, no siempre controlables, ni continuistas ni constructivistas.

3. Programar complementariamente como una medida de atención a la diversidad en base a principios de interdepartamentalidad, contextualidad, simplicidad, competencialidad, creatividad, progresividad.

4. Aprovechar las actividades programadas en el Proyecto Educativo de Centro (actuaciones extraescolares, conmemoraciones institucionales,...) para trabajar aspectos geográficos del entorno intentando hacer comprender las claves territoriales en cuanto a la configuración y funcionamiento de la sociedad local (Luque, 2012 y 2013).

5. Usar el conocimiento geográfico contextual para la ordenación, valoración y protección de los elementos patrimoniales (naturales y humanos) y para la mejora de los descuidos, abandonos o agresiones que la actividad antrópica provoque en el territorio (Pedraza, 2009a).

6. Expresar a través de todas las técnicas literarias estudiadas como textos académicos (descripción, narración, exposición) o de medios de comunicación (reportaje, crónica) una selección de contenidos geohistóricos, artísticos, socioeconómicos, políticos, morales o éticos, que permitan aflorar la comprensión y valoración crítica o protectora del medio vivenciado de manera pluridimensional y participada. 


\section{Paseo geoliterario por Villaviciosa}

\subsection{La vía literaria impresionista}

Ese espíritu intrépido, desenfadado, competitivo, singular, individual y sensitivo, sirvió para optar por una vía literaria y no fotográfica y aprehender el territorio vivido siguiendo un ejemplo dado. El mismo era un texto del escritor cordobés Francisco A. Carrasco Jiménez titulado "Oculta tranquilidad" (vid. Anexo I), que ha servido, como título, para dar slogan y publicidad a campañas turísticas locales y comarcales. Dicho texto fue seleccionado como ejemplo idóneo para ser trabajado previamente (justo el día anterior a su realización) en la clase de Literatura por el profesorado de $3^{\circ}$ de ESO, a fin de concretar la idea que se pretendía realizar: describir un itinerario en un tiempo marcado en el que, por sorpresa, habría que desarrollar algunos aspectos formales que se incluirían en un formato diseñado al efecto y entregado justo en el momento de la salida (ver ilustración).

Consensuadamente con el profesor Rafael Murillo $(L Y L)^{15}$, las indicaciones y requisitos que el alumnado debía tener en cuenta para que la creación escrita fuese evaluada lo más positivamente fue del siguiente tenor:

\footnotetext{
${ }^{15}$ En una nota de prensa del citado profesor, éste escribió como reseña para constancia pública de lo realizado: "Previamente a la Semana Cultural, se leyó el texto que aparece en la colección Los Pueblos de Córdoba de Francisco A. Carrasco Jiménez sobre un paseo que realiza el autor por el pueblo describiendo lo que ve, oye y siente por las calles de la localidad. Una vez leído el texto durante la Semana Cultural se le pidió al alumnado de tercero de la ESO que realizara un paseo por diferentes calles de la localidad emulando a Francisco A. Carrasco y que fueran plasmando por escrito lo que veían, escuchaban y sentían".
} 


\section{ACTIVIDAD:}

\section{"TALLER: PASEO GEOLITERARIO POR VILLAVICIOSA"}

Tras la lectura, a modo de ejemplo e inspiración, del texto de F. Carrasco, redacta en unos 25 renglones en el formato que se entrega, y en $1 \mathrm{~h} 45^{\prime}$ elabora un relato sobre Villaviciosa teniendo en cuenta los siguientes requisitos:

1. Movimiento y referencias. Que se note el movimiento del viajero: deberás recorrer al menos 5 calles como mínimo. Referencia a topónimos (calles, lugares, establecimientos,...).

Figura $n^{\circ}$ 6. Alumno entregando su ficha

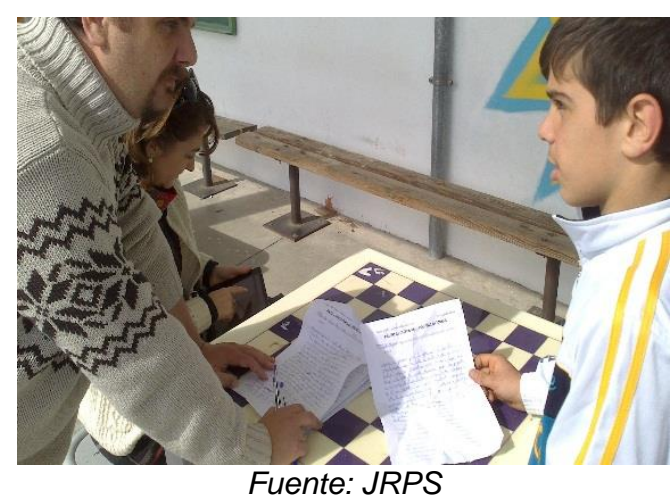

2. La gente. Paisanos hablando (cita entrecomilladas las palabras que digan o que más te llamen la atención). Descripción de alguna persona con la que te cruces en tu viaje.

3. Tono anecdótico. Busca esos detalles que hacen único tu pueblo y única tu percepción. Busca lugares poco frecuentados, vistas poco conocidas, recodos para la tranquilidad típicos de tu pueblo.

4. Referencia a los sentidos y a los sentimientos. Vista, olfato, tacto, gusto, oído; belleza, alegría, desencanto,....

5. El caserío. Describe una casa típica/moderna o una casa/bodega abandonada. Puedes utilizar la objetividad o la subjetividad y expresar lo que sientes al verlas.

El texto deberás entregarlo dentro del tiempo establecido en el Instituto al profesor/a convenido (a modo de un rally literario). Además de la evaluación sumatoria en las áreas de Lengua y Literatura y Ciencias Sociales, participarás con tu elaboración en el Concurso "Paseo geoliterario por Villaviciosa". Tu reconocimiento tendrás en caso de ser distinguido. 


\section{2 "Impresiones y paisajes"}

Distintas rutas fueron las elegidas por el alumnado. A modo de ejemplo, y sin que necesariamente sirvan los siguientes extractos como los más brillantes, sino como variadas demostraciones del nivel medio (más allá de algún que otro pasaje extraordinario o sobresaliente, mas breve), reproducimos algunos sucintos fragmentos que pueden dar una buena muestra de lo conseguido, que, profesionalmente, valoramos de manera muy positiva en el plano intelectual (lingüístico, resolutivo, relacional,...), perceptivo y participativo, y como para Federico García Lorca (1918), fueron las impresiones de sus paisajes ${ }^{16}$.

- "Y subiendo la gran cuesta de la calle Toledo, con el cantar de los pájaros en mis oídos, llego a los depósitos, como mi abuela dice "el rincón más bonito del pueblo", al situarse de forma que se puede ver nuestro pueblo, único en todos los sentidos. Se ve como éste se esparce a lo largo de los montes, observándose a lo lejos una especie de valle. (...) Los sentidos del viento, la hierba, las personas, el mercado, el sonido de la vida cotidiana, este sentimiento rural. Pueblo de bodegas y viña, de campo y modernidad" (Atenea Doctor, $3^{\circ} \mathrm{A}$ )

- "En todas estas calles que he recorrido, Manuel Arribas, Coronel Rafael Vargas, Sevilla, Pozuelo y Portugalejo, me he dado cuenta de que todas las casas, en la parte superior, son blancas, y en la parte de abajo son de azulejos de colores o de piedras. Mi pueblo es un pueblo con mucha belleza, la gente es amable y simpática. Tiene un olor a algo natural". (Sergio Cantero, $3^{\circ} \mathrm{B}$ )

- "Yo enseguida me doy cuenta de que nada es como era antes, mi pueblo había cambiado por completo, las casas eran muy modernas y ya no quedaban bodegas, estaban abandonadas las calles, no desprendían ese olor a vino. Todo había cambiado. Echaba de menos esas casas con dos ventanas y la cámara arriba, blancas, que desprendían alegría..." (Miriam Hernández, 3ํㅡ)

\section{a. Evaluación de las creaciones}

Dicha actividad fue inserta en la Programación Didáctica y por ello ha merecido su correspondiente valoración (algo así como el peso de la corrección de actividades en una unidad didáctica). A tal efecto, y omitiendo las valoraciones y el listado (algunas de ellas fueron especialmente elevadas), la tabla aplicada de valoración fue la siguiente:

\footnotetext{
${ }^{16}$ Una amplia selección de las producciones del alumnado en el Paseo geoliterario de 2014, agrupadas por cada uno de los requisitos, se pueden encontrar en <blogdepaisaje.blogspot.com> / 5. Paseo geoliterario 2014 (Citas de los paseos ordenadas por requisitos).
} 


\begin{tabular}{|l|c|c|c|c|c|c|c|c|c|c|c|c|}
\hline & \multicolumn{9}{|c|}{ CIENCIAS SOCIALES } & \multicolumn{7}{|c|}{ LENGUA Y LITERATURA } & Total & $\begin{array}{c}\text { Nota } \\
\text { final }\end{array}$ \\
\hline flumnado & 1 & 2 & 3 & 4 & 5 & 1 & 2 & 3 & 4 & 5 & & \\
\hline & & & & & & & & & & & & \\
\hline & & & & & & & & & & & & \\
\hline & & & & & & & & & & & & \\
\hline & & & & & & & & & & & & \\
\hline
\end{tabular}

1. Movimiento; 2. La gente; 3. Tono anecdótico; 4. Sentidos y sentimiento; 5. Caserío

\section{Conclusiones}

1. Una actividad complementaria y pluridepartamental como un paseo descriptivo, narrativo o relatado, en el que el espacio geográfico vivido se convierte en escenario de desarrollo y objeto de interés, ayuda a que la maltratada Geografía, ciencia de síntesis, sea trabajada con una extraordinaria gama de recursos 'complementarios' que allegan al alumnado una comprensión y (posible) querencia de los espacios y las sociedades de manera multiescalar y relacional como ninguna otra disciplina.

2. Aunque el aula, tras años de experimentación innovadora, colaborativa y extraescolar, vuelve a ser el reducto en el que hallamos el mejor (a veces único) ámbito para la enseñanza, es siempre recomendable aprovechar cualquier situación o momento educativo (como conmemoraciones o invitaciones de otros seminarios) para converger en proyectos de interacción profesional y contextual.

3. La practicidad y aplicación del conocimiento siempre es motivadora para el alumnado, y así lo valoran en sus percepciones, además cuando la obtención de su calificación procede de recursos evaluativos consabidos, variados, porcentuales y sumatorios, lo cual se traduce en mejores resultados que en cursos precedentes que tuvieron una menor oferta de actividades geográficas (talleres, lecturas, cartografías,...).

4. El índice de aprobados en $3^{\circ} \mathrm{ESO}$, con diferencia, es mayor que en años precedentes, por lo que nos atrevemos a suponer que es el desglose de la nota trimestral en actividades complementarias -más que nunca- y, por otra parte, es el aliciente de disponer de una variada y contrastada gama de ejercicios y prácticas, lo que conduce a obtener una aceptable situación académica y un mejor trato 
interpersonal, una madurez no frecuentemente cultivada, encontrada $y / 0$ conseguida en enseñanzas medias.

\section{Bibliografía}

Benejam, P. y Pagès, J. (2004). Enseñar y aprender Ciencias Sociales, Geografía e Historia en la Educación Secundaria. Barcelona; ICE UAB- Horsori. Col. Cuadernos de Formación del Profesorado, 6. 4를 edic.

Hernández, F. X. (2011). Didáctica de las Ciencias Sociales, geografía e historia. Barcelona, Graó. Serie Didáctica de las Ciencias Sociales, 169 (1ª ed., $7^{\text {ạ }}$ reimpresión) López, A. (1991). La imagen geográfica de Córdoba en la literatura viajera de los siglos XVIII y XIX. Córdoba: Cajasur

Luque, R. M. (2012). "Vivienda y paisajes rurales en Sierra Morena", en Investigaciones Geográficas, 57, 169-192. Instituto Interuniversitario de Geografía, Universidad de Alicante; URI: http://rua.ua.es/dspace/handle/10045/24887

Luque, R. M. (2013). "Paisajes rotos: algunas consideraciones sobre el hábitat rural mariánico a partir de la imagen fotográfica" en Méditerranée, Revue géographique des pays méditerranéens, 120, 101-109. Presses Universitaires de Provence

Pedraza, J. R. (2009a). El conocimiento geográfico del entorno escolar: actividades experimentales de observación y análisis del paisaje vivido, (72-85) en A Inteligencia Geográfica na Educação Século XXI. APG. IV Congreso Ibérico de didáctica de la Geografía 'La inteligencia geográfica en la educación del siglo XXI. Asociación de Profesores de Geografía de Portugal y Asociación de Geógrafos de España. 67/XI/2009. Lisboa

Pedraza, J. R. (2009b). El 'rally' fotográfico: un recurso interdisciplinar para el conocimiento del entorno. Aula de Innovación Educativa, 186, 56-60. Barcelona: Graó

Pedraza, J. R. (2015). Recursos complementarios en la enseñanza geográfica. eCO, 12; 138-186 (49 páginas). Revista digital del Centro de Profesorado de Córdoba. <http://revistaeco.cepcordoba.org/images/pdfcompletos/eco12/\#p=138>

VV. AA. (1994): Los pueblos de Córdoba. Córdoba: La Caja (Fasc. 5); 1731-1754 


\section{ANEXO I}

\section{PASEO GEOLITERARIO POR VILLAVICIOSA}

\section{Oculta tranquilidad ${ }^{17}$}

Villaviciosa aguarda al viajero escondida tras un cerro. Nadie diría que hay un pueblo a su derecha cuando se topa de bruces con el hostal y el colegio público. Y, sin embargo, antaño fue paso obligado, encrucijada de caminos. Aquí se encontraban las rutas de Córdoba a Extremadura -la carretera de Villaviciosa de toda la vida- y de Toledo a Sevilla por el Calatraveño. Hoy, si bien los caminos se mantienen, los tiempos han cambiado y prácticamente nadie los utiliza. Las viejas rutas serranas no han sido capaces de sobrevivir a la modernidad y las prisas.

Ahora, para gozar del aire limpio de Villaviciosa y empaparse de su tranquilidad hay que ir expresamente a ella. El camino más utilizado, si viajamos desde Córdoba, es la carretera N-432, Badajoz-Granada, hasta la comarcal 411, que lleva al pueblo pasando por la misma presa del pantano de Puente Nuevo. Una vez en el pueblo, hay que dejar la carretera, que continúa hasta Posadas, y penetrar en él desviándonos a la derecha por la calle Córdoba, que nos llevará hasta el núcleo originario y centro urbano de la población: la ermita de la Virgen de Villaviciosa.

Hacia la calle Córdoba se descuelgan por la derecha una serie de callecitas situadas en pendiente, como la del Cerretillo, que tiene un apreciable desnivel. "Aquí hay una pechuga buena -comenta Acisclo Arribas al principio de la calle, levantando la mirada hacia lo alto-, pero corre el aire. Usted es que no sabe lo bien que se está en este pueblo". No sé si correrá el aire, porque esta mañana veraniega se ha debido estancar en algún sitio y no se deja sentir. Lo que sí noto es la hospitalidad de la gente, la amabilidad con que responden cuando se les pregunta algo.

En la calle Córdoba, explica Juan Gregorio Nevado, cronista oficial de la localidad y acompañante en este paseo por Villaviciosa, no se permiten balcones porque su estrechez impediría el paso de los camiones. Algunas fachadas de azulejos alteran un paisaje urbano generalmente blanco y de casas discretas. Las casas típicas suelen tener dos ventanas abajo - una a cada lado de la puerta- y otra arriba, en el centro. Son casas de planta baja y cámara en la parte superior, que se usaba como granero.

La calle Córdoba desemboca en la plaza de Andalucía, la Plaza a secas para todo el mundo. Al final de la calle, a la izquierda, queda la ermita de Nuestra Señora de

\footnotetext{
17 Carrasco Jiménez, F. (1994): "Oculta tranquilidad", en VV. AA.: Los pueblos de Córdoba. Córdoba. La Caja; 1735-1738
} 
Villaviciosa, del siglo XVIII, que fue restaurada en 1992. Es el núcleo originario de la población, si bien anteriormente hubo otra ermita cuya ubicación exacta se desconoce. El edificio actual tiene una portada barroca, con un frontón en el que destacan unos azulejos que representan a la Virgen. "La imagen que se venera aquí no es la original -manifiesta Juan Gregorio Nevado-, ya que la original se conserva en la catedral de Córdoba y es diferente".

También en la plaza de Andalucía se encuentra el nuevo Ayuntamiento, para cuya construcción, a principios de los años setenta, se derribó el antiguo pósito, el único edificio público del siglo XVIII que había en Villaviciosa. Un derribo que se hizo en contra de los deseos de muchos vecinos, según apunta Nevado, y privó al pueblo carente de grandes atractivos monumentales- de una de sus construcciones más antiguas. El nuevo Ayuntamiento es un edificio moderno de tres plantas con un soportal de arcos en la más baja. Se inauguró en julio de 1973, siendo alcalde Juan Ruiz Escobar, precisamente quien había ordenado la demolición del pósito. A la entrada, junto a la escalera de acceso a la primera planta, hay un busto de Manuel Arribas Carrillo, alcalde entre los años 1979 y 1987, obra del escultor Juan Polo, realizado por suscripción popular.

Frente al Ayuntamiento está el Casino de Villaviciosa, y a la derecha, el Casino de Currillo, lugar de encuentro de los trabajadores por las mañanas para tomar el café antes de irse al trabajo. Junto a la plaza de Andalucía, separada tan sólo por un paso de cebra, se halla la de España (el Paseo), lugar de encuentro y recreo, de charla con los amigos, verdadero centro humano de la población. El Paseo, que da a un lateral de la iglesia de San José, era antes un cementerio, "y por eso está tan cuadrado", asegura Juan Gregorio Nevado. "No se sabe sin embargo -añade- cuándo dejó de serlo, siempre ha sido paseo". Fue reformado en 1989. En el centro hay una fuente de granito, como las losas del suelo y los poyos que lo rodean, que sirven a la gente de asiento, y frente a la fuente, una puerta lateral de la iglesia. Debajo del Paseo, aprovechando el desnivel existente, se ha hecho la biblioteca. Entre el Paseo y la Plaza se ponen las atracciones de la feria, que se celebra entre los días 15 y 18 de agosto.

La fachada de la iglesia de San José da a la calle Juan Ruiz. Este templo, de bóveda de cañón corrido, fue construido a principios del siglo XIX. El frontal es de estilo neoclásico, y en él destaca una ventana con vidrieras de colores. Las campanas, según Nevado, tienen un tañido perfecto, y el reloj de pesas del campanario, que da la hora en cuartos, se oye a más de siete kilómetros de Villaviciosa. 
Bajando del Paseo por la calle Pérez Galdós, antigua calle Mesones- debido a los establecimientos que había de este tipo que había en ella a finales del siglo XVIII y primeros del XIX-, se va a la plaza dedicada a Juanito Maravillas, cantaor de flamenco natural de Villaviciosa. La plaza queda a la derecha de la calle, y surge como un espacio irreal entre la sobriedad de las casas que la rodean. Se accede a ella por medio de un arco carpanel y está enlosada de baldosas rojas con chinas en las juntas. En el centro tiene dos arriates de azulejos sevillanos y una fuente con la escultura de una mujer con un cántaro, que se ilumina por las noches.

De Pérez Galdós sale también la calle Sevilla, así denominada porque lleva a la carretera que conduce a dicha ciudad. En esta calle se encuentra el mercado municipal de abastos. En su último tramo pasa a llamarse calle del Teniente Coronel Rafael Vargas Nevado, en honor de este militar nacido en la localidad. A su término se halla la zona industrial.

La calle Pérez Galdós desemboca en Manuel Arribas Carrillo, de la que salen otras muchas calles típicas, similares en su estética: Portugalejo, llamada vulgarmente La Cuestezuela, que desemboca en la plaza Arrayanes, dirección Villanueva del Rey; Pozuelo, así denominada porque tiene un pozo del que se surte el mercado de abastos; la calle de la Fuente...”. Artísticamente no hay nada destacable, esto hay que decirlo -señala Juan Gregorio Nevado-. Villaviciosa se ha hecho a base de construir agregando unas casas a otras sin planificación previa. Entonces, como todos eran gente corriente....".

Villaviciosa no tiene ese pozo de misterio que sugieren las casas señoriales, es cierto; ni siquiera tiene grandes calles a las que asomarse; pero goza del encanto y la intimidad que le proporcionan sus calles estrechas y su arquitectura popular. Es un pueblo tranquilo, extendido hacia el sur, que recoge toda la luz y el aire de la sierra.

A la derecha de la iglesia de San José, a la que hemos regresado de nuevo, está la calle Ramón y Cajal, donde se encuentra la zona de diversión juvenil. En esta calle están más definidas las dos plantas en las casas y la superior suele tener balcones de forja artística. Aun así, las casas, al igual que en el resto de la población, no tienen dinteles de granito. De Ramón y Cajal, por la calle Cádiz, se llega a la plaza del Pozo Grande. Aquí es donde acuden los novios del pueblo a hacerse las fotos el día de la boda. Es una plaza pequeñita y coqueta. Al fondo, junto a la pared, hay una fuente de azulejos sevillanos con una gárgola de cabeza de león y una concha que recoge el agua. En el centro -de piedra artificial, como la anterior- hay otra fuente de un niño 
con una oca. El colorido lo ponen los arriates de flores que hay rodeándolo todo, y la sombra, un par de árboles.

Por la calle Agustín López se regresa de nuevo a la Plaza. Cruzándola, a la derecha de la ermita, se encuentra la calle Saúco. Justo a su inicio está la bodega de José Areales, que nos invita a tomar una copa desde la puerta. El olor penetrante del vino impregna el ambiente. De Saúco se desemboca en la calle Ancha o de Juan Carlos I, y a la izquierda, por Tomás Carretero, se abandona la población. Tomás Carretero es una calle de bodegas que da a la carretera comarcal C-411. Girando a la izquierda se va para Almadén y Córdoba -a 48 kilómetros por esta carretera, a 43 por la de los Arenales- y cogiendo a la derecha, a 44 kilómetros, está Posadas. El tramo de carretera que cruza el pueblo con la denominación de calle Nueva se halla también lleno de bodegas. "Todo el pueblo está lleno de bodegas -asegura Juan Gregorio Nevado-. La riqueza de Villaviciosa ha estado siempre en las bodegas". Hay calles incluso, según manifiesta el cronista, que están dedicadas íntegramente a ellas. A la entrada del pueblo, a la derecha, hay una calle que ni siquiera tiene nombre: "Es que no vive nadie -afirma-, todo son bodegas".

Figura no 7 Plano de Villaviciosa, espacio de desarrollo del paseo

Quizás exagere Juan Gregorio Nevado, quizá..., pero no queda mal el olor penetrante y agrio de las bodegas como última impresión de este paseo.

Francisco A. Carrasco Jiménez

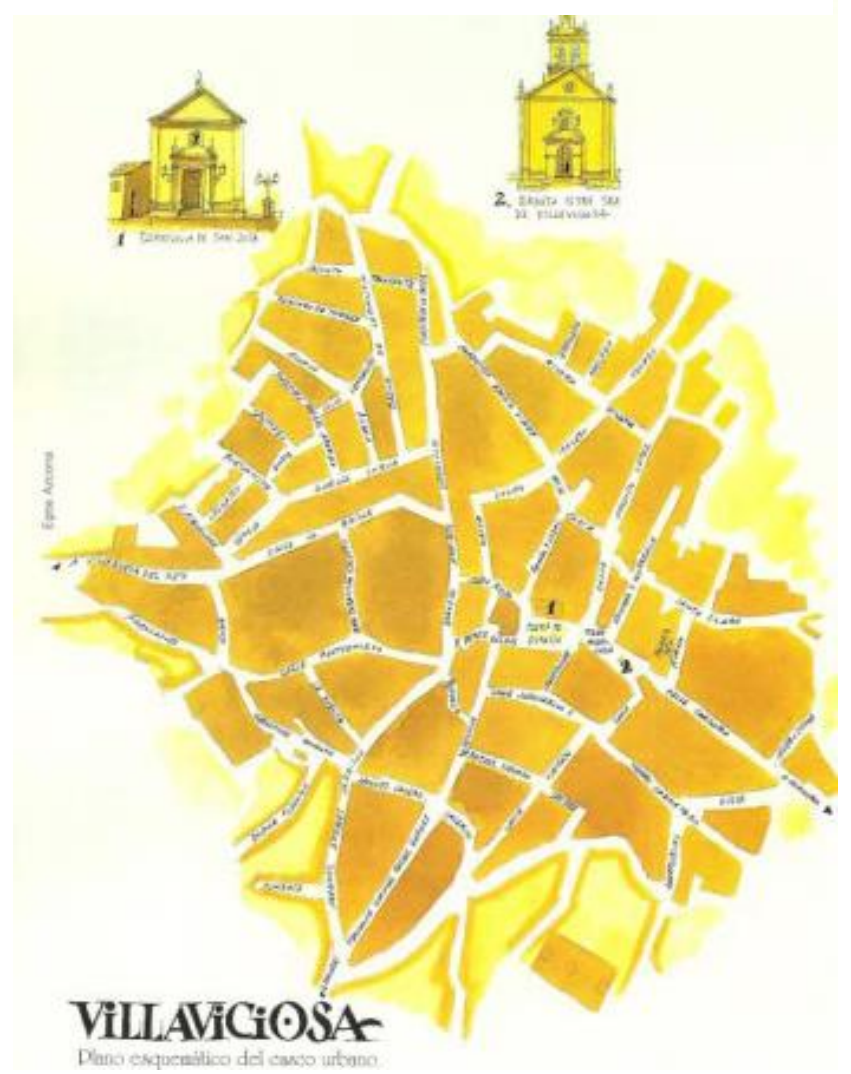




\section{Conhecendo os problemas de saúde urbana nas aulas de Geografia: proposta de sequência didática no Município de Olinda, Brasil}

José Roberto Henrique Souza Soares ${ }^{1}$

Anselmo Cesar Vasconcelos Bezerra ${ }^{2}$

\section{Resumo}

As relações entre Geografia e Saúde estão cada vez mais intensas, tanto no plano teórico quanto metodológico. Entretanto, observa-se que as questões de saúde ainda são pouco abordadas no ensino de Geografia. Neste sentido, objetivamos contextualizar as contradições urbanas relacionadas à saúde da população no município de Olinda, situado no Nordeste Brasileiro, com o ensino de Geografia. Assim, elaboramos sequências didáticas que relacionaram os conhecimentos geográficos com a problemática da saúde urbana, aplicadas no ensino de Geografia. Esta investigação foi de natureza aplicada e exploratória, constituindo-se como uma pesquisa participante. Os resultados do trabalho foram materializados a partir destas estratégias pedagógicas, nas quais propomos momentos de diálogo entre os profissionais da saúde e os estudantes, elaboração de mapas mentais e uma exposição sobre a obra de Josué de Castro, um dos pioneiros dos estudos em Geografia da Saúde no Brasil. Estes recursos didáticos estimularam e sensibilizaram os estudantes da escola pesquisada a compreenderem melhor seu habitat para proporem soluções com vistas a melhoria das condições de vida, numa perspetiva de cidadania terriorial.

\footnotetext{
1 Mestrando em Geografia pela Universidade Federal de Pernambuco. henrqsouza@outlook.com

${ }_{2}$ Doutor em Geografia e Professor do Instituto Federal de Pernambuco. anselmo@recife.ifpe.edu.br
} 
Palavras-chave: Ensino de Geografia; Geografia da Saúde; Saúde Urbana; Sequência Didática; Olinda-BR.

\section{Abstract}

The relationship between Geography and health is increasingly intense, both at the theorical plan as in the methodological. However, it is observed that health issues are still rarely addressed in Geography teaching. Starting with this presupposition, this paper objected to contextualize the urban contradictions associated with the population health at Olinda city, located at Northeast of Brazil. So, we elaborated didactical sequences that relate the geographic thought with the problematic of urban health, applied in the geography teach. The research was of an applied and exploratory nature, constituting itself as a participant research. The results of the work were materialized from some pedagogical strategies, in which field activities were proposed, moments of dialogue between health professionals and students, elaboration of mental maps and an exhibition about the work of Josué de Castro, one of the pioneers in Health Geography studies from Brazil. These didactic strategies stimulated and sensitized the students of the researched school to better understand their habitat to propose solutions for the improvement of living conditions.

Keywords: Geography Teaching; Health Geography; Urban Health; Didactic Sequences; Olinda-BR.

\section{Introdução}

O conhecimento geografico é indispensável para compreender os problemas de saúde que se materializam no espaço. Partindo do pressuposto de que a saúde é pouco abordada nas escolas e que o ensino de Geografia, na maioria das vezes, não trabalha de maneira integral os temas transversais, obrigatórios a todas as ciências. Buscamos assim, compreender se o ensino de geografia pode contribuir para 0 entendimento dos problemas de saúde locais. De que forma o ensino de geografia pode trabalhar a saúde como tema transversal nos conteúdos geográficos? E se o campo da geografia da saúde tem espaço de atuação no ensino básico de geografia.

Assim, o presente artigo visa contextualizar os problemas urbanos relacionados à saúde da população do município de Olinda, localizado no estado de Pernambuco Brasil, com o ensino de Geografia, a fim de propor estratégias de intervenção pedagógica na Escola Estadual Guedes Alcoforado. Relacionando os estudos geográficos com a saúde, destacamos abordagens epistemológicas entre o ensino de 
geografia na Educação Básica e a Saúde. Nesta perspectiva, propomos estratégias didáticas que contemplem a compreensão dos problemas de saúde a partir das condições de sobrevivência e habitação dos educandos.

Este trabalho foi desenvolvido por meio de uma abordagem qualiquantitativa. Através da pesquisa exploratória utilizamos o método de estudo de caso para desenvolver nossas atividades. Os instrumentos utilizados foram a revisão bibliográfica, das áreas pertinentes ao tema, o levantamento e coleta de dados secundários nos bancos oficiais, além de se tratar de uma pesquisa participante. Este tipo de pesquisa segundo Brandão e Borges (2007) se caracteriza como uma pesquisa originária dos problemas sociais de determinada comunidade e que se concretizam nos espaços cotidianos dos agentes envolvidos na pesquisa, com destaque inclusive para 0 pesquisador.

As propostas pedagógicas aplicadas ao ensino da geografia, que contemplaram a compreensão dos problemas de saúde foram desenvolvidas com base nos Parâmetros Curriculares Nacionais (PCN), atendendo as necessidades da comunidade escolar em que o trabalho se desenvolveu. Estas propostas foram aplicadas em sala com os estudantes e os educadores, por meio da organização em forma de sequência didática, a qual segundo Zabala (1998) se apresenta como um conjunto de atividades com fins e meios diversos, que relacionadas por meio de um tema comum, auxiliam os educandos na aprendizagem do conteúdo ensinado. Estas atividades foram propostas e desenvolvidas com base nos conteúdos programáticos de cada nível do ensino, buscando elencar atividades lúdicas e eficazes para o ensino de Geografia da Saúde na educação básica.

A escola escolhida para que desenvolvêssemos as atividades de intervenção em saúde aliadas ao ensino de Geografia foi a Escola Estadual Guedes Alcoforado, que se localiza na Avenida Joaquim Nabuco, número 838, no bairro do Varadouro, situado no município de Olinda. Optamos por esta instituição em função de nossa vivência com a comunidade escolar, ocorrida através do cumprimento das atividades do Estágio Curricular, componente obrigatório dos sétimo e oitavo períodos do Curso de Licenciatura em Geografia, no Instituto Federal de Educação, Ciência e Tecnologia de Pernambuco (IFPE). Nossas intervenções foram realizadas com uma turma do primeiro ano do ensino médio, que é constituída por aproximadamente 35 estudantes, frequentadores regulares, no ano de 2017.

A localização da escola estudada é considerada atualmente como uma das mais importantes para o Município de Olinda-PE, ela localiza-se as margens do Sítio 
Histórico deste município, considerado Patrimômio Histórico e Cultural da Humanidade. A avenida Joaquim Nabuco é uma das mais importantes avenidas do município, uma vez que dá acesso ao sítio histórico e aos espaços de turismo tão marcantes desta localidade. Esta área da unidade territorial estudada, de acordo com Silva, Xavier e Lins (2013), é uma dos espaços geradores de renda mais importantes do município, ligada às atividades do terceiro setor econômico, com destaque para o turismo.

No entanto, apesar de sua localização privilegiada, as condições de habitação no entorno da escola ainda são precárias, principalmente no que se refere a prevenção de doenças ligadas às deficitárias condições de saneamento do município. Em consequência desta constatação, elaboramos atividades que buscaram relacionar os problemas urbanos, vivenciados pelos estudantes em seu cotidiano, aos problemas de saúde enfrentados pelos mesmos.

Desta forma, este trabalho se fundamenta na discussão dos problemas urbanos encontrados no município de Olinda-PE e em suas consequências para a saúde da população. Para tanto, propusemos estratégias de intervenção, nas quais a saúde seja valorizada e tratada de maneira imprescindível no ensino de Geografia. Este levantamento de ideias e temas se concretizam a partir da reflexão que o ensino de geografia também seja um aliado na prevenção de doenças.

\section{A Geografia da Saúde na Educação Básica}

Para Moraes (1994), a Geografia, ao se firmar como ciência que busca alicerçar seus conceitos e conhecimentos na vivência cotidiana dos indivíduos, deve ter por base as relações sociais e o meio físico e natural em que se insere. Esta ciência passou por diversos momentos e foi influenciada por algumas vertentes históricas do conhecimento que a ajudou a definir seu objeto e método próprios.

Assim, ao longo dos anos, dentre tantos meios de se aplicar o conhecimento geográfico vem surgindo uma vertente que busca relacionar as categorias desta ciência com as questões de saúde. Alieve e Pienese (2013) discutem que dentre tantos no Brasil, o primeiro e principal geógrafo a conceber esta relação foi Josué de Castro, que apesar de sua formação médica, possuía uma sensibilidade suficiente para o criar geográfico. Com a obra Geografia da Fome, este pesquisador inaugurou um novo momento para a ciência geográfica brasileira. 
Os questionamentos abordados entre a ciência geográfica e a saúde foram concebidos a séculos atrás. Guimarães, Pickenhayn e Lima (2014), descrevem a importância dos estudos de Hipócrates, durante os anos de 460 a.C. a 377 a. C. Para este filósofo grego, o médico ao exercer seu oficio em uma nova cidade, necessita primeiro conhecer sua posição com relação aos ventos e aos movimentos do sol, além de compreender a qualidade da água consumida pela população. Hipócrates foi o primeiro a perceber a saúde como resultado da relação entre as populações e o local em que habitam.

A Geografia Médica foi um pressuposto, que serviu como base para os conceitos e conhecimentos que formam a atual Geografia da Saúde. De acordo com Junqueira (2009), a geografia dos médicos era uma geografia voltada para estudar apenas os problemas relacionados a prevenção e ao controle das enfermidades, muito ligada a Reforma Sanitária. A geografia da saúde, por sua vez, preocupa-se com os eventos ligados a saúde que se materializam no espaço e no tempo.

A saúde é parte integrante das modificações e adaptações dos seres humanos ao espaço. Guimarães (2015) concebe a saúde como uma reprodução do espaço vivido, e assim como as categorias geográficas surgem da necessidade do homem se relacionar com a natureza transformando-a, a saúde também é concebida por este autor a partir das necessidades humanas. O espaço vivido, torna-se o lugar onde se concretizam as relações de saúde e doença, constituindo-se assim como um objeto de estudo da Geografia.

A ciência geográfica que surgiu como conhecimento restrito, que influenciou chefes de estado e os poderes militares, conforme disserta Lacoste (2012), ficou conhecida como uma disciplina escolar dispensável e desconectada da realidade, uma vez que, o real sentido deste conhecimento foi camuflado e abordado de maneira simplória, constituindo o que o autor chamou de "Geografia dos Professores" (idem, p. 31). Entretanto, ao longo de sua história, esta ciência passou a ganhar novos sentidos, se aliando cada vez mais, a causas próximas da realidade vivida pela sociedade.

A saúde e o meio ambiente, de acordo com Brasil (1998) estão dispostos como temas transversais e interdisciplinares nos PCN. Estes temas devem ser abordados integralmente por todas os componentes curriculares da educação básica. Devido a sua abrangência e importância, não é mais suficiente tratarmos destes conteúdos isoladamente. Os temas transversais ao serem definidos apresentam como critérios: a urgência social, abrangência nacional, possibilidade de ensino e aprendizagem no ensino fundamental, além de favorecer a compreensão da realidade e a participação 
social. Através destes critérios se torna imprescindível que as disciplinas escolares, da qual a Geografia faz parte, abordem as temáticas transversais de maneira a contribuir com a formação humana e intelectual dos educandos.

Para Freire (1993), a escola se constitui como um local onde o cidadão torna-se livre por meio do conhecimento que adquire. Assim sendo, a escola necessita assumir um papel crítico da realidade em que está inserida. Para tal utopia, o estudo do lugar, do bairro ou das áreas vivenciadas pelos estudantes podem leva-los a compreender a dinâmica social em que a escola se insere como nos aponta Cavalcanti (2012). Entendendo assim, as segregações e divergências que são típicas destes espaços somos capazes de compreender também, as doenças que assolam a população.

O ensino da Geografia aliado as preocupações da saúde na educação básica, pretende garantir o acesso dos estudantes a discussão dos temas transversais de forma contextualizada. Porém, não é eficaz que se tratem as questões de saúde em momentos isolados, focando apenas uma doença. A escola necessita despertar para seu papel como formadora de pessoas críticas, capazes de compreender os diversos problemas que os circundam. Assim, o estudo da Saúde por meio da Geografia se mostra como uma maneira do educador ensinar o conteúdo básico e relaciona-lo com as questões de saúde que são tão marcantes no cotidiano dos estudantes.

Conforme Braga (2015) a formação profissional dos educadores de geografia no Brasil não contempla temas referentes à Geografia da Saúde. No entanto essa área do conhecimento geográfico está presente como um dos temas transversais presentes nos PCN e é um dos objetivos a serem alcançados também pelos educadores de Geografia do Brasil. A saúde deve ser compreendida na educação pelo caminho da prevenção. Os conhecimentos que se relacionam diretamente com a Geografia necessitam ser entendidos de maneira integral e ligada as doenças que acometem os educandos na própria comunidade. Os educadores devem ser sensíveis à ligação constante entre tantos conceitos geográficos com as questões relacionadas à saúde.

\section{Propostas de Intervenção no Ensino de Geografia aliado à Saúde na Escola Estadual Guedes Alcoforado}

Os problemas relacionados ao saneamento ambiental no município de Olinda-PE, apresentam consequências para toda população que habita este território, dentre estes, os agravos de saúde são os que mais tem causado complicações. Nesta perspectiva foram elaboradas algumas propostas de intervenção no ensino de Geografia que correlacionadas com as questões de saúde buscaram sensibilizar os 
estudantes da Escola Estadual Guedes Alcoforado, com relação ao adoecimento por parte da precariedade no saneamento ambiental.

Como recurso pedagógico, elaboramos intervenções em forma de sequências didáticas, que objetivaram sensibilizar os estudantes para o seu papel como cidadãos críticos e atuantes na realidade em que estão inseridos. Na proposta foram abordadas as contradições presentes nos espaços urbanos, materializados nos lugares de convivência cotidiana da população, buscando refletir sobre a importância dos mapas para a representação dos espaços, que devido aos problemas de infraestrutura e organização são propícios a ocorrência de doenças.

Por meio de uma abordagem que considera o conhecimento cartográfico como indispensável na formação crítica dos estudantes, foi elaborada uma proposta de intervenção, organizada também em sequência didática, na qual os estudantes foram convidados a refletirem como a representação do espaço vivido, em forma de mapas mentais, pode ser utilizada para denunciar as precárias condições que impulsionam a ocorrência de algumas doenças que acometem as populações. A cartografia, conforme destaca Castrogiovanni (2000), possui o caráter de representar os problemas através de projeções, desenhos ou representações, contribuindo com a formação crítica dos educandos. Neste sentido, utilizamos este conhecimento como suporte para que o ensino de Geografia esteja mais atento para as questões relacionadas à saúde da comunidade escolar.

Diante da constatação que vários estudantes não dominam elementos cartográficos, buscamos facilitar a compreensão dos mesmos e propor aulas mais atrativas, nas quais os educadores possam estimular os educandos sensibilizando-os que a representação do espaço é algo indispensável em suas vidas. Desse modo, com base em Zabala (1998) buscou-se, através de metodologias construtivistas voltadas para o desenvolvimento crítico dos estudantes, proporcionar uma interação mais forte entre os mesmos e o conteúdo vivenciado, conforme pode ser observado no quadro 1.

Quadro 1 - Planejamento de Sequência didática que relaciona a cartografia com a Saúde na Escola Estadual Guedes Alcoforado, em Olinda-PE

\begin{tabular}{|c|c|c|c|c|}
\hline \multicolumn{5}{|c|}{$\begin{array}{l}\text { A Cartografia como um pressuposto ao Ensino da Geografia da Saúde na Escola Guedes } \\
\text { Alcoforado (Olinda-PE) }\end{array}$} \\
\hline \multicolumn{5}{|c|}{$\begin{array}{l}\text { Escola Estadual Guedes Alcoforado } \\
\text { Disciplina: Geografia } \\
\text { Série: } 1^{\circ} \text { ano do Ensino Médio } \\
\text { Número de aulas: Quatro (4) aulas }\end{array}$} \\
\hline Aulas & 1 & 2 & 3 & 4 \\
\hline Tema & Cartografia & $\begin{array}{l}\text { Os Problemas } \\
\text { Urbanos } \\
\text { relacionados à }\end{array}$ & $\begin{array}{lr}\text { Os } & \text { Mapas } \\
\text { Mentais } & \text { dos } \\
\text { Profissionais de }\end{array}$ & $\begin{array}{lr}\text { Os } & \text { Mapas } \\
\text { Mentais } & \text { da } \\
\text { Saúde } & \text { na }\end{array}$ \\
\hline
\end{tabular}




\begin{tabular}{|c|c|c|c|c|}
\hline & & Saúde & Saúde & $\begin{array}{l}\text { Comunidade } \\
\text { Escolar }\end{array}$ \\
\hline Objetivos & $\begin{array}{lr}\text { Apresentar } & \text { os } \\
\text { conceitos e } & \text { a } \\
\text { importância } & \text { do } \\
\text { estudo } & \\
\text { cartográfico. } & \end{array}$ & $\begin{array}{l}\text { Discutir a relação } \\
\text { entre } \\
\text { problemas } \\
\text { urbanos } \\
\text { saúde. }\end{array}$ & $\begin{array}{l}\text { Exemplificar como } \\
\text { os profissionais } \\
\text { da Saúde utilizam } \\
\text { os mapas Mentais } \\
\text { para o controle e } \\
\text { prevenção das } \\
\text { doenças. }\end{array}$ & $\begin{array}{l}\text { Construir os } \\
\text { Mapas Mentais } \\
\text { de cada } \\
\text { estudante, } \\
\text { destacando as } \\
\text { áreas de risco à } \\
\text { saúde. }\end{array}$ \\
\hline $\begin{array}{l}\text { Recursos } \\
\text { Didáticos }\end{array}$ & $\begin{array}{l}\text { Data show, } \\
\text { quadro branco, } \\
\text { mapas, globos } \\
\text { terrestres, } \\
\text { bussolas. }\end{array}$ & $\begin{array}{l}\text { Data show, } \\
\text { quadro branco e } \\
\text { textos } \\
\text { complementares. }\end{array}$ & $\begin{array}{l}\text { Quadro branco, } \\
\text { data show e } \\
\text { mapas. }\end{array}$ & $\begin{array}{l}\text { Folhas } \\
\text { Branco } \\
\text { lápis de colorir, } \\
\text { pasta decorada } \\
\text { e canetas } \\
\text { hidrocores. }\end{array}$ \\
\hline $\begin{array}{l}\text { Procedimentos } \\
\text { Metodológicos }\end{array}$ & $\begin{array}{l}\text { Por meio de uma } \\
\text { aula participativa, } \\
\text { apresentar aos } \\
\text { estudantes } \\
\text { mapas, bussolas, } \\
\text { globos terrestres, } \\
\text { mapas mentais, e } \\
\text { demais } \\
\text { instrumentos } \\
\text { cartográficos. }\end{array}$ & $\begin{array}{l}\text { Discutir com os } \\
\text { estudantes, por } \\
\text { meio de mapas } \\
\text { que relacionam o } \\
\text { saneamento } \\
\text { ambiental de } \\
\text { Olinda e os casos } \\
\text { de Dengue como } \\
\text { o saneamento } \\
\text { ambiental se } \\
\text { relaciona com os } \\
\text { problemas de } \\
\text { saúde } \\
\text { população. }\end{array}$ & $\begin{array}{l}\text { Por meio de uma } \\
\text { aula dinâmica e } \\
\text { participativa } \\
\text { iremos ouvir a } \\
\text { experiência do } \\
\text { ACE, em relação } \\
\text { a sua localização } \\
\text { no espaço em que } \\
\text { trabalha e quais } \\
\text { instrumentos } \\
\text { cartográficos ele } \\
\text { utiliza. }\end{array}$ & 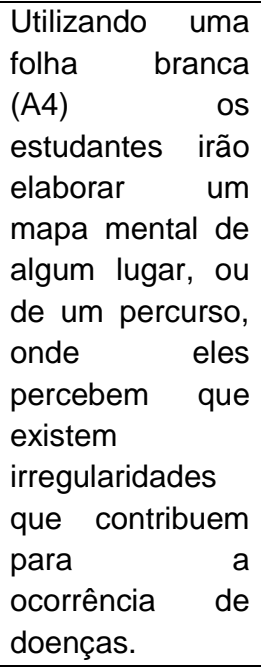 \\
\hline Avaliação & $\begin{array}{l}\text { Participação na } \\
\text { aula }\end{array}$ & $\begin{array}{l}\text { Participação na } \\
\text { aula. }\end{array}$ & $\begin{array}{l}\text { Participação na } \\
\text { aula e interação } \\
\text { com o formador } \\
\text { convidado. }\end{array}$ & $\begin{array}{l}\text { Elaboração e } \\
\text { organização dos } \\
\text { mapas mentais. }\end{array}$ \\
\hline Observações & $\begin{array}{l}\text { Os estudantes } \\
\text { terão o primeiro } \\
\text { contato com os } \\
\text { instrumentos } \\
\text { cartográficos e } \\
\text { assim, } \\
\text { despertarão para } \\
\text { a produção de } \\
\text { mapas. }\end{array}$ & & $\begin{array}{l}\text { O ACE será } \\
\text { convidado para } \\
\text { falar sobre as } \\
\text { técnicas utilizadas } \\
\text { para identificar e } \\
\text { localizar as áreas } \\
\text { que apresentam } \\
\text { problemas de } \\
\text { saúde. }\end{array}$ & $\begin{array}{lr}\text { Depois de } \\
\text { finalizados todos } \\
\text { os mapas } \\
\text { mentais eles } \\
\text { serão } \\
\text { depositados } \\
\text { numa pasta que } \\
\text { constituirá o } \\
\text { Álbum de Mapas } \\
\text { da Saúde na } \\
\text { Escola Guedes } \\
\text { Alcoforado. } \\
\end{array}$ \\
\hline
\end{tabular}

Como ilustrado no quadro 1, a principal técnica abordada durante nossas atividades de intervenção está ligada a produção de mapas mentais. Os Mapas Mentais geralmente são representações do espaço vivido, referências que guardamos ao longo de nossa história com os lugares experimentados, e que ficam guardados como recordação em nossas mentes. São também de acordo com Pereira (2008), 
representações da realidade em que se envolve a cognição por meio de intensos níveis de representação. Sendo ainda, produtos da cognição, o mapa mental possui a capacidade de sintetizar no desenho a visão de mundo, as experiências, valores culturais, nível social, dentre outros elementos.

O Planejamento necessitou ser organizado em três momentos, buscando se enquadrar na realidade espacial e temporal na qual a escola está consolidada. Dividindo-se no primeiro momento na discussão acerca da importância da Cartografia e dos Mapas Mentais para a geografia e a vida cotidiana dos indivíduos. Num segundo momento, foi apresentada aos estudantes a relação entre os mapas e a saúde, ressaltando como os produtos cartográficos podem ser utilizados na área da saúde. $E$ posteriormente, na última parte de nossa sequência didática realizamos a exposição destes mapas para a comunidade escolar. Nesta mesma data, unimos a exposição dos mapas mentais da saúde a exposição da vida e obras de Josué de Castro.

Na primeira parte das intervenções, realizamos uma aula dinâmica e participativa, muito ligada às metodologias construtivistas da educação, que conforme Freire (2016) são indispensáveis no processo de ensino aprendizagem voltada para a formação crítica e política das pessoas. Assim, foram expostos em sala de aula um planisfério, alguns mapas políticos do país, cartas topográficas e globos terrestres, que auxiliaram os estudantes a melhor compreender a importância da Cartografia.

O contato direto como os produtos cartográficos foi uma experiência enriquecedora no desenvolvimento cognitivo dos estudantes. Ao relacionarem as diversas maneiras de perceber e representar o espaço geográfico os estudantes passaram a identificar com maior clareza os elementos que compõem cada produto cartográfico. A liberdade de se aproximarem, tocarem e vivenciarem estes produtos também foi uma condição indispensável no processo de formação, por isso optamos por levar os recursos físicos, e não apenas ilustrações em apresentações cansativas e desestimulantes.

Devido à deficiência expressada pela educadora da disciplina de geografia na escola estudada, fez-se uma parte primordial este primeiro contato com os estudantes, onde abordamos os conteúdos e práticas ligados aos conhecimentos cartográficos. A referida educadora, em conversas informais enquanto organizávamos o planejamento das intervenções, comunicou a falta de aprofundamento na área cartográfica durante sua formação acadêmica e consequente dificuldade para trabalhar com a temática em sala de aula.

Os estudantes assim, revisaram e se aprofundaram um pouco mais no conteúdo vivenciado durante outro momento de sua formação, passando agora a compreender 
os conceitos e elementos cartográficos com base na vivência cotidiana dos mesmos. Estes conhecimentos foram construídos de maneira coletiva, de uma forma em que os estudantes puderam expressar suas recordações com relação a temática exposta e observaram na prática os elementos da Cartografia expostos em sala.

Como segunda parte de nossa proposta, foram expostos aos educandos diferentes tipos de mapas que ilustram a distribuição das doenças em várias escalas, partindo desde o global até o local. Primeiro analisamos mapas que refletem a distribuição dos casos de dengue pelo planeta, vimos o mapa dos casos de Zika no Brasil e analisamos na escala local os mapas que relacionam o saneamento ambiental inadequado e os casos de Dengue no município de Olinda-PE, durante o ano de 2016.

Para exemplificar aos estudantes como os mapas são imprescindíveis nas atividades de saúde, foi mostrado o vídeo "Agentes em Ação: mapeamento, desenhando a sua área", ilustrando como os mapas são utilizados pelos profissionais da Saúde e contando com algumas declarações de uma Agente Comunitária de Saúde (ACS) do município de Olinda. Nesta entrevista, concedida a equipe do Projeto Agentes em Ação, a ACS explica seu mapa mental e descreve a importância deste instrumento cartográfico para o desenvolvimento das atividades de prevenção e atenção à saúde.

Posteriormente os estudantes foram convidados a produzirem o mapeamento das condições de saúde do local onde moram, levando em conta os aspectos específicos dos espaços vividos por eles, retratando os problemas que podem condicionar a ocorrência de algumas enfermidades. Nestes desenhos os educandos puderam retratar o modo como eles percebem os lugares em que convivem, e refletiram sobre as condições que estes lugares possuem para tornarem-se potenciais geradores de males para a saúde. Levando em conta as noções básicas de escala e de conhecimentos gerais sobre o nome do bairro, da rua e até mesmo dos centros comerciais. Os estudantes desenvolveram mapas que podem contribuir para a localização de possíveis focos de doenças, como a dengue, ou como uma forma do educador em geografia compreender a realidade socioespacial em que seus educandos estão inseridos.

Dentre tantas realidades ilustradas pelos estudantes, algumas se destacaram com relação a aceitação e a facilidade de identificação dos problemas. A maioria dos estudantes representaram o caminho de casa até a escola, destacando os canais poluídos que existem no entorno. Outros delimitaram sua escala e ilustraram a área próxima à sua residência, com enfoque para as áreas de deposição irregular dos resíduos sólidos, ou os problemas hídricos que se intensificam durante os períodos 
mais chuvosos. Na figura 1 pode ser observado um dos mapas mentais oriundos de nossa intervenção, que destaca as áreas próximas a residência do estudante e o corpo hídrico que passa no entorno totalmente poluído.

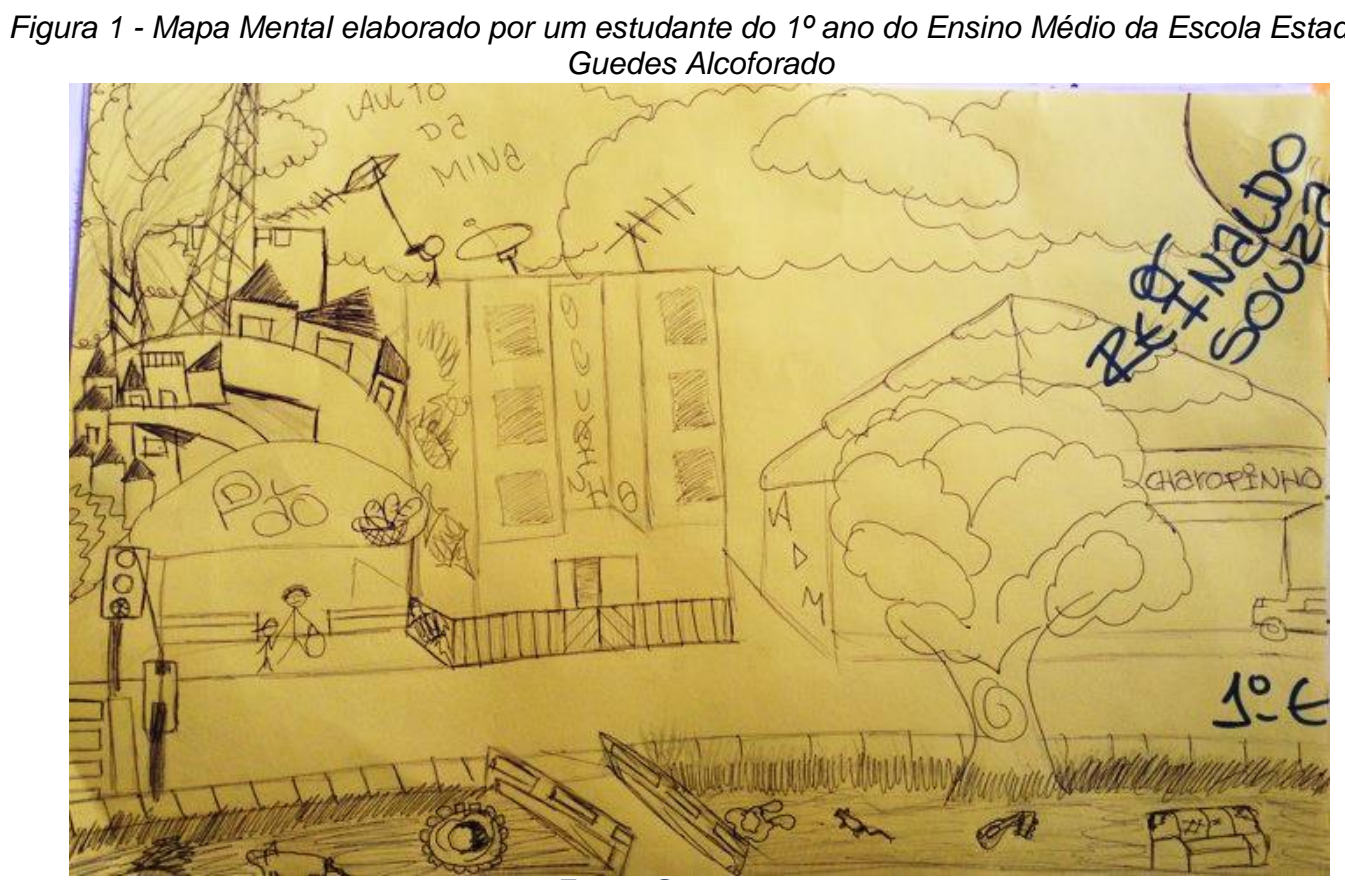

Fonte: Soares, 2017.

A representação dos contrastes socioespaciais, ilustrados na figura 1 , se torna uma questão muito marcante na obra do referido estudante. As áreas de morros, ilustradas no mapa mental, apresentam características de serem as áreas mais poluídas visualmente, enquanto que na parte mais baixa onde foi representada a avenida, predomina uma certa limpeza visual, exceto pelo contraste da poluição hídrica marcante no riacho que passa paralelo a avenida. Estes recursos artísticos são muito importantes para a compreensão da realidade cartografada, conforme destacou Castrogiovanni (2000), os mapas mentais são capazes de nos fazer compreender a percepção da realidade social em que os educandos estão inseridos e é apreendida pelos mesmos.

A contradição expressa na figura 1 se dá pela falta de assistência e cuidados necessários por parte das instituições governamentais, que se preocupam muito com as áreas que geram algum lucro, menosprezando as áreas habitadas pela classe mais baixa da sociedade. Essa falta de interesse por algumas áreas é um dos maiores problemas que a população enfrenta, uma vez que as condições mínimas de habitação são negligenciadas, provocando muitas patologias.

Outro ponto marcante nos mapas mentais elaborados diz respeito as condições dos corpos hídricos presentes no entorno do lugar em que eles moram. Como na figura 1 , 
em que foi representado o corpo hídrico totalmente poluído, outros estudantes também ilustraram esta realidade caracterizando assim, a dimensão espacial que este problema apresenta no entorno da escola pesquisada. Uma ilustração mais marcante a este respeito pode ser observada na figura 2 , em que se representou a realidade de uma das mais importantes avenidas do município de Olinda-PE, localizada no bairro de Peixinhos a menos de dois quilômetros de distância da Escola Estadual Guedes Alcoforado.

Figura 2 - Mapa Mental de uma das estudantes do $1^{\circ}$ ano "E" do Ensino Médio da Escola Estadual Guedes Alcoforado, representando uma avenida próxima de sua residência

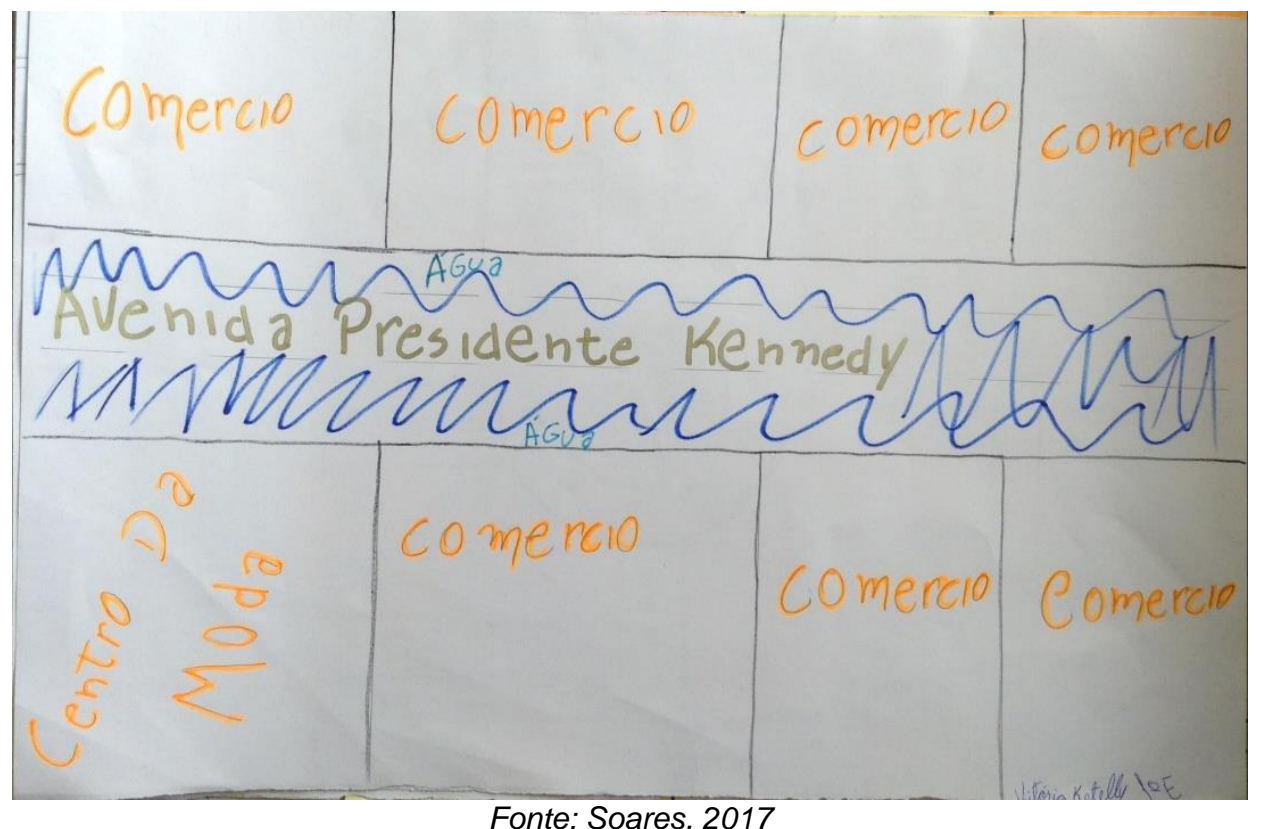

No mapa mental, ilustrado na figura 2, pode ser observado um dos problemas mais intensos que a comunidade próxima a escola enfrenta nos períodos chuvosos, que são os alagamentos e as inundações. A avenida Presidente Kennedy, localizada no Bairro de Peixinhos que é vizinho ao bairro do Varadouro, onde se localiza a Escola que realizamos as intervenções, é uma das mais problemáticas com relação ao esgotamento sanitário. Consequentemente durante os períodos chuvosos apresenta maiores problemas devido aos intensos alagamentos, que foi representando pela estudante autora do mapa mental da figura 2.

Costa et al (2002) destaca que as áreas em que se concentram os problemas referentes a má condição de drenagem e abastecimento hídrico estão mais propicias a contração de enfermidades. Estas patologias se intensificam por meio da forma de contração pelas pessoas, as diarreicas são contraídas por meio do contato feco-oral, a dengue e outras tantas como as que vêm surgindo nos últimos anos, são transmitidas por meio de inseto-vetor, a esquistossomose e a leptospirose são transmitidas por 
meio do contato com água contaminada. Além destas existem ainda algumas outras que podem ser contraídas por meio da falta de higiene como as doenças da pele e dos olhos e as transmitidas através de geo-helmintos e teníases, por meio do contato com o solo.

Estas doenças se tornam mais intensas nas áreas em que ocorrem inundações, por estarem de alguma forma ligadas as péssimas condições de saneamento. As enchentes, contribuíem para a elevação do nível dos esgotos, poluem as águas e podem gerar diversos males a saúde da população. Estas enfermidades se relacionam com o saneamento ambiental, de acordo com Costa et al (idem) por meio do abastecimento de água irregular, do esgotamento sanitário ineficiente como é o caso do município em estudo, pela coleta e disposição de resíduos sólidos, pela drenagem das águas e resíduos despejados, de maneira irregular, pelo controle de vetores, como os mosquitos causadores da dengue, ou ainda pelas condições de habitação precárias.

Os mapas mentais ilustrados nas figuras 1 e 2 foram elaborados apenas com base na experiência vivida pelos estudantes e no conhecimento prévio dos problemas que 0 município de Olinda apresenta, devido as deficientes condições do saneamento ambiental. Assim, podemos observar ilustrações de avenidas alagadas, corpos hídricos totalmente poluídos, locais de serviço e atenção à saúde, além das áreas de deposição irregular dos resíduos sólidos.

Entre tantas dificuldades partilhadas pelos estudantes na produção dos mapas metais, a que mais se destacou diz respeito as noções de escala adquiridas pelos mesmos. A maioria não concordou em produzirmos nossos mapas em papel comum de tamanho A4, por alegarem não conseguir ilustrar um percurso muito grande em tão pouco espaço. Mesmo depois de compreenderem que poderíamos reduzir a escala de nossas produções, concordamos em elaborar os mapas em papel maior, como a cartolina, para realizarmos uma exposição destes mapas com toda a comunidade escolar.

$\mathrm{Na}$ terceira e última parte de nossa sequência didática, conforme combinado com os estudantes em acordo pedagógico, elaboramos os mapas mentais para realizarmos uma exposição destes mapas para toda a comunidade escolar. Portanto, na semana posterior a elaboração dos mapas se realizou a exposição dos Mapas Mentais da Saúde da Escola Estadual Guedes Alcoforado, que contou com um número de 20 mapas mentais expostos, conforme pode ser observado na figura 3. Estes mapas se aproximam pela presença em todos de aspectos ligados as questões de saúde, ao 
mesmo tempo que se diferenciam uns dos outros pelo individualismo da localização de cada moradia, dos serviços prestados em cada área e da relação entre os lugares e os centros de atendimento médico.

Figura 3 - Exposição dos Mapas Mentais da Saúde na Escola Estadual Guedes Alcoforado em Olinda-PE, produzida pelos estudantes do $1^{\circ}$ ano do Ensino Médio "E", no ano de 2017

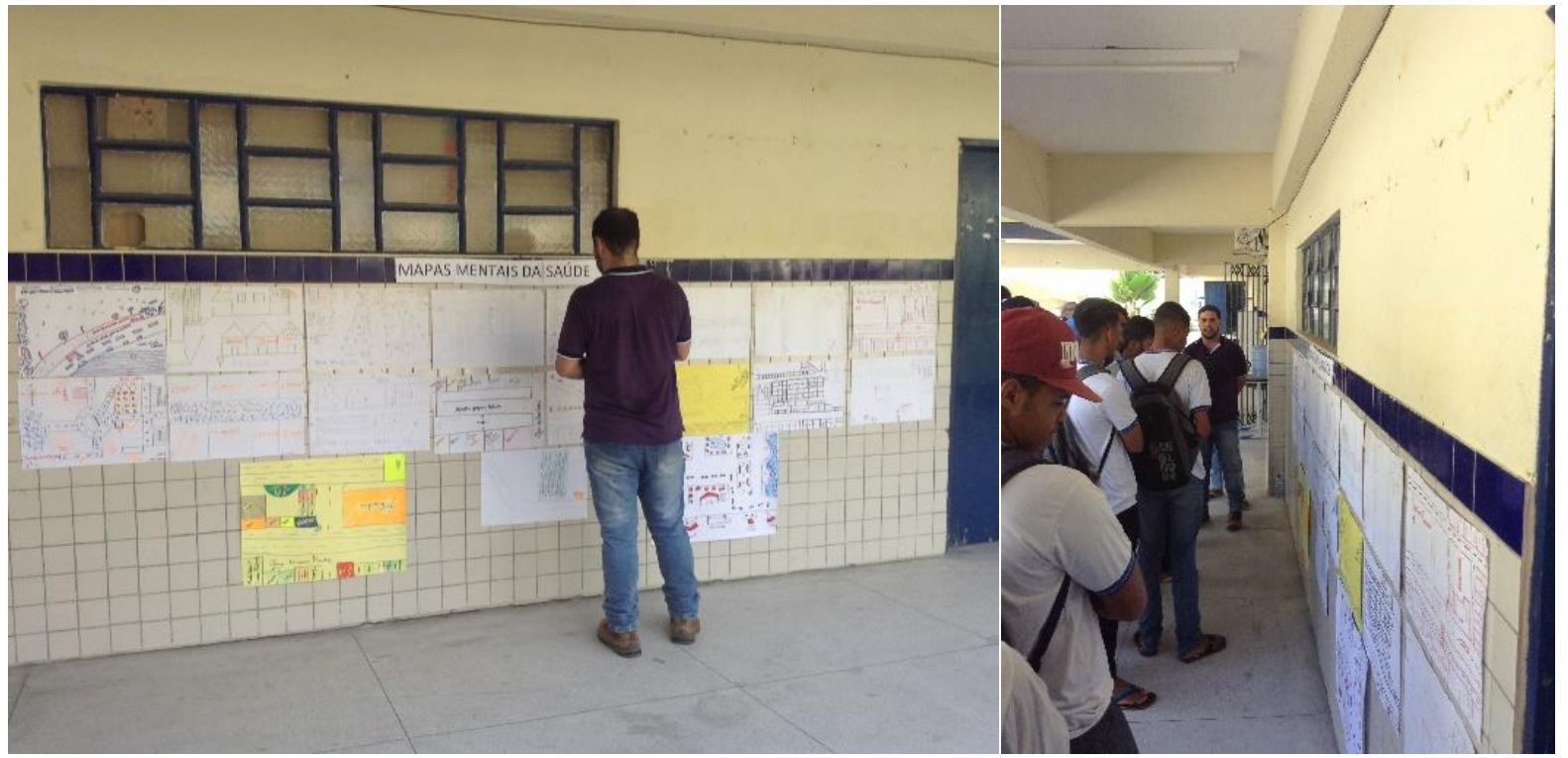

Fonte: Leite, 2017

Esta exposição aberta a toda comunidade escolar, foi importante para despertar nos demais estudantes os cuidados com os espaços que também são comuns a estes outros. Muitos questionamentos foram sendo construídos por parte da comunidade escolar que visitou a exposição. Foi possível perceber que as práticas cotidianas e comuns aos frequentadores do lugar onde a escola se insere, não são realizadas de maneira reflexiva, uma vez que os próprios utilizadores ao perceber os problemas do entorno da escola, como a deposição irregular dos resíduos ou a poluição dos corpos hídricos reconhecem a parcela de contribuição que os mesmos representam para aquelas condições.

Paralelamente a esta exposição, e como uma proposta de complementar seus objetivos, levamos à escola a exposição Josué de Castro: por um mundo sem fome, que é parte do Projeto Memória (2004). Com auxílio da Equipe do Programa Institucional de Bolsas de Iniciação à Docência (PIBID) do curso de Licenciatura em Geografia do IFPE, em parceira com o Centro Josué de Castro, como ilustrado na figura 4. Esta exposição retrata a vida e obra do recifense Josué de Castro, autor renomado na Geografia da Saúde, foi um dos pioneiros deste ramo da Geografia, abordando as questões da fome e das condições de habitação dos moradores dos mocambos, as margens dos mangues de Recife-PE. 
Figura 4 - Exposição Josué de Castro: por um mundo sem fome, na Escola Guedes Alcoforado em 2017

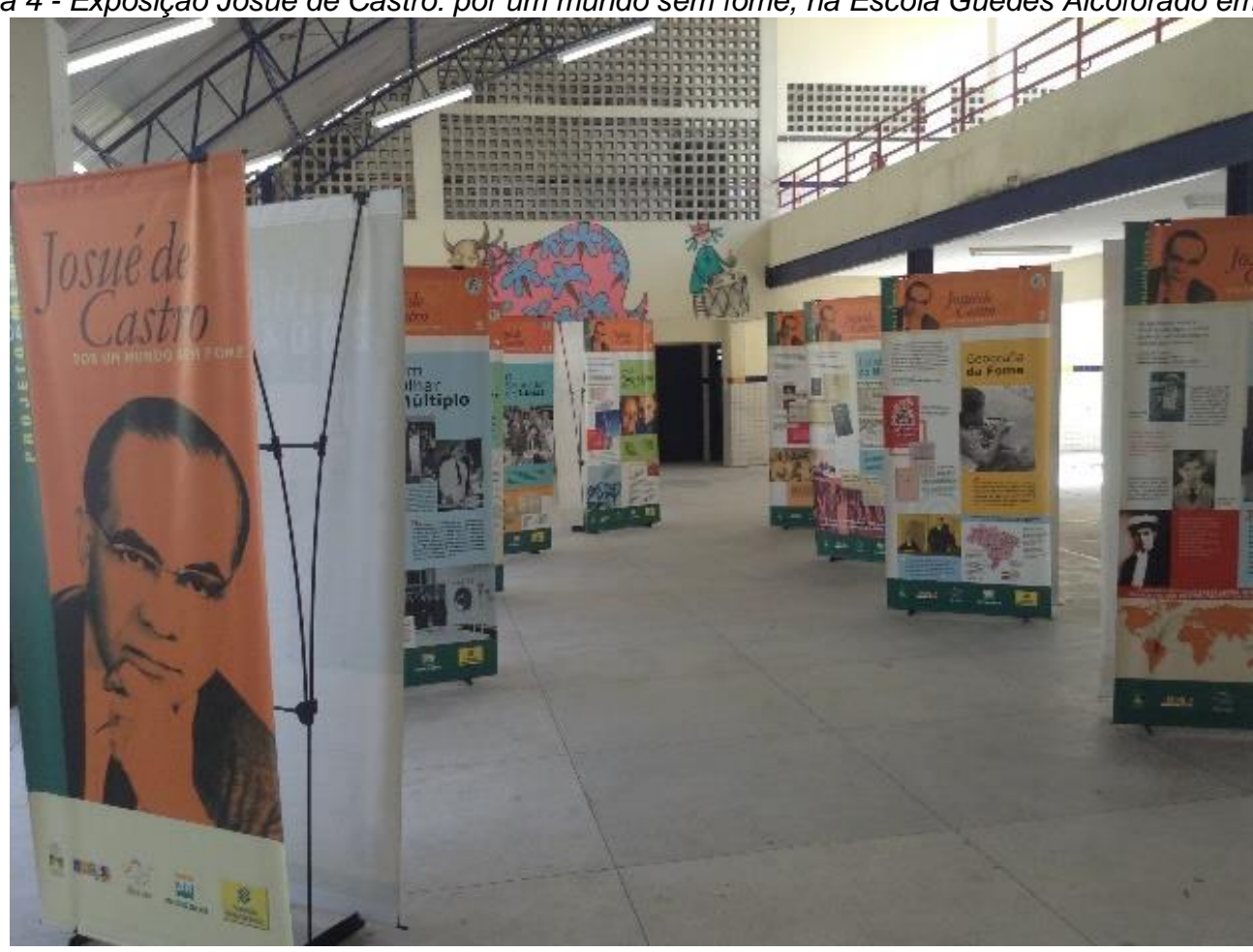

Fonte: Soares, 2017

A contribuição externa auxiliou os educandos a compreenderem as bases iniciais dos estudos geográficos relacionados a saúde no Brasil. Complementando a exposição da vida de Josué de Castro, a comunidade escolar também foi convidada a apreciar uma história repleta de feitos extremamente importantes para a Geografia, o quanto foram as obras deste autor com seus estudos sobre a fome, nos livros Geografia da Fome e Geopolítica da Fome, e os voltados para as condições de habitação e saúde, como a ilustre obra que retrata a realidade recifense, intitulada Homens e Caranguejos.

\section{Considerações Finais}

Hoje em dia a escola não consegue mais negligenciar as vivencias e experiências empiricas dos estudantes, este é também o caso das várias doenças que acometem nossos educandos principalmente nos lugares em que habitam. Assim, buscamos neste trabalho elencar algumas possibilidades para se trabalhar no ensino de geografia a sensibilização dos problemas de saúde, enfrentados pela população que habita os espaços com condições mais precárias. Estas propostas se firmam a partir de nossas experiências e vivências em sala de aula, por meio da interligação dos temas abordados na Geografia e da necessidade de uma atenção integral e permanente com as doenças, por meio da escola. 
As estratégias de ensino de Geografia, aqui propostas em forma de sequência didática podem servir como uma maneira de sensibilizar os estudantes, com relação aos problemas urbanos e suas consequências para a saúde. A aproximação do conhecimento científico com o conhecimento empírico é essencial no ensino de geografia. Transmitir os conhecimentos de maneira a conciliar o conhecimento dos estudantes, principalmente os relacionados com o bairro e a cidade em que vivem, faz com que o conhecimento científico seja mais prazeroso, dando significado e importância ao conhecimento geográfico. Sobre esta metodologia, a geografia escolar se torna uma possibilidade para o combate e prevenção de doenças.

Compreender os diversos mecânicos propulsores das enfermidades do lugar em que habitamos, necessita ser também uma das competências a serem alcanças pelo ensino de Geografia. Mesmo que a formação básica dos educadores em Geografia, não contemple tal abordagem ela se faz essencial para que o conhecimento possa se tornar acessível e palpável pelos estudantes. Como destacado nos PCN, que regularizam o ensino no Brasil, os temas referentes a saúde devem ser abordados de maneira transversal por todas as disciplinas trabalhadas na educação básica. 0 conhecimento geográfico, por sua vez, pode contribuir imensamente com a disseminação destes conhecimentos, se utilizando dos conteúdos específicos desta ciência atrelados ao conhecimento da Saúde.

A Geografia como disciplina escolar é imprescindível na formação de um cidadão crítico. O ensino desta ciência deve fazer com que o estudante possa compreender o lugar onde ele vive, saiba interpretar mapas, seja capaz de realizar estudos sobre o espaço geográfico, os aspectos sociais e políticos da sociedade da qual faz parte e desenvolva o espírito de um bom observador sempre apto a entender e contribuir para a compreensão dos problemas do mundo atual. Desse modo, a Saúde pode ser trabalhada de maneira paralela ao ensino da Geografia, contribuindo para que os estudantes se tornem cidadãos comprometidos e atuantes da realidade em que estão inseridos.

Neste sentido, os educandos passam a ser peças primordiais no processo de ensino e aprendizagem. Por meio do conhecimento geográfico, aliado a saúde na educação básica, os jovens estudantes passam a ser disseminadores das informações construídas na sala de aula, e posteriormente praticadas em seus locais de convívio, auxilio na manutenção de espaços saudáveis. Constituindo-se como agentes de prevenção e controle dos espaços no lugar onde vivem, evitando que patologias se intensificam pela falta de saneamento ou do contato com áreas poluídas 


\section{Referências bibliográficas}

Alievi, A. A., Pienese, J. P. (2013). A geografia da saúde no Brasil: precedentes históricos e contribuições teóricas. Encuentro de Geógrafos de América Latina, V(14), 2013, Lima. Reencuentro de saberes territoriales latinoamericanos: Anais. Lima: Biblioteca Nacional de Peru. 1-17

Braga, R. O. B. (2015). A Geografia da Saúde na Geografia Escolar do Ensino Médio, no contexto dos colégios estaduais de Curitiba/Pr: Uma Análise Crítica. 2015. $132 f$. Dissertação (Mestrado em Geografia). Curso de Pós-Graduação em Geografia, Setor de Ciências da Terra. Universidade Federal do Paraná. Curitiba.

Brandão, C. R., Borges, M. C. A. (2007). Pesquisa Participante: um momento da educação popular. Revista Educação Popular. V(6), 51-62.

Brasil. Ministério da Educação. (1998). Secretaria de Educação Básica. Parâmetros Curriculares Nacionais: Geografia. Brasília: MEC/SEB.

Castrogiovanni, A. C. (2000). Ensino de geografia: práticas e textualizações no cotidiano. Porto Alegre: Mediação.

Cavalcanti, L. S. (2012) A Geografia escolar e a cidade: ensaios sobre o ensino de geografia para a vida urbana cotidiana. $3^{\underline{a}}$ ed. Capinas-SP: Papirus.

Costa, A. M., Pontes, C. A. A., Melo, C. H., Lucena, R. C. B., Gonçalves, F. R., Galindo, E. F. (2002). Classificação de Doenças Relacionadas a um Saneamento Ambiental Inadequado (DRSAI) e os Sistemas de Informações em Saúde no Brasil: Possibilidades e Limitações de Análise Epidemiológica em Saúde Ambiental. Proceedings of the 28th Congresso Interamericano de Ingeniería Sanitaria y Ambiental; 2002 Oct 27-31; Cancun, México.

Freire, P. (1993). Política e educação. São Paulo: Cortez. (2016). Pedagogia do Oprimido. 60 ed. São Paulo: Editora Paz e Terra.

Guimarães, R. B. (2015). Saúde: fundamentos de Geografia humana. São Paulo: Editora UNESP [Online]. Retirado de http://books.scielo.org/id/4xpyq.

Guimarães, R. B., Pickenhayn, J. A., Lima, S. C. (2014). Geografia e Saúde: sem fronteiras. Umberlândia-MG: Assis editora.

Junqueira, R. D. (2009). Geografia Médica e Geografia da Saúde. HYGEIA, Revista Brasileira de Geografia Médica e da Saúde. V(5), 57-91. 
Lacoste, Y. (1988). A Geografia: isso serve, em primeiro lugar, para fazer a guerra. Tradução de Maria Cecília França. Campinas-SP: Editora Papirus.

Moraes, A. C. R. (1994). Geografia: Pequena História Crítica. São Paulo: Hucitec.

Pereira, M. P. B. (2008). Conhecimento geográfico do agente de saúde: competências e práticas sociais de promoção e vigilância à saúde na cidade do Recife - PE. Tese de Dourado em Geografia. Programa de Pós-Graduação em Geografia da Faculdade de Ciências e Tecnologia da UNESP - Presidente Prudente. Presidente Prudente - SP.

Silva, D. M. C., Xavier, M. G. P., Lins, S. L. B. (2013). O Turismo e sua Influência no Comércio, Comunidade e Desenvolvimento Local do Sítio Histórico de Olinda-PE. REN. Revista Econômica do Nordeste. V(44), 59-72.

Zabala, A. (1988) A prática educativa: como ensinar. Trad. Ernani F. da F. Rosa. Porto Alegre: Artmed. 


\title{
Uso educativo de la bicicleta y formación ciudadana
}

\author{
LILIANA ANGÉLICA RODRÍGUEZ PIZZINATO
}

\section{Resumo}

A comunicação localiza-se no domínio B Geografia, Educação e Cidadania no eixo 5 Educação e cidadania, na qual se mostra uma possibilidade de formação cidadã por médio do uso educativo da bicicleta. Assim, se apresenta a sistematização de uma prática de saídas de campo em bicicleta que vem desenvolvendo faz aproximadamente dois anos, o Semillero de investigação Formação e Educação Geográfica Itinerantes (SIFEGI) orientado pela autora da comunicação, o qual se encontra vinculado à Licenciatura em ciências sociais da Universidade Distrital Francisco José de Caldas (Bogotá - Colômbia). A reflexão e a acção sobre este esquema de trabalho, tem permitido desenvolver até o momento cinco experiências de Ciclo saídas educativas, nominación atual do que inicio como saídas de campo em bicicleta. O anterior, consegue-se a partir do desenho de percursos urbanos, a preparação dos mesmos, a validação realizada com sua implementação e a avaliação preliminar dos efeitos que têm no exercício cidadão dos participantes as CSE.

Palavras-chave: formação cidadã; ciclo saídas educativas; uso educativo da bicicleta.

\section{Resumen}

La comunicación se ubica en el dominio B Geografía, Educación y Ciudadanía en el eje 5 Educación y ciudadanía, en la cual se muestra una posibilidad de formación ciudadana por medio del uso educativo de la bicicleta. Así, se presenta la sistematización de una práctica de salidas de campo en bicicleta que viene desarrollando hace aproximadamente dos años, el Semillero de investigación Formación y Educación Geográfica Itinerantes (SIFEGI) orientado por la autora de la

\footnotetext{
${ }^{1}$ Docente titular de tiempo completo. Licenciatura en ciencias sociales. Universidad Distrital Francisco José de Caldas. Directora Semillero de investigación Formación y educación geográfica. Itinerantes (SIFEGI). Grupo de investigación Geopaideia. larodriguezp@udistrital.edu.co
} 
comunicación, el cual se encuentra vinculado a la Licenciatura en ciencias sociales de la Universidad Distrital Francisco José de Caldas (Bogotá - Colombia). La reflexión y la acción sobre este esquema de trabajo, ha permitido desarrollar hasta el momento cinco experiencias de Ciclo salidas educativas, nominación actual de lo que inicio como salidas de campo en bicicleta. Lo anterior, se logra a partir del diseño de recorridos urbanos, la preparación de los mismos, la validación realizada con su implementación y la evaluación preliminar de algunos de sus efectos en el ejercicio ciudadano de los participantes las CSE.

Palabras clave: formación ciudadana; ciclo salidas educativas; uso educativo de la bicicleta.

\section{Introducción}

La iniciativa de la Ciclo Salida Educativa (CSE) surge en la práctica de formación de docentes, por parte de la autora de la comunicación, frente a una reflexión sobre un ejercicio ciudadano considerado frágil en el país y particularmente en su capital. En esta iniciativa confluyen sus experiencias, saberes personales, orientación de espacios de trabajo con estudiantes en diferentes niveles de escolaridad, prácticas sociales y pedagógicas abordadas en dichos niveles, intercambios académicos, discusiones con pares y/o expertos y desarrollos profesionales.

Algunos aspectos que ilustran lo anterior, se refieren por ejemplo a un ejercicio en el que el ciudadano es anónimo e invisible en el espacio, por ello, lo usa pero no lo apropia; asume una condición individual en la que no interactúa con el otro, sino que se enfrenta con él. Un ciudadano que exige derechos pero no ejerce deberes en y con el espacio en el que se encuentra; que piensa el espacio público como algo de todos, pero que en su práctica experimenta como algo ajeno e indiferente, que no hace parte de su cotidianidad. Así, lo asume igualmente como objeto de privatización material y/o simbólica, en el cual reside pero no habita en términos de Heidegger (1951).

Lo anterior, se constituye en el inicio de una idea que comienza pensando en realizar salidas de campo en bicicleta, para luego integrar en ellas la dimensión pedagógica buscando algunos cambios en los comportamientos ciudadanos. Sin embargo, el planteamiento sugerido de esta manera no es suficiente, por ello, se piensa en la salida de campo en bicicleta con un carácter educativo, en la cual se puedan vincular diferentes actores sociales y no sólo los asociados con la escuela. 
Compartir estas ideas y madurarlas conjuntamente a partir de experiencias personales y/o grupales, búsquedas documentales, análisis de las mismas y reflexión de los hallazgos con los estudiantes que conforman el Semillero de investigación SIFEGI, permite concretar el proceso de la CSE como una propuesta de formación ciudadana, aprovechando la bicicleta no solo como una forma de movilidad alternativa y sostenible con el ambiente, sino una fuente de interacción más tolerante, solidaria y democrática entre ciudadano y ciudad.

En tal sentido, la comunicación aborda de manera general unos antecedentes sobre el uso de la bicicleta, una presentación conceptual y metodológica de las CSE, una ilustración de las CSE realizadas y algunos resultados de evaluación sobre su implementación en el marco de la formación ciudadana.

\section{Antecedentes generales}

\subsection{Uso de la bicicleta}

Las aproximaciones teóricas que se presentan sobre la bicicleta y sus posibilidades formativas, nace de la preocupación por una educación espacial en la cotidianidad y la constitución de una ciudadanía más real, consciente y propositiva. Para ello, se realiza una revisión documental sobre el uso de la bicicleta como una forma alternativa de movilidad en la ciudad de Bogotá (Colombia), cuyos hallazgos se ubican en bases de datos de algunas universidades públicas y privadas a nivel local, nacional e internacional, utilizando la estrategia de mapeamiento informacional bibliográfico propuesta por André (2009).

Dicha estrategia plantea una metodología para la ubicación, selección y codificación de la información presente en artículos en revistas especializadas, monografías, tesis de maestría y doctorado, relacionadas con temáticas sobre dinámica y movilidad urbana, sistemas de cicloruta instalados en la ciudad, prácticas del uso de la bicicleta en la ciclovía y bici usuarios que usan la bicicleta como un sistema de transporte alternativo en la ciudad.

De esta búsqueda se clasifican 87 documentos de los cuales 18 corresponden específicamente a la categoría mencionada, cuyas referencias aluden especialmente a: 1) normatividad sobre el uso de la bicicleta presente en el Código de tránsito (2002) y Alcaldía de Bogotá (2013); 2) la bicicleta como medio de desplazamiento tratado por Suero (2010), Casabianca (2012) y Arbelaez (2015); 3) infraestructura y mobiliario 
urbano definido para su uso referido por el IDU (2002) y Melo (2012); y 4) ventajas y desventajas asociadas con su uso planteado por Ballesteros (2104).

Además, se aprecia la preocupación en los últimos años por el uso de la bicicleta en relación con el espacio público y los procesos de movilidad urbana, que en el caso de ciudades como Bogotá, plantea otras opciones de desplazamiento como afirma Hernández (2011), que hacen más sostenibles estas dinámicas y mejoran las condiciones de calidad de vida de sus ciudadanos. De igual forma, se muestran resultados en estudios como el de Sarmiento (2009) para incentivar el uso de la bicicleta para combatir el sobrepeso y la vida sedentaria característica de los entornos urbanos actuales.

Así mismo, el análisis documental identifica especialmente tres tipos de uso de la bicicleta de acuerdo con Sandoval \& Osorio (2011), Mosquera \& Mañana (2012) y Gómez (2013). El primero es un uso individual para fines laborales o recreativos, el segundo el que desarrollan colectivos organizados que trabajan sobre el tema de la bicicleta y el tercero al sistema de bicicletas compartidas, consistente en el préstamo temporal a los ciudadanos como medio de transporte.

Por otra parte, la organización de antecedentes se realiza mediante categorías definidas por la autora de la comunicación, que luego son discutidas y ajustadas conjuntamente con el semillero SIFEGI (Tabla 1), lo que permite tematizar los documentos encontrados sobre el uso de la bicicleta en distintos escenarios urbanos y buscar reflexiones específicas sobre su uso educativo, como fuente para fundamentar la propuesta de salidas de campo en bicicleta.

Tabla 1 - Categorías identificadas en el uso de la bicicleta

Categorías

$\begin{array}{cl}\text { Medio de transporte } & \begin{array}{l}\text { Al modo o instrumento que utiliza el ciudadano para desplazarse en la } \\ \text { ciudad. }\end{array} \\ \text { Bicicleta pública } & \begin{array}{l}\text { Al uso de la bicicleta como servicio de transporte integrado al sistema de } \\ \text { movilidad de las ciudades, de acuerdo con programas para el alquiler, } \\ \text { pago de tarifa diaria, mensual o anual y/o préstamo de las mismas } \\ \text { incentivando una alternativa sostenible de movilidad. }\end{array} \\ \text { Calidad de vida/ Salud } & \begin{array}{l}\text { A las condiciones de bienestar físico, material, social, emocional y } \\ \text { productivo que tiene una sociedad. El indicador más común usado para } \\ \text { medir la calidad de vida es el índice de desarrollo humano, establecido } \\ \text { por las Naciones Unidas para medir el grado de desarrollo de los países, } \\ \text { cuyo cálculo se realiza a partir de las siguientes variables: esperanza de } \\ \text { vida, educación y producto interno bruto per cápita. }\end{array}\end{array}$

Ventajas uso de la
Definición/Hace referencia... vida, educación y producto interno bruto per capita.

A las bondades que tiene el uso de la bicicleta a nivel económico, 
El proceso anterior, ubica las mayores referencias en las categorías de calidad de vida/salud y ventajas sobre el uso de la bicicleta. Las primeras se encuentran por ejemplo en estudios de Gámez, et al., (2006), Uribe (2010), Rengifo (2011) y Marilson et al., (2014) y las segundas en trabajos como los de Vergara (2102) y Acero (2001). Los principales resultados en estas categorías, muestran que a pesar de que Bogotá ha experimentado importantes cambios en su infraestructura física y social que incrementan oportunidades para la actividad física, el sedentarismo continúa siendo un problema en los centrosn urbanos; por lo cual la alternativa del uso de la bicicleta en desplazamientos habituales (estudio, trabajo, recreación) favorecerían la salud de sus ciudadanos.

Así mismo, se muestran ventajas sobre montar en bicicleta como un símbolo de cambio que impacta positivamente la vida en sociedad al modificar hábitos físicos, sociales y ambientales. Al respecto, se analizan algunas experiencias en municipios aledaños a Bogotá, en las cuales se evidencian esfuerzos y avances en la promoción del uso de la bicicleta, que permiten avanzar en el desarrollo de proyectos de transporte no motorizado y contribuyen a mejorar las condiciones de movilidad de la ciudad-región.

En las categorías de medio de transporte y bicicleta pública (estudios mencionados anteriormente), se encuentran las menores pero no menos importantes referencias, cuyos resultados más representativos hacen referencia a las falencias del sistema de transporte público y privado en Bogotá, existiendo la necesidad de optar por un medio de transporte eficiente y económico que mejore sustancialmente la movilidad en la ciudad. Otras referencias aluden a la posibilidad de modelar la disposición del uso de la bicicleta frente a otros modos motorizados y el desafío que supone un esquema en línea de alquiler de bicicletas, que haga parte del sistema integrado de transporte de la ciudad.

Frente al uso educativo de la bicicleta, es importante destacar que los planteamientos que aparecen se refieren como indican por Ramos (2000) y Linfati et al., (2014), especialmente a campañas para incentivar su empleo como medio de transporte, pero sin relaciones explicitas con el ejercicio ciudadano. Esto sugiere reflexiones, sobre algunas transformaciones en las formas de habitar la ciudad en relación con el desplazamiento, uso del espacio público y acercamiento a esquemas alternativos de 
transporte como la bicicleta, no solo como medio de locomoción, sino como un pretexto para la formación ciudadana que es el interés central en la iniciativa de las CSE.

Así, el espacio en el que se desarrollan procesos diferenciados en torno a la convivencia urbana comienza a responder a necesidades de quienes se encuentran en este, posibilitando no solo la transformación en el equipamiento urbano sino en las relaciones sociales que se producen en él. La vinculación del uso de la bicicleta se constituyen entonces, en una opción para ingresar al espacio público de manera distinta y cambiar algunos procesos en la movilidad y relación ciudadana.

Lo anterior, invita a reflexionar sobre estos elementos en el ámbito educativo y la manera en la que esto se puede convertir en una posibilidad para la enseñanza y aprendizaje ciudadano. Por ello, la CSE se configura como una alternativa para realizar un acercamiento distinto a la ciudad en el marco de la formación ciudadanía.

\subsection{Ciclo salidas educativas: conceptualización y diseño}

La CSE es una apuesta por reconocer la ciudad desde las vivencias y experiencias ciudadanas de sus participantes, aprovechando el uso de la bicicleta como forma de movilidad alternativa con un contenido educativo. Busca además, acercar al ciudadano a realidades socioespaciales relacionadas por ejemplo, con problemáticas de movilidad, transporte, ambiente, sostenibilidad y seguridad en la ciudad. En este sentido, la CSE se fundamenta en tres ideas principales, la primera se refiere a la salida de campo como experiencia directa sobre el espacio, la segunda a la formación ciudadana como un proceso que le permite al sujeto participar activamenente en sociedad y la tercera al uso educativo de la bicicleta como una forma de interacción más horizontal y democrática del ciudadano con su ciudad.

La salida de campo se asume de acuerdo con Moreno et al., (2011) como una escuela de aula sin muros, que permite un conocimiento y reconocimiento de actores y dinámicas que se expresan en un espacio, particularmente en el urbano en el cual se ha desarrollado la propuesta de las CSE. Por su parte, la formación ciudadana se entiende como un ejercicio de socialidad del sujeto de acuerdo con Sacristán (2001), que se desarrolla en una sociedad regulada, que le garantiza ciertas prerrogativas como igualdad, libertad, autonomía y derechos de participación. Así mismo, el uso educativo de la bicicleta, se reconoce como una alternativa pública para resignificar el ejercicio ciudadano, frente a lo que vive en su cotidianidad en distintos roles que desarrolla a nivel personal, familiar, social, laboral y politico. 
Lo anterior, orienta la organización del diseño de la CSE a partir de las reflexiones realizadas acerca de lo consultado sobre el uso de la bicicleta y su impacto en la ciudad de Bogotá. Así, se define una estructura flexible que va madurando hasta establecer unos criterios generales que facilitan su planeación. Estos criterios corresponden a objetivos, descripción, momentos de realización, tiempos y materiales.

En cuanto a los objetivos se establecen unos generales y otros específicos, que se piensan transversales para el desarrollo de las CSE. Por su parte, la descripción plantea una referencia detallada del recorrido a realizar y los participantes con los que se espera interactuar. En cuanto a los momentos en la CSE se definen uno preparatorio, otro de desarrollo y uno de cierre. En el primero, se realiza al diseño específico de la CSE con la ruta, tiempos de realización (3 a 4 horas aproximadamente), elementos de uso opcional y obligatorio, paradas estratégicas, explicaciones y posibles actores sociales que se pueden vincular al proceso.

El momento de desarrollo, corresponde a la realización propiamente dicha de la CSE, que incluye la presentación del itinerario, la preparación física con el estiramiento, las contextualizaciones en las paradas estratégicas, el registro de información por parte de los participantes y los momentos para hidratación, refrigerio y/o almuerzo. Finalmente, en el momento de cierre se lleva a cabo la socialización del ejercicio y las reflexiones respectivas planteadas por los asistentes en este proceso.

Frente a los participantes el esquema es abierto en términos de género, edad y rol social, ya que se propone para quienes estén interesados en vivir la experiencia de una ciudad bajo una mirada a dos ruedas (estudiantes, trabajadores, amas de casa, ejecutivos). Finalmente, los recursos corresponden a los materiales requeridos para el desplazamiento en bicicleta: casco, reflectivo, luces, cadena y candado y aquellos necesarios para aprovechar en conjunto la CSE, por ejemplo planos de la ciudad y/o ciclo rutas, información de hemeroteca, dispositivos móviles, hojas, esfero, colores, entre otros.

Los criterios anteriores, se concretan en un formato para la realización de las CSE que inicia estableciendo un contraste entre lo pensado y lo que se va a realizar a nivel de ruta, objetivos, responsabilidades de organizadores y participantes, actividades y resultados. Luego de varias elaboraciones se puntualiza un guión que incluye: nombre y justificación de la CSE, hora de inicio y finalización, material obligatorio para responsables y participantes, recursos, sitio y hora de encuentro y finalización, ruta, roles de los responsables y participantes, objetivos y actividades a desarrollar, resultados esperados para los responsables y para los participantes, criterios de 
evaluación de la CSE y otras observaciones de considerarlas pertinentes. El guión mencionado se utiliza para la planificación de las CSE realizadas hasta la fecha, que se presentan en el siguiente apartado de la comunicación.

\section{Ciclo salidas educativas: experiencias vividas}

La elaboración de las CSE se hace sobre la base de las ciclorutas existentes en la ciudad, las cuales se plantean en el Plan Maestro de Ciclorutas, consigado a su vez en el Plan de desarrollo por la Bogotá que queremos (1998 - 2001) de la Alcaldía de Enrique Peñalosa. Este se complementa con el Proyecto de Transporte AlternativoCicloruta dentro del Plan de Ordenamiento Territorial, presente en los artículos 179 y 180 de este, relacionados con los corredores que conforman el sistema de ciclorutas en la ciudad.

Esta infraestructura se constituye según Prada (2013) en un corredor vial alterno a la calzada, destinado al tránsito exclusivo de ciclistas, que permiten a los ciudadanos que deseen desplazarse de un lugar a otro en bicicleta, patines o similares hacerlo en forma segura. Dichas ciclorutas además de ser una adecuación urbanística, son consideradas por la autora de la comunicación, como un texto en el que se pueden conocer, reconocer, examinar y develar dinámicas, visiones, concepciones e interacciones de los ciudadanos con su espacio urbano.

Por ello, la tematización de las CSE es un ejercicio que intenta formalizar percepciones y vivencias sobre algunas ciclorutas de uso frecuente en recorridos diarios realizados por los miembros del semillero, que de acuerdo a sus experiencias significativas son capturadas por medio de la definición de toponimias, que intentan recoger el sentido y significado producto de las mismas. Este proceso, genera una tematización de 12 ciclorutas para la organización de sus respectivas CSE, de las cuales a la fecha se han desarrollado cinco (Tabla 2). 
Territorios del miedo

Entre el orden y el desorden

Del caos: una observación confrontada

Entre lo local y lo global

Segregación socio espacial: entre lo físico y lo simbólico
Realizar un proceso de observación sistemática sobre la ciclo ruta objeto de trabajo.

Realizar un ejercicio de georeferenciación de algunos fenómenos identificados en la ciclo ruta.

Contrastar algunas percepciones de los participantes y organizadore con las encontradas en la realización de la ciclo salida educativa.

Reconocer la ciclo ruta como un texto educativo para los participantes en su condición de ciudadanos.

Comprender en el ámbito socio espacial el uso de la bicicleta como un elemento de movilidad que aporta en configuración de nuevas ciudadanías.

Aprovechar la CSE como una alternativa educativa para comprender relaciones entre lo local y lo global.

Caracterizar distintas identidades y funcionalidades que pueden ser evidencias del fenómeno de segregación socio espacial, en sentido positivo y/o negativo en el recorrido urbano objeto de análisis.

Reflexionar sobre el papel de intercambios académicos para conocer la ciudad y experiencias de sus habitantes en ella.

Valorar la importancia de la realización de recorridos urbanos como una fuente de reflexión del ejercicio ciudadano.

Fuente: Guiones de preparación Semillero Semillero de investigación SIFEGI.

Las CSE mencionadas, se proponen por una parte comprender en el ámbito socio espacial el uso de la bicicleta como un elemento de movilidad que aporta en configuración de nuevas iudadanías. Por otra parte, buscan reconocer la cicloruta objeto de estudio, como un texto educativo para los ciudadanos en Bogotá. Finalmente, pretende aprovechar este esquema de trabajo como una alternativa urbana de salida de campo, en la que pueden poner en diálogo las experiencias de los diferentes participantes en la misma.

Las tres primeras tres CSE realizadas tienen la particularidad que se llevan a cabo en la misma cicloruta, con actores y ejes de reflexión difrerenciados. Así, la denominada Territorios del miedo, parte de las experiencias personales y/o sociales referidas por el semillero, en relación con situaciones de inseguridad y desorden en el uso de la misma por parte de los ciudadanos. La CSE Entre el orden y el desorden, enfatiza en la tensión entre orden y desorden que se percibe en algunos sectores del recorrido, entre usos y ocupación que se hace de la cicloruta, tipos de usuarios de ella, prácticas 
y niveles de apropiación que los actores sociales hacen de la cicloruta y formas de organización que se instalan en ella.

Finalmente, la CSE del caos: una observación confrontada, privilegia situaciones que contrastan caos y orden en algunos sectores del recorrido, como la existencia de un espacio suficiente o estrechez en la cicloruta, suficiencia o insuficiencia de espacio público en la misma, ocupación de la cicloruta por ciclistas o por actores distintos a ellos, el moderado o intenso flujo y congestión de bicicletas en diferentes horas del día y el exceso o no de velocidad por parte de algunos ciclistas. Los elementos mencionados, se consideran significativos por parte de los organizadores de las CSE, ya que son motivo de contraste en su realización con los participantes, para confirmar y/o transformar las percepciones que se tienen a partir de los recorridos realizados.

A diferencia de las anteriores, las dos últimas CSE se realizan en ciclorutas distintas. La CSE Entre lo local y lo global, propone la identificación de múltiples manifestaciones locales y globales en un recorrido de $3,5 \mathrm{Km}$, que es relativamente corto, en relación con las distancias que se manejan en Bogotá. La CSE Segregación socio espacial: entre lo físico y lo simbólico, plantea reflexiones sobre ciertas condiciones de desigualdad en capacidades y recursos en áreas urbanas que se caracterizan por tener distintos medios para la interacción social y que implican también la posibilidad de romper barreras físicas y simbólicas que instalan los ciudadanos como parte de una colectividad.

Estos reconocimientos de fragmentos de ciudad por medio de las CSE, permiten un acercamiento entre los asistentes a las mismas a partir de sus experiencias, así como la visibilización de comportamientos ciudadanos y/o anticiudadanos que incentivan no sólo su reflexión, sino sus posibilidades de transformación en el ejercicio ciudadano a partir de los elementos que resalta el esquema de las CSE.

\section{Conclusiones}

Los resultados de las experiencias de las CSE realizadas, muestran algunas incidencias tanto en organizadores como participantes, al generar algunos cambios en la percepción de la dinámica urbana que estos tienen y en algunas de sus acciones ciudadanas, cuando realizan un recorrido en bicicleta que no solo corresponde a un desplazamiento de un lugar a otro, sino a una relación más conciente con los ámbitos que se recorren. 
Al respecto, algunas expresiones de los participantes que aluden a aprendizajes obtenidos en las CSE, se refieren a los actores sociales que habitan las ciclorutas y a sus vivencias signficativas, que enriquecen la planeación y desarrollo de estas. Otro elemento que se destaca es la visibilización de realidades que están ahí, pero sobre las que el ciudadano no necesariamente se detiene por el afán y prisa de sus compromisos cotidianos.

Lo anterior, ilustra potencialidades de este tipo de esquema de trabajo para contribuir en la formación ciudadana de niños, jóvenes y adultos que viven en la ciudad de Bogotá. Así mismo, las CSE y su vinculación directa con las ciclorutas desborda su consideración como infraestructura, para descubrir en ellas textos y pre-textos de interacción ciudadana vital y significativa en su cotidianidad.

Así, las ciclorutas en las que se realizan las CSE pensadas como un sistema alternativo para la movilidad, también son una fuente de información, flujos de personas, bienes, servicios e ideas que muestra relaciones y formas de convivencia que no necesariamente se reconocen por la condición de normalidad que adquieren en la cotidianidad. En este escenario, se encuentran distintos actores con roles sociales diferenciados, que muestran formas distintas de relación con la ciudad, en una vivencia que muestra el valor del espacio más allá de ser usuarios de la ciudad.

Es importante tener en cuenta, que circular por las calles es un acto de comunicación, como propone el Colectivo SOS Bici (2014), en un manual de convivencia para apoyar a aquellos ciudadanos que desean iniciar la experiencia de montar en bicicleta de manera habitual. Por ello, desplazarse en bibicleta es interrelacionarse constantemente con peatones, conductores de vehículos, otros biciusuarios y con ese otro sistema vivo y orgánico que es la ciudad.

Es claro, que el número de CSE aun es pequeño para evaluar sus impactos en los comportamientos ciudadanos, sin embargo, su implementación y validación progresiva sugiere posibilidades interesantes, para vincular al ciudadano con su contexto de una forma directa, conciente y participativa, lo que puede contribuir a mediano y largo plazo, no solo a mejorar las condiciones de movilidad de la ciudad con el uso de la bicicleta, sino a un ejercicio más solidario, equitativo y tolerante por parte del ciudadano con otros ciudadanos y con los espacios urbanos que hacen parte de sus rutinas habituales.

En síntesis, la realización de CSE en sus diferentes versiones contribuye a la ampliación de la mirada sobre dinámicas socio espaciales de la ciudad, reconociendo en ella un espacio dinámico y mutable, producto de diversas relaciones de prácticas 
sociales habituales o no, que incluso ponen en tensión la consideración del espacio público. Así mismo, las CSE se perfilan como una propuesta educativa con capacidad para convertirse en sí mismas en una práctica ciudadana, en tanto es posible, alrededor de la reflexión sobre el contexto urbano construir identidad, representaciones de ciudad y especialmente configurar de manera colectiva una visión participativa de lo público en el espacio.

\section{Referencias bibliográficas}

Acero, J. (2011). Los sistemas de bicicleta pública, una opción de movilidad sostenible desde el esquema servicio - producto. Estudio de caso: el Programa de bicicletas BicirrUN de la Universidad Nacional de Colombia, sede Bogotá. (Tesis de maestría). Disponible en: http://www.bdigital.unal.edu.co/6547/1/696651.2011.pdf

Alcaldía de Bogotá. (2013). Seguridad vial para los ciclousuarios. Documento Técnico de

Soporte.

Disponible

en:

http://www.movilidadbogota.gov.co/hiwebx_archivos/audio_y_video/Documento\%20Te cnico\%20CicloUsuarios\%20Version\%20final.pdf

Andrè, C. (2009). A prática dá pesquiza e bibliográficos apoidos Mapeamento informativos por recursos tecnológicos: impactos não Formação de professores. (Tèsis doutoral). Facultade de Educacao Universidade de Sao Paulo.

Arbeláez, O. (2015). Modelación de la elección de la bicicleta pública y privada en ciudades.

Disponible en:

http://www.bdigital.unal.edu.co/47399/1/713813562015.pdf

Ballesteros, J. (2014). Obstáculos y limitaciones para la implementación de política de uso de la bicicleta en Colombia. Casos: Bogotá D.C., Medellín y Pereira. Disponible en: http://www.bdigital.unal.edu.co/12883/1/10006354.2014.pdf

Casabianca, L. (2012). Movilidad urbana: estado y caracterización de la movilidad en bicicleta para las principales ciclorutas de las localidades de Usaquén y Chapinero. (Monografía).

Disponible

en: http://repository.javeriana.edu.co/bitstream/10554/12458/1/CasabiancaGonzalezLuisMi guel2012.pdf

Gámez, R., Parra, D., Pratt, M., Schmid, T. (2006). Muévete Bogotá: promoting physical activity with a network of partner companies. $\mathrm{V}(13) 2,138-151$. Disponible en: 
http://search.proquest.com.bdigital.udistrital.edu.co:8080/socialsciences/docview/2333 62101/BD05AD8E086D4EF5PQ/6?accountid=34687

Gómez, A. (2013). La bicicleta como agente de cambio cultural. Revista Agnala. V(1), 17-25.

Disponible

en:

http://revistas.curnvirtual.edu.co/index.php/aglala/article/view/395/329

Heidegger, M. (1951). Construir, habitar, pensar. Disponible en: http://www.geoacademia.cl/docente/mats/construir-habitar-pensar.pdf

Hernández, G. (2011). Flexiscu: dispositivo de transporte individual. (Tesis de Maestría).

Disponible

en:

repository.javeriana.edu.co/bitstream/10554/13835/1/HernandezMoraGabrielAlejandro 2011.pdf

Instituto de Desarrollo Urbano. (2002). Infraestructura cicloinclusiva. Disponible en: https://www.idu.gov.co/page/cicloruta.

Instituto Nacional de Tránsito y Transporte. (2002). Código de tránsito. Disponible en: https://www.transitoarauca.gov.co/data/archivos/.../codigo_nacional_de_transito_2015. pdf.p

Linfati, R., Escobar, J., \& Cuevas, B. (2014). Un algoritmo basado en búsqueda tabú granular para el problema de balanceo de bicicletas públicas usando múltiples vehículos. Dyna; $\quad$ V(81) 186, 284-294. Disponible en: http://www.bdigital.unal.edu.co/42815/1/45220-217212-1-PB.pdf

Marilson, K., Siqueira, R., \& Cassiano, R. (2014). Actores individuales y comportamentales asociados con el uso de la bicicleta en adulto de Curitiba, Paraná, Brasi. Cadernos de Saúde Pública. V(30)1, 79-87. Disponible: en http://www.scielo.br/pdf/csp/v30n1/0102-311X-csp-30-01-00079.pdf

Melo, E. (2012). El mobiliario urbano destinado al uso de la bicicleta en la ciudad de Bogotá. (Tesis de Maestría). Disponible en: http://fido.palermo.edu/servicios_dyc/proyectograduaciono/archivos/1554_pg.pdf

Moreno, N., Rodríguez, L. \& Sánchez, J. (2011). La salida de campo...se hace escuela al andar. Disponible en http://www.geopaideia.com

Mosquera, S., \& Mañana, J. (2012). El modelo de ecobici como ejemplo de ecoeficiencia de la ciudad de México y su aplicabilidad en Bogotá. (Tesis de Maestría). Disponible

en: 
http://repository.javeriana.edu.co/bitstream/10554/10674/1/MosqueraCalvacheSantiag 02012.pdf

Prada, A. (2013) El uso de la bicicleta como alternativa en los procesos de revitalización y recuperación de áreas degradadas. Caso de estudio: Sector de las universidades en el centro de Bogotá. Periodo: 1998-2010. (Monografía). Disponible en: $\quad$ http://repository.urosario.edu.co/bitstream/handle/10336/4390/10986600502013.pdf?sequence $=1$

Ramos, J. (2000). Citibikes de Colombia. La bicicleta pública: sistema alternativo de transporte para Santafé de Bogotá. Revista INNOVAA, Revista de ciencias administrativas $\quad y \quad$ sociales. Disponible en: http://www.bdigital.unal.edu.co/26732/1/24384-85409-1-PB

Rengifo, D. (2011). Caracterización de la actividad física en los jóvenes de la Universidad del Quindío. (Tesis de Maestría). Disponible en: http://www.bdigital.unal.edu.co/7058/\#sthash.OvqzYMZW.dpuf

Sacristán, J. (2001). Educar y Convivir en la Cultura Global. Editorial Morata: Madrid. Sandoval, A. \& Osorio, L. (2011). CVYB, conceptualización de un sistema de transporte público alternativo complementario para trayectos cortos en Bogotá. (Monografía). Disponible en: http://repository.javeriana.edu.co/bitstream/10554/13859/1/SandovalMedinaAndresCa milo2011.pdf

Sarmiento, O. (2009). Manual para implementar y promocionar la ciclovia recreativa. (Documento inédito). Disponible en: http://www.cicloviasrecreativas.org/pdf/cicloviasmanual_espanol-cra.pdf

Suero, D. (2010). Factibilidad del uso de la bicicleta como medio de transporte en la ciudad de Bogotá. Disponible en: http://www.unilibre.edu.co/revistaavances/avances_12/r12_art7.pdf

Uribe, J. (2010). Inactividad física y factores de riesgo: construcción de un modelo explicativo en Bogotá. (Tesis de Maestría). Disponible en: http://www.bdigital.unal.edu.co/2790/\#sthash.hbVpKU9I.dpuf

Vergara, A. (2012). Bicicleta urbana como propuesta de ciudad sostenible. (Monografía). Disponible en: http://revistasupuestos.uniandes.edu.co/?p=3794 


\title{
Mouse nas mãos, ideias para construir uma geografia cidadã
}

\author{
LUIZ MARTINS JUNIOR ${ }^{1}$ \\ ROSA E. M. W. MARTINS ${ }^{2}$
}

\section{Resumo}

Este texto pertence a uma pesquisa de doutorado que está em construção pelo Programa de Pós-Graduação em Educação da Universidade do Estado de Santa Catarina - FAED/UDESC, 2018. Tal estudo trata sobre a Tecnologia Digital da Informação e Comunicação e o Ensino de Geografia, sob a ótica da centralidade da cultura. A metodologia adotada se dá na qualitativa com enfoque na pesquisa colaborativa. O percurso metodológico será desenvolvido em duas direções: uma é examinar como ocorre a conexão entre a Geografia Escolar e as tecnologias digitais na sala de aula e outra é propor a prática pedagógica "Fábrica de Aplicativo" com estudantes do Ensino Médio da Educação básica para trabalhar o tema cidadania. Essa pesquisa se preocupa por meio do uso do aplicativo construir uma Geografia escolar pensando nos movimentos do mundo, nas questões da Geografia do lugar e, principalmente, na formação cidadã diante das injunções globais que se materializam nos lugares específicos e, sobretudo, de oferecer para o professor (a) de Geografia outras possibilidades pedagógicas e metodológicas inovadoras e possíveis de concretizá-las na unidade educativa.

Palavras-chave: Geografia Escolar. Tecnologia. Cidadania.

\footnotetext{
${ }^{1}$ Doutorando em Educação pelo Programa de Pós-Graduação em Educação pela Universidade do Estado de Santa Catarina na Linha Pesquisa, Ensino e Formação, luizmartins.j@@hotmail.com

${ }^{2}$ Licenciada em Geografia; Mestre em Educação; Doutora em Geografia; Professora da área do ensino de Geografia, supervisora de estágios do curso de Geografia Licenciatura da FAED/UDESC; Coordenadora do LEPEGEO - Laboratório de Estudos e Pesquisas de Educação em Geografia; Coordenadora PIBID Geografia da FAED/UDESC; Professora do curso de Pós-Graduação em Educação da FAED/UDESC. rosamilitzgeo@gmail.com
} 


\section{Abstratct}

This text belongs to a doctoral research that is under construction by the Graduate Program in Education of the State University of Santa Catarina - FAED / UDESC, 2018. This study deals with the Digital Information and Communication Technology and the Teaching of Geography, from the point of view of the centrality of culture. The methodology adopted is qualitative with a focus on collaborative research. The methodological course will be developed in two directions: one is to examine how the connection between the School Geography and the digital technologies in the classroom occurs and another is to propose the pedagogical practice "Application Factory" with students of the High School of Basic Education for work on citizenship. In this sense, this research is concerned with using the application to build a school Geography thinking about the movements of the world, the issues of the geography of the place and, mainly, the citizen training before the global injunctions that materialize in the specific places and, above all, to offer to the teacher of Geography other pedagogical and methodological possibilities innovative and possible to materialize them in the educational unit.

Keywords: School Geography. Technology. Citizenship.

\section{Ligando a tela}

Em pleno século XXI, os avanços das tecnologias digitais e sua inserção crescente na Educação e no ensino tem se tornado um grande desafio para a política educacional e a formação de professor de modo geral, e, em se tratando deste estudo, particularmente para 0 ensino de Geografia. A Pós-modernidade, era do conhecimento, da WEB 2.0 e 3.0 e da Geração Y e Z, é caracterizada por uma sociedade moderna comumente líquida (Bauman, 2001), na qual as ideias aparecem em movimentos significativamente rápidos, mas são inseridos, incorporados e substituídos de forma efêmera, acelerada e, principalmente, penetrando e implicando em nossa maneira de comunicar, agir, pensar e expressar.

Atualmente, as mudanças tecnológicas que a cada momento acontecem, tem manifestado e modificado instantaneamente todos os segmentos que envolvem as relações sociais. Nesta linha de reflexão, Castells (2005) não hesita em declarar que estamos vivendo uma fase de intensas transformações informacionais, comunicacionais, políticas, econômicas e, principalmente o modo da espécie humana pensar, agir, decidir e expressar-se diante da mutante era digital global. 
Quanto a isso, Costa (2000, p. 110) sintetiza essa realidade dizendo que a principal característica da era atual não é a facilidade em adquirir o conhecimento e informação, mas sim à "interação, a globalização, a relativização, o imediatismo, a agilidade, a derrubada de fronteiras, a extraterritorialidade, o nomadismo". Nesse movimento, a sociedade tem se caracterizado por um rompimento geográfico de espaço-tempo polarizado de informações e noticias compartilhada, nas quais os nativos digitais são protagonistas privilegiados. Dito em termos de Coracini (2010) em concordância com Gobbi (2010) as tecnologias invadem a vida da humanidade de forma incerta, despreparada e ubíqua, ${ }^{3}$ feita para ser consumida como se fosse realmente algo que se propõe agregar conhecimento e cultura aos nativos digitais que circulam, vivenciam e se relacionam com a rede do ciberespaço ${ }^{4}$.

Esse processo líquido, de fluidez e de incerteza, indubitavelmente oriundo das tecnologias digitais, tem substancialmente e tecnicamente transformado a todos os aspectos da sociedade contemporânea. Essa velocidade de mudanças também se repercute no cotidiano escolar, na cultura da escola, no currículo e nas práticas educativas. Tais práticas requerem, em virtude do movimento e da própria da estrutura social, constantes transformações que envolvem desde o espaço escolar e sua estética, até as decisões em torno dos conceitos a ensinar, das metodologias a utilizar, das ferramentas e critérios de avaliação a selecionar.

Nesse espaço e tempo contemporâneo em que se constituem e se reproduzem relações sociais dentro e fora da sala de aula, se torna imperativa a reflexão sobre a vida cotidiana do estudante e a cultura escolar, o que implica, sobretudo, em pensar, organizar, refletir, elaborar e planejar práticas pedagógicas utilizando as ferramentas da contemporaneidade, que possibilitem multiplicar sentidos, significados, discursos, conhecimentos e sujeitos, além de discutir sobre os desafios de operar com as tecnologias digitais e as mídias em sala de aula. (Giordani et al, 2014).

Os sentidos e os rumos que a Geografia, nomeadamente o ensino de Geografia pode tomar nesses novos tempos fazem-se no momento em que as constantes mudanças socioeconômicas, geopolíticas e tecnológicas têm requerido cada vez mais estudantes competentes, operantes, críticos, participativos, capazes de aprender os conhecimentos múltiplos e complexos que compõem os conhecimentos geográficos contemporâneo.

\footnotetext{
${ }^{3} \mathrm{O}$ conceito é relativo à capacidade do ubíquo estar presente ao mesmo tempo em todos os lugares. (Santaella, 2013)

${ }^{4} \mathrm{O}$ conceito é relativo à capacidade do ubíquo estar presente ao mesmo tempo em todos os lugares. (Santaella, 2012)
} 
O ensino de Geografia na contemporaneidade, os autores Giordani et al (2014, p.04) sinalizam reiteradamente que os conhecimentos geográficos devem ser problematizados, discutidos e refletidos diferentemente dos modos convencionais e do clichê que majoritariamente estão incrustados na sala de aula, "para que possamos ler o espaço geográfico intrinsecamente relacionado com os significados que emergem de outros tempos e espaços". Do ponto de vista epistemológico e pedagógico, os autores deixam claro que o ensino de Geografia contemporâneo deve estar estreitamente amparado e pautado no processo da ação, reflexão e do estranhamento sobre tudo o que nos cerca no espaço geográfico, histórico e cultural.

É justamente com a ciência desse desafio que objetivamos trazer a sugestão da proposta pedagógica "Fábrica de aplicativo" para trabalhar os temas, conceitos e conteúdos concernentes com a geografia escolar. Neste caso, essa proposta direciona-se com uma possibilidade de trabalhar o conteúdo de cidadania entrelaçado aos conceitos basilares da Geografia direcionada para o público alvo do Ensino Médio. Essa proposta que está em processo de investigação delimitou como percurso metodológico uma abordagem qualitativa com enfoque no trabalho colaborativo. A delimitação da pesquisa colaborativa se deu pelo fato de que todo o procedimento de co-construção se dá com a base num processo de troca, interação, criatividade e colaboração dos sujeitos envolvidos no processo de ensino e aprendizagem.

A proposta ora pretendida constitui rica contribuição para o campo do ensino de Geografia, da aprendizagem colaborativa e apropriação dos conceitos e conteúdo de cidadania, bem como, também para o campo da formação de professores de Geografia. A esse respeito, Bannel et al (2016) mencionam que o acesso à informação, agenciado pelas tecnologias digitais, é o primeiro passo para construção e profusão dos conhecimentos, e a promoção de dinâmicas colaborativas se torna condição fundamental para gerar práticas educacionais inovadoras consoantes com a realidade dos estudantes na contemporaneidade. Para discutir as pressupostas temáticas, este texto está dividido em três partes principais: a primeira parte se detém sobre o ensino de Geografia sob a égide dos atuais acontecimentos na sociedade, e na segunda parte se concentra na metodologia de pesquisa com objetivo de subsidiar a proposta didática-pedagógica sobre o uso da Fábrica de aplicativo no ensino de Geografia e, na última parte, localiza-se as reais potencialidades que as tecnologias digitais, nomeadamente a Fábrica de aplicativo para trabalhar a disciplina de Geografia no Ensino Médio. 


\section{O ensino de Geografia na atual conjuntura globalizada}

O ensino de Geografia no cenário da contemporaneidade é de fundamental importância no âmbito das discussões com a educação, pois coloca em destaque aspectos complexos envolvendo a prática letiva, o currículo de Geografia, e, principalmente, a diversidade cultural neste princípio do século XXI. O mundo atual tem colocado novos desafios para a escola e para o ensino de Geografia, tornando a disciplina um espaço que pode contribuir significativamente no processo educativo, pois ela é uma ciência em que suas lentes possibilitam a leitura da Geografia do espaço, a morada do homem, o "lugar" das múltiplas relações sociais, culturais e digitais.

Isso pressupõe que se repense em novas estratégias de ensino e que se supere as formas tradicionais de ensinar, ultrapassando a mera transferência de conteúdos, de um elenco de disciplinas, especialmente, a Geografia, baseada num processo aprendizagem que leve em conta o estudante como agente social, sujeito desse processo (Callai, 2012). Diante destes novos desafios de ensinar, o uso dos dispositivos tecnológicos como: plataformas digitais, os aplicativos educativos e os ambientes virtuais livres e gratuitos acrescentam como uma possibilidade alternativa de ensino e aprendizagem para as disciplinas que compõem a propostas curricular, em especial, para a Geografia.

Principalmente em promover uma aprendizagem centrada no sujeito tornando pertinente a compreensão, a partida, do modo como os próprios sujeitos se posicionam face à aprendizagem por meio da mediação pedagógica. No caso específico do ensino de Geografia, os dispositivos tecnológicas podem servirem de apoio e reforço no ato educativo para analisar, relacionar e aprofundar os conceitos chaves desta ciência para entender o espaço geográfico em suas diferentes escalas: local, regional, nacional e global.

Nesta ótica, Tonini e Giordani (2014), destacam que para o ensino de Geografia, as tecnologias digitais contribuem tanto para auxiliar a aprendizagem dos conhecimentos Geográficos como viabilizar a reconversão de conceitos e conteúdos designamente estáticos e básicos para conteúdos e conceitos variados, dinâmicos e comparados. Pois a simulação dos conhecimentos geográfico por meio do ambiente virtual possibilita a aproximação do estudante com seu objeto de investigação, além de democratizar o acesso e aumentar a capacidade de análise e informação. Tornando assim, a tecnologia uma geradora e promotora de transformações qualitativas no trabalho escolar e no estudante como cidadão. 
Aproximação das tecnologias com a Geografia no fazer educativo permitir que o estudante estabeleça relações geográficas, ambientais e sociais com outro lugar, cultura e território. Não obstante, elas incidem em provocar deslocamentos no campo dos discursos e dos significados geográficos e, principalmente, das textualidades geográficas, por meio de uma gama de dispositivos de que dispõem para aprender Geografia consentânea às linguagens cotidianas dos estudantes.

Nesta perspectiva, as autoras Tonini e Silva (2014) chamam atenção que é de fundamental importância que o professor realize uma busca criteriosa de dispositivos, e se esforce em contextualizar com a realidade do contexto educativo, por meio dos seus temas e conteúdos, bem como a realidade cultural que o estudante está inserido. A adequada atuação do professor é, sobretudo, uma ação pessoal, intuitiva e subjetiva na mediação pedagógica.

No entanto, é preciso compreender de forma mais profunda o papel das dispositivos tecnológicas vendo-os como meios de trabalho, de consulta e de comunicação que podem potencializar o pensamento, a memória, a linguagem e a ação do estudando no ato educativo, tomando-se, assim, também, um dispositivo de apoio à autonomia e à realização pessoal que não podem estar ausentes de qualquer projeto de vida e participação social (Pretto; Pinto, 2006).

\section{Metodologia da Pesquisa}

A abordagem epistêmica metodológica desta investigação está inspirada num enfoque qualitativo na modalidade da pesquisa colaborativa. Nesse contexto, a pesquisa de natureza qualitativa insere novos olhares para pesquisa social e cultural, implicando novas leituras para os problemas e proporcionando outros novos mecanismos de ação para a edificação do espírito crítico e democrático da sociedade.

Nesse movimento, Martins (2004, p.01) não se hesita em declarar que a esse tipo de pesquisa trazida para dentro da educação e do ensino contribui em "privilegia a análise de microprocessos, através do estudo das ações sociais individuais e grupais, realizando um exame intensivo dos dados e caracterizando pela heterodoxia no momento da análise". Com base no caráter qualitativo, Lakatos e Marconi, indicam cinco características básicas principais,

a pesquisa qualitativa tem ambiente natural como fonte direta e 0 pesquisador como seu principal instrumento [...] os dados coletados são predominantemente descritivos [...] A preocupação com o processo é muito maior do que com o produto [...] O significado que as pessoas dão às coisas e a sua vida são focos de atenção especial do pesquisador [...] a análise 
dos dados tende a seguir um processo dedutivo (Lakatos; Marconi, 2017 p.09)

A abordagem da pesquisa qualitativa possibilita o pesquisador investigar os objetos complexos, envolver os dados heterogêneos, analisar com profundidade a riqueza interpretativa dos dados e das informações, além disso, proporciona a contextualização do ambiente ou entorno, dos detalhes ou experiências únicas do objeto investigado (Pires, 2008).

A pesquisa colaborativa insere-se em uma abordagem qualitativa e tem sua origem na pesquisa-ação, que busca a colaboração de um pesquisador para transformar o mundo da prática, visando à formação de qualidade de todos envolvidos com a Educação. No espaço escolar, esse tipo de investigação não busca apenas gerar nova teoria e conhecimento, mas também contemplar situações problemas imediatos do dia a dia da prática escolar (Ibiapina, 2008).

Vinculada a essa questão, Ibiapina (2008, p. 25) acrescenta que o pesquisar colaborativamente envolve a necessidade de compreender que "para mudar a teoria, a política e a cultura escolar, é necessário optar pelo desafio de co-produzir conhecimentos com pares envolvidos com a escola, aproximando o mundo da pesquisa ao da prática". Dessa forma, esse fazer construtivo, rompe com a lógica pura e empírico-analítica, na medida em que parte do uso da reflexão e da prática de colaboração como estratégias para a compreensão das ações, desenvolvendo entre os participantes a capacidade de resolução dos desafios e/ou problemas que são colocados em xeque.

Ao dirigirmos seu o foco para a experiência da prática no ensino de Geografia, a proposta da pesquisa colaborativa surge como fio condutor na importância da aprendizagem dos conceitos geográficos; na troca; no diálogo por meio do qual as pessoas se conhecem, se tocam e se movimentam; na cooperação; na integração; por meio da participação de todos (as) na "Fábrica de Aplicativo", conforme desenhada no quadro 1.

Levando em conta esses pressupostos, os autores Ibiapina (2008) e Capellini (2004), ressaltam que a pesquisa colaborativa consiste em propiciar a colaboração dentro e fora da sala de aula, incluir todos na prática escolarizada, e ainda, proporcionar a comunicação com e para o mundo a partir do lugar que o sujeito atua. Isso denota que, o fazer colaborativo revela ser uma potente pesquisa que evidência dar visualidade às diferenças, heterogenizar os espaços, bem como, aos modos com que 
as diferenças se relacionam e se percebam com os pares no próprio local em que aprendem juntos.

Portanto, a pesquisa colaborativa, segundo Cavalcanti e Souza (2014, p. 141) inspirado em Ibiapina (2008) constrói-se por duas direções que se entrecruzam "uma da integração do pesquisador na construção de propostas junto com o professor, no interior da escola, e a outra da integração e a aprendizagem colaborativa dos participantes na prática pedagógica". Nesse âmbito, observamos que pesquisa em tela nos possibilita gerar e propor para a Geografia escolar propostas pedagógicas analógicas ou digitais que garantam efetivamente a participação e a colaboração de todos os estudantes na construção do conhecimento. Entende-se que pesquisa dessa natureza qualifica ainda mais caminhos possíveis para ensinar Geografia colaborativamente e a promover a inclusão de todos (as) em seu espaço de convivência social e cultural. 


\section{(Re) inventando saberes e fazeres: Passos da prática pedagógica}

Prática: Fábrica de Aplicativo

Conteúdo: Cidadania

Conceito: Espaço Geográfico, Lugar, Território, Região e Paisagem

Duração: 4 aulas/hora

\section{PLANEJAMENTO}

1) Objetivo: Criar um aplicativo móvel na Plataforma Web fábrica de aplicativos $^{5}$

2) Dinâmica: a) organização e divisão dos grupos; b) distribuição dos temas estudados; c) explicação e orientação da funcionalidade do aplicativo; d) socialização dos aplicativos.

3)Recurso: computador, smartphones, tablet.

4) Desenvolvimento:

a) Criação de um aplicativo móvel para smartphones, por meio da plataforma Web Fábrica de aplicativos ${ }^{6}$;

b) Criação/formatação do perfil (título e designer) do aplicativo móvel pelos grupos com a finalidade de administrar e organizar página da mídia;

c) Apresentação e discussão da proposta com a turma:

- Divisão do grupo de trabalho proporcionalmente ao número de estudantes na classe;

Orientações gerais para execução da proposta pelos grupos de trabalho: postagens, inserção de comentários, pesquisa tanto no ciberespaço quanto na linguagem digital Google Earth, interação colaborativa entre os grupos, captura e postagens de imagens, vídeos e textos de cada temática proposta, dentre outras;

d) Atividade de pesquisa, com os tópicos baseados na temática relativa conteúdo selecionado pelo professor da turma:

- Atividade de pesquisa I:

\footnotetext{
${ }^{5}$ Disponível em http://fabricadeaplicativos.com.br/ e o tutorial de como montar o aplicativo https://youtu.be/IDVgUhylJb4

${ }^{6}$ Sem a necessidade de ter conhecimento em programação, consegue-se criar um aplicativo na plataforma brasileira Web Fábrica de Aplicativos, apenas arrastando e inserindo em seu projeto cada funcionalidade disponível.
} 
- $\quad$ Atividade de pesquisa II:

- Atividade de pesquisa III:

e) Apresentação e discussão da pesquisa efetuada pelos grupos, em sala de aula, narrando os saberes e as informações coletadas a partir dos temas propostos, além de refletir a temática central, e suas influências no Espaço Geográfico, estendendo o debate para os âmbitos de diferentes escalas de ocorrências. As intervenções e orientações do professor/pesquisador direcionavam a produção do conhecimento para os conteúdos selecionados/trabalhados;

f) Seleção dos textos, imagens e vídeos dos temas correlacionados que reflitam a temática pesquisada;

g) Compartilhar o link do aplicativo entre os grupos por meio das redes sociais, adotadas pela classe (grupo no Whatsapp e Facebook) para que todos possam fazer o download do aplicativo.

h) Postagens dos conteúdos produzidos, textos, vídeos, slides, imagens de forma colaborativa pelos grupos no respectivo aplicativo.

i) Avaliação das postagens efetuadas dos trabalhos publicados pelos envolvidos.

Fonte: autores.

\section{Apontamentos Finais}

O cenário atualmente denota um movimento em direção a um sentido de transformações sociais, culturais e econômicas onde presenciamos uma revolução científico-tecnológica, um mundo globalizado e interconectado por redes digitais, onde vivemos "imersos" num turbilhão de informações que invadem nosso cotidiano. Iniciase o novo milênio com sérios desafios que exigem o repensar, o recriar e ressignificar desse modelo civilizatório. Não obstante, algumas relevantes conquistas ocorreram no campo dos direitos humanos e na formação de um novo paradigma, que traz a consciência ao ser humano e diz respeito a todos e todas - somos um só corpo social integrado e intrinsecamente interdependente por cabos e fio conectados.

Ressalta-se, para finalizar, que o intuito maior dessa pesquisa é apontar as reais potencialidades que as tecnologias digitais tem para ensinar Geografia. Tendo em vista essa proposta em que pretendemos efetivar, nos permite salientar que esse 
dispositivo para Geografia é de caráter inovador; pelas aprendizagens geridas coletivamente e colaborativamente pela via do contato entre o estudante e a tecnologia na construção do conhecimento. Além disso, é uma possibilidade didática que permite com que o professor de Geografia utilize em seu fazer pedagógico abordando os conceitos geográficos e por excelência o conteúdo de cidadania.

\section{Referências bibliográficas}

Bannell, R. I; DUARTE, R; CARVALHO, C; PISCHETOLA, M; MARAFON, G; CAMPOS, G. H. B. de. Educação no século XXI: Cognição, Tecnologias e aprendizagens. Petrópolis, Rio de Janeiro: Vozes: Editora PUC, 2016.

Callai, H. C. Estudar o lugar compreender o mundo. Porto Alegre: Mediação, 2012.

Castells, M. A sociedade em rede. Vol. I 6 edição. Tradução: Roneide Venancio Majer. Ed. Paz e terra, 2005.

Cavalcanti, L. S.; Souza, V. C. A pesquisa colaborativa na formação de professores de Geografia e seus desdobramentos no ensino. In: MARTINS, R. E. M. W. (Org.) Ensino de Geografia no contemporâneo: experiências e desafios. Santa Cruz do Sul: EDUNISC, 2014.

Coracini, E. G. R. A formação de professores para o uso das tecnologias digitais nos cursos de pedagogia. Dissertação (Mestrado em Educação) Universidade do Estado de Santa Catarina, Florianópolis, 2010.

Costa, S. R. Oralidade e escrita e novos gêneros (hiper)textuais na internet. In: Conferência de Pesquisa sociocultural. Campinas: UNICAMP/PE, 2000.

Gatti, Bernadete Angelina. Grupo focal na pesquisa em Ciências Sociais e Humanas. Brasília: Líber livro editora, 2005.

Giordani, A. C. Aprender geografia: a vivência como metodologia. (Org). In: GIORDANI, Ana Claudia; TONINI, I. M. TECNOLOGIAS DE INFORMAÇÃO E COMUNICAÇÃO DISPONÍVEIS NO CIBERESPAÇO PARA ENSINAR E APRENDER GEOGRAFIA. [ et. al.] - Porto Alegre: Evanfraf, 2014.

Ibiapina, I. M. L. M. Pesquisa colaborativa investigação, formação e produção do conhecimento. São Paulo. Liber livros, 2008.

Lakatos, E. M.; Marconi, M. A. Metodologia cientifica. 7 ed. - São Paulo: Atlas, 2017.

Lévy, P. Cibercultura. São Paulo: Ed.34, 2000. 
Martins, H. H. T. de. Metodologia qualitativa de pesquisa. In: Educação e Pesquisa. São Paulo, v.31, n 3, maio/ago, 2004.

Peres, B. M. et.al. Olhando a escola contemporânea. In: GIORDANI, Ana Claudia. Aprender geografia: vivência como metodologia. Porto Alegre: Evangraf, 2014.

Pretto, N.; Pinto, C. C. Tecnologias e Novas Educações. Universidade Federal da Bahia, Faculdade de Educação, 2006.

Santaella, L. A ecologia pluralista da comunicação: conectividade, mobilidade, ubiquidade. São Paulo: Paulus, 2012.

Tonetto, E. P.; Tonini, I. M. Redes sociais: Plataformas para a construção de uma Geografia onlaine. In: GIORDANI, A C. (Org) Aprender a ensinar geografia: a vivência como metodologia. [ et. al.] - Porto Alegre: Evanfraf, 2014.

Tonini, I. M. Giordani, A. C. UM CLIC NO ENSINO DE GEOGRAFIA. In: TONINI, I. M. (Org). O ensino de geografia e da historia: saberes e fazeres na contemporaneidade. [et. al.]. Porto Alegre: Evanfraf, 2014.

. SANTOS, L. P.; BenAduCE, G. M. C.; PERES, B. M. Olhando a escola contemporânea. In: TONINI, I. M (Org). O ensino de geografia e da historia: saberes e fazeres na contemporaneidade. [ et. al.]. Porto Alegre: Evanfraf, 2014 


\title{
O estudo dos espaços públicos: propostas para o ensino de Geografia e cidadania
}

\author{
Mugiany OLIVEIRA BRITO PORTELA ${ }^{1}$ \\ Josivane José de ALENCAR ${ }^{2}$
}

\section{Resumo}

O ensino de Geografia contribui para o exercício da cidadania, especialmente na educação básica, de modo que através dos conhecimentos veiculados por essa disciplina escolar, o estudante pode entender-se como cidadão ativo e desenvolver ações sobre os espaços públicos, transformando-os em um fio condutor para a efetivação do projeto Nós Propomos!. Nessa premissa, é possível fazer com que a Geografia Escolar se torne uma disciplina teórico-prática e com significado para a vida cotidiana. Neste sentido, o presente estudo traz a seguinte indagação: de que forma o estudo dos espaços públicos da cidade de Campo Maior - Piauí / Brasil contribui para relacionar os conhecimentos da Geografia Escolar com o exercício da cidadania? Por meio da articulação de conteúdos geográficos com ações de intervenção social, objetivamos, conjuntamente com os alunos do ensino médio do Instituto Federal de Campo Maior, promover o fortalecimento desses espaços como locais de encontros das pessoas e de reforço de vínculos afetivos com o lugar vivido. Para tanto, o presente trabalho apresenta como metodologia: o levantamento de problemas referentes aos espaços públicos no bairro Santa Cruz; a realização de encontros de mobilização com estudantes acompanhados da discussão de textos e a proposição de ações de intervenção em espaços públicos vividos no bairro. Entendemos que o estudo dos espaços públicos colabora para que os alunos percebam que através de suas práticas sociais, eles podem articular os conhecimentos geográficos com as suas ações e, na mesma medida, contribuir para a transformação dos espaços de sua vivência.

Palavras chaves: Cidadania; Geografia Escolar; Espaços Públicos; Brasil.

\footnotetext{
${ }^{1}$ Professora do Curso de Licenciatura em Geografia da Universidade Federal do Piauí, mugiany@yahoo.com.br.

${ }^{2}$ Professor do Ensino Médio do Instituto Federal do Piauí, josivane@ifpi.edu.br.
} 


\section{Abstract}

The teaching of Geography contributes to the exercise of citizenship, especially in basic education. This way through the knowledge conveyed by this school discipline, the student could understand himself as an active citizen and develop actions on public spaces, transforming them into a tool for the implementation of the project we proposed. In this premise, it is possible to make School Geography become a theoretical-practical and meaningful discipline for everyday life. Thinking like this, the present study brings the following question: in what way does the study of the public spaces in the city of Campo Maior, Piauí - Brazil contribute to relate the knowledge of the School Geography to the exercise of citizenship? Through the articulation of geographic contents with social intervention actions, we aim, together with the high school students of the Federal Institute of Piauí, to promote the strengthening of these spaces as places to meet people and strengthen affective bonds with the local place. To reach it, the present work presents as methodology the survey of problems related to public spaces in the Santa Cruz neighborhood; the holding of mobilization meetings with students accompanied by the discussion of texts; and the proposition of intervention actions in public spaces lived in the neighborhood. We understand that the study of public spaces helps students to realize that through their social practices, they can articulate geographic knowledge with their actions and, in this same way, it contributes to the transformation of their own spaces.

Keywords: Citizenship; School Geography; Public spaces; Brazil

\section{Introdução}

O projeto "Nós Propomos!" representa um marco para o ensino de Geografia, pois se volta para a promoção do projeto de cidadania nos espaços das escolas brasileiras. Ressalta-se que a cidadania estabelecida no engajamento dos projetos, parte do princípio da participação extensiva das universidades, escolas, professores formadores, professores da educação básica. E, o mais importante, provoca maior engajamento social para a vida cotidiana de muitas crianças e jovens, o que não foi diferente em nossa experiência realizada no município de Campo Maior, no estado do Piauí, localizado na região do Nordeste brasileiro.

Nossa aproximação com o projeto "Nós Propomos!" foi motivada, inicialmente, pelo desejo de incluir o curso de Geografia da Universidade Federal do Piauí - UFPI no espaço escolar de um Instituto Federal de Educação Ciência e Tecnologia do Piauí. A participação ativa na realidade escolar nos permite pensar em caminhos para formar 
melhor os futuros professores. Com intuito semelhante, muitos professores que estão na escola básica acabam se distanciado da universidade, depois concluir a graduação São ainda poucos os professores que continuam sua formação em um programa de Pós-Graduação ou sistematizam e publicam as suas experiências de sala de aula algo que o projeto Nós Propomos! possibilita.

Mencionamos, ainda, que o projeto Nós Propomos! incentiva um ensino de Geografia em que as ações do cotidiano colaboram para que a cidadania esteja presente e se efetive, sempre que possível, em nossas vidas. Nesse sentido, firmamos uma parceria entre o referido projeto, a Geografia da UFPI e o Instituto Federal do Piauí-IFPI, Campus Campo maior.

No IFPI, os alunos do ensino médio, especificamente de $1^{\circ}$ e $2^{\circ}$ anos, ficaram motivados a pensar nos problemas e possíveis soluções para a realidade do município de Campo Maior. Sobre esse aspecto, debateram algumas possibilidades de desenvolvimento de um trabalho que envolvesse a comunidade do município. Nessa medida, decidiram por pesquisar e elaborar um projeto local relacionado à mobilidade urbana e à cidadania nos espaços públicos do município, sobretudo relacionado ao sistema viário.

Quanto a nós, professores, acatamos os encaminhamentos sugeridos pelos alunos na compreensão de promover o fortalecimento dos espaços públicos como locais de encontros das pessoas e de reforço de vínculos afetivos com o lugar vivido. Para tanto, o presente trabalho apresenta como metodologia: o levantamento de problemas referentes aos espaços públicos no bairro Santa Cruz, na cidade de Campo Maior; a realização de encontros de mobilização com estudantes acompanhados da discussão de textos e a proposição de ações de intervenção em espaços públicos vividos no bairro.

Para a compreensão geral das atividades desenvolvidas, organizamos a discussão deste texto em três partes, as quais são: a compreensão do espaço público e da cidadania; a investigação sobre os espaços públicos locais - o caminho metodológico trilhado e alguns encaminhamentos para futuros trabalhos.

\section{A compreensão do espaço público e da cidadania}

Consumir o espaço público é um ato de cidadania (Cavalcanti, 2008). Esse consumo refere-se a usufruir o direito aos espaços do município que são destinados ao convívio público. Nesses espaços é possível o encontro entre as pessoas e o usufruto que 
dado local propicia para quem o frequenta, o que pode ocorrer em uma praça pública, nas ruas e em outros lugares. No Brasil, os espaços públicos encontram-se cada vez mais ameaçados devido a uma produção cada vez mais voltada aos espaços privados. Para Carlos (2007, p. 12) pensar o urbano enquanto reprodução da vida em todas suas dimensões remete a uma,

Articulação indissociável dos planos local/mundial - o que incluiria, necessariamente, as possibilidades de transformação da realidade (a dimensão virtual). Já a cidade permitiria pensar o plano do lugar revelando o vivido e a vida cotidiana através dos espaços-tempo da realização da vida.

A produção do espaço urbano brasileiro tem fragmentado a relação social entre as pessoas que compõe as sociedades das cidades, fato agravado pela sensação de insegurança pública e falta de infraestrutura adequada aos diferentes contextos sociais existentes. Por esse pressuposto, tem sido recorrente, nas grandes cidades brasileiras, o encontro das pessoas em shoppings e outros locais, administrados pela iniciativa privada, que procuram espaços onde o comércio e os serviços são oferecidos com maior comodidade e segurança. $O$ fato é que o distanciamento dos espaços públicos por parte de alguns brasileiros pode contribuir para a não efetivação da cidadania. Mas, em que medida, os espaços públicos contemplam a vivência cidadã?

Trataremos dessa questão sob duas frentes: na primeira buscaremos a compreensão do espaço público como promotor da cidadania e, na segunda, apresentaremos o trabalho desenvolvido no município de Campo Maior.

A princípio, Cavalcanti (2008) afirma que o espaço urbano é, sobretudo, um espaço público, no qual o cidadão pode viver e exercitar seu direito pleno à vida coletiva, à vida digna. Por essa razão, a autora salienta que os valores urbanos, a segregação, a criação de periferias e de centralidades são processos interligados e decorrentes da estratégia de ocupação e apropriação dos espaços pelas diferentes classes sociais. Diante isso, a discussão versa para a compreensão da cidade enquanto espaço público de/para todos e como lugar de uma participação ativa, democrática e cidadã de seus habitantes.

Em compreensão semelhante, Gomes (2002) ressalta que a cidade é hoje concebida de forma fragmentada, como soma de parcelas mais ou menos independentes, havendo uma multiplicação de espaços que são comuns, mas não públicos. Há um confinamento dos terrenos de sociabilidade e diversas formas de nos extrairmos do espaço público (telefones celulares, fones de ouvido, etc.), os modelos de lugares se 
redefiniram, shopping centers, ruas fechadas, paredes "cegas" etc. Ou seja, o recuo do espaço público corresponde a um recuo paralelo da própria cidadania.

Os espaços públicos colaboram para o exercício da cidadania, pois são locais que proporcionam o encontro, o debate de ideias e onde exercemos nossa ação política. Neste sentido, Carlos (2004, p.148) adverte que: "é preciso permitir a apropriação plena dos lugares da cidade como forma de negação da segregação".

A esse respeito, Alburqueque \& Gomes (2016, p. 59) corroboram que estes "são espaços de materialização da cidadania". Nesse sentido, ser cidadão representa exercer direitos e cumprir deveres, os quais são estabelecidos, criados e recriados conforme haja necessidade para o convívio social. Esse contexto tem relação direta com o exercício democrático de pensamentos e ações. A cidade é antes de tudo "uma obra perpétua de seus habitantes" (Lefebvre, 1991 apud Carlos, 2004, p. 149).

Contudo, um entrave relevante para o exercício da cidadania está no desconhecimento desse projeto de vida. Especificamente no Brasil, há grande interesse por parte de alguns líderes políticos, de que os conhecimentos relativos ao exercício da cidadania fiquem inacessíveis. Nesse aspecto, o ensino de Geografia na educação básica é de grande relevância para fomentar o engajamento dos alunos na construção/modificação do espaço vivido, exercendo assim, de maneira mais plena, sua cidadania.

A Geografia é estudada nas escolas brasileiras durante os ensinos fundamental e médio. Nesta disciplina escolar, as crianças e jovens têm a oportunidade, por meio da vivência dos espaços públicos, de analisar as relações sociais estabelecidas e também as práticas espaciais executadas pela sociedade. Em outros termos, o estudo dos espaços públicos promove uma compreensão do processo de produção/transformação do espaço geográfico, a partir do estabelecimento de relações sociais e reforçam elementos de identidade com o lugar (Albuquerque \& Gomes, 2016). É preciso entender ainda que:

Se o espaço público é, sobretudo, social, ele contém antes de tudo as representações das relações de produção, que, por sua vez enquadram as relações de poder, nos espaços públicos [...]" (Lefebvre, 2000, apud, Serpa, 2004, p. 25).

No que diz respeito à caracterização dos espaços públicos, Campos (1995) define como todo tipo de espaço intermediário entre edifícios em áreas urbanas, com o acesso permitido ao público, sendo agrupados em abertos (situados em uma construção urbana, não cobertos por edifícios ou estruturas permanentes, permitindo o livre acesso e o movimento de pessoas sem restrição, por exemplo, sistema viário, 
parques, lagoas, praças abertas) e fechados (edifícios institucionais de uso predominantemente público).

São nos espaços públicos que ocorrem as evidências das nossas identidades, expressas em cada rua, praça, calçada e o que mais viabilize a mobilidade entre os lugares. Nesses espaços são aguçados nossos sentidos, desenvolvemos a crítica sobre as condições de vida e estabelecemos as conexões com algumas categorias de análise (lugar, paisagem, território...).

Sobre a cidade como espaço público, Gurevich e Caso (2011) tratam-na sob três circunstâncias. A primeira diz respeito aos valores associados a três conceitos: liberdade e coesão social; proteção e desenvolvimento dos direitos individuais e de expressão; e construção de uma identidade coletiva, democrática, participativa e igualitária. A segunda circunstância refere-se às noções de espaço público no sentido físico: centralidade, mobilidade e acessibilidade socializadas, zonas sociais e funcionalmente diversificadas, lugares com atributos e significantes. A terceira referese ao sentido político e cultural: expressão e representação coletiva, identidade, coesão social, integração cidadã. No sentido de orientar atividades para essas três possibilidades, Gurevich e Caso (2011) apontam as seguintes propostas: identificar na cidade os mecanismos políticos; os instrumentos que administram a cidade e verificar em que medida essas políticas contribuem para a cidadania, bem como observar os serviços, os trâmites e programas de governo nos bairros.

Acerca da mobilidade que se dá entre os espaços públicos e privados, Gomes (2012) sugere o espaço público com base em duas perspectivas: material, como as praças, as ruas etc.; e imaterial, o que representa a "condição da expressão de uma individualidade que deve conviver com um universo plural - ele depende, pois, da permanente reafirmação do contrato social que o funda" (Gomes, 2012, p. 30).

Nesse contexto, cabem as seguintes problemáticas: os espaços públicos de Campo Maior colaboram para o encontro, a convivência e ao reforço da identidade dos moradores com o seu local de vivência? As avenidas da cidade contribuem para o trânsito seguro dos diferentes usuários das vias que compõem o sistema viário local? Que ações podem ser desencadeadas visando a requalificação dos espaços públicos locais? De que modo o estudo dos espaços públicos contribui para a ressignificação do ensino de Geografia Escolar?

\section{A investigação sobre os espaços públicos locais: o caminho metodológico trilhado.}


Para a investigação sobre os espaços públicos locais promovemos encontros com os alunos para a discussão de textos referentes ao estudo da cidade, dos espaços públicos e a construção da cidadania a partir do estabelecimento de práticas espaciais. O estudo dos textos colaborou para a realização das discussões sobre as problemáticas vivenciadas pelos estudantes no seu cotidiano. Das discussões realizadas, optamos pelo estudo de problemáticas relacionadas ao sistema viário de Campo Maior, especialmente, sobre as condições de trafegabilidade da avenida Nilo de Oliveira, situada no entre os bairros Santa Cruz e Fazendinha.

A avenida Nilo de Oliveira é uma importante via da cidade que liga os bairros Santa Cruz à zona rural da cidade (figura 1). A via recebeu recapeamento asfáltico no ano de 2016, porém não foram realizadas melhorias relacionadas à sinalização, construção de calçadas e de ciclovias. A via é utilizada cotidianamente por pedestres e ciclistas que se utilizam do espaço para a prática de atividade física, deslocamento cotidiano, bem como para a contemplação da paisagem.

Figura 1 - Localização espacial da Avenida Nilo de Oliveira

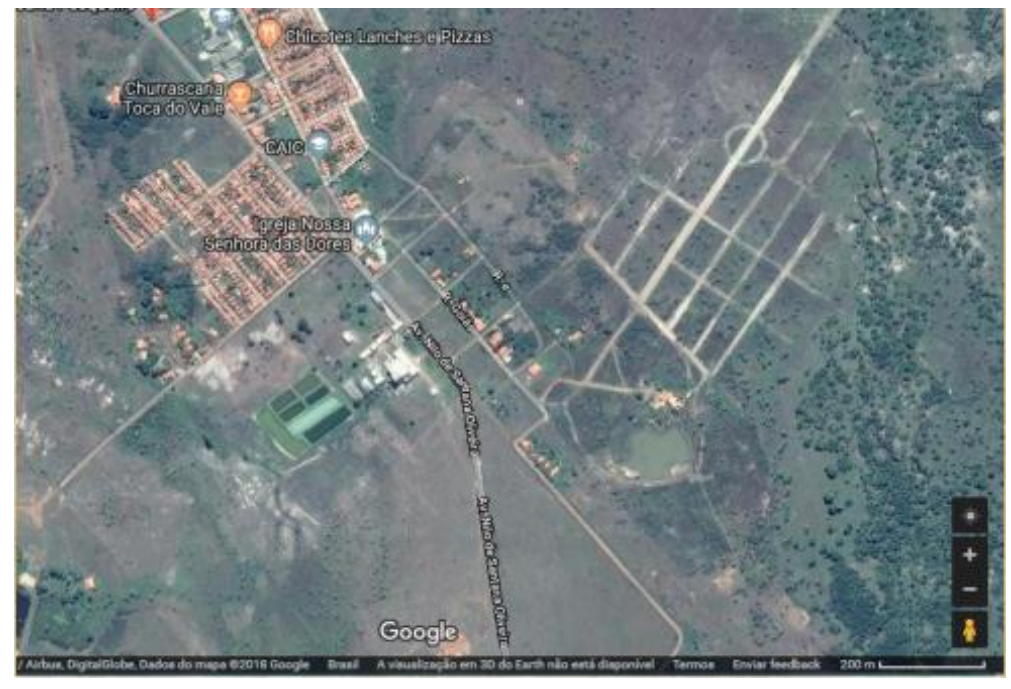

Fonte: Google Earth. Acesso em 17/10/2018.

Para um estudo mais elaborado da situação em que estavam expostos os frequentadores da via, aplicamos trinta questionários contendo perguntas abertas e fechadas com os moradores e frequentadores do local para levantamento de um diagnóstico sobre os usos do espaço com vistas à indicação de melhorias para a otimização do uso da avenida Nilo de Oliveira (figura 2). Os dados foram tratados com auxílio do software Excel. 


\section{Figura 2 - Aplicação de questionários com os usuários da via}

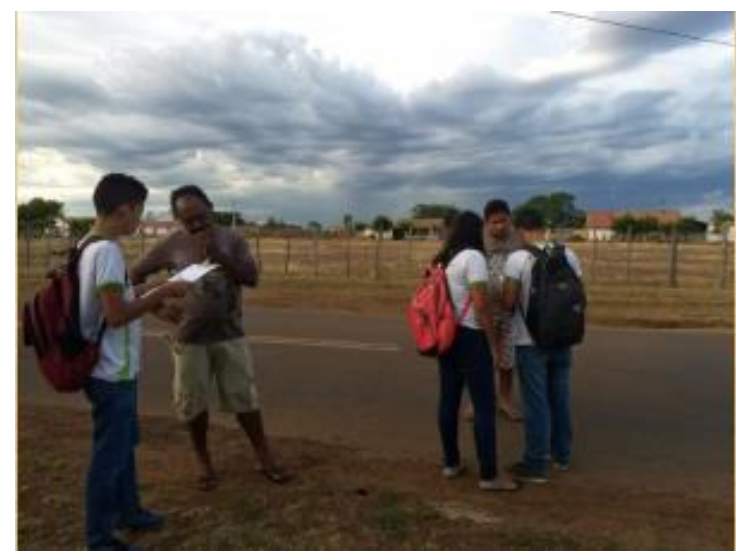

Fonte: créditos diretos dos autores, 2018.

A realização da pesquisa demonstrou que a maioria dos entrevistados utiliza a via para a prática de caminhadas e ciclismo. O uso da avenida para a prática de exercícios físicos é verificado, sobretudo, ao final do dia quando é ocupada por moradores do bairro Fripisa e comunidades adjacentes. O uso diário do espaço para a realização de exercícios físicos demonstra que este equipamento público tem uma importância para a comunidade local, servindo como elo entre a zona urbana e rural da cidade de Campo Maior.

Ao serem indagados sobre as sensações que têm ao transitar pela via, os moradores apontaram que sentem medo/insegurança, representando um quantitativo de $83 \%$, contra $10 \%$ que revelou uma sensação de desconforto térmico e $7 \%$ que demonstrou bem-estar ao transitar pela avenida, conforme pode ser visualizado no gráfico 1.

\section{Gráfico 1 - Usuários da via: sensação dos moradores ao frequentarem o espaço público.}

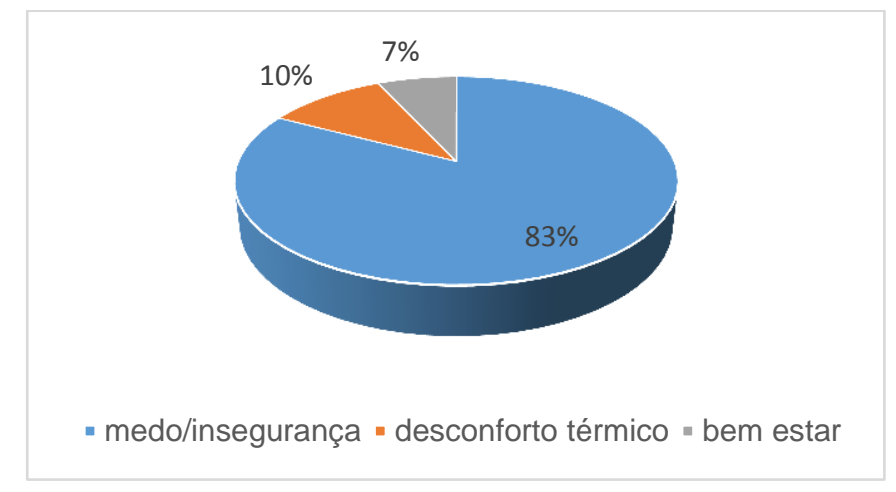

Fonte: créditos diretos dos autores

Chama a atenção o elevado número de pessoas que se sentem inseguras ao transitarem na avenida Nilo de Oliveira. Essa sensação, despertada na maioria dos 
entrevistados, provém da falta de sinalização da via, bem como de calçadas e ciclovias que permitiriam uma travessia mais segura. $O$ que se verifica entre os usuários do espaço público é que tanto carros, ciclistas e pedestres disputam o mesmo espaço na pista de rolamento, tornando o uso desse lugar para a realização de atividade física arriscada.

Ao inquirirmos sobre o estado de conservação da via, os moradores apontaram que as condições de trafegabilidade são consideradas ruins, com um total de $39 \%$, seguido de $36 \%$ dos usuários que a consideram que a avenida tem uma boa conservação, ao passo que $25 \%$ dos entrevistados a consideram péssima, conforme pode ser visualizado no gráfico 2 .

Diante das precárias condições de uso da via, solicitamos que os moradores apontassem sugestões visando a requalificação do espaço público. As sugestões apontadas pelos usuários do espaço público incluem: sinalização, construção de calçadas, iluminação pública e arborização (Quadro 1). Estas medidas, segundo os moradores tornariam o espaço mais atrativo para a prática de exercícios físicos, bem como ofereceriam uma maior segurança aos que nela transitam no cotidiano.

Gráfico 2 - Opinião dos usuários da via sobre condições de trafegabilidade

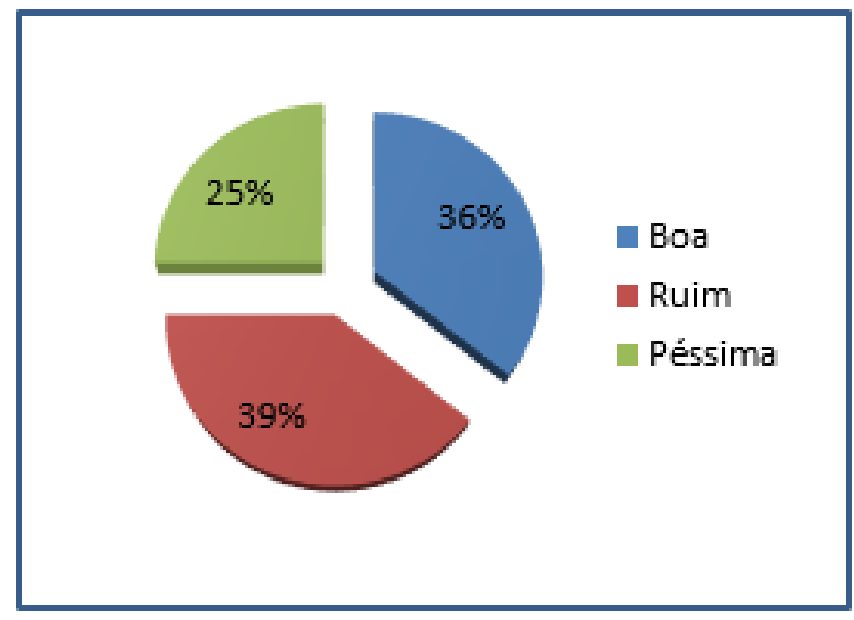

Fonte: crédito direto dos autores, 2018.

Os dados indicados no quadro 1 apontam para a necessidade de intervenções na avenida Nilo de Oliveira, como forma de requalificar este espaço público. A indicação de sinalização da via é a medida mais urgente a ser tomada segundo os usuários, uma vez que muitos acidentes já foram registrados no local. Logo a falta de sinalização horizontal e vertical colabora para a ocorrência de um clima de insegurança entre pedestres, ciclistas e condutores de veículos automotores. 
Quadro 1 - Sugestões apontadas pelos moradores para a requalificação do espaço público 3.

\begin{tabular}{|l|l|l|}
\hline Sugestão & Valor absoluto & Valor relativo (\%) \\
\hline Sinalização & 29 & 22 \\
\hline Iluminação & 27 & 21 \\
\hline Construção de calçadas & 27 & 21 \\
\hline Arborização & 23 & 18 \\
\hline Colocação de lixeiras & 22 & 17 \\
\hline Outras ações & 02 & 1 \\
\hline Total & 130 & 100 \\
\hline
\end{tabular}

Fonte: créditos diretos dos autores (2018).

A iluminação é outra reivindicação solicitada pela comunidade, pois está atrelada à melhoria da sensação de segurança tanto dos adeptos de atividades físicas, bem como para demais usuários da via como estudantes, profissionais liberais e agricultores. A presença de iluminação pública ao longo da via colabora para uma travessia mais segura no período noturno.

A presença de calçadas e ciclovia constituem importantes reivindicações apontadas pelos moradores e que contribui para a diminuição de acidentes registrados sistematicamente ao longo da via. A ausência destes equipamentos públicos contribui para que pedestres e motoristas arrisque suas vidas ao transitarem pelo local. A arborização e colocação de lixeiras são também medidas que proporcionam um maior conforto térmico para a realização de atividades físicas, ao tempo em que a colocação de lixeiras contribui para a limpeza da via.

\section{Encaminhamentos para futuros trabalhos.}

Como forma de dar vazão às demandas apontadas pela comunidade, bem como pelos estudantes que participam do projeto Nós Propomos!, articulamos um conjunto de ações visando a requalificação da avenida Nilo de Oliveira. As ações propostas para requalificação do espaço estão pautadas teoricamente no Código de Trânsito Brasileiro que, em seu artigo 72, enfatiza:

"Todo cidadão ou entidade civil tem o direito de solicitar, por escrito, aos órgãos ou entidades do Sistema Nacional de Trânsito, sinalização,

\footnotetext{
${ }^{3}$ Os usuários da via apontaram mais de uma sugestão para requalificação do espaço público. Aqui apontamos o número de vezes em que cada sugestão foi enunciada.
} 
fiscalização e implementação de equipamentos de segurança, bem como sugerir alterações em normas, legislação e outros assuntos pertinentes a este código" (Brasil, 2008).

Visando a efetivação das mudanças desejadas pelos usuários da via, articulamos algumas atividades como forma de chamar atenção da comunidade e autoridades locais para a necessidade de requalificação do espaço. Uma delas incluem da realização de um passeio ciclístico ao longo de toda a extensão da via com moradores, estudantes e demais membros da sociedade civil organizada de Campo Maior. A realização do Pedal Nós Propomos!, consiste em conscientizar os usuários da via sobre a importância da sinalização, iluminação e construção de passeio público, como forma de garantir uma maior segurança e diminuição dos acidentes envolvendo os diferentes públicos que pela avenida transitam no cotidiano.

Paralela à realização de um passeio ciclístico, será feita a pintura de um mural no Instituto Federal do Piauí, situado à margem da Avenida Nilo de Oliveira. A pintura do mural será feita por alunos e professores da instituição participantes do projeto Nós Propomos!. A ação visa levar arte aos usuários que transitam pela avenida, tornando o espaço público da avenida um local de contemplação. No mural, serão inseridos elementos da cultura local, tais como espécies da caatinga e Mata dos Cocais, além de elementos simbólicos da cultura campo-maiorense como: gado; o vaqueiro e a representação de templos religiosos existentes na cidade.

Findada a realização do passeio ciclístico, bem como a pintura do mural, realizaremos uma visita à câmara de vereadores para solicitar aos parlamentares que encaminhem uma proposta, via requerimento legislativo, para a requalificação da avenida, com as sugestões indicadas pelos estudantes.

\section{Considerações finais}

O estudo dos espaços públicos constitui um importante instrumento de ressignificação do ensino de Geografia Escolar. À medida que pesquisamos a dinâmica dos espaços públicos, seus usos e estado de conservação atual, provocamos em sala de aula reflexões sobre o processo de construção/transformação dos espaços, entendendo-os como fruto da ação dos diferentes atores sociais.

A análise de práticas espaciais promovidas pelos moradores nos espaços públicos nos conduz a um conhecimento de como se dão as relações dos habitantes de uma cidade com seus espaços de vivências. A realização de intervenções colabora para a 
compreensão da produção espacial a partir da ação de diferentes agentes produtores, incluindo o estudante como protagonista deste processo.

O levantamento de problemáticas relacionadas aos espaços públicos e a proposição de ações de requalificação dos espaços tornam o estudante de Geografia da educação básica um partícipe da produção do espaço vivido. Quando envoltos em atividades que estimulam práticas cidadãs, os estudantes despertam o senso crítico, desenvolvendo diferentes habilidades e competências para atuarem de modo mais efetivo no cotidiano.

Através das ações desenvolvidas no âmbito do projeto Nós Propomos!, damos um novo sentido ao ensino de Geografia enquanto matéria escolar. De uma disciplina com caráter mnemônico e enciclopédico, produzimos uma Geografia com conteúdo de grande significação para o aluno, haja vista que os estudos teóricos, vistos em sala de aula, têm uma aplicabilidade prática. Por meio dos conhecimentos geográficos, o estudante percebe que pode colocar em prática ações que fortalecem a cidadania, contribuindo desse modo para a transformação dos espaços da realidade vivida.

\section{Referências}

Albuquerque, Mariana Zerbone Alves de; GOMES, Edvânia Torres Aguiar. (2016). Espaços livres públicos: lócus da cidadania no espaço urbano? Revista Continentes

Brasil. (2008). Código de Trânsito Brasileiro. 1aㅡ edição. Brasília: DENATRAN.

Campos, Heleniza Ávila. (1995). A conservação de conjuntos históricos a partir do uso dos espaços públicos abertos: um recorte no centro expandido da cidade de Recife: Dissertação de Mestrado em Desenvolvimento Urbano. UFPE. 174p.

Carlos, Ana Fani Alessandri. (2004). O espaço urbano: novos escritos sobre a cidade. São Paulo: Contexto.

2007. O espaço urbano: novos escritos sobre a cidade. São Paulo: Labur.

Cavalcanti, L. de S. (2008). A cidadania, o direito à cidade e a Geografia escolar elementos para o estudo do espaço urbano. In: (_). A Geografia escolar e a cidade. Campinas, SP: Editora Papirus.

Gomes, Paulo Cesar da Costa. (2002). A condição urbana. Rio de Janeiro: Editora Bertrand Brasil, pp. 129-191. 
(2012). Espaços públicos: um modo de ser do espaço, um modo de ser no espaço. In: Castro, Iná e. de; Gomes, Paulo César da C.; Corrêa, Roberto L. (Org.). Olhares geográficos: modos de ver e viver o espaço. Rio de Janeiro: Bertrand Brasil.

Gurevich, Raquel; CASO, Maria Victoria Fernandez Caso. (2011). Buenos Aires: intinerarios para su enseñanza. In: Lanche, Núbia Moreno. Ciudades leídas, ciudades contadas: la ciudad latino-americana como escenario didático para la enseñanza de la geografia. Bogotá: Universidad Distrital Francisco José de Caldas.

Serpa, Ângelo. (2004). Espaço público e acessibilidade: notas para uma abordagem geográfica. Geousp - espaço e tempo. São Paulo, n. 15, p. 21-37 


\section{Educação Geográfica e População - analogias entre a Geografia que se pratica e a que se almeja}

NAJLA MEHANNA MORMUL ${ }^{1}$

\section{Resumo}

O presente trabalho visa discutir como a temática da população fora abordada pela educação geográfica ao longo do século XX. Para tanto, optamos por analisar como o elemento populacional foi percebido e tratado pela Geografia praticada na escola. Para fins de organização textual categorizamos a Geografia em três grandes momentos: clássica, moderna e crítica. A riqueza desse debate reside no fato que esse tema é pouco trabalhado pela Geografia brasileira, mas, ao mesmo tempo, ele revela questões importantes, que merecerem ser reconhecidas como objetos de investigação e análise. Assim, deve-se considerar que a população é um conceito chave, intrínseco ao desenvolvimento da cidadania - uma vez que nem toda população é formada por cidadãos -, liberdade, isonomia material. Isto porque através da Convenção Interamericana de Direitos Humanos e a Constituição Federal de 1988, a cidadania foi elevada a patamar de direito fundamental, possível de ser alçado por todo aquele que é nacional e preenche certos requisitos formais, não se admitindo discriminações de raça, cor, etnia, religião. Estudar a população é, então, evidenciar os componentes que a integram sejam eles sociais, econômicos, culturais. Partindo da premissa que todo aquele que é cidadão compreende certo grupo populacional, faz-se possível analisar grupos populacionais por meio da política, cidadania ativa e passiva. A cidadania torna-se um direito transindividual, que expressa muito de um povo e sua cultura educacional. Portanto, a educação geográfica se contextualizada pode potencializar o estudo de diversos temas, inclusive população/cidadania, tornando-os mais ricos, vivos e dinâmicos, em especial, nos tempos atuais.

\footnotetext{
${ }^{1}$ Professora Doutora do Curso de Goegrafia da Universidade Estadual do Oeste do Paraná, campus de Francisco Beltrão/PR, endereço eletrônico: najlamehanna@gmail.com
} 
Palavras-chave: Geografia; Escola; População; Ensino; Cidadania.

\section{Abstract}

The present work aims to discuss how the thematic population was approached by geographic education throughout the twentieth century. Therefore, we opted to analyze how the population element was perceived and treated by the Geography practiced in the school. For purposes of textual organization we categorize Geography into three great moments: classical, modern and critical. The richness of this debate lies in the fact that this subject is little worked by Brazilian Geography, but at the same time it reveals important questions that deserve to be recognized as objects of investigation and analysis. Thus, it must be considered that the population is a key concept, intrinsic to the development of citizenship - since not all population is formed by citizens -, freedom, material isonomy. This is because, through the Inter-American Convention on Human Rights and the Federal Constitution of 1988, citizenship has been elevated to a level of fundamental right, which can be raised by everyone who is a national and meets certain formal requirements, without discrimination of race, color, ethnicity, religion. Studying the population is, then, to highlight the components that integrate it are social, economic, cultural. Starting from the premise that everyone who is a citizen understands a certain population group, it is possible to analyze population groups through politics, active and passive citizenship. Citizenship becomes a transindividual right, which expresses much of a people and its educational culture. Therefore, geographic education if contextualized can potentiate the study of diverse subjects, including population/citizenship, making them richer, livelier and dynamic, especially in the present times.

Key-words: Geography; School; Population; Teaching; Citizenship.

\section{Introdução}

A discussão ora apresentada começa como uma indagação relativamente simples, porém extremamente válida. O que é educação geográfica? Para respondermos a essa pergunta, certamente precisamos entender o que é educação e o que é geografia, uma vez que se presume que educação geográfica passa pela compreensão desses dois termos e/ou conceitos. Posto isto, relativizamos que educação geográfica depreende-se de um processo educativo-formativo, no qual professores e alunos buscam apropriar-se dos conhecimentos historicamente produzidos pela ciência geográfica. Codificar e decodificar esses saberes são o que 
compreendemos como educação geográfica, ou seja, ler e interpretar o mundo de modo consciente e propostivo, entendendo a espacialidades dos fenômenos nas suas múltiplas escalas.

Logo, o rol de conteúdos pertencentes à geografia é algo importante a ser explorado, dado as possibilidades de interpretação e interação entre eles e a vida humana. Nesse sentido, ao escolhermos o temário da população o fazemos por acreditar que esse possui potência formativa, na medida em que articula a produção da vida com a cidadania e o espaço geográfico. Contudo, no transcorrer da história da geografia escolar melhor da educação geográfica, [visto que a geografia é una, portanto, não há uma geografia para os escolares e outra para os universitários], a população enquanto conteúdo fora tratada com pouca acuidade e na maior parte das vezes abordada de forma generalizada, repleta de dados e números estéries sem relação direta ou contextualizada com a produção e manutenção da vida em sociedade.

Com esse intuito organizamos esse texto, a fim de desilustrar um tema importante que pode contribuir de forma incisiva para que uma efetiva educação geográfica-cidadã aconteça. Para tanto, abordaremos o tema do seguinte modo, incialmente far-se-á uma breve incursão pelo pensamento geografico com ênfase na educação geográfica e nos estudos da população. Por fim, será realizada uma discussão sobre os alinhamentos entre esse tema no constructo da cidadania e teceremos as considerações finais.

\section{Educação geográfica e população: caminhos e descaminhos}

Durante o século $X X$ no Brasil muitas foram as tendências geográficas entre elas destacamos a Geografia tradicional (clássica) difundida nas primeiras décadas do século XX centrada na observação e descrição principalmente do quadro natural, estruturava-se basicamente em três partes: aspectos físicos, humanos e econômicos. Sendo os aspectos físicos considerados os mais importantes, já as questões referentes à ação humana estavam inseridas no quadro natural, como se a paisagem tivesse sido modelada para receber a humanidade e fornecer a ela os recursos necessários à sua sobrevivência, a parte econômica era enfatizada com o intuito de demonstrar a relação homem e natureza por meio das diferentes atividades econômicas desenvolvidas como o extrativismo, agricultura, pecuária, mineração etc (Mormul, 2013).

Em relação aos estudos de população, predominava a ênfase nos conceitos e números, com pouca contextualização com a realidade, ou seja, não se levava em 
conta os fatos cotidianos, as relações político-sociais e econômicas e adotava-se um estudo do espaço de maneira fragmentada. Por conta dessa fragmentação, era difícil estabelecer relações entre o homem e o meio físico e suas particularidades (Mormul, 2013). Portanto, na escola este conteúdo era para ser observado e não interpretado, ou seja, os aspectos populacionais eram naturalizados, não contextualizados e tão pouco relacionados com a cidadania.

Nas décadas seguintes a Geografia passou a ser reformulada, especialmente, porque se entendia que ela não mais atendia as transformações econômicas e sociais que estavam ocorrendo no mundo após a Segunda Guerra Mundial. Culminando nos meados de 1950 com a crítica contudente a Geografia dos Estados Maiores denunicada por Yves Lacoste (1993) e, posteriormente ao processo de renovação da Geografia brasileira coroado com a realização do XVIII Congresso Internacional de Geografia que ocorreu no Rio de Janeiro em 1956 e contou com a presença de geógrafos oriundos de outros países que inclusive permaneceram no país ministrando palestras e cursos por um bom período de tempo. Mormul (2013) lembra-nos que em 1957 os cursos de Geografia e História foram separados, contribuindo assim, para a valorização dessas áreas em nível superior, após alguns anos foram implantados laboratórios especializados na Universidade de São Paulo o que fortaleceu a Geografia difundindo-a para outras universidades do país.

O processo de renovação na Geografia fez com que as concepções teóricometodológicas até então adotadas fossem revistas. Assim, a chamada Geografia tradicional foi assolada por diversas críticas, sobretudo, pela ausência de criticidade relegando-a ao passado que deveria ser superado. Para Moreira (1987, n/p.) os estudos da população puseram em questão as abordagens apenas quantitativas com relação ao crescimento e à estrutura. Questionando-nos até onde foram as mudanças? Para o autor o método de estudos de população na Geografia apresentavam duplo aspecto: a ausência de historicidade populacional; e sua "fragmentação-colagem". O autor ofereceu uma importante contribuição ao criticar esse recorte temático em crescimento, estrutura e distribuição da população e ao propor que se integre o homem e a sociedade da qual faz parte; que não se dissolvam essas duas categorias (Moreira apud Rua, 1977, n/p).

A crítica de Moreira (1987, n/p.) denuncia a ausência de pensamento crítico ao se abordar a população, sobretudo, nas aulas de Geografia. Tornando o conteúdo enfandonho e inútil, logo, o desinteresse e a falta de problematização em torno das questões populacionais aparecem e enfraquecem aquilo que defendemos como 
necessário para uma educação geográfica, isto é, uma educação que seja capaz de dialogar com as demandas das vidas dos sujeitos e possam dotá-los de conhecimentos para que consigam decodificar os fenômenos populacionais.

Corroborando as numerosas críticas apresentadas à forma como vem se desenvolvendo o estudo da população, é forçoso reconhecer que, tanto na universidade como nos livros didáticos, a tradicional "fragmentação-colagem" ainda está presente como afirma Moreira (1987). Portanto, superar essa leitura desprovida de senso crítico é o que se almeja ao ensinar e aprender a população por meio da educação geográfica.

É importante destacar que a crítica por si só não atua como transformadora do modo como se ensinará e se aprenderá geografia, a questão é mais profunda e depende não apenas de mudanças de pedagogias e de metodologias. Mas, sobretudo, mudanças de atitudes e, também, de concepções de professores e alunos no trato dos temas geográficos. O que significa que não se deve banalizar, naturalizar ou ir de um extremo a outro, sem fazer as devidas críticas das ideias que surgem ou são reformuladas. É preciso sim, ressignificar o estudo da população. Bem como a educação geográfica, sempre que se fizer necessário. Contudo isso siginifica que é imperativo entender o contexto de elaboração das ideias, os sujeitos e os territórios dos quais essas emergem, pois as manifestações de diferentes perspectivas podem ocorrer tanto em tempos alternados como concomitantes, visto que a história não é linear.

Durante o período de maior predomínio da denominada nova Geografia (moderna) os trabalhos gráficos vinculados a dados estatísticos ganharam projeção. Nesse período os estudos populacionais ficavam atrelados aos números, à busca pela coesão metodológica e a necessidade de produção científica pautadas em dados mensuráveis fortalecia o emprego de modelos matemáticos. Todavia, os trabalhos desenvolvidos por essa Geografia mais pragmática, contavam com dados mais precisos, contudo, as análises mantinham-se atreladas a quantidade pela quantidade, como se o números pudessem explicar sozinhos a dinâmica da população (Mormul, 2013).

Essa Geografia derivava de um conjunto de postulados, fundamentalmente, econômicos, sobretudo, baseados no comportamento dos consumidores e fornecedores, conforme lembra-nos Harvey (1969). Almejavam-se reduzir gastos com transportes de produtos, ou seja, estes estavam atrelados a uma teoria na qual era possível diminuir o arranjo espacial dos centros de serviço. Para tanto, foram criados alguns modelos de arranjos espaciais, com formas e contextos diferenciados. Mormul 
(2013) ressalta que durante o predomínio da nova Geografia os indicadores estatísticos invadiram os estudos populacionais, havia certa obsessão numérica em torno das questões populacionais e no entendimento desses estudiosos estas questões podiam ser explicadas por meio do emprego de números, tabelas, gráficos e pirâmides etárias que dominaram o campo de estudos da Geografia da População, sobretudo, pela ânsia em transformar a Geografia em uma ciência exata, quantificável.

Para David Harvey (1992) o reconhecimento de que as dimensões do espaço e do tempo são relevantes, e de que há geografias reais de ação social, territórios e espaços de poder reais e metafóricos se tornaram vitais como forças organizadoras na geopolítica do capitalismo. Para ele o materialismo histórico enfim começa a levar a sério a Geografia. O materialismo histórico-geográfico é, portanto, um modo de pesquisa aberto e dialético, em vez de um corpo fixo e fechado de compreensões.

A denominada Geografia pragmática intensificou-se nos anos 1960 e 1970, especialmente, por conta dos interesses governamentais. Vivemos, nesse período, uma intensa participação governamental nas diferentes esferas da vida pública. $\mathrm{O}$ arcabouço oferecido pela Geografia pragmática servia para sustentar a ideologia do governo, tendo em vista que a ciência estava seu serviço, assim faziam uso das descobertas científicas para alcançarem os objetivos almejados. Se por um lado as descobertas científicas colaboravam para o aprimoramento de métodos e técnicas, por outro podia cercear 0 direito individual e coletivo, uma vez que o governo tinha em suas mãos a possibilidade de controlar os variados segmentos da sociedade visando com isso atender seus interesses. Deste modo, dependia para quem o conhecimento científico era ofertado, quais os reais anseios de quem o direcionava, bem como, os investimentos destinados (Mormul, 2013, p.169).

Para Gramsci (1996) a individualidade e personalidade se constrõem pela consciência e pelo agir do homem a partir das circunstâncias, através da tomada de consciência das relações do que o limita ou o liberta. Assim, está atrelada à compreensão da relação da formação do indivíduo a partir do envolvimento do sujeito no contexto social, num compromisso constante com a sociedade.

É importante relembrar que o aparecimento de uma concepção geográfica não rompe totalmente com as antigas, muitas vezes, ambas se sobrepõem. As origens do movimento que culminou com a chamada nova Geografia estão presentes na ação científica que buscava solucionar ou encontrar meios para amenizar a crise econômica capitalista, além de buscar criar mecanismos ou instrumentos de controle social, culminado em ações voltadas ao planejamento regional e urbano (Mormul, 2013).

Dessa forma há de considerar que cada momento histórico expressa as condições materiais que o formou, assim com o passar o tempo altera-se as terminologias e o sentido da Geografia, não se trata de um processo natural, mas sim historicamente 
produzido, como o que ocorreu com a Geografia pragmática e a Geografia da percepção. Em oposição a Geografia pragmática desponta-se a Geografia da percepção que estava voltada em recuperar importância do homem na Geografia. Em Topofilia Tuan (1980) propõe a abordagem dos conceitos de percepção, atitudes e valores do ser humano em relação ao meio ambiente, entendido como "[...] tudo aquilo que rodeia o homem, quer como indivíduo, quer como grupo, e dessa forma ele não é apenas composto de cores, formas e extensões, mas também de sons, odores e sensações" (Oliveira, 2000, p. 21).

A percepção é a resposta dos sentidos aos estímulos externos, como a atividade proposital na qual certos fenômenos são claramente registrados, enquanto outros retrocedem para a sombra ou são bloqueados. Muito do que percebemos tem valor para nós, para a sobrevivência biológica e para propiciar algumas satisfações que estão enraizadas na cultura (Tuan, 1980, p. 101).

Conhecida, também, como Geografia humanística ou comportamental, essa Geografia busca através da adoção de diferentes procedimentos metodológicos investigarem como as pessoas sentem e se relacionam com o espaço, usando para isso explicações oriundas da psicologia. Para a Geografia da percepção o estilo de vida de um povo é a soma de suas atividades econômicas, sociais e ultraterrenas. Estas atividades geram padrões espaciais; requerem formas arquitetônicas e ambientes materiais que influenciam o padrão das atividades e o habitante da cidade parece ter uma necessidade psicológica de possuir uma imagem da totalidade do meio ambiente para localizar o seu próprio bairro (Mormul, 2013).

É notável que o historicismo, bem como o neopositivismo, e também a fenomenologia atribuiu aos estudos de população um olhar a partir da individualidade, das sensações, do empirismo e por meio disso instigou uma maior aproximação com relação à natureza, formando neste momento uma mescla teórica e metodológica que ora aconchegava-se com o positivismo, em outros momentos refutava ou reativava-o com mais intensidade atribuindo-o nova "roupagem", e em outros se apropriava dos pressupostos da fenomenologia (Mormul, 2013).

Durante o advento da chamada Geografia crítica as abordagens teóricas e metodológicas dos estudos de população sofreram maiores transformações, por conta da incorporação da dialética e da elaboração de análises mais acuradas acerca dos desdobramentos e interfaces do sistema capitalismo e das relações humanas, com ênfase na questão do trabalho, na sobrevivência da população, na expectativa de vida, nos movimentos de mobilidade e mobilização, e, ainda as discussões sobre cadastro de reserva, acúmulo de capital, desigualdade social, entre outros (Mormul, 2018). A 
abordagem desse tema sobre essa concepção tornou o estudo da população na escola, mas dinâmico, pois permitiu que as questões populacionais fossem problematizadas e não naturalizadas, ou seja, elementos ligados aos fatores socioeconômicos passaram a serem interpretados a partir de uma perspectiva histórico-crítica possiblitando reflexões mais signficativas, tanto para a formação intelectual, mas, sobretudo, humana das pessoas, reforçando e fortalecendo a cidadania na Geografia.

Com esse breve ensaio bucamos mostrar que a Geografia ao longo de sua história abordou o tema da população sob diversas concepções, muitas das vezes determinadas pelo projeto de país, soceidade e educação engendrado. O esforço realizado pautou-se na vontade de mostrar que houve diferentes abordagens da população na Geografia, ora com ênfase na Geografia tradicional de âmbito posistivista, ora com ênfase na Geografia Pragmática, Geocrítica e também na Geografia humanística, esse hibridismo de concepções marcaram a ciência geográfica e consequentemente a forma de abordagem dos conteúdos por ela trabalhados. Nesse sentido, reforçamos a importância de conteúdos como a população atuar como articulador dos temas que afetam direta e indiretamente a vida, tornando-a os conteúdos atrativos e ricos.

\section{População, Cidadania e Educação Geografia}

O que é cidadania?

Nem todos aqueles que residem em um país são cidadãos, contudo, todos os cidadãos são nacionais (natos ou naturalizados). Explica-se que conforme a Convenção Interamericana de Direitos Humanos (San José, Costa Rica, 22 de novembro de 1969) cidadão é aquele que está em pleno gozo de seus direitos-deveres civis e políticos, podendo votar e ser votado. Senão vejamos:

1. Todos os cidadãos devem gozar dos seguintes direitos e oportunidades:

a) de participar na direção dos assuntos públicos, diretamente ou por meio de representantes livremente eleitos;

b) de votar e ser eleitos em eleições periódicas autênticas, realizadas por sufrágio universal e igual e por voto secreto que garanta a livre expressão da vontade dos eleitores; $\mathrm{e}$

c) de ter acesso, em condições gerais de igualdade, às funções públicas de seu país.

2. A lei pode regular o exercício dos direitos e oportunidades a que se refere o inciso anterior, exclusivamente por motivos de idade, nacionalidade, residência, idioma, instrução, capacidade civil ou mental, ou condenação, por juiz competente, em processo penal (CIDH, 1969). 
Sabe-se que a população de um país é composta por milhares de indivíduos, pertencentes a variadas culturas, etnias, religiões e, não raras vezes, existirão aqueles que estarão impedidos de exercer a cidadania, como os condenados à pena privativa de liberdade, os imigrantes ilegais, entre outros. Assim, por mais que esses indivíduos componham a população de uma nação, nem todos podem ser considerados cidadãos. Uma nação, em linha de princípio, é formada por um governo, seu povo e sua população. O povo representa, propriamente, aqueles que gozam plenamente de seus direitos-deveres. Já a população representa aqueles que residem no território.

Por mais que a Constituição Federal de 1988 tenha elevado a cidadania ao patamar de direito fundamental, nem todos aqueles que residem um país são cidadãos. Para a Ciência Jurídica, um indivíduo passa a ser considerado cidadão quando realiza o seu alistamento eleitoral, sendo este, no Brasil, facultativo dos 16 (dezesseis) aos 18 (dezoito) anos de idade e obrigatório a partir dos 18 (dezoito). De se realçar que no Brasil o voto não é obrigatório, porém o alistamento eleitoral o é.

A noção de cidadania está intrinsecamente ligada à noção de povo, população. Não se pode estudar a cidadania sem se considerar quem são os indivíduos integrantes do território analisado. Quem são? Imigrantes? Quantos votam? Quantos podem ser eleitos? Quantos não exercem seus direitos-deveres políticos? Por quê? Eles exercem plenamente sua cidadania? Sabem o que isso representa? Todas essas perguntas e muitas mais só podem ser respondidas com o estudo acerca do povo, população. Não há falar em cidadãos sem a existência de povos, populações.

Em decorrência dessa linha de raciocínio ratificamos a importância da educação geográfica no trato com as questões populacionais. Estudar a dinâmica da população passa pelo entedimento de vários fatores: o que é população; o que são políticas públicas voltadas a população; como é o comportamento populacional de um dado país; território ou região e como professores de Geografia podem trabalhar a fim de promover uma educação geográfica-cidadã etc.

Em tempos atuais, países como o Brasil, sofrem pela falta de uma educação de qualidade que possa fornecer a população condições para se tornarem sujeitos autonômos e conscientes. Tem sido uma constante o descaso com educação, especialmente com os mais pobres e necessitados, o que gera desconforto e medo frente aos demandos dos representantes políticos da nação. A corrupção, o ódio, a desigualdade econômica e social tem gerado um cenário hostil em que as pessoas se sentem amendrotadas e ameaçadas por seus semelhantes. Não há um reconhecimento de povo enquanto classe, a uma disputa por poder em que oprimidos 
querem ser opressores, como lembra-nos Paulo Freire (2011). A meritocracia, o individualismo, a privatização em laga escala, a livre concorrência, a competetividade vem sendo almejada por boa parte dos brasileiros que não compreendem a origem das desigualdades e os caminhos para sua superação, apostando que uma política liberal de extrema direita seja a solução para um país tão desigual como o Brasil. Não podemos nos esquecer de que se trata de uma sociedade capitalista, voltada ao consumo pelo consumo, sendo a educação nesse cenário, apenas mais uma mercadoria, ou seja, uma propriedade.

As maiorias que auferiram ascensão econômica nos últimos anos se sentem ameaçadas por políticas públicas que atendam as necessidades dos mais pobres, políticas assitencialistas e/ou estadistas são vistas como predatórias e estimuladoras da "vagabudagem". Absurdos são proferidos, ódio é destilado e a jovem democracia brasileira se vê ameaçada, porque a busca pelo "salvador da pátria" passa a ser almejado por boa parte da população, que não se forma apenas se informa, especialmente por meio de comunicações e redes sociais altamente alienantes. Mas, posto isto, pergunta-se é possível promover uma educação geográfica cidadã nesse contexto?

Enquanto professores de Geografia somos desafiados constantemente a pensar e repensar o lugar da Geografia na escola, na vida das pessoas. Portanto, entende-se que a razão de uma disicplina passar ou não a compor o currículo é repleta de intencionalidades, assim a Geografia que chega a escola pode até não ser capaz de promover a educação geográfica-cidadã, mas a praticada, essa sim, pode fazer a diferença. Logo, essa diferença está condicionada a formação do professor, ou seja, esse profissional precisar ter os requisitos necessários para operar a Geografia de modo comprometido com a transformação, sempre que essa for necessária. Obviamente que não se trata de um trabalho fácil, e muito menos de uma formação doutrinária, ideológica e cheia de fanatismo. Mas sem dúvidas é importante que professor conheça não só a Geografia, mas, sobretudo que tenha acesso a diferentes saberes, pois esses propriciaram maior capacidade de ação, ou seja, para ser professor de Geografia é preciso saber Geografia, mas também dominar outros saberes essenciais para a formação de um bom professor (Tardif, 2010). Nesse ínterim, o conteúdo populacional poder ser um aliado, visto que por meio dos fenômenos afetos a população os professores podem desvendar e abordar temas relacionados à vida e contribuir para a formação cidadã de milhares de brasileiros, promovendo uma educação geográfica capaz de dialogar com os diferentes sujeitos e permitir que vejamos o mundo pelos olhos de nossos alunos. 
Exercer cidadania dispõe que os sujeitos reconheçam suas identidades, suas culturas, seus direitos e deveres. Portanto, saiba que ser cidadão é muito mais que votar de 04 (quatro) em 04 (quatro) anos. Nesse sentido, a Geografia é uma ciência fantástica para formação política e cidadã, visto que ela engloba temas potencializadores de uma formação científica e humana.

Assim, negligenciar o estudo da população na Geografia é amputá-la, ou seja, destituíla de algo que é extremamente significativo, há muitas possibilidades para estudar população e estimular a cidadania, não são poucas as ações que podemos adotar para estimular as crianças, adolescentes e jovens, reconhecerem esse tema como algo orgânico, que pertencem à eles e que pode ser interpretado e reinterpretado à luz de várias perspectivas.

A simbiose entre tempo-espaço atribui aos estudos da população na Geografia elementos importantíssimos para que se possa agir, interpretar o mundo de modo consciente e propositivo, permitindo que os sujeitos deixem de ser expectadores e possam ser protagonistas de suas vidas. Entendemos que somos responsáveis por nossas ações e também omissões, e só teremos um mundo melhor na medida em que as fronteiras - não seja entre quem tem dinheiro e quem não tem -, pois, uma sociedade desigual se não for repensada tende a reforçar a distância entre os que têm e os que não têm. E quanto maior for o abismo entre os que detêm os meios de produção e os que vendem sua forma de trabalho, mais difícil será para enfretarmos as contradições inerentes ao sistema capitalista dos países pobres, pois precisamos ter um projeto de nação que respeite as diferenças e realmente acredite num projeto de união do país e de seu povo. O aprofundamento da desigualdade precisa ser algo a ser veementemente combatido e não reforçado.

A escola como locus do conhecimento precisa ser um espaço privilegiado para que o conhecimento chegue a todos de modo sério. Não se pode admitir em tempos atuais que as escolas, especialmente a pública se transforme em lugar onde deixar pessoas e não formá-las. Portanto, essa instituição precisa ser respeitada por todos, professores, alunos, comunidade. Para tanto, seu valor e significado precisa ser ressignificados, e esse processo de ressignificação perpassa por políticas públicas que realmente insiram a escola e seus professores no bojo de demandas urgentes, por meio de injeção de recursos financeiros e cuidado e zelo na formação de professores com qualidade, e que esses tenham rendimentos e salários atrativos. Somente com ações políticas estruturantes poderemos colocar a escola no lugar que Ihe é justo, e formar cidadãos capazes de ler e interpretar o mundo. 
Essa breve discussão sobre a escola é tão somente para situar que o debate da educação geográfica alinhavada à cidadania requer condições materiais para sua efetivação, enquanto professores realizamos mudanças e almejamos formar sujeitos críticos e emancipados. Portanto, para isso é importante que tenhamos condições, pois independente do conteúdo e/o assunto que abordaremos nas aulas de Geografia conseguiremos assegurar uma educação geográfica-cidadã desde que as condições necessárias para sua efetivação existam e estejam disponíveis aos professores.

\section{Conclusão}

A partir do exposto buscamos dialogar com população e educação geográfica cidadã, para tanto, realizamos uma breve retrospectiva de como a população fora abordada pela Geografia, pois esse tratamento revela como a população enquanto conteúdo escolar foi se desenhando na escola. Entedemos que a educação geográfica tem como finalidade levar os estudantes a desenvolver pensamento crítico para agir de forma comprometida e consciente na sociedade. Portanto, os conteúdos afetos a população proporcionaria isso, uma vez que eles refeltem o contexto de vida de milhares de pessoas.

O exercício de pinçar do universo dos estudos populacionais questões que possibilitem ler o mundo geograficamente é uma tarefa que se revela cada vez mais necessária. É inadmissível que em pleno século XXI escola, estudantes e professores interajam de modo tão frágil e superficial com as demandas da vida moderna. A ponto da escola, sobretudo a pública voltada às classes menos favorecidas, se torne uma ambiente hostil e não acolhedor, que professores e alunos se coloquem como adversários.

É triste presenciar o esguarciamento das relações educativas nas escolas, ressignificar a escola, a Geografia, enfim, o vim a ser dessas, torna-se tarefa imperiosa para todos que buscam ter uma sociedade mais justa, igualitária e provida de meios para acolher os necessitados. Urge reposicionar a escola pública em um lugar de maior visibilidade social, econômica e, especialmente humana, para que possamos formar seres cada vez melhores e para isso não podemos nos omitir e nos calar frente às injustiças. Ser professor é ser resistente, resiliente e acreditar que hoje é sempre uma nova possibilidade para sermos melhores do que fomos ontem, é assim que formamos cidadãos, com educação e ensino de qualidade, é por isso que defendemos a educação geográfica, pois ela é um meio para um fim muito maior e melhor. 


\section{Referências bibliográficas}

Brasil (1988). Constituição da República do Brasil de 1988. In: Diário Oficial da República Federativa do Brasil, Brasília, DF, 05 out. 1988.

(1969). Convenção Interamericana de Direitos Humanos. In: Diário Oficial da República Federativa do Brasil, Brasília, DF, 06 nov. 1992.

Freire, P. (2011). Pedagogia do Oprimido. 50 ed. rer. e atual. Rio de Janeiro: Paz e Terra, 2011.

Harvey, D. (1969). Explanation in Geography. Londres: Edward Arnold.

Harvey, D. (1992). Postmodern morality Plays. Antipode, 24 (3), 300-326.

Gramsci, A., (1996). Lettere dal Carcere, a cura di A. Santucci. Palermo : Sellerio Editore, 2 vol

Lacoste, Yves. (1993). A Geografia - Isso serve, em primeiro lugar, para fazer a guerra. 3. ed. Campinas: Papirus.

Mormul, Najla Mehanna (2013). As Abordagens sobre População na Geografia Brasileira (1934-2010): permanências, transformações e rupturas. 340 f. Tese (Doutorado em Geografia) - Programa de Pós-graduação em Geografia, Universidade Estadual de Maringá/UEM. Maringá/PR.

MOREIRA Rui.(1987). O discurso do avesso - para a crítica da geografia que se ensina. Rio de Janeiro: Dois Pontos Editora.

OLIVEIRA, L.(2000). Percepção da paisagem geográfica: Piaget, Gibson e Tuan. Geografia. Vol. 25, n. 2, Rio Claro.

TARDIF, Maurice.(2010). Saberes docentes e formação profissional. 4⿳亠丷厂 Ed. Rio de Janeiro: Vozes.

TUAN, Yi-Fu. (1980). Topofilia: um estudo da percepção, atitudes e valores do meio ambiente. São Paulo: DIFEL.

RUA, João.(1977). Repensando o estudo da população. AGB/UPEGE, Jan. 1977. Disponível em: file://C:/Users/user/Downloads/21753-69854-1-SM.pdf 


\section{Diálogos com a experiência de estágio supervisionado I e II no ensino de Geografia}

NAJLA MEHANNA MORMUL ${ }^{1}$

GiLVANA FATIMA CARVALHO ${ }^{2}$

\section{Resumo}

O presente resumo é resultado do trabalho de conclusão de curso de Geografia Licenciatura, o qual tem como objetivo discutir a Pedagogia Histórico-Crítica e seus desdobramentos para o ensino de Geografia promotora de cidadãos atuantes. Pesquisar esse tema nos possibilitou pensar os pressupostos da Pedagogia HistóricoCrítica, bem como sua abordagem no ensino de Geografia. Na prática de Estágio Supervisionado I e II, realizadas no $3^{\circ}$ e $4^{\circ}$ ano do curso de Geografia/Licenciatura, buscamos incorporar essa perspectiva nas aulas desenvolvidas com $08^{\circ}$ ano do Ensino Fundamental II e com o $1^{\circ}$ ano Ensino Médio do Colégio Estadual Cristo Rei, localizado no município de Francisco Beltrão/PR. É importante ressaltar que essa abordagem teórica e metodológica permitiu avaliarmos em que e/ou quais condições o emprego dessa perspectiva de ensino contribui para a aprendizagem da Geografia. Enfrentamos dificuldades na implementação dessa proposta, por conta da ênfase que a educação escolar atribuiu aos conteúdos ou pela dificuldade na execução metodológica dessa proposta. Nesse sentido, procuramos realizar um ensino pautado na interação entre sujeitos (professor e aluno) e na produção de conhecimentos. A partir do senso comum almejamos atingir o conhecimento sistematizado. Porém, isso é uma tarefa difícil, por conta da realidade escolar em que predomina a ideia de ensino como transmissão de conhecimentos, no qual cabe ao aluno, muitas vezes, apenas receber conhecimentos e, não, produzi-los, também na perspetiva do desenvolvimento de atitudes e de capacidades que os habilitem como cidadãos comprometidos com a transformação da comunidade em que se inserem, em diferentes escalas.

\footnotetext{
${ }^{1}$ Professora Doutora do curso de Geografia da Universidade Estadual do Oeste do Paraná, Campus de Francisco Beltrão, najlamehanna@gmail.com

${ }^{2}$ Mestranda do Programa de Pós-Graduação da Universidade Estadual do Oeste do Paraná, Campus de Francisco Beltrão, gilvanafcarvalho@gmail.com
} 
Palavras-chave: Ensino de Geografia; Educação Escolar; Pedagogia Histórico-Crítica; Cidadania.

\section{Resumen}

El resumen actual es resultado del trabajo de conclusión del curso de Geografía Licenciatura, que objetiva discutir la Pedagogía Histórico-Crítica y sus consecuencias para el enseñar de Geografía promotora de ciudadanos actuantes. Investigar ese tema nos ha permitido pensar las presuposiciones de la Pedagogía Histórico-Crítica de crítico, tanto como su enfoque en el enseñar de Geografía. En la Práctica Supervisada de Aprendizaje I y II, logrado en el $3^{\circ}$ y $4^{\circ}$ año del curso de Geografía/Licenciatura, buscamos incluir esa perspectiva en las clases desarrolladas con el $8^{\circ}$ año de la Enseñanza Fundamental II y con el $1^{\underline{a}}$ año de la Enseñanza Mediana de la Escuela Cristo Rei, ubicada en el distrito municipal de Francisco Beltrão/PR. Es importante enfatizar que ese enfoque teórico y metodológico ha permitido valorar en que y/o cuales condiciones el trabajo de esa perspectiva de enseñanza contribuye al aprender de la Geografía. Enfrentamos los apuros en la puesta en práctica de esa propuesta, debido a el énfasis que la educación de la escuela atribuyó a los contenidos o para la dificultad en la ejecución metodológica de esa propuesta. En ese juicio, tratamos de hacer una enseñanza basada en la interacción entre sujetos (profesor y estudiante) y en la producción de conocimientos. Empezar del sentido común que anhelábamos para llegar a los conocimientos sistematizados. Sin embargo, ésa es una tarea difícil, debido a la realidad de la escuela en que prevalece la idea de enseñanza como transmisión de conocimientos, en cuál corresponde al estudiante, muchas veces, sólo recibir conocimientos y no producir ellos, también en la perspectiva del desarrollo de actitudes y de la capacidad que los habiliten como ciudadanos comprometidos con la transformación de la comunidad en que se enseren, en deferentes escalas.

Palabras-clave: Enseñanza de Geografía; Educación Escolar; Pedagogía HistóricoCrítica; Ciudadanía.

\section{Introdução}

Neste trabalho buscamos expor o contexto da Pedagogia Histórico-Crítica e sua relação com o ensino de Geografia. Abordamos as Pedagogias críticas e não críticas e 
procuramos contextualizar a Pedagogia Histórico-Crítica no cenário social em que foi pensada, relacionando com as teorias que a embasam.

A escolha por esta temática ocorreu por considerarmos a importância de compreender a Pedagogia Histórico-Crítica e como ocorre sua realização no ensino, porque esta Pedagogia possibilita ao professor partir do senso comum do educando e, assim transformar o conhecimento prévio em científico. Acreditamos que esta Pedagogia potencializa o saber do aluno e ao ensinar Geografia o professor pode estabelecer relações entre as várias dimensões da vida do educando com o conhecimento geográfico, possibilitando desenvolvimento do aluno enquanto cidadão atuante da sociedade.

Para a realização deste artigo, foram necessárias as leituras das obras dos seguintes autores: Saviani (2012 e 2013); Gasparin, (2008 e 2012); Cortella, (2008), entre outros. Boa parte destas leituras foram realizadas durante a disciplina de Estágio Supervisionado I e II. Na primeira parte desse trabalho abordamos como os autores apresentam a Pedagogia Histórico-Crítica, enfatizando a importância de conhecê-la para que a mesma possa ser desenvolvida na prática escolar. Após, discutimos as práticas do Estágio Supervisionado I e II e como essas se vincularam as discussões ligadas a Pedagogia Histórico-Crítica. Diante do exposto, esperamos com esse trabalho contribuir para compreensão da temática, que consideramos fundamental no processo de ensino e aprendizagem em Geografia.

\section{Segunda parte}

\subsection{Contextualizando a Pedagogia Histórico-Crítica}

Segundo Saviani (2012) durante o período da Ditadura Militar (1964-1985), grande parte dos alunos das escolas eram marginalizados, sem acesso, excluídos. Para esse autor as teorias da educação podem ser divididas em dois grandes grupos, sendo elas: Teorias não críticas e teorias críticas.

Para as Teorias não críticas a educação é capaz de mudar a sociedade, por desconsiderar os fatores sociais envolvidos no processo educativo, partindo do pressuposto que a educação resolveria todos os problemas no âmbito social, e que transformaria o seu entorno intervindo diretamente na sociedade.

Já as Teorias críticas vislumbram analisar a educação a partir de seus condicionantes econômicos e sociais. Neste grupo aparecem também às Teorias crítico- 
reprodutivistas, que desempenha o papel de revelar que a escola visa reproduzir e reforçar o sistema capitalista (Saviani, 2012). Assim, temos de um lado as Teorias não críticas, visando resolver o problema social por meio da escola, e do outro lado às Teorias pertencentes a vertente crítico-reprodutivista, que denunciavam a desigualdade social realizada pela educação escolar.

Saviani (2012, p. 30) indaga: "[...] é possível, articular a escola com os interesses dos dominados"? É possível pensar ações que levem uma cultura de liberdade pelo processo educativo para aqueles considerados segregados e/ou marginalizados do meio social?

Para que a escola não esteja vinculada com os interesses dos dominados, necessitase de uma teoria que não reproduza elementos da classe dominante. Neste contexto há necessidade de reflexões e ações que dão origem as propostas pedagógicas contra-hegemônicas, que são aquelas que se posicionam contra os interesses da classe dominante, em defesa dos que lutam pela educação em favor de uma sociedade justa e igualitária. Neste sentido destacam-se as pedagogias: Socialista, Libertária, Comunista, Libertadora, Histórico-Crítica, que apresentam concepções com a finalidade de superar as práticas reprodutivistas presentes no âmbito educacional.

Os pressupostos que foram de ideais contra-hegemônicos deram origem a Pedagogia Histórico Crítica, organizada no Brasil a partir da década de 1980, podendo considerar que ela "[...] é tributária da concepção dialética, especificamente na versão do materialismo histórico, tendo fortes afinadores, no que se refere às suas bases psicológicas, com a psicologia histórico-cultural desenvolvida pela Escola de Vigotski." (Saviani, 2013, p.421).

Estudos relacionados à Pedagogia Histórico-Crítica implicam na efetivação e modificação das diferentes práticas de ensino. Muitos educadores não tinham compreensão de que pressuposto seguir, fazendo uma espécie de combinação de tendências pedagógicas, porque na realidade não era claro nem uma, nem outra para o professor. Desta forma Gasparin e Petenucci (2008, p. 03) esclarecem que:

Nas duas últimas décadas a Pedagogia Histórico-Crítica tem sido citada como uma perspectiva educacional que visa resgatar a importância da escola e a reorganização do processo educativo. Porém, percebemos que os conhecimentos que a maioria dos educadores possuem sobre esta são superficiais, dificultando assim a sua implementação como metodologia de ensino. 
A Pedagogia Histórico-Crítica tem a finalidade de organizar o processo educativo, estabelecendo uma sequência coerente no ensino, esclarecendo que existe uma lógica nos passos que compõe esta Pedagogia, que se constitui de um começo, meio e fim. A dificuldade em relação aos educadores é nítida, muitas vezes eles não compreendem, não conhecem a Pedagogia Histórica - Crítica, desta forma dificulta o trabalho e a efetivação concreta na prática do que esta tendência orienta.

Precisamos levar em consideração que esta Pedagogia é atual em relação à história da educação e está relacionada com o social do educando, dialogando com o meio em que vive. Por isso ela é Histórica, pois leva em consideração o social, pessoal, cultural do educando e Crítica porque considera a vivência do educando. Promovendo um processo de transformação do senso comum em conhecimento científico. Gasparin (2012, p. 03) pode nos ajudar a entender isso da seguinte maneira:

O ponto de partida do novo método não será a escola, nem a sala de aula,
mas a realidade social mais ampla. A leitura crítica dessa realidade torna
possível apontar um novo pensar e agir pedagógicos. Desse enfoque,
defende-se o caminhar da realidade social, como um todo, para a
especificidade teórica da sala de aula e desta para a totalidade social
novamente, tornando possível um rico processo dialético de trabalho
pedagógico.

Com esta reflexão é possível compreender que a educação não esta restrita a escola e tão pouco a sala de aula, uma vez que a escola é fruto do contexto políticoeconômico e social a qual está inserida. Todo processo de ensino, considerado a partir da realidade social envolve os educandos em uma relação além das paredes da sala de aula, fornecendo significado para a aprendizagem escolar. Como nos orienta Cortella (2008, p.85).

[...] uma das questões cruciais para as nossas práticas pedagógicas é a concepção sobre o conhecimento dentro da sala de aula; no mais das vezes, o conhecimento é entendido como algo acabado, pronto, encerrado em si mesmo, sem conexão com sua produção histórica.

Desta forma o papel do professor educador é estabelecer uma ponte entre o conhecimento que o aluno traz consigo que é resultado de sua vivência e aquilo que o professor almeja. A aprendizagem acontece de maneira recíproca, em que o educando aprende com o educador e vice-versa, aproximando a realidade do educando com a realidade escolar, Saviani $(2013$, p.80) indica: 
[...] pode-se dizer que a relação entre a Pedagogia Histórico-Crítica e a realidade escolar presente é muito íntima. Com efeito, como se mostrou, a referida concepção pedagógica surgiu em decorrência de necessidades postas pela prática dos educadores nas condições atuais. É, pois, na realidade escolar presente que se enraíza a proposta da Pedagogia Histórico Crítica.

Segundo Saviani (2012) a Pedagogia Histórico-Crítica visa contribuir para que os professores revejam sua ação pedagógica, auxiliados e/ou provocados por essa Pedagogia. É importante que o professor avalie sua formação cotidianamente, pois isso contribui na melhoria do processo de ensino e aprendizagem. Desse modo, ter domínio teórico e metodológico dessa Pedagogia favorece um maior dinamismo no processo educativo.

Em relação ao ensino de Geografia predominou por muito tempo a chamada Pedagogia tradicional que enfatizava o conteúdo e a memorização. Assim, a Geografia auxiliada pela Pedagogia Histórico-Crítica, pode proporcionar ao educando a compreensão dos elementos sociais, políticos e econômicos, possibilitando desenvolvimento crítico de mundo enquanto cidadão participativo da sociedade ao tempo que compreende o contexto social que vive e as relações estabelecidas.

\subsection{A Pedagogia Histórico-Crítica a partir de Gasparin}

João Luiz Gasparin em (2002) escreveu a obra Uma didática para a Pedagogia Histórico-Crítica, baseada na perspectiva do professor Dermeval Saviani. Gasparin organizou uma proposta didática para a implantação da Pedagogia Histórico-Crítica em sala de aula, essa proposta foi organizada em cinco passos, definidos como: Prática Social Inicial; Problematização; Instrumentalização; Catarse e Prática Social Final.

A Prática Social Inicial orienta o que podemos realizar no momento da introdução do conteúdo, começando pela realidade do aluno, valorizando o conhecimento em que o aluno traz consigo. Neste momento será exposta qual dimensão (social, econômica, cultural, ambiental, etc.) o conteúdo será trabalhado e seus objetivos. É, também, neste instante que se conversa com os alunos sobre o que eles sabem a respeito do conteúdo e o que eles esperam aprender. Como lembra-nos Gasparin (2012, p. 21):

A prática social inicial é sempre uma contextualização do conteúdo. É um momento de conscientização do que ocorre na sociedade em relação àquele tópico a ser trabalhado, evidenciando que qualquer assunto a ser desenvolvido em sala de aula já está presente na prática social, como parte constitutiva dela. 
Mesmo o aluno não tendo afinidade com o conteúdo, o professor tem a possibilidade de estabelecer relações imediatas com a vivência dos alunos, através deste primeiro contato, sendo esse o ponto de partida para o ensino. O educador contextualiza os aspectos gerais, relaciona e os insere na vida do aluno, isso atribui sentido e significado na aprendizagem escolar.

No segundo passo encontramos a Problematização, nela professor e alunos estabelecem relações de trocas de experiências. É viável que haja discussão com as contribuições dos alunos e o conteúdo científico, para isso esse diálogo pode ser seguido de questões, que vão contribuir para transformar a visão do aluno em relação ao conteúdo, provocando nos alunos mais questionamentos. De acordo com Gasparin, (2012, p. 33), "é o momento em que se inicia o trabalho com o conteúdo sistematizado". Porque todo questionamento que o professor for realizar vai estar relacionado ao que ele pretende expor e aprofundar.

Em seguida na Instrumentalização podemos observar melhor a ação do professor diretamente vinculada com o conteúdo e, também, sua relação com o aluno, pois o professor terá que constituir comparações mentais com aspectos que os alunos vivenciam no cotidiano. Basicamente a Instrumentalização para Gasparin (2012, p.51) seria "o caminho pelo qual o conteúdo sistematizado é posto à disposição dos alunos para que o assimilem e o recriem e, ao incorporá-lo, transformem-no em instrumento de construção pessoal e profissional". O professor pode auxiliar na demanda deste conhecimento sistematizado proporcionando e fazendo uso de diversas ferramentas para auxiliar na construção pessoal e profissional, que contribuirá na apropriação que o aluno terá do conteúdo (Gasparin, 2012).

O quarto passo é a Catarse, que possibilita o processo de construção do conhecimento científico, neste momento verifica-se o que o aluno assimilou, processou e internalizou, vai ser um resumo de tudo aquilo que ele aprendeu, é o que nos diz Gasparin (2012, p. 124):

A Catarse é a síntese do cotidiano e do científico, do teórico e do prático a que o educando chegou, marcando sua nova posição em relação ao conteúdo e à forma de sua construção social e sua reconstrução na escola. É a expressão teórica dessa postura mental do aluno que evidencia a elaboração da totalidade concreta em grau intelectual mais elevado de compreensão.

$\mathrm{Na}$ Catarse podemos verificar a aprendizagem do aluno, aquilo que compreendeu que assimilou a síntese que resultou da combinação do processo teórico e da vivência prática, o que vai gerar novo pensamento sobre o conteúdo, possibilitando ao 
educando transformar, por meio do processo de ensino aprendizagem sua própria concepção enquanto ser social.

O último passo é a Prática Social Final em que é verificado o saber elaborado pelo aluno, bem como o seu nível de desenvolvimento. Assim, a Prática Social Final está vinculada diretamente a transformação da ação do educando no meio social em que vive e atua como cidadão consciente resultado do conteúdo trabalhado na escola/sala de aula. Podemos observar também as mudanças nas atitudes dos alunos, na maneira que se expressam e na forma como associam o que aprenderam na escola com a vida, Gasparin (2012, p. 143):

A prática Social Final é a nova maneira de compreender a realidade e de posicionar-se nela, não apenas em relação ao fenômeno, mas a essência do real, do concreto. É a manifestação da nova postura prática, da nova atitude, da nova visão do conteúdo no cotidiano. É, ao mesmo tempo, o momento da ação consciente, na perspectiva da transformação social, retornando à Prática Social Inicial, agora modificada pela aprendizagem.

Essa etapa propicia algo novo, modificado, entretanto, sua relação com a Prática Social Inicial ainda existe, mas agora conectada com 0 conhecimento sistematizado/científico. Será então o agir, a prática do novo entendimento sobre o conteúdo, processo completo de aprendizagem o qual partiu do educando e finalizou na sua ação. A Pedagogia Histórico-Crítica é, portanto, uma possibilidade de promover a aprendizagem, em que os conhecimentos prévios dos educandos são valorizados para se alcançar o conhecimento sistematizado. Sendo assim, a proposta de Gasparin (2012) é um meio para a realização dessa Pedagogia em sala de aula.

A Pedagogia Histórico-Crítica pode colaborar com o ensino de Geografia, uma vez que a Geografia estuda o espaço geográfico e relações nele estabelecidas. Posto isto, no subtítulo a seguir buscar-se-á discutir a perspectiva apontada por Saviani, e, também Gasparin voltada ao ensino de Geografia, com ênfase na prática de Estágio Supervisionado I E II desenvolvido com o 8ํano do Ensino Fundamental II e com o $1^{\circ}$ ano do Ensino Médio do Colégio Estadual Cristo Rei, localizado em Francisco Beltrão/PR, respectivamente nos anos de 2016 e 2017.

\section{Terceira Parte}

\subsection{Reflexões sobre o ensino de Geografia a partir do Estágio Supervisionado}

No Estágio Supervisionado I e II as experiências foram distintas, contudo significativas para o processo de formação tanto pessoal quanto profissional. Percebemos que 
vivenciar a escola na prática nos amplia a visão de ensino que aprendemos na universidade. Alguns desafios são vivenciados com a realização da prática de Estágio Supervisionado, como: domínio do conteúdo, adequação dos conteúdos curriculares a realidade dos alunos, domínio de sala, emprego e uso de metodologias variadas, manuseio de recursos didáticos e proporcionar desenvolvimento aos alunos enquanto cidadãos critícos e atuantes na sociedade, visto que a realidade escolar muitas vezes delimita o trabalho do professor.

O Estágio Supervisionado I foi desenvolvido com o $8^{\circ}$ ano "A" do Colégio Estadual Cristo Rei no ano de 2016. A turma era composta por 22 alunos, as observações do espaço escolar compuseram 15 horas/aulas e a regência 12 horas/aulas em que houve participação da turma. O conteúdo abordado foi Capitalismo e Socialismo, para verificarmos o conhecimento prévio que os alunos tinham, foi sugerida a interpretação individual da seguinte frase: "A desvantagem do capitalismo é a desigual distribuição das riquezas; a vantagem do socialismo é a igual distribuição das misérias" (Winston Churchill). Motivamos os alunos que descrevessem o que compreenderam e se possível relacionasse com alguns aspectos da realidade.

Após a atividade diagnóstica, citada acima, mostramos imagens que retratavam o capitalismo e socialismo, a fim de verificar visualmente o que os alunos sabiam sobre 0 assunto. As imagens compunham diversas realidades, inclusive da cidade de Francisco Beltrão, que possibilitou comparações e questionamentos sobre o que visualizavam nas imagens com o que vivenciam no seu cotidiano, essa ação caracterizou-se como prática social inicial.

$\mathrm{Na}$ sequência apresentamos o trecho do vídeo "Professor Rafão Capitalismo $\mathrm{x}$ Socialismo", disponível em: https://www.youtube.com/watch?v=p5cPKFf2lvM, que mostra imagens do capitalismo e socialismo no mundo todo, possibilitando associações realizadas com as imagens anteriormente apresentadas aos alunos. Também, foram expostas seis frases aleatórias, questionando os educandos sobre qual sistema eles acreditavam que aquelas frases representavam. Dividimos a sala em dois grupos e para cada frase os grupos se manifestaram a respeito, justificando sua resposta com a opinião dos outros integrantes do grupo.

Buscamos realizar também aula dialogada, na qual utilizamos o quadro para transcrição de esquemas práticos que foram elaborados com as contribuições dos alunos. Fizemos registros das fases do capitalismo questionando os alunos sobre os elementos que o compõe esse sistema. Igualmente, abordamos a organização geral do sistema socialista. No decorrer das aulas desenvolvemos atividades impressas com 
questões de relacionar, completar, analisar e descrever, a fim de verificar o que os alunos já assimilaram das aulas. Como parte de finalização das aulas realizamos uma atividade em grupo, o qual cada grupo teria que representar as principais características do socialismo ou capitalismo. Os grupos tinham pistas para ler, explicar o que entenderam e se preparar para encenar com seus colegas o modo de produção do sistema indicado pela professora. A apresentação foi breve, pois tínhamos o objetivo de contextualizar aspectos que os alunos encenaram com o que vivenciamos atualmente na sociedade, buscamos mediar o senso comum com o conhecimento sistematizado.

Foi trabalhado com o $8^{\circ}$ ano um texto síntese que pontuava elementos referentes a alguns impactos sociais causados pelo capitalismo, os alunos leram o texto e depois falaram o que entenderam a respeito dele. Procuramos ressaltar alguns aspectos do capitalismo em relação sociedade, como a qualidade de vida de muitas pessoas que sobrepõe o supérfluo ao necessário. Depois de realizado o estudo do texto, exploramos o conteúdo através de uma apresentação de slides composta pelo trecho do filme "Wall-e", charges com questões reflexivas, buscando relacionar com o texto, proporcionando sustentabilidade na discussão realizada.

Para finalizar as aulas, conversamos com os alunos sobre o que fora trabalhado nas aulas anteriores, buscando estabelecer relação entre o inicio e o término das aulas. Depois de conversarmos sobre as aulas, entregamos a frase diagnóstica utilizada no primeiro dia de aula com algumas considerações, no intuito de despertar questionamento referente ao que escreveram.

Por fim, expomos um trecho do filme "O Livro de Eli", disponível em: http://www.geografia.seed.pr.gov.br/modules/video/showVideo.php?video=11868 que mostra como o mundo em que vivemos se torna estranho para as pessoas do tempo retratado no filme, o qual a humanidade teria consumido em excesso os recursos naturais. Refletimos que a produção em massa não garante a existência das coisas no futuro, e como cidadãos conscientes, devemos refletir sobre as consequências do consumismo.

Durante o Estágio Supervisionado I, buscamos nos embasar na Pedagogia HistóricoCrítica, procuramos desenvolver os passos desta Pedagogia indicado por Gasparin, ao partir do saber do aluno para instigá-los a pensar sobre o tema proposto. No decorrer das aulas verificamos a apropriação dos conhecimentos através de participação dos alunos em momentos de socialização e atividades descritivas. Percebemos a mudança de pensamento de alguns alunos perante a mediação que 
realizamos, entre os saberes comuns e o conhecimento científico. Porém, tivemos dificuldades em desenvolver a Pedagogia Histórico-Crítica em todas as aulas, porque havia alguns limites como: domínio metodológico, duração da aula, sistematização adequada, entre outros. Todavia, percebemos que poderíamos ter aprofundado alguns aspectos do conteúdo em determinados momentos das aulas.

No entanto, a forma como foi abordado o conteúdo possibilitou estabelecermos relações sobre a influência do capitalismo em nossas vidas, no nosso ponto de vista o processo foi exitoso. Contudo, a dificuldade nesse processo também é fruto de uma educação com resquícios da pedagogia tradicional, no qual o professor é detentor do conhecimento e o aluno mero receptor. Reconhecemos que essas características estão presentes na formação de muitos professores, inclusive, na nossa. Apesar disso, buscamos superar essas limitações e realizar a intervenção de maneira a atingir os objetivos propostos, nos apropriando para isso dos pressupostos da Pedagogia Histórico-Crítica.

$\mathrm{Na}$ prática de Estágio supervisionado II desenvolvido com o $1^{\circ}$ ano "B" do Ensino Médio, do mesmo colégio no ano de 2017, a turma era composta por 25 alunos, durante as 12 horas de regência houve participação e envolvimento dos alunos. Os conteúdos abordados nas 12 horas/aulas foram - Eras Geológicas e Placas tectônicas.

Para iniciarmos a aula desenvolvemos com os alunos uma dinâmica de apresentação, denominada a "teia do envolvimento", utilizando um rolo de barbante, os alunos se organizaram em círculo. Foi solicitado aos alunos que amarrassem um nó do barbante no dedo, falassem o nome, e respondesse a duas perguntas: O que chama atenção ao estudar Geografia e o que ele espera aprender ao estudar Eras Geológicas; feito isso poderia jogar o rolo para outro aluno e, assim, por diante até todos os alunos responderem as indagações. Ao final da dinâmica formou-se uma teia, em que foi possível refletir sobre os saberes Geográficos que estão interligados e o qual fazemos parte. Compreender o espaço a nossa volta nos remete: questionar, observar e interagir diretamente com o meio. Ao estudar as Eras Geológicas buscamos dialogar com a formação da Terra, ao mesmo tempo atribuir sentido a aprendizagem do aluno.

Por meio de uma conversa realizamos o diagnóstico sobre o que os alunos sabiam a respeito das Eras Geológicas. Partindo das informações trazidas pelos alunos, expomos que esse seria o foco de estudo inicialmente, para tanto, procuramos entender a origem do planeta, e minimamente abordar os aspectos relacionados ao processo de desenvolvimento da Terra. 
Através de imagens, trabalhamos sobre tempo geológico, com a intenção de situar o aluno no tempo e no espaço, com isso ele pode perceber que a história da Terra é bem maior do que a existência do homem no universo. O tempo que vivemos e habitamos o planeta, por menor que seja, em comparação ao tempo de desenvolvimento da Terra não deixa de afetar e degradar o planeta, correlacionamos assim o tempo Geológico ao tempo histórico.

Para dar seguimento ao conteúdo, mostramos imagens referentes às Eras Geológicas com ênfase nos acontecimentos mais importantes de cada Era. Questionamos os alunos sobre o que eles visualizavam nas imagens, quais animais haviam; qual clima era predominante e assim por diante. Buscamos expor a relação de algumas Eras com a vida existente naquele período.

Cada aluno recebeu uma tabela para preencher, ela continha nome da Era, nome do período, a idade geológica, a marcação dos milhões de anos, nela os alunos deveriam preencher os principais acontecimentos de cada Era.

Depois que trabalhamos as Eras Geológicas e seus principais acontecimentos, questionamos sobre o que os alunos sabiam a respeito do processo de fossilização dos seres vivos. Expomos algumas imagens de fósseis, e os principais tipos de fossilização, o objetivo era relacionarmos com os acontecimentos das Eras Geológicas e a importância da datação para o conhecimento da história da Terra e evolução das espécies.

Enfatizamos que o processo da evolução dos seres vivos ocorre em virtude das mudanças climáticas, físicas, químicas, e, também, pela presença de substâncias tóxicas na atmosfera durante um longo período. Na sequencia, por meio de slides mostramos aos alunos as principais placas tectônicas, como elas estavam dispostas nos períodos correspondentes a cada Era Geológica e suas mudanças no decorrer do tempo geológico. Finalizamos essas aulas com uma atividade, composta por questões descritivas, de interpretação, de assinalar e relacionar, sobre o que foi trabalhado e dialogado em sala de aula. No transcorrer das aulas, notamos que em alguns momentos do conteúdo foi possível a utilização de alguns passos da Pedagogia Histórico-Crítica. Porém, essa não pode ser empregada efetivamente em todas as aulas, pois algumas dificuldades foram surgindo, por exemplo, o domínio de conteúdo, troca de professor regente e a dificuldade de interação entre o conteúdo e a vida dos alunos. Não obstante, os resultados foram positivos, pois a turma participava das aulas, desenvolviam todas as atividades e realizavam os debates que thes eram propostos. 
Como visto, por meio das descrições realizadas das aulas, foi possível notar que tivéssemos certa dificuldade de inserir a Pedagogia Histórica-Critica durante os Estágios Supervisionados em Geografia I e II. Isso de certo modo significa afirmar que convencionalmente a concepção predominante de aula é a tradicional. Assim, propor algo diferente do que estamos habituados torna-se um desafio, pois reconhecemos que é difícil problematizar os conteúdos curriculares com vistas a contribuir para a formação intelectual, cidadã do sujeito e, sobretudo, humana. Uma vez que, a lógica do sistema econômico dominante tem transformado sujeitos em mercadorias e as escolas em lugares, apenas, preparatórios para vestibulares e para o mercado de trabalho. Todavia, enquanto professores precisamos acreditar e lutar por um ensino e aprendizagem mais solidário, coletivo e humano, e esta é uma tarefa que não vamos nos eximir e tentar realizar.

\section{Considerações finais}

A Pedagogia Histórico-Crítica pertence a vertente crítica, com base no materialismo histórico dialético, surge à luz do marxismo em uma época que predominava no Brasil a Pedagogia Tradicional. No entanto, não foi uma substituição de tendências pedagógicas, pelo contrário, elas passaram a coabitar o mesmo espaço nas escolas. A construção deste artigo possibilitou compreendermos a contextualização desta Pedagogia e como essa poderia se desenvolver na prática escolar. Entendemos que o ensino tem sentido na medida em que o aluno se apropria do conhecimento científico e é capaz de mudar o seu raciocínio, transformando o espaço a sua volta.

A Geografia enquanto ciência que engloba saberes sociais, culturais, econômicos, estabelece relação com o meio e busca compreendê-lo. Por meio da Pedagogia Histórico-Crítica é possível articular os conteúdos com a vida dos alunos e propiciar que sejam capazes de refletir sobre relações de poder acerca dos fenômenos que ocorrem na sociedade, tornando-se cidadãos capazes de refletir sobre processos políticos sociais do seu entorno. Contudo, percebemos que no decorrer dos anos a escola modificou os documentos que norteiam a prática em sala de aula, várias escolas aderiram a Pedagogia Histórico-Crítica, outras não. Porém, o ensino e a aprendizagem em grande parte permaneceram vinculados a Pedagogia tradicional, por conta que essa Pedagogia se relaciona ao projeto de sociedade dominante, então, mesmo contando nos documentos outra perspectiva, como a Pedagogia HistóricoCrítica, na prática escolar pouca coisa mudou. 
A prática do ensino possibilita ampliar as noções de conhecimento e aprendizagem que norteiam o trabalho do professor, assim podemos pensar que a maneira como compreendemos esse processo faz diferença. O professor como mediador do processo de ensino-aprendizagem, atribuiu sentido a aula, pois tem clareza do que pretende ensinar e entende em que sua ação está fundamentada. Em sala de aula encontramos realidades distintas de aprendizagens, nem todos os alunos estão no mesmo nível de desenvolvimento, sendo importante o professor ter nitidez de seus objetivos para estabelecer relação de troca de saberes, possibilitando ao aluno o acesso ao saber sistematizado/científico.

Consideramos que a Pedagogia Histórica-Crítica pode auxiliar no ensino de Geografia, em virtude de sua característica dialética, que permite retroalimentar o processo educativo. Contudo, nem sempre a teoria se realiza na prática de forma automática, ou seja, a prática não é necessariamente um espelho da teoria, entendemos que tanto a prática quanto a teoria são imprescindíveis e tem o mesmo grau de importância no ensino e aprendizagem de Geografia. Os desafios para a concretização de um ensino e aprendizagem de qualidade são muitos, porém o objetivo não é desenvolver a teoria pela teoria, nem tão pouco realizar a prática por si só, o aluno é detentor de conhecimento e está em constante formação e aprendizado, assim como nós professores.

\section{Referências bibliográficas}

Cortella, M. S. (2008). A escola e o conhecimento: fundamentos epistemológicos e políticos. São Paulo: Cortez.

Gasparin, J. L. (2012). Uma didática para a pedagogia histórico-crítica. Campinas: Autores Associados.

Gasparin, J. L. Petenucci, M. C. (2008). Pedagogia histórico crítica: da teoria a prática no contexto escolar. [versão eletronica]. Disponível em:<http://www.google.com.br/url?sa=t\&rct=j\&q=\&esrc=s\&source=web\&cd=1\&cad=rja \&uact=8\&ved=0ahUKEwjL_KPFtJfXAhWMEpAKHf0BDS4QFggmMAA\&url=http://www. diaadiaeducacao.pr.gov.br/portals/pde/arquivos/2289-

8.pdf\&usg=AOvVaw3Y7LrQyTmOeqUKJb3siV1C>.

Saviani, D. (2013). Pedagogia histórico-crítica: primeiras aproximações. Campinas, São Paulo: Autores Associados. . (2012). Escola e democracia. Campinas, São Paulo: Autores Associados. 
(2013) História das ideias pedagógicas no Brasil. Campinas, São Paulo: Autores Associados. 


\title{
La enseñanza del río \\ Guadalquivir: experiencias didácticas en Educación Infantil y Primaria
}

\author{
RICARDO MANUEL LUQUE REVUELTO ${ }^{1}$ \\ JOSÉ RAMÓN PEDRAZA SERRANO²
}

\section{Resumen}

En el contexto del proyecto NósPropomos!, que promociona hacer efectiva una ciudadanía territorial, desde la perspectiva de la gobernanza y de la sustentabilidad, la consideración de los ríos cobra una nueva dimensión en la didáctica de las Ciencias Sociales. El Guadalquivir es un objeto de estudio con gran potencial educativo que permite incorporar la visión de los contrastes espaciales e incluir la perspectiva de cambio y de continuidad en el tiempo. El modelo de investigación escolar, el trabajo en grupo y la mirada interdisciplinar preside el desarrollo de esta experiencia didáctica con alumnos de Educación Primaria e Infantil. El objetivo principal de este trabajo es la presentación y la validación de una metodología activa y unas experiencias educativas, basadas en el autodescubrimiento, la experimentación, el juego y la fluviofelicidad. El marco teórico atiende a los aspectos relacionados con la Geografía física, los aprovechamientos humanos, la regulación de los recursos hídricos, el patrimonio natural y monumental, y su papel como conformador de identidad regional a través del devenir histórico y la literatura. El plan de actividades se centra en el empleo de la cartografía interactiva y las maquetas, el diseño de itinerarios, los juegos (GuadalOca, Triviwater`s, puzles, ...), o el dibujo del aprendizaje, mediante el empleo de lapbooks o visual-thinking. También se ponen en práctica las técnicas literarias o la teatralización infantil, mediante la elaboración e interpretación de narraciones originales, como las de Gotina, Don Embalse o La Patita Andalucía.

\footnotetext{
${ }^{1}$ Profesor del Dpto. de Didáctica de las Ciencias Sociales. Universidad de Córdoba, ch1lurer@uco.es

${ }^{2}$ Profesor del Departamento de Ciencias Sociales. I.E.S. Averroes (Córdoba), joserramonps@gmail.com
} 
Palabras clave: Enseñanza de las Ciencias Sociales; Didáctica de la Geografía; Hidrografía; Río Guadalquivir.

\section{Abstract}

In the context of the We Propose! Project, which promotes effective territorial citizenship, from the perspective of governance and sustainability, the consideration of rivers takes on a new dimension in the didactic of Social Sciences. The Guadalquivir river, which has seen its channel and water modeled to respond to the needs of human beings, has also become one of the main shapers of regional identity. Therefore the Guadalquivir is, an object of study with great educational potential, which allows to incorporate the vision of spatial contrasts and to include the perspective of change and continuity over time. The school research model, the group work and the interdisciplinary view preside over the development of this didactic experience with students of primary and infant education. The main objective of this work is the presentation and validation of both an active methodology and some educational experiences, based on self-discovery, experimentation, game and fluviofelicidad. The theoretical framework addresses aspects related to physical geography, human exploitation, regulation of water resources, natural and monumental heritage, and its role as a shaper of regional identity through historical evolution and literature. The activity plan focuses on the use of inter-dimensional cartography and models, the design of itineraries, games (GuadalOca, Triviwater's, puzles, ...), or the drawing of learning, using lapbooks or visuals-thinking. Literary techniques or children's dramatization are also put into practice, through the elaboration and interpretation of original narrations, such as Gotina, Don Embalse or La Patita Andalucía.

Key words: Social Sciences Teaching; Geography Teaching; Hydrography; Guadalquivir river.

\section{Introducción}

El Guadalquivir es uno de los principales ríos de la Península Ibérica y también un eje fundamental de articulación del territorio andaluz. En el presente, como en el pasado, ha sido una línea de población y poblamiento, fuente de recursos y alimento de los principales aprovechamientos agrarios del valle Bético. En sus riberas, río y civilizaciones han ido conformando un espacio multifuncional, de gran densidad histórica, donde se mezclan símbolos del poder y de la vida de los pueblos, y donde se aspira, en el presente, a unos usos sostenibles compatibles con la vida vegetal y 
animal que subsiste en sus cauces. Fruto de estas relaciones el Guadalquivir alberga un valioso patrimonio que comprende desde los usos económicos y sociales preindustriales hasta la monumentalidad práctica de sus puentes. Ese río, que ha visto modelado su cauce y su agua para responder a las necesidades del hombre ha devenido también en uno de los principales conformadores de identidad regional. Pero el Guadalquivir constituye también un valioso objeto de estudio, que posee un gran potencial educativo por el carácter básico y organizador de sus contenidos, con un moderado nivel de abstracción y complejidad, y una estrecha relación con la experiencia personal de muchos escolares andaluces. La consideración del río bético permite incorporar la visión de los contrastes espaciales e incluir la perspectiva de cambio y de continuidad en el tiempo. El objetivo principal de este trabajo es la presentación y la validación de una metodología activa y unas experiencias educativas, basadas en el autodescubrimiento, la experimentación, el juego y la fluviofelicidad ${ }^{3}$,que permitan abrir líneas de reflexión hacia una mejor y eficaz utilización de los entornos fluviales para la educación de una ciudadanía territorial, desde la perspectiva de la gobernanza y de la sustentabilidad. Con dicha finalidad se establece un marco teórico que recoge los fundamentos pedagógicos, referentes, actuaciones y experiencias educativas relacionadas con la enseñanza de los cursos fluviales. A continuación, se detalla un conjunto de actividades y experiencias educativas de alumnos del Grado de Educación Infantil y del Grado de Educación Primaria de la Universidad de Córdoba que, con un formato abierto, aplican un modelo de investigación escolar basado en el trabajo en grupo y el enfoque interdisciplinar.

\section{El contexto socio educativo}

La consideración de los ríos aúna en la actualidad un complejo y variado conjunto de puntos de vista por parte de actores públicos y privados que está dando lugar, no solo intervenciones de diferente signo, sino también a una percepción diferente de los cauces fluviales. El conocimiento y la conservación de los aspectos culturales y de los ecosistemas fluviales urbanos, en el presente, han pasado a formar parte de la ordenación y gestión cotidiana del territorio (González, 2017). La apreciación del agua como un recurso valioso y escaso -máxime en una comunidad autónoma con un gran déficit hídrico, que se encuentra en grave peligro de desertización y en la que aumenta sin cesar el consumo de agua- ya está plenamente enraizada en una sociedad que aboga por la recuperación del uso público del agua.

\footnotetext{
${ }^{3}$ Término acuñado por el hidrogeólogo F. Javier Martínez Gil, profesor de la Universidad de Zaragoza y miembro de la Fundación Nueva Cultura del Agua.
} 
Es lo que se ha denominado Nueva Cultura del Agua (Martínez Gil, 1997). Así, frente a la consideración productivista de los regantes o las hidroeléctricas, se reivindica el derecho a todas las heterogéneas funciones del agua y de los ríos, y su puesta en valor dentro del derecho a la identidad que confiere cada cuenca hidrográfica al territorio que avena y que se enraíza en unas peculiaridades naturales, históricas y culturales. Dicha consideración conduce a un proceso de participación de toda la ciudadanía y no sólo de las instituciones y los usuarios económicos del agua (Estevan y Naredo, 2004).

La expresión redundante de "participación activa" que utilizó La Directiva Marco Europea del Agua desde su entrada en vigor el 22 de diciembre de 2000 ha inducido, igualmente, a profundas transformaciones, tanto de los mecanismos actuales de participación como también de la Administración del agua, tal y como como se recogen en el artículo 129 de la Ley 62/2003, de 30 de diciembre que traspone la Directiva 2000/60/CE y que modifica la Ley de Aguas española.

En el mismo sentido, la toma de conciencia de los problemas ambientales y el cambio climático está promoviendo un cambio de actitudes que modifica los hábitos de consumo y que está promoviendo el uso racional de los recursos hídricos. La Educación Ambiental se va a constituir en la acción que entrelace el conocimiento del medio ambiente con la concienciación, el compromiso y la acción en todos los ámbitos de la ciudadanía (Marcén, 1996). Y lo va a hacer desarrollando en los educandos los comportamientos, las aptitudes y habilidades necesarias para dicha transformación, con Iniciativa, valores éticos y sentido de la responsabilidad, sin perder de vista un enfoque global, mediante un renovado proceso educativo, tal y como se propone en la Conferencia de Tbilisi (abril de 1978).

Tanto la Consejería de Medio Ambiente y Ordenación del Territorio como la de Educación, de la Junta de Andalucía, haciéndose eco de estos principios, han ido desarrollando campañas de sensibilización y comunicación relacionadas con los recursos hídricos. La de Medio Ambiente, como actividades destacadas, realizó en 2006 las Rutas del Agua, dirigidas al público en general e implementadas con una serie de recorridos por toda la geografía andaluza. Entre 2007 y 2008, la Caravana del Agua y la Exposición itinerante El agua recorrió todas las provincias andaluzas. Por otro lado, los Jurados Ciudadanos fue un programa que pretendía investigar y dar cabida a las opiniones sobre la gestión del agua, entre los años 2008 y 2010, junto con la Campaña de Educación Ambiental Agua Prestada, Devuélvela Depurada desde 2009 hasta 2013. En los últimos años destaca la realización del programa Conoce tus 
Fuentes, que intenta dar a conocer la riqueza de este patrimonio a través de una exposición itinerante y un concurso fotográfico, junto con el programa de Voluntariado Ambiental para la Conservación de los Ríos de Andalucía Andarríos, cuyo objetivo es la implicación activa en la conservación y mejora de los ecosistemas fluviales.

Por su parte, la Consejería de Educación promueve el programa de educación ambiental Aldea, dirigido a la comunidad educativa. A través de la Red Andaluza de Ecoescuelas se han venido realizando actividades diversas que, en sus líneas de intervención más recientes, se estructuran en proyectos y actuaciones de educación ambiental sobre sostenibilidad y cambio global, y conservación de la biodiversidad y espacios naturales protegidos. Con todo, las experiencias llevadas a cabo en este marco educativo que tengan como eje temático el Guadalquivir o los cursos fluviales andaluces han sido muy escasas.

Habría que hacer referencia también al conjunto de iniciativas vinculadas a programas de sostenibilidad urbana que promueven las ciudades que están atravesadas por un importante cauce fluvial como es en nuestro caso las ciudades de Córdoba o Sevilla (Gabardon, 2014), las cuales ya incluyeron en sus planes de ordenación la integración urbana y la recuperación paisajística de sus riberas. Dichos espacios se han convertido, como afirma Cuello (2010 y 2011), en un paradigma para entender la ciudad y su relación con el río, ciudades educadoras que intentan hacer de sus espacios y procesos contextos de aprendizaje, en los que los ríos han de ser ejemplo para entender la ciudad en un nuevo marco de sostenibilidad, recuperando así los cursos fluviales para la ciudadanía y la educación (Cobos y Pedraza, 2018; Pedraza, 2018).

Ahora estos nuevos espacios urbanos, en los que el río aparece domesticado y embellecido, van a ser objeto del desarrollo de multitud de eventos culturales como, por ejemplo, el Festival Internacional de Experiencias Riomundi, en junio de 2018, que estructuró una programación en base a los grandes ríos del mundo, del Ganges al Misisipi en lo relacionado con la música, la artesanía, el deporte, la gastronomía o el medio ambiente ${ }^{4}$.

Los enfoques amplios, como el que se acaba de describir y que se basan en el fomento del desarrollo sostenible y la conservación de los recursos naturales, sin duda contribuyen a alcanzar una sociedad más proambiental, solidaria y justa, impulsando el logro de una educación integral. Es por lo que el currículo de Infantil y Primaria

\footnotetext{
4 Cobos Maroto y Pedraza Serrano, J. R. (2018). "El Proyecto Río del Averroes, en Río Mundi" (Plataforma IES Averroes, Córdoba)
} 
debiera asumir cambios en este sentido (Ibarra, 2007), aminorando los aspectos más descriptivos e incorporando otros relacionados con los entornos fluviales sostenibles.

Sin embargo, en la normativa educativa apenas encontramos referencias al tema, ni en un sentido ni en el otro. En Educación Infantil ${ }^{5}$, en el Área de Conocimiento del Entorno se alude al conocimiento de los componentes básicos del medio natural entre los que habría que incluir el ciclo del agua- y de las relaciones que se producen entre ellos, valorando su influencia en la vida de las personas, desarrollando actitudes de respeto hacia el medio ambiente y adquiriendo conciencia de la responsabilidad de su conservación y mejora. Por otro lado, también se alude al acervo cultural de Andalucía para que sea conocido y valorado como patrimonio propio, sin mayor concreción.

En el Área de Ciencias Sociales de Educación Primaria ${ }^{6}$ se profundiza en el conocimiento de las características de la litosfera y la hidrosfera, así como de las masas de agua continentales y marinas, la formación del relieve y sus principales formas en España y Andalucía. También se alude al estudio los principales ríos de España, Andalucía, reconociéndolos en un mapa, identificando y nombrando los tramos de un río y las características de cada uno de ellos, o diferenciando entre cuencas y vertientes hidrográficas, además de saber mostrar el uso que hace el ser humano del medio, valorando el impacto de su actividad, su organización y transformación.

Con todo, no aparece en dichas normativas ni una sola mención al Guadalquivir o al valle Bético. Sin embargo, con la incorporación al currículo de las competencias básicas, el trabajo por proyectos, la consideración de los elementos transversales del currículo y otros elementos relacionados con la autonomía de los centros o de la participación del profesorado en diferentes planes o proyectos educativos permitiría incluir en las aulas de Primaria e Infantil la enseñanza del río Guadalquivir.

En definitiva, se puede convenir que existe una contradicción manifiesta entre el potencial educativo de los ríos y su débil tratamiento en el currículo o en los programas de la Consejería de Educación y Ciencia. La Consejería de Medio Ambiente ha desarrollado programas más amplios en esta temática, pero dirigidos a todos los

\footnotetext{
${ }^{5}$ DECRETO 97/2015, de 3 de marzo, por el que se establece la ordenación y el currículo de la Educación Primaria en la Comunidad Autónoma de Andalucía (BOJA 13-03-2015).

ORDEN de 17 de marzo de 2015, por la que se desarrolla el currículo correspondiente a la Educación Primaria en Andalucía (BOJA 27-03-2015).

${ }^{6}$ DECRETO 97/2015, de 3 de marzo, por el que se establece la ordenación y el currículo de la Educación Primaria en la Comunidad Autónoma de Andalucía (BOJA 13-03-2015).

ORDEN de 17 de marzo de 2015, por la que se desarrolla el currículo correspondiente a la Educación Primaria en Andalucía (BOJA 27-03-2015).
} 
niveles y a la ciudadanía en general. Así pues, los escolares andaluces parecen estar alejados del conocimiento de su río principal y de sus problemas más acuciantes. Por todo ello, urge volver la mirada a nuestro principal ecosistema hidrográfico y recuperar toda una cultura fluvial en buena parte desaparecida.

\section{La propuesta de intervención en el aula}

Con el fin de indagar el potencial educativo de los ríos y tomando como objeto de estudio el río más importante y próximo a los escolares de la geografía andaluza se propone, en dos aulas de Grado, dentro de la asignatura de Didáctica de las Ciencias Sociales, una de Educación Infantil y otra de Educación Primaria, la elaboración, a lo largo de un cuatrimestre, de proyectos educativos adaptadas a dichas etapas.

Los objetivos principales que persigue la propuesta de intervención en el aula son:

- Analizar las causas que dificultan o impiden el escaso uso educativo de los ríos.

- Aquilatar el potencial educativo de los ríos, ejemplificado en el río Guadalquivir.

- Analizar las peculiaridades que caracterizan los tramos fluviales como recurso para la educación ambiental.

- Abrir líneas de reflexión hacia una mejor y eficaz utilización de los entornos fluviales para la educación de una ciudadanía territorial, desde la perspectiva de la gobernanza y de la sustentabilidad.

En el diseño de las propuestas educativas se propuso un formato abierto, a elección del alumnado: unidad didáctica, plan de actividades, proyecto multidisciplinar, preparación de materiales auxiliares como folletos, videos, poster, etc. Pero todas las propuestas educativas debían presentar las siguientes premisas: partir de un marco teórico que incluyese una revisión bibliográfica y un estado de la cuestión, elaborar un esquema de contenidos que comprenda los aspectos estudiados, una explicación en donde se reflejen los objetivos, competencias, actividades, evaluación, etc. de la propuesta, y un apartado final que incluyera los resultados alcanzados y las fuentes empleadas.

El acercamiento a la multitud de aspectos y contenidos que comprende la consideración del Guadalquivir se realizó diferenciando grupos de cuatro o cinco alumnos y alumnas que debían escoger entre los siguientes conjuntos de contenidos:

- La enseñanza del Guadalquivir en los manuales escolares.

- El medio físico: localización, descripción, características. 
- Los paisajes agrarios que dibuja el rio Guadalquivir.

- El río Guadalquivir y otros aprovechamientos económicos: acuicultura, industria, servicios, turismo, etc.

- El río domesticado. La regulación de los recursos hídricos: embalses, presas, canales, etc.

- El río Guadalquivir y sus espacios protegidos. Problemas medioambientales.

- El Guadalquivir en sus diferentes etapas históricas.

- Patrimonio artístico y monumental en torno al rio Guadalquivir: puentes, molinos, etc.

- Personalidad del Río. El Guadalquivir en la conformación de la identidad regional y en la Literatura.

Desde el punto de vista metodológico esta propuesta educativa se basa en la evolución cognitiva del alumnado de estas etapas y en las necesidades de aprendizaje, relacionando las orientaciones pedagógicas recientes del modelo de investigación en la Escuela con los principios, crítico, sistémico y constructivista que lo fundamentan. Las intenciones educativas presentes en el currículo y las especiales características del conocimiento de las Ciencias Sociales, que fundamentan su capacidad educativa en un concepto integrador y dinámico de las sociedades en el marco del espacio geográfico y del tiempo histórico, constituyen otros de los pilares fundamentales de la propuesta.

Al tratarse de investigaciones grupales en el aula se fomentó una metodología centrada en la actividad y participación del alumnado que favoreciera tanto el trabajo individual como el cooperativo, el pensamiento racional y crítico, así como el desarrollo de las competencias referidas a la lectura y expresión escrita y oral. La consideración de la atención a la diversidad no está ausente, pues se arbitraron métodos que tuviesen en cuenta los diferentes ritmos de aprendizaje y que favorecieran la capacidad de aprender por sí mismos. El tratamiento de aspectos geográficos, históricos, sociales o culturales pone de manifiesto el ineludible enfoque multidisciplinar de estas etapas educativas, del mismo modo que las tecnologías de la información y de la comunicación formaron parte del uso habitual, como instrumento facilitador para el desarrollo del conocimiento de los contenidos propuestos. 


\section{Desarrollo de las experiencias educativas}

El desarrollo de las experiencias educativas propuestas se realizó en el Facultad de Ciencias de la Educación de Córdoba (España) durante el segundo cuatrimestre de 2018 en sendos grupos de tercer curso de Educación Infantil y Educación Primaria.

Como punto de partida se consultó en fondos bibliográficos los manuales de texto que se utilizaban en la escuela. Desde una edición de 1897, de Saturnino Calleja, titulada Rudimentos de Geografía para niños, hasta la Enciclopedia General Básica de 1983, pasando por El parvulito de 1965 o y las enciclopedias anteriores de Luis Vives, Dalmau o Álvarez. Más de una veintena de textos que transitaban todas las leyes educativas y modelos educativos como: la pedagogía tradicional, la Escuela Nueva, La Educación Integral de la Institución Libre de Enseñanza, la Pedagogía Crítica, etc. Es decir, un siglo de manuales escolares y enfoques educativos, en los que, sin embargo, la consideración de los ríos apenas si experimenta alguna modificación. Predomina un análisis descriptivo, con la enumeración de las distancias de los principales ríos peninsulares -incluido el Guadalquivir-, su localización en el mapa, el inventario de sus afluentes según su margen, la descripción de las poblaciones que atraviesan y la singularidad de ser el Guadalquivir el único río navegable. En los capítulos generales de geografía física también se incluyen definiciones de términos como arroyo, torrente, caudal, cuenca, cauce o vertiente. En cuanto a los ejercicios propuestos son en su mayoría memorísticos, de autocompletar conceptos o de localizar sobre un mapa.

Una vez analizados los referentes educativos, el alumnado de grado comenzó a preparar sus propuestas educativas para posteriormente exponerlas en el grupo clase. A continuación, se resume solo una parte de las propuestas, las del apartado de actividades y que se consideraran más significativas. El orden de exposición coincide con el anterior esquema de contenidos propuestos:

- El medio físico: localización, descripción, características.

Sobre este aspecto, en Infantil, se presentaron a Gotina y a su hija Gotita a todos los niños y niñas de la clase. Gotina y Gotita (Fig. 1) fueron las encargadas de explicar el recorrido del río y de acompañarnos a lo largo de distintas actividades. Los niños podrán manipularla y experimentar para aprender no solo las partes del río sino también colores, formas o texturas, entre otros. 
Figura 1 - Gotina y a su hija Gotita.

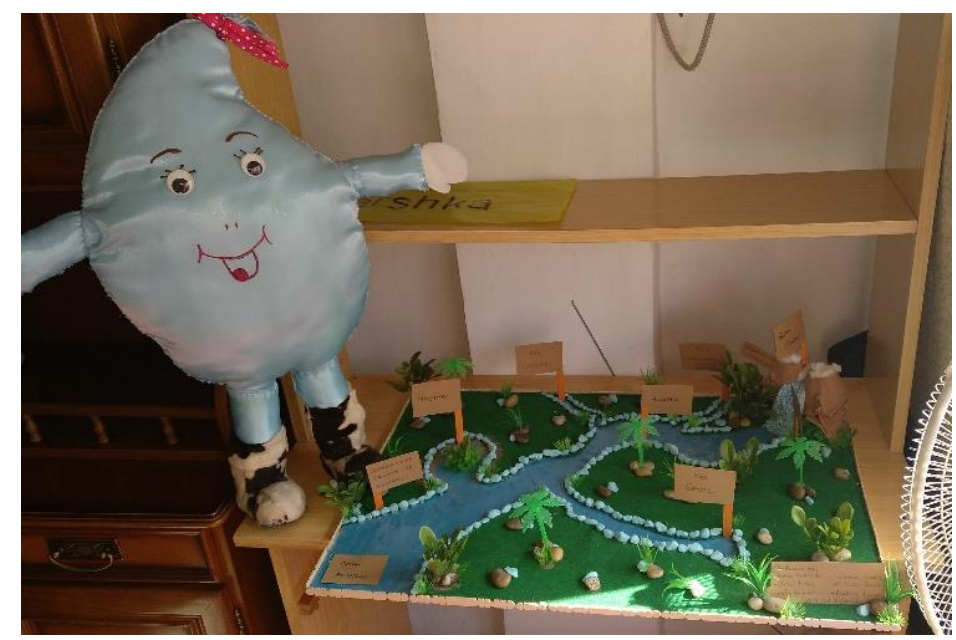

Fuente: Elaboración del alumnado de Infantil.

Para Primaría se realizó un Visual-thinking (Fig. 2) con ayuda de materiales llamativos y los rasgos más importantes del río: los kilómetros que recorre, los cursos medio, alto y bajo, dónde se encuentra su nacimiento y su desembocadura... Los niños y niñas irán rellenando los huecos con la palabra correcta. Con este material didáctico se afianzan los conceptos básicos y se trabaja de forma cooperativa, interaccionando y divirtiéndose mientras aprenden.

Figura 2 - Visual-thinking.

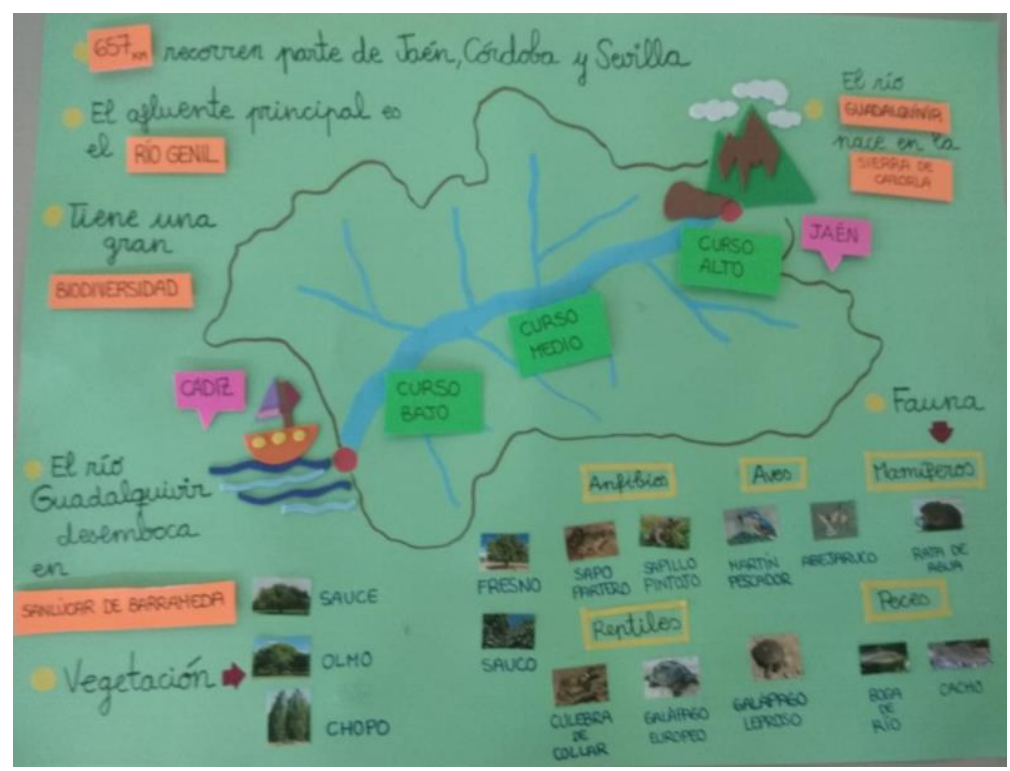

Fuente: Elaboración del alumnado de Primaria.

En Primaría se elaboró también un lapbook, "libro" desplegable", adaptado a $4^{\circ}$ curso (Fig. 3). En el interior se recopilan dibujos, fotos, objetos, actividades, esquemas, desplegables, etc. relacionados con la descripción física del Guadalquivir. De este 
modo los niños y niñas aprenden manipulando e interactuando con la información, siendo protagonistas de su propio aprendizaje.

Figura 3 - Lapbook.

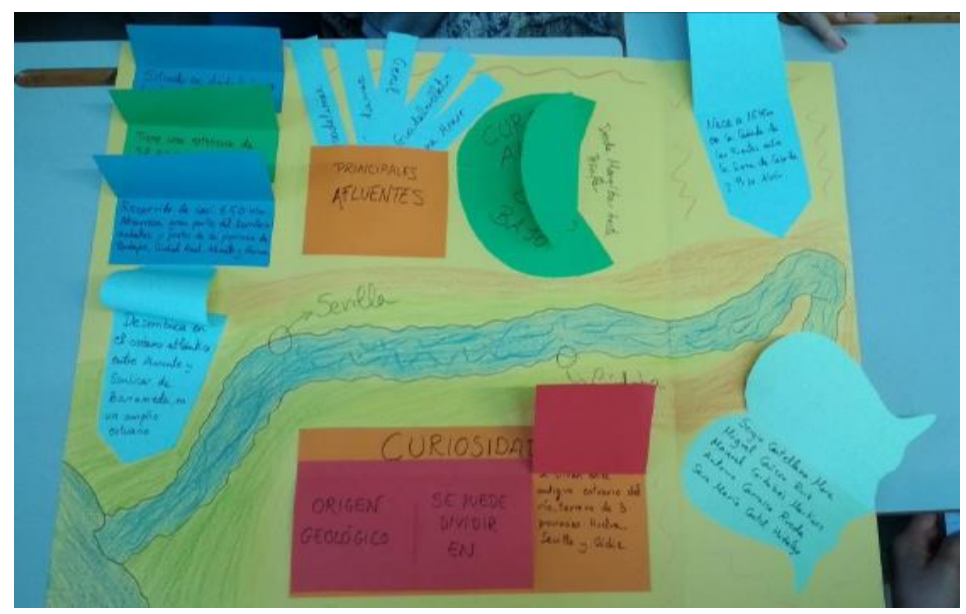

Fuente: Elaboración del alumnado de Primaria.

Para finalizar se propuso una sesión de relajación en la sala de psicomotricidad. Con luz tenue se explicará que van a convertirse en pececitos que están nadando por el río, mientras escuchan un audio con sonido del agua. Habrá diferentes ritmos marcados por el nacimiento del río, su curso medio y la desembocadura. Los pececitos nadan tranquilamente unas veces, otras más rápido para luchar con la corriente y, por último, habrán llegado a la desembocadura donde la corriente es lenta y empiezan a disminuir su ritmo relajándose, de manera que finalmente quedan dormidos en el lecho del río.

- Los paisajes agrarios que dibuja el rio Guadalquivir.

Figura 4 - Maqueta de identificación de los paisajes del Río.

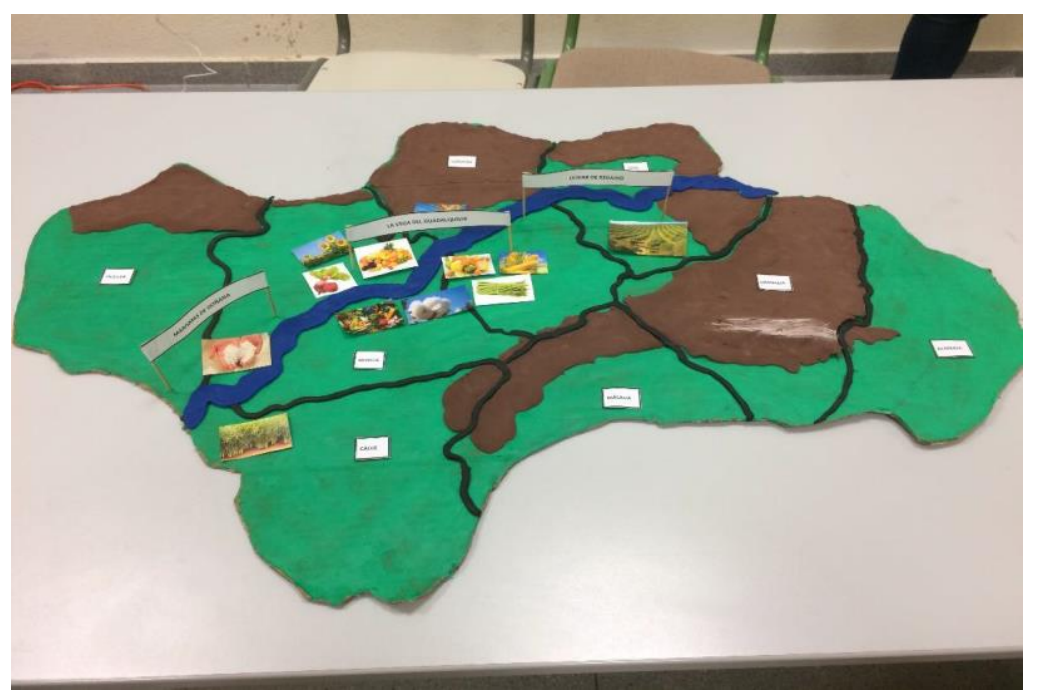


En este caso, el objetivo fundamental era la identificación y caracterización de los paisajes agrarios de campiña, vega y marisma, y de los principales cultivos que tapizan cada uno de ellos: olivar, viñedo, cereal, cultivos de huerta o arrozales marismeños. Las actividades propuestas se centraron en la visualización de paisajes y el reconocimiento de cultivos mediante el empleo de imágenes fijas y documentales como los de Tierra y Mar. Como recurso de carácter manipulativo se hizo un mapa grande de Andalucía con relieves de plastilina e imágenes superpuestas (Fig. 4) que permitía la localización e identificación de los paisajes agrarios a lo largo del curso del río.

- El río Guadalquivir y otros aprovechamientos económicos: acuicultura, industria, servicios, turismo, etc.

En este apartado la mayoría de las propuestas de Infantil y Primaria se decantaron por las excursiones y actividades extraescolares: una visita guiada por molinos, ya restaurados y que fueron también batanes y fábricas de luz, otra a una piscifactoría y una tercera que consistía en organizar un crucero por Guadalquivir desde Sevilla a Sanlúcar. Cada una de ellas con sus correspondientes actividades iniciales, cuadernillo o fichas durante la visita y actividades de síntesis a la vuelta de la excursión y ya en el aula.

- El rio domesticado. La regulación de los recursos hídricos: embalses, presas, canales, etc.

Un cuento teatralizado: El señor Embalse y la Lluvia fue la actividad más aplaudida por el alumnado de Infantil. En él se narra como el señor Embalse se encuentra vacío (muy delgado) porque sus amigas las nubes se han marchado. Los niños ayudan a don Embalse evitando que pierda más agua reduciendo su consumo y enseñando a otros niños como hacerlo. 


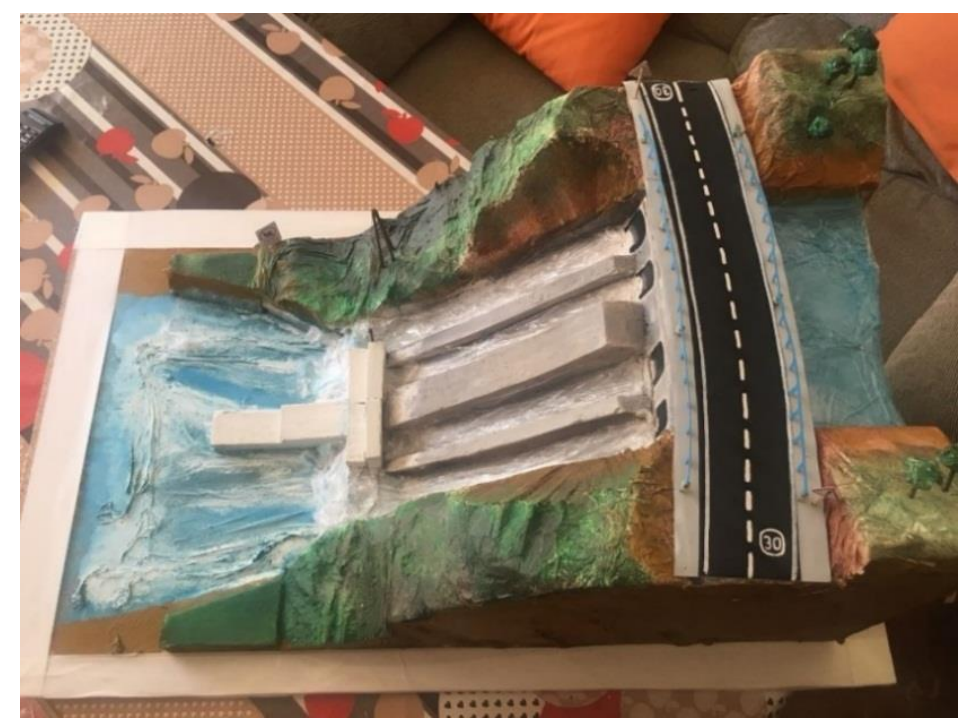

Fuente: Elaboración del alumnado de Primaria

Para Primaria se expusieron, mediante imágenes, diferentes tipos de infraestructuras hidráulicas y se confeccionó una maqueta (Fig. 5), de grandes dimensiones, de una presa en escayola que diferenciaba los elementos que la componen y su funcionamiento.

También se organizó un Triviwater's de 30 cuestiones que premiaba al alumnado según sus respuestas, la gamificación y el empleo de las TIC eran la base de una propuesta que medía el conocimiento acerca de los tipos y la importancia de recursos hídricos del valle del Guadalquivir.

- El río Guadalquivir y sus espacios protegidos. Problemas medioambientales. Para Infantil se elaboró un cuento en formato tangible titulado El viaje de Gotita (Fig. 6) que concibe la historia del personaje como un viaje en el espacio (partes del curso fluvial) y en el tiempo vivido. Los niños y las niñas pueden interactuar con los personajes del cuento, que se corresponden con las diferentes especies vegetales y naturales con las que Gotita se va relacionando a medida que desciende por el Guadalquivir. 

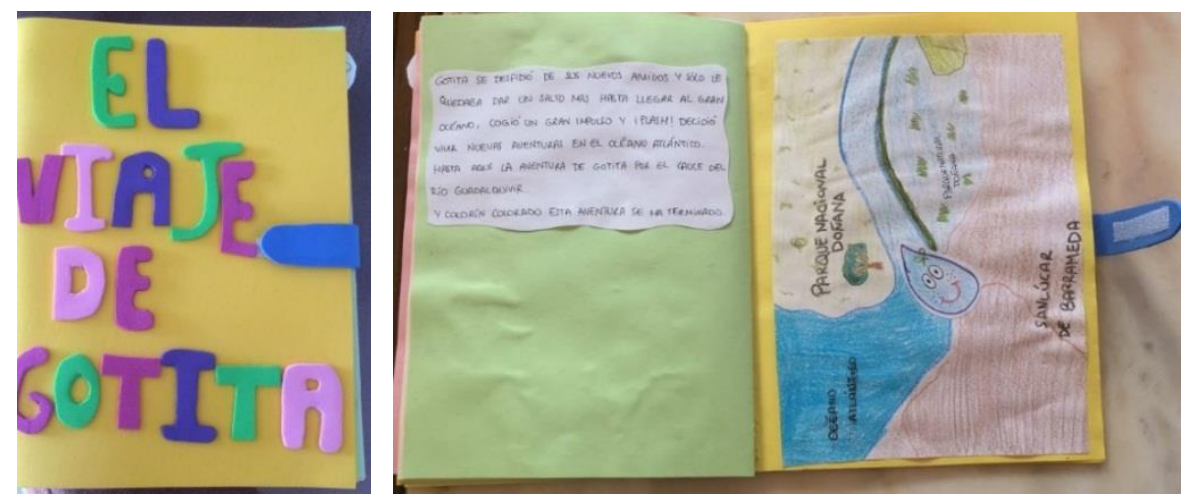

Fuente: Elaboración del alumnado de Infantil.

En Primaria se elaboraron mapas temáticos que recogían la localización de los espacios naturales protegidos que jalonan el Guadalquivir, identificando las relaciones entre los elementos de los distintos ecosistemas y los factores que explican su deterioro, a la vez que se aportan soluciones para su protección y regeneración. Los principios de globalidad territorial, el de agotamiento de los recursos naturales y su uso racional estuvieron presentes en dichas propuestas.

Otro recurso realizado fue un juego de mesa para niños de segundo ciclo de Primaria denominado Guadal-Oca (Fig.7) con el que se aprende la importancia del cuidado al medio ambiente a la vez que actitudes de compañerismo y colaboración con el grupo que se participe.

Figura 7- Guadal-Oca.
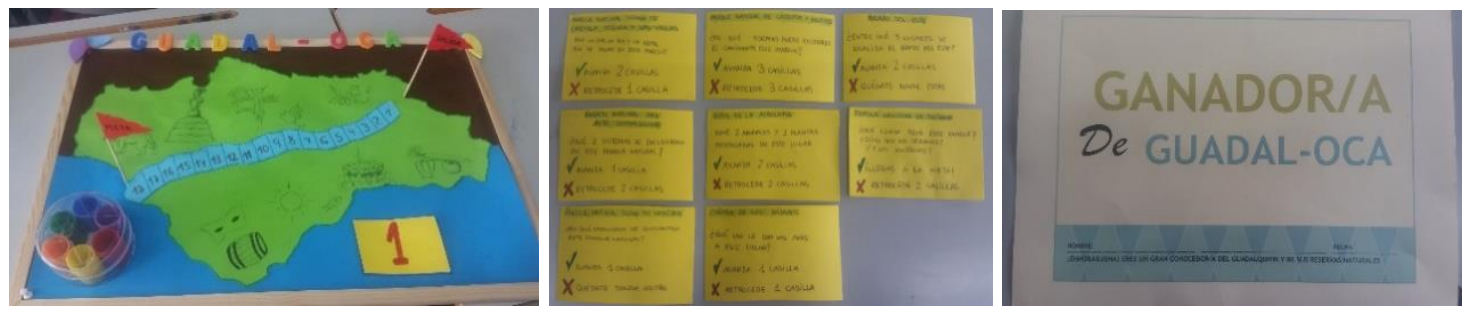

Fuente: Elaboración del alumnado de Primaria.

- El Guadalquivir en sus diferentes etapas históricas.

En esta parte no se descuidó la consideración de las peculiaridades que reviste el aprendizaje del tiempo histórico en cada una de las etapas educativas, insistiéndose en la idoneidad de las propuestas conforme a cada una de las edades a las que fuesen dirigidas. Las ideas principales que fundamentaron las distintas intervenciones fueron las reflexiones acerca de la importancia del río en la configuración del 
poblamiento y los aprovechamientos de las civilizaciones que se asentaron en sus riberas, así como de sus principales logros y aportaciones a la sociedad actual.

Figura 8 - En Busca del Tesoro.

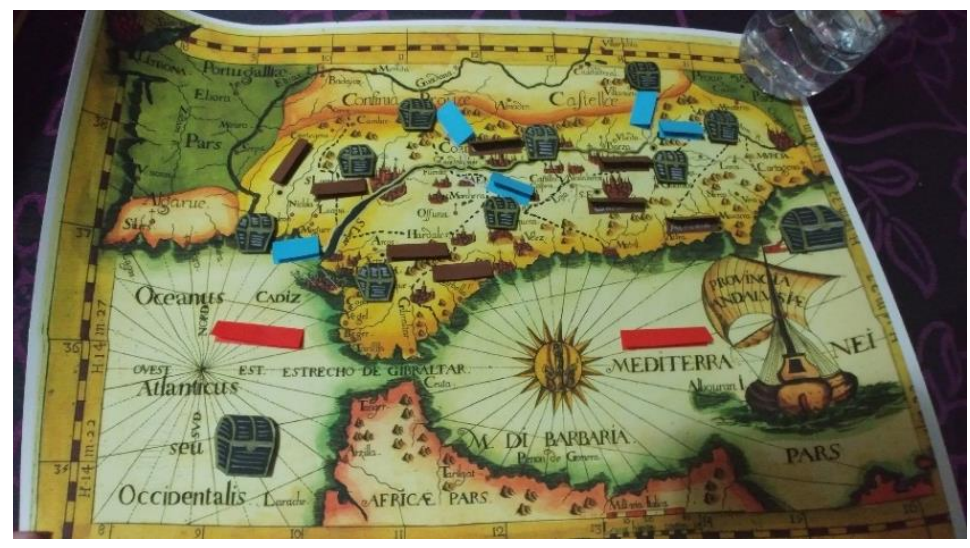

Fuente: Elaboración del alumnado de Infantil.

En Busca del Tesoro (Fig.8) propone una navegación desde Sanlúcar hacia el curso alto del río, descubriendo las riquezas, escondidas en cofres y que nos legaron cada una de las culturas que se asentaron en sus riberas.

Para los más pequeños se propone también un cuento en viñetas (Fig. 9), cada una de las cuales muestra una civilización y las características que las identifican. El desarrollo de la actividad de forma secuencial conforme al devenir histórico, la manipulación de las viñetas y su ordenación siguiendo una línea del tiempo, permite introducir conceptos básicos en relación con el tiempo construido.

Figura 9- Cuento.

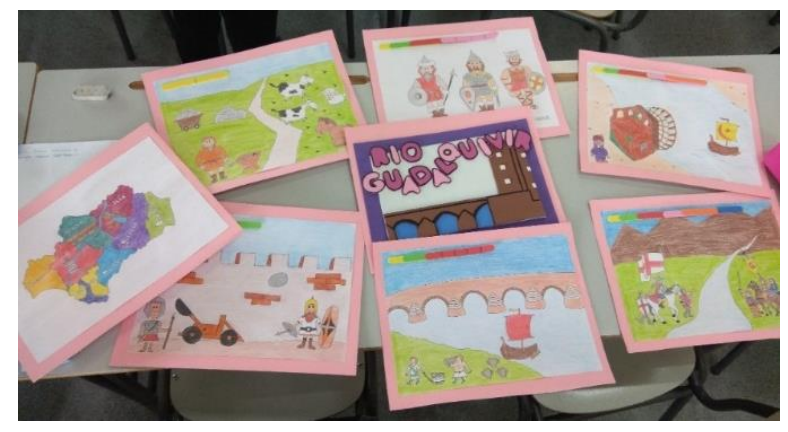

Fuente: Elaboración del alumnado de Infantil.

En Primaria se trabajó el marco temporal con dos ejes cronológicos (Fig. 10): uno de ellos de vasos de plástico transparente superpuestos, con etiquetas o dibujos de forma que, sobre el acontecimiento histórico más antiguo, se van acumulando encima los demás acontecimientos, en el orden que ocurrieron, hasta que el superior y último sea el hecho más próximo a la actualidad. 

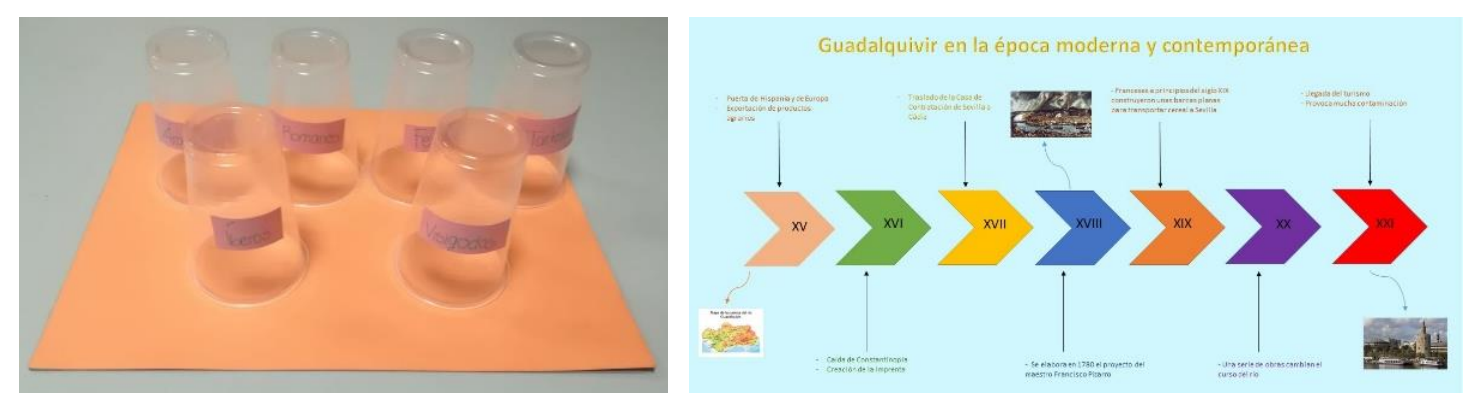

Fuente: Elaboración del alumnado de Primaria.

Seguida a esta actividad de carácter manipulativo, se llegó a otra que requería el uso de las TIC. Se trata de un Genially en línea ${ }^{7}$, que centrándose en la Historia Antigua y Medieval plantea ejercicios de clase en relación con dichas etapas históricas.

- Patrimonio artístico y monumental en torno al rio Guadalquivir: puentes, molinos, etc.

Fruto de la continua humanización del valle Bético, Andalucía cuenta con un rico patrimonio artístico. Dicho patrimonio se dio a conocer con diferentes propuestas (Fig. 11) que van desde la consideración del patrimonio monumental hasta el arte efímero. La primera consistía en un puzle de Andalucía que se forma entre todos los alumnos y a continuación con velcro pegan en cada provincia algunos monumentos y puentes.

Figura 11 - Puzle y Hombre del Río.
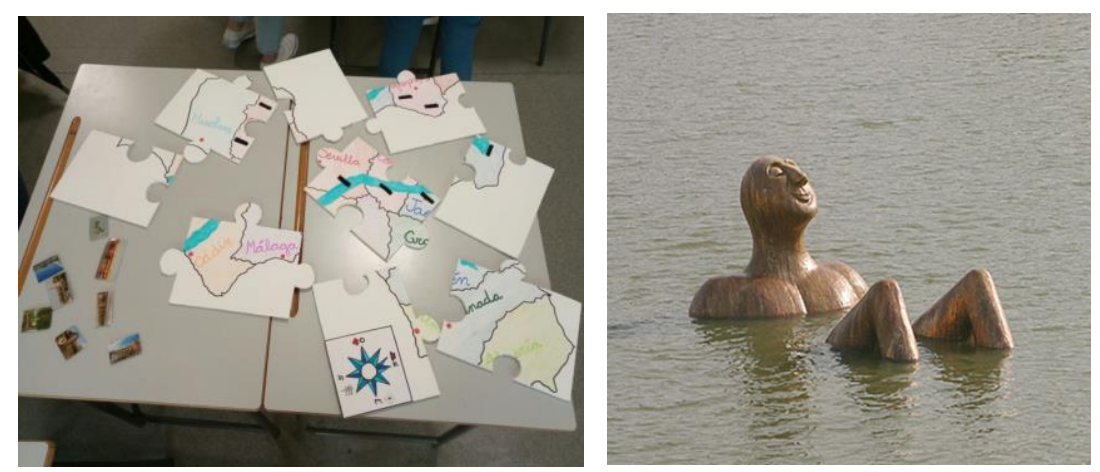

Fuente: Elaboración del alumnado de Primaria.

También se expuso una unidad didáctica completa dirigida a 5o de Primaria titulada Patrimonio histórico, cultural y monumental del río Guadalquivir en la que se propone, entre otras actividades, un itinerario didáctico (Fig. 12) por uno de los espacios con mayor densidad patrimonial de Andalucía, como es el paso del Guadalquivir por la ciudad de Córdoba.

\footnotetext{
${ }^{7}$ https://view.genial.ly/5ad5b55f84b82e1eb773cb53/guadalquivir
} 


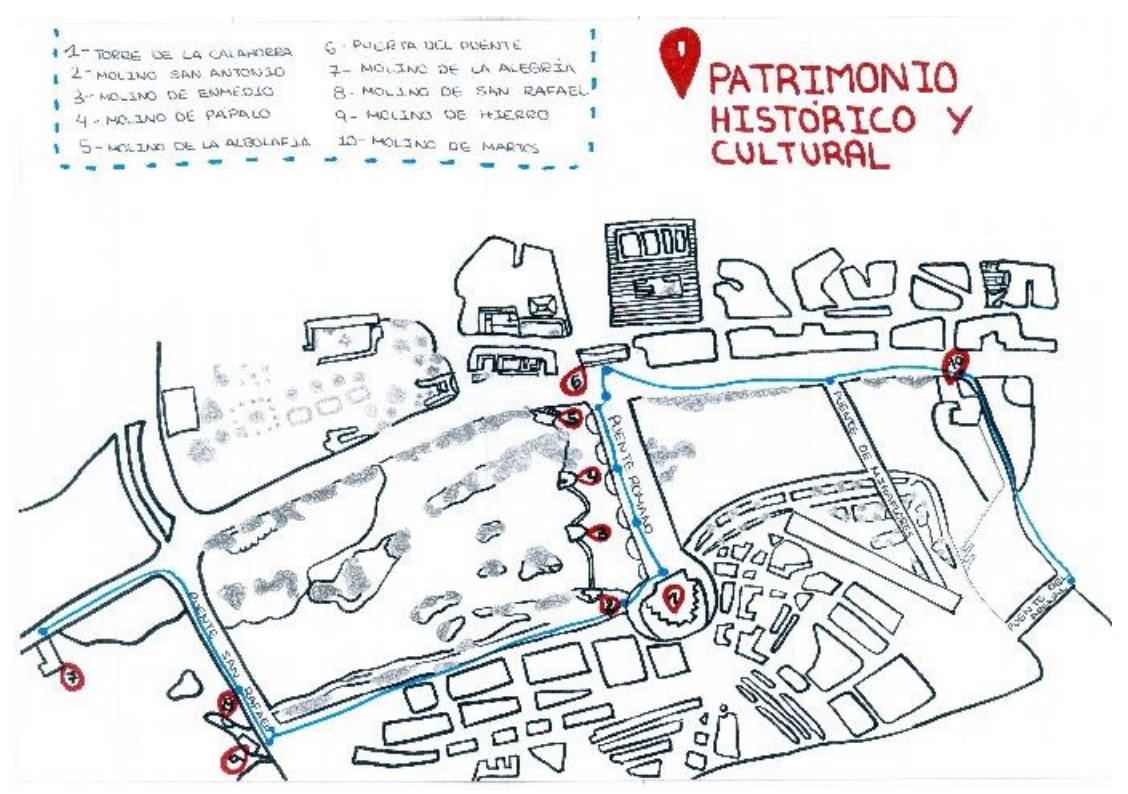

Fuente: Elaboración del alumnado de Primaria.

- Personalidad del Río. El Guadalquivir en la conformación de la identidad regional y en la Literatura.

En este último apartado se trabaja en el aula la importancia del Guadalquivir como conformador de identidad regional a través de la visión que del mismo hacen poetas, literatos o dramaturgos de todas las épocas, desde Marco Valerio o Avieno, pasando por Abulbeca de Ronda, Juan de la Cueva, Jorge Manrique, Quevedo, Góngora, Cervantes, el Duque de Rivas, Juan Ramón Jiménez, Gerardo Diego, García Lorca hasta a Antonio Gala o Pablo García Baena.

La principal aportación consistió en la dramatización de un cuento para Infantil que utiliza guiñoles: La patita Andalucía. Los guiñoles confeccionados son ocho patos que conforman Andalucía, identificado con un color distinto. A su vez los patos de aquellas provincias andaluzas por las que pase el río portan la imagen de un autor relevante junto con un verso o estrofa en las que ha servido de inspiración el río Guadalquivir. Se refuerzan conceptos ya adquiridos en Infantil como los colores y la asociación de ideas a formas, que en este caso son las de las provincias, promoviendo el conocimiento y la adquisición de cultura andaluza, la literatura y sus autores.

Para el alumnado de Primaria se organizó un Paseo Geoliterario por los Sotos de Abolafia, con una batería de autores y textos de diferentes épocas. En este marco natural e histórico, la poesía o la narrativa traza un Guadalquivir que es símbolo de vida y del transcurso del tiempo, donde el agua fluyente se identifica con la vida humana. El río es vida y fecundidad: vida abocada a la muerte, como afirmaba Jorge 
Manrique. El río es también símbolo de la esperanza frente a la tristeza y la desdicha. En otras ocasiones el río es un recuerdo, que se almacena en la memoria y permite visualizar el tránsito de la infancia a la vejez. Pero el Guadalquivir ha sido y se muestra en ocasiones inquieto, desbordado, turbulento y cambiante como los avatares históricos que se han vivido en sus riberas, pudiéndose asimilar su caudal a los estados de ánimo de una persona: agitado, calmado...

\section{Valoración de los resultados obtenidos}

El planteamiento de los objetivos y de la temática propuesta al alumnado puso de manifiesto, desde el primer momento, la complejidad del tema de estudio. No solo por la incompleta formación inicial del alumnado de Grado, sino por la dificultad de una investigación que entrelaza distintos ámbitos de conocimiento, a caballo entre las Ciencias Sociales y las Ciencias Experimentales. El trabajo con las fuentes más adecuadas para cada uno de los ejes temáticos resultó también complejo, pues requería también de recursos variados que comprendían desde el manejo de la cartografía y la estadística, a la consulta de manuales de diferentes disciplinas, el conocimiento y la identificación de diferentes épocas históricas o de elementos patrimoniales, amén de tener que refrescar sus conocimientos de literatura. Así pues, la investigación y las propuestas didácticas han estado sometidas a constantes y frecuentes reformulaciones en función de los problemas que surgían. Cuestión que no deja de ser positiva, puesto que una exploración y observación participativa que reinterpreta y se ajusta a las exigencias de cada contexto es la que ha permitido obtener unos resultados, creemos, ciertamente significativos.

Se pudo comprobar como el estudio del río aún conserva cierta carga peyorativa pues no se ha llegado a completar todavía una accesibilidad cognitiva, visual o emocional en muchos de sus tramos, que aparecen contaminados o sin acondicionar.

También se puso de manifiesto la existencia de una visión simplista o parcial del río, que reduce su riqueza y complejidad a aspectos coyunturales o anecdóticos. Por lo que se valida la necesidad de pergeñar nuevas experiencias didácticas y se pone de manifiesto, también, la necesidad de transferir a la población más joven unos conocimientos y una conciencia fluvial que registre la multitud de matices acumulados a lo largo del tiempo.

El currículo, el diseño de los libros de texto, la propia organización de las materias y otros aspectos pueden dificultar esta propuesta, u otras similares, dentro de un marco 
complejo en el que se vislumbra la necesidad de trabajar en la Escuela objetos de estudio que hagan efectiva una ciudadanía territorial, desde la perspectiva de la participación o la sustentabilidad, como es el caso del río Guadalquivir, reduciendo las distancias entre el contenido y la práctica escolar, que se aproxima de nuevo a la realidad local y a sus problemas.

Un obstáculo didáctico, que se logró en gran parte superar con la pericia y la imaginación del alumnado de Grado, fue la adecuación de los niveles competenciales a la comprensión del espacio geográfico y el tiempo histórico en alumnos de tan corta edad. La clave del éxito de las propuestas educativas expuestas ha residido, en buena parte, en el uso de la gamificación. El juego crea un ambiente de esfuerzo conjunto, de colaboración, pone en práctica la creatividad y supone vencer retos para obtener una recompensa. El otro componente clave de las experiencias didácticas ha sido la fluviofelicidad, aplicada en un sentido más amplio que el que induce la práctica de los deportes acuáticos, y relacionada más bien con el conjunto de reacciones, experiencias vividas y satisfacciones que produce el verdor de las riberas, el olor de su flora, el rumor de su corriente, la sorpresa de descubrir su fauna, es el río vivido y sentido que facilita la motivación y supone nuevas oportunidades para el aprendizaje, la educación ambiental y en valores.

En definitiva, se puede concluir acerca de la enseñanza del rio Guadalquivir que:

- La potencialidad educativa del río Guadalquivir radica en buena medida en su proximidad, en un moderado nivel de dificultad en sus contenidos y en la transparencia de su aprendizaje e interpretación.

- Desde el punto de vista didáctico el río presenta un enorme potencial. Es un objeto de estudio inigualable para el tratamiento interdisciplinar y el uso de metodologías diversas. Igualmente permite trabajar todas las competencias básicas y los elementos comunes del currículo.

- El Guadalquivir es un recurso idóneo para abordar en el aula problemas relevantes y elaborar propuestas de educación ambiental, haciendo efectiva una ciudadanía territorial desde la perspectiva de la gobernanza y de la sustentabilidad.

- En el presente concurren circunstancias oportunas para abordar los entornos fluviales desde una perspectiva educativa, que es a la vez complementaria e ineludible dentro de otras iniciativas como son: el desarrollo de la Directiva Marco Comunitaria de Aguas, el desarrollo de las Agendas Locales, la 
Estrategia de Desarrollo Urbano Sostenible e Integrado (EDUSI), La Estrategia Europa 2020 y sus propuestas de participación ciudadana, etc.

\section{Referencias bibliográficas}

Cobos Maroto, J y Pedraza Serrano, J. R. (2018). Proyecto Río (Guadalquivir): contextualizar un entorno natural y urbano. eCO, V (15), 19 pp. Disponible en: <http://revistaeco.cepcordoba.org/index.php/2018/04/11/proyecto-rio-guadalquivircontextualizar-un-entorno-natural-y-urbano/> (Último acceso, 20 julio 2018)

Cuello Gijón, A. (2010). Los tramos fluviales urbanos como ámbitos de aprendizaje. Una valoración de su potencial educativo y los obstáculos que plantea su utilización. En M. Junyent Pubill y L. Cano Muñoz (Coords.), Investigar para avanzar en educación ambiental (pp. 63-84). Madrid: Organismo Autónomo Parques Nacionales. Ministerio de Medio Ambiente y Medio Rural y Marino.

Cuello Gijón, A. (2011). Ríos, ciudades y educación. En VII Congreso Ibérico sobre gestión y planificación del agua. Talavera de la Reina: Fundación Nueva Cultura del Agua.

Estevan A, Naredo J.M. (2004). Ideas y propuestas para una nueva política del agua. Bilbao: Fundación Nueva Cultura del Agua.

Gabardón de la Banda, J. F. (2014). La ciudad y el río como paisaje geohistórico y su proyección en el ámbito educativo. Escuela Abierta, V (17), 211-240.

González Rojas, D. (2017). Bases conceptuales y metodológicas para el estudio de los espacios fluviales urbanos. Un estudio de caso en Andalucía. Estudios Geográficos, LXXVIII/283, 657-679.

Ibarra, J. (2007). Nuevos contenidos educativos sobre el agua y los ríos desde una perspectiva CTS. Revista Electrónica de Enseñanza de las Ciencias. V (6), 714-728. Disponible en: http://www.saum.uvigo.es/reec/

Marcén Alvaro, C. (1996). El río vivido. Propuesta didáctica de Educación Ambiental. Madrid: MEC.

Martínez Gil, J. (1987). La nueva cultura del agua en España. Bilbao: Editorial Bakeaz.

Pedraza Serrano, J. R. (2018). Proyecto-Río-Averroes (Guadalquivir por Córdoba): paisaje vivido, jugado, interiorizado. En XII Congreso Nacional de Didáctica de la Geografía. Madrid:(en prensa). 
Unesco (abril de 1978). Informe Final de la Conferencia Intergubernamental sobre Educación Ambiental, organizada por la Unesco con la cooperación del PNUMA. Realizado entre el 14 al 26 de octubre de 1977. Tbilisi (URSS). París: Unesco. 


\section{A Educação Geográfica e o desenvolvimento de competências de pesquisa no Ensino Secundário: uma experiência didática}

RICARDO COSCURÃO ${ }^{1}$

\section{Resumo}

A presente comunicação centra-se no contributo da educação geográfica para a mobilização de competências de pesquisa, partindo de uma sequência letiva na disciplina de Geografia A, lecionada numa turma do $11^{\circ}$ ano que participou no Projeto "Nós Propomos!" - o que permitiu explorar as relações entre cidadania e a mesma educação geográfica. Em momentos de aprendizagem diversificados e, especialmente, na realização de pesquisas, os alunos recorrem, mais frequentemente, a motores de busca na Internet. Podem, ainda, aperfeiçoar procedimentos neste âmbito, para além de se revelar fundamental um maior cuidado quanto à credibilidade e rigor da informação utilizada. Os alunos envolvidos contactaram com informações e fontes de informação diversificadas, para além da aposta nas suas competências ao nível da cidadania territorial, dimensão incontornável quando pensamos em educação geográfica. Esta experiência pretende ser um pequeno contributo, no âmbito de um processo mais amplo e contínuo, cuja continuação constitui um desafio futuro: avaliar o papel de diferentes experiências de aprendizagem no desenvolvimento das competências dos alunos em Geografia.

Palavras-chave: Competências de pesquisa; Educação Geográfica; Experiências de aprendizagem; Diversificação de estratégias de ensino-aprendizagem; Cidadania territorial.

\footnotetext{
${ }^{1}$ Doutorando em Geografia, Instituto de Geografia e Ordenamento do Território - Universidade de Lisboa, rcoscurao@campus.ul.pt.
} 


\section{Abstract}

The present communication focusses on the contribution of geographic education to the mobilization of research skills, starting from a teaching sequence within the subject of "Geography A" taught to an $11^{\text {th }}$ grade class that participated in the "Nós Propomos!" Project - that enabled exploring the relations between citizenship and geographic education. Throughout various learning moments and especially when doing research, students most frequently resort to Internet browsers. They can also improve procedures within this scope, and it is fundamental for greater care to be used insofar as to the credibility and accuracy of the information. At the end of this experience, we highlight the opportunity of the students involved of having contact with a variety of information and information sources, besides the wager on their skills insofar as to territorial citizenship, an undeniable sphere when we think of geographic education. This experience intends to be a small contribution within the scope of a broader and continuous process, whose continuation is a challenge for the future: to evaluate the contribution of different learning experiences towards the development of students' skills in Geography.

Key words: Research Skills; Geographic Education; Learning Experiences; Diversification of teaching-learning strategies; Territorial citizenship.

\section{Introdução}

O presente texto tem por base o Relatório de Prática de Ensino Supervisionada com o mesmo título, desenvolvido no âmbito do Mestrado em Ensino de Geografia no 3ํㅜㅇ Ciclo do Ensino Básico e no Ensino Secundário, em 2016/17, ministrado pelo Instituto de Geografia e Ordenamento do Território e pelo Instituto de Educação da Universidade de Lisboa.

Num momento em que a frequência do ensino superior é uma realidade para um número cada vez maior de estudantes e num contexto em que a competitividade é, também ela, cada vez mais vincada, a aposta no desenvolvimento das competências dos alunos surge como um desafio central na escola, de forma a que estes estejam preparados para os desafios com que se vão deparar - tornando-se cidadãos mais competentes e melhores profissionais. Falamos de competências de diferentes naturezas, como é o caso das relacionadas com a pesquisa, por parte dos alunos. Estas competências constituem um conjunto de ferramentas que se tornam fundamentais para o sucesso do percurso universitário destes alunos, podendo o 
ensino secundário ser encarado como um momento particularmente relevante no âmbito deste processo, já que coincide com o chamado período pré-universitário. Neste seguimento, o presente artigo incide sobre uma investigação realizada junto de uma turma do $11^{\circ}$ ano de escolaridade, no âmbito da disciplina de Geografia $A$, na Escola Secundária Jorge Peixinho, na cidade do Montijo. Como principal questão de partida, esta investigação procurou compreender de que forma a educação geográfica pode contribuir para a mobilização de competências de pesquisa de alunos do $11^{\circ}$ ano de escolaridade, no âmbito de uma sequência de aulas da disciplina de Geografia A. A partir desta questão principal, foram, também, definidas algumas questões secundárias, nomeadamente: Quais as ideias prévias dos alunos quanto às suas próprias competências de pesquisa? Que transformações podem ser observadas, ao nível das competências de pesquisa dos alunos, através da implementação de diferentes estratégias de ensino, tendo em conta um contexto específico? E ainda quais das estratégias de ensino utilizadas se podem revelar mais pertinentes no sentido de potenciar as competências de pesquisa dos alunos, neste caso concreto?

\section{Contextualização}

\section{A competência como aplicação prática de conhecimento}

$\mathrm{Na}$ base da investigação em análise, encontramos a noção de competência, recorrente em numerosos trabalhos científicos.

Definir "competência" não será propriamente simples e direto, variando de acordo com o respetivo autor e com o contexto em que for formulada, o qual pode, também, ser muito vasto e diversificado. Perrenoud (2001) destaca as relações entre saberes e competências, defendendo que as segundas não podem existir sem os primeiros. Wood (2013), no quadro da reflexão que desenvolve sobre a educação geográfica, reconhece a dificuldade em a definir, dado o amplo espectro de contextos que este conceito pode abranger, salientando as ideias de utilização prática e aplicação do conhecimento, associadas a este mesmo conceito. Poder-se-á dizer que, independentemente das particularidades das definições apresentadas por cada autor, a ideia de aplicação prática do conhecimento, tendo em conta situações e contextos específicos, acaba por ser transversal a qualquer aceção de "competência".

Tal como já vimos, o conceito de "competência" e a respetiva promoção aplicam-se a diferentes contextos. O âmbito educativo é, precisamente, um deles, tal como podemos observar em trabalhos de autores como Alberto (2001), Perrenoud (2001) e 
Baptista (2014). Esta preocupação quanto ao desenvolvimento de competências, em contexto educativo, começou a assumir maior protagonismo especialmente a partir de meados dos anos 90 , do século passado. Tal como refere Claudino (2001, p. 73), "os anos de crise económica que pontuam os decénios de 70 e 80 renovam as atenções pelo ensino profissionalizante", o que nos remete para a importância das competências, no âmbito de um ensino que se desejava mais prático.

Não perdendo de vista o âmbito educativo, que mais nos interessa, as competências relacionadas com a informação podem assumir um papel de especial relevo. Por outras palavras, será útil, ao aluno, em contexto escolar, desenvolver competências ligadas ao contacto com as várias informações de que necessita e a que tem acesso, aspetos que nos remetem, precisamente, para o tema da investigação em análise. Perante a abundância de informação que caracteriza a sociedade atual, os alunos devem dar atenção a vários aspetos, nomeadamente a credibilidade da informação. Porém, muitas vezes, as competências evidenciadas pelos alunos, neste âmbito, parecem não estar à altura da realidade acima apresentada, tal como nos mostram Cordeiro (2011) e Loureiro e Rocha (2012). Poder-se-á, assim, dizer que, de um modo geral, os alunos apresentam algumas lacunas em termos de literacia informacional, ou literacia da informação. Tal, alerta-nos para a necessidade de uma aposta em competência de pesquisa, para que o aluno, futuro profissional, saiba "pesquisar, ser seletivo, analisar criticamente e interpretar a informação recolhida, incorporando-a no seu conhecimento, de maneira a utilizá-la eficazmente, solucionando o seu problema inicial" (Cordeiro, 2011, pp. 25-26).

A implementação de experiências, diretamente relacionadas com as competências de pesquisa, na educação geográfica, não tem sido privilegiada entre nós. No entanto, é reconhecida a importância e o lugar que a aposta em competências pode ter, neste âmbito. Desde logo, a Carta Internacional da Educação Geográfica, da União Geográfica Internacional, na sua primeira versão, de 1992, reconhece que "a educação geográfica . . contribui para o desenvolvimento de competências pessoais e sociais, particularmente no que diz respeito à dimensão espacial da vida diária e à compreensão internacional” (UGI, 1992, p. 10). Já antes, numa publicação da UNESCO para o ensino da Geografia, Pinchemel (1989) defendera uma "educação para uma competência espacial". Para este autor, a educação geográfica, através de atividades como o trabalho de campo e a utilização de mapas, entre outras, permite desenvolver competências, no sentido de contrariar o que prefere designar de "incompetência espacial" (Pinchemel, 1989). Encontramos idêntico tipo de perspetivas nos trabalhos de Cachinho (2000) e Alberto (2001). Mérenne-Schoumaker (2002) 
defende que a Geografia, no ensino secundário, deve desenvolver, junto dos alunos, competências ligadas à análise de territórios, permitindo que estes alunos se "situem" espacial e socialmente, agindo de uma forma responsável. Wood (2013) destaca a importância do desenvolvimento de competências para a construção de um conhecimento geográfico efetivamente coerente, possibilitando estruturar, manipular, criticar e discutir este conhecimento. De acordo com o mesmo autor, o desenvolvimento de competências no âmbito da educação geográfica pode manifestar-se no trabalho com mapas, no trabalho de campo, na tomada de decisões sobre problemas concretos, entre outros.

Apesar de pouco explorada, a relação entre educação geográfica e competências de pesquisa, tema base da investigação em análise, não é totalmente ignorada. Cachinho (2000) refere, por exemplo, que "através da geografia os alunos . . . aprendem a levantar questões, emitir hipóteses, a pesquisar, selecionar e organizar a informação necessária à compreensão e interpretação dos problemas" (p. 89), o que nos remete, precisamente, para este tipo de competências. De igual modo, Olatunde Okunrotifa (1989), refletindo sobre a recolha de informação no âmbito da educação geográfica, defende que os alunos devem saber: quando e como obter a informação de que necessitam; preparar a informação recolhida para processá-la; que métodos de análise devem usar; como obter conclusões a partir da informação tratada.

\section{A valorização da observação e da interpretação}

Do ponto de vista metodológico, a investigação, na base deste artigo, baseou-se num paradigma de tipo interpretativo. A propósito deste tipo de paradigma de investigação, Almeida e Freire (2003) referem mesmo uma investigação humanista-interpretativa. No caso da investigação em análise, esta decorreu num contexto de pequena escala, ao nível de uma turma, algo que se enquadra, precisamente, nos aspetos associados a um paradigma de investigação interpretativo. Mais do que generalizar, o foco principal direcionou-se para uma interpretação das ações desenvolvidas, essencialmente em termos de competências evidenciadas pelos alunos e tendo em conta as suas próprias perceções, não esquecendo que esta experiência decorreu num contexto particular, mais concretamente uma sequência de aulas da disciplina de Geografia A, numa turma do $11^{\circ}$ ano de escolaridade.

Quanto à abordagem selecionada no caso da investigação em análise, foi privilegiada uma perspetiva qualitativa. Basicamente, procurou-se interpretar as ações e perceções dos alunos à luz das respetivas competências de pesquisa, tendo em conta 
a influência de determinadas estratégias de ensino face a estas competências e centrando atenções no interesse prático destas relações de influência.

Relativamente aos instrumentos de recolha de dados no âmbito da investigação em análise, importa destacar, desde logo, a observação. Trata-se de uma técnica privilegiada para a obtenção de informações-chave numa investigação de índole qualitativa, ideia que encontramos em trabalhos de autores como Bell (2004) e Tuckman (2005). No caso da investigação referida, a observação incidiu essencialmente sobre as competências de pesquisa evidenciadas pelos alunos, tal como já foi especificado anteriormente. Nesta mesma investigação, foi importante recolher os testemunhos dos alunos envolvidos, com vista a conhecer as suas perceções acerca de todo o processo. Para tal, foram construídos instrumentos de recolha, nomeadamente diários de aula, a preencher por todos os alunos, no final de cada aula. Estes instrumentos possibilitaram um acompanhamento do percurso dos alunos, bem como das respetivas perceções, quer quanto à sequência de aulas, de um modo geral, quer quanto à questão das competências de pesquisa.

Relativamente à análise das informações recolhidas, uma das preocupações principais consistiu no rigor e organização desta análise. Assim, procurou-se uma adoção dos procedimentos básicos associados à análise de conteúdo, uma técnica frequentemente utilizada em investigações de cariz qualitativo.

\section{Uma sequência letiva de onze aulas}

A investigação em análise decorreu tendo por base uma sequência letiva, composta por onze aulas sequenciais. Olhando para o Programa da disciplina de Geografia A, esta sequência de aulas incidiu sobre o terceiro módulo, "Os espaços organizados pela população", ao nível da unidade de conteúdos "A rede urbana e as novas relações cidade-campo". As opções tomadas quanto à organização desta sequência letiva não foram, naturalmente, aleatórias, tendo-se privilegiado uma adoção de estratégias diversificadas, não esquecendo o próprio tema de investigação associado a esta mesma sequência. Na Tabela 1, encontramos a correspondência entre os conteúdos abordados e as experiências de aprendizagem implementadas. 
Tabela 1- Conteúdos abordados e respetivas experiências de aprendizagem implementadas

\begin{tabular}{|c|c|}
\hline Conteúdos & Experiências \\
\hline - As aglomerações urbanas no território & $\begin{array}{l}\text { - Exploração do manual escolar; } \\
\text { - Construção de um esquema-síntese (trabalho } \\
\text { de pares); } \\
\text { - Análise de mapas e exploração do portal } \\
\text { "Night Earth"; } \\
\text { - Recolha, organização e análise de dados } \\
\text { estatísticos (trabalho de grupo). }\end{array}$ \\
\hline $\begin{array}{l}\text { - A hierarquia dos lugares na rede } \\
\text { - Vantagens e limitações da dispersão ou da } \\
\text { concentração do povoamento }\end{array}$ & $\begin{array}{l}\text { - Análise de obras científicas no âmbito do } \\
\text { tema em estudo (trabalho de grupo); } \\
\text { - Exploração do manual escolar; } \\
\text { - Preenchimento de um esquema-síntese. }\end{array}$ \\
\hline $\begin{array}{l}\text { - O papel das cidades médias } \\
\text { - O atenuar do crescimento das grandes } \\
\text { aglomerações }\end{array}$ & $\begin{array}{l}\text { - Análise de um artigo científico (trabalho } \\
\text { individual); } \\
\text { - Exploração do manual escolar. }\end{array}$ \\
\hline - A inserção na rede urbana europeia & $\begin{array}{l}\text { - Visionamento de um vídeo; } \\
\text { - Análise de uma notícia; } \\
\text { - Exploração do portal da "Rede para a } \\
\text { Promoção das Cidades Médias da União } \\
\text { Europeia" (trabalho de pares); } \\
\text { - Exploração do manual escolar. }\end{array}$ \\
\hline $\begin{array}{l}\text { - As complementaridades funcionais } \\
\text { - As estratégias de cooperação institucional }\end{array}$ & $\begin{array}{l}\text { - Visionamento de um vídeo; } \\
\text { - Preenchimento de um esquema-síntese } \\
\text { (trabalho individual); } \\
\text { - Exploração do manual escolar; } \\
\text { - Construção de um mapa de uso e ocupação } \\
\text { do solo, recorrendo a Sistemas de } \\
\text { Informação Geográfica (SIG). }\end{array}$ \\
\hline
\end{tabular}

Fonte: Elaboração própria.

Sublinhe-se, ainda, que, ao longo de todo o ano letivo, a turma participou, de uma forma empenhada, no Projeto "Nós Propomos!", no âmbito do qual foram apresentadas cinco propostas de intervenção face a problemas identificados pelos alunos, na sua cidade. A participação neste projeto, para além de todos os objetivos relacionados, constituiu mais uma oportunidade para explorar as potencialidades da turma, ao nível do trabalho em grupo. Para além disto, esta participação pode, até, ser encarada como um contributo no sentido da promoção de hábitos e métodos de trabalho. É, também, possível estabelecer uma relação entre a participação no projeto e o próprio tema da investigação em análise, na medida em que os alunos, ao desenvolverem os trabalhos, necessitaram de mobilizar, entre outras, competências de pesquisa, podendo experienciar as várias fases que compõem um trabalho de investigação, desde a identificação do problema, à apresentação da proposta de intervenção. De igual modo, importa salientar as potencialidades deste tipo de 
experiência ao nível da exploração das relações entre cidadania e educação geográfica.

\section{Melhorias na seleção, diversificação e organização da informação}

Segue-se uma análise centrada em resultados diretamente relacionados com o tema da investigação, tendo por base a informação recolhida através dos instrumentos aplicados.

No início da sequência letiva, foi aplicado um questionário, aos alunos, com o objetivo de efetuar um diagnóstico relativamente às suas competências de pesquisa. De igual modo, no final da sequência letiva, os alunos da turma responderam a um outro questionário, de estrutura muito idêntica à do questionário de diagnóstico. Procurouse, assim, possibilitar uma comparação das perceções dos alunos, relativamente às suas próprias competências de pesquisa, em dois momentos específicos.

Relativamente às fontes de informação mobilizadas pelos alunos, aquando da realização de trabalhos escolares, a Tabela 2 expressa a frequência com que estes alunos recorrem a diferentes tipos de fontes de informação, tendo por base 0 questionário de diagnóstico.

Tabela 2 - Fontes de informação: frequência de utilização (questionário de diagnóstico)

\begin{tabular}{|l|c|c|c|}
\cline { 2 - 4 } \multicolumn{1}{c|}{} & Frequentemente & Pontualmente & Nunca \\
\hline Manuais escolares & 11 & 9 & 0 \\
\hline Outros livros & 2 & 17 & 1 \\
\hline Blogues & 8 & 6 & 6 \\
\hline Inquéritos & 1 & 13 & 6 \\
\hline Motores de busca & 20 & 0 & 0 \\
\hline Revistas científicas & 0 & 8 & 12 \\
\hline Imprensa & 2 & 13 & 5 \\
\hline Entrevistas & 1 & 14 & 4 \\
\hline
\end{tabular}

Fonte: Elaboração própria.

Tal como podemos observar na tabela, os motores de busca revelaram-se o tipo de fonte de informação utilizado mais frequentemente, pelos alunos. De igual modo, os manuais escolares registaram, também, um resultado significativo. Estes resultados mostram-nos, assim, que estes alunos dão primazia à pesquisa através da internet, salientando, igualmente, o manual escolar. Apesar de apenas dois alunos terem referido que utilizam outros livros, como fontes de informação em trabalhos escolares, de uma forma frequente, dezassete reconheceram uma utilização pontual, o que nos mostra que estes alunos não ignoram a importância deste tipo de fonte. Este facto 
pode, ainda, ser encarado como indicador de uma certa preocupação quanto à diversificação de fontes, algo que fica expresso, igualmente, pelos resultados quanto às fontes de informação que os alunos admitem nunca ter usado. Neste grupo, apenas se destacam as revistas científicas, fontes de informação com que, habitualmente, os alunos estão menos familiarizados.

Ainda quanto à frequência de utilização de diferentes fontes de informação, tendo, agora, por base o questionário final, os resultados respetivos encontram-se na Tabela 3.

Tabela 3- Fontes de informação: frequência de utilização (questionário final)

\begin{tabular}{|l|c|c|c|}
\cline { 2 - 4 } \multicolumn{1}{c|}{} & Frequentemente & Pontualmente & Nunca \\
\hline Manuais escolares & 12 & 7 & 0 \\
\hline Outros livros & 3 & 15 & 1 \\
\hline Blogues & 6 & 2 & 11 \\
\hline Inquéritos & 3 & 12 & 3 \\
\hline Motores de busca & 15 & 4 & 0 \\
\hline Revistas científicas & 0 & 8 & 11 \\
\hline Imprensa & 4 & 11 & 4 \\
\hline Entrevistas & 1 & 15 & 3 \\
\hline
\end{tabular}

Fonte: Elaboração própria.

Comparando as respostas obtidas nos dois questionários, poder-se-á dizer que os manuais escolares e os motores de busca continuaram a liderar, em termos de frequência de utilização, neste questionário final. De salientar, no entanto, a diminuição do número de ocorrências no caso da utilização de motores de busca. $\mathrm{Na}$ base desta diminuição poderá estar uma maior consciencialização face à importância da diversificação de fontes de pesquisa e aos critérios na base da sua seleção, dois aspetos que foram realçados, precisamente, ao longo da sequência letiva. De um modo geral, poder-se-á dizer que o panorama, em termos de frequência de utilização de diferentes fontes de informação, manteve-se, merecendo destaque a diminuição do número de ocorrências, ao nível das fontes de informação que os alunos referiram nunca ter utilizado.

Outra questão pertinente quando pensamos em competências de pesquisa diz respeito aos critérios tidos em conta, aquando da seleção de fontes de informação. $A$ Tabela 4 mostra-nos como os alunos da turma classificaram, no questionário de diagnóstico, um conjunto de critérios para a seleção de fontes de informação.

Tabela 4- Fontes de informação: critérios de seleção (questionário de diagnóstico)

\begin{tabular}{|c|c|c|c|c|}
\hline $\begin{array}{c}1 \\
\text { (nada }\end{array}$ & 2 & 3 & 4 & $\begin{array}{c}5 \\
\text { (muito }\end{array}$ \\
\hline
\end{tabular}




\begin{tabular}{|l|c|c|c|c|c|}
\cline { 2 - 6 } \multicolumn{1}{c|}{} & importante) & & & & importante) \\
\hline Vocabulário simples & 1 & 3 & 8 & 6 & 2 \\
\hline Rigor da informação & 0 & 2 & 1 & 4 & 13 \\
\hline Facilidade de acesso & 4 & 2 & 4 & 8 & 2 \\
\hline Credibilidade da fonte & 2 & 0 & 1 & 1 & 16 \\
\hline Informação mais sintetizada & 2 & 3 & 2 & 7 & 5 \\
\hline
\end{tabular}

Fonte: Elaboração própria.

Pela análise da tabela, podemos, assim, concluir que a credibilidade da fonte e o rigor da informação são os critérios que ocupam os lugares de maior destaque. Estes resultados podem ser encarados como um bom indício quanto às competências de pesquisa destes alunos, atendendo a que falamos de critérios diretamente relacionados com a qualidade da informação mobilizada. Destaque, ainda, para a facilidade de acesso, a que oito alunos atribuíram o nível 4, numa escala de importância entre 1 e 5, para além do facto de a informação ser mais sintetizada, critério que sete alunos classificaram, igualmente, com nível 4. Tratando-se de questões de ordem mais prática, contribuindo para a própria facilidade do processo de pesquisa, compreende-se que estes aspetos sejam, também, destacados pelos alunos. De salientar, ainda, o reduzido número de ocorrências no caso do nível 1, o que nos pode indicar que estes alunos reconhecem a importância da diversificação de critérios.

Em jeito de ponto de situação relativamente aos resultados já analisados, uma comparação entre as fontes de informação mais utilizadas pelos alunos e os critérios de seleção destas fontes, poderia, numa primeira leitura, revelar algumas incongruências. Se, por um lado, os motores de busca são, claramente, a fonte mais utilizada pelos alunos, por outro lado os critérios de seleção mais destacados são a credibilidade das fontes e o rigor da informação. Ora, sabemos que, muitas vezes, a credibilidade e o rigor das informações e páginas sugeridas por um motor de busca, numa qualquer pesquisa, estão longe de ser garantidos. Esta situação relembra-nos da necessidade de uma postura suficientemente crítica na análise deste tipo de resultados. Não estará, propriamente, em causa a pertinência destes dados, no entanto não será demais uma certa ponderação aquando da análise dos mesmos, procurando evitar conclusões precipitadas. Neste caso concreto, não restarão grandes dúvidas de que os alunos reconhecem a importância de critérios como a credibilidade das fontes e o rigor da informação, não querendo deixar de os destacar. Porém, tal facto não significará que estes critérios estejam, necessariamente, sempre na base das seleções efetuadas, por estes mesmos alunos. 
Num diagnóstico às competências de pesquisa dos alunos, seria, igualmente, importante saber quais os momentos em que estes alunos sentem mais dificuldades, num trabalho de pesquisa. Adotando, mais uma vez, os procedimentos próprios de uma análise de conteúdo, foi possível agrupar a informação recolhida em cinco categorias, tendo por base os resultados do questionário de diagnóstico (Figura 1).

Figura 1 - Maiores dificuldades num trabalho de pesquisa (questionário de diagnóstico)

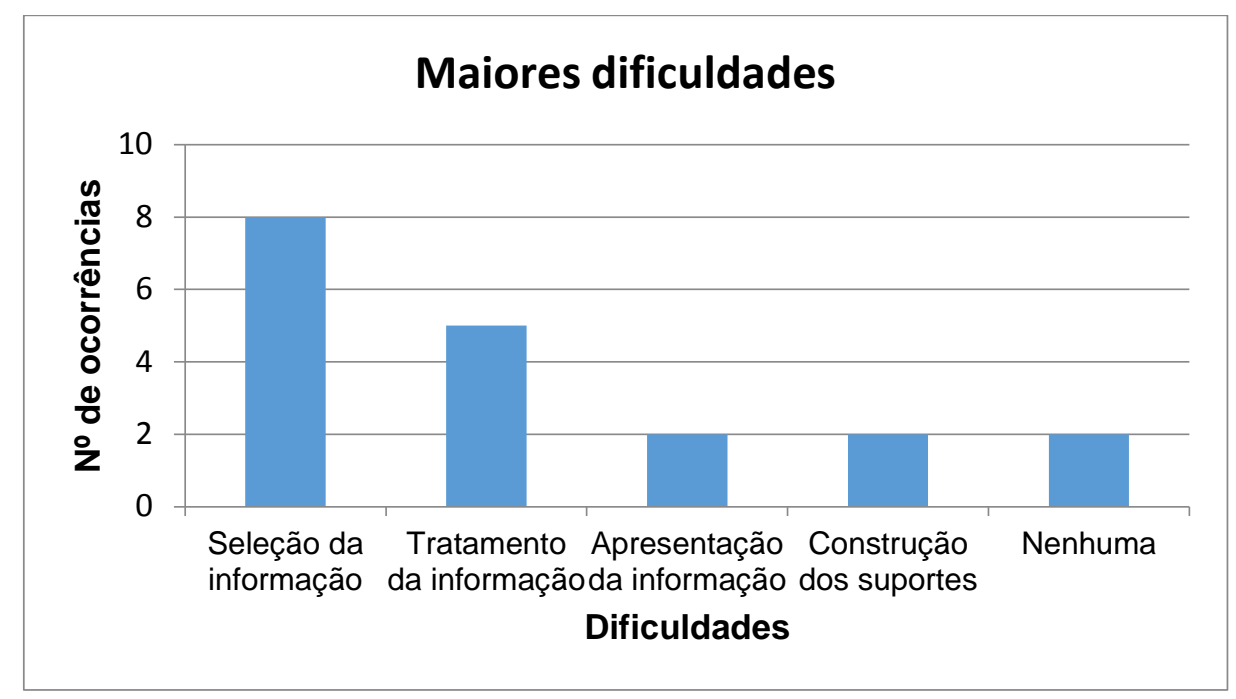

Fonte: Elaboração própria.

A seleção da informação apresenta-se, assim, como a fase em que é possível enquadrar um maior número de respostas, o que nos poderá indicar que este é um dos momentos que mais dificuldades desperta, no caso destes alunos. Entre os aspetos apontados pelos mesmos, quanto a esta fase, encontramos a credibilidade $\mathrm{e}$ rigor das fontes, bem como as dificuldades em encontrar a informação pretendida. $O$ tratamento da informação é o segundo momento mais destacado, com os alunos a realçarem as dificuldades na interpretação de determinadas informações, bem como do vocabulário utilizado, em algumas situações.

Procurando estabelecer uma relação mais direta com as atividades desenvolvidas ao longo da sequência letiva em análise, foi solicitado, aos alunos, no questionário final, que indicassem quais destas atividades, na sua opinião, mais contribuíram para as suas competências de pesquisa. As respostas dos alunos foram agrupadas em diferentes categorias, consoante o respetivo conteúdo (Tabela 5).

Tabela 5- Competências de pesquisa: contributo das atividades da sequência letiva

\begin{tabular}{|l|c|}
\cline { 2 - 2 } \multicolumn{1}{c|}{} & No Ocorrências \\
\hline Exploração do portal do INE e do software "QGIS" & 5 \\
\hline Trabalho sobre o tema "cidades saudáveis" & 2 \\
\hline Pesquisa em livros & 1 \\
\hline
\end{tabular}




\begin{tabular}{|l|c|}
\hline Atividades envolvendo a utilização de computadores & 7 \\
\hline Trabalhos em grupo & 2 \\
\hline Diários de aula & 1 \\
\hline
\end{tabular}

Fonte: Elaboração própria.

Alguns alunos acabaram por não referir atividades concretas, destacando algumas aulas, ou tipos de atividades, em geral. Foi o que aconteceu com sete alunos, que salientaram as atividades que envolveram a utilização do computador, o que aconteceu ao longo da sequência letiva. Porém, algumas respostas foram um pouco mais específicas, salientando-se a exploração do portal do INE e a utilização do software "QGIS", entre outras.

Retomando os resultados do questionário de diagnóstico, os alunos tiveram a oportunidade de referir, no final do mesmo questionário, os aspetos que, para si, poderiam ser melhorados, quanto às suas próprias competências de pesquisa (Tabela $6)$.

Tabela 6 - Competências de pesquisa: aspetos a melhorar (questionário de diagnóstico)

\begin{tabular}{|l|c|}
\cline { 2 - 2 } \multicolumn{1}{c|}{} & No Ocorrências \\
\hline Diversificação de fontes de pesquisa & 6 \\
\hline Rigor e organização na recolha e tratamento da informação & 6 \\
\hline Nenhum & 3 \\
\hline Não sabe & 3 \\
\hline
\end{tabular}

Fonte: Elaboração própria.

A diversificação de fontes pesquisa foi um dos aspetos mais referidos, reunindo seis respostas. De igual modo, seis alunos apresentaram respostas que podem ser enquadradas numa preocupação com o rigor e a organização na recolha e tratamento da informação. No fundo, este tipo de respostas cruza-se com a importância de uma sensibilização dos alunos para a importância da diversificação de fontes de pesquisa, bem como para a necessidade do rigor e organização na recolha e tratamento da informação, aspetos enquadrados nas preocupações desta investigação.

Importa, então, perceber se é possível estabelecer alguma relação entre estas informações, obtidas antes do início da sequência letiva e os resultados obtidos no final da mesma sequência, tendo por base as representações dos alunos. Estes foram, assim, convidados a refletir, no questionário final, sobre o que consideram ter melhorado, quanto às suas competências de pesquisa, após a sequência letiva (Tabela 7). 
Tabela 7- Competências de pesquisa: melhorias percecionadas pelos alunos

\begin{tabular}{|l|c|}
\cline { 2 - 2 } \multicolumn{1}{l|}{} & № Ocorrências \\
\hline Tratamento da informação & 4 \\
\hline Diversificação de fontes de pesquisa & 5 \\
\hline Recolha e seleção da informação & 6 \\
\hline Ausência de melhoria & 1 \\
\hline
\end{tabular}

Fonte: Elaboração própria.

Poder-se-á dizer que os resultados foram relativamente equilibrados. O processo de recolha e seleção da informação constituiu o aspeto com um maior número de ocorrências, sendo que os alunos referiram, nomeadamente, uma maior facilidade quanto aos procedimentos próprios deste processo, associada a um maior rigor no âmbito do mesmo processo. A diversificação de fontes de pesquisa foi outro dos aspetos destacados, essencialmente pelo contacto com diferentes fontes, ao longo das várias atividades desenvolvidas durante a sequência. As questões ligadas ao tratamento da informação mereceram, também, destaque, por parte de quatro alunos, que referiram, por exemplo, a utilização de dados estatísticos, bem como a realização de esquemas.

Procurando estabelecer relações entre estes últimos resultados (Tabela 7) e as perceções dos alunos, no questionário de diagnóstico, relativamente ao que poderiam melhorar em termos de competências de pesquisa (Tabela 6), não será difícil encontrar pontos em comum. De um modo geral, as questões ligadas à diversificação de fontes de pesquisa e à recolha, seleção e tratamento da informação estiveram na base dos aspetos apontados pelos alunos, em ambos os momentos.

No questionário final, voltou a ser solicitado, a estes alunos, que indicassem o que, na sua opinião, poderia, ainda, ser melhorado, neste âmbito (Tabela 8). 
Tabela 8- Competências de pesquisa: aspetos a melhorar (questionário final)

\begin{tabular}{|l|c|}
\cline { 2 - 2 } \multicolumn{1}{c|}{} & No Ocorrências \\
\hline Diversificação de fontes de pesquisa & 3 \\
\hline Aplicação regular dos novos hábitos de pesquisa & 3 \\
\hline Análise de textos & 2 \\
\hline Exploração de ferramentas online & 3 \\
\hline Tratamento da informação & 4 \\
\hline Nada a melhorar & 1 \\
\hline
\end{tabular}

Fonte: Elaboração própria.

De um modo geral, fica patente que os alunos têm a noção de que existem aspetos que podem, ainda, ser melhorados, quanto às suas competências de pesquisa, designadamente no tratamento da informação, na diversificação de fontes de pesquisa, na exploração de algumas ferramentas online e, ainda, na análise de textos. Podem-se destacar as respostas de três alunos, que reconheceram o desafio de continuar a aplicar, regularmente, os vários procedimentos, em termos de pesquisa, com que tiveram contacto através das atividades desenvolvidas ao longo da sequência letiva.

\section{A educação geográfica tem um papel efetivo no desenvolvimento de competências de pesquisa}

Quando se insiste na importância da promoção do desenvolvimento das competências dos alunos, em contexto educativo, ficou patente que a educação geográfica pode contribuir para a exploração de competências de pesquisa de informação, através das várias atividades implementadas. Da exploração do manual escolar, à utilização de Sistema de Informação Geográfica, passando pela recolha e tratamento de dados estatísticos, entre várias outras atividades, todas contribuíram para mostrar que a abordagem de uma determinada unidade temática, no âmbito da disciplina de Geografia A, no $11^{\circ}$ ano de escolaridade, pode (e deve) estimular a pesquisa e 0 tratamento de informação, como a generalidade dos autores sobre educação geográfica reclamam, acompanhada da reflexão sobre os resultados da investigação, pelos próprios alunos.

Esta experiência desenrolou-se junto de uma turma, cujo perfil inicial mostrou-nos algumas semelhanças com realidades já identificadas em investigações anteriores, nomeadamente indicando hábitos de pesquisa algo limitados, muito centrados na utilização de motores de busca, na Internet. A diversificação de fontes de informação e o maior rigor e organização na recolha e tratamento da informação foram, de resto, 
aspetos cuja necessidade de melhoria foi reconhecida pelos próprios alunos, desde o início de toda a experiência. Em relação às principais dificuldades, os momentos de seleção da informação foram os mais destacados pelos alunos, o que reforça, mais uma vez, a importância da aposta em competências de pesquisa.

Questões como a diversificação de fontes de informação, a credibilidade e rigor da informação selecionada, não sendo, à partida, totalmente estranhas, para estes alunos, estarão, hoje, mais presentes e, possivelmente, o seu reconhecimento, no futuro, poderá ser mais claro. Não esqueçamos, porém, que há um caminho a continuar. Não estamos a falar de processos propriamente imediatos e existem desafios que se vão mantendo. Os próprios alunos reconhecem esta situação.

Em termos de contributo das atividades implementadas, ao nível das competências de pesquisa, poder-se-á dizer que, neste caso, a diversidade assumiu um papel de especial importância, pelo que as atividades com que os alunos estavam menos familiarizados revelaram-se mais ricas, a este nível, significando novas aprendizagens e possibilitando uma melhoria das existentes. Destaque-se, a este propósito, a recolha e tratamento de dados estatísticos, a análise de livros, entre outras. De salientar, ainda, a participação no Projeto "Nós Propomos!" que, não estando diretamente relacionada com a sequência letiva em questão, contribuiu para os alunos vivenciarem, na prática, os vários momentos que fazem parte de um trabalho de investigação, necessitando de mobilizar, ao longo de todo o processo, as suas competências de pesquisa.

Apesar de existirem aspetos que poderiam, sempre, ser melhorados, quanto à presente investigação, não restam dúvidas de que a educação geográfica pode contribuir para a mobilização e desenvolvimento de competências de pesquisa de alunos do ensino secundário. Para tal, importa apostar em estratégias de ensino diversificadas que, para além da mobilização de conhecimentos, privilegiem atividades que mobilizem aquelas competências.

\section{Referências bibliográficas}

Alberto, A. (2001). O Contributo da Educação Geográfica na Educação Ambiental. A Geografia no Ensino Secundário. Lisboa: Centro de Estudos Geográficos da Universidade de Lisboa.

Almeida, L., \& Freire, T. (2003). Metodologia da investigação em psicologia da educação. Braga: Psiquilibrios. 
Baptista, J. (2014). O contributo do Projeto Curricular Integrado no desenvolvimento das competências de pesquisa (Tese de Mestrado, Universidade do Minho). Disponível em: http://hdl.handle.net/1822/38117

Bell, J. (2004). Como realizar um projecto de investigação. Lisboa: Gradiva.

Cachinho, H. (2000). Geografia Escolar: orientação teórica e praxis didáctica. Inforgeo, 15, 73-95.

Claudino, S. (2001). Portugal através dos manuais escolares de geografia: século XIX: as imagens intencionais (Tese de Doutoramento). Universidade de Lisboa, Lisboa.

Cordeiro, R. (2011). Competências em literacia da informação Estudo de caso: alunos de uma escola E.B. 2,3 (Tese de Mestrado, Universidade Portucalense). Disponível em: http://repositorio.uportu.pt/bitstream/11328/86/2/TMEB\%206. pdf

Loureiro, A., \& Rocha, D. (2012, nov/dez). Literacia Digital e Literacia da Informação competências de uma Era digital. Comunicação apresentada no II Congresso Internacional TIC e Educação. Instituto de Educação da Universidade de Lisboa. Disponível em: http://ticeduca.ie.ul.pt/atas/pdf/376.pdf

Mérenne-Schoumaker, B. (2002). Analyser les territoires: savoirs et outils. Rennes: Presses Universitaires de Rennes.

Olatunde Okunrotifa, P. (1989). Recogida de información. In N. Graves (Coord.), Nuevo método para la enseñanza de la geografía (pp. 151-179). Barcelona: Editorial Teide.

Perrenoud, P. (2001). Porquê construir competências a partir da escola? Desenvolvimento da autonomia e luta contra as desigualdades. Porto: ASA Editores.

Pinchemel, P. (1989). Fines y valores de la educación geográfica. In N. Graves (Coord.), Nuevo método para la enseñanza de la geografía (pp. 7-21). Barcelona: Editorial Teide.

Tuckman, B. (2005). Manual de investigação em educação. Lisboa: Gulbenkian.

UGI (União Geográfica Internacional) (1992). Carta Internacional da Educação Geográfica, Separata da revista Apogeu, Associação de Professores de Geografia. Lisboa.

Wood, P. (2013). How is the learning of skills articulated in the geography curriculum? In D. Lambert \& M. Jones (Eds.), Debates in Geography Education (pp. 169-179). Londres: Routledge. 


\section{Aprendizagem Geográfica baseado em problemas. $\mathrm{O}$ pensamento (geo)computacional no ensino secundário}

Roberto de Oliveira Machado ${ }^{1}$

\section{Resumo}

O presente texto tem como objetivo apresentar uma atividade desenvolvida em duas turmas de $10 . .^{\circ}$ ano, no âmbito da disciplina de Geografia $A$, mobilizando competências associadas ao pensamento (geo)computacional, na abordagem do conteúdo programático "2.3.1 - A especificidade do clima português". A premissa é a relação entre o pensamento computacional, enquanto processo de formulação e resolução de problemas, e a Aprendizagem Baseada em Problemas, metodologia de aprendizagem ativa e colaborativa que assenta no uso de problemas, para o desenvolvimento de atividades de enfoque interdisciplinar. A finalidade será avaliar a eficácia das atividades, num quadro de promoção de aprendizagens significativas e contextualizadas, que desafiam os alunos a desenvolver competências multidisciplinares e que colocam, em última análise, as competências da literacia informática e do pensamento computacional nos horizontes da Educação do Século $\mathrm{XXI}$.

Palavras-chave: Educação; Geografia A; Cidadania; Pensamento (Geo)computacional; Aprendizagem Baseada em Problemas.

\section{Abstract}

This paper aims to present an activity conducted in two $10^{\text {th }}$ grade classes of Geography A, mobilizing (geo) computational thinking skills, in the approach of the programmatic content "2.3.1 - The Portuguese climate specificity". Its premise is the relationship between the computational thinking as a process of formulation and

\footnotetext{
${ }^{1}$ Professor de Geografia no 3. Ciclo do Ensino Básico e do Ensino Secundário, doutorando em Geografia Física pelo Instituto de Geografia e Ordenamento do Território (IGOT-UL), roberto.machado@campus.ul.pt.
} 
problem solving, and Problem-Based Learning, an active and collaborative learning methodology that uses problems as the starting point for tasks with an interdisciplinary approach. The purpose is to assess the effectiveness of the tasks in a framework of promoting meaningful and contextualized learning that challenges students to develop multidisciplinary skills that ultimately place the computer literacy and computational thinking skills in the horizons of the $21^{\text {st }}$ Century Education.

Keywords: Education; Geography A; Citizenship; (Geo)computational Thinking; Problem-Based Learning.

\section{Introdução}

Enquanto objeto de estudo, a Geografia parte de questões fundamentais como "Onde se localiza?", "Porque se localiza?", "Como se distribui?”, "Quais as caraterísticas?", "Que impactes?", "Que gestão?" para a compreensão dos fenómenos físicos e humanos à superfície do nosso planeta. Adicionalmente, os objetivos gerais e competências da disciplina de Geografia A salientam as mais valias, em termos de aprendizagem, do uso das Tecnologias de Informação Geográfica (TIG) "como fator de desenvolvimento na compreensão e utilização individual e social do espaço geográfico" (Alves et al., 2001:10).

A relação entre as tecnologias de informação e a educação, nomeadamente a aplicação da primeira no contexto escolar, apresenta, hoje, uma inegável atualidade. É também indiscutível como a escola se tem integrado na evolução tecnológica que tem exercido um influxo na sociedade e na cultura do tempo presente, com os benefícios, dificuldades, problemas e, até, malefícios decorrentes. Neste sentido, não podemos entender as Tecnologias de Informação e Comunicação (TIC) como inerentemente educativas, pois dependem antes do modo como são utilizadas, nos termos em que "deve ser dado lugar ao papel central de quem aprende e de quem ensina".

Num dia-a-dia que é um misto de interações e acontecimentos offline e online, é importante equacionar de que forma se pode ensinar literacia digital. Nas últimas décadas, houve uma necessidade de introduzir o pensamento computacional nos currículos europeus do Ensino Básico e Secundário (Cf. Horizon Report 2017). Em Portugal, iniciativas como o programa Probótica, têm procurado contribuir para o desenvolvimento de capacidades e competências-chave transversais ao currículo, nomeadamente as que se encontram referidas nos referenciais de competências do 
séc. XXI (Vide P21, ATC21S, UE, UNESCO, OCDE TEM DE CONCRETIZAR BIBLIOGRAFIA ${ }^{2}$ ).

É neste enquadramento que se propõe aplicar um estudo de caso a propósito da especificidade do clima português, conteúdo programático do 10. ano de Geografia $A$, utilizando a aprendizagem baseada em problemas (ABP) como metodologia facilitadora para desenvolver competências associadas ao pensamento (geo)computacional. Em primeiro lugar, apresentar-se-á a atividade desenvolvida, depois, descrever-se-á a sua aplicação e, por último, avaliar-se-á a sua eficácia como potencial pedagógico para a abordagem de temas e conceitos multidisciplinares de forma prática, tangível e motivadora, utilizando as evidências recolhidas ao longo das sessões.

Em suma, procurar-se-á estabelecer o papel da aprendizagem baseada em problemas e do pensamento (geo)computacional na valorização das várias vertentes do conhecimento (saber-saber, saber fazer, saber ser/estar) e antever as suas potencialidades no desenvolvimento pessoal (saber questionar o adquirido, saber pensar, saber gerir emoções e negociar conflitos), de cidadania (ativa e participativa princípio da civilidade e ética da responsabilidade para com os outros e a sociedade) e profissional (conhecimento, habilidades/aptidões e atitudes, indispensáveis à aquisição de qualificações) - as três dimensões contempladas pelas finalidades do sistema educativo (Conselho Nacional de Educação, 2015).

\section{A Aprendizagem Baseada em Problemas na aula de Geografia}

A aprendizagem baseada em problemas é uma abordagem ativa de ensinoaprendizagem, centrada no aluno, através da qual este adquire novos conhecimentos e desenvolve competências através da resolução de problemas de enfoque interdisciplinar. Nesta metodologia, os problemas desempenham uma dupla função: organizam o currículo em termos de conteúdos e fornecem o contexto para a aprendizagem. Outro aspeto relevante desta metodologia prende-se com o resultado final, que pode ser apenas uma ou várias propostas de solução para o problema inicialmente formulado, já de si de natureza aberta ou semiaberta.

\footnotetext{
${ }^{2}$ A esse respeito, leia-se: "As aptidões e conhecimentos considerados fundamentais para o século XXI nos países-membros da OCDE (...) incluem (...) criatividade / inovação, pensamento crítico, resolução de problemas, tomada de decisão, comunicação, colaboração, literacia no uso e acesso à informação, investigação e pesquisa, literacia mediática, cidadania digital, operações e conceitos em TIC, flexibilidade e adaptabilidade, iniciativa e auto-orientação, produtividade, e liderança e responsabilidade. (...) Será ainda de relevar a importância dada à pesquisa e resolução de problemas e ao conhecimento científico (...) que serão fundamentais num mundo em constante mudança” (Diário da República 104/2017).
} 
As raízes da aprendizagem baseada em problemas remontam ao método socrático da Grécia Antiga e a sua base filosófica tem origem no trabalho de John Dewey e dos seus discípulos, nomeadamente Kilpatrick. Assenta sobre uma perspetiva cognitivoconstrutivista, que defende que o conhecimento não é estático, e colhe um importante contributo nos estudos de Vygotsky, que enfatiza o especto social da aprendizagem, e de Bruner, um dos teóricos da aprendizagem pela descoberta. De igual modo, servese da aplicação da aprendizagem pela descoberta às Ciências Sociais - veja-se, a propósito, a abordagem a que Suchman chamou "treino de formulação de questões" (Arends, 2008).

A aprendizagem baseada em problemas tem três objetivos instrucionais: desenvolver nos alunos competências de investigação e de resolução de problemas, proporcionarIhes a experimentação de papéis de adulto e permitir que ganhem confiança na sua capacidade para pensar e que se tornem aprendentes autónomos. Assim, o ambiente em aula deve ser caracterizado pela abertura, pelo envolvimento ativo dos alunos e por uma atmosfera de liberdade intelectual. Ao professor cabe-lhe a função de colocar problemas reais, facilitar a investigação e apoiar a aprendizagem. Consequentemente, as tarefas de classificação e de avaliação requerem procedimentos alternativos, que meçam o potencial para a resolução de problemas dos alunos bem como o trabalho em grupo.

$\mathrm{Na}$ aula de Geografia, uma das formas de aplicar esta metodologia é através do método The Maastricht Seven Jump, assim designado devido às sete etapas que o compõem: 1) Apresentação e leitura compreensiva do cenário; 2) definição do(s) problema(s); 3) Brainstorming, sugerindo soluções para o problema com base em conhecimentos prévios; 4) organização das ideias de acordo com soluções possíveis; 5) formulação dos objetivos e produtos da aprendizagem; 6) investigação autónoma para recolha de informação relacionada com os objetivos de aprendizagem; 7) apresentação dos resultados das pesquisas individuais e discussão da nova informação adquirida (Sola, 2006).

Para monitorizar de modo eficaz a aplicação das sete etapas, Duch (2001) afirma que há que ter em conta os seguintes pressupostos: 1) os cenários abordam questões da vida real ou que lhe são próximas; 2) a pesquisa e as respostas devem ser apoiadas em factos e informação científica; 3) os cenários são concebidos, em termos de conteúdos e complexidade, tendo consciência do potencial dos grupos de trabalho e o valor da discussão no seio dos grupos; 4) os problemas são suficientemente abertos para que a discussão não seja eliminada numa fase precoce do processo; e 5) os 
problemas apresentados suscitam a mobilização de conhecimento base de outras unidades curriculares, encorajando a multidisciplinaridade.

\section{O pensamento (geo)computacional}

A centralidade do pensamento computacional na educação é defendida por autores como Wing (2006), que alega que o pensamento computacional não se restringe à noção de tecnologia ou equipamentos, designando antes os processos de resolução de problemas de forma computacional. O pensamento computacional não se resume, portanto, à programação, e a utilização das tecnologias na escola "não pode passar apenas por ensinar a usar este ou aquele software" (Gonçalves, 2012). Neste incluemse diversas dimensões como a recolha e análise de dados, a decomposição do problema em partes, o reconhecimento de padrões, a abstração ou a generalização, o desenho de algoritmos e a avaliação ou julgamento objetivo e sistemático.

Neste quadro, o domínio da programação pretende desenvolver a capacidade de codificação de algoritmos em ambientes e linguagens específicos, concebidos para solucionar um dado problema ou solução. Por sua vez, a robótica permite tornar tangíveis os conceitos ligados à programação e ao pensamento computacional fora do espaço de um ecrã. O seu lugar fundamental na educação consubstancia-se através de iniciativas como a "Programação e Robótica no Ensino Básico" (Probótica), que decorre da evolução do projeto-piloto "Iniciação à Programação no $1 .{ }^{\circ}$ Ciclo do Ensino Básico" e tem por objetivo promover o ensino da programação em Portugal e aumentar os níveis de literacia digital dos alunos das escolas nacionais (Equipa de Recursos e Tecnologias Educativas/ERTE).

A geocomputação corresponde à aplicação do pensamento computacional à Geografia, ou "o processo de aplicação da tecnologia informática aos problemas geográficos" (Rees e Turton, 1998) ou "o universo das técnicas computacionais aplicáveis aos problemas espaciais" (Couclelis, 1998). Esta permite ao investigador testar a teoria através da simulação, criar novas teorias pela experimentação, "visualizar o que era invisível, explorar o inexplorável e modelar o anteriormente imodelável" (Openshaw, 2000) - agregando novas técnicas computacionais com os SIG, a computação de alto desempenho, a inteligência artificial e a ciência. A geocomputação seria, enfim, toda e qualquer análise quantitativa feita com informação georreferenciada, e mediante o uso da computação.

Para Torrens (2004), a geocomputação é composta por três componentes interrelacionadas que a definem: trata a informação de base geográfica, sem 
constrangimentos de fonte ou formato, utiliza tecnologias computacionais capazes de formular matematicamente um problema geográfico e de criar possíveis soluções e tem elevada performance de processamento computacional. Ao ser referida como o uso de diferentes tipos de dados espaciais e como o desenvolvimento de ferramentas para a ciência espacial, a geocomputação potencializa a solução de diversos tipos de problemas, enriquecendo as abordagens e permitindo a associação a teorias e a verificação de hipóteses.

Em Portugal, a introdução do pensamento computacional nas ciências geográficas ocorreu essencialmente na educação universitária em torno de abordagens geocomputacionais: autómatos celulares, multi-agentes, estatística espacial (geoestatística), redes neuronais artificiais, fractais, algoritmos genéticos, sistemas caóticos e catastróficos, a teoria das redes e dos grafos, entre outras. Assim, qualquer esforço que relacione as ciências informática e a geográfica deverá ser encorajado na Educação Básica e Secundária. De seguida, veja-se como é possível aliar, em Educação, o pensamento computacional e os conteúdos e competências geográficas essenciais, mediante a adoção de metodologias ativas como a aprendizagem baseada em problemas.

\section{Um estudo de caso: a especificidade do clima em Portugal continental}

Uma das etapas mais importantes na planificação do professor passa por decidir quais os objetivos específicos de uma aula de aprendizagem baseada em problemas, além de preparar a logística necessária, comunicar claramente os objetivos e criar situações problemáticas interessantes e apropriadas. Uma situação problemática apropriada deve ser real, ter significado para os alunos e ser adequada ao seu nível de desenvolvimento intelectual. De igual modo, deve beneficiar do esforço do grupo e ser simultaneamente abrangente para que os objetivos possam ser alcançados, e restrita, de forma a ter em conta as limitações de tempo, espaço e recursos. 
A experiência de aprendizagem que irá ser descrita neste capítulo incide sobre um tema programático do $10 .{ }^{\circ}$ ano de escolaridade - os recursos naturais de que a população dispõe: usos, limites e potencialidades, nomeadamente sobre a especificidade do clima português -, tendo por base a planificação que aqui se apresenta. A planificação e desenvolvimento das atividades respeitam as sete etapas da aprendizagem baseada em problemas (definir; explorar; identificar; investigar; avaliar; solucionar e apresentar), e traduzem, de modo semelhante, a valorização das competências de pensamento de ordem superior da Taxonomia de Bloom e a estrutura dados-informação-conhecimento-sabedoria, da Hierarquia DIKW.

Quadro 1: Planificação da atividade

\begin{tabular}{|c|c|l|c|c|}
\hline Objetivo & \multicolumn{1}{|c|}{ Estratégia } & \multicolumn{1}{|c|}{ Atividades } & Recursos & Avaliação \\
\hline Relacionar a & Estudo de caso realizado & 1. Identificação do problema; & Guião de & Formativa: \\
latitude com & de forma prática (com & 2. Produção de ambientes & trabalho; & participação \\
a & recurso a programação & práticos; & PC's & na elaboração \\
temperatura & Python), expositiva e & 3. Análise do ambiente gráfico; & Software & das atividades \\
e a & dialogada. & 4. Apresentação dos & WingPython & e discussão \\
precipitação & & resultados; & IDE & dos \\
média anual. & & 5. Discussão dos resultados. & & resultados. \\
\hline
\end{tabular}
Fonte: Elaboração própria

O método privilegiado foi o estudo de caso, visto compreender fenómenos reais, bem demarcados e contextualizados no espaço e no tempo e que pressupõem a recolha de informação circunstanciada. Em termos didáticos, é imperativo estabelecer objetivos e mobilizar saberes prévios, bem como definir o(s) problema(s), os objetivos de aprendizagem, as tarefas a realizar, os recursos e as fontes documentais, os constrangimentos que os alunos poderão encontrar na resolução da atividade, o tempo estimado para a duração da atividade e a logística necessária (Ayape et al, 2006; Azer et al, 2012) - Quadro 1 e Quadro 2.

Quadro 1: Operacionalização da atividade

\begin{tabular}{|c|c|c|}
\hline & Pensamento geocomputacional & Temperatura/Precipitação \\
\hline Objetivo geral & $\begin{array}{l}\text { Executar gráficos sobre a temperatura e } \\
\text { precipitação, utilizando linguagem de } \\
\text { programação Python. }\end{array}$ & $\begin{array}{l}\text { Relacionar a latitude com os valores } \\
\text { médios mensais da temperatura e da } \\
\text { precipitação em Portugal continental. }\end{array}$ \\
\hline $\begin{array}{l}\text { Conhecimentos prévios e } \\
\text { temas relacionados }\end{array}$ & $\begin{array}{l}\text { Conhecimentos básicos de utilização do } \\
\text { software WingIDE. }\end{array}$ & Movimento de translação. \\
\hline Definição do problema & $\begin{array}{l}\text { Como podemos utilizar o pensamento } \\
\text { (geo)computacional nas aprendizagens } \\
\text { geográficas? }\end{array}$ & $\begin{array}{l}\text { Como é que a latitude influencia a variação } \\
\text { da temperatura e da precipitação anual? }\end{array}$ \\
\hline Fontes documentais & Guião de trabalho. & Guião de trabalho. \\
\hline Constrangimentos & $\begin{array}{l}\text { Pouca familiaridade com a utilização de } \\
\text { linguagens de programação. }\end{array}$ & $\begin{array}{c}\text { Integração de outros fatores, como a } \\
\text { orografia e a proximidade e afastamento } \\
\text { do oceano. }\end{array}$ \\
\hline Tempo & 120 minutos. & 120 minutos. \\
\hline
\end{tabular}

Fonte: Elaboração própria 


\section{Guião de trabalho}

A atividade realizou-se em quatro sessões, de sessenta minutos cada. As quatro sessões foram distribuídas em três grandes fases de trabalho: 1) apresentação do problema e ambientação ao programa WingPythonIDE ${ }^{3}$ (primeira sessão); 2) elaboração dos gráficos sobre a temperatura e sobre a precipitação de quatro estações meteorológicas, usando um código-fonte em Python para os representar graficamente (segunda sessão); 3) apresentação e discussão das tarefas propostas (terceira e quarta sessão). O processo de avaliação e feedback foi realizado ao longo das quatro sessões, de modo formativo. Os alunos trabalharam em equipa na resolução das questões propostas e na apresentação e discussão dos resultados (Quadro 3).

Quadro 3. Guião de trabalho

\begin{tabular}{|l|l|}
\hline Problema & $\begin{array}{l}\text { Portugal apresenta uma dimensão reduzida à escala mundial, mas a variabilidade } \\
\text { verificada na distribuição dos elementos do clima, como a precipitação e a temperatura, } \\
\text { traduz-se numa diversidade climática: a) clima temperado Mediterrâneo de influência } \\
\text { marítima; b) clima temperado Mediterrâneo de influência continental e c) clima temperado } \\
\text { Mediterrâneo típico. }\end{array}$ \\
\hline $\begin{array}{l}\text { A elaboração } \\
\text { de um } \\
\text { ambiente } \\
\text { gráfico }\end{array}$ & $\begin{array}{l}\text { Para representar as características climáticas (valores médios mensais da temperatura e } \\
\text { precipitação) de três estações meteorológicas de Portugal continental e mostrar os } \\
\text { resultados através de um gráfico insere o código apresentado nos quadros 4, 5, } 6 \text { e } 7 \text { no } \\
\text { software Wing Python IDE. }\end{array}$ \\
\hline Questões & $\begin{array}{l}\text { 1. Identifica a estação meteorológica que regista valores de precipitação mais elevados. } \\
\text { 2. Indica a diferença de precipitação entre as estações meteorológicas de Braga e Faro, no } \\
\text { mês de janeiro. }\end{array}$ \\
$\begin{array}{l}\text { 3. Explica o facto de os valores de precipitação diminuírem no sentido oeste-este e norte- } \\
\text { sul. } \\
\text { 4. Identifica a estação meteorológica que regista valores de temperatura médios mensais } \\
\text { mais reduzidos. } \\
\text { 5. Indica a diferença de temperatura entre as estações meteorológicas de Braga e } \\
\text { Bragança, nos meses de janeiro e agosto. } \\
\text { 6. Explica o facto de os valores de temperatura médios mensais diminuírem no sentido } \\
\text { oeste-este e norte sul, considerando o período de novembro a fevereiro. }\end{array}$ \\
\hline $\begin{array}{l}\text { Apresentação/discussão dos gráficos e das respostas elaboradas pelos alunos. } \\
\text { resulise dos }\end{array}$
\end{tabular}

Fonte: Elaboração própria

\footnotetext{
${ }^{3}$ Disponível em: https://wingware.com/
} 
Numa fase inicial, foram distribuídos aos alunos notícias sobre a ocorrência de situações de seca e de ondas de calor no território continental português. A leitura permitiu lançar a discussão sobre as diferenças climáticas que se verificam no nosso país devido a influência de fatores como a latitude e a continentalidade, que, conforme a área, agravam ou amenizam a ocorrência de situações de seca e a ocorrência de ondas de calor. A aplicação de um inquérito prévio à elaboração dos gráficos revelou que os alunos não dispunham de conhecimentos no domínio da programação ou na área de multimédia, o que exigiu uma ambientação prévia ao software WingPythonIDE.

Após esta fase introdutória, desenvolveu-se a atividade inicial de inserção de um código-fonte pré-estabelecido para um Ambiente de Desenvolvimento Integrado, que é um programa de computador que reúne características e ferramentas de apoio ao desenvolvimento de um programa/ambientes gráficos com o objetivo de agilizar processos. De seguida, os alunos trabalharam a pares na inserção do código-fonte no WingPythonIDE (Quadro 4, 5, 6 e 7). A análise dos gráficos foi realizada em grupos de quatro elementos, favorecendo a discussão entre dois grupos de pares. Depois, os alunos procederam à resposta do questionário e confrontaram as respostas intra e extragrupalmente antes apresentação dos resultados à turma.

Quadro 4: Código utilizado para a elaboração do gráfico sobre temperaturas médias mensais de quatro estações meteorológicas em Portugal continental

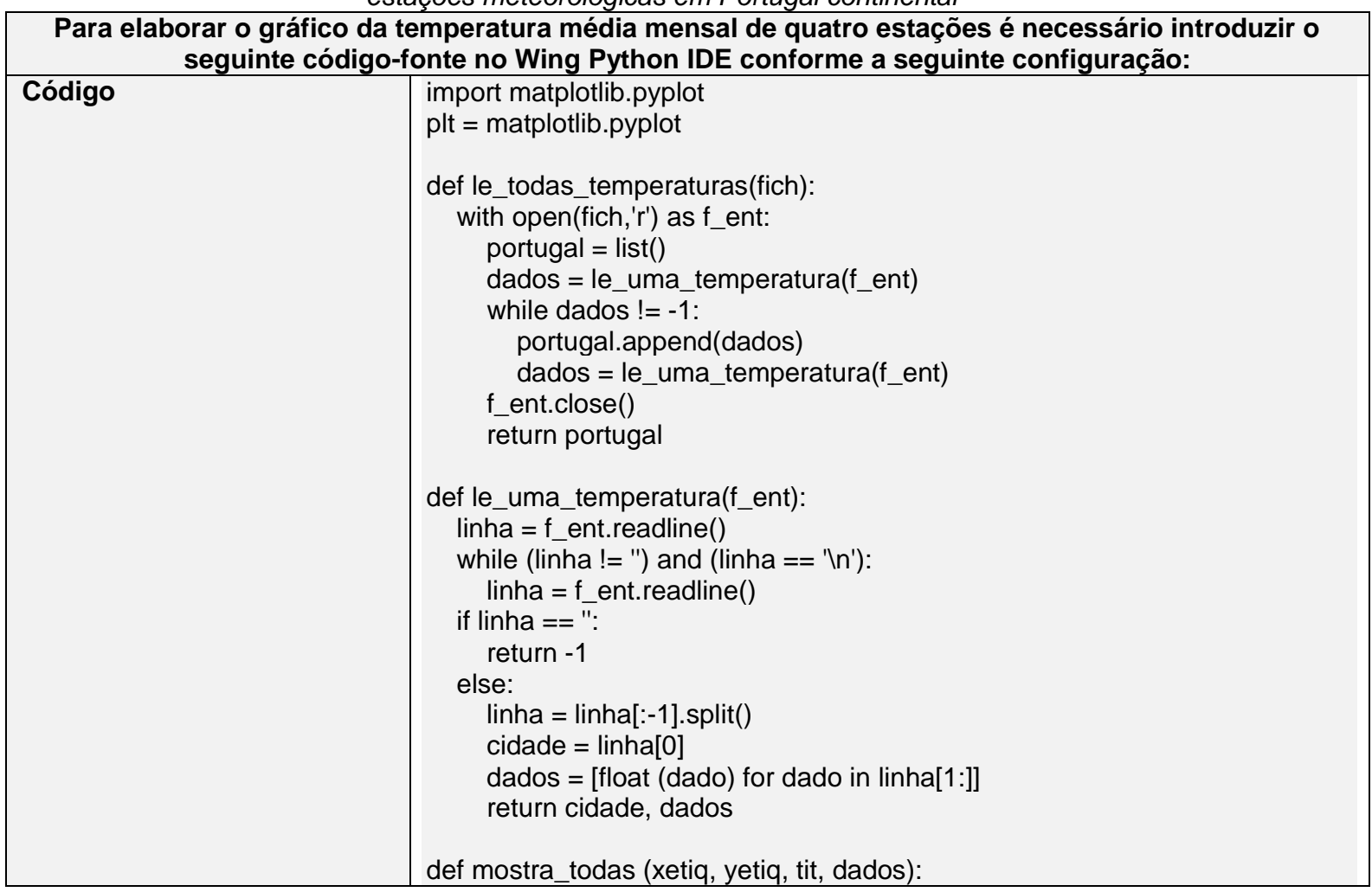




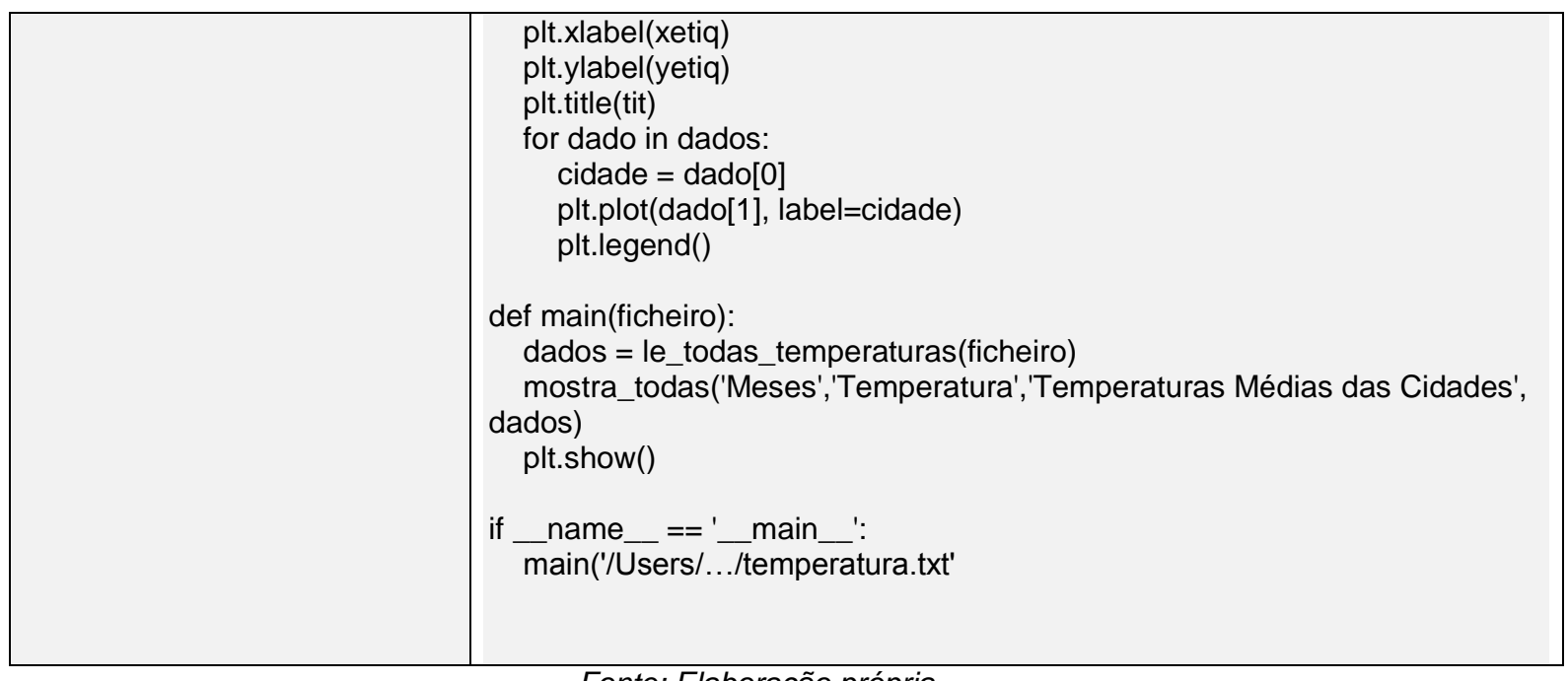

Fonte: Elaboração própria

\begin{tabular}{|l|l|}
\multicolumn{2}{l}{ Quadro 5: Elaboração do ficheiro temperatura.txt } \\
\hline Criação do ficheiro: & Para concluir a elaboração do gráfico é necessário consultar o sítio \\
& eletrónico www.ipma.pt e recolher informação sobre os valores médios \\
& temperatura médias para as seguintes estações meteorológicas: Braga; \\
& Bragança; Coimbra; Portalegre e Faro. Assim, utilizando um editor de \\
& texto insere na primeira linha o nome da estação meteorológica e os 12 \\
& valores médios mensais. Exemplo: \\
& Braga $99.912 .7 \ldots$ \\
& Bragança .... \\
& Coimbra ... \\
& Portalegre ... \\
& Faro .... \\
& Após este processo cria um ficheiro com o nome "temperatura.txt" e \\
depois observa o resultado.
\end{tabular}

Fonte: Elaboração própria

Gráfico 1: Exemplo de um gráfico sobre a temperatura média mensal elaborado através da introdução do código-fonte anterior no software WingPythonIDE

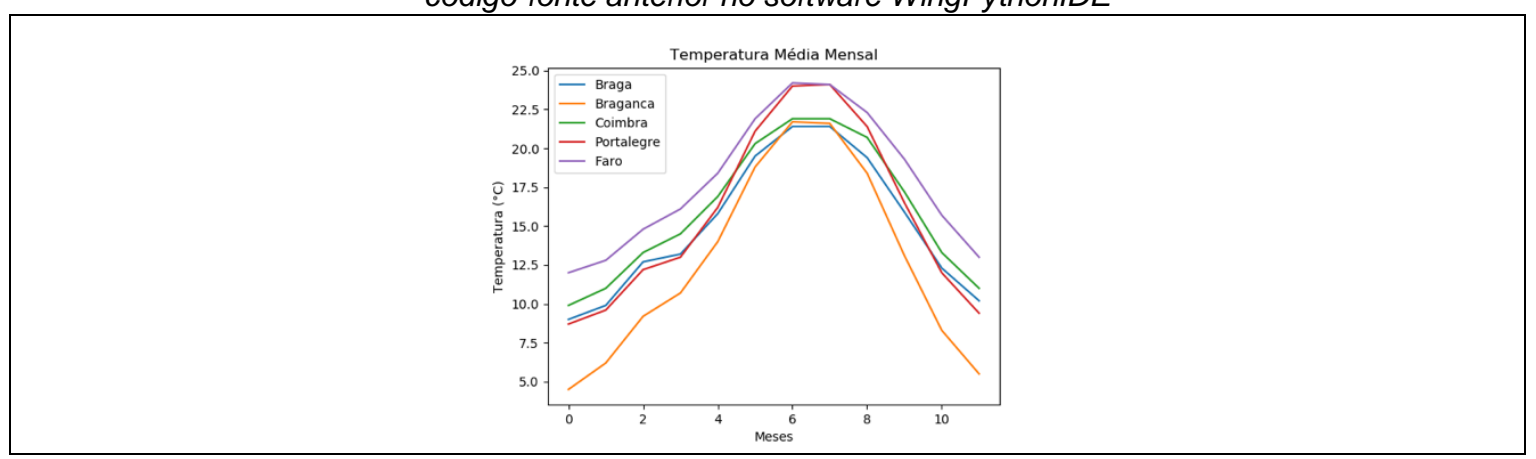

Fonte: Elaboração própria

Quadro 6. Código utilizado para a elaboração do gráfico sobre precipitação média mensal de quatro estações meteorológicas em Portugal continental

\begin{tabular}{|l|l|}
\hline \multicolumn{2}{|l|}{ Para elaborar o gráfico da precipitação média mensal de quatro estações é necessário introduzir o seguinte código-fonte } \\
no WingIDE conforme a seguinte configuração
\end{tabular}




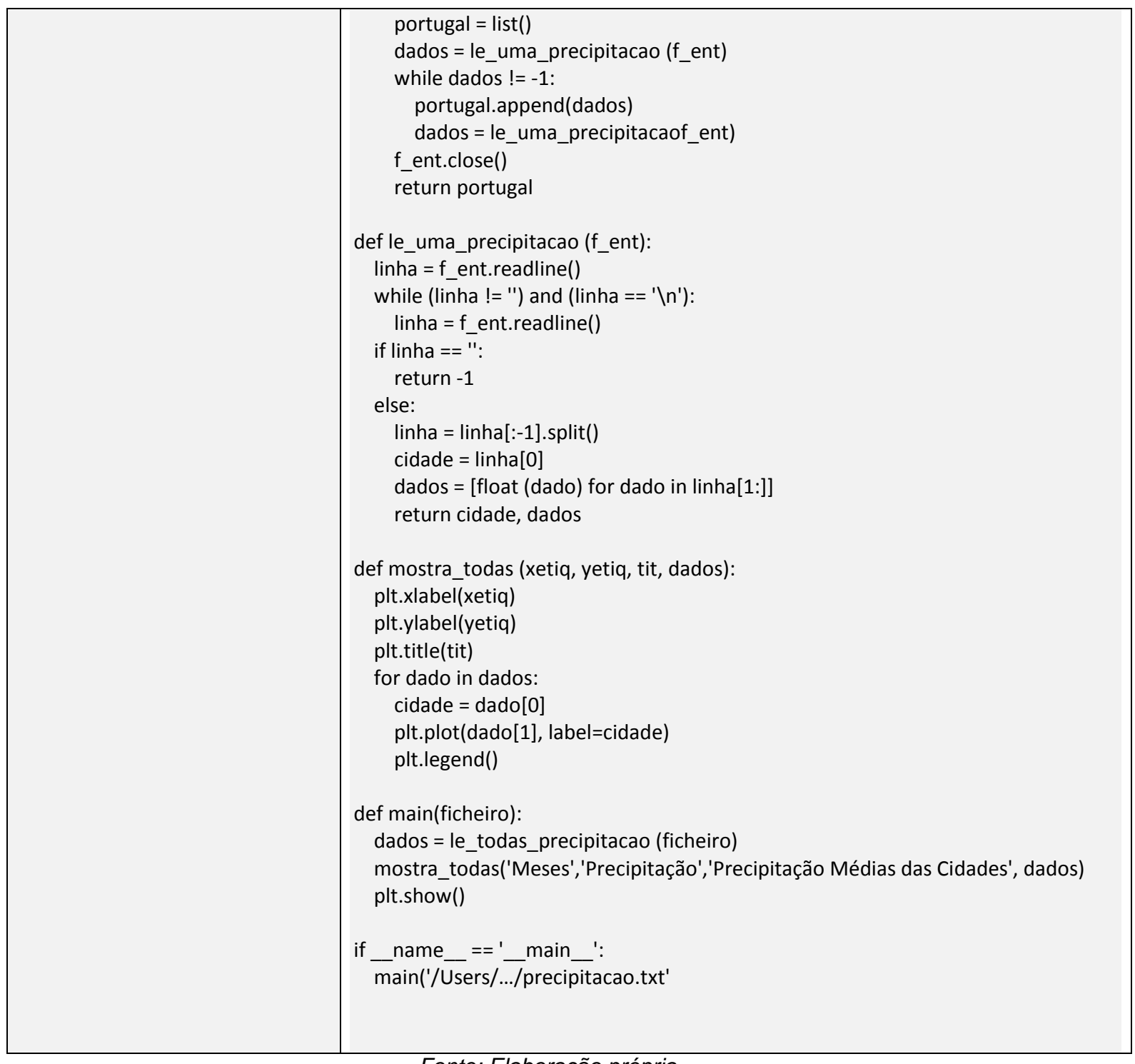

Fonte: Elaboração própria

Quadro 7. Elaboração do ficheiro "temperatura.txt

\section{Criação do ficheiro:}

"temperatura.txt"
Para concluir a elaboração do gráfico é necessário consultar o sítio eletrónico www.ipma.pt e recolher informação sobre os valores da média da quantidade mensal da precipitação para as seguintes estações meteorológicas: Braga; Bragança; Coimbra; Portalegre e Faro. Assim, utilizando um editor de texto insere na primeira linha o nome da estação meteorológica e os 12 valores médios mensais. Exemplo:

Braga $176.4114 .8121 .6 \ldots$

Bragança ...

Coimbra ...

Portalegre ...

Faro ...

Após este processo cria um ficheiro com o nome "precipitacao.txt" e depois observa o resultado. Fonte: Elaboração própria

Gráfico 2: Exemplo de um gráfico sobre a precipitação média mensal elaborado através da introdução do código-fonte anterior no software WingPythonIDE 


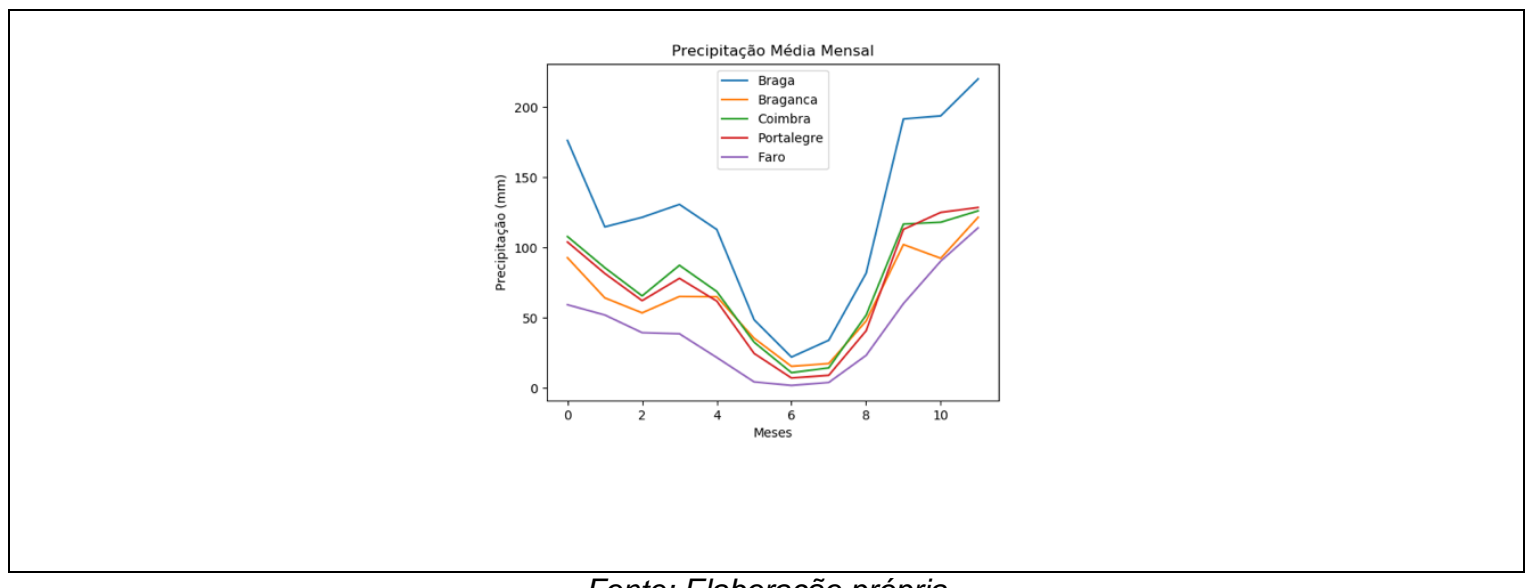

Fonte: Elaboração própria

\section{Avaliação}

Foram utilizados quatro instrumentos na avaliação da atividade desenvolvida: um questionário de diagnóstico dos hábitos e competências no âmbito da programação e multimédia, os "exit slips" (i.e. Estratégia 3, 2, 1 - Quadro 4) no final de cada aula, a observação direta das discussões e da apresentação de resultados e, por último, a reflexão acerca da qualidade da sua participação e da participação dos colegas, através do preenchimento de um questionário de avaliação (Quadro 5). Todos os instrumentos e critérios de avaliação foram disponibilizados e discutidos em aula e os alunos receberam feedback constante. Os recursos e evidências utilizadas integraram o portfólio de aprendizagem individual - o geofólio.

\section{Quadro 8: Estratégia 3-2-1}

Indica três (3) coisas que aprendeste na aula de hoje:

Lista duas (2) tarefas que gostaste de realizar:

Faz uma (1) pergunta sobre o tópico em estudo:

Fonte: Elaboração própria

Sobre os quatro elementos de avaliação salientam-se os exit slips e o questionário de avaliação, adaptado de Wiggins, 1993. Quanto aos primeiros, serviram para orientar e reformular as práticas em sala de aula, apoiando o papel do professor enquanto de guia da aprendizagem. Por sua vez, a aplicação do questionário visou um melhor entendimento sobre o desempenho individual e em grupo dos alunos, como elemento complementar à observação direta. Os resultados da aplicação do questionário de avaliação foram muito positivos, com todos os parâmetros acima de 3 (escala de 1 a 5). A própria atividade surge, assim, avaliada e conclui-se a sua eficácia no 
desenvolvimento de competências no domínio cognitivo, intrapessoal e interpessoal e na aquisição de conteúdos.

Quadro 9: Questionário de auto, hetero e coavaliação

\begin{tabular}{|l|l|l|l|l|l|l|}
\hline \multicolumn{7}{|c|}{ Questionário de avaliação } \\
\hline Tratamento de questões pela turma & \multicolumn{1}{|l|}{} \\
\hline Superficial & 1 & 2 & 3 & 4 & 5 & Completo \\
\hline Utilidade da discussão para a tua compreensão sobre o problema \\
\hline Baixa & 1 & 2 & 3 & 4 & 5 & Alta \\
\hline O teu nível de envolvimento na realização da aprendizagem \\
\hline Baixo & 1 & 2 & 3 & 4 & 5 & Alto \\
\hline Nível geral de envolvimento da turma & & & \\
\hline Baixo & 1 & 2 & 3 & 4 & 5 & Alto \\
\hline Qualidade da tua participação & & & \\
\hline Pobre & 1 & 2 & 3 & 4 & 5 & Excelente \\
\hline Comentários: &
\end{tabular}

Fonte: Elaboração própria

A avaliação deve ser autêntica, participada e reflexiva. De um modo geral, as estratégias de avaliação em ambientes computacionais englobam a autoavaliação, a avaliação do trabalho em grupo e a avaliação por pares e privilegia-se a avaliação formativa e a observação. Como instrumentos e técnicas salienta-se o uso de questionários, grelhas de avaliação, entrevistas, reflexões dos alunos, relatórios, quizzes, etc. Os procedimentos alternativos que melhor permitem avaliar o trabalho do aluno, como a execução de tarefas e as exposições, têm o nome de avaliação de desempenho, avaliação autêntica, portfólios e classificação por esforço cooperativo (Arends, 2008). As rubricas são estratégias de avaliação eficazes, mobilizando atividades, objetivos, indicadores e critérios.

\section{Conclusão}

A aprendizagem baseada em problemas e o pensamento (geo)computacional têm como benefícios responsabilizar os alunos pelo processo de ensino-aprendizagem, promover competências relacionadas ao trabalho em grupo, o pensamento crítico, a resolução de problemas e a apresentação e discussão das respostas formuladas de forma a proporcionar uma aprendizagem significativa. A aprendizagem baseada em problemas é um método que promove a mudança do centro de gravidade do professor para o aluno, através de um processo que envolve questões, dúvidas, dificuldades e incerteza que os alunos vão resolvendo ao longo da experiência de aprendizagem.

Com o desenvolvimento de uma atividade que uniu esta metodologia ao pensamento (geo)computacional, constatou-se que os alunos, quando motivados, podem envolver- 
se ativamente na busca de novos conhecimentos e, em particular, quando estes conhecimentos se relacionam com a sua realidade e/ou são considerados, por si, relevantes ou interessantes. De um modo geral, os alunos valorizam a cultura digital, e envolveram-se, com entusiasmo, na tarefa de inserção de instruções de código-fonte para que o WingPythonIDE elaborasse gráficos sobre a temperatura e a precipitação. De igual modo, demostraram predisposição para o trabalho em grupo, embora nem sempre tenham revelado competências relacionadas com o trabalho em equipa.

Com efeito, são vários os obstáculos de implementação da aprendizagem baseada em problemas e do pensamento computacional em sala de aula. Sobre a primeira, destacam-se as estruturas organizacionais das escolas, cujos recursos são insuficientes para as investigações e cujo período típico de duração das aulas não permite que os alunos se envolvam profundamente em atividades no exterior. Acerca do segundo, muitos alunos mantêm uma perspetiva centrada nos conteúdos e nos processos de cada disciplina, decorrentes de uma perceção do conteúdo disciplinar como um conjunto de saberes mais ou menos estáticos. A avaliação, que privilegia sobretudo os testes de lápis e papel e os exames estandardizados, são outros constrangimentos para a implementação destas dinâmicas.

Neste sentido, recomenda-se a construção de bons estudos de caso e de cenários de apresentação de problema. Um estudo de caso que conta uma história, que se baseia em factos reais e cria empatia, que provoca conflitos e força decisões terá maior relevância e utilidade pedagógica. O cenário de apresentação do problema é igualmente importante; este deve ser sugestivo, ter coerência lógica e espicaçar a curiosidade. O conhecimento do professor sobre os assuntos em estudo, a planificação e gestão da operacionalização e a interação entre os alunos e entre professor e alunos são decisivos na implementação destas práticas. Por outro lado, a transparência quanto aos métodos e instrumentos de avaliação ajuda a estabelecer expetativas elevadas para o trabalho em aula.

Pela sua relevância e abrangência, o pensamento computacional pode e deve ser aplicado em qualquer disciplina e deve ser encorajada, inclusive, uma cultura interdisciplinar nas escolas, uma vez que o saber técnico e tecnologias, a informação e resolução de problemas, o pensamento crítico e pensamento criativo e as linguagens e textos são áreas de desenvolvimento transversais ao currículo. Concomitantemente, valores como a responsabilidade e integridade, a excelência e exigência, a curiosidade, reflexão e inovação, a cidadania e participação e a liberdade devem pautar o ethos da escola. Importa criar condições de equilíbrio entre conhecimento, 
compreensão, criatividade e sentido crítico para formar pessoas autónomas e responsáveis e cidadãos ativos.

\section{Referências bibliográficas}

Alves, M.; Brazão, M., Martins, O. (2001). Programa de Geografia A 10. e 11.ำ anos Cursos Científicos-Humanísticos de Ciências Socioeconómicas e de Línguas e Humanidades. Lisboa: Ministério da Educação (disponível em: http://www.dge.mec.pt/sites/default/files/Secundario/Documentos/Documentos_Discipli nas_novo/Curso_Linguas_e_Humanidades/geografia_a_10_11.pdf)

Arends, R. I. (2008). Aprender a Ensinar. Lisboa: McGraw-Hill.

Azer, S., A. et al. (2012). Twelve tips for constructing problem-based learning cases. Medical Teacher, vol.34, 261-367. doi.org/10.3109/0142159X.2011.613500.

Ayape, C. (2006). Aprendizage basado em problemas. De la teoria a la prática. Perfiles educativos, vol.28, n.ำ11. México.

CNE (2015) Estado da Educação 2015. Conselho Nacional da Educação (consultado em maio de 2018 em: http://www.cnedu.pt/content/noticias/CNE/Estado_da_Educacao_2015_versao_digital. pdf)

Couclelis H., (1998) Geocomputation in context. (URL: www.geog.ucsb.edu/ kclarke/Geography232/Couclelis98.pdf, consultado em 02.11.2017).

Duch, B., J.; Groh, S., E.; Allen, D., E. (2001) The power of problem-based learning: a practical "how to" for teaching undergraduate courses in any discipline. Stylus.

Duch, B. (2001) "Writing problems for deeper understanding", in The Power of Problem-Based Learning, Sterling, Stylus Publishing, edited by B. Duch, E. Groh and D. Allen, p.47-58.

Gonçalves, S. (2012). Educação: a urgência da literacia digital. Público. (Consultado em maio de 2018 em: http://p3.publico.pt/vicios/hightech/5102/educacao-urgencia-daliteracia-digital).

ME (2001) Programa de Geografia A: 10. e 11.ำ anos. Ministério da Educação Departamento do Ensino Secundário.

Openshaw, S., Abrahart R., (2000) GeoComputation. London: Taylor and Francis.

Pedro, A. et al. (2017). Probótica: Programação e Robótica no Ensino Básico. Ministério da. Instituo de Educação da Universidade de Lisboa (Consultado em maio de $2018 \quad$ em: http://erte.dge.mec.pt/sites/default/files/probotica_linhas_orientadoras_2017.pdf).

Philips, P. (2008) Computational Thinking: A Problem-Solving Tool for Every Classroom. Disponível em: http://education.sdsc.edu/ resources/CompThinking.pdf 
Rees, P. H., Turtton, I. (1998) Geocomputation: solving geographicalproblems with new computing power. Environment and Planning. Elibrary.

Sola, C. A. (2006) Fundamentos de la técnica didáctica ABP, in Carlos Sola et al. Aprendizaje Basado en Problemas: De la teoría a la práctica, p. 37-50, Sevilla, Editorial Trillas.

Torrens, P., M. (2004) Geosimulation: Automata-based modeling of urban phenomena. John Wiley \& Sons, Ltd.

Wiggins, G. P. (1993). The Jossey-Bass education series. Assessing student performance: Exploring the purpose and limits of testing. San Francisco, CA, US: Jossey-Bass

Wing, J. (2006). Computational thinking. Communications of the Association for Computing Machinery, pp. 152-155.

Equipa de Recursos e Tecnologias Educativas (ERTE). Disponível em http://erte.dge.mec.pt/. 


\section{Os conteúdos escolares de Geografia no estágio supervisionado em Pedagogia}

VANICE SCHOSSLER SBARDELOTTO ${ }^{1}$

\section{Resumo}

O que os conteúdos de Geografia ensinados durante o estágio do curso de Pedagogia ensinam sobre a Geografia da escola? O estágio realizado ao logo do curso de Pedagogia é um período em que o acadêmico tem contato com o currículo escolar em movimento, sendo ele também um agente imerso na realidade da escola. Os estudantes do quarto ano do curso desenvolvem seus estágios de docência em turmas de $1^{\circ}$ ao $5^{\circ}$ ano e os conteúdos ensinados de Geografia podem ser reveladores de uma perspectiva da disciplina de Geografia nessa etapa da educação básica, assim como são igualmente fatores de formação para os novos professores. A questão considerada neste texto se refere ao potencial formativo dos conteúdos ensinados ao longo do estágio. Os conteúdos designados para o ensino, de certa forma, apresentam a "Geografia da escola". O que os conteúdos de Geografia "ensinaram" sobre a Geografia dos anos iniciais? Que "Geografia" se depreende dos conteúdos indicados para o ensino destes acadêmicos em particular? Essa Geografia que se depreende dos conteúdos designados para o ensino considera as questões ambientais, sociais e cidadã da Geografia? É possível que o estudante de Pedagogia, por meio dessa experiência compreenda o processo formativo, voltado à cidadania, proporcionado pela Geografia? Os resultados preliminares destas questões apontam que os conteúdos ensinados guardam pouca conexão com os demais aspectos desenvolvimento do curso e expressam uma perspectiva, que podemos chamar de ilustrativa e contemplativa da Geografia, em que os conteúdos geográficos servem para conhecer um mundo pronto e acabado.

Palavras-chave: formação de professores; estágios curriculares; conteúdos escolares; ensino de Geografia.

\footnotetext{
${ }^{1}$ Doutoranda em Geografia e Professora do Curso de Pedagogia da Universidade Estadual do Oeste do Paraná, membro dos grupos de pesquisa Represetanções, Espaços, Tempos e Linguaguens em Experiências Educativas - RETLEE e Educação Superior, Formação e Trabaho Docente - GESFORT, vanice.sbar@gmail.com
} 


\section{Abstract}

What do the contents of Geography taught during the internship of the Pedagogy course teach about the geography of the school? The internship, held in the undergraduate course in Pedagogy, is a period in which the academic has contact with the school curriculum in movement, being also an agent immersed in the reality of the school. Fourth year students of the course develop their teaching internships from the 1st to the 5th grade classes and the taught contents of Geography can be revealing from a perspective of the Geography discipline, in this stage basic education, as well as training for the new teachers. The question considered in this text refers to the formative potential of the contents taught during the internship. The contents designated for the teaching, in a certain way, present the "Geography of the school". What are the contents of Geography "taught" about the geography of the early years? What "Geography" can be inferred from the contents indicated for the teaching of these academics in particular? Does this Geography that derives from the contents designated for teaching consider the environmental, social and citizen issues of Geography? Is it possible that the student of Pedagogy, through this experience, understands the formative process, geared towards citizenship, provided by Geography? The preliminary results of these questions, indicate that the contents taught have little connection with the other development aspects of the course and express a perspective, which we can call illustrative and contemplative of Geography in which the geographic contents serve to know a ready and finished world.

Keywords: teacher training; curricular stages; school content; Geography teaching.

\section{Introdução}

A dialética entre o ensino e a aprendizagem se apresenta como fenômeno central para a compreensão de problemas que envolvem o cotidiano da sala de aula. Desta forma, a preparação dos professores precisa, potencialmente, considerar essa dimensão ao organizar o processo formativo. Isso implica em pensar na dinâmica da aprendizagem para organizar o ensino. Cada conteúdo, área do conhecimento, concentra em si a lógica do seu ensino, assim também a Geografia. Pensar em ensinar Geografia, perpassa por compreender o meio pelo qual se formulam os conceitos e categorias geográficas, que dependem da concepção ideológica dada à área, ao sujeito que vai 
se apropriar desses conceitos, a partir de sucessivas mediações e finalidades desse ensino.

Desta forma, neste artigo, pretende-se apresentar aspectos da ánalise do processo formativo, ao qual são submetidos os pedagogos para o ensino que desenvolvem nos anos inciais do Ensino Fundamental. Entre as áreas que ensinam, de acordo com a legislação curricular brasileira, se encontra a Geografia. Ou seja, busca explicitar se a dialética entre ensino e aprendizagem está presente na formação dos pedagogos, de modo particular, daqueles que se formam no Curso da Unioeste, em Francisco Beltrão.

\section{A formação do pedagogo para o ensino de Geografia}

A formação dos pedagogos, assim como outros cursos, no Brasil, é regulamentada por Diretrizes Curriculares Nacionais, emanadas pelo Conselho Nacional de Educação, por deliberação da LDBEN 9394/96. Assim, a Resolução CNE/CP nํ1, de 15 de maio de 2006, institui Diretrizes Curriculares Nacionais para o curso de graduação em Pedagogia, licenciatura e a Resolução ํㅡㄹ 2, de 1ํ de julho de 2015 define as Diretrizes Curriculares Nacionais para a formação inicial em nível superior, estabelecem o perfil e o processo formativo desses professores.

A política curricular brasileira garante para esse professor, o pedagogo, a prioridade da atuação nos anos iniciais do Ensino Fundamental. Logo, seu processo formativo precisa conferir as competências necessárias para essa atuação. Essa situação encerra uma problemática complexa que vem sendo enfrentada a anos na formação desses professores. A organização curricular brasileira segue a tradição disciplinar, de forma que os currículos escolares acompanham essa tendência. Nos anos iniciais todas as disciplinas, portanto, serão ministradas pelo mesmo professor e nos anos finais, as disciplinas são ministradas por professores formadas nas respectivas licenciaturas. Assim, cursos de graduação de Licenciatura em Geografia, formam os professores para os anos finais do Ensino Fundamental e para o Ensino Médio, o que também ocorre em outras licenciaturas, como História, Ciências Biológicas, etc. Nesses cursos, há espaço curricular para a discussão epistemológica, técnica e metodológica para o ensino. Entretanto, nos cursos de Pedagogia, cujos egressos que atuarão nos Anos Iniciais como unidocente, o tempo curricular destinado para a formação em cada área impede o aprofundamento em diversas áreas - essa questão foi tratada por diferentes atores como Libâneo (2009), Pimenta (2002), entre outros. Isso obriga o docente do curso de graduação em Pedagogia a realizar uma verdadeira 
"ginástica" para encerrar em poucas horas o conteúdo necessário para formação do professor em cada área do conhecimento.

Ao discutir essa problemática na formação do Pedagogo “(...) os estudos em Pedagogia vão sendo pulverizados por um rol de estudos de temáticas concernentes à sociedade contemporânea. Reserva-se ao licenciado uma formação geral prevalecendo um tratamento superficial sem a possibilidade de aprofundamento específico". (Portelinha, 2015, p. 114). A autora ainda argumenta que essa tendência nos cursos de Pedagogia pode ser entendida como uma adesão à flexibilização na formação, indicando um neotecnicismo. A hipótese inversa, em que os licenciados das diferentes áreas atuariam desde os anos iniciais também resulta em uma falta de espaço curricular nos cursos de formação para abrigar as discussões específicas deste nível de ensino. Não pretende-se, neste texto, problematizar essa segunda hipótese, mas discutir a formação na Pedagogia.

Esta problemática tem acompanhado a Pedagogia nos últimos trinta anos, a saber, o debate sobre a premência na formação do "(...) domínio dos conteúdos que serão objeto do processo educativo e o domínio das formas por meio das quais se realiza o referido processo" (Saviani, 2012, p.132). Este debate, defendido pelo autor, apresenta uma questão situada na dissociação entre forma e conteúdo, ensejando projetos formativos que ora defendem a ênfase em um ou em outro polo.

Libâneo (2009) demostra a atualidade da crise, apresentando essa discussão sobre os rumos do curso de Pedagogia e da própria Pedagogia, a partir das definições da LDB de 1996, e na emergência das Diretrizes Curriculares do Curso de Pedagogia que, mediatizada pelas discussões da ANFOPE (Associação Nacional pela Formação dos Profissionais da Educação), aponta a docência como central no processo formativo. Posiciona-se, esse autor, de forma contrária à defesa da ANFOPE, alegando que dessa forma se faz uma redução da Pedagogia à educação escolar. Ele questiona: “(...) onde estão os especialistas de planejamento da educação, administração de sistemas, avaliação educacional e avaliação da aprendizagem, pesquisa pedagógica específica?”. (Libâneo, 2009, p.11).

Neste contexto que se apresenta, da organização dos cursos de Pedagogia, de acordo com a DCN (2006), de que é possível assegurar o domínio de conhecimento para ensinar os conteúdos das diferentes áreas do conhecimento, entre elas a Geografia? No tempo curricular destinado à formação em Geografia no curso de Pedagogia, quais aspectos desta área são conservados? Há espaço para o debate da importância da Geografia para a formação cidadão dos sujeitos? 
De acordo com Saviani (2005) a atuação prática, exige do professor o domínio dos conhecimentos científicos convertidos em saberes escolares, e sua correlata forma de ensino. Esse processo é indissociável e compreende a gênese da ação do professor. Assim, para que se ensine Geografia é necessário conhecer esse campo científico e sua inter-relação com a sociedade, as tecnologias e a ciência, de forma mais ampla, na produção e seleção dos conteúdos escolares, a na forma metodológica de ensino.

De forma particular, nesta fase da pesquisa, analisa-se a hipótese que, diante do escasso tempo destinado à formação em Geografia, ao longo do Curso de Pedagogia, a forma curricular da disciplina, por meio dos estágios supervisionados tem mostrado a Geografia escolar, ou a educação geográfica, de forma mais contundente aos acadêmicos de Pedagogia, do que a própria disciplina curricular. A validade dessa hipótese, implica em que a concepção curricular da Geografia escolar, encontrada nas escolas, em que os acadêmicos realizam estágios, desempenha um papel fundamental da formação desses professores e orienta o como ensinam Geografia e o próprio ensino de Geografia na formação do Pedagogo e de que isto pouco ou nada contribuem para a formação desse profissional.

\section{Que Geografia se quer ensinar? Que professor se quer formar?}

A questão considerada neste texto, se refere ao potencial dos conteúdos ensinados ao longo do estágio para a formação do pedagogo. Os conteúdos designados para o ensino, de certa forma, apresentam a "Geografia da escola". Assim, o que os conteúdos de Geografia "ensinaram" sobre a Geografia dos Anos Iniciais e, que concepção de "Geografia" se depreende dos conteúdos indicados para o ensino? Essa Geografia que se depreende dos conteúdos designados para o ensino considera as questões ambientais, sociais e cidadã da Geografia? É possível que o estudante de Pedagogia, por meio dessa experiência compreenda o processo formativo, voltado à cidadania, proporcionado pela Geografia?

O estágio de docência no quarto ano do Curso de Pedagogia é um período em que o estudante tem o contato com a docência, nas turmas dos Anos Inicias. Em estágio de anos anteriores tem outro tipo de contato com a escola, a docência fica reservada a este momento no útlimo ano curso. A forma de organização desse estágio tem variado de acordo com os projetos políticos pedagógicos dos cursos de Pedagogia. No caso do Curso aqui definido, os estudantes são organizados em duplas para realização deste estágio sob orientação de um professor do curso; escolhem uma turma dos Anos Inciais para realizar o estágio, na qual realizam observações, inserções mensais, 
nas quais assumem a docência, da turma, por dois dias e lecionam as disciplinas do currículo do município e, por fim, assumem a turma por uma semana de regência, em que se responsabilizam por toda a rotina e ensino. Os conteúdos que planejam para lecionar são indicados pelo docente regente da turma lá da escola do campo do estágio, que superviona o estagiário. Essa designação de conteúdos, a partir de Sacristán (2000), é chamado de currículo real; pois os professores nem sempre se pautam pela sequência do currículo do município ou dos livros didáticos, mas obedecem a lógica de trabalho que vem sendo desempenhada na turma.

Problematiza-se, aqui que este tipo de estágio exerce um papel significativo no processo de formação dos professores, pois a escola seleciona, organiza, planeja e ensina os conteúdos. Contreras (2012) afirma que se tornar um professor não significa somente um profissional que domina determinados conhecimentos específicos da área de conhecimento, mas que é necessário adquirir o que ele chama de profissinalidades, características que englobam um conjunto de conhecimentos requisitados para a docência, como empatia, domínio de turma, ética, comprometimento. Para ele,

A profissionalidade se refere às qualidades da prática profissional dos
professores em função do que requer o trabalho educativo. [...] Falar em
profissionalidade significa, nessa perspectiva, não só descrever o desenho
do trabalho de ensinar, mas também expressar valores e pretenções que se
deseja alcançar e desenvolver nessa profissão.(Contreras, 2012, p.82,
grifos no original).

Deste modo, por meio do estágio, os acadêmicos se apropriam do currículo em movimento, do que se consolidou e se mantém nas escolas. Assim, entram em contato com a Geografia da/na escola. Podem verificar e constatar o que se ensina, as ênfases dadas aos conhecimentos, os objetivos que sustentam determinadas escolhas conceituais, ideológicas e práticas. Os conteúdos que são designados para o ensino de Geografia nos Anos Inciais evidenciam as marcas desta Geografia escolar, que nem sempre se encontra com a Geografia da universidade. Portanto esta é uma das contradições existentes no processo formativo dos estudantes quando a "Geografia da escola", explicitada por meio dos conteúdos designados para o ensino são solenemente ignorados pela "Geografia da universidade". Se não completamente ignorados, mas pouco explorados.

Assim, a hipótese que gerada, neste contexto, é de que a formação dos pedagogos na universidade não explora objetivamente as contradições políticas, ideológicas, culturais existentes na Geografia. De acordo com Moraes (2005), Santos (2012), Tonini (2006), entre outros, existem "Geografias" em disputa, no que se refere aos 
objetivos da disciplina, função desta na escolarização, fato que não é ignorado no processo formativo acadêmico, mas que, se refere à perpectiva geográfica contida nos conteúdos designados para o ensino. Desta forma, pode-se inferir que, possivelmente, haja uma contradição entre o que se discute no âmbito formativo e o que se executa nos estágios, por exemplo.

A esse aspecto, Callai (2014) lança um importante questionamento, “(...) aprende-se geografia nos anos inciais?" e pondera que "o currículo da geografia que se ensina nos anos inciais nos leva a questionamentos que remetem também à formação docente, seja a destinada aos professores dos anos inciais ou a dos cursos específico" (Callai, 2014, p.31). O que exige a investigação sobre o próprio processo formativo que se destina aos professores.

O "Quadro 1" apresenta os conteúdos ministrados pelos acadêmicos/as que realizaram o estágio no ano de 2017, em escolas municipais de Francisco Beltrão. Estes mesmos acadêmicos, questionados sobre a relação entre o processo formativo na disciplina de Fundamentos Teóricos e Metodológicos do Ensino de Geografia, cursada no mesmo ano, e os conteúdos do estágio, afirmaram que guardam pouca ou nenhuma relação.

Os conteúdos apresentados no "Quadro 1" foram designados pelos professores regentes das turmas onde se realiza o estágio. Não se fez, nesse momento, uma análise se estes conferem ou não com o exposto no currículo oficial do município, por definir que, nesta fase da pesquisa se trabalhará com os dados do currículo real, aquele que pode diferir do prescrito, mas que se realiza no âmbito da sala de aula.

Os conteúdos aparecem dispostos em duas colunas: na primeira, "Agosto - inserção Geografia" estão os conteúdos que foram ministrados durante a inserção de dois dias do mês de agosto. Neste mês, as acadêmicas trabalharam com as disciplinas de Geografia e História; na segunda coluna "Setembro - estágio de regência", estão listados os conteúdos trabalhados durante a semana de regência. Nesta semana, ministraram conteúdos de todas as disciplinas curriculares.

Quadro 1- Conteúdos da disciplina de Geografia ensinados no estágio de docência - 4º ano Pedagogia

\begin{tabular}{|c|c|}
\hline \multicolumn{2}{|c|}{$1^{\circ}$ ano } \\
\hline Agosto - inserção Geografia & Setembro - estágio de regência \\
\hline
\end{tabular}




\begin{tabular}{|c|c|}
\hline $\begin{array}{l}\text { Orientação e localização. } \\
\text { Noções Topológicas. } \\
\text { Pontos de referência para localização e } \\
\text { compreensão do espaço vivido. } \\
\text { Paisagem natural e modificada. } \\
\text { As diferentes paisagens no município de Francisco } \\
\text { Beltrão. } \\
\text { Diferenças do meio urbano e rural. } \\
\text { Meios de transporte. }\end{array}$ & $\begin{array}{l}\text { Transformação do espaço. } \\
\text { Zona Rural e Zona urbana. } \\
\text { A criança e a escola. } \\
\text { Orientação e localização. } \\
\text { Manifestações Culturais: hábitos, costumes e } \\
\text { tradições. } \\
\text { Animais em extinção. } \\
\text { Preservação da natureza (Educação Ambiental) } \\
\text { Trabalho e Espacialidade. }\end{array}$ \\
\hline \multicolumn{2}{|c|}{$2^{\circ}$ ano } \\
\hline $\begin{array}{l}\text { Crosta terrestre. } \\
\text { Construção e modificação do espaço geográfico: o } \\
\text { rural e o urbano. } \\
\text { Evolução da tecnologia no meio urbano e rural. } \\
\text { Paisagem natural e cultural: degradação e } \\
\text { preservação. } \\
\text { Grupos étnicos. } \\
\text { Trajetos: caminho de casa até a escola. } \\
\text { Meios de transporte. } \\
\text { Alimentação humana. }\end{array}$ & $\begin{array}{l}\text { Meio ambiente (seres bióticos e abióticos); } \\
\text { Preservação ambiental. } \\
\text { Produção de alimentos em Francisco Beltrão. } \\
\text { Evolução dos instrumentos de trabalho. } \\
\text { As diferentes profissões. } \\
\text { Profissões da zona urbana e da zona rural. } \\
\text { Tipos de moradia. } \\
\text { Espaço/ sala de aula } \\
\text { Localização da sala de aula. } \\
\text { Orientação e localização. } \\
\text { Cultura. } \\
\text { Meio de comunicação. }\end{array}$ \\
\hline \multicolumn{2}{|r|}{$3^{\circ}$ ano } \\
\hline $\begin{array}{l}\text { Zona urbana e zona rural. } \\
\text { Formação da cidade de Francisco Beltrão. } \\
\text { Aspectos geográficos de Francisco Beltrão. } \\
\text { Pontos turísticos do município. } \\
\text { Grupos étnicos: os Indígenas } \\
\text { Diferentes tipos de moradias. } \\
\text { Alimentação; }\end{array}$ & $\begin{array}{l}\text { Espaço Geográfico; } \\
\text { Paisagem. } \\
\text { Grupos étnicos: Cultura Afro Brasileira. } \\
\text { Necessidades básicas (alimentação e saúde); } \\
\text { Saneamento Básico e o Meio Ambiente. }\end{array}$ \\
\hline \multicolumn{2}{|c|}{$4^{\circ}$ ano } \\
\hline $\begin{array}{l}\text { Os movimentos da Terra (Rotação e Translação). } \\
\text { Equinócios e solstícios; } \\
\text { Estações do ano; } \\
\text { Ciclos da Natureza; } \\
\text { Pecuária e agricultura. } \\
\text { Paisagem natural (aspectos físicos naturais, fauna, } \\
\text { flora, solo relevo, hidrografia) }\end{array}$ & $\begin{array}{l}\text { Trabalho } \\
\text { Profissões } \\
\text { Necessidades básicas: moradia } \\
\text { Energia elétrica e os impactos ambientais }\end{array}$ \\
\hline
\end{tabular}

Fonte: Relatórios de Estágio Curricular Obrigatório, 4º ano de Pedagogia, 2017, turmas do período matutino e noturno. Elaboração própria.

Observa-se, pela disposição dos conteúdos, que se mantém, no currículo real, a perspectiva de círculos concêntricos, avaçando de relações mais elementares e próximas às crianças no primeiro ano, para a compreensão de um espaço mais amplo no segundo ano, chegando às especificidades das características geográficas do município, no terceiro ano e mais amplas, abordando o planeta e aspectos econômicos no quarto ano. Não são listados conteúdos no quinto ano do Ensino Fundamental, por não ter havido estagiários nessas turmas.

A seleção dos conteúdos enfatiza o conhecimento de um mundo estático, pronto. Diferenciar as características dos diferentes espaços, apropriar-se de ferramentas para localização, distinguir as diferenças de habitação, transporte, depreendem que o espaço não será "pensado", mas conhecido como uma realidade objetiva. A perspectiva da educação ambiental, que direciona-se para uma corrente resolutiva, 
conservacionista foge uma pouco a essa regra, de forma que pretende potecializar, junto às crianças, práticas de intervenção no mundo.

Ainda que existam diferenças entre estes conteúdos de ensino e o currículo oficial do município, são estes que, de certa forma, explicitaram a Geografia escolar aos novos professores/pedagogos, em que prepondera a Geografia dos professores, como problematiza Lacoste (2012) e que muito pouco ajuda a formar um pensamento sobre a produção do espaço, direcionando-se mais para a memorização de características espaciais.

Nos objetivos expostos nos planos de ensino dos estágio foi possível depreender, ao menos, cinco categorias preponderantes ao longo dos quatro anos, são elas, estudo sobre localização e orientação, transformação do espaço, estudos sobre questões ambientais e saúde, elementos da cultura e relações de trabalho. Não foram encontrados objetivos de ensino referentes à educação ambiental, nos planos de aula dos quatros anos, conforme pode ser observado na "Quadro 2".

Os objetivos de ensino, produzidos a partir dos conteúdos designados pelos professores, revelam um ajustamento à concepção "evolutiva" e linear do conteúdos escolar do corrículo real. Em poucos observa-se a tentativa de estabeler relações multi-escalares, por exemplo ou ainda desenvolver o pensamento espacial, para além na nomeação e reconhecimento dos diferentes aspectos observáveis no meio.

Desta forma, os conteúdos ensinados no estágio expressam uma concepção de Geografia. A formação para o ensino de Geografia no curso de Pedagogia ocorre, particularmente, na disciplina de Fundamentos Teóricos e Metodológicos do Ensino de Geografia, questiona-se se a concepção de Geografia do currículo real, percebida por meio dos estágios, é problematizada a fim de que o pedagogo possa posicionar-se frente ao ensino desta disciplina. Isso seria possível se a práxis, como aponta Vásquez (2007) fosse o príncipio da formação.

No "Quadro 2" os objetivos encontrados nos planos de ensino foram agrupados por categorias. Estas categorias foram desenvolvidas a partir da análise do conjunto dos planos de ensino e não se referem ao currículo oficial adotado no município. 
Quadro 2: Objetivos de ensino dos planos de aula (continua)

\begin{tabular}{|c|c|c|c|c|}
\hline & $1^{0}$ & $2^{o}$ & $3^{\circ}$ & $4^{\circ}$ \\
\hline 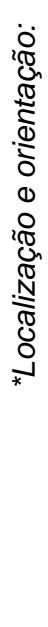 & $\begin{array}{l}\text { - Reconhecer } \\
\text { relações espaciais } \\
\text { projetivas. } \\
\text { - Estabelecer relações } \\
\text { espaciais topológicas. } \\
\text { - Desenvolver pa } \\
\text { noção do pensamento } \\
\text { da espacialidade. } \\
\text { - Desenvolver noções } \\
\text { de lateralidade. } \\
\text { - Desenvolver a } \\
\text { compreensão na } \\
\text { necessidade na de } \\
\text { utilização de pontos } \\
\text { de referência para o } \\
\text { deslocamento no no } \\
\text { espaço. }\end{array}$ & $\begin{array}{l}\text { - Aprender a se } \\
\text { localizar-se pelos } \\
\text { pontos cardeais e } \\
\text { colaterais.. } \\
\text { - Descrever, } \\
\text { interpretar e analisar a } \\
\text { localização de pessoas } \\
\text { e objetos. } \\
\text { - Reconhecer } \\
\text { caminho da casa a } \\
\text { escola. a } \\
\text { - Desenvolver } \\
\text { capacidade de ler e } \\
\text { construir mapas. }\end{array}$ & $\begin{array}{l}\text { - Saber localizar } \\
\text { cartograficamente } \\
\text { algumas regiões como } \\
\text { Europa, Índia, e litoral } \\
\text { do Brasil. }\end{array}$ & $\begin{array}{l}\text { - Diferenciar os } \\
\text { movimentos da Terra e } \\
\text { seus efeitos sobre a } \\
\text { vida na Terra. } \\
\text { - Analisar o fenômeno } \\
\text { das estações do ano } \\
\text { com base na } \\
\text { formulação de } \\
\text { modelos explicativos. }\end{array}$ \\
\hline 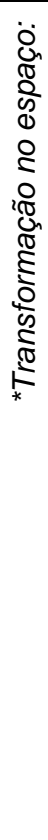 & $\begin{array}{lr}\text { - Entender } & \text { as } \\
\text { transformações que } \\
\text { ocorreram no espaço. } \\
\text { - Reconhecer as } \\
\text { diferenças } \\
\text { características das } \\
\text { zonas rural e urbana. } \\
\text { - Conhecer a história } \\
\text { da escola e as suas } \\
\text { transformações } \\
\text { internas externas. } \\
\text { - Diferenciar } \\
\text { paisagem cultural e } \\
\text { natural. }\end{array}$ & $\begin{array}{l}\text { - Compreender os } \\
\text { conceitos de paisagem } \\
\text { natural e paisagem } \\
\text { modificada/cultural. } \\
\text { - Compreender que } \\
\text { a maior parte da } \\
\text { produção de alimentos } \\
\text { se dá no espaço rural. } \\
\text { - Diferenciar } \\
\text { diferentes tipos de } \\
\text { moradias existente. } \\
\text { - Compreender as } \\
\text { mudanças que } \\
\text { ocorreram no processo } \\
\text { de avanços da } \\
\text { tecnologia em relação } \\
\text { aos meios de } \\
\text { comunicação. } \\
\text { - Aprender sobre os } \\
\text { diferentes tipos, } \\
\text { importância, } \\
\text { permeabilidade } \\
\text { textura do solo. }\end{array}$ & $\begin{array}{l}\text { - Compreender parte } \\
\text { dos múltiplos aspectos } \\
\text { que formam a } \\
\text { paisagem do lugar. } \\
\text { - Detalhar } \\
\text { paisagem do seu } \\
\text { bairro trazendo os } \\
\text { elementos das plantas. } \\
\text { - Entender r as } \\
\text { condições de moradia } \\
\text { de diferentes grupos } \\
\text { sociais. } \\
\text { - Reconhecer qual } \\
\text { moradia é retratada } \\
\text { nas diversas } \\
\text { localizações } \\
\text { geográficas. }\end{array}$ & $\begin{array}{l}\text { - Diferenciar paisagem } \\
\text { natural e modificada } \\
\text { do município. } \\
\text { - Reconhecer os } \\
\text { aspectos físicos } \\
\text { naturais do município. } \\
\text { - Conhecer a } \\
\text { diferença entre } \\
\text { Agricultura e Pecuária. } \\
\text { - Reconhecer os } \\
\text { produtos produzidos } \\
\text { no município. } \\
\text { - Identificar os vários } \\
\text { tipos de moradia. } \\
\text { - Reconhecer } \\
\text { moradia como espaço } \\
\text { de } \\
\text { familiar. convivência }\end{array}$ \\
\hline 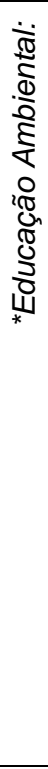 & $\begin{array}{l}\text { - Aprender as regras } \\
\text { de proteção e uso dos } \\
\text { recursos naturais. } \\
\text { - Conhecer os perigos } \\
\text { da extinção para os } \\
\text { seres vivos e } \\
\text { identificar animais em } \\
\text { extinção. } \\
\text { - Conscientizar sobre } \\
\text { a importância da } \\
\text { preservação } \\
\text { ambiental. } \\
\text { - Despertar } \\
\text { interesse } \\
\text { problemas ambientais. }\end{array}$ & 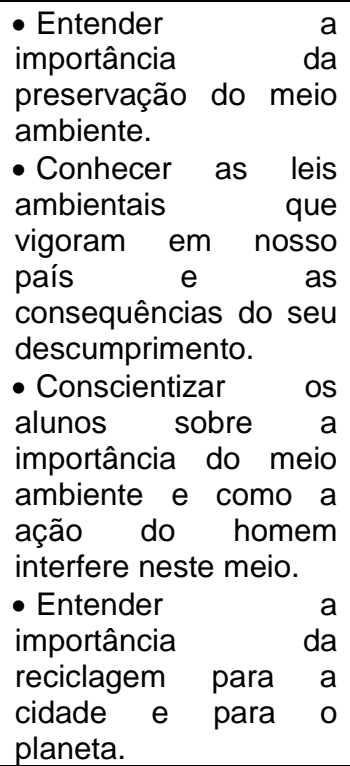 & $\begin{array}{l}\text { - Identificar o que é o } \\
\text { saneamento básico. } \\
\text { - Compreender os } \\
\text { cuidados necessários } \\
\text { com o lixo. } \\
\text { - Compreender a } \\
\text { importância das } \\
\text { necessidades básicas } \\
\text { para a saúde. } \\
\text { - Identificar os hábitos } \\
\text { para uma alimentação } \\
\text { saudável. } \\
\text { - Conhecer quais são } \\
\text { os alimentos de origem } \\
\text { animal e vegetal. } \\
\text { - Conhecer quais são } \\
\text { os alimentos naturais e } \\
\text { industrializados. }\end{array}$ & $\begin{array}{ll}\text { - Perceber } & \text { a } \\
\text { degradação ambiental: } \\
\text { causas } \\
\text { consequências. } \\
\text { - Compreender fontes } \\
\text { que podem ser } \\
\text { transformadas em } \\
\text { energia elétrica. } \\
\text { - Relacionar } \\
\text { alterações do curso } \\
\text { das águas aos } \\
\text { impactos ambientais. } \\
\text { - Apresentar a } \\
\text { conceito de Usina } \\
\text { Hidrelétrica. }\end{array}$ \\
\hline
\end{tabular}




\begin{tabular}{|c|c|c|c|c|}
\hline 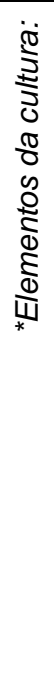 & $\begin{array}{l}\text { - Reconhecer-se } \\
\text { como parte integrante } \\
\text { do grupo de convívio } \\
\text { escolar. } \\
\text { - Compreender o que } \\
\text { é uma manifestação } \\
\text { cultural. } \\
\text { - Conhecer algumas } \\
\text { manifestações } \\
\text { culturais da região em } \\
\text { que o aluno vive. } \\
\text { - Conhecer as danças } \\
\text { e praços típicos de } \\
\text { diferentes povos e } \\
\text { regiões. } \\
\text { - Valorizar os hábitos } \\
\text { e costumes da região. }\end{array}$ & $\begin{array}{l}\text { - Conhecer os grupos } \\
\text { étnicos. } \\
\text { - Identificar aspectos } \\
\text { culturais e de relação } \\
\text { entre os grupos. }\end{array}$ & $\begin{array}{l}\text { - Compreender o } \\
\text { modo de vida de } \\
\text { diferentes grupos } \\
\text { humanos, a maneira } \\
\text { como se relacionam } \\
\text { entre si e com a } \\
\text { natureza. } \\
\text { - Compreender como } \\
\text { a população brasileira } \\
\text { se formou. } \\
\text { - Identificar as } \\
\text { diferentes etnias } \\
\text { básicas que formam a } \\
\text { cultura brasileira. } \\
\text { - Conhecer a história } \\
\text { dos negros no Brasil. } \\
\text { - Compreender e } \\
\text { valorizar a cultura } \\
\text { indígena. }\end{array}$ & \\
\hline $\begin{array}{l}0 \\
0 \\
0 \\
10 \\
0 \\
\frac{\pi}{0} \\
\frac{1}{0} \\
* \\
*\end{array}$ & $\begin{array}{l}\text { - Compreender a } \\
\text { espacialidade do } \\
\text { trabalho. } \\
\text { - Conhecer alguns } \\
\text { meios de transporte. }\end{array}$ & $\begin{array}{l}\text { - Compreender o } \\
\text { conceito de trabalho e } \\
\text { a importância do } \\
\text { trabalho na sociedade. } \\
\text { - Conhecer as a } \\
\text { diferentes profissões } \\
\text { que integram o } \\
\text { mercado de trabalho. }\end{array}$ & $\begin{array}{l}\text { - Identificar a } \\
\text { localização dos pontos } \\
\text { turísticos de Francisco } \\
\text { Beltrão. } \\
\text { - Identificar as } \\
\text { características que } \\
\text { compõe o surgimento } \\
\text { de Francisco Beltrão. }\end{array}$ & $\begin{array}{l}\text { - Conhecer como } \\
\text { surgem as diferentes } \\
\text { profissões e a divisão } \\
\text { social do trabalho } \\
\text { - Discutir o conceito } \\
\text { de trabalho como um } \\
\text { conjunto de atividades } \\
\text { produtivas ou criativas } \\
\text { que o ser humano } \\
\text { exerce para atingir } \\
\text { determinado fim. }\end{array}$ \\
\hline
\end{tabular}

Fonte: Relatórios de Estágio Curricular Obrigatório, 4ª ano de Pedagogia, 2017, turmas do período matutino e noturno. Elaboração própria.

* Categorias apontadas pela autora.

Para que o ensino de Geografia faça sentido, no ensino de Anos Inicias é preciso que ela tome a "materialização do espaço social" (Callai, 2014, p.37), como fenômeno de análise, superando um ensino que se guie pelo elenco de elementos da natureza, da sociedade ou da cultura, facilmente apreendido pela criança por meio dos sentidos.

Não se trata de negar a importância e a necessidade de se conhecer e reconhecer o espaço social, mas a concepção de Geografia, que se depreende trata esse processo com um momento de apropriação passiva dos estudantes da realidade já produzida. Visto que a Geografia, enquanto campo da ciência pode, potencialmente auxiliar na compreensão do processo dinâmico de produção do espaço, essa geografia ensinada pouco contribui.

De forma geral, os conteúdos ensinados guardam relação com a estrutura curricular dos Parâmetros Curriculares Nacionais (1997), nos quais os conteúdos devem ser relacionados com o desenvolviento de competências e habilidades, respeitando o ritmo de desenvolvimento da criança e com objetivos de formá-la para sua inserção social. Para isso, deve compreender o espaço, não necessariamente, pensá-lo. Essa constatação pode ser observada na organização dos conteúdos e objetivos de ensino, 
na medida que expandem de relações mais próximas para relações mais amplas, além de estabelecer prioridade em determinados anos a alguns assuntos, como formação das populações e culturas, no terceiro ano, transformações do espaço e educação ambiental no segundo ano.

Essa inferência corrobora com a defesa apresentada por Straforini (2014) no que se refere ao caráter eclético e fenomenológico do currículo oficial, expresso pelos PCNs (1997), que correlata explicitação de uma concepção de Geografia. Ou seja, a prática desenvolvida a partir de culturas curriculares muito próximas dos princípios dos PCNs informam uma determinada concepção de Geografia e seus objetivos.

Entretanto, isso fica explícito no processo formativo do pedagogo? Essa contradição é explorada no processo formativo? Esas questões são objetivo da investigação desenvolvida em âmbito de doutorado e buscará evidenciar, problematizar e analisar, de forma objetiva o processo formativo do pedagogo para o ensino de geografia nos anos inciais. Neste momento, pode-se inferir que os conteúdos ensinados no estágio, reverberam uma determinada concepção de Geografia e essa concepção associa-se ao processo formativo do pedagogo e pode informar-lhe o que deverá, como professor, ensinar desta disciplina.

\section{Conclusão}

Os resultados, preliminares da pesquisa, indicam que os conteúdos ensinados no estágio curricular guardam pouca conexão com os demais aspectos desenvolvimento do Curso e expressam uma perspectiva, que chamaria de, ilustrativa e contemplativa da Geografia, em que os conteúdos geográficos servem para conhecer um mundo pronto e acabado.

O processo de discussão da Geografia, como disciplina curricular, culminou com a inseção desta nos curriculos oficiais, após redemocratização do país na década de 1980, em detrimento da antiga disciplina de Estudos Sociais, foi um importante estágio para o reconhecimento deste campo da ciência para a formação das novas gerações. Entrento, faz-se necessário adentrar aos debates internos à disciplina, enfrentar as questões ideológicas e superar os limites da análise geográfica reduzida ao economicismo, e problematizar as correntes que tem se hegemonizado no debate escolar, como a Geografia Cultural, marcada pela concepção fenomenológica, que se expressa pela compreensão e valorização do local vivido, para avançar na construção da Geografia nos anos iniciais que colabore com a formação do pensamento espacial, como requisito para a produção coletiva do espaço. 
$\mathrm{Na}$ medida em que os pedagogos absorvem, de forma mediatizada, a "função" e organização da Geografia escolar por meio dos conteúdos ensinados no estágio, corre-se o risco de perder o espaço de enfrentamento desta polêmica. Enquanto os pedagogos seguirem ensinando Geografia nos anos iniciais, deve-se seguir perseguindo a forma mais adequanda da sua formação.

\section{Referências bibliográficas}

Brasil. (20 de dezembro de 1996). Lei № 9394, de 20 de dezembro de 1996. Fixa as Diretrizes e Bases da Educação Nacional. Brasília: Diário Oficial da República Federativa do Brasil.

Brasil. (1997). Parâmetros Curriculares Nacionais - Introdução. Brasília: MEC/SEF.

Brasil. (16 de maio de 2006). Resolução CNE/CP 1/2006. Diretrizes Curriculares Nacionais para o Curso de Graduação em Pedagogia, licenciatura. Brasília: Diário Oficial da União.

Brasil. (01 de julho de 2015). Resolução CNE/CP no 02/2015. Define as Diretrizes Curriculares Nacionais para a formação inicial em nível superior e para a formação continuada. Brasília: Diário Oficial da União.

Callai, H. C. (2014). A Geografia é ensinada nos anos iniciais? Aprende-se Geografia nos anos iniciais? Em I. M. Tonini, (et al). O ensino de Geografia e suas composições curriculares. Porto Alegre: Mediações.

Contreras, J. (2012). A autonomia de professores (2 ed.). São Paulo: Cortez.

Lacoste, Y. (2012). A Geografia - isso serve, em primeiro lugar, para fazer a guerra. (19 ed.). Campinas: Papirus.

Libâneo, J. C. (2009). Pedagogia e Pedagogos, para quê? (11 ed.). São Paulo: Cortez. Moraes, A. C. (2005). Ideologias Geográficas: espaço, cultura e políticas no Brasil. (5 ed.). São Paulo: Annablume.

Pimenta, S. G. (2002). Pedagogia e pedagogos: caminhos e perspectivas. São Paulo: Cortez.

Portelinha, A. M. (2015). A Pedagogia nos Cursos de Pedagogia: teoria e prática pósdiretrizes curriculares nacionais. Jundiaí: Paco Editora. 
Sacristán, J. G. (2000). O currículo: uma reflexão sobre a prática (3 ed.). Porto Alegre: Artmed.

Santos, M. (2012). Por uma Geografia Nova: da crítica da Geografia a uma Geografia Crítica (6 ed.). São Paulo: Editora da Universidade de São Paulo.

Saviani, D. (2012). A pedagogia no Brasil: história e teoria. (2 ed.). Campinas, SP: Autores Associados. (2013). Pedagogia Histórico-Crítica: primeiras aproximações. Campinas, SP: Autores Associados.

Straforini, R. (2014). O currículo de Geografia do ensino fundamental: entre conhecer o que se diz e o vivenciar o que se pratica. Em I. M. Tonini (et al). O ensino de Geografia e suas composições curriculares. Porto Alegre: Media.

Tonini, I. M. (2006). Geografia Escolar: Uma história sobre seus discursos pedagógicos (2 ed.). ljuí: Unijuí.

Vásquez, A. S. (2007). Filosofia da práxis. São Paulo: Expressão Popular. 


\section{DOMÍNIO C}

Educação e Multidisciplinaridade 


\title{
O uso de dispositivos móveis na Educação Básica brasileira: um Mapeamento na Pesquisa Educacional
}

\author{
ADILSON TADEU BASQUEROTE ${ }^{1}$ \\ EDUARDO S. HEUSSER ${ }^{2}$ \\ MORGANA SCHELLER ${ }^{3}$ \\ ROSEMY DA SILVA NASCIMENTO ${ }^{4}$
}

\section{Resumo}

O artigo apresenta um mapeamento de estudos realizados nos últimos cinco anos (2013-2018) sobre o uso dos dispositivos móveis na Educação Básica brasileira no ensino de Geografia. Para tal, utilizou-se o procedimento de Mapeamento na Pesquisa Educacional, onde foram analisados estudos teóricos sobre as concepções de educação ubíqua e dispositivos móveis, seguido do levantamento das produções com esses artefatos em teses, dissertações e artigos publicados em revista. Identificou-se inicialmente quarenta produções de relevância que tratam do tema "dispositivos móveis na Educação Básica". A partir da leitura, utilizaram-se 10 desses trabalhos para compor o mapa, organizando-os em práticas de sala de aula na Educação Básica ou ensaios teóricos. Para elaboração do Mapa de produções acadêmicas, considerouse: o objetivo da utilização dos dispositivos móveis, base teórica, concepção de metodologias ativas, contexto da pesquisa, metodologia e resultados. Evidenciou-se que as práticas descritas nas pesquisas priorizam melhor qualidade de ensino e na aprendizagem, sucesso e permanência dos alunos na escola, bem como procuram

1 Doutorando em Geografia, PPGG-UFSC, "Bolsista da CAPES - Processo no 88881.189678/2018-01. abasquerote@yahoo.com.br 2 Mestrando em Geografia, PPGG-UFSC, eduardo.heusser@gmail.com 3 Doutora em Educação em Ciências e Matemática, IFC, morgana.scheller@ifc.edu.br 4 Doutora em Engenharia de Produção, UFSC, rosemy.nascimento@gmail.com 
estimular o espírito investigativo utilizando a aprendizagem sob o viés da pesquisa. Comprovou-se que entre as dificuldades que as escolas e os professores possuem em utilizar esses recursos, advém a frágil formação instrumental e pedagógica que possuem, capacitando-os para empregar ou permitir que os estudantes utilizem esses aparatos tecnológicos como mais um recurso pedagógico.

Palavras-chave: dispositivos móveis; mapeamento; pesquisa educacional.

\section{Resumen}

El artículo presenta un mapa de estudios realizados en los últimos cinco años (20132018) sobre el uso de los dispositivos móviles en la Educación Básica brasileña. Para ello, se utilizó el procedimiento de Mapeo en la Investigación Educacional, donde se analizaron estudios teóricos sobre las concepciones de educación ubicua y dispositivos móviles, seguido del levantamiento de las producciones con esos artefactos en tesis, disertaciones y artículos publicados en la revista. Se identificó inicialmente cuarenta producciones de relevancia que tratan del tema "dispositivos móviles en la Educación Básica". A partir de la lectura, se utilizaron 10 de esos trabajos para componer el mapa, organizándolos en prácticas de aula en la Educación Básica o ensayos teóricos. Para la elaboración del Mapa de producciones académicas, se consideró: el objetivo de la utilización de los dispositivos móviles, base teórica, concepción de metodologías activas, contexto de la investigación, metodología y resultados. Se evidenció que las prácticas descritas en las encuestas priorizan mejor calidad de enseñanza y en el aprendizaje, éxito y permanencia de los alumnos en la escuela, así como procuran estimular el espíritu investigativo utilizando el aprendizaje bajo el sesgo de la investigación. Sin embargo, se comprobó dificultades que las escuelas y los profesores tienen el uso o permitir que los estudiantes utilicen esos aparatos tecnológicos como un recurso pedagógico.

Palabras-clave: dispositivos móviles; mapeo; investigación educativa.

\section{Introdução}

A busca por conhecimento e informação é cada vez mais necessária e instantânea. A sociedade atual apresenta-se amplamente envolta por recursos tecnológicos e dentre os mais populares encontram-se aqueles ligados as Tecnologias de Informação e 
Comunicação $\left(\mathrm{TIC}^{5}\right)$. Nela, o contexto tecnológico tem promovido transformações, à medida, que condiciona parte das nossas atividades cotidianas. A evolução tecnológica, centrada nas TIC, em especial a digital, vêm relativizando distâncias, gerando mudanças culturais, políticas, econômicas, entre outros. Contudo, no uso, recuperação, acesso e disseminação da informação, as alterações são mais intensas. Nesse cenário destacam-se os dispositivos móveis ${ }^{6}$, que por suas características, promovem conexão contínua, sendo conhecidos também como tecnologias móveis, telefonia móvel, computação móvel ou mídias locativas (Santaellla, 2014).

Dentre as características centrais desse processo encontra-se a ubiquidade, centrada na portabilidade, a miniaturização e a mobilidade que redimensionam a necessidade dos artefatos computacionais estarem presos, fixos a cabos, dependentes de energia elétrica e ambientes físicos para funcionarem. Além disso, o processo de digitalização gerou o que Santaella $(2010,2013)$ classifica como Multimídia, quando permite a conversão de distintas mídias em um único dispositivo eletrônico. Por ele é possível tratar, articular e combinar distintas informações por meio de vídeos, texto, imagem e som integrando informação e comunicação. Nas palavras da autora:

Foram assim fundidas, em um único setor do todo digital, as quatro formas
principais da comunicação humana: o documento escrito (imprensa,
magazine, livro); o audiovisual (televisão, vídeo, cinema), as
telecomunicações (telefone, satélites, cabo) e a informática (computadores,
programas informáticos). É esse processo que tem sido referido pela
expressão "convergência das mídias". (Santaella, 2010, p. 84). Ao analisar os impactos que as TIC vem promovendo na sociedade atual, centrada nos dispositivos móveis, Fontes e Gomes (2013, p. 73) destacam que a grande quantidade de instrumentos tecnológicos disponíveis atualmente, são instrumentos que "desterritorializam" pela mobilidade e pelas informações que facilitam o acesso fluído e ao mesmo tempo, "territorializam" ao permitir que os usuários tenham mais domínio sobre o espaço-tempo".

Assim, a evolução gerada por esses instrumentos, permite a mobilidade de informações, altera a maneira de interagir com as tecnologias digitais, ao permitir utilização contínua, instantânea e de forma simplificada. Por meio de teclados ou telas

5 Nesse estudo, o termo TIC abrange as demais designações para as Tecnologias da Informação e Comunicação, como as Tecnologias Digitais de Informação e Comunicação (TDIC), Novas Tecnologias de Informação e Comunicação (NTIC), entre outros.

6 Dispositivos móveis são definidos como qualquer equipamento ou periférico que pode ser transportado com informação que fique acessível em qualquer lugar. São eles, palms, lap-tops, $i$-pads, até mesmo os pendrives e, certamente, os celulares multifuncionais, tais como smartphones e i-phones (Santaella, 2013, p. 23). 
táteis, mantem-se contato com distintos locais e pessoas, interferindo significativamente nas relações humanas. Facilitou a comunicação, a difusão de informação e sendo assim, influencia nos processos educativos formais e não formais, na produção e partilha de conteúdo, na mediação pedagógica dentro e fora do espaço e horário escolar.

Nessa perspectiva, evolução sem precedentes nas TIC interseccionam-se aos processos de ensino e de aprendizagens. O advento da cibercultura imprimiu aos processos educativos, oportunidades para o uso das tecnologias como recursos capazes de potencializar as aprendizagens e gerar ambiente fecundos à construção do conhecimento. Segundo Batista et al (2017) as TIC são recursos tecnológicos que auxiliam na obtenção, distribuição e compartilhamento de informações e contribuem para facilitar de maneira geral, o cotidiano das pessoas, incluindo os espaços escolares. Como pontua Moran (2013, p. 8)

Sem dúvida, a tecnologia nos atingiu como uma avalanche e envolve a todos. Começa a haver um investimento significativo em tecnologias telemáticas de alta velocidade para conectar alunos e professores no ensino presencial e a distância. Sem dúvida, as tecnologias nos permitem ampliar o conceito de aula, de espaço e de tempo, estabelecendo novas pontes entre os estar juntos fisicamente e virtualmente.

Nesse contexto, distintas experiências vêm sendo realizadas na Educação Básica visando a utilização das TIC. Dentre elas, destaca-se o Projeto Nós Propomos! Cidadania e Inovação na Educação Geográfica ${ }^{7}$ que possui entre outros objetivos, o de "mobilizar alunos/as e professores/as para a utilização de tecnologias de informação em estudos de âmbito prático" (Portugal, 2018, p. 2).

Diante do exposto, a fim de apresentar um mapeamento de estudos realizados nos últimos cinco anos sobre o uso dos dispositivos móveis na Educação Básica brasileira abordam-se inicialmente as concepções de Ubiquidade e de dispositivos móveis. Posteriormente, apresenta-se a perspectiva metodológica da pesquisa contendo a caracterização, o corpus de dados, bem como a metodologia de análise utilizada. $\mathrm{Na}$ sequência, descrevem-se os principais resultados obtidos, decorrentes da análise das publicações.

\footnotetext{
${ }^{7}$ O projeto foi criado no Instituto de Geografia e Ordenamento do Território da Universidade de Lisboa, expandindo-se pelo território Português e também às Regiões Autónomas dos Açores e da Madeira. Atuamente, é desenvolvido também em escolas e universidades do Brasil, Colômbia, Espanha, México, Moçambique e Peru.
} 


\section{Dispositivos Móveis}

\subsection{Dispositivos Móveis e Mediação Pedagógica}

Os dispositivos móveis popularizam-se em todo o mundo e influenciam as formas como as pessoas se comunicam e acessam informações. Os estudantes da Educação Básica, amplamente imersos a contextos permeados pelas TIC chegam a escola diferentes na fala, nas gírias, na expressão corporal, no estilo e até nas roupas (Silva, 2013). Assim, a escola, de modo geral, e os professores necessitam estar atentos ao perfil dos estudantes ao selecionarem os recursos ou materiais didáticos a serem utilizados na mediação pedagógica, que implicarão no ensino e na aprendizagem.

Ao relacionar a prática pedagógica ao uso das TIC, Tonini (2014, p. 2) defende que "a conexão entre práticas escolares e tecnologias digitais amplia as capacidades cognitivas, conecta novos recursos e formas de atuar e de relacionar-se tanto dos estudantes como dos professores". Em contexto semelhante, Santaella (2014), aponta o uso dos dispositivos móveis como ferramenta adequada para promoção da aprendizagem. Segundo ela, esses materiais e recursos de multimídia interativos, podem auxiliar os professores no processo de mediação e facilitar os estudantes na compreensão dos conteúdos. Na mesma direção, a autora destaca a presença da Educação Ubíqua, que corresponde "as novas formas de aprendizagem mediada pelos dispositivos móveis" (Santaella, 2013, p. 23). Segundo ela, por meio deles, potencializa-se o ensino e a aprendizagem ao ampliar a capacidade dos estudantes em obter informações, maximizar sua liberdade e desenvolver habilidade para aprender a qualquer momento. No entanto, Prenski (2003) destaca que esses aparatos tecnológicos são apenas recursos ajustáveis ao processo educativo, jamais uma ferramenta autônoma na sala de aula.

Mantovani e Moura (2012) destacam que os dispositivos móveis combinam realidade e virtualidade e sendo assim, geram relações em um "contexto social e cognitivo, que abrange um comportamento multitarefa" (p. 68). Segundo as autoras, a ubiquidade promovida por eles, ao reconfiguraram as noções de presença e ausência. Em contexto semelhante, Dias (2010) e Fontes e Gomes (2013, p. 72) destacam a importância do acesso contínuo a à internet e as possibilidades de acesso que ela possibilita, ao defender que é por meio dela, que "uso das tecnologias móveis e do acesso a rede que os usuários podem estar em vários lugares ao mesmo tempo".

Santaella $(2013,2014)$ enfatiza a formação de redes de conectividade e do uso das TIC no contexto escolar promovidos pela aprendizagem ubíqua. Para a autora, essa 
forma de aprendizagem amplamente facilitada por dispositivos eletrônicos e em especial por dispositivos móveis, onde a informação circula livre, ligeira e continuamente entre as telas luminosas dos celulares, que ao estarem conectadas com a internet possibilitam que milhares de pessoas, ao redor do mundo, tenham contato com diferentes fontes e uma diversificada gama de dados. Segundo ela, desse processo origina-se uma destreza cognitiva sem precedentes para orientar-se entre nós (pessoas) e nexos multimídias. Corroborando, Moran (2013) defende que a educação, que antes acontecia em espaços e tempos determinados como na escola, na sala de aula, com calendário escolar e estrutura curricular rígida, atualmente tem se expandido para diferentes espaços e tempos não-formais, especialmente para 0 espaço virtual.

No entanto, Silva (2013) adverte que o uso dos dispositivos móveis no processo de ensino e de aprendizagem vai muito além da substituição do caderno ou livro impresso pela tecnologia digital. Faz-se necessário que o professor se torne um mediador de conceitos e reflexões e que os estudantes desenvolvam o espírito investigativo, a criticidade e o princípio da autonomia.

\section{Perspectivas metodológicas}

\section{Os caminhos da pesquisa}

A pesquisa em tela possui caráter qualitativo (Bogdan \& Biklen, 1994) ao consistir em um estudo de caso (Yin, 2001) que objetiva apresentar um mapeamento de estudos realizados nos últimos cinco (2013-2018) anos sobre o uso dos dispositivos móveis na Educação Básica brasileira.

Para tal, utilizou-se o procedimento de Mapeamento na Pesquisa Educacional (Biembengut, 2018), onde foram analisados trabalhos sobre práticas de sala de aula na Educação Básica ou ensaios teóricos sobre as concepções e o uso de dispositivos móveis em pesquisas divulgadas no Brasil, na forma de, teses, dissertações e artigos publicados em revistas, abordando o uso dos dispositivos móveis na Educação Básica. Inicialmente, realizou-se uma revisão sistemática na Biblioteca Digital Brasileira, Banco de Teses e Dissertações (BDTD), Portal de Periódicos Capes, Scielo, Google Acadêmico e revistas especializadas na área de Educação e de Ensino. 
A partir da aderência ao tema, após a apreciação do resumo, o trabalho foi selecionado ou descartado, resultando na seleção inicial, quarenta produções de relevância que tratam do tema "dispositivos móveis na Educação Básica". Para compor o mapa teórico, utilizaram-se 10 desses trabalhos que contemplavam plenamente os seguintes critérios: o objetivo da utilização dos dispositivos móveis, base teórica, concepção de metodologias ativas, contexto da pesquisa, metodologia e resultados.

\section{Produções acadêmicas sobre o uso dos dispositivos móveis na Educação Básica}

\section{Mapa teórico}

Segundo Biembengut (2008), defensora do Mapeamento Teórico, inteirar-se desses estudos amplia o conhecimento sobre o tema e permite ao pesquisador identificar os objetos de estudos existentes na área em que deseja realizar uma pesquisa, bem como definições teóricas do tema. Nesse sentido, elaborar o Mapa Teórico é uma tarefa essencial na atividade do pesquisador, pois permite identificar os saberes divulgados por pesquisadores sobre o tema de estudo, ampliar o leque de conhecimentos e direcionar um espaço para situar sua questão de investigação no mapa das produções existentes (Biembengut, 2008). O Mapa 1 apresenta esquematicamente a distribuição dos trabalhos selecionados de acordo com a natureza da publicação e quantidade.

\section{Mapa 7 - Mapa geral da publicações selecionadas}

\begin{tabular}{|c|c|}
\hline Natureza do trabalho & Quantidade \\
\hline Teses & 4 \\
\hline Dissertações & 2 \\
\hline Artigos & 6 \\
\hline Total & $\mathbf{1 0}$ \\
\hline
\end{tabular}

Fonte: Elaboração própria.

Entre as pesquisas consideradas de maior aproximação ao objetivo desse trabalho, optou-se em codificar as Teses pela letra "T", dissertações pela letra "D" e os artigos pela letra "A", identificando cronologicamente o ano de publicação, o(s) autor (es), título e local de publicação. O Mapa 2 apresenta esquematicamente as teses selecionadas, de acordo com o Mapeamento Teórico realizado. 
Mapa 2 - Mapa de codificação das produções acadêmicas selecionadas sobre o uso dos dispositivos móveis na Educação Básica na forma de teses de doutorado.

\begin{tabular}{|c|c|c|c|}
\hline $\begin{array}{l}\text { Tese/ } \\
\text { ano }\end{array}$ & Autor & Título da Tese & PPG. Instituição \\
\hline $\begin{array}{l}\mathrm{T} 1 \\
2017\end{array}$ & KOBSS, F.F. & $\begin{array}{l}\text { Os possíveis efeitos do uso dos dispositivos } \\
\text { móveis por adolescentes: análise de atores de } \\
\text { uma escola pública e uma privada }\end{array}$ & $\begin{array}{l}\text { PPG em Tecnologia e } \\
\text { Sociedade - UTFPR }\end{array}$ \\
\hline $\begin{array}{l}\text { T2 } \\
2017\end{array}$ & $\begin{array}{l}\text { TONETTO, } \\
\text { É.P. }\end{array}$ & $\begin{array}{l}\text { Geografia, educação e comunicação: dispersões, } \\
\text { conexões e articulações na cibercultura }\end{array}$ & $\begin{array}{l}\text { PPG em Geografia - } \\
\text { UFRGS }\end{array}$ \\
\hline $\begin{array}{l}\text { T3 } \\
2017\end{array}$ & ROSA, H.V & $\begin{array}{l}\text { Tecnologias Digitais e Educação: Os dispositivos } \\
\text { móveis nas políticas públicas de inserção das } \\
\text { tecnologias na escola }\end{array}$ & $\begin{array}{l}\text { PPG em Educação - } \\
\text { UFBA }\end{array}$ \\
\hline $\begin{array}{l}\text { T4 } \\
2014\end{array}$ & $\begin{array}{l}\text { PINTO, } \\
\text { P.R.R.D.M }\end{array}$ & $\begin{array}{l}\text { O uso limitado de dispositivos móveis em sala de } \\
\text { aula por uma geração sem limites }\end{array}$ & $\begin{array}{l}\text { PPG em Educação, } \\
\text { Arte e História da } \\
\text { Cultura - UBM }\end{array}$ \\
\hline
\end{tabular}

Fonte: Elaboração própria.

A T1 intitulada: Os possíveis efeitos do uso dos dispositivos móveis por adolescentes: análise de atores de uma escola pública e uma privada, levantou os possíveis efeitos pelo uso dos dispositivos móveis por adolescentes no convívio familiar e no aprendizado com alunos, pais e professores de dois colégios um público no estado do Paraná e outro Privado no estado de Santa Catarina. O estudo concluiu como positivo o uso dos dispositivos móveis no uso para pesquisas, lazer, comunicação, aprendizagem, por vídeo aulas, acesso à informação e compartilhamento de conteúdo educacional. Como fatores negativos apontou-se a tendência ao sedentarismo e os riscos ligados à saúde sobretudo dos adolescentes: má postura corporal, à visão, à audição e ao sono, radiação, descarte incorreto. O estudo apontou ainda uma leve redução nas notas dos estudantes, apontadas pelo frágil aproveitamento do recurso com fim pedagógico.

Compreender que formas de aprender estão envolvidas nas práticas comunicacionais através dos dispositivos móveis da conexão contínua, e como estas formas podem ser apropriadas no/pelo campo da Geografia nos processos educacionais formais é o objetivo da T2, Geografia, educação e comunicação: Dispersões, conexões e articulações na cibercultura, Para coleta de dados utilizou-se a autoetnografia e a netnografia, por meio de caderno de campo, onde emergiram dos fluxos comunicacionais vivenciados pela própria autora em diferentes espaços. A autora concluiu por um lado, que as tecnologia apresentam-se como a "salvação para os problemas educacionais", onde o papel do professor é relativizado e o do estudante centralizado. Por outro, conclui que inúmeras possibilidades de aprender relativos a esses dispositivos. No entanto, a autora baseou-se apenas nas suas próprias impressões para coleta de dados, não explicitando claramente, quem são os sujeitos analisados. 
Tecnologias digitais e educação: os dispositivos móveis nas políticas públicas de inserção das tecnologias na escola é a T3. A pesquisa percebeu quais as concepções de educação presentes nos programas de inserção das tecnologias digitais na educação que determinaram as características técnicas e conceituais dos dispositivos móveis disponibilizados para as escolas públicas e se seriam necessárias características específicas, como as encontradas nos citados dispositivos, tanto de hardware quanto de software, para que estes fossem destinados às escolas. Como resultado, o trabalho concluiu que o custo dos dispositivos implementados foi o fator essencial na escolha dos artefatos. Prevalecendo sobre aspectos como desempenho, ergonomia, usabilidade e durabilidade, o que denota a necessidade de maior atenção quanto a relação custo-benefício quando da especificação dos equipamentos para as escolas públicas, com o intuito de buscar pela proposta mais vantajosa à gestão pública e a Educação. A pesquisa, contudo, não observou os espaços escolares e os processos de mediação pedagógica com os dispositivos móveis.

A T4, O uso limitado de dispositivos móveis em sala de aula por uma geração sem limites, identificou quais dispositivos tecnológicos em quatro escolas de são Paulo (1 pública municipal e 3 privadas) estão levando para a salas de aula e se as escolas efetivamente estão pensando atividades pedagógicas com seu uso. O estudo concluiu que a educação atualmente pode ser sócio conectiva, que os docentes necessitam ser capacitados para utilizar as tecnologias móveis e que são reduzidas as atividades desenvolvidas com esses dispositivos no espaço empírico estudado.

Quanto ao mapeamento de dissertações (D) selecionou-se as duas pesquisas. O Mapa 3 apresenta de forma esquemática os trabalhos.

Mapa 3 - Mapa de codificação das produções acadêmicas selecionadas sobre o uso dos dispositivos móveis na Educação Básica na forma de dissertações de mestrado.

\begin{tabular}{|c|c|c|c|}
\hline $\begin{array}{l}\text { Disser/ } \\
\text { Ano }\end{array}$ & Autor & Título da dissertação & PPG. Instituição \\
\hline $\begin{array}{l}\text { D1 } \\
2017\end{array}$ & $\begin{array}{l}\text { KINITTEL, } \\
\text { T.F. }\end{array}$ & $\begin{array}{l}\text { A utilização de dispositivos móveis como } \\
\text { ferramenta de ensino-aprendizagem em sala } \\
\text { de aula }\end{array}$ & $\begin{array}{l}\text { PPG em tecnologia } \\
\text { Inteligência e } \\
\text { Digital - PUC/SP }\end{array}$ \\
\hline $\begin{array}{l}\text { D2 } \\
2017\end{array}$ & JUNIOR, W.F. & $\begin{array}{l}\text { O uso de dispositivos móveis em sala de aula } \\
\text { em uma perspectiva sociocomunitária }\end{array}$ & $\begin{array}{l}\text { PPG em Educação - } \\
\text { CUS - UNISAL/SP }\end{array}$ \\
\hline
\end{tabular}

Fonte: Elaboração própria.

A D1, A utilização de dispositivos móveis como ferramenta de ensino-aprendizagem em sala de aula, analisou os desafios e as perspectivas que se abrem a alternativas inovadoras para estudantes e professores, a D1, a pesquisa envolveu estudantes e 
professores de uma escola particular do estado de São Paulo. A pesquisa concluiu que os dispositivos móveis apresentam-se como facilitadores de aprendizagem, por serem multitelas e possibilitarem acesso contínuo. No entanto, também configuram-se como elementos que tiram a atenção dos estudantes, em relação ao conteúdo da aula e possuem telas de tamanho reduzido dificultando a visualização.

A D2, O uso de dispositivos móveis em sala de aula em uma perspectiva sociocomunitária, compreendeu os usos do smartphone por alunos do Ensino Médio dentro da sala de aula no contraponto à Lei que proíbe seu uso em ambiente escolar. Os dados obtidos por meio de questionários, com questões abertas e fechadas com estudantes e professores do $1^{\circ}$ e $3^{\circ}$ ano o Ensino Médio integrado ao técnico em Informática, revelaram que os dispositivos móveis são recursos importantes para a mediação pedagógica se os docentes os utilizarem para esse fim. Evidenciou o uso com maior ênfase a racionalidade técnica em detrimento a racionalidade científica. Contatou-se que os professores poderiam utilizar essa ferramenta com maior intensidade, à medida que para os estudantes, o uso desses aparatos tecnológicos apresentam-se incorporados ao seu cotidiano.

Em relação a mapa de artigos, foram selecionados pesquisas com diferentes campos empíricos, conforme Mapa 4.

Figura 4 - Mapa de codificação das produções acadêmicas selecionadas sobre o uso dos dispositivos móveis na Educação Básica na forma de artigos publicados em revista

\begin{tabular}{|c|c|c|c|}
\hline $\begin{array}{l}\text { Art. } \\
\text { ano }\end{array}$ & Autor(es) & Título do artigo & Revista \\
\hline $\begin{array}{l}\text { A1 } \\
2018\end{array}$ & BASQUEROTE, et al & $\begin{array}{l}\text { Percepções dos estudantes do Ensino Médio sobre o } \\
\text { uso dos celulares na sala de aula }\end{array}$ & $\begin{array}{l}\text { Tec. na } \\
\text { Educação }\end{array}$ \\
\hline $\begin{array}{l}\text { A2 } \\
2017\end{array}$ & $\begin{array}{l}\text { CRONEMBERGER, } \\
\text { A.G.et al }\end{array}$ & $\begin{array}{l}\text { Reflexões sobre o uso das tecnologias móveis como } \\
\text { uma ferramenta auxiliar ao ensino }\end{array}$ & $\begin{array}{l}\text { Scientia } \\
\text { Plena }\end{array}$ \\
\hline $\begin{array}{l}\text { A3 } \\
2017\end{array}$ & $\begin{array}{l}\text { COSTA, C.M.M.; } \\
\text { MARINHO, M.M.; } \\
\text { MARINHO, G.S. }\end{array}$ & $\begin{array}{l}\text { M-learning no ensino de libras: avaliação de objetos } \\
\text { de aprendizagem }\end{array}$ & $\begin{array}{l}\text { Expressão } \\
\text { Católica }\end{array}$ \\
\hline $\begin{array}{l}\text { A4 } \\
2017\end{array}$ & $\begin{array}{l}\text { NASCIMENTO, K.A.S.; } \\
\text { CASTRO FILHO, J.A. }\end{array}$ & $\begin{array}{l}\text { Abordagens pedagógicas na literatura sobre a } \\
\text { aprendizagem móvel no ensino fundamental }\end{array}$ & Holos \\
\hline $\begin{array}{l}\text { A5 } \\
2016\end{array}$ & $\begin{array}{l}\text { SILVA, C. B.; SOUZA, } \\
\text { C. H. M.; CARMO, C. T }\end{array}$ & $\begin{array}{l}\text { Educação de jovens e adultos e novas tecnologias da } \\
\text { informação: uma abordagem educacional }\end{array}$ & Holos \\
\hline $\begin{array}{l}\text { A6 } \\
2015\end{array}$ & CAMPELO, L.F. & Dispositivos móveis nas aulas de geografia & $\begin{array}{l}\text { Prát.Peda- } \\
\text { gógicas }\end{array}$ \\
\hline
\end{tabular}

Fonte: Elaboração própria.

O A1, Percepções dos estudantes do Ensino Médio sobre o uso dos celulares na sala de aula, apresenta as percepções de estudantes de Ensino Médio a respeito do uso dos telefones celulares na sala de aula, para a aprendizagem. Os dados coletados 
com uma turma de Segunda Série do Ensino Médio de uma escola pública do sul do Brasil evidenciaram a disponibilidade de acesso aos aparelhos durante as aulas apresenta-se como uma forma de ampliar as possibilidades de aprendizagens por meio do acesso imediato a distintas fontes de informação e atualização. Por outro lado, constatou-se que os estudantes percebem os aparelhos como uma forma de dispersar-se dos objetivos da aula. Além disso, o estudo revelou que os professores pouco utilizam os dispositivos móveis com fins pedagógicos no ambiente escolar.

Reflexões sobre o uso das tecnologias móveis como uma ferramenta auxiliar ao ensino, a A2 discutiu e apresentou uma revisão sistemática sobre o uso dispositivos móveis em sala de aula como ferramenta de aprendizagem. Os dados evidenciaram que com a adoção dos os dispositivos móveis não promoveram aumento significativo da aprendizagem, ao comparar os percentuais de acertos dos estudantes antes e depois do uso dos dispositivos móveis. Por outro lado, conclui-se que eles apresentam-se como ferramentas de ensino motivadoras para a promoção de estímulos emocionais e afetivos como facilitadores para a compreensão de novos saberes, quando operacionalizados de forma adequada.

Tendo como título: M-learning no ensino de libras ${ }^{8}$ : avaliação de objetos de aprendizagem, o A3 avaliou os principais objetos de aprendizagem desenvolvidos para dispositivos móveis (sistema Android $(\AA)$ ), orientado para o ensino de libras, quanto ao grau de satisfação dos usuários. As autoras avaliaram o grau de satisfação dos usuários que utilizam os programas ProDeaf Tradutor® e Hand Talk® Tradutor para Libras. Elas concluíram que os objetos de aprendizagem ProDeaf® e Hand Talk $\AA$, possuem um alto grau de satisfação, sendo acessível e com boa usabilidade, apresentando um alto potencial para serem utilizados no M-Learning em LIBRAS. No entanto, não apresentaram dados empíricos sobre o uso na Educação Básica.

O A4, Abordagens pedagógicas na literatura sobre aprendizagem móvel no Ensino Fundamental, apresenta evidencias empíricas sobre a utilização dos dispositivos móveis no ensino e na aprendizagem de professores e estudantes do $5^{\circ} a o 9^{\circ}$ ano. As autoras analisaram publicações em periódicos nacionais e internacionais que abordassem o tema e a e o nível de ensino proposto. Concluíram haver poucas publicações sobre a etapa de ensino pretendido e além disso, a maior parcela de publicações encontram-se em nível internacional. As experiencias descritas por elas, reposusam na racionalidade técnica, com frágeis evidências empíricas

8 Língua Brasileira de Sinais. 
Como A5, elegeu-se: Educação de jovens e adultos e novas tecnologias da informação: uma abordagem educacional. Tal estudo analisou e discutiu quais características os professores que participaram do curso de formação continuada do Programa "Nova EJA", elencavam como necessárias para a utilização das novas tecnologias da informação e da comunicação com fins educacionais no ambiente escolar para jovens e adultos. Segundo os autores, para os docentes pesquisados, além das dificuldades de infraestrutura apresentadas pelas das escolas, há uma defasagem na sua formação inicial, para atuarem de forma consciente com as novas tecnologias. Ademais os dados revelaram que compor um grupo de formação continuada em tecnologias, nem sempre reflete na atuação docente de forma efetiva com estes recursos, o que se refletirá na atuação docente na educação Básica para jovens e adultos.

O A6, Dispositivos móveis nas aulas de Geografia, apresenta uma prática pedagógica realizada com estudantes do $1^{\circ}$ ano do Ensino médio de uma escola pública federal de Minas Gerais onde, baseada no uso de celulares ou tablets desenvolveu-se uma aula prática de Global Position Sistem (GPS), usando o aplicativo Commander Compass Lite. Os dados evidenciaram que os estudantes aprovaram a prática pedagógica e conseguiram relacionar os conceitos geográficos aprendidos em sala com o trabalho de campo e comprovaram a viabilidade dos dispositivos móveis nas práticas pedagógicas.

\section{Conclusão}

O artigo apresentou um mapeamento de estudos realizados nos últimos cinco anos (2013-2018) sobre o uso dos dispositivos móveis na Educação Básica brasileira. Os dados evidenciaram que os dispositivos móveis estão presentes na maior parcela dos estudantes da educação Básica brasileira e que estes representam importantes recursos a serem implementados nas práticas pedagógicas das unidades de ensino. Sem contudo, não considera-lo um fim em si mesmo.

Verificou-se que ao portarem os dispositivos móveis conectados à internet, os estudantes possuem acesso fluido, o que torna os espaços escolares ambientes fecundos a construção de conhecimentos, ao possibilitar aos estudantes liberdade para construírem seus itinerários formativos e construir seu próprio conhecimento, distanciando-se das práticas meramente reprodutivas, preceitos amplamente 
pontuados pelos estudos de Santaella (2014, 2013) Moran, Masseto e Behrens (2013) e Sibilia (2012), Tonini (2014), dias (2010), entre outros.

Evidenciou-se que no Brasil de modo geral, as redes e unidades de ensino optam em proibir ou coibir o uso dos dispositivos móveis nos espaços escolares. Embora constata -se que por meio desse recurso é possível desenvolver atividades de caráter colaborativo dentro e fora da sala de aula. Além disso, os dados evidenciaram que aulas mediadas por dispositivos móveis promovem atualização constante e diversidade de informações, aulas mais dinâmicas, interativas e prazerosas, diminuindo a evasão escolar. Por outro lado, parte dos estudos mencionaram que o acesso livre e contínuo aos aparatos tecnológicos promove distração dos estudantes e perda da concentração nos objetivos propostos para a aula. No entanto, aulas planejadas, organizadas para que os estudantes utilizem esses recursos de forma efetiva e com finalidade pedagógica diminuiriam a distração dos estudantes?

Constatou-se a necessidade de formação continuada para os professores como forma de instrumentá-los para utilizar os dispositivos móveis como mais um recurso na mediação pedagógica. Evidenciou-se que os estudantes estão habituados a práticas que privilegiam a racionalidade técnica em detrimento a científica e que recursos tecnológicos afastariam a mediação pedagógica de práticas transmissivas e possibilitariam ao professor mediar conteúdos e conceitos de forma mais efetiva, crítica onde o estudante seria o centro do processo formativo.

Comprovou-se que a maior parcela das publicações no pais, referem-se ao uso dos dispositivos moveis no Ensino Superior e na Pós Graduação, o que denota haver ou pouco divulgação das experiências com esses recursos na Educação Básica, ou pouco se realizam práticas com esses recursos nesse nível de ensino.

\section{Agradecimento e apoio}

As autores agradecem à Coordenação de Aperfeiçoamento de Pessoal de Nível Superior (CAPES) pela concessão da bolsa de Doutorado Sanduíche 


\section{Referências bibliográficas}

Batista, G. C., Silva, L. C. C., Marinho, M. M., Marinho, G. S. \& Marinho, E. S. (2017). Avaliação e Descrição de Objetos no Repositório PHET(2017). Anais do III Encontro Internacional de Jovens Investigadores. Fortaleza, BR.

Bogdan, R. C. \& Biklen, S. K. (1994). Investigação qualitativa em educação: uma introdução à teoria e aos métodos. Lisboa: Porto Editora.

Biembengut, M. S. (2008) Mapeamento na Pesquisa Educacional. Rio de Janeiro: Ciência Moderna.

Dias, R. A. (2010). Tecnologias digitais e currículo: possibilidades na era da ubiquidade - Revista de Educação do Cogeime, V (36). doi: 10.15599/01044834/cogeime.v19n37p71-74.

Fontes, G. S. \& Gomes, I. R. (2013). Cibercidades: as tecnologias de comunicação e a reconfiguração de práticas sociais. Revista Informação \& Informação. 60-76. doi: 10.5433/1981-8920.2013v18n2p60

Mantovani, C. M. C. A. \& Moura, M. A. (2012). Informação, interação e mobilidade. Revista Informação \& Informação. 55-76. doi: 10.5433/1981-8920.2012v17n2p55.

Moran, J. M. (2013) Ensino e aprendizagem inovadores com apoio de tecnologias. In: Moran; Masetto, M. T., Behrens, M. A. Novas tecnologias e mediação pedagógica (pp.11-72) Campinas: Papirus.

Moran, J. M., Masseto, M. T. \& Behrens, M. A. (2013). Novas tecnologias e mediação pedagógica. Campinas: Papirus.

Portugal. (2018) Projeto Nós Propomos! Cidadania e Inovação na Educação Geográfica. Disponível em: http://www.igot.ulisboa.pt/wpcontent/uploads/2018/07/Regulamento-Projeto-N\%C3\%B3s-Propomos-2018_19.pdf.

Prensky, M. (2001). Digital Natives, Digital Immigrants. On the Horizon. V(9). 1-6. doi: 10.1108/10748120110424816.

Santaella, L. (2010). Culturas e artes do pós-humano: da cultura das mídias à cibercultura. São Paulo: Paulus. 
Santaella, L. (2013). Desafios da ubiquidade para a educação. Revista de Ensino Superior. V(9), 19-28. ISSN: 2178-1567.

Santaella, L. (2014) A aprendizagem ubíqua na educação aberta. Revista Tempos e Espaço na educação. V(7)15-22. doi: 10.20952/revtee.v0i0.3446.

Sibilia, P. (2012). Redes ou paredes: a escola em tempos de dispersão. Rio de Janeiro: Contraponto.

Silva, P. K. L. (2013). A escola na era digital. In C. N. Abreu, E. Eisenstein \& S. G. B. Estefenon. Vivendo esse mundo digital: impactos na saúde, na educação e nos comportamentos sociais (pp. 137-145). Porto Alegre: Artmed.

Tonini, I. M. (2014). O livro didático: textualidades em rede. In I. M. Tonini, A. C. Castrogiovanni, L. B. Goulart, N. A. Kaercher \& R. E. M. W. Martins (Orgs.) O ensino de geografia e suas composições curriculares (pp. 149-159). Porto Alegre: Mediação. Yin, R. K. (2001). Estudo de caso: planejamento e métodos. Porto Alegre: Bookman. 


\title{
O processo de gestão escolar nos Centros Municipais de Educação Infantil em Francisco Beltrão - Paraná - Brasil
}

\author{
ANDREIA ZUCHELLI CUCCHI \\ MAFALDA NESI FRANCISCHETT ${ }^{2}$
}

\section{Resumo}

O propósito nesse texto é de apresentar aspectos levantados na pesquisa no Mestrado de Educação da Universidade Estadual do Oeste do Paraná - Unioeste sobre o processo de gestão escolar adotado nos Centros Municipais de Educação Infantil (CMEls), em Francisco Beltrão - Paraná - Brasil. Para tal, considerar-se-á a gestão escolar no âmbito da educação infantil, na formação inicial do diretor na Universidade, por meio da análise dos Projetos Políticos Pedagógicos do Curso e nas principais atribuições relacionadas à sua atuação no ambiente das instituições de educação infantil, do município. Além de buscar elencar as perspectivas e desafios da função, a partir da prática cotidiana vivenciada pelos próprios diretores, nos ambientes que atuam. Pretende-se apresentar sugestões de melhorias, a partir dos pontos deficitários apresentados durante a pesquisa, a qual dar-se-á, por meio de questionários e de entrevistas, numa caracterizacão de estudo de caso enquanto metodologia de pesquisa.

Palavras-chave: gestão escolar; formação docente; educação infantil.

\section{Abstract}

The purpose this text is to present aspects raised in research the Master's in Education in State University Western of Parana about the process of school

\footnotetext{
${ }^{1}$ Mestranda em Educação, Universidade Estadual do Oeste do Paraná - Unioeste/ Campus de Francicso Beltrão, andreiazu@yahoo.com.br

2 Professora Orientadora do Mestrado em Educação, Universidade Estadual do Oeste do Paraná - Unioeste/ Campus de Francicso Beltrão, mafalda@wln.com.br
} 
management adopted in Municipality's Centers of Children Education (Centros Municipais de Educação Infantil - CMEls), in Francisco Beltrão - Paraná - Brazil. For such, will be consider the school management scope of children education, on manager's start formations at University, between analysis of Course's Projects Political Pedagogical and principals attribution related your actuation in ambient of the children education's institutions, in municipality. Besides searching listing the perspectives and function's challenge, from the practice quotidian lived by manager in yours work places, actuation in ambient. Presents the best suggestion, starting the deficit points presented during the research, wich will be by means of questionnaires and interviews, in description of case study as research's methodologies.

Keywords: school management; formation teaching; children education.

\section{Introdução}

Os diretores das instituições de educação infantil atuam em concordância com os demais profissionais, famílias e representantes da comunidade local, exercendo papel fundamental no sentido de garantir que o processo educativo das crianças seja realizado no campo da formação educacional e da cidadania. As ações práticas vivenciadas pelo diretor escolar são primordiais para o desenvolvimento das atividades pedagógicas e administrativas que cerceiam o cotidiano dos Centros Municipais de Educação Infantil (CMEIs). (Brasil, 2006).

Para a elaboração deste texto, consideramos as contribuições teóricas dos seguintes autores: Aquino (2009), Freire (1999), Libâneo (2008), Luz (2006), Morgado (2012), Oliveira (2008), Sanches (2003), e Yin (2001), entre outros, que apresentam subsídios para o entendimento da gestão escolar e dos principais avanços na educação infantil, também sobre as contribuições na pesquisa. As instituições contribuintes como campo da pesquisa foram três: a Associação de Proteção, Maternidade, Infância e Família Dr. Haroldo Beltrão (APMIF); a Secretaria Municipal de Educação de Francisco Beltrão (SME/FB) e a Universidade Estadual do Oeste do Paraná - UNIOESTE/ campus de Francisco Beltrão, as quais disponibilizaram documentos para consulta e registro que compuseram o corpo deste texto.

A metodologia de investigação foi o Estudo de Caso e os instrumentos para a coleta de dados da pesquisa foram: questionário, entrevista e a análise de Projetos Políticos Pedagógicos, além de documentos como atas, ofícios e materiais impressos das instituições contribuintes. Os instrumentos da pesquisa foram apreciados e aprovados 
pelo Comitê de Ética e Pesquisa da Universidade Estadual do Oeste do Paraná (UNIOESTE). Foram participantes da pesquisa: 19 diretores dos CMEls de Francisco Beltrão - Paraná - Brasil e 3 (três) participantes da APMIF e SME/FB.

A questão norteadora trata sobre o processo de gestão escolar nos CMEls de Francisco Beltrão - Paraná - Brasil. Visando compreender como ocorre a atuação do diretor escolar nestas instituições. E a importância da formação inicial neste processo. Além de buscar elencar as perspectivas e desafios da função, a partir da prática cotidiana vivenciada pelos próprios diretores, nos ambientes que atuam, por meio das ações desenvolvidas e realizadas no exercício da função.

\section{0 processo de gestão escolar na educação infantil}

\subsection{A gestão escolar no âmbito da educação infantil: contribuições de teóricos}

Com a aprovação da Lei 9394/96 ${ }^{3}$, a gestão escolar no âmbito da educação infantil passou a fazer parte do processo de democratização das instituições escolares. A legislação brasileira implantada a partir de 1996 (Lei 9394/96) possibilitou a participação da comunidade, no processo de gestão da escola, na construção do Projeto Político Pedagógico e na tomada de decisão no ambiente escolar. Desta forma, gestou a participação de vários segmentos da comunidade escolar, que passaram a fazer parte do contexto escolar, por meio de ações de envolvimento e de compromisso nas atividades educativas e formativas das crianças desde o seu nascimento até os 3 (três) anos de idade.

Libâneo (2008) apresenta alguns conceitos que auxiliam no entendimento da organização, da gestão da escola e do processo de gestão, dos ambientes de educação infantil. No campo da educação, o significado de gestão, organização e administração se aproximam. Pois, a gestão escolar acaba envolvendo aspectos de organização e administração na prática adotada pelo diretor na instituição de educação infantil.

"[...] a gestão é a atividade pela qual são mobilizados meios e procedimentos para se atingir os objetivos da organização, envolvendo, basicamente, os aspectos gerenciais e técnico-administrativos. Neste sentido, é sinônimo de administração". (Libâneo, 2008, p.101). O processo de gestão necessita apresentar resultados de aprendizagem e desenvolvimento no processo educativo. "[...] a organização e os processos de

\footnotetext{
${ }^{3}$ Lei 9394/96, de 20 de dezembro de 1996, estabelece as Diretrizes e Bases da Educação Nacional, publicada no Diário Oficial da União em 23 de dezembro de 1996.
} 
gestão, incluindo a direção, assumem diferentes significados conforme a concepção que se tenha dos objetivos da educação em relação à sociedade e a formação dos alunos [...]". (Libâneo, 2008, p.101).

Cabe ao diretor, junto à comunidade escolar, definir os objetivos e atividades que pretendem desenvolver, considerar a proposta de Projeto Político Pedagógico e a relação com a comunidade escolar. Pois é uma atividade que visa: a) prover as condições, os meios e todos os recursos necessários ao ótimo funcionamento da escola e do trabalho em sala de aula; b) promover o envolvimento das pessoas no trabalho por meio da participação e fazer o acompanhamento e a avaliação desta participação, tendo como referência os objetivos de aprendizagem; c) garantir a realização da aprendizagem de todos os alunos. (Libâneo, 2008).

A participação, no processo de gestão é considerada o principal meio de assegurar a gestão democrática da escola, possibilitando o envolvimento de profissionais e usuários no processo de tomada de decisões e no funcionamento da organização escolar. (Libâneo, 2008).

Com a participação dos sujeitos no processo de gestão, é possível criar estratégias e condições para melhorar o trabalho desenvolvido no ambiente da instituição de educação infantil. A autonomia é outra questão importante que ganha destaque no processo de gestão, além da participação direta dos envolvidos. Visto, que o conceito de participação se fundamenta no de autonomia, que significa a capacidade das pessoas e dos grupos de livre determinação de si próprios, isto é, de conduzirem sua própria vida. Uma gestão democrática e participativa tem na autonomia um dos seus importantes princípios, implicando a livre escolha de objetivos e processos de trabalho e a construção conjunta do ambiente de trabalho. (Libâneo, 2008).

O princípio da autonomia possibilita que as instituições tenham mais condições de decidir e de buscar alternativas na resolução de questões administrativas, pedagógicas e administrativas que cerceiam o cotidiano das instituições. Por meio da autonomia, que as escolas passam a contar com maiores possibilidades de decidir e resolver suas questões cotidianas com mais agilidade, essa abertura vem estimulando as escolas a buscar complementação orçamentária por sua própria conta junto à iniciativa privada e a outras formas de contribuição da população (Oliveira, 2008).

O trabalho em equipe também é uma questão que ganha notoriedade na gestão democrática das instituições de educação infantil, pois um grupo de pessoas que trabalham juntas, de forma colaborativa e solidária, atingem objetivos satisfatórios no processo formativo e na aprendizagem das crianças. Uma modalidade de gestão que, 
por meio da distribuição de responsabilidades, de cooperação, do diálogo, do compartilhamento de atitudes e modos de agir, favorece a convivência, possibilita encarar as mudanças necessárias, rompe com as práticas individualistas e leva a produzir melhores resultados de aprendizagem para as crianças. (Libâneo, 2008).

Com o envolvimento das pessoas, por meio do trabalho em equipe, nas atividades propostas e na ação prática fica possível a constituição de uma gestão democrática, com resultados que promovam e proporcionam uma formação adequada para as crianças.

De acordo com Libâneo (2008), um trabalho em equipe necessita: a) uma definição conjunta de objetivos e metas comuns, compreendidos e desejados, por todos; b) existência de sólida estrutura de organização e gestão, em que haja um forte comprometimento da direção e da equipe técnica; c) definição clara de responsabilidades e capacidade de liderança para motivar e mobilizar as pessoas em torno de objetivos e metas comuns; d) estabelecimento de canais de comunicação, em que sejam passadas informações, realizadas consultas, envolvendo troca de ideias entre a direção, equipe técnica e professores; e) desenvolvimento de habilidades necessárias para a participação eficaz nas atividades da escola e no trabalho em equipe; f) estabilidade do corpo técnico e docente e, preferencialmente, com tempo integral numa escola; g) utilização ao máximo das capacidades criadoras de cada um dos membros da equipe.

A tarefa básica da institituição escolar é o ensino, que se cumpre pela atividade docente. Sendo que, a organização escolar é necessária, à medida que favorece o cumprimento dos objetivos e assegura as melhores condições de realização do trabalho docente. Há, assim, uma interdependência entre os objetivos e funções da escola e a organização e gestão do processo de trabalho na escola, de forma que os meios estejam em função dos objetivos (Libâneo, 2008).

Há necessidade de que o processo de gestão escolar esteja em sintonia com os objetivos e com a proposta de formação adotada pela instituição, para a efetivação dos objetivos e das condições para a realização das atividades de trabalho.

Libâneo (2008) destaca a importância da cultura organizacional no processo de organização e da gestão escolar, no que diz respeito ao conjunto de fatores sociais, culturais, psicológicos que influenciam os modos de agir da organização como um todo e do comprometimento das pessoas em particular. 
As instituições de educação infantil possuem caraterísticas particulares, relacionadas ao meio onde estão inseridas. O trabalho desenvolvido pela equipe de colaboradores, nestes ambientes, geralmente acaba reproduzindo ou se assemelhando aos aspectos culturais interiorizados nestas instituições, a partir da interação entre diretores, coordenadores pedagógicos, professores, funcionários e alunos, a escola vai adquirindo, na vivência com traços culturais próprios, vai formando crenças, valores, significados, modos de agir, práticas. Essa cultura própria vai sendo internalizada pelas pessoas e gerando um estilo coletivo de perceber as coisas, de pensar os problemas, de encontrar soluções.

A atividade de interação entre os sujeitos, por meio do trabalho em equipe realizado no cotidiano, contribui para que a cultura organizacional da instituição seja formada e alimentada diariamente, e principalmente, na ação de refletir sobre as atividades propostas e desenvolvidas no ambiente institucional.

Para que uma gestão seja qualificada, democrática, é necessário que os processos desenvolvidos respeitem a vontade e o interesse da coletividade, assumindo formas flexíveis e participativas. Que privilegie o trabalho coletivo, a construção de formas consensuais de tomada de decisões e a opção por estratégias que possibilitem a apresentação, discussão e resolução de divergências ou resistências que possam impedir a consecução dos objetivos do grupo. Envolve, portanto, uma variedade de interlocutores nas decisões e ações envolvidas nas diversas políticas, o que implica maiores responsabilidade para todos (Luz, 2006).

O processo de gestão, na educação infantil, é um processo dinâmico e participativo que requer dos sujeitos envolvidos, compromisso e responsabilidade nas diferentes circunstâncias que cerceiam toda a prática pedagógica e administrativa inerente a instituição, assim como, no atendimento integral, que visa o cuidar e o educar da criança no ambiente educativo.

As contribuições teóricas sobre a gestão escolar no âmbito da educação infantil possibilitam conhecer os principais conceitos e elementos atrelados à gestão. Os quais possiblitam aos diretores o desenvolvimento de uma gestão democrática e participativa. No próximo item, se apresenta sobre a importância da formação inicial do diretor escolar e a contribuição da Universidade.

\subsection{Formação inicial do diretor e a Universidade}


Falar de formação inicial do diretor que atua na educação infantil no Brasil, requer a compreensão histórica da criação e implantação das primeiras instituições de educação infantil. Para tanto, Aquino (2008) ajuda a compreender algumas das questões históricas que permeiam a formação inicial do profissional da educação infantil, e que, de certa forma não fogem do processo de formação dos diretores, e da forma de atuação destes profissionais. Ele diz que é preciso lembrar que o atendimento à criança em idade anterior a escolaridade obrigatória se organizou predominantemente na informalidade. Em função da informalidade, nas ações dos movimentos populares e da influência de determinadas concepções de infância, nas quais a criança pequena não era reconhecida como sujeito social e cultural, o atendimento dispensado as crianças menores de sete anos se fez com pessoa sem formação profissional, às vezes até sem escolaridade básica. Os critérios para trabalhar com as crianças se basearam na disponibilidade, no gosto, na ideia, que ainda persiste, de que para trabalhar em creche basta gostar de criança, basta ser mulher.

Para Aquino (2008), o processo de organização das instituições de educação infantil foi sendo implantado, em muitos casos, sem considerar os critérios formativos e de seleção adequada para a escolha destes profissionais. Limitando a consideração do lado maternal, e a questão do ser mulher, como atividade restrita ao gênero feminino, principalmente.

Ao considerar que a formação do diretor contribui diretamente na realização de práticas pedagógicas, administrativas e na atenção dada às crianças que frequentam estas instituições, se propõe a busca de informações sobre a formação inicial do gestor da educação infantil e a importância da formação adequada para melhorar a qualidade da educação oferecida as crianças desde o seu nascimento até aos 3 (três) anos de idade.

Segundo Freire (1999), para que a educação infantil se concretize como um segmento importante no processo educativo, não basta leis que garantam isso no papel, nem tampouco teorias elaboradas sobre o desenvolvimento infantil. É necessário, que as pessoas que trabalham diretamente com as crianças, busquem formação contínua e capacitações, de modo que possam exercer sua função da melhor maneira possível, buscando contribuir no desenvolvimento infantil em diversos aspectos, promovendo a ampliação das experiências das crianças e de seus conhecimentos. Ele evidencia a importância da formação dos profissionais que atuam na educação infantil, seja esta formação a partir do ingresso na docência ou na formação continuada, seja a partir 
das experiências vivenciadas com as crianças no ambiente dos Centros de Educação Infantil e nas relações que se estabelece além do espaço físico ocupado pela instituição.

A partir do movimento de diálogo, de contradições, pela busca do conhecimento novo proporcionado pela reflexão de sua prática cotidiana, o profissional da educação se qualifica e adquire os conhecimentos necessários para a sua formação e para a sua vida. O que possibilita melhorar a sua prática e a vivência com a equipe pedagógica e de apoio, com as crianças e com as famílias atendidas no $\mathrm{CMEI}$.

Sanches (2003) considera que o processo de construção do conhecimento requer dos profissionais diretores, das unidades de educação infantil, o envolvimento e a participação direta na construção do conhecimento que permeia as atividades da gestão. Como também interferem diretamente nas ações administrativas e pedagógicas da prática infantil adotada pela instituição.

Ao considerar as perspectivas e os desafios dos professores de educação infantil que ocupam a função de diretor, nas instituições de educação infantil, é necessário considerar algumas dimensões essenciais, dentre elas: a constituição e a integração da equipe de trabalho da instituição; as relações com as famílias das crianças atendidas; a relação com a equipe de apoio e acompanhamento da Secretaria Municipal de Educação; e as demais interações com a comunidade interna e externa, as quais permeiam e interferem direta e indiretamente nas ações e realizações do CMEI. Haja visto, que uma série de elementos precisam andar em sintonia, para que de fato, o processo de gestão ocorra de forma democrática e participativa.

Os conceitos historicamente constituídos e as discussões atuais sobre o tema, além da compreensão do processo de gestão, com ações relacionadas aos aspectos pedagógicos e administrativos, possibilitam refletir sobre a importância da formação e o papel da Universidade nesta abordagem. Como exemplo, o Curso de Pedagogia da UNIOESTE/ Campus de Francisco Beltrão ${ }^{4}$, que oferece formação para os professores que atuam na gestão escolar dos Centros Municipais de Educação Infantil.

A formação é realizada pelo Curso de Pedagogia e também pelas parcerias, a qual se dá pelos projetos de extensão e de pesquisa que são realizados pelos docentes do curso. Visando atender uma demanda específica ou contribuir para melhorar e capacitar os professores que atuam na gestão escolar da educação infantil do

\footnotetext{
${ }^{4}$ As Universidades promovem por meio dos cursos de formação acadêmica na área da educação e na oferta de cursos de capacitação e aprimoramento por meio de projetos de extensão e de pesquisa.
} 
município por meio de cursos de curta duração, palestras, seminários, encontros de debates e elaboração de materiais de apoio.

Desta forma, refletir sobre a formação inicial e o papel das Universidades implica meditar sobre a formação integral da criança da educação infantil, enquanto ser histórico e social, capaz de aprender, de conhecer e de provocar mudanças a partir do conhecimento adquirido no ambiente no qual esteja inserido.

\section{Os CMEIS de Francisco Beltrão - Paraná - Brasil}

\subsection{Contextualização dos CMEIS de Francisco Betrão - Paraná - Brasil (Ano base 2018)}

O município de Francisco Beltrão - Paraná - Brasil, iniciou as atividades com as crianças de 0 (zero) a 3 (três) anos de idade em 1980, quando inaugurou a primeira Creche ${ }^{5}$ denominada Nice Braga, no bairro Miniguaçu.

Nos anos seguintes, foram sendo criadas as demais instituições, as quais eram implantadas nos bairros da cidade, considerando a necessidade de criar espaços de acolhimento e assistência as crianças de menor idade, tendo em vista, que muitas mães executavam atividades externas ao lar e precisavam de um local apropriado para deixar os filhos menores.

Durante muito tempo, as atividades realizadas com as crianças tinham como objetivo, o cuidado e a assistência. Nesta época (1980-1998) o acompanhamento das instituições municipais de educação infantil era realizado pela Associação de Proteção, Maternidade e Infância - Dr. Haroldo Beltrão - APMI ${ }^{6}$.

Com a aprovação da Lei 9394/1996, as instituições municipais de educação infantil, passaram por algumas alterações, dentre elas, o acompanhamento da gestão pedagógica e administrativa, sendo que a Secretaria Municipal de Educação passou a coordenar e organizar toda a dinâmica desenvolvida nos CMEls.

E consequentemente, ocorreu à alteração do objetivo das instituições de educação infantil, que passaram a primar pelo educar e cuidar das crianças pequenas.

\footnotetext{
${ }^{5}$ Creche foi à expressão utilizada por vários anos para denominar os atuais Centros Municipais de Educação Infantil.

${ }^{6}$ Entidade sem fins lucrativos, criada em 1952 por um grupo de senhoras da sociedade, que buscava em suas ações, parcerias com entidades públicas e privadas para manter em funcionamento as creches da cidade.
} 
Os CMEls oferecem atendimento às crianças, com atividades direcionadas ao cuidar $\mathrm{e}$ ao educar. As turmas são divididas em: Berçário, Maternal I, Maternal II, Pré-escola. As crianças recebem alimentação, cuidados de higiene e formação educativa.

Os CMEls são mantidos com recursos financeiros do governo municipal, sendo geridos e acompanhados pela Secretaria Municipal de Educação, por meio do Departamento de Educação Infantil.

A normatização e legislação, seguida e praticada nas instituições, segue o disposto pelas instâncias superiores de ensino, estadual e federal. E o acompanhamento das atividades internas do $\mathrm{CMEI}$, são registradas, formalizadas, e posteriormente, encaminhadas para a Secretaria Municipal de Educação, e aos órgãos superiores, por meio de relatórios e de pareceres. Sendo estes publicizados a comunidade em geral.

O município de Francisco Beltrão - Paraná - Brasil, dispõe de 19 Centros Municipais de Educação Infantil, situados nos diversos bairros da cidade e na área central, atendendo aproximadamente $2.180^{7}$.

A estrutura de colaboradores conta com $374^{8}$ profissionais da educação, sendo que 19 professores efetivos ocupam a função de diretor escolar e 355 ocupam a função de professor na educação infantil (deste número 195 são profissionais efetivos, 110 estagiários e 50 profissionais contratados por prazo determinado). Ainda conta com profissionais de apoio, num total de $109^{9}$ profissionais, sendo, 57 efetivos, 37 estagiários e 15 contratados por prazo determinado, que realizam a função de: cozinheiras e de serviços gerais (manutenção e limpeza).

Gráfico 01 - Faixa etária dos diretores

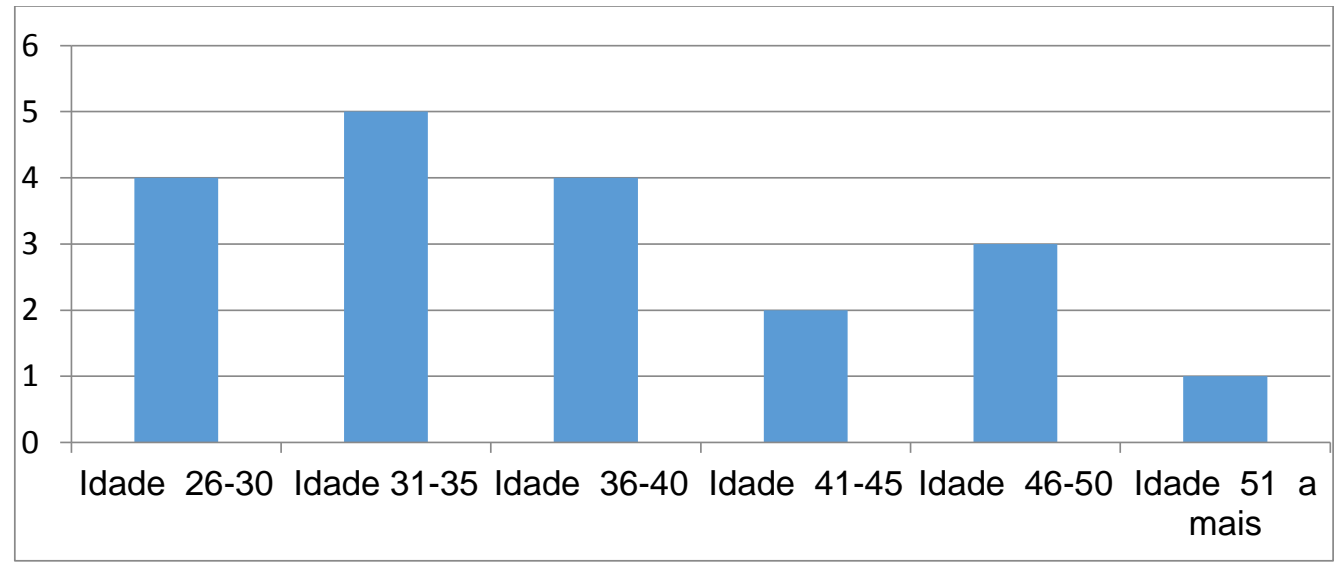

Fonte: Elaborado por Cucchi, 2018.

\footnotetext{
${ }^{7}$ Dados coletados na pesquisa de campo, realizada em junho/2018.

8 Dados coletados na pesquisa de campo, realizada em junho/2018.

9 Dados coletados na pesquisa de campo, realizada em junho/2018.
} 
O quadro de diretores escolares (triênio 2018-2020) dos CMEls é formado com perfil de jovens profissionais da educação, conforme contemplado na caracterização dos sujeitos pesquisados, sendo que, aproximadamente 68\% (sessenta e oito por cento) apresentam idade entre 26 a 40 anos, conforme apresentados no gráfico 1 (um).

A função de diretor escolar dos CMEls, é ocupado atualmente, por um número expressivo de profissionais jovens, entre 26 a 40 anos de idade. São profissionais da educação que atenderam os requisitos da candidatura a função, conforme 0 estabelecido na Lei ํㅡ 3818/2011, de 13 de abril de 2011 e o Decreto Municipal oㅡ 655 , de 30 de outubro de 2017. Ou que foram nomeados pela Secretaria Municipal da Educação para assumir a função de diretor no CMEl.

Exercem a função de direção dos CMEIS, 18 diretoras, o equivalente a 94\%, e 01 (um) diretor, o equivalente a $6 \%$. Sendo majoritariamente uma função ocupada por professoras.

Com relação a escolaridade dos profissionais o índice é expressivo de diretores com Pós-Graduação lato sensu, tanto na área de educação quanto em outras áreas de formação. O gráfico 2 (dois) apresentado na sequência, a representação "PósGraduação 1", significa o número de diretores que possuem a pós-graduação lato sensu na área da educação, o equivalente a 53\%, a representação "Pós-graduação 2", significa o número de diretores que possuem a pós-graduação lato sensu em outra área de formação, o equivalente a $37 \%$, e, $10 \%$ do quadro de diretores possuem graduação.

Gráfico 02 - Escolaridade dos diretores

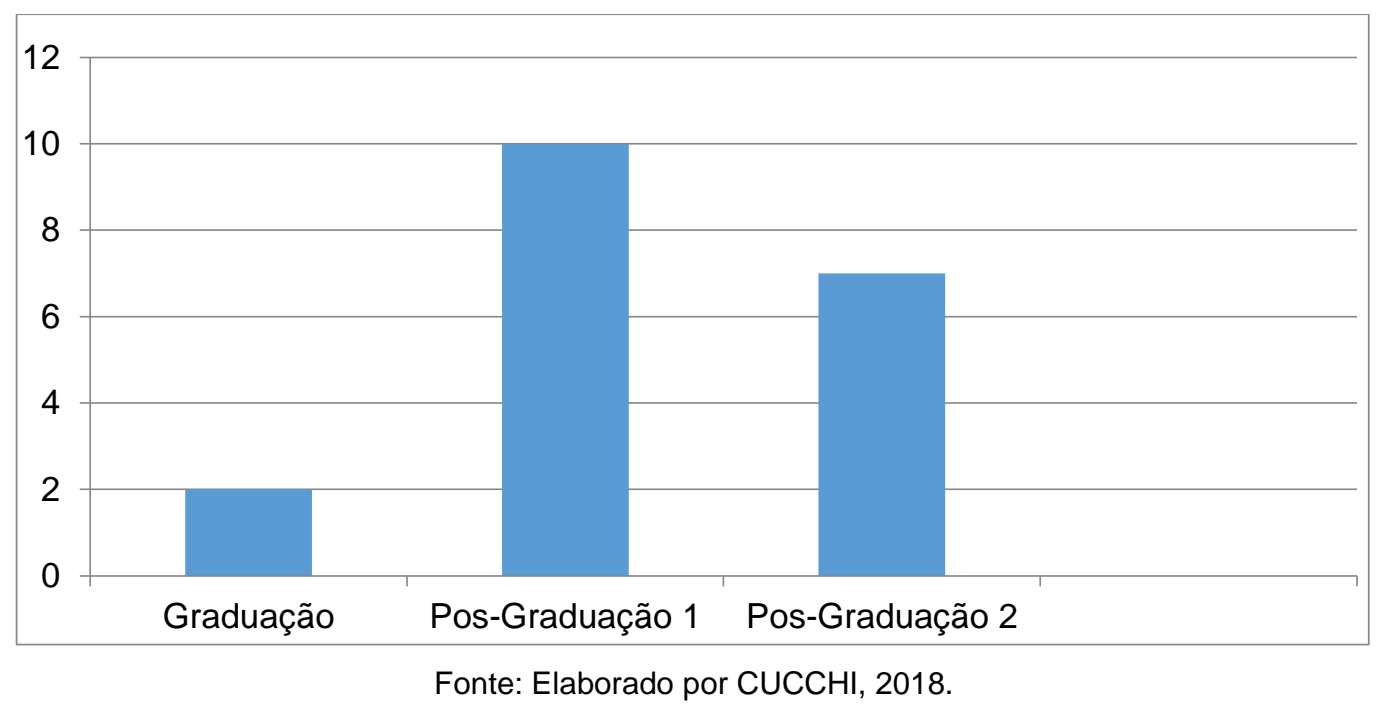

No quadro de diretores dos CMEIS de Francisco Beltrão, com relação a formação acadêmica que há capacitação dos profissionais para o exercício da função. Os quais 
estão, qualificados academicamente. Buscam conhecimentos e informações a respeito da atividade que exercem enquanto diretores na educação infantil.

Cabe registrar, que a normatização e legislação, atendida e praticada nas instituições, segue o disposto pelas instâncias superiores de ensino, a nível estadual e federal. E o acompanhamento das atividades realizadas internas do $\mathrm{CMEI}$, são registradas, formalizadas, e posteriormente, encaminhadas para a Secretaria Municipal de Educação, e aos órgãos superiores, por meio de relatórios e de pareceres.

\subsection{Perspectivas e desafios da atividade do diretor escolar alguns indicativos ${ }^{10}$}

Sobre as principais atribuições do diretor escolar (legais e formais) com relação às atividades que realiza na prática cotidiana no $\mathrm{CMEI}$, os diretores listaram os principais limites, possibilidades, desafios e perspectivas da atividade do diretor escolar no CMEI a partir da prática cotidiana vivenciada. As informações descritas na sequência do texto foram obtidas por meio de questionários, os quais foram respondidos pelos 19 diretores participantes da pesquisa.

Com relação aos limites destacamos dificuldades: a) de acompanhar as atividades desenvolvidas com as crianças; b) de acompanhar os professores no planejamento das atividades pedagógicas; c) de recursos que são escassos; d) de infraestrutura; e) de material pedagógico; f) de envolver os colaboradores, pais e a comunidade nas ações internas e externas promovidas nos CMEIS; g) há falta de vagas para atender a demanda; h) há dificuldade de exercer as funções requeridas e exigidas na prática diária da gestão (coordenação, supervisão, secretária, direção); i) há falta de conhecimento teórico sobre a gestão escolar; j) há falta de comprometimento de alguns colaboradores; I) há morosidade administrativa na resolução de problemas e contratação de serviços essenciais.

Como possibilidades da atividade do gestor escolar, elencamos: a) desenvolvimento de liderança administrativa e pessoal; b) contribuição no processo de ensino e aprendizagem das crianças; c) busca de parcerias com entidades e instituições do poder público e privado; d) gestão adequada e com transparência dos recursos financeiros; e) busca da manutenção do equilíbrio emocional da equipe de colaboradores; f) resolução de conflitos e de situações constrangedoras entre os colaboradores e com os pais; g) valorização dos colaboradores e dos pais no processo de ensino e de aprendizagem; h) reflexão sobre a prática de gestão nos CMEls; i)

\footnotetext{
${ }^{10}$ Registrados conforme dados coletados por meio da aplicação de questionários aos gestores escolares dos Centros Municipais de Educação Infantil (junho/2018).
} 
planejamento de ações de melhoria; j) traçar metas e estratégias para alcançar melhores resultados de desenvolvimento e de aprendizagem das crianças; I) busca de conhecimentos para resolver problemas e ou situações adversas que ocorrem na instituição; m) busca de capacitações/ formação para embasamento teórico sobre o processo de gestão; n) participação em eventos e palestras formativos.

A prática cotidiana vivenciada pelos gestores dos CMEls apresenta alguns desafios: a) dificuldade de proporcionar as crianças um ambiente formativo e acolhedor; b) dificuldade de lidar e de relacionar-se com determinados colaboradores; $c$ ) dificuldade de mobilizar a equipe de trabalho de maneira harmoniosa; d) dificuldade de acompanhar a prática pedagógica dos colaboradores; e) mediar conflitos e interesses adversos na equipe de trabalho; f) lidar com a escassez de recursos financeiros para compra direta de materiais pedagógicos e lúdicos; g) conscientizar os pais e ou responsáveis, da importância da família no acompanhamento e na educação dos seus filhos; h) organizar e manter estruturas físicas deficitárias e inadequadas para a idade das crianças atendidas; i) superar as expectativas da equipe de trabalho, dos pais e da Secretaria Municipal de Educação, com relação a atuação no cargo de gestor; j) resolver situações problemas com o mínimo de tempo, considerando a morosidade administrativa do setor público; I) manter o diálogo e o respeitos com todos os sujeitos envolvidos; m) desenvolver de fato, uma gestão democrática e participativa; n) conciliar todas as funções que são atribuídas e requeridas na prática do gestor escolar do CMEl.

Sobre as perspectivas da gestão no CMEl: a) valorização dos profissionais que atuam diretamente na educação infantil; b) melhorar o processo de ensino e de aprendizagem das crianças atendidas; c) ter a disposição, da gestão escolar do CMEI, uma coordenação pedagógica, que possa auxiliar no planejamento pedagógico dos professores e no acompanhamento das atividades formativas com as crianças; d) dispor de um quadro de colaboradores efetivos, visando diminuir a rotatividade de profissionais; e) ampliar e melhorar a estrutura física, com espaços adequados e apropriados a idade das crianças; f) melhorar a participação dos pais e ou responsáveis nas atividades promovidas e organizadas; g) melhorar a participação dos pais e ou responsáveis no processo de desenvolvimento e de aprendizagem das crianças; h) buscar ampliar o número de parcerias e de apoiadores, bem como, o envolvimento da comunidade local, na busca de melhorias; i) melhorar a qualidade do atendimento prestado as crianças; j) oferecer condições apropriadas de cuidado, higiene e de formação integral a criança; I) propiciar formação e capacitação aos 
colaboradores; m) qualificar e melhorar a qualidade da atuação do gestor, diante de um cenário de adversidades e de desafios diários.

As informações apresentadas sintetizam as contribuições dos 19 diretores, participantes da pesquisa, com relação aos aspectos questionados sobre a atuação no processo de gestão escolar nos CMEls. Assim como, apresentam questões importantes que interferem no processo de gestão escolar e que necessitam serem revistas pela Secretaria Municipal de Educação, visando melhorar a qualidade da educação e o atendimento das crianças do município.

\section{Considerações}

\subsection{Considerações iniciais sobre a pesquisa}

A atuação do diretor escolar, no $\mathrm{CMEI}$, é uma função que exige e requer dedicação exclusiva. Na maioria das instituições pesquisadas ${ }^{11}$, o diretor é o único responsável por realizar as atividades de caráter administrativo, financeiro e pedagógico da instituição. Desta forma, as atividades cotidianas acabam ocupando todo o tempo deste profissional. Há preocupação, da maioria dos diretores, com relação ao acompanhamento dos recursos destinados a manutenção do espaço físico, alimentação, higiene e no atendimento as crianças. Também se destaca nas falas individuais, a importância das parcerias com entidades públicas e privadas, na intenção de melhorar a infraestrutura disponível e na aquisição de materiais pedagógicos e lúdicos para a aprendizagem e desenvolvimento das crianças.

Há esforço dos diretores, em valorizar a família no ambiente escolar e no convívio com as crianças. E também, no engajamento dos pais em cuidar e melhorar o espaço destinado ao cuidado e a educação de seus filhos. As informações mostram a preocupação destes profissionais com a busca de conhecimentos, visando qualificar a atividade de gestão na prática cotidiana. Assim como, o envolvimento que vai além do registrado nos documentos formais da instituição.

Outro registro importante, a considerar, foi à disponibilidade destes professores da educação infantil na função de direção em colaborar com a pesquisa, dedicaram seu tempo para responder ao questionário e as informações solicitadas. Permitiram, assim, conhecer um pouco das atividades desenvolvidas na rotina diária no CMEl.

\footnotetext{
${ }^{11}$ Somente um Centro Municipal de Educação Infantil conta com um profissional de nível médio (técnico administrativo), o qual foi realocado nesta instituição, e auxilia o gestor nas questões administrativas do CMEI.
} 
Os indicativos sobre as atividades mostram as limitações, dificuldades e desafios da prática cotidiana do diretor no exercício da função no CMEI. Nas possibilidades e perspectivas mencionadas, destaque para o esforço destes profissionais em proporcionar um ambiente educativo acolhedor para as crianças, para os profissionais que atuam na instituição e para as famílias das crianças atendidas.

A pesquisa sobre o processo de gestão escolar nos CMEls, pelo estudo de caso de Francisco Beltrão/ PR possibilitou explicitar a atuação do diretor no processo de gestão, com as mais diversas atribuições desenvolvidas, por este profissional, na prática cotidiana do exercício da função. Ressaltando a sobrecarga de atribuições a este profissional, o que interfere na qualidade do trabalho dos diretores no ambiente educativo, considerando que o diretor exerce todas as funções atreladas a gestão escolar da instituição

\section{Referências bibliográficas}

Aquino, Ligia Maria Leão de. (2009). A gestão democrática nas instituições de educação infantil: questões para pensar a formação de gestores. Juiz de Fora: Minas Gerais: Revista Educação em Foco.

Brasil. (2006). Ministério da Educação. Secretaria de Educação Básica. Parâmetros Nacionais de Qualidade para a Educação Infantil. Vol. 2. Brasília: MEC, SEB.

Freire, Adriani. (1999). Formação de educadores em serviço: Construindo sujeitos, produzindo singularidades. In Kramer, Sonia; Leite, Maria Isabel; Nunes, Maria Fernanda; Guimarães, Daniela. (Orgs.). Infância e Educação Infantil. Campinas, SP: Papirus.

Libâneo, José Carlos. (2008). Organização e gestão da escola: teoria e prática. Goiânia: MF Livros.

Luz, Ana Maria de Carvalho; Jesus, Tércio Rios de. (2006). A formação de gestores educacionais: desafios e perspectivas de saberes em construção. Salvador: ISP/ UFBA.

Morgado, José Carlos. (2012). O estudo de caso na investigação em educação. Portugal: De facto editores.

Oliveira, Dalila Andrade. (2008). Mudanças na organização e na gestão do trabalho na escola. In: Oliveira, Dalila Andrade (Org.). Política e gestão da educação. Belo Horizonte: Autêntica.

Sanches, Emília Cipriano. (2003). Creche: realidade e ambiguidades. Petrópolis, RJ: Vozes.

Yin, Robert K. (2001). Estudo de caso: planejamento e métodos. Porto Alegre: Bookman. 


\title{
A Geografia na espacialização dos Centros Municipais de Educação Infantil em Francisco Beltrão - Paraná - Brasil
}

\author{
ANDREIA ZUCHELLI CUCCHI ${ }^{1}$ \\ MAFALDA NESI FRANCISCHETT ${ }^{2}$
}

\section{Resumo}

Este texto apresenta aspectos sobre o papel da Geografia no processo da distribuição espacial, de implantação dos primeiros Centros Municipais de Educação Infantil (CMEls), em Francisco Beltrão/Paraná/Brasil. Foi de 1980 a 2017, num período de 37 anos, quando iniciaram os primeiros CMEls, no bairro Miniguaçu, mantidos pela Associação de Proteção a Maternidade e a Infância (APMI) Dr. Haroldo Beltrão, entidade sem fins lucrativos, que por meio de suas ações proporcionava alimentação e cuidados às crianças de 0 (zero) a 6 (seis) anos de idade. Atualmente o município de Francisco Beltrão, possui 19 CMEls, atendem aproximadamente 2180 crianças, localizados em 18 bairros e 01 (um) na área central. A metodologia da pesquisa se caracteriza por análise documental, com o propósito de resgatar o processo histórico e identificar de que modo a Geografia se apresenta no processo de criação dos CMEls do município.

Palavras-chave: geografia; educação infantil; história; proteção.

\section{Abstract}

This text presents the aspects about the Geography's role on the spatial distribution process, firsts implantation of Municipality's Centers of the Children's Education (Centro Municipal de Educação Infantil - CMEls), in Francisco Beltrão/Paraná/Brazil. Since 1980 to 2017, period of 37 years, when started the firsts CMEls, in Miniguaçu

\footnotetext{
${ }^{1}$ Mestranda em Educação, Universidade Estadual do Oeste do Paraná - Unioeste/ Campus de Francicso Beltrão, andreiazu@yahoo.com.br

2 Professora Orientadora do Mestrado em Educação, Universidade Estadual do Oeste do Paraná - Unioeste/ Campus de Francicso Beltrão, mafalda@wln.com.br
} 
neighborhood, were kept by Association for Maternity and Child Protection (Associação de Proteção à Maternidade e a Infância - APMI) Dr. Haroldo Beltrão, organization without lucratively, that in between the action's provided feeding and child's care since 0 (zero) that 6 (six) years old. The Francisco Beltrão municipality, have $19 \mathrm{CMEls}$, attended approximately 2180 children, to localize in 18 neighborhood's and 01 (one) in central area. The methodology's research is characterized by documental analysis, with purpose of redeeming the historic process and identification that Geography's mode features in the process.

Keywords: geography; children's education; history; protection.

\section{Introdução}

A proposta do texto objetiva resgatar o processo histórico e identificar de que modo a Geografia se apresenta no processo de criação dos CMEls do município. A metodologia de pesquisa se caracteriza por análise documental, a qual foi realizada por meio de análise de documentos arquivados e de registrados na Secretaria Municipal de Educação de Francisco Beltrão (SME/FB). Mais a Base Nacional Comum Curricular da Educação Infantil (2018) com relação aos conhecimentos de Geografia direcionados a formação da criança na educação infantil.

A Geografia desempenhou importante contribuição no processo de criação dos CMEls, em Francisco Beltrão - Paraná - Brasil. A implantação dos primeiros, denominados creches, ocorreu a partir do ano de $1980^{3}$ nas regiões periféricas e com maior concentração de habitantes. Em 1980, Francisco Beltrão contava com uma população de 48.762 habitantes ${ }^{4}$.

A atividade de implantação visava contemplar os bairros periféricos, com maior concentração de população carente e tinha como objetivo proporcionar atividades de proteção e de assistência às crianças menores de idade. Assim como, assistir as crianças com problemas de saúde e controlar as epidemias contagiosas, que se propagavam com maior intensidade nas áreas com maior concentração de pessoas. A proliferação das epidemias, na maioria das vezes, ocorria pela falta de saneamento básico, de água tratada e de rede de esgoto.

\footnotetext{
${ }^{3}$ Inaugurado em 10 de dezembro de 1980, a creche Nice Braga - bairro Miniguaçu.

${ }^{4}$ IBGE. Disponível em http://www.mineropar.pr.gov.br/arquivos/File/economia_mineral/ Populacao_Censitaria_do_Parana_por_municipio_1980_a_2010.pdf. Acesso em 02 de janeiro de 2019.
} 
Desta forma, a Geografia se apresenta no processo pela distribuição espacial, devido à criação dos primeiros CMEls estarem centrados nas atividades de proteção e de assistência as crianças de famílias com condições de renda inferiores. Como forma de garantir a criança a possibilidade de receber atendimento, assistência e proteção. Destaque para a formação cidadã, na prática dos direitos e deveres do sujeito.

Os direitos e os deveres do cidadão implicam, necessariamente, numa obrigação do poder público. Trata-se de um conjunto de meios, de recursos e de práticas que dá à criança a possibilidade de participar ativamente da vida e receber formação. A ação cidadã possibilita a participação social, na qual ela está inserida.

Nesta intenção, o poder público, por meio de parcerias com entidades, no caso a Associação de Proteção à Maternidade e Infância - APMI promoveu a implantação dos CMEls, como forma de garantir condições de saúde, proteção e assistência às crianças das classes sociais menos favorecidas, como forma de garantir que as crianças condições dignas de cuidados e proteção. Os CMEls foram sendo implantados de maneira gradativa nos bairros, devido a demanda de outras questões como saneamento básico, com água tratada, rede de esgoto e coleta de lixo, pavimentação de ruas e estruturação urbana condizente e adequada com a oferta do serviço público a população do local. E estas questões, dependiam e ainda dependem da disponibilidade de investimentos do poder público municipal e dos poderes, estadual e federal.

\section{A Geografia na espacialização dos CMEls em Francisco Beltrão/PR}

\section{O município de Francisco Beltrão/Paraná/Brasil}

O município de Francisco Beltrão foi criado oficialmente no dia 14 de dezembro de 1952 e em 1980 apresentava uma população estimada em 48762 habitantes. Em junho de 2017, sua população era de 88.465 pessoas (IBGE). Localizado geograficamente na região sudoeste do estado do Paraná - Brasil. 
Mapa 1 - Localização de Francisco Beltrão no estado do Paraná

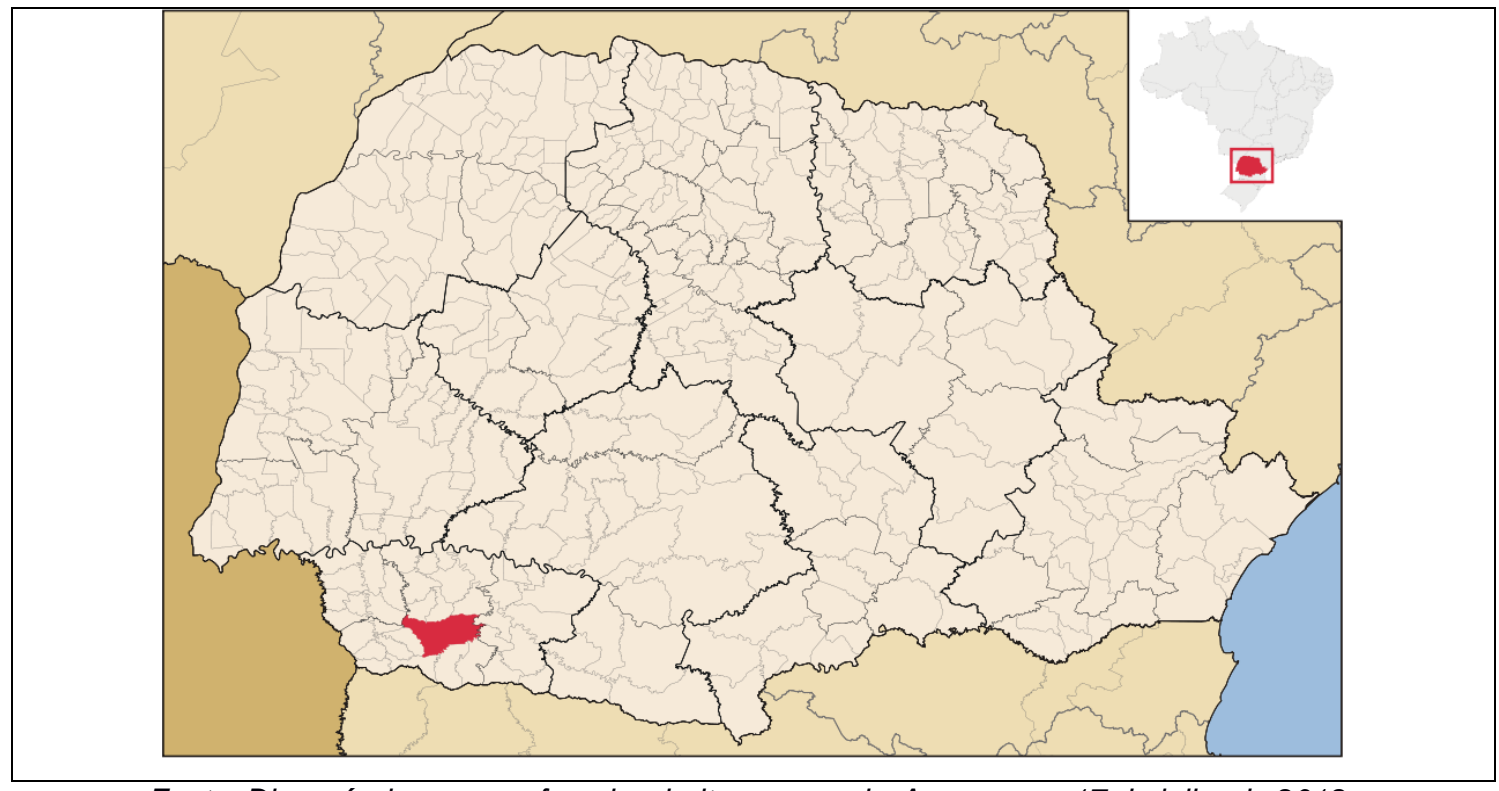

Fonte: Disponível em: www.franciscobeltrao.pr.gov.br Acesso em: 17 de julho de 2018.

O destaque, no município, é para o setor de serviços, comércio, indústria e atividades do agronegócio. Criação de aves para exportação e produção de grãos, principalmente soja e milho. Destaque ainda, para o setor de educação, pública e privada, com oferta de cursos nas diversas áreas de formação. Com relevante contribuição da Universidade Estadual do Oeste do Paraná, na oferta de cursos de pós-graduação em nível de mestrado e doutorado. E outras instituições públicas e particulares de ensino.

Na sequência, imagem da área urbana do município.

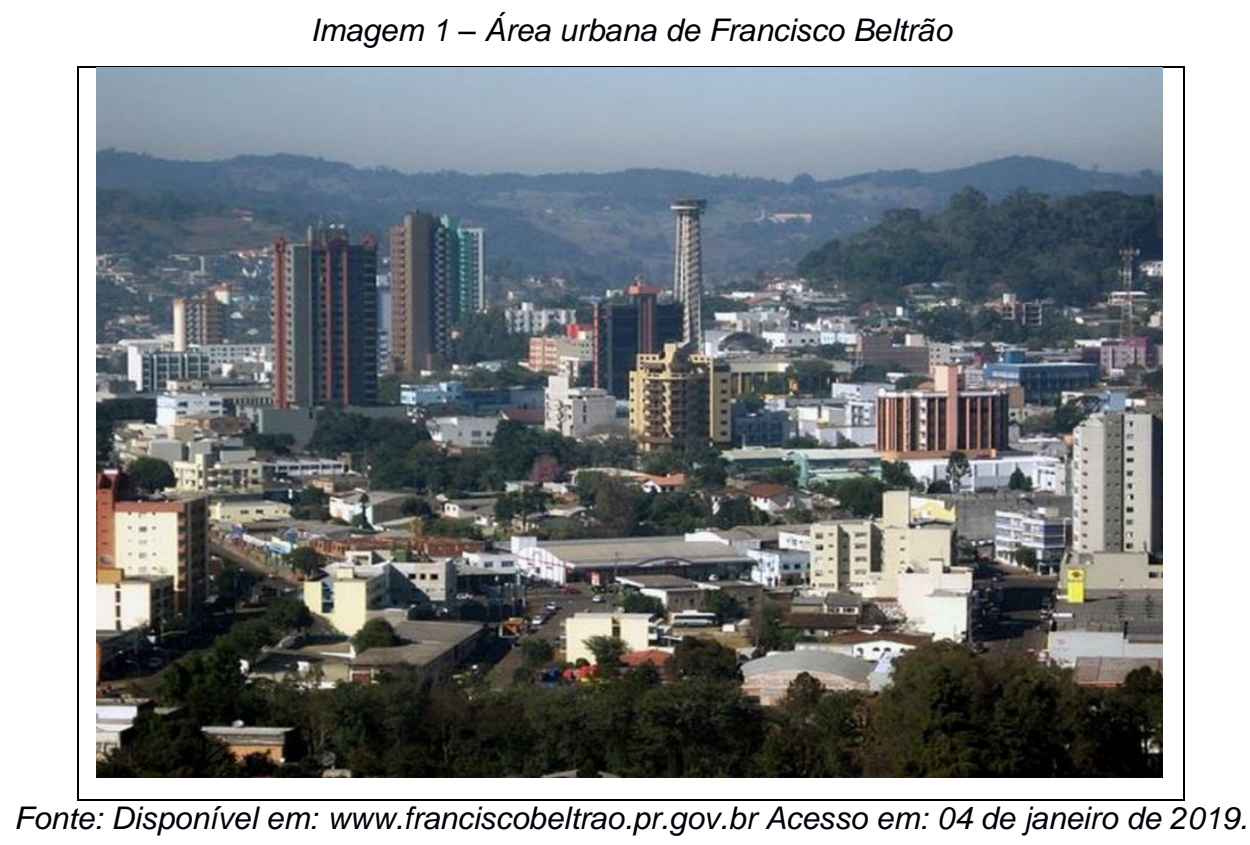


Destaque ainda no município, para as atividades de preservação de áreas nativas e para as pequenas propriedades da agricultura familiar. As quais realizam o cultivo da terra, tendo como mão de obra, o núcleo familiar e produzem alimentos orgânicos para o consumo e comercialização. Há um trabalho importante realizado pela Secretaria Municipal de Agricultura e Meio Ambiente que consiste na preservação de fontes e nascentes de água no município. (FRANCISCO BELTRÃO, 2019).

\section{Contextualização da educação infantil em Francisco Beltrão/PR}

O município de Francisco Beltrão/ PR iniciou as atividades com as crianças que compreende a faixa etária do nascimento até os 3 (três) anos em 1980, quando inaugurou a primeira Creche ${ }^{5}$ denominada de Nice Braga, situada no bairro Miniguaçu, em Francisco Beltrão/PR. Nos anos seguintes, foram sendo criadas as demais instituições, as quais inicialmente eram implantadas, considerando a necessidade de criar espaços de acolhimento e assistência as crianças mais necessitadas do município, tendo em vista, que muitas mães executavam atividades externas ao lar e precisavam de um local apropriado para deixar seus filhos.

O quadro 1 (um) na sequência, apresenta a ordem cronológica por ano da implantação das primeiras creches do município.

Quadro 1 - Criação das primeiras creches do município (1980 a 1983)

\begin{tabular}{|c|c|c|}
\hline $\begin{array}{l}\text { Ano de } \\
\text { Criação }\end{array}$ & Localização & Nome da Creche/ CMEI \\
\hline 1980 & Bairro Miniguaçu & $\begin{array}{l}\text { Creche Nice Braga } \\
\text { Atual CMEI Nice Braga }\end{array}$ \\
\hline 1980 & Bairro Entre Rios & Creche Lea Sanderson Camilotti \\
\hline 1980 & Bairro Cango & $\begin{array}{l}\text { Creche Maria Helena Vandresen (Centro Social Maria Helena } \\
\text { Vandresen) } \\
\text { Atual CMEI Pequeno Príncipe }\end{array}$ \\
\hline 1982 & Bairro Industrial & Creche Industrial \\
\hline 1983 & Bairro São Miguel & $\begin{array}{l}\text { Creche São Miguel } \\
\text { Atual CMEl Carrossel }\end{array}$ \\
\hline
\end{tabular}

Elaborado por CUCCHI, 2018.

Com relação à criação dos Centros Municipais de Educação Infantil (CMEI), foi inaugurado em 10 de novembro de 1980, pelo Senhor governador Nei Amintas Braga e pela Senhora Nice Braga, a primeira creche do município no bairro Miniguaçu, a qual ganhou o nome de "Creche Nice Braga", em homenagem a primeira dama do governo do estado. De 1980 a 1983 foram implantadas cincos creches no município, sendo elas: Creche Nice Braga (1980), junto ao Centro Social Urbano (atual Casa Abrigo

\footnotetext{
${ }^{5}$ Creche Nice Braga - Bairro Miniguaçu.
} 
Anjo Gabriel) no bairro Miniguaçu (depois em 1990 a Creche Nice Braga ganhou espaço próprio no mesmo bairro), Creche Léa Sanderson Camilotti ${ }^{6}$ (1980-1983), no bairro Entre Rios, Creche Maria Helena Vandresen ${ }^{7}$ (1980), no bairro da Cango, Creche Industrial $^{8}$, no bairro Industrial (1982-1984) e Creche São Miguel $^{9}$ (1983) no bairro São Miguel. Nos anos seguintes, houve a desativação da Creche Léa Sanderson Camilotti, no bairro Entre Rios (1983) e da Creche do bairro Industrial (1984).

As primeiras creches implantadas no período de 1980 a 1983, visaram garantir condições de sáude, proteção e assistência às crianças das classes sociais menos favorecidas. Nestes bairros, o poder municipal necessitou investir em saneamento básico, com água tratada, rede de esgoto e coleta de lixo, pavimentação de ruas e estruturação urbana condizente e adequada com a oferta do serviço público a população do local. O que proporcionou transformações no espaço geográfico do local e contribuiu para o desenvolvimento econômico e social do bairro.

Durante vários anos, as atividades realizadas com as crianças tinham como objetivo, o cuidado e a assistência. Nesta época (1980-1998) o acompanhamento das instituições municipais de educação infantil era realizado pela Associação de Proteção, Maternidade e Infância - Dr. Haroldo Beltrão - APMI ${ }^{10}$, entidade sem fins lucrativos, que trabalhava em parceria com a Secretaria Municipal de Assistencia Social, igrejas, empresas e órgãos governamentais.

Com a aprovação da Lei 9394/1996, as instituições municipais de educação infantil, passaram por algumas alterações, dentre elas, o acompanhamento da gestão pedagógica e administrativa das instituições de educação infantil, sendo que a coordenação e organização da dinâmica desenvolvida nos CMEls passaram a ser gerida pela Secretaria Municipal de Educação.

Consequentemente, as atividades relacionadas ao processo educativo e assistencial adotado nas instituições municipais de educação infantil, passou a atender aos

\footnotetext{
${ }^{6}$ A Creche Lea Sanderson Camilotti no bairro Entre Rios foi instalada nas antigas estruturas do Colégio Bom Pastor, sendo desativada em 1983.

${ }^{7}$ A Creche Maria Helena Vandresen foi implantada inicialmente na estrutura do Colégio Frei Deodato em 1980. Sendo que em janeiro de 1983, começa a atender na sede própria.

${ }^{8}$ A Creche Industrial funcionou em casa alugada para a atividade, sendo o inicio das atividades em 15/06/1982 e desativada em 1984

${ }^{9}$ A Creche São Miguel iniciou suas atividades em novembro de 1983, sendo que atendia inicialmente em espaço cedido pela Igreja Adventista, depois em espaço cedido pela igreja católica no Centro Comunitário da Igreja São Sebastião até a inauguração de sede própria em 1985, atendendo principalmente as crianças mais carentes.

${ }^{10}$ Entidade sem fins lucrativos, criada em 1952 por um grupo de senhoras da sociedade, que buscava em suas ações, parcerias com entidades publicas e privadas para manter em funcionamento as creches da cidade.
} 
objetivos atrelados ao educar e ao cuidar das crianças desde o nascimento até os 3 (três) anos de idade.

A partir de 1990 ocorre a criação do CMEI Marli Abdala no bairro Pinheirinho (1990); CMEI Diva Martins no bairro Padre Ulrico (1991); CMEI Nancy Pinto de Moraes no bairro Alvorada (1992); CMEI Zelir Vetorello no bairro Jardim Floresta (1993); CMEI Professora Ivanir de Albuquerque no bairro Cristo Rei (1994); CMEI Sonho Meu, no bairro Pinheirinho (1994); CMEI Mater Day ${ }^{11}$, no bairro Luther King (1996); CMEI Herbet de Souza "Betinho", bairro Padre Ulrico (1998); CMEI Idalino Rinaldi, bairro Sadia (2000); CMEI Delfo João Fregonese, bairro Industrial (2000); CMEI Mundo Encantado, bairro Novo Mundo (2004); CMEl Cantinho do Céu, bairro Marrecas (2009); CMEI Dalva Paggi Claus, Bairro Luther King (2011); CMEI Professora Carmen Vargas Vanin, bairro Cantelmo (2014); CMEI Luiz Carlos da Silva - Tio Didio, bairro Jardim Seminario (2015), CMEI Aqaurela, centro (2017) e CMEI Arco Iris, bairro Alvorada (2017).

Os CMEls atendem cerca de $2180^{12}$ crianças de 0 (zero) a 3 (três) anos de idade, ofertando alimentação, higiene, cuidado e educação, nos 19 Centros Municipais de Educação Infantil, situados nos bairros e na área central da cidade.

Os CMEIS de Francisco Beltrão/PR são destaque pela qualidade pedagógica e na valorização dos profissionais que atuam nestas instituições. A um esforço coletivo da Secretaria Municipal de Educação em parceria com o poder executivo municipal, na criação de novas unidades de CMEls, visando sanar a lista de espera por vagas e atender a população que necessita de vagas para matricular as crianças da faixa etária atendida.

Na sequência, o mapa dos bairros de Francisco Beltrão/PR.

\footnotetext{
${ }^{11}$ Em 1998 houve a desativação do Centro e as crianças passam a serem atendidas no Centro Municipal de Educação Infantil Pequeno Príncipe, no bairro da Cango.

${ }^{12}$ Dados da pesquisa realizada em junho de 2018.
} 
Mapa 2 - Mapa dos bairros de Francisco Beltrão/ PR

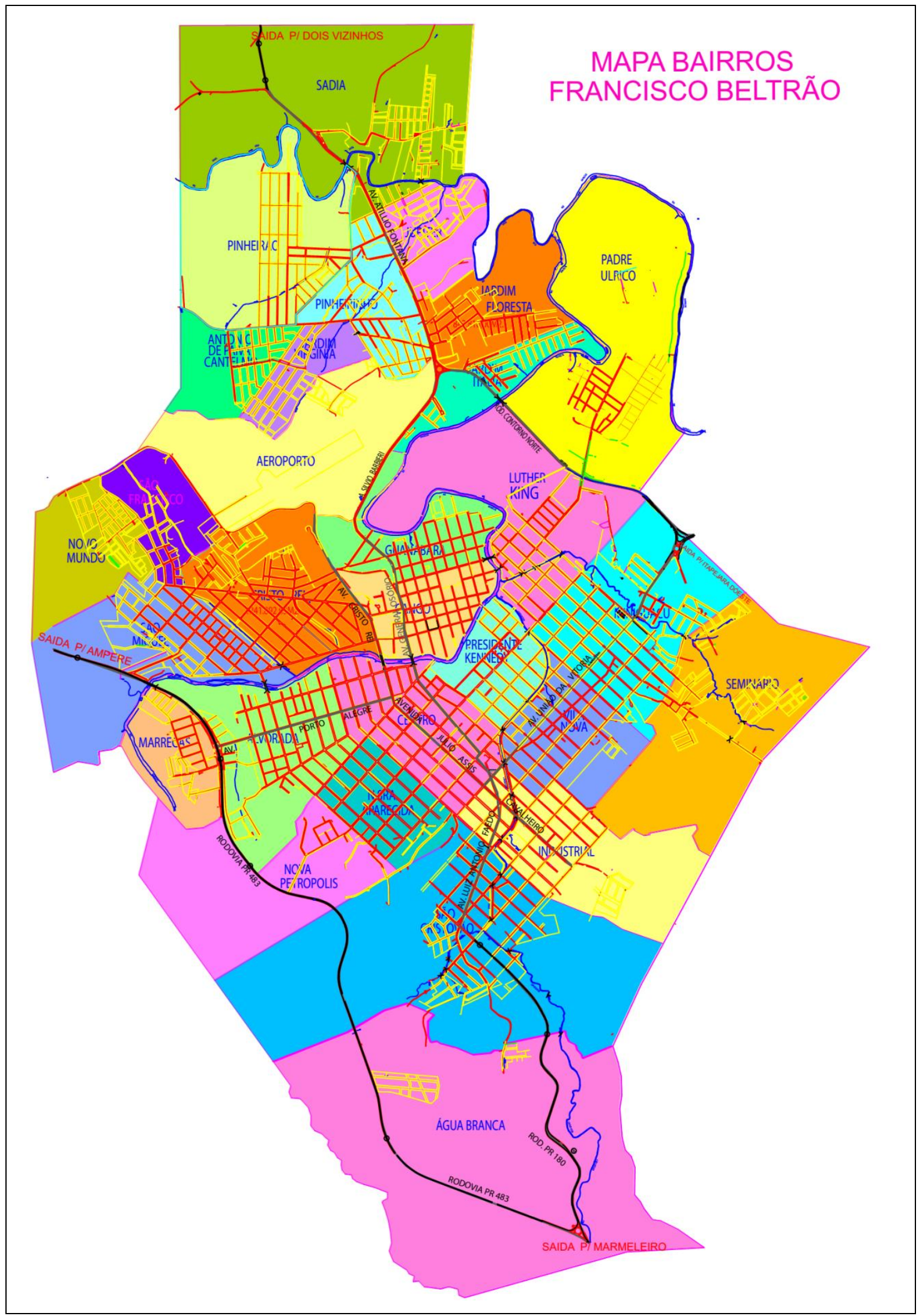

Fonte: www.franciscobeltrao.pr.gov.br. Acesso em 04 de janeiro de 2019. 
No quadro 2, na sequência apresenta-se os CMEIS do município, considerando o seu ano de criação e o bairro de localização.

Quadro 2 - Ano de criação/ localização dos CMEls (1980 a 2017)

\begin{tabular}{|c|c|c|}
\hline $\begin{array}{l}\text { Ano de } \\
\text { Criação }\end{array}$ & Localização & Nome da Creche/ CMEI \\
\hline 1980 & Bairro Miniguaçu & $\begin{array}{l}\text { Creche Nice Braga } \\
\text { Atual CMEI Nice Braga }\end{array}$ \\
\hline 1980 & Bairro Entre Rios & Creche Lea Sanderson Camilotti \\
\hline 1982 & Bairro Industrial & Creche Industrial \\
\hline 1980 & Bairro Cango & $\begin{array}{l}\text { Creche Maria Helena Vandresen (Centro Social Maria Helena } \\
\text { Vandresen) } \\
\text { Atual CMEI Pequeno Príncipe }\end{array}$ \\
\hline 1983 & Bairro São Miguel & $\begin{array}{l}\text { Creche São Miguel } \\
\text { Atual CMEI Carrossel }\end{array}$ \\
\hline 1990 & Bairro Pinheirinho & $\begin{array}{l}\text { Creche Marli Abdala } \\
\text { Atual CMEI Marli Abdala }\end{array}$ \\
\hline 1991 & Bairro Padre Ulrico & $\begin{array}{l}\text { Creche Diva Martins } \\
\text { Atual CMEI Diva Martins }\end{array}$ \\
\hline 1992 & Bairro Alvorada & $\begin{array}{l}\text { Creche Nancy Pinto de Moraes } \\
\text { Atual CMEI Nancy Pinto de Moraes }\end{array}$ \\
\hline 1993 & Bairro Jardim Floresta & $\begin{array}{l}\text { Creche Zelir Vetorello } \\
\text { Atual CMEI Zelir Vetorello }\end{array}$ \\
\hline 1994 & Bairro Cristo Rei & $\begin{array}{l}\text { Creche Criança Esperança } \\
\text { Atual CMEI Professora Ivanir de Albuquerque }\end{array}$ \\
\hline 1994 & Bairro Pinheirinho & $\begin{array}{l}\text { Creche Recanto Feliz, junto ao CAIC } \\
\text { Atual CMEI Sonho Meu }\end{array}$ \\
\hline 1996 & Bairro Luther King & Creche Mater Day \\
\hline 1998 & Bairro Padre Ulrico & $\begin{array}{l}\text { Creche Herbet de Souza "Betinho" } \\
\text { Atual CMEl Herbet de Souza "Betinho" }\end{array}$ \\
\hline 2000 & Bairro Sadia & $\begin{array}{l}\text { Creche Idalino Rinaldi } \\
\text { Atual CMEI Idalino Rinaldi }\end{array}$ \\
\hline 2000 & Bairro Industrial & $\begin{array}{l}\text { Creche Delfo João Fregonese } \\
\text { Atual CMEI Delfo João Fregonese }\end{array}$ \\
\hline 2004 & Bairro Novo Mundo & CMEI Mundo Encantado \\
\hline 2009 & Bairro Marrecas & CMEI Cantinho do Céu \\
\hline 2011 & Bairro Luther King & CMEl Dalva Paggi Claus \\
\hline 2014 & Bairro Cantelmo & CMEI Professora Carmen Vargas Vanin \\
\hline 2015 & Bairro Seminário & CMEI Luiz Carlos da Silva - Tio Didio \\
\hline 2017 & Centro & CMEI Aquarela \\
\hline 2017 & Bairro Alvorada & CMEI Arco Iris \\
\hline
\end{tabular}

Os dados do quadro 2 (dois) mostram a criação dos Centros Municipais de Educação Infantil, nos bairros, considerando a cronologia do tempo (1980 a 2017). Percebe-se que a educação infantil do município tem ganhado destaque, nos últimos anos, por meio da implantação de uma estrutura pedagógica direcionada ao cuidado e a educação das crianças. Os professores são selecionados por meio de concurso público, sendo exigida formação acadêmica dos profissionais na área da educação, assim como formação continuada, primando pelo bem estar, cuidado e formação integral da criança. 
As leis e normatizações que asseguram a qualidade na educação infantil são priorizadas pela equipe de acompanhamento da educação infantil, assim como, em todo o processo de gestão realizado nos CMEls.

\section{A importância da Geografia na educação infantil}

\section{A contribuição da Geografia na criação dos CMEls}

A importância da Geografia consiste na compreensão da transformação e na ocupação do espaço geográfico. Desta forma, conhecer implica no entendimento do espaço, tempo e movimento e de como o processo é produzido e transformado pelo homem ao longo da História.

O ensino de geografia nos CMEls provoca o desenvolvimento cultural, social da criança por meio do reconhecimento do local. Proporcionando melhoria na qualidade de vida das crianças e das famílias atendidas bem como dinamizam o papel social e educativo, ao ofertar atendimento voltado à formação da criança a partir do seu nascimento.

A Base Nacional Comum Curricular da Educação Infantil (2018) estabelece que a Educação Infantil seja o início e o fundamento do processo educativo das crianças, sendo que a geografia exerce papel importante ao auxiliar a criança no desenvolvimento e na forma de conhecer e de transformar o mundo a sua volta.

Desta forma, a entrada da criança na creche ou na pré-escola significa, na maioria das vezes, a primeira separação dos seus vínculos afetivos familiares para se incorporarem a uma situação de socialização estruturada.

Consolida na Educação Infantil, a concepção que vincula educar e cuidar, entendendo o cuidado como algo indissociável do processo educativo. Nesse contexto, as creches e pré-escolas, ao acolher as vivências e os conhecimentos construídos pelas crianças no ambiente da família e no contexto de sua comunidade, e articulá-los em suas propostas pedagógicas, têm o objetivo de ampliar o universo de experiências, conhecimentos e habilidades dessas crianças, diversificando e consolidando novas aprendizagens, atuando de maneira complementar a educação familiar especialmente quando se trata da educação dos bebês e das crianças bem pequenas, que envolve aprendizagens muito próximas aos dois contextos (familiar e escolar), como a socialização, a autonomia e a comunicação. 
A contribuição da Geografia de acordo com a Base Nacional Comum Curricular da Educação Infantil (2018) é uma oportunidade para a criança de compreender o mundo em que se vive, na medida em que esse componente curricular aborda as ações humanas construídas nas distintas sociedades existentes nas diversas regiões do planeta. Ao mesmo tempo, a educação geográfica contribui para a formação do conceito de identidade, expresso de diferentes formas: na compreensão perceptiva da paisagem, que ganha significado à medida que, ao observá-la, nota-se a vivência dos indivíduos e da coletividade; nas relações com os lugares vividos; nos costumes que resgatam a nossa memória social; na identidade cultural; e na consciência de que somos sujeitos da história, distintos uns dos outros e, por isso, convictos das nossas diferenças. (BASE NACIONAL CURRICULAR COMUM DA EDUCAÇÃO INFANTIL, 2018).

A proposta de conteúdos da Geografia visa trabalhar a questão dos espaços, tempos, quantidades, relações e transformações, objetivando identificar, nomear adequadamente e comparar as propriedades dos objetos, estabelecendo relações entre eles; interagir com o meio ambiente e com fenômenos naturais ou artificiais, demonstrando curiosidade e cuidado com relação a eles; utilizar vocabulário relativo às noções de grandeza (maior, menor, igual etc.), espaço (dentro e fora) e medidas (comprido, curto, grosso, fino) como meio de comunicação de suas experiências; utilizar unidades de medida (dia e noite; dias, semanas, meses e ano) e noções de tempo (presente, passado e futuro; antes, agora e depois), para responder a necessidades e questões do cotidiano; identificar e registrar quantidades por meio de diferentes formas de representação (contagens, desenhos, símbolos, escrita de números, organização de gráficos básicos etc.).

Quadro 3 - Objetivos, conteúdos e estratégias para trabalhar a Geografia na educação infantil13

\begin{tabular}{|c|c|c|}
\hline \multicolumn{3}{|c|}{ Berçário/ Maternal I e II - Ciências Naturais } \\
\hline Objetivos & Conteúdos & Estratégias \\
\hline $\begin{array}{l}\text { Perceber elementos da } \\
\text { paisagem a fim de que } \\
\text { as crianças observem o } \\
\text { meio em que vivem }\end{array}$ & \begin{tabular}{l}
\multicolumn{2}{l}{ Lugares e paisagens } \\
-Mudanças nas \\
paisagens
\end{tabular} & $\begin{array}{l}\text {-Passeio: exploração da paisagem da instituição } \\
\text { e vizinhança. } \\
\text {-Gravuras de paisagens, conversando sobre as } \\
\text { características, transformações e preservação, } \\
\text { construindo painéis. }\end{array}$ \\
\hline $\begin{array}{l}\text { Explorar os diferentes } \\
\text { tipos de objetos e } \\
\text { materiais a fim de que, } \\
\text { através do contato, as } \\
\text { crianças desenvolvem a } \\
\text { percepção e autonomia. }\end{array}$ & $\begin{array}{l}\text { Objetos e processos de } \\
\text { transformação } \\
\text {-Vivenciar o processo } \\
\text { de transformação de } \\
\text { objetos e materiais }\end{array}$ & $\begin{array}{l}\text { - Confecção de brinquedos } \\
\text {-Organização dos brinquedos (autonomia). } \\
\text {-Mistura de tintas/textura, } \\
\text {-Objetos que produzem sons: brinquedos, } \\
\text { talheres, bandinhas. } \\
\text {-Exploração de areia/som, textura, construção de } \\
\text { castelos... }\end{array}$ \\
\hline Perceber o movimento & Fenômeno da natureza & -Observação do sol (luz, calor...), da chuva \\
\hline
\end{tabular}

${ }^{13}$ Quadro elaborado a partir do Projeto Político Pedagógico do Centro Municipal de Educação Infantil, Delfo João Fregonese - Bairro Industrial (2015). 


\begin{tabular}{|c|c|c|}
\hline $\begin{array}{l}\text { da natureza e seus } \\
\text { fenômenos a fim de fazer } \\
\text { a relação dos } \\
\text { acontecimentos com a } \\
\text { vida, educando os } \\
\text { sentidos. }\end{array}$ & $\begin{array}{l}\text {-Fenômenos naturais: } \\
\text { água, ar, sol, chuva, } \\
\text { geada, dia e noite, } \\
\text { estações do ano. }\end{array}$ & $\begin{array}{l}\text { (som, intensidade...), da geada (forma, cor, } \\
\text { temperatura...), da água (cheiro, cor, forma...), } \\
\text { do ar (pressão: encher balão, sacos plásticos, } \\
\text { estourar...). } \\
\text {-Observação do dia e da noite no real, em } \\
\text { painéis e em literatura. } \\
\text {-Observação do clima, meses, frutas, flores, } \\
\text { mudanças nas árvores... (Literatura infantil, } \\
\text { painéis). }\end{array}$ \\
\hline $\begin{array}{l}\text { Observar algumas } \\
\text { características das } \\
\text { espécies de seres vivos } \\
\text { e suas necessidades } \\
\text { vitais a fim de perceber } \\
\text { os grupos e preservar o } \\
\text { meio }\end{array}$ & $\begin{array}{l}\text { Seres vivos } \\
\text {-Ser humano } \\
\text {-Animais } \\
\text {-Vegetais } \\
\text {-Meio ambiente }\end{array}$ & $\begin{array}{l}\text {-Espelho: exploração das partes do corpo. } \\
\text {-Recorte de figuras de pessoas (revista, jornais, } \\
\text { panfletos...). } \\
\text {-Desenho em papel pardo do corpo da criança, } \\
\text { da professora. } \\
\text {-Conversa e práticas sobre os cuidados com o } \\
\text { corpo (banho, higiene bucal...) } \\
\text {-Conhecimento de alguns animais através de } \\
\text { histórias, explorando características, cuidados e } \\
\text { preservação. dos } \\
\text {-Painel com animais domésticos. } \\
\text {-Experiências: desenvolvimento } \\
\text { vegetais/necessidades } \\
\text {-Partes dos vegetais. } \\
\text {-Passeios, filmes, histórias, cuidados } \\
\text { necessários à preservação da vida e do meio } \\
\text { ambiente. }\end{array}$ \\
\hline \multicolumn{3}{|c|}{ Pré-Escola - Ciências Naturais } \\
\hline Objetivos & Conteúdo & Estratégias \\
\hline $\begin{array}{l}\text { Perceber elementos da } \\
\text { paisagem do lugar onde } \\
\text { vive, a fim de possibilitar } \\
\text { a compreensão da } \\
\text { realidade social, } \\
\text { modificações e as } \\
\text { transformações diversas } \\
\text { em função da ação } \\
\text { humana. }\end{array}$ & \begin{tabular}{l}
\multicolumn{2}{l}{ Lugares e Paisagens } \\
-Mudanças nas \\
paisagens \\
-Elementos \\
paisagem
\end{tabular} & $\begin{array}{l}\text {-Exploração da paisagem da instituição e } \\
\text { vizinhança (transformações ocorridas) } \\
\text {-Gravuras de paisagens. Conversando sobre as } \\
\text { características e preservação (painéis). } \\
\text { - Observação das mudanças realizadas pelo e } \\
\text { para o homem no espaço em que vive. }\end{array}$ \\
\hline $\begin{array}{l}\text { Explorar os diferentes } \\
\text { tipos de objetos e } \\
\text { materiais a fim de } \\
\text { perceber características, } \\
\text { propriedades, funções e } \\
\text { uso em diferentes } \\
\text { contextos. }\end{array}$ & $\begin{array}{l}\text { Objetos e processos de } \\
\text { transformação } \\
\text {-Propriedades } \\
\text { características e } \\
\text { objetos e materiais } \\
\begin{array}{l}\text { produzidos } \\
\text { diferentes épocas }\end{array} \\
\end{array}$ & $\begin{array}{l}\text {-Confecção de brinquedos-Objetos que } \\
\text { produzem sons: brinquedos, bandinhas, } \\
\text { talheres... } \\
\text {-Construção de brinquedos } \\
\text {-Mistura de tintas (operacionalizar em atividade: } \\
\text { mural, painel, madeira...) }\end{array}$ \\
\hline $\begin{array}{l}\text { Conhecer algumas } \\
\text { espécies da fauna e da } \\
\text { flora, distinguir algumas } \\
\text { características das } \\
\text { espécies dos seres vivos } \\
\text { e suas necessidades } \\
\text { vitais, a fim de perceber } \\
\text { cuidados necessários à } \\
\text { preservação da vida e do } \\
\text { meio ambiente. }\end{array}$ & $\begin{array}{l}\text { Seres vivos } \\
\text {-Ser humano } \\
\text {-Animais } \\
\text {-Vegetais/partes } \\
\text {-Meio ambiente }\end{array}$ & $\begin{array}{l}\text {-Exploração das partes do corpo em frente ao } \\
\text { espelho. } \\
\text {-Recorte de figuras de pessoas. } \\
\text {-Desenho em papel pardo do corpo da criança e } \\
\text { da professora, nomeando as partes do corpo. } \\
\text {-Exploração dos órgãos do sentido. } \\
\text {-Necessidades do homem (alimento, água, ar, } \\
\text { calor, luz) } \\
\text {-Conhecimento dos animais através de histórias } \\
\text { explorando características, cuidados e } \\
\text { preservação. } \\
\text { Diferenças entre animais domésticos e } \\
\text { selvagens } \\
\text {-Experiências, desenvolvimento dos vegetais e } \\
\text { suas necessidades. } \\
\text {-Cuidados necessários à preservação da vida e } \\
\text { meio ambientes (passeio, filmes e histórias). }\end{array}$ \\
\hline
\end{tabular}


O estudo da Geografia possibilita atribuir sentidos às dinâmicas das relações entre pessoas e grupos sociais, e desses com o meio ambiente. A educação infantil ofertada as crianças de 0 (zero) a 3 (três) ano de idade é uma oportunidade de proporcionar a criança o desenvolvimento e a aprendizagem dos conhecimentos geográficos.

A prática do ensino de Geografia nos CMEls de Francisco Beltrão/ PR com as crianças que frequentam estas instituições tem contribuído nas atividades formativas com as crianças. As atividades visam o desenvolvimento e o conhecimento das questões geográficas que cercam o cotidiano da criança. A partir da experiência e da associação aos elementos naturais disponíveis no mundo da criança.

$\mathrm{Na}$ faixa etária que compreende desde o nascimento até os 3 (três) anos de idade, a maioria das atividades pedagógicas que envolvem o ensino da Geografia são realizadas por meio de atividades práticas, com o intuito de que a criança sinta e experimente cada elemento trabalhado com ela, como por exemplo: o solo, a água, as plantas, entre outros. (SME/FB, 2018).

Desta forma, a contribuição da Geografia no processo de espacialização dos CMEIS de Francisco Beltrão/Paraná/ Brasil vai além dos subsídios para a implantação das instituições. Haja visto, que o conhecimento da Geografia adquirido pela criança que frequenta o CMEI, possibilita a mesma, conhecer a sua história, o seu bairro, o seu município. Possibilita compreender as questões do espaço e do meio ambiente e cidadania. Além de compreender o papel transformador da ação do homem no ambiente.

\section{Considerações}

Para as crianças da Educação Infantil é necessário que compreendam os diferentes tipos de organizações sociais, cujas relações se efetivam em distintos lugares, suas formas e funções. Também o tamanho, a localização, a forma, a cor, existentes nesses locais para que possam estabelecer relações entre os elementos que constituem aquele arranjo espacial, a semelhança entre os lugares. E que conheçam seus direitos e deveres a partir do exercício da cidadania.

No processo formativo dessas crianças a compreensão relativa aos arranjos espaciais estará, num primeiro momento, centrado na escala do espaço vivido. Na percepção e observação, que são elementos fundamentais para a análise e reflexão dos referidos 
arranjos. Estas relações espaciais, sobretudo, com a representação geográfica de trajetos do espaço da criança.

A Geografia traz aspectos referentes às relações espaciais topológicas, projetivas e euclidianas subsidia a criança a observar, analisar, compreender e representar as paisagens. Noções de lateralidade, orientação e localização geográficas e as formas históricas de produção da cultura e dos espaços vividos, percebidos e concebidos em suas semelhanças e diferenças, características e propriedades dos objetos: grosso, fino, áspero, liso, exploração da cor, forma, Conceitos topológicos: dentro/fora, em cima/embaixo, perto/longe, frente/atrás, largo/estreito, separação, proximidade e afastamento, tamanho, parte e todo.

Os trajetos percorridos pela criança ao $\mathrm{CMEI}$, à escola ou sua casa e outros espaços: descrever e representar percursos com diferentes materiais de manipulação, construção de maquetes, elaboração de mapas etc. Os fenômenos geográficos: identificação dos fenômenos naturais, localização.

No período inicial escolar é onde ocorre a apropriação do legado histórico e social construído pelos homens a partir da ampliação das formas de interação da criança, como o nome dos membros da família e o relacionamento direto com o espaço de sua casa. Por isso, sistematizar da compreensão dos arranjos espaciais. Pelas capacidades que a criança desenvolve para ler imagem, bem como a paisagem, o que permite a ampliação de sua capacidade de compreender os diferentes espaços, ou seja, a partir da observação, representa a dimensão da localização dos objetos e fenômenos a fim de interpretar o significado da geograficidade destes.

Compreender a importância da Geografia no processo de espacialização do meio onde vivemos é fundamental para conhecer a história da implantação dos CMEls e a importância da criação das instituições no desenvolvimento social e econômico do município. A implantação dos mesmos contempla uma dinâmica cidadã de oferta de atendimento e educação com qualidade e responsabilidade as crianças que frequentam estes espaços educativos. Ao menos esta é a proposta.

\section{Referências bibliográficas}

Brasil. (2018). Base Nacional Comum Curricular da Educação Infantil - Educação é a base. MEC/ Brasília/ DF.

Libâneo, José Carlos. (2008). Organização e gestão da escola: teoria e prática. Goiânia: MF Livros. 
Oliveira, Z. M. de (1994). A universidade na formação dos profissionais de educação infantil. In: BRASIL. Ministério da Educação e Cultura. Por uma política de formação do profissional de educação infantil. Brasília: MEC/SEF/DPE/COEDI.

Sanches, Emília Cipriano. (2003). Creche: realidade e ambiguidades. Petrópolis, RJ: Vozes.

Spada, Ana Carolina Machado (2007). O cuidado e a educação no ambiente da creche - considerações acerca dos aspectos históricos e da formação de professores. Revista Científica Eletrônica de Pedagogia. Garça/ SP. Ano V, Número 10, Julho de 2007. 


\title{
Elaboração e publicação de um jornal escolar: uma proposta colaborativa na Educação Básica
}

\author{
Eduardo S. HeUsSeR ${ }^{1}$ \\ Adilson TADEu BASquerote SILVA ${ }^{2}$ \\ ROSEMY S. NASCIMENTO 3
}

\section{Resumo}

Este artigo apresenta uma experiência pedagógica realizada com estudantes do Ensino Fundamental e do Ensino Médio, em que os estudantes captam e filtram informações de diversas fontes e transformam em conhecimento, que pode ser comunicado por meio da elaboração e publicação de um jornal escolar. Trata-se de uma pesquisa qualitativa de caráter exploratório, por meio de um estudo de caso com dados obtidos a partir da análise de um jornal interdisciplinar produzido e publicado por estudantes da Educação Básica de uma escola privada da região Sul do Brasil e de entrevistas semiestruturadas realizadas com os sujeitos da pesquisa. A análise dos dados realizada por meio da análise do discurso evidenciou que a elaboração e publicação de um jornal escolar apresenta-se como um recurso didático que pode ser implementado com sucesso na Educação Básica, possibilitando que os estudantes tornam-se capazes de contextualizar o conteúdo estudado em sala de aula com as experiências vividas em sociedade, tornando-se críticos no tratamento da informação, à medida que vão questionando tanto a sua veracidade quanto o seu valor. Comprovou-se que as tecnologias da informação e comunicação apresentam-se como recursos dinâmicos de ensino, por favorecerem a capacitação dos estudantes para discutir e propor soluções para as mais variadas problemáticas contemporâneas. Nesse sentido, a construção do jornal torna-se uma ferramenta de metodologia ativa, auxiliando no processo de ensino e de aprendizagem. Outro aspecto valorizado é o processo de educar pela pesquisa.

\footnotetext{
${ }_{1}^{1}$ Mestrando em Geografia, PPGG-UFSC, eduardo.heusser@gmail.com.

2 Doutorando em Geografia, PPGG-UFSC, abasquerote@yahoo.com.br. Bolsista da CAPES Processo no 88881.189678/2018-01. abasquerote@yahoo.com.br.

${ }^{3}$ Doutora em Engenharia de Produção, PPGG-UFSC, rosemy.nascimento@gmail.com. O presente trabalho foi realizado com apoio da Coordenação de Aperfeiçoamento de Pessoal de Nível Superior - Brasil (CAPES) - Código de Financiamento 001.
} 
Palavras-chave: informação; conhecimento; pesquisa; interdisciplinaridade; tecnologias.

\section{Abstract}

This article presents a pedagogical experience carried out with students of Elementary School, Middle School and High School, in which students collect and filter information from various sources and transform into knowledge, which can be communicated through the elaboration and publication of a school newspaper. This is a qualitative exploratory research, through a case study with data obtained from the analysis of an interdisciplinary journal produced and published by students of Basic Education of a private school in the southern region of Brazil and semi-structured interviews carried out with the research subjects. The data analysis performed through discourse analysis showed that the preparation and publication of a school newspaper presents itself as a didactic resource that can be successfully implemented in Basic Education, enabling students to become able to contextualize the content studied in the classroom with the experiences lived in society, becoming critical in the treatment of information, as they question both its truthfulness and its value. It was verified that the information and communication technologies present themselves as dynamic teaching resources, because they favor the training of the students to discuss and propose solutions for the most varied contemporary problems. In this sense, the construction of the newspaper becomes a tool of active methodology, aiding in the process of teaching and learning. Another valued aspect is the process of educating by research.

Keywords: information; knowledge; research; interdisciplinarity; technologies.

\section{Introdução}

Vivemos em uma sociedade em que o fluxo de informações é acelerado e acompanhado de uma avalanche de atualidades e subjetividades que vêm de todos os quatro cantos do planeta. Desde seu início na década de 1950, a Terceira Revolução Industrial, também chamada de Revolução Técnico-Científico-Informacional, deu início à mais nova fase da globalização: a globalização neoliberal. Esse período trouxe à luz - Capitalismo Informacional. Como as próprias nomenclaturas adotadas indicam, percebe-se claramente que a informação se tornou o "núcleo" da sociedade pósguerra.

Conforme considera Porto-Gonçalves (2017, p. 38), nesse período de globalização neoliberal, "o território é uma categoria analítica que nos remete à inscrição da 
sociedade da natureza e, assim, nos obriga a considerar as relações sociais e de poder que estão imbricadas na relação das sociedades com a natureza". Diante deste cenário informacional em que a escola também está inserida, surge uma questão pedagógica: Como receber, processar e aproveitar toda essa informação na Educação Básica? Além disso, considerando que as crianças e adolescentes do século XXI são nativos digitais, amplamente discutido por Prensky (2001), como criar nesses estudantes a consciência de que eles precisam filtrar e analisar toda essa informação de forma cautelosa e proveitosa, bem como desenvolver a habilidade de ser desde bem cedo tanto leitores, quanto escritores, críticos da sociedade em que vivemos?

$\mathrm{Na}$ busca por essas respostas, a experiência pedagógica a ser compartilhada neste artigo pautou-se nas contribuições de Bogdan e Biklen (1994), Coll (1996), Demo (1996), Prensky (2001), Yin (2001), Caldas (2006), Faria e Zanchetta Jr. (2012), Oliveira, Moura e Sousa (2015), Young Digital Planet (2016), Porto-Gonçalves (2017), entre outros.

A experiência aqui descrita alia interdisciplinaridade e tecnologia. Sua pertinência atrela-se tanto a experiência pedagógica dos autores neste projeto de ensino, quanto a discutir sobre os desafios e os benefícios de se utilizar as Tecnologias da Informação e Comunicação (TIC) como aliadas ao processo de ensino e de aprendizagem. Além do mais, é notável reconhecer o valor da interdisciplinaridade como pedra angular na construção do material a ser publicado em cada edição do jornal, contextualizando o conteúdo estudado em sala de aula com as experiências vividas pelos estudantes.

Segundo Demo (1996), existe uma forma de fazer a diferença na educação. Se trata de "educar pela pesquisa". De acordo com ele, "educar pela pesquisa tem como condição essencial primeira que o profissional da educação seja pesquisador, ou seja, maneje a pesquisa como princípio científico e educativo e a tenha como atitude cotidiana." O professor precisa estar instrumentalizado da pesquisa como um princípio educativo para que se possa ser feita educação. Demo afirma ainda que "não se faz antes pesquisa, depois educação, ou vice-versa, mas, no mesmo processo, educação por através da pesquisa." Demo trata também das relações entre pesquisa, aluno e professor, definindo o papel do professor como o orientador do trabalho conjunto, coletivo e individual. O aluno é o parceiro na construção do conhecimento e deve ser estimulado para saber argumentar e questionar. Isso vai bastante de encontro com a proposta apresentada neste artigo. 


\section{0 projeto de ensino "Jornal A VOZ DA HUMANIDAVI": contexto de criação}

A partir da problemática apresentada na introdução deste artigo, propõe-se que professores de uma escola de Educação Básica possam aliar-se aos seus estudantes na empreitada de construir seus próprios recursos didáticos, se tornando coautores de um material muito rico em informações de qualidade. Essa parceria pode se traduzir na elaboração e publicação de edições semestrais de um jornal autoral da escola, tanto impresso (em formato comercial padrão) quanto digital (publicado em página na internet e compartilhado nas mais variadas redes sociais ou blogs). Nesse sentido, são úteis as colocações de Faria e Zanchetta Jr. (2012), na apresentação de seu livro "Para ler e fazer o jornal na sala de aula":

O objetivo é mostrar o jornal impresso como um multifacetado material didático para professores, sobretudo aqueles que lidam mais diretamente com a palavra e com imagens, como os de Português, História e Geografia. Nesta etapa, a intenção é aproximar e tornar possível ao professor em sala de aula 0 uso de expedientes técnicos, mas também linguísticos e semiológicos, que norteiam as linguagens verbal e visual dos jornais escritos. Não é, portanto, uma obra para jornalistas, mas um exercício de apropriação de expedientes jornalísticos potencialmente úteis para 0 trabalho com questões linguísticas, éticas, estéticas e de cidadania. Embora professores e alunos sejam convidados, a partir deste livro, a produzir jornais - e com isso sintam-se estimulados a aprender a ler tais veículos -, não se pretende reproduzir o que se faz na iniciativa privada. Mudam-se os propósitos: como diz Manuel Pinto, "o jornal escolar não é um fim, mas um meio para o trabalho pedagógico". Vale mais o processo de leitura e elaboração do que o resultado final. (Faria \& Zanchetta Jr, 2012, p. 6-7).

Nesse sentido, o objetivo da criação do "Jornal A VOZ DA HUMANIDAVI" é proporcionar ao estudante a possibilidade de ser um agente ativo no processo de ensino e de aprendizagem, desenvolvendo habilidade de relacionar teoria e prática de forma interdisciplinar nas áreas das Ciências Humanas e Linguagens. Os objetivos específicos desse jornal são: Estabelecer relações entre tempo e espaço geográfico, observando aspectos sociais e filosóficos; Escrever diferentes gêneros textuais, demonstrando o domínio da norma culta da Língua Portuguesa; Pesquisar e analisar fontes históricas; Valorizar a história e a geografia local e regional, analisando aspectos culturais; Perceber-se como sujeito histórico; Promover a análise crítica nos diferentes gêneros textuais e artísticos; Mostrar iniciativa ao desenvolver as atividades propostas; Criar formas artísticas a partir da abstração da realidade; Identificar elementos da linguagem visual que se encontram em múltiplas realidades; Dar visibilidade ao trabalho desenvolvido no ambiente escolar; Desenvolver o hábito da leitura de periódicos escolares e acadêmicos, tanto por meio impresso quanto por meio digital. 
Quanto ao título do jornal, pensou-se em como ele instigaria tanto a curiosidade dos prospectivos leitores, bem em como poderia provocar o estudante à motivação de participar da sua elaboração semestral. A respeito disso, Faria e Zanchetta Jr. (2012, p. 10-12) explicam que "o título chama a atenção do leitor, antecipando a informação considerada pelo jornal. Do ponto de vista linguístico, trata-se de uma macroproposição semântica, isto é, o título porta uma ideia considerada em princípio a mais abrangente sobre o assunto reportado". Além disso, o título auxilia no desenho estético do jornal, somando-se aos demais elementos como o texto, fotos, gráficos, propagandas, entre outros.

Nesta perspectiva, entendendo que somos professores das Ciências Humanas, optouse pelo título "Jornal A VOZ DA HUMANIDAVI". A primeira parte do título (A VOZ) remete à ideia de comunicação e tratamento da informação. A esse respeito, PortoGonçalves (2017) esclarece algo que se deve deixar bem claro aos estudantes, fazendo-os refletir sobre a séria responsabilidade que lhes é imposta nesse projeto:

\begin{abstract}
A palavra comunicação parece cada vez mais destituída de sentido quando separada da expressão "meios de". A comunicação tornou-se, efetivamente, uma indústria e, a partir de então, só pode estar associada a meios, posto que sem eles não há comunicação. Os donos dos meios de comunicação tornam-se, portanto, protagonistas privilegiados do processo de produção da subjetividade e já não podem mais ser vistos simplesmente como comunicadores que reportam, que noticiam uma realidade que thes oferece, mas vistos, sobretudo, como produtores de realidade, de tal sorte são parte interessada no mundo. Mais do que noticiar o que acontece, fazem acontecer. (Porto-Gonçalves, 2017, p. 131-132).
\end{abstract}

A segunda parte do título (HUMANIDAVI) é uma palavra autoral que, na realidade, é a soma de duas palavras, HUMANAS + UNIDAVI, fazendo referência às Ciências Humanas, que é a Área do Conhecimento temática do jornal, e ao nome da instituição de ensino. Portanto, destaca-se que, majoritariamente, o periódico concentra temas relacionados a Área das Ciências Humanas - Geografia (Geo), História (His), Sociologia (Soc), Filosofia (Fil) e Ensino Religioso (ER).

Nesse sentido, são úteis as considerações de Caldas (2006) em seu artigo intitulado "Mídia, escola e leitura crítica do mundo". Nele, discute-se a qualidade da narrativa jornalística e os riscos que ela encerra se não houver uma leitura crítica da mídia. Caldas também defende a necessidade de trabalho integrado entre educadores e jornalistas para a real compreensão do processo de produção da imprensa, construção da linguagem e da linha editorial dos veículos de comunicação.

Em contexto semelhante, Young Digital Planet (2016, p. 54), ao abordar a questão da tecnologia na sala de aula, diz que "a personalização na educação significa ter acesso aos conteúdos sempre que necessário. Além disso, pressupõe fornecer aos alunos 
materiais adaptados utilizando as ferramentas mais adequadas para eles. Graças a tecnologia, essas diretrizes podem ser seguidas com a ajuda dos dispositivos móveis".

\section{Metodologia}

Este estudo de natureza qualitativa (Bogdan \& Biklen, 1994) caracterizado como um Estudo de Caso (Yin, 2001) foi realizado desde 2015 no "Colégio UNIDAVI", situado na cidade de Rio do Sul - SC. Esta Instituição de Ensino localiza-se dentro do Centro Universitário UNIDAVI, onde existem distintos níveis de ensino: Educação Infantil, Ensino Fundamental, Médio, Superior e Pós-graduação. O projeto compreende 0 segundo e o terceiro nível respectivamente. Inicialmente, participavam do projeto apenas os estudantes das turmas do $9^{\circ}$ ano do Ensino Fundamental Final e $1^{\circ}, 2^{\circ}$ e $3^{\circ}$ anos do Ensino Médio. No entanto, para o ano de 2018 ampliou-se a participação, com todas as turmas do Ensino Fundamental e Médio, compreendendo aproximadamente 300 alunos, bem como os professores das Ciências Humanas, Língua Portuguesa e Arte.

Primeiramente, nas reuniões pedagógicas de planejamento que ocorrem nas semanas que antecedem o início de cada ano escolar, os professores dos componentes curriculares integrantes do projeto elaboram seu roteiro anual, dividido em dois semestres letivos. Nessa ocasião, define-se um cronograma, uma pauta dos temas, os gêneros textuais e os gêneros artísticos que serão trabalhados em cada edição daquele ano escolar, organizados adequadamente por turma, de acordo com o nível de cada turma.

Quanto ao desenvolvimento das atividades para inclusão no jornal, optou-se por nos primeiros dois meses do semestre, cada componente curricular desenvolve suas atividades correspondentes aos objetivos do jornal. Nas duas semanas seguintes são avaliadas e escolhidas as produções que serão publicadas. No mês seguinte, ocorre a edição e a revisão ortográfica e gramatical. Nas duas semanas seguintes, ocorre a normatização, diagramação e impressão do jornal, realizada por uma equipe externa, terceirizada, para que o jornal possua um aspecto similar ao formato comercial padrão. No mês subsequente, é realizado o evento de lançamento e distribuição dos exemplares impressos e eletrônicos. Como modelo, a Tabela 1 apresenta sequencialmente cada uma das atividades desenvolvidas e os respectivos períodos de tempo para cada uma. 
Tabela 1 - Modelo de cronograma de atividades do projeto.

\begin{tabular}{|c|l|}
\hline $\begin{array}{c}\text { Período de } \\
\text { tempo }\end{array}$ & \multicolumn{1}{c|}{ Atividade desenvolvida } \\
\hline 2 meses & $\begin{array}{l}\text { Pesquisa e estudo dos conteúdos e desenvolvimento dos textos e imagens em cada } \\
\text { componente curricular }\end{array}$ \\
\hline 2 semanas & Seleção do material que será publicado, realizada pelo professor da disciplina \\
\hline 1 mês & $\begin{array}{l}\text { Elaboração da edição e revisão ortográfica e gramatical realizada pelos professores de } \\
\text { língua portuguesa e pelo professor editor-chefe }\end{array}$ \\
\hline 2 semanas & Normatização, diagramação e impressão do jornal (etapa terceirizada) \\
\hline 1 mês & $\begin{array}{l}\text { Evento de lançamento da edição e campanha de distribuição geral dos exemplares } \\
\text { impressos e eletrônicos }\end{array}$ \\
\hline
\end{tabular}

Fonte: elaborado pelos autores (2018).

Quanto à pauta dos temas, os professores das disciplinas das Ciências Humanas definem de forma interdisciplinar quais temas estudados durante o semestre letivo serão direcionados para publicação no jornal. Para isso, elabora-se uma tabela para cada edição. Para cada edição semestral são selecionados novos temas. Do 1A EFI (1ำ ano do Ensino Fundamental Inicial) ao 8ํA EFF (8ํㅜ ano do Ensino Fundamental Final) optou-se por desenvolver apenas uma temática por edição do jornal, comum entre as Ciências Humanas. Isso possibilita que os estudantes dessas etapas da Educação Básica se concentrem em um tema central. Já para as turmas do 9A EFF (9ํ ano do Ensino Fundamental Final) e do EM (Ensino Médio) oportuniza-se que desenvolvam um tema para cada disciplina das Ciências Humanas. Destaca-se a necessidade de não haver sobreposição de conteúdos curriculares em cada etapa de ensino. Baseado no exemplo da $6^{\underline{a}}$ edição do Jornal A VOZ DA HUMANIDAVI, a Tabela 2 apresenta de forma esquemática a distribuição dos temas selecionados em cada componente curricular (disciplina) das Ciências Humanas, em cada etapa (turma) da Educação Básica.

Tabela 2 - Exemplo de pauta dos temas de uma edição do jornal.

\begin{tabular}{|c|c|l|}
\hline Disciplina & Turma & \multicolumn{1}{|c|}{ Tema } \\
\hline Geo/His/ER & $1^{\circ} \mathrm{A}$ EFI & Brinquedos e brincadeiras de outros povos \\
\hline Geo/His/ER & $2^{\circ} \mathrm{A}$ EFI & Família \\
\hline Geo/His/ER & $3^{\circ} \mathrm{A}$ EFI & O município de Rio do Sul \\
\hline Geo/His/ER & $4^{\circ} \mathrm{A}$ EFI & A história do livro \\
\hline Geo/His/ER & $5^{\circ} \mathrm{A}$ EFI & Africanidade: como surgiu a chuva? \\
\hline Geo/His/ER & $6^{\circ} \mathrm{A}$ EFF & O Reino do Alto Vale do Itajaí \\
\hline Geo/His/ER & $7^{\circ} \mathrm{A}$ EFF & Formação do território brasileiro \\
\hline Geo/His/ER & 8ํA EFF $^{\circ}$ & Riquezas e diversidades brasileiras \\
\hline
\end{tabular}




\begin{tabular}{|c|c|c|}
\hline \multirow[t]{4}{*}{ Geografia } & 9스 EFF & As missões de paz da ONU \\
\hline & $1^{\circ} \mathrm{A} \mathrm{EM}$ & Biomas do Sul do Brasil versus conservação \\
\hline & $2^{\circ} \mathrm{A} E M$ & Espaço urbano brasileiro e os setores da economia \\
\hline & $3^{\circ} \mathrm{A} E M$ & Geopolítica internacional: muros físicos formam barreiras ideológicas \\
\hline \multirow[t]{4}{*}{ História } & 9A EFF & Belle Époque: vida burguesa no Brasil \\
\hline & $1^{\circ} \mathrm{A} E M$ & Pré-História: tremores da caça \\
\hline & $2^{\circ} \mathrm{A} E M$ & Os Dois Corpos do Rei: a construção do absolutismo \\
\hline & 3A EM & Em Nome do Progresso: neocolonialismo \\
\hline \multirow[t]{3}{*}{ Sociologia } & $1^{\circ} \mathrm{A} \mathrm{EM}$ & No Limite entre o natural e o cultural \\
\hline & $2^{\circ} \mathrm{A} E M$ & A definição sociológica da política \\
\hline & $3^{\circ} \mathrm{A} E M$ & Modernização na transição do Império para a República \\
\hline \multirow[t]{3}{*}{ Filosofia } & 1으 EM & Conhece-te a ti mesmo: o sujeito e a realidade \\
\hline & $2^{\circ} \mathrm{A} E M$ & Antecedentes da metafísica \\
\hline & 3A EM & Ética na Idade Média \\
\hline
\end{tabular}

Fonte: elaborado pelos autores (2018).

Baseado na 6 a $^{\text {e }}$ edição do Jornal A VOZ DA HUMANIDAVI, a Tabela 3 apresenta um exemplo de conteúdos articulados pelos professores de Língua Portuguesa e de Arte, que compreendem os gêneros textuais e artísticos em que os temas selecionados pelos professores das Ciências Humanas serão desenvolvidos em cada turma na edição em pauta no semestre letivo. Para cada edição do jornal pode-se escolher diferentes gêneros textuais e artísticos.

Tabela 3 - Exemplo de gêneros textuais e artísticos de uma edição do jornal.

\begin{tabular}{|c|c|c|}
\hline Turma & Gênero textual & Gênero artístico \\
\hline $1^{\circ} \mathrm{A} \mathrm{EFI}$ & Curiosidade & Desenho Infantil \\
\hline $2^{\circ} \mathrm{A} E F I$ & Poema & Animação \\
\hline $3^{\circ} \mathrm{A}$ EFI & Carta & Retrato \\
\hline $4^{\circ} \mathrm{A}$ EFI & Resenha & Fotografia \\
\hline 5으 EFI & Conto Etiológico & Arte Africana \\
\hline 6A EFF & Conto Maravilhoso & Liberdade de Criação \\
\hline $7^{\circ} \mathrm{A}$ EFF & Mito & Desenho Colonial \\
\hline $8^{\circ} \mathrm{A}$ EFF & Conto Fantástico & Desenho Narrativo \\
\hline 9ㅇA EFF & Crônica Jornalística & Arte Concreta \\
\hline 1으 EM & Crônica Narrativa & Tirinha \\
\hline $2^{\circ} \mathrm{A} E M$ & Conto de Cenário & História em Quadrinhos \\
\hline 3으 EM & Artigo de Opinião & Charge \\
\hline
\end{tabular}

Fonte: elaborado pelos autores (2018). 
Quanto às estratégias, opções metodológicas, instrumentos e aos materiais de apoio utilizados, destacam-se, aulas expositivas dialogadas e interdisciplinares, ferramentas do Google for Education (sala de aula, documentos e apresentações virtuais, na nuvem), mídias digitais (filmes, documentários, notícias, músicas), referências para leitura e pesquisa (revistas, livros, sites, blogs), laboratórios de informática, tablets e smartphones com acesso à internet, biblioteca universitária, e por fim, normatização, diagramação e impressão do jornal (etapa terceirizada). O trabalho envolvendo o projeto é desenvolvido durante cada semestre letivo tendo como fortes aliados as TIC e a interdisciplinaridade sem, contudo, negligenciar as atualidades da sociedade e as vivências dos alunos.

Fortemente atrelado a isto está a questão de como a divulgação do jornal (produto final), tanto na versão impressa quanto na versão eletrônica, é feita nas esferas escolar, municipal, regional, estadual, e graças à internet, até mesmo nacional e global. Portanto, o trabalho desenvolvido resulta na produção de um jornal, de doze páginas, em formato comercial padrão, com duas edições anuais, publicadas no período que antecede o término de cada semestre letivo. Como mencionado, também há a versão digital do mesmo, distribuída por e-mail, página oficial do jornal na internet (hospedada no site oficial da Instituição de ensino) e redes sociais.

Naturalmente, todo esse processo de elaboração e publicação de um jornal escolar envolve avaliação. Conforme as contribuições de Coll (1996, p. 151), a avaliação pode ser feita em três modalidades: inicial, formativa e somatória. A avaliação inicial é feita no início de uma nova fase de aprendizagem, a avaliação formativa permeia todo o processo de aprendizagem e a avaliação somatória é feita no final de uma etapa de aprendizagem. Ainda, Coll (1996, p. 152) enfatiza que "a aprendizagem escolar deve ser, por definição, significativa, e que pode referir-se tanto a fatos, conceitos e princípios, quanto a procedimentos, valores, normas e atitudes." Portanto, no proposto projeto de jornal escolar, cabe a cada professor avaliar o trabalho desenvolvido em sua disciplina de acordo com seu planejamento e proposta junto aos estudantes, ficando a seu critério o estabelecimento da valoração das notas nos conteúdos trabalhados (conceitual, procedimental e atitudinal). Todos os estudantes participam do projeto, no entanto apenas um texto e uma imagem destaques de cada turma, dentro de cada uma das disciplinas das Ciências Humanas, são selecionados para compor a nova edição do jornal em pauta no semestre. 


\section{Resultados}

Ao avaliar os resultados alcançados nos primeiros anos do projeto, considera-se uma experiência exitosa, à medida que implementa a interdisciplinaridade e o uso das TIC na escola. A respeito, Oliveira, Moura e Sousa (2015) consideram que o ambiente escolar necessita dispor de laboratórios de informática com capacidade de velocidade, memória e armazenamento compatíveis ao acesso à internet considerada de boa qualidade para busca, manuseio e emissão de dados. Neste sentido, ponderam:

É significativo interligar sempre o ensino com a vida do educando. Se lançar ao aluno por todos os caminhos existentes, tais como: conhecimento, imagem, som, via representação (dramatizações, simulações), multimídia, interação online e off-line. Faremos com as tecnologias mais avançadas o mesmo que fazemos conosco, com os outros, com a vida. Se formos pessoas abertas, as utilizaremos para comunicar-nos mais, para interagir melhor. Se formos pessoas fechadas, desconfiadas, utilizaremos as tecnologias de forma defensiva, superficial. Se formos pessoas autoritárias, utilizaremos as tecnologias para controlar, para aumentar o nosso poder. 0 poder de interação não está fundamentalmente nas tecnologias, mas nas nossas mentes. (Oliveira, Moura, \& Sousa, 2015, p. 86).

Destaca-se que à medida que o projeto avança, torna-se cada vez mais evidente que além de os estudantes necessitarem da mediação pedagógica eficaz, o professor deve proporcionar o acesso às diversas tecnologias no ambiente escolar. Além disso, ele necessita instrumentalizar-se no uso destes recursos. Percebemos que os estudantes se tornaram mais críticos no tratamento da informação que lhes está à disposição na mídia e na internet, à medida que vão questionando tanto a veracidade quanto o valor de cada informação obtida.

Quanto ao uso das TIC na sala de aula, Oliveira, Moura e Sousa (2015) fazem uma importante consideração quando afirmam que a inserção das TIC no cotidiano escolar anima o desenvolvimento do pensamento crítico criativo e a aprendizagem cooperativa, uma vez que torna possível a realização de atividades interativas. É interessante perceber que as tecnologias da comunicação e da informação operam como molas propulsoras e recursos dinâmicos de educação. À medida que são bem utilizadas pelos professores e estudantes proporcionam a intensificação e a melhoria das práticas pedagógicas.

E o que dizer do "ensinar pela pesquisa"? Nesse sentido, quando fala do "desafio de educar pela pesquisa na Educação Básica", Demo (1996) passa a ideia de que é preciso repensar a educação guiada pela simples reprodução do conhecimento, estruturada na aula repassada pelo professor e copiada pelo estudante. Assim, questiona o poder transformador da educação, que se mantido nessa perspectiva, impede o cidadão da construção da sua própria história. Na concepção de Demo, a 
educação não é só ensino, instrução, treino, mas, sobretudo, formação da autonomia crítica e criativa do sujeito histórico competente. Portanto, observou-se que a proposta apresentada neste artigo caminha nessa direção, incentivando a autonomia do estudante diante da construção do conhecimento por meio da pesquisa.

Portanto, por falar em resultados, a Figura 1 apresenta a capa da 6aㅡ edição do Jornal A VOZ DA HUMANIDAVI, com 1.000 (um mil) exemplares impressos e disponível gratuitamente para download em sua página oficial na internet. Cada uma das cinco edições anteriores do jornal tiveram a mesma quantidade de exemplares impressos e também estão disponíveis eletronicamente no mesmo sítio da internet. Isso tem sido um marcante êxito deste projeto, pois possibilita a concretização e a ampla divulgação do conhecimento produzido ao longo do processo de ensino e de aprendizagem do projeto. Além disso, os estudantes se sentem valorizados ao verem seus trabalhos publicados.

Figura 1 - Capa da 6aㅡ edição do Jornal A VOZ DA HUMANIDAVI, publicado em junho de 2018.

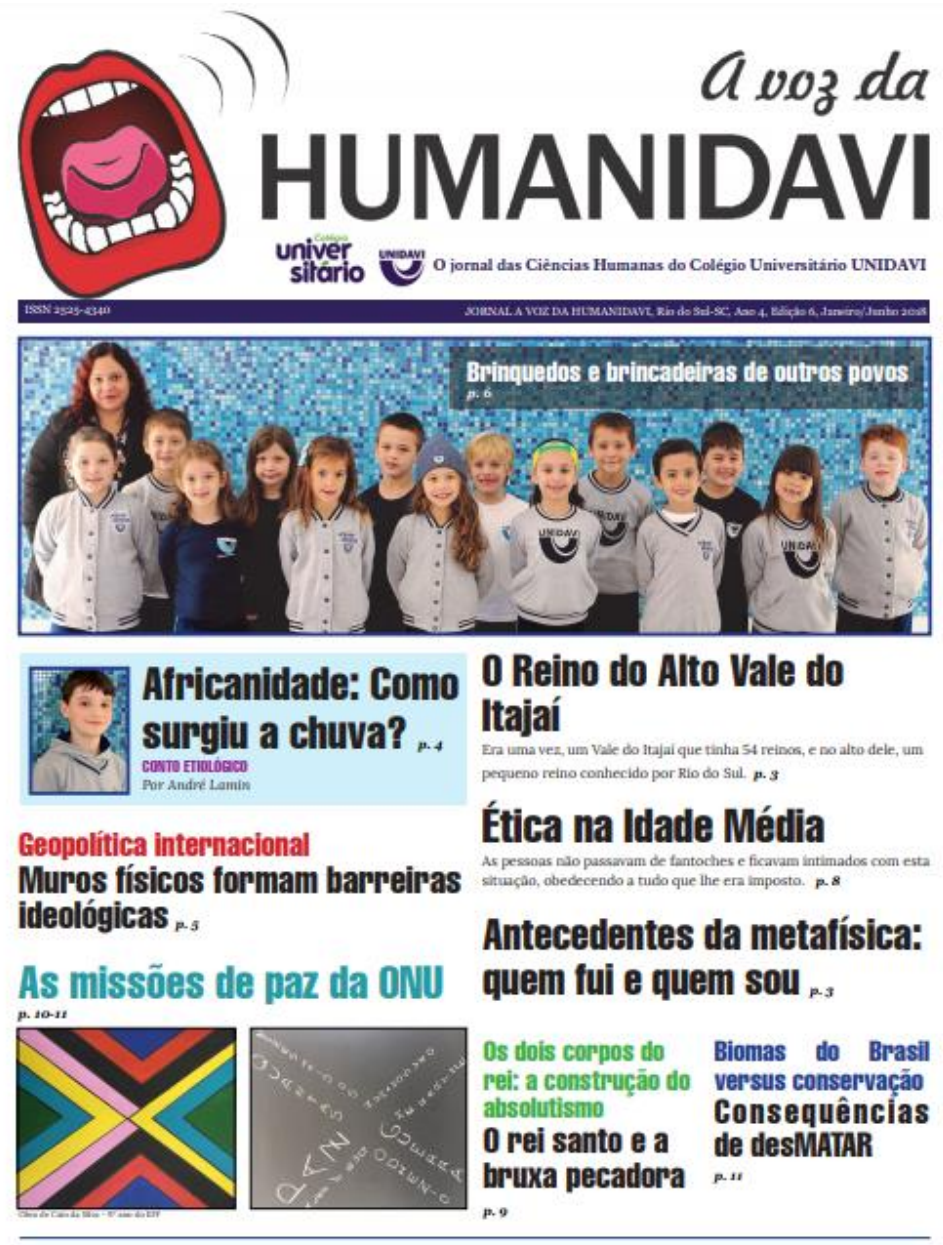

Fonte: https://unidavi.edu.br/colegio/jornal (2018).

\section{Conclusão}


À análise das edições anteriores do Jornal A VOZ DA HUMANIDAVI permite-se inferir que ele proporciona aos estudantes a capacidade de tornarem-se capazes de relacionar a teoria estudada em sala de aula com o mundo real em que se inserem. Além disso, capacitam-se para discutir e por vezes propor soluções para as mais variadas problemáticas contemporâneas na esfera local, nacional e global.

Evidencia-se a necessidade de os estudantes instrumentalizarem-se para transformar informações em conhecimento. Nesse sentido, enfatiza-se a atuação do professor, que por meio da mediação pedagógica e do domínio dos recursos didáticos são capazes de promover a aprendizagem e utilizar a seu favor o livre acesso a informação em que os estudantes estão inseridos, transformando o espaço escolar em um ambiente propício à construção do conhecimento.

Incentiva-se aqui a autonomia do estudante diante da construção do conhecimento por meio da pesquisa. Voltando a Demo (1996), educar pela pesquisa na Educação Básica inclui estimular o estudante a curiosidade pelo desconhecido, incitá-lo a procurar respostas, a ter iniciativa, a compreender e iniciar a elaboração de suas próprias ideias. Nesse sentido, é também um desafio ao professor para transformar suas estratégias didáticas, (re)construir um projeto pedagógico próprio, (re)construir seus próprios textos científicos, (re)fazer material didático e recuperar constantemente sua competência.

Assevera-se que atualmente, mais do que em qualquer outra época da história humana, é altamente significativa a figura do professor. À medida que ele é o profissional capaz de capacitar os estudantes para receber, tratar e disseminar 0 conhecimento, fato consolidado na elaboração do Jornal A VOZ DA HUMANIDAVI, os estudantes são orientados sobre tais prerrogativas.

Destaca-se a importância da construção do jornal na formação integral destes estudantes, bem como sua importância na vida acadêmica dos mesmos ao possibilitar que eles, já nas etapas da Educação Básica, possam obter registros na plataforma Lattes do Conselho Nacional de Desenvolvimento Científico e Tecnológico (CNPQ), algo um tanto incomum para as suas faixas etárias.

Por fim, evoca-se a necessidade de que os professores assumam seu papel de mediadores, mitigadores e construtores do conhecimento, sempre em parceria com os seus estudantes. Nesse sentido as TIC apresentam-se como facilitadores desse processo dentro e fora da sala de aula. 


\section{Referências bibliográficas}

Bogdan, R. C., \& Biklen, S. K. (1994). Investigação qualitativa em educação: uma introdução à teoria e aos métodos. Lisboa: Porto Editora.

Caldas, G. (2006, Janeiro/Abril). Mídia, Escola e Leitura Crítica do Mundo. Educação \& Sociedade: Revista de Ciências da Educação. Campinas, v. 27, n. 94, p.117-130.

Coll, C. (1996). Psicologia e Currículo: uma aproximação psicopedagógica à elaboração do currículo escolar. São Paulo: Ática.

Demo, P. (1996). Educar pela pesquisa. Campinas: Editora Autores Associados.

Faria, M. A., \& Zanchetta Jr, J. (2012). Para ler e fazer o jornal na sala de aula. 3. ed. São Paulo: Contexto.

Heusser, E. S. (2015-2018). Jornal A VOZ DA HUMANIDAVI: O jornal das Ciências Humanas do Colégio Universitário UNIDAVI (ISSN 2525-4340). Rio do Sul/SC. Disponível em: <www.unidavi.edu.br/colegio/jornal>.

Oliveira, C. D., Moura, S. P., \& Sousa, E. R. D. (2015). TIC's na educação: a utilização das tecnologias da informação e comunicação na aprendizagem do aluno. Pedagogia em Ação: Revista eletrônica do curso de Pedagogia da PUC de Minas. Belo Horizonte, v. 1, n. 7, p.75-95.

Porto-Gonçalves, C. W. (2017). A globalização da natureza e a natureza da globalização. 7. ed. Rio de Janeiro: Civilização Brasileira.

Prensky, M. (2001). Digital Natives, Digital Immigrants. On the Horizon. v. 9, n. 5, p. 16. Disponível em: <https://www.marcprensky.com/writing/Prensky\%20\%20Digital\%20Natives,\%20Digital\%20Immigrants\%20-\%20Part1.pdf >.

Yin, R. K. (2001). Estudo de caso: planejamento e métodos. 2. ed. Porto Alegre: Bookman.

Young Digital Planet. (2016). Educação no Século 21: tendências, ferramentas e projetos para inspirar. São Paulo: Moderna. 


\section{¿Es posible educar para la participación ciudadana dentro de la estructura escolar?}

Francisco F. García PÉrez ${ }^{1}$

\section{Resumen}

El núcleo básico de la ciudadanía es la participación. Participar no es solo un derecho sino una obligación, como ciudadanos de un mundo con problemas que exigen la implicación de todos. Pero ¿es posible aprender a ser ciudadanos participativos dentro de la estructura escolar? A pesar de los numerosos programas que trabajan la educación para la participación ciudadana, el funcionamiento de la práctica escolar nos muestra las dificultades para su desarrollo: el carácter tradicional de las disciplinas escolares, la estructura de los espacios y los tiempos, la función de la evaluación como instrumento de control o el papel de los profesores como transmisores de la cultura escolar. Por ello, hay que buscar alternativas: estructurar el conocimiento escolar en torno al estudio de problemas sociales y ambientales, generar espacios de aprendizaje que conecten escuela y sociedad, dirigir la evaluación hacia la mejora del aprendizaje de los alumnos y reorientar el papel de los profesores para ser acompañantes expertos de estos procesos.

Palabras clave: educación para la ciudadanía; participación ciudadana; cultura escolar; problemas sociales y ambientales; formación del profesorado.

\section{Abstract}

The basic core of citizenship is participation. Participation is not only a right but an obligation, as citizens of a world with problems that require the involvement of all. But is it possible to learn to be participatory citizens within the school structure? In spite of the numerous programs that work on education for citizen participation, the functioning of school practice shows us the difficulties for its development: the traditional nature of

\footnotetext{
${ }^{1}$ Catedrático de Didáctica de las Ciencias Sociales. Facultad de Ciencias de la Educación, Universidad de Sevilla (España), ffgarcia@us.es.
} 
school disciplines, the rigid structure of spaces and times, the function of the evaluation as an instrument of control or the role of teachers as transmitters of school culture. Therefore, alternatives must be explored: structuring school knowledge around the study of social and environmental problems, generating learning spaces that connect school and society, directing evaluation towards improving student learning and reorienting the role of teachers to accompany these processes as experts.

Keywords: education for citizenship; citizen participation; school culture; social and environmental problems; teacher training.

\section{Introducción}

La necesidad de una educación para la ciudadanía es hoy reconocida y proclamada en todos los contextos educativos y por parte de personas, colectivos e instituciones implicadas en la educación, siendo una de las finalidades incuestionables de la enseñanza, en especial en la enseñanza básica (Torney-Purta \& Barber, 2005; UNESCO, 2015; Pausch, 2016; Haeberli, Pagoni, \& Maulini, 2017). La Unión Europea se ha mostrado especialmente interesada en este campo, considerado como un tema clave y un objetivo fundamental. Todo ello ha tenido reflejo en la información educativa europea, difundida a través de la red Eurydice en sus diversos informes (European Commission, 2005; 2012), y en los informes internacionales de la IEA (Schulz, Ainley, Fraillon Losito, Agrusti, \& Friedman, 2018). De ahí, entre otras razones, la necesidad de una ciudadanía activa, que, en gran medida ha de ser responsabilidad de la institución escolar.

Más allá del mero conocimiento y posterior reconocimiento de los derechos (y deberes) de los ciudadanos, más allá del ejercicio controlado y regulado de esos derechos en un marco preestablecido, la clave y núcleo fundamental de una ciudadanía activa es la participación real y el compromiso con los problemas del mundo (Pagès \& Santisteban, 2010; Bolívar, 2016; Oraisón, 2016; García Pérez, 2016), pues a través de esa participación comprometida se establece la vinculación entre los conocimientos adquiridos y la intervención en la sociedad. Si no se participa en la sociedad, no se ejerce realmente la ciudadanía. Es más, como ciudadanos de nuestro mundo, participar no es solo un derecho, es una obligación, si de verdad creemos en la idea de una sociedad democrática. Esta participación comprometida es tanto más necesaria cuanto que el mundo en que vivimos tiene hoy gravísimos problemas que exigen, para su solución, la implicación de toda la población, desbordando, si fuera necesario, la actuación de los poderes establecidos, actuación 
muchas veces demasiado tímida, muchas otras condicionada por intereses espurios, otras incluso contraria a las necesidades de la sociedad.

Pero a participar solo se aprende "participando", como nos recuerda Tonucci (2009). Así que la única manera de aprender a ser ciudadanos activos, participativos, es ejercitando de manera natural, no artificiosa ni constreñida, la acción de participar. Y eso debería ocurrir en los diversos contextos sociales en que nos desenvolvemos, también, por tanto, y muy especialmente, en el ámbito escolar. En ese sentido, resulta indispensable, como señala E. Morin (2001), una educación claramente orientada a afrontar las incertidumbres, no a transmitir certezas, dado que la incertidumbre es una de las características fundamentales de nuestro mundo globalizado. A este respecto, Morin afirma que el conocimiento tradicional se muestra inadecuado para este requerimiento, por lo que sería necesario un profundo replanteamiento del sentido del conocimiento, y específicamente del conocimiento escolar, y, por consiguiente, una revisión del papel del profesorado como mediador entre dicho conocimiento y el alumnado que ha de aprenderlo. En definitiva, para el siglo XXI sería necesaria una ciudadanía con un enfoque planetario y claramente comprometida con la resolución de los problemas mundiales, capaz de ser operativa a escala local y a escala global (Davies, 2006; García Pérez, Moreno-Fernández, \& Rodríguez-Marín, 2015).

¿Y es la escuela, tal como hoy la conocemos, con su rígida estructura, el contexto más adecuado para proporcionar una educación ciudadana con estas características? La respuesta más inmediata vendría teñida de escepticismo. Pero ¿podríamos construir alguna alternativa para educar en una ciudadanía participativa a pesar de las limitaciones del marco escolar?

\section{Las dificultades de educar para la participación ciudadana en el sistema escolar}

El problema planteado es una cuestión ineludible para los educadores y educadoras: ¿es posible aprender a ser ciudadanos participativos en el marco de la estructura escolar?, ¿es posible educar para la participación ciudadana dentro de esa estructura? La respuesta no es fácil ni puede ser inmediata. En efecto, si atendemos a los numerosos ejemplos de programas y proyectos que están trabajando la educación para una ciudadanía activa y participativa de niños y jóvenes, parecería que es posible. Si, además, analizamos las declaraciones de intenciones presentes en los currículos escolares, así como los documentos de organismos internacionales sobre el tema -como antes se ha señalado-, consideraríamos que, además de posible, es deseable y obligado. Pero, si observamos el funcionamiento real de la práctica escolar, 
si escuchamos las declaraciones de los docentes sobre las dificultades para desarrollar una educación para la ciudadanía realmente activa y participativa, nos invaden muchas dudas acerca de esa posibilidad.

En ese sentido, un análisis mínimo del sistema escolar nos muestra que tanto la cultura escolar como la estructura de la escuela en tanto que institución constituyen un marco que condiciona y constriñe todo lo que ocurre en dicho sistema, de tal forma que resulta muy difícil que se desarrollen en su seno acciones que entren en contradicción con los rasgos básicos de esa estructura y de esa cultura (Pérez Gómez, 1998; Viñao, 2002). Y, lamentablemente, hemos de reconocer que una educación para la participación ciudadana basada en la acción concreta y en el protagonismo de los alumnos y alumnas es algo que entra en contradicción con aspectos claves del sistema, como los siguientes (sin pretensión de exhaustividad): el carácter del conocimiento escolar habitual, en definitiva, de las disciplinas escolares (tal como suelen ser entendidas); la estructura tradicional de espacios y tiempos escolares; la función de la evaluación como mecanismo de "medición" de los aprendizajes y de acreditación de los sujetos; el papel de los profesores como transmisores de una determinada cultura y como piezas de un engranaje rutinario .

Como nos demuestran las investigaciones sobre la historia y características de las disciplinas escolares, el conocimiento escolar dominante se ha ido configurando históricamente en forma de conocimiento específicamente regulado y adaptado al sistema en el que se incluye, por tanto, compartimentado en disciplinas, fragmentado en bloques para poder ser impartido en el marco escolar y para poder ser objeto de evaluación mediante exámenes (Cuesta Fernández, 1997; Viñao, 2006; Merchán, 2005; García Pérez, 2015). De esa forma, ha terminado por configurarse con una naturaleza distinta del conocimiento científico de referencia, al tiempo que ha quedado encapsulado en el ámbito escolástico y desconectado del contexto social real. Y por muy absurda que parezca esta situación, este tipo de conocimiento se ha hecho perdurable, y ha sobrevivido tanto tiempo precisamente porque es el más adaptativo para el sistema escolar convencional.

Lo anterior es, en parte, explicable por la especial estructura espaciotemporal del sistema escolar, que se organiza en tiempos de enseñanza (y supuesto aprendizaje) repartidos en tramos (los horarios) para las diferentes asignaturas, que se imparten en espacios poco "naturales" (las aulas) delimitados al efecto. Una estructura, en definitiva, artificiosa, pero que se ha revelado adecuada sobre todo para cumplir 
algunas de las funciones no explícitas de la escuela: disciplinar al alumnado, preparándolo más que para ejercer como ciudadanos, para ser "súbditos".

La evaluación, tal como suele ser entendida tradicionalmente, mediante pruebas y exámenes, se convierte en un mecanismo fundamental para "medir" el conocimiento escolar (con la estructura antes descrita) y para clasificar a los pequeños ciudadanos, poniendo, por decirlo así, "a cada uno en su sitio" y transfiriendo esa clasificación más allá de los muros de la institución (Merchán, 2005).

Los rasgos expuestos nos muestran un marco no solo alejado sino contrario a lo que debería ser un ámbito de educación para empezar a ejercer una ciudadanía activa. Pero ¿qué papel juega en todo esto el profesorado? El profesorado no deja de ser un elemento más -si bien con un papel de especial relevancia- en el engranaje del sistema; por tanto, los profesores suelen actuar según las pautas de una cultura docente que guarda coherencia con la cultura escolar dominante. No es de extrañar, pues, que se conviertan -según la acertada calificación de Cuesta Fernández \& Mainer (2014)- en "guardianes de la tradición y esclavos de la rutina". En ese sentido, los profesores -especialmente en la etapa secundaria- suelen pensar que lo que tienen que hacer es enseñar su disciplina -por lo general a partir de los libros de texto-, desechando, o dejando en segundo plano, el oficio de "educador", que, de alguna forma, pareciera rebajar su estatus profesional. Por eso no acaban de asumir el papel de ser educadores de ciudadanía (García Pérez \& De Alba Fernández, 2009; De Alba Fernández \& García Pérez, 2017).

Así, pues, la estructura tradicional del sistema escolar se ha mostrado resistente a la integración real, en la práctica, de la educación para la ciudadanía, pese a que "oficialmente" su inclusión haya sido ampliamente proclamada. En el ámbito curricular, no ha resultado funcional el intento de incorporar la educación para la ciudadanía como "eje transversal" en una estructura fuertemente organizada por disciplinas "verticales", pues, al final, ninguna disciplina concreta (ni sus respectivos docentes) se hacía responsable del desarrollo de esa temática. Por lo demás, el establecimiento muy tardío, en el caso español, con la LOE, en 2006- de una asignatura específica de educación para la ciudadanía tampoco ha tenido una incidencia valorable, por motivos diversos: desde los antecedentes poco favorables a esta materia arrastrados desde la época de la dictadura franquista (la nefasta consideración de aquel remedo de educación cívica denominada "Formación del espíritu nacional") hasta la escasa entidad de la nueva asignatura y la poca consideración hacia la misma de la administración educativa (presencia mínima en el currículum, carencia de profesorado 
específico...), pasando por la resistencia de sectores sociales conservadores, en especial de la jerarquía eclesiástica católica (González Pérez, 2014; Romero \& Estellés, 2015; Muñoz Ramírez, 2016).

Bien es verdad que -como se ha señalado antes- existen muchas iniciativas que podemos considerar en un amplio sentido como de educación ciudadana y que llegan a la escuela desde el ámbito de la educación no formal. Pero, sin minusvalorar estas aportaciones, hay que terminar admitiendo que no llegan a integrarse de manera coherente en los procesos habituales de enseñanza, manteniéndose en un plano que podríamos considerar como de inferioridad con respecto al conocimiento escolar curricular, por diversas razones, entre otras por tratarse de aportaciones que en último término no son objeto de evaluación académica.

Más concretamente, la mayor parte del profesorado no llega a implicarse a fondo en el desarrollo de esos programas (De Alba Fernández \& García Pérez, 2017), quizás condicionados por su concepción del conocimiento escolar y por una interpretación restrictiva de lo que consideran que es el currículum oficial (identificado con los contenidos presentes en los libros de texto). En ese sentido, los profesores muestran una contradicción: suelen valorar positivamente los programas extraescolares relacionados con temáticas transversales, pero no se implican en los mismos porque se ven constreñidos por las circunstancias o porque no saben integrarlos en su actividad profesional habitual. Para entender esta posición contradictoria de los profesores, habría que analizar el conflicto que existe en el seno de la cultura docente -como antes se ha esbozado- entre la dimensión del profesor como especialista en un campo de conocimiento (una posición avalada por la cultura escolar tradicional) y su dimensión de educador (que tiene escasa tradición entre los docentes, a pesar de ser una dimensión contemplada en el currículum oficial y requerida, por lo demás, por el contexto social). La reticencia del profesorado se ve reforzada por la concepción de que el ámbito propio de la participación ciudadana no es tanto el contexto escolar sino el contexto social, donde la actuación cívica se canalizaría a través de los cauces convencionales, institucionalizados. Dicha concepción, a su vez, es coherente con una actitud -también frecuente- de cierta desconfianza en la capacidad de los alumnos -no solo de los niños sino también de los jóvenes- para desarrollar actividades de participación como ciudadanos, pues se les tiende a considerar simplemente como estudiantes en edad escolar, no como "ciudadanos jóvenes" de pleno derecho (García Pérez \& De Alba Fernández, 2009; De Alba Fernández \& García Pérez, 2017). 
¿El dibujo de este panorama significa que es imposible desarrollar una educación para la ciudadanía activa y participativa en el marco escolar? En absoluto. El análisis crítico de la situación y el conocimiento de las dificultades reales es el punto de partida para poder diseñar y poner en práctica estrategias de cambio que hagan posible educar, realmente, para la ciudadanía en la escuela.

\section{Alternativas para educar en una ciudadanía activa y participativa}

Así, pues, a pesar de las dificultades señaladas, nuestra hipótesis de trabajo es positiva: se puede educar a los niños y jóvenes para ser ciudadanos activos y participativos en el marco escolar; pero para ello habría que trabajar no simplemente con propuestas que nos parezcan coherentes e ilusionantes, sino diseñando y haciendo seguimiento del desarrollo de las mismas en ese contexto que se ha presentado antes como dificultoso y constrictivo.

Desde este supuesto, es preciso ofrecer respuestas alternativas a las principales dificultades y obstáculos señalados, conscientes de que empezamos a trabajar en una tarea que es, de hecho, "contracultural", en el sentido de que es opuesta a la cultura escolar (y docente) mayoritaria. Más concretamente, pensamos que habría que trabajar en los aspectos que se esbozan a continuación.

a. Sustituir progresivamente la estructura disciplinar del conocimiento escolar organizada en torno a temas tradicionales de una cultura académica heredada (cuasi decimonónica) por una estructura alternativa organizada en forma de trabajo en torno a problemas sociales y ambientales relevantes como núcleos de una nueva cultura escolar (Legardez \& Simonneaux, 2006; Simonneaux, 2008; Santisteban, 2012). Esta opción de trabajo en torno a problemas presenta, al menos, tres grandes ventajas para la educación (García Pérez, 2014): desde una perspectiva sistémica y compleja, los problemas favorecen un enfoque más abierto y lleno de posibilidades -por tanto, más complejo- del conocimiento; desde una perspectiva constructivista, trabajar en torno a problemas constituye un planteamiento coherente con los procesos de construcción del conocimiento; y, desde una perspectiva social crítica, esta opción sitúa como objeto explícito de la enseñanza los problemas sociales y ambientales, y no el conocimiento académico, legado por las tradiciones disciplinares, que tendría que estar, en todo caso, al servicio del tratamiento de aquellos problemas.

b. Romper la estructura tradicional de espacios y tiempos escolares, para generar otro tipo de ámbitos de aprendizaje y de convivencia cívica que favorezca el abordaje educativo de los problemas reales y abra definitivamente las puertas de la institución 
escolar (mantenida como burbuja con vida independiente durante tanto tiempo) a las dinámicas sociales.

c. Abandonar el uso de la evaluación escolar como instrumento sancionador y clasificador y reorientarla hacia sus dimensiones más nobles: seguimiento y rediseño de las propuestas educativas, orientación para la mejora del aprendizaje de los alumnos y oportunidad para la reflexión de los docentes sobre sus actuaciones como tales.

d. Ir transformando el papel de los profesores y profesoras de meros expertos en enseñar una disciplina académica hacia otro papel, que hoy nos reclama la sociedad: ser guías y acompañantes de los procesos de aprendizaje de nuestros alumnos y alumnas; en el caso que nos ocupa, aprendizaje de una auténtica ciudadanía activa y participativa. Pero somos conscientes de que la formación inicial de profesores en el ámbito universitario, basada en la transmisión de saberes fragmentados, presenta muchos déficits y no resulta útil para formar a los docentes en un modelo alternativo, centrado en la interacción teoría-práctica y que trabaje en torno a "problemas prácticos profesionales"; tampoco la formación permanente soluciona esta carencia. Nos detendremos un poco más en este aspecto, por su especial interés.

En efecto, teniendo como referencia el marco teórico del programa de investigación IRES (Investigación y Renovación Escolar)² (García Pérez, 2000 y 2006; García Pérez, De Alba Fernández, \& Navarro Medina, 2015; García Pérez \& Porlán, 2017), defendemos la validez de un modelo de formación de profesores basado en el tratamiento de "problemas prácticos profesionales", es decir, los problemas básicos a los que se enfrentan, a diario, los profesores en el ejercicio de su profesión, como, por ejemplo, estos: la historia y significado de las materias escolares; el trabajo con las concepciones de los alumnos; la formulación de los contenidos escolares; la metodología de enseñanza; la evaluación y la calificación; la planificación y desarrollo de unidades didácticas; la planificación y desarrollo de proyectos para un curso o para una etapa de enseñanza; la construcción progresiva de un modelo didáctico personal; etc.

En ese sentido, consideramos, más específicamente, que el conocimiento y la experimentación práctica de una metodología didáctica basada en la investigación de

\footnotetext{
${ }^{2}$ EI Proyecto IRES (Investigación y Renovación Escolar) es un programa de investigación y acción educativa, en cuyo marco se vienen desarrollando desde 1991 diversas experiencias de innovación y distintas líneas de investigación, relacionadas tanto con la educación del alumnado como con la formación del profesorado.
} 
problemas sociales y ambientales relevantes preparan mejor a los futuros docentes para educar a los alumnos para ser ciudadanos activos y participativos. Se trata de un modelo de formación que sitúa la práctica docente en el centro del proceso y que entiende que la relación entre la teoría y la práctica tiene que basarse en una interacción fluida, superando la tradicional relación entre ambas, en la que la práctica suele ser simplemente el campo de aplicación de la teoría. En definitiva, si se trabaja sobre problemas prácticos profesionales, se puede formar mejor a los profesores para ser educadores que, a su vez, sean capaces de trabajar con sus (futuros o actuales) alumnos y alumnas los graves problemas del mundo, haciendo de ellos ciudadanos críticos y comprometidos con esos problemas (Estepa, 2012; García Pérez, De Alba Fernández, \& Navarro Medina, 2015).

Poner en marcha y mantener un modelo formativo de estas características no es fácil ni inmediato. Por ello, habría que ir dando pasos en esa dirección en la medida en que se pueda intervenir en las instituciones de formación del profesorado y contando con la disponibilidad de grupos y colectivos de docentes dispuestos a implicarse en este tipo de proceso. En ese sentido, hay que destacar la potencialidad que tienen los equipos mixtos de profesores universitarios (que desarrollan investigación educativa) y de profesores que experimentan innovaciones en su práctica docente, con la posibilidad de integrar a estudiantes de formación inicial (futuros docentes) en prácticas; trabajando en el mismo plano, pero realizando aportaciones complementarias.

En todo caso, los cambios en la formación del profesorado son lentos y, por tanto, también son lentos los cambios en su práctica profesional como docentes. No en vano se trata de cambios de una gran envergadura, pues son -como se ha indicadotransformaciones culturales; y esos procesos ocurren en interacción con las transformaciones sociales. Es un reto complejo que afecta a los profesores, pero también, en definitiva, a todos los ciudadanos. Por eso -parafraseando a Edgar Morin (2001; 2012)- habría que centrarse en la definición e implementación de "estrategias", no de recetas ni de programas, en su sentido convencional. El trayecto es largo, y la meta probablemente lejana, pero lo importante es elegir el camino y seguirlo. En ese aspecto, el proyecto Nós Propomos! es un ejemplo estimulante.

\section{Referencias bibliográficas}

Bolívar, A. (2016). Educar democráticamente para una ciudadanía activa. Revista Internacional de Educación para la Justicia Social, 5(1). https://revistas.uam.es/riejs/article/view/4344 
Cuesta Fernández, R. (1997). Sociogénesis de una disciplina escolar: la Historia. Barcelona: Pomares-Corredor.

Cuesta Fernández, R. \& Mainer, J. (2014). Guardianes de la tradición y esclavos de la rutina: historia del campo profesional de los catedráticos de Instituto. Historia y Memoria de la Educación, 1, 351-393.

Davies, L. (2006). Global citizenship: abstraction or framework for action? Educational Review, 58(1), 5-25. https://www.tandfonline.com/doi/full/10.1080/00131910500352523

De Alba Fernández, N. \& García Pérez, F. F. (2017). L'implication des professeurs dans les programmes d'éducation à la participation citoyenne. Le cas du «Parlement des Jeunes » à Séville. In Ph. Haeberli, M. Pagoni \& O. Maulini (dirs.), La participation des élèves: effet de mode ou nécessité? (pp. 219-236). Paris: L'Harmattan.

Estepa, J (2012). La formación del profesorado para enseñar la participación en el Grado de Maestro y en el Máster en Profesorado de Secundaria. Una alternativa basada en los problemas prácticos profesionales. In N. De Alba Fernández, F. F. García Pérez, \& A. Santisteban (coords.), Educar para la participación ciudadana en la enseñanza de las Ciencias Sociales (vol. 2, pp. 211-220). Sevilla: Díada. Accesible en: https://dialnet.unirioja.es/servlet/articulo?codigo=3978529

European Commission (2005). Citizenship Education at School in Europe. Brussels: Eurydice.

http://www.indire.it/lucabas/lkmw_file/eurydice/Citizenship_schools_Europe_2005_EN. pdf.

European Commission (2012). Citizenship Education in Europe. Brussels: Eurydice. http://ec.europa.eu/citizenship/pdf/citizenship_education_in_europe_en.pdf

García Pérez, F. F. (2000). Un modelo didáctico alternativo para transformar la educación: el Modelo de Investigación en la Escuela. Scripta Nova. Revista Electrónica de Geografía y Ciencias Sociales, IV(64). http://www.ub.edu/geocrit/sn-64.htm

García Pérez, F. F. (2006). Formación del profesorado y realidades educativas: una perspectiva centrada en los problemas prácticos profesionales. In J. M. Escudero, \& A. Luis (Eds.), La formación del profesorado y la mejora de la educación. Políticas y prácticas (pp. 269-309). Barcelona: Octaedro.

García Pérez, F. F. (2014). Ciudadanía participativa y trabajo en torno a problemas sociales y ambientales. In J. Pagès, \& A. Santisteban (eds.), Una mirada al pasado y un proyecto de futuro: investigación e innovación en didáctica de las ciencias sociales 
(vol. 1, pp. 119-126). Barcelona: Universitat Autònoma de Barcelona y Asociación Universitaria de Profesorado de Didáctica de las Ciencias Sociales. Accesible en: http://didactica-ciencias-sociales.org/wp-content/uploads/2013/11/XXVSIMPO1_v2.pdf.

García Pérez, F. F. (2015). El conocimiento escolar en el centro del debate didáctico. Reflexiones desde la perspectiva docente. Con-Ciencia Social, 19, 49-62. https://dialnet.unirioja.es/servlet/articulo?codigo $=5566721$

García Pérez, F. F. (2016). Educar en la escuela para afrontar los problemas del mundo. In Más allá de lo imposible. La dimensión política de los derechos humanos en el siglo XXI (pp. 145-171). Tafalla: Txalaparta.

García Pérez, F. F. \& De Alba Fernández, N. (2009). Educar para la participación ciudadana. Análisis de las dificultades del profesorado a partir de la experiencia del programa "Parlamento Joven". In R. M. Ávila, B. Borghi, \& I. Mattozzi, L'educazione alla citadinanza europea e la formazione degli insegnanti. Un progetto educativo per la “strategia di Lisbona” (pp. 515-521). Bologna: Pàtron Editore.

García Pérez, F. F., De Alba Fernández, N., \& Navarro Medina, E. (2015). La formación inicial del profesorado para enseñar ciudadanía. Experiencias en los niveles de grado y de máster. In B. Borghi, F. F. García Pérez, \& O. Moreno Fernández (eds.), Novi Cives. Cittadini dall'infanzia in poi (pp. 137-148). Bologna: Pàtron Editore.

García Pérez, F. F., Moreno Fernández, O., \& Rodríguez Marín, F. (2015). Problemas del mundo y educación: hacia una ciudadanía planetaria. In B. Borghi, F. F. García Pérez, \& O. Moreno Fernández (eds.), Novi Cives. Cittadini dallinfanzia in poi (pp. 3341). Bologna: Pàtron Editore.

García Pérez, F. F. \& Porlán, R. (2017). Los Principios Didácticos y el Modelo Didáctico Personal. In R. Porlán (Coord.). Enseñanza universitaria. Cómo mejorarla (pp. 93-104). Madrid: Morata.

González Pérez, T. (2014). La educación cívica en España: Retrospectiva y perspectiva. Revista História da Educação, 18. http://www.redalyc.org/articulo.oa?id=321629404007

Haeberli, Ph., Pagoni, M., \& Maulini, O. (dirs.) (2017). La participation des élèves: effet de mode ou nécessité? (pp. 219-236). Paris: L'Harmattan.

Legardez A. \& Simonneaux, L. (2006). L'école à l'épreuve de l'actualité. Enseigner les questions vives. Issy-les-Moulineaux: ESF. 
Merchán, F. J. (2005). Enseñanza, examen y control. Profesores y alumnos en la clase de Historia. Barcelona: Octaedro.

Morin, E. (2001). Los siete saberes necesarios para la educación del futuro. Barcelona: Paidós. Accesible en: http://unesdoc.unesco.org/images/0011/001177/117740so.pdf

Morin, E. (2012). La Voie: Pour l'avenir de l'humanité. Paris: Fayard.

Muñoz Ramírez, A. (2015). ¿Secularización o política católica neoconfesional? La problemática de Educación para la Ciudadanía. In J. A. Caballero Machí, R. Mínguez Blasco, \& V. Rodríguez-Flores Parra (coords.), Culturas políticas en la contemporaneidad. Discursos y prácticas políticas desde los márgenes a las élites (pp. 13-16). Valencia: Asociación de Historia Contemporánea y Universitat de València.

Oraisón, M. (2016). La participación como generadora y garante de democracia y ciudadanía. Revista Internacional de Educación para la Justicia Social, 5(1), 89-107. https://revistas.uam.es/riejs/article/view/4345

Pagès, J. \& Santisteban, A. (2010). La educación para la ciudadanía y la enseñanza de las ciencias sociales, la geografía y la historia. Íber. Didáctica de las ciencias sociales, geografía e historia, 64, 8-18.

Pausch, M. (2016). Citizenship Education in Times of Crisis. Foro de Educación, 14(20), 3-9. http://forodeeducacion.com/ojs/index.php/fde/article/view/460

Pérez Gómez, A. I. (1998). La cultura escolar en la sociedad neoliberal. Madrid: Morata.

Romero, J. \& Estellés, M. (2015). Educación para la ciudadanía y currículum: sus regímenes de verdad en perspectiva histórica. In B. Borghi, F. F. García Pérez, \& O. Moreno Fernández (eds.), Novi cives: cittadini dall'infanzia in poi (pp. 6376). Bologna: Pàtron Editore.

Santisteban, A. (2012). La investigación sobre el desarrollo de la competencia social y ciudadana para una participación crítica. In N. De Alba Fernández, F. F. García Pérez \& A. Santisteban (coords.), Educar para la participación ciudadana en la enseñanza de las Ciencias Sociales (vol. I, pp. 277-286). Sevilla: Ed. Díada y Asociación Universitaria de Profesorado de Didáctica de las Ciencias Sociales.

Schulz, W., Ainley, J., Fraillon, J., Losito, B., Agrusti, G., \& Friedman, T. (2018). Becoming Citizens in a Changing World. IEA International Civic and Citizenship Education Study 2016. International Report. New York: Springer. 
Simonneaux, L. (2008). L'enseignement des questions socialement vives et l'éducation au développement durable. Pour, 198(3), 179-185. https://www.cairn.info/revue-pour2008-3-page-179.htm

Tonucci, F. (2009). ¿Se puede enseñar la participación? ¿Se puede enseñar la democracia? Investigación en la Escuela, 68, 11-24. http://www.investigacionenlaescuela.es/articulos/68/R-68_2.pdf.

Torney-Purta, J. \& Barber, C. (2005). Democratic School Engagement and Civic Participation among European Adolescents: Analysis of Data from the IEA Civic Education Study. Journal of Social Science Education, Special Edition: European Year of Citizenship through Education, 2005. http://www.jsse.org/2005/2005-3/judith-torneypurta-carolyn-barber-democratic-school-engagement-and-civic-participation-amongeuropean-adolescents

UNESCO (2015). Global Citizenship Education. Topics and Learning Objectives. Paris: United Nations Educational, Scientific and Cultural Organization. http://unesdoc.unesco.org/images/0023/002329/232993e.pdf

Viñao, A. (2002). Sistemas educativos, culturas escolares y reformas. Continuidades y cambios. Madrid: Morata.

Viñao, A. (2006). La historia de las disciplinas escolares. Historia de la educación: Revista interuniversitaria, 25, 243-269. http://revistas.usal.es/index.php/02120267/article/viewFile/11181/11603 


\section{A pesquisa participante na formação continuada de professores}

Geliane TOFFolo ${ }^{1}$

ROBERTO GRECO ${ }^{2}$

\section{Resumo}

Com a constante agitação do mundo moderno, nos falta tempo para pensarmos coletivamente. Nesse sentido, propomos analisar um processo de formação continuada de professoras em Educação Ambiental utilizando a pesquisa participante. Para isso, procuramos entender como tal pesquisa possibilita uma formação cidadã e se promove mudanças na visão e nas ações das professoras que cursaram a formação em educação ambiental. Escolhemos as professoras do $4^{\circ}$ ano, das escolas do município de Francisco Beltrão/PR, por serem formadas no curso de Pedagogia, que as habilita a trabalhar com diferentes disciplinas, de forma interdisciplinar, em uma mesma turma e com diversas áreas do saber, entre elas, a ambiental. A pesquisa participante envolve diversas e múltiplas experiências coletivas de criação de conhecimentos que visam superar a dicotomia entre sujeito/objeto, pesquisador/pesquisado, conhecedor/conhecido, cientista/cientificado e teoria/prática. Esses motivos se relacionam com o trabalho da EA numa perspectiva crítica, emancipatória e cidadã, porque possuem princípios igualitários, como diálogo, participação coletiva, elaboração do conhecimento em grupo, valorização do conhecimento das professoras e abordagem de problemas cotidianos no locus de trabalho. Desenvolvemos a formação durante dois anos e quatro meses (2013-2015). Nesse período, treze (13) encontros foram realizados, dos quais participaram aproximadamente cem (100) professoras, das vinte e uma (21) escolas. A pesquisa participante promoveu uma formação cidadã, as professoras mudaram a forma de ver, entender e atuar em sala de aula, pois compreenderam a importância de valorizar a criança, como sujeito em construção, que tem

\footnotetext{
${ }^{1}$ Professora Doutora do curso de Geografia Licenciatura da Universidade Estadual do Oeste do Paraná - UNIOESTE - Campus de Francisco Beltrão/PR. geliane_unioeste@hotmail.com

${ }^{2}$ Professor Doutor do Programa de Pós-graduação de Ensino e História de Ciências da Terra da Universidade Estadual de Campinas - UNICAMP - Campinas/SP. robertogreco01@yahoo.it
} 
muito a contribuir, como cidadão, nas transformações socioambientais cotidianas.

Palavras-chave: experiências educativas; pesquisa participante; formação cidadã; educação ambiental.

\section{Abstract}

With the constant agitation of the modern world, the lack time to think collectively. In this sense, we propose to analyze a process of continuous training of teachers in Environmental Education using the Participant Research (PR). For this end, we try to understand how such research makes possible a citizen formation and if it promotes changes in the vision and the actions of the teachers who attended the training in Environmental Education. We chose the 4th grade teachers from the schools of the municipality of Francisco Beltrão/PR, because they were trained in the Pedagogy course, which enables them to work with different disciplines, in an interdisciplinary way, in the same class and with several areas of knowledge, as the environment. The PR involves several and multiple collective experiences of knowledge creation that aim to overcome the dichotomy between subject/object, researcher/researched, knowledgeable/known, scientist/be scientist and theory/practice. These motives are related to Environmental Education work in a critical, emancipatory and citizen perspective, because they have equal principles, such as dialogue, collective participation, group knowledge elaboration, appreciation of the teachers' knowledge and approach to everyday problems in the workplace. We developed the training for two years and four months (2013-2015). During this period, thirteen (13) meetings were held, of which approximately one hundred (100) teachers from twenty-one (21) schools participated. The PR promoted a citizen training, the teachers changed the way they see, understand and act in the classroom, because they understood the importance of valuing the child, as a subject under construction, that has much to contribute, as a citizen, in the daily socio-environmental transformations .

Keywords: educational experiences; participant research; teacher participation; citizen training; environmental education.

\section{Introdução}

Vivemos em um período de profundas transformações, em que os sujeitos são bombardeados de informações cotidianamente, e com essas informações e as transformações constantes surgem perguntas, e juntamente com elas a necessidade de 
respostas. Assim, decidimos desenvolver uma pesquisa, visando verificar qual a contribuição da pesquisa participante na formação continuada das professoras $^{2}$ em Educação Ambiental (EA) nos anos iniciais. Desenvolvemos uma pesquisa com objetivo de analisar um processo de formação continuada de professoras em EA utilizando a pesquisa participante. Para isso, procuramos entender como a pesquisa participante possibilita a formação continuada e se promove mudanças na visão das professoras que cursaram a formação continuada em EA.

Escolhemos as professoras do $4^{\circ}$ ano de maneira aleatória e as séries iniciais, devido às professoras serem formadas no curso de Pedagogia, que as habilita a trabalhar com diferentes disciplinas, de forma interdisciplinar, em uma mesma turma e com diversas áreas do saber, entre elas, a ambiental, conforme a Resolução CNE/CP № 1, de 15 de maio de 2006, que institui Diretrizes Curriculares Nacionais para o Curso de Graduação em Pedagogia, licenciatura.

Desenvolvemos a formação continuada durante dois anos e quatro meses (2013-2015), nesse período treze (13) encontros foram realizados, dos quais participaram aproximadamente cem (100) professoras, das vinte e uma (21) escolas do município de Francisco Beltrão/PR. Os encontros foram organizados em três fases: na primeira fase Diagnóstico e estudo preliminar dos dados -, realizamos o diagnóstico sobre 0 conhecimento de EA que as professoras possuíam e sobre as problemáticas ambientais que consideravam importantes abordar com as crianças; na segunda fase - Elaboração e realização de um plano de ação -, elaboramos o plano de ação com vista a superar as necessidades expostas pelas professoras e o seu desenvolvimento na prática; e, a terceira fase - Avaliação do plano de ação -, desenvolvido ao longo dos treze encontros, porque em todos era realizada uma avaliação coletiva sobre os trabalhos desenvolvidos no dia e, com base nessa avaliação, os passos seguintes da pesquisa eram delimitados.

Desenvolvemos a formação continuada, a partir da pesquisa participante, com a utilização de alguns instrumentos para a coleta de dados, como: observação participante, história e relatos de vivência, questionários, cartazes, gravações de pequenos vídeos, fotografias, desenhos e anotações.

Organizamos a apresentação da pesquisa em quatro etapas. Na primeira, a pesquisa participante e a EA na formação de professoras, abordamos o histórico e o conceito da pesquisa participante e da EA, com o auxílio dos autores Brandão (2006), Gabarrón e Landa (2006) e Layrargues e Lima (2014). Na segunda etapa, o primeiro contato com as

\footnotetext{
${ }^{2}$ Utilizamos o termo professoras porque o público era composto por mulheres.
} 
professoras, apresentamos o diagnóstico realizado no primeiro encontro, com a contribuição de Gajardo (1987), Guimarães (2006) e Molon (2009). Na terceira etapa, professoras em ação, organizamos e desenvolvemos o Plano de Ação, com base na pesquisa participante de Bortef (1987) e consideramos a necessidade das professoras para elaboração das atividades de EA. Na quarta fase, vamos avaliar?, as professoras avaliaram coletivamente todo o Plano de Ação.

\section{A pesquisa participante e a EA na formação de professoras}

A pesquisa participante latino-americana, conforme Brandão (2006), teve início com as experiências pioneiras de Orlando Fals Borda e de Paulo Freire, durante os anos de 1970 e 1980. Para Brandão (2006, p. 21), "[...] possui características peculiares, a começar por sua vinculação histórica com os movimentos sociais populares e com seus projetos de transformação social emancipatória". A educação popular se aproxima de comunidades eclesiais de base que tem origem na teologia da libertação.

A pesquisa participante, de acordo com Brandão (2006), pode ser compreendida como uma opção de ação participante, por considerar os sujeitos sociais populares como atores com presença ativa e crítica que projetam a pesquisa participante por meio da sua participação ativa e crescente, e por integrar a investigação social as trajetórias de organização popular, para que ocorra a participação em vastos processos de ação social.

$\mathrm{Na}$ pesquisa participante, de acordo com Brandão (2006), é importante conhecer para formar sujeitos populares com motivação para transformar cenários sociais de suas próprias vidas, e não apenas para resolver problemas locais restritos e isolados. Essa construção do conhecimento comprometido com a transformação social, conforme Silva (2006), implica em fazer da realidade seu objeto de pesquisa e inserir o pesquisador na realidade social, para que ele consiga se identificar com os interesses e demandas das classes sociais, sujeitos a quem interessa a mudança.

Segundo Gabarrón e Landa (2006), a pesquisa participante pode instigar os sujeitos a desenvolver uma consciência de suas capacidades e uma confiança maior em si mesmo, já que o objetivo final da pesquisa é a transformação social da realidade e a melhoria da qualidade de vida das pessoas que fazem parte dessa realidade, ou seja, formar cidadãos.

Para Brandão (2006), a pesquisa participante agrega quatro finalidades: conhecer as questões sociais a serem trabalhadas participativamente; possuir aptidão educativa e política formadora, por meio do diálogo de aprendizado partilhado; participar de processos 
de construção amplos e contínuos de um saber popular; partilhar com a educação popular a trajetória de empoderamento dos movimentos populares e de seus integrantes. Nesse sentido, segundo Brandão (2006), faz parte de programas de educação e de gestão ambiental, pois, esses programas necessitam de abordagens e investigações participativas.

A educação ambiental crítica, também conhecida como, emancipatória, transformadora, ecopedagógica e popular, segundo Layrargues e Lima (2014), opção pedagógica que se sustentou no pensamento de Paulo Freire, nos princípios da Educação Popular, na Teoria Crítica, na Ecologia Política e em autores marxistas e neomarxistas que expunham ser imprescindível incluir no debate ambiental a apreensão dos mecanismos da reprodução social, da relação entre o ser humano e a natureza, intercedida por relações socioculturais e de classes construídas historicamente, trazendo uma abordagem pedagógica que problematizava os contextos sociais em sua interface com a natureza, assim, os problemas ambientais não eram concebidos dissociados dos conflitos sociais. Para os autores, as causas dos problemas ambientais tinham origem nas relações sociais e no modelo socioeconômico vigente.

$\mathrm{Na}$ atualidade, segundo Layrargues e Lima (2014), a educação ambiental crítica não comporta reduções, mas exige abertura, inclusão, diálogo e capacidade de ver o novo e de formular respostas para além do conhecido, ou seja, o aprendizado e a mudança são indissociáveis, não é possível aprender algo novo sem mudar o ponto de vista, nem mudar uma realidade sem descobrir algo novo com e sobre ela. Por isso, a educação ambiental cresceu expressivamente na última década, principalmente no âmbito acadêmico, mostrando grande vitalidade para sair da condição de contra-hegemonia e ocupar o lugar da macrotendência pragmática.

\section{0 primeiro contato com as professoras}

Realizamos o primeiro encontro com as professoras do $4^{\circ}$ ano do Ensino Fundamental em 2013, para expor e discutir o projeto de pesquisa participante e verificar o interesse dos sujeitos na pesquisa. Conseguimos a adesão da maioria, que concordou em desenvolver um trabalho de educação ambiental com viés crítico e emancipatório, por meio da pesquisa participante, já que queriam participar de um processo formativo que contribuísse para a abordagem das problemáticas ambientais presentes na escola de atuação e contribuíssem para sua formação cidadã.

Consideramos a educação ambiental crítica e emancipatória aliando-a a pesquisa participante, porque, conforme Gajardo (1987), tem como objetivos promover: 1) a produção 
coletiva de conhecimentos; 2) a análise coletiva do ordenamento da informação e de sua utilização; 3) a análise crítica da informação ordenada e classificada, para verificar as origens e as causas dos problemas e as probabilidades de solução; 4) o estabelecimento de relações entre os problemas individuais e coletivos, funcionais e estruturais, para buscar soluções coletivas. Organizamos a pesquisa em três fases: a primeira denominada "diagnóstico e estudo preliminar dos dados", a segunda "elaboração e realização de um plano de ação" e a terceira "avaliação do plano de ação".

$\mathrm{Na}$ primeira fase, realizamos um diagnóstico por meio de questionários respondidos e debatidos, em grupo, sobre a compreensão das professoras e como abordavam a educação ambiental. Durante os três encontros diagnosticamos alguns elementos, entre eles que: as professoras não possuíam conhecimento sobre a legislação na esfera municipal, estadual e federal sobre a educação ambiental; as professoras acreditam que as disciplinas que devem abordar a EA são: História e Geografia; havia falta de material didático alternativo para trabalhar a educação ambiental do município; e não havia envolvimento dos órgãos ligados à questão ambiental, como: IAP ${ }^{3}$, Secretaria do Meio Ambiente, SANEPAR ${ }^{4}$, com as escolas e nem com a formação de professoras.

Com o diagnóstico realizado, fizemos um estudo preliminar dos dados, detectamos que a educação ambiental presente nas escolas estava voltada para o processo educativo do indivíduo e na transformação do seu comportamento. Além de a educação ambiental ser "mais enfatizada nas datas comemorativas, mas procuramos envolver no nosso dia a dia". Esse relato demonstra uma abordagem da educação ambiental pontual, sem continuidade, que começa e termina em ações soltas.

A visão ingênua, fragmentária e reduzida da realidade presa a essa armadilha paradigmática, segundo Guimarães (2006) e Molon (2009), tende à reprodução de práticas educativas consolidadas, porque se acredita que transmitindo ao indivíduo os conhecimentos necessários e proporcionando nele uma sensibilização sobre a questão ambiental, o indivíduo pode mudar seu comportamento, se tornar um cidadão, e assim, transformar a sociedade.

Apesar da abordagem da educação ambiental estar baseada no indivíduo, as professoras compreendem que as ações precisam ser no âmbito mais geral, que é necessário envolver todo o município porque a educação ambiental é "tarefa de todos, não somente dos professores, mas da sociedade como um todo. Porque a questão ambiental é abordada em

\footnotetext{
${ }^{3}$ Instituto Ambiental do Paraná.

${ }^{4}$ Companhia de Saneamento do Paraná.
} 
sala de aula, mas a criança quando chega a suas casas, a realidade é outra". Que é necessário atingir e envolver a sociedade, porque ações desenvolvidas somente em âmbito escolar ficam enfraquecidas. E ainda complementam que "as crianças têm o conhecimento sobre educação ambiental, mas não praticam muitos por preguiça ou por comodismo". Para que haja mudança é preciso fazer uma reflexão crítica e propor ações para o enfrentamento da problemática. Não há prática educativa voltada à coletividade, para uma transformação socioambiental.

A perspectiva crítica da educação ambiental, para Guimarães (2006), concebe, problematiza e complexifica os antagonismos da realidade, em suas diversas cotações materiais, epistemológicas, culturais, políticas e econômicas, a fim de instrumentalizar uma prática de transformação da realidade, uma prática baseada na teoria e prática, ação e reflexão, na práxis dialógica da diversidade na unidade e da unidade na diversidade. Ou seja, uma práxis que cause transformações significativas para superar as expectativas individualizantes se realizando no coletivo e pelo coletivo, assim, se forma cidadãos.

\section{As professoras em ação}

$\mathrm{Na}$ segunda fase da pesquisa elaboramos e realizamos um plano de ação. Foram realizados encontros com debates sobre os principais problemas e necessidades, levantados pelas professoras. Houve escolha, preparação e avaliação de atividades de educação ambiental, palestras, oficinas e estudos, conforme suas necessidades. Essa fase foi desenvolvida em dez (10) encontros, distribuídos nos anos de 2013, 2014 e 2015. As temáticas abordadas foram sugeridas pelas professoras e fizemos a mediação da discussão.

A metodologia participante ajudou as professoras na elaboração do plano de ação, porque segundo Bortef (1987), auxilia os sujeitos envolvidos a identificar, por si mesmos, os seus problemas, a analisá-los criticamente, buscando soluções apropriadas. As professoras estavam engajadas na pesquisa e desenvolveram um plano de ação de forma coletiva, com base nas suas necessidades de trabalhar educação ambiental e nas possibilidades de realização das ações.

Organizamos sete formações por meio de palestras, a pedido das professoras. As temáticas abordadas foram: na primeira, coleta seletiva do município; na segunda, conceitos de lugar e paisagem; na terceira, leitura de mapas e escalas; na quarta, clima, relevo e solo. A palestra sobre coleta seletiva do município foi ministrada pela Secretária do Meio Ambiente, que expôs os trabalhos desenvolvidos pela Secretaria com a interação das professoras na discussão. A segunda, a terceira e a quarta foram ministradas por duas mestrandas da 
UNIOESTE e pela pesquisadora. Todas tiveram duração de uma hora e meia cada. Todas as temáticas abordadas foram relacionadas ao município. Com exceção da palestra sobre a coleta seletiva, nas demais, algumas atividades que poderiam ser desenvolvidas com as crianças em sala de aula e mapas sobre clima, relevo, vegetação e hidrografia $^{5}$ foram disponibilizadas para que as professoras utilizassem com suas crianças.

$\mathrm{Na}$ quinta formação, a temática abordada foi Cartografia Básica, ministrada por uma professora do município, teve duração de quatro horas cada período (matutino e vespertino), foram trabalhadas as noções básicas sobre a leitura de mapas para reconhecer: lateralidade, orientação, localização e posição geográfica, importantes para a questão ambiental. A professora disponibilizou materiais com atividades para o desenvolvimento com as crianças, em sala de aula. E elaboramos um mapa atualizado sobre a hidrografia do município.

No sexto encontro de formação, intitulado "Expansão urbana e verticalização: o mercado imobiliário de Francisco Beltrão/PR (1998 a 2012)" e ministrado por um professor doutor do curso de Geografia da UNIOESTE, foram apresentados conceitos de: cidade, município e urbano, além de abordar o histórico do município e a expansão urbana.

No sétimo encontro, a palestra foi com uma professora doutora do curso de Geografia da UNIOESTE, sobre "Princípios de educação ambiental aplicados à gestão de recursos hídricos". Foram abordados: a distribuição de água no Planeta; a escassez de água no mundo; e, o que é água virtual? Foi disponibilizado às professoras um material paradidático intitulado "Elaboração de materiais didáticos para oficinas de educação ambiental: uma proposta voltada ao cotidiano do ensino fundamental", o qual aborda atividades sobre a água.

Desenvolvemos com as professoras uma oficina sobre fauna e flora, ministrada pela pesquisadora. Nela, foi trabalhada a identificação das espécies de fauna e flora presentes no município e na região Sudoeste do Paraná, e a verificação das espécies em extinção na região. A oficina teve duração de quatro horas, cada período (matutino e vespertino), e nela as professoras avaliaram e confeccionaram nove dinâmicas - jogos e brincadeiras - sobre a temática.

Realizamos dois estudos com as professoras, as temáticas abordadas nesses estudos foram: legislação ambiental e conceito de educação ambiental. Em relação à legislação

\footnotetext{
${ }^{5} \mathrm{O}$ mapa de hidrografia foi reelaborado a partir de levantamentos realizados a campo, onde foram identificados os rios que, até então, não estavam identificados e, também, confeccionado o mapa para fins didáticos. Esse material também foi disponibilizado para as professoras que fizeram parte da formação.
} 
ambiental, foram apresentadas e debatidas as seguintes leis: Lei $n^{0} 9.795$, de 20 de dezembro de 1996, que institui a Política Nacional da Educação Ambiental (PNEA); Lei $n^{\circ}$ 17.505, de 11 de janeiro de 2013, institui a Política Estadual de Educação Ambiental (PEEA); Lei $n^{\circ} 3.187$, de 13 de setembro de 2005, estabelece a Política Municipal de Francisco Beltrão para a Educação Ambiental (PMEA), e também cria o Grupo Interdisciplinar de educação ambiental. A finalidade foi esclarecer que existem leis sobre a temática, e a responsabilidade de trabalhar a educação ambiental é de todas as professoras, porque deve ser abordada de forma interdisciplinar e não restrita a algumas disciplinas. O conceito de educação ambiental foi tratado a partir da legislação e de documentos importantes a nível mundial sobre a questão ambiental, como o Tratado de educação ambiental para as Sociedades Sustentáveis e Responsabilidade Global; e a Carta da Terra.

Também desenvolvemos um trabalho de campo ao "Aterro Sanitário" e ao "Barracão de Reciclagem" do município, com a finalidade de compreender como se desenvolve o trabalho nesses locais de destino final do lixo. Nos dois locais havia uma pessoa responsável para explicar o funcionamento e esclarecer dúvidas das professoras. Toda a saída de campo foi documentada com vídeos e fotografias, para produção de material sobre os locais visitados, que serão disponibilizados às escolas para o trabalho com as crianças.

Durante todo o período de formação das professoras, a pesquisadora atuou como mediadora, como pesquisadora e pesquisada, porque segundo Brandão (1999), pesquisadora e pesquisados são sujeitos de um trabalho comum, ainda que com situações e tarefas diferentes. Eles descobrem, juntos, as causas e as soluções dos problemas detectados. As soluções se constituem em planos de ação conjuntos, que buscam a solução da problemática socioambiental.

Em seis dos sete encontros, desenvolvidos na segunda fase, entre os anos de 2013 a 2015 pesquisamos e elaboramos coletivamente, com base nas necessidades das professoras, trinta e oito (38) atividades de educação ambiental, sendo destas, quatro brincadeiras e cinco jogos, elaborados, readaptados e avaliados pelas professoras. Destas, trinta e sete (37) foram escolhidas e destacadas para a sua realização com as crianças, porque apresentavam os requesitos fundamentais, conforme avaliação das professoras: necessidade, motivo e finalidade. Para elaboração das atividades, foi necessário considerar a vivência das professoras durante sua trajetória em sala de aula. 
A escolha, adaptação e elaboração das atividades tiveram como base a COM-VIDA ${ }^{6}$, as políticas públicas de educação ambiental (Diretrizes Curriculares Nacionais para a Educação Ambiental, Normas Estaduais para Educação Ambiental, Parâmetros Curriculares Nacionais de Educação Ambiental e a Proposta Pedagógica Curricular do município sobre Educação Ambiental) e as categorias lugar e paisagem, já que são essas categorias da Geografia que as professoras contemplam no $4^{\circ}$ ano do Ensino Fundamental I, e não tinham material que abordasse a realidade do lugar. Utilizamos atividades do livro "Atividades interdisciplinares de educação ambiental: práticas inovadoras de educação ambiental" do autor: Genebaldo F. Dias (2006), da dissertação "Concepções e práticas de educação ambiental na formação de professores", de Meiri A. Rezler (2008), e da "Oficina de jogos pedagógicos de ensino de ecologia e educação ambiental como estratégia de ensino na formação de professores" dos autores Antonio F. Nascimento Junior e Laise V. Gonçalves, as quais foram adaptadas conforme a realidade dos sujeitos da pesquisa.

\section{Vamos avaliar?}

$\mathrm{Na}$ terceira fase avaliamos coletivamente todo o Plano de Ação, elaborado em conjunto com as professoras. Utilizamos, para avaliação, as anotações, as gravações, os vídeos, as fotografias, os desenhos, cartazes e atividades desenvolvidos no decorrer da pesquisa, além da exposição verbal das professoras. A avaliação ocorreu durante todo o processo da pesquisa participante. Conforme as atividades eram desenvolvidas, também eram avaliadas, ou seja, a avaliação ocorreu conforme a pesquisa foi se delineando.

A pesquisa obteve êxito na elaboração de diversas ações de educação ambiental, com os estudos, a oficina, as palestras e os trabalhos de campo. Com elas, foram supridas algumas das necessidades expostas pelas professoras na fase diagnóstica, devido à utilização de uma metodologia de pesquisa participante.

Em relação às palestras realizadas, as professoras avaliaram como pertinentes, porém, solicitaram continuidade de palestras sobre a temática. E, também, solicitaram que fossem abordados outros conteúdos, por exemplo, sobre a cartografia do município, porque necessitam de esclarecimentos sobre orientação e localização, para trabalharem com as crianças a partir da sua realidade, independente se a escola é urbana ou rural.

\footnotetext{
${ }^{6}$ De acordo com a Formação Com-Vida (2012), a Comissão de Meio Ambiente e Qualidade de Vida Com-vida - é uma forma de organização na escola, que junta a ideia dos jovens da I Conferência Nacional Infantojuvenil pelo Meio Ambiente, de criar "conselhos de meio ambiente nas escolas", com os Círculos de Aprendizagem e Cultura, proposto por Paulo Freire, onde todos participam da vivência e da construção coletiva do conhecimento, onde as crianças são os principais articuladores.
} 
Para a falta de colaboração dos órgãos ambientais, conseguimos parceria com a Secretaria do Meio Ambiente, para elaboração de palestra e trabalhos de campo a respeito da Coleta Seletiva e do trabalho desenvolvido no Aterro Sanitário. Essa parceria supriu as necessidades expostas pelas professoras e promoveram o conhecimento a respeito da coleta e tratamento do lixo no município.

A falta de material didático atualizado com dados sobre a realidade local e a falta de tempo para elaboração de material foi suprida, em parte, com as parcerias realizadas para elaboração das palestras, oficina e estudos, pois todos disponibilizaram materiais sobre as temáticas abordadas e, inclusive, houve a reelaboração do mapa da hidrografia do município, solicitado pelas professoras. E as próprias professoras escolheram, elaboraram e reelaboraram atividades de educação ambiental, coletivamente, com base no seu conhecimento sobre a forma de aprendizagem das crianças e as problemáticas socioambientais, presentes no seu local de trabalho, durante o período em que ocorreu a formação.

\section{Conclusão}

A utilização da pesquisa participante na formação continuada em educação ambiental para professoras do $4^{\circ}$ ano do Ensino Fundamental priorizou a valorização do conhecimento das professoras, por considerar a escola como lugar de formação e a educação ambiental por colaborar com esses princípios. Por isso, as professoras transformaram suas salas de aula em locus da pesquisa.

A pesquisa participante contribuiu para o êxito na formação continuada em educação ambiental, que promoveu a cidadania das professoras, pois muitas conseguiram superar a abordagem reducionista da educação ambiental, a partir da reflexão e ação sobre a problemática ambiental oriunda do conflito entre os interesses privados e o bem coletivo. Conseguiram promover uma práxis que promoveu transformações significativas, como superar o enfoque individualista, e atuar no coletivo e pelo coletivo.

As professoras promoveram mudanças, também, na forma de ver, entender e atuar em sala de aula, pois compreenderam a importância de valorizar a criança como sujeito em construção, que tem muito a contribuir nas transformações socioambientais cotidianas. Passaram a utilizar, no desenvolvimento de suas práticas, a atividade reflexiva, complexa e contraditória das condições sociais, políticas, econômicas, históricas, ecológicas e ambientais determinantes da sociedade atual, a fim de desenvolver atividades que 
contemplem necessidade, motivo e finalidade, pois assim, suas ações promovem a aprendizagem das crianças e contribuem para a formação cidadã delas.

A pesquisa participante possibilitou a formação continuada, por ser um trabalho coletivo, com vista à cidadania, onde se estabelece uma relação sujeito-sujeito, não há uma hierarquia, nesse caso, se estabelece uma relação de parceria, em que um aprende com o outro e vice-versa. Durante toda essa pesquisa, as professoras participaram do diagnóstico, na elaboração do plano de ação, no desenvolvimento das ações escolhidas e na avaliação do trabalho. Assim, com um trabalho coletivo de educação ambiental Crítica, é possível diagnosticar as problemáticas ambientais presentes na escola, propor soluções, resolver ou enfrentar os problemas ambientais locais.

\section{Referências}

Boterf, G. L. (1987). Pesquisa participante: propostas e reflexões metodológicas. In C. R. Brandão. Repensando a pesquisa participante. São Paulo: Brasiliense.

Brandão, C. R. (Org.). (1999). Pesquisa participante. São Paulo: Brasiliense.

Brandão, C. R. (Org.). (2006). A pesquisa participante e a participação da pesquisa: um olhar entre tempos e espaços a partir da América Latina. In C. R. Brandão \& D. R. Streck (Orgs.). Pesquisa participante: a partilha do saber. Aparecida-SP: Ideias \& Letras.

Brasil. Lei $n^{\circ}$ 9.795, de 27 de abril de 1999. Dispõe sobre a educação ambiental, institui a Política Nacional de Educação Ambiental. Disponível em: http://www.planalto.gov.br/ccivil_03/leis/L9795.htm

Brasil. Resolução CNE/CP no 1, de 15 de maio de 2006. Institui Diretrizes Curriculares Nacionais para o Curso de Graduação em Pedagogia, licenciatura. Disponível em: http://portal.mec.gov.br/cne/arquivos/pdf/rcp01_06.pdf

Brasil. Resolução № 2, de 15 de junho de 2012. Estabelece as Diretrizes Curriculares Nacionais para a Educação Ambiental. Disponível em: http://portal.mec.gov.br/index.php?option=com_docman\&view=download\&alias=10988rcp002-12-pdf\&category_slug=maio-2012-pdf\&ltemid=30192

Brasil. (2012). Formando Com-vida: comissão de Meio Ambiente e qualidade de vida na escola: construindo a Agenda 21 na escola. Disponível em: http://conferenciainfanto.mec.gov.br/images/pdf/com_vida_isbn_final.pdf 
Dias, G. F. (2006). Atividades interdisciplinares de educação ambiental: práticas inovadoras de educação ambiental. São Paulo: Gaia.

Francisco Beltrão (Município). Lei $\mathrm{n}^{\circ}$ 3.187, de 13 de setembro de 2005. Estabelece a Política Municipal de Educação Ambiental, cria o Grupo Interdisciplinar de Educação Ambiental e dá outras providências. Disponível em: http://www.franciscobeltrao.pr.gov.br/legislacao/

Francisco Beltrão (Município). Proposta Pedagógica Curricular (PPC). (2011). Francisco Beltrão: Secretaria da Educação.

Gabarrón, L. R.; Landa, L. H. (2006). O que é a pesquisa participante? In C. R. Brandão \& D. R. Streck (Orgs.). Pesquisa participante: a partilha do saber. Aparecida-SP: Ideias \& Letras.

Gajardo, M. (1987). Pesquisa participante: propostas e projetos. In C. R. Brandão Repensando a pesquisa participante. São Paulo: Brasiliense.

Guimarães, M. (2006). Armadilha paradigmática na educação ambiental. In C. F. Loureiro, P. P. Layrargues \& R. S. Castro (Orgs.). Pensamento complexo, dialética e educação ambiental. São Paulo: Cortez.

Layrargues. P. P. \& Lima, G. F. da C. (2014). As macrotendências político-pedagógicas da Educação ambiental brasileira. Disponível em: https://www.researchgate.net/publication/275607720_As_macrotendencias_politicopedagogicas_da_educacao_ambiental_brasileira

Molon, S. I. (2009). As contribuições de Vigotsky na formação de educadores ambientais. In C. F. Loureiro, P. P. Layrargues \& R. S. Castro (Orgs.). Repensar a educação ambiental: um olhar crítico. São Paulo: Cortez.

Nascimento Junior, A. F.; Gonçalves, L. V. Oficina de jogos pedagógicos de ensino de ecologia e educação ambiental como estratégia de ensino na formação de professores. Disponível em: http://web.unifoa.edu.br/praxis/numeros/09/71-76.pdf

Paraná. Deliberação n. 04, de 12 de novembro de 2013. Normas estaduais para a Educação Ambiental no Sistema Estadual de Ensino do Paraná. Disponível em: http://www.cee.pr.gov.br/arquivos/File/pdf/Deliberacoes/2013/deliberacao_04_13.pdf

Rezler, M. A. (2008). Concepções e práticas de educação ambiental na formação de professores. (Dissertação de Mestrado em Ensino de Ciências e Educação Matemática). Disponível em: file:///C:/Users/free/Downloads/Rezler_Meiri_A_Me_2008.pdf 
Silva, M. O. S. (2006). Reconstruindo um processo participativo na produção do conhecimento: uma concepção e uma prática. In C. R. Brandão \& D. R. Streck (Orgs.). Pesquisa participante: a partilha do saber. Aparecida-SP: Ideias \& Letras. 


\section{Programa Institucional de Bolsa de Iniciação à Docência (PIBID): instrumentos de construção da relação universidade e escola}

LIANA RAQUEL LIMA VIEIRA ${ }^{1}$

RAIMUNDO LENILDE de ARAúJO²

\section{Resumo}

A complexidade que envolve a dinâmica da escola e do fazer pedagógico é imprescindível para a formação acadêmica e profissional, em função da relação universidade-escola e da articulação entre a formação teórica e a prática escolar. Nesse contexto, surgiu em 2007, o Programa Institucional de Bolsa de Iniciação à Docência-PIBID, de iniciativa da Coordenação de Aperfeiçoamento de Pessoal de Nível Superior-CAPES. A partir de 2009 o programa incluiu a Licenciatura em Geografia, tendo como objetivo melhorar a qualidade da formação docente oferecida pelas instituições de ensino superior. Neste trabalho o objetivo foi analisar de que forma o programa alterou a atitude dos professores de Geografia bem como as contribuições para formação docente. $O$ trabalho consistiu de pesquisa bibliográfica e de roda de conversas com professores de Geografia do Ensino Médio na escola. A partir de 2012, houve melhoria nos índices de desempenho escolar dos alunos na Geografia, sendo identificados como fatores positivos o desenvolvimento de atividades pedagógicas, principalmente com oferta de estudos de monitoria. A formação continuada, ofertada pelo programa, constou de socialização de metodologias de ensino, entre alunos (bolsistas), professores (supervisores) e coordenadores, sendo de fundamental importância para reflexão do trabalho escolar de todos os envolvidos nesse processo. Os professores foram unânimes ao colocar que a proposta do PIBID na escola alterou suas posturas em sala de aula, pois devido à necessidade de desenvolver habilidades e competências exigidas pelo modelo do programa, buscouse melhorar a preparação para o desenvolvimento do seu trabalho pedagógico.

\footnotetext{
Professora da Escola de Tempo Integral Dirceu Arcoverde. Teresina/Piauí, liana_raquell@hotmail.com

2 Professor do Curso de Geografia da Universidade Federal do Piaui. Teresina/Piauí, raimundolenilde@ufpi.edu.br
} 
Palavras-chave: Geografia. Ensino. Projetos. Universidade. Escola.

\section{Abstract}

The complexity involved in the dynamics of school and pedagogical achievement is essential for academic and professional formation, due to the university-school relationship and the articulation between theoretical formation and school practice. In this context, in 2007, the Institutional Program of the purse de initiation à TeachingPIBID, initiated by the Coordination for the Improvement of Higher-Level PersonnelCAPES. As of 2009, the program included the Degree in Geography, aiming to improve the quality of teacher education offered by higher education institutions. In this work, the objective was to analyze how the program changed the attitude of Geography teachers as well as the contributions to teacher training. The work consisted of a bibliographical research and a round of conversations with professors of Geography of the High school in the school. Starting in 2012, there was an improvement in the educational performance of students in Geography, and the development of pedagogical activities was identified as positive factors, mainly with the provision of monitoring studies. Continuing education, offered by the program, consisted of a socialization of teaching methodologies, among students (scholarship holders), teachers (supervisors) and coordinators, being of fundamental importance for reflection on the school work of all those involved in this process. Teachers were unanimous in stating that the proposal of PIBID in the school changed their postures in the classroom, because due to the need to develop skills and competences required by the model of the program, it was sought to improve the preparation for the development of their pedagogical work.

Keywords: Geography. Teaching. Projects. University. School

\section{Introdução}

Compreender o processo educativo pressupõe, antes de tudo, perceber um processo formativo de sujeitos autônomos e criativos, capazes de transformar a realidade. Para que isso seja possível, é preciso que as diferentes experiências vividas por professores e alunos e os conceitos científicos articulem-se, ganhando convergência em um processo de troca e construção do conhecimento.

O ensino, em especial o de Geografia, assume papel fundamental nessa perspectiva, por fornecer instrumentos para a formação de alunos críticos. Dias (2002) argumenta 
que a complexidade e diversidade do mundo em que vivemos torna o conhecimento geográfico imprescindível. Para o autor, nenhuma outra área do conhecimento pode dotar melhor os alunos da competência de saber pensar o espaço para o exercício da cidadania responsável.

A educação geográfica passa por significativas transformações que caracterizam a sua nova conjuntura e significado para a vida da sociedade. Por ser uma disciplina com características próprias, é necessário ter espírito crítico, vocação, afinidade e responsabilidade por parte dos docentes, evidenciando um dos grandes desafios da atualidade, que é, desenvolver uma prática docente que conceba um diálogo efetivo entre o que se ensina e o que está presente no cotidiano do aluno. Segundo Freire (2006) é fundamental diminuir a distância entre o que se diz e o que se faz, de tal maneira que num dado momento a tua fala seja a tua prática.

Para alcançar tal objetivo é necessário que o professor disponha de procedimentos de ensino que possam estabelecer esta articulação, de tal maneira que, possa tornar a aprendizagem mais significativa, fornecendo ao aluno as possibilidades de acesso às informações e saberes necessários para apropriação do conhecimento.

Nesse sentido, existe, portanto, uma preocupação em se estabelecer objetivos específicos que norteiem todos os aspectos indispensáveis ao desenvolvimento do aprendizado no aluno e isto requer planejamento e articulação nas relações que se estabelecem dentro da sala de aula. Afinal, não é possível ter êxito na prática docente quando o educador não faz uma reflexão sobre a totalidade do contexto no qual irá lecionar.

Diante desse contexto, para que haja mudanças no processo de ensino aprendizagem e um ensino de Geografia diferenciado, é necessário formar bons professores nas universidades, para que estes posteriormente, cheguem à escola e possam contribuir, de forma significativa, na formação dos discentes da educação básica.

Partindo dessa necessidade e com o intuito de minimizar a desarticulação entre a teoria e a prática escolar, bem como implantar ações que valorizem o magistério, foi criado no ano de 2007, o Programa Institucional de Bolsas de Iniciação à Docência (PIBID), sendo coordenado pela Diretoria de Educação Básica Presencial (DEB) da Coordenação de Aperfeiçoamento de Pessoal de Nível Superior (CAPES). Neste trabalho, o objetivo foi analisar de que forma o programa alterou a atitude dos professores de Geografia do Ensino Médio nas escolas públicas atendidas pelo programa na cidade de Teresina-PI, bem como as contribuições para formação docente. 


\section{PIBID - caracterização do Programa}

O Brasil tem investido em políticas públicas que contribuam para a melhoria da formação de seus professores. Em meados de 2007, foi criada a Diretoria de Educação Básica (DEB), e a Lei 11.502 conferiu à Capes as atribuições de "induzir e fomentar a formação inicial e continuada de profissionais da Educação Básica e estimular a valorização do magistério em todos os níveis e modalidades de ensino". A Capes institui, então, o PIBID, que vem estabelecer a relação permanente entre Educação Superior e Educação Básica. É uma proposta que incentiva os futuros profissionais desde o processo de formação, visando à melhoria da educação brasileira diante da importância da formação de professores para uma educação de qualidade.

O programa é uma política pública brasileira de valorização do magistério para a Educação Básica, sendo executado pelas universidades e viabilizado por meio da destinação de bolsas a três segmentos: licenciandos, professores da rede pública e professores de universidades. O PIBID objetiva introduzir o licenciando no contexto escolar, para que ele possa compreender seu cotidiano e aprender a lidar com outras situações além da sala de aula, desenvolvendo projetos de caráter inovador. A proposta é que o licenciando passe, assim, a ter uma formação mais sólida, uma vez que se torna mais evidente a correlação entre prática e teoria.

Os projetos ofertados pelo programa devem incentivar e promover a vivência dos estudantes no cotidiano das escolas públicas durante a sua formação acadêmica, para que desenvolvam atividades didático-pedagógicas sob a orientação de um docente do curso de licenciatura e de um professor da escola com formação na área de atuação do licenciando. Dessa forma, os licenciandos tiveram como co-formadores os professores supervisores que atuam na rede como os responsáveis pela sua introdução no cotidiano escolar, designados para supervisionar as atividades dos bolsistas de iniciação à docência. Eles acompanhavam as atividades presenciais dos licenciandos, ao mesmo tempo que orientavam os projetos desenvolvidos nas escolas, a partir da participação em seminários, reuniões, atividades de formação, avaliação e reflexão pertinentes ao programa.

Esses profissionais, ao se envolverem com o Programa, se inserem num movimento de formação continua por meio de cursos e em desenvolvimento de projetos na escola junto com os licenciandos. Por outro lado, os coordenadores de área - professores universitários - passaram a participar também da rotina da Educação Básica, qualificando as atividades curriculares desenvolvidas na universidade. Dessa forma, 
há uma interlocução entre a universidade e a Educação Básica, ou seja, parceiras na formação dos futuros professores. Arroyo (2010, p. 136) argumenta que "temos que ampliar o olhar sobre os processos formadores dos educadores-docentes. A formação acontece na totalidade de práticas e, sobretudo, no movimento educativo que as propostas legitimam e incentivam".

\section{O programa nas escolas}

A intenção do PIBID tem sido o aperfeiçoamento dos bolsistas por meio da imersão na realidade das escolas parceiras, buscando a inserção nos contextos, de forma que passem a vivenciar de maneira investigativa e interventiva a multiplicidade de relações constituídas ao longo do tempo, uma vez que, com a vivência os laços se estreitam, ampliando as visões e aprofundando as raízes dos conhecimentos diversos adquiridos nesse entremeio escola/universidade/escola.

Direcionado inicialmente às Instituições Federais de Ensino Superior e atendendo conforme dados do Relatório de Gestão PIBID, 2013, cerca de 3.000 bolsistas em 2007, Brasil, (2013) das áreas de Física, Química, Biologia e Matemática para o Ensino Médio, o PIBID expandiu-se rapidamente, incluindo Universidades Públicas Estaduais, Municipais e Comunitárias, abrangendo todas as licenciaturas. Segundo o mesmo relatório, em 2012 chegou-se a 40.092, Brasil, (2013), licenciandos-bolsistas, 3052 Coordenadores de Área e 6177 Professores Supervisores, num total de 49.321 bolsas, e tem continuado seu crescimento. Em 2014 envolve em torno de 90.000 bolsistas entre todos os participantes, abrangendo perto de cinco mil escolas de educação básica, com a participação de 284 instituições. O objetivo desse programa está associado à importância crescente de políticas de indução de valor e mudanças em posturas formativas de docentes para a educação básica no âmbito das Instituições de Ensino Superior (IES). Brasil, (2015).

Até 2012, após a implementação de 05 (cinco) editais PIBID, o Programa alcançou um total de 196 instituições participantes, das quais 03 (três) no Piauí, sendo estas a Universidade Federal do Piauí (UFPI), a partir do edital MEC/CAPES/ FNDE PIBID 2007, o Instituto Federal de Educação, Ciência e Tecnologia do Piauí (IFPI), a partir do edital CAPES/PIBID n. 02/2009; e a Universidade Estadual do Piauí (UESPI), a partir do edital CAPES/PIBID n. 01/2011 (Brasil, 2013).

A ampliação, a abrangência e o investimento na formação e valorização do magistério reafirmam que as escolas de Educação Básica podem ser partícipes e beneficiárias de estudos e projetos. Também sinaliza que as licenciaturas passaram a ter outro status, 
pois sempre foram cursos que recebiam poucas bolsas de incentivo. Essa ampliação do número de instituições envolvidas criou um movimento nas escolas que desacomodou práticas pedagógicas e imprimiu um ritmo mais dinâmico ao cotidiano escolar. Além disso, demonstra o envolvimento da Educação Básica na formação dos futuros professores, uma vez que o saber docente é um saber plural, como indica Tardif (2005), que se compõe de saberes não apenas oriundos da formação profissional e de saberes disciplinares, mas também curriculares e experienciais. $O$ saber dos professores é inerente às outras dimensões do ensino ou de qualquer outra nas quais os professores encontram-se mergulhados, ou seja, o saber é sempre de alguém que trabalha em algo com um objetivo determinado. Em outras palavras, o saber do professor está relacionado à sua identidade e a elementos que constituem seu trabalho, devendo ser compreendido em relação à prática em sala de aula e ao saber plural e temporal. Tendo em vista essa premissa, a proposta metodológica orientadora do PIBID buscou enriquecer a formação de saberes da docência por meio de experiências e vivências de ensino e aprendizagem, que partiram da observação, análise e de planejamento de processos educativos. Um dos objetivos foi elaborar materiais didáticos e instrucionais que auxiliem e dinamizem o processo de ensino e aprendizagem, assim como incentivar a participação dos licenciandos em atividades, como: produção de materiais didático-pedagógicos que compreendem estratégias de ensino, sequências didáticas, oficinas, elaboração de objetos de aprendizagem, cartazes didáticos, vídeos, construção e aplicação de questionários, mural informativo, jogos didáticos, slides em Powerpoint, banners, materiais instrucionais e informativos, blogs, cartas, projetos educacionais e outros materiais didáticos diversos. Além de atividades extracurriculares como: reuniões de professores e pais e conselhos de classe, para que eles participem do cotidiano da escola.

\section{PIBID e construção de uma identidade docente}

Dentre as tantas realizadas, no decorrer de uma vida, sem dúvida, a escolha profissional é umas das mais importantes. Diversas são as razões que motivam a escolha de uma profissão, dentre elas pode-se salientar a possibilidade de destaque social, a influência familiar, a questão salarial, as perspectivas do mercado, entre outras. Ser professor é algo importante e significativo socialmente, mas, ninguém se faz docente ou se identifica como tal a partir de uma simples adentrada em sala de aula, ou por ter vivenciado um estágio curricular. A identidade docente é construída no dia a dia das práticas, das experiências, do reconstruir das concepções, do acesso a novos conhecimentos, da revisão dos seus conceitos, do exercer de uma postura 
crítica e reflexiva sobre a própria existência no exercício do magistério, da afirmação de si como sujeito de um constante vir a ser.

A identidade se constrói no desafio de viver cotidianamente o magistério com as suas múltiplas dimensões, conseguindo se portar em meio a elas sempre de maneira afirmativa. Ao pensar em educação percebe-se que ela existe em todos os lugares e em todos os momentos da vida do ser humano. A realidade mostra que sempre se aprende e ensina desde o momento do nascimento. Castrogiovanni (2011) discute que, o contato com a complexidade da cultura escolar transforma a vida de qualquer sujeito e tem contribuições importantes enquanto experiência do sujeito comprometido com a busca do conhecimento.

Nessa perspectiva, é preciso maior atenção e aperfeiçoamento referente às questões da profissionalização docente, evidenciando que os desafios educacionais são imensos, requerendo a necessária relação entre a teoria e a prática. A formação docente não pode ser definida como recriação/surgimento de novas técnicas, práticas, métodos pedagógicos, mas como possibilidade de mudança, de avanço, de transformações no cenário educacional, da gestão democrática e do planejamento participativo, situado no PPP (Projeto Político Pedagógico) da escola, com uma práxis vinculada às necessidades da comunidade escolar, como princípio fundamental da emancipação humana.

Portanto, a formação universitária oferecida pelo PIBID é necessária para o processo de profissionalização do acadêmico enquanto futuro professor de Geografia, sendo importantíssimo para a formação de sua identidade docente, uma vez que possibilita ao mesmo que adquira experiências e reflita sobre que ensino irá aplicar em sala de aula. Além disso, as ações do Programa são agentes fortalecedores do ensino de Geografia.

\section{O Projeto sob a ótica dos docentes}

Com o intuito de analisar de que forma o programa alterou a atitude dos professores, especificamente os que atuaram na área de Geografia no Ensino Médio, coletou-se informações a partir das rodas de conversas com os professores, supervisores inseridos no programa, cujo os relatos contribuíram na reflexão sobre a realidade do processo de ensino aprendizagem em Geografia.

A avaliação dos professores a respeito das ações desenvolvidas a partir da proposta do programa aponta para a importância das novas e inovadoras estratégias de ensino, 
pois a participação no programa os faz refletir constantemente sobre suas atribuições e responsabilidades enquanto educador.

Os professores destacaram que com a participação do programa há, uma preocupação em se estabelecer objetivos específicos que norteiem todos os aspectos indispensáveis no desenvolvimento do aprendizado no aluno, e isto requer planejamento e articulação nas relações que se estabelecem dentro da sala de aula, pois não é possível ter êxito na prática docente quando o educador não faz uma reflexão sobre a totalidade do contexto no qual irá lecionar. Neste aspecto, a ação da reflexão possibilita ao educador um ensino distinto daquele que geralmente se faz presente na realidade escolar, especificamente no ensino de Geografia, um ensino de meras descrições, sem muitas possibilidades e estímulos, no qual a aprendizagem limita-se no reproduzir ou/e decodificar os conteúdos geográficos.

Foi possível ao longo de todas as conversas, verificar que os professores de Geografia estão empenhados em traçar estratégias dinâmicas que forneçam os subsídios necessários para a implementação de uma nova prática geográfica, baseada em uma metodologia de construção de conhecimentos significativos, que permitam aos alunos se situarem no âmbito social, levando em conta as relações predominantes em cada realidade. Evidenciamos, portanto, a perspectiva de que a atuação do professor de Geografia deve despertar em todo alunado os ideais de reconhecimento de uma Geografia capaz de fazer a leitura não somente do espaço geográfico isoladamente, mas como também do mundo, da vida, dos costumes, da infinita relação entre o homem e a natureza, compreendendo a sua construção humana e consequentemente, sua realidade social

Os relatos de muitos professores demonstram a importância de terem uma experiência mais dinâmica e participativa nas atividades do PIBID do que nas que realizaram nos projetos do Plano Pedagógico da Escola. Esta constatação aponta para a importância do aprimoramento das atividades realizadas no âmbito escolar.

Alguns destacaram, também, que o desenvolvimento das ações do projeto resultou em significativo estreitamento das relações da Universidade com a rede pública de ensino, conforme fica evidenciado no relato abaixo:

Refletindo sobre minha participação no PIBID, em meio as muitas lembranças de atividades que tive a oportunidade de participar, posso afirmar que hoje me sinto uma profissional bem mais consciente da importância do meu papel e da responsabilidade das minhas ações enquanto educadora. Me fez perceber também que a necessidade de busca por uma melhor formação na prática docente tem que ser constante, que o planejamento pedagógico é imprescindível para o fazer docente, bem como 
a avaliação também... participar do PIBID foi uma oportunidade maravilhosa de agregar conhecimento, compartilhar possibilidades e ideias, me lançar a superação de desafios, além de uma grande alegria em poder estar novamente presente no universo da Universidade. (Vieira, 2018)

Percebe-se que todas as ações que envolvem o PIBID são de grande importância para os professores, sendo apontadas como mais exitosas: a participação dos licenciandos em sala de aula fazendo a observação e o acompanhamento pedagógico, as reuniões semanais com todo o grupo para realização de estudos, planejamento de atividades, apresentação de trabalhos realizados, socialização de metodologias e produção de materiais pedagógicos. Outro aspecto apontado pelos professores foi a importância da atividade de monitoria realizada pelos alunos licenciandos para alunos com baixo desempenho na disciplina. É notório os avanços alcançados, com expressiva elevação dos índices de desempenho dos alunos participantes dessa atividade.

Fica evidente nos relatos dos professores, que são muitas as contribuições do PIBID para a vida profissional, e até mesmo pessoal, é possível notar que o PIBID, além de capacitar a formação dos docentes, também tem possibilitado o domínio de habilidades e competências relacionadas ao processo de ensino aprendizagem.

\section{Considerações finais}

As demandas e os desafios práticos que só a vivência em sala de aula pode proporcionar não é tarefa das mais simples, o bom exercício da licenciatura vai muito além do que o simples conhecimento acadêmico.

A oportunidade que se coloca a partir do Projeto PIBID é relevante para diminuir a ainda existente distância entre o ensino básico e a universidade, além de proporcionar reflexões que levam a ressignificação da identidade docente, colaborando para uma qualificação adequada na formação dos PIBIDianos, futuros professores, e, também, aos professores-supervisores, coordenadores e todos que fazem parte desse processo, os quais podem estar compartilhando suas experiências. Valoriza a docência, promove o debate da inter-relação nas disciplinas, contextualiza os conteúdos, elevando a qualidade da formação inicial de professores nos cursos de licenciatura.

Os debates promovidos pelo programa, as trocas de experiências, os planejamentos, as muitas reuniões, todo esse conjunto de atividades, foi extremamente necessário para construção coletiva de novas possibilidades e caminhos a serem seguidos na 
busca de superação das dificuldades encontradas e comum a todos/as - a escola como lócus da socialização e construção de saberes; a universidade como agência de formação de novos docentes; aos docentes da rede básica por estarem entranhados nas suas vivências muitas vezes enraizadas em uma perspectiva compreendida como o melhor caminho; dos bolsistas de supervisão e de iniciação à docência por se desafiarem entre o instituído enquanto práticas, concepções e as descobertas de que não há uma única formula ou caminho a seguir.

\section{Referências}

Arroyo, M. G. Uma celebração da colheita. In: TEIXEIRA, J. A. C.; LOPES, J. S. M. A escola vai ao cinema. Belo Horizonte: Autêntica, 2008.

. Ofício de mestre: imagens e autoimagens. 12. ed. Petrópolis: Vozes, 2010.

Brasil. 2013a. Relatório de gestão PIBID - 2009-2013.Diretoria de Formação de Professores da Educação Básica. Brasília, CAPES.

Castrogiovanni, Antonio Carlos (org.). Iniciação a Docência em Ciências Sociais, Geografia e História. São Leopoldo: OIKOS, 2011.

Dias, A. Para Quê Ensinar Geografia: as Dimensões do Ensino da Geografia. Adaptado de CACHINHO, Herculano, Geografia Escolar: Orientação Teórica e Praxis Didáctica, Inforgeo 15, Lisboa, Edições Colibri, 2002, p. 83-84.

Freire, Paulo. Conscientização: teoria e prática da libertação: uma introdução ao pensamento de Paulo Freire. 3. ed. São Paulo: Centauro, 2006.

Tardif, M. Saberes docentes e formação profissional. Petrópolis: Vozes, 2005. 


\title{
¿Qué contenidos se enseñan y aprenden en la Universidad? Influencia de la formación del profesorado en el fomento de la ciudadanía
}

\author{
NOELIA PÉREZ-RODRÍGUEZ ${ }^{1}$ \\ NICOLÁS DE-ALBA-FERNÁNDEZ ${ }^{2}$ \\ ELISA NAVARRO-MEDINA ${ }^{3}$
}

\section{Abstract}

Different official documents highlight the importance of teacher training at the university. But what content is present in Higher Education, do teachers take into account the social and citizen problems of the context surrounding the different disciplines in their classrooms, and does the use of more innovative methodologies influence the inclusion of content associated with citizenship? The contents that are taught and learned in the university are often decontextualized in relation to the professional profile and interests of the students. Considering these co-protagonists and autonomous agents in their learning is an increasingly present need for the exercise of responsible citizenship. Allowing them to put into practice skills that promote not only the acquisition of the concepts of the discipline, but also the connection with existing social and environmental problems, with their own previous ideas, as well as with the ethical consequences associated with their profession will favour a more critical and broad view of their reality. Given this circumstance, we present a brief review of the issue of citizenship in the university, proposing a review of the theoretical references that defend the close relationship between two currents:

\footnotetext{
${ }^{1}$ Universidad de Sevilla, nperez4@us.es

2 Universidad de Sevilla, ndealba@us.es

3 Universidad de Sevilla, enavarro5@us.es
} 
training and university teacher improvement and inclusion of contents associated with citizenship.

Keywords: Higher Education; citizenship; Pedagogical Content Knowledge; Teacher improvement; critical thinking.

\section{Resumen}

Son numerosos los documentos oficiales que resaltan la importancia de la formación docente en la Universidad. Pero, ¿qué contenidos están presentes en la Educación Superior?, ¿tienen los docentes en cuenta los problemas sociales y ciudadanos del contexto que rodea a las distintas disciplinas en sus aulas?, ¿influye la utilización de metodologías más innovadoras en la inclusión de contenidos asociados a la ciudadanía? Los contenidos que se enseñan y aprenden en la Universidad, a menudo, están descontextualizados en relación al perfil profesional y los intereses del alumnado. Considerar a estos coprotagonistas y agentes autónomos en su aprendizaje es una necesidad cada vez más presente para el ejercicio de una ciudadanía responsable. Permitir que pongan en práctica habilidades que promuevan no solo la adquisición de los conceptos de la disciplina, sino también la conexión con los problemas sociales y ambientales existentes, con sus propias ideas previas, así como con las consecuencias éticas asociadas a su profesión favorecerá una visión más crítica y amplia de su realidad. En este artículo presentamos un breve repaso de la cuestión de la ciudadanía en la Universidad, planteando una revisión de los referentes teóricos que defienden la estrecha relación entre dos corrientes: formación y mejora docente universitaria e inclusión de contenidos asociados a la ciudadanía.

Palabras clave: Educación Superior; ciudadanía; Conocimiento Pedagógico del Contenido; mejora docente; pensamiento crítico.

\section{Introducción}

Durante años la Universidad ha seguido un enfoque centrado en la enseñanza que se aleja de tener en cuenta el relevante papel que el alumnado debe tener en su propio aprendizaje. Este hecho ha motivado que las diferentes disciplinas se situasen descontextualizadas de sus ámbitos de referencia, de forma que el conocimiento construido no respondía a las problemáticas sociales presentes, ni permitía al alumnado desarrollar habilidades que fuesen más allá de la memorización, 
fomentando una participación en la sociedad con un sentido más crítico, ético y responsable.

La situación descrita lleva a repensar el papel de la Universidad. Desde dicha institución debe permitirse al alumnado tener un papel activo en su propio aprendizaje, así como problematizar las diferentes disciplinas. Ello implica de forma necesaria un cambio en la docencia desarrollada. Implantar programas formativos que permitan al profesorado contar con las habilidades necesarias para impulsar dicho cambio es un hecho cada vez más latente. En consonancia con ello, la Comisión Europea (European Comission, 2014) ya propuso como uno de los grandes retos en la mejora de la calidad en la Educación Superior la formación docente del propio profesorado. Asimismo, desde la Ley Orgánica 6/2001, de 21 de diciembre, de Universidades $(\mathrm{LOU})^{4}$ se considera relevante la formación de los docentes a nivel universitario dentro del perfil profesional de los mismos.

El profesorado puede contribuir a cambiar el enfoque de enseñanza mediante la reformulación de los contenidos que imparte, al ser uno de los elementos curriculares que más impide el vínculo entre el conocimiento disciplinar y otro tipo de saberes (saber estar, saber hacer y saber ser). Usar un tipo de contenidos frente a otros, reflexionar sobre las relaciones que se establecen entre los mismos, permitiendo su interacción y jerarquización, fomenta de un modo natural el paso de contenidos propiamente disciplinares a contenidos que incluyen el desarrollo de habilidades, procedimientos y actitudes en el alumnado, que permiten la aproximación a un perfil de ciudadano comprometido.

Por tanto, el papel que juega la formación del profesorado universitario en metodologías innovadoras en la transformación de contenidos hacia una perspectiva más problematizadora permite el desarrollo de habilidades ciudadanas en el alumnado, siendo cada vez más capaces de enfrentarse a los problemas sociales y económicos existentes.

\section{Ciudadanía y Universidad}

Desde la Conferencia Mundial "La educación superior en el siglo XXI: Visión y acción" (UNESCO, 1998) se recoge como una finalidad y función de la Educación Superior formar ciudadanos que participen de una forma activa en su contexto, desarrollándose integralmente.

\footnotetext{
${ }^{4}$ La Ley Orgánica 6/2001, de 21 de diciembre, de Universidades (LOU) regula el funcionamiento de la Universidad en el ámbito español.
} 
Si entendemos la educación y la ciudadanía desde un enfoque humanista debemos considerar el Objetivo de Desarrollo Sostenible (ODS) número 4 propuesto por la UNESCO y la Agenda 2030 (Naciones Unidas, 2015, p.3) en el que se explicita que una Educación de Calidad debe "Garantizar una educación inclusiva, equitativa y de calidad, promoviendo el aprendizaje durante toda la vida". Concretamente, se recoge como una propuesta de indicador mundial en la Declaración de Incheon y Marco de Acción ODS 4 (UNESCO, 2015):

"De aquí a 2030, asegurar que todos los alumnos adquieran los conocimientos teóricos y prácticos necesarios para promover el desarrollo sostenible, entre otras cosas mediante la educación para el desarrollo sostenible y los estilos de vida sostenibles, los derechos humanos, la igualdad de género, la promoción de una cultura de paz y no violencia, la ciudadanía mundial..." (p. 21).

Por tanto, la Universidad debe garantizar el cumplimiento de este objetivo. Considerar al alumnado coprotagonistas y agentes autónomos en su aprendizaje conlleva incluir en la metodología de enseñanza el principio de incertidumbre con una orientación innovadora (Medina Rivilla, 1988, citado en García-Valcárcel Muñoz-Repiso, 2001). A través de dicho principio se garantiza que el alumnado pueda adaptarse a diversos modos de entender la realidad, así como de colaborar aportando soluciones a los problemas sociales y ciudadanos de su contexto. La Universidad tiene una nueva misión que afrontar, fomentando el paso de un enfoque basado en la enseñanza a uno centrado en el aprendizaje (Bowden \& Marton, 2014). De esta forma, se podrá constituir una Universidad en red, que permita no solo la vinculación con el conocimiento de la disciplina, sino con las necesidades, problemas e intereses del alumnado y de la propia sociedad. La mejor forma de impulsar el cambio será contar con el profesorado. No solo sirve que este colectivo piense de forma diferente, sino que también actúe en consecuencia a ese cambio de ideas (Biggs, 2005). La reflexión e investigación del profesorado sobre su propia práctica de aula (Zabalza, 2010), así como el papel de los equipos docentes (Herrán \& Paredes, 2012) en la inclusión de programaciones más realistas y adaptadas es primordial para fomentar dicho vínculo, pues establecen el puente de unión entre la Universidad y la sociedad a través del propio alumnado. Por tanto, el papel del profesorado universitario debe centrarse en formar no solo en las disciplinas, sino en el propio perfil ciudadano. Tal y como describe Imbernón (2000) "no podremos afrontar el futuro sin enseñar (y aprender) la complejidad de ser ciudadano y las diversas sensibilidades en las que se materializa: democrática, social, solidaria, igualitaria, intercultural y medioambiental” (p.39). 
No obstante, para afrontar este gran reto, los docentes deben contar con las habilidades pedagógicas necesarias, para lo que será primordial impulsar programas de formación docente que promuevan un cambio en las prácticas de aula.

\section{La formación docente universitaria: estado de la cuestión}

Ya en la Conferencia Mundial sobre la Educación Superior (UNESCO, 1998) se introduce la idea de la formación del personal universitario como una misión permanente. Zabalza (2011) afirma que para conseguir una enseñanza universitaria de calidad se debe potenciar la formación docente como un modo de acercamiento y promoción de los nuevos roles a adquirir por el profesorado, que les permita adaptarse al desafío de su doble profesionalidad (docente e investigadora), así como a las competencias didácticas necesarias para el desarrollo de su profesión.

Sepúlveda, Opazo, Sáez \& Lemarie (2015) resaltan la importancia de la formación pedagógica en el profesorado universitario. Los autores mencionados destacan que el profesorado universitario no solo debe transmitir conocimientos sino asegurarse de que el alumnado lo adquiere, utilizando estrategias constructivas que faciliten el trabajo autónomo.

Desde el informe "Nuevos modos de aprender y enseñar en la Educación Superior" de la Comisión Europea (European Comission, 2014) se plantea que para modernizar la Educación Superior se deben, entre otras medidas, a) compartir materiales de alta calidad y utilizar enfoques pedagógicos más actualizados y creativos; b) fomentar el aprendizaje para toda la vida; $c$ ) internacionalizar las prácticas educativas de calidad; y d) crear redes de cooperación y colaboración educativas; además de conseguir un aprendizaje más individualizado.

De entre los estudios con más impacto sobre la formación y mejora docente encontramos el de Bain (2007) y colaboradores, en el que examinan las prácticas de profesorado universitario para determinar las características con las que debe contar un "buen profesor". Las conclusiones principales que extrajeron fueron las siguientes: a) los profesores extraordinarios conocen su materia en profundidad; b) otorgan a la preparación de sus clases y, por tanto, a la docencia, la misma importancia que a la investigación; c) los mejores profesores crean un entorno crítico de aprendizaje proponiendo retos y desafíos al alumnado que les motiven a seguir aprendiendo y a cuestionarse su realidad; d) fomentan en el alumnado el espíritu crítico y la iniciativa; y e) comprueban de forma continua sus progresos evaluando sus resultados e iniciando cambios en la práctica, que impulsen a la mejora. 
Por otro lado, Gibbs \& Coffey (2004) en una investigación realizada sobre la eficacia de la formación de profesores de 22 Universidades distintas de 8 países obtienen como resultados al estudiar al profesorado mientras realizaban la formación y un año después, y tras compararlo con un grupo similar que no había recibido formación, que en el primero de ellos se habían dado cambios positivos en los procesos de enseñanza aprendizaje.

Amundsen \& Wilson (2012) en una revisión realizada sobre el desarrollo educativo y profesional en la Educación Superior en los últimos 30 años extraen como resultados de la revisión que: las habilidades docentes deben desarrollarse en la práctica, a través de técnicas interactivas; El profesorado que aprende a enseñar mediante un método basado en problemas y en la práctica después es capaz de transferirlo a su alumnado, convirtiéndose en guía de aprendizaje; La reflexión del profesorado sobre sus propias concepciones sobre la enseñanza y el aprendizaje es un paso fundamental para la mejora docente; La mejora de la enseñanza requiere de un conocimiento profundo de la disciplina; y, La mejora docente debe partir de la investigación y autorreflexión sobre la práctica de forma individual y grupal.

Pero, ¿cuáles son las mejores estrategias puestas en marcha para formar al profesorado universitario? De Rijdt, Tiquet, Dochy \& Devolder (2006) señalan el uso del portafolio docente como un instrumento que favorece la reflexión sobre la propia práctica, el cuestionamiento de nuevos métodos, técnicas y estrategias de enseñanza. Otra de las herramientas que se proponen es la revisión por pares. En un estudio realizado sobre la formación entre pares Da Silva \& Guimarães (2016) obtienen como resultados que la interacción entre pares, el estudio y la formación favorece la reflexión sobre su práctica diaria y facilita la actitud necesaria para implementar cambios en sus aulas. Thomas, Chie, Abraham, Jalarajan \& Beh (2014), en la misma línea, defienden la revisión por pares como una estrategia que podría aumentar el control sobre las prácticas docentes. Murray \& Grant (1998) avalan de igual forma la revisión por pares como un modo de mejorar la evaluación de la enseñanza y garantizar un incremento de la calidad de la misma.

Aun así, tal y como señalan Louie, Drevdahl, Purdy \& Stackman (2003), pocos son los profesores/as universitarios que reciben formación pedagógica especializada. Los autores mencionados muestran como el proceso de auto-análisis facilita la formación docente, al desarrollar nuevos conocimientos prácticos y al promover la investigación sobre su propia docencia. 
En la Universidad de Helsinki, Postareff, Lindblom-Ylänne \& Nevgi (2007), evaluaron un programa en base a una muestra de 200 profesores divididos en cuatro grupos en función de su formación pedagógica. Los resultados muestran cómo el programa formativo supone un cambio conceptual en el que la enseñanza se centra más en el alumnado, modificando sus propias creencias sobre la eficacia de la enseñanza. Ramsden, Prosser, Trigwell \& Martin (2007) también avalan cómo la calidad del aprendizaje de los estudiantes mejora cuanto mayor es la conexión entre la enseñanza y la calidad de los procesos de enseñanza-aprendizaje, y, por tanto, de la formación docente del profesorado. De igual forma, Parpala \& Lindblom-Ylänne (2007) en un estudio realizado sobre "buenas prácticas" apuntan a que las categorías que emergen reflejan un enfoque centrado en el alumnado frente a un enfoque centrado en la enseñanza y/o el profesorado. Por tanto, se deriva de ello como las buenas prácticas de enseñanza favorecen el enfoque centrado en el alumnado, algo que debe ser extensible, mediante programas formativos que favorezcan dichas prácticas.

A nivel nacional, también existen distintos estudios sobre la formación docente. Zabalza (2010) destaca la importancia de la necesidad de la formación docente y el desarrollo de sus competencias para la mejora de los propios procesos de enseñanza y aprendizaje. Benito \& Cruz (2012) profundizan en las claves necesarias para la mejora de la docencia universitaria proponiendo elementos y herramientas que facilitan métodos más activos centrados en el alumnado y enfatizados en la evaluación como mejora.

Por tanto, los distintos estudios mencionados resaltan como la formación docente mejora el aprendizaje en la Universidad. No obstante, ¿cómo influye la formación recibida en el cambio de enfoque de enseñanza y en la inclusión de contenidos más asociados a la ciudadanía?

\section{Una visión problematizadora: el tratamiento de los contenidos en la Universidad}

La necesidad de un nuevo modelo de Universidad, donde el docente se replantee su propia práctica de aula es una cuestión que se aborda desde teorías críticas en el ámbito educativo. A través de dicho paradigma se entiende que la relación docentealumnado debe estar mediada por el diálogo y el aprendizaje conjunto, así como por el fomento de la autonomía, el pensamiento crítico y la acción. Por tanto, tal y como plantea Rigal (2011), las prácticas de aula deben considerar el diálogo como negociación cultural, la construcción de la subjetividad, es decir, la influencia del sujeto 
en la reestructuración del conocimiento para definirlo en función de sus experiencias; todo ello encaminado hacia una Universidad crítica y democrática. Uno de los grandes retos que presentan estas teorías actualmente es la construcción crítica del conocimiento; defienden, por tanto, la necesidad de preservar una visión de la realidad a la vez que se potencia una pedagogía ética en dicha construcción para la diversidad y contra la desigualdad (Bazán, 2002). Por tanto, los contenidos que se enseñan y se aprenden en la Universidad juegan un papel relevante en la propia construcción del conocimiento y de la ciudadanía.

Del Río Martínez \& Celorio Díaz (2018) proponen igualmente repensar el currículo en la Universidad, de forma que cada vez sea más autónomo y relevante. Para ello ponen de manifiesto distintos elementos que deben integrar dicho currículo: "complejidad; ecodependencia; interdependencia; pensamiento crítico; cuestionamiento de los "centrismos" (eurocentrismo, androcentrismo, antropocentrismo); lectura ética de la realidad; aprendizaje de la movilización, de la acción colectiva, del cambio social" ( $p$. 11).

En la misma línea, se resalta el interés emancipador del conocimiento (Habermas, 2007). Profesorado y estudiantes deben colaborar en la construcción social y colectiva del mismo, reflexionando de forma conjunta y actuando en la propia transformación de su realidad. De forma paralela, Bowden \& Marton (2014) plantean que la Universidad no solo debe centrarse en la investigación y la enseñanza, sino también en el aprendizaje consciente, colectivo y ético, que sea capaz de integrar las particularidades del contexto en torno a ejes transversales y desde una visión problematizadora. Desde el enfoque de Educación para la Transformación Social propuesto por Del Río Martínez \& Celorio Díaz (2018) se defiende que para conseguir dicho aprendizaje se deben usar metodologías activas, participativas, colaborativas, que promuevan la colectividad frente a la individualidad y, sobre todo, que permitan el empoderamiento de los distintos agentes participantes en el acto de aprendizaje.

Pero para que la Universidad promueva competencias ciudadanas más justas y participativas, es necesario que dicha institución también estreche lazos con lo que realmente ocurre en la sociedad, creando espacios colectivos para la participación, promoviendo investigación sobre la propia práctica y vinculada a aspectos sociales de interés en el contexto, mejorando la calidad y formación docente, y, en definitiva, tendiendo puentes con la realidad.

Para conseguir desarrollar en el alumnado competencias que le permitan aprender a aprender, la Universidad debe funcionar como un agente de transformación con vistas 
a conseguir consolidar el modelo democrático (Gasca-Pliego \& Olvera-García, 2011). Ello implica que la enseñanza debe ir enfocada a crear una identidad de ciudadano responsable y participativo preocupado por lo que ocurre en otras partes del mundo, pasando de una conciencia más local a una más global (Boni, Peris \& Hueso, 2012).

Por tanto, existe una necesidad de que la enseñanza esté basada en el pensamiento crítico, la reflexión, la iniciativa, etc. Distintos estudios refuerzan la idea de la interrelación entre estrategias de enseñanza y aprendizaje innovadoras y la estimulación del pensamiento crítico en el alumnado (Dam \& Volman, 2004; Loes \& Pascarella, 2017). El objetivo de la Universidad no debe ser, únicamente, formar a profesionales especializados en las diferentes disciplinas, si no ir más allá, abordando dimensiones, contenidos, habilidades, valores y actitudes que promuevan su compromiso y responsabilidad como ciudadanos globales, activos y críticos (Biesta, 2009; Boni \& Pérez-Foguet, 2006).

Las metodologías innovadoras de enseñanza promueven la contextualización de las disciplinas en los problemas reales del contexto en el que se ubican, permitiendo al alumnado reflexionar y conectar con sus ideas previas. Los contenidos de enseñanza/aprendizaje en la Universidad deben ser, por tanto, una vía para conectar con el desarrollo de la ciudadanía sin abarcar, de forma exclusiva, los conceptos de la disciplina que se imparte, sino incluyendo "cuestiones como los problemas sociales relacionados con la materia, las consecuencias éticas asociadas al ejercicio de la profesión, las propias ideas y niveles de los estudiantes en relación con asuntos relevantes de la disciplina..." (García, Porlán \& Navarro, 2017, p. 57). Los contenidos que se enseñan y se aprenden deben estar conectados con la realidad, con el fin último de promover una ciudadanía más justa y ética (Escámez \& Sanz, 2017).

\section{Conclusión}

La revisión de la literatura realizada ha permitido poner en relación dos cuestiones importantes desde el punto de vista educativo: la necesidad de fortalecer y mejorar los procesos de enseñanza y aprendizaje en la Universidad y el gran papel que juega la formación de los docentes universitarios en dicho cambio. Por tanto, de dicha revisión se extraen tres principales conclusiones:

En primer lugar, la Universidad debe potenciar vínculos con la sociedad que permitan una conexión con los problemas sociales y con la propia realidad, que potencien una ciudadanía más justa y comprometida. 
En segundo lugar, los estudios mencionados obtienen como resultados que los programas de formación docente en metodologías innovadoras favorecen una práctica de aula de calidad, y, por tanto, mejoran el aprendizaje. Por ello, la Universidad, además de tender puentes con la sociedad debe fortalecer la formación del profesorado universitario. Los docentes no solo deben conocer su propia disciplina, sino también su didáctica (Zabalza, 2011).

En tercer y último lugar, es imprescindible que el profesorado universitario reflexione sobre su propia práctica, teniendo en cuenta las ideas de sus estudiantes, replanteando su metodología, su concepción del currículo, y consiguiendo que los contenidos respondan a problemas profesionales y de ámbito social. En definitiva, que la Universidad sea un espacio de participación ciudadana y de construcción del conocimiento colectivo.

\section{Referencias bibliográficas}

Amundsen, C., \& Wilson, M. (2012). Are We Asking the Right Questions?: A Conceptual Review of the Educational Development Literature in Higher Education. Review of Educational Research, 82 (1), 90-126. https://doi.org/10.3102/0034654312438409.

Bain, K., (2007). Lo que hacen los mejores profesores universitarios. Valencia: Universitat de València.

Bazán, D. (2002). Pedagogía social y pedagogía crítica: nexos y fundamentos básicos. Paulo Freire. Revista de Pedagogía Crítica, (1), 49-61.

Benito, Á., \& Cruz, A. (2012). Nuevas claves para la Docencia Universitaria en el Espacio Europeo de Educación Superior. Madrid: Narcea.

Biesta, G. (2009). What kind of citizenship for European Higher Education? Beyond the competent active citizen. European Educational Research Journal, 8 (2), 146-158.

Biggs, J. (2005). Calidad del aprendizaje universitario. Madrid: Narcea.

Boni, A., Peris, J. \& Hueso, A. (2012). Cómo cultivar la ciudadanía cosmopolita en la Educación Superior: El caso de la Universidad Politécnica de Valencia. Revista electrónica interuniversitaria de formación del profesorado, 15 (2), 131-139.

Boni, A. \& Pérez-Foguet, A. (2006). Construir la ciudadanía global desde la Universidad. Barcelona: Federación Española de Ingeniería Sin Fronteras. 
Bowden, J. \& Marton, F. (2014). La Universidad: un espacio para el aprendizaje: más allá de la calidad y la competencia. Madrid: Narcea.

Da Silva, M. M. \& Guimarães, B. (2016). Peer Instruction: Continuing Teacher Education in Higher Education. Procedia - Social and Behavioral Sciences, 217, 249256. https://doi.org/10.1016/j.sbspro.2016.02.078.

Dam, G. T. \& Volman, M. (2004). Critical thinking as a citizenship competence: teaching strategies. Learning and instruction, 14, 359-379. doi: 10.1016/j.learninstruc.2004.01.005.

De Rijdt, C., Tiquet, E., Dochy, F., \& Devolder, M. (2006). Teaching portfolios in higher education and their effects: An explorative study. Teaching and Teacher Education, 22, 1084-1093. https://doi.org/10.1016/j.tate.2006.07.002.

Del Río Martínez, A. \& Celorio Díaz, G. (2018). Hacia una Universidad socialmente comprometida. Vías estratégicas para su integración en la Universidad del País Vasco (UPV/EHU). País Vasco: Universidad del País Vasco.

Escámez, J. \& Sanz, R. (2017). La misión actual de la Universidad en la construcción ética de la ciudadanía. En M. A., Prados, Educación para la vida ciudadana en una sociedad plural (pp. 145-150). Murcia: EDITUM. Ediciones de la Universidad de Murcia.

European Comission. (2014). High Level Group on the Modernisation of Higher Education. European Comission. Luxembourg. Disponible en: http://ec.europa.eu/dgs/education_culture/repository/education/library/reports/modernis ation-universities_en.pdf.

García, E., Porlán, R. \& Navarro, E. (2017). Los fines y contenidos de enseñanza. En R. Porlán (Coord.), Enseñanza universitaria. Cómo mejorarla (pp. 55-72). Madrid: Morata.

García-Valcárcel Muñoz-Repiso, A. (Coord.). (2001). Didáctica universitaria. Madrid: La Muralla.

Gasca-Pliego, E. \& Olvera-García, J. C. (2011). Construir ciudadanía desde las Universidades, responsabilidad social universitaria y desafíos ante el siglo XXI. Convergencia, Revista de Ciencias Sociales, (56), 37-58.

Gibbs, G. \& Coffey, M. (2004). The Impact Of Training Of University Teachers on their Teaching Skills, their Approach to Teaching and the Approach to Learning of their 
Students. Active Learning in Higher Education, 5 (1), 87-100. https://doi.org/10.1177/1469787404040463.

Habermas, J. (2007). La lógica de las ciencias sociales. Madrid: Tecnos.

Herrán, A. \& Paredes, J. (2012). Promover el cambio pedagógico en la universidad. Madrid: Pirámide.

Imbernón, F. (2000). Un nuevo desarrollo profesional del profesorado para una nueva educación. Revista Interuniversitaria de Formación del Profesorado, (38), 37-46.

Ley Orgánica 6/2001, de 21 de diciembre, de Universidades. Boletín Oficial del Estado, núm. 307, de 24 de diciembre de 2001, pp. 49400-49425. Recuperada de https://www.boe.es/boe/dias/2001/12/24/pdfs/A49400-49425.pdf.

Loes, C. N. \& Pascarella, E. T. (2017). Collaborative Learning and Critical Thinking: Testing the Link. The Journal of Higher Education, 88 (5), 726-753. doi: 10.1080/00221546.2017.1291257.

Louie, B. Y., Drevdahl, D. J., Purdy, J. M., \& Stackman, R. W. (2003). Advancing the Scholarship of Teaching through Collaborative Self-Study. The Journal of Higher Education, 74 (2), 150-171.

Medina Rivilla, A. (1988). Didáctica e interacción en el aula. Madrid: Cincel.

Murray, C. E., \& Grant, G. (1998). Teacher peer review: Possibility or pipedream? Contemporary Education, 69 (4), 202-204.

Naciones Unidas. (2015). Transformar nuestro mundo: la Agenda 2030 para el Desarrollo Sostenible. Buenos Aires: Programa de las Naciones Unidas para el Desarrollo.

Parpala, A., \& Lindblom-Ylänne, S. (2007). University teachers' conceptions of good teaching in the units of high-quality education. Studies in Educational Evaluation, 33, 335-370. https://doi.org/10.1016/j.stueduc.2007.07.009.

Postareff, L., Lindblom-Ylänne, S., \& Nevgi, A. (2007). The effect of pedagogical training on teaching in higher education. Teaching and Teacher Education, 23, 557571. https://doi.org/10.1016/j.tate.2006.11.013.

Ramsden, P., Prosser, M., Trigwell, K., \& Martin, E. (2007). University teachers' experiences of academic leadership and their approaches to teaching. Learning and Instruction, 17, 140-155. https://doi.org/10.1016/j.learninstruc.2007.01.004. 
Rigal, L. (2011). Lo implícito y lo explícito en los componentes pedagógicos de las teorías críticas en educación. En F. M, Hillert, N. Graziano \& M. J. Ameijeiras, La mirada pedagógica para el siglo XXI. Teorías, temas y prácticas en cuestión. Reflexiones de un encuentro. (pp. 40-50). Buenos Aires: Editorial de la Facultad de Filosofía y Letras. Universidad de Buenos Aires. Disponible en: http://biblioteca.clacso.edu.ar/clacso/coediciones/20130823043844/miradapedagogica. pdf.

Sepúlveda, A., Opazo, M., Sáez, D., \& Lemarie, R. (2015). ¿Existe diferencia significativa, en la enseñanza, entre profesores y docentes en la Universidad?: percepción de los estudiantes. Revista de Orientación Educacional, 29 (60-73), 88123.

Thomas, S., Chie, Q. T., Abraham, M., Jalarajan, S., \& Beh, L. S. (2014). A Qualitative Review of Literature on Peer Review of Teaching in Higher Education: An Application of the SWOT Framework. Review of Educational Research, 84. https://doi.org/10.3102/0034654313499617.

UNESCO (2015). Declaración de Incheon y Marco de Acción para la realización del Objetivo de Desarrollo Sostenible 4. Educación 2030. París: UNESCO. Disponible en: http://unesdoc.unesco.org/images/0024/002456/245656s.pdf.

UNESCO. (1998). Conferencia Mundial sobre la Educación Superior. La educación superior en el siglo XXI. Visión y acción. París.

Zabalza, M. Á. (2010). Competencias docentes del profesorado universitario. Calidad y desarrollo profesional. Madrid: Narcea.

Zabalza, M.A. (2011). Formación del profesorado universitario: mejorar a los docentes para mejorar la docencia. Educação, 36 (3), 397-424. 


\section{Posse da terra e organização na Região do Baixo Amazonas}

PAULO FERREIRA ${ }^{1}$

\section{Resumo}

A comunicação pretende refletir sobre as relações sociais e os mecanismos de apropriação da terra, a luta de resistência pelos direitos e o reconhecimento da cidadania, através da posse, fixação e produção no território habitado pelas várias populações, na região do Baixo Amazonas, ao longo rio Trombetas, extremo oeste do Pará, cenário do projeto da Hidrelétrica de Cachoeira Porteira, e em alguns dos seus afluentes, espaço das Comunidades Quilombolas. A invasão deste território por grupos econômicos específicos (famílias de comerciantes e fazendeiros) em busca da extração das riquezas naturais e produtos da floresta, através das vias fluviais, desrespeitando o espaço de longa data ocupado e provocando desequilíbrios nas relações de produção das comunidades tradicionais (ribeirinhos, negros e indígenas), gera conflitos sangrentos na luta pela manutenção das terras comunais, na união e organização de diferentes grupos de posseiros, no sentido de fazer valer os seus direitos pelo reconhecimento da cidadania. Direitos e cidadania, pensamos que é tema mais que pertinente no atual contexto político Brasileiro.

Palavras-chave: Grandes projetos, conflito de modelos, propriedade privada da terra, organização comunitária, reconhecimento da cidadania.

\section{Abstract}

The present research aims to reflect on the social relations and mechanisms of land appropriation, the struggle of resistance for the rights and the recognition of citizenship, through the possession, fixation and production in the territory inhabited by the

\footnotetext{
${ }^{1}$ Professor Dr. da Faculdade de Letras Dalcídio Jurandir, Universidade Federal do Pará/UFPA, campus Universitário de Altamira - PA, paulojorg58@ yahoo.com.br
} 
populations, in the region of the Baixo Amazonas, along Trombetas river, Pará extreme west, scenario of the Cachoeira Porteira Hydroelectric Plant, and in some of its tributaries, Quilombola Communities region. The invasion of this territory by specific economic groups (families of merchants and farmers) in search of extraction of natural resources and products of the forest, through the waterways, disrespecting the space of long time occupied and provoking imbalances in the production relations of the traditional communities (blacks, and indigenous peoples), creates bloody conflicts in the struggle for the maintenance of communal lands, in the union and organization of different groups of squatters, in order to assert their rights for the recognition of citizenship. Rights and citizenship, we think it's a pertinent theme, in the current Brazilian political scene.

Keywords: Large projects, models conflict, private land property, community organization, citizenship recognition.

\section{Introdução}

Este artigo é fruto de uma pesquisa de campo, em agosto de 2014, no BaixoAmazonas, junto a algumas comunidades quilombolas (Comunidades da Cachoeira da Pancada, S. Joaquim, Espírito Santo, Araçá (de dentro) e Jaruarı), em Oriximiná, Oeste do Pará, no rio Erepecuru, braço do rio Trombetas, para recolha de material para a elaboração da tese de doutoramento. O objetivo principal da minha visita a essa área foi o de poder apreciar comparativamente o cenário, no respeitante ao modus vivendi das comunidades visitadas, quase duas décadas após as pesquisas, na mesma área, levadas a cabo pelas professoras Rosa Acevedo e Edna Rosa. Este trabalho se fez ainda mais necessário, avaliado em oportunidade posterior, pelo contexto que gradativamente viria a tomar forma e a se configurar, sobretudo, após o golpe "branco" de 2016 e de tudo o que a partir dele tristemente viria a decorrer até chegarmos à questão referida na conclusão deste artigo. A metodologia usada por mim, na pesquisa de campo, consistiu principalmente na escuta das várias vozes protagonistas do processo, quer em reuniões realizadas pelos comunitários, quer ainda nas visitas informais às famílias e na recolha de material e informações, em pequenas "rodas de conversas".

Durante um jantar, no Hotel Vale do Xingu, à margem esquerda do rio Xingu, na cidade de Altamira-Pará, no final de 2017, numa conversa sobre a realidade e os impactos de um grande projeto como o da Hidrelétrica de Belo Monte; conversa essa 
entre o Professor Sérgio Claudino impulsionador do projeto Nós Propomos!, por estas amazônicas paragens - e alguns colegas da Faculdade de Geografia, da UFPA, campus universitário de Altamira, Pará --, momento então, no decorrer desse fraterno jantar, em que foi aventada a possibilidade de participação de um pequeno grupo no Congresso Ibero-americano a ser realizado em Lisboa, para setembro de 2018. E aqui chegámos.

\section{Um primeiro momento que antecede à chegada dos grandes projetos hidrelétrico-mineradores.}

Após um longo período de quase completo isolamento, as comunidades do rio Trombetas, do Cuminá, do Erepecuru, vão assistindo à entrada de novos elementos num movimento de conquista de terras ricas em castanha e madeiras.

Os regatões que subiam o Trombetas até quase ao limite das primeiras cachoeiras efetivavam um elo entre o mundo urbano (Óbidos, Oriximiná, principalmente) e o território dessas diversas comunidades, dos lagos e margens do rio e seus afluentes, que se dedicavam à prática agro-extrativa, e desenvolviam um comércio considerável (com produtos tais como: a mandioca, a farinha, o tabaco, a castanha e madeira).

A recomposição das relações de dominação na sociedade pós-cabanagem, foi feita tendo a figura do regatão como agente de intermediação entre os negros e o mundo branco. Personagem que teve dupla investidura, de conquistador daquelas paragens e de articulador de novas relações de dominação entre brancos e os grupos colocados à sua margem (Acevedo \& Castro, 1998: 67).

Com a quebra gradual do cacau, nas duas primeiras décadas do século $X X$, as atenções de grupos econômicos específicos (famílias de comerciantes e fazendeiros) voltaram-se para as riquezas naturais e alternativas da floresta, em relação aos produtos como a castanha, cumaru, pau-rosa, balata e madeiras. Esses grupos se organizaram na tentativa de tomarem os espaços dos regatões, através das vias fluviais, aproveitando-se do avanço tecnológico (a navegação a vapor) e de apropriarse das terras comunais usadas secularmente pelas comunidades negras rurais, por intermédio de falcatruas cartoriais.

Em relação ao primeiro ponto referido: o da navegação, Rosa Acevedo e Edna Castro mencionam que "... comerciantes e fazendeiros recorreram à transferência desses domínios (...), à reacomodação através da intensificação do interesse no extrativismo da madeira e da castanha" (Acevedo \& Castro, 1998: 129). E acrescentam: 
Os estaleiros de Óbidos e Oriximiná chegaram a ser famosos pela construção de embarcações que serviam às linhas regulares de navegação a vapor na região. Ali eram recebidas as madeiras extraídas por negros e tapuios. Posteriormente, a castanha ocuparia o lugar destacado, o segundo na economia do estado do Pará, desde o início do século (Acevedo \& Castro, 1998: 129).

Em relação ao segundo ponto da questão - a apropriação indevida de terras por meio de titulação cartorial falsificada -, achamos oportuna a referência de Vicente Salles: "Bom, é verdade que enquanto os negros lavravam a terra para nutrir a economia de Óbidos, do Estado, do País, desde priscas eras, alguém, que não traças e cupins, lavrava termos nos cartórios" (Salles, 2013: 24).

A propriedade da terra era garantida não pela posse, o uso através do trabalho, mas garantida por papéis oportuna e habilmente falsificados: "E a propriedade da terra é garantida pelos papéis. Não pelo trabalho. Esses papéis sustentam a veracidade das traças e dos cupins" (Salles, 2013: 24). Para além do transtorno e do constrangimento evidentemente das comunidades posseiras.

Assim, assegurado por um título forjado, o comerciante metamorfoseia-se em donoda-terra e dos castanhais. O que outrora era um trabalho coletivo e comunal, efetuado sob o controle das famílias de negros e tapuios, no tempo da safra da castanha, os quais dispunham do produto e vendiam a quem queriam, demarcando e determinando o preço, tal prática costumeira infelizmente perdeu-se e foi alterada com a chegada de novos elementos (famílias de comerciantes e fazendeiros) e com a imposição de novas regras. Essa mudança, segundo Acevedo \& Castro (1998: 141) "somente poderia ser assegurada com a proibição ou controle da coleta até então livre. Esse procedimento de privatização dos castanhais avançou com apoio na legislação agrária que, através de compra e venda, favoreceu um grupo particularizado da elite do município".

Quer dizer: "A coleta da castanha, realizada tradicionalmente sob forma familiar em castanhais, consideradas pelos negros como parte de suas terras comunais, foi transferida para os castanhais dos patrões" (Acevedo \& Castro, 1998: 145). Essa é uma forma não muito original, digamos, mas afinal bastante eficiente, de roubo institucionalizado legalmente, mas uma prática, segundo o Direito Natural, nada legítima! E digamos também que na perspectiva do Direito Positivo, apesar de, como lei humana, não poucas vezes, brilhantemente justificá-lo.

Desde aproximadamente os meados do século XIX, refletindo e confrontando-se com os grandes teóricos da Economia Política - tais como David Ricardo, Adam Smith - e 
referindo-se ao "rendimento bruto e líquido" de Say, Karl Marx escreveu: "O direito do proprietário agrário tem sua origem no roubo. Os senhores de terras, como todos os outros homens, gostam de colher onde não plantaram e exigem mesmo uma renda pelo produto natural da terra" (Marx, 2011: 96).

A prática secular dessas comunidades negras rurais não se encaixava na concepção e prática do direito burguês e nas cláusulas do ponto de vista fundiário, segundo Rosa Acevedo e Edna Castro, pois segundo as pesquisadoras "dificilmente suas pretensões de terra comunal poderiam encaixar-se na ordem jurídica privativa da propriedade" (Acevedo \& Castro, 1998: 134-135).

O modo de produção desses descendentes de quilombolas está baseado, portanto, na posse e uso comum da terra. Ora, tal concepção choca-se com a noção de propriedade privada da terra, sem dúvida. E essa mesma noção de terra comum no confronto com o poder e os interesses do capital seguramente sai enfraquecida no jogo institucional da sociedade.

É necessário compreender que a concepção de territorialidade e de terra comum, como é o caso dos negros do Trombetas, só pode ser percebida no interior das relações que estruturam a organização dessas comunidades. Não pode ser subordinada portanto à lógica da propriedade que preside o direito brasileiro, por ter a natureza distinta. Os negros mantêm, na prática e na concepção, terras comuns, pois institucionalizaram um sistema de regras que alimentam o seu modo de produção (Acevedo \& Castro, 1998: 158).

A Floresta, o espaço da terra firme - além das várzeas e das vias fluviais - não é percepcionada apenas como uma fonte exclusiva de recursos materiais propícios à sobrevivência do ser humano - é oportuno afirmá-lo --, mas ainda como "um dos símbolos-chave da resistência à escravidão, a floresta é um lugar de iniciação histórico-cultural e, portanto, identitárias. Comparada a um 'ventre-mãe' (...) lugar do renascimento onde o velho escravo aciona a reconstrução de seu ego" (Walter, 2009: 133). A terra como um ventre-materno! Um ventre que dá a vida e a sustenta! “... que mostra o ser humano preso à terra e nela abrindo covas que o alimentam vivo e 0 abrigam morto" (Bosi, 1992: 14).

Já refletimos a este respeito no capítulo anterior (e inclusive na parte final do primeiro, quando fizemos referência aos benandanti) e constatamos que há uma relação entre o "amanho da terra" e o "culto dos mortos". Para esse fato chama-nos a atenção Alfredo Bosi: "Quanto a cultus, us, substantivo, queria dizer não só o trato da terra como também o culto dos mortos, forma primeira de religião como lembrança, chamamento 
ou esconjuro dos que já partiram" (Bosi, 1992: 13). Segundo o estudioso, a Antropologia não tem mais dúvidas quanto à precedência do "enterro sagrado" em relação ao "amanho do solo" - este último vem do período Neolítico, fase correspondente à Revolução Agrícola, fase determinante para o desenvolvimento da Humanidade (aproximadamente há 7.000 anos a. C.); enquanto que o primeiro, a inumação dos mortos, é bem mais antiga, pois já se realizava nos tempos do Homem de Neardenthal (há mais ou menos 80 mil anos atrás).

Do pó viemos e ao pó retornaremos. A terra, efetivamente, se comporta como um ventre, que dá vida e a sustenta e ao final da qual se alimenta. É daqui que provém o culto à fertilidade: "Os espíritos dos antepassados devem ter sido considerados, seguramente, como cooperadores na germinação das plantas cultivadas" (Bosi, 1992: 14). E associado ao culto da fertilidade vêm a das famigeradas figurinhas, encontradas em povoados ou em tumbas, conhecidas por "deusas da fertilidade".

Nos campos da idade paleolítica encontram-se figurinhas, talhadas em pedra ou marfim, com os caracteres sexuais muito acentuados. Figurinhas semelhantes, só que agora modeladas geralmente em argila, são muito comuns nos povoados e tumbas neolíticas. Com frequência chamam-nas 'deusas da fertilidade'. Por acaso a terra, de cujas entranhas brota o pão, teria sido concebida à semelhança de uma mulher com cujas funções geradoras o homem estava certamente familiarizado (Bosi, 1992: 14).

Nesse espaço, o da floresta tropical, equaciona-se então a posse e o uso da terra comum, o modelo familiar de uma economia agroextrativista e do trabalho em grupo expresso através do putirum (mutirão). Assim, as relações de produção são expressas através da participação de "Todos os membros da família" que "envolvem-se nas diferentes tarefas que garantem a produção comercializada ou não" (Acevedo \& Castro, 1998: 162).

As crianças, no conjunto da família, também participam desse processo: "A participação de crianças resulta em práticas que regulam a socialização das novas gerações e a aprendizagem dos processos produtivos" (Acevedo \& Castro, 1998: 162). E ainda: "O trabalho em grupo", não apenas no que diz respeito a um modelo familiar de produção, mas ainda pelo seu caráter comunitário, expresso através da associação de várias famílias (putirum ou mutirão) "é uma forma de racionalizar suas forças produtivas e maximizar os resultados e limites impostos pela natureza a uma economia agro-extrativa" (Acevedo \& Castro, 1998: 162) .

Este modelo de produção, familiar-comunitário, de uma economia agroextrativista, que vive dos ciclos da natureza para a extração dos produtos que ela oferta nos "tempos 
certos" e previstos e de uma agricultura de subsistência, segue os ritmos impostos pela própria natureza, vive de acordo com ela, sob uma relação baseada no respeito e no reconhecimento da Natureza como uma Mãe, como um Ser vivo que precisa ser respeitado, amado e principalmente preservado.

Em seguida, quando olharmos aos grandes projetos minero-hidrelétricos e ao impacto que eles provocarão na Natureza, veremos mais uma vez que esta concepção e prática das seculares e sábias comunidades negras rurais, no seu contato com a natureza, vão ser não apenas desconsideradas, mas ainda consideradas como primitivas e, numa perspectiva do "progresso", consideradas como atividades anacrônicas.

Esta visão capitalista-colonialista discriminatória - fruto de uma falsa superioridade arrogante - é denominada de etnocentrismo. É em nome de tal atitude etnocentrista que lhes é permitido olhar o(s) Outro(s) como "bárbaros" e/ou "selvagens". A este respeito escreve Claude Lévi-Strauss o seguinte: "Esta atitude do pensamento, em nome do qual se rejeitam os 'selvagens' (ou todos aqueles que escolhemos considerar como tais) para fora da humanidade, é justamente a atitude mais marcante e a mais distintiva destes mesmos selvagens" (Lévi-Strauss, 2008: 18).

Revela não olhar além do seu próprio umbigo (atitude egótica), não descortinar seus interesses além das fronteiras do seu grupo (aldeia ou tribo), não se "abrir" ao diferente, à diversidade, mas, pelo contrário, se amedrontar e recear confrontar-se com o que é diferente... O renomado antropólogo remata: "Recusando a humanidade àqueles que surgem como os mais 'selvagens' ou 'bárbaros' dos seus representantes, mais não fazemos que copiar-Ihes as suas atitudes típicas. O bárbaro é, em primeiro lugar, o homem que crê na barbárie" (Lévi-Straus, 2009: 19).

\section{Projeto hidrelétrico-minerador: a resistência e o reconhecimento vitorioso do estatuto de 'Comunidades Remanescentes de Quilombos'.}

O Imperialismo no seu auge voraz que grassava por toda a África em busca da satisfação insaciável das abundantes riquezas do continente africano, cujo exemplo do Congo (atual Zaire), com Patrice Lumumba, referido acima, na década 60, é um vivo exemplo, entre várias possíveis Repúblicas Africanas, é o mesmo que invade o Baixo Amazonas, atingindo as comunidades negras ribeirinhas e rurais (agroextrativistas) do rio Trombetas e seus importantes afluentes, causando poluição, desarmonia e desequilíbrio, e trazendo a morte em nome do progresso. 
Alfredo Bosi utiliza uma expressão interessante, "barbarização ecológica" que designa adequadamente este "progresso" bem intencionado - e é pertinente, neste caso, a conhecida asserção: de que de boas intenções está o inferno cheio... - que causa tanto transtorno, divisão e morte, aos lugares e comunidades por onde estende sua "benéfica sombra"! O que o pesquisador comparativamente afirma em relação à realidade brasileira das décadas 70 e 80, época da ditadura militar no Brasil (e esse triste cenário se repete em outras nações do Centro e Sul-América, enquanto na Europa por essa época era instituída a concepção e prática neoliberal da economia, que receberá a denominação de globalizada - um eufemismo para a crítica fase imperialista, pós-moderna...) encaixa perfeitamente e corresponde à expansão multinacional do capitalismo: "O projeto expansionista dos anos 70 e 80 foi e continua sendo uma reatualização em nada menos cruenta do que foram as incursões militares e econômicas dos tempos coloniais" (Bosi, 1992: 22).

O ímpeto violento, o desrespeito à vida, a sanha voraz e exploradora do ser humano (enquanto mão-de-obra), a destruição da natureza em nome do lucro, enfim, de um modo geral, os "métodos coloniais", são justificados pelas potências imperialistas segundo Alfredo Bosi - em termos de "válvulas de segurança". Acrescentarei ainda: não menos do que "válvulas de escape".

Carl Siger, uma mente ao serviço da justificação das práticas colonialistas realizadas além-mar-metropolitana, defende os métodos coloniais como verdadeiras "válvulas de segurança":

Les pays neufs sont un vaste champ ouvert aux activités individuelles, violentes, qui, dans les metrópoles, se heurteraient à certains préjugés, à une conception sage et réglée de la vie et qui, aux colonies, peuvent se développer plus librement et mieux affirmer, par suíte, leur valeur. Ainsi les colonies peuvent, à un certain point, servir de soupapes de sûreté à la societé moderne. Cette utilité serait-elle la seule, elle est immense (Siger apud Bosi, 1992: 22).

Interessante filosofia... No geral, a ideia é a de manter a ordem em casa (os países do centro) e bagunçar a alheia (os países periféricos)! Isso não apenas é recomendado como ainda é imensamente útil e benéfico para os países ditos centrais. Não consta que alguém houvesse processado tal sujeito por sua mente prática, racista e tão desrespeitosamente discriminatória... Quem sabe o direito, ao serviço do mais forte, não o protegesse?!

"Países novos": significa aqueles que alcançaram recentemente sua independência, que se livraram, de certa forma, do jugo político-administrativo direto do colonizador. 
Mesmo se tratando de povos e nações com uma história de longa data no percurso da Humanidade. Semelhantemente àquelas comunidades quase duplamente seculares do Trombetas que ressurgem assim como quase do nada, por simples passe de magia, na forma daquelas "novas" comunidades de negros... em notícia revelada pelo O Liberal.

É claro que, ao longo dos tempos, essas comunidades rurais negras sempre gozaram de visibilidade, mesmo quando procuravam se ocultar e, por questão de segurança própria, manter uma relativa distância do "mundo branco". Foram vistos e reconhecidos por pesquisadores, entraram em contato com os pequenos regatões, depois destes vieram os novos comerciantes (famílias) de Oriximiná, mais e melhor aparelhados, que "trilharam os mesmos caminhos dos regatões mas gerenciam outras formas de concorrência" (Acevedo \& Castro, 1998: 191).

Desse veio mercantil, seguem-se as famílias de menores posses, que acabaram por tornarem-se grandes proprietários através da prática de apropriação e arrendamento dos castanhais a que já fizemos referência anterior. Todo este gradual processo de primeiro contato, com os regatões, aprofundado com a chegada dos novos elementos, com barcos mais equipados, que criam novas relações comerciais, baseadas na desapropriação e desterritorialização de territórios secularmente comunais, preparava o terreno afinal à chegada dos grandes projetos, que se fariam presentes a partir dos finais da década 60. Alguns dos grandes proprietários, como foi o caso dos herdeiros de Raimundo da Costa Lima, acabaram por vender as suas propriedades para a Empresa Rio Xingu/SA.

Registre-se casos de antigos patrões desistirem de organizar os empreendimentos da safra. Esses mecanismos coincidem com interesses manifestados por empresas do Sul do País ou multinacionais, de se instalarem nas áreas. Estavam motivados pelos resultados dos estudos de prospecção de jazidas minerais, realizados por órgãos oficiais em meados dos anos 60. O interesse pelas terras deslocou-se do castanhal para os recursos minerais, como as iniciativas de compra conduzidas pela Empresa Jari - Santa Patrícia - e a Mineração Rio do Norte (Acevedo \& Castro, 1998: 192).

Vai dar-se início a um processo de invasão. Este termo é devidamente aplicado, pois de uma verdadeira invasão se trata a essas comunidades negras rurais, perpetrado por empresas de capital misto -- tanto nacional quanto multinacionais -- com inteiro apoio do Governo Federal e de órgãos públicos (estaduais e federais), ligados à área de preservação ambiental, tais como: IBDF, IBAMA, INCRA, etc. São os agentes da nova "frente branca" invasora. 
O curioso é que esse processo ocorre com idênticas semelhanças em todo mundo. A voz de Toiá Verequête que soa em relação à África e se faz escutar aqui também: "E pai Verequête falou como um príncipe/da terra africana que o branco assaltou" (Menezes, 1993: 242). Em face de essa desafiadora realidade urge (re)-criar novas "formas de rebeldia" e "estratégias de luta" com o escopo de manter esse tradicional território de conquista, tão cuidadosamente preservado, ao longo de quase dois séculos, através de várias gerações, ao custo de luta, resistência, sacrifício e superação, diante das pretensões das grandes empresas de mineração (sobretudo com o olho na bauxita) e do setor elétrico com o aproveitamento das cachoeiras (Acevedo \& Castro, 1998: 205).

Essas empresas representantes do capital (nacional e internacional) procuram configurar-se dentro das normas do Direito. Mas trata-se de uma situação ilusória, pois sabemos o que isso significa enquanto prática concreta: jogo de influências (políticoeconômicas), propinas, lobby, enganação através de falsas promessas em meio à comunidade, criando uma divisão interna (entre os que apoiam o projeto e os que são contra) que lhes facilita o domínio e o controle da situação... É a "velha" estratégia do colonialismo britânico: "dividir para melhor e mais facilmente dominar".

Gozando essas empresas de várias prerrogativas, desde concessões governamentais até à isenção de impostos, para atrair ao local e fixar esse capital multinacional, símbolos de progresso e de riqueza para a região. O quadro ou cenário vai-se configurando como uma opus irreversível. Como um monstro ou dragão que a tudo e a todos domina, gozando de invencibilidade, e do poder e da força que brotam do capital.

A Mineração do Rio Norte que teve concessão de 65. 552 ha de terra para a lavra do minério e três anos depois adquiriu uma posse de 400 ha. Entretanto, fez solicitação adicional, em 1977, de uma doação de 87. 258 ha ao INCRA (Acevedo \& Castro, 1998: 205).

A voracidade dessas empresas, nunca satisfeitas, que quase sempre começam de uma forma aparentemente humilde, pedindo até licença para chegar. E que não muito tempo depois começam a mostrar ao que vieram. De quase setenta mil hectares de terra iniciais exigem depois quatro vezes e um pouco mais outro tanto de área e não satisfeitos, ainda solicitam mais uma fatia boa através de órgão público (INCRA). Quase sempre essa extensa área acrescida representa uma área extensa (maior ainda e de implicações muitas vezes incalculáveis e não previstas) de devastação e destruição ambiental. 
Num espaço previamente escolhido a empresa (Mineração do Rio Norte) acaba por criar um verdadeiro enclave. Segue um modelo de cidade fechada e discriminatória. Quanto ao primeiro aspecto, cria-se uma estrutura social elogiável, própria de uma sede urbana relativamente bem planejada (Porto Trombetas, distante a $80 \mathrm{~km}$ de Oriximiná), seguindo uma "linha de intervenção priorizada pela sua principal acionista, a Companhia Vale do Rio Doce, o Projeto Trombetas foi planejado com todo o rigor de um empreendimento enclave, recolhido sobre si mesmo" (ACEVEDO \& CASTRO, 1998: 219).

Quanto ao segundo aspecto, o de assumir uma atitude discriminatória, divisória, enquanto assumido como um espaço fechado segue o pertinente testemunho das autoras: "Tal política obriga as pessoas que pretendem ter acesso pelo porto de chegada a serviços como supermercados, agência de viagens ou hospital, a aguardarem liberação (ou não) no portão de acesso" (Acevedo \& Castro, 1998: 209).

Para escamotear essa real situação - no caso do Trombetas, a vegetação degradada do Igarapé Água Fria pela sedimentação da bauxita -- cria-se uma Reserva Biológica do Trombetas. "Vejam como eles são sensíveis à Natureza, preocupados efetivamente com o Meio Ambiente" -- poderão alguns até arguir. Segundo Rosa Acevedo e Edna Castro tal fato não deixa de representar uma "séria" ironia: "Isso parece uma ironia depois de ter sido reconhecida sua contribuição para a degradação do Lago Batata e para o desmatamento do terreno previsto para a formação do reservatório da UH Cachoeira Porteira" (Acevedo \& Castro, 1998: 206).

A essa altura, depois de criados todos os inconvenientes, de se ter alastrado a confusão e a perplexidade intra e intercomunitárias, de se sentirem as várias comunidades locais acoitadas e cerceadas, com seu espaço vital reduzido e degradado e com mobilidade restrita, essas empresas diante da sociedade regional começam a mostrar sua verdadeira face: nada mais do que consórcios conservadores e autoritários. É que, efetivamente, eles não estão ali para efetuarem melhorias nas condições de vida das populações locais, mas exclusivamente para se beneficiarem das riquezas utilizando-se cinicamente de um ilusório e enganador discurso em nome do progresso e do bem-estar da população.

Afinal, "os impactos de grandes projetos na região do Trombetas", quando realisticamente analisados, "manifestaram-se nos problemas ambientais e na desestruturação do modo de produção da vida presente entre os seus antigos ocupantes" (Acevedo \& Castro, 1998: 208). 
A criação da Reserva Biológica do Trombetas não serviu apenas, eventualmente, para escamotear os graves problemas de destruição ambiental, mas numa associação de Estado e Empresas, que se utilizaram do "discurso preservacionista" para efetivarem na prática um cerco aos modos seculares e condições reais de vida das populações aí residentes.

Residindo aí há quase dois séculos, sempre o modo de vida comunal dessas populações respeitou a natureza mantendo um saudável equilíbrio com todas as formas vivas do meio ambiente. A preocupação da Reserva Biológica foi com as tartarugas e a madeira de lei, segundo as pesquisadoras, essas "foram as válvulas de sensibilização para justificar tal medida governamental" (Acevedo \& Castro, 1998: 209).

$\mathrm{Na}$ realidade, o verdadeiro significado da Reserva Biológica, não deixa de ser apontado abertamente pelas pesquisadoras:

Literalmente, a Reserva Biológica foi aprisionadora das fontes de produção: os peixes dos lagos, de rios e igarapés, as sementes e os frutos coletados na mata, os cipós e as palhas para fabricação de artesanato e de suas casas e a madeira para fazer canoas (itaúba). Na área da Reserva encontram-se os mais ricos castanhais, cuja atividade de extração, não importa absolutamente em nenhum prejuízo à natureza, mas pelo contrário, sua retirada realimenta o novo ciclo da natureza, pela alimentação do homem que ali vive e dos animais que também se beneficiam comendo as cascas de ouriços quebrados (Acevedo \& Castro, 1998: 209).

Essa intervenção associada Estado/Empresa, através de um processo de desterritorialização pela concessão do uso da terra pelo ITERPA (órgão de âmbito estadual) e o INCRA (da esfera federal) aos novos agentes do capital, deixou as populações rurais e ribeirinhas do Trombetas e seus afluentes sem possibilidade de pescar, de abrir roças ou coletar castanha, impedidos de se utilizarem dos recursos naturais na área englobada pela criada unidade de conservação.

A reconquista dos direitos violados das comunidades tornou-as conscientizadas da urgência da luta. Criaram cooperativas, fortaleceram os sindicatos, passaram a se reunir com mais frequência e a deslocar-se às sedes políticas dos poderes públicos (municipal, estadual e federal). Dessa resistência e luta seu nível de consciência e formação identitária apurou-se. A identidade grupal assume então uma dimensão político-ideológica a partir do sentimento reconhecido da exclusão a que até então o grupo havia sido submetido. Na linha do que escreve Kabengele: 
... persistimos em afirmar que a identidade negra mais abrangente, seria a identidade política de um segmento importante da população brasileira excluída de sua participação política e econômica e do pleno exercício da cidadania (Munanga, 2012: 16).

A etnia, por exemplo, "é construída a partir de conflitos sociais" e "É a luta que forja os valores", escreve Roger Bastide. Assim, a partir do início dos anos 90,

No rio Trombetas, os moradores de Cachoeira Porteira, menos aderentes, até o presente, ao Movimento das Associações dos Remanescentes de Quilombos, parecem mais interessados em seguir o projeto estadual de Criação da Área de Turismo. Os de Erepecuru-Cuminá pretendem manter-se enquanto camponeses AgroExtratores (Acevedo \& Castro, 1998).

O estatuto de camponeses e posseiros, de acordo com a opção de algumas comunidades, corresponde a uma identidade política diferenciada das denominadas comunidades remanescentes de quilombos. Tal denominação tem íntima relação com as chamadas terras de preto ou terras de quilombolas, "associadas ao forte sentimento de fazer parte da história de um grupo identificado com um território" (Acevedo \& Castro, 1998).

Alecsandro Ratts atribui um impulso jurídico decisivo a partir da Constituição Federal da República de 1988 e do Artigo 68 em cujo conteúdo reza o seguinte: "Aos remanescentes das comunidades de quilombos que estejam ocupando suas terras é reconhecida a propriedade definitiva, devendo o Estado emitir-lhe os títulos respectivos" (Rattz, 2010: 316). Sabedores de tamanho respaldo jurídico e baseados na ancianidade da ocupação.

Os vários grupos assentados no alto dos rios Trombetas, Erepecuru e Cuminá, abaixo das Cachoeiras que outrora encobriram e protegeram os Quilombos, resgatam da memória os saberes sobre o tempo e a lógica da natureza apreendidos e compartilhados com sociedades indígenas, habitantes das planícies e dos altos das cachoeiras desses rios e do Mapuera. O domínio de saberes, perigos e magias sobre a natureza incorpora-se no imaginário, recodificando experiências, como condição do sucesso nas fugas do cativeiro e de permanência nos quilombos (Acevedo \& Castro, 2010: 29).

$\mathrm{Na}$ continuidade da nossa reflexão, e a título conclusivo, percebemos que o tema da modernização, tão premente e atual, não deixa, todavia, de significar para muita gente, uma mera utopia. Associado à modernização estão também o desenvolvimento e 
progresso. Um implica o outro. E devemos conceber tal, o desenvolvimento, como um direito de todos os povos do planeta. Direito ao conhecimento que gera a tecnologia. Mas o que vemos, lamentavelmente, é um pequeno grupo de nações, que, pelo seu status de nações economicamente poderosas e com avanço técnico e, consequentemente, tecnológico, se aproveitarem desse fato para controlarem, dominarem e explorarem outros povos e nações, em benefício próprio.

Kwame A. Appiah aponta-nos o pensador ganês Wiredu que concebe a modernização como um projeto essencialmente filosófico. É o projeto central da África negra. Segundo esse pensador, "a busca do desenvolvimento (...) deve ser vista como um processo histórico mundial contínuo, no qual todos os povos, ocidentais e não ocidentais, estão empenhados" (APPIAH, 1997: 150). Não um modo de conhecimento que gera poder e avanço tecnológico em mãos de uns poucos e em seu benefício próprio, sacrificando desrespeitosamente todos os outros povos.

Mas sim conhecimento e desenvolvimento ao serviço da vida e do bem-estar e progresso dos povos, fato que deverá ser percepcionado e reconhecido efetivamente como um direito de todos. Desse modo, "a modernização não está 'jogando fora impensadamente' os modos de pensar tradicionais e adotando hábitos estrangeiros, mas é, antes, um processo em que 'os africanos, juntamente com todos os outros povos, procuram alcançar um destino especificamente humano"' (Appiah, 1997: 150).

Afinal, teríamos de descobrir qual o sentido e como darmos razão à interessante sugestão de Appiah: “... o que significa ser moderno é uma pergunta que africanos e ocidentais podem formular juntos. E, como pretendo sugerir, nenhum de nós compreenderá o que é a modernidade enquanto não compreendermos uns aos outros" (A,ppiah 1997: 155).

\section{Conclusão}

Esta é uma conclusão, digamos, atemporal, no sentido em que fiz minha pesquisa e recolha do material desse artigo em 2014; em 2016 o Brasil seria submetido a um terrível golpe "branco" -- levado a cabo pela corrupta classe política articulada com o Poder Judiciário --, e que viria a interromper abruptamente o caminho seguido pela sociedade civil; para, hoje, outubro de 2018, às vésperas do segundo turno das Eleições Presidenciais, termos um candidato na disputa com forte destaque porcentual e com um discurso fascista de incitação à violência e ao ódio, sonegação dos direitos trabalhistas e civis, discriminação de certos setores da Sociedade brasileira, entre 
eles, por exemplo, os Negros periféricos, as Comunidades Quilombolas e Indígenas. O que fazer? Não cruzar os braços, sem dúvida, e RESISTIR.

Homenagem a MARIELLE, DOROTHY STANG e DEMA. Assassinados, mas SEMPRE VIVOS!

\section{Referências bibliográficas}

Acevedo, R., Castro, E. (1998). Negros dos Trombetas: Guardiães de Matas e Rios. Belém-PA: Cejup/UFPA-NAEA.

Appiah, K. A. (1997). Na Casa de Meu Pai: A África na filosofia da cultura. Rio de Janeiro: Contraponto.

Bastide, R. (1973). Estudos Afro-Brasileiros. São Paulo-SP: Editora Perspectiva.

Bosi, A. (1992). Dialética da Colonização. São Paulo -SP: Companhia das Letras.

Lévi-Strauss, C. (2009). Raça e História. Lisboa: Editorial Presença.

Marx, K. (2011). Manuscritos Econômico-Filosóficos. São Paulo -SP: Martin Claret.

Munanga, A. K. (2012). Negritude: usos e sentidos. Belo Horizonte-- MG: Autêntica Editora.

Ratts, A. (2010). (Re)conhecer Quilombos no Território Brasileiro: Estudos e Mobilizações. Belo Horizonte -MG: Autêntica Editora.

Salles, V. (1992). Memorial da Cabanagem: esboço do pensamento político revolucionário no Grão-Pará. Belém -PA: Cejup.

Salles, V. (2013) Os Mocambeiros e outros ensaios. Belém - PA: Instituto de Artes do Pará (IAP).

Salles, V. (1971). O negro no Pará sob o Regime da escravidão. Rio de Janeiro --RJ: Fundação Getúlio Vargas, Universidade Federal do Pará (UFPA).

Salles, V. (2004). O Negro na Formação da Sociedade Paraense. Belém --PA: PakaTatu. 


\title{
El patrimonio minero como propuesta de innovación educativa para la educación ciudadana y sus valores
}

\author{
TERESA Pulido NEVAdo ${ }^{1}$ \\ FRANCISCO JAVIER JARAÍZ CABANILLAS ${ }^{2}$
}

\section{Resumen}

Los recursos minerales encontrados en la zona que posteriormente ocuparía el poblado minero de Cáceres y su explotación centran el trabajo educativo propuesto para trabajar con el alumnado, enseñar los orígenes de su barrio y los antecedentes culturales que han hecho de Aldea Moret el barrio que actualmente es. Por consiguiente, se crea un proyecto de innovación educativa para que el alumnado de educación Infantil, Primaria y Secundaria conozca la importancia que tiene el patrimonio que les rodea. Para ello, se diseñan una serie de actividades que puedan ser aplicadas en el aula con la intención final de crear un proyecto que reconozca la importancia que el antiguo poblado minero se merece, ofreciendo al alumnado un enriquecimiento cultural basado en la educación ciudadana que supone el tratamiento de la realidad social de un barrio degradado en el que pervive la falta de visibilidad de un patrimonio histórico y cultural que fue esencial para la consolidación de Cáceres como ciudad.

Palabras clave: Didáctica; Ciencias Sociales; Patrimonio cultural; Ciudadanía; Minería.

\section{Abstract}

The mineral resources that were found in the zone and later would be occupying the mining town of Caceres and its strip-mining focus on the educative work proposed with

\footnotetext{
${ }^{1}$ Graduada en Educación Infantil. teresa.pulido@hotmail.es

${ }^{2}$ Docente en la Universidad de Extremadura. jfjaraiz@gmail.com
} 
the students, so with this, they can teach the origins of their neighborhood and the cultural backgrounds. These ones have become Aldea Moret in the neighborhood that it currently today. In order to the students from childhood education, primary and secondary learn the importance of the patrimony that surrounds them; a project of educative innovation is created. For this reason, a series of activities have been designed, created with the intention of creating a project that recognizes the importance of the old mining town deserves. In this way, this project offers to the students' cultural enrichment burred on citizen education that involves the care of social reality of a degraded neighborhood where there is a lack of visibility a historical and cultural patrimony that was essential for the consolidation of Caceres, as a city.

Keywords: Didactics; Social sciences; Cultural heritage; Citizens; Mining.

\section{Introducción}

El desconocimiento por parte de los habitantes de Aldea Moret de la historia que engloba al antiguo poblado minero, motiva la idea de dar a conocer de una manera más activa entre sus pobladores la relevancia del mismo. La mejor forma, sin duda, es enseñar todo lo que fue y lo que actualmente es, desde las edades más tempranas, momento en el que más curiosidad y ganas de aprender se observan, además de ampliar los horizontes culturales del alumnado, los cuales pueden ser reforzados con mayor facilidad en los años siguientes.

El centro de Educación Primaria en el que se realizaría el proyecto de innovación educativa es el ubicado en el propio barrio de Aldea Moret, por lo que se considera el más idóneopara la implementación de la propuesta de intervención abordada en el trabajo. De igual modo, podría trasladarse a los institutos de Educación Secundaria adyacentes el barrio, pues este no cuenta con uno propio. Estos son el Al-Qázeres, Javier García Téllez o el Ágora, donde los alumnos del barrio suelen continuar con su trayectoria académica.Se considera que lo más importante para enseñar a un niño no es su edad, sino la metodología a utilizar. Así pues, se puede llevar a cabo la intervención en todos los cursos presentes en el colegio en cuestión ( $y$ en los institutos), si se adaptan los contenidos y los objetivos a cada nivel deseado.

Para aportar aún más información, los propios hijos de mineros, los cuales han vivido en las cercanías de las minas o en el poblado minero, aún presente en la parte antigua de Aldea Moret, podrían aportar sus relatos de vida, todo ello, adaptado a los alumnos de Educación Infantil, Primaria o Secundaria. Lo que se lleva a cabo dentro del aula, 
puede ser complementado con el Centro de Interpretación de la Minería en Extremadura, ofreciéndoles unas fuentes de información muy amplias.

Por lo tanto, se consideraráun proyecto de innovación educativa al tratar un tema no desarrollado anteriormente en el proceso de enseñanza-aprendizaje como es el patrimonio minero cacereño. No se ha datado aún ningún trabajo de investigación educativa referente al patrimonio minero cacereño, y menos aún se ha realizado un proyecto de innovación educativa sobre él, así pues, se desea poder dar a conocer todo este patrimonio histórico y cultural con el que se cuenta, y que realmente no mucha gente conoce.

Hay que considerar que las minas se convirtieron en un hito para Cáceres, pues dotaron a la ciudad de importancia a nivel nacional e incluso europeo, con las exportaciones de minerales (como el fosfato) que se realizaban gracias a la construcción de una red ferroviaria, unido todo ello al crecimiento urbano vinculado. Desde 1864, cuando se data la primera concesión minera en Cáceres, hasta 1974, que se cierra la última fábrica en Aldea Moret, se produjo una gran revolución.

Debido al incremento de la demanda habitacional por parte de los trabajadores de las minas y empresas asociadas, se crea en las cercanías de las mismas un pequeño poblado minero, el cual albergaría a los trabajadores y a sus familias. Con el paso de los años este poblado va creciendo al tiempo que se le dota de equipamientos y servicios: un colegio, una iglesia, un comedor que hacía las veces de cine, un bar e incluso una piscina. Con posterioridad, el barrio adquirió la denominación de Aldea Moret en honor a Segismundo Moret y Pendergast, político que ayudó, gracias a su alta influencia, a la creación de un asentamiento en el que residían cientos de familias cuyo trabajo estaba vinculado a la mina. De igual modo, se encargaría de comercializar y gestionar el abastecimiento de recursos mineros, abriendo una línea de comercio que estableció un auge en la economía cacereña.

Se pretende con el proyecto de intervención educativa, ofrecer un merecido reconocimiento a aquellos que trabajaron en las explotaciones mineras que sirvieron para dotar de cierto crecimiento económico a la ciudad de Cáceres. La concienciación ciudadana en relación a esta realidad histórica local es esencial para el desarrollo de la actividad docente. Por ello, se trata de adaptar para el alumnado todos los contenidos vinculados, creando un proyecto de innovación educativa que les enseñe de una manera lúdica una de las partes más importantes y representativas de su barrio. 


\section{Fundamentación teórica}

Enseñar Historia al alumnado de educación Infantil y primeros cursos de Primaria puede ser muy complicado. Por eso, una de las formas más pertinentes de hacerlo en estos niveles es de manera lúdica, siendo necesario para ello asentar unas bases metodológicas para esta propuesta de enseñanza: aprendizaje significativo, metodología intuitiva, enfoque globalizador, aprendizaje por descubrimiento, importancia de lo lúdico, etc., que responden a la premisa de que trabajar la historia en esta etapa, no depende tanto de la edad o las características de estos/as niños/as, como de la manera de acercarles los contenidos (Miralles y Rivero, 2012).

Los primeros años de la enseñanza de un/a niño/a son clave para el desarrollo cognitivo, además de establecer unas bases claras que servirán de cimiento para todos los conocimientos que obtendrán en las etapas posteriores. Es por ello que las Ciencias Sociales forman una parte importante en la enseñanza, pues tienen como fin que el alumnado adquiera un conocimiento basado en la comprensión de ideas prácticas, valores éticos y democráticos que les permita convivir en sociedad, además de respetar los derechos humanos y construir una ciudadanía crítica, participativa, responsable y comprometida (San Miguel, 2014).

Dentro de las ciencias sociales, se desarrolla todo lo referente al patrimonio, pero quizás pueda ser un término demasiado amplio por las diversas ramificaciones que el concepto presenta, ya que consta de elementos materiales e inmateriales y ambos parten de un importante proceso que ha llegado a convertir ese elemento en lo que se reconoce como patrimonio. Así, Ballart (1997) define el patrimonio como los objetos que conforman un legado patrimonial en la antigüedad y que actualmente permiten obtener información, además del cambio entre el pasado y el presente, con la conformación de una identidad social.

Afrontar la posibilidad de impartir los conocimientos referentes a las ciencias sociales, y más concretamente los vinculados con el patrimonio histórico-artístico, se plantea más factible a través de un proyecto de innovación educativa, tanto en los primeros cursos de educación Primaria como en los de Secundaria. Este proyecto puede comenzar a ejecutarse en el Colegio Público Gabriel y Galán de Cáceres, ubicado en el barrio objeto de estudio, a los que se les ofrece los principales conceptos acerca del patrimonio cultural que existe en su barrio, para intentar inculcarles un sentimiento y unos valores de respeto y curiosidad, respecto a estos puntos de interés cultural. Además, modificando los contenidos y la metodología se puede adaptar a otros cursos y niveles educativos de Secundaria. 
Tras la revisión bibliográfica, se puede indicar que el patrimonio minero no ha estado presente en la agenda educativa actual, con lo que el único trabajo referente a la minería es una unidad didáctica creada en el Colegio Sagrada Familia (Ricardo, 2015). Esta se centraba en los asuntos concernientes a las minas, más específicamente los vinculados con la extracción del carbón, teniendo como planteamiento enseñar a sus alumnos la vida minera, las herramientas, las galerías y el material extraído, para finalmente, conseguir todos los objetivos que se plantearon.

Si se busca información actual referente al patrimonio, en la inmensa mayoría de los museos y archivos, hay actuaciones relacionadas con la educación patrimonial, aunque es un poco diferente en las bibliotecas, quizás debido a la concepción que tienen sus responsables del concepto de educación patrimonial, pues no lo ven ligado a las actividades didácticas que realizan en sus centros (Cuenca et al., 2014). Es por ello que llevar a cabo un proyecto de innovación educativa como este, podría esclarecer la relación que existe entre el patrimonio, los valores y conocimientos que se pretenden desarrollar en el aula.

Se debe reconocer la importancia del patrimonio para la sociedad y la cultura actual, pues es un recurso poco usado en los niveles educativos indicados y puede ayudar a crear un sentimiento de cercanía hacia la ciudad donde se resida y a las raíces de uno mismo, todo ellos a través del patrimonio próximo al alumnado afectado.Como reflexión final, se observa que el patrimonio cultural puede convertirse en el nexo de unión que ayude a comprender el pasado y entender la realidad social y cultural presente, además de concienciar sobre el futuro que debe construirse, fruto de un proceso o evolución histórica donde aún se puede y debe incidir (González, 2006).

\section{Contextualización}

Aldea Moret, el barrio objeto de estudio, presenta las características de barrio conflictivo debido, entre otras cosas, a los enfrentamientos que existen entre los vecinos del mismo, además del choque de culturas que se producen entre las diferentes etnias allí presentes.En la comunidad que habita en Aldea Moret, predominan principalmente gitanos y payos, en menor medida, mercheros y en gran minoría, musulmanes. Cuatro culturas diferentes que, en ocasiones, producen los conflictos anteriormente citados.El centro educativo en el que se desarrollaría el proyecto de innovación educativo social, sería el Colegio Público de Infantil y Primaria Gabriel y Galán, el cual presenta unas características que lo catalogan como centro de 
difícil desempeño, con un acusado absentismo escolar, por lo que acaba de mencionarse.

El barrio se ubica en la periferia de Cáceres, a tres kilómetros al sur del centro de la ciudad y a casi un kilómetro del barrio más cercano. Aldea Moret presenta solo dos entradas desde la ciudad, una carretera de entrada desde el norte del barrio, tras cruzar por encima de las vías del tren y una carretera al suroeste que comunica con la salida urbana en dirección a Badajoz.

La historia que precede al barrio es tan extensa como importante para Cáceres, pues es apodado "Las minas" por los yacimientos mineros que existen, dando lugar estos al antiguo poblado minero que allí se asentó gracias a Segismundo Moret y Pendergast. Debido a la influencia que las minas supusieron, el poblado minero presentó un auge significativo hasta convertirse en lo que hoy en día se puede observar, ya que muchas de sus edificaciones originales siguen aún en pie.

Debido al declive de las explotaciones mineras y el definitivo cierre de estas, el poblado minero fue abandonado. Tras este suceso, las viviendas del barrio perdieron su utilidad al ofrecer residencia a los trabajadores, algunos de los cuales decidieron marcharse. el resto de viviendas se convirtieron en residencias de protección oficial, lo que hizo que la población gitana, e incluso en la actualidad, varios refugiados, acabasen asentándose allí. Algunas de las edificaciones de la época fueron restauradas y actualmente hacen las veces de centro de interpretación o bloque de oficinas.

\section{Desarrollo de la intervención}

La propuesta de intervenciónconcreta referente al proyecto de innovación educativa, va destinada al alumnado de Educación Primaria. En el centro propuesto para su desarrollo existe un absentismo muy acusado debido principalmente a los padres, pues estos no son partícipes del proceso de enseñanza-aprendizaje y un número considerable de veces los/as alumnos/as pierden el día de clase porque los progenitores no quieren madrugar o por llevarlos a aprender el negocio familiar, que en la mayoría de los casos es la venta ambulante.

Por lo tanto, la relación que presentan los padres con el centro es deficiente, pese a que este no cesa de crear e innovar con proyectos que incluyen tanto al alumnado como a ellos mismos, para tratar así de solventar el problema tan acusado de absentismo que existe, además de convocarlos a reuniones periódicas. Puede decirse 
que estos no muestran interés por ninguno de los proyectos, actividades o reuniones y, simplemente, deciden no asistir ni ser partícipes de la enseñanza de sus hijos/as.

A pesar de la actitud de los padres, el alumnado de la misma etnia presentan una buena relación entre sí, presentándose el mayor inconveniente cuando estos ofrecen una actitud de rechazo hacia sus compañeros, sentimiento inculcado por los padres, llevando sus rivalidadhasta el aula. Así pues, fomentar el compañerismo en el aula es un objetivo importante, pues en esta deben acatar la normativa del centro escolar, en el que todos son iguales, independientemente de su procedencia o etnia.

El alumnado no tiene ningún conocimiento previo de la historia minera de Cáceres, principalmente porque sus padres tampoco saben nada al respecto pese a vivir al lado del antiguo poblado minero y las explotaciones mineras en sí.Así, el objetivo didáctico general es enseñar al alumnado todos los contenidos conceptuales, procedimentales y actitudinales posibles sobre el patrimonio minero de Cáceres y lo importante que fue para la ciudad.

Teniendo en cuenta el objetivo general planteado, los objetivos específicos serían: 1) aprender acerca del paso del tiempo, a través de fotos e historias de vida; 2) fomentar el compañerismo a través de las actividades grupales; 4) concienciar y conocer los riesgos que conllevan determinados trabajos en aras de trabajar la educación para la ciudadanía; y 5) conocer los diferentes estatus sociales y económicos.

\subsection{Visita al poblado minero}

Esta actividad supondría la primera toma de contacto del alumnado con el poblado minero y las minas al plantear llevarlos de excursión al centro de interpretación para, más tarde, realizar una visita guiada por el antiguo poblado minero, explicada por uno de los representantes de la Asociación Minera de Aldea Moret, el cual podría ofrecer sus propios relatos y vivencias en la salida de campo.

Como recurso humano, se presentaría a disposición del proyecto un representante de la Asociación Minera de Aldea Moret que haría las veces de guía. Como espacios se utilizarían el aula, el centro de interpretación y el poblado minero.

\subsection{Visita sorpresa}

Para esta actividad se contaría con la presencia de un familiar directo de un trabajador de la mina de San Salvador, el cual narraría sus vivencias en la misma aportando 
fotografías de diferentes momentos históricos de las explotaciones y del poblado minero, enseñando al alumnado la base necesaria para comprender la dinámica del proyecto.

Como recurso humano se contaría con un invitado especial que hablaríasobre de su experiencia en las minas.Como recursos materiales, se usarían fotografías de minerales en diferentes estados de refinado, de herramientas y utensilios, de las minas pasadas y presentes, de los trabajadores, del poblado minero y de la ropa de trabajo. Finalmente, como espacio se utilizaría el aula.

Junto a la visita al poblado, esta actividad, aporta los datos necesarios para el desarrollo de las siguientes, aprendiendo conceptos como el paso del tiempo sobre las cosas y elementos de las minas gracias a los elementos fotográficos aportados.Para motivar al alumnado y fomentar una mayor concentración en la actividad, se recurriría a una gran cantidad de elementos visuales para que permanecieran atentos.

Figura 1. Ejemplo de una de las fotografías que podría aportarse por parte de la persona invitada para hablar de la minería.

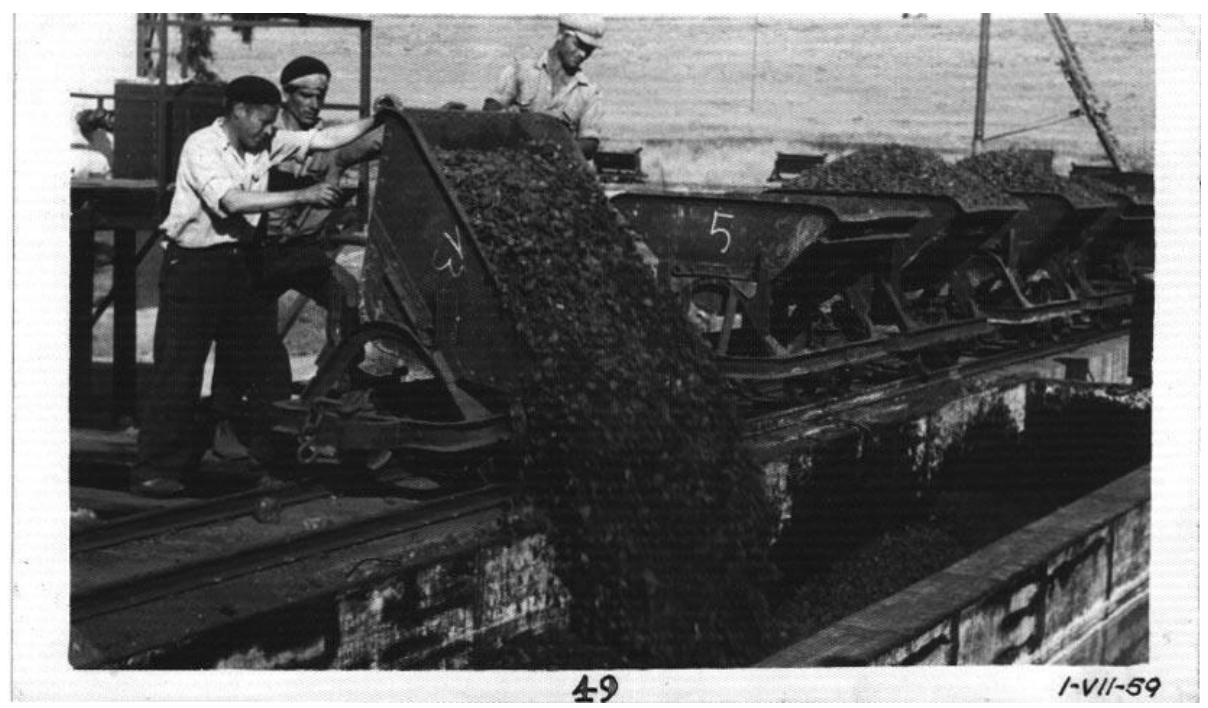

Fuente: Archivo Histórico de Cáceres, Caja 19/429, Aldea Moret (Minas), Unión Española de Explosivos Riotinto 1727-1898. 
Figura 2. Ejemplo de contrato que podría aportarse por parte de la persona invitada.

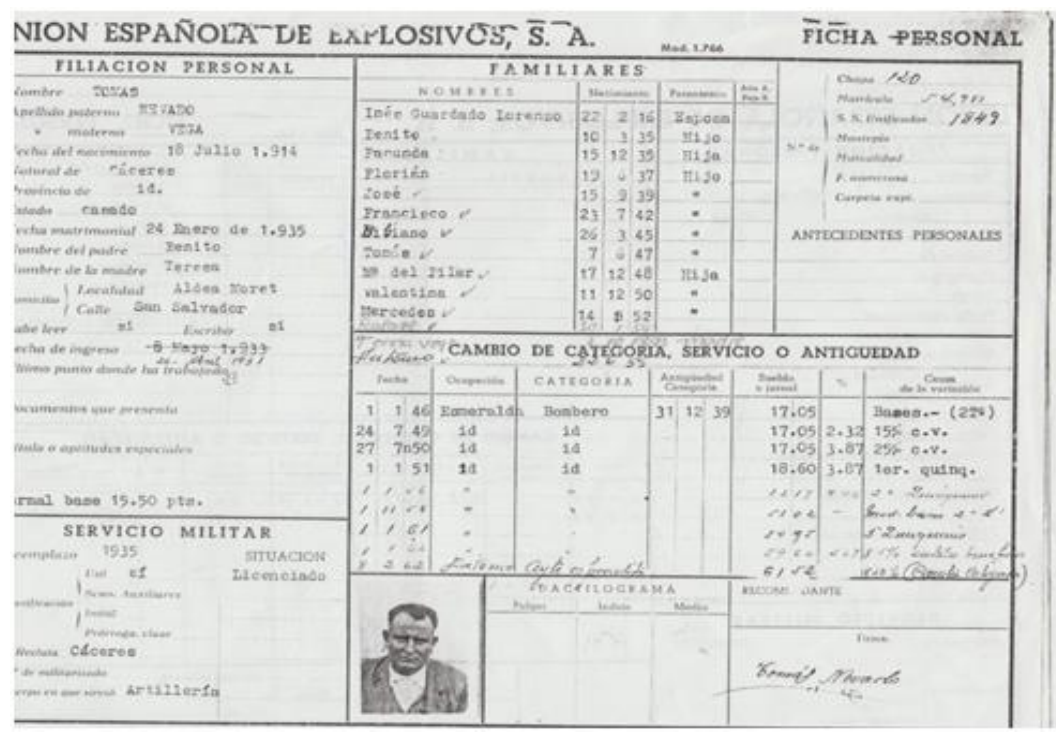

Fuente: Familia Nevado. Herencia familiar.

\subsection{Mapa mental}

Durante la actividad se realizaría un mapa mental estructurado en tres subapartados: 1) el primero de ellosdestinado a las fotografías de los utensilios y herramientas que utilizaban los mineros; 2) otro con las fotografías de las minas más importantes que hubo en Cáceres, así como su estado actual; 3) y un último con las diferencias en el estatus socioeconómico que existía entre los diferentes trabajadores de las minas, así como la función de las diferentes profesiones que existían.

Como recursos materiales, se usarían fotografías de herramientas, de las minas pasadas y presentes y fotografías del oficio.Las ventajas que presentaría esta actividad, son que está asociada a la repetición de conceptos a lo largo de las semanas, así como a los elementos visuales que el alumnadoobserva. 
Figura 3. Ejemplo de mapa mental.

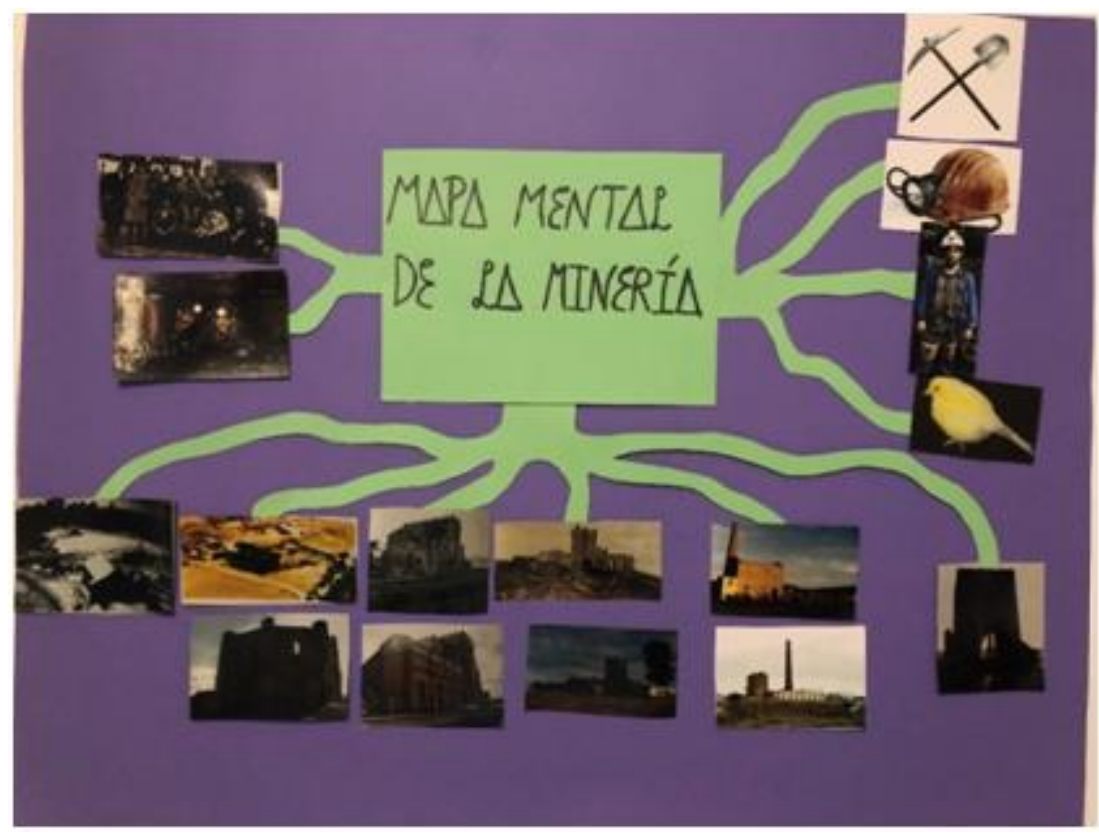

Fuente: Creación propia.

\subsection{Tres rincones, tres nuevas aventuras}

En esta actividad, el alumnado se trasladaría a tres espacios o zonas diferentes del aula. El rincón de los minerales, donde crearían los suyos propios con diferentes materiales tras haber visualizado y manipulado un mineral auténtico de la mina, además de poder contarlos y clasificarlos según sus características. Después, en el rincón de los disfraces, se explicaría el uso de cada prenda de ropa y vestirían de minero a un muñeco, para más tarde, disfrazarse ellos también. $Y$, por último, en el rincón de los instrumentos, podrían ver las herramientas que utilizaban los mineros, así como el ya conocido canario, que los acompañaba en las minas y les servía de aviso frente a diversos peligros invisibles.

Tras la realización de los minerales en el primer rincón, procedería a fomentarse la higiene, lavándose las manos, para posteriormente, explicar las diferentes afecciones respiratorias que se dan en la mina si no se tenía el suficiente cuidado. Tras ver los otros dos rincones restantes, realizarían un juego de verdadero o falso, en el que se intercambiaría algún elemento del muñeco, previamente disfrazado de minero, en el que el alumnado deberían decir si el elemento modificado serviría o no.

Acto seguido se les explicaría cómo prevenir accidentes en las minas y evitar situaciones peligrosas. Además, realizarían un juego para poder utilizar el canario; en este, el alumnado debería tomar el rol de mineros, en el momento en el que el canario 
dejase de cantar, los mineros, alertados, dejarían las herramientas en el suelo y saldrían ordenadamente del área de trabajo.

Como recursos materiales se usaría un muñeco, así como elementos secundarios para la actividad de verdadero y falso: ropa para el muñeco, el alumnado y el /la tutor/a, plastilina y arcilla, un dispensador de jabón, herramientas de minería de juguete, minerales reales y un canario de juguete que cantara.

Figura 4. Foto de mineral de fosfato extraído en la mina y usado como referencia para el alumnado.

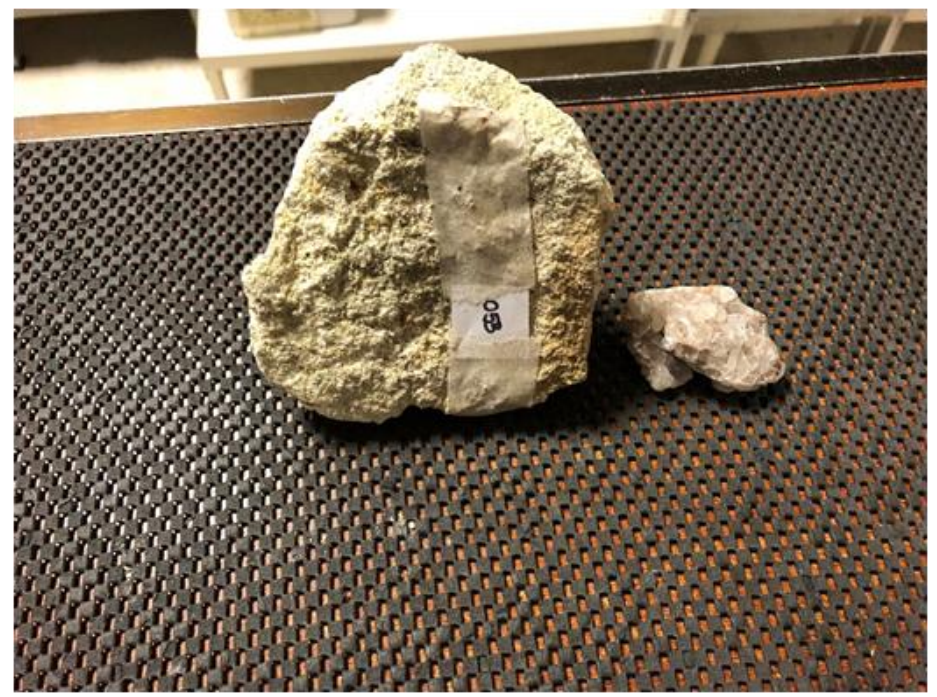

Fuente: Asociación Minas Aldea Moret.

\subsection{Coloreamos al minero y creamos nuestro propio tren}

En la actividad, el alumnado colorearía una ficha con el dibujo de un minero, tras esto, en un papel continuo, con una locomotora dibujada, estos deberían plasmar la palma de la mano impregnada en pintura de dedos, una detrás de otra, para simular los vagones de un tren. La actividad presentaría una temporalización de una hora.Como recursos materiales, se usaría papel continuo, fichas para colorear, ceras de colores y pintura de dedos de diferentes colores.

La fortaleza de esta actividad radica en la capacidad de evaluación del alumnado respecto a si colorearon al minero con los colores adecuados o no, además de poder observar si guardarían turno para utilizar las pinturas y respetarían el material asignado.La debilidad más palpable se vería en el caso de que el alumnado tuviera diferentes niveles en su motricidad fina, además de dispares capacidades a la hora de reconocer colores, con lo que demostrarían desconocimiento sobre los elementos presentados. 
Figura 5. Ejemplo de ficha para trabajar en el aula.

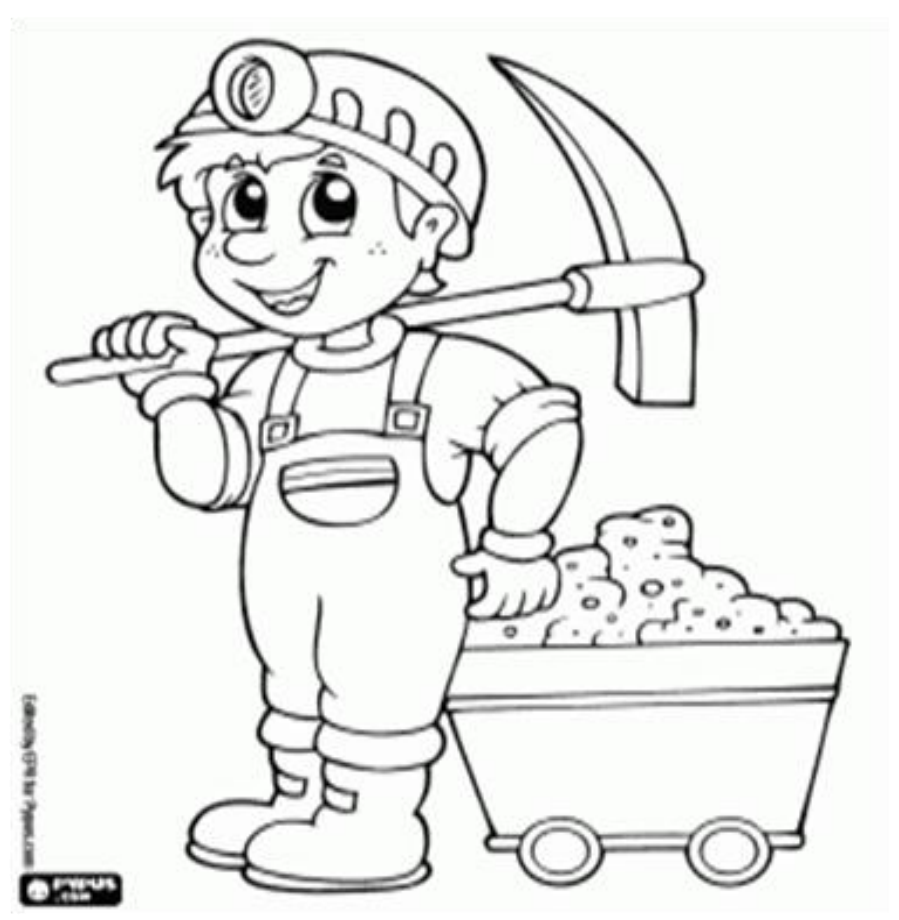

Fuente: Extraída de la web:https://www.colorearjunior.com/dibujos-para-pintar-de-minero-y-vagoneta-demina_16859.html[consultado: el 27 de abril de 2018].

Figura 6. Alumnos trabajando la ficha.

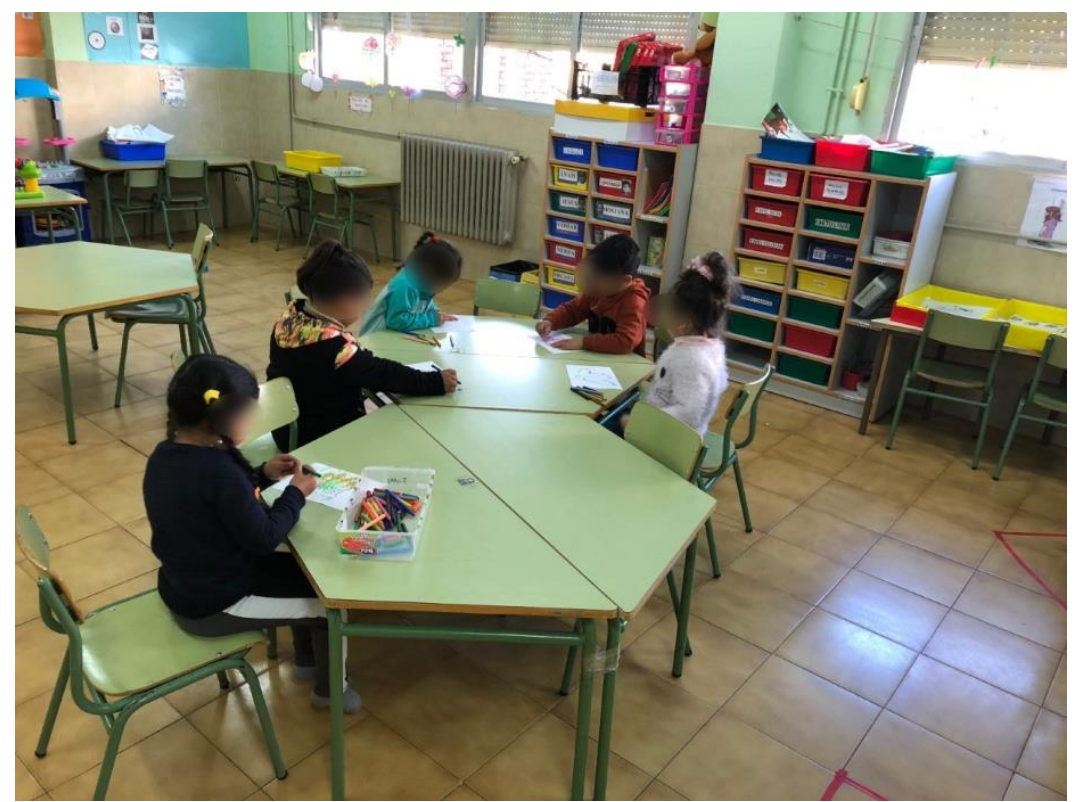

Fuente: Elaboración propia. 


\subsection{Atendiendo a la diversidad}

En esta actividad se ahondaría aún más en el concepto del estatus socioeconómico de la época, explicándoles las ventajas y las desventajas que poseían entre los diferentes trabajadores y dónde vivía cada uno de ellos, además se apoyarían las explicaciones con fotografías y elementos visuales. Se les expondrían las diferencias socioeconómicas de los trabajadores y las ventajas y desventajas que existían, con una temporalización de una hora.

Como recursos materiales se volverían a usar fotografías de los trabajadores, del poblado minero y de la ropa de trabajo.Las ventajas de esta actividad recaen sobre todo en la posibilidad de explicar las diferencias que existía en la época, llevándolo al terreno actual, en el que poder enseñar a no discriminar a los demás, independientemente del trabajo que posean. El principal inconveniente sería que los conceptos deberían ser muy básicos para que pudiesen entender la diversidad que existía, limitando los ejemplos que se pudieran usar.

Figura 7. Fotografía de la piscina de la barriada.

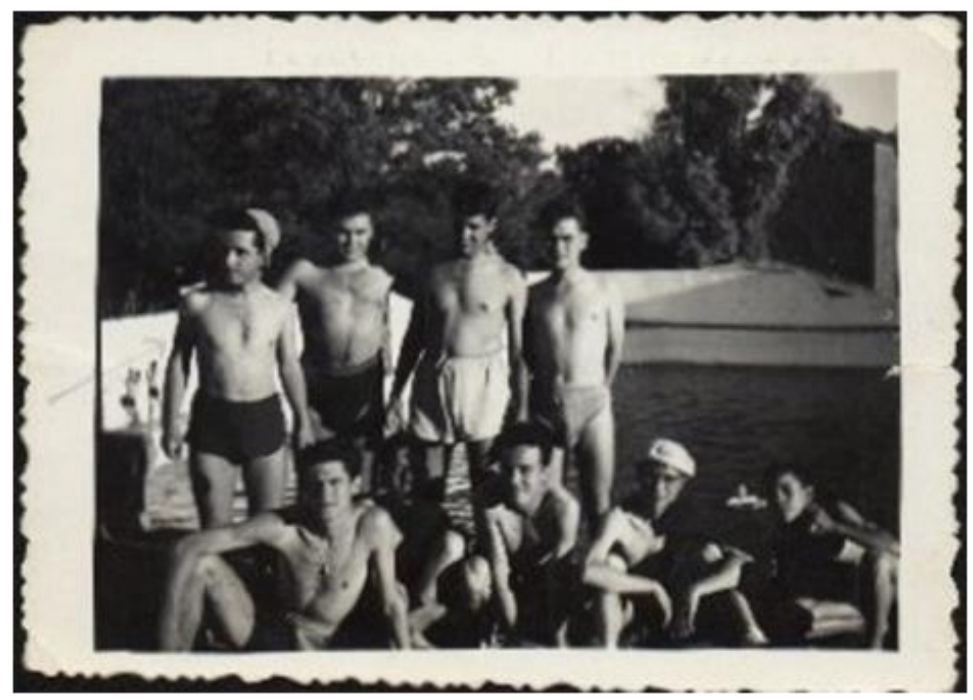

Fuente: Familia Nevado. Herencia familiar.

\subsection{Cantamos y bailamos todos juntos}

Para finalizar, tras disfrazarse, pues es una actividad de teatralización musical, todo el alumnado escucharía primero la canción "Hi-Ho" de la película "Blancanieves y los 7 enanitos", para en la segunda reproducción, cantarla y bailarla juntos. Finalizando así las actividades del proyecto. 
Como recursos materiales, se usaría ropa para el alumnado y el/la tutor/a y herramientas de minería de juguete.Como recursos tecnológicos se contaría con un ordenador y una pizarra digital.La fortaleza de la actividad, recaería en las repeticiones de la coreografía, pues la aprenderían a la primera; mientras que las debilidades podrían ser la necesidad de improvisación de los trajes y la falta de herramientas.

\section{Resultados y discusión de datos}

Gracias a estas actividades se conseguiríaque el alumnado adquiriera gran parte de las competencias pretendidas pues, con independencia de los contenidos conceptuales propios de la historia del barrio minero, mejorarían notablemente su actitud respecto al medio que les rodea, interesándose por el patrimonio que posee su ciudad, mejorando la conducta hacia elementos innovadores y sobre todo hacia sus compañeros/as, aceptando las diferencias que pueda haber entre ellos, sin excluirlos por su apariencia o su etnia.

Los problemas que se presentan en diversos casos son los métodos para enseñar esa historia que se quiere desarrollar, pues en muchas ocasiones aún se tiene en mente el modelomemorístico del proceso de enseñanza-aprendizaje clásico de la Historia, recordando múltiples fechas y escenarios que más tarde se olvidan. Se hace necesario por lo tanto profundizar en la epistemología de la Historia, ya que es la mejor manera de comprender su valor educativo (Puig, 2017). Si los docentes no tienen el control del contenido que desarrollan, difícilmente podrán proceder a seleccionar aquellos que quieran desarrollar en sus propuestas educativas. Por lo tanto, la innovación en el aula vinculada con aspectos relacionados con la educación para la ciudadanía ayuda a dar un paso adelante, olvidando momentáneamente los sistemas educativos tradicionales para ofrecer un repertorio de actividades que se sientan vivas en el aula, desarrollando unos contenidos que perduren en la memoria del alumnado, más por el método con el que las aprendieron, que por el concepto en sí.

Cambiar el estado en el que se encuentra la enseñanza necesita de un proceso complejo que requiere una actuación en múltiples ámbitos, siendo uno de los más importantes fortalecer el conocimiento práctico del profesorado haciendo que estos puedan construir unas pautas de acción que desarrollen la capacidad del alumnado (Porlán et al., 2010). De acuerdo a la reflexión anterior, para modificar un sistema tan extenso y complejo como es el educativo de un país, lo principal es actuar sobre aquellos que van a desarrollarlo, por lo que los proyectos de innovación educativa 
como este pueden servir de prueba directa para ofrecer un punto de vista diferente, adaptando aquellas limitaciones que se presenten y reutilizando aquellas ventajas que puedan ser útiles.

\section{Conclusiones}

La valoración general de la importancia del poblado minero cacereño y el relato de vida de sus trabajadores está presente en la historia que hay detrás de todos y cada uno de los edificios aún en pie, en todos los ladrillos y piedras que forman parte de las paredes de las edificaciones de las minas, y en todas las evidencias fotográficas que existen del proceso de construcción de esas edificaciones, de la vida de esos trabajadores y de todo lo que han supuesto para Cáceres. Es importante poder explicar qué sucedió a Aldea Moret después de que los trabajos que aportaban las minas cesasen, y el barrio pasase de ser uno de los que contaba con mayor dinamismo a convertirse en una zona con grandes dificultades y síntomas de marginalidad. Revisar el pasado ayuda a esclarecer qué sucedió y cómo solucionarlo, el problema es que, aunque la ciudadanía general cacereña mire hacia el pasado,el esfuerzo que conlleva solucionar los problemas que actualmente se presentan puede no ser suficiente. Así pues,son proyectos como este, trabajando con la base de la sociedad y ciudadanos del futuro, los que pueden inculcar todo lo que las minas aportaron a la ciudad y a las familias de los trabajadores.

Las oportunidades educativas que aquí se presentan para todos los niveles educativos se basa en el ofrecimiento de una metodología de adquisición de contenidos conceptuales, procedimentales y actitudinales novedosa que favorece la interdisciplinariedad y multidisciplinariedad en los últimos cursos de Primaria, pero principalmente en los de Secundaria (Geografía, Historia, Física o Química). Ofrecer un recorrido histórico por el patrimonio cultural del que dispone la ciudad de Cáceres (o cualquier otra), puede ayudar a romper los esquemas de la memorización de datos en un aula. Tal es así que, realizar una investigación de campo, sería un elemento compatible con el proyecto de innovación aquí presentado. Así, nuevas actuaciones de innovación e investigación docente podrían guiar la continuidad del trabajo, viable para adaptarlo a niveles superiores como ya se ha apuntado. 


\section{Referências bibliográficas}

Ballart, J. (1997). El patrimonio histórico y arqueológico: valor y uso. Barcelona: Ariel.

Cuenca, J. M.ạ, Martín-Cáceres, M. J., Ibáñez, A. y Fontal, O. (2014). La educación patrimonial en las instituciones patrimoniales españolas. Situación actual y perspectivas de futuro. CLIO. History and Historyteaching, 40.

García, F., Jiménez, F., Martín, J. C. (2009). La vida minera en Aldea Moret. Cáceres: Excmo. Ayuntamiento de Cáceres.

González, N. (2006). El valor educativo y el uso didáctico del patrimonio cultural (Trabajo de investigación). Barcelona: UniversidadAutónoma de Barcelona.

Miralles, P. y Rivero, P. (2012). Propuestas de innovación para la enseñanza de la historia en Educación Infantil. Revista Electrónica Interuniversitaria de Formación del Profesorado, 15(1), 81-90.

Porlán, R., Martín, R., Rivero, A. Harres, J. y Azcárate, P. (2010). El cambio del profesorado de ciencias I: Marco teórico y formativo. Enseñanza de las Ciencias, 28(1), 31-46.

Puig, M. (2017). Construyendo el rincón de Historia: análisis de una experiencia con futuros docentes de Educación Infantil. Revista de Investigación en Didáctica de las Ciencias Sociales1, 118-131.

Ricardo, D. (2015). Proyecto de la mina y el carbón. (Unidad Didáctica) Colegio Sagrada Familia. Asturias, España.

San Miguel, R. (2014). La enseñanza aprendizaje de las Ciencias Sociales en la etapa de Educación Infantil (Trabajo de fin de grado). La Rioja: Universidad de la Rioja. 


\section{A Educação Ambiental nos Projetos Políticos Pedagógicos de Escolas Municipais}

VANICE SCHOSSLER SBARDELOTTO ${ }^{1}$

\section{Resumo}

A política brasileira de Educação Ambiental, expressa na legislação vigente, dispõe sobre a prática de educação ambiental ao enfatizar a preocupação com a sua realização em ambientes de educação formal e não formal. Entretanto, essa mesma legislação guarda incongruências ao apresentar pluralidade de concepções, o que pode ensejar dúvidas quando da inclusão de aspectos da educação ambiental nos currículos da educação formal, considerando que esta é uma preocupação central, no que tange à formação cidadã dos estudantes. Destacam-se na legislação as perspectivas conservacionistas, resolutivas, naturalistas e que enfatizam a sustentabilidade. No âmbito da educação formal, a legislação indica que a Educação Ambiental deve ser desenvolvida articulada às demais práticas escolares e aos conhecimentos relativos à esta temática devem constar nos currículos dos diferentes níveis de ensino, sem caracterizar-se como uma disciplina específica, entretanto, pode ser desenvolvida articulada à Geografia, considerando que o processo formativo se dirige para a formação do pensamento espacial e desenvolvimento da consciência crítica. Nesse sentido, neste texto, pretende-se problematizar como a Educação Ambiental tem sido expressa nos Projetos Políticos Pedagógicos das escolas municipais de Francisco Beltrão, Paraná/BR. Serão analisados três projetos. As escolas se localizam em espaços distintos: uma no campo; uma no espaço urbano central e a outra em espaço urbano periférico. Entende-se que os projetos políticos pedagógicos expressam a intencionalidade curricular de uma determinada comunidade, que pode não coincidir com as práticas concretas, mesmo tendo

\footnotetext{
${ }^{1}$ Doutoranda em Geografia e Professora do Curso de Pedagogia da Universidade Estadual do Oeste do Paraná, Membro dos grupos de pesquisa Represetanções, Espaços, Tempos e Linguaguens em Experiências Educativas - RETLEE e Educação Superior, Formação e Trabaho Docente - GESFORT, vanice.sbar@gmail.com..
} 
presente que os currículos oficiais representam um marco legal quanto aos conhecimentos veiculados na escola.

Palavras-chave: política de educação ambiental; educação formal; projetos pedagógicos; cidadania.

\section{Abstract}

The Brazilian policy of environmental education, expressed in the current legislation, deals with the practice of environmental education by emphasizing the concern with its realization in formal and non-formal education. However, this same legislation has inconsistencies in presenting a plurality of conceptions, which may raise doubts when including aspects of environmental education in curricula of formal education, considering that this is a central concern, regarding the training of the students' citizenship. Legislation highlights the conservationist, resolutive, naturalistic perspectives that emphasize sustainability. In the context of formal education, legislation indicates that environmental education must be developed in articulation with other school practices and knowledge related to this subject should be included in the curricula of different levels of education, without being characterized as a specific discipline, however, can be developed articulated to Geography, considering that the formative process is directed towards the formation of spatial thinking and the development of critical consciousness. In this sense, in this text, we intend to problematize how environmental education has been expressed in the pedagogical political projects of the municipal schools of Francisco Beltrão, Paraná / BR. There will be three projects analyzed. Schools are located in different places: one in the countryside; one in the central urban space and the other in peripheral urban space. It is understood that political pedagogical projects express the curricular intentionality of a given community, which may not coincide with concrete practices, even though the official curricula represent a legal framework for the knowledge disseminated in the school.

Keywords: environmental education policy; formal education; pedagogical projects; citizenship.

\section{Introdução}

A política nacional de Educação Ambiental, Lei no. 9.795/1999, dispõe sobre a prática de Educação Ambiental adotado pelo Estado. Em seu artigo primeiro enfatiza que a 
preocupação com a realização de Educação Ambiental em ambientes de educação formal e não formal é com prática que leve a "[...] conservação do meio ambiente, bem como de uso comum do povo, essencial à sadia qualidade de vida e sua sustentabilidade" (Brasil, 1999, p. 1).

Como uma legislação emanada do Estado, esta também apresenta uma concepção, fins e princípios da Educação Ambiental. Na pesquisa relativa a essas práticas, observa-se uma pluralidade de perspectivas, ora confluentes, ora divergentes; destacando-se as perspectivas conservacionistas, resolutivas, naturalistas e que enfatizam a sustentabilidade. Estas posições são decorrentes de distintas matizes teóricas, que problematizam as questões ambientais de diferentes formas e, inevitavelmente, exercem influência sobre o exposto da citada legislação.

No âmbito da educação formal, a legislação indica que a "[...] educação ambiental será desenvolvida como uma prática educativa integrada, contínua e permanente em todos os níveis e modalidade" (Brasil, 1999, p. 3), devendo os conhecimentos relativos à Educação Ambiental constar dos currículos dos diferentes níveis de ensino, sem caracterizar-se como uma disciplina específica. Indica ainda que os professores devem ser formados para considerar esses conhecimentos em sua prática educativa.

Corroborando com essa premissa, as Diretrizes Curriculares Nacionais para a Educação Ambiental de 2012, Resolução 02/2012 do Conselho Nacional de Educação, explicita que “[...] o atributo 'ambiental' [...] não é empregado para especificar um tipo de educação, mas se constitui em elemento estruturante que demarca um campo político de valores e práticas". (Brasil, 2012, p. 1). Desta forma, essa Diretriz considera que existe uma pluralidade de concepções em relação à Educação Ambiental. Entretanto, as escolas devem inserir esse debate em seus currículos, sustentando sua prática em decisões conscientes e coletivas, com vistas a superar uma "[...] visão despolitizada, acrítica, ingênua e naturalista" (Brasil, 2012, p. 2).

Nesse sentido, as escolas, pautadas por seus marcos legais, considerando também a legislação para a Educação Ambiental, devem elaborar seus Projetos Políticos Pedagógicos (PPPs), explicitando a concepção de educação, de ser humano, de sociedade que pretende formar e como inserem a Educação Ambiental na prática pedagógica escolar. Desta forma, questiona-se se os referidos Projetos têm superado as visões naturalistas, despolitizadas e acríticas de Educação Ambiental e desenvolvido na perspectiva crítica. 
Entende-se, portanto, que ao discutir sobre a inserção da Educação Ambiental crítica nos currículos escolares, desenvolve-se ao mesmo tempo, um processo formativo dos sujeitos envolvidos no processo, sejam eles professores ou estudantes e a própria comunidade escolar.

Considerando que o processo de produção do conhecimento não se separa da realidade, entendida como expressão da vivência coletiva em sociedade, este artigo expressa a relação do processo formativo em nível de doutorado com a produção efetiva dessa área do conhecimento junto às escolas do município de Francisco Beltrão. Desta forma, pretende-se expor o resultado do processo investigativo acerca da consecução da Política de Educação Ambiental em escolas do município, em nível de seus projetos, haja vista que, nesse momento, não é possível adentrar à investigação e análise de práticas pedagógicas.

Nos estudos desenvolvidos identificou-se a concepção de Educação Ambiental presente no PPP, sobretudo a inserção de conhecimentos pertinentes no currículo escolar em três escolas de realidades distintas, do município: "escola A" - escola urbana de área central; "escola B" - escola urbana de área periférica; "escola C" escola do campo. Optou-se por escolas dessas localidades, a fim de investigar se, a partir do local onde a escola está, há diferenciação na abordagem da Educação Ambiental.

Buscou-se identificar a presença da Educação Ambiental, desvelar as concepções de Educação Ambiental e problematizar a concepção de Educação Ambiental, com a concepção da Pedagogia Histórico-Crítica, que norteiam os PPPs das escolas.

\section{O estabelecimento do currículo escolar: expressão das necessidades sociais}

A organização curricular escolar expressa o "[...] estabelecimento de prioridades segundo as finalidades da educação, de acordo com o público a que se destina e com as interesses dos atores em disputa" (Saviani, 2010, p. 43). Nesse sentido, a concepção de Educação Ambiental presente dos currículos escolares também não é neutra, mas expressa os valores e concepções que foram se hegemonizando em diferentes espaços escolares.

Entretanto, pondera-se que a escola é um espaço social específico, cujos fins e intencionalidades são objeto de intensas disputas, devido ao seu potencial e abrangência. A concepção que orienta a formação dos jovens, durante um longo processo formativo, de uma sociedade não é algo desinteressado, ao contrário, 
fomenta o interesse de diferentes segmentos sociais, que veem nesse espaço um rico campo para profusão de suas concepções. Esse espaço social é, portanto, palco de inúmeras disputas; notadamente observa-se o embate entre projetos formativos alinhados à sociabilidade capitalista e projetos que visam a superação desse modo de produção.

Nesse sentido, a escola produziu-se historicamente como um espaço que transmite às novas gerações aquilo que uma determinada sociedade considera relevante para sua manutenção e desenvolvimento. Assim, a sociabilidade capitalista indica seus valores e conhecimentos necessários para que sejam difundidos via escolarização.

Distinto desse pensamento, Saviani (2013, p. 13) expõe que o "[...] trabalho educativo é o ato de produzir, direta e intencionalmente, em cada indivíduo singular, a humanidade que é produzida histórica e coletivamente pelo conjunto dos homens", devendo priorizar os conhecimentos clássicos, que podem explicar o modo como vivem os sujeitos e produzem a sua existência. Nesse sentido, o desenvolvimento de uma Educação Ambiental crítica se alia a essa perspectiva, pois pretende problematizar o modo pelo qual eles produzem sua vida, como motor dos problemas ambientais que tem decorrido desse modo de produção.

A escola, por meio da seleção de conteúdos pode problematizar essa questão, considerando o aspecto ambiental presente neles e no ensino. Nesse sentido,

Um dos grandes desafios que se colocam à humanidade nos dias atuais é o
de realizar uma transformação radical da forma de organização da
sociedade, de tal maneira que se consiga preservar as conquistas da
sociedade capitalista em termos de desenvolvimento das forças humanas,
porém superando sua forma capitalista, inserindo essas conquistas numa
dinâmica social voltada à promoção da dignidade, liberdade e
universalidade da vida humana, o que não será possível sem o
estabelecimento de novas relações de produção e novas formas de
metabolismo entre a sociedade e a natureza. (Duarte, 2016, p. 13).

Faz-se necessário perceber que, quando se aborda a Educação Ambiental, fala-se de um conjunto teórico heterogêneo que

Podemos nos dar conta de que apesar de sua preocupação comum com o meio ambiente e do reconhecimento do papel central da educação para a melhoria da relação com este último, os diferentes autores (pesquisadores, professores, pedagogos, animadores, associações, organismos, etc.) adotam diferentes discursos sobre a EA e propõem diversas maneiras de conceber e de praticar a ação educativa neste campo. Cada um predica sua própria visão e viu-se, inclusive, formarem-se "igrejinhas" pedagógicas que propõem a maneira "correta" de educar, "o melhor" programa, o método "adequado". (Sauvé, 2005, p.17). 
As concepções, em geral, conservam muitas semelhanças, sobretudo porque, de acordo com Montibeller (2001) essas diferentes concepções surgem com o agravamento dos problemas ambientais e visam dar soluções à essa problemática, sem, no entanto, alterar a ordem social. Para Leher (2016), trata-se de deixar a cargo do estado burguês a gestão da questão ambiental, o que corresponde a deixar o "lobo a cuidar do galinheiro", ou seja, a regulamentação, a Educação Ambiental, não tocaria na essência da problemática, que é a "[...] exploração desenfreada dos recursos da natureza e a degradação ambiental com caráter global" (Montibeller, 2001, p. 35), apontando apenas para ações paliativas no tocante à preservação ambiental.

A hegemonia dessa perspectiva pode ser percebida em muitos projetos de Educação Ambiental que são desenvolvidos e que trazem nas suas perspectivas a lógica, que visa manter o padrão de consumo capitalista. De acordo com essa perspectiva, do desenvolvimento sustável, seria possível manter os padrões de consumo e resolver as questões ambientais no mesmo movimento. Ou seja, essa lógica promete,

a) Que o padrão de consumo vigente no mundo industrializado pode ser mantido, expandindo e difundindo mundialmente; b) Que prevalece o status do consumidor; c) Que a tecnologia será capaz de produzir cada vez mais utilizando menos recursos (otimismo tecnológico). (Montintibeller, 2001, p. $50)$.

Entretanto, essa concepção negligencia a informação de que seriam necessários sete planetas para manter o padrão de consumo norte-americano, por exemplo. Então, seria possível resolver a questão ambiental sem questionar o consumo, o próprio sistema capitalista? É possível via Educação Ambiental recursista, conservacionista ou naturalista resolver os problemas da degradação ambiental?

Nesse sentido, desenvolver práticas de Educação Ambiental no espaço escolar, que não rompem com a perspectiva hegemônica da sociedade capitalista pouco ou nada contribuem com a classe trabalhadora, que vê socializado apenas os problemas ambientais, enquanto o lucro da exploração segue sendo privado.

Assim, a Educação Ambiental crítica, vinculada a problematização da realidade, considerando o atual modo de produção como motor dos problemas ambientais e desigualdade social pode desenvolver uma visão de mundo que colabore com a compreensão da realidade tal como é. (Guimarães, 2004). Dessa forma, a Educação Ambiental crítica não é uma "evolução" mas uma contraposição às formas conservadoras de Educação Ambiental, de forma que se propõe a questionar o ordenamento social e a lógica da exploração do trabalho e da natureza com vistas à acumulação privada. 
A escola "por si só não faz a revolução, mas lutar para que a escola transmita os conteúdos clássicos é uma atitude revolucionária". (Duarte, 2016, p. 27). Logo, os conteúdos de ensino, na escola, estão articulados a uma determinada visão de mundo. Selecionar os conteúdos é, portanto, tarefa complexa e política. Os conhecimentos científicos desenvolvidos, por meio da pesquisa, são convertidos em conhecimentos escolares para que sejam compreendidos e assimilados pelos estudantes. Assim, faz-se necessário articular os conhecimentos pertinentes à questão ambiental aos saberes disciplinares escolares, considerando que estes não se afastam da vida concreta dos sujeitos, ao contrário, os conhecimentos humanos são resultantes da relação humana no mundo concreto.

Nesse sentido, há uma articulação entre a perspectiva da Educação Ambiental crítica com a Pedagogia Histórico-Crítica. Esta última defende que a função social da escola é universalizar os conhecimentos humanos e problematizar a sociedade em que se vivemos. Saviani (2013, p. 14) afirma que "[...] a escola existe, pois, para propiciar a aquisição dos instrumentos que possibilitam o acesso ao saber elaborado (ciência), bem como o próprio acesso aos rudimentos desse saber". Atividades de Educação Ambiental de cunho conservador não teriam espaço nessa perspectiva educativa emancipadora.

Entretanto, como apontado por Sauvé (2005) não há um consenso em torno de como a Educação Ambiental deva ser trabalhada na escola. Entretanto, pondera-se que, quando as escolas fazem opções político pedagógica para realizar o trabalho educativo, convém que haja uma intersecção entre os fundamentos da pedagogia defendida e os elementos metodológicos dos quais se lança mão. Nesse sentido, na medida em que os PPPs apontam a defesa da Pedagogia Histórico-Crítica, entendese que a Educação Ambiental também deva filiar-se à concepção crítica, problematizando as questões ambientais vividas socialmente.

Desta forma, passa-se à analise de como os projetos das "escolas A, B e C" apresentam a Educação Ambiental.

\section{A Educação Ambiental do currículo e nos Projetos Políticos Pedagógicos das escolas}

De acordo com a legislação brasileira, cada unidade escolar deve realizar seu planejamento de trabalho, o seu PPP em que expressa as concepções de educação da comunidade escolar e as especificadades da comunidade para o funcionamento da escola. Desta forma, mesmo que exista no plano político, conforme diferencia Linuesa 
(2013), um currículo básico, comum às escolas de um sistema, cada unidade pode, no seu PPP, apresentar suas estratégias de funcionamento e organização do trabalho pedagógico e questões específicas, como horários, turnos, da forma que melhor represente a comunidade escolar.

No caso do município de Francisco Beltrão, a Secretaria de Educação sistematizou em 2012, a Proposta Pedagógica Curricular da Rede Municipal de Ensino (PPC) para orientar as vinte e uma escolas municipais, entre elas, escolas urbanas e escolas do campo. Este documento apresenta uma divisão em Educação Infantil e Educação Fundamental - Anos Inciais, e é o documento que apresenta os conteúdos que serão ensinados nas escolas. Nos PPPs analisados das três escolas, portanto, não há apresentação de conteúdos e organização em anos, ciclos ou outras estruturas, apenas indicam que, no que se refere à seleção e organização de conteúdos, seguese a proposta oficial do município. Por esse motivo, para atingir o objetivo de investigar as questões postas neste artigo, foi necessário analisar também e, primeiramente, esse documento, porque é nele que se selecionam os conteúdos para ensino.

Nesta PPC, para os anos iniciais mantêm-se a estrutura disciplinar, divididas em primeiro ( $1^{\circ}, 2^{\circ}$ e $3^{\circ}$ ano) e segundo ciclo ( $4^{\circ}$ e $5^{\circ}$ ano). O texto apresenta uma concepção única de cada disciplina e metodologias, objetivos e avaliação por ciclos. A exposição dos conteúdos é antecedida pela apresentação dos objetivos de aprendizagem, que apontam aquilo que deve ser atingido pelos estudantes no que se refere aos conhecimentos de cada disciplina.

A legislação preconiza que a Educação Ambiental não seja acrescida aos currículos, como uma disciplina adicional, mas que essa discussão ocorra de forma ambrangente e permeando os demais conteúdos disciplinares, a fim de promover uma formação que considere essa problemática social na formação dos sujeitos, acentuando o debate da cidadania.

A PPC, após apresentar a Educação Infantil e todas as disciplinas da Educação Fundamental anuncia os "Desafios Educacionais". Nesse espaço, a proposta apresenta discussões que são inseridas no currículo por força legal, ou seja, pleitos que foram abarcados por legislações específicas e que devem, portanto, ser tratadas nos currículos escolares. São eles: Educação Ambiental; Educação para o Trânsito; Educação Fiscal; Educação das Relações Étnico-Raciais e Ensino de História e Cultura Afro-Brasileira e Africana; Educação Especial e Inclusiva, além de descrever as atividades complementares e a abordagem da literatura infantil. 
Desta forma, a PPC apresenta a forma com a Educação Ambiental deve ser discutida e ensinada no cotidiano da escola. Anuncia o respeito à legislação nacional e aponta a criação de Lei Municipal para fazer cumprir o disposto na nacional. Trata-se da Lei Municipal $n^{\circ} 3.187$, de 13 de novembro de 2005, que estabelece "[...] a Política Municipal de Educação Ambiental, voltada para o trabalho de conscientização com conteúdos factuais, conceituais e atitudinais, de forma emotiva e dinâmica, sensibilizando e criando responsabilidade em relação ao meio ambiente." (Francisco Beltrão, 2012, p. 162).

O documento explicita a concepção de Educação Ambiental subjacente à legislação e, deste modo, a concepção que orienta o fazer pedagógico. Enfatiza que essa discussão deve ocorrer nas escolas a fim de que o "[...] indivíduo e a coletividade implementam valores sociais, conhecimentos, atitudes, interesses ativos voltados para a conservação e recuperação do meio ambiente e a sustentabilidade". (Francisco Beltrão, 2012, p. 162). Ainda que se perceba na legislação nacional um misto de concepções, a legislação do município de Francisco Beltrão e o currículo oficial posicionam-se, em favor de uma Educação Ambiental resolutiva, em que a aprendizagem de modos conservacionistas leve a uma preservação ambiental e conservação dos recursos às futuras gerações. Assinala-se que a proposta não posiciona-se filosoficamente no que se refere a fins e objetivos da educação e educação escolar, por exemplo. Assim, não há contradições entre a concepção de Educação Ambiental e dos conteúdos curriculares, aspecto que há de ser observados nos PPPs das escolas analisadas.

Considerando que os conteúdos referente à Educação Ambiental devem ser apontados nas diferentes disciplinas, observou-se a presença destes nas disciplinas de Ciências e Geografia, conforme Quadro 1 em que se apresentam os objetivos de aprendizagem, que mais genericamente expõe o que deverá ser ensinado:

Quadro 8-Objetivos de aprendizagem das disciplinas de Ciências e Geografia

\begin{tabular}{|l|l|l|}
\hline Disciplinas & Objetivos de aprendizagem: \\
\hline Ciências & Primeiro ano & $\begin{array}{l}\text { - Perceba o ambiente a sua volta: mudanças e necessidade de } \\
\text { preservação. }\end{array}$ \\
\cline { 2 - 3 } & Segundo ano & $\begin{array}{l}\text { - Possua noção dos elementos naturais que formam o planeta Terra - } \\
\text { poluição e preservação. }\end{array}$ \\
\cline { 2 - 4 } & Terceiro ano & $\begin{array}{l}\text { - Identifique animais ameaçados de extinção e a necessidade de proteção } \\
\text { dos mesmos. } \\
\text { - Perceba os diferentes tipos de solo sua importância e degradação. }\end{array}$ \\
\cline { 2 - 4 } & Quarto ano & $\begin{array}{l}\text { - Conheça o processo da poluição e do efeito estufa. } \\
\text {-Relacione o saneamento básico à preservação do ambiente e da saúde. } \\
\text { - Perceba as formas de agressão do homem ao meio ambiente (natureza) } \\
\text { e suas consequências. }\end{array}$ \\
\hline
\end{tabular}




\begin{tabular}{|l|l|l|}
\hline \multirow{3}{*}{ Geografia } & Quinto ano & $\begin{array}{l}\text { - Conheça a importância da conservação do solo. } \\
\text { na sociedade. }\end{array}$ \\
\cline { 2 - 3 } & Primeiro ano & $\begin{array}{l}\text { - Reconheça a utilização dos recursos naturais para o bem estar do ser } \\
\text { humano. } \\
\text { - Apresente atitudes de preservação do meio ambiente. }\end{array}$ \\
\cline { 2 - 3 } & Segundo ano & - Perceba o uso dos recursos naturais pelas pessoas. \\
\cline { 2 - 3 } & Terceiro ano & $\begin{array}{l}\text { - Demonstre atitudes de respeito ao indivíduo e na preservação do meio } \\
\text { ambiente. }\end{array}$ \\
\cline { 2 - 3 } & Quarto ano & $\begin{array}{l}\text { - Reconheça a importância da preservação do meio ambiente. } \\
\text { - Demonstre atitudes de responsabilidade com as questões ambientais. } \\
\text { - Perceba a degradação ambiental: causas e conseqüências. }\end{array}$ \\
\cline { 2 - 3 } & Quinto ano & $\begin{array}{l}\text { - Perceba a degradação ambiental. } \\
\text { - Desenvolva atitudes de responsabilidade com as questões ambientais. }\end{array}$ \\
\hline
\end{tabular}

Fonte: Francisco Beltrão, 2012. Elaboração própria.

Cabe ressaltar que os objetivos de aprendizagem apontados no Quadro 1 foram selecionados no rol de objetivos de todas as disciplinas, como alusivos à Educação Ambiental, a partir da concepção presente no próprio documento, ou seja, que refletem a preocupação resolutiva a conservacionista. Assim, o documento enfatiza a importância de que essas discussões se dêem de forma interdisciplinar e conduzam a alteração das ações dos sujeitos.

No que se refere aos PPPs das escolas, os três documentos expressam a adesão à Pedagogia Histórico-Critíca, cujos marcos iniciais foram formulados por Dermeval Saviani e expressos na obra Pedagogia Histórico-Crítica: primeiras aproximações (Saviani, 2013) que preconiza uma educação escolar que permita que os sujeitos acessem ao patrimônio cultural humano. Essa Pedagogia assume a perspectiva crítica, ao modo de produção capitalista e advoga que, somente por meio da sua superação, os homens poderão desenvolver-se livremente.

Entretanto, no que se refere à Educação Ambiental, os projetos, contraditoriamente, aderem à proposta conservacionista e resolutiva presente na PPC do município, sem apontar a contradição com a Pedagogia Histórico-Crítica.

A "escola A" apresenta em seu projeto um tópico específico para a Educação Ambiental em que expressa "[...] entende-se por Educação Ambiental os processos através dos quais o indivíduo e a coletividade implementam valores sociais, conhecimentos, atitudes, interesses ativos voltados para a conservação e recuperação do meio ambiente e a sustentabilidade." (Francisco Beltrão, 2013, p. 27). O texto apresentado é idêntico ao texto da PPC da rede municipal. 
As escolas "B" e "C" apresentam um texto único para os "Desafios Contemporâneos" e neles abordam os Direitos Humanos, Sexualidade, Diversidade Sexual e Gênero, Educação do Campo, Educação Ambiental, Prevenção ao uso indevido de Drogas, Educação para as Relações Étnico-raciais, História e Cultura Afro-Brasileira e Africana, enfrentamento à violência e Cultura Indígena, sem, no entanto, fazer alusão de forma específica à Educação Ambiental. Discutem a competência da escola em proporcionar uma educação para a cidadania, com o desenvolvimento de valores como solidariedade, respeito à diversidade e fomentando a abordagem das diferentes temáticas de forma interdisciplinar.

Ressalta-se que tanto na PPC quanto nos PPPs das escolas enfatiza-se que o processo de ensino se fará por um unidocente, ou seja, um professor que desenvolverá todas as disciplinas curriculares com os estudantes, favorecendo as práticas interdisciplinares. E nestes documentos observa-se a adesão a mesma concepção de Educação Ambiental.

Como os PPPs não reelaboram os conteúdos da PPC, esta última passa a orientar os professores no que se refere aos conteúdos que devem ser ensinados e, conforme o Quadro 1, os objetivos de aprendizagem apontam para uma concepção mais conservadora de Educação Ambiental. Não aparece em outro espaço, nos PPPs das três escolas, menções a como essa discussão poderia ser desenvolvida no cotidiano escolar.

A forma como a Educação Ambiental é apresentada nos documentos oficiais das escolas, denota que este debate tem sido tangente na sua elaboração, pois no PPP da escola "A" o texto está bastate próximo do texto da PPC, comum à todas as escolas e nos PPPs das escolas "B" e "C", pouco trata-se da Educação Ambiental, sendo que as outras temáticas dos "Desafios Contemporânos" apresentam-se com maior relevância.

\section{Tecendo conclusões...}

Os PPPs das escolas atendem ao disposto na legislação nacional, estadual e municipal, na medida em que expõem a necessidade de discussão das questões ambientais e sua inegável contribuição para a participação responsável dos sujeitos na vida social. Ainda, apresentam os objetivos de aprendizagem e conteúdos em diferentes disciplinas, não isolando essa questão em uma disciplina específica.

Ainda que os Projetos superem a visão naturalista, observa-se que há uma contradição entre a Pedagogia anunciada pelos PPPs e a concepção de Educação 
Ambiental, sendo uma crítica e outra mais conservadora, sem apontar o enfrentamento das questões centrais à problemática da Educação Ambiental, qual seja, o enfrentamento ao próprio modo de produção capitalista, aspecto central para a Pedagogia Histórico-Crítica.

Da forma como os textos se apresentam pode depreender-se que a discussão em torno da Educação Ambiental é tangenciada pelo coletivo que produziu os documetnos. Enfatizando que, não se analisaram práticas concretas, mas o que é exposto no documento oficial que apresenta os princípios da escola. Os três projetos, embora de realidades espaciais distintas, apresentaram a inserção da Educação Ambiental de forma semelhante, ou seja, muito próxima daquela apresentado na proposta curricular do município. Não observou-se, por exemplo, uma relação mais orgânica entre a escola do campo e a Educação Ambiental. Dessa observação pode depreender-se que a forma de inserção da Educação Ambiental não tem sido tomada como temática de debates no planejamento escolar, pois adere-se à proposição do currículo do município, ainda que esse documento indique na sua introdução ser fruto de uma construção coletiva. O momento de elaboração do PPP garante que as comunidades escolares expressem seu pensamento educacional traduzido na forma de organização do processo pedagógico.

A Pedagogia Histórico-Critíca oferece fundamentos teóricos e práticos para sustentar uma Educação Ambiental crítica, que trate de problematizar com os estudantes os problemas ambientais vividos atualmente. Entretanto, os conteúdos curriculares apontam para um ensino atitudinal, em que prevalece a ação individual para conter os problemas ambientais.

Essa corrente resolutiva atribui aos sujeitos atomizados a responsabilidade pelas mazelas ambientais, no sentido em que atribui-lhe a responsabilidade pela conservação. Assim como apontou Montibeller (2001), socializam-se os problemas ambientais e os lucros da exploração dos recursos naturais, seguem privados. Não trata-se de descartar o desenvolvimento da consciência coletiva de produção da vida, o que encerra também as ações individuais. Trata-se de questionar se essas ações individuais, sem que se altere o atual modo de produção da vida, pode conter a destruição do meio ambiente e se esta opção, no que se refere à concepção de Educação Ambiental, conduzirá a solução dos problemas ambientais.

De forma geral, entende-se que é necessário compreender as práticas pedagógicas que são desenvolvidas nas escolas, no que tange à Educação Ambiental para um 
posterior debate com as comunidades escolares acerca da articulação dessas concepções à proposta pedagógica defendida.

\section{Referências bibliográficas}

Brasil. Lei no 9.795, de 27 de abril de 1999. Institui a Política Nacional de Educação Ambiental.

Brasil. (2012). Resolução $\mathrm{n}^{\circ}$ 2, de 15 de junho de 2012. Estabelece diretrizes curriculares nacionais para a educação ambiental.

Duarte, N. (2016). Os conteúdos escolares e a ressurreição dos mortos: contribuição à teoria histórico-crítica de currículo. Campinas. SP: Autores Associados.

Francisco Beltrão. (2005). Lei Municipal № 3.187, de 13 de novembro de 2005. Estabelece a Política Municipal de Educação Ambiental.

Francisco Beltrão. (2012). Proposta Pedagógica Curricular: uma Construção Coletiva. (mimeo).

Francisco Beltrão. (2013a). Proposta Pedagógica da Escola Municipal Professora Maria Helena Vandresen. (mimeo).

Francisco Beltrão. (2013b). Proposta Pedagógica da Escola Municipal Recanto Feliz. (mimeo).

Francisco Beltrão. (2017). Projeto Político Pedagógico da Escola Municipal Basílio Tiecher. (mimeo).

Guimarães, M. (2004). Educação Ambiental Crítica. In.: BRASIL, Identidades da educação ambiental brasileira / Ministério do Meio Ambiente. Diretoria de Educação Ambiental; Philippe Pomier Layrargues (coord.). - Brasília: Ministério do Meio Ambiente.

Leher, R. (2016). A Educação Ambiental como crítica ao desenvolvimento sustentável: notas sobre o método. Pesquisa em Educação Ambiental, vol.11, n.2.

Linuesa, M. C. (2013). Elaborar o currículo: prever e representar a ação. In: Sacristán, J. G. (org). Saberes e incertezas sobre o currículo. Porto Alegre: Penso.

Montibeller-Filho, G. (2001). O mito do desenvolvimento sustentável: meio ambiente e custos sociais no moderno sistema de produtor de mercadorias. Florianópolis: Ed. Da UFSC. 
Sauve, L. (2005). Uma cartografia das correntes em Educação Ambiental. In: Sato, M.; Carvalho, I. C. M. (Orgs.). Educação Ambiental -pesquisas e desafios. Porto Alegre:Artmed.

Saviani, D. (2013). Pedagogia Histórico-Crítica: primeiras aproximações. Campinas, SP: Autores Associados.

Saviani, N. (2010). Saber escola, currículo e didática: problemas da unidade conteúdo/método no processo pedagógico. Campinas, SP: Autores Associados. 


\section{As tecnologias digitais de informação na formação continuada dos professores do ensino superior}

VERA LUCIA FORTES ZENI ${ }^{1}$

ELTON ZENI ${ }^{2}$

\section{Resumo}

Essa pesquisa visa identificar as tecnologias da informação e comunicação utilizadas pelos docentes de uma instituição de ensino superior produzem resultados favoráveis no ensino e na tarefa de qualificar seu quadro docente para enfrentar as assimetrias entre docentes e estudantes presentes no século XXI. O estudo de natureza qualitativa, teve com espaço empírico a Unidade Central de Educação Faem Faculdade-UCEFF, tendo como sujeitos, 158 professores que lecionam em cursos noturnos, nas áreas da engenharia, agrárias, saúde e ciências sociais através de questionário estruturado. A escolha pautou-se na especificidade, de que esses docentes majoritariamente possuem outras atividades laborais durante o dia e possuem reduzidas cargas horárias no período noturno, desse modo, não possuindo dedicação exclusiva na instituição. Como resultado, foi possível constatar que nem todas as tecnologias utilizadas são eficientes para o propósito do ensino e da aprendizagem dos estudantes. Percebeu-se que a baixa utilização das tecnologias de informação deve-se a formação tradicional que esses professores receberam e como consequência reproduz com seus estudantes. Comprovou-se, que por não possuírem familiaridade com o uso das tecnologias, faz-se necessário que as instituições proporcionem espaços de capacitação para essa finalidade, designadamente numa

\footnotetext{
${ }^{1}$ Professora da Uceff Faculdades Doutora em Geografia - UFSC, verazeni@yahoo.com.br.

2 Professor e diretor de ensino da Uceff Faculdades. Doutor em engenharia de produção URGS, elton@uceff.edu.br
} 
perspetiva de formação cidadã, que possivelmente se refletirá no processo de ensino e de aprendizagem de seus estudantes.

Palavras-chave: Tecnologias digitais; Educação superior; Formação continuada; cidadania.

\section{Abstract}

In this context, this paper present the importance of inducing the use of technologies, searching for new paths to decrease the gap between professors and students. Since the questioning about which information technologies, produce favorable results for the education in the task of qualify its professor's staff to face the contradictions of the $21^{\text {st }}$ century. This qualitative research had as its empirical space the educational institution Uceff Faculdades - Chapecó SC, having the number of 158 professors who teach in night courses, in the engineering, agrarian, health and applied social areas. This choice is giving by having specific characteristics where the majority of the professors have other activities in their days and work small shifts at night, not having exclusive dedication to the educational institution. It was possible to verify that not all the technologies used by them are known, and it is necessary that the institutions are able to provide learning spaces for such need, as a way to contribute in the continued academic education, that possibly will reflect in the teaching process and the student's learning process.

Key-words: Digital technologies; higher education; continued academic education; citizenship.

\section{Introdução}

Nenhuma civilização foi tão desenvolvida intelectualmente quanto a nossa, muito desse progresso é diretamente ligado com a evolução tecnológica, que tudo transformou, em inúmeras linguagens digitais, no entanto, esse processo de mudanças é lento e deficitário nas práticas docentes, a educação não se apropriou da tecnologia, a formação inicial dos professores não condiz com a realidade do aluno digital, que sente necessidade de interações e tem fascinação e facilidade de domínio com os aparelhos móveis: tablet, smartphone, notebook entre outros. Esses "nativos digitais," comparecem nas instituições de ensino munidos de informações, dados, ideias e dispositivos na mochila para aprender, são os principais protagonistas 
que levam o professor enfrentar as adversidades, que muitos momentos não está apto:

[...] a utilização das TIC por parte dos professores só se efetivará no momento em que o mesmo se libertar das amarras que o caracterizam como único detentor do conhecimento. Na sociedade contemporânea, vivese momento de compartilhamento, construção não linear do conhecimento, onde professor e aluno constroem o conhecimento ao mesmo tempo. $\mathrm{Na}$ formação para utilização das tecnologias digitais é necessário que o professor seja curioso, como uma criança na educação infantil, não tenha medo de explorar as novidades que lhe estão sendo apresentadas [...] (Pereira \& Batistela, 2016, p.801).

A cultura que adentra o fazer pedagógico no espaço educativo diverge da formação dos professores que estão atuando, pelo fato de que muitos destes profissionais tiveram uma formação baseada no quadro, giz e livro didático. Para Freire (1997, p.14) "O educador democrático não pode negar-se o dever de, na sua prática docente, reforçar a capacidade crítica do educando, sua curiosidade, sua submissão". As novas demandas exigem uma urgência de reconfiguração da prática pedagógica do conhecimento:

[...] a presença das Tecnologias Digitais Móveis (TDM) permite-nos perceber a necessidade e a urgência da educação atentar-se para as demandas de uma nova cultura digital. Neste sentido, a escola, principalmente, o professor tem um papel fundamental na formação dos estudantes e por esta razão, o nosso olhar centra-se na formação continuada do professor, para que ele possa reconstruir a sua prática, integrando o uso das Tecnologias Digitais Móveis aos conteúdos curriculares [...] (Prado et al. 2016,p.41).

As colocações do autor, concede total entendimento que o ensino, a prática, a cultura é marcada por um novo espaço ligado ao mundo digital. Espaço este que tem requerido outras abordagens didáticas, novas formas de relacionar em sala de aula e, principalmente, exigindo professores que deem conta de lidar com o ensino ligados as tecnologias de informação e comunicação. Nesse sentido, Gasperin (2005) complementa dizendo que para o ensino e aprendizagem efetivamente ocorrer é necessário que os professores se atualizem epistemologicamente e tecnicamente para dar conta de ensino que tenha real sentido com a cultural que caracteriza neste tempos e espaços contemporâneos.

Diante dessa a realidade, perpassa os seguintes questionamentos: a formação do professor é importante para aprender a lidar com essa cultura, para saber transformar as informações, dados e notícias em conhecimentos que tenham reais sentidos e significados para os estudantes?

Como a formação continuada pode favorecer aos professores o aprendizado dos recursos tecnológicos indo além dos aspectos operacionais do software, no sentido de 
propiciar a reflexão e a conceituação de conteúdos numa perspetiva de formação cidadã?

Embasados nesta problemática, elencamos como objetivo geral: identificar as tecnologias da informação e comunicação utilizadas pelos docentes de uma instituição de ensino superior privada do Sul do Brasil.

Como objetivos específicos delinearam-se: (1) Investigar como se processa a relação dos professores com o uso das ferramentas na prática didática; (2) Organizar práticas pedagógicas para potencializar a formação na tarefa de qualificar seu quadro docente e, (3) Possibilitar trocas colaborativas de conhecimentos através de diálogos com os professores por meio da formação continuada.

Para dar conta da problemática e dos objetivos traçados, definimos como percurso metodológico uma abordagem qualitativa com enfoque na pesquisa-ação. A pesquisa qualitativa possibilita captar de forma apropriada as minúcias que revelam a estrutura, o processo, a forma e as contradições do objeto de estudo: a formação do professor de ensino superior em tempos e espaços contemporâneos e tecnológicos.

\section{Percurso Metodológico}

Do ponto de vista metodológico, a pesquisa buscou uma abordagem qualitativa na modalidade de pesquisa-ação, alimentado com estudos teóricos. A opção por esse método efetivou porque objetiva reunir o maior número de informações de diferentes fontes para compreender a situação do uso das Tecnologias digitais de informação e Comunicação para ensino no contexto da formação dos professores. O que permitirá que o pesquisador possa participar da realidade da vida cotidiana de um grupo, podendo ter um contato direto com o mesmo. Conforme Tripp (2005, p. 443):

[...] a pesquisa-ação educacional é principalmente uma estratégia para o desenvolvimento de professores e pesquisadores de modo que eles possam utilizar suas pesquisas para aprimorar seu ensino e, em decorrência, o aprendizado de seus alunos.

Em síntese, a pesquisa-ação possibilita a compreensão de um todo a partir de vivenciar o objetivo delineado, através do contato, da investigação, do planejamento bem como da organização e sistematização dos materiais a serem utilizados. Sendo assim, esse é um tipo de pesquisa que visa à investigação de uma situação específica, bem definido e delimitado, contextualizado em tempo e lugar para que se possa realizar uma busca circunstanciada de informações. 
Nesta perspectiva, é possível, por meio da pesquisa-ação, estudar de forma dinâmica as dificuldades e necessidades, considerando a realidade investigada e seus agentes. Serão definidos atos, acordos e momentos propícios às tomadas de consciência que ocorrem entre os envolvidos e a demanda dos mesmos comprometimentos durante 0 processo de construção/transformação da situação. Nesse sentido, Thiollent (2003, p. 16) fundamenta os principais aspectos básicos da pesquisa-ação:

[...] a) há uma ampla e explícita interação entre pesquisadores e pessoas implicadas na situação investigada; b) desta interação resulta a ordem de prioridade dos problemas a serem pesquisados e das soluções a serem encaminhadas sob forma de ação concreta; c) o objeto de investigação não é constituído pelas pessoas e sim pela situação social e pelos problemas de diferentes naturezas encontrados nesta situação; d) o objetivo da pesquisaação consiste em resolver ou, pelo menos, em esclarecer os problemas da situação observada; e) há, durante o processo, um acompanhamento das decisões, das ações e de toda a atividade intencional dos atores da situação; f) a pesquisa não se limita a uma forma de ação (risco de ativismo): pretende-se aumentar o conhecimento dos pesquisadores e o conhecimento ou o 'nível de consciência' das pessoas e grupos considerados. Ao mesmo tempo em que o processo busca o envolvimento dos sujeitos, implica em acréscimos no conhecimento e nas reflexões dos participantes [...].

Nas palavras de Barbier (2007), esse tipo de proposta é possível a continuação das ações planejadas com base na ação/reflexão/ação possibilitando aos educadores a ampliação de suas abordagens, pois suas práticas e conhecimentos serão discutidos e ampliados em novas possibilidades de mediação pedagógica. Essa reflexão permite, ainda, que se delineiem novas experiências, práticas e ressignifiquem outras, visando emancipar os sujeitos que participaram das problemáticas discorridas, já que eles são os atores que medeiam o processo educativo no ambiente de aprendizagem. Os avanços, os limites e as possibilidades da pesquisa sempre estarão atrelados às realidades a que estão vinculados e ao momento em que acontecem.

Nessa perspectiva, este tipo de abordagem ultrapassa os aspectos metodológicos da maioria das pesquisas convencionais. Ela supera "[...] a mera descrição, buscando realmente acrescentar algo à discussão já existente sobre o assunto focalizado" (Lüdke e André, 1986, p.49) e projeta uma ação na realidade observada, uma vez que passa a ser um estudo de caso, ou seja, de uma realidade, envolvendo contornos definidos por apresentar-se como uma unidade de análise dentro de um sistema mais amplo e, por muitas vezes complexo.

Assim, este tipo de metodologia permite que os professores envolvidos na ação a aprendam juntos, ampliando as possibilidades de trocas de experiências e de aprendizagens que auxiliarão em suas práticas diárias, proporcionando que o conhecimento seja gerado em processos investigativos e de preenchimento de 
lacunas, tanto na formação docente. A educação é um pilar que permite transformações sociais e culturais da sociedade. Essas mudanças perpassam pela formação de sujeitos capazes de construir, a partir de um senso crítico, ideias novas em relação ao mundo que a cada dia se reinventa.

O professor é beneficiário de diversas ferramentas tecnológicas, oferecida pela instituição de ensino para aplicar conteúdos científicos e atividade formais de forma prática e autêntica. Dessa, forma, foi proporcionada atividade de extensão e pesquisa, visando interação entre diferentes sujeitos possibilitando trocas de saberes e o conhecimento das diversas fases de produção de uma atividade colaborativa e interativa que foi e está sendo proporcionada em três etapas.

A escolha das ferramentas da pesquisa objetivou estudar $e$ analisar os acontecimentos e movimentos pedagógicos e metodológicos a partir do uso das tecnologias digitais pelo corpo docente da instituição investigada. Desse modo, definiu algumas etapas metodológicas para a realização da investigação empírica a partir de três etapas:

\section{A) Caracterização do espaço e sujeitos da pesquisa:}

A pesquisa foi realizada na Unidade Central de Educação FAEM Faculdades - UCEFF instituição de ensino superior que iniciou suas atividades em 2004 após a publicação da Lei 9394/1996, a qual possibilitou à iniciativa privada o oferecimento de ensino superior. Acolhe demanda da região oeste de Santa Catarina- Brasil preenchendo uma lacuna não atendida pelas Universidades Comunitárias presentes na região, tampouco pelas Universidades Federais que na época estavam completamente ausentes desta grande região com notável importância econômica. Ampara uma região de abrangência de 118 municípios que possui uma população de 1.114 .699 habitantes

Atualmente conta com 1.591 alunos matriculados nos cursos de graduação e 330 alunos nos cursos de pós-graduação lato senso.

Em torno de $80 \%$ desses alunos, trabalham durante o dia, e estudam no período noturno. Nesse sentido, impossibilitados de estudar na universidade pública que geralmente oferece cursos diurnos.

O valor das mensalidades, é mais vantajoso economicamente para esses estudantes, em comparação com as duas universidades comunitárias mesmo que essas universidades filantrópicas não visam lucro.

A faixa salarial dos professores é maior em relação as demais instituições da região. Contudo, $73,42 \%$ dos professores são profissionais liberais durante o período diurno, 
esses docentes majoritariamente possuem outras atividades laborais durante o dia e possuem reduzidas cargas horárias no período noturno, desse modo, não possuindo dedicação exclusiva na instituição.

\section{B) Caracterização do ponto de partida:}

Conhecer a prática didática tendo como instrumento de coleta questionário com 158 professores de todas as áreas científicas quanto ao uso das tecnologias, através dos seguintes questionamentos: O que faço com tecnologias digitais com os estudantes? Com que objetivos? Em que áreas disciplinares? Está programado para utilizar tecnologias no próximo semestre?

Esse questionamento foi respondido por todos os professores da instituição de ensino através de aplicação de um questionário online com os participantes através do Google Drive - formulários.

C) Suporte pedagógico: Organizar prática pedagógica para qualificação docente a partir das etapas anteriores objetivando produzir inquietações capazes de estimular no corpo docente para o desenvolvimento de novas ações para a promoção de práticas de ensino e aprendizagem.

Baseado nesse procedimento formativo, este texto se destina discutir o material coletado a partir do questionário aplicado com os sujeitos da pesquisa, evidenciando $o$ uso direto e indireto das tecnologias nas práticas educativas e culturais.

\section{A Tecnologia e o exercício da cidadania}

Diante dos novos desafios de ensinar, o uso das tecnologias como: a plataforma digitais, os aplicativos educativos e ambientes virtuais acrescentam como uma possibilidade alternativa de práticas educativas. Principalmente em promover uma aprendizagem centrada no sujeito tornando pertinente a compreensão, a partida, do modo como os próprios sujeitos se posicionam face à aprendizagem por meio da mediação pedagógica.

Fernando Costa (2004, p.22) deixou explícito a necessidade de capacidades técnicas diante das tecnologiae e suas potencialidades pedagógicas e didáticas, ou seja, o que com ela alunos e professores podem realizar, o que com ela se pode aprender e como, ao afirmar que:

A questão essencial não residirá pois nos atributos que fazem de uma determinada tecnologia uma nova tecnologia, mas a de nos interrogarmos sobre quais as mais-valias que ela traz para o processo de aprendizagem. 
Dito de outra forma, como poderão os professores ensinar melhor e os alunos aprender de modo mais eficiente (Costa,2004, p.22).

Nesta perspectiva, as autoras Silva e Tonini (2014) chamam atenção que é de fundamental importância que o professor se esforce em associar com o tangível do contexto educativo, por meio dos seus temas e conteúdos, bem como a realidade do estudante. A adequada atuação do professor é, sobretudo, uma ação pessoal, intuitiva e subjetiva na mediação pedagógica.

No entanto, é preciso compreender de forma mais profunda o papel das ferramentas tecnológicas como meios de trabalho, de consulta e de comunicação que podem potenciar a formação docente constituindo em seu prolongamento de memória e de ação, tomando-se, assim, também, instrumentos de apoio à autonomia e à realização pessoal que não podem estar ausentes de qualquer projeto de vida contribuindo para que cada um desenvolva sentidos de participação social (Pretto, 2006).

A utilização das ferramentas tecnológicas na escola, ao proporcionarem a inclusão digital e a vivência da contemporaneidade, quer no domínio dos aspectos progressivos quer no domínio dos aspectos regressivos da sociedade, confronta os estudantes com a sua responsabilidade na aprendizagem podendo favorecer ao estudante e, inclusive ao professor conhecimento científico e social, e assim, proporcionando o desenvolvimento da autoria e autonomia.

Nesse contexto questiona-se: Qual seria a função das instituições de ensino quando a tecnologia contemporânea não está na disponível somente nos laboratórios com acesso a computadores, mas está nas mãos da grande maioria dos alunos, mesmo com legislação3 para negar a entrada de celulares nas instituições de ensino, essa lei nunca foi posta em prática, isso comprova que a educação convencional está em processo de decadência e vive uma passagem de "Buraco negro" temporal da guerra pelo celular, nesse panorama é essencial as instituições oportunizarem a formação pedagógica a partir do uso da tecnologia como ferramenta cognitiva.

O uso de tecnologias no ensino podem potencializar a novas experiências de aprendizagem, conforme Silva et al (2018.p.08) "os professores possibilitam, ao permitir aos estudantes contribuam para a construção de seus próprios itinerários

\footnotetext{
${ }^{3}$ O presente Projeto de Lei de Lei 2246/07 visa assegurar a essência do ambiente escolar, onde a atenção do aluno deve estar integralmente direcionada aos estudos, na fixação do aprendizado passado pelos professores, sem que nada possa competir ou desviá-lo desse objetivo. O uso do celular no ambiente escolar compromete o desenvolvimento e a concentração dos alunos.
} 
formativos, além de interatividade, flexibilidade, diversidade de informações e aulas mais atrativas e dinâmicas".

Conforme a pesquisa efetuada por Silva et al (2018) com estudantes do ensino médio, a respeito do uso de celulares em sala de aula com fins pedagógicos, concluíram que,

[...] pra nós seria mais interessante se os professores organizassem aulas em que a gente pudesse utilizar o celular. Ao invés de eles sempre trazerem o conteúdo, a gente poderia ir buscar. Eu acredito que poderíamos ter informações mais variadas e atualizadas. Já que ele está conosco e a escola tem a rede wifi aberta, nós poderíamos ampliar nossas informações sobre o tema que estamos estudando e ainda tornar nossa aula mais prazerosa e dinâmica. Por outro lado, não sei se a turma em geral tem maturidade pra não se desviar do assunto da aula e ficar nas redes sociais [...] (Silva et al 2018, p.08).

Para os estudantes uso de celulares e outros dispositivos tecnológicos em sala de aula é significativo elemento de maior autonomia na aprendizagem, conveniência, novo espaço, por outro viés, a fala remete a "maturidade para não desviar o assunto", nesse caso, o professor deverá assumir a competência de líder condutor do processo de ensino de forma colaborativa e ativa, exigindo um novo função no espaço temporal contemporâneo. Essa abordagem fortalece os laços na relação professor/aluno,

[...] o fundo, o essencial nas relações entre o educador e educando, entre autoridade e liberdades, entre pais, mães, filhos e filhas é a reinvenção do ser humano no aprendizado de sua autonomia. Me movo como educador porque, primeiro, me movo como gente [...] (Freire, 1997, p.57).

Nessa perspectiva outros questionamentos aparecem no cenário educativo moderno: até que ponto os professores tem habilidade interpessoal em sala de aula? O desafio está, portanto, nas palavras de Magalhães (2001) na "incorporação de novas tecnologias a novos processos de aprendizagem que oportunizem ao discente atividades que exijam não apenas o seu investimento intelectual, mas também emocional, sensitivo, intuitivo/estético."

Gasperin (2005) enfatiza a necessidade de envolver intelectualmente e afetivamente os alunos na elaboração e reelaboração ativa do conhecimento. No entanto, Pereira \& Batistela, (2016, p.802) "a utilização das tecnologias digitais nas escolas ainda está longe de exercer sua função primordial, que é a de proporcionar o protagonismo ao estudante, onde os mesmos têm condições de construir o conhecimento, através de seus próprios questionamentos."

Para tanto Masetto (2003, s/p) propõe substituir "a ênfase no ensino pela ênfase na aprendizagem. Simples troca de palavras? Não. Quando falamos em aprendizagem, 
estamos nos referindo ao desenvolvimento de uma pessoa." Só assim poderemos falar em mudança, em dinamizar as aulas, em tornar essas "aulas vivas", em fazer das aulas um espaço privilegiado de aprendizagem, de formação de profissionais competentes e cidadãos (Masetto, 2003).

[...] é esperado que os modelos de formação possam romper com as tradicionais práticas de isolamento, estimulando o desenvolvimento de uma profissionalidade docente baseada na interação, socialização e cooperação na construção de conhecimentos, capacidades e atitudes [...] (Costa et al, 2015, p.151).

Entre os pesquisadores não há dúvida da necessidade da tecnologia aliada a atributos da liderança com inteligência emocional, oportunizando habilidades de confiabilidade, paciência, respeito e incentivo ao aluno a buscar e interagir com o conhecimento, visando atingir determinado objetivos para o bem comum.

\section{Partilha dos resultados}

A partir dos questionamentos efetuados com os 158 professores um fato que chamou a atenção da direção de ensino da instituição, foi o conhecimento de que 53,85\% dos professores que nunca utilizaram TICs e não pretendiam fazer uso no próximo semestre. Esse indicativo vai além das competências profissionais que normalmente são objeto do trabalho com os professores, a ideia era, em síntese, a de dar uma especial atenção ao desenvolvimento da habilidade de manipular as novas tecnologias enquanto ferramentas cognitivas de ensino/aprendizagem, em harmonia com a reflexão sobre os novos papéis do professor e tendo como objetivo ajudar os estudantes a serem eles próprios construtores de currículo, a refletirem sobre o sentido da aprendizagem e, bem assim, desenvolverem estratégias de instrução autônoma induzida pelo uso de tecnologias.

$\mathrm{Na}$ recolha de informação a partir dos questionários foram verificadas algumas ferramentas mais utilizadas e valorizadas pelos professores, tais como, AVA, Youtube, e whatsapp. Esse conjunto de ferramentas evidenciam a supremacia de tecnologias que atravessam cotidianamente a realidade desses profissionais. Isso nos toca no sentido de propiciar formações continuadas tanto no plano virtual quanto presencial com ferramentas ligadas a aplicativos, plataformas e ambientes educacionais. Pois a rede do ciberespaço é inundado de ferramentas que possibilitem o professor fazer o uso direto no seu fazer pedagógico, mas para isso efetivamente tornar-se real, é necessário de formações que visem a obtenção de como operar, manipular e mobilizar essas as ferramentas. 
Após identificar áreas deficitárias e dificuldades demonstradas pelos professores na apropriação das tecnologias digitais em suas práticas quotidianas, esse foi ponto de partida na atividade de formação que lhes permitam adequar as atividades com TICs para usos cognitivos mais exigentes e complexos.

Este item pertence à terceira fase da pesquisa, ou seja, o suporte pedagógico

do percurso metodológico, que visa trabalhar com a prática pedagógica com ferramentas digitais, baseada na construção colaborativa de diferentes áreas de ensino. Essas formações específicas estão sendo aplicada a cada 30 dias por meio do programa de formação denominado Centro de Aperfeiçoamento Docente - CAD.

Para a elaboração e desenvolvimento da proposta foi definida uma organização de equipes entre os participantes, definição dos conteúdos relacionados à proposta curricular dos cursos, explicação e orientação de como funciona cada prática pedagógica apresentada pelos consultores contratados pela instituição, bem como, também as potencialidades, as restrições deste no ato educativo e, por fim, o compartilhamento dos produtos finais criado no decorrer da formação por meio da socialização entre os envolvidos.

A formação continuada promoveu inúmeras possibilidades ao professor para aprender a trabalhar com os conteúdos e conceitos na sala de aula, bem como também, aprender a lidar com as tecnologias digitais de modo pedagógico e contemporâneo. Isto é, O CAD incluiu componente não presencial, equivalente a 10 horas a cada período de 30 dias, de trabalho autónomo, os professores tiveram de elaborar e implementar atividades com tecnologias digitais para trabalhar no próximo semestre.

Por meio da formação pedagógica objetivando a integração das TICs nas atividades do ensino superior esperam-se os seguintes resultados para os próximos semestres:

1. Praticar aprendizagens significativas ligadas ao universo das tecnologias, isso é, propiciar encontros em que os professores possam aprender outras ferramentas que não fazem parte do seu universo didático, a fim de que, possam expandir em matéria de aprendizagem;

2. Oportunizar mudanças comportamentais pedagógicas. Essa constatação caracteriza-se como a complementaridade da primeira evidência deparada. Entende-se que, o contato direto e imersivo com as tecnologias possibilitarão os professores vivenciarem outros abordagens do que já estão habituados a desenvolverem em seu cotidiano educativo. Tal modo 
que, poderão desempenhar novas roupagens educativas e, assim, tornando-os suas aulas mais atrativas, interessantes e ricas.

3. Promover o trabalho em equipe e a autonomia dos estudantes. Observa-se que, a introdução das tecnologias precisam serem pensadas a partir de um trabalho que possibilitem cada um e todos trocarem suas experiencias, criatividades, conhecimentos e ideias tanto do ponto de vista do professor para o professor quanto do ponto de vista do professor para o estudantes;

4. Aprender a resolução de problemas;

5. Construir novos conhecimentos. Ambos aspectos se interseccional, ou seja, na medida em que o professor for desafiado a pensar, contruir e resolver, automaticamente, irá adquirir novos conhecimentos, habilidades e competências técnicas, operacionais e de mobilidade.

Certamente as primeiras formações já produziram inquietações capazes de estimular no corpo docente o desenvolvimento de novas ações para a promoção de práticas de ensino e aprendizagem que ocorrem intimimanente no âmbito educacional.

\section{Considerações finais}

$\mathrm{Na}$ esfera do Projeto "Nós Propomos!" que a finalidade é promover uma efetiva cidadania, neste contexto, a educação deve preparar cidadãos para os desafios contemporâneos, a tecnologia poderá ser uma fonte geradora de mudanças qualitativas na função pedagógica e no estudante como cidadão. Esta proposta de formação docente parte da constatação de que, apesar da massiva implantação das tecnologias digitais nas diferentes áreas da sociedade, ainda é incipiente a sua utilização quotidiana em contexto pedagógico, nomeadamente para apoio às aprendizagens formais, o que acaba por colocar as instituições de ensino relegando no que à sua função de preparação dos cidadãos para os desafios da sociedade contemporânea.

Todos os parâmetros analisados convergem para a conclusão que usar as tecnologias com fins educativos não é uma ameaça à profissão docente, mas uma possiblidade de inovar, pois somente a raça humana tem a capacidade de racionar e ensinar, oportunizando processos pedagógicos personalizados, flexíveis e envolventes.

No mundo contemporâneo a figura do professor, diferente do que se pensava tornase mais importante, pois os estudantes chegam às escolas com uma grande possibilidade de conceber o que está sendo informado e com pouca capacidade de 
refletir sobre estas informações. O papel do educador é ensinar a refletir, transformar e aplicar os conceitos em diferentes situações. Como argumenta Morin (2011, p.55), "na era das telecomunicações, da informação, da internet, estamos submersos na complexidade do mundo - as incontáveis informações sobre o mundo sufocam nossas possibilidades de inteligibilidade". O movimento dialógico entre estudante, o professor, o conteúdo e o mundo é o que precisamos reforçar. Este movimento é necessário e se efetiva cada vez que paramos para observar, interagir e pesquisar o estudante.

\section{Referências bibliográficas}

Barbier, R. (2007). A pesquisa-ação. Trad. Lucie Didio. Brasília: Líber Livro Editora.

Costa, F., Cruz, E., Rodriguez, C., Viana, J. (2015). As TIC na formação inicial de professores em Portugal e no Brasil: desafios e possibilidades. In Rocha, C. H., Braga, D., Caldas, R. R.(Orgs.). Políticas linguísticas, ensino de línguas e formação docente: desafios em tempos de globalização e internacionalização. Campinas, Br: Pontes. 129-154.

Costa, F. A. (2004). O que justifica o fraco uso dos computadores na escola? Lisboa: Polifonia. (EdiçõesColibri, n.7), 2004. p. 19-32. Disponível em: www.fl.ul.pt/unil/pol7/pol7_txt2.pdf

Freire, P. (1997). Pedagogia do oprimido. Rio de Janeiro: Paz e Terra.

Lüdke, M. André. M. E. D. (1986). Pesquisa em educação: abordagens qualitativas. São Paulo: EPU.

Magalhães, H. G. D. (2001).A prática docente na era da globalização. Pedagogia em Foco, Rio de Janeiro.

Masetto, M. T. (2003). Docência Universitária: Repensando a aula in vasconcelos, M.L (org). Ensinar e aprender no Ensino Superior. São Paulo: Mackenzie; Cortez.

Morin, E. (2011). A via para o futuro da humanidade. Rio de Janeiro, Bertrand.

Pereira, A. M.O., Batistela,F. (2016). Uma reflexão sobre a inclusão social proporcionada pelo uso das tecnologias digitais nas aulas de geografia no Brasil. Atas do Congresso ticEDUCA. Disponível em: https://cld.pt/dl/download/876b2f28-c5ea42b8-ace5-5c94719d9127/Livro_Atas.pdf. 
Prado, M. E. B. B. (2016) .Tecnologias digitais móveis e o processo de apropriação do professor para a reconstrução da prática pedagógica. Atas do Congresso ticEDUCA. Disponível em: https://cld.pt/dl/download/876b2f28-c5ea-42b8-ace55c94719d9127/Livro_Atas.pdf

Pretto, N., Pinto, C. C. (2006).Tecnologias e Novas Educações. Universidade Federal da Bahia, Faculdade de Educação.

Silva, A. T. B. (2018). Percepções dos estudantes do Ensino Médio sobre o uso dos celulares na sala de aula. Revista Tecnologias na Educação - Ano 10 Número/Vol.24 - Edição Temática VII- Simpósio IberoAmericano de Tecnologias Educacionais (SITED). Disponível em: http://tecedu.pro.br/wpcontent/uploads/2018/06/Art8-vol.24-Edi\%C3\%A7\%C3\%A3o-Tem\%C3\%A1tica-VIIJunho-2018.pdf.

Thiollent, M. (2003). Metodologia da pesquisa-ação. 12ª ed. São Paulo: Cortez.

Tripp, D. (2005). Pesquisa-ação: uma introdução metodológica. Educação e Pesquisa, v.31, n 3, p.443-446. São Paulo. 


\section{MAPEAMENTO \\ GEOPARTICIPATIVO 3P: informação, formação e

\author{
empoderamento
}

DANIELA CAMPOLINA ${ }^{4}$

LUSSANDRA GIANASI ${ }^{5}$

\section{Resumo}

A metodologia do "Mapeamento Geoparticipativo 3P" foi desenvolvida e aplicada ao longo de 5 anos, por meio de projetos de extensão, vinculados à Universidade Federal de Minas Gerais - Brasil em várias bacias hidrográficas de Minas Gerais. O processo do mapeamento objetiva envolver alunos e professores na produção de conhecimentos sobre o território de microbacias hidrográficas, como processo didático de formação crítica, além de auxiliar na gestão ambiental participativa. Nos aproximamos, assim, nas várias etapas dessa metodologia, com os desafios do Projeto Nós Propomos!. São etapas da metodologia 3P: 1. Mobilização de escolas e parceiros; 2. Capacitação por meio de oficinas de formação de professores/alunos; 3. Produção do Mapa mental da região do entorno; 4. Construção da Maquete da microbacia; 5. Participação do Trabalho de Campo com identificação/cadastro e mapeamento de (1P) Problemas e (2P) Potencialidades, georreferenciando e fotografando fatos, dados, paisagem e o lugar; 6. Discussão pós-campo com identificação de (3P) Possibilidades; 7. Estruturação de banco de dados, mapas e

\footnotetext{
${ }^{4}$ Doutoranda em educação pela Universidade Federal de Minas Gerais-Brasil, professora do ensino fundamental na rede pública brasileira, danicampolina@gmail.com

${ }^{5}$ Doutora em Geografia e professora no Instituto de Geociências da Universidade Federal de Minas Gerais-Brasil, lussandrams@gmail.com
} 
imagens de satélite utilizando software Google Earth; 8. Elaboração e divulgação do Plano de Diretor da Microbacia.

Palavras-chave: mapeamento; formação de professores; bacias hidrográficas; gestão participativa; cidadania.

\section{Abstract}

The methodology "Geoparticipative Mapping 3P" was developed and applied over 5 years, through extension projects, linked to the Federal University of Minas Gerais Brazil in several river basins around Minas Gerais. The process of mapping aims to involve students and teachers in the production of knowledge about the territory of hydrographic basins, as a didactic process of critical formation, besides assisting in participatory environmental management. We approach, therefore, the various stages of the methodology, relating it to the challenges of the Project We Propose. The stages of the 3P methodology are: 1 . Mobilization of schools and partners; 2 . Training workshops to teacher and student; 3. Construction of mental map of the surrounding territory; 4. Production of watershed model; 5. Participation in a field work with identification/registration and mapping of (1P) Problems and (2P) Potentialities, georeferencing and photographing facts, data, landscape and place; 6. Drawing up and discussing after field work with identification of (3P) Possibilities; 7. Structuring of databases, maps and satellite images using Google Earth software; 8. Elaboration and dissemination of the Director Plan of the microbasin.

Keywords: mapping; teacher training; watersheds; participative management; citizenship

\section{Gestão das águas no Brasil: desafios da construção de uma gestão participativa}

Apesar do Brasil ser considerado uma potência hídrica, a água em seu território não é distruibuidade igualmente. Convive-se com situações de abundância e escassez. No território brasileiro se encontra $12 \%$ do total de água doce do mundo, $90 \%$ dos seus rios são perenes, abriga a bacia amazônica - a maior do Brasil e do mundo - além de estar localizado 70\% do Aquífero Guarani (maior do mundo), bem como a maior extensão da Amazônia e Pantanal, que são áreas úmidas de grande importância mundial (Rebouças, 2001; Ribeiro, 2008). 
Mesmo em meio à grande quantidade de água, em algumas regiões, o mau uso do solo e da água faz com que não se possa usufruir desse recurso. As extensas bacias hidrográficas, territórios por onde as águas escoam e fluem, tornam a gestão das águas no país um grande desafio.

A preocupação com a gestão dos recursos hídricos no Brasil é recente. Apesar da primeira legislação re-ferente ao uso das águas ser do ano de 1934, o Código das Águas, a ideia de gestão democrática era inexistente, havendo a predominância do uso da água pelos setores industriais. Somente a partir da década de 1970, com o agravamento da poluição das águas e início de situações de escassez em regiões que antes não sofriam com a falta de água, é que se iniciaram discussões sobre a criação de uma legislação que proporcionasse o uso múltiplo das águas e que possibilitasse a manutenção da quantidade e qualidade desse recurso. Quase 30 anos depois, em 1997, foi promulgada e Lei Federal 9.433, a Política Nacional de Recursos Hídricos, também conhecida como "Lei das Águas".

A Lei das Águas define que a água é um bem público, de uso múltiplo e que em situação de escassez a prioridade de uso é para abastecimento humano e dessedentação de animais. Segudo a legislação, a gestão das águas deve ser descentralizada, participativa e integrada, tendo a bacia hidrográfica como unidade territorial de planejamento e gestão. As decisões devem ser realizadas por meio dos Comitês de Bacias Hidrográficas ( $\mathrm{CBHs}$ ), conselhos gestores, formados paritariamente por representantes de usuários $^{6}$, poder público e sociedade civil.

Mas, mesmo após 10 anos da promulgação dessa lei, o Sistema Nacional de Recursos Hídricos está em estruturação e a concepção de uma gestão democrática, participativa e integrada está mais no campo teórico do que no prático. Podemos considerar dois grandes desafios nesse contexto: a participação legítima da sociedade na tomada de decisões e um Sistema de Informações sobre Recursos Hídricos que deixa a desejar, especialmente pela inexistência de informações locais e de grande escala geográfica, sobre a maioria das microbacias que integram as bacias hidrográficas de grandes extensões, as que geralmente temos mais informações e por vezes generalizada.

\footnotetext{
6 "Usuários ou usuário de água - termo usado na gestão de recursos hídricos para designar todos aqueles que utilizam diretamente as águas superficiais ou subterrâneas de uma bacia hidrográfica. O usuário pode ser pessoa física ou jurídica, de direito privado ou público e que independente da necessidade de outorga prevista nos termos da lei, faz uso dos recursos hídricos, captando água diretamente de cisternas, açudes, córregos, rios lagos ou que faz qualquer lançamento de efluentes (esgotos industriais, agrícolas ou domésticos) diretamente nos corpos d'água" (Mata-Machado et al., 2011, p. 98).
} 
Apesar da presença de representantes da sociedade civil nos CBHs, as decisões geralmente são condicionadas a conhecimentos técnico-científicos concentrados em representantes do poder pú $b$ blico e usuários que, geralmente, ao final das discussões, acabam direcio $\neg$ nando as decisões. Autores como Abers (2010) e Júnior \& Fidelman (2009) afirmam que os conhe $\neg$ cimentos técnico-científicos deveriam auxiliar nos processos de tomada de decisões democráticas, mas, tem muitas vezes, legitimado decisões que beneficiam apenas alguns grupos. A sociedade civil, que vivencia e influencia na dinâmica de seu território de vida, não tem poder de decisão sobre esse território.

Outro desafio considerável é falta de um sistema integrado de informações municipais e estaduais que contemplem o território das bacias hidrográficas. Cada município, por exemplo, organiza suas informações por regionais administrativas e bairros, e cada estado organiza suas informações por municípios e regiões. O território das grandes bacias hidrográficas brasileiras ultrapassa estados e até países, o que dificulta ainda mais a estruturação de um Sistema de Informações dos territórios de bacias. Além disso, as informações que existem estão em uma escala que não contempla as microbacias. Há um vazio de informações locais o que a nosso ver, inviabiliza uma gestão realmente participativa, descentralizada e integrada.

Diante desse contexto, a escola possui papel importante na formação de alunos não apenas sobre questões conceituais envolvendo o dinamismo de seu território de vida, mas produção de conhecimento local, participação e cidadania (Vieira; Gianasi \& Pinheiro (2013); Vieira (2011). Os Parâmetros Curriculares Nacionais (PCNs), um dos documentos nacionais diretriz da educação brasileira, definem dentre os objetivos da educação escolar brasileira, a formação de jovens capazes de "posicionar-se de maneira crítica, responsável e construtiva nas diferentes situações sociais, utilizando o diálogo como forma de mediar conflitos e de tomar decisões coletivas" (BRASIL, 1998a). Os PCNs também definem meio ambiente como um tema transversal que deveria ser trabalhado de maneira interdisciplinar. Mas, na prática a educação brasileira talvez vivencie o que o educador Freire (2017) designa de "cultura do silêncio". Em um país que em seus 518 anos, viveu apenas respiros de democracia, a participação ainda é um desafio.

Nesse contexto foi desenvolvida a metodologia do "Mapeamento Geoparticipativo 3P". Por meio de três projetos de extensão ${ }^{7}$, a metodologia foi utilizada por mais de 70

\footnotetext{
${ }^{7}$ Projeto de extensão financiado pela Fundação de Amparo a Pesquisa de Minas Gerais (Fapemig) edital no 08/2010; Projeto extensão financiado pelo Ministério da Educação (PROEXT-MEC/SESu) edital no05/2010; Projeto de Extensão (Proex-UFMG) edital 2014.
} 
escolas no estado de Minas Gerais, ao longo da bacia hidrográfica do rio das Velhas (Figura 1), entre os anos de 2011 e 2018.

Figura 1: Bacia do Rio das Velhas no contexto da Bacia do São Francisco/ Minas Gerais - Brasil.

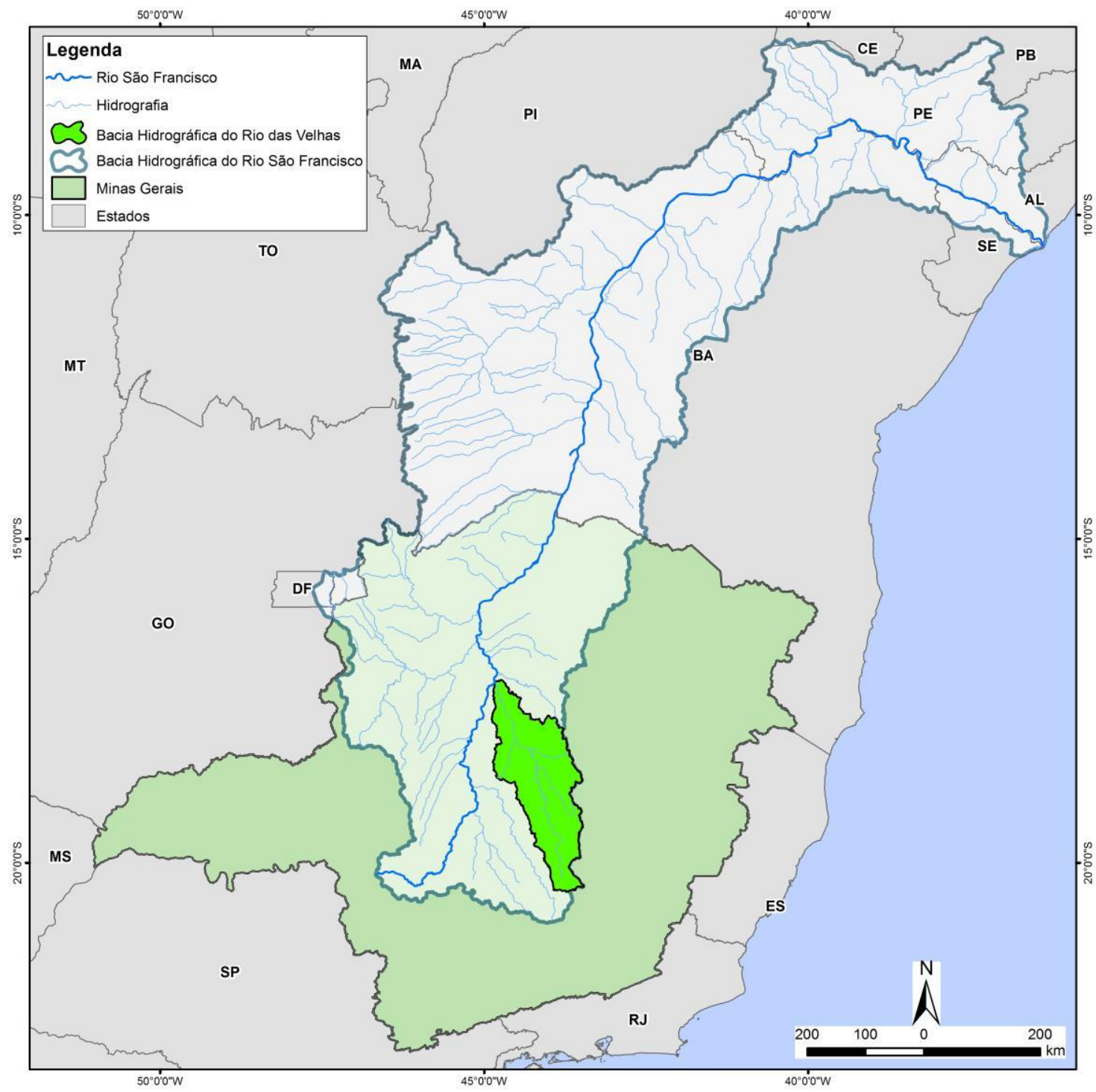

Fonte: Plano Diretor de Recursos Hídricos da Bacia do Rio das Velhas, 2015, pg. 51. Disponível em: http://200.98.167.210/site/arquivos/RE_VELHAS_Rev01.pdf.

O Mapeamento Geoparticipativo 3P objetiva não apenas levantar (1P) Problemas e (2P) Potencialidades que interferem na quantidade e qualidade das águas, mas 
discutir (3P) Possibilidades para a região. Nesse processo didático também são produzidos banco de dados com planilhas com informações locais de problemas e potencialidades, imagens de satélites e mapas locais, com o objetivo de serem apresentados e disponibilizados à comunidade e aos gestores de bacias e do município, no intuito da busca de melhorias na qualidade de vida. Acreditamos que essa metodologia possa contribuir significantemente na formação de alunos e professores, assim como na produção de informações locais que auxilie na gestão e socioambiental local a partir das águas.

\section{Etapas do Mapeamento Geoparticipativo 3P}

A diversidade do mapeamento foi grande, tanto em relação às cidades, quanto ao número e tipos de parcerias envolvidas. A metodologia foi basicamente desenvolvida em oito etapas, descritas a seguir. No entanto, de acordo com a realidade as etapas podem sofrer alteração, adaptação e ou acréscimo de fases. Disso depende o rol de professores que aderem e que participam, as condições tecnico-adminstrativas e também a disponibilidade de tempo de cada escola para com o projeto.

\subsection{Mobilização de escolas e parceiros}

A primeira etapa, para realização do mapeamento, consiste em identificar e contactar possíveis instituições parceiras. No caso das escolas, o contato ocorreu por meio de convites realizados por meio de ofícios enviados a Secretarias Municipais e Estadual de Educação, que os encaminhava às unidades escolares. As que tivessem interesse enviavam nomes de professores para realizarem as oficinas de formação. Ocorreram também parcerias com escolas técnicas e outras faculdades de cidades menores, nesse caso o contato fez-se com a coordenação de cursos técnicos e graduações de áreas afins como: Técnico em Meio Ambiente, Tecnólogo em Gestão Ambiental, Graduação em Biologia e Graduação em Geografia.

Nos primeiros anos de projetos de extensão desenvolvendo a metodologia, a participação de escolas foi grande devido a rede de mobilização já existente envolvendo comitês de bacia em formação e grupos de escolas e lideranças comunitárias vinculadas ao Projeto Manuelzão ${ }^{8}$.

\footnotetext{
${ }^{8}$ Projeto Manuelzão é um projeto de extensão interdisciplinar e intersetorial da Universidade Federal de Minas Gerais, que inciou em 1998, vinculado inicialmente a Faculdade de Medicina e ligado a ideia de qualidade de vida associada a qualidade da água. Ao longo dos anos, integrou departamentos do Instituto de Ciências Biológicas e Geográficas. Desenvolveu várias
} 
Outras instituições formam captadas como parcerias, tanto pela sua capacidade de mobilização, quanto de ceder infra-estrutura nem sempre possível de conseguir, apenas com o financiamento dos editais de extensão. Dentre parcerias que tivemos em momentos dos projetos podemos citar: Secretarias Municipais de Educação, de Saúde e de Meio Ambiente; Organizações não governamentais atuantes na região em questão; Associações de Moradores de Bairros; Comitês de Bacia Hidrográfica. As parcerias também são importantes no momento da apresentação dos resultados e na busca por efetuar as propostas do Plano Diretor da Microbacia elaborada pelos alunos a partir do mapeamento.

\subsection{Oficinas de formação de professores/alunos}

As oficinas de formação foram ministradas em sua maioria para grupos de professores de escolas distintas em uma mesma região. Mas, ocorreu momentos em que foram realizadas para professores juntamente com alunos, como no caso de escolas técnicas, faculdades e quando uma escola apenas da região em questão, realizaria o mapeamento. Durante as oficinas foram abordados conceitos curriculares que poderiam ser trabalhados antes, durante e/ou após o mapeamento. Apesar da concentração maior de professores de geografia, biologia e ciências nas oficinas, também participaram professores de história, português e matemática. A abordagem interdisciplinar é uma premissa no Mapeamento 3P e para auxiliar a articulação de atividades interdisciplinares, no primero projeto de extenção foi produzido um material específico: "Bacias Hidrográficas como instrumento pedagógico" (Vieira; Polignano; Silva, 2011). Os PCNs consideram que a interdisciplinaridade "questiona a segmentação entre os diferentes campos de conhecimento, produzida por uma abordagem que não leva em conta a inter-relação e a influênica entre eles" (BRASIL, 1998b), o que corrobora com a didática de trabalho envolvendo bacias hidrográficas e Mapeamento 3P.

A metodologia do Mapeamento 3P considera que a referência do território de bacias hidrográficas e todo o seu dinâmismo, contemplam diferentes disciplinas e possibilidades - como mostrado na Figura 2.

atividades de mobilização, pesquisa e educação ambiental e participaram atividamente da estruturação comitês e subcomitês de bacia no território da bacia hidrográfica do rio das Velhas. Para mais informações acesse: http://www.manuelzao.ufmg.br/ 
Figura 2- Possibilidades de interação e ação de cada disciplina

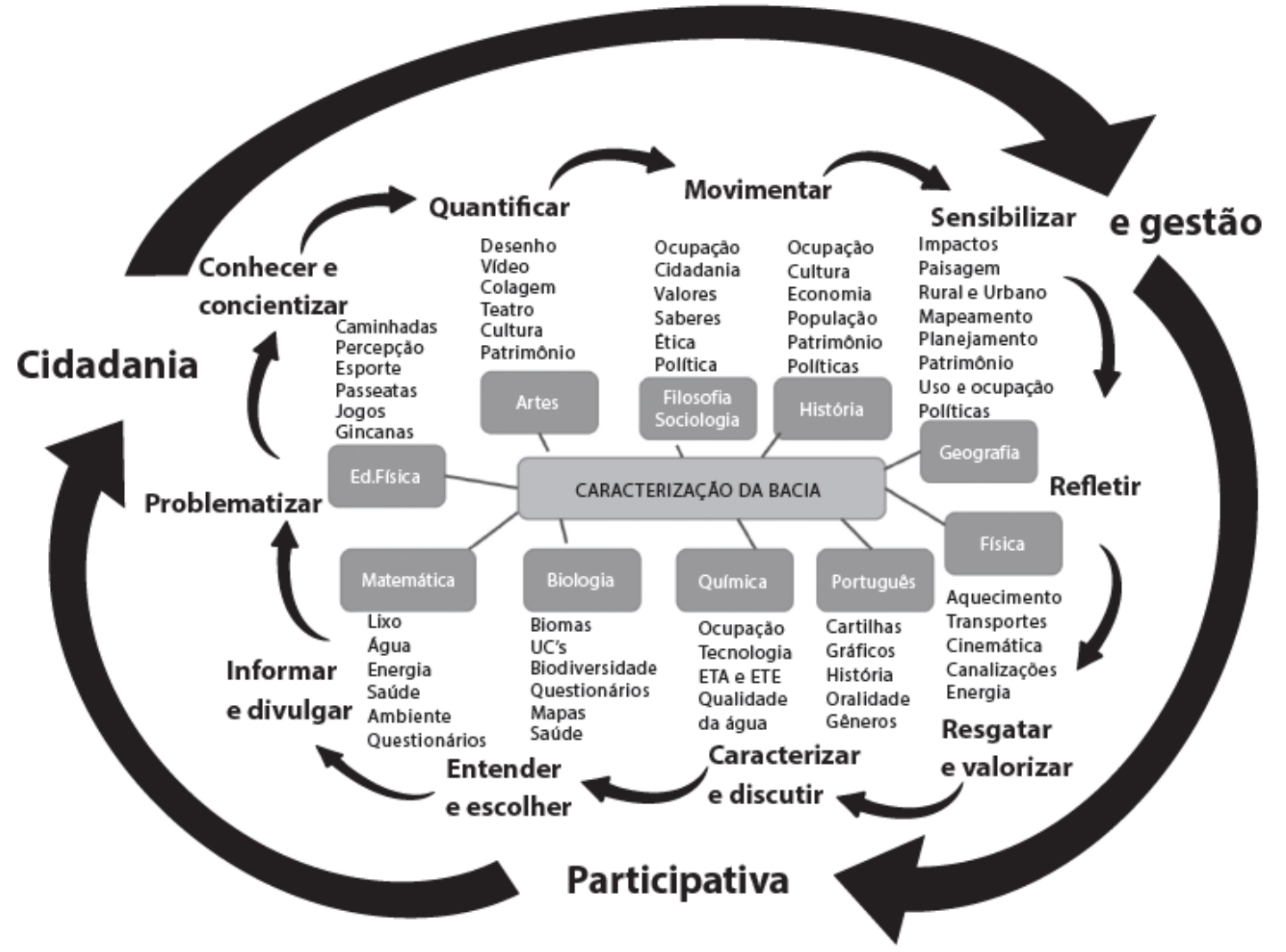

Fonte: Vieira et al. (2011); Gianasi \& Campolina (2016) produzido pelo curso de formação para professores do projeto extensão 2011-2012.

A figura assim como descreve diversas aberturas para atividades pedagógicas interdisciplinares que culmine na Cidadanie e Gestão Participativa, aspectos que se aproximam sobremaneira do Projeto Nós Propomos! do O Projeto "Nós Propomos!" tem por finalidade promover uma efetiva cidadania territorial local, numa perspetiva de governança e sustentabilidade que é desenvolvido pelo Instituto de Geografia e Ordenamento do Território, Lisboa. 
Isso demanda dos professores e da escola, uma pré-disposição em trabalhar de maneira interdisciplinar, por isso o papel do professor no desenvolvimento do Mapeamento 3P é essencial. Para Japiassu (1976), Fazenda (1999) e Gattás (2006), as atividades interdisciplinaridades devem ser construídas por meio de um processo participativo, em equipe. Para tal, as pessoas envolvidas devem possuir o que Fazenda (1999) define de "atitude interdisciplinar" que se caracteriza pela ousadia na busca, nas práticas capaz de transformar a insegurança em um exercício de pensar e construir coletivo. Esses projetos nas escolas são viáveis e os autores França; Solar; Hughes e Callisto (2018) enfatizam que "the implementation of participatory monitoring programs in schools can be an effective and economically viable tool to change social perceptions regarding environmental issues".

Além de possibilidades de abordagens interdisciplinares de conteúdos curriculares, nas oficinas são ministradas noções de geoprocessamento, apresentação do software Google Earth e suas respectivas ferramentas e possibilidades de utilização no mapeamento de (1P) Problemas, (2P) Potencialidades e (3P) Possibilidades. Professores que lecionavam a mais tempo, apresetaram dificuldades no uso do Google Earth. Com inuito de minimizar as dúvidas, elaborou-se um tutorial de uso do software que foi disponibilizado a todos os participantes.

\subsection{Mapa Mental}

O mapa mental é ferramenta pedagógica (Kozel, 2007) que demanda de materiais simples, de baixo custo e não necessita de conhe $\neg$ cimentos geográficos mais específicos, apenas que o professor tenha uma noção dos bairros próximos à escola e a localização dos mesmos, para auxiliar na orientação dos alunos e principalmente na pergunta a ser elaborada para a partir dela se obter o resultado de interesse para o mapeamento. Durante a oficina de formação houve a orientação para o realização do mapa mental.

A maioria dos Mapeamentos $3 \mathrm{P}$ realizados nessa fase ocorreu em sala de aula com orientação do professor, pois não havia equipe dos projetos de extensão sufiente para acompanhar essa atividade em todas as escolas participantes. Mas, foram feitos registros dos mapas mentais elaborados e estes eram retomados no momento das discussões pós-campo.

O método do mapa mental consiste no registro do que os alunos recordam quanto a caracte $\neg$ rísticas descritivas do entorno da escola e próximo a suas casas, como uma forma de relembrar (re)conhecer o território. Segundo Lima \& Kozel (2009, p. 229) “O 
mapa mental, uma expressão do sensível, carrega consigo a formalidade da expressão territorial, nele, a pessoa se põe como elemento simbólico, ou seja, expõe seus símbolos internalizados". Estas percepções foram registradas em uma folha de ofício, A3, cartolina ou papel Craft por alunos agrupados, seguindo o critério de proximidade de suas residências.

\subsection{Maquete da microbacia}

A construção da maquete junto a alunos e professores, contou com o acompanhamento e apoio dos bolsistas de extensão que não estiveram presentes em todos os momentos dos projetos de extensão. A realização dessa atividade demandou recursos financeiros para compra de materiais, assim como disponibilidade de um tempo significativo, o que justifica essa atividade ter sido realizada em um número reduzido de escolas. Mas, o livro Geotecnologias na Educação para Gestão das Águas: Mapeamento Geoparticipativo 3P (Gianasi \& Campolina, 2016) possui um roteiro de orientação bem simples no intuito de auxiliar os professores na confecção da maquente, mesmo sem o auxílio de bolsistas.

A atividade pedagógica de confeção de uma maquete da microbacia, na qual a escola está inserida e os estudantes residem, promove interação e produção de conhecimento do/sobre o território. É uma prática didatica na qual o professor pode trabalhar e enfatizar certos conceitos já apresentados, evidenciar a interação dos elementos constituintes do território e analisar as mudanças ocorridas e impactos existentes. Por meio dessa atividade didática também alunos e professores venciam o território da bacia em três dimensões, em uma escala que tende a facilitar o entendimento quanto aos (1P) Problemas e (2P) Potencialidades, assim como auxilia nas reflexões e discuções sobre o futuro nesse território, as (3P) Possibilidades.

Figura 3 - Interação e produção de conhecimento sobre o território a partir da construção de maquete 


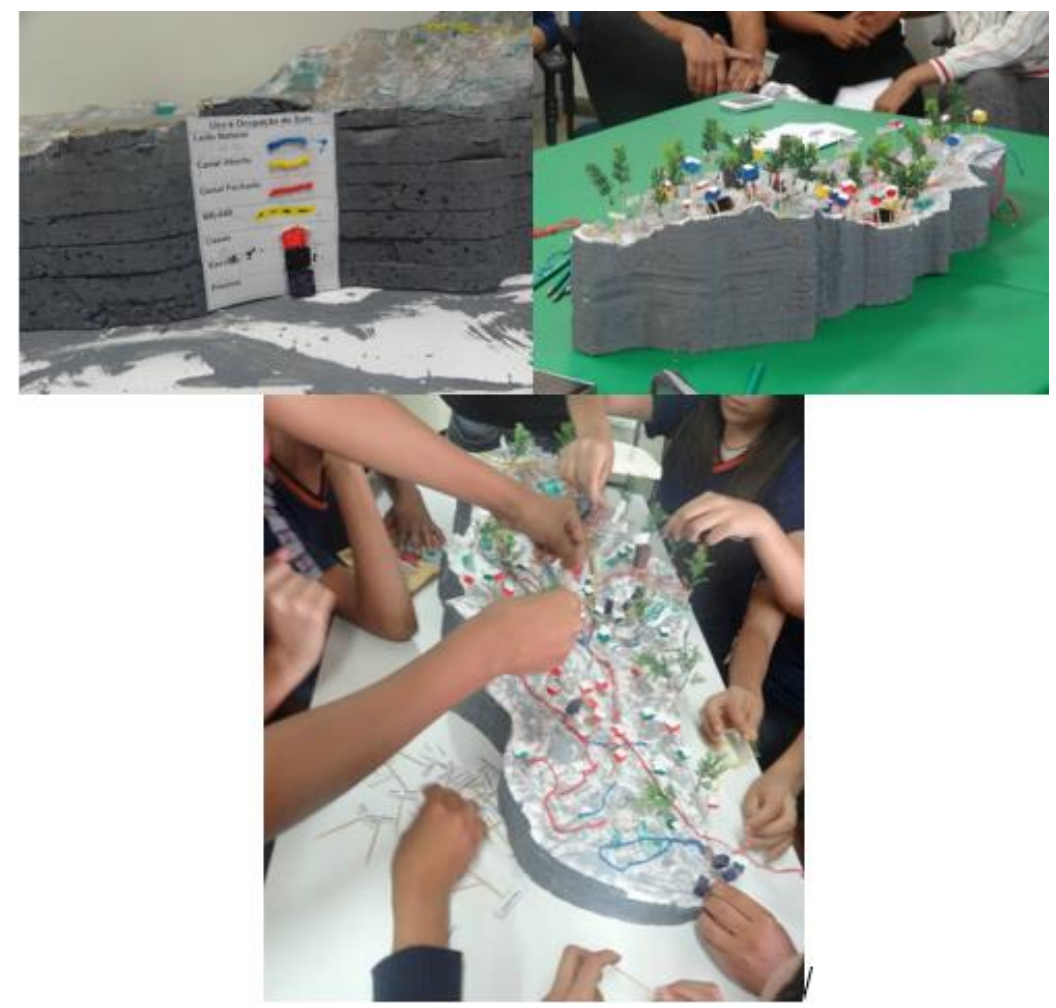

Fonte: Oficina maquete nas E.E.Lígia Maeria de Magalhães e E.M.Maria Silva Lucas. Acervo do Projeto Mapeamento e Monitoramento, 2014. Proex UFMG-SIEX no: 401831

https://sistemas.ufmg.br/siex/AuditarProjeto.do?id=53271

Em seguida, utilizou-se isopor para a construção de cada cota que foram coladas pos $\neg$ teriormente uma sobre a outra, produzindo o efeito tridimensional (3D) desejado. Posteriormente a estrutura foi coberta com gesso e inicou-se a pintura da maquete. Esta foi pintada com auxílio dos alunos. Os principais elementos discutidos em grupo durante a atividade do mapa mental foram representados como, por exemplo: matas, áreas degradadas, rios, estradas, pontos de referência e a própria escola.

\subsection{Trabalho de Campo e mapeamento}

A equipe dos projetos de extensão realizou um trabalho de campo com cada grupo de professores e alunos que realizou as oficinas de formação, no intuito destes vivenciarem um Mapeamento 3P.

A orientação era que os professores e equipe do projeto de extensão interferissem o mínimo possível no que os alunos designavam de (1P) Problemas e (2P) Potencialidades. No campo, a turma de alunos se dividia em grupos e cada grupo preenchia uma planilha que solicitava a descrição do Problema e ou Potencialidade, assim como sua localização. Os dados dessa planilha impressa eram posteriomente digitados para um planilha em excel na qual também eram inseridas fotos (Figura 4). 


\begin{tabular}{|c|c|c|c|}
\hline 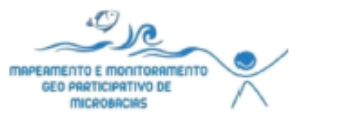 & \multicolumn{2}{|c|}{ Mapeamento Geoparticipativo Metodologia $3 \mathbf{P}$} & \\
\hline Escola: & Data: & \multicolumn{2}{|l|}{ Ponto: } \\
\hline Prof./Monitores: & & \multicolumn{2}{|l|}{ Alunos: } \\
\hline \multicolumn{4}{|c|}{ Informaçōes Gerals dos Pontos que foram Mapeados } \\
\hline \multirow{2}{*}{$\begin{array}{c}\text { Pontos negativos do lugar/ } \\
\text { território } \\
\text { (PROBLEMA) }\end{array}$} & \multirow{2}{*}{$\begin{array}{l}\text { Descrição problema do ponto/ } \\
\text { Critério utilizado para a escolha } \\
\text { desse ponto }\end{array}$} & \multirow[b]{2}{*}{ Endereço/Local de referência } & Foto \\
\hline & & & $\begin{array}{l}\mathrm{N}^{\circ} \text {, Legenda, Autor (ano) } \\
\text { coordenada geográfica }\end{array}$ \\
\hline \multirow[t]{2}{*}{ Nascente com esgoto a céu aberto } & \multirow[t]{2}{*}{$\begin{array}{l}\text { Esgoto escorrendo para a nascente } \\
\text { de água limpa que compromete a } \\
\text { permanência da mesma no local }\end{array}$} & \multirow[t]{2}{*}{$\begin{array}{l}\text { na rua } x \text {, número y, próximo ao } \\
\text { posto de saúde do bairro } b\end{array}$} & $\begin{array}{l}\text { 1- Nascente com esgoto. Silva (2015) } \\
\text { Latitude } 601054.69 \mathrm{~m} \mathrm{E;} \mathrm{Longitude} \\
7797939.46 \mathrm{~m} \mathrm{~S} \text { (UTM) }\end{array}$ \\
\hline & & & 2 \\
\hline \multirow{2}{*}{$\begin{array}{c}\text { Pontos positivos do lugar/ } \\
\text { território } \\
\text { (PONTENCIALIDADE) }\end{array}$} & \multirow{2}{*}{$\begin{array}{l}\text { Descrição do ponto/Critério utili- } \\
\text { zado para a escolha desse ponto }\end{array}$} & \multirow{2}{*}{ Endereço/Local de referência } & Foto \\
\hline & & & $\mathrm{N}^{\circ}$, Legenda, Autor (ano) \\
\hline Área de lazer & $\begin{array}{l}\text { Área utilizada para brincar e realizar } \\
\text { esportes }\end{array}$ & $\begin{array}{l}\text { na rua b, número d, próximo à } \\
\text { escola } x\end{array}$ & $\begin{array}{l}\text { Latitude } 601381.32 \mathrm{~m} \text { E; Longitude } \\
1 \text { - Lugar de lazer. Silva (2015) } \\
\text { Latitude } \\
7797625.17 \mathrm{~m} \mathrm{~S} \text { (UTM) }\end{array}$ \\
\hline
\end{tabular}

Fonte: Acervo do Projeto Mapeamento e Monitoramento, 2014, Proex UFMG-SIEX no: 401831.https://sistemas.ufmg.br/siex/AuditarProjeto.do?id=53271

Esse material integra o banco de dados construido a partir do Mapeamento 3P. Em área urbana utilizou-se 0 endereço em que se localizava o problema ou potencialidade. Em área rural utilizou-se equipamentos de GPS empresados pela universidade para esse trabalho de campo especificamente.

O trabalho de campo preparado pela equipe dos projetos de extensão já era intensionalmente didático, com passagem por pontos que contemplassem diferentes tipos de (2P) Pontencialidades e (3P) Possibilidades, como por exemplo: nascentes, partes do córrego em leito natural e outras com canalização, trechos com matas ciliares e trechos com assoreamento, locais com lixo e esgoto e ocupações irregulares.

Após o trabalho de campo realizado com a equipe dos projetos de extensão, os professores organizavam trabalhos de campo com alunos e/ou dividiam as turmas em grupos, por proximidade de residênciam e pediam para fazer o Mapeamento 3P. Nas escolas em que os professores ou a própria equipe dos projetos de extensão havia trabalhado as ferramentas do Google Earth, os grupos de alunos já registravam os pontos mapeados utilzando-se as ferramentas do sofware, salvavam os arquivos em extensão $\mathrm{kml}$ ou kmz e envivam para que os professores preparassem o momento de discussão pós-campo. 


\subsection{Discussão pós-campo: levamento de possibilidades}

As discussões pós-campo ocorreram com a equipe dos projetos de extensão, após os trabalho de campo estruturado por esta, e também em sala de aula após os alunos realizarem seus Mapeamentos 3P, em grupo. As discussões após os Mapeamentos realizados pelos alunos, em sua maioria, não foram acompanhadas pela equipe dos projeto de extensão devido ao número elevado de escolas. Esperava-se também que o professor fosse protagonista na discussão junto aos alunos.

$\mathrm{Na}$ oficina de formação, foram ministradas orientações quanto a importância da discussão pós-campo em relação ao que é considerado como potencialidade e problema pelos alunos, assim como as mudanças da paisagem, seus motivos e impactos ambientais e na quantidade e qualidade da água na região.

Após a apresentação do Mapeamento 3P, realizado por cada grupo de alunos e suas conclusões quanto a (3P) Possibilidades, estas eram discutidas também em conjunto turma e registradas tendo como exemplo a Figura 5. Durante as discussões, comparações foram realizadas com o mapa mental e maquetes elaborados.

Figura 5 - Exemplos de registros de (1P) Problemas, (2P) Potencialidades e (3P) Possibilidades em mapeamentos realizados

\begin{tabular}{|c|c|c|}
\hline \multicolumn{3}{|c|}{ RESULTADOS OBTIDOS PELA PELA METODOLOGIA ${ }_{3}$ P } \\
\hline $\begin{array}{l}\text { Pontos positivos do lugar/território } \\
\text { (POTENCIALIDADES) }\end{array}$ & $\begin{array}{l}\text { Pontos negativos do lugar/território } \\
\text { (PROBLEMAS) }\end{array}$ & $\begin{array}{l}\text { Pontos a melhorar no lugar/ território } \\
\text { (POSSIBILIDADES) }\end{array}$ \\
\hline $\begin{array}{l}\text { Áreas verdes e quintais arborizados em } \\
\text { areas particulares }\end{array}$ & $\begin{array}{l}\text { Ausência de áreas verdes ou degradadas; } \\
\text { desmatamnento. }\end{array}$ & $\begin{array}{l}\text { Plantio de mudas e revitalizaçào de áreas verdes; proteçāo } \\
\text { de matas nativas }\end{array}$ \\
\hline Nascente, olhos de água, nascedouros & $\begin{array}{l}\text { Ausência de nascentes ou degradadas; } \\
\text { presença de piscinas e lagos artificiais } \\
\text { em propriedades particulares, muitos } \\
\text { sem outorga de água. }\end{array}$ & $\begin{array}{l}\text { Registro de nascentes existentes, realizar campanhas de } \\
\text { proteçăo e revitalizaçăo de nascentes. }\end{array}$ \\
\hline $\begin{array}{l}\text { Cursos d'água preservados em leito } \\
\text { natural }\end{array}$ & $\begin{array}{l}\text { Lançamento de esgotos, efluentes indus- } \\
\text { triasis, lixo; aterro clandestino. }\end{array}$ & $\begin{array}{l}\text { Implantar intercepção e tratamento dos esgotos mobili- } \\
\text { zando o poder público, associaçōes de bairro e núcleos } \\
\text { Manuelzảo. }\end{array}$ \\
\hline $\begin{array}{l}\text { Cursos d'água preservados em leito natu- } \\
\text { ral com mata ciliar e ou vegetaçăo nativa } \\
\text { (matas primárias ou secundárias) }\end{array}$ & $\begin{array}{l}\text { Sem vegetação nativa, córregos } \\
\text { canalizados. }\end{array}$ & $\begin{array}{l}\text { Realizar campanhas para manter cursos de água em leito } \\
\text { natural com vegetaçăo nativa; promover plantio de espé- } \\
\text { cies nativas em margem dos cursos de água; promover } \\
\text { campanhas para a conscientizaçăo das pessoas quanto a } \\
\text { näo canalizaçăo dos rios e córregos. }\end{array}$ \\
\hline Ecossisterna saudável & $\begin{array}{l}\text { Córrego poluido; presença de lixo e es- } \\
\text { goto de vetores transmissores de doença; } \\
\text { registro de casos de dengue e doenças } \\
\text { de veiculaçào hidrica; Area intensamente } \\
\text { impermeabilizada. }\end{array}$ & $\begin{array}{l}\text { Mobilizar a comunidade eas unidades de saúde informando } \\
\text { e conscientizando-as sobre as consequências do compro- } \\
\text { metimento do ecossisterna de saúde coletiva. }\end{array}$ \\
\hline Destino adequado de lixo & $\begin{array}{l}\text { Disposiç̧ăo inadequada de residuos sóli- } \\
\text { dos (lixo): a céu aberto e ou em cursos de } \\
\text { água; Sem coleta de lixo pela prefeitura. }\end{array}$ & 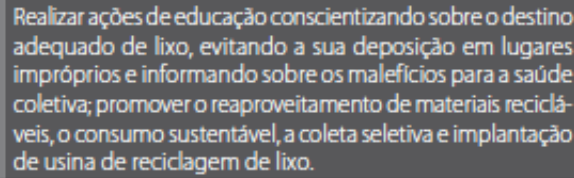 \\
\hline
\end{tabular}

Fonte: Resultados de aplicação da Metodologia nos Núcleos Manuelzão e projetos de pesquisa e extensão de 2010-2015.

\subsection{Banco de dados}


Dentre as cidades em que foi realizado o mapeamento, somente Belo Horizonte, capital do estado de Minas Gerais, possuia uma setor de geoprocessamento com um banco de dados socioambientais que pode ser utilizado. Mas, mesmo em Belo Horizonte as informações não se encontram disponibilizadas tendo como referência o território de bacias, sub-bacias e microbacias. Em termos de gestão ambiental, a falta e/ou presença de informações/dados não contempla a delimitação de bacias no nível micro e isso limita e dificulta a tomada de decisões. Por exemplo, Como decidir-se por mais unidades de conservação ambiental em áreas de recarga? Como discutir a não canalização, especialmente em áreas na porção baixa da bacia, que recebe quantidade significativa de água durante a época de chuva, especialmente devido a impermeabilização das cidades e desmatamento, se não temos informações georreferenciadas e numa escala de detalhe de microbacias?

Durante o mapeamento alunos e professores registraram não apenas (1P) Problemas e (2P)Potencialidades referentes a questões ambientais. Seus conceitos de qualidade de vida incluiam equipamentos sociais e culturais.

Nos mapeamentos realizados em microbacias de Belo Horizonte foi possível realizar um banco de dados mais completo a partir tanto do que foi mapeado quanto da base de dados georreferrenciados já existente, disponibilizada pela prefeitura. Dentre os dados oficias do município foi possível identificar, após inserirmos a delimitação da microbacia: área total da microbacia; extensão da rede hidrográfica; extensão do córrego principal; trecho canalizado de córregos; presença de unidades de conservação; hospitais; escolas; centros de saúde; praças; patrimônio tombado; academias da cidade; campos de futebol.

Mas, a maioria das cidades não dispunha destes dados georreferenciados, assim como, também não possuia dados mais específicos que foram registrados durante o Mapeamento 3P: presença e situação de nascentes; presença de mata ciliar em trechos de córregos, terrenos abandonados com muito acúmulo de lixo; áreas verdes que não são unidades de conservação; regiões com risco de deslizamento e erosão.

As Figuras 6 e 7 exemplificam mapas gerados a partir de (1P) Problemas e (2P) Potencialidades mapeadas durante trabalho de campo, realizado por alunos. Com esses mapas especificamente, lideranças comunitárias tentaram barrar um projeto da prefeitura do município de Contagem de canalização de um trecho de córrego. Como pode ser observado no mapa, a maioria do corpos d'água da microbacia do córrego João Gomes se encontra já canalizados e moradores alegavam que nos poucos 
trechos em leito natural, era comum enchentes. A prefeitura queria canalizar esses trechos enquanto que parte da população lutava para mantê-los em leito natural. 
Figura 6 e 7- Mapa gerados a partir do Mapeamento Geoparticipativo 3P.
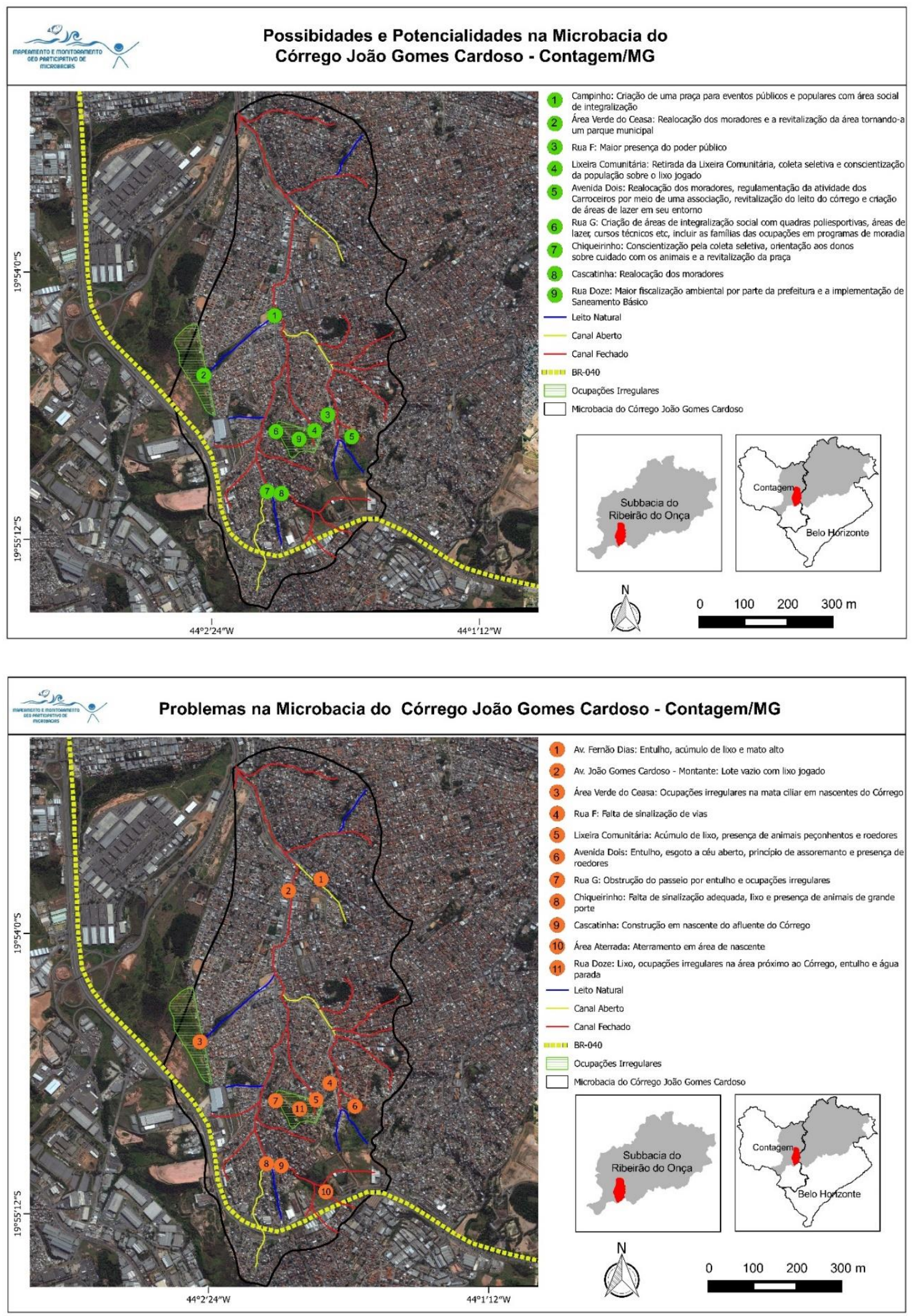

Fonte Acervo do Projeto Mapeamento e Monitoramento, 2014. Proex UFMG - SIEX no: 401831.

https://sistemas.ufmg.br/siex/AuditarProjeto.do?id=53271 


\subsection{PI ano Diretor da bacia e divulgação}

São previstos na Lei das Águas como instrumentos de gestão dos recursos hídricos, o Plano de Recursos Hídicos e o Plano Diretor de cada grande bacia hidrográfica do Brasil e de seus principais afluentes. Segundo a legislação, nos Planos de Recursos Hídicos e nos Planos Diretores de Bacias, devem constar desde registro de informções socioambientais - como crescimento demográfico, evolução de atividades produtivas, modificações dos padrões de ocupação do solo, identificação de conflitos envolvendo o uso da água - com também visões e propostas referentes ao futuro da bacia que envolva o balanço entre disponibilidades e demandas futuras de água, em quantidade e qualidade.

Mas, a maioria dos Planos Diretores de Bacias existentes no Brasil são recentes e não existem na escala de microbacias. A proposta é que, por meio da metodologia de mapeamento proposto, possa-se elaborar um pequeno Plano Diretor de Microbacia, a luz das diretrizes legais nacionais.

A decisão do que se fazer com os materiais produzidos cabe aos alunos, professores, escola e parceiros envolvidos. A proposta é que todos os dados gerados durante 0 mapeamento sejam reunidos em um relatório descritivo das potencialidades e possibilidades, devidamente georreferenciados e fotografados.

Esse relatório seria no formato de um Plano Diretor de Bacia e finalizaria com as possibilidades, as propostas apontadas e demandadas pelos alunos e professores após a discussão pós-campo.

\section{Conclusões}

Apesar de várias temáticas envolvendo a questão hídrica estarem disseminadas no currículo básico comum brasileiro, muitas vezes ocorre na prática, a ausência de atividades didáticas interdisciplinares que conecte infor $\neg$ mações diversas sobre as águas e o não relacionamento dessas atividades com a dinâmica dos territórios de bacias hidrográficas.

Não é comum a formação pedagógica específica e nem a produção de materiais que tratem da realidade local, presentes em uma microbacia na qual a escola está inserida. Isso tende a dificultar o entendimento do aluno e consequentemente a expectativa de uma formação crítica que colabore na gestão das águas. 
Portanto, envolver a escola no uso da metodologia 3Ps e fazer o levantamento de (1P) Problemas e (2P) Potencialidades em uma microbacia, e no apontamento de (3P) Possibilidades de enfrentamento, de soluções de problemas presentes no seu entorno - sob a perspectiva de bacias hidrográficas e gestão participativa das águas - é uma maneira de estimular a reflexão sobre o cenário atual da bacia. Isso aguça alunos e professores a agir como cidadãos críticos que sabem como e de onde partem as políticas públicas e como podem intervir nesse processo.

Acselrad (2010, p.31) afirma que "nas tramas territoriais em que se recorre à produção de mapas por atores não-hegemônicos, a cartografia pode estar servindo, assim, alternativamente, de instrumento do chamado em $p$ poderamento (...)". Acreditamos que empoderamento pode ocorrer tanto pela comunidade quanto pela escola, assim como pelos comitês de bacias ou subcomitês de bacias, por meio do Mapeamento Geoparticipativo 3Ps.

A escola, por meio do Mapeamento 3Ps, apresenta-se como importante aliada não apenas na disseminação de co $\neg$ nhecimentos técnico-científicos que são importantes na gestão, mas também na produção de informações referentes a microbacias hidrográficas. E muitas delas ligadas aos saberes populares e empíricos, que envolvem tam $\neg$ bém o sentimento de pertencimento local, auxiliando assim, na construção de uma real gestão participativa, descentralizada e integrada das águas. E dessa forma a metodologia colabora com a ideia do Nós Propomos! que é o de disseminar não só práticas cotidianas na escola sobre cidadania, mas também a de fazer parte do processo de investigação e de solução de problemas diários próximos à escola, bairro e região.

\section{Referências bibliográficas}

Abers, R. (2010). Introdução: pensando politicamente a gestão da água. In: ABERS, Rebecca (org). Água e política: atores, instituições e poder nos Organismos Colegiados de Bacia Hidrográfica no Brasil. São Paulo: Annablume.

Acselrad, H. (org) (2010). Cartografia social e dinâmicas territoriais: marcos para o debate. Rio de Janeiro: Universidade Federal do Rio de Janeiro, Instituto de Pesquisa e Planejamento Urbano e Regional.

Brasil, Secretaria de Educação Fundamental (1998a). Parâmetros Curriculares Nacionais - Terceiro e quarto ciclos: apresentação de temas transversais. Brasília: MEC/SEF. 
Brasil. Secretaria de Educação Fundamental (1998b). Parâmetros Curriculares Nacionais - Terceiro e quarto ciclos do ensino fundamental: introdução aos parâmetros curriculares nacionais. Brasília: MEC/SEF.

Fazenda, I. C. (1999). Interdisciplinaridade: um projeto em parceria. São Paulo: Loyola.

França, J.S., Solar, R., Hughes, R.M. et al. Student monitoring of the ecological quality of neotropical urban Streams. Ambio (2018). https://doi.org/10.1007/s13280-018-1122

Freire, P. (2017). Pedagogia do Oprimido. Rio de Janeiro: Paz e Terra.

Júnior, Wilson Cabral de Sousa; Fidelman, Pedro Isaac Japiassu. A Tecnopolítica da água no Brasil. In: RIBEIRO, Wagner Costa (org.). Governança da água no Brasil: uma visão interdisciplinar. São Paulo: Annablume; Fapesp; CNPq, 2009.

Gattás, M. L. B. (2006). Interdisciplinaridade, formação e ação na área de saúde. Ribeirão Preto: Holos Editora.

Gianasi, L. M.; Campolina, D. V. (2016). Geotecnologias na educação para a gestão das águas: mapeamento geoparticipativo 3P. Belo Horizonte - MG: Fino Traço.

Japiassu, H. (1976). Interdisciplinaridade e patologia do saber. Rio de Janeiro: Imago.

Kozel, Salete (2007). Mapas mentais - uma forma de linguagem: Perspectivas metodológicas in: Kozel S. et al. (org): Da percepção e cognição à representação. São Paulo. Terceira Margem. p.114-138.

Lima, A. M. L., Kozel, S (2009). Lugar e mapa mental: uma análise possível. Geografia - v. 18, n. 1, jan./jun.

Lei Federal 9.433, de 08/1/1997. Institui a Política Nacional de Recursos Hídricos.

Mata-Machado, A. T. G.; Vieira, D. C; Procópio, J.C; Polignando, M. V. (org.) (2011). Bacia Hidrográgica como instrumento pedagógico para a transversalidade. Belo Horizonte: Instituto Guaicuy.

Rebouças, A. C. (2001). Água e Desenvolvimento Rural, In.: Estudos Avançados 15 (43), (p.327-344), IEA-USP: São Paulo.

Ribeiro, W. C. (org.) (2008). Governança da água no Brasil: uma visão interdisciplinar. São Paulo: Annablume; Fapesp; CNPq.

Vieira, D. C.; Gianasi, L. M.; Pinheiro, T. M. M. (2013). Gestão das Águas no Brasil: vamos participar? Mapeamento geo-participativo, participação social e gestão das 
águas na bacia hidrográfica do ribeirão Onça do estado de Minas Gerais/Belo Horizonte: Instituto Guaicuy. Retrieved from https://manuelzao.ufmg.br/biblioteca/gestao-das-aguas-no-brasil/

Vieira, D. C; Polignano, M. V.; Silva, B. M.M.N. (2011). Bacias Hidrográficas como instrumento pedagógico. In: Mata-Machado, A. T. G.; Vieira, D. C; Procópio, J. C; Polignando, M. V. (org.). Bacia Hidrográgica como instrumento pedagógico para a transversalidade. (p.43-84). Belo Horizonte: Instituto Guaicuy. 


\section{Cidadania territorial em pesquisa: Nós Propomos em Chapecó/SC}

ADRIANA MARIA ANDREIS ${ }^{9}$

\section{Resumo}

Em diálogo com os pressupostos do projeto internacional "Nós Propomos!", neste texto explicitamos a configuração articulada em Chapecó/SC, Brasil. O objetivo é apresentar os elementos teóricos e metodologicos que sustentam o projeto de pesquisa em desenvolvimento. Assim, a configuração geral do texto, implica em uma reflexão teórica sobre os sentidos de ensinar e de aprender na universidade e na escola, por meio da pesquisa. A proposta é permeada pela investigação da realidade do lugar, para detectar, estudar e prospectar alternativas aos problemas locais, reconhecendo a importância da pesquisa científico-acadêmica do cotidiano na resolução de problemas do lugar, para a construção da cidadania territorial, integrando graduação, pós-graduação e escola, e envolvendo pesquisa, ensino e extensão. Envolve interlocução entre as dimensões geográficas de lugar, cotidiano e território e, metodologicamente, compreende diálogos sistemáticos entre universidade e escola. Relaciona-se com o enfrentamento de limites educacionais, que dizem respeito às dificuldades de aprendizagens significativas das noções conceituais, especialmente geográficas, nas Licenciaturas e no Ensino Médio, e que corroboram para a evasão e reprovação. Compreende, na universidade, professores e acadêmicos, e na escola, professores e juventudes, para estudar noções geográficas, prospectando problemas da realidade do lugar e construindo percursos propositivos de alternativas aos obstáculos detectados e investigados. Organizamos o texto em introdução, contexto em pesquisa no qual expressamos premências e horizontes, discriminamos as etapas do processo e concluímos apresentando resultados esperados relacionados com a força formativa da pesquisa, na escola e na universidade, por meio da identificação e estudo de problemas do lugar, e da prospecção de percursos alternativos aos mesmos.

Palavras-chave: cidadania territorial; universidade e escola; lugar e cotidiano; pesquisa, ensino e extensão.

9 Professora na Universidade Federal da Fronteira Sul - UFFS, Chapecó SC, adriana.andreis@uffs.edu.br 


\section{Resumen}

En diálogo con los supuestos del proyecto internacional “¡Nosotros proponemos!", en este texto explicitamos la configuración articulada en Chapecó / SC, Brasil. El objetivo es presentar los elementos teóricos y metodológicos que sustentan el proyecto de investigación en desarrollo. Así, la configuración general del texto, implica una reflexión teórica sobre los sentidos de enseñar y de aprender en la universidad y en la escuela, a través de la investigación. La propuesta está permeada por la investigación de la realidad del lugar, para detectar, estudiar y prospectar alternativas a los problemas locales, reconociendo la importancia de la investigación científicoacadémica de lo cotidiano en la resolución de problemas del lugar, para la construcción de la ciudadanía territorial, integrando graduación, posgrado y escuela, e involucrando investigación, enseñanza y extensión. Teóricamente, comprende la implicación de interlocución entre las dimensiones geográficas de lugar, cotidiano y territorio y, metodológicamente, comprende diálogos sistemáticos entre universidad y escuela. Se relaciona con el enfrentamiento de límites educativos, que se refieren a las dificultades de aprendizajes significativos de las nociones conceptuales, especialmente geográficas, en las Licenciaturas y en la Enseñanza Media, y que corroboran para la evasión y reprobación. De la universidad, hay participación de los profesores y académicos, y en la escuela participan profesores y juventudes, a fines de estudiar nociones geográficas, prospectando problemas de la realidad del lugar y construyendo itinerarios propositivos de alternativas a los obstáculos detectados y investigados. Organizamos el texto en introducción, contexto en investigación en el que expresamos retos y horizontes, discriminamos las etapas del proceso y concluimos presentando los resultados que san esperados, y que tiene relación con la identificación y el estudio de problemas del lugar, y la prospección de rutas alternativas a los mismos.

Palabras clave: ciudadanía territorial; universidad y escuela; lugar y cotidiano; investigación, enseñanza y extensión.

\section{Introdução}

O lugar é o objeto em investigação na pesquisa que compreende a cidadania territorial, por assumir como dispositivo relacional entre os conhecimentos e a vida e por implicar estudos teóricos e empíricos, realizados com a participação dos professores e acadêmicos da universidade e dos professores e alunos da escola. Configura-se como percurso de enfrentamento de desafios que envolvem a pesquisa 
enquanto princípio educativo e enquanto possibilidade às aprendizagens significativas. Compreende assim, uma interlocução com a noção de professor reflexivo e professorpesquisador. Dialoga com as demandas educacionais que as estatísticas e as análises dos pesquisadores vem apontando, acerca da problemática relacionada às dificuldades no processo de ensinar a pesquisar, e apresenta uma proposta de enfrentamento desse desafio, por meio da pesquisa do lugar.

O objetivo deste texto é apresentar os elementos teóricos e metodologicos que sustentam o projeto de pesquisa em desenvolvimento. Por meio da investigação da realidade do lugar, explicitamos a pretensão de detectar, estudar e prospectar alternativas aos problemas locais, reconhecendo a importância da pesquisa científicoacadêmica do cotidiano na resolução de problemas do lugar, para a construção da cidadania territorial, integrando graduação, pós-graduação e escola, e envolvendo pesquisa, ensino e extensão. Assim, a configuração geral do texto, implica em uma reflexão teórica sobre os sentidos de ensinar e de aprender na universidade e na escola, por meio da pesquisa.

O acento na potência investigativo-formativa é entendido pela possibilidade de aprendizagem da pesquisa na formação inicial do acadêmico e na formação continuada do professor da escola, diretamente envolvidos nesse movimento. É no caminho dessa dimensão relacional e participativa, que coloca em diálogo direto acadêmicos com os estudantes da escola em interlocução com os professores da escola e os pesquisadores da universidade, que esta relação envolve o trabalho direto com uma escola de Ensino Médio de Chapecó. Os estudantes da escola e os acadêmicos da graduação em Geografia, em diálogo com o professor formador da universidade e com o professor da escola, pesquisam o lugar e prospectam possibilidades de enfrentamento dos problemas, que aos jovens estudantes sejam coletivamente importantes.

A seguir, apresentamos a figura 1, que expressa essa interlocução. 
Figura 1 - Interações em diálogo no projeto em Chapecó/SC

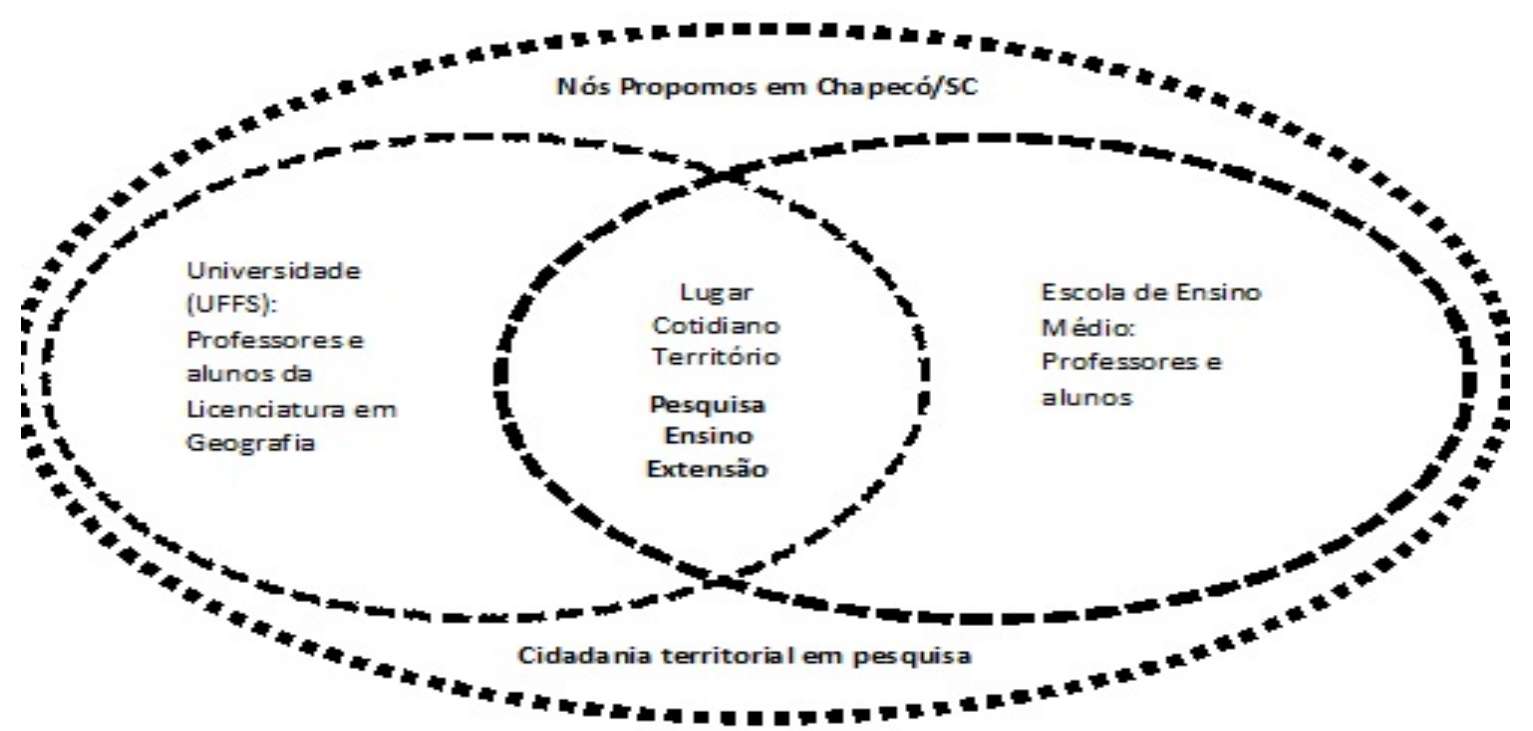

Fonte: Elaborado pela autora, 2018

Em Chapecó/SC, a interlocução entre universidade e escola de Ensino Médio, tem como elo as noções de lugar, cotidiano e território e, metodologicamente, implicam movimento de pesquisa, ensino e extensão. É assim que este movimento integrador e investigativo abarca os princípios do projeto internacional "Nós Propomos!", coordenado pelo Instituto de Geografia e Ordenamento do Teritório (IGOT), da Universidade de Lisboa. Compreende o compromisso de cooperação no domínio da investigação e docência ao nível da graduação e da pós-graduação. Abrange o objetivo geral de Investigar criticamente os problemas locais com vistas a despertar a consciência cidadã em relação ao território, conjugando a dimensão educativa, por meio da realização de atividades e ações prospectivas em interação com jovens estudantes, contribuindo na identificação de problemas urbanos e formulação de propostas para a resolução.

Nesse processo, sobressai-se a dimensão pedagógico-formativa, pois entrelaça a aprendizagem da pesquisa dos acadêmicos da universidade em diálogo com os estudantes da escola. Tem um caráter teórico e prático, e se justifica enquanto ação à qualificação das aprendizagens, relacionado a realidade com os conhecimentos conceituais. Trata-se de enfrentar o desafio educativo que se entrecruza "com o apelo, cada vez mais forte, à participação das populações nas tomadas de decisão públicas, na mudança de paradigma do governo para o de governança" (Claudino, 2018, p. 268).

A par desse desafio e, de mãos dadas com a escola, enfocando na relação de ensino e aprendizagem da dimensão investigativa, o texto ora apresentado, explicita 0 
percurso que vem sendo realizado em Chapecó, no estado de Santa Catarina (SC), acentuando a perspectiva da cidadania territorial, por compreender pesquisa e ação nos lugares de vida e estudo dos estudantes.

\section{Contexto em pesquisa}

\section{Premências no contexto educacional}

A relação entre universidade e escola é fundamental para ambas. As dificuldades de enfrentamento dos limites na formação na educação básica e na graduação, tem relação, também, com a formação do professor fechada no campus de uma universidade e com o trabalho de escola realizado de modo isolado. Embora ocorram muitas inciativas para essa aproximação, ainda hoje, essa distância precisa ser atenuada.

Os debates e os indicadores expressam as dificuldades de aprendizagem na graduação e, também, na escola, especialmente, no Ensino Médio. Exemplificam essa lacuna e demanda, os enunciados dos professores e alunos das escolas, reiterados nos cursos de formação continuada ministrados, e nos diálogos frequentes relacionados aos acompanhamentos de estágios. Essa premência é escancarada no acompanhamento ainda mais sistemático, pela coordenação do subprojeto de Geografia, no contexto do Programa de Residência Pedagógica (PRP), na Universidade Federal da Fronteira Sul (UFFS), em desenvolvimento nos estados de Santa Catarina e do Rio Grande do Sul.

Outros achados investigativos, com os desafios detectados, na pesquisa realizada com o Ensino Médio em Chapecó/SC, relacionada à fatores de evasão e reprovação ${ }^{10}$. O diagnóstico de todas as Vinte e cinco (25) escolas Ensino Médio noturno, vinculadas a regional Chapecó, envolve 1.913 alunos (de um total de 2.712), 103 professores (de um total de 260) e 47 gestores (de um total de 86) participantes. Na análise dos dados, decorreram constatações de natureza qualitativa, relacionados com a dimensão singular do Ensino Médio, apontando a necessidade de formação continuada dos professores, e de estratégias que envolvam também de forma direta, os estudantes da escola. Estes, apontam haver relações de não identificação com os conhecimentos, e entre evasão e reprovação e os sentidos atribuídos aos conhecimentos trabalhados. Essa constatação, abarca, também, o conjunto do Ensino Médio.

\footnotetext{
${ }^{10}$ Projeto institucionalizado na UFFS/SC processo ํㅜ 23205.003612/2016-29 e parecer do Comitê de Ética em Pesquisa - CEP número 1.737.949.
} 
Paralelamente, há muitos anos vêm sendo questionadas as dificuldades formativas do pesquisador, especialmente, nos cursos de licenciatura e, também, na Educação Básica. A crítica à cópia e colagem de fragmentos, que Demo (2006) expressa redundar em mero "café requentado". Nos Projetos Pedagógicos dos Cursos (PPC) de formação de professores, em geral, essa dificuldade pode ser percebida pela dificuldade de integrar os componentes específicos com os pedagógicos, mesmo apesar de esforços como os realizados na UFFS com a criação, por exemplo, de domínios comum e conexo entre os cursos. Também, nos Projetos Políticos Pedagógicos (PPP) das escolas, a dimensão da pesquisa aparece na forma de ação disciplinarizada, estanque e desvinculada dos conteúdos.

Pode-se notar, que há uma confluência na problemática central que configura esse movimento de pesquisa, perseguindo a resposta ao desafio: como a pesquisa do lugar pode auxiliar na aprendizagem dos conhecimentos conceituais? Reconhecendo a potência da formação em processo realizado com a escola (não sobre a escola ou para a escola) "Nós Propomos em Chapecó/SC" é um modo de realizar a pesquisa elando lugar dos sujeitos (acadêmicos e alunos da escola), conhecimentos e sistematização.

Esse modo de pesquisa enquanto princípio educativo é apontada como potência, também, nos documentos das políticas educacionais (por exemplo nas Diretrizes Curriculares Nacionais - DCN). Ao encontro desses desafios, no Plano de Desenvolvimento Institucional (PDI) da Universidade Federal da Fronteira Sul (UFFS) e no Projeto Pedagógico do Curso (PPC) da Licenciatura em Geografia, por exemplo, é apontada a importância da aprendizagem da pesquisa que contribua, sobremaneira, com o âmbito regional e com pesquisas que construam conhecimentos importantes a partir dos lugares dos sujeitos. Ao encontro desses documentos, na UFFS o Fórum das Licenciaturas, criado no ano de 2017, vêm debatendo caminhos à realização de um ensino e uma extensão por meio do princípio investigativo.

\section{Horizontes contextuais}

Esse movimento visa fundamentalmente, investigar a realidade do lugar com vistas à construção significativa dos conhecimentos, por meio da pesquisa como princípio educativo-formativo. Isso, porque compreende uma interlocução direta entre universidade e escola, bem como a tomada da pesquisa do lugar como elo às aprendizagens significativas dos conhecimentos. 
Os horizontes estão compreendidos no objetivo geral de investigar a realidade do lugar, com vistas a detectar, estudar e prospectar alternativas aos problemas locais, e reconhecer a importância da pesquisa científico-acadêmica do cotidiano na resolução de problemas do lugar, para a construção da cidadania territorial, integrando graduação, pós-graduação e escola, e envolvendo pesquisa, ensino e extensão.

Especificamente, envolve objetivos que percorrem passos em diferentes frentes que visam: compreender a política educacional na vida do lugar, pela interlocução entre pesquisa teórica e empírica pautada no lugar e nos sujeitos do lugar; compreender a relação entre noções geográficas e históricas à construção da cidadania territorial, por meio da relação entre a vida cotidiana e os conhecimentos conceituais; promover a aprendizagem da pesquisa em diálogo dos graduandos e mestrandos com a escola, enquanto processo de construção de conhecimentos que atribuam sentidos aos significados sistemáticos dos conhecimentos escolares e científicos; exercitar percursos investigativos com vistas a proposição de alternativas para os problemas do lugar; integrar graduação e pós-graduação e estes com escola, envolvendo processos de pesquisa com ensino e extensão, pressupostos na formação do professor pesquisador, previstos no Plano Institucional, na Pós-Graduação em Educação, e nos Projetos de Curso das licenciaturas; fortalecer a internacionalização por meio da integração com universidades e institutos no exterior; e desenvolver processos de sistematização e compilações de dados da realidade em diálogo com referenciais teóricos e documentais, abarcando o objetivo de detectar e estudar problemas do lugar, prospectando percursos alternativos.

\section{Complexos de estudos relacionados}

Ao encontro do enfrentamento desses desafios educativos, pressupostos na cidadania territorial, a obra de Freire (1967, 1992, 1996, 2000), por exemplo, é configurada assentando a argumentação na fundamentalidade da construção de conhecimentos à emancipação intelectual dos sujeitos jovens, por meio de relações com o lugar. 0 pesquisador permite acentuar a relação entre o incômodo ou a indignação acerca dos limites educativos, em diálogo com a esperança que reconhece o lugar dos sujeitos, como percurso à libertação.

A formação do pesquisador nos cursos de Licenciatura é complexa, uma vez que é separada da formação do professor. Rodrigues (2012) aponta que há um movimento para proporcionar aos educandos condições para enfrentar com proficiência e criatividade os problemas de sua prática profissional, produzir e difundir 
conhecimentos, como também refletir criticamente sobre a realidade que os envolve. Contudo, afirma que há uma dificuldade de coadunar ensino e pesquisa, embora "no que diz respeito à universidade, nos deparamos com um considerável número de artigos e estudos que consideram ser essencial que a pesquisa seja colocada como prioridade ao lado do ensino na graduação, caminhando articuladamente com a pósgraduação" (Rodrigues, 2012, p. 4).

Essa dificuldade tem relação com o desafio da sistematização, que compreende "fazer o pensamento funcionar de forma ordenada, coerente", como destaca Falkenbach (1991, p. 8). A pesquisadora completa a ideia, afirmando que envolve "fazer isso a partir do real, do concreto [...]". No processo de formação do pesquisador Marques (2008) reitera a importância do escrever enquanto princípio da pesquisa, e afirma que o escrever é o melhor modo de pensar. O pesquisador argumenta a importância da formação do pesquisador nos cursos de graduação e destaca a força de um professor que constrói uma postura e adota uma atitude investigativa, pois isso o torna um produtor de conhecimento e não um mero repetidor. Lüdke (2001) reitera essa dimensão falando acerca da escola, de seus professores e em colaboração com os alunos ao analisar os limites e possibilidades do professor, seus saberes e suas possibilidades e desafios com a pesquisa.

No caso da Geografia, Callai (2013) problematiza, e Rego (2012, p. 9) textualiza que "o ensino de geografia pode significar meramente a exposição de um programa de conteúdos, supostos como [...] já estabelecidos, acompanhada pela avaliação de sua assimilação [...]". Como contraponto o pesquisador refere que uma geografia educativa deve "significar a possibilidade de transformar temas da vida em veículos para a compreensão do mundo, entendido não como conjunto de coisas, mas como obra de criadores - sendo a compreensão sobre os criadores parte indesligável da compreensão sobre a construção contínua da obra". Notamos, no fragmento destacado, o acento no entendimento de espaço-tempo e de conhecimento como abertos, relacionais e em permanente elaboração pelo humano. Isso compreende a pesquisa, na qual o objeto de estudo está no processo de construção de conhecimentos significativos, ou seja, vinculados a dimensão do lugar.

Paralelamente, os desafios na formação do professor-pesquisador se acentuam, tendo em vista que os alunos dos cursos noturnos de Licenciatura, precisam compatibilizar horários de trabalho com estudo (Rissi \& Marcondes, 2011, p. 49). Assim, também, nesta proposta de pesquisa, as noções de território, lugar e cotidiano são centrais. E, por isso, cabe referir que lugar não pode ser confundido com local. Tem uma 
conjugação com o cotidiano, como permite entender Massey (2008, p. 203): "[...] o que é especial a respeito do lugar não é algum romantismo de uma identidade coletiva preconcebida ou de uma eternidade das montanhas". Reitera a pesquisadora, que "ao contrário, o que é especial sobre o lugar é, precisamente, esse acabar juntos, o inevitável desafio de negociar um aqui-e-agora ([...] de "entãos" e "lás"), e a negociação [...] dentro e entre ambos, o humano e o não humano".

Essa assertiva da pesquisadora escancara que lugar não pode ser confundido com local e que há inseparabilidade mas, também, indissolubilidade do lugar e do cotidiano, porque os sujeitos têm um cotidiano que tem relação com o que pensa, sente e vive (abertamente) em um lugar (aberto e em movimento), ambos, sempre em relações com outros lugares (Andreis, 2014). Porque o lugar "não é apenas um quadro de vida, mas um espaço vivido, de experiência sempre renovada" (Santos, 2010, p. 114). Lugar é componente de um território multiescalar no qual as relações de poder têm relação com o saber. Esse e outros entendimentos têm vinculação com a cidadania, pois se assentam na relação do espaço assumido como "dimensão do social" que é de natureza coletiva, intrincado com o tempo enquanto "dimensão da mudança" que é de natureza mais complexa que a duração, portanto, assume o "espaço geográfico" como revolucionário (Massey, 2008).

As relações de força tem forte vinculação com o lugar, pois o território não é mera superfície onde e quando acontecem os confroencontros (Andreis, 2014). São espaços-tempo, fronteiras de disputas, como propõe Simões (2015). Por isso, lugar e território são noções que compreendem o cotidiano de todos os sujeitos. É um modo de entender as relações formativas, na universidade e na escola, como forças emancipadoras do pensar e transformadoras do mundo.

Trata-se da "teoria como aquilo que dá sentido à realidade específica, enquanto permite entendê-la por dentro [...]" (Falkenbach, 1991, p. 8). Então, vincula lugar ao território da ação, e da cidadania como ética, uma vez que a escola e a universidade, também, são cada vez mais, chamadas a investigação, para "responder às solicitações de cidadania territorial" (Claudino, 2018, p. 267). A problemática implicada reporta ao modo como ocorrem as mediações formativas.

Nesse complexo, a pesquisadora da educação Silva (2016) destaca a especificidade das juventudes que estudam no Ensino Médio e, Callai, pesquisadora do ensino de geografia, em 1999 realiza uma pesquisa na qual dialoga diretamente com os jovens. Pelos enunciados dos alunos, a pesquisadora infere que a "geografia humana é muito pouco presente e aparece por meio de itens também fragmentando a realidade" ( $p$. 
67), afirmando que deve ser trabalhada "de acordo com a realidade em que estão" (id. p. 69).

É nesse sentido que Claudino (2018) refere a centralidade do movimento investigativoformativo, que vem sendo realizado em relações criadas entre professores, acadêmicos e mestrandos da universidade e professores e estudantes do EM. O projeto internacional "Nós Propomos!" "cruza-se com a preocupação em promover uma educação geográfica comprometida com o desenvolvimento sustentável e que ganha particular relevância à escala local" (Claudino, 2018, p. 268). Mostra-se como dispositivo que envolve e promove aprendizagens significativas dos conhecimentos, por meio da pesquisa.

Portanto, a problemática apontada vem sendo reiterada, e o enfrentamento tem se mostrado mais potente quando o processo implica diferente grupos da escola e da universidade, atribuindo assim um caráter investigativo multidimensional e multiescalar.

\section{Metodologia dialógica: ensino, extensão e pesquisa}

As etapas a seguir apresentadas, compõem o movimento formativo-investigativo em Chapecó/SC, a ser concretizado entre novembro de 2018 e outubro de 2019. Ainda, enquanto percurso metotodológico, é fundamental destacar e esclarecer que os sujeitos, estudantes da escola, professores da escola, acadêmicos e professores da universiade, não figuram como o objeto que esta sendo pesquisado. O objeto de pesquisa é o lugar e seus problemas e um acento importante é o trabalho de campo com o lugar. Os sujeitos envolvidos, compõem enquanto participantes do processo de aprendizagem do pesquisar e sistematizar, tendo como pano de fundo o território do lugar, portanto, implicando conhecimentos (acadêmicos e escolares) e, consequentemente, a atribuição de sentidos e significação prospectiva conceitual dos mesmos. O objeto que está em investigação é o território do lugar, tensionado a dimensão do social e da cidadania. O Quadro 1 apresenta as etapas para a caminhada. 
Quadro 1 - Etapas e atividades envolvidas

\begin{tabular}{|c|c|}
\hline Etapa & Atividade envolvida \\
\hline 01 & $\begin{array}{l}\text { Realizar seleção de acadêmico bolsista e voluntários (preferencialmente, das } \\
\text { licenciaturas, da área da Geografia, devido aos conceitos centrais da proposta, mas } \\
\text { abertos para outros cursos de Licenciatura e Bacharelado da UFFS/SC). }\end{array}$ \\
\hline 02 & $\begin{array}{l}\text { Realizar a escolha da escola de Ensino Médio com a qual será desenvolvida a } \\
\text { pesquisa, em ação conjunta com a Gerência Regional (GERED) de Chapecó e } \\
\text { contanto com a ciência e concordância da escola de Ensino Médio. }\end{array}$ \\
\hline 03 & Apresentar o projeto detalhado aos gestores da escola de Ensino Médio. \\
\hline 04 & $\begin{array}{l}\text { Realizar reuniões na escola, para dialogar com os professores para explicitar projeto } \\
\text { e planejar ações e cronogramas com alunos do Ensino Médio. }\end{array}$ \\
\hline 05 & $\begin{array}{l}\text { Apresentar projeto e convidar os estudantes do Ensino Médio, para participar do } \\
\text { projeto. Em princípio, a pretensão é convidar alunos do } 1^{\circ} \text { e } 2^{0} \text { ano do EM matutino e } \\
\text { noturno, por manterem o vínculo com a até o final do projeto (outubro de } 2019 \text { ) }\end{array}$ \\
\hline 06 & $\begin{array}{l}\text { Com os grupos participantes (acadêmicos, mestrandos, professor(es) da escola, } \\
\text { Direção e alunos da escola de Ensino Médio) adequar o cronograma de trabalho, } \\
\text { priorizando horários em turno inverso ao da escola e da licenciatura da universidade, } \\
\text { para não confroentar com o curriculo da escola e da universidade e, também, para } \\
\text { incentivar a participação de outras áreas. Por exemplo, vespertino ou aos sábados de } \\
\text { manhã. Em acordo com a escola e os alunos, ss encontros serão semanais ou } \\
\text { quinzenais }\end{array}$ \\
\hline 07 & $\begin{array}{l}\text { Com o aluno bolsista da universidade e com grupo de estudantes do Ensino Médio já } \\
\text { constituido, sob a coordenação do professora da universidade e auxilio do(s) professor } \\
\text { (es) da escola: buscar e organizar bibliografias para estudar e pesquisar as noções } \\
\text { conceituais de território, lugar e cidadania; e os documentos das políticas educacionais } \\
\text { locais (ex: lei municipal e Plano Diretor) e nacionais (ex. Constituição federal, PCNEM e } \\
\text { BNCC). }\end{array}$ \\
\hline 08 & $\begin{array}{l}\text { Realizar o processo investigativo acerca do lugar, por meio de diálogos com a } \\
\text { comunidade escolar (enquetes, dados das pesquisas que a escola realiza, dados do } \\
\text { Projeto Político Pedagógico - PPP da escola). }\end{array}$ \\
\hline 09 & $\begin{array}{l}\text { Realizar trabalho de campo para escolher problemas que tensionarão a pesquisa } \\
\text { acerca do lugar, tendo como pano de fundo o estudo da relação entre os problemas } \\
\text { locais e as noções conceituais de lugar, território e cidadania, para investigar e } \\
\text { identificar os problemas do lugar, com enfoque no local (escola, bairro, comunidade } \\
\text { escolar, cidade). }\end{array}$ \\
\hline 10 & $\begin{array}{l}\text { Sistematizar projeto acerca dos problemas detectados, prospectando percursos para } \\
\text { construir alternativas para os problemas considerados inportantes e escolhidos pelos } \\
\text { alunos da escola. }\end{array}$ \\
\hline 11 & $\begin{array}{l}\text { Realizar encontros entre os participantes da projeto (na escola e, também, na } \\
\text { universidade, com vistas à integrá-los no âmbito da universidade), com vistas } \\
\text { pesquisar percursos ao encontro de alternativas ao problema do lugar. }\end{array}$ \\
\hline 12 & $\begin{array}{l}\text { Sistematizar processualmente os achados na forma registros que se configurem em } \\
\text { pelo menos um artigo científico. }\end{array}$ \\
\hline 13 & $\begin{array}{l}\text { Apresentar e publicizar a pesquisa (na escola, na universiade, na(s) instância(s) } \\
\text { pública(s) municipal ou outra(s), em evento(s) e, na forma de artigo(s)). Neste aspecto, } \\
\text { considerando que o projeto dialoga com o "Nós Propomos!" internacional, envolve, } \\
\text { também, a possibilidade de publicização no site nas redes sociais do mesmo. }\end{array}$ \\
\hline
\end{tabular}

As etapas 1 e 2 já estão em andamento, pois o projeto foi aprovado e, atualmente, está institucionalizado na UFFS/SC11. Cabe reiterar, a atenção à centralidade dos

\footnotetext{
${ }^{11}$ Projeto aprovado e institucionalizado na Universidade Federal da Fronteira Sul, Chapecó/SC, no edital n 1010/GR/UFFS/2018, de Fomento à Pós-Graduação Stricto Sensu da UFFS, em
} 
pressupostos do "Nós Propomos" internacional, marcadamente pelo respeito ao prognóstico do lugar, a palavra dos jovens da escola e a metodologia desenvolvida em diálogo com trabalho de campo.

\section{Conclusão}

Atendendo ao objetivo de apresentar os elementos teóricos e metodológicos do projeto de pesquisa Nós Propomos em Chapecó/SC, neste texto, apresentamos o argumento de sustentação teórico-metodológico do processo investigativo, em interlocução com o cotidiano e o lugar, enquanto elo prospectivo às aprendizagens significativas, potencializadas pela relação entre escola e universidade e seus professores e alunos. Trata-se de um percurso que apreende uma potente e importante pretensão investigativo-formativa, que abraça o ensino e a extensão, pois compreende ensinar-aprender e relações com a comunidade. Apresentamos, assim, a afirmação de um elo com o projeto internacional, dotando-o de uma espécie de especificidade de cunho didático-pedagógico, por acentuar o estudo do lugar, situado geograficamente no local da escola e dos alunos, o trabalho de campo como elo territorial, e a construção da cidadania por meio da postura e atitude de investigar e prospectar alternativas aos problemas detectados.

Apesar do texto ser marcado pela expressão mais geral dos elementos teóricos e metodológicos do projeto em desenvolvimento, apresenta os pressupostos na força formativa da pesquisa, pelo processo de aprendizagem da pesquisa pelos acadêmicos da universidade e, também, entremeada com aprendizagens por meio da pesquisa, pelos alunos do Ensino Médio. Então, o resultdo é a afirmação teórica da importância da pesquisa na formação do professor na universidade e na atuação na escola de Educação Básica. Esses acentos, estão conjugados com a valorização do lugar, a relação entre conceitos e conhecimentos e a vida cotidiana, a aprendizagem da cidadania territorial como ética e ação de natureza social, numa integração entre universidade e escola e, também, de confluência entre ensino e pesquisa, perpassando pela extensão, que compõem o tripé da UFFS.

É assim, que a centralidade na aprendizagem do processo investigativo, pelos participantes da pesquisa da universidade e da escola, compreende a relação entre a vida e os conhecimentos conceituais e contribui para o enfrentamento do desafio 
apontado nas pesquisas, relacionado com a atribuição de significados prospectivos em relações com a vida.

\section{Referências bibliográficas}

Andreis, A. M. (2014). Cotidiano: uma categoria Geográfica para ensinar e aprender na escola. (Tese de Doutorado). Universidade Regional do Noroeste do Estado do Rio Grande do Sul (UNIJUI), ljuí/RS.

Callai, H. C. (1999). A Geografia no Ensino Médio. Revista Terra Livre, n. 14, 60-99, jan/jul.

Callai, H. C. (2013). A formação do profissional de Geografia: o professor. ljui/RS: Editora da UNIJUI.

Claudino, S. (2018). Educação Geográfica, Trabalho de Campo e Cidadania. O Projeto Nós Propomos!. In: F. H. Veiga (Org.), O ensino na escola de hoje: teoria, investigação e aplicação. (pp 265-303) Rio de Janeiro: Climepsi Editores.

Demo, P. (2006). Pesquisa: princípio científico e educativo. São Paulo: Cortez.

Lüdke, M. (2001). O professor, seu saber e sua pesquisa. Educ. Soc. [online]. V(22), n.74, 77-96. doi: 10.1590/S0101-73302001000100006.

Falkenbach, E. (1991). Sistematização. ljuí/RS: Editora da UNIJUI.

Freire, P. (1967). Educação como prática da liberdade. Rio de Janeiro: Paz e Terra.

Freire, P. (1992). Pedagogia da Esperança: reencontro com a Pedagogia do Oprimido. Rio de Janeiro: Paz e Terra.

Freire, P. (1996). Pedagogia da Autonomia: saberes necessários à prática educativa. São Paulo: Paz e Terra.

Freire, P. (2000) Pedagogia da Indignação: cartas pedagógicas e outros escritos. São Paulo: Ed. UNESP.

Marques, M. O. (2008). Escrever é preciso: o princípio da pesquisa. Petrópolis: Vozes, 2008.

Massey, D. (2008) Pelo Espaço. Rio de Janeiro: Bertrand Brasil.

Santos, M. (2010). Por uma outra globalização: do pensamento único à consciência universal. São Paulo: Record.

Rego, N.; Castrogiovanni, A. C.; Kaercher, N. A. (2007) Geografia: Práticas pedagógicas para o Ensino Médio. Porto alegre: Artmed.

Rissi, M. C.; Marcondes, M. A. S. (2011). Estudo sobre a reprovação e retenção nos cursos de graduação. Londrina/PR: UEL.

Rodrigues, M. E. F. (2012) A pesquisa no ensino de graduação e a articulação com a pós-graduação na ciência da informação: reflexões e proposições. Ponto de Acesso, V(6), n.2, 03-20. doi. 10.9771/1981-6766rpa.v6i2.6099. 
Silva, M. R. da. (2016). O Ensino Médio: suas políticas, suas práticas: estudos a partir do Programa Ensino Médio Inovador. Curitiba: UFPR/ Setor de Educação.

Simões, W. (2015) Territorialidades da juventude faxinalense: entre a produção de invisibilidades, a precarização dos territórios de vida e os desafios da construção de um bem viver. (Tese de Doutorado). Universidade Federal do Paraná (UFPR), Curitiba/PR. 


\section{"Nós Propomos..." Um Projeto à frente do seu tempo"}

ANABELLA VAZ ${ }^{12}$

\section{Resumo}

Fazer melhor educação geográfica é refletir sobre os percursos de aprendizagem e, com isso, delinear caminhos de incentivo, de gosto pelo Conhecimento, pela descoberta local, pela identificação com o Território, pela participação pública. Participar, continuamente, durante os sete anos de existência do Projeto "Nós Propomos - Inovação e Cidadania na Educação Geográfica ..." possibilitou uma reflexão, mesmo que sentimental e de sentido de pertença, sobre o olhar que os jovens alunos têm do seu território, pois muitos dos seus trabalhos têm incidido sobre a qualidade do espaço urbano de Faro, onde se localiza a Escola, e sobre as perspetivas dos seus professores acerca das potencialidades educativas do mesmo. Ainda antes do ano letivo 2011/12, em que a Escola Secundária João de Deus - Faro integrou este Projeto, e através do Tema "Estudo de Caso" constante no Programa de Geografia do $11^{\circ}$ ano do Ministério da Educação, desenvolvia-se nos alunos valores, atitudes, conhecimentos e competências, hoje constantes no atual "Perfil do Aluno à saída da escolaridade obrigatória". A importância deste Projeto também reside na orientação, na formação e no acompanhamento dado pelo Instituto de Geografia e Ordenamento do Território da Universidade de Lisboa, e residiu ainda, na partilha entre as escolas do Projeto, que iam fazendo as suas sugestões de melhoria, dadas as experiências de aprendizagem entre alunos das diversas regiões do país. Assim, foi possível trilhar um caminho de segurança, renovação e qualidade, no ensino e na aprendizagem da Geografia.

Palavras-chave: Ensino da geografia; Perfil do aluno na escolaridade obrigatória; Cidadania territorial; Parcerias educativas; Projeto "Nós Propomos - Inovação e Cidadania na Educação Geográfica”.

\section{Abstract}

Reflection on the learning paths, promotion of learning curiosity for knowledge and local discovery, identification with the territory and public participation are required in

12 Professoa de Geografia do quadro da escola Secundária João de Deus, anabella.vaz@aejdfaro.pt 
order to promote a better education in Geography.Participating continuously for the seven-year existence of the Project "We Propose ..." has allowed us a reflection, even if sentimental and with a sense of ownership, on the young students' view of their territory and on the perspective of teachers of the educational potential of this Project. Even before the 2011/12 school year, during which João de Deus High School - Faro, integrated this Project, with the Theme "Case Study" integrated in our curriculum of the secondary education level, students values, attitudes, knowledge and skills were already being developed, which are now included in the current "Profile of Student" leaving compulsory schooling. The importance of this oriented work, which was promoted by the Institute of Geography and Territorial Planning from the University of Lisbon, which also provided training, is due to the promotion of sharing practices between participating schools on the Project that gave their suggestions for improvement, based on the learning among students of the different regions of the country. This way, it was possible to follow a safe and renovated route and to improve the teaching/learning process in Geography.

Keywords: Geographic education; Profile of the student in compulsory schooling; Territorial citizenship; Educational partnerships; Projeto "Nós Propomos - Inovação e Cidadania na Educação Geográfica".

\section{Introdução}

Desde a implementação do Projeto Nós Propomos que a Escola Secundária João de Deus, do Agrupamento com o mesmo nome, tem participado nele continuamente. Esta escola situa-se em Faro, capital da Região do Algarve, ou seja, é uma escola urbana com uma importante história na localidade e na região, situada num ponto alto em que domina a paisagem desta cidade de média dimensão.

O texto que se segue pretende ser uma reflexão que fizemos desta nossa prática e da experiência partilhada com o Instituto de Geografia e Ordenamento do Território e com a Câmara Municipal de Faro, cujas parcerias foram determinantes na qualidade do trabalho desenvolvido.

Organizou-se a comunicação nos seguintes eixos orientadores:

- A aprendizagem no Projeto "Nós Propomos..."

- Do urbanismo à educação ambiental, cidadania e sustentabilidade

- "Nós propomos" inovação e cidadania - onde o passado e o presente se encontram 
- Nós com os outros.

\section{Segunda parte}

\subsection{A aprendizagem no Projeto "Nós Propomos"}

A primeira reflexão que nos surge é:

- Onde se encontra o Projeto "Nós propomos...", no Programa de $11^{\circ}$ ano de Geografia A?

Trata-se de um Projeto Curricular, previsto no tema "Estudo de Caso" do Programa nacional de Geografia A para o ensino secundário, em vigor, e que no âmbito das opções curriculares realizadas, aborda conteúdos do tema 3.2. As áreas Urbanas: Dinâmicas Internas - 3.2.3.Problemas urbanos.

A figura 1 compara as finalidades do estudo de caso, no Programa de Geografia, e do Projeto.

Figura 1 - Do Estudo de Caso (11ano Geo. A) ao Projeto "Nós Propomos"

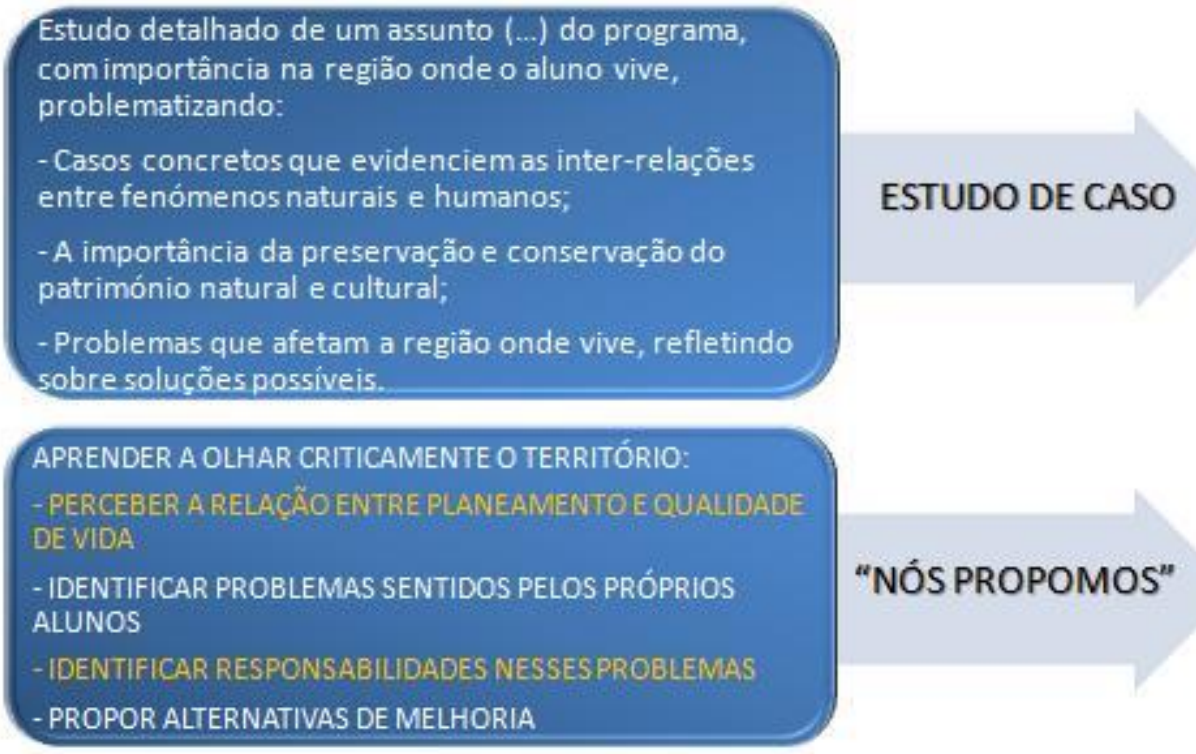

Fonte: ME, Programa de Geografia A e Projeto Nós Propomos 2017-2018

Assim, pode-se concluir que o Projeto "Nós propomos..." pressupõe o desenvolvimento de uma atitude mais interventiva e crítica, e de "comprometimento social" como referido pelo mentor deste Projeto o Professor Doutor Sérgio Cláudino (2018).

\subsection{Do urbanismo à educação ambiental, cidadania e sustentabilidade}


A segunda reflexão que nos surge é:

- Que aprendizagens o Projeto "Nós propomos..." desenvolve?

As potencialidades que fomos encontrando na metodologia de projeto - estudo de caso que se adotou, levou-nos a permanecer no Projeto durante todos estes anos. Esta metodologia, centrada na realidade urbana, parte para uma educação ambiental, cívica e para a sustentabilidade, mais ampla e abstrata.

Figura 2 - Esquema conceptual do nosso Projeto

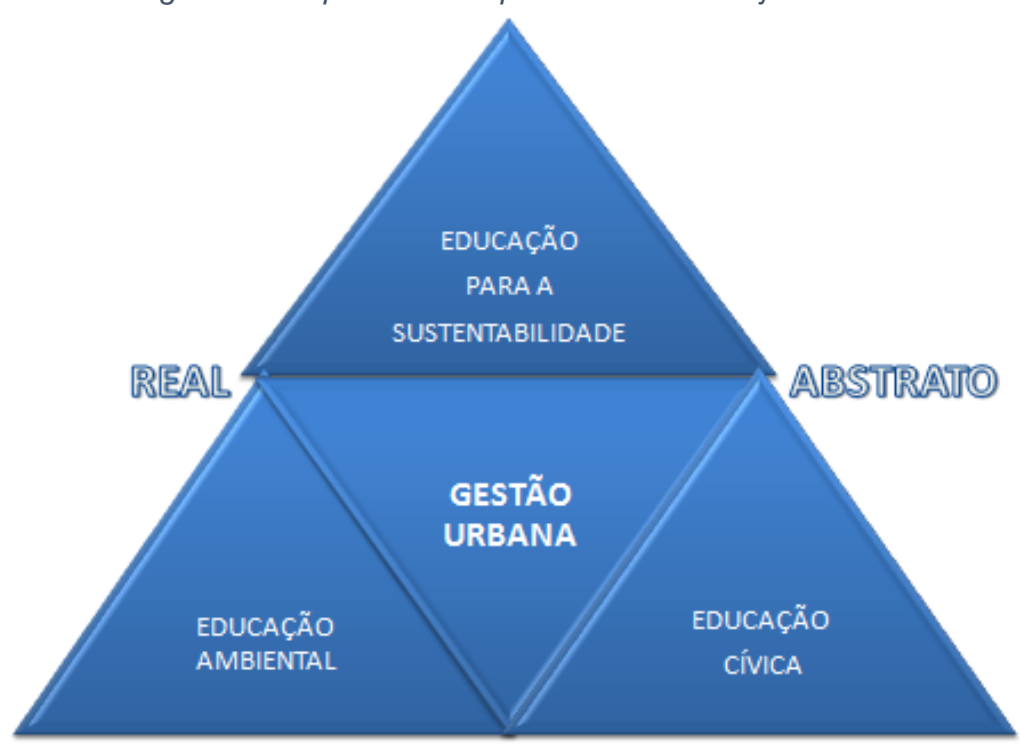

Assim, reforça-se uma aprendizagem em que a gestão urbana tenha em conta a qualidade ambiental, a solidariedade social e o bem - estar, no presente, e cujas propostas de melhoria tenham em conta a sustentabilidade dessas ações para as futuras gerações e para o ambiente.

A aprendizagem cognitiva que parte do conhecimento da realidade que nos rodeia $e$ da sua explicação, facilita futuramente a aquisição do pensamento abstrato, com vista à formulação das propostas ideais e emocionalmente construídas, de resolução de problemas, (Mora, 2013). Essa aprendizagem que se quer sólida, é construída em grupo através de uma aprendizagem cooperativa e colaborativa, partilhando saberes e aprendendo a gerir contrariedades (Kagan, 2013). 
Figura 3 - Percurso de Aprendizagem no Projeto "Nós Propomos"

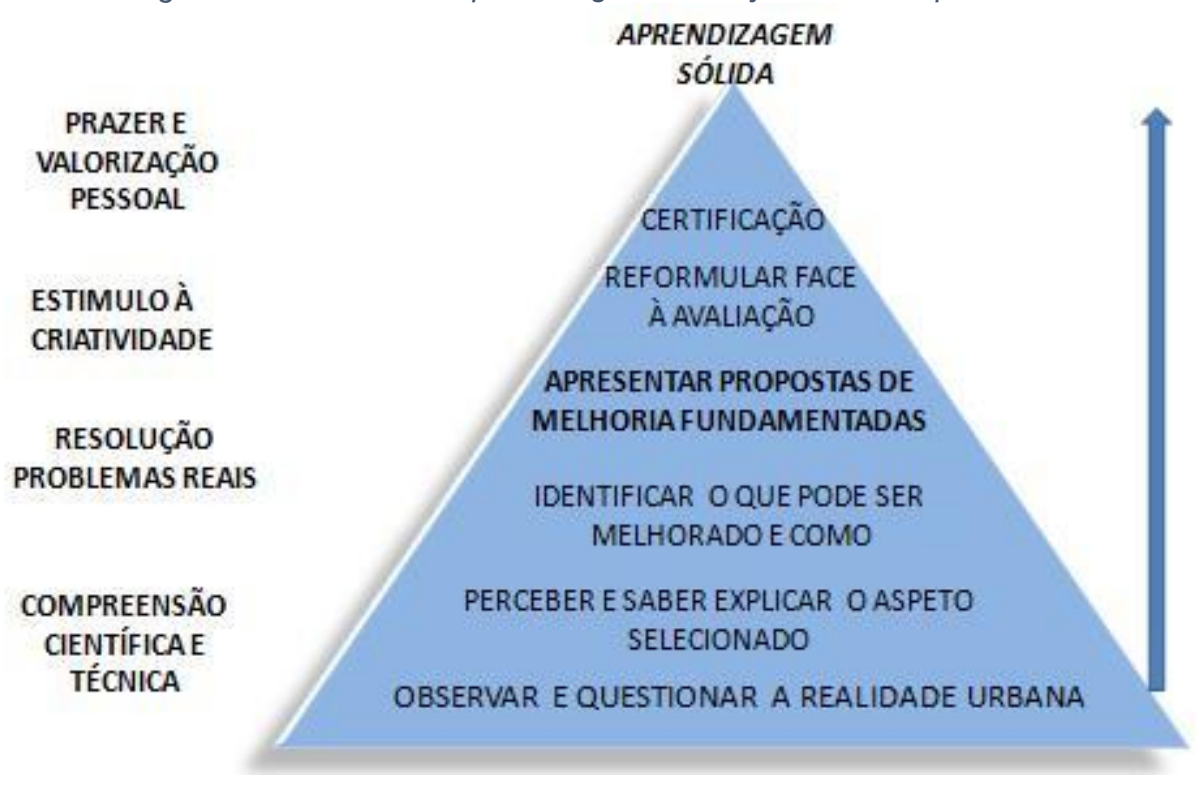

Fonte: (Kagan, 2013)

Figura 4 - Potencialidades deste trabalho de projeto a nível pedagógico

\begin{tabular}{|c|c|}
\hline $\begin{array}{l}\text { * Tem em conta as experiências prévias e trabalha-se com todos os } \\
\text { sentidos; }\end{array}$ & $\begin{array}{l}\text { Trabalho de campo em } \\
\text { grupo }\end{array}$ \\
\hline $\begin{array}{l}\text { Aprende-se com os outros através de objetivos partilhados, numa } \\
\text { aprendizagem cooperativa; }\end{array}$ & Finalidade comum \\
\hline $\begin{array}{l}\text { Utilizam-se estratégias de metacognição, de consciência da sua } \\
\text { aprendizagem; }\end{array}$ & $\begin{array}{l}\text { Aluno construtor da sua } \\
\text { aprendizagem }\end{array}$ \\
\hline Expressa-se construtivamente e negoceia-se; & \multirow{2}{*}{$\begin{array}{l}\text { Constroem-se emoções e } \\
\text { sentimentos }\end{array}$} \\
\hline Resolvem-se conflitos, interajuda-se; & \\
\hline Gere-se o tempo e o trabalho autónomo; & Treino da autonomia \\
\hline $\begin{array}{l}\text { Desenvolvem-se técnicas de investigação em ciências sociais e } \\
\text { cartografia de dados; }\end{array}$ & $\begin{array}{l}\text { Conhecimento gráfico e } \\
\text { estético }\end{array}$ \\
\hline Desenvolve-se o empreendedorismo; & $\begin{array}{l}\text { Procuram-se soluções, } \\
\text { justificam-se propostas }\end{array}$ \\
\hline Auto avalia-se e avalia-se os outros e o trabalho realizado. & $\begin{array}{l}\text { Feedback das } \\
\text { aprendizagens }\end{array}$ \\
\hline
\end{tabular}

Fonte: (Kagan, 2013).

\section{3 "Nós Propomos" inovação e cidadania - onde o passado e o presente se encontram}

A terceira reflexão que surge:

- Porque é o Projeto “Nós Propomos..."um projeto à frente do seu tempo? 
No site do IGOT (Instituto de Geografia e Ordenamento do Território) podemos encontrar um repositório de todos os trabalhos dos alunos desenvolvidos desde o ano letivo 2011/2012, de início do Projeto. Fez-se um estudo dos trabalhos efetuados pelos alunos da nossa escola até $2017 / 18$, no intuito de identificar as suas áreas de interesse, uma vez que os grupos de trabalho são autónomos nessa escolha.

Figura 5 - O que os alunos identificaram, estudaram e propuseram - 2011/2018

\section{QUESTÖES AMBIENTAIS}

- 24

ESPAÇO EDIFICADO

- 20

DESPORTO E OUTROS

$\cdot 20$

SOCIAIS

- 17

TRANSPORTES

- 8

Fonte: ME, Programa de Geografia A e Projeto Nós Propomos 2017-2018

Os problemas ambientais estão hoje na ordem do dia e para os alunos também foi essa a preocupação do seu trabalho. Relacionados com as áreas verdes da cidade, os resíduos sólidos urbanos, a qualidade do ar, a poupança de água e energia e a qualidade da paisagem. Estes são os temas/problemas preferidos dos alunos.

Seguem-se os problemas relacionados com os edifícios devolutos, os bairros degradados, a desertificação da baixa. Com o mesmo grau de importância aparecem os relacionados com os espaços desportivos, porque os afetam diretamente. Os problemas sociais são menos abordados e relacionam-se com o isolamento de idosos, os sem-abrigo, a toxicodependência e a pobreza que numa cidade de média dimensão, não têm grande visibilidade. Por essa mesma razão, os problemas relacionados com a mobilidade, acesso, mau estado das vias e passeios, sinalização e falta de conclusão de estradas, são os menos referidos.

Por outro lado, podemos estabelecer uma relação entre os documentos oficiais atuais do Ministério da Educação 2017/2018, e evidências do trabalho desenvolvido pelos alunos, quer ao nível da Educação Ambiental para a Sustentabilidade quer ao nível da Educação para a Cidadania. 
O Referencial de Educação Ambiental para a Sustentabilidade (ME 2018) orienta, desde abril de 2018, o procedimento dos professores de todas as áreas do conhecimento:...", no sentido de desenvolverem um processo de sensibilização, de promoção de valores, de mudança de atitudes e de comportamentos face ao Ambiente, numa perspetiva do Desenvolvimento Sustentável."

Segundo o mesmo documento, "num quadro mais abrangente da educação para a cidadania, esta constitui atualmente uma vertente fundamental da educação".

Salienta-se a sua relação com o trabalho efetuado no Projeto "Nós Propomos":

Figura 6 - Temas da Educação para a Sustentabilidade (de fundo cidade de Faro)

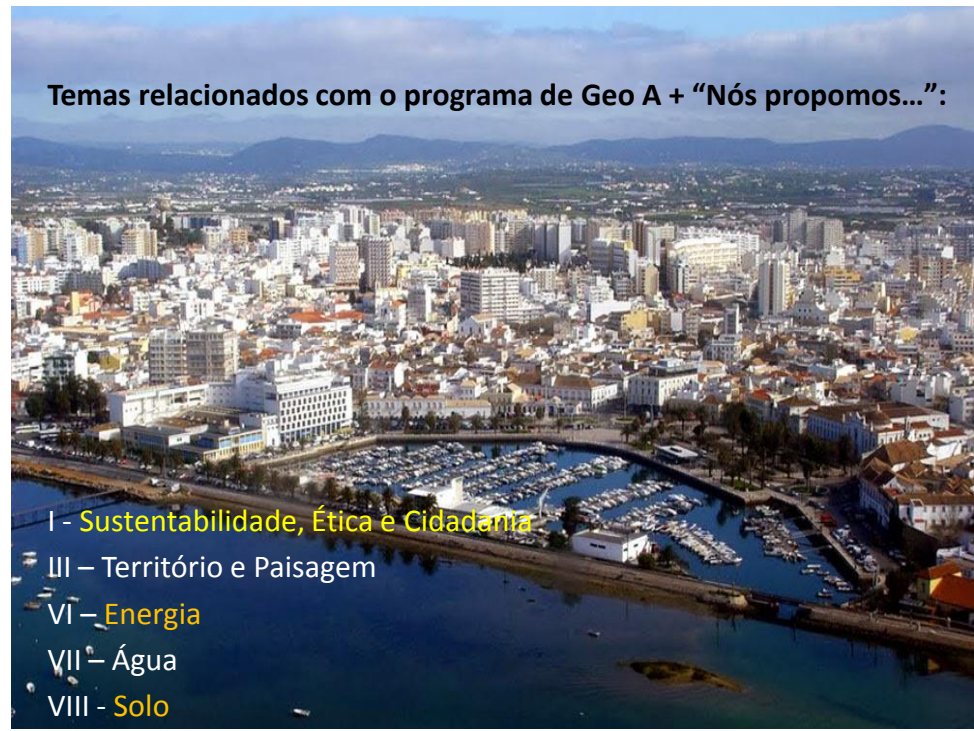

O trabalho de duas alunas no ano letivo 2013/14, Inês Neto e Jéssica Rosário, é já revelador desta preocupação:

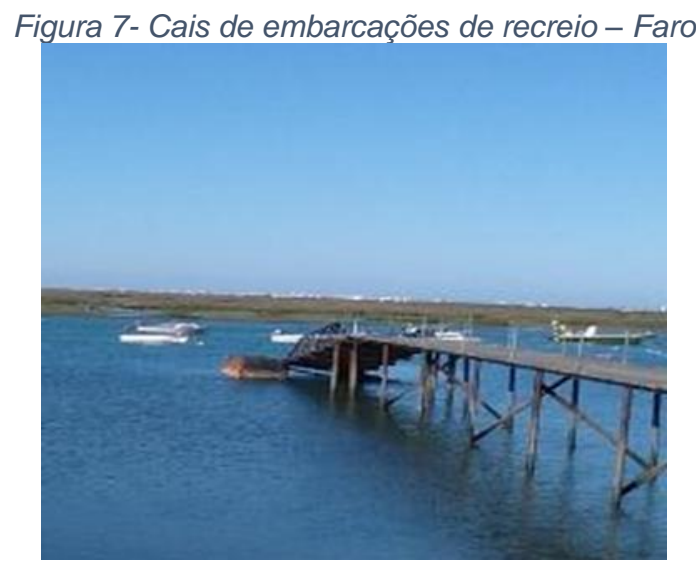

Torna-se necessária uma intervenção de requalificação urgente que devolva o acesso, agora interdito ao passadiço, devido à sua destruição pelo último temporal, embora este estivesse em estado muito degradado e a precisar de obras; e, ainda, uma estrutura de amarração de embarcações uma vez que: 
- A "marina" de Faro é muito pequena e tem umaenorme lista de espera;

- As embarcações que não têm lugar na"marina" encontram todas espalhadas pela Ria.

Por sua vez o documento "Estratégia Nacional de Educação para a Cidadania" (2017), refere que sendo esta "relação entre o indivíduo e o mundo que o rodeia, construída numa dinâmica constante com os espaços físico, social, histórico e cultural, coloca à escola o desafio de assegurar a preparação dos alunos para as múltiplas exigências da sociedade contemporânea."

No Projeto "Nós Propomos..." de entre outros tantos trabalhos, um grupo de alunas estudou em 2015/16, as causas da situação em que se encontra o Bairro da Horta da Areia e fizeram a afirmação que se segue.

Figura 8- Ruínas no bairro industrial Horta da Areia em Faro

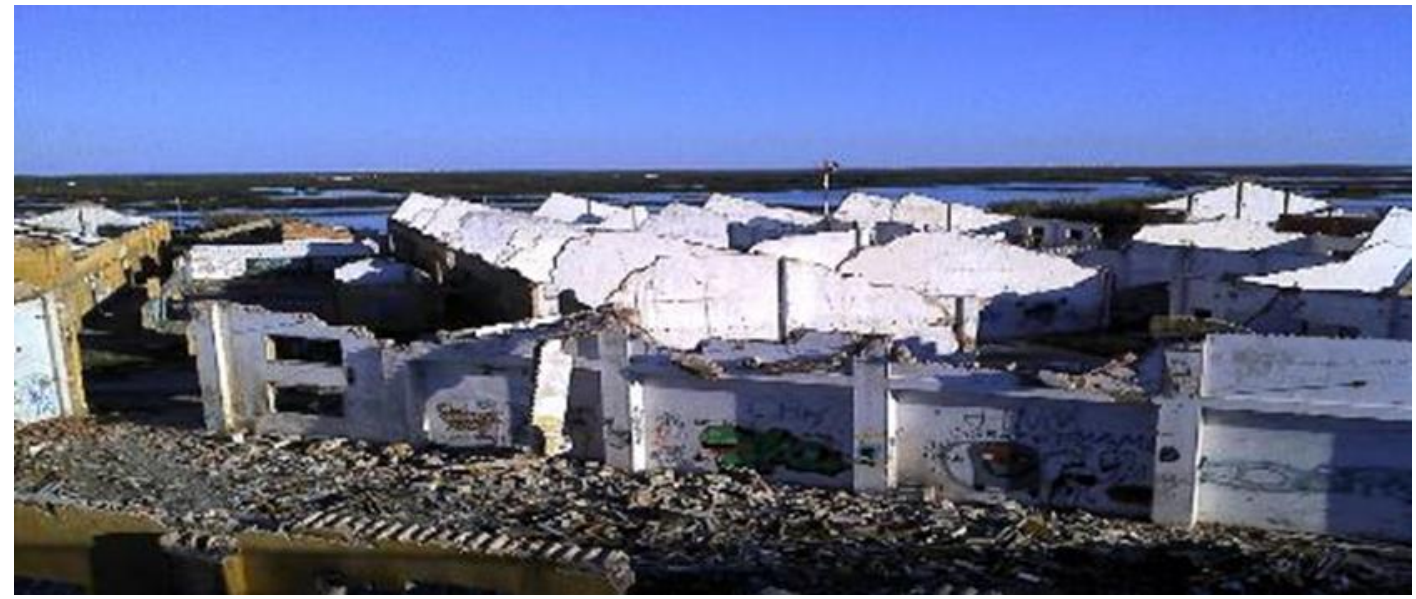

"Imaginem esta paisagem renovada, sem escombros e sem lixo, um lugar amplo, tranquilo e de grande capacidade arquitetónica. Este espaço podia ser utilizado:

- Para eventuais concertos, como por exemplo na Semana Académica;

- Na construção de cafés, restaurantes com uma paisagem sobre a Ria;

- Para passeios turísticos de bicicleta, segway, tuctuc, usufruindo da Natureza".

(Ana Ricketts, Mariana Martins e Marta Belchior, 2015/16)

Por sua vez, o Decreto-lei no 55 de julho de 2018, salienta em relação à Educação para a Cidadania que esta: "visa o desenvolvimento de competências para uma cultura de democracia e aprendizagens com impacto na atitude cívica individual, no relacionamento interpessoal e no relacionamento social e intercultural". 
Ora um grupo de alunos em 2016/17, por exemplo, ao estudar no Projeto "Nós propomos" a problemática dos sem-abrigo na cidade diferenciou os nacionais dos estrangeiros.

Figura 9- Quantos sem-abrigo são cidadãos nacionais e quantos são estrangeiros, em Faro

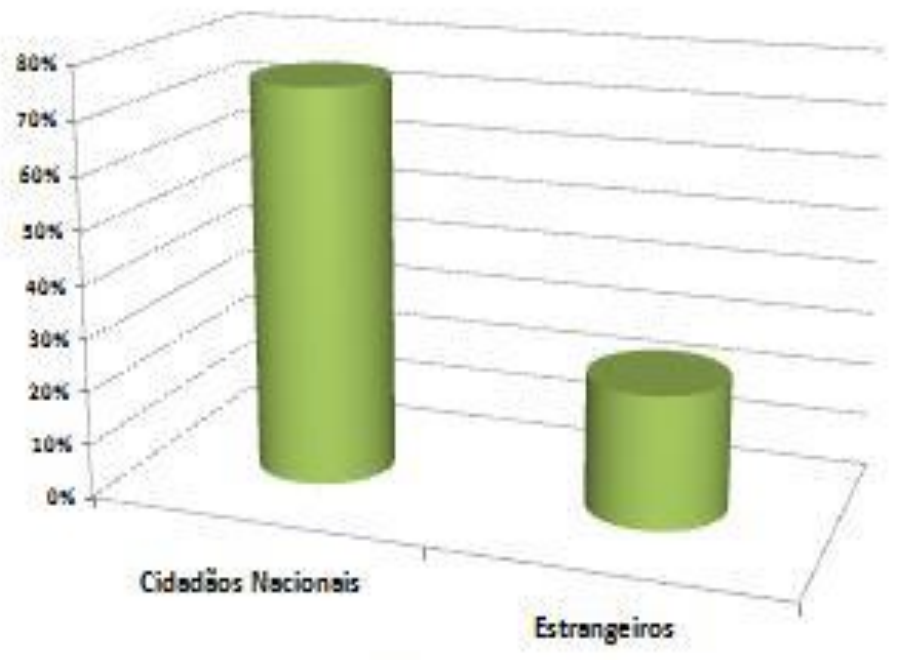

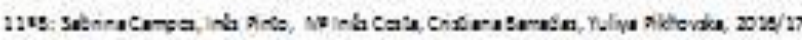

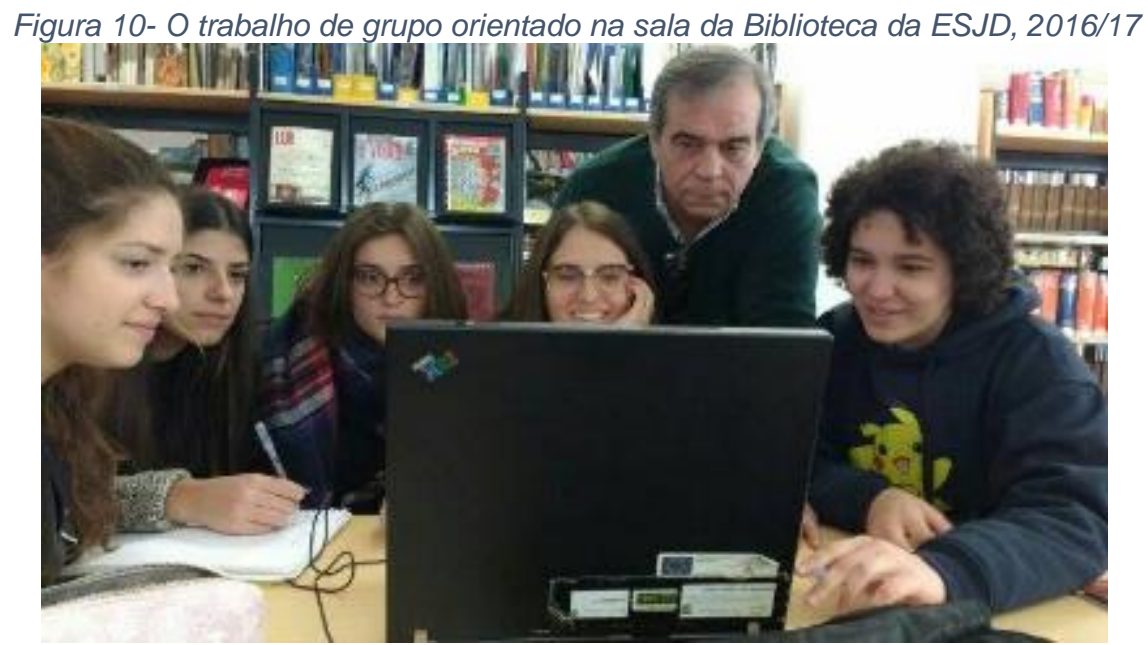

Mas, não são só os alunos os protagonistas desta mudança que há muito se iniciou, o documento "Linhas Orientadoras de Cidadania e Desenvolvimento" refere que "os professores têm como missão preparar os alunos para a vida, para serem cidadãos democráticos participativos e humanistas", o que sempre norteou o trabalho de todos os que têm participado no "Nós Propomos".

\subsection{Nós com os outros}

Quarta reflexão:

- Quem são os parceiros da escola neste Projeto? 
Tratando-se de um Projeto de génese territorial, as Câmaras Municipais são parceiros imprescindíveis, não só na obtenção de informação privilegiada, como de resposta a questões do passado e de explicação sobre os vários processos de elaboração do PDM e das opções dos diversos Planos.

A Câmara Municipal de Faro, tornou-se desde o primeiro ano uma parceira imprescindível, através do gabinete de Coordenação do PDM e da Vereação do Urbanismo:

$\checkmark$ Apoio individualizado a grupos de trabalho e sessões em sala de aula;

$\checkmark$ Orientação para entrevistas com a respetiva vereação;

$\checkmark$ Críticas aos trabalhos no sentido da melhoria e da participação;

$\checkmark$ Ajuda a que este Projeto fosse obrigatório e gratuito, através da cedência de transporte.

Seguidamente, testemunha-se através de fotografias que falam mais que palavras, os momentos mais importantes que fazem do "Nós Propomos um Projeto à frente do seu tempo".

Figura 11- A imprescindível parceria da Câmara Municipal de Faro

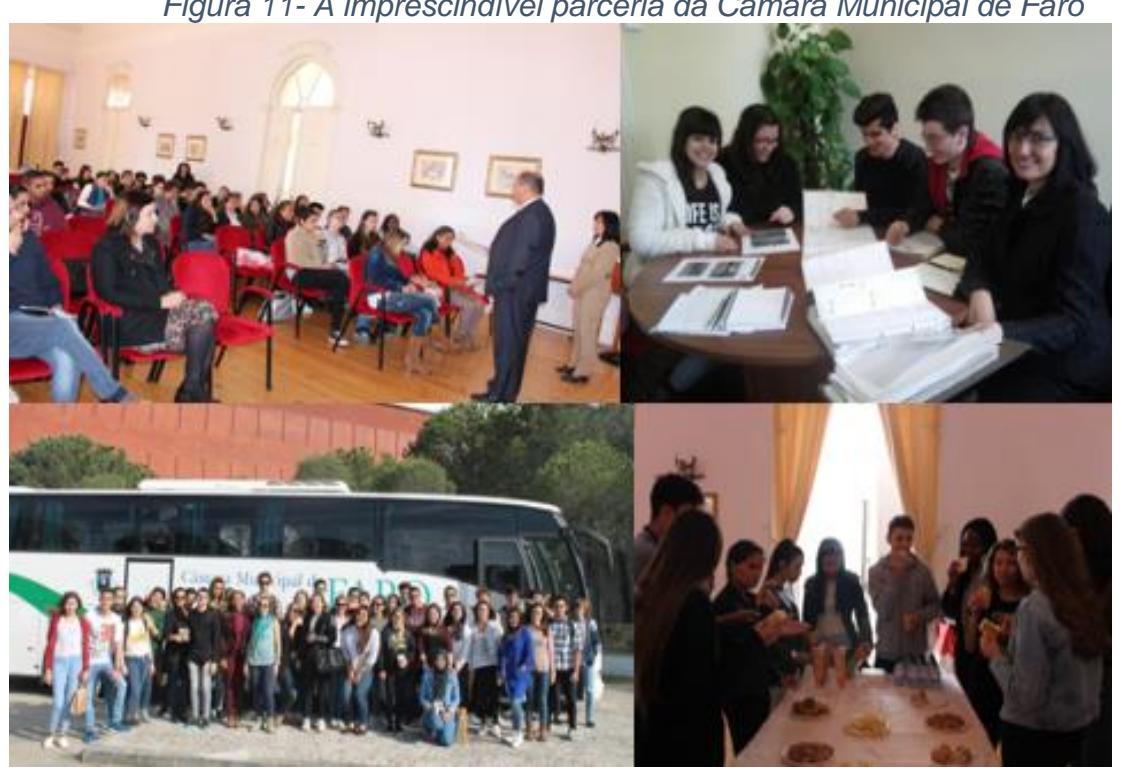

O ponto culminante dos trabalhos não podia deixar de ser a sua apresentação pública.

Depois da apresentação na Câmara Municipal em que temos oportunidade de escutar preciosas recomendações e felicitações pelo esforço efetuado, chegamos ao Seminário Nacional Anual, momento tão esperado de encerramento dos trabalhos!

Aí aprende-se com as apresentações dos alunos de outras escolas:

$\checkmark$ as formas inovadoras e os caminhos percorridos na realização dos trabalhos;

$\checkmark$ as soluções propostas para problemas idênticos; 
$\checkmark$ a identificar e valorizar as dificuldades e os sucessos dos colegas que também são os seus;

$\checkmark$ as grandiosas sessões plenárias na Reitoria da Universidade de Lisboa onde se identificam com o Projeto - "a causa".

Tudo isto e muito mais faz deste um dia inesquecível para quem nele participa anualmente.

Figura 12- - Apresentação dos trabalhos no IGOT - Universidade de Lisboa

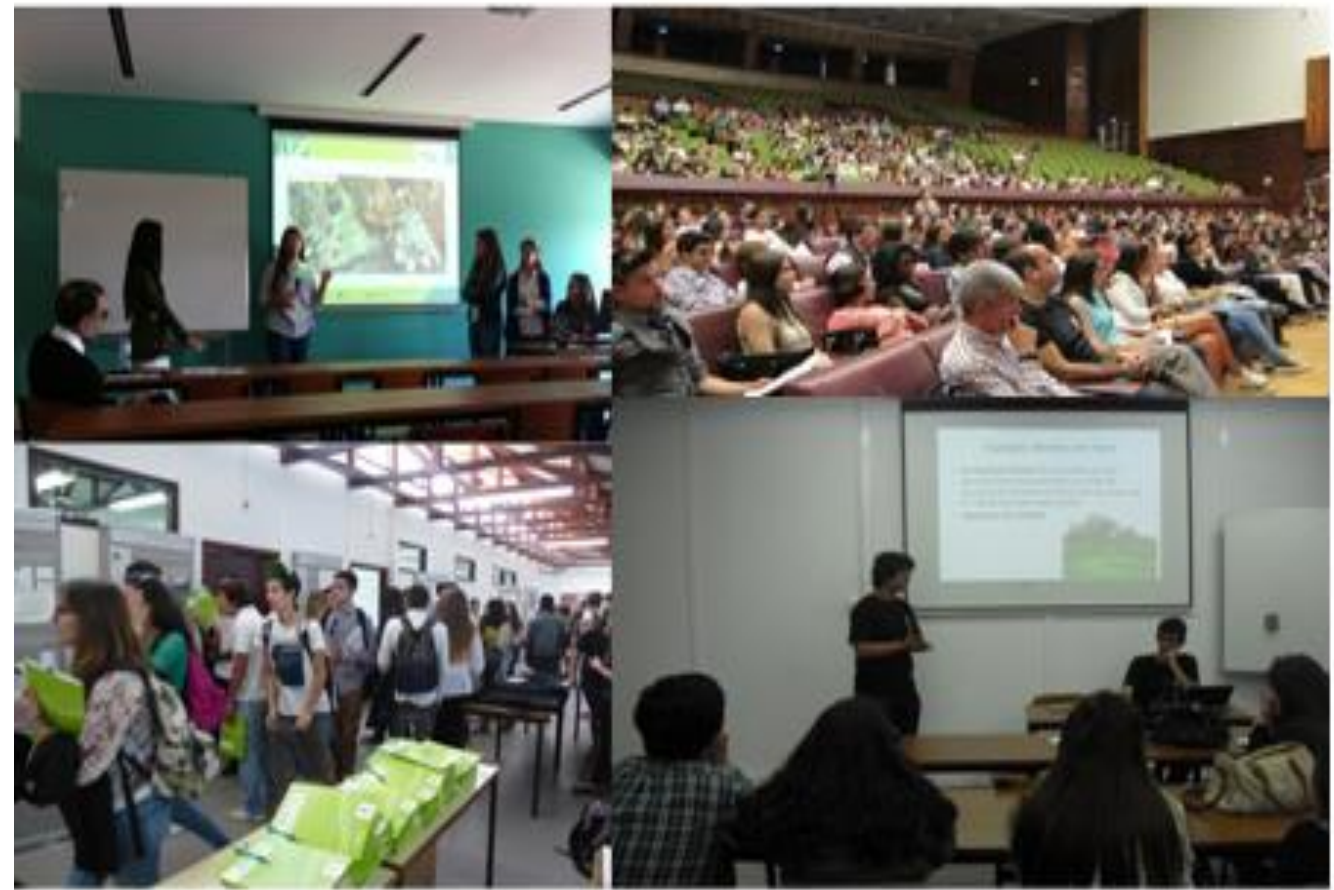

Outro aspeto, de grande valor, trata-se da certificação de alunos e professores. Esta assume cada vez maior importância, no registo e valorização do trabalho efetuado e na promoção pessoal de cada um. 


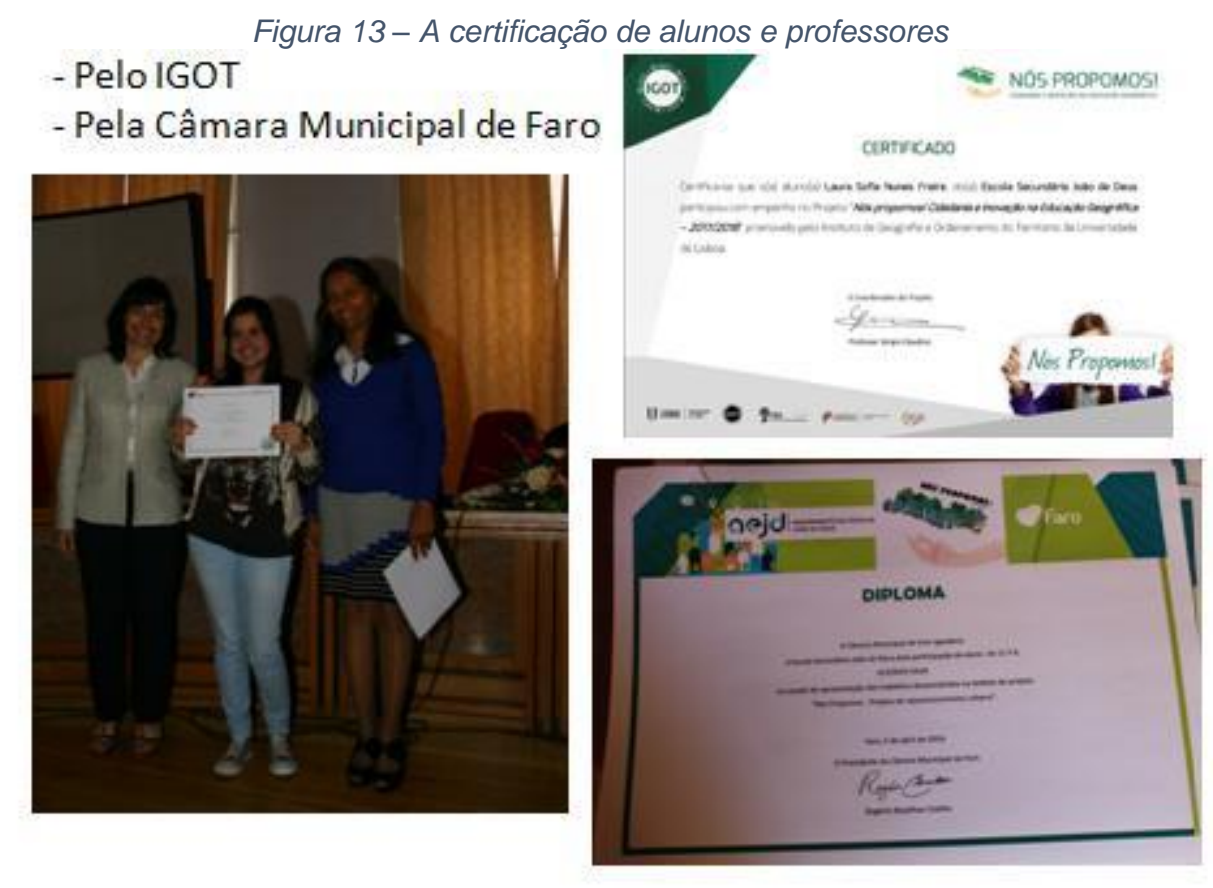

De seguida registam-se alguns momentos muito marcantes na história do nosso percurso, no Projeto "Nós Propomos".

Figura 14 - Atividades fundamentais do Projeto

Sessão inicial de formação/abertura anual do Projeto

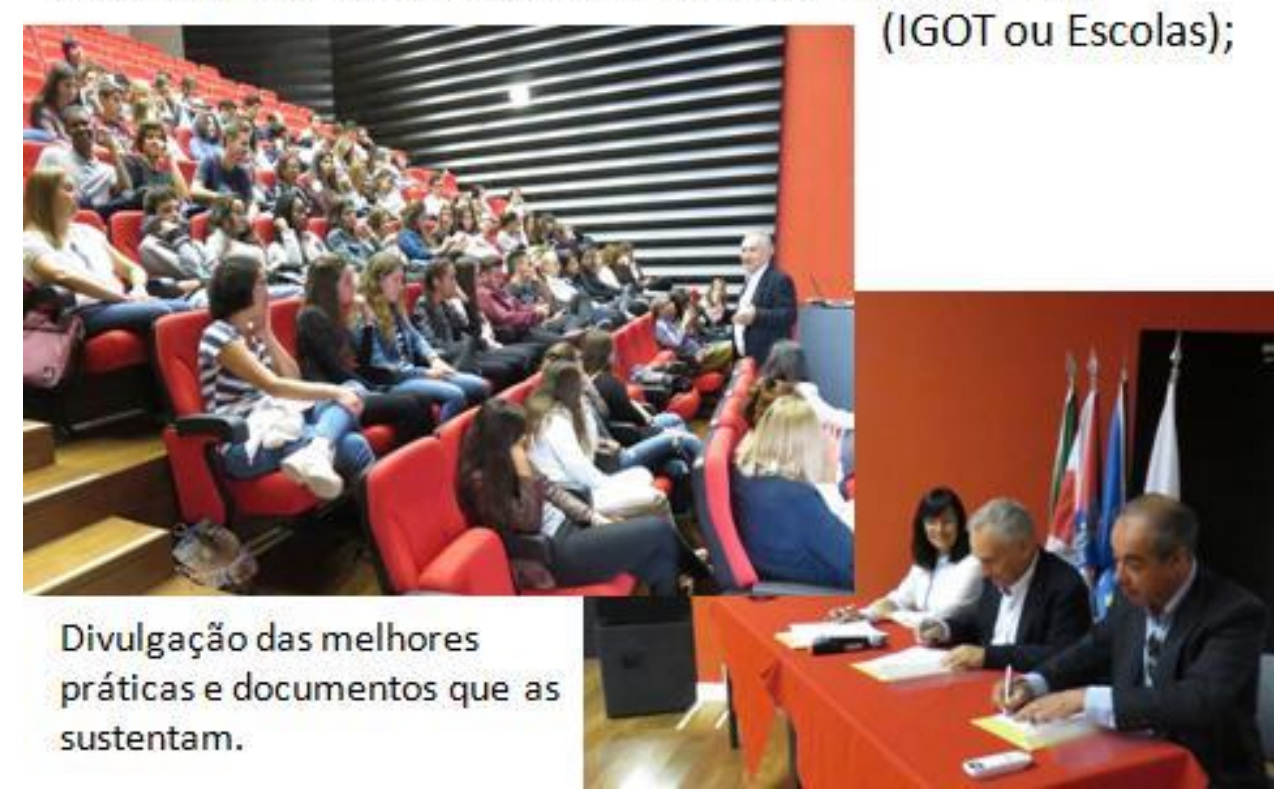

Em 2013, o "Green Project Award" premiou, na primeira iniciativa jovem - Projeto "Dá o teu 80" a nível nacional, o conjunto de trabalhos que os alunos da Escola Secundária João de Deus - Faro designaram de: "Nós propomos: Conhecer para melhorar Faro", fundamentados em dois grandes objetivos que lhes valeram o galardão: 
- Pensar criticamente o espaço geográfico, numa perspetiva de sustentabilidade;

- Desenvolver o sentido de pertença e uma cidadania ativa e participativa.

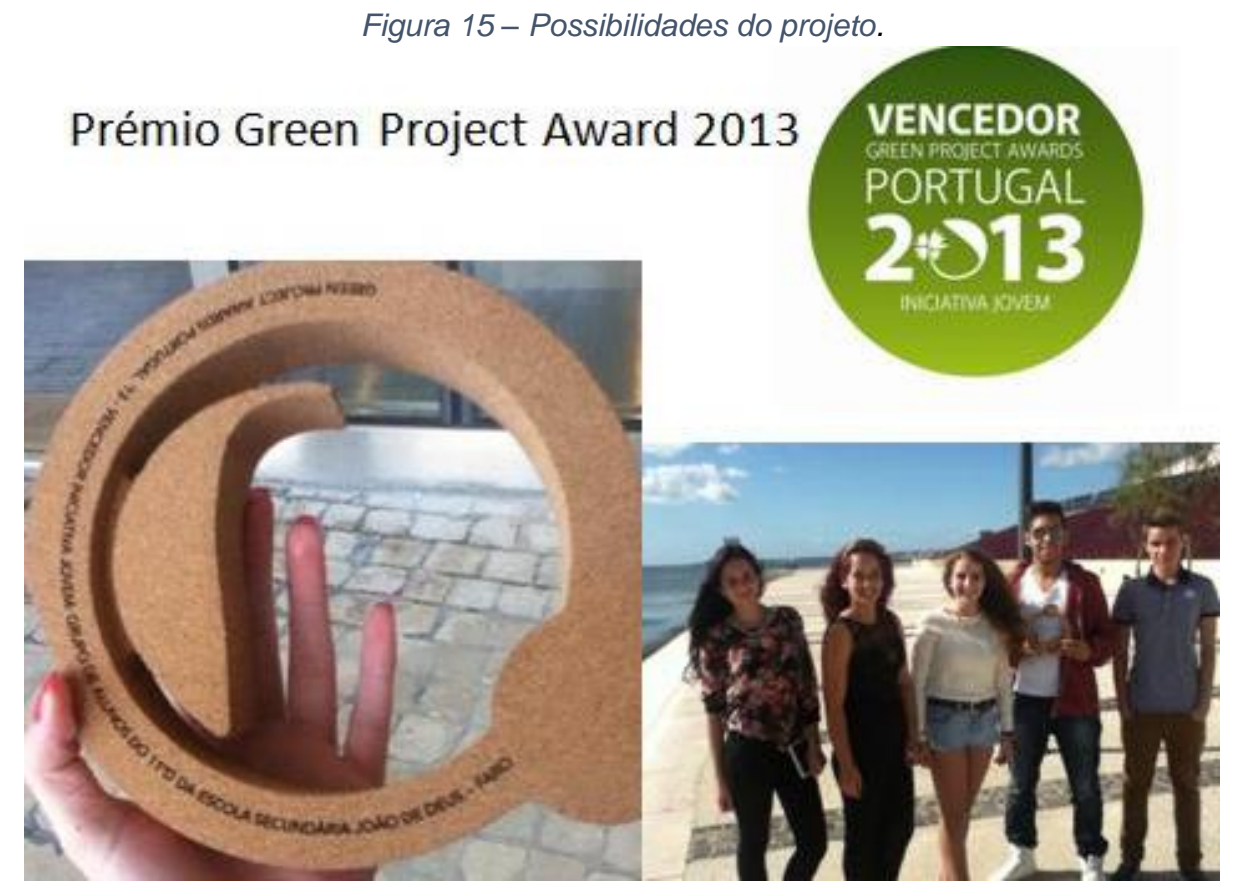

Os nossos alunos também se esforçam por dinamizar o Projeto "Nós Propomos"..., neste caso apresentando - o, num dos Encontros Nacionais da Associação dos Professores de Geografia que em 2014, se realizou no Algarve, em Silves.

Figura 16 - Outras Possibilidades do Projeto Apresentação do Projeto no Encontro Nacional Anual da A.P.G. Silves, $12 / 04 / 2014$

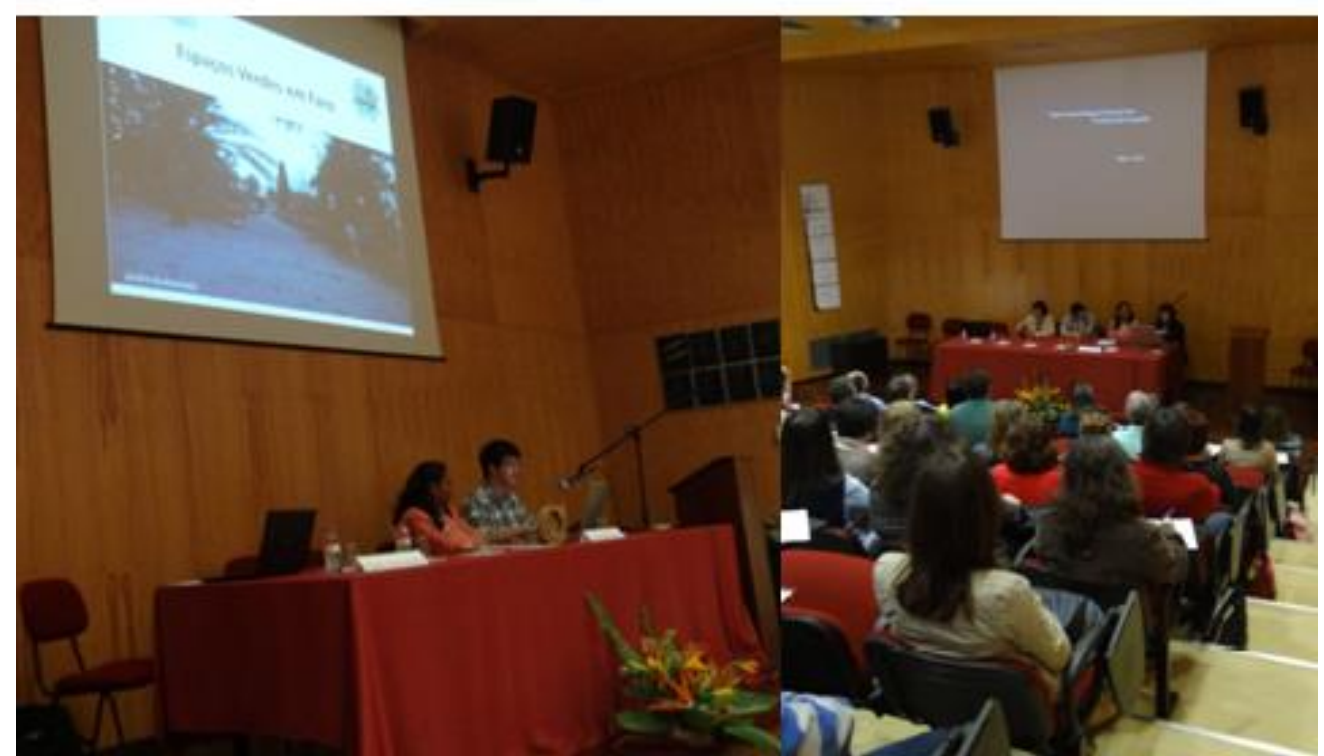


O Projeto "Nos Propomos..." tem premiado outras iniciativas como a elaboração do logotipo anual, da melhor fotografia, do melhor vídeo e do melhor texto ou seja preocupa-se também com os valores estéticos (Cláudino 2018).

Mas, desta vez houve uma iniciativa transfronteiriça de formação de professores, uma Visita de Estudo em que não faltou História e histórias, cultura e Geografia como não podia deixar de ser.

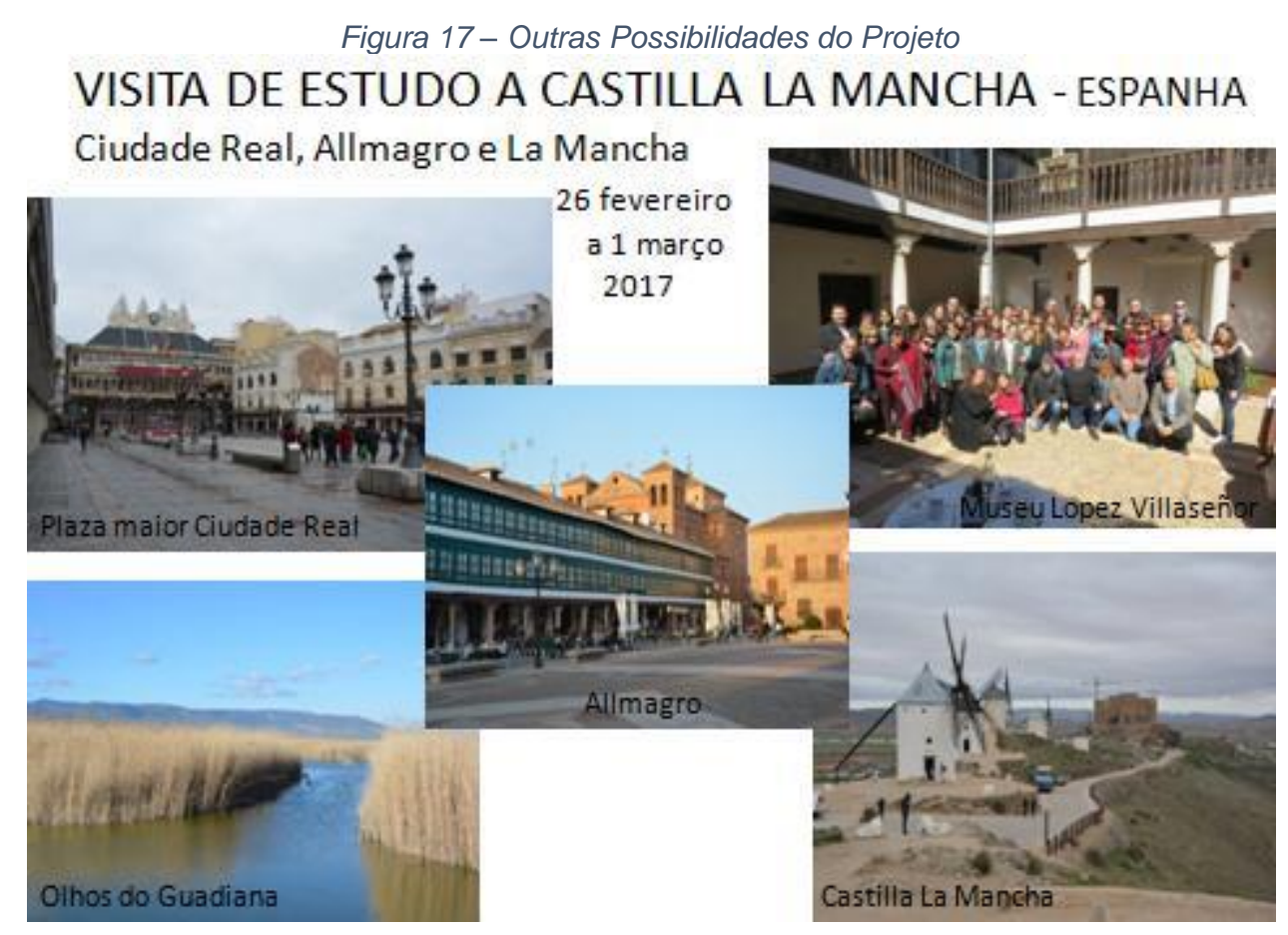

\section{Conclusão}

Está assim, completo o círculo, registos do passado que se confundem com o presente, alunos que agem sobre o território e professores que orientam e ajudam.

Do perfil de aluno que hoje nos é exigido, resta aos professores de Geografia que partilham este Projeto, continuar a estimular os seus alunos a procurarem melhor informação sobre o seu território e a refletirem sobre que futuro querem para o mesmo, a exigirem livremente mas com consciência cidadã, uma melhor qualidade de vida nesses espaços. 


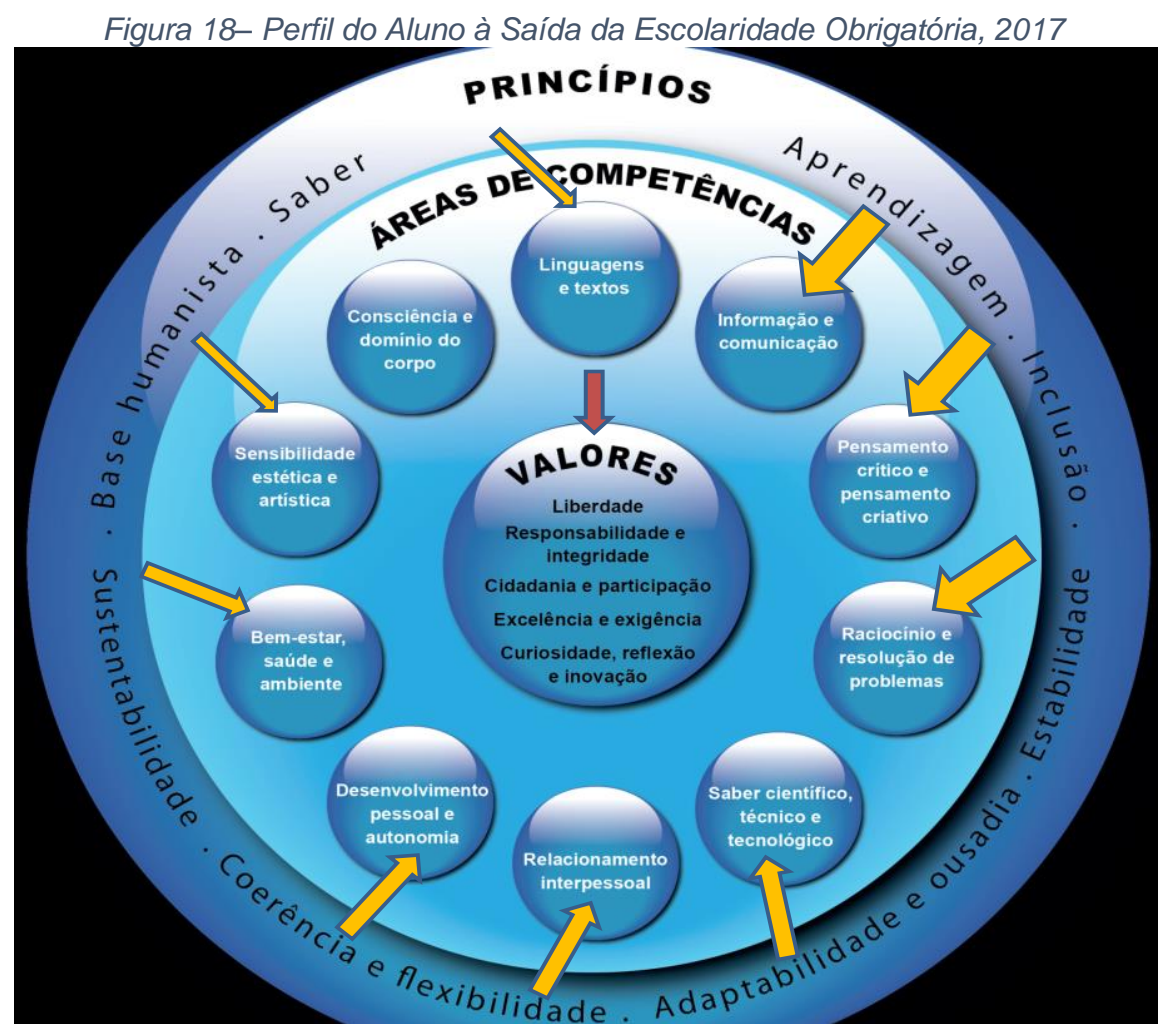

Fonte: ME, 2017

De hoje em diante, quer-se do aluno que: "mobilize valores e competências que the permitem intervir na vida e na história dos indivíduos e das sociedades, tomar decisões livres e fundamentadas sobre questões naturais, sociais e éticas, e que disponha de uma capacidade de participação cívica, ativa, consciente e responsável." (in Perfil do Aluno à saída da escolaridade obrigatória, 2017).

Este tem sido o lema do Projeto "Nós propomos": Inovação e Cidadania a Educação Geográfica desde o ano letivo 2011/12 em que se iniciou em Portugal. Hoje estas virtudes, colocaram-no já em mais 3 países, Espanha, Brasil e Moçambique.

\section{Referências bibliográficas}

Documentos produzidos para o Projeto de Autonomia e a Flexibilidade Curricular 2017/18:

ME (2017) Estratégia Nacional de Educação para a Cidadania. Disponível em http://www.dge.mec.pt/sites/default/files/ECidadania/Docs_referencia/estrategia_cidad ania_original.pdf

ME (2017) Perfil do aluno à saída da escolaridade obrigatória. Disponível em http://www.dge.mec.pt/sites/default/files/Curriculo/Projeto_Autonomia_e_Flexibilidade/ perfil_dos_alunos.pdf 
ME (2018) Aprendizagens Essenciais - Geografia A. Disponível em http://www.dge.mec.pt/sites/default/files/Curriculo/Aprendizagens_Essenciais/10_geogr afia a.pdf $10^{\circ}$ ano http://www.dge.mec.pt/sites/default/files/Curriculo/Aprendizagens_Essenciais/11_geogr afia_a.pdf - $11^{\circ}$ ano

Documentos estruturantes da Educação para o séc.XXI:

APA (2017). Estratégia Nacional de Educação Ambiental 2020. Disponível em https://www.apambiente.pt/zdata/DESTAQUES/2017/ENEA/AF_Relatorio_ENEA2020 .pdf

DGE (2018). Referencial de Educação Ambiental para a Sustentabilidade,ME

ONU (2017).Objetivos do Desenvolvimento Sustentável para 2030, nํํํㅡㄹ Educação de Qualidade e $11^{\circ}$ Cidades e Comunidades Sustentáveis

Estratégia Nacional de Educação para o Desenvolvimento 2018-2022, Diário da República, $1^{\text {a }}$ série, ํํำ 135 de 16 de julho

Documentos de base pedagógico-didática:

Claudino, S.(2018). Educação Geográfica, trabalho de campo e cidadania. O projeto "Nós Propomos" in Veiga, F. (coord.). O Ensino na Escola de Hoje - teoria, investigação e aplicação, cap.9, Climepsi Editores

Galeana, L. (2016). Aprendizaje basado en proyectos. Disponível em:http: www.ceupromed.ucol.mx/revista/PdfArt/1/27.pdf, em 25 de agosto de 2018

Kagan, S. (2013). Cooperative learning structures. San Clemente, CA: Kagan Publishing

Mora, F. (2013). Neuroeducación. Solo se puede aprender aquello que se ama. Madrid: Alianza Editorial

Murga, M. (2018). Trabalho por Projetos. Manual de formação docente, 43-110. Editora Santillana 999. 


\title{
A representação do lugar: um repensar sobre a realidade vivida
}

\author{
GABRIELA GERON ${ }^{13}$ \\ ROSEMY DA SILVA NASCIMENTO ${ }^{14}$
}

\section{Resumo}

No ensino da Geografia, a utilização de mapas, traz noções espaciais que são compreendidas pela mediação de teorias e práticas, essas representações, quando vistas como recursos mecanicistas, constituem-se em meras atividades sem sentido. É importante rompermos essa visão e utilizarmos as representações cartográficas como fonte de conhecimento e reflexão. Desenvolvemos um trabalho relacionando a Geografia e a cidadania com alunos do 9 ano do Ensino Fundamental, objetivando de proporcionar aos estudantes a construção de uma visão crítica sobre o seu lugar cotidiano, utilizando como base a articulação entre a Geografia escolar e a cartografia social. No decorrer do trabalho os alunos observaram o caminho até a escola e o representaram a partir de desenhos, socializaram e elaboraram um texto coletivo apontando o resultado da análise espacial que realizaram. Buscamos nesse trabalho instigar a criticidade, pois os conhecimentos foram contextualizados a partir dos interesses dos estudantes.

Palavras-chave: Geografia escolar, criticidade, cartografia social.

\section{Resumen}

En la enseñanza de la Geografía, la utilización de mapas, trae nociones espaciales que son comprendidas por la mediación de teorías y prácticas, esas representaciones, cuando vistas como recursos mecanicistas, se constituyen en simples actividades sin sentido. Es importante romper esa visión y manejar las representaciones cartográficas como fuente de conocimiento y reflexión. Desarrollamos un trabajo relacionando la Geografía y la ciudadanía con alumnos del 9 año de la Enseñanza Fundamental, con

\footnotetext{
${ }^{13}$ Doutoranda, Programa de Pós-Graduação em Geografia da Universidade Federal de Santa Catarina,gabi_geron@hotmail.com

${ }_{14}$ Docente permanente do Programa de Pós-Graduação em Geografia da Universidade Federal de Santa Catarina, rosemy.nascimento@gmail.com
} 
el objetivo de proporcionar a los estudiantes la construcción de una visión crítica sobre su lugar cotidiano, utilizando como base la articulación entre la Geografía escolar y la cartografía social. En el transcurso del trabajo los alumnos observaron el camino hasta la escuela y lo representaron a partir de dibujos, socializaron y elaboraron un texto colectivo apuntando el resultado del análisis espacial que realizaron. Buscamos en ese trabajo instigar la criticidad, pues los conocimientos fueron contextualizados a partir de los intereses de los estudiantes.

Palabras clave: Geografía escolar, criticidad, cartografía social.

\section{Introdução}

As representações cartográficas são confundidas com recursos mecanicistas, constituindo, em sala de aula, em atividades sem sentido, meramente empíricas. Essa visão metodológica faz com que os alunos não desenvolvam o entendimento da realidade a partir da cartografia. Uma maneira de construir um elo entre a cartografia e o cotidiano dos alunos é utilizando da cartografia social, esta que é uma metodologia que inicialmente era utilizada na luta e defesa de território por comunidades tradicionais e grupos sociais, hoje, em sala de aula, contribui de forma significante para o ensino e aprendizagem.

O objetivo desse trabalho foi proporcionar aos estudantes a construção de uma visão crítica sobre o seu lugar cotidiano, utilizando como base a articulação entre a Geografia escolar e a cartografia social. No decorrer do trabalho, os alunos observaram o caminho até à escola e o representaram a partir de desenhos, socializaram e elaboraram um texto coletivo, apontando o resultado da análise espacial que realizaram. Buscamos nesse trabalho instigar a criticidade, pois os conhecimentos foram contextualizados a partir dos interesses dos estudantes. Utilizando, como base bibliográfica, leituras sobre Geografia escolar, cartografia escolar e social, e ensino emancipatório de Paulo Freire.

Conforme Kimura (2010), o professor vai ao encontro das necessidades dos alunos, cabe-nos, enquanto professores, fazermos a iniciação ao desenvolvimento do mundo. Trata-se de uma maneira de analisar o mundo, explicitada pelos filósofos da Escola de Frankfurt. Crítica esta que ressalta que o encantamento pela aprendizagem pode ser restaurado pelas transformações que podemos realizar, principalmente quando o aluno desenvolve a sua imaginação, em especial através da arte, no nosso caso a arte relacionada a cartografia social. 
As representações cartográficas possuem um papel importante no processo de ensino e aprendizagem de abstração do concreto. Se utilizadas e contrastadas com a realidade, os alunos estimulam os conceitos espontâneos e desenvolvem os conhecimentos científicos da Geografia. Mas para isso é necessário, segundo Francischett (2014), que o mapa seja abordado de um ângulo que permita explicar a percepção e a representação da realidade geográfica como parte de um conjunto maior, que é o próprio pensamento do sujeito.

Ler graficamente o espaço faz parte do processo de aprendizagem, um processo de produção de significados, e, ao trabalhar com diversas representações elaboradas pelos alunos, contribui para a produção de significados e para a compreensão do conteúdo concreto.

O trabalho está organizado em duas partes. Na primeira, apresentamos algumas bases teóricas sobre a Geografia escolar e a importância do uso de representações em sala de aula, após apresentamos uma breve discussão sobre o ensino emancipatório para a cidadania, a partir do livro "Pedagogia da Autonomia", de Paulo Freire, e finalizamos a primeira parte relacionando a metodologia da cartografia social com a Geografia escolar para o ensino e a cidadania. $\mathrm{Na}$ segunda parte, apresentamos os caminhos trilhados para o desenvolvimento do projeto na escola epor fim, apresentamos os resultados obtidos.

\section{Reflexões}

\section{Geografia escolar e o uso de mapas}

A Geografia é uma ciência que utiliza, como um dos recursos básicos, as representações cartográficas, dentre elas também as imagens. Por isto, recorre a diferentes linguagens e informações, como forma de expressar suas interpretações, hipóteses e categorias.

No ensino da Geografia, a utilização de mapas traz noções espaciais que são compreendidas pela mediação de teorias e práticas. Tanto que, se apresentarmos um mapa para os alunos, sem explicar teoricamente o que ele contém, nada vai adiantar, eles verão apenas uma figura meramente ilustrativa, eles precisam entender a sua finalidade.

O ensino pelo mapa, que segundo Martinelli (2014), é praticado em Geografia para o conhecimento do mundo, desde o próximo vivenciado e conhecido - o lugar - ao 
distante desconhecido - o espaço mundial -, não de forma linear, mas mediante cotejamento entre os vários níveis de abordagem. Assim, haverá compreensão de como a realidade local se relaciona com o todo mundial.

Para Oliveira (2007), a Cartografia é fundamental para o ensino de Geografia, é importante recurso metodológico na educação contemporânea, tanto para que o aluno tenha a capacidade de analisar o espaço em que vive, quanto para atender às necessidades do seu dia-a-dia. Por meio dessa linguagem se torna possível realizar a síntese de informações, como também representar conteúdos. Mas, precisamos ficar atentos, pois, segundo Cavalcanti (2002), os tópicos de conteúdo da Cartografia como escala, por exemplo, não podem ser considerados como temas a mais no ensino dessa ciência. Ao contrário, se trata de um conhecimento cujo tratamento deve perpassar todos os outros conteúdos, fazendo parte do cotidiano das aulas dessa matéria.

O trabalho com imagens e a representação dos lugares são recursos didáticos interessantes, pelos quais os alunos poderão construir e reconstruir, de maneira cada vez mais ampla e estruturada, as percepções da paisagem local, por meio de seus vínculos afetivos e de identidade com o lugar, no qual se encontram inseridos. Principalmente para a orientação e compreensão dos fenômenos por categorias, usados tanto para representação do conhecimento, bem como para o seu desenvolvimento, numa abordagem geográfica escolar. Ou seja, a representação cartográfica é voltada para a interpretação, entendimento e explicitação dos conteúdos geográficos.

A representação do espaço geográfico ocorre por meio de cartas, plantas, croquis, mapas, globos, fotografias, imagens de satélite, gráficos, perfis topográficos, maquetes, textos e outros meios que utilizam a linguagem cartográfica. A função da linguagem cartográfica é a de comunicação de informações sobre o espaço, daí a necessidade de haver uma situação comunicativa para que a atividade seja significativa e ocorra aprendizagem e avaliação do processo, além de contribuir para que mais pessoas tenham acesso ao conhecimento. Pelas representações cartográficas, é possível mediarmos o conhecimento do espaço que, como fator social, é um espaço vivido e um campo de representações simbólicas.

Ao utilizar o mapa no ensino do espaço geográfico, segundo Francischett (2012), não pode ficar na condição de levantar categorias. Mas de entendê-las para configurar o objeto de estudo, o que é possível por meio da Geocartografia, que concebe o espaço geográfico como espaço social, numa realidade em que alunos e professores estão 
situados, localizados na prática que vivenciam e, a partir disso, se relacionam com o cotidiano, o lugar.

As representações, quando vistas como recursos mecanicistas, se constituem em meras atividades sem sentido. Essa visão metodológica prepara mal os alunos para o entendimento da realidade.

Uma boa análise da representação cartográfica é condição necessária para indicar se, no mapa, há conhecimento que possibilite, ao leitor, entender a espacialidade que ele representa. Por isso, é a linguagem cartográfica que vai auxiliar na compreensão do espaço representado, que, por vezes, pode ser o lugar em que os alunos residem.

\section{Ensino para a cidadania}

O ensino para a cidadania tem como objetivo formar para a vida, formar um cidadão, um ser racional. Fazer da prática de ensinar não ser somente repassar o que estão nas diretrizes, mas transformar os alunos. Freire (1996) explicita que ensinar é muito mais do que puramente treinar o educando no desempenho de destrezas. É necessário refletir sobre as práticas em sala de aula, nos questionarmos se estamos preparando seres condicionados, que vão sendo construídos e modificados com o tempo ou objetos já construídos e determinados para o mundo.

Ao iniciar a discussão com os alunos podemos compreender a razão de ser de alguns desses saberes, em relação com o ensino dos conteúdos. "Aproveitar da experiência que têm os alunos de viver em áreas da cidade descuidadas pelo poder público para discutir (Freire, 2001, p. 31)". Essa é uma das metodologias utilizadas para tornar os alunos participantes, trazendo a realidade concreta e suas diversas opiniões sobre 0 espaço vivido, para que consequentemente possamos discutir o conteúdo que está sendo apresentado.

Freire (1996) é enfático ao citar que ensinar não é transferir conhecimento, mas criar as possibilidades para a sua própria produção ou a sua construção. Humanos são diferentes de animais, pois somos inacabados, nos construímos com o tempo, já os animais são predestinamos a viver sem opção de escolhas e, como educadores, precisamos reconhecer que nossos educandos são seres inacabados e, ao termos consciência de que somos inacabados, sabemos que precisamos ir em busca de conhecimento sobre nossa experiência vivida e é contextualizando com a realidade que conseguimos trazer os alunos a participar das aulas. 
Desafiar os alunos leva a curiosidade, que torna o diálogo aberto de diferentes opiniões, fazendo com que sejam analisadas diferentes formas de pensar, é outra maneira de tornar os alunos mais autônomos e capazes de ter um raciocino próprio. Paulo Freire (1996) cita que exercendo como ser humano a irrecusável prática de inteligir, desafiar o educando com que se comunica, a quem comunica, a produzir sua compreensão do que vem sendo comunicado, os alunos passarão a ter a curiosidade pela pesquisa e, assim, tornando-se autores do próprio conhecimento.

Através da curiosidade e os estímulos aos alunos, os resultados são melhores, pois eles passam a não ser apenas receptores de conteúdos e sim participantes e em busca de conhecimentos. Freire (1996) assume que não tem dúvida nenhuma do enorme potencial de estímulos e desafios à curiosidade que a tecnologia põe a serviço das crianças e dos adolescentes das classes sociais chamadas favorecidas. Assim os alunos se tornam epistemologicamente curiosos e, por consequência, cidadãos ativos na sociedade.

A partir do momento em que o aluno começa a obter a percepção de que é algo pertencente e opinante crítico no mundo, ele passa a ter liberdade mesmo que esteja sendo ensinado dentro do modelo autoritário, diferentemente do que muitos pensam. "Quanto mais criticamente a liberdade assuma o limite necessário tanto mais autoridade tem ela, eticamente falando, para continuar lutando em seu nome (Freire, 1996, p. 103)". E é com essa liberdade crítica que os educandos vão cada vez se tornando mais autônomos ao longo do tempo, a autonomia vai se constituindo na experiência de várias, inúmeras decisões que vão sendo tomadas.

\section{Cartografia social e Geografia escolar}

A escola pública que desejo é a escola onde tem lugar de destaque a apreensão crítica do conhecimento significativo através da relação dialógica. É a escola que estimula o aluno a perguntar, a criticar, a criar; onde se propõe a construção do conhecimento coletivo articulando o saber popular e o saber crítico, científico, mediados pelas experiências no mundo (Freire, 2001). A partir dos ideais de Freire, busca-se uma maior participação dos alunos nas aulas de Geografia, onde eles sejam sujeitos ativos ao apresentarmos situações problemas relacionadas com a matéria escolar.

Uma forma de levar aos alunos uma Geografia Escolar crítica é transformando os alunos em protagonistas do conhecimento, para que eles, a partir de suas experiências compartilhadas, criem possibilidades pedagógicas para desenvolvermos 
um processo educacional com maior interesse de todos, contrapondo cada vez mais a "educação bancária" criticada por Paulo Freire.

A Cartografia Social aparece como metodologia participativa que acrescenta muito às aulas de Geografia, pois ela é uma ferramenta que permite inserir os alunos no processo de produção de mapas. Segundo Acselrad (2013), a Cartografia Social é compreendida como um processo e não uma técnica de representação em si, que tem como princípio a auto representação do sujeito. Esse processo envolve percepção, concepção e representação. Ela não se restringe a localizar e distribuir os elementos do espaço representado, mas sim expressar, por meio da representação, suas necessidades, que muitas das vezes são negligenciadas pelos representantes do poder público.

A Cartografia Social é um ramo da ciência cartográfica que trabalha, de forma crítica e participativa, com a demarcação e a caracterização espacial de territórios em disputa, de grande interesse socioambiental, econômico e cultural, com vínculos ancestrais e simbólicos (Gorayeb \& Meireles, 2014). Diferente da Cartografia Convencional, a Cartografia Social valoriza o espaço vivido e percebido. O conteúdo dos símbolos e o posicionamento político são tomados como princípio.

Por meio da cartografia social as consciências espaciais, sociais, ambientais e econômicas podem aparecer, o que é um grande diferencial relacionado à amplitude de temáticas que podem ser envolvidas e trabalhadas com o uso dessa metodologia nas aulas, favorecendo o posicionamento dos alunos. O cotidiano se torna o ponto de partida. Ao compartilhar suas representações com os demais colegas, começa-se a tracejar o que há de comum e o que há de discordante.

A participação na elaboração das representações é uma maneira de fortalecer a mobilização, onde os alunos se apropriam da cartografia para seus interesses. E a participação de alunos, não deve se restringir à confecção dos mapas, pois a partir do processo de construção de mapas, demandas são fortalecidas e há o reconhecimento de direitos, o que pode direcionar estratégias de atuação coletiva (Plessman, 2013).

O estudo do lugar vivido, conforme Straforini (2008), possibilita ao professor de Geografia trabalhar a realidade dos alunos, para além dos limites administrativos e do município, embora esses conceitos políticos administrativos sejam importantes, uma vez que revelam a sua história. $\mathrm{E}$, quando relacionado à Cartografia Social, levamos a sala de aula a uma categoria que não menospreza o real, o vivido. 


\section{Desenvolvimento}

A partir das leituras de Paulo Freire, procuramos levar para a sala de aula uma nova metodologia de ensino para envolver os alunos como atores no ensino e, por consequência, cidadãos reflexivos e participantes no lugar em que vivem.

Desenvolvemos um trabalho relacionando a Geografia e a cidadania com alunos do 9. ano do Ensino Fundamental do Centro Educacional Roberto Trompowsky, localizado na área central do município de Joaçaba, no estado de Santa Catarina, Brasil, conforme mostra o mapa de localização a seguir.

Figura 14 - Localização do município onde foi desenvolvido o trabalho

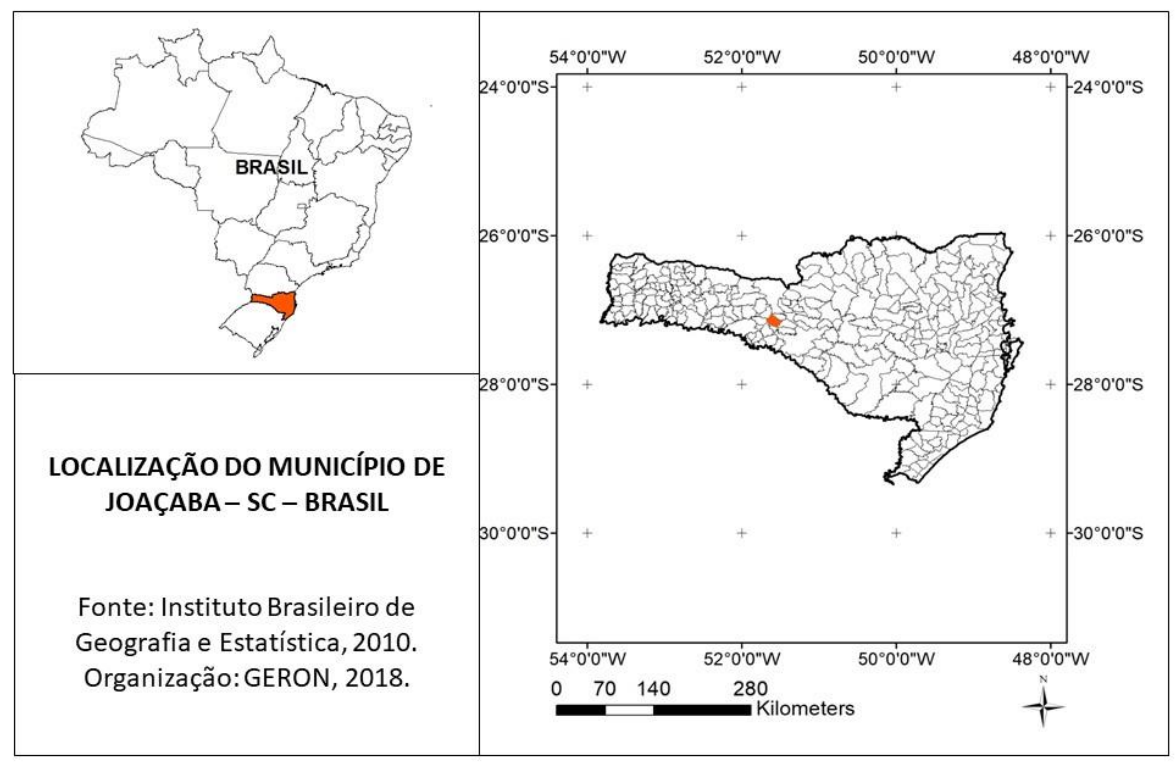

Fonte: IBGE, 2010. Organização: Geron, 2018.

O trabalho foi desenvolvido em 5 etapas:

1a etapa: Conversa sobre como desenvolveríamos o projeto e a importância da observação do caminho percorrido entre sua casa e a escola.

2a etapa: Observação e elaboração de representações cartográficas do caminho de casa até a escola, destacando coisas que lhe chamam a atenção e o que acreditam que poderia ser modificado. Apresentamos, a seguir, uma das representações dos alunos. 

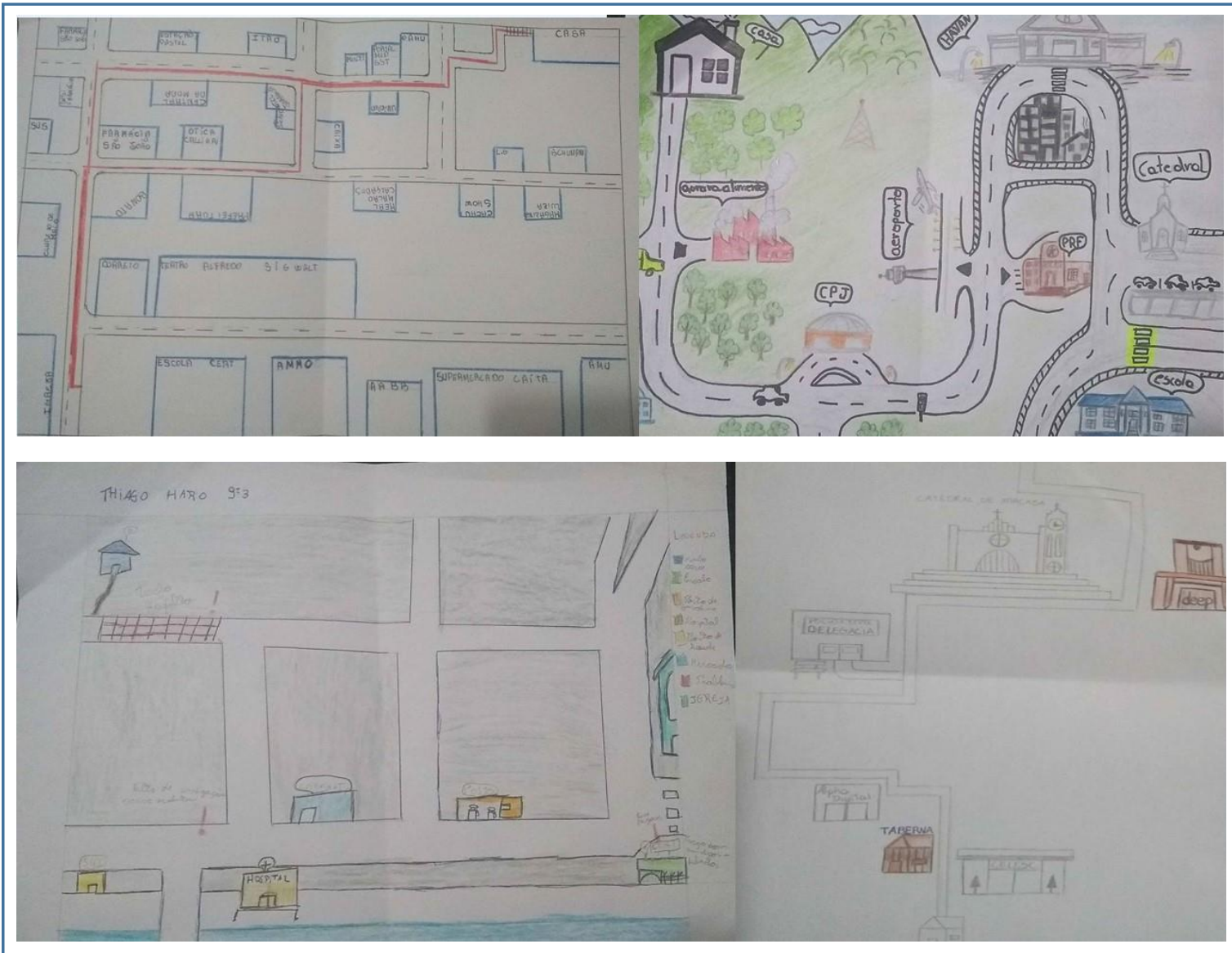

Fonte: Arquivo pessoal, 2018

3aㅡ etapa: Apresentação das representações em roda de conversa durante a aula, para assim discutirmos quais os principais pontos destacados pelos alunos. Nessa etapa foram elencados 10 problemas que mais apareceram nas representações.

4a etapa: Discussão de soluções apontadas pelos alunos para melhorar os dez pontos apresentados como problemas em suas representações. Conforme demonstra a tabela 1.

Tabela 9 - Síntese da discussão

LOCAL

FRENTE A

PREFEITURA

FAIXA DE PEDESTRE NA FRENTE DA ESCOLA

\section{PROBLEMÁTICA}

Problemas com usuários de drogas que ficam no local durante a noite, e com isso a comunidade não sente segurança em passar pelo local.

Muitos motoristas não dão preferência aos pedestres e como consequência já aconteceram alguns acidentes no local.

\section{PROPOSTA}

Melhorar a vigilância com uso de câmeras de monitoramento; e campanhas publicitárias sobre maneiras de denunciar tráfico de drogas para polícia.

Instalar um semáfaro no local, o que auxiliaria as crianças que atravessam a rua para chegar na escola e também diminuiria o congestionamento. 
PONTE DE

ACESSO A

HERVAL

D'OESTE (SÃO

MIGUEL)

LOCAIS DE

FESTAS PELA

CIDADE

RUAS DE

BAIRROS QUE

ESTÃO

ABANDONADAS

POSTES DE

ILUMINAÇÃO

PÚBLICA NO

MEIO DAS

CALÇADAS E

ACESSIBILIDADE

PARA CEGOS

PRAÇA EM

FRENTE A

ESCOLA

\section{CIRCULAÇÃO DE \\ CAMINHÕES NO \\ CENTRO DA \\ CIDADE}

A presença de caminhões de carga no centro da cidade prejudica o andamento do trânsito.

Existem alguns postes de iluminação pública que ficam instalados no meio da calçada, o que prejudica a circulação de pessoas principalmente em dias de chuva e atrapalham a acessibilidade de cegos.

Utilizada como estacionamento, local de festas de carnaval, local de tráfico de drogas, pessoas dormindo de forma desumana, má utilização do espaço público.

\section{* O valor que não corresponde a qualidade dos automóveis.}

TRANSPORTE * $\quad$ Os horários que não são cumpridos e nem PÚBLICO divulgados para a população.

* Motoristas que andam em alta velocidade e muitas vezes não respeitam as regras de
Instalar um novo semáforo.

Maior controle do volume dos locais.

Olhar mais para os bairros do município, melhorando, principalmente, a iluminação pública.

Realocar os postes e melhorar a sinalização para cegos, e fazê-las de forma contínua, pois em alguns locais não possui sinalização e outros possuem.

* Proibir o estacionamento durante todos os dias da semana, 24 horas por dia.

* Solicitar que o carnaval seja realizado em outro local, onde não atrapalhe o funcionamento de escolas.

* Oferecer abrigo para pessoas que não têm moradia.

* Vigilância para inibir o tráfico de drogas no local.

Criar uma rota alternativa para caminhões de carga e proibir a circulação dos mesmos pelo centro da cidade.

${ }^{*} \mathrm{O}$ valor do transporte é mais alto que o valor do transporte de Florianópolis, e os carros não estão em bom estado de uso.

* Divulgar os horários das linhas do transporte em um site, para acesso de todos. 
trânsito.

Presença de muitos usuários de drogas, NOVO PARQUE

\author{
* Seria importante fiscalizar os \\ acordos feitos durante o processo \\ de licitação, principalmente em \\ questão de horários e condução \\ de motoristas. Realizar uma \\ campanha de denuncia da \\ população para esses casos \\ ajudaria na fiscalização.
}

Melhorar a vigilância com uso de câmeras de monitoramento; e campanhas publicitárias sobre maneiras de denunciar tráfico de drogas para polícia.

Fonte: Elaboração própria, 2018.

5a etapa: Elaboração coletiva e entrega ao poder público de um texto com as intervenções coletivas da análise espacial realizada em sala de aula, a partir das representações cartográficas apresentadas pelos alunos.

Por ser uma escola central, a escola acolhe alunos de vários bairros do município, o que foi muito rico para esse trabalho, pois conseguimos observar pontos de vista sobre vários locais do município. Mas destacamos que as maiores preocupações dos alunos são sobre as redondezas da escola, como exemplo temos a praça que fica em frente à escola, onde os alunos participantes apontaram que ela é subutilizada, como: a) estacionamento, o que pode ocasionar atropelamento de alunos; b) durante 0 carnaval é utilizada como ponto de festa e é urinado e jogado lixo no pátio da escola; c) presença de pessoas que dorme em situação desumana em um depósito localizado na praça; d) presença de tráfico de drogas; e) acreditam que é um espaço que o poder público poderia dar para a escola, pois a escola é pequena em relação ao número de estudantes matriculados.

Como resultado, obtivemos representações cartográficas a partir de diferentes visões de jovens moradores do município, o que aproxima os alunos da cartografia, da Geografia e do lugar.

Utilizando da cartografia social, foi dada voz aos alunos, todos participaram de todo 0 processo, dando opinião e principalmente apontando soluções. O desenvolvimento do trabalho auxiliou no desenvolvimento de uma visão crítica e cuidadosa sobre o município e, com isso, estamos formando jovens cidadãos reflexivos e opinantes. 


\section{Conclusão}

Fazer da prática de ensinar não ser somente repassar o que está nas diretrizes, mas transformar os alunos. "Formar é muito mais do que puramente treinar o educando no desempenho de destrezas, e por que não dizer também da quase obstinação com que falo do meu interesse por tudo o que diz respeito aos homens e às mulheres (Freire, 1996, p. 16)". Assim, estamos preparando seres condicionados, que vão sendo construídos e modificados com o tempo e não como objetos já construídos e determinados para o mundo. Não é utilizando de métodos meramente teóricos, transferindo conteúdos, tendo alunos como receptores de conteúdos e sim formando alunos cidadãos autónomos através da relação ensino e aprendizagem.

Utilizando da cartografia social na Geografia escolar conseguimos, nesse trabalho, envolver os alunos no processo de aprendizagem, onde, como atores do processo, desenvolveram representações e puderam expor e, por consequência, discuti-las com os demais. Ao instigá-los a pensar sobre o lugar que vivem, os alunos passaram a perceber que pertencem a esse lugar, que ele não é desconexo da vivencia diária deles e que, como cidadãos, podem ter voz ativa nesse meio.

A turma na qual foi realizado o trabalho é considerada de pouca participação e baixo rendimento na aprendizagem, mas durante o desenvolvimento do trabalho, desde a confecção das representações, até à do texto, todos os alunos participaram, dando suas opiniões e apresentando sua visão sobre o assunto.

Depois do momento da entrega do texto para o poder público foi realizada uma roda de conversa, onde os alunos citaram que o exercício realizado foi interessante, pois eles passaram a observar melhor o lugar por onde passam diariamente e perceberam que o Estado não é algo distante deles, que o direito à cidadania Ihes pertence e, como jovens, precisam se aproximar da gestão municipal para melhorar a sua realidade.

\section{Referências bibliográficas}

Acselrad, H. et al. (org). (2013). Guia Para Experiência de Mapeamento Comunitário, Rio de Janeiro, Versão brasileira: ETTERN/IPUR/UFRJ.

Cavalcanti L de S. (2002). Geografia e práticas de ensino: Geografia escolar e procedimentos de ensino numa perspectiva sócio construtivista. Goiânia: Alternativa.

Francischett N. M. (2012). Leitura de imagens para o entendimento do espaço Geográfico. In Revista Visão Global Edição Especial, Unoesc. 
Francischett N. M. (2014). Construindo elos metodológicos na linguagem cartográfica. Revista Brasileira de Cartografia n/ 66/4. Sociedade Brasileira de Cartografia, Geodésia, Fotogrametria e Sensoriamento Remoto. Disponível em: http://www.Isie.unb.br/rbc/index.php/rbc/article/viewFile/926/714

Freire, P. (1996). Pedagogia da autonomia: saberes necessários à prática educativa. São Paulo: Paz e Terra.

Freire, P. (2001). A educação na Cidade. $5^{\circ}$ ed. São Paulo: Cortez.

Gorayeb, A., Meireles, J (2014). Cartografia social vem se consolidando com instrumento de defesa de direitos. Rede Mobilizadores. Disponível em: <http://www.mobilizadores.org.br/coep/Publico/consultarConteudoGrupo.aspx?TP=V\& CODIGO=C20142610482831 >.

Kimura, S (2010). Geografia no ensino básico: questões e propostas. 2 ed. São Paulo. Contexto.

Martinelli, M., Hess-Machado, de S. E. (2014). Mapas estáticos e dinâmicos, tanto analíticos como de síntese, nos atlas geográficos escolares: a viabilidade metodológica. Revista brasileira de Cartografia. Disponível em: http://www.Isie.unb.br/rbc/index.php/rbc/article/view/930

Oliveira, L de (2007). Estudo Metodológico e Cognitivo do Mapa. In: ALMEIDA, Rosângela Doin de. (Org). Cartografia Escolar (pp. 15-42). São Paulo: Contexto.

Plessman, F (2013). Unidade M03U01, Módulo M03: Introdução à Participação; in: ETTERN/IPPUR/UFRJ, Guia Para Experiências de Mapeamento Comunitário. CTA, Países Baixos; Rio de Janeiro. Disponível em: http://www.ettern.ippur.ufrj.br

Straforini, R (2008). Ensinar Geografia: o desafio da totalidade-mundo nas séries iniciais. São Paulo: Annablume. 


\title{
O Processo de Revitalização do Centro Histórico de João Pessoa, Paraiba, Brasil.
}

\author{
REGINA CELLY NOGUEIRA DA SILVA ${ }^{15}$ \\ ANNA THERESA ROSENHAIM ${ }^{16}$ \\ MARIA EDUARDA VIANA PONTES DOS SANTOS ${ }^{17}$
}

\section{Resumo}

O Projeto "Nós Propomos Paraíba: revitalizando a cidadania através da educação" foi implementado no ano de 2018, através de um convênio institucional entre o Centro Estadual Experimental de Ensino-Aprendizagem Sesquicentenário, Escola Pública da Rede Estadual de Ensino, e a Universidade Estadual da Paraíba com o objetivo de compreender o processo de revitalização do Centro Histórico de João Pessoa, Paraíba, Brasil. A presente pesquisa teve como objetivo analisar as formas através das quais o processo de revitalização do Centro Histórico de João Pessoa repercute na dinâmica socioespacial da área, bem como a interação dos elementos intervenientes na construção de sua realidade atual. Da mesma maneira, é parte do nosso interesse a identificação dos tipos de políticas levadas a efeito pelo Estado a partir da década de 1980 até os dias atuais, juntamente com as ações postas em prática pelas representações de setores do poder econômico da nossa sociedade, no interesse de redimensionar a produção e a reprodução do mencionado espaço. Visamos analisar as contradições existentes entre o discurso oficial e a sua efetiva prática, nas ações direcionadas ao chamado processo de revitalização.

\footnotetext{
${ }^{15}$ Professora Dr do Departamento de Geografia da Universidade Estadual da Paraíba-UEPB, Campus III Guarabira. recelly51@hotmail.com

${ }^{16}$ Estudante do $3^{\circ}$ Ano do Ensino Médio do Centro Estadual Experimental de EnsinoAprendizagem Sesquicentenário, Rede Estadual de Ensino do Estado da Paraíba-PB annatheresarosenhaim@gmail.com

${ }^{17}$ Estudante do $2^{\circ}$ Ano do Ensino Médio do Centro Estadual Experimental de EnsinoAprendizagem Sesquicentenário, Rede de Ensino Estadual da Paraíba-PB mariaeduardapontes69@gmail.com
} 
Palavras-Chave: Centro Histórico; Revitalização; Patrimônio

\section{Abstract}

The project "Nós Propomos Paraiba: revitalizing citizenship through education" was implemented in the year 2018, through an institutional agreement between experimental state teaching-learning center Sesquicentenário, public school of the state education network, and the state university of Paraiba with the objective of understanding the revitalization process of the historical center of João Pessoa, Paraiba, Brazil. This research aims to analyze the ways how the revitalization process of the Historical Center of João Pessoa/PB is linked to the sociospatial dynamics of this area, as well as the existing interaction among the elements of its present situation. On the same way, is part of our interest the identification of the kind of policies carried on by the State, together with the economic power constitutive representation. We defined the period between the 1980 years until nowadays as the scope of our work, looking forward the production and reproduction of the mentioned space. We also analyze the contradiction between the government official speech and its effective practice through the actions toward the revitalization process.

Keyword: Historical Center, Revitalization, Patrimony

\section{Introdução}

O projeto Nós Propomos! Paraíba: revitalizando a cidadania através da educação passou a ser desenvolvido em João Pessoa na Escola Pública Centro Estadual Experimental de Ensino-Aprendizagem Sesquicentenário em parceria com a Universidade Estadual da Paraíba (UEPB), Campus III, Guarabira-PB e o IGOTInstituto de Geografia e Ordenamento do Território da Universidade de Lisboa, Portugal, a partir do primeiro semestre de 2018. Os encontros são semanais nas quintas-feiras turno da tarde, horário oposto às aulas regulares, com a participação da dos Professores do Sesquicentenário Joazadaque Lucena de Souza (Geografia) e Lara Torezzan Gonçalves Ramalho Nitão (Artes) e uma média de 15 estudantes do 1‥ $2^{\circ}$ e $3^{\circ}$ anos do Ensino Médio. Esses encontros tem me proporcionado momentos de inspiração e alegria para continuar na luta por uma educação de qualidade no nosso país nesse momento de tantas incertezas. O contato com os alunos e professores do Sesquicentenário me leva a acreditar que é possível sim termos uma educação púbica de qualidade e levarmos nossos alunos do ensino médio a cursar uma universidade pública. 
Nosso projeto conta também com uma rede de parceiros como o Departamento de História da Universidade Federal da Paraíba (UFPB), na figura da Professora Regina Célia Gonçalves e o Projeto Memória João Pessoa um projeto de extensão do Departamento de Arquitetura e Urbanismo da UFPB, representado pela professora Maria Berthilde de Barros Lima e Moura Filha. Vale ressaltar ainda que esse texto recebeu a contribuição de três alunas do ensino médio que juntas realizaram o levantamento da bibliografia e leituras acerca da temática abordada, Williana da Silva Santos, Conceição Aparecida de Souza, Thaís Soares de Araújo, obrigada pelas contribuições.

O projeto tem como objetivo principal estudar o processo de revitalização do Centro Histórico de João Pessoa, capital do estado da Paraíba, Brasil a partir de leituras, pesquisa e coleta de dados sobre o tema, fomentar práticas educativas exitosas entre docentes e discentes, intercâmbio entre escola e universidade; difusão de práticas cidadãs a partir da identificação de problemas socioambientais existentes no espaço urbano e a respectiva formulação de propostas para as resoluções dos mesmos. Se propõe a fomentar a consciência cidadã e incentivar uma efetiva cultura de cidadania territorial entre os jovens estudantes, estimulando o debate e à participação popular democrática com a finalidade de se garantir o direito à cidade e uma gestão democrática do espaço urbano.

As práticas educativas desenvolvidas consistem no levantamento de material bibliográfico e iconográfico sobre as temáticas escolhidas; leitura de livros, artigos científicos e matérias jornalísticas; realização de trabalhos de campo e visita de estudos às localidades e instituições; elaboração de relatórios, comunicações para congressos, capítulos de livro e artigos científicos a serem publicados em periódicos nacionais e internacionais, mas, sobretudo, estimular a discussão e o debate junto aos alunos do ensino médio acerca dos problemas existentes no Centro Histórico através de um processo permanente e sistemático de trabalho educacional centrado no Patrimônio Cultural como fonte primária de conhecimento e enriquecimento individual e coletivo. É a partir da experiência e do contato direto com as evidências e manifestações da cultura, em todos os seus múltiplos aspectos, sentidos e significados, que o projeto ganha relevância e busca levar os jovens a um processo ativo de conhecimento, apropriação e valorização de sua herança cultural, conscientizando-os da importância destes bens e de seu usufruto, propiciando a geração e a produção de novos conhecimentos, num processo permanente de criação cultural. 


\section{Processo de Revitalização do Centro Histórico de João Pessoa}

Nas últimas décadas do século $X X$, temos assistido ao desenvolvimento de novas dinâmicas que afetam diretamente o Centro Histórico de nossas cidades. Esses espaços são hoje objeto de dinâmicas múltiplas, de reinvestimentos importantes, tanto por parte do poder público, como das agências internacionais e da iniciativa privada. Operações complexas, embasadas quase sempre em projetos urbanísticos, que buscam a denominada "revitalização urbana", visam a introduzir novos parâmetros de desenvolvimento urbano.

Segundo seus idealizadores (quase sempre urbanistas, consultores internacionais e técnicos vinculados aos governos locais), essas intervenções visam a retomar e reescrever a história desses espaços, resgatar suas tradições e memórias, buscando, por meio da preservação e revitalização do patrimônio cultural, devolver aos espaços históricos a dinâmica perdida ou enfraquecida ao longo do tempo, mas, sobretudo, resgatar a centralidade do poder econômico, político e social que esses espaços possuíam.

Orientados por estratégias que visam à apropriação dessas áreas para o consumo visual, muitas vezes envolvendo seu enobrecimento e seu uso como produtos de consumo, na disputa entre os agentes das cidades em um mercado globalizado, como ressalta Motta (2000), esses projetos, embora utilizem a argumentação da preservação e do resgate da memória do lugar, têm como resultado a apropriação cenográfica desses espaços. Segundo Scocuglia (2004, p.19), "são processos que buscam dar novos usos ao patrimônio na tentativa de viabilizar o sistema econômico utilizando como recurso o dinamismo cultural e turístico de sítios de valor histórico, artístico, arqueológico e ambiental". No nosso entendimento, as novas intervenções pouco têm se preocupado em considerar as cidades como objetos socialmente construídos e seu patrimônio cultural como fonte fundamental de conhecimento e construção da cidadania.

Tais questões norteiam as reflexões deste capítulo e objetivam compreender os paradigmas que embasam essa denominada "revitalização" e suas especificidades. Para elaborá-lo, foram consultadas as referências bibliográficas que discutem a temática em nível nacional e internacional: teses, dissertações, textos e demais documentos embasaram as reflexões, bem como a análise do Projeto de Revitalização do Centro Histórico de João Pessoa e demais documentos produzidos pela Comissão Permanente de Desenvolvimento do Centro Histórico de João Pessoa ao longo dos anos. Para o enriquecimento da análise, utilizamos entrevistas com membros da 
Comissão Permanente de Desenvolvimento do Centro Histórico, Técnicos do IPHAN, estudiosos da área de humanas (geografia, história, arquitetura), além dos comerciantes e moradores da área.

Pretende-se, ainda, compreender esse modelo de intervenção urbana, assim como analisar se existe relação entre o discurso e a prática no âmbito do processo de revitalização urbana do Centro Histórico de João Pessoa. Visa-se, também, a compreender o que preconiza essas ações urbanísticas e de que forma essas ações repercutem na dinâmica socioespacial do Centro Histórico para a reprodução do capital.

Para que compreendamos as transformações nos centros históricos das cidades brasileiras nas últimas décadas do século $X X$ e a emergência dos projetos de "revitalização urbana", é necessário que depreendamos as mudanças no capitalismo desde a década de 1970, com a emergência da crise de reestruturação do capitalismo e como esse modo de produção produz o espaço, pressionado pelas novas exigências da acumulação.

Segundo Alvarez (2008), a emergência da crise e das alternativas de reestruturação do capitalismo que avançou na década de 1970 nos países centrais, abatendo-se nos países periféricos nos anos de 1980 e 1990, tomou expressão como uma crise da cidade, sobretudo nas metrópoles, nas cidades de maior infraestrutura, grandes unidades produtivas do período fordista, com grande concentração populacional e operária. Mas as cidades, fossem grandes, médias ou pequenas, sofreram as consequências desse modelo de desenvolvimento.

Nesse período, nossas cidades lidavam com o intenso, crescente e complexo processo de urbanização que se delineava desde a década de 1950 e transformava a paisagem urbana e a sociedade brasileira. Essas transformações ocorriam calcadas nas necessidades e contradições da acumulação capitalista e alicerçada pelo crescimento da atividade industrial - sobretudo, nas grandes metrópoles brasileiras marcadas por uma profunda segregação socioespacial. Neste sentido, as cidades brasileiras conviviam com o intenso processo de segregação socioespacial, com elevados custos de infraestrutura urbana, com carências no transporte urbano e com uma desmedida expansão horizontal e/ou ações urbanísticas demolitórias, justificadas pelos grandes projetos de renovação urbana.

Sánchez (2001), analisando alguns processos de reestruturação urbana na década de 1990, destaca que, nesse período, observam-se processos de reestruturação urbana, tendo como principais parceiros os governos locais e as agências internacionais na 
elaboração de políticas urbanas. A autora ressalta que é possível identificar interessantes convergências:

O capitalismo só se realiza produzindo novos espaços, pressionados pelas exigências da acumulação, mediante sua própria lógica e estratégia à escala mundial. $\mathrm{O}$ capitalismo estendeu-se mundialmente e, ao mesmo tempo, constituiu novos setores de produção e de dominação: o cotidiano, o conhecimento, a arte e a urbanização. $\mathrm{Na}$ produção desses espaços, operam diversos agentes e interesses combinados em diferentes campos políticos e arranjos territoriais para cada caso. Sánchez (2001) ainda ressalta que sujeitos, instituições, práticas e produtos circulam, de maneira relacionada, no âmbito de diferentes mercados, materiais e símbolos.

Novas estratégias constituem-se para dinamizar a reprodução do capitalismo na sua fase atual. A cidade-mercadoria constrói-se sob a égide do poder político dos governos locais, "perfila-se através dos processos de reestruturação urbana (como exigência da economia competitiva) e através da construção de imagem para inseri-la no mercado" (sánchez, 2001, p. 33). Desse modo, a cidade, considerada uma mercadoria especial, incorpora novas estratégias especiais de promoção que se consolidam ao longo do tempo. No bojo desse processo, são produzidas representações da cidade que obedecem a uma determinada visão de mundo, criando-se novos discursos referentes à cidade, onde a imagem passa a ter importância fundamental enquanto instrumento de difusão e afirmação no cenário mundial. Para isso, a mídia terá um papel fundamental, será uma das principais difusoras desse processo.

É nesse quadro de mudanças que as cidades tornam-se o principal foco de discussão e de ações no sentido de inseri-las para a nova etapa de desenvolvimento do capitalismo com o processo de globalização. No bojo desse processo, o que iremos observar é a formulação de estratégias empresariais que emergem com o intuito de minimizar os problemas ocasionados pelo processo de globalização (Fernandes, 2000), e, sobretudo, a elaboração de projetos de renovação urbana que visam a uma maior rapidez da reprodução do capital nas áreas mais antigas da cidade.

Assim, as cidades passam a ser essenciais no atual período histórico do capitalismo, fundamentais tanto para as relações em nível internacional, quanto para a vida cotidiana de seus cidadãos. Alvarez (2008), ressalta o papel fundamental das cidades diante do processo de globalização. Aponta ainda as potencialidades que este novo momento histórico engloba no que diz respeito às cidades e destaca a necessidade de maior autonomia aos governos locais, no que denomina de protagonismo de cidades. 
$\mathrm{Na}$ visão da autora, as cidades são atores políticos, questão que foi abordada pelos autores em relatório apresentado na Conferência das Nações Unidas Sobre Assentamentos Humanos, conhecidos como Habitat II.

A Conferência promovida pela Organização das Nações Unidas, realizada em Istambul em julho de 1996, contou com a participação não apenas de chefes de Estado ou seus representantes, mas de líderes políticos locais, prefeitos, governadores e representantes da sociedade civil. No final da Conferência, os presentes firmaram o compromisso com a melhoria das condições de vida de toda a humanidade, por meio da constituição de políticas e ações que levassem às cidades e também às áreas rurais, moradias dignas, salubres e sustentáveis, sobretudo nos países não desenvolvidos. Esses processos poderiam se dar de forma solidária, por meio da troca de experiência entre os países e da transferência de tecnologia e financiamento de políticas públicas.

Nas últimas décadas do século $X X$, o que se constitui é a necessidade da realização de um ajuste urbano. Esse ajuste visou a potencializar o espaço enquanto uma mercadoria, sobretudo as cidades, de modo a transformá-las em bens solváveis, capazes de atrair investidores produtivos e viabilizar novos investimentos. As cidades brasileiras, dada a natureza, característica e complexidade que tomou o processo da urbanização periférica, fizeram com que este ajuste urbano incluísse políticas públicas de alcance restrito, ou seja, de amenizar a pobreza urbana e de oferecer uma maior oferta de serviços urbanos, além de grandes investimentos públicos e privados em fragmentos específicos da cidade.

No Brasil, o desencadeamento dessa política urbana data da década 1980, como já ressaltado, momento em que a economia mundial vivencia um processo de reestruturação econômica e de reajustamento social e político. Assim, o Brasil também conhecera a flexibilidade dos processos de trabalho: o mercado de trabalho passara por uma radical reestruturação, diante da volatilidade do mercado, aumento da competição e do estreitamento das margens de lucro, mudanças e estreitamento das relações dos poderes públicos e empresa privada. Nesse contexto, os patrões tiraram proveito do enfraquecimento do movimento sindical e da grande quantidade de mão de obra excedente, visando a impor regimes e contratos de trabalho mais flexíveis.

Dessa forma, a cidade brasileira estará no âmago dessas mudanças. Embora saibamos que a cidade moderna sempre estivera associada à divisão social do trabalho e à acumulação capitalista, a partir da década de 70 e 80 do século XX, novas relações se estabeleceram entre a configuração espacial urbana e a produção e 
reprodução do capital. Nesta fase do capitalismo, a cidade, ela mesma, passa a ser gerida e consumida como mercadoria.

No Brasil, a sociedade restabelecia sua democracia e os municípios conquistavam maior autonomia política, fiscal e financeira. A Constituição Federal do Brasil, promulgada em 1988, consagrou alguns princípios que consolidaria a elaboração das constituições estaduais, leis orgânicas municipais e planos diretores das cidades, documento esse de fundamental importância para o planejamento urbano. Com a abertura política, a partir de meados da década de 1980, os prefeitos ganham mais visibilidade - principalmente os das capitais - e passam a aliar uma sólida base de arrecadação de tributos municipais e participação acrescida nos impostos federais e estaduais recolhidos em seus territórios.

A Constituição Federal, promulgada em 5 de Outubro de 1988, concedeu aos municípios os direitos: à auto-organização, regendo-se por meio de leis orgânicas próprias; autogoverno pela eleição do prefeito, do vice-prefeito e dos vereadores e à autoadministração, podendo instituir e arrecadar tributos, aplicar agendas, legislar sobre assuntos de interesse local, organizar e prestar serviços, e promover o ordenamento territorial (Arts. 29 e 30). Segundo Compans (2005), a descentralização administrativa do Estado brasileiro ampliou as competências dos municípios, dandoIhes maior autonomia política, fiscal e financeira. Essa transferência de responsabilidade foi acompanhada pelo aumento dos repasses de recursos estaduais e federais, bem como pela liberdade para instituir e arrecadar tributos próprios. Os municípios passaram a ter competências exclusivas na organização e na prestação dos serviços de transportes coletivos, na educação pré-escolar, no ensino fundamental e no ordenamento territorial.

Apesar disso, os municípios passam a concentrar os problemas advindos do processo de urbanização periférica que caracteriza as cidades brasileiras - tais como a crescente expansão urbana, o desemprego e a pobreza urbana, a proliferação de áreas insalubres, a distribuição desigual de equipamentos e serviços coletivos, a violência urbana e a decadência e desvalorização das áreas centrais.

Compans (2004) ressalta ainda que os governos municipais, mesmo com uma maior autonomia política e financeira, não conseguiram enfrentar sozinhos o agravamento dos problemas urbanos, sobretudo nos grandes centros, decorrentes da política econômica adotada até então:

Diversos foram os fatores que contribuíram para que os municípios exercitassem com dificuldade suas competências: a política de ajuste fiscal do Governo Federal, que 
reduziu substancialmente o financiamento público destinado a investimentos sociais e a obras de infraestrutura urbana; a problemática situação financeira dos Estados, em face da elevação da dívida pública interna; a falta de competência dos executivos municipais para efetuar convênios e captar recursos externos.

Por outro lado, se, durante muito tempo, a discussão acerca da questão urbana remetia a temas como o crescimento desordenado da cidade, a carência dos equipamentos urbanos, a reprodução da força de trabalho, o aumento da cidade ilegal, a nova questão urbana teria, agora, como problemática central a competitividade urbana, a cidade concebida enquanto mercadoria, enquanto empresa.

Assim, ao investigarmos as transformações por que vem passando o capitalismo e consequentemente a cidade, devido sobretudo às mudanças nas relações de trabalho, temos visto que, de forma geral, essas transformações associam-se a indícios de mudanças no espaço urbano onde novos paradigmas se constituem. No entanto, como afirma Leite (2006), nem sempre as práticas sociais que colonizam certos espaços se coadunam com os usos esperados e projetados para determinados fins. Sobretudo, quando os paradigmas, os modelos, os projetos e as ideias são impostos a realidades que não se harmonizam com as experiências desenvolvidas.

Nos últimos anos, as políticas de revitalização urbana têm sido adotadas enquanto uma das vertentes que visam a resolver os problemas enfrentados pelas áreas mais antigas da cidade. No entanto, supõe-se que essas políticas não têm conseguido superar as práticas urbanísticas tidas como convencionais, embora visem muito mais a adequar esses espaços às novas demandas do capitalismo em nível global do que atender às demandas da população local.

Podemos dizer que a cidade de João Pessoa também será alvo dessa política e adotará esse ideário, principalmente e de maneira mais intensa, a partir dos anos 1990. A partir da análise do Projeto de Revitalização do Centro Histórico de João Pessoa, busca-se compreender o perfil dessas políticas urbanas, os conceitos e noções que as orientam, relacionando-as com a produção de novos espaços e com o tipo de imagem que se deseja para a cidade. O projeto de revitalização da cidade de João Pessoa, de um modo geral, pauta-se e se justifica pelo estigma da obsolescência do seu centro antigo, recorrente em várias cidades brasileiras que passaram por processos semelhantes.

Nesse sentido, o mundo da aquisição contínua de mercadoria, que assegura a reprodução do capital, refletir-se-á, assim, também na construção da cidade. No discurso do poder público, dos empreendedores imobiliários e até mesmo de 
arquitetos, nada antigo parece servir, sendo considerado, então, 'obsoleto', palavra que os arquitetos e promotores imobiliários costumam repetir para justificar as intervenções e as propostas de revitalização para a destruição de velhos edifícios, de antigas fábricas, galpões, moradias com duas, três ou mais décadas de antiguidade, como ressalta Horácio Capel "Para eles, a destruição e a tabula rasa parecem constituir o ideal, para poder construir edifícios totalmente novos, com os quais ganharão dinheiro e prestígio".

Segundo Scocuglia (2004), os pontos de articulação entre as experiências e legislação nacionais e internacionais e a experiência de revitalização do patrimônio cultural em João Pessoa aproximam-se a partir do estabelecimento do Convênio de Cooperação Internacional entre o Brasil e a Espanha. Esse Convênio visou à elaboração do Estudo de Revitalização Integral do Centro Histórico de João Pessoa, iniciado em 1987, durando até 2002.

\subsection{O convênio de cooperação internacional e o processo de revitalização do Centro Histórico de João Pessoa}

Em 09 de maio de 1987, contando com esforços do então Ministro da Cultura, o paraibano e economista Celso Furtado, estabeleceu-se o Convênio de Cooperação Internacional, envolvendo o Governo do Brasil e da Espanha. A assinatura desse convênio integrou o Centro Histórico de João Pessoa ao Programa de Preservação do Patrimônio Cultural da Ibero-América. Mantido pela Agência Espanhola de Cooperação Internacional (AECI), o convênio era formado entre o Governo do Brasil, por meio do Ministério da Cultura e do IPHAN; o Governo da Espanha, por meio da AECl; o Governo do Estado da Paraíba por intermédio do IPHAEP; e a Prefeitura Municipal de João Pessoa, como relata em entrevista a pesquisadora Sonia Gonsalez:

Em 13 de abril de 1987, em Brasília, estabeleceu-se o Termo de Cooperação entre o Ministério da Cultura, o Ministério do Desenvolvimento Urbano e Meio Ambiente, o Governo do Estado da Paraíba e a Prefeitura Municipal de João Pessoa. Em 07 de maio de 1987, o Jornal A União publica, sob o título Espanha Participa de Plano para a Cultura da Paraíba, uma reportagem sobre a assinatura do Convênio de Cooperação. $\mathrm{Na}$ matéria jornalística, o Ministro das Relações Exteriores da Espanha, Francisco Fernandez Ordonez, ressalta a importância do convênio e seus objetivos:

A partir da assinatura desse convênio, o Centro Histórico de João Pessoa passa a ser objeto de uma política urbana e cultural que já vinha sendo adotada em vários centros históricos nacionais e internacionais. O discurso do poder público é o de que essas 
políticas buscam recuperar o patrimônio cultural para torná-lo passível de reapropriação por parte da população, mas, sobretudo, visando a adequá-lo às demandas do turismo. Assim, mediante o Convênio Brasil/Espanha, buscava-se agregar recursos potenciais para uma melhor inserção do Centro Histórico de João Pessoa no contexto da desregulamentação neoliberal da economia mundial.

Uma das características principais do Projeto de Revitalização do Centro Histórico de João Pessoa foi a longa participação da Agência Espanhola de Cooperação Internacional-AECI. Essa entidade vinha desenvolvendo vários programas de cooperação junto aos países ibero-americanos em comemoração aos 500 anos de descobrimento da América. No entanto, a principal intenção da Espanha com as intervenções da $\mathrm{AECl}$ será a atuação no continente latino-americano, por meio de práticas urbanísticas que adaptem esses espaços às demandas do capitalismo.

Segundo Scocuglia (2004), o Convênio Brasil/Espanha foi muito importante para o processo de revitalização do Centro Histórico de João Pessoa, pouquíssimas cidades tiveram esse respaldo. Ao mesmo tempo, a Espanha pleiteava sua entrada na Comunidade Econômica Europeia, assim, necessitava melhorar sua imagem junto a comunidade europeia e uma das formas que encontro foi investir nos Centros Históricos das cidades Latino Americanas.

Dentre as primeiras atuações da $\mathrm{AECl}$, estava a restauração do Convento de San Francisco, em Quito, e a elaboração do estudo de revitalização integral do Centro Histórico de Tlacotalpan, no México. A atuação da $\mathrm{AECl}$, junto aos países iberoamericanos, se dá por intermédio da cooperação técnica e financeira, conforme relato da Coordenadora da Comissão Permanente de Desenvolvimento do Projeto de Revitalização do Centro Histórico de João Pessoa, Sonia Gonsalez, segundo a qual, a $\mathrm{AECl}$, na sua atuação, não pretendia impor um projeto, nem um modelo a seguir, tampouco um processo de gestão: a agência buscava um intercâmbio de experiências e o fortalecimento das relações entre as culturas. Na visão de Sonia Gonsalez, a Espanha possuía conhecimentos em determinadas áreas vinculadas à preservação e à restauração de áreas históricas, principalmente as áreas ligadas à preservação do patrimônio cultural e restauração de monumentos, uma prática que nós, paraibanos, não dominávamos. Porém, não é isso que ficará explícito na atuação dos consultores internacionais espanhóis ao longo do processo de desenvolvimento do projeto de revitalização do centro histórico de João Pessoa.

$\mathrm{Na}$ concepção da $\mathrm{AECl}$, dois foram os motivos que justificaram a atuação junto ao Centro Histórico de João Pessoa. Primeiro, a importância histórica entre as duas 
nações, tendo-se em vista que, no período colonial, o Reino Português esteve unificado ao Reino da Espanha, momento em que a capital da Paraíba passou a se chamar Filipéia de Nossa Senhora das Neves, em 1588, em homenagem ao rei Felipe Il de Espanha. Segundo, a importância patrimonial do seu sítio histórico.

O discurso da Agência Espanhola de Cooperação Internacional é que o patrimônio cultural urbano é um bem de valor inestimável para as sociedades locais, um capital para a sociedade que, como tal, deve ser utilizado e desfrutado por todos. Este direito de uso e desfrute social traz implícita a obrigação, também social, de sua conservação. Logo, para essa instituição, o patrimônio cultural é considerado como fator capaz de gerar benefícios sociais de vários tipos, desde a formação de jovens na área da preservação e restauro, como a possibilidade de gerar emprego e renda para a população local por meio da indústria do turismo. Nesse processo, é dada prioridade aos bens culturais pertencentes, em termos temporais, à origem histórica comum ibero-americana, embora não seja um critério rígido, sendo mais importantes os valores culturais e históricos em escala mundial e os benefícios sociais implícitos (Scocuglia, 2004).

Segundo o Memorial Geral do Projeto de Revitalização do Centro Histórico de João Pessoa, o compromisso e a participação dos governos locais eram fundamentais no aporte de recursos humanos e técnico-financeiros. Scocuglia (2004) ressalta que, no início do processo de revitalização, o Governo do Estado e da Prefeitura Municipal tiveram uma participação marcada pela ambiguidade, atitude que refletia a concepção de patrimônio cultural e a preservação dos gestores à frente das instituições. Todavia, alguns membros da Comissão Permanente não compartilham dessa visão. $\mathrm{Na}$ visão de Claudio Nogueira, que, à época, era membro da Comissão Permanente do Centro Histórico e hoje se encontra à frente do IPHAN, o Governo do Estado e a Prefeitura Municipal sempre mantiveram uma participação no processo de revitalização do Centro Histórico de João Pessoa. Na visão do arquiteto, o que mudou foi a forma de participação ao longo do tempo. Em sua fase inicial (1987 -1997), ocorreu um processo capitaneado muito mais pelo Governo do Estado, tanto do ponto de vista da gestão do processo, por meio da Comissão Permanente do Centro Histórico, como das intervenções realizadas no centro histórico. Num segundo momento (1997 2005), há uma ampliação da participação da Prefeitura Municipal de João Pessoa, acompanhando as intervenções da Comissão Permanente, enquanto o Governo do Estado adota uma postura muito mais voltada para a gestão e o planejamento estratégico ligado ao desenvolvimento do turismo na área. A partir de 2005, a prefeitura assume a gestão do processo de revitalização, com a criação da 
Coordenadoria de Patrimônio Cultural (COPAC), e começa a assumir a gestão do centro histórico, enquanto temos uma retração na participação do Estado.

\section{Conclusão}

No caso de João Pessoa, revitalizaram-se as edificações, largos, e praças representativos do final do século XIX e início do século XX, e da denominada Belle Époque. Um dos aspectos importantes do processo de revitalização de João Pessoa a ser ressaltado nesse processo é a criação da imagem de Centro Histórico que, até então, não era considerado pelo poder público nem pela população, tampouco pelos órgãos ligados à preservação do patrimônio. Esse reconhecimento só veio com o processo de revitalização da Praça Anthenor Navarro e do Largo de São Frei Pedro Gonçalves, em 1998, no bairro do Varadouro.

Esse modelo insere-se no contexto surgido no final do século $X X$, marcado pelo aparecimento de novas práticas de intervenção do poder público no espaço urbano. A partir de 1980, assiste-se ao surgimento do que se convencionou chamar de empresariamento urbano, um novo modelo de gestão urbana, cujo foco é o ajustamento das economias em desenvolvimento às necessidades de expansão do capitalismo na sua fase atual. Uma nova ordem orienta a produção do espaço urbano, redefinindo novos usos e funções reorientados pelas políticas urbanas (Carlos, 2004). Esses são pressupostos essenciais para se pensar o que comumente no Brasil se denominou por revitalização das áreas centrais.

O mundo da aquisição contínua da mercadoria, que assegura a reprodução do capital, reflete-se diretamente na construção da cidade. Na fase atual, com o processo de urbanização generalizada, "nada antigo parece servir, e acabam sendo obsoletos, palavra que os arquitetos e promotores imobiliários gostam de repetir para justificar a destruição de velhos edifícios", ressalta Horácio Capel de modo que esses espaços, "antigas fábricas, moradias com duas ou três décadas de antiguidade", sobretudo na área central das cidades, são transformados em restaurantes, bares, ateliês, para quem pode pagar. 


\section{Referências Bibliográficas}

Motta, Lia. A apropriação do patrimônio urbano: do estético estilístico nacional ao consumo visual global. Arantes neto, Antônio Augusto (Org.). O espaço da diferença. Campinas: Papirus, 2000.

Alvarez, Isabel Aparecida Pinto. A reprodução da metrópole: o projeto Eixo Tamanduatehy. Tese (Doutorado) Programa de Pós-Gradução em Geografia Humana, Faculdade de Filosofia Letras e Ciências Humanas, Universidade de São Paulo USP, 2008.

Carlos, Ana F A. O Espaço Urbano: novos escritos sobre a cidade. São Paulo: Contexto, 2004.

Compans, Rose. Empreendedorismo Urbano: entre o discurso e a prática. São Paulo: Editora Unesp, 2005.

Fernandes, A. C. Da reestruturação coorporativa á competição entre cidades: lições urbanas sobre os ajustes de interesses globais e locais no capitalismo contemporâneo. In: Revista Espaço e Debates, São Paulo, no 41, Ano XVII, 2001, p.26 a 45.

Harvey, David. Condição Pós-Moderna. São Paulo: Edições Loyola, 2000.

Leite, Rogério Proença de Sousa. Espaço Público e político dos lugares: usos do patrimônio cultural na reinvenção contemporânea do Recife Antigo. UNICAMP, Instituto de Filosofia e Ciências Humanas, São PAULO, 2001.

Sánchez, F. A reinvenção das cidades para um mercado mundial. São Paulo. Tese (Doutorado em Ciências: Geografia Humana). FFLCH, Departamento de Geografia, Universidade de São Paulo. 2001.

Scocuglia, Jovanka Baracuhy Cavalcanti. Revitalização Urbana e $(R e)$ invenção do Centro Histórico na Cidade de João Pessoa (1987-2002). João Pessoa: Ed Universitária/UFPB, 2004.

\section{Artigo de Jornal}

Espanha participa de plano para a cultura da Paraíba. Jornal a União, 07 de Maio de 1987, p. 04. 


\section{Xàbia, ¿es posible vivir en un pueblo más sostenible? Proyecto "Nós Propomos!"}

ISABEL HENAREJOS CRESPO ${ }^{18}$

ESTHER CARDONA SANZ ${ }^{19}$

\section{Resumen}

El objetivo de este trabajo, desde quinto nivel de Educación Primaria, es proponerle a la sociedad el desarrollo de un "Turismo Sostenible", más relacionado con los parajes naturales de Xàbia y, menos agresivo con el medioambiente. Además, desde sexto de Educación Primaria queremos profundizar en el conocimiento de la España seca donde vivimos, para animar al "Ahorro de Agua", modificando la tendencia en el consumo y, animando a la población al cambio de costumbres de los últimos tiempos (volver a los jardines mediterráneos), retomando las especies de plantas autóctonas (necesitan poca agua y favorecen menos los incendios forestales). Con este estudio queremos contribuir al proyecto "Nosotros proponemos", ya que los niños y niñas están muy sensibilizados con la Sostenibilidad del Planeta y pueden transmitir esta idea, de manera fácil y accesible a los adultos.

Palabras Clave: turismo, agua, sostenibilidad, alumnos, competencias.

\section{Resumo}

O objetivo deste trabalho desde o quinto ano de Educação Primária é propor à sociedade o desenvolvimento de um "Turismo sustentável", mais relacionado com as paisagens naturais de Xábia e menos agressivo com o meio ambiente. Desde o sexto ano de Educação Primária queremos aprofundar o conhecimento da Espanha seca e que vivemos, para animar a "Poupança de Água", modificando a tendência no consumo e, estimulando a população à alteração de costumes dos últimos tempos

\footnotetext{
${ }^{18}$ Maestra de Educación Primaria, Directora del Colegio Público Vicente Tena de Xàbia (Alicante - España), isabelhenarejos@gmail.com

${ }_{19}$ Maestra de Educación Primaria, Jefe de Estudios del Colegio Público Vicente Tena de Xàbia (Alicante - España), esthercardonasanz@hotmail.com
} 
(regressar aos jardins mediterrâneos), retomando s espécies de plantas autóctones (necessitam pouca água e favorecem menos os incêndios florestais). No final deste estudo podemos contribuir para o Projeto “Nós Propomos!", já que os meninos e as meninas estão muito sensibilizados para a Sustentabilidade do Planeta e podem transmitir esta ideia, de maneira fácil e acessível aos alunos.

Palavras-chave: turismo, água, sustentabilidade, alunos, competências.

\section{Introducción}

EI CEIP VICENTE TENA está situado en la Comunidad Valenciana, el levante español, a orillas del mar Mediterráneo.

En el marco socioeconómico, cabe destacar que Xàbia es una localidad turística y las actividades económicas principales pertenecen al sector servicios y a la construcción.

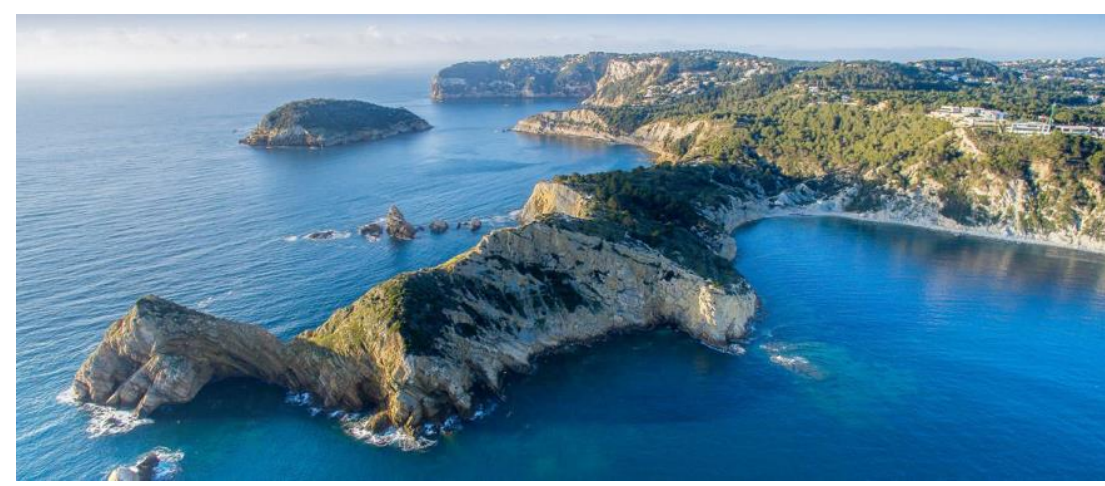

Figura 1 - Xábia

Fuente: Ayuntamiento de Xàbia

En el ámbito medioambiental Xàbia ofrece una gran diversidad de parajes protegidos, zonas verdes y espacios ambientales únicos. EI CEIP Vicente Tena se encuentra a pocos kilómetros del Parc Natural El Montgó y de la Reserva Marina del Cap de Sant Antoni, lo que nos facilita el contacto directo con la naturaleza.

El Ayuntamiento organiza, a menudo, actividades familiares con el fin de que disfruten de estos espacios y para concienciar a los más pequeños del respeto al medio ambiente. En relación al contexto sociolingüístico, nos encontramos en la Comunidad Valenciana y tenemos dos lenguas oficiales, el valenciano y el castellano. Estamos en zona de predominio lingüístico valenciano.

Gran parte de los niños que se matriculan en el centro presentan un desconocimiento alto de las dos lenguas oficiales, esto supone un trabajo añadido para el profesorado. Aunque muchos de los alumnos han nacido en España y por tanto su nacionalidad es 
española, a la hora de comunicarse desconocen totalmente las dos lenguas y, en algunos casos incluso el inglés.

\section{Nuestro Colegio}

EI CEIP VICENTE TENA de Xàbia es un centro Plurilingüe, Público de Educación Infantil y Primaria, con más 450 alumnos, entre 3 y 12 años, de unas 27 nacionalidades diferentes. Es un colegio integrador (Zabalza, 1994), donde todos los niños y niñas que llegan se sienten parte importante del centro, así como sus familiares.

La Asociación de madres y padres de alumnos han desarrollado un proyecto de materiales escolares para que todos los alumnos disfruten de: tabletas digitales, material fungible, además de, escuela de padres, actividades extraescolares y complementarias. Trabajan mucho para realizar jornadas de puertas abiertas donde todos disfrutamos juntos en cenas, chocolatadas, excursiones y viajes de estudios. Con esto fomentamos la convivencia y el trabajo en equipo de nuestras familias.

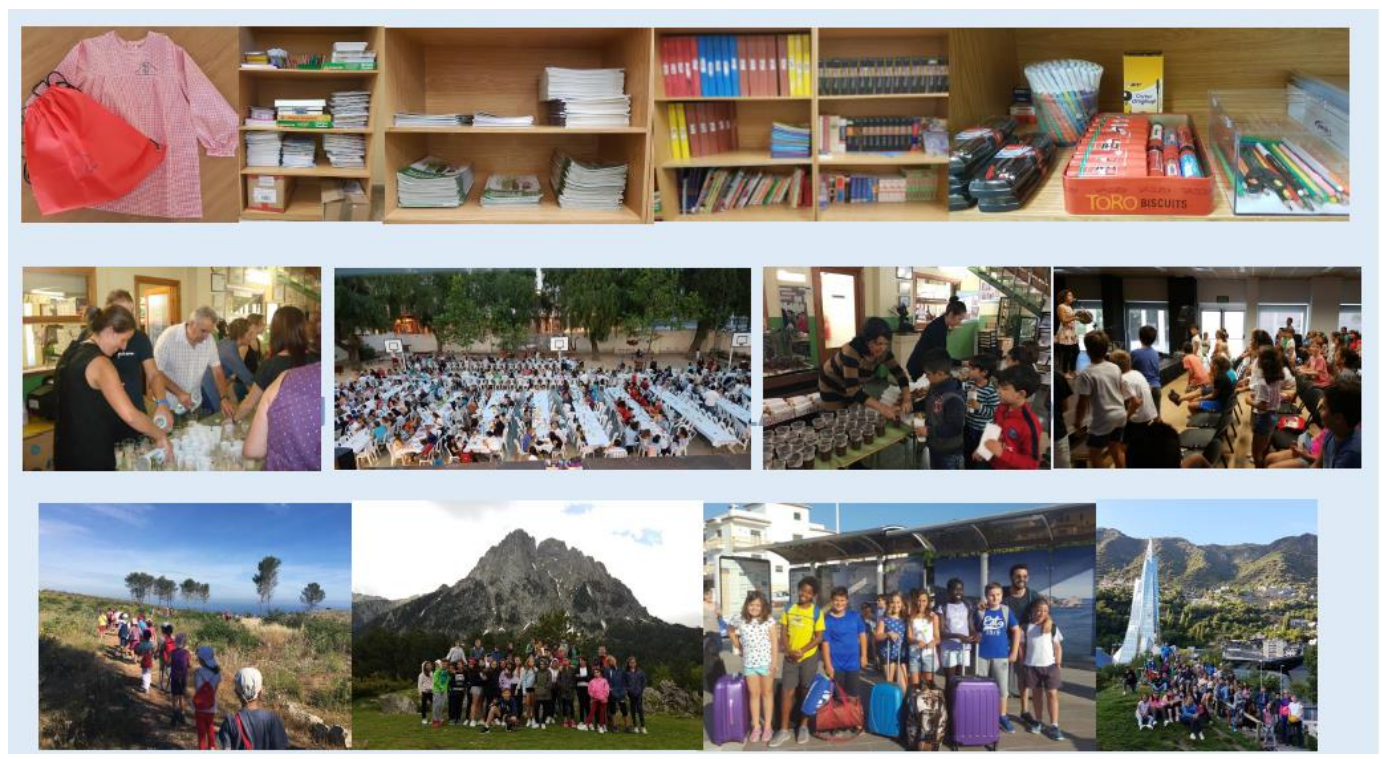

Figura 2 - Desarrollo de actividades complementarias

\subsection{Nuevas metodologías}

Una premisa básica de nuestra metodología es el fomento de la participación e interacción de los alumnos, de manera que se impliquen en el proceso de enseñanza - aprendizaje, por medio de la selección de temas, la reflexión, el análisis, la crítica 
constructiva, la observación, el descubrimiento y la elaboración de trabajos y experiencias dentro y fuera del aula.

Por metodología activa entendemos la elaboración de Unidades didácticas integradas multidisciplinares, el trabajo por competencias, el aprendizaje manipulativo, la creación y organización de talleres y rincones, la investigación en el entorno, el trabajo cooperativo, exposiciones, estudios en gran grupo o por equipos, las salidas fuera del aula, etc. (Henarejos Crespo, Cardona Sanz, 2017). Pensamos que el aprendizaje vinculado a la actividad y al compartir, es la mejor manera posible de aprender. Queremos asegurar la construcción del aprendizaje significativo y competencial.

También utilizaremos el principio de actividad y experiencias para llegar a la reflexión del tema tratado (Ainscow, Beresford, Harris, Hopkins, \& West, 2001). Por lo tanto, tenemos que poner en práctica las siguientes estrategias:

- Activar la curiosidad y el interés del alumnado

- Favorecer las actividades cooperativas

- Desarrollar la creatividad y la originalidad

- Buscar información, profundizar en el tema y evaluar la actividad, considerando la evaluación como una ocasión más para aprender.

\subsection{Proyectos que desarrollamos}

Como ejemplos del trabajo que realizamos en el centro, queremos destacar cuatro proyectos importantes:

- Las lecturas intergeneracionales, que desarrollan los alumnos de segundo de Educación Primaria todos los martes, con los ancianos del Centro de Día (Figura 3). 


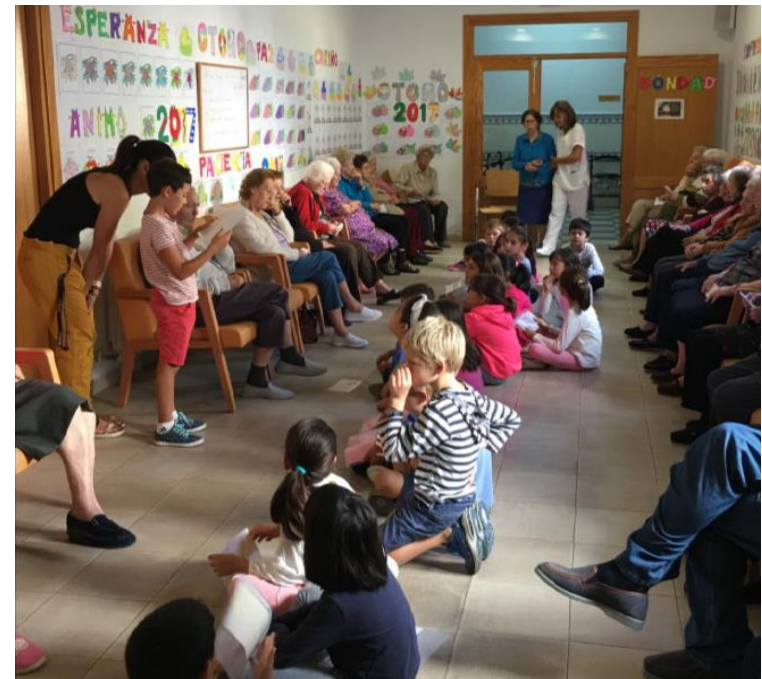

- Y el estudio de las migraciones humanas más actuales del que tuvimos unos productos resultantes importantes: escribimos un libro "El Viatge més dur del Món”, "El viaje más duro del Mundo", que trata de las dificultades de los migrantes visto por los ojos de una niña, que se representó en el XXI Ajedrez Viviente de Xàbia, que es Fiesta de Interés Turístico Nacional.

- El Proyecto "ECOESCOLES" basado en los huertos y comedores escolares ecológicos. Buscamos que nuestros alumnos aprendan sobre la tierra y el sector agroalimentario y que esto pueda tener efectos decisivos sobre su salud, la ecología y el desarrollo local-rural (Figura 4).

Figura 4 - Proyecto ESCOLESCOLES

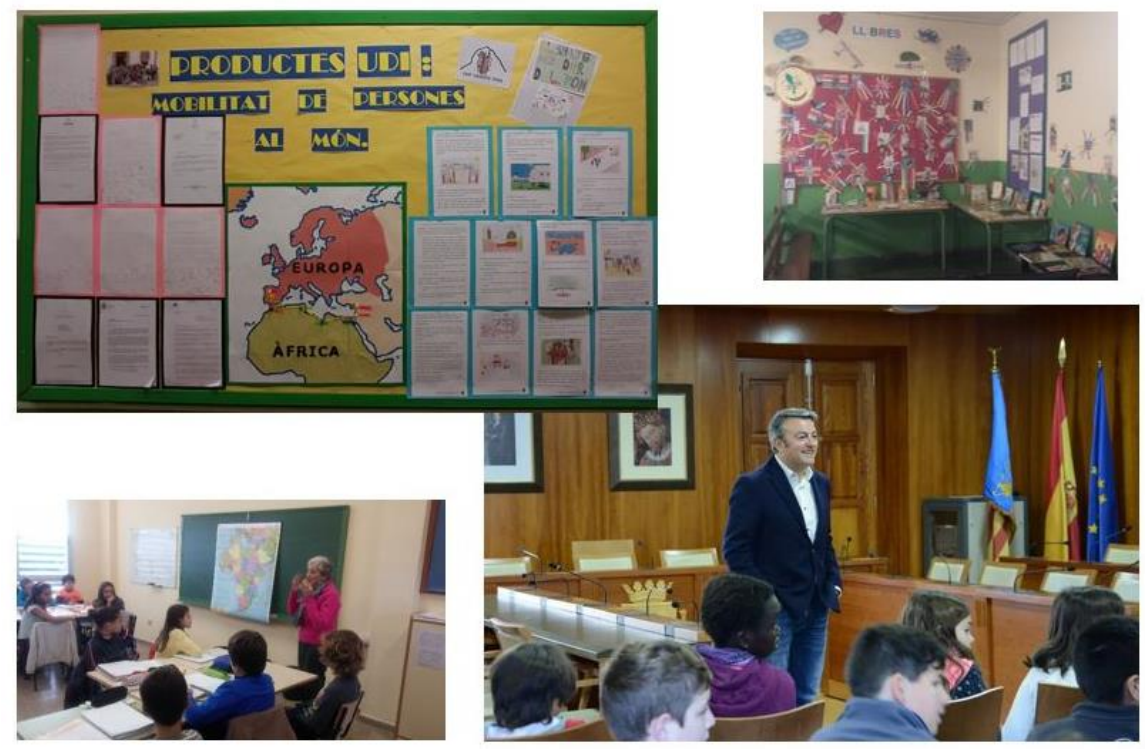




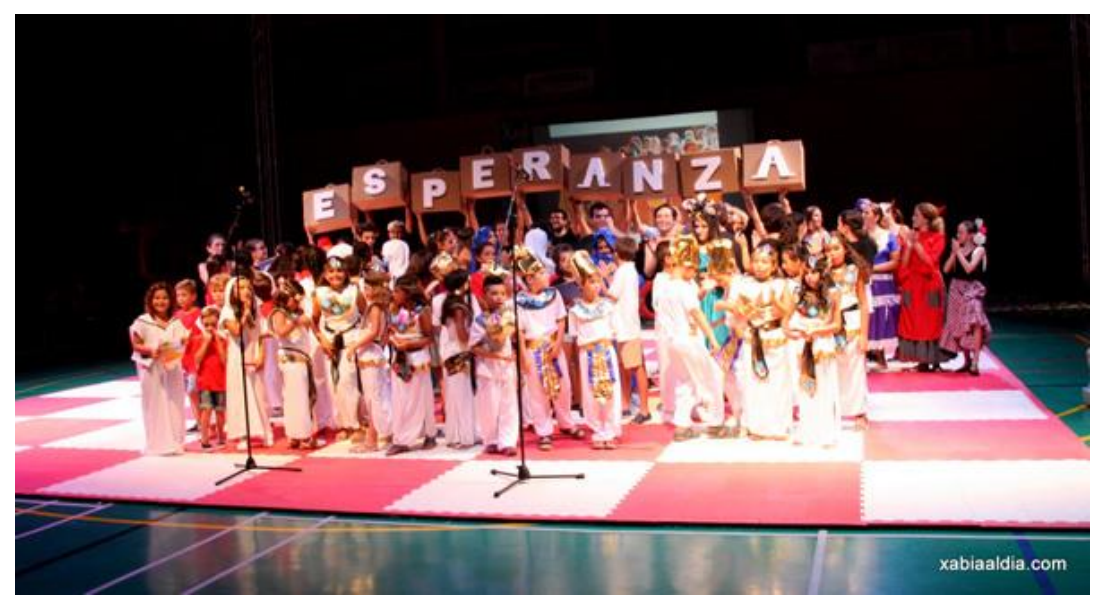

- El Proyecto de Centro, en el que trabajamos todos, docentes y alumnado, es “Mestres per uns dies", "Maestros por unos días" (Figura 5). Ahora nuestros alumnos participan activamente en la preparación y desarrollo de los temas de trabajo. Son "maestros" de alumnos de infantil, primero, segundo, tercero y cuarto de primaria $y$, durante unos días les enseñan cosas sobre Xàbia (naturaleza, historia...).

Figura 5 - Proyecto Mestres per uns dies
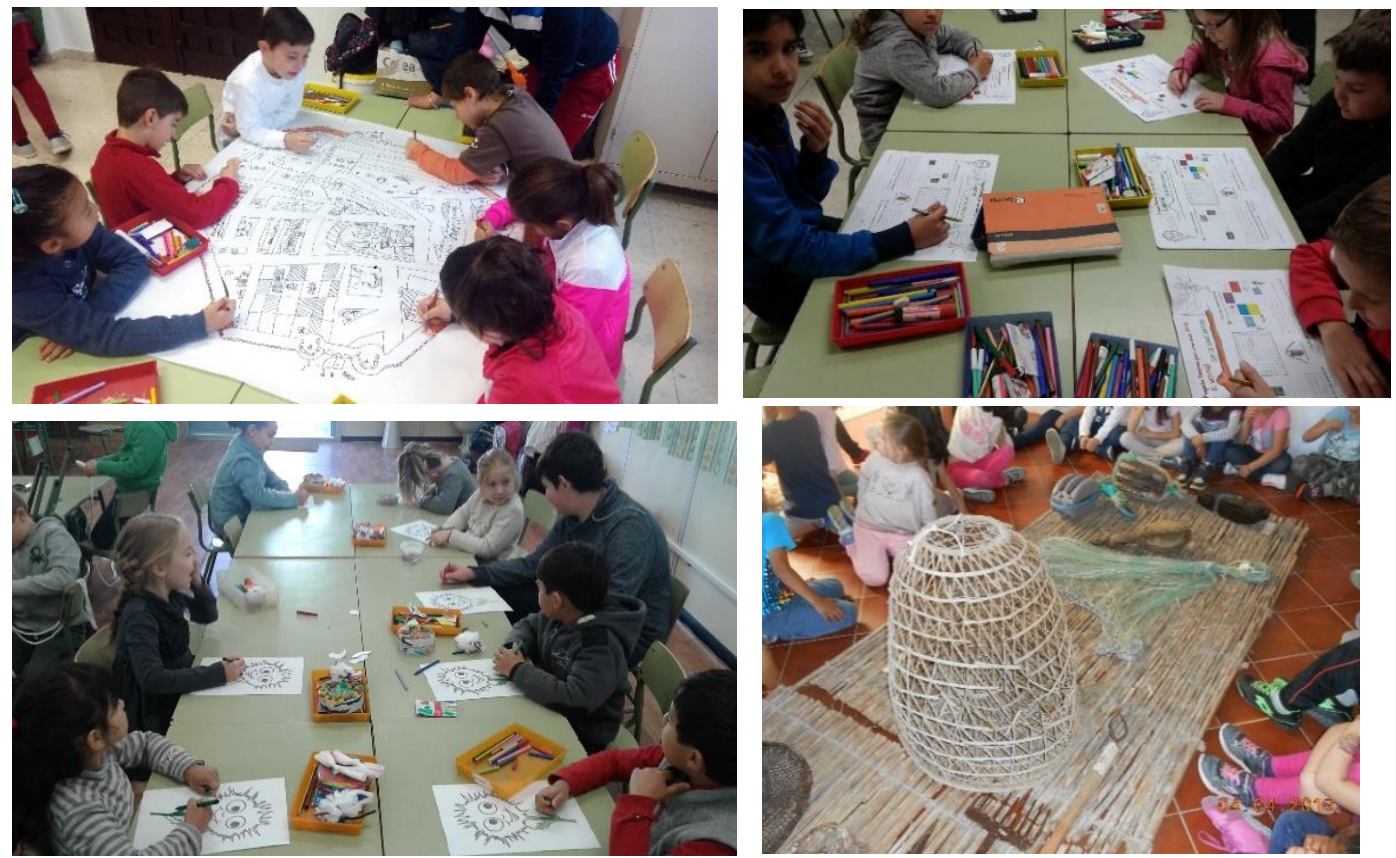

Se presentan a continuación algunos de trabajo realizados por los alumnos/as. 


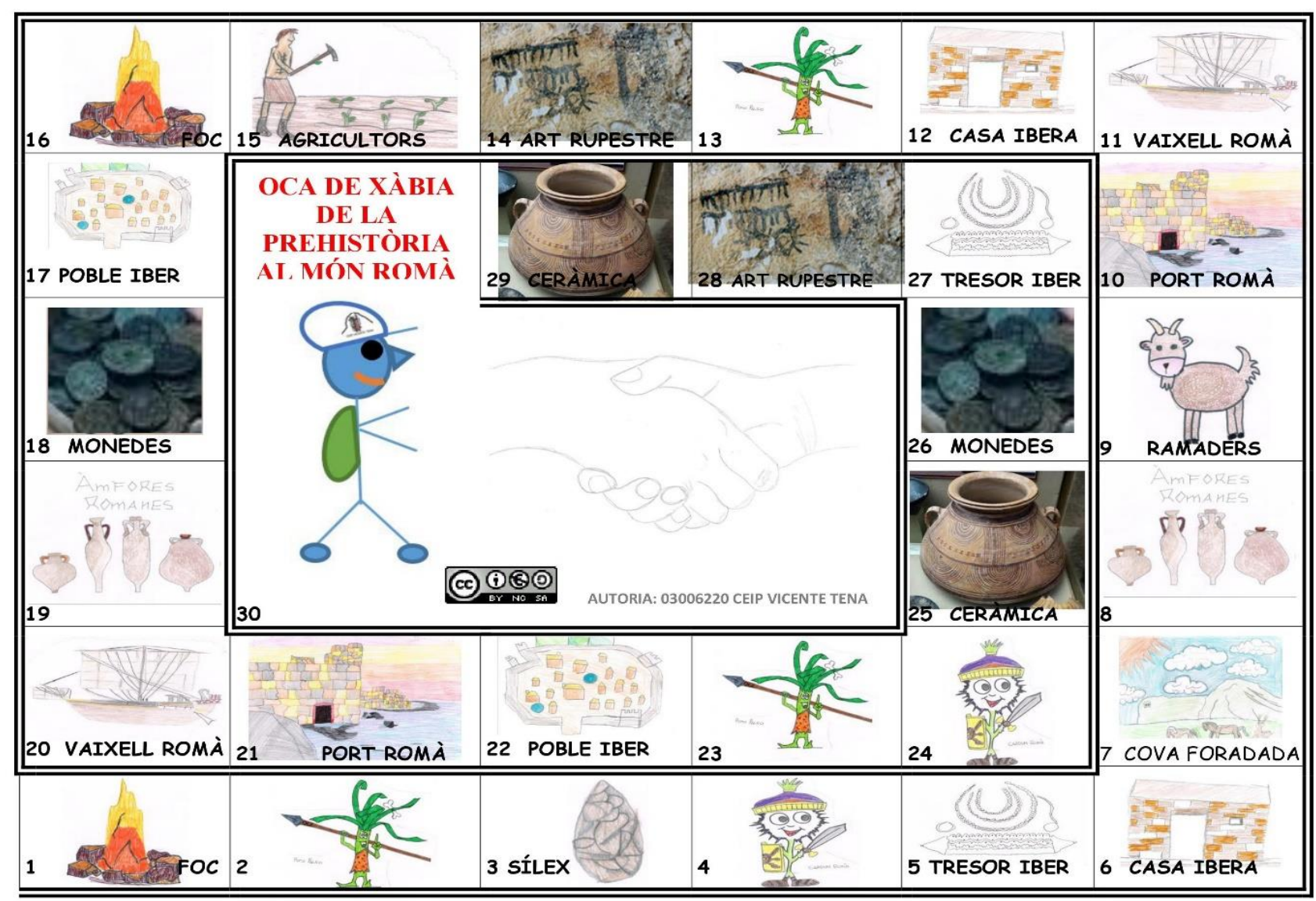



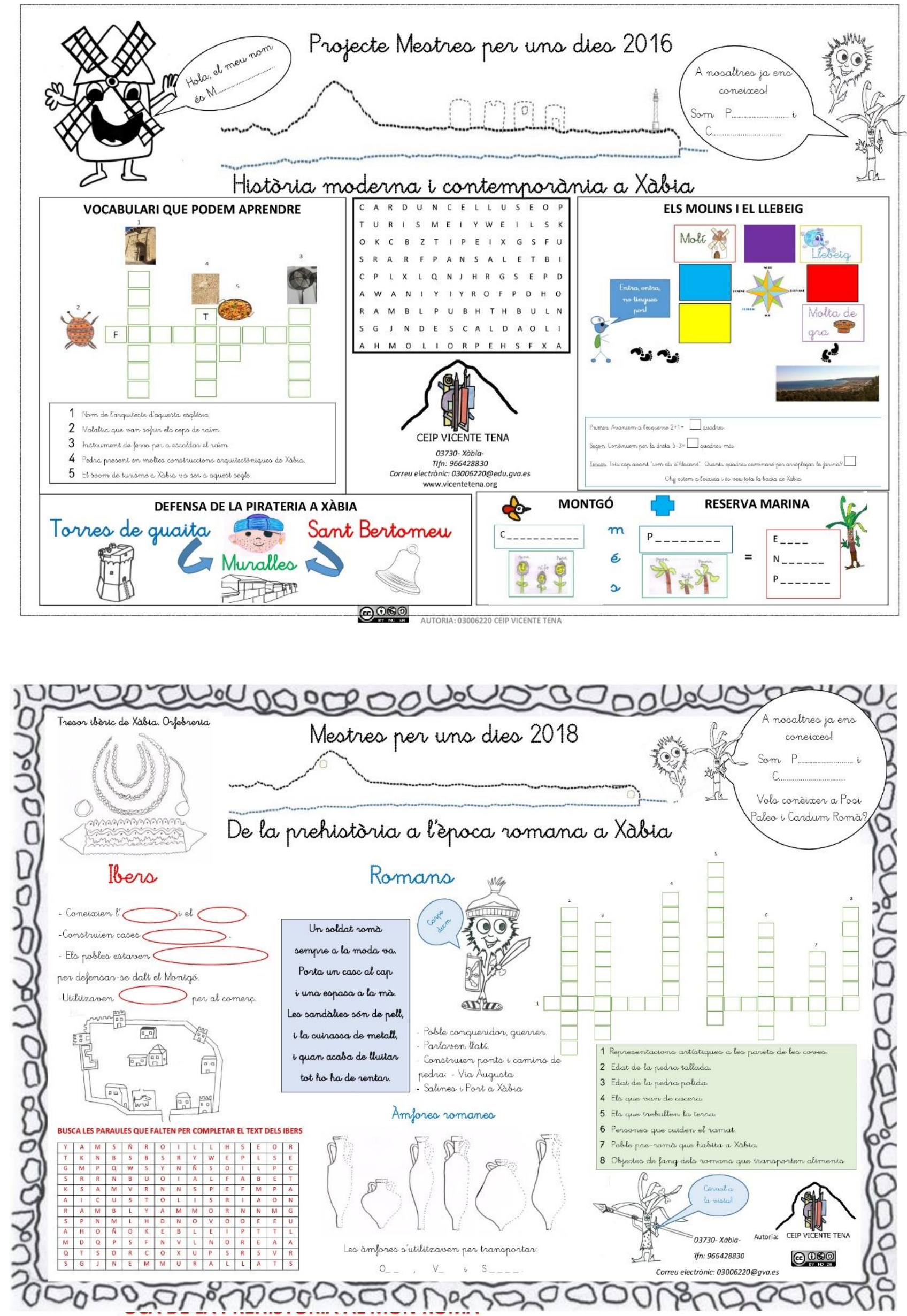

MESTRES PER UNS DIES- 2017/2018

Ordre de jugada: tots tiren el dau i, comença el joc el de més puntuació. 

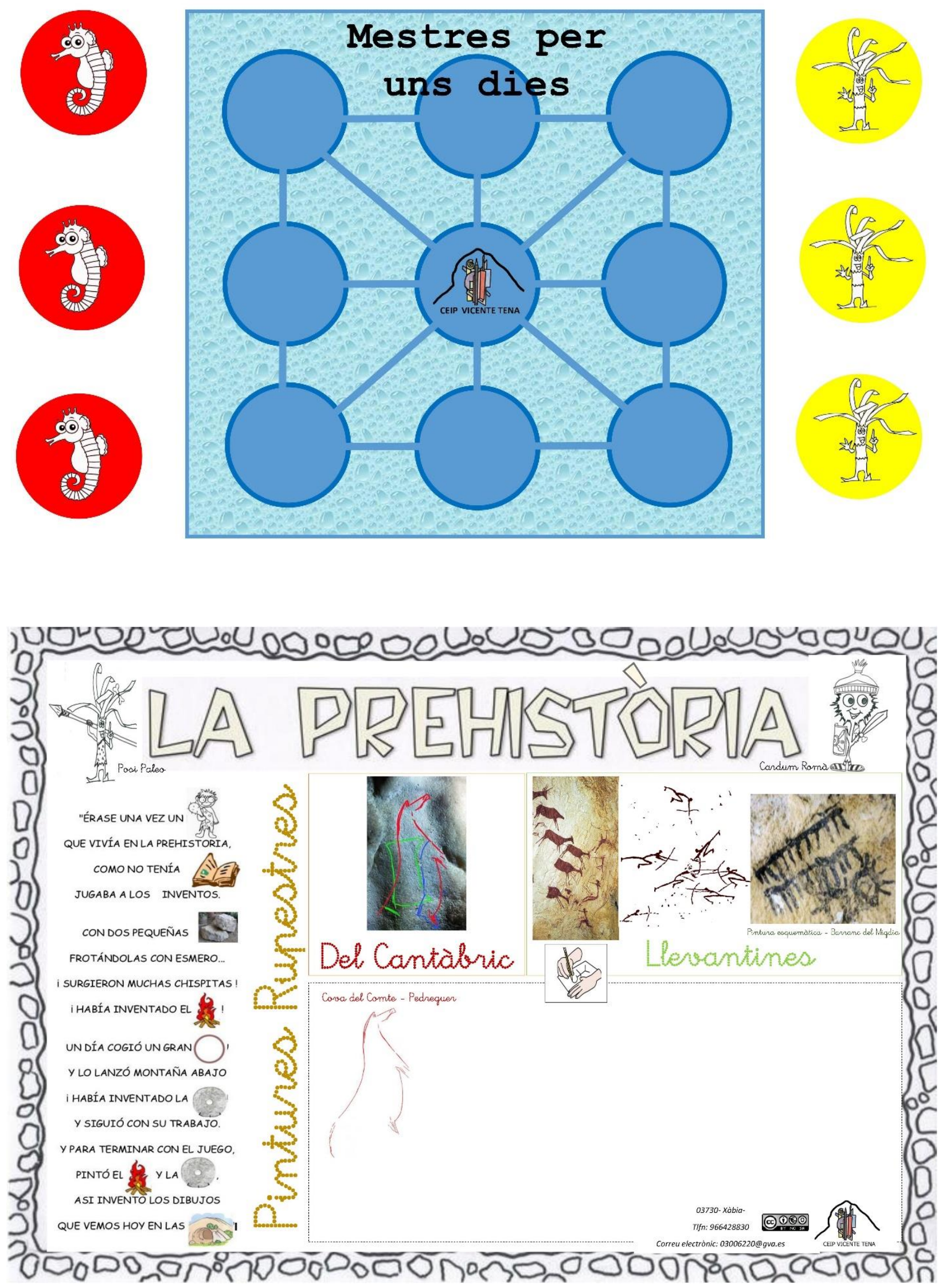


\section{MESTRES PER UNS DIES}

\section{CEIP VICENTE TENA-XÀBIA}

L'alumnat de sisè investiga, treballa, prepara, aprofundeix i estudia sobre la història del poble de Xàbia, concretament en la contemporània, per adaptarlo, estructurar-lo i exposar-lo en grups de 6 alumnes de manera lúdica i creativa als nivells de tercer i quart del centre. Aquesta UDI està dividida en quatre tasques amb l'elaboració dels seus corresponents productes. Aquests serviran per a, posteriorment, posar-los en pràctica amb els alumnes de $3 r$ i 4 t. Els productes són:

\section{preparació d'una estovalla didáctica \\ creació d'una mascota \\ realització d'una presentació en PowerPoint \\ elaboració del joc de l'oca}

Té una gran repercussió familiar i social. El nostre centre treballa actualment en dos projectes d'Innovació Educativa. Un musical, que ens relacionarem amb diferents centres de Xàbia i, l'altre, és aquest que hem dut endavant altres anys, els xiquets ja coneixen el seu funcionament i estan motivats per treballar en ell.

\section{MÉS INFORMACIÓ}
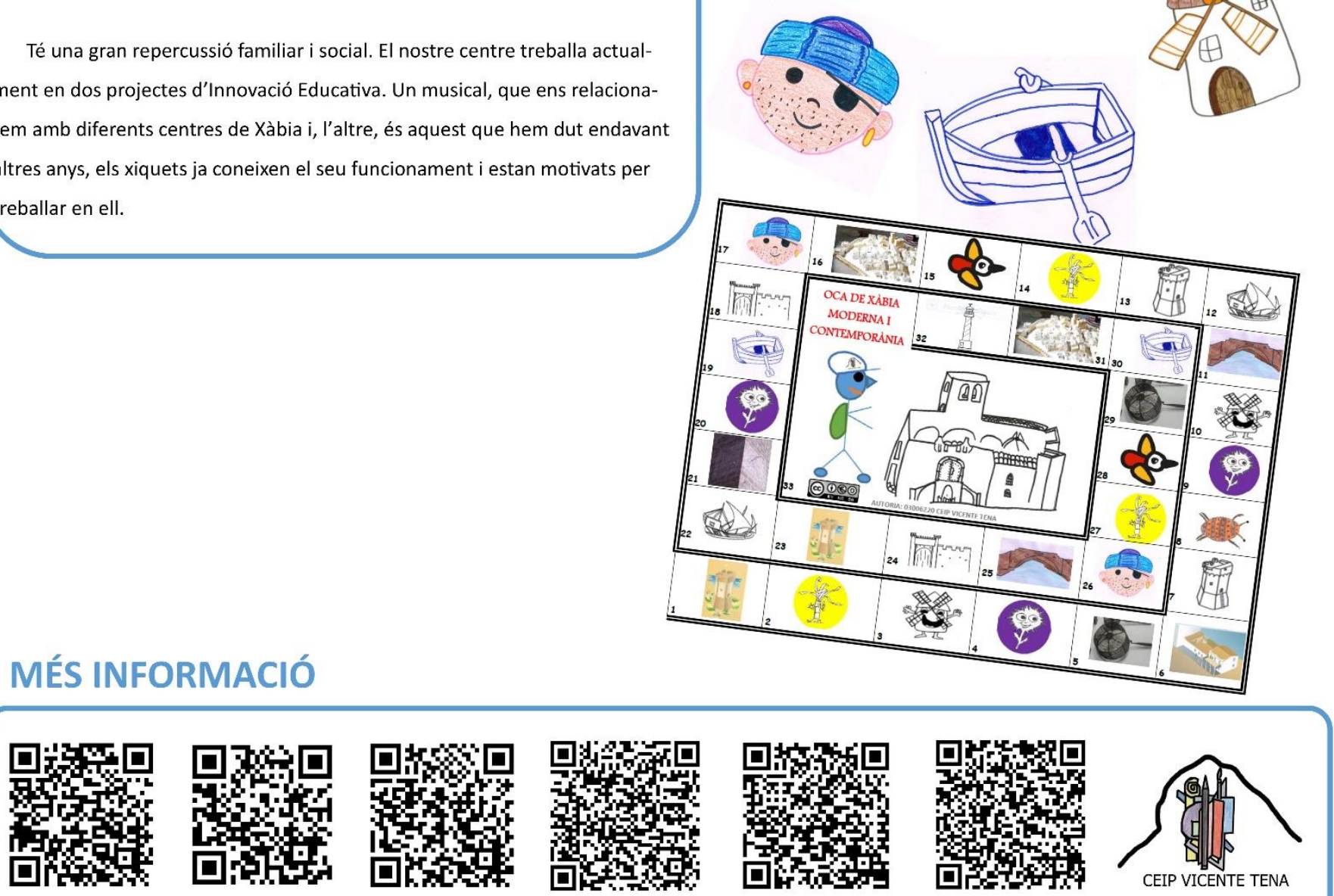


\section{Compartir experiencias}

Tenemos compartido nuestras experiencias en:

15 de mayo de 2016 - I Jornada de experiencias innovadoras en Valencia - Primavera educativa

15 de julio de 2016 - II Jornadas del itinerario de competencias. Espacios de inclusión, competencias clave y desarrollo profesional - Facultad de Educación de Alicante.

22 de marzo de 2017- Buenas prácticas educativas: Banco de experiencias y buenas prácticas. Jornada de intercambio de experiencias - CEIP Llebeig- Denia (Centros de Xàbia, Denia y Altea).

10 de Julio de 2017- I encuentro intercambio de experiencias de innovación en Geografía e Historia - Facultad de Magisterio de Valencia

26 de octubre de 2017 - Socialización de tabletas táctiles digitales- SIMO, IFEMA Madrid

Del 7 al 12 de septiembre de 2018 - I Congreso iberoamericano Nós Propomos: Geografía, Educación y Ciudadanía - IGOT, Lisboa

27 de septiembre de 2018- II Encuentro nacional de centros innovadores DIM (Didáctica, Innovación, Multimedia)- Facultad de Educación de Alicante.

Por otro lado, hemos compartido las mismas experiencias en publicaciones:

1. Coautoras del DVD “Gestión de Centros" ISBN 978-84-482-6057-6, editado por la Conselleria de Educación, Elda noviembre 2015.

2. Las personas que firmamos este trabajo somos coautoras de un capítulo de un libro editado por la Universitat de Valencia (Henarejos y Cardona, 2017) sobre las buenas praxis escolares, donde exponemos el trabajo del proyecto educativo del centro Vicente Tena. La presentación de este libro sirvió como aliciente, a la comunidad escolar, para insertarse en el proyecto ¡Nós Propomos!

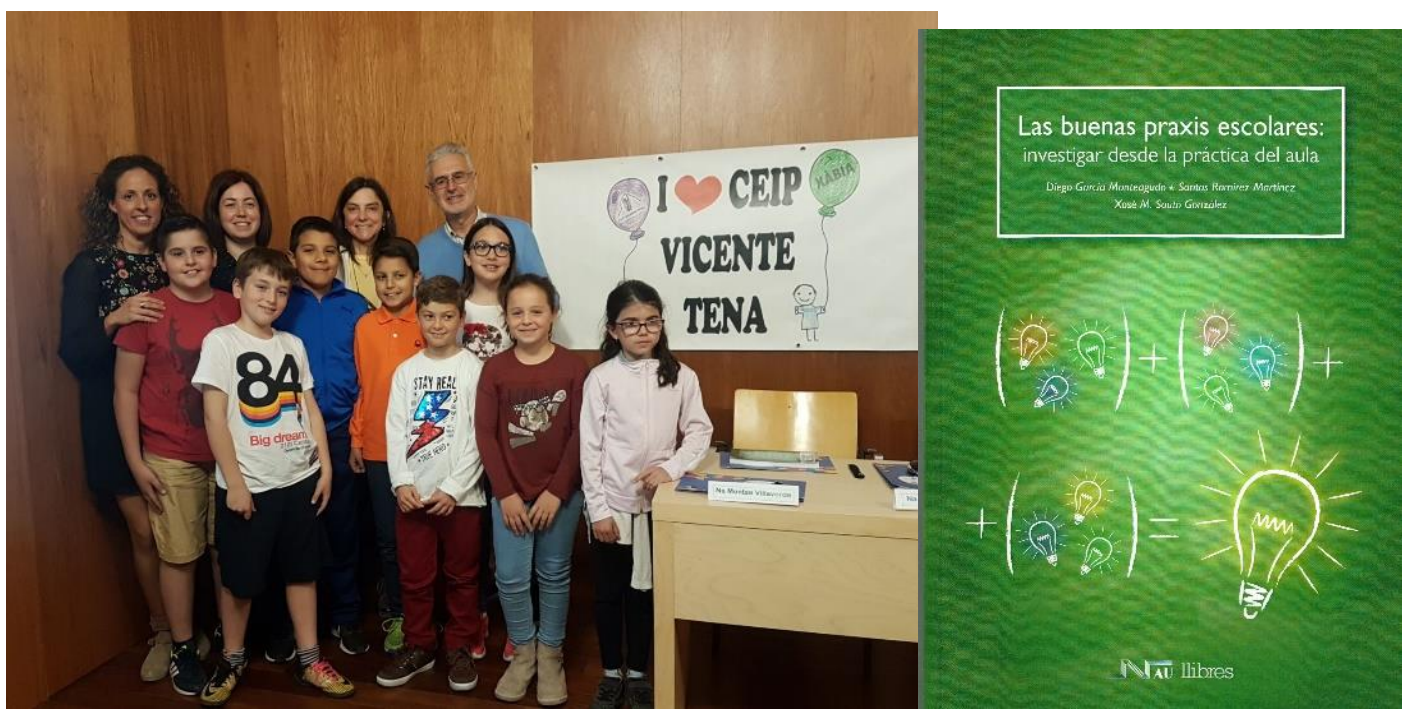


Este curso 2018-19, somos miembros de Nós Propomos, trabajando dos grandes temas: "Turismo Sostenible" y "Agua y vida". Es para nosotros, para nuestro colegio y para nuestro Ayuntamiento una gran oportunidad y un gran reto que aceptamos con mucha ilusión. Gracias por contar con nosotros. Esperamos implicarnos a fondo y desarrollar unos buenos trabajos.

\section{Conclusión}

Formamos una Comunidad Educativa plural, diversa, respetuosa, donde nos enriquecemos con lo mejor de cada uno, para alcanzar una formación integral. El trabajo cooperativo y el aprendizaje servicio, junto con la empatía, ilusión y la investigación, nos dan la alegría y la fuerza para avanzar cada día. Queremos que nuestro alumnado sean, el día de mañana, personas adultas con valores y preparada para todos los retos que se le presenten.

\section{Referencias bibliográficas}

Ainscow, M., Beresford, J., Harris, A., Hopkins, D. \& West, M. (2001). Crear condiciones para la mejora del trabajo en el aula. Madrid: Narcea.

Henarejos Crespo, I., Cardona Sanz, E. (2017). Mestres por uns dies. Història moderna i contemporània del poble de Xàbia In D. Monteagudo, S. Ramírez Martínez \& X. M. Souto González. Las buenas praxis escolares: investigar desde la práctica del aula (pp. 46-60). Valencia: Nau Llibres.

Zabalza, M. Á. (1994), Diseño y desarrollo curricular. Madrid: Ediciones Narcea. 


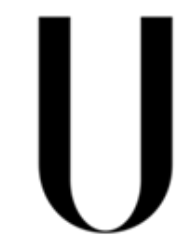

LISBDA

UNIVERSIDADE DE LISBOA

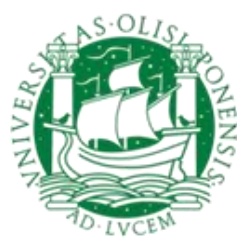

IGOT

UNIVERSIDADE DE LISBOA

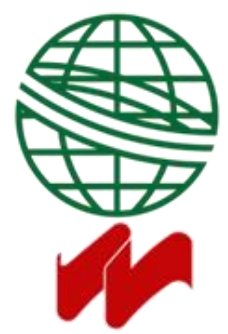

CEG 